
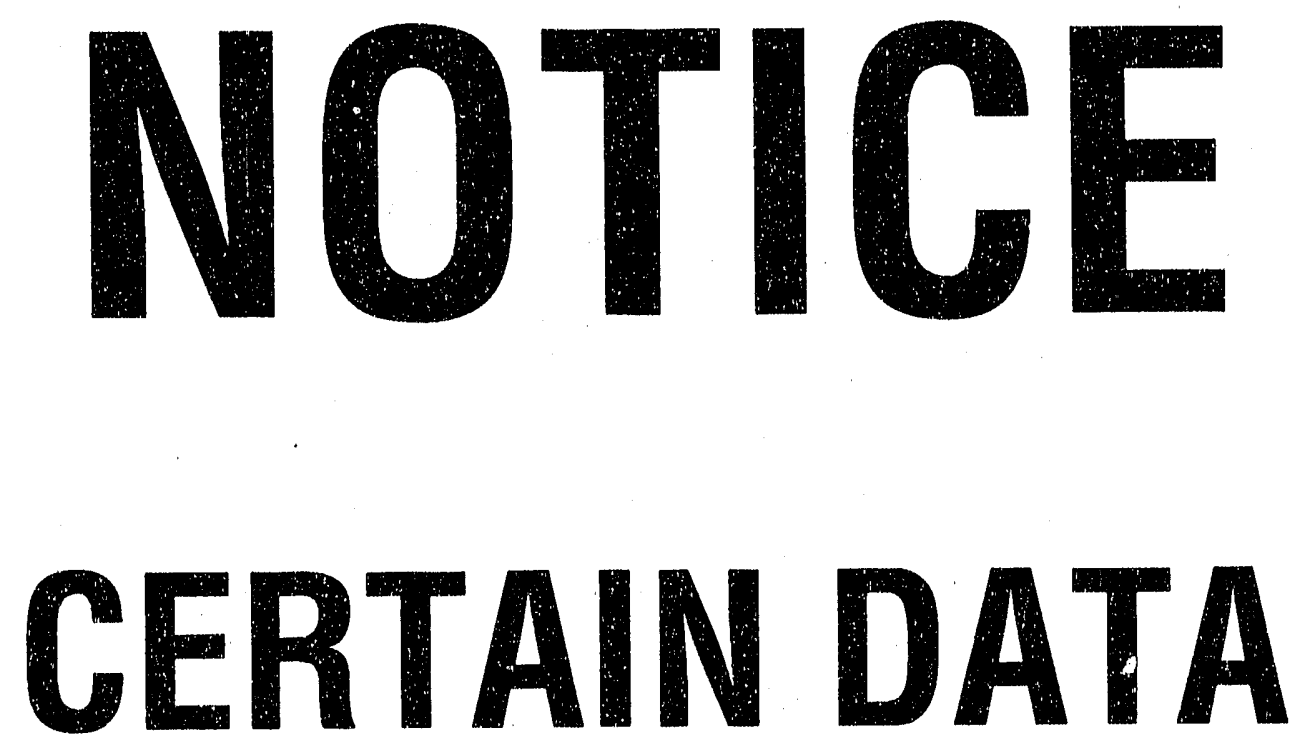

CONTAINED IN THIS
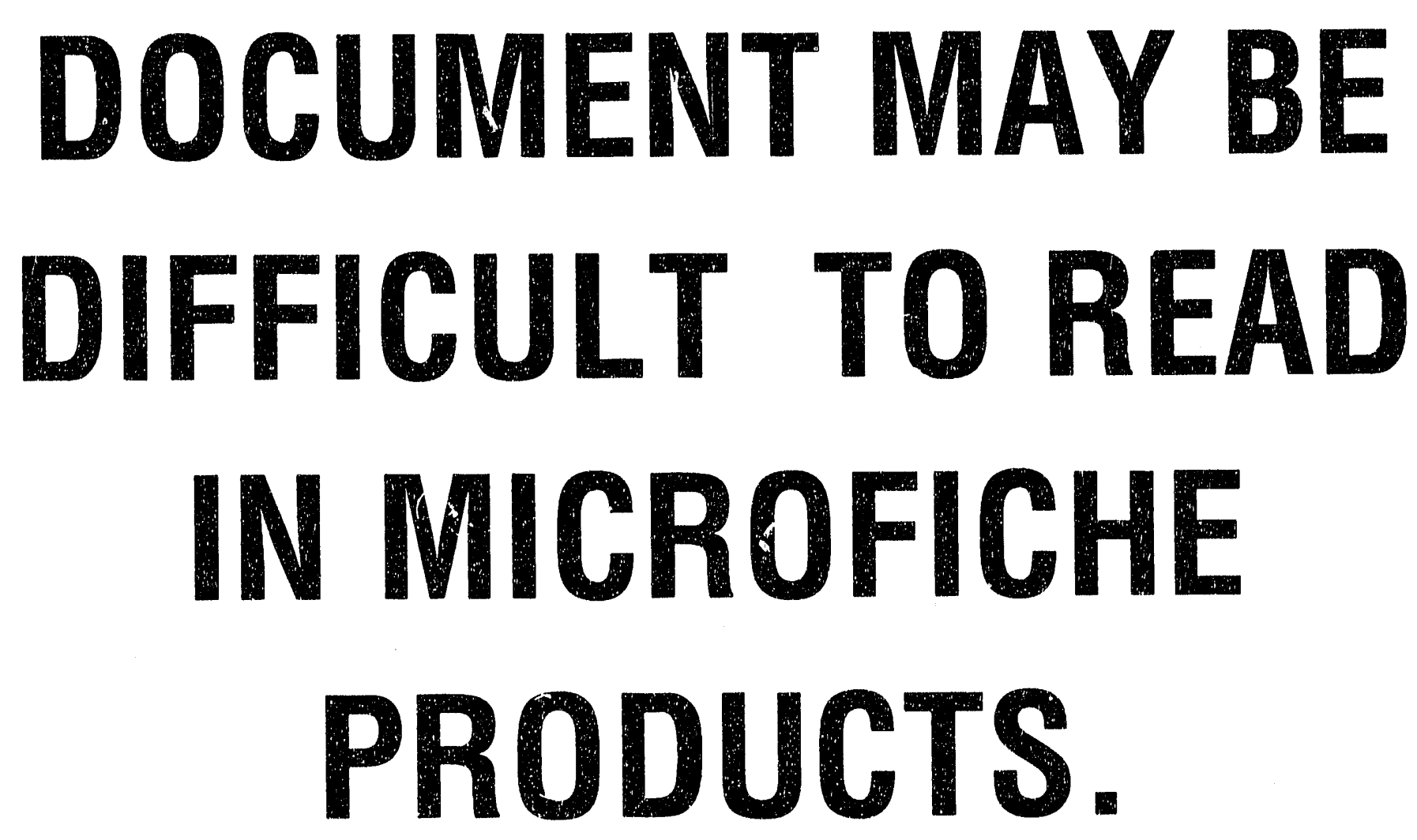


\title{
DOE/WIPP 91-005
}

Revision 1.0

$$
\begin{aligned}
& \text { Prom ThT } \\
& \text { JUN } 051992
\end{aligned}
$$

\section{Resource Conservation and Recovery Act Part B Permit Application}

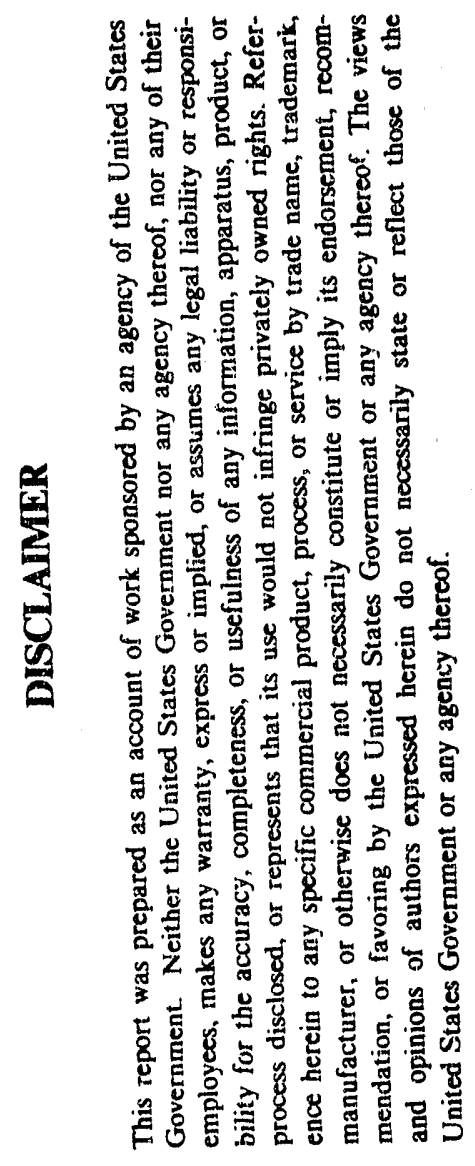

\section{Volume V of VII}

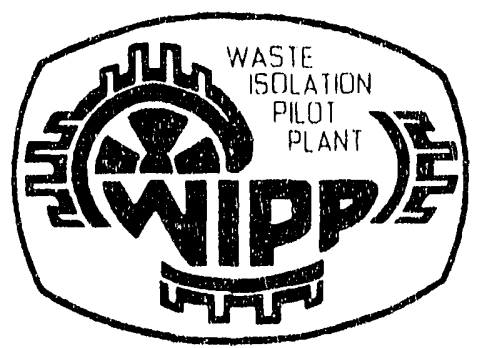

\author{
Aco4-86A231950 \\ Waste Isolation Pilot Plant \\ Carlsbad, New Mexico
}


ENGINEERING CHANGE ORDERS

1736
2450
3378
3690
4048
4127
4463
4983
4998
5022
5071
5166
5189

DOE/WIPP--91-005-Vol. 5-Rev. 10 DE92 014821
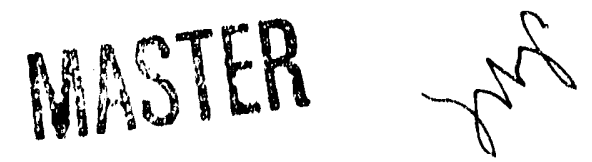

DISTRIBUTION OF TIHO LO ZUMENT IS UNLIMITED 
E:0. 1736 ENGINEERING FILE AOQAA SEOYY ECO

TYOE REO. _AET._ DESIGN CLASS IIB

$\operatorname{Cacoc} 1-2=5$

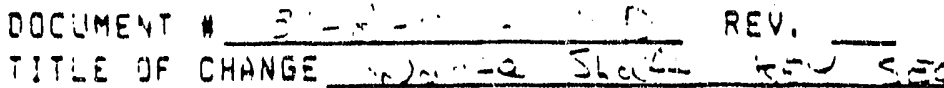

DATE

EWP

COST ESTIMATE REQUTEED: YES

COST ACSOUNT

SCHEDULE IMFACT

NO

COST ESTIMATE IS

SCHEDULE IMPACT

GETAIL DESCRIPTION GF CHANGE: USe continuation sheets as nesessary, list af eeted documents and note total nuguer of pages on page ore.

This is a reguest to show as-built aininsions -.of waive shart key witl the acilition of

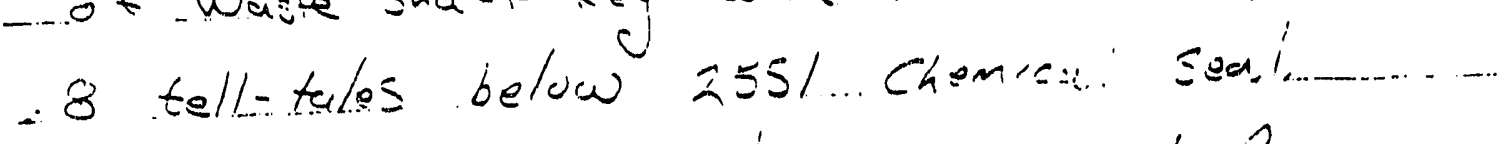

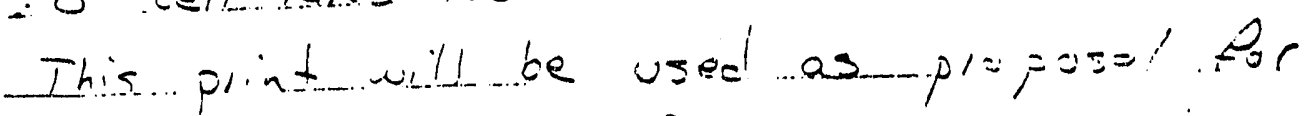

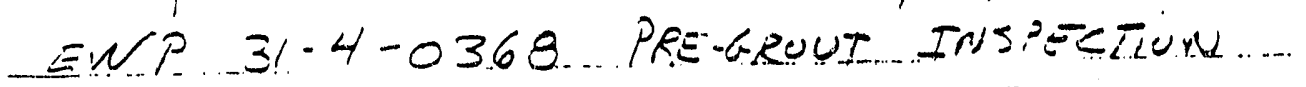

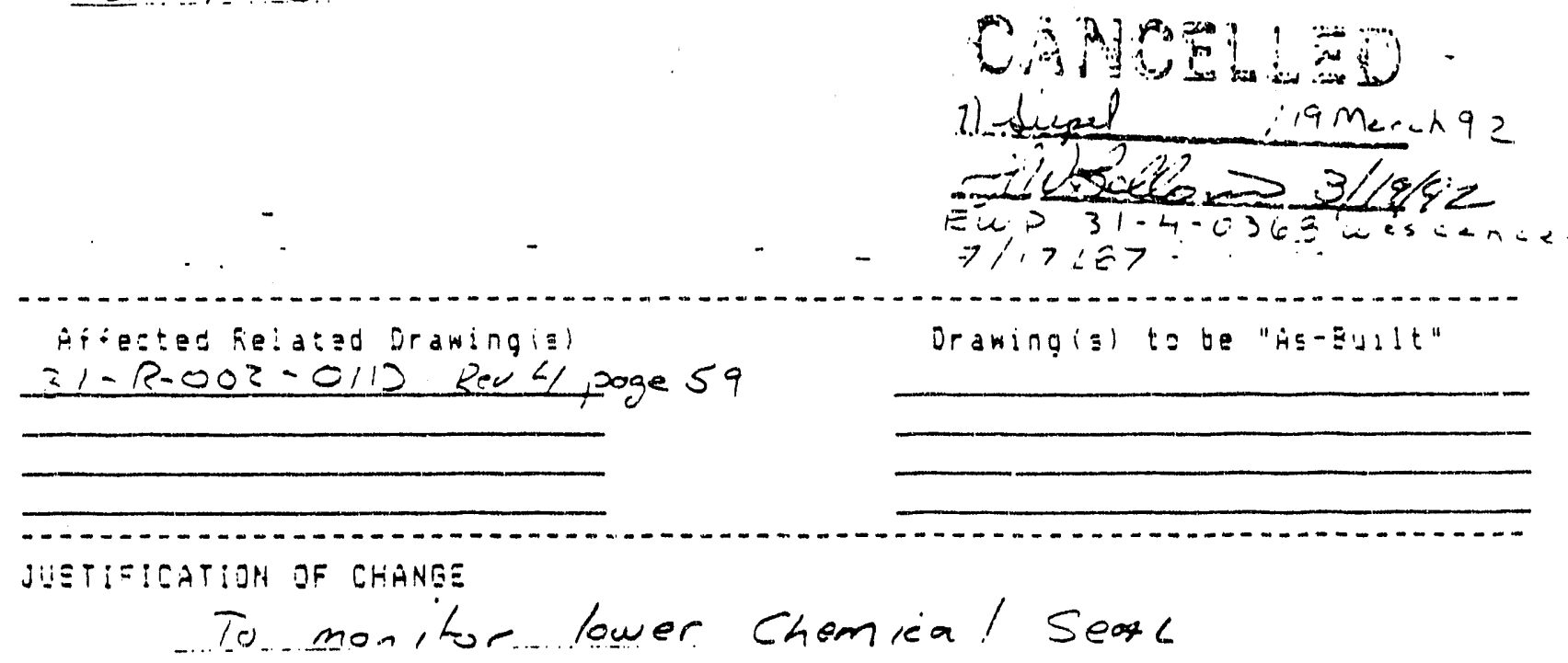

AFPEIVALS/OATE

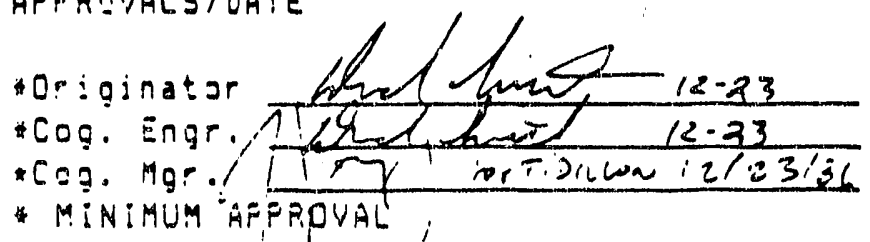
$Q A$ Sa:e:y

FINAL DISPOSITON

FINAL DISPOSITION

Cog Enọr. Date

Eigneture verafies that ali requirenents o: the Eco haye been complated including any itemz checked at the right.

Fop 1200
Drawang(s) As-Eudl: Document Cinanges Completod Other 


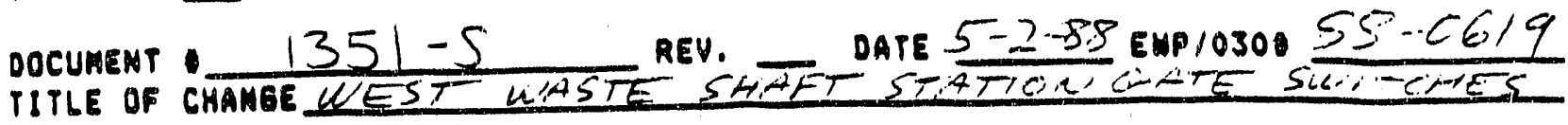
COST ESTIMATE REQUIAED, YES__ NO $x$ COST ESTIMATE IS COST ACCOUNT SCHEDULE IMPACT

DETALL DESCRIPTION OF CHANGE: USe continuation sheets as necessary, dist affected documents and note total nusber of oages on page one.

-.PRCIULE A SKETCW WUIRER HUL APR TWE

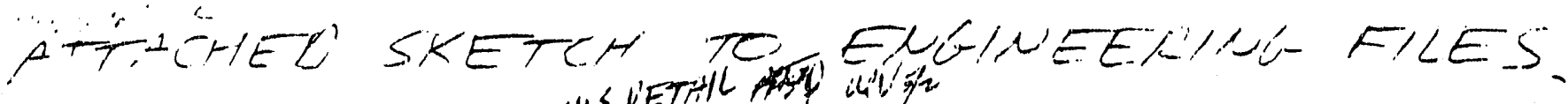

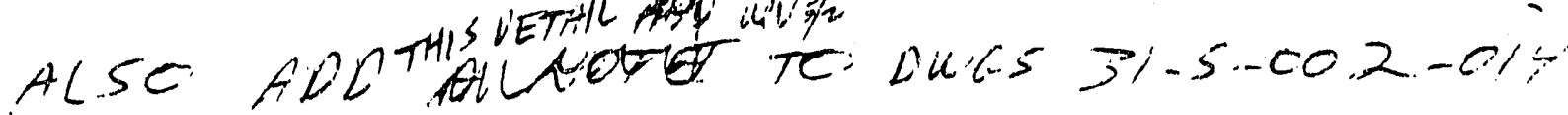
AUD $41-D . C T$ REFEREXCING THIS SRETCH Fettetts:

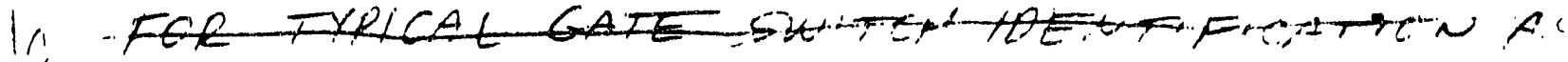

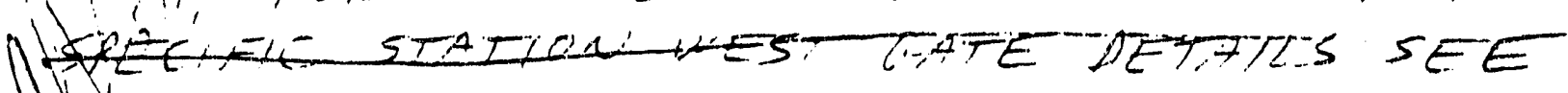
SKETCH

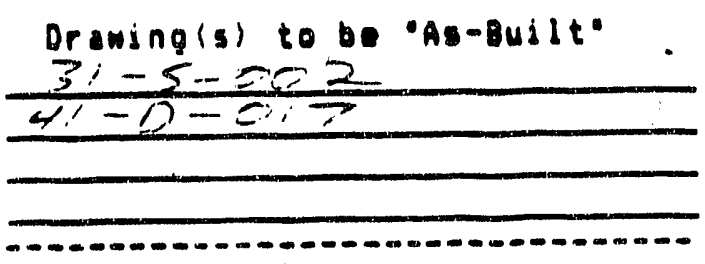

JUSTIFICATION OF CHANGE

$$
\text { SAFETY SVSTEM INTEMLOCK }
$$

APPROVALS/DATE

- Orjajinator

- Cog. Engr.

- Cog. Mgr.
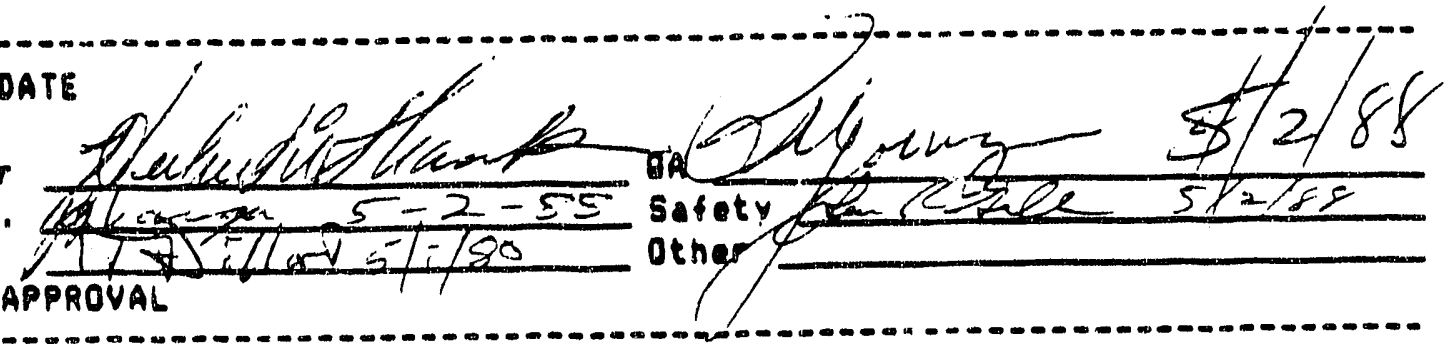

FIMAL DISPOSITION

Cog Engr.

Date

Signature verifios that ald peouipeaents of the ECO have been comoleted including ony itaes checked at the right.
Drawing(s) As-Duilt Docuaent Changes Coapleted other

Forn 1200 


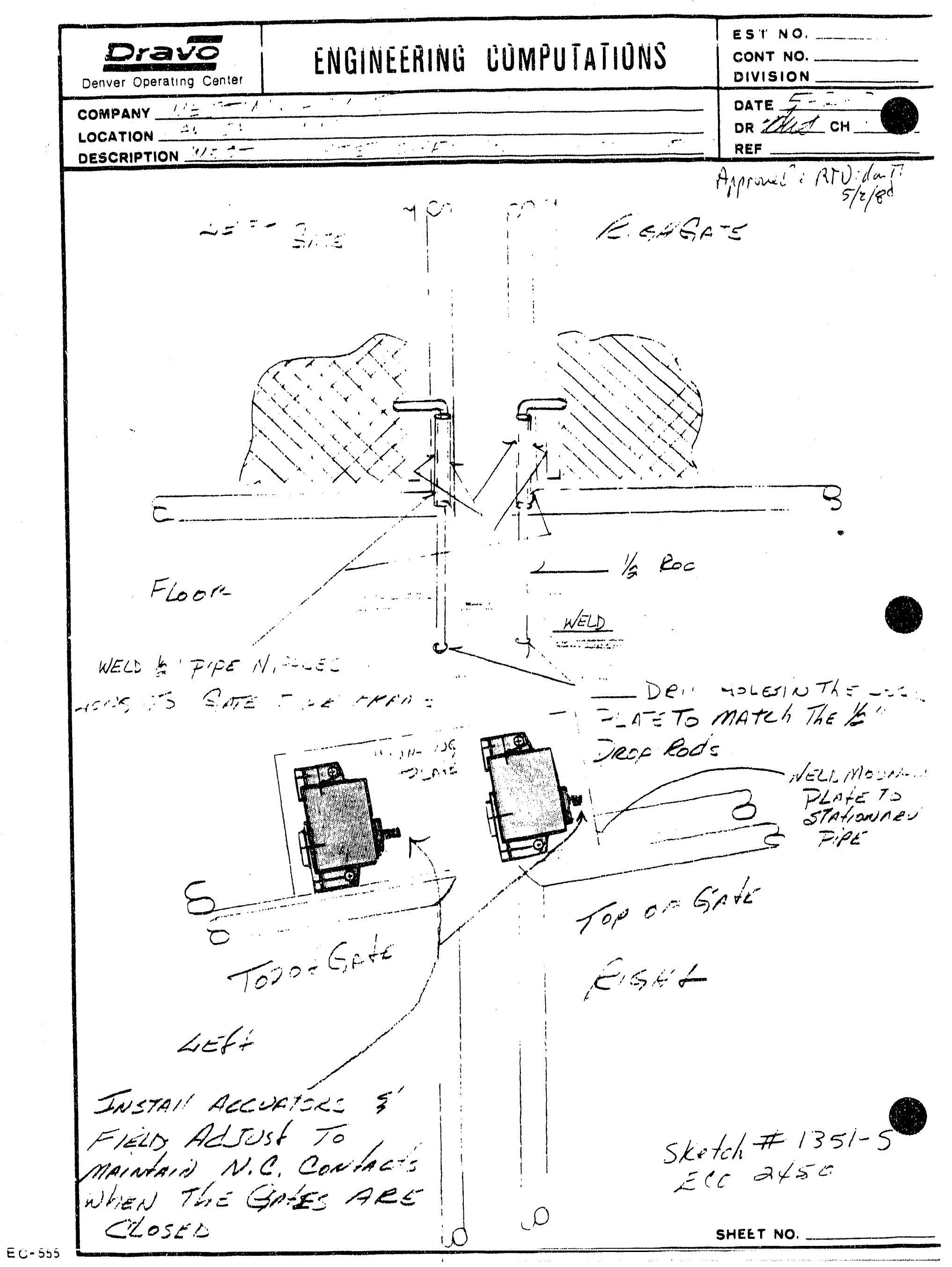




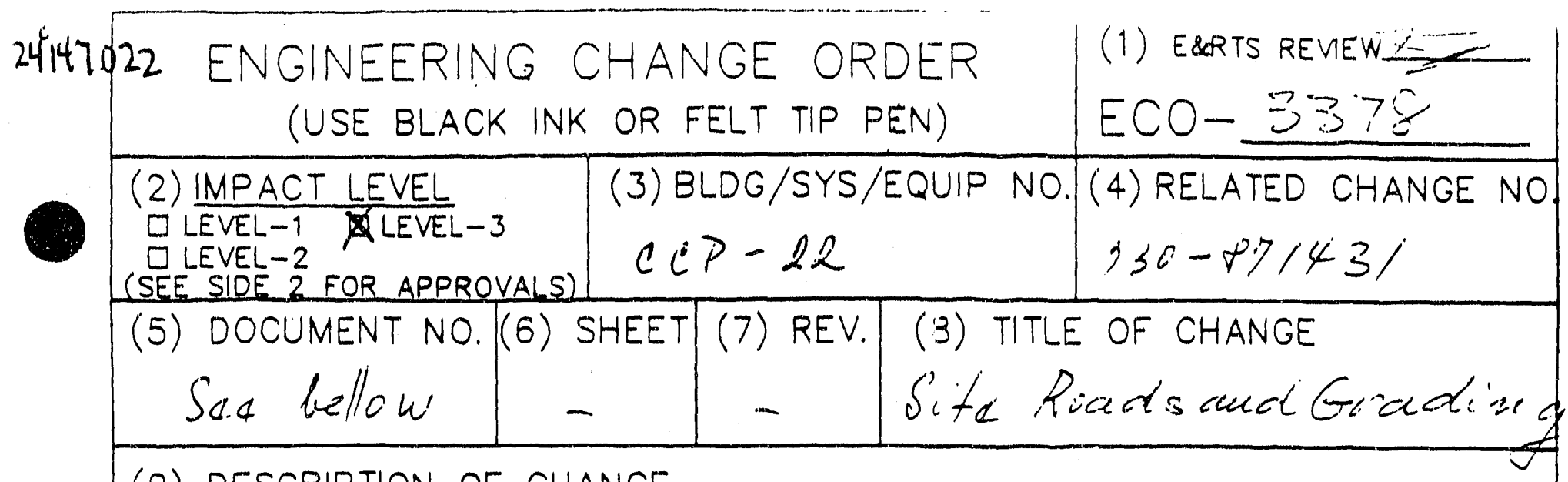

(9). DESCRIPTION OF CHANGE

"As beulf" diraureys drown by the eviteaction.

Incorporate cos built ohouges in to $c \subset P-22$ drautiugs as fer draviag. iudex 76-B-147-022

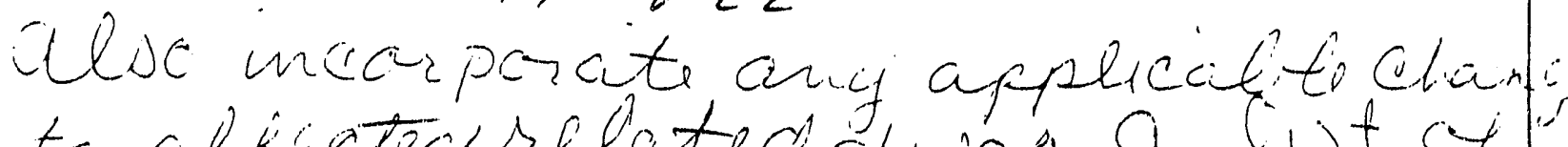
to afticeter related clugs a bist ck those diaurnas te le attached to this ECO letor completion 4ty-89.

(10) JUSTIFICATION

Reguitement of the corcteret.

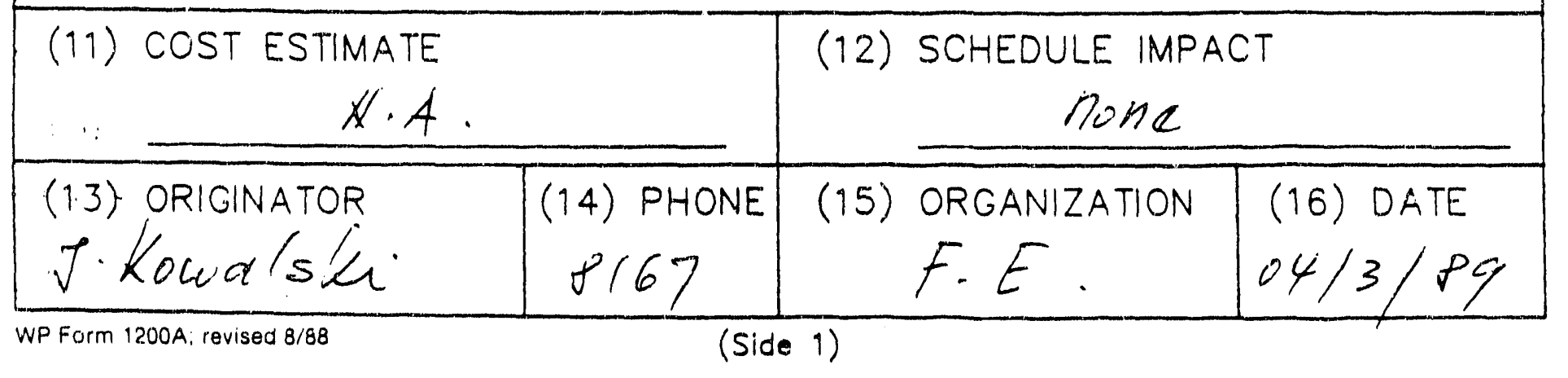


(17) RELATED CHANGES: INDICATE THE DOCUMENTS, DRAWINGS, INSTRUCTIONS OR PROCEDURES (OTHER THAN THE DRAWINGS OR DOCUMENTS IDENTIFIED IN EITHER 5 OR 9) THAT WILL BE AFFECTED BY THE CHANGE DESCRIBED IN BLOCK 9. ENTER THE DOCUMENT NUMBER(S) IN BLOCK 18.

YES NO

$\square \bowtie$ 1. CONCEPTUAL DESIGN REPORT

$\square$ 2. EQUIPMENT SPECS.

$\square \square$ 3. DESIGN SPECS.

$\square$ 4. VENDOR DATA

$\square$ 5. O\&M MANUAL

$\square$ 6. FSAR/SAR

$\square$
$\square \square$
$\square \square$
$\square \square$

7. SEISMIC/STRESS ANALYSIS

8. STRESS/DESIGN REPORT

9. INTERFACE CONTROL DWGS.

10. CALIBRATION PROCEDURES

11. INSTALLATION PROCEDURES

12. MAINTENANCE PROCEDURES
YES NO

$\square \square$ 13. TRAINING MANUAL

14. OPERATING INSTRUCTIONS

15. OPERATING PROCEDURES

16. SPARES/MULTIPLE UNIT LISTINGS

17. TEST PROCEDURES/SPECS.

18. COMPONENT INDICES

19. ASME CODED ITEMS

20. HUMAN FACTOR CONSIDERATIONS

21. PROCUREMENT SPECS.

22. COMPUTER SOFTWARE

23. ELECTRIC CIRCUIT SCHEDULE

24. ICRS PROCEDURES

(18) RELATED DOCUMENT NO.; INSTRUCTION NO.; DRAWING NO.; IDENTIFIED IN BLOCK 17. (DESIGN DOCUMENTS LISTED IN BLOCK 18 WILL NOT BE INCORPORATED BY THIS ECO)

DOCUMENT NO./REV. INSTRUCTION/PROCEDURE NO. DWG. SHT. REV.

(19) DISTRIBUTION

NAME
ORG.
(20) SIGNATURE REQUIREMENTS IMPACT

LEVEL

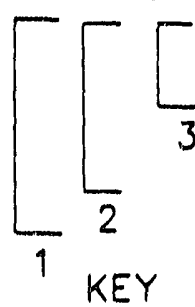

$A=A P P R$.

$R=R E V E W$

$P R=P O S T$

REVIEW,

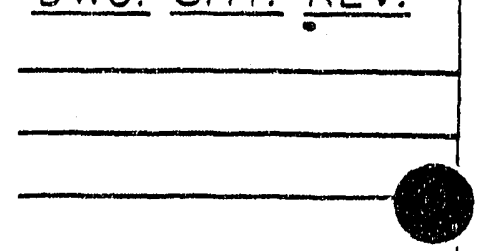

(21) ACTIONS REQUIRED TO IMPLEMENT CHANGES

- incosporate duga into Eng. File \&yater 
ENGINEERING CHANGE ORDER CONTINUATION SHEET

$$
\begin{aligned}
& J=5-J-533-009 \\
& V=5-J-531-009 \\
& V 25-J-530-009 \\
& 25-C-046-010 \\
& 25-C-045-010
\end{aligned}
$$

3ろ78

$$
\begin{aligned}
& 24-i-c 01-022 \text { isistax } \\
& 24-c-140-i 22200
\end{aligned}
$$

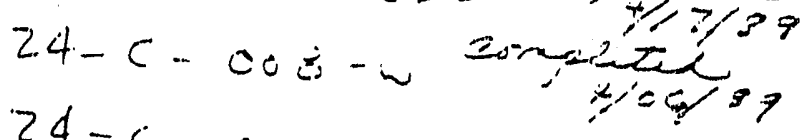

$24-c-010-$ h compl 12/21/89

$24 \cdot c-143-6.22$ empaite $\$ 1 / 8 / 89$

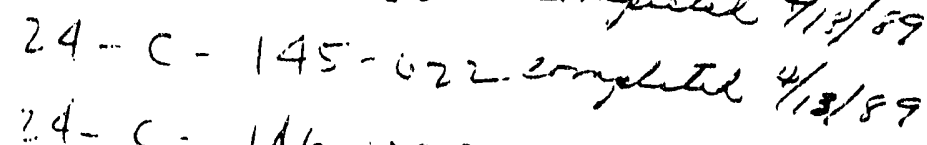

$24-c \cdot 146-022$.

$24-c \cdot 147-022$

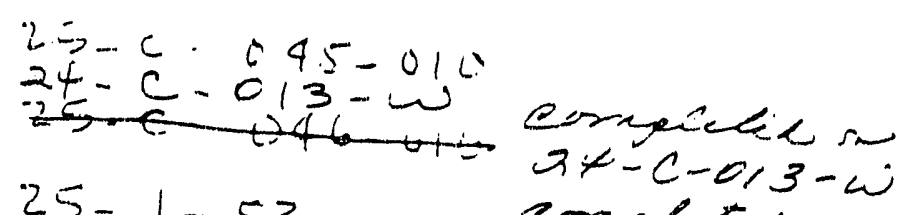

$$
\begin{aligned}
& 25-1-53 u-009 \text { congletiz } \\
& 25-J-531-009 \text { ermesize } \\
& 25-J-533-009 \text { ampleti } 11 / 3
\end{aligned}
$$




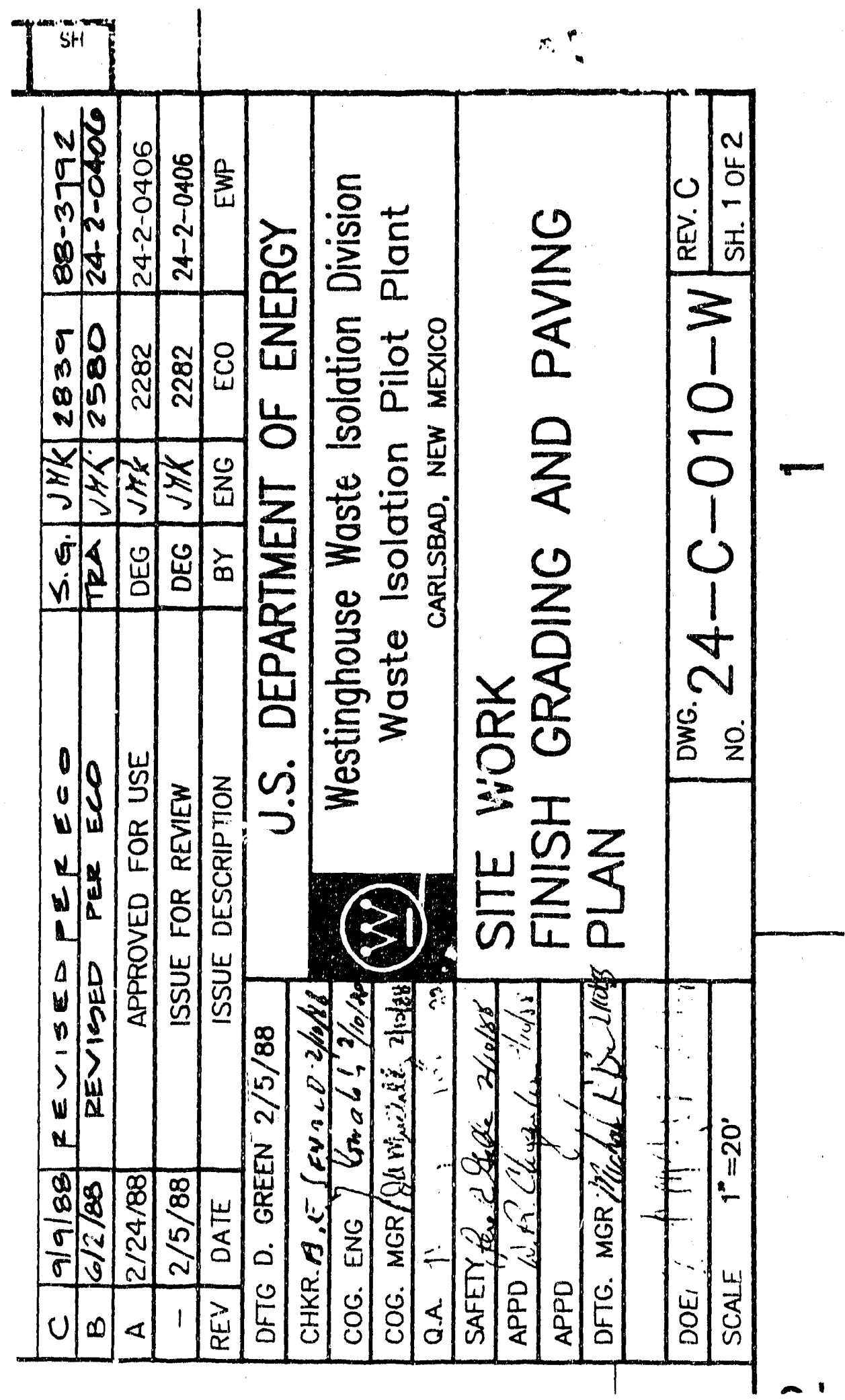




\section{ENGINEERING CHANGE ORDER ADDENDUM SHEET}

1. Addendum Sheet to ECO Number: 3378 Drawing Number: $25 \cdot c \cdot 045-010$

2. Description of change:

DRAWING 25-C.045-0I0 HAS BEEN REMDVBO From

the active draning reglster (ELO 5235). THEREEFore,

DELETE THE REQUIREMENT TO REVISE THS DRANING

AND ClOSE ELO 3378. AS IT RELATES TO 25-C-045-010.

3. Approvals

Cognizant Engineer:

CC\&D Mgr. /Desig. Rep::
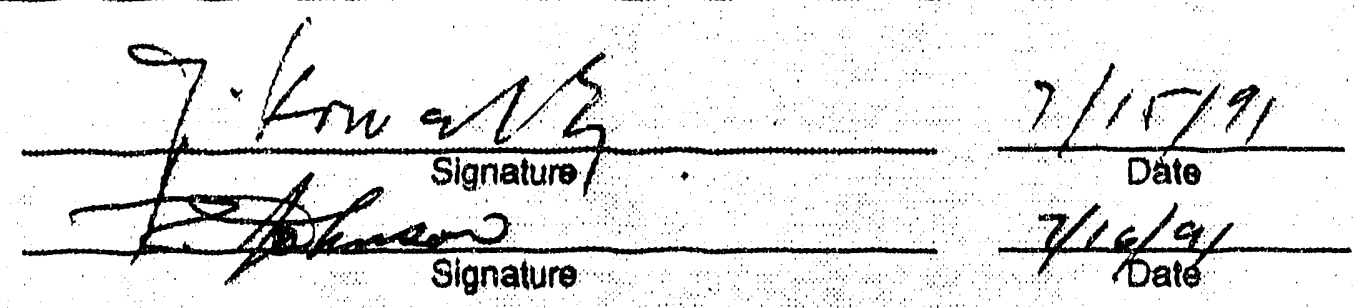

Signature

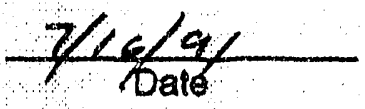

Other Approval:

Other Approval::

Date 


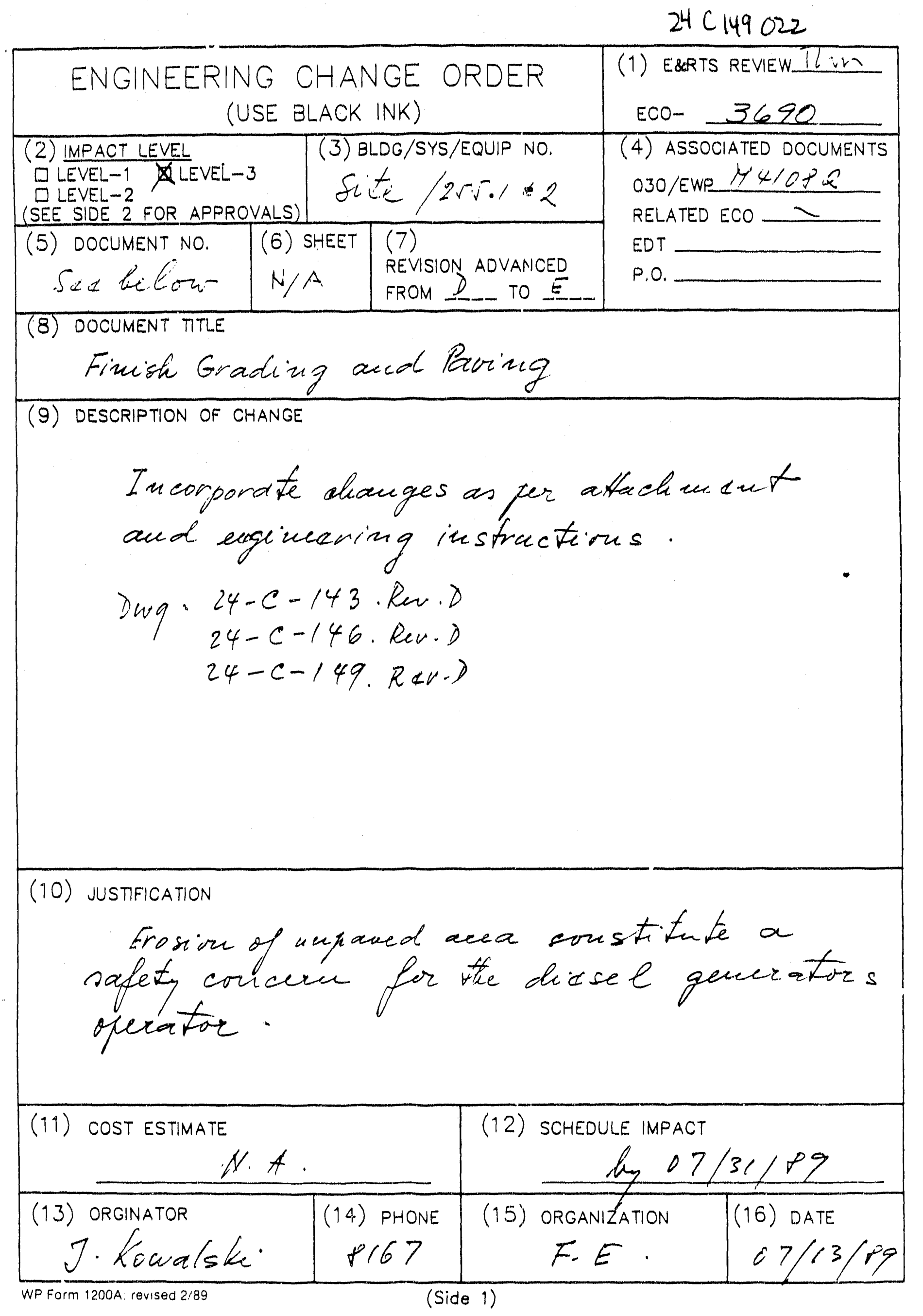


(17) RELATED CHANGES: INDICATE THE DOCUMENTS, INSTRUCTIONS OR PROCEDURES (OTHER THAN THE DRAWINGS OR DOCUMENTS IDENTIFIED IN EITHER 5 OR 9) THAT WILL BE AFFECTED BY THE CHANGE DESCRIBED IN BLOCK 9 . ENTER THE DOCUMENT NUMBER(S) IN BLOCK 18.

YES NON/A

$\square$ 如 $\square$ 1. CONCEPTUAL DESIGN REPORT

$\square$ 2. EQUIPMENT SPECS.

$\square \square \square$ 3. DESIGN SPECS.

$\square \square \square$ 4. VENDOR DATA

$\square \notin \square$ 5. O\&M MANUAL

$\square \nsubseteq \square$ 6. FSAR/SAR

$\square$ 7. SEISMIC/STRESS ANALYSIS

$\square$ 8. STRESS/DESIGN REPORT

$\square \boxplus$ 9. INTERFACE CONTROL DWGS.

$\square \square 10$. :ALIBRATION FROCEDURES

$\square \square$ 11. INSTALLATION PROCEDURES

$\square \square \square$ 12. MAINTENANCE PROCEDIJRES

$\square \square \square$ 13. TRAINING MANUAL
YES NQ, N/A

$\square \square: \square$ 14. OPERATING INSTRUCTIONS

$\square \square$ 15. OPERATING PROCEDURES

$\square$ 由 16. SPARES/MULTIPLE UNIT LISTINGS

$\square \square \square$ 17. TEST PROCEDURES/SPECS.

$\square \square$ 18. COMPONENT INDICES

$\square \square \square$ 19. ASME CODED ITEMS

$\square \square$ 20. HUMAN FACTOR CONSIDERATIONS

$\square \square$ 21. PROCUREMENT SPECS.

$\square \square$ 22. COMPUTER SOFTWARE

$\square \oplus \square$ 23. ELECTRIC CIRCUIT SCHEDULE

$\square \oplus \square$ 24. ICRS PROCEDURES

$\square \square \square$ 25. EL.ECTRICAL LOAD LIST $(25-X-001-W)$

(18) RELATED DOCUMENT NO.; INSTRUCTION NO.; IDENTIFIED IN BLOCK 17 . (DESIGN DOCUMENTS LISTED IN BLOCK 18 WILLNOT BE INCORPORATED BY THIS ECO).

DOCUMENT NO. /REVISIONV

(19) DISTRIBUTTON NAME

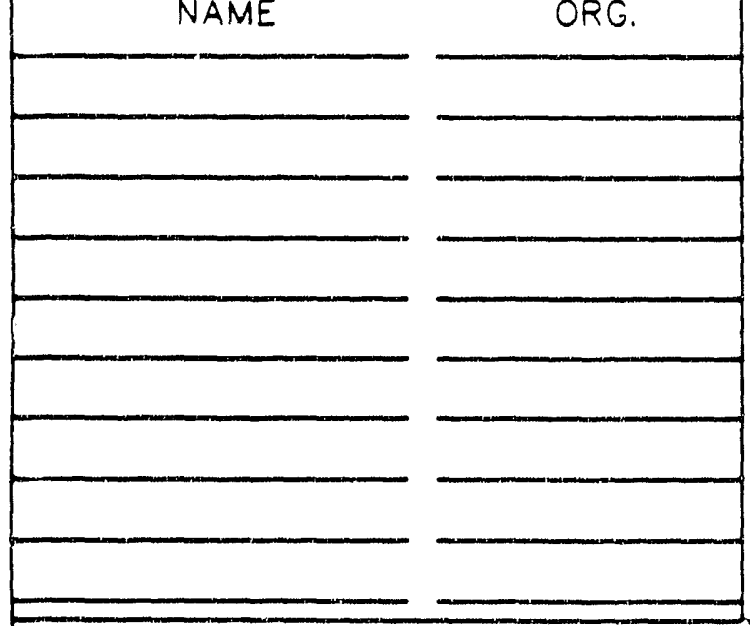

(20) SIGNATURE REQUIREMENTS

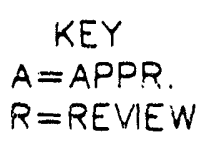

$\square$ PRE-OPS TEST/OPS

$\square$ CESIGN/FAB./GONST.

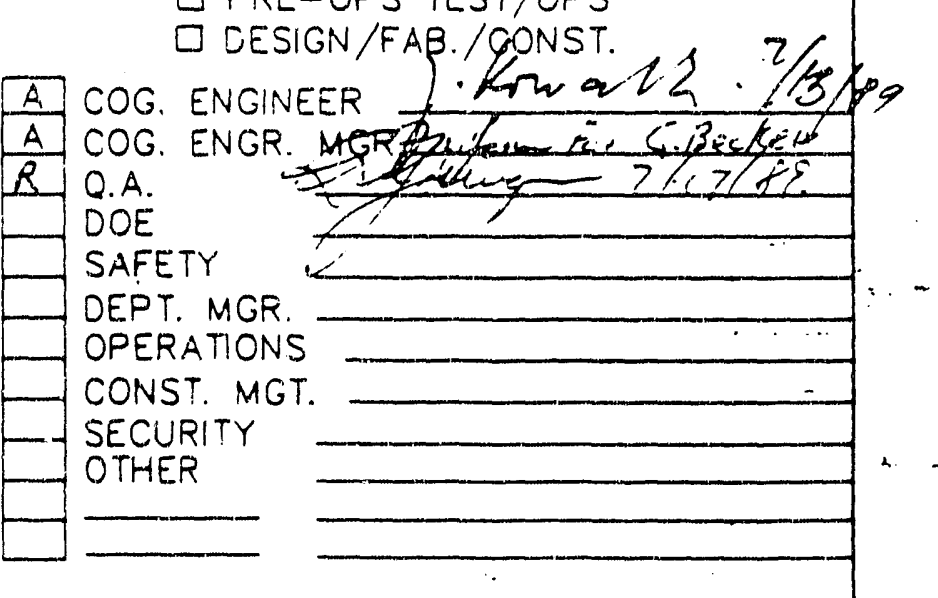

(21) DESIGN VERIFICATTIOH REQUIREMENTS 2. 32 T. REQUIREMENTS SATISFIED BY REVIEW/APPROVAL OF DESIGN DOCUMENT
2 2. INDEPENDENT REVIEW

3. ALTERNATE CALCULATIONS

4. OEVELOPMENT TESTING

5. DESIGN REVIEW

6. OTHER

$\bar{\square}$

E.DT\# 


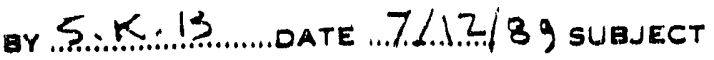

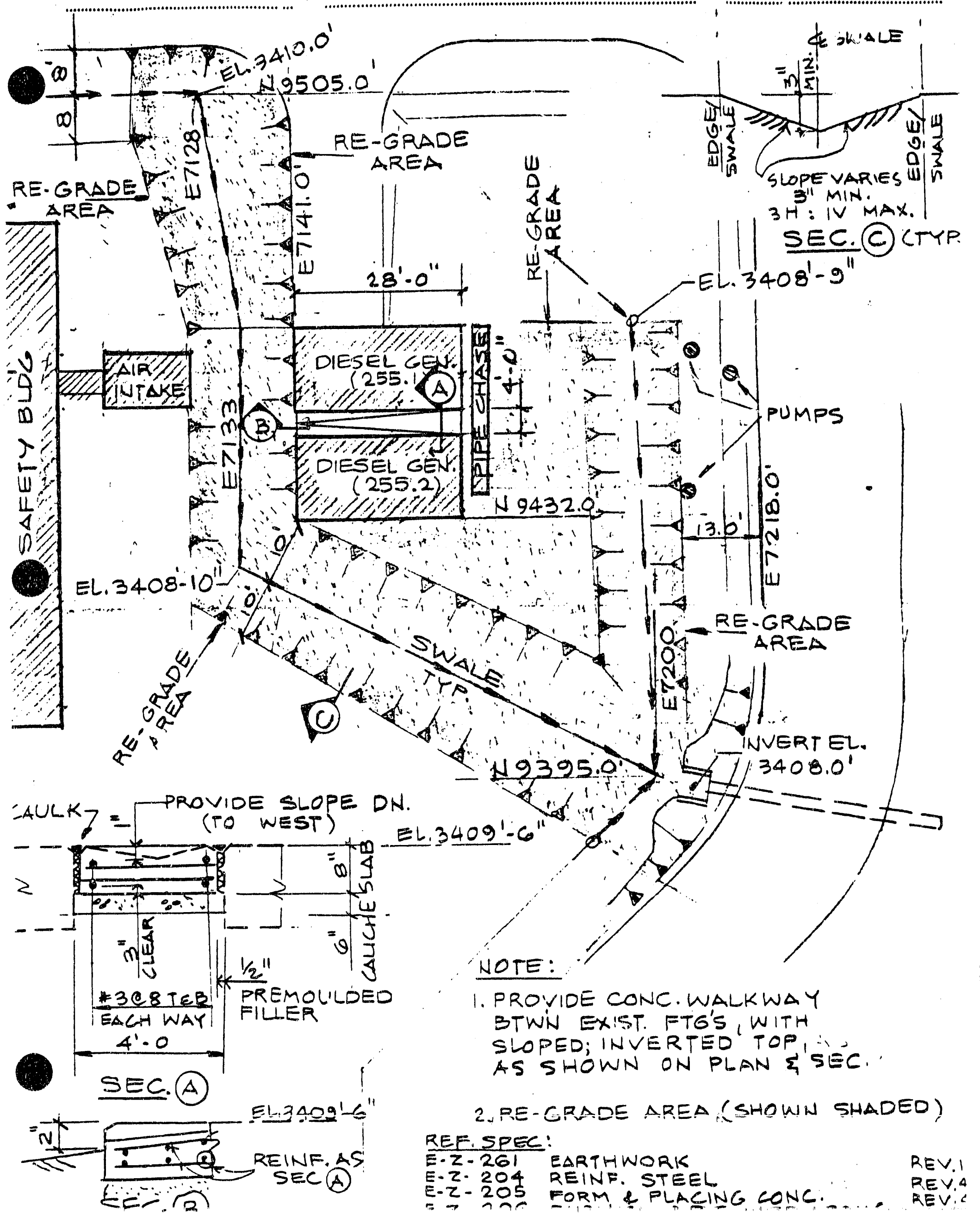




$$
24 C 1400122
$$

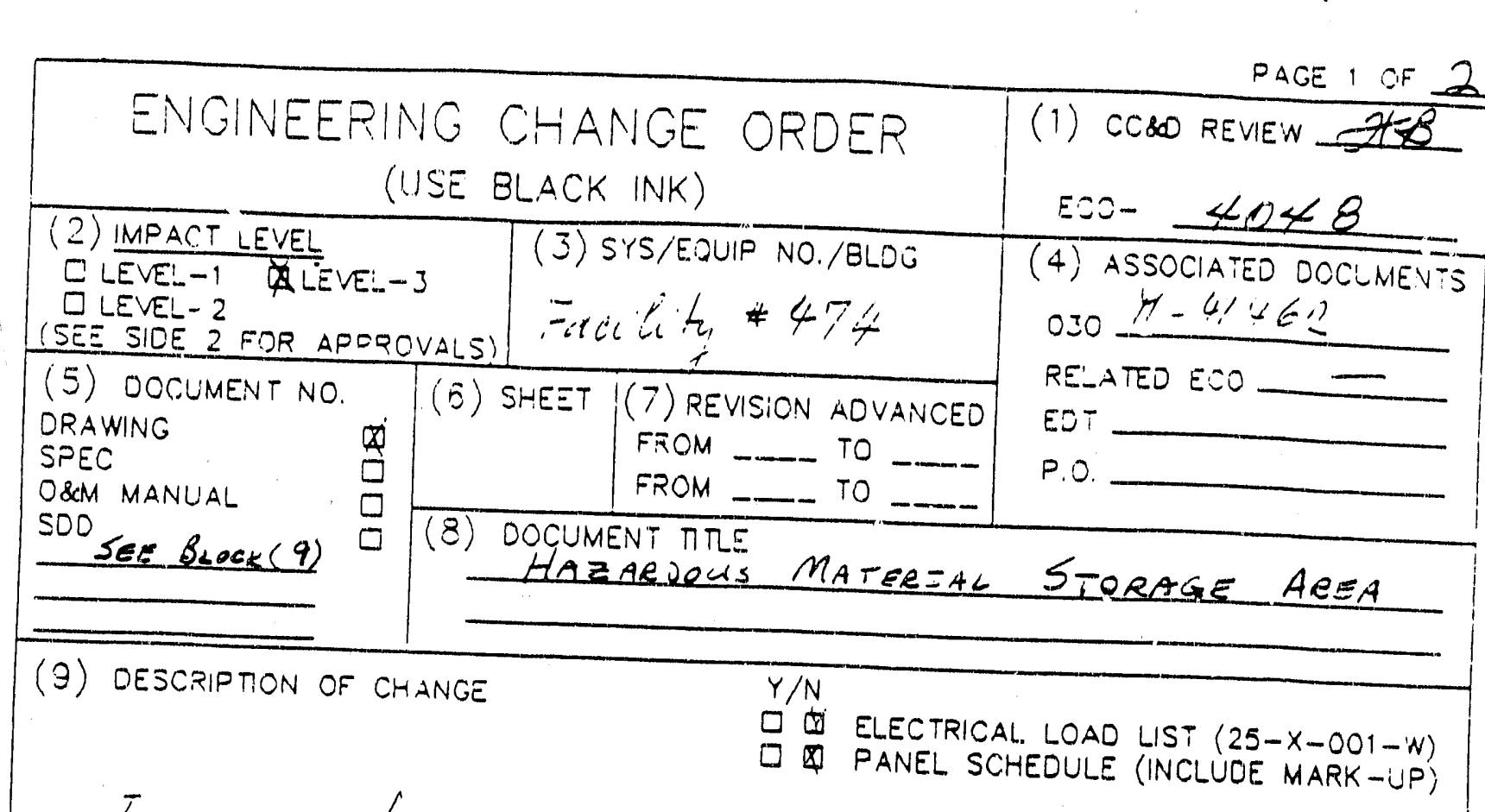

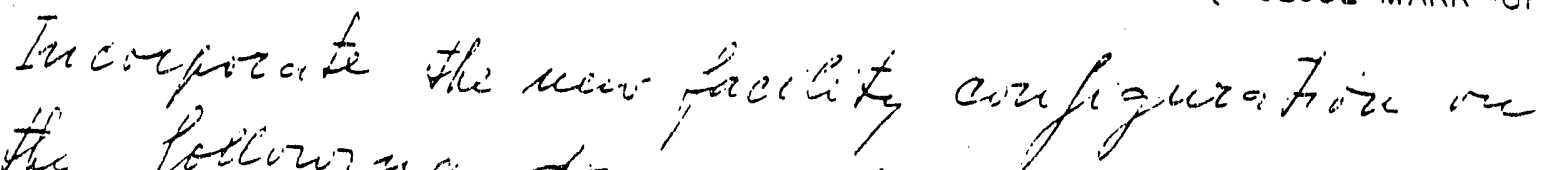

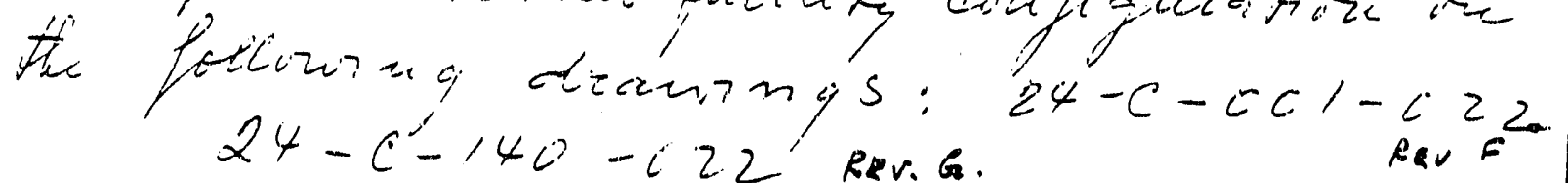

$$
\begin{aligned}
& 24-C-140-622 \text { ReV.G. } \\
& 24-c-14 \cdot-622 \text { REV.G. }
\end{aligned}
$$

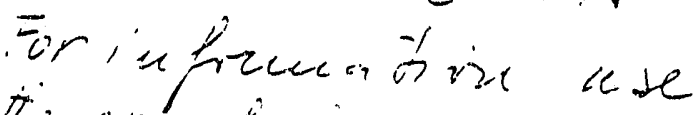

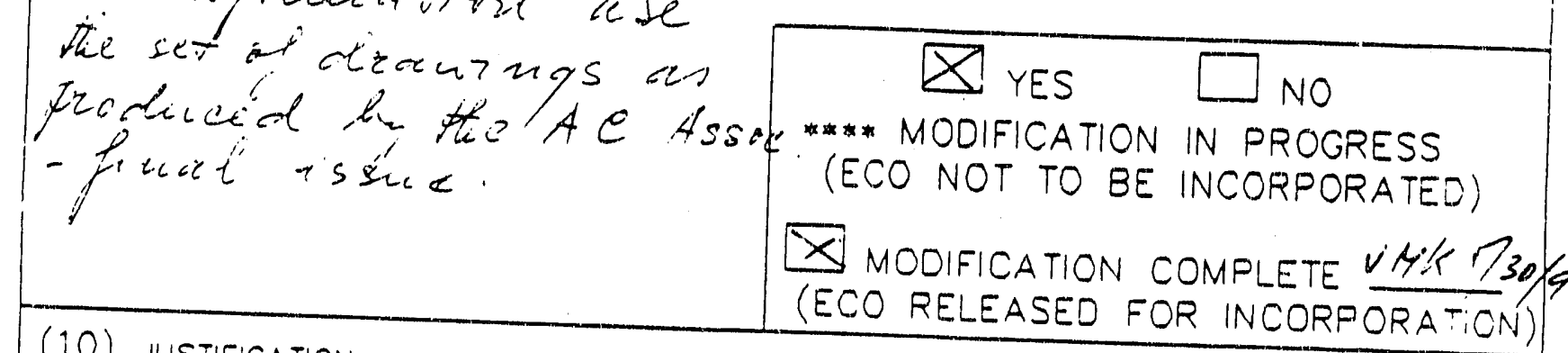

(10) JUSTIFICATION

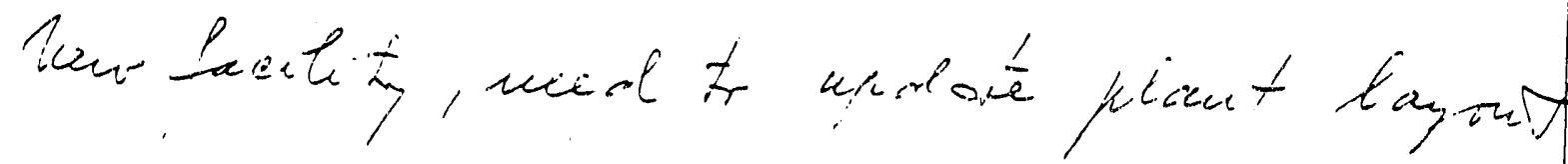

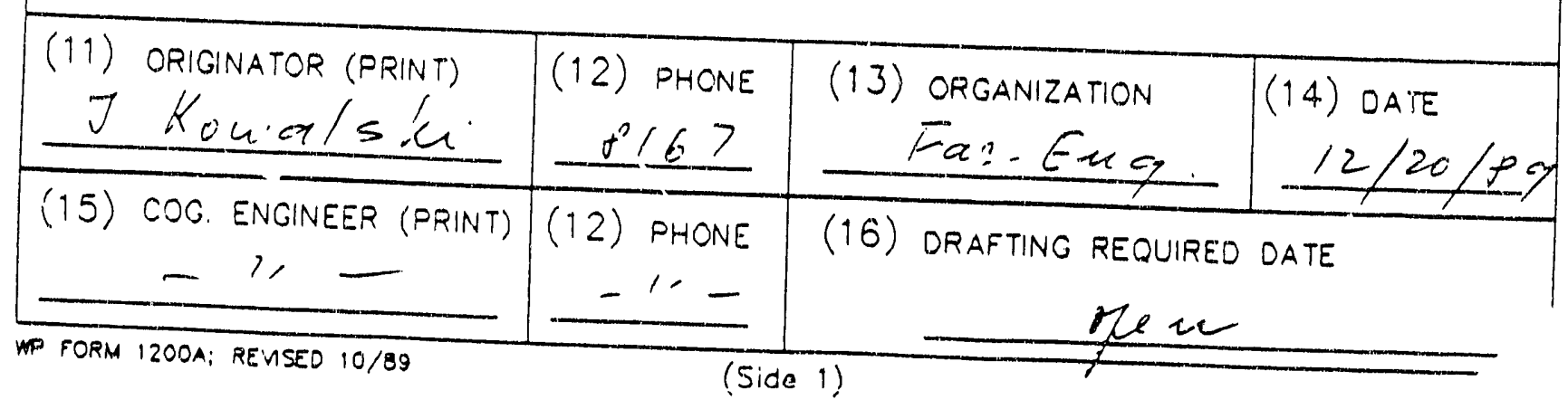


(17) RE:ATED CHANGES: INCICATE THE DOCUMEVITS, INSTRUCTIONS OR FROCE:LRES (OTHER THAN THE DRAMNGS DR OOCUMEN TS IDENTIFIED IN EITHER : OR 9 ) THAT WILL BE AFFECTED BY THE CHANGE OESCRIEEJ IN BLOCK 9. ENTER THE DOCUMENT NUMBER(S) IN BLOCK 18

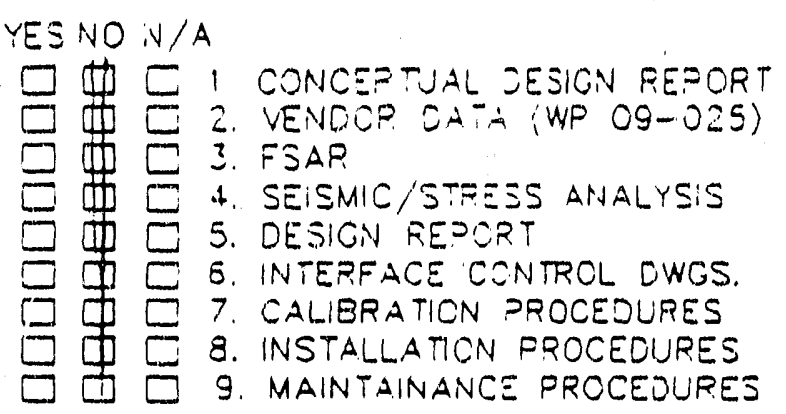

YES NC N/A

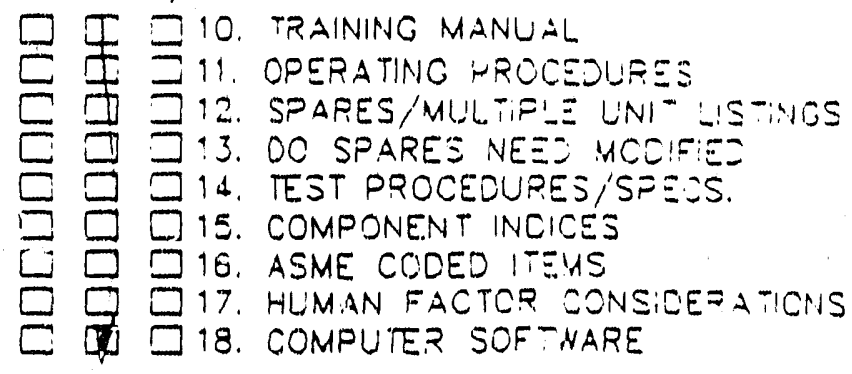

(3) PEL A TEO OOCUMEYT MO: INSTRUCTION NO: ICENTIFIED IN BLOCK 17 'CHANGES TO DOCUMENTS LISTED IN BLOCK IR WILI NOT EE INCOPRORATED BY TH'S ECO).

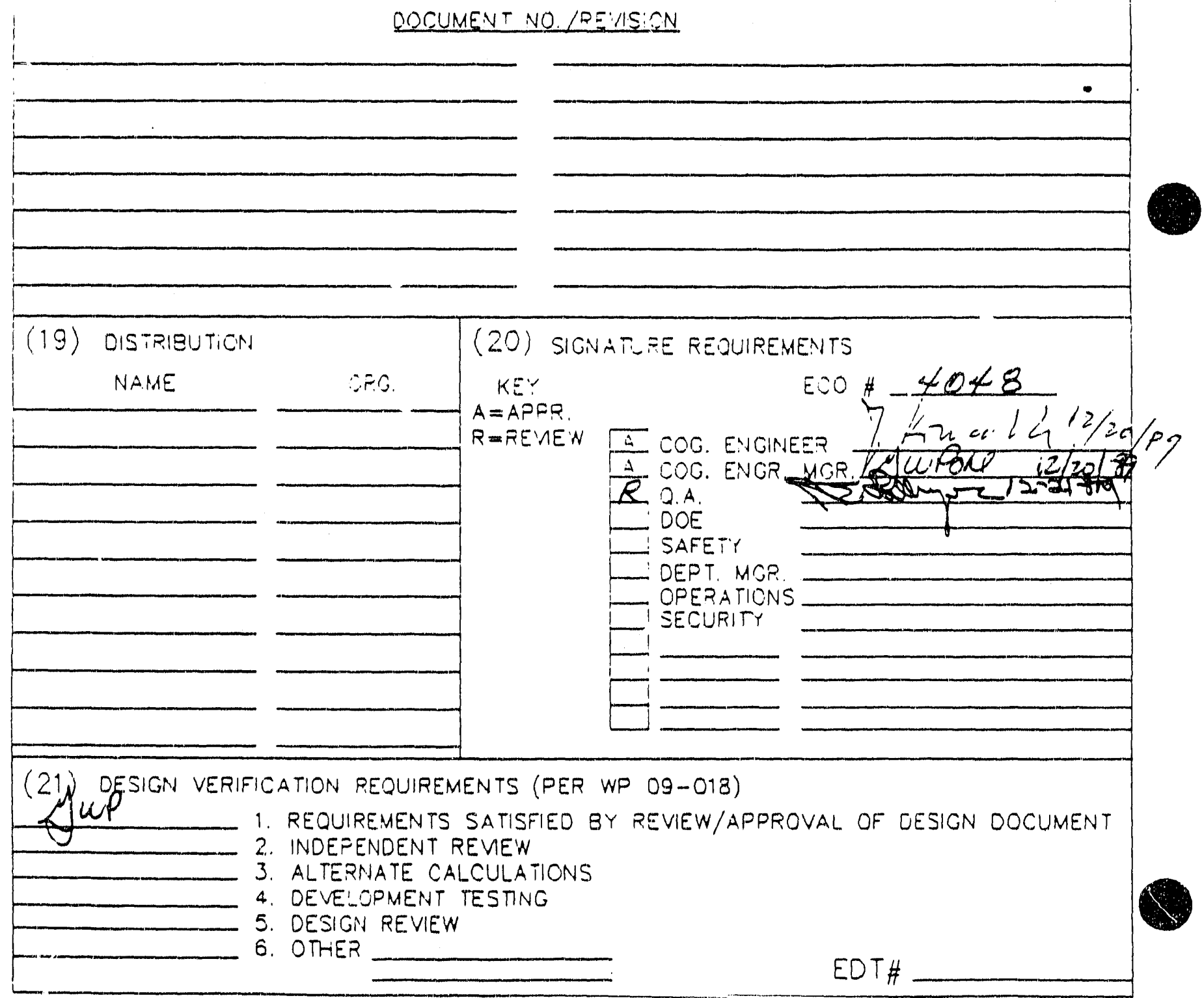




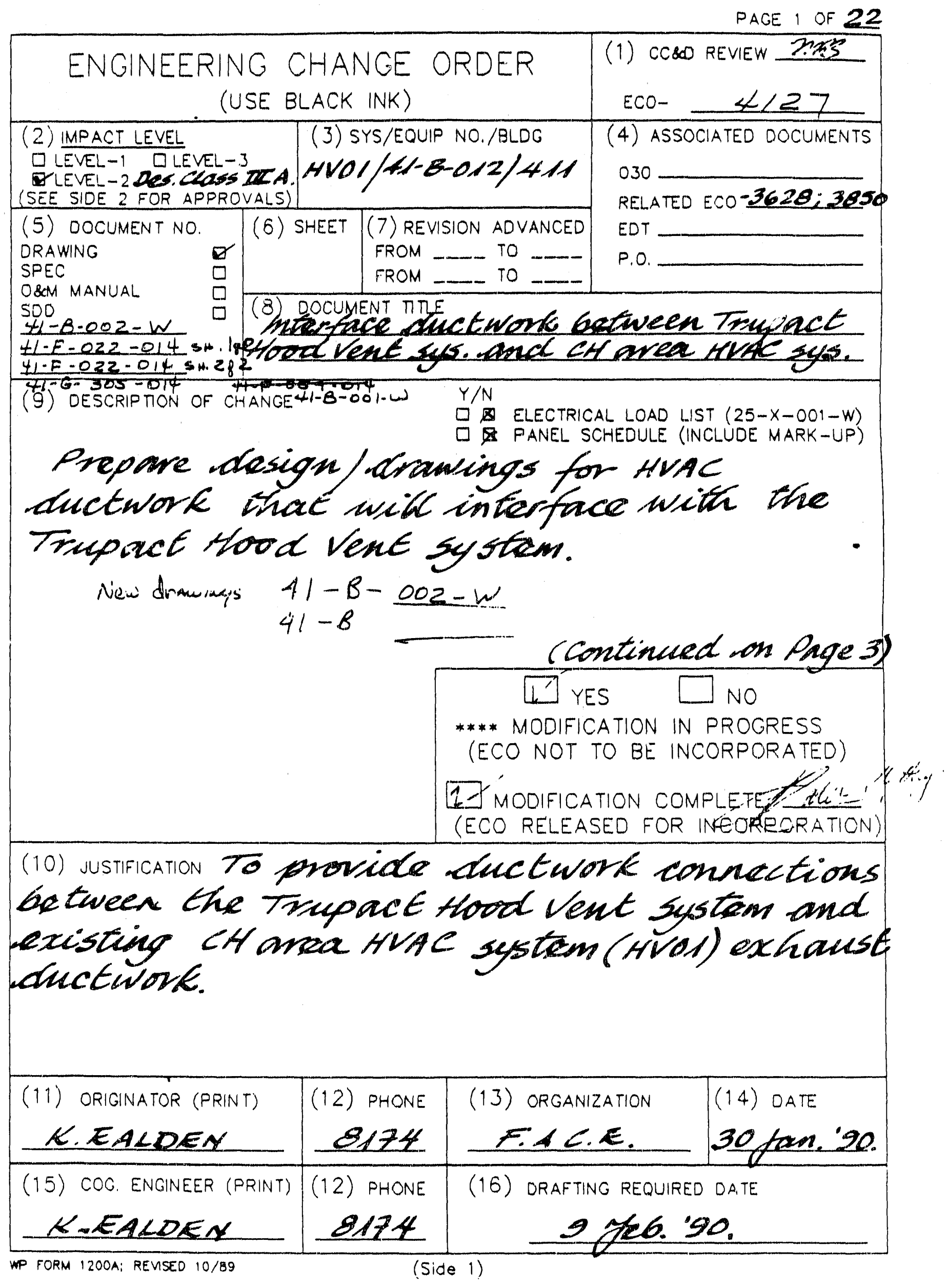


(17) RELATED CHANGES: INOICATE THE DOCUMENTS, INSTRUCTIONS OR PROCEUURES (OTHER THAN THE DRAMINGS OR DOCUMENTS IDENTIFIED IN EITHER 5 OR 9) THAT WILL BE AFFECTED BY THE CHANGE DESCRIBED IN BLOCK 9 . ENTER THE DOCUMENT NUMBER(S) IN BLOCK 18.

YES NON/A

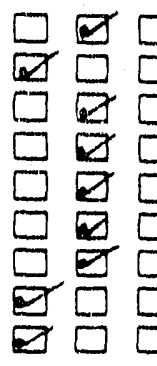

CONCEPTUAL DESICN REPORT

2. VENDOR OATA (WP O9-O25)

3. FSAR

4. SEISMIC/STRESS ANALYSIS

5. DESIGN REPORT

6. INTERFACE CONTROL DWGS.

7. CALIBRATION PROCEDURES

8. INSTALLATION PROCEOURES

9. MAINTAINANCE PROCEDURES
YES NO N/A

$\square \square \square$ 10. TRAINING MANUAL

$\square \square$ 11. OPERATING PROCEDURES

$\square \square \square$ 12. SPARES/MULTIPLE UNIT LISTINGS

$\square \square \square$ 13. DO SPARES NEED MODIFIED

$\square \square \square 14$. TEST PROCEDURES/SPECS.

$\square \square$ 15. COMPONENT INDICES

$\square \square$ 16. ASME CODED ITEMS

$\square \square$ 17. HUMAN FACTOR CONSIDERATIONS

$\square \square 18$. COMPUTER SOF TWARE

(18) RELATEO DOCUMENT NO.; INSTRUCTION NO.; IDENTIFIED IN BLOCK 17. (CHANGES TO DOCUMENTS LISTEO IN BLOCK 18 WILL NOT BE INCOPRORATEO BY THIS ECO).

DOCUMENT NO. LREVISION

\begin{tabular}{|c}
\hline \\
\hline \\
\hline \\
\hline \\
\hline \\
\hline
\end{tabular}

(19) DISTRIBUTION
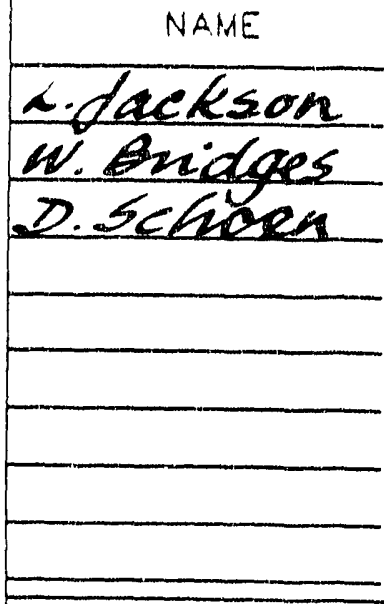

ORG.

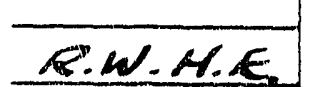

(20) KEY $A=A P P R$ $R=R E V E W$

SIGNATURE REQUIREMENTS

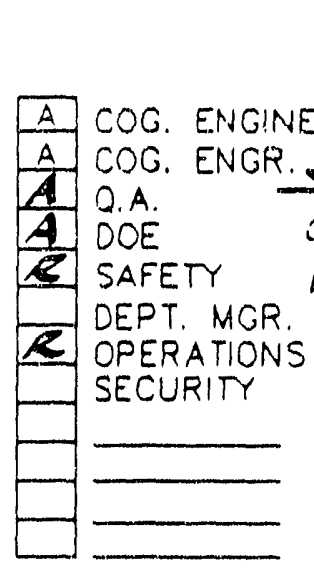

ECO \#-4127.
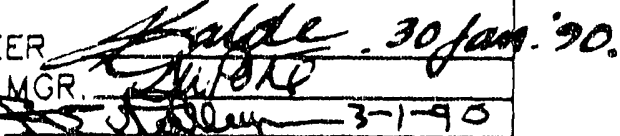

$7530 \mathrm{ew}-3-1-90$

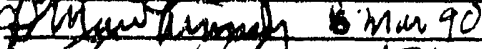
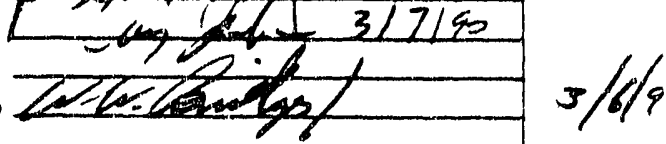

$5 / 6 / 9$

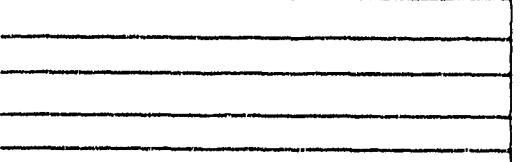

(21) DESIGN VERIFICATION PEQUUREMENTS (PER WP 09-018)

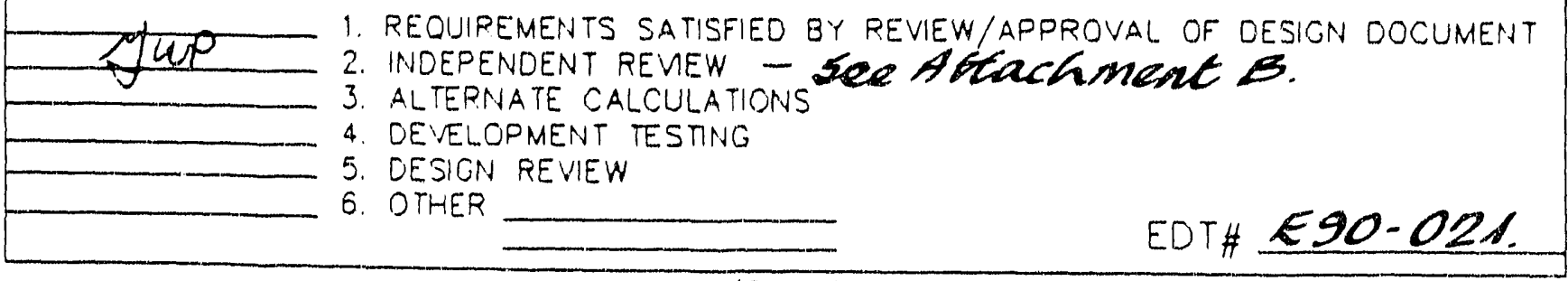

(Side 2) 
(9) Description of change (continued)

Scape

A Hood Vent System is being implemented at each Trupact dock, see ECD-3850 and specification D-0070. The purpose of this ECD is to provide the design and drawings required to implement the Inlet Manifold Duct and the ductwork interface between the Trupact Hood Vent System fans and the existing $\mathrm{CH}$ area HVAC exhausi duct.

Desseription

The basic design has been provided by the Hood Vent Systern supplier, EDS. See Attachment A for a copy of their preliminary design information and calculations.

The design information contained in Attachment $A$ has been used to produce the ductwork layout shown in the sketches on pages 4 through 17. These sketches are to be the basis of new drawing 41-8-002-W.

The sketch on page 18 is to be used to create a new flow diagram for the additions to the CH area HVAC system, 41-F-O22-014, Sht. 2 of 2. Existing flow diagram 41-F-022-014 to be labelled sht. 1 of 2 and is to be revised to show the changes required by pages 19 and 20 .

The sketch on page 21 shows the new automatic dampers that are to be installed in the CH area HVAC system exhaust duct. Drawing 41-G-305-014, Rev. D is to be revised accordingly.

The sketch on page 22 shows the revisions that are required to P. \& I. D. 41-F-059-014, ReV. E. 


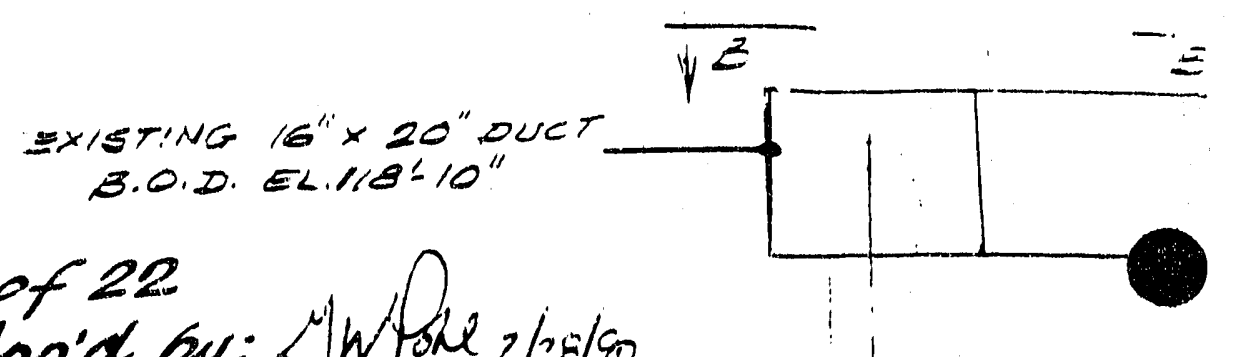

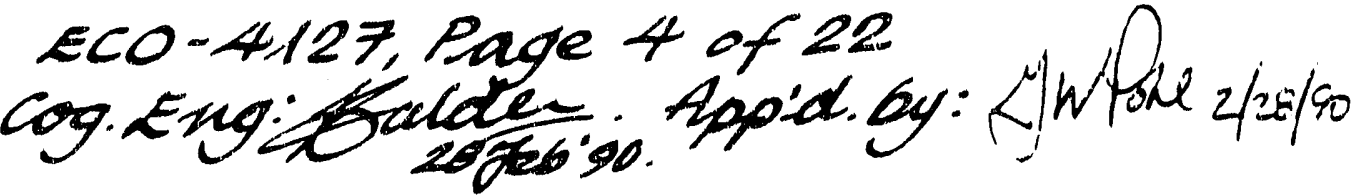

Trupact thood vent Syotern.

$C A$ area HWAC interfouce duct.

West Dock

Pont ang. 36-131-D-1-102, pev. 4.

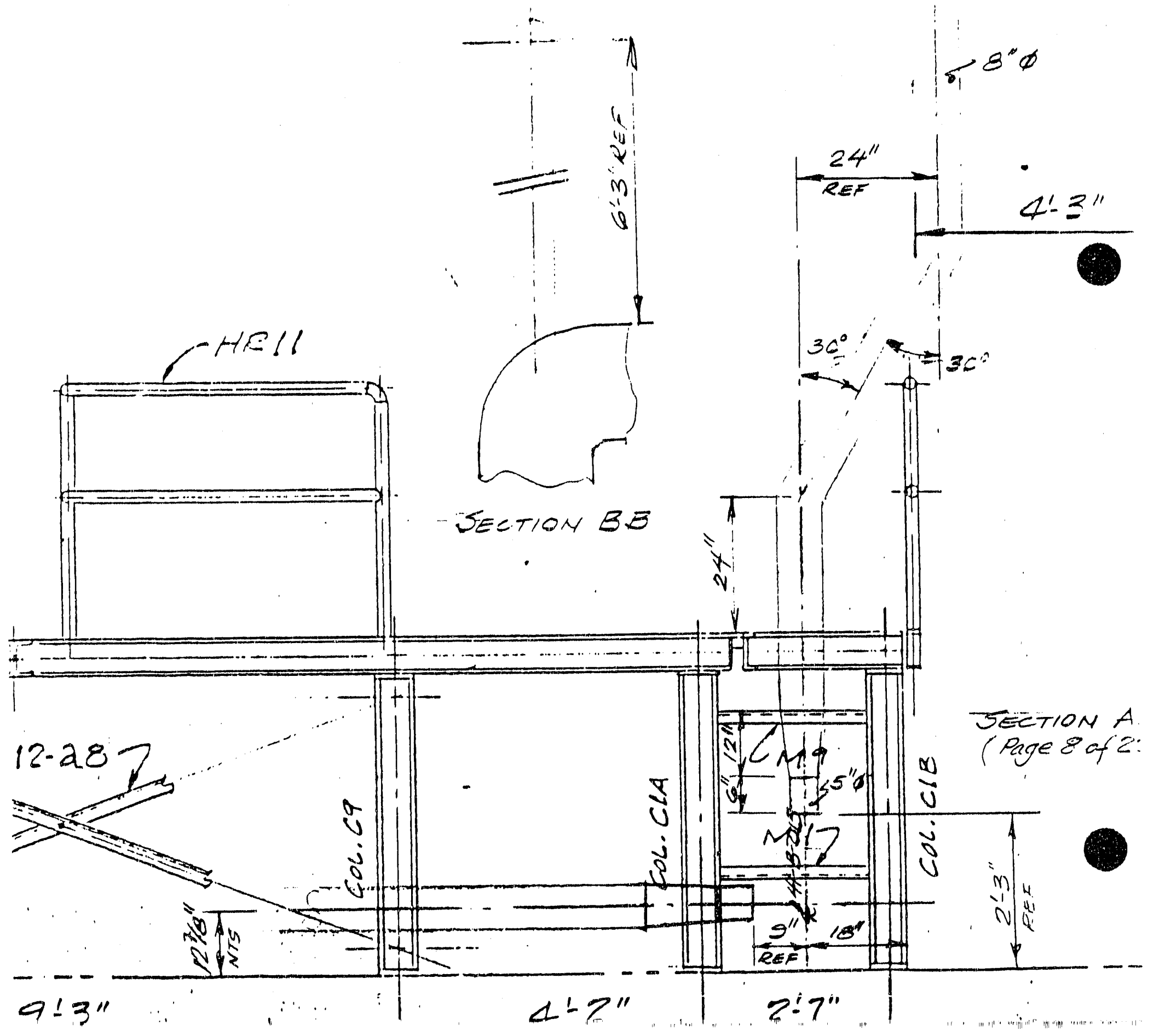




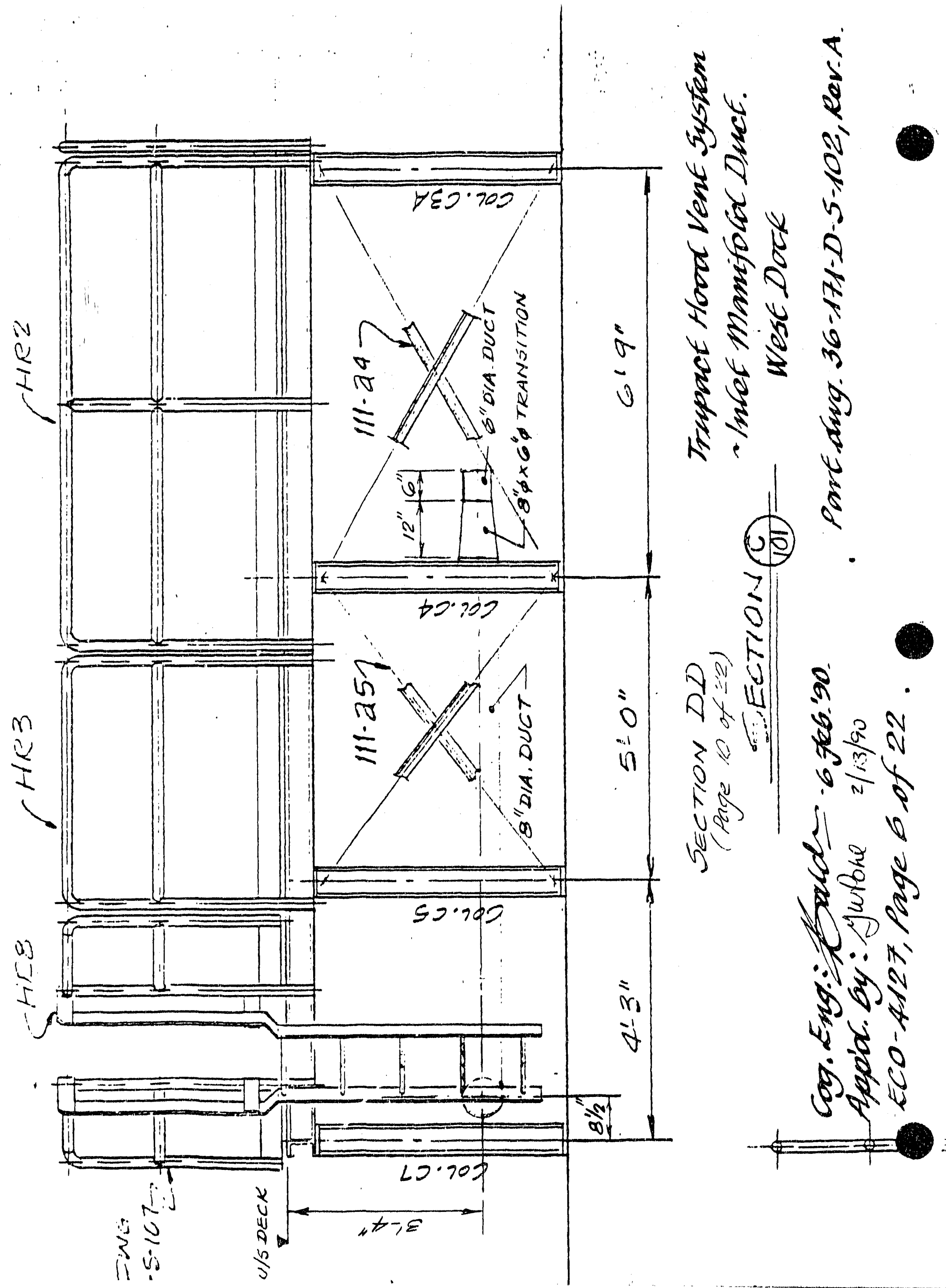




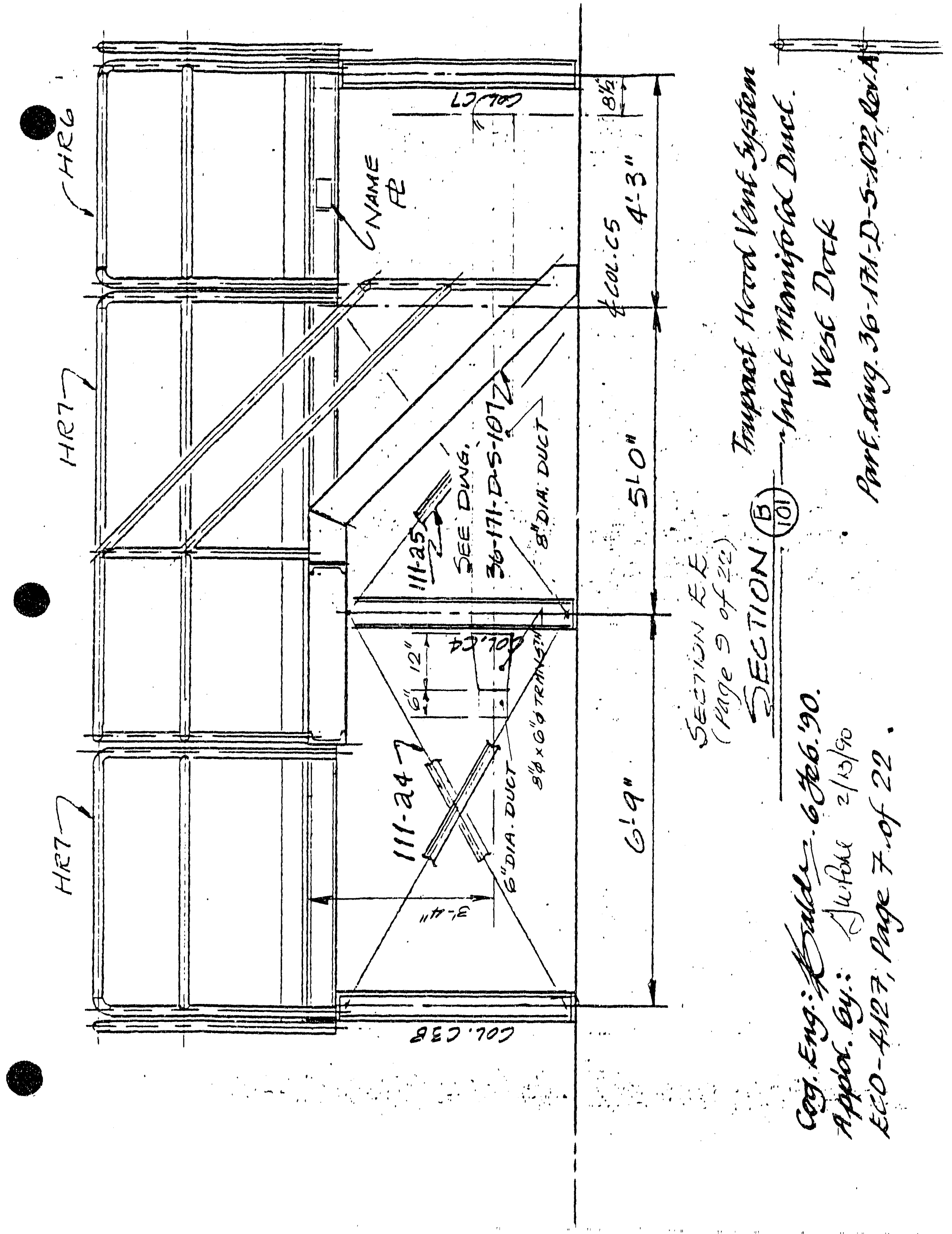




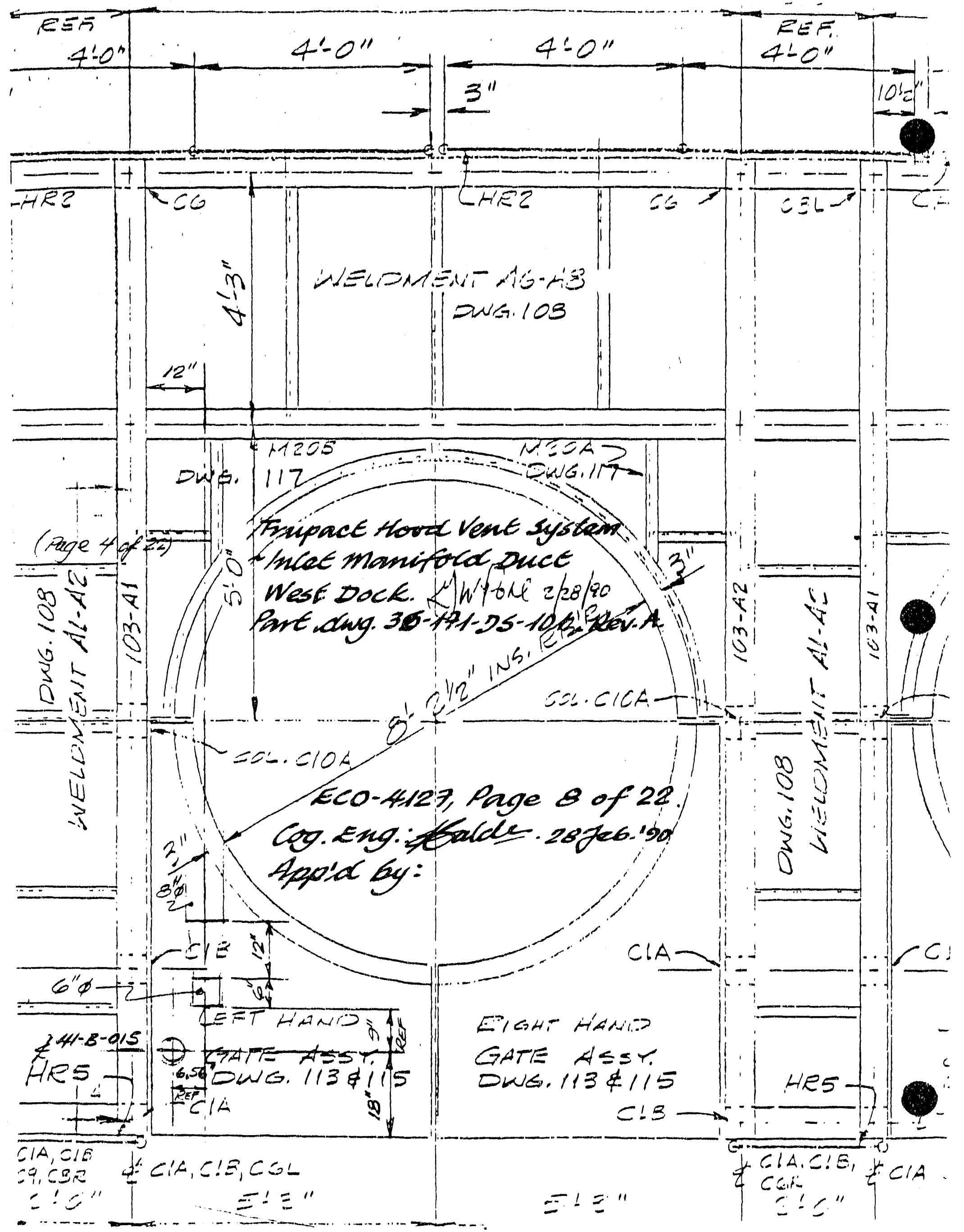




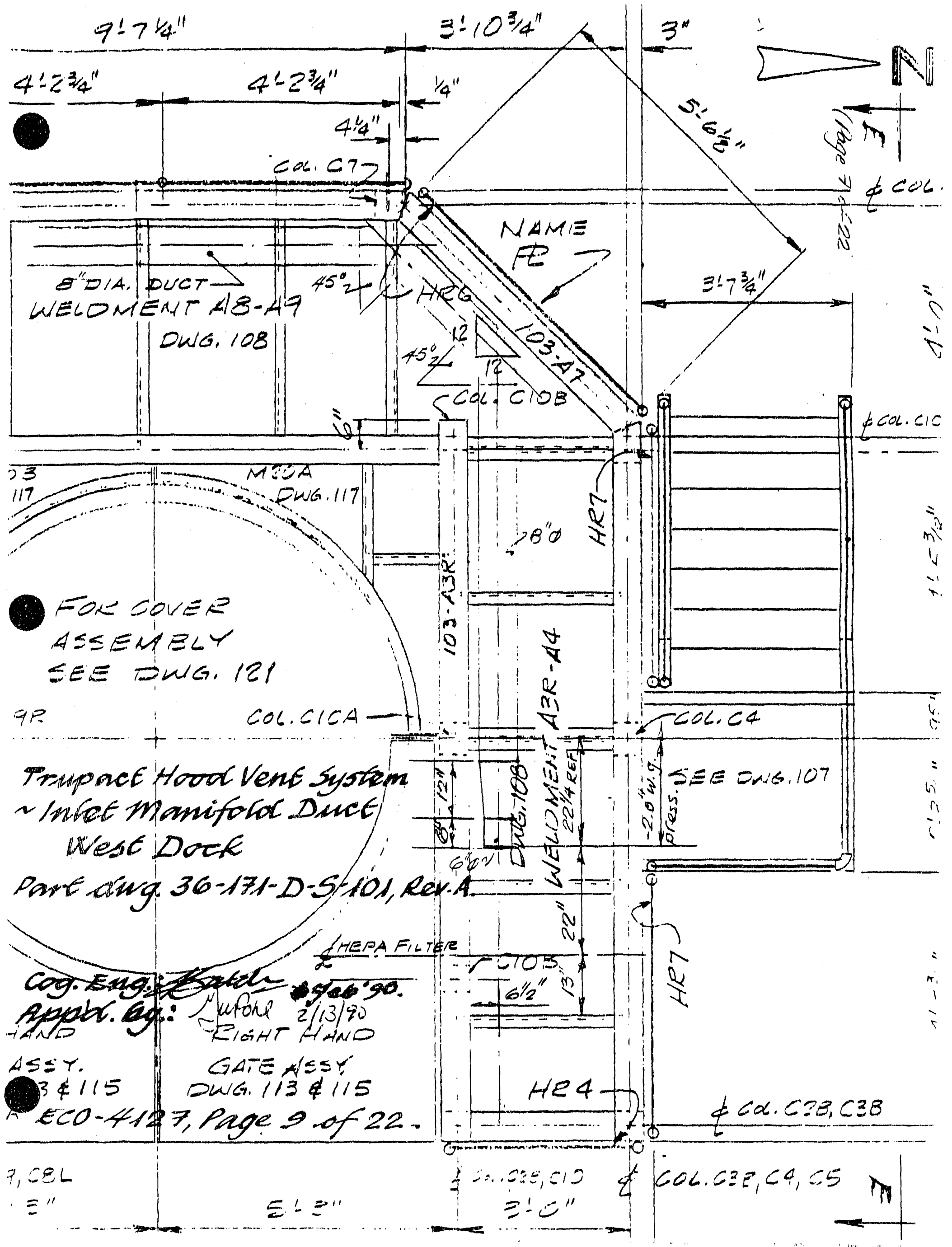




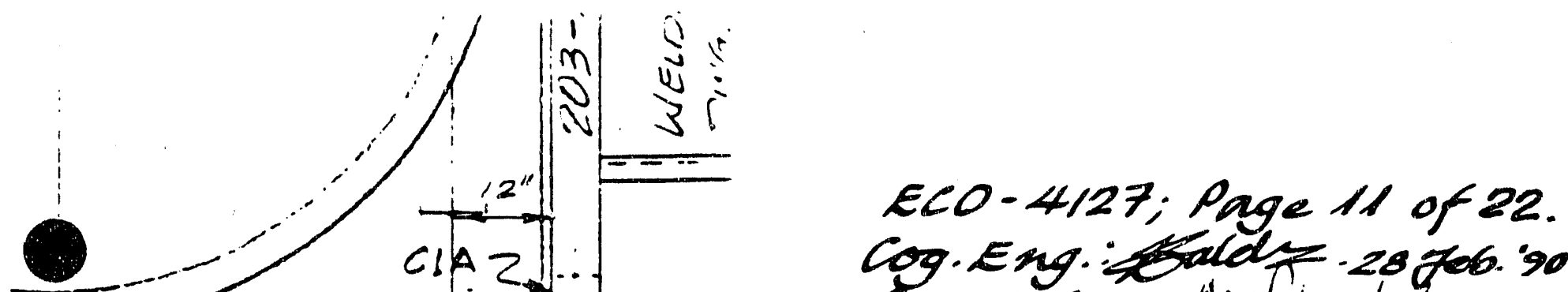

Cog. Eng. 28 to6."90

Appod. Gy: Hwtole 2posic

Trupact Hood Vent Systan CH area HVAC Sys. interface.

Eart Dock.

Part duy 36-17A-D-5-201, RevA.

$\stackrel{1}{+}$
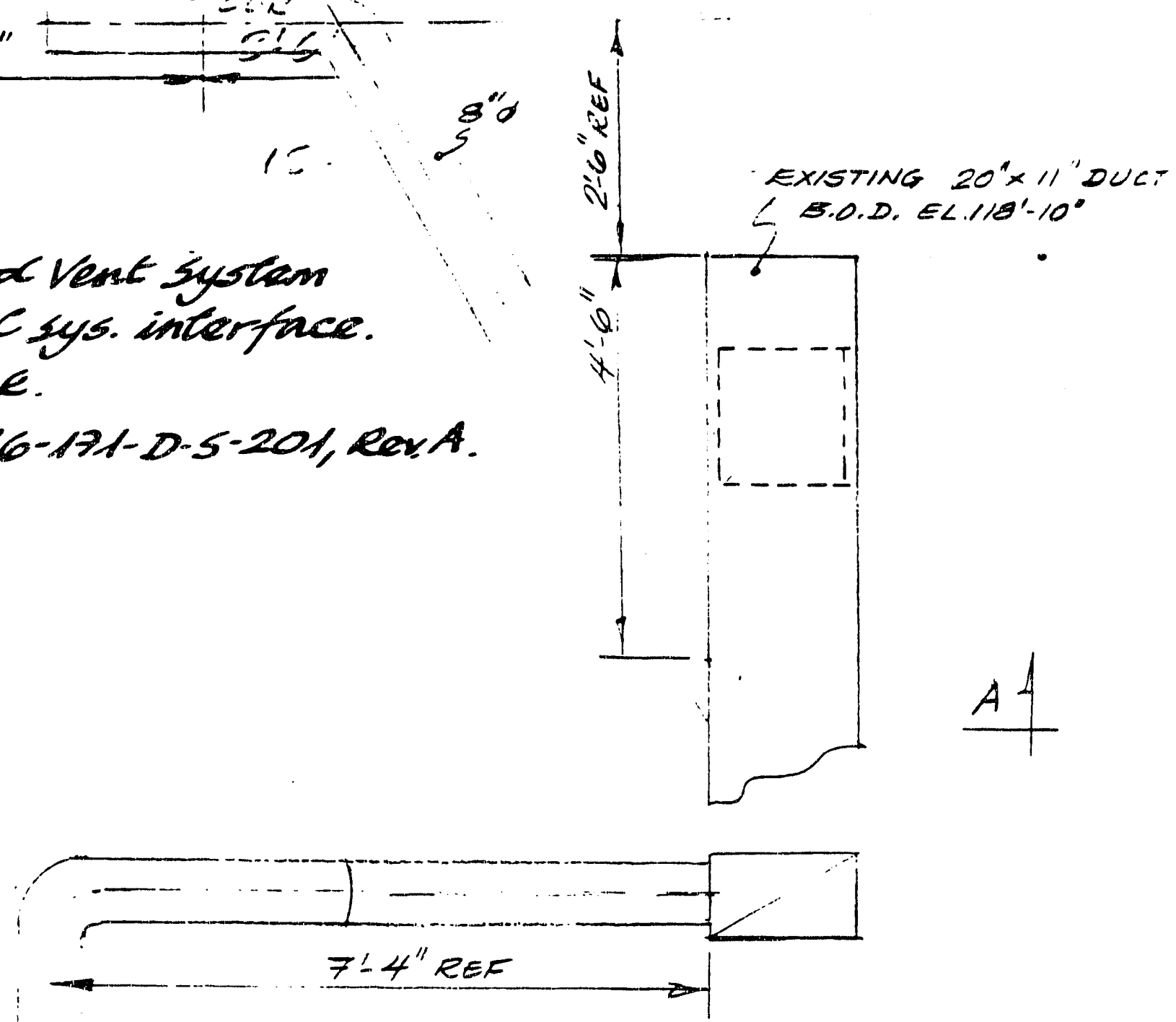

SECTION AA 
Ec0-4127, Page 12 of 22 . Cog. Eng.: balde.28\%6.'90. Appid. Gy: Jyhitone 2/28/90

Trupact Hood Vent Systen. intet Manifold Duct East Dack Partedwg. 36-171-0-5-202, en. A.
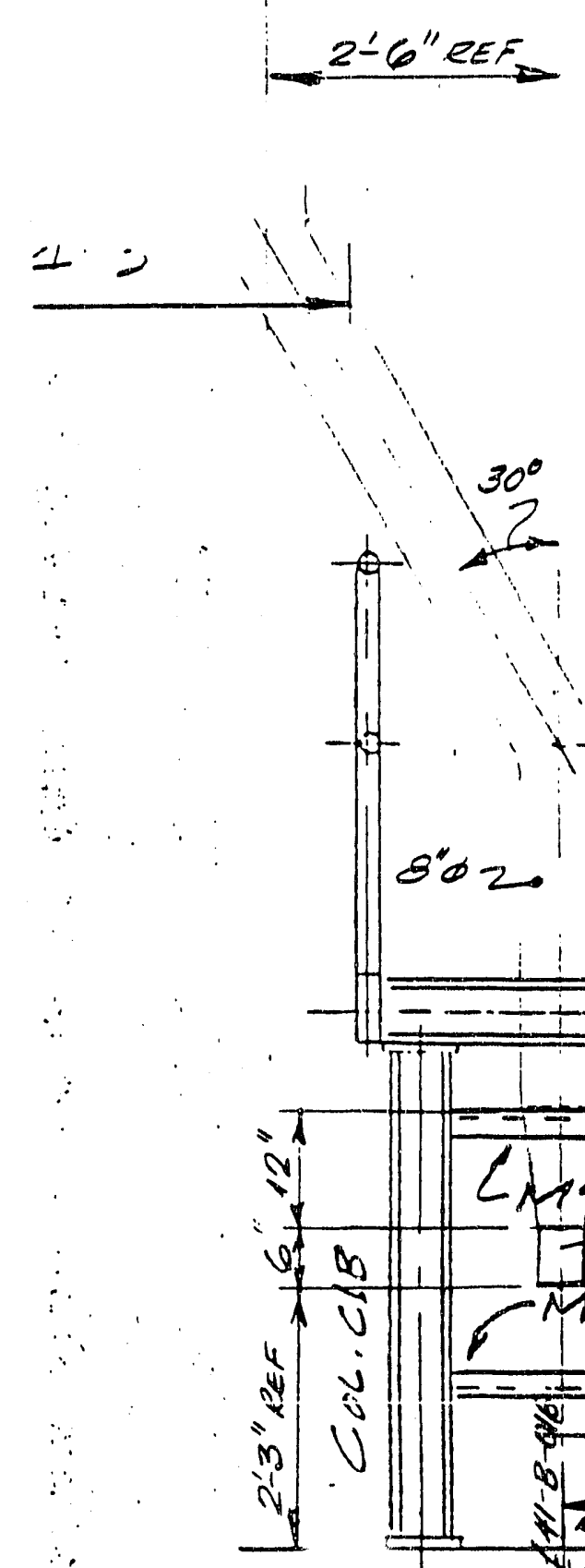

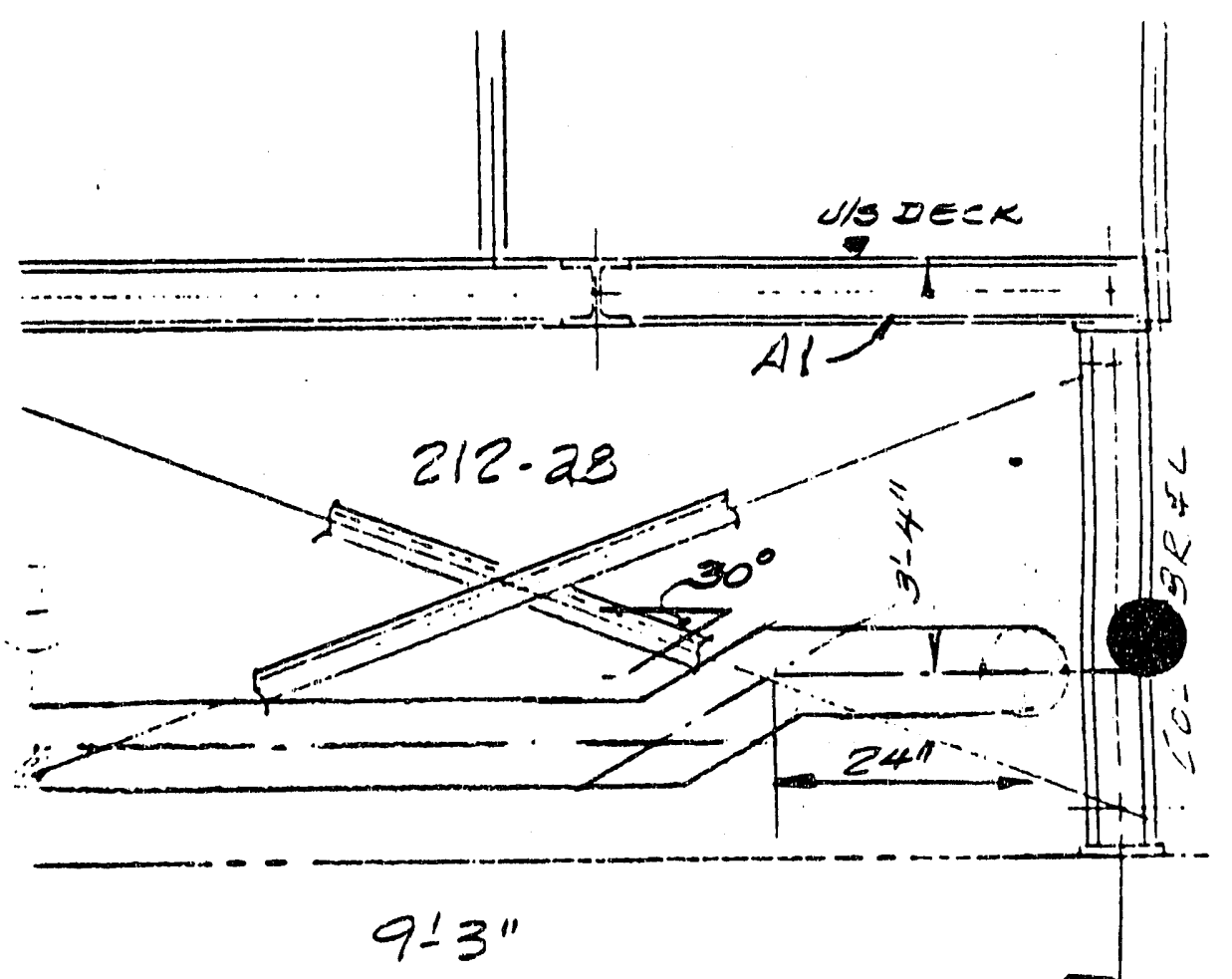




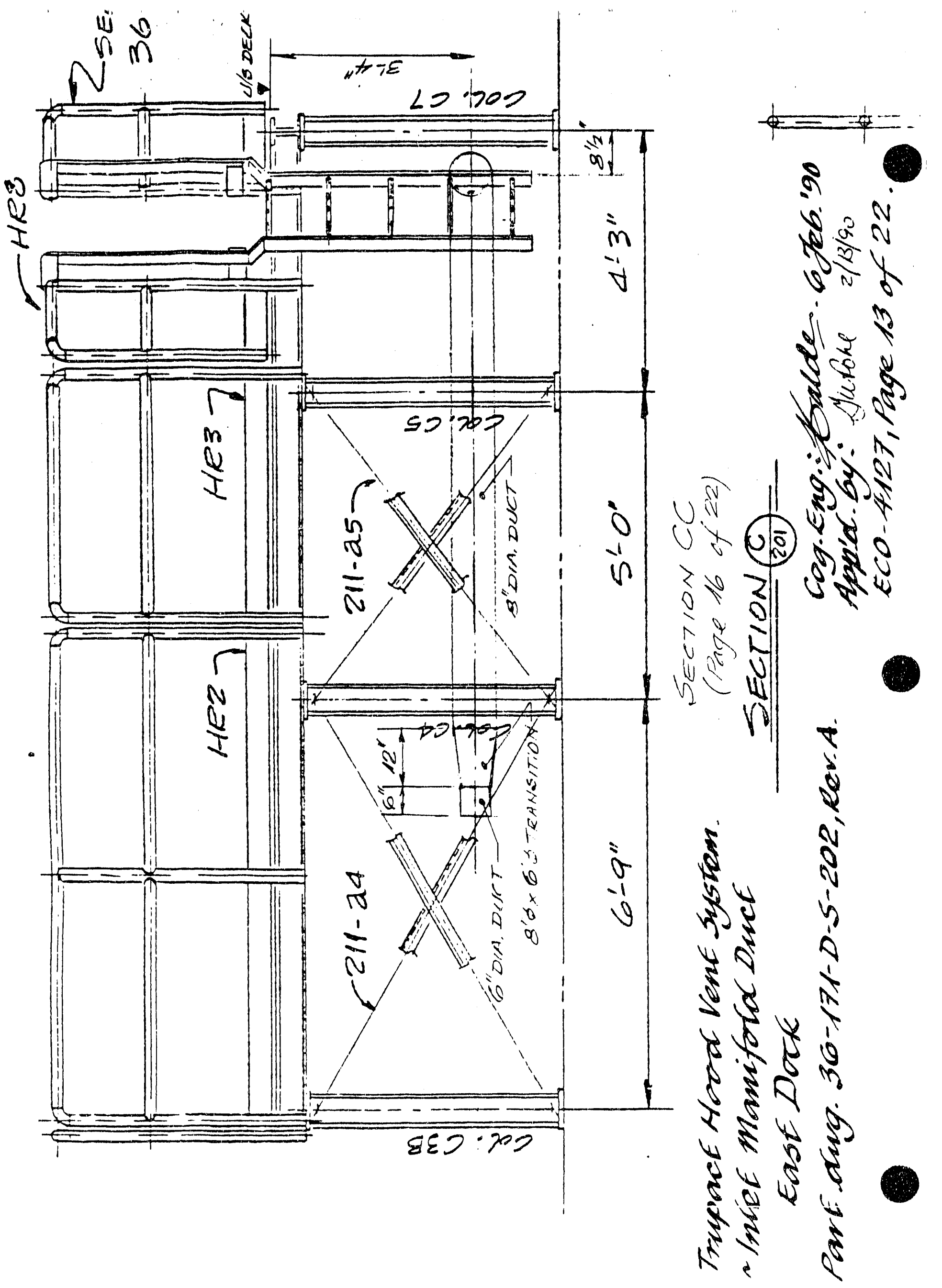




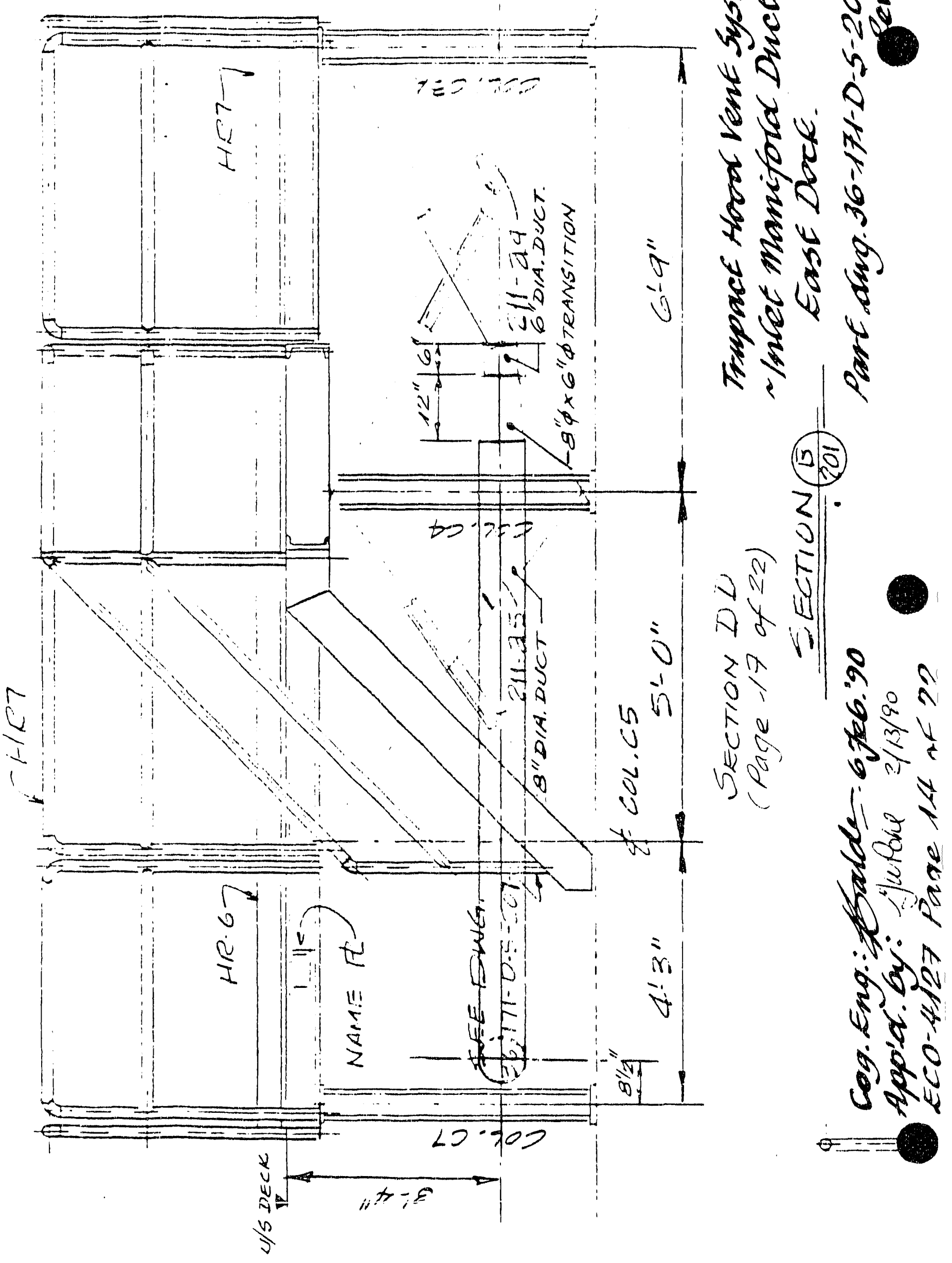




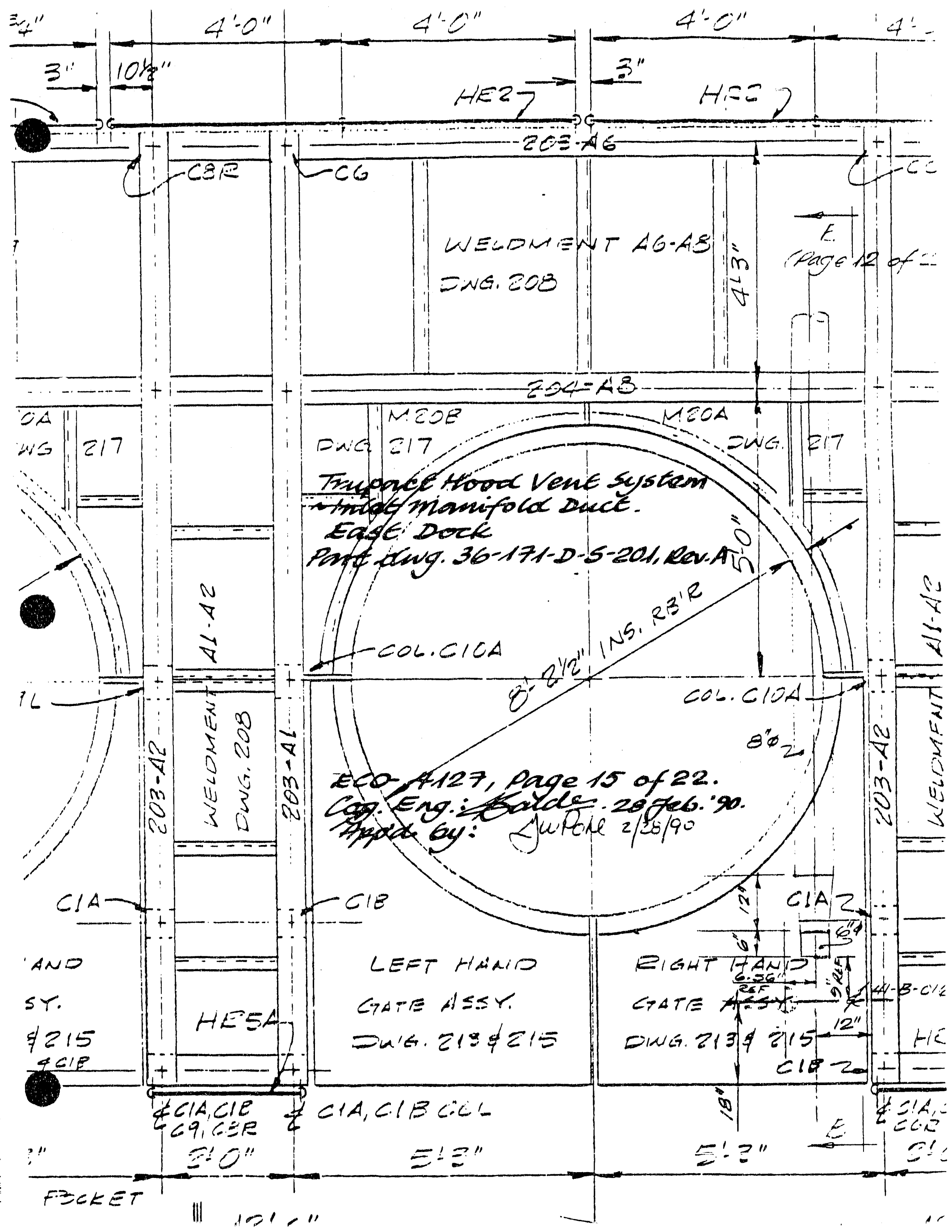




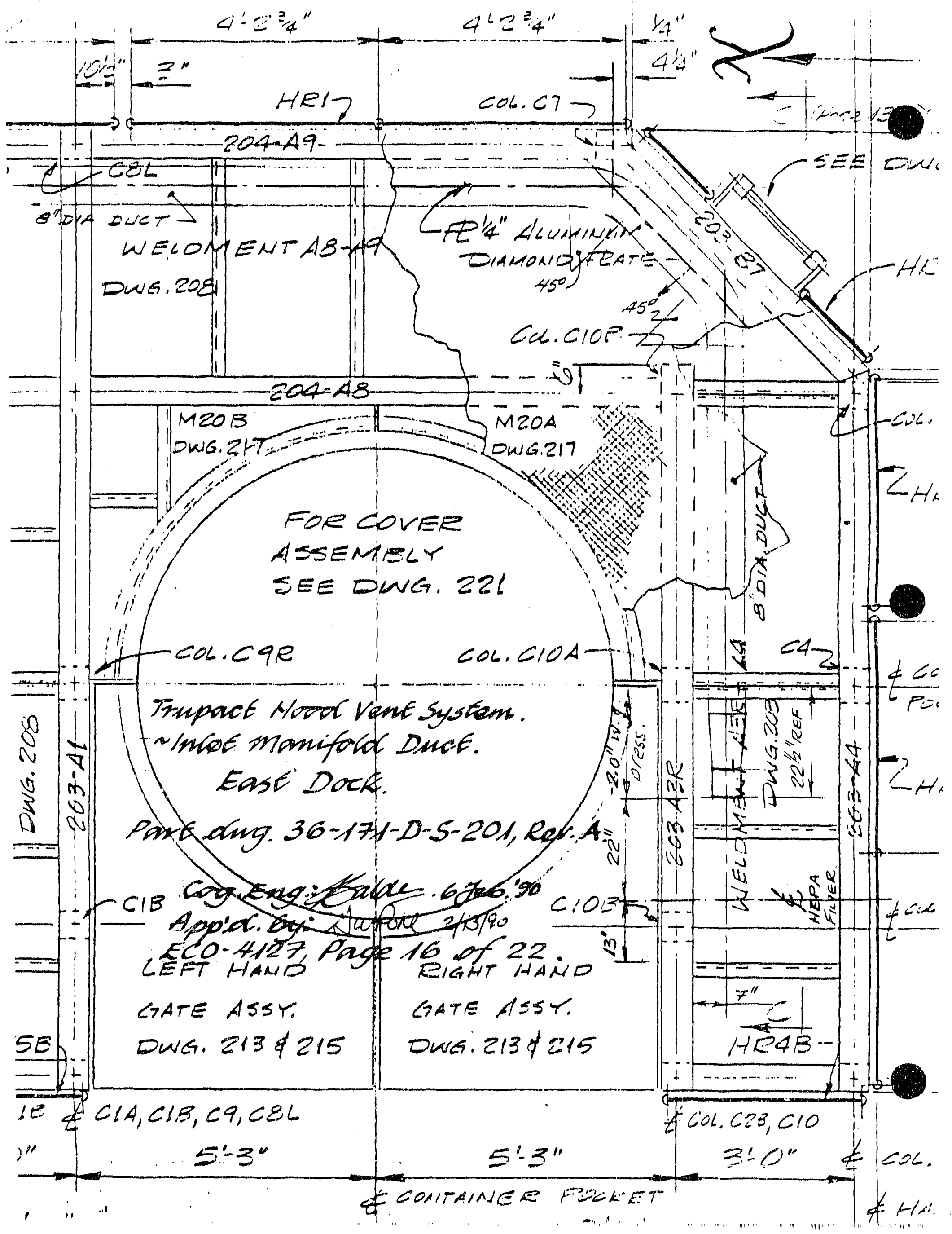




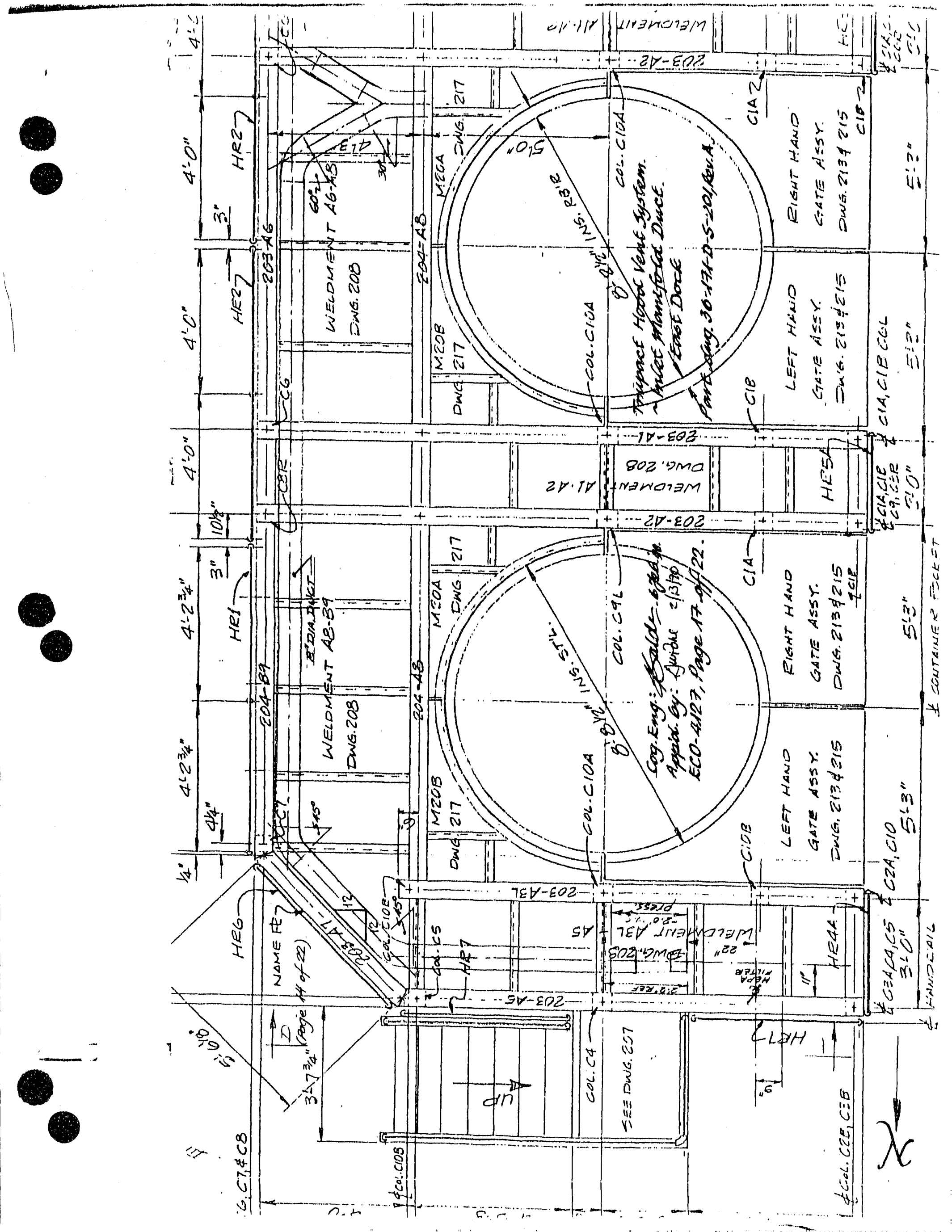




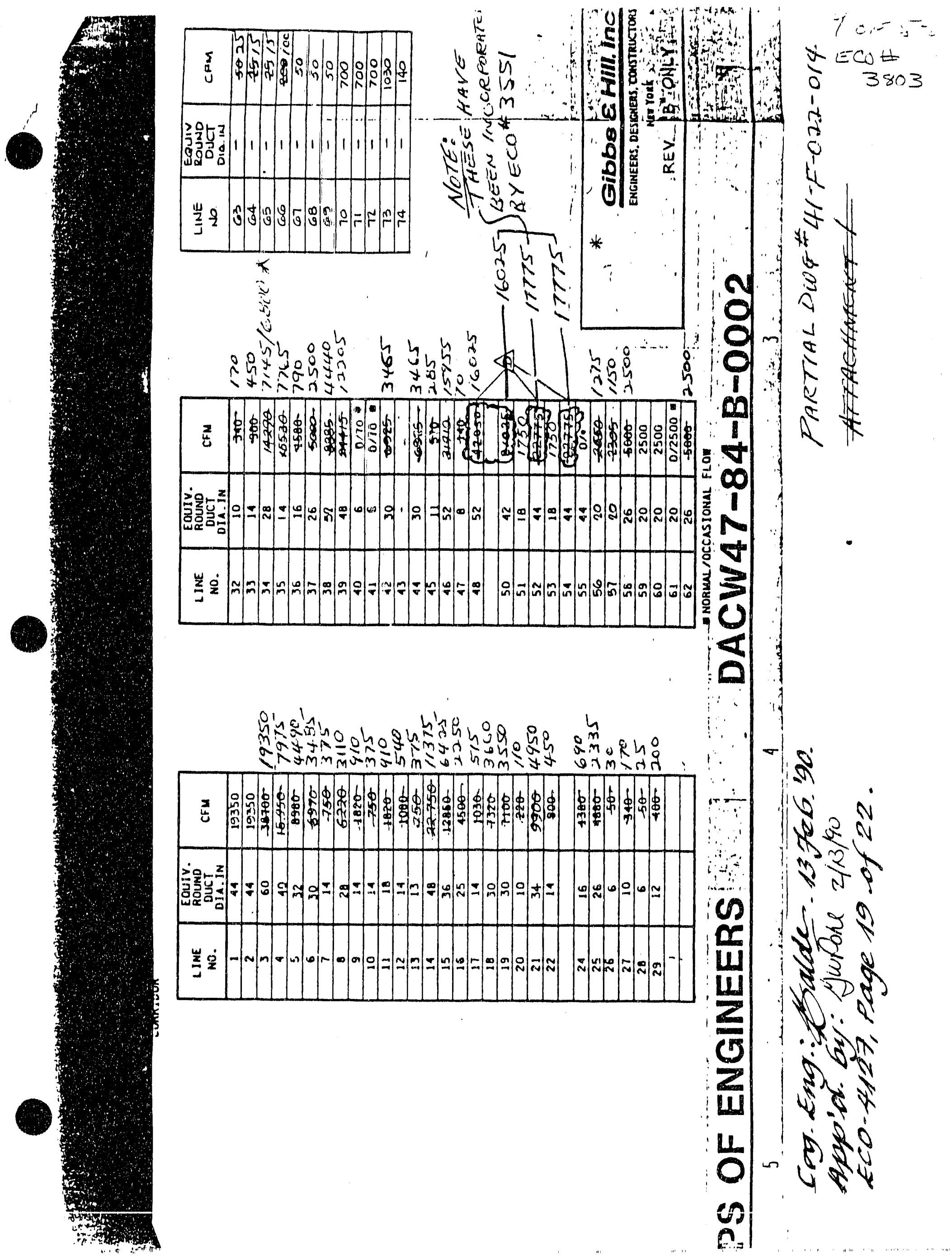



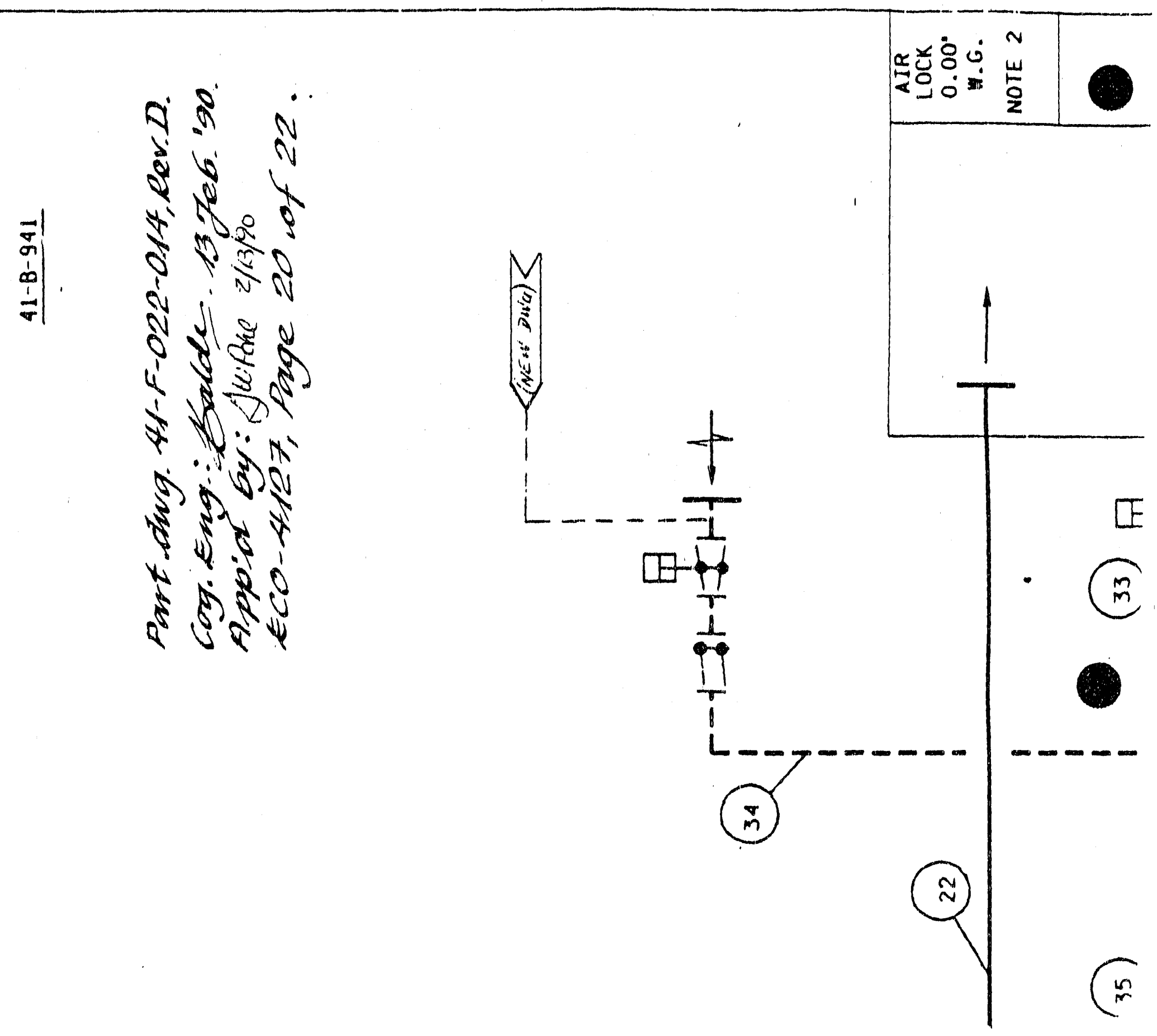

可哭 


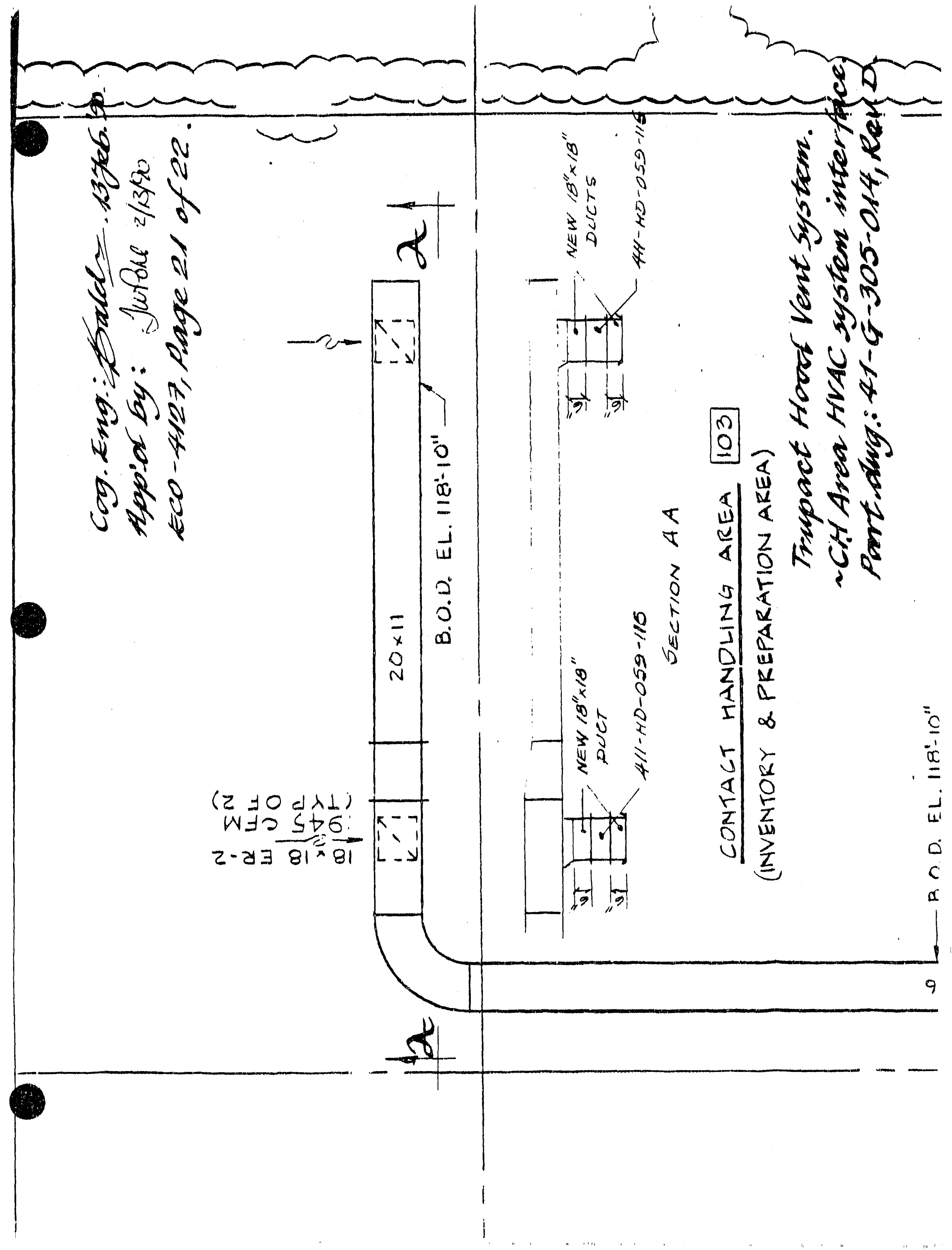



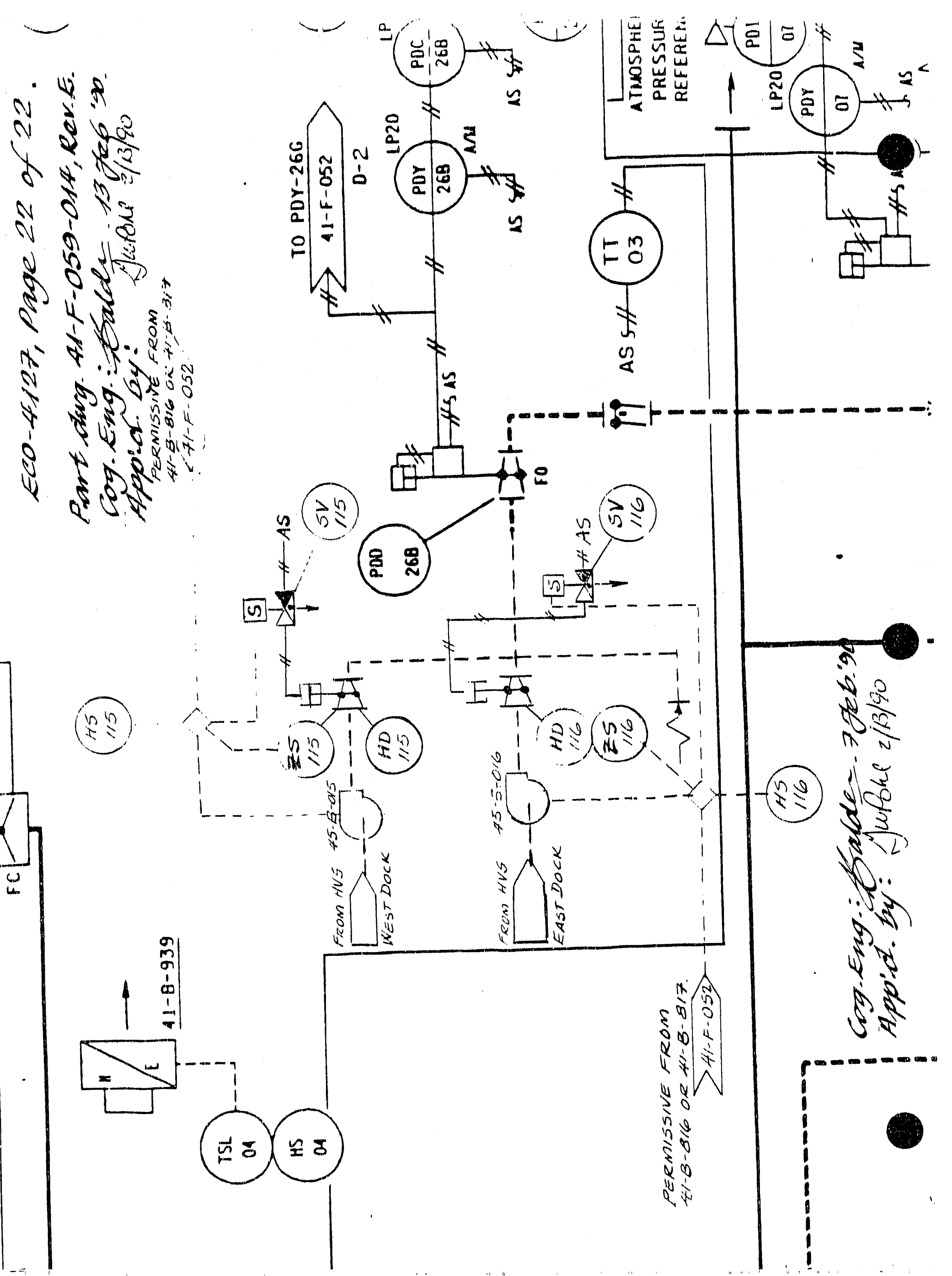


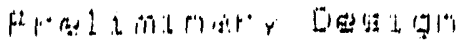

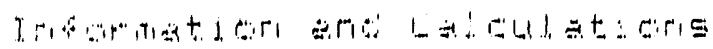

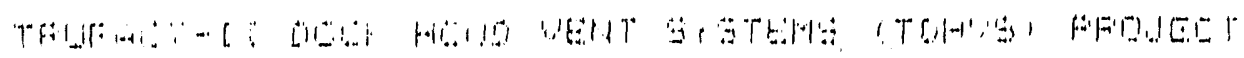

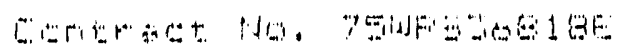

\author{
LAF \\ W.

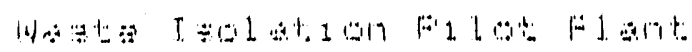 \\ G+1.]

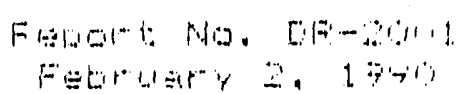

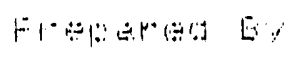

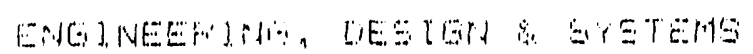

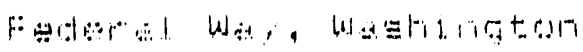

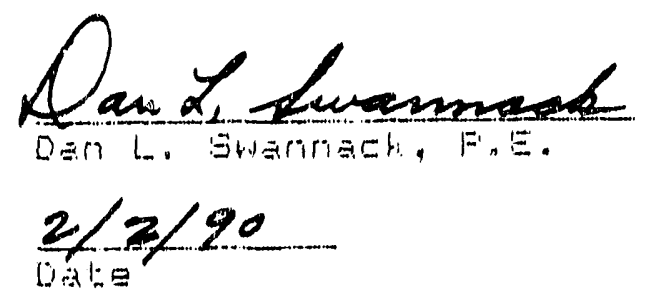




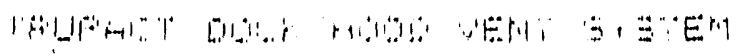

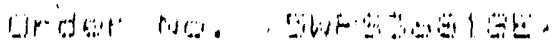

$$
\begin{aligned}
& \text { inf }
\end{aligned}
$$

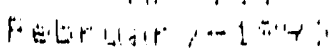

\section{$\because+a b$ G}

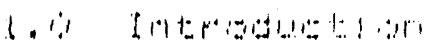

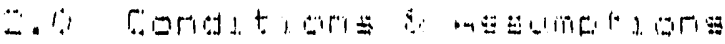

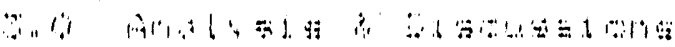

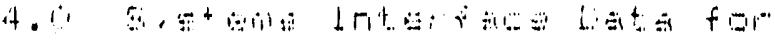

Hollo.

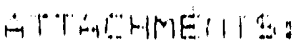

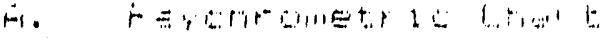

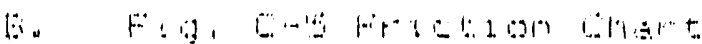

1.. D Girr

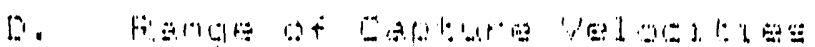

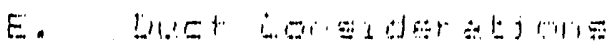

COוn

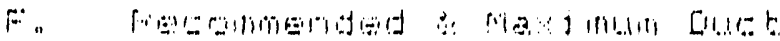

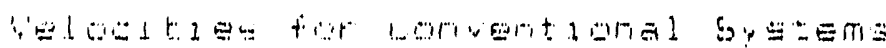

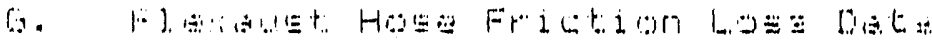

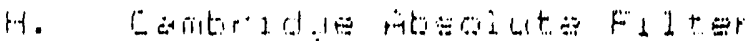

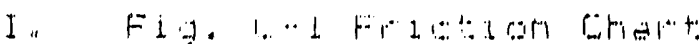

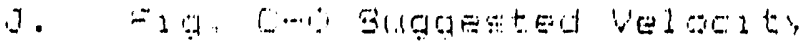

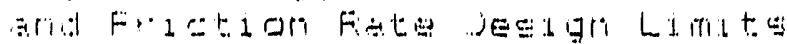

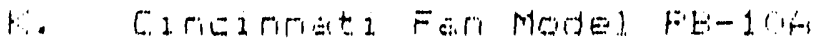

L" 「Able s

$" 7$

9

11

1

1.

$1 \Xi$

29

$\therefore$

in

26

28

1 


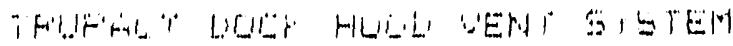

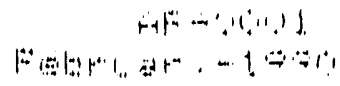

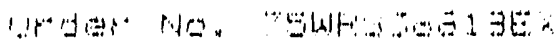

\subsection{INTKODUCT I ON}

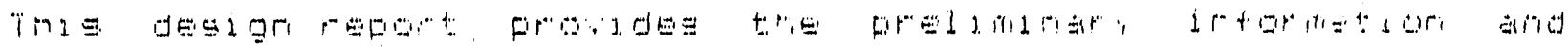
: TLHW'

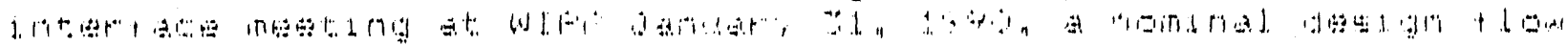
p at +

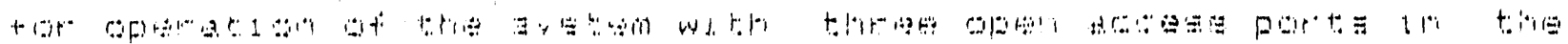

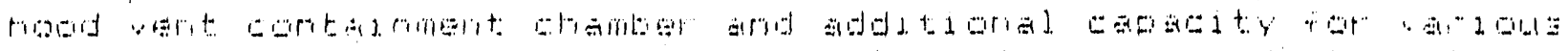
an

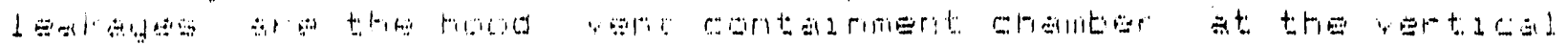

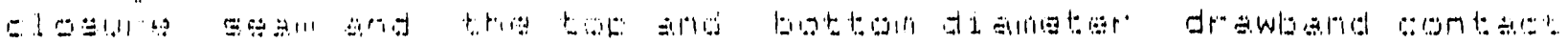
足

Tha

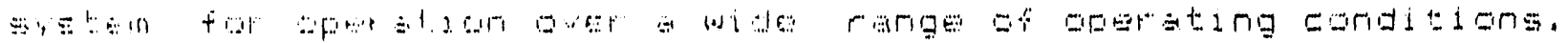
Tl, ب $\therefore \quad 32+t]$.

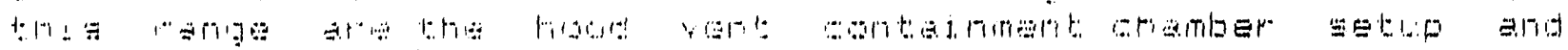

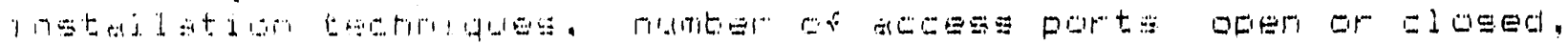

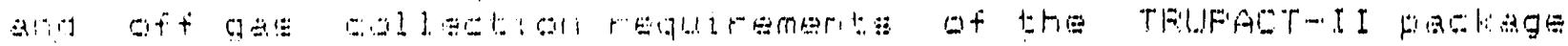

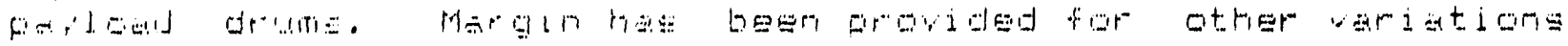

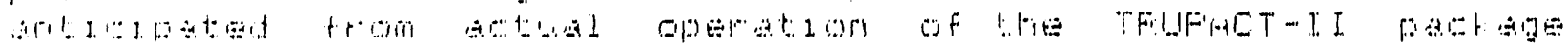

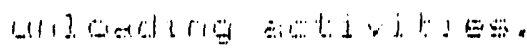

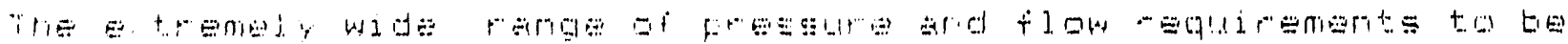

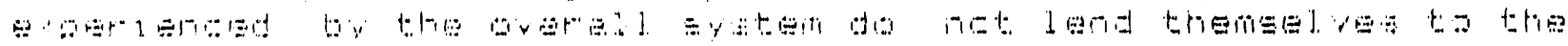

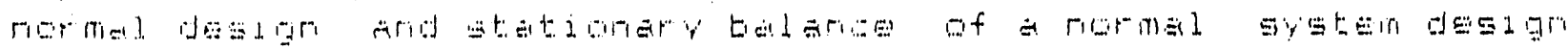

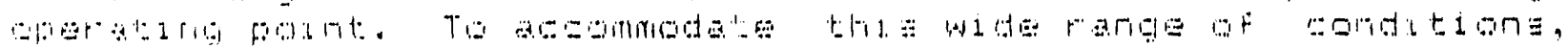
ㅁ

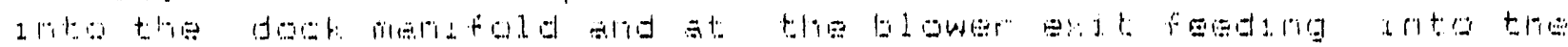
f. 
TRUPACT DOCR MOOD VBNT SYEITRS

Order No. TERRS38818RX

AR-0001

Jebruary-1880

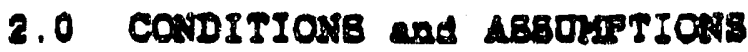

The following 1tem deplet the fac1lity conditlans stated fer the Carlabad are and otber assumptions about the design features. Thi. data 19 presented so that the ensinoer may undergtand the nature of selection and the lexpblitity of nome of the parametery

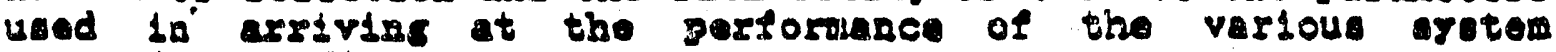
oparatinc conditions.

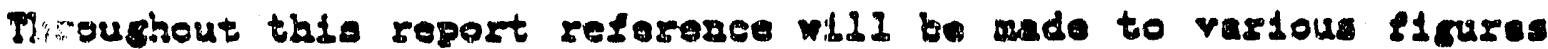
of table 1ten which aro ueed a relorence data. Coples of the - loctod pases aro lnoluded as attachments and aro relerred to by ebe1x om 1dent1licsion as used in the Asaras landbocks, the Trane Al Condstioninc Marual, vendor cataloge, otc.

Bac1l1ty Cond1tions: Elevation $=3,408 \mathrm{It}$.

$$
\begin{aligned}
& \text { Temparature }=\text { Max. } 100 \mathrm{~F} \text { dry bulb } \\
& 71 \text { I wat bulb } \\
& \text { M12, } 18 \text { dry bulb }
\end{aligned}
$$

Ral. Bum. $=60-80 \%$

WTB APAC $=0.2128$.

Adjustnenta Por Temperaeure ol Iovation:

Trea the Parchravetric Chart: sp.vol. $=14.32 \mathrm{cu}$ ft/lb

(Attachmont A)

deustey $=0.0698 \mathrm{ib} / \mathrm{cu}$ st (200 db 71 db)

Jren Fie. C-5 Chart: Tumporatizfo Correction Jactor $=0.96$ (Attrehmont B)

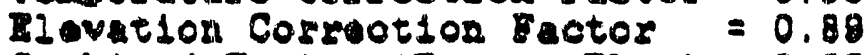

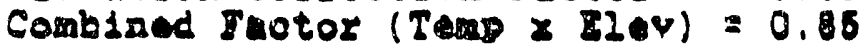

Relative Hundd1ty affoot w1ll not be droluded fron adyjoo of AbtiRnt gandbook (Ret. 2881 Eundamentais Volumo, Pago 33.6) (Attachront C)

Othar Sourse Sugreated/Racommended Operating Peatures -

Capture Pelosdtles for Eragoration froo Tarka : 50 to 100 fon

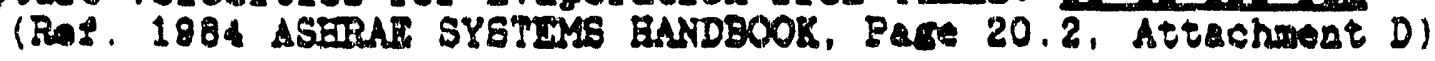

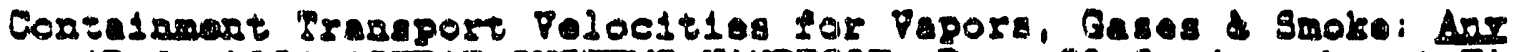

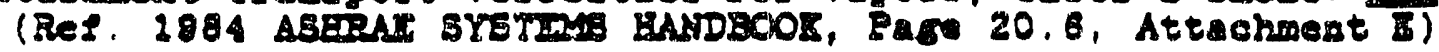

Recommerded Duer Falocities: (Trase Als Cond1tioning Manual) (Attachent I)
Branch Ducts, 600-800 Ipar Riser Ducts, Bo0-700 stom 


\subsection{ANALYSIS and DISCUSSIONS}

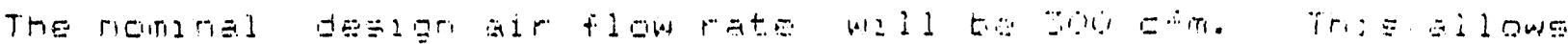

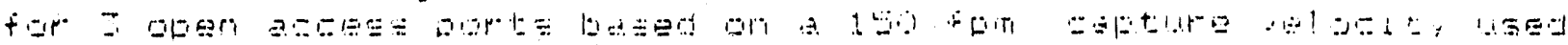
נh the [rof

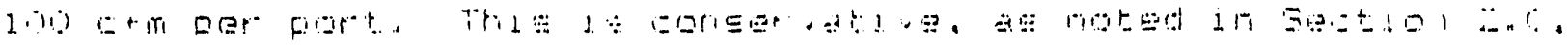

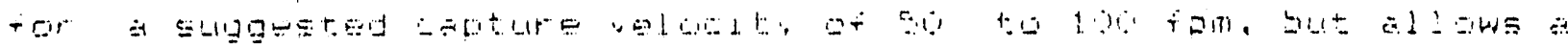

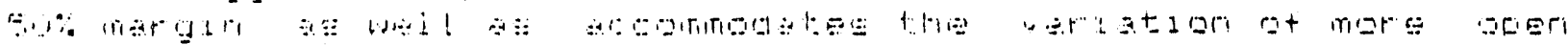

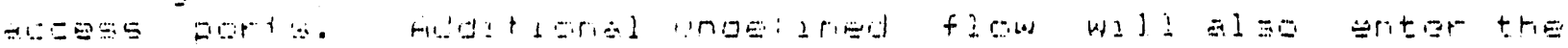

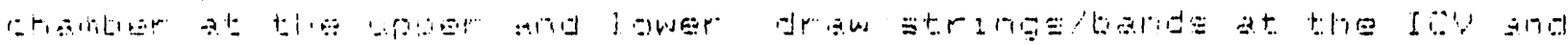

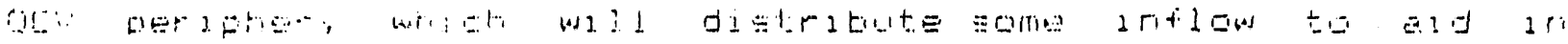
与

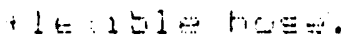

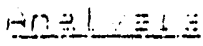

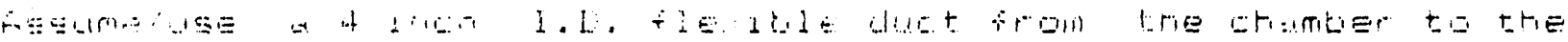

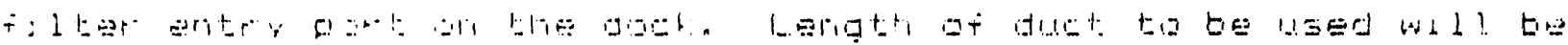

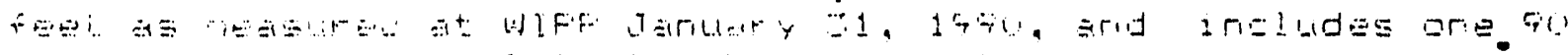
口ы

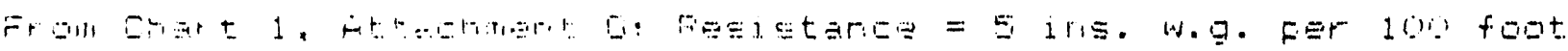

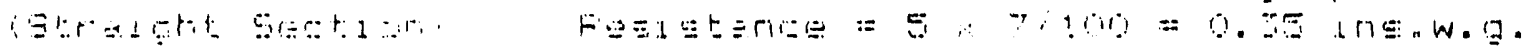

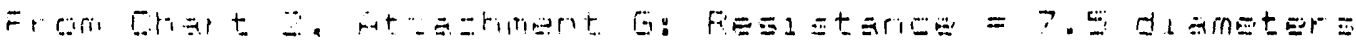

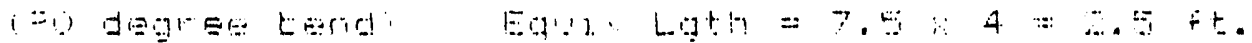

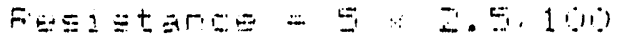

$\therefore \quad \therefore 12=21 \%$.

Tot.al = 0.

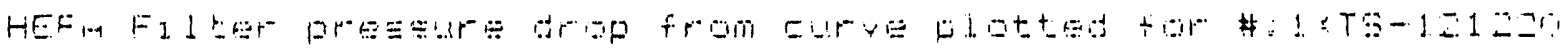

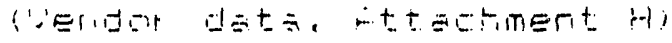

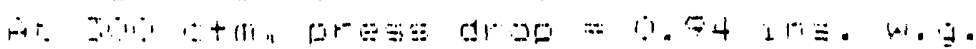

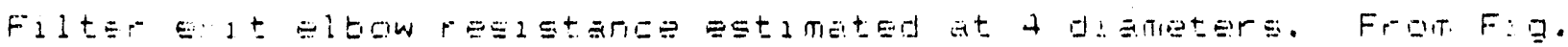

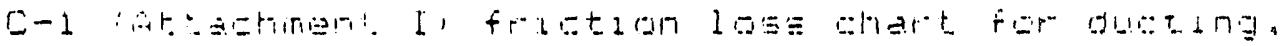

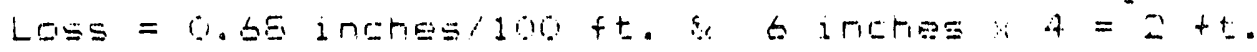

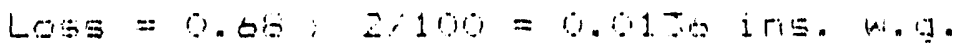

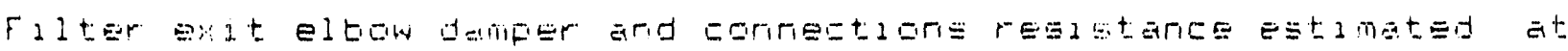

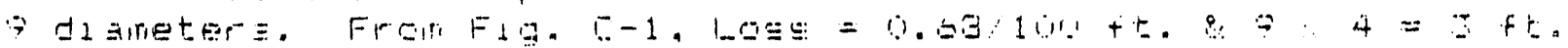
L.GS =

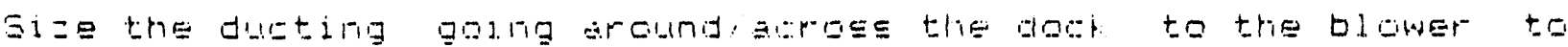

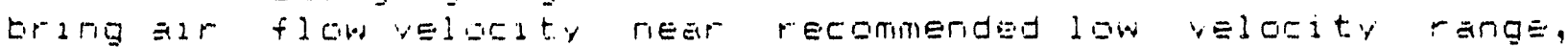

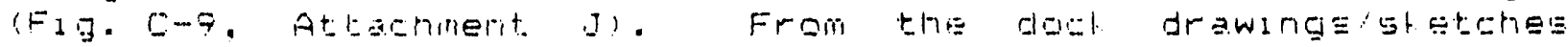
Frowdded of the WIFF Dogl and profosed duct routdrg, the length of duct was deterllired as followe:

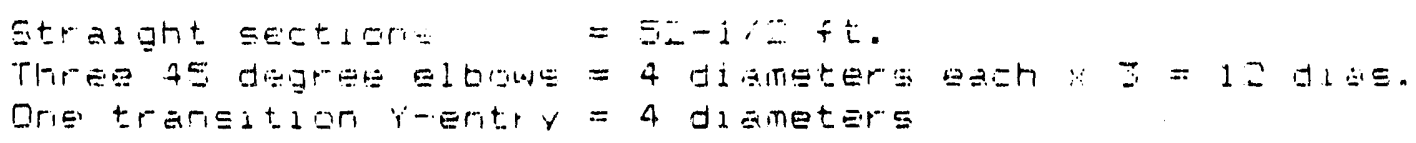




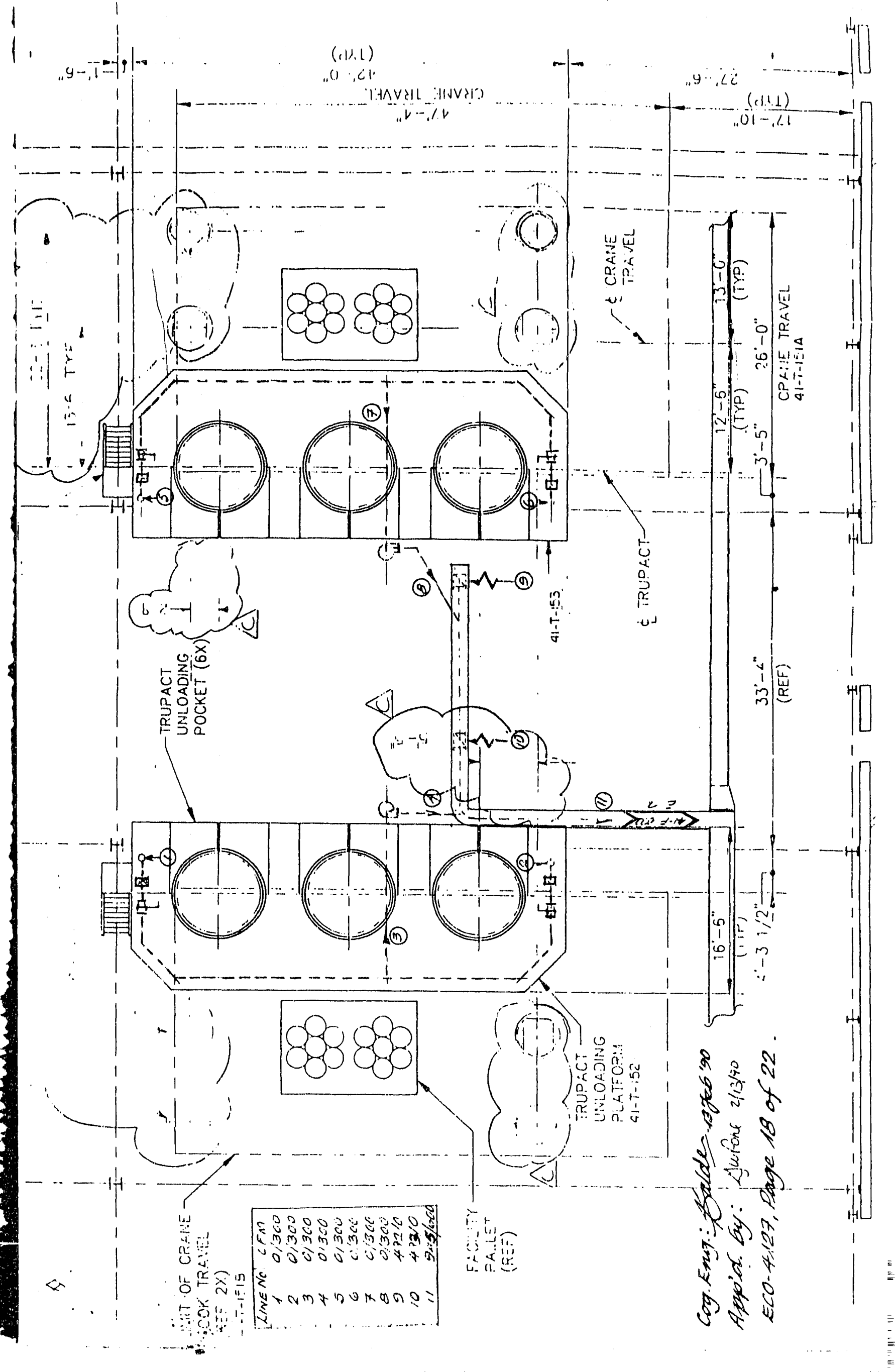




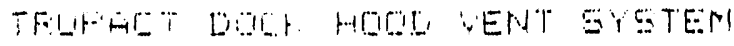

Dr.

nafi- $\because \because 1$

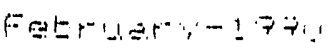

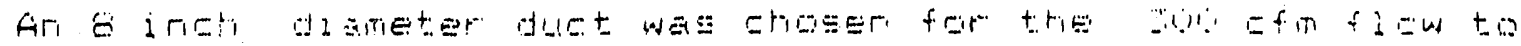

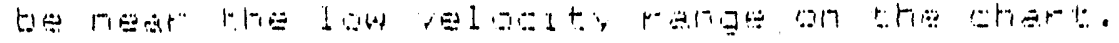

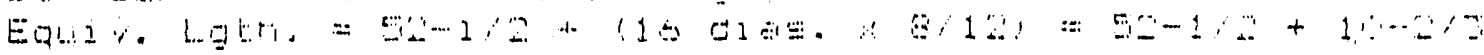

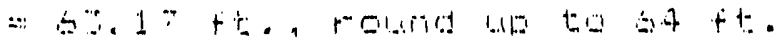

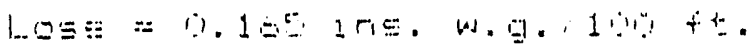

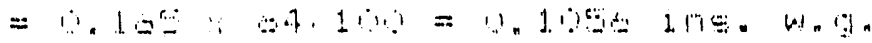

Tr.

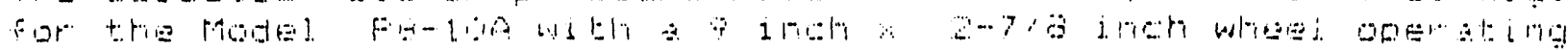

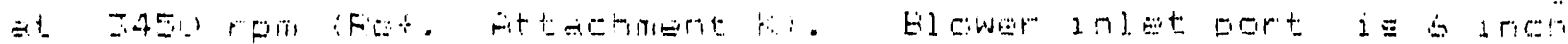
1. 6.

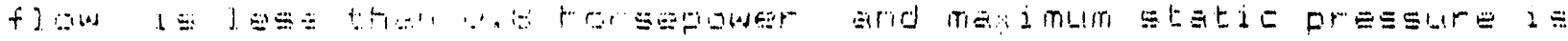

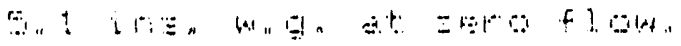

A Go

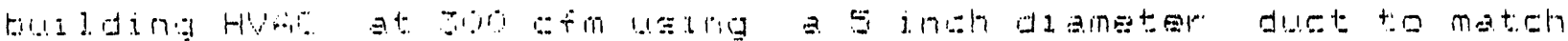

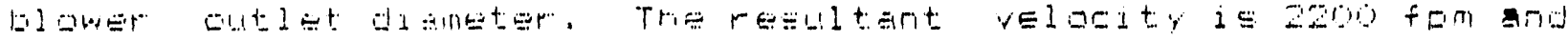
r. 10 ب

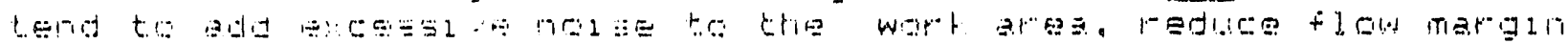

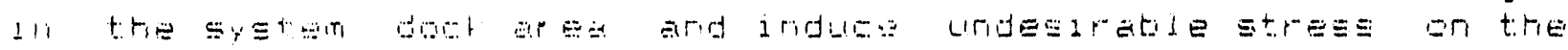

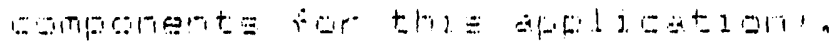

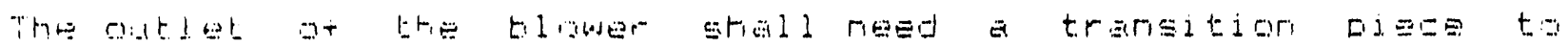

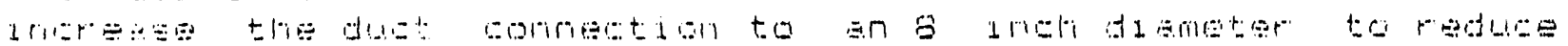

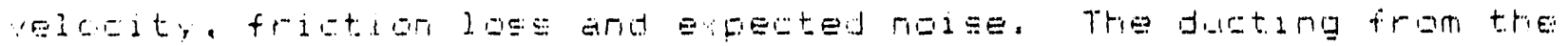

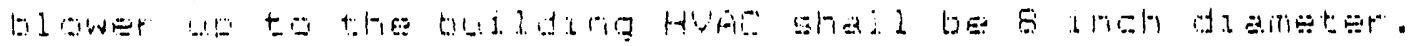

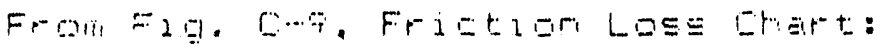

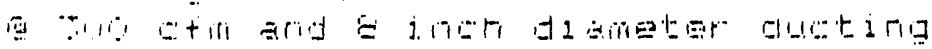

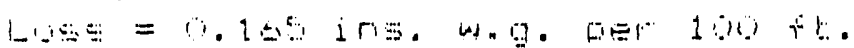

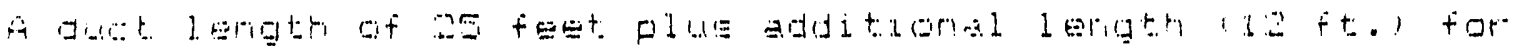

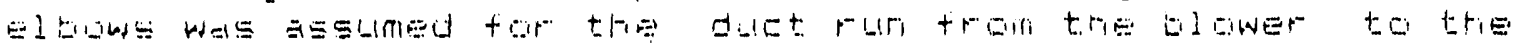

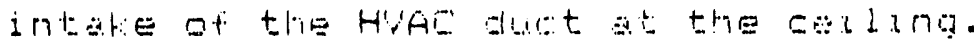

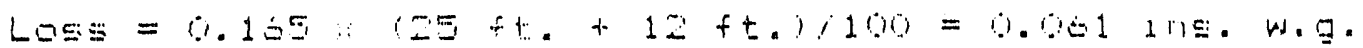

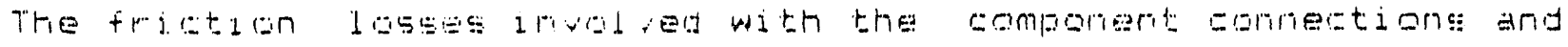

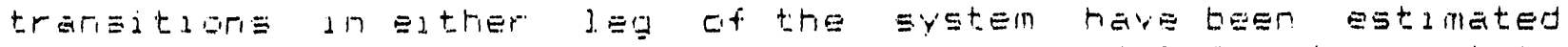

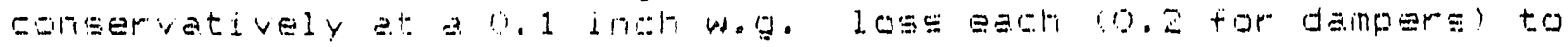

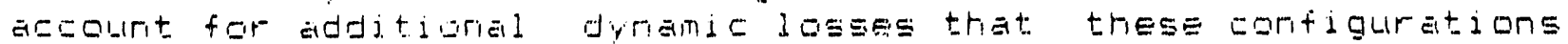

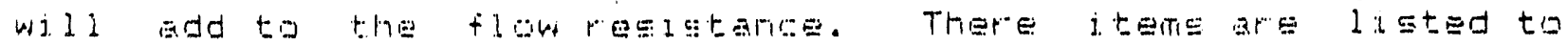
lderitity the quantity of features considered ir the system est 1 in $e^{\prime}$.

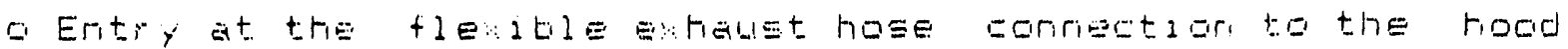
vorit: contal minent chimber exit."

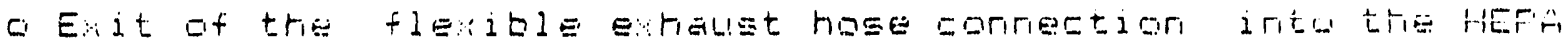
filoer inlet port:.

c Dimper flow device at the filter elbow esit to the doch 


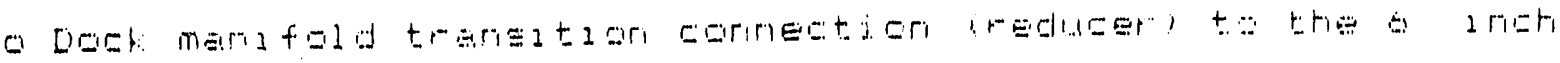
Q 1 ج)

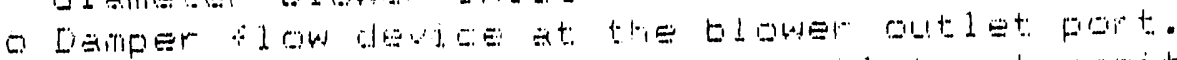

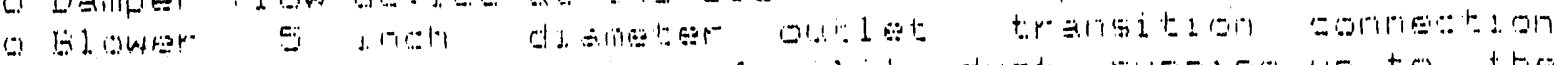
(a)

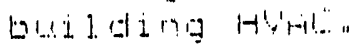

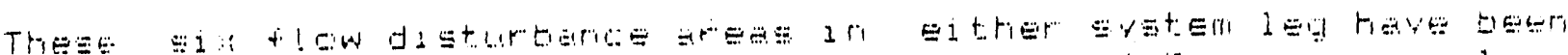

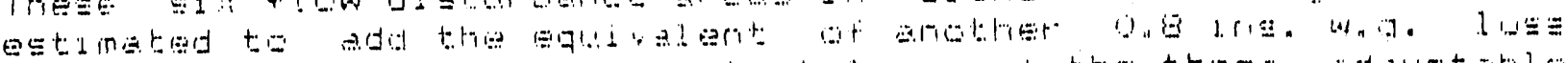

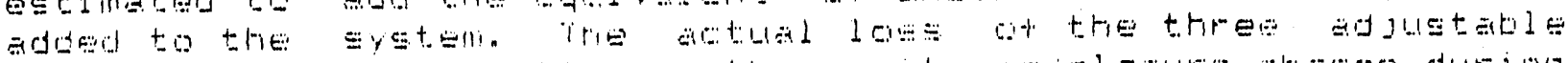

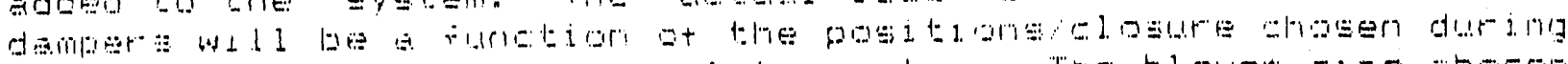

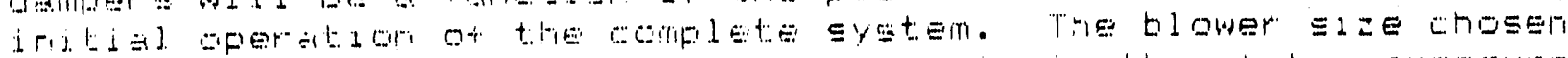
pa

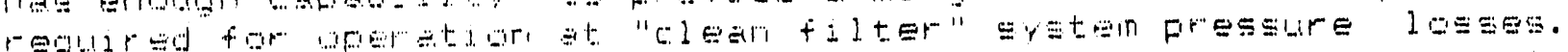

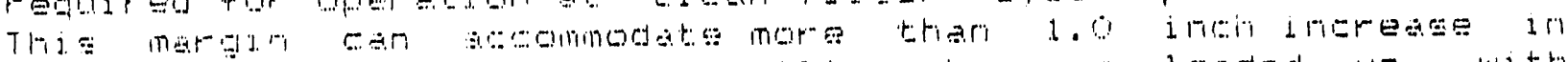

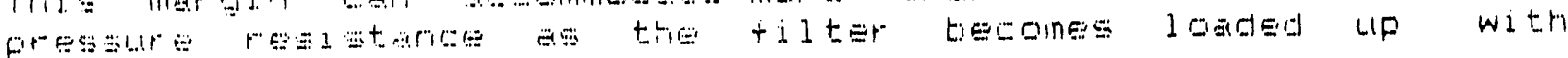

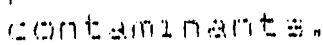

\section{SL1min):}

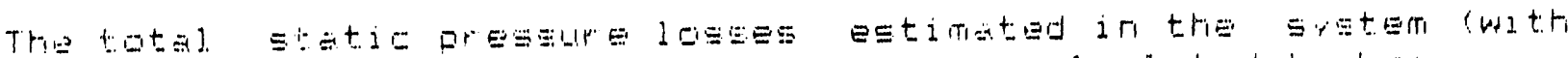

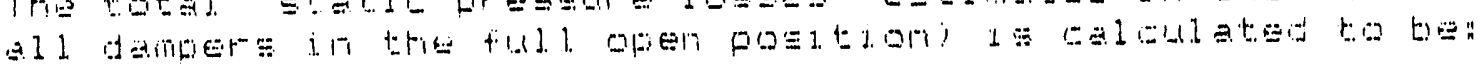

L.

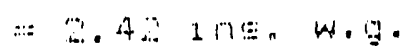

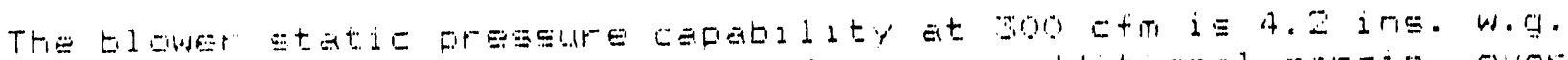
(Fet. At a

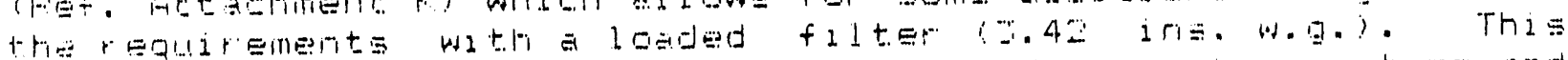
10

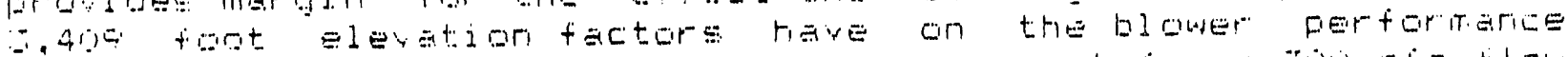

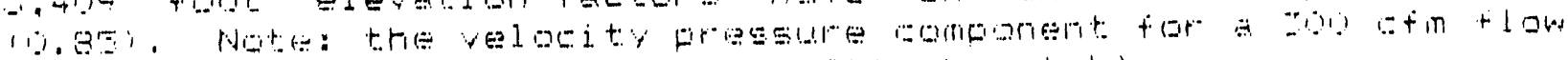

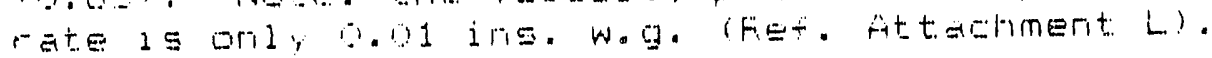

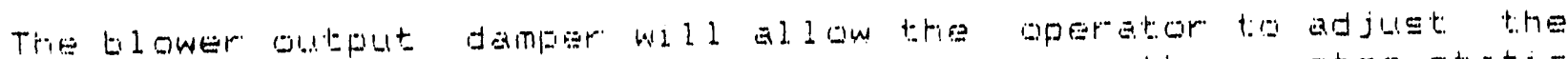

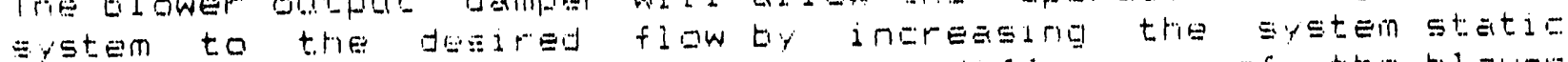
pressure ries at tore blower by the differenge af the blower

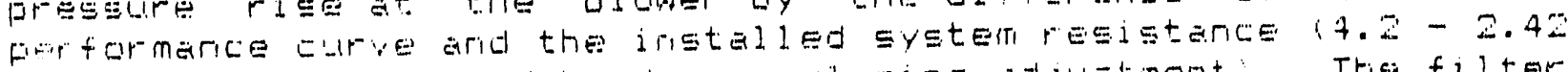

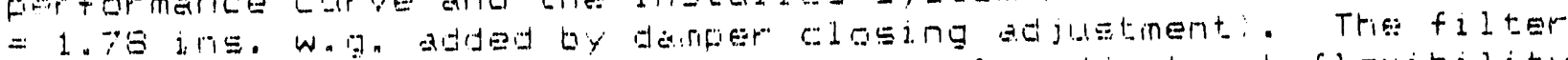

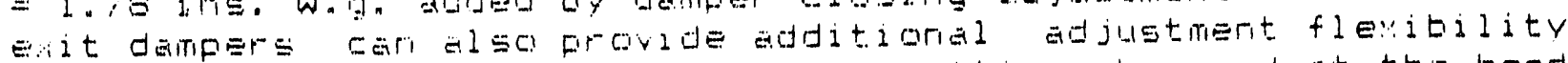
in the operation of the Jystem as astivities observed at the hood vent contairiment aringut may reculare. 
MRUPACT DOCK EOOD VINT SYSTEM

Oxder No. TSWRs36018IT

AR-0001

Tobruary -1880

4.0 Byatom Iaterfmee Dete for BVAC and alootrical Bratems

Blower Motor S1ze: $9 / 4$ Horsepower, 480 VAC, 3 Fhase

Blower Contorldne Helahto: Inlet $=11-1 / 2$ 1nches out lot $=4-15 / 26$ or $18-1 / 16$ inches

Blower Inlat/Outlet Blras: Inlot $=8$ inch 0.0 . outlet $=1$ ses $0 . D$.

Dock IMDS duct diameter to be 8 1noher $0 . D$.

BIPA P1Iter Damper Connection Duct Diameter $=6$ Ineh $0 . D$.

ERPA P11ter Damper Duet Hortrontal Run Conterline Dimenolon

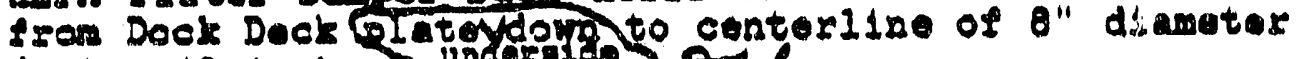

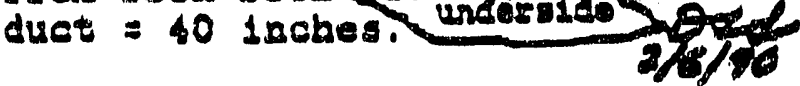

BMPA F11ter Duct Fordoontal Run Posit1on:

Nest Dock:

Duct oonterline to be $1 / 2$ 1nches North of 103-ASR bean odes. Duct conterilno to be 7 laches south of 103-15I beam edse.

E1:ter location to be centered in the ahst-knst direotion at the 2nd panel position of ench dock corner (near columen (LOB).

ERPA I1Iter outlet lbow damper duct connecion position to dock manliold to be 22 1nchos KEST of eliter centeriline.

Sast Dock: Duet centexl1ae to be 11 lnches south of 209-A5 beam adge. Duot contorilino to be 7 Isobes Soutb of 203-A3R ban odge.

T11tex location to bo contered 1a tho RABT-MRST dirootion at the 2nd panel position of the Bouth dock corrar.

Filtar locetion to be 8 1wohes rast of croce member at the and panel postion of tho Nopth dook coxnor (near oolume (108).

HEPA I11tex outlet elbow damper duot conarotion position to dook manifold to be 22 incher IAAT of lilter centerilne. 


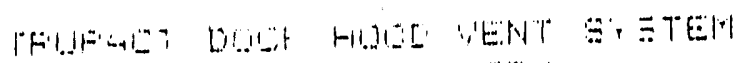

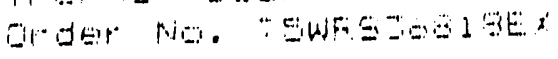

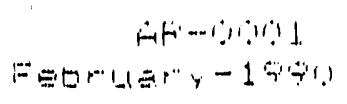

ATTACHMENT A

Trane Air Conditioning Manblal

FISYCHFIOMETFIC CHART 


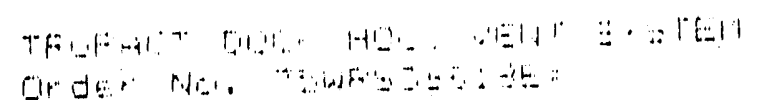

$\therefore F-B(1) 1$

FEt

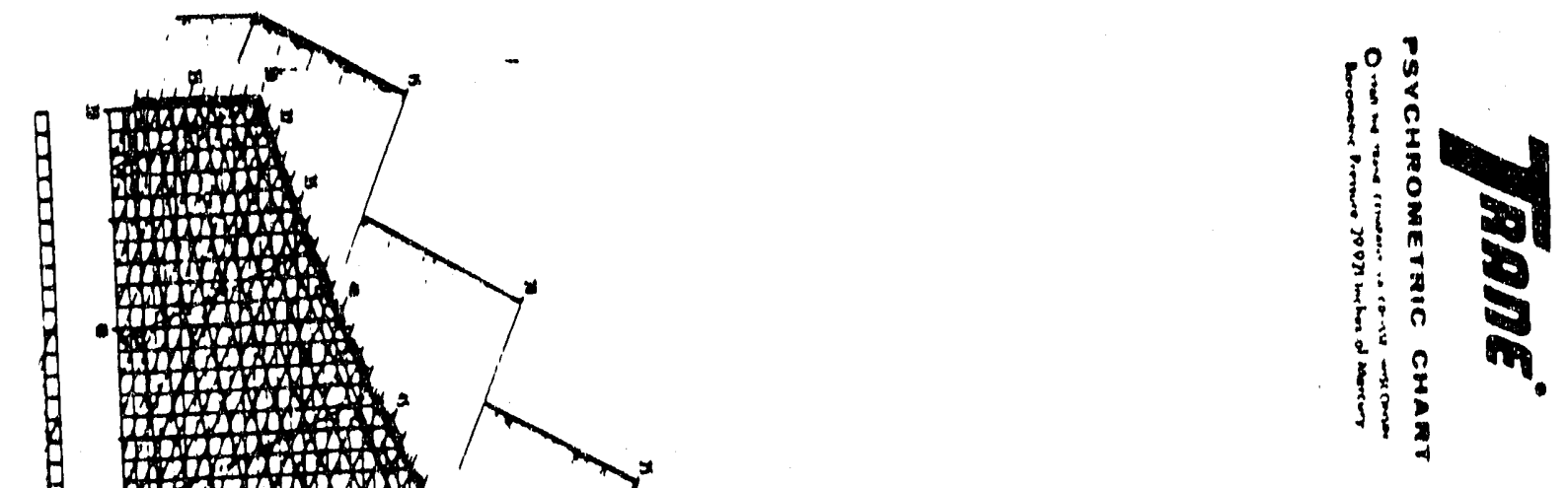

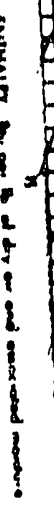
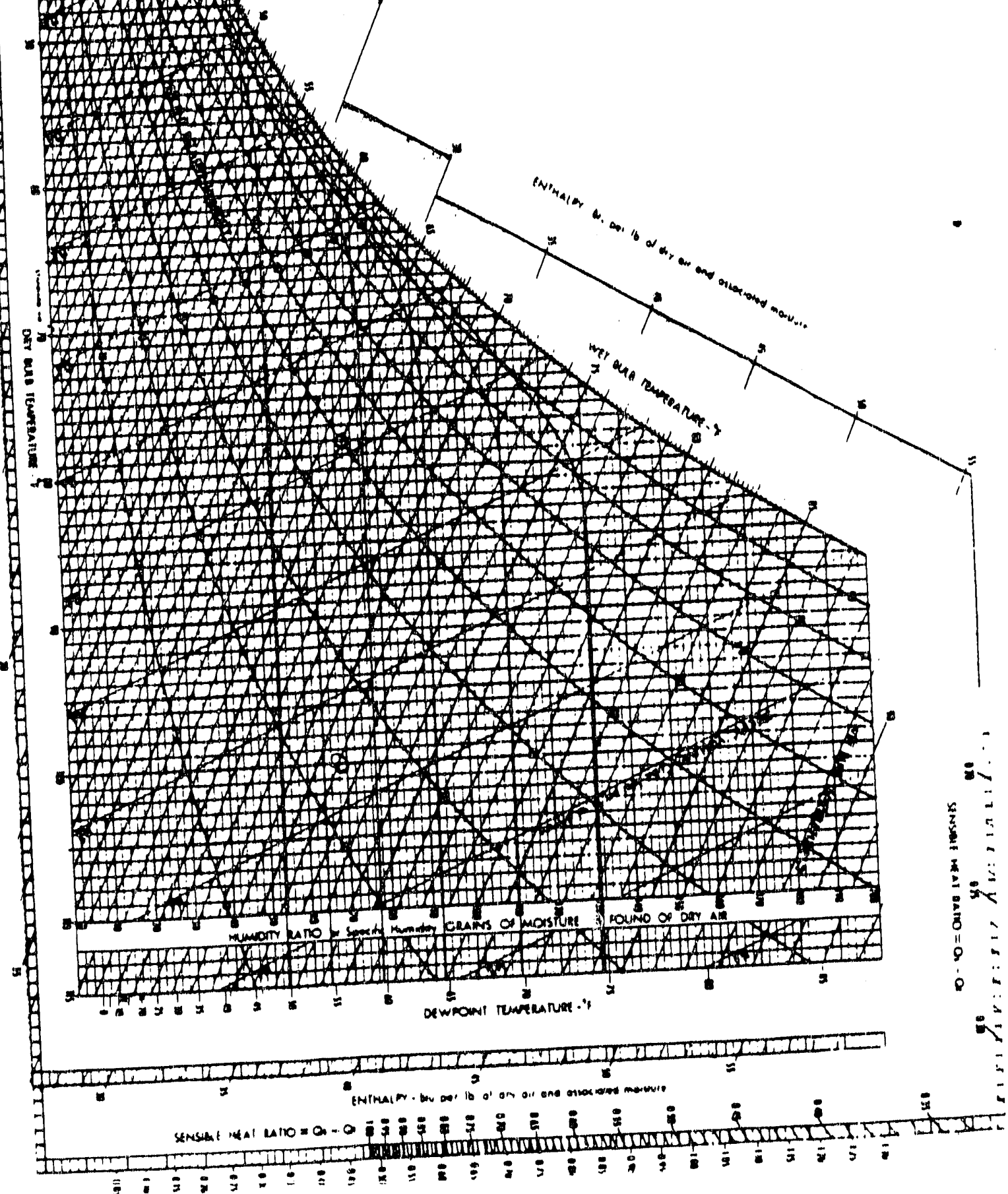


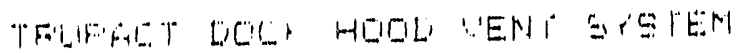

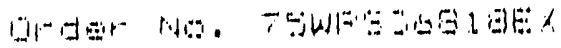

Fif $5-1119: 1$

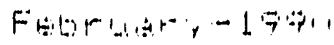

\title{
ATTACHMENT E
}

\author{
ASHFAE Handbool: \\ 1981 Fundamentals \\ FIG. C-E Friction Chart \\ Correction Factors for \\ Elevation and Temperature \\ (F'age 3.48)
}




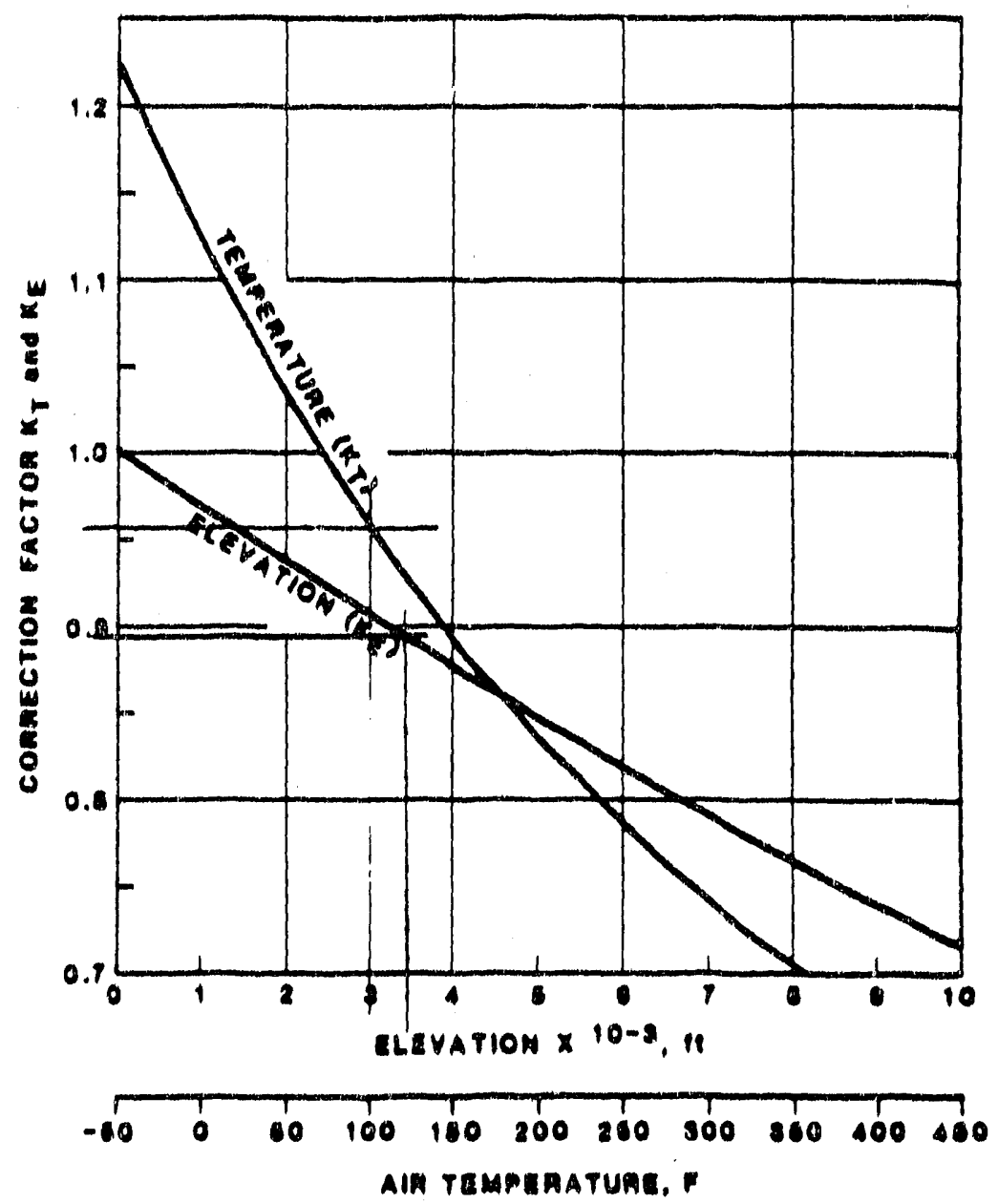

Fig. C.5 Friction Chart Correction Factors for Elevation and Temperature 


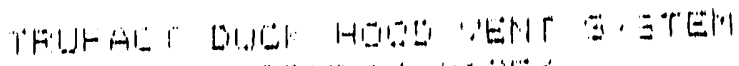

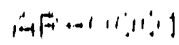

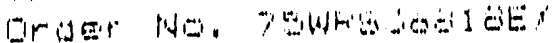

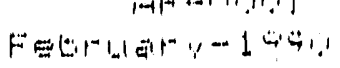

ATTACHMENT C

ASHFAE Handuook:

1961 Fundamentals

Correction Factors

(Fage 3.6.6) 
$m(100(t)$, which is oquivalent 10 an absolule roughness factor of $0.15 \mathrm{~m}(0,000 \mathrm{~s}(3)$.

Change is beromerric pressure, cemperaturo, and ab. soluted relauve humidliy ohanee boih the densily and viscosity of ar, and hence the Reynalds number. No corrections to the Firction Char are needed for: (1) duct maserials with an averase roughriess facturi (2) temperature vatiations in the averase roughros $20 \mathrm{~F}$ (rom $20^{\circ} \mathrm{C}(70 \mathrm{~F})$ and $(3)$ the usual order of $\pm 11^{\circ} \mathrm{C}( \pm 20$ n) exculate au through low pressure duet systems.

\section{CORRECTION FACTORS}

For duct matortals other than those indleried as having an por duct mase of pouchness in Table 2, and for significant

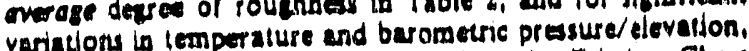
correction lactors should be applied to the Friction Char values as:

$$
\Delta P_{n, c}=K_{N} \Delta P_{p a d}
$$

where

10p of fiction low in lerms of towal ptesure al actual conditions.

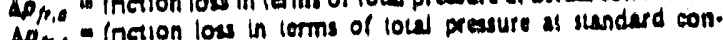

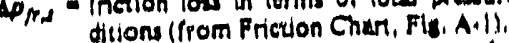

$X$ - Inetion chart correction fector for densuly and/or necosicy, dimensionleas.

$K_{M}$ - Iricuon chan correction lactor for duct roughnass, dimensiondeas.

For correcion of material roughneess, un Fis. 3. The seneric clasuifleacloos (smooth, medium smooth, average, medium pough, rough) in Fis. 3 are the same poughness calezories as it routh, rouph. provides an additional correction factor for Table 2. Fis. provides an insulled in the fully extended position.

For corrections of $(\theta)$ density, and viscosity $(\mu)$ use the rollowing relacionship. ${ }^{\circ}$

$$
K=\left(Q_{0} / Q_{2}\right)^{0.00}\left(\mu_{2} / \mu_{0}\right)^{0.10}
$$

Where the subseript a refers to actual conditions and the subscripl s fefers 10 standurd condicions. It is sugested that friction chars be developed usins Eqs 21 and 23 for duce materials; and or nuid densities and viscositica frequentry
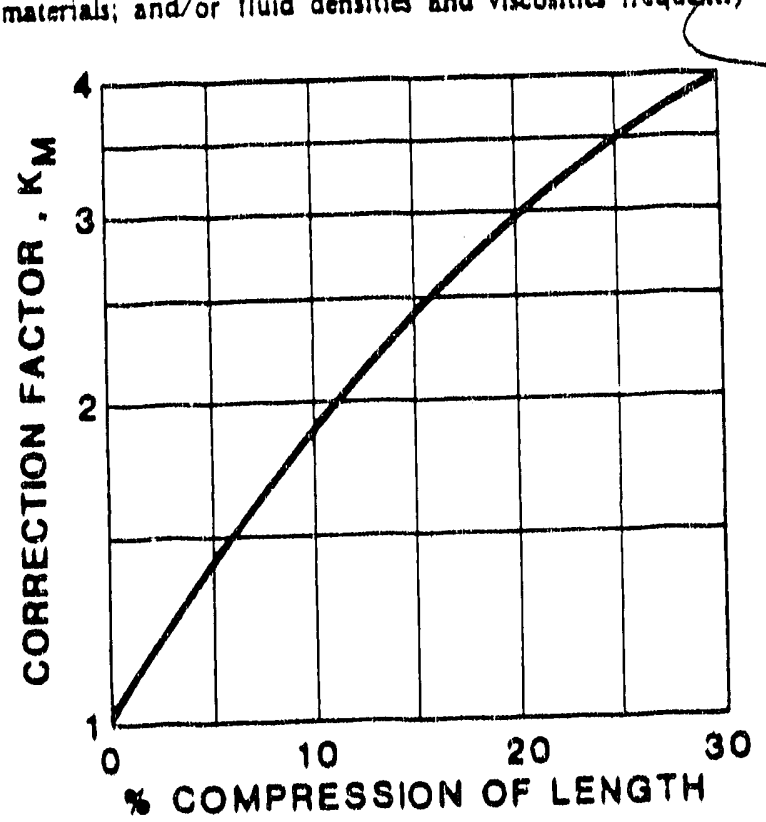

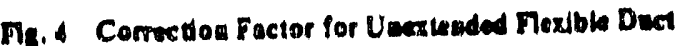

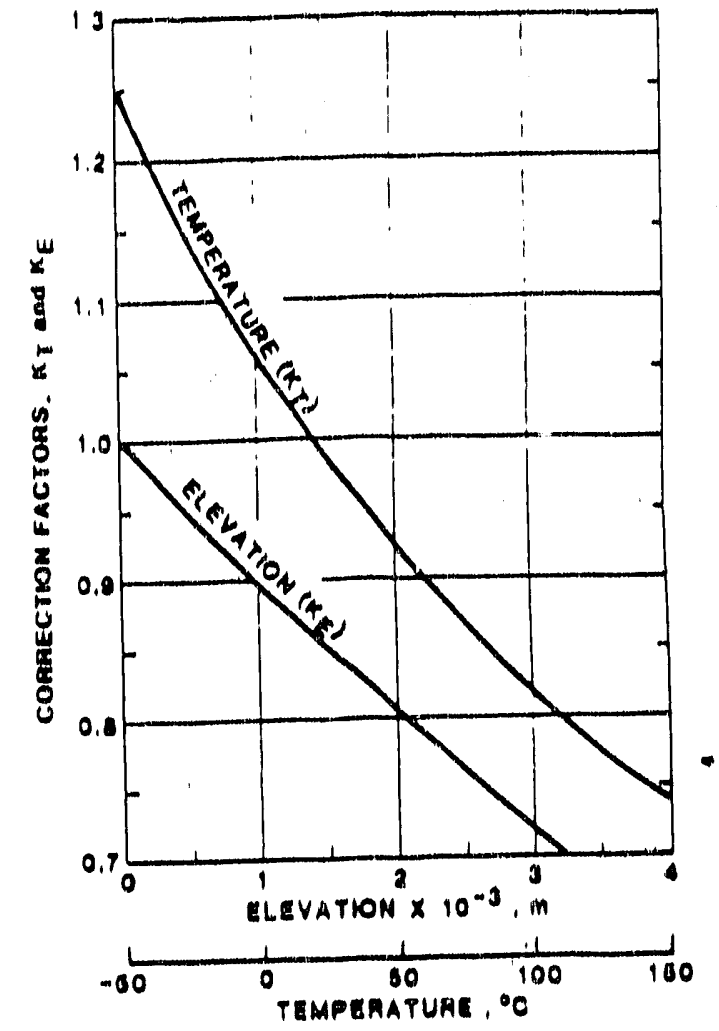

Dis. 5 Prietlos Char Comedion Fectors for Dervadon and Tomperatare

used. Ref 4 presents the compunes alnorithins necessary 10 senerate a frictionitsuncr.

Fhe yiscosity of air is ensentially a function of tempermuche while density depends on both cempesuture and baromertic pressure (elevation). Humidity effect is sufficiently small and an be neslecred. For Individual lemperature and elevacion correction famors, use Fis. 5 or Eqs $2{ }^{\circ}$ and 28 , since:

$x-k_{1} k_{-}$ (26)

where

$K_{r}=$ Iriction charl correction factor for lemper ulure, dimension. less.

$K_{E}$ - friction chan correction factor for elevation, dimensiondeus.

Temperature correction factor:

$$
K_{r}=\left[\frac{c f}{T_{1}+\sigma_{1}}\right]^{0.00 s}
$$

where

$r$ - actual lemperaluse of air, ${ }^{\circ} \mathrm{C}$ (F).

of - conversion factor, 293 ( 330$)$

$d_{1}$ - conversion factor, 273 (460).

Barometric pressura (elevation) correction factor:

$$
K_{x}=(8 / c)^{2.9}
$$

whers

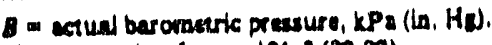
of = osaveridoa foctor, 101.3 (20,98).

If the berometrle pressure for a sporallic elevaciod is nor known, It may be exdinated by Eq 29, 9 


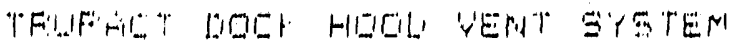

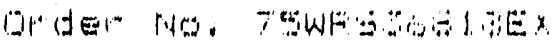

$\dot{A} F-1111.11$

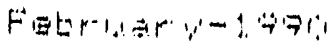

ATTACHMENT D

ASHFAE Handbook:

1984 Systems

Table 1

Fiange of Capture Velocitieg

(Fige 20.2 ) 


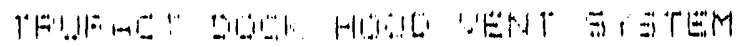

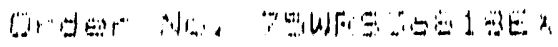

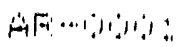

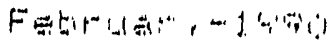

20.2

CHAPTER 20

1984 Systems Handbook

Table 1 Range of Capiure Velocities.

Cinndilion o) C'oniaminani Dispersion

Released wilh assenliall nu erivills inlo still allt

Released al lon relocill inlo mouser Jiels still air

fuilie generalion inio sune ul ramid dir molion

Released al high relacill inlo colle ol

verserapid alt molion

Eramples

Esadoralion Irom lanks, Jegreasing. plaling

Cunlabluer lilling, low ineed conseyor Iranslers, llelding

Barrel tilling, w hule loading of

convevors, crushing. wol shakeour Grinding. abrasive blasting. Iumbiling.
hol shaheoui
Caplure icioniroli lelocils

\begin{tabular}{|c|c|}
\hline Ipm & $m$ \\
\hline 1010100 & $11: 1011$. \\
\hline 10010200 & $11: 101 \mathrm{v}$ \\
\hline 50010500 & 11102.5 \\
\hline 00102000 & $\therefore \therefore 10100$ \\
\hline
\end{tabular}

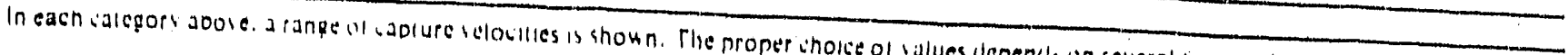

\section{Lumer tind ol Kange}

I Room air currenis or Iarorable lo ianeure.

L'pper tind of Range

j. Coniaminanis ol low lovisils in ol nilisance salue only.

$\$$ Large hood.large dir mass in molion.

1. Distrubing room air currenis.

2. Contaminancs ol figh tovicils.

3. High production, heavi use.

1. Small hood-local conirol only.

nant. Hood performance $11 . e$, how well it controls the con-

Laminani) should be checked by an indusirial hyglenist.

\section{Copture Velocities}

Enough air per unit ume must be exhausted through a hood to establish an air velocity (called capture velocity) at or be. yond the point of contaminant release strong enough 10 carry the contaminant with it into the hood. Capture velocities for a range of values for ach situation. These velocities have air currenes, the con the size of the air mass in motion. value for the capture velocity. Each sife, there is no single separately. 


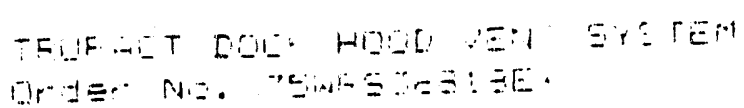

.F......... 1

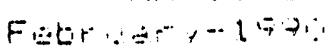

ATTACHMENT E

ASHFAE Handbook

1984 Systems

Duct Considerations

(Fagle 20.5)

Table 2

Contaminant Transport Velocities

(Fage 20.6) 


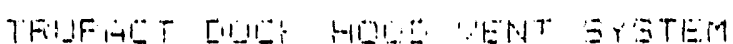

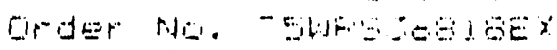

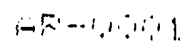

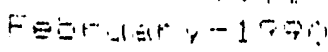

\section{Industrial Exhaust Systems}

overhang equal to $40 \%$ of the distance from the hot process 10 the hood face on all sides. "The hood now rate can be in. creased by using:

$$
Q_{T}=Q_{0}+V_{i}\left(A_{t}-A_{0}\right) c f
$$

where

$Q_{T}=$ !olal now raie entering hood. cim (L.; S)

$Q_{0}=$ ine llow rale delermined by Eq. (8) or 1121

$V_{1}=$ ine desired indrall velocity through the perimeter area. ipm $(\mathrm{m} / \mathrm{s})$

$A_{f}=$ nood face area. $11^{2}\left(\mathrm{~m}^{2}\right)$

$A_{p}=$ plan view area of EQ. (8) or (12) as discussed above

$\left.c^{f}=111000\right)$

A minimum indraft velocity of $100 \mathrm{fpm}(0.5 \mathrm{~m} / \mathrm{s})$ should be used for most design cenditions. However, when room air currents are appreciable or if the concaminant discharge rate is high and the design exposure limit is low, higher values of $V$, might be required.

Sutton't reported that the volumetric flow rate for a high canopy hood (more than $10 \mathrm{ft}(3 \mathrm{~m})$ above the process) can be predicted empirically from round, square or nearly square sources by

$$
Q:=c f Z^{\prime \prime 2} q^{1, s}
$$

\section{where}

$Q_{i}=$ olumetric llow rale al any elevalion $Z . \operatorname{cim}(L / s)$

$Z=$ ierlical distance isee Fig. $71,111 \mathrm{~m}$ )

cf $=: \$ 18.01$

$Z$ can be obtained from:

$$
Z=Y+2 B
$$

\section{where}

$Y=d$ istance from the hor process 10 the hood face isee $F$ $f(m)$

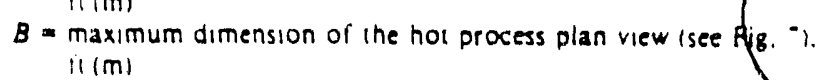
At 2 . the rising air stream will be nearly round, with diameter determined by

$$
D:=c f Z^{011}
$$

where

$D_{:}=$llow diameler at any clevalion $Z$ above the appareni noint cuurce. $11(\mathrm{~m})$

$$
c f=0.5(0.43)
$$

High canopy hoods are extremely susceptible to room aif currents. Therefore, they are typically much larger loiten (wice as large) (than indicaled by Eq. (16) and are used only if :he low canopy hood cannol be uned. The lolal how rale ex. hausted from the hood should be evaluated using Eq. (13) if $Q_{0}$ is replaced by $Q$ :

\section{Special Situations}

Some operaltons may reouirc ahaust volumes different irom the quantilies generated by the above equations. Typical reasons for different flow races include:

1 Inducied arr irrents are created whenever anvihing is projecled inio an alr space. For example, high sperd rolaling machines such as culverizers, high speed belt malerial iransier systems. Ialing granular macerials, and escaping compressec air trom pneumalic 1001 all pro. Juce alr currenis. The size and direcion of the air llow should be con. sidered in hood design.

$\therefore$ Exhaust volumes that are insulficient 10 dilute combusible apor-air inixiures 10 less chan about $25 \%$ of the lower explosive limit of the vapor. is

?. Room air currents caused bv cross drafis, compensaling air. spor cuoling or molion of the machinery or operators. This is expeciallv ignilicant when designing high canopy hoods tor hol process exhaust.

\section{DUCT CONSIDERATIONS}

The second component of a local exhaust venulation system is the duct through which contaminated ait is transported from the hood(s). Round ducts are preferred because they (1) offer a more uniform air velocity to resist settling of material and (2) can withstand the higher static pressures normally found in exhaust systems. When design limitacons require rec. langular tocts the aspect ratro thaight 10 widith ratio) should (15) te as close to unity as possible.

Minimum transport velocity is that velocity required to transport particulate without settling. Table 2 lists some generally accepted transport velocities as a function of the nature of the contaminant.16 The values listed are iypically higher than theoretical and experimental values to account for: (1) damage to ducts, which would increase system resistance and reduce volume and duct velocily, (2) duct leakage. which temdadecr ase velocity in the duct system upstream of be leak. (3) fan Tettorros stipage. which could i'. 'uce fan volume and ( 4 ) re-encrainment of sel. lled particulatl caused by improper operation of the exhaust jysters. Design velocities can be higher than the minimum iran'sport velocities but should never be significantly lower.

Scandard duct sizes and fittings should be used for economis and delivery time reasons. Information on available sizes and the cost impact of non-standard sizes should be obtained from the contractor(s). 


\begin{tabular}{|c|c|c|c|}
\hline \multirow[b]{2}{*}{ Valure of Contaminani } & \multirow[b]{2}{*}{ Examples } & \multicolumn{2}{|c|}{ Minimum Transport lelocil } \\
\hline & & Lpm & m/s \\
\hline Vapors. gases. smohe & tll rapors. gases and smokes & $\operatorname{tnv}$ & $\ln x$ \\
\hline Fumes & Zinc and aluminum oxide fumes & $1+0010: 000$ & $\cdot 1010$ \\
\hline lerv line light dust & Collon lint, wood llour. litho powder & $: 000102500$ & 101013 \\
\hline Dry dusis and powders & $\begin{array}{l}\text { Fine rubber dust, Bakellie molding powder dust, Jule } \\
\text { lint, collon dust, shavings llightl, soap dust, leaither } \\
\text { shavings }\end{array}$ & $: 500103500$ & 131018 \\
\hline Average industrial dust & 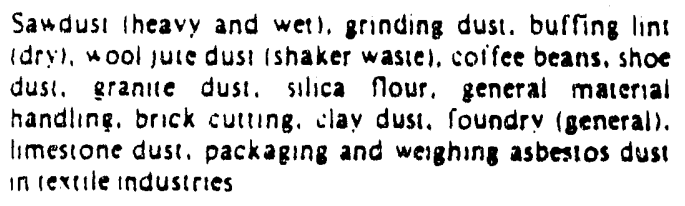 & 3900104000 & 181020 \\
\hline Heavy dusis & $\begin{array}{l}\text { Metal turnings, foundry lumbling barrels and } \\
\text { shakeoul. sand blast dust. wood blocks. hog waste. } \\
\text { brass iurnings, cast iron boring dust, lead dust }\end{array}$ & $\$ 000104500$ & .01023 \\
\hline Heavy or moist dusts & $\begin{array}{l}\text { Lead dust with small chips, moisi cement dust, } \\
\text { asbestos chunks from transice pipe cuttuns machines. } \\
\text { buifing lini (slicky). guick.lime dusi }\end{array}$ & 4500 and up & IJ and up \\
\hline
\end{tabular}




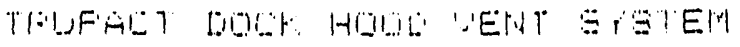

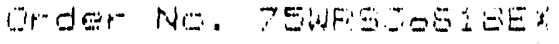

$A F-\theta 101$

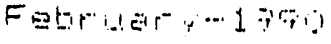

\section{ATTACHMENT $F$}

Trane Air Conditioning Manual

Table $9-3$

Fiecommended \& Maximum Duct Velocities for Conventional Systems 


\section{Table 9-3}

\section{Recommended And Maximum Duct} Velocities For Conventional Systems

\begin{tabular}{|c|c|c|c|}
\hline \multirow[b]{2}{*}{ OESIGNATION } & \multicolumn{3}{|c|}{ AECOMMENDED VELOCITIES, FPM } \\
\hline & RESIDENCES & \begin{tabular}{|} 
SCHOOLS. \\
THEATERS. \\
PUELIC \\
BUILDINGS
\end{tabular} & $\begin{array}{l}\text { INDUSTAIAL } \\
\text { BUILDINGS }\end{array}$ \\
\hline $\begin{array}{l}\text { OUTOOOA AIR INTAKES' } \\
\text { FILTERS' } \\
\text { HEATING COILS } 1,2 \\
\text { COOLING COILS' }\end{array}$ & $\begin{array}{l}500 \\
250 \\
450 \\
450\end{array}$ & $\begin{array}{l}500 \\
300 \\
500 \\
500\end{array}$ & $\begin{array}{l}500 \\
350 \\
600 \\
600\end{array}$ \\
\hline $\begin{array}{l}\text { AIR WASHERS' } \\
\text { FAN OUTLETS }\end{array}$ & $\begin{array}{c}500 \\
1000-1600\end{array}$ & $\mid \begin{array}{c}500 \\
1300 \cdot 2000\end{array}$ & $\begin{array}{c}500 \\
1600-2400\end{array}$ \\
\hline \multirow[t]{2}{*}{$\begin{array}{l}\text { MAIN OUCTS } \\
\text { ORANCH OUCTS } \\
\text { GRANCH RISERS }\end{array}$} & $\begin{array}{c}700-900 \\
600 \\
500\end{array}$ & $\left|\begin{array}{c}1000 \cdot 1300 \\
600 \cdot 900 \\
600 \cdot 700\end{array}\right|$ & $\begin{array}{c}1200 \cdot 1800 \\
800 \cdot 1000 \\
000\end{array}$ \\
\hline & \multicolumn{3}{|c|}{ MAXIMUM VELOCITIES, FPM } \\
\hline $\begin{array}{l}\text { OUTDOOR AIR INTAKES' } \\
\text { FILTERS' } \\
\text { MEATING COILS', } \\
\text { COOLING COILA' }\end{array}$ & $\begin{array}{l}800 \\
300 \\
500 \\
450\end{array}$ & $\begin{array}{l}900 \\
350 \\
600 \\
500\end{array}$ & $\begin{array}{r}1200 \\
350 \\
700 \\
600\end{array}$ \\
\hline $\begin{array}{l}\text { AIA WASHERS' } \\
\text { FAN OUTLETS }\end{array}$ & $\begin{array}{r}500 \\
1700\end{array}$ & $\begin{array}{c}500 \\
1500-2200\end{array}$ & $\begin{array}{c}500 \\
1700-2800\end{array}$ \\
\hline $\begin{array}{l}\text { MAIN DUCTS } \\
\text { DAAMCH DUCTS } \\
\text { DAANCH AISERS }\end{array}$ & $\begin{array}{l}800 \cdot 1200 \\
700.1000 \\
650.800\end{array}$ & $\left|\begin{array}{r}1100-1600 \\
800-1300 \\
800-1200\end{array}\right|$ & $\begin{array}{l}1300-2200 \\
1000-1800 \\
1000-1600\end{array}$ \\
\hline
\end{tabular}

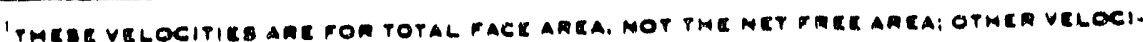

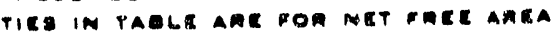

'pon Low relocity gretems onLY.

Reprinted with permission from 1965 ASHRAE Guide And Data Book 
ATTACHMENT G

The Flexaust Company

TC 860-2.5

Flexaust Hose Friction Loss Data 


\section{FLEXAUST HOSE FRICTION LOSS DATA}

In the destan of most dust collection, air conditioning, industrial ventilation and fume removal systems, air flow caiculations are an integral part of the planning for high efficiency operation. This information is provided as a general guide to the friction loss values for all Flexaust hose types.

The air flow through flexible ducting is dependent upon its diameter. length, interior wall surtace condition and contiguration. When straight lengths of Flexaust hose are used, resistance values may be obtained from Chart 1

EXAMPLE 1 - STRAIGHT RUNS

Q. What is the resistance in inches, w. g. of a $25 \mathrm{H}$. straight length of 4 in. ID Flexaust hose with air velocity $2500 \mathrm{fpm}$ ?

A. Value obtained directly from Chart 9 is 1.00 ins. w. g. tor $100 \mathrm{ft}$. For $25 \mathrm{Ht}$. the resistance would be $1.0 \mathrm{ins}$. w. g.

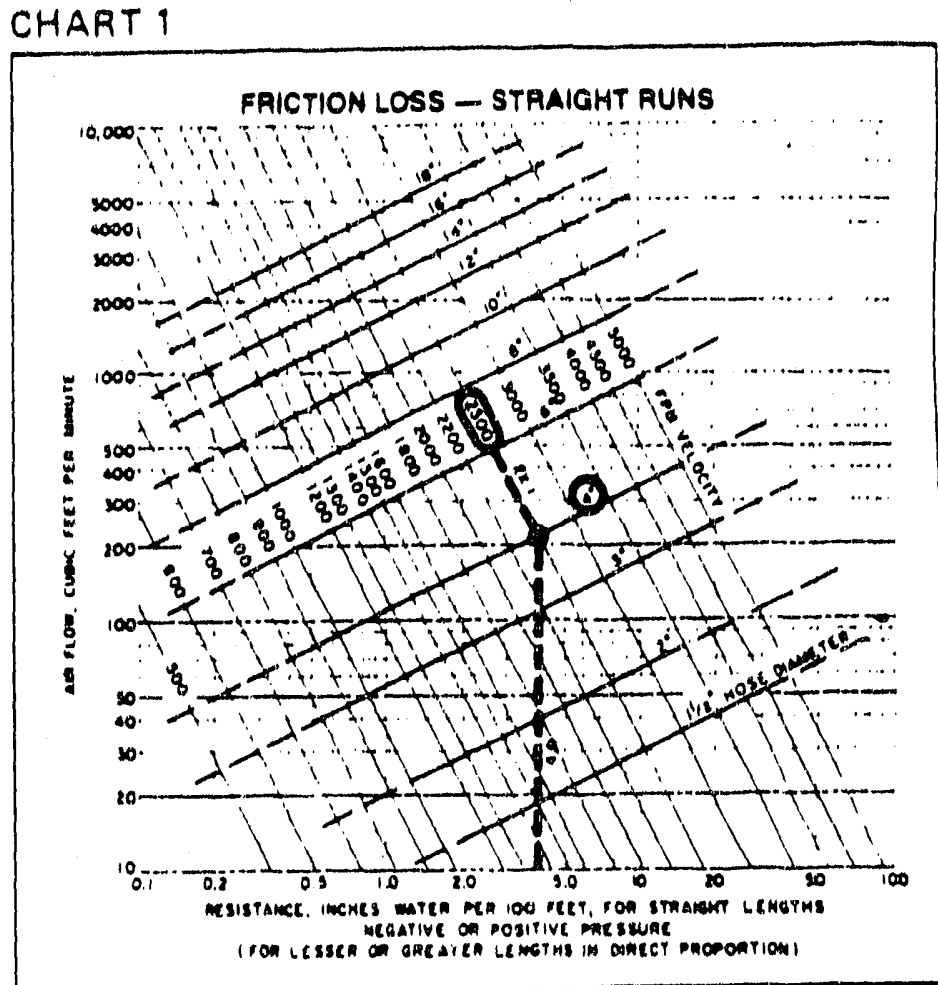

When the hose length cited in Example 1 includes a bend, its resistance is increased. This increase is calculated as equivalent added length to the actual straight length of hose, and is shown on Chart 2 as a number of equivalent diameters. These are converted to length in feet, for which the appropriate resistance value is then obtained from Chart 1 .

EXAMPLE 2 - BENOS

Q. What is the resistance in inches, w. g., for same hose as in Example 1, same velocity, but having in its length a $90^{\circ}$ elbow with centerline bending radius of two hose diameters (8 ins.)?

A. (1) Value from Chart $2=7.5$ diameters

(2) $7.5 \times 4$ ins. $=2.5 \mathrm{H}$

(3) Value for $2.5 \mathrm{ft}$. (Chart 1) $=0.10$ ins. w. $g$.

(4) Resistance of straight hose plus resistance of elbow 1.0 plus 0.10 is total resistance factor $=1.10$ ins. w. 9 .

An alternate procedure is as follows:

(5) Add 2.5 to $25=27.5 \mathrm{ft}$.

Using value trom Chart 1 as above the resistance is $\frac{27.5}{100} \times 4=1.10$ ins. $w . g$.

\section{CHART 2}

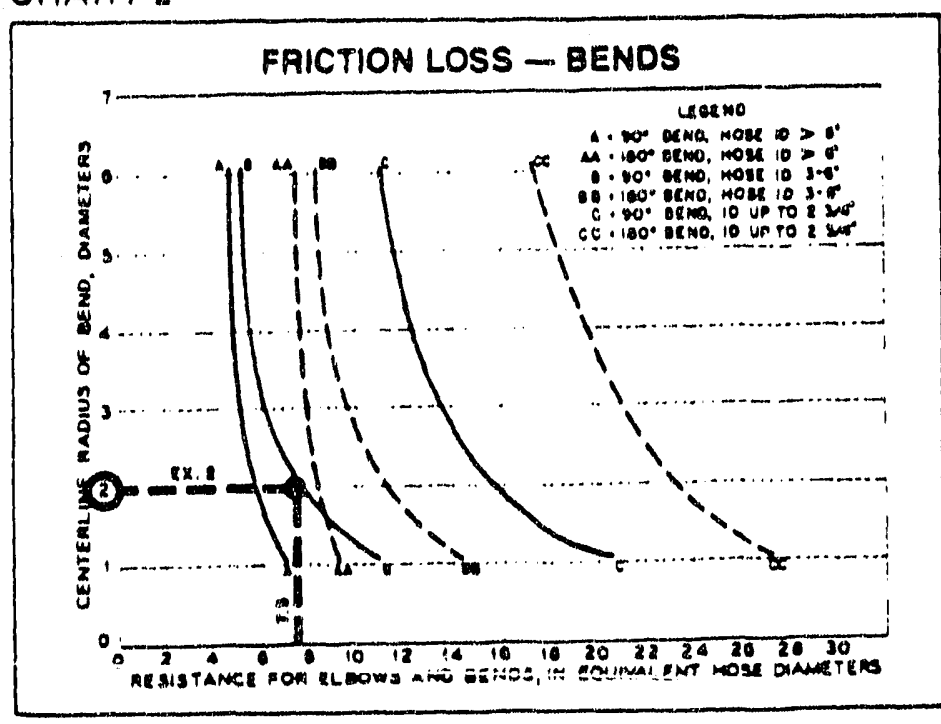




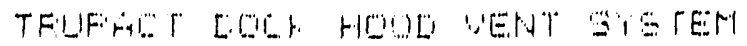

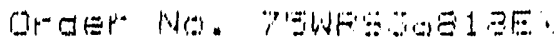

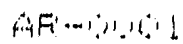

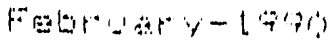

ATTACHMENT H

Cambridge Filter Corporation

Eulletin 12-104A

Cambridge Absolute Filter

Capacity vs Fressume Drop 


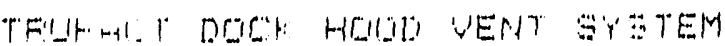

Or-

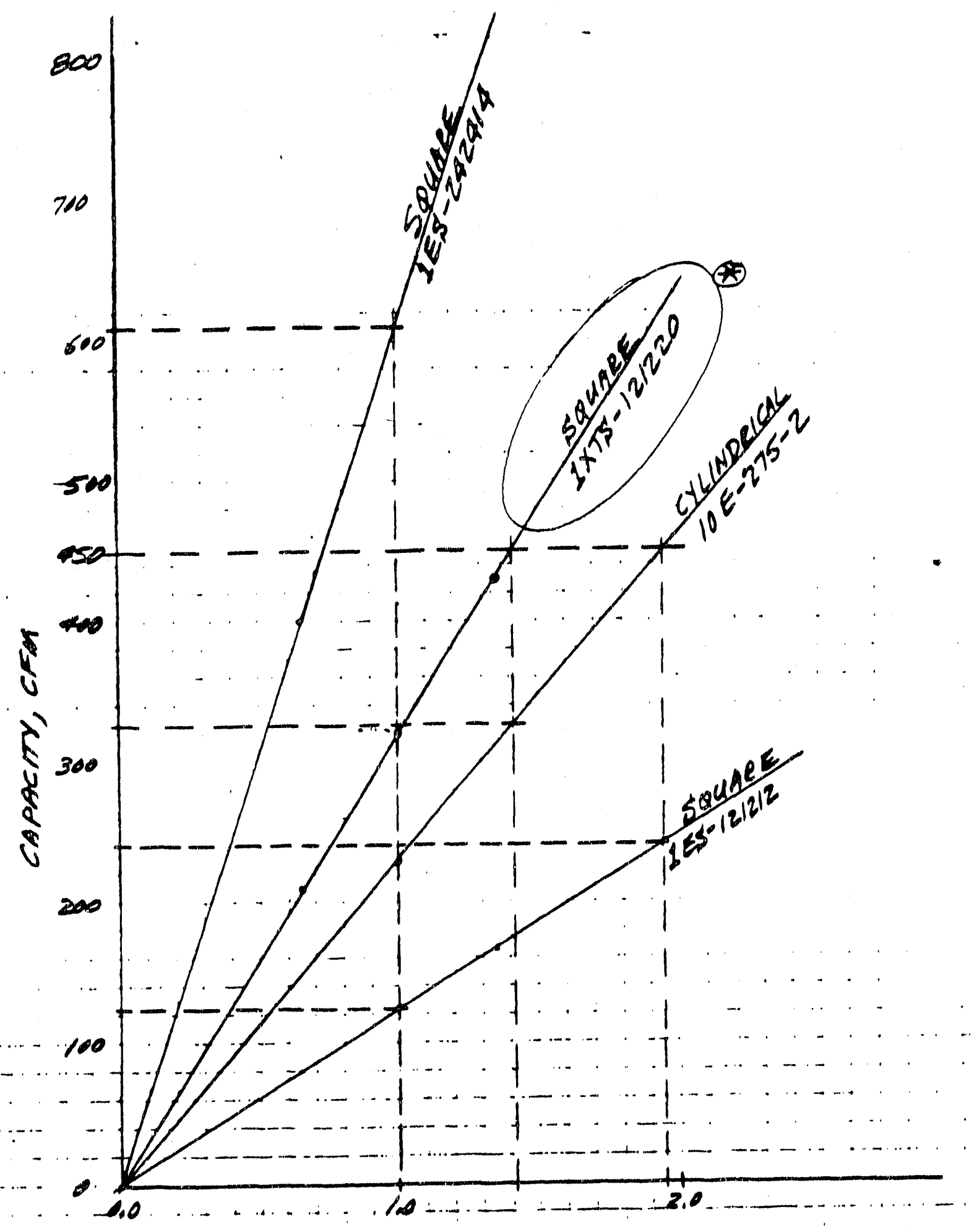

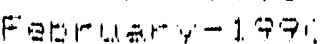


TFI!H

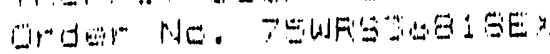

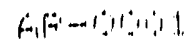

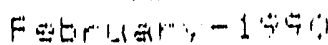

\title{
ATTACHMENT I
}

\begin{abstract}
ASHF'AE Handuook: 1981 Fundamentals
\end{abstract}

\author{
FIG. C-1 Friction Chart \\ For Average Ducts \\ ( $F$ age 33.44)
}




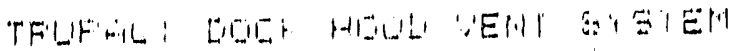

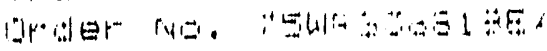

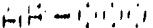

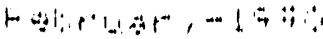

33.4

CHAPTER 33

1981 Fuadameatals Handbook

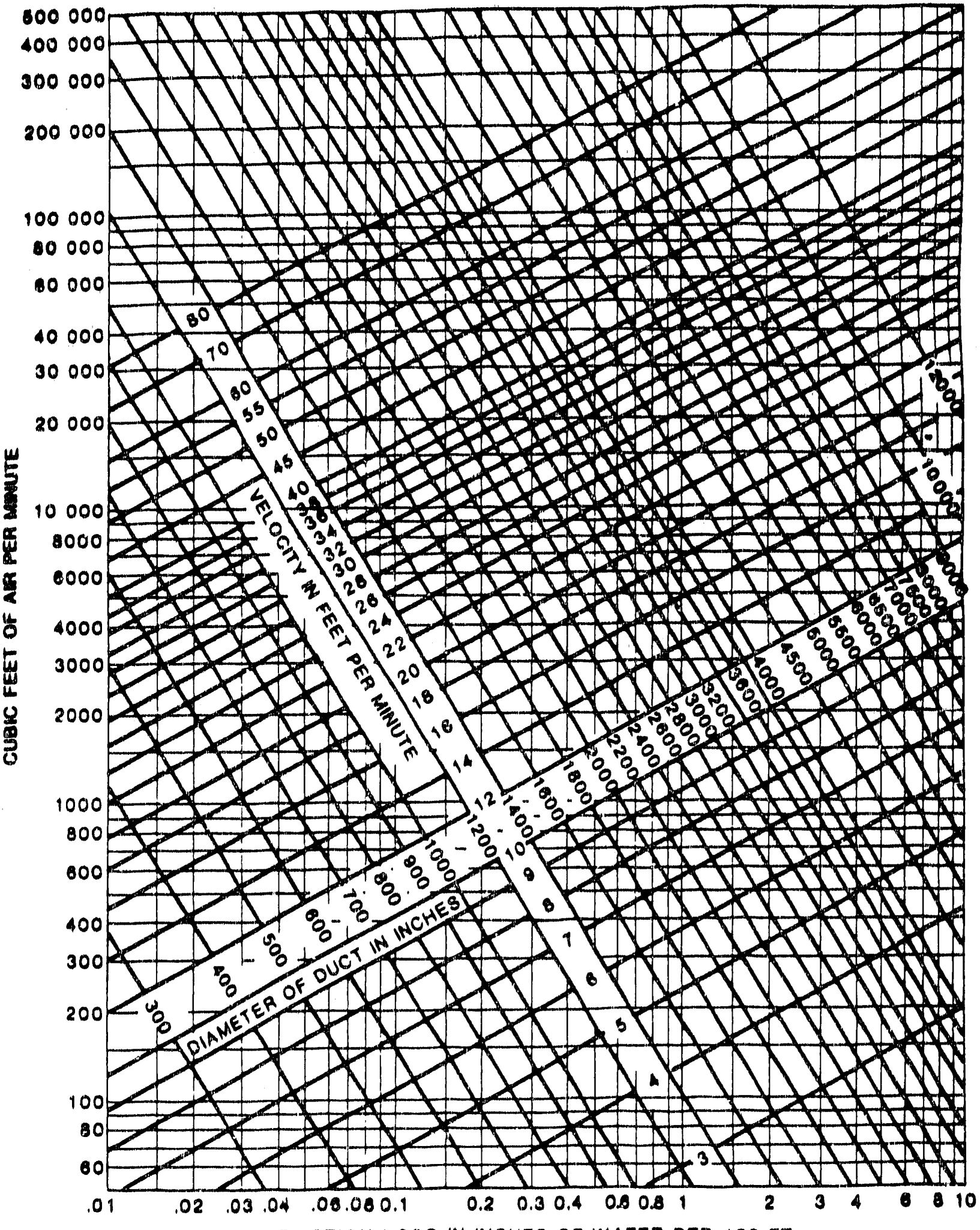

FRICTION LOSS IN INCHES OF WATER PEA 100 FT

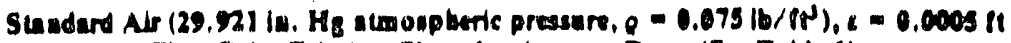

Th. C.A Frictoon Chan for A veraze Ducts (Sen Table 1) 


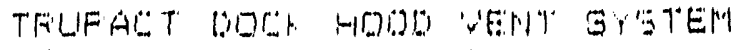

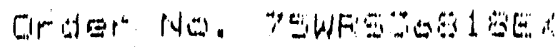

मिंfi-rind

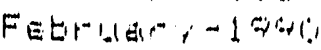

\section{ATTACHMENT J}

ASHFAE Handbook.

1901 Fundamentals

FIG. C-9 Suggested Velocity and Friction Rate Design Limits 


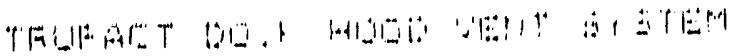

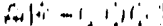

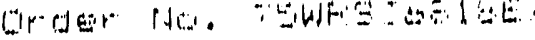

\section{Duct Dealen}

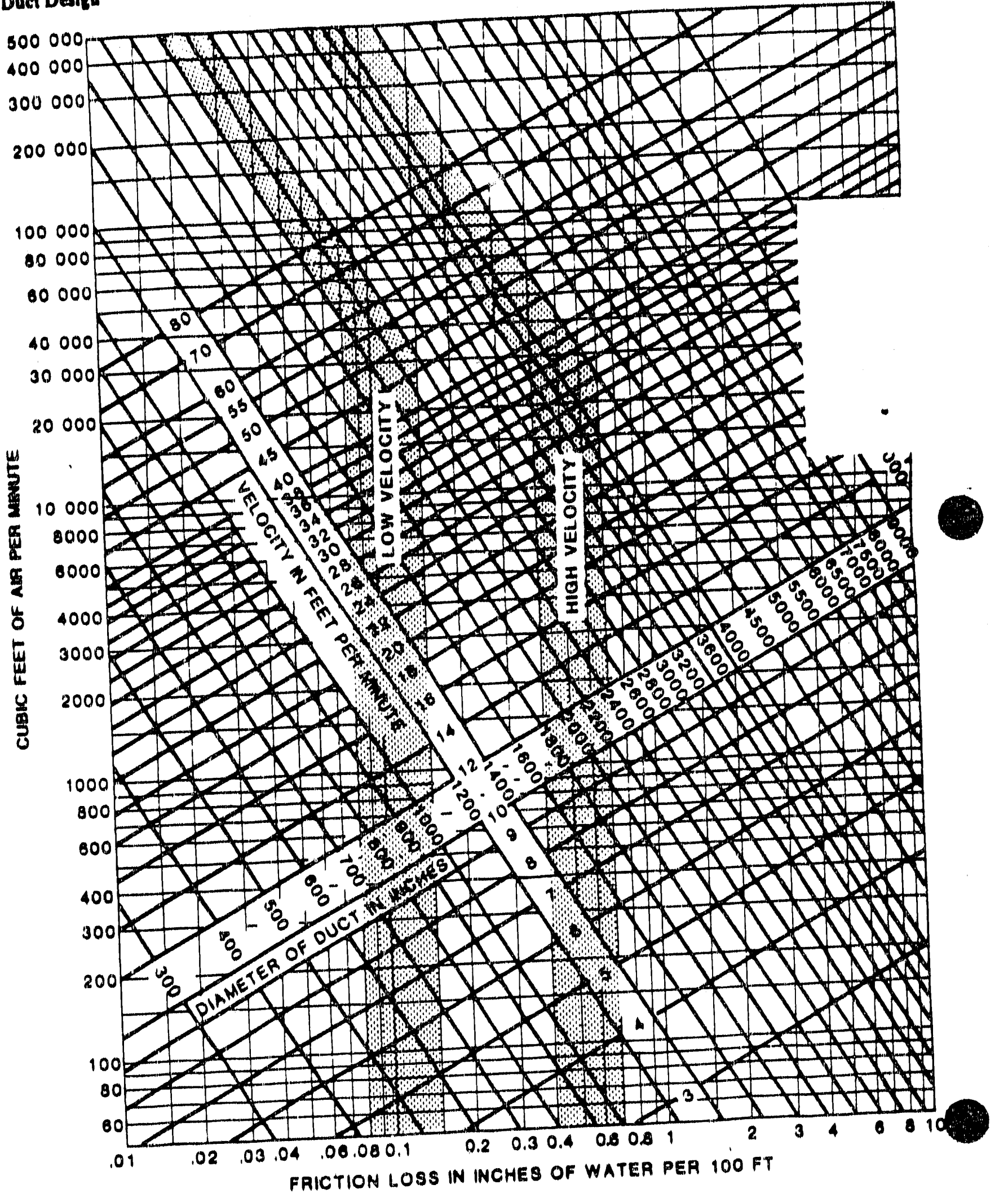

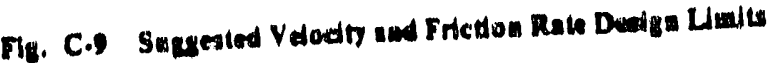




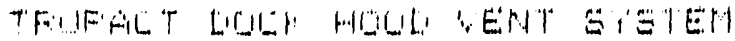

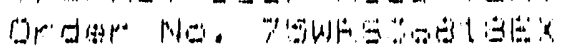

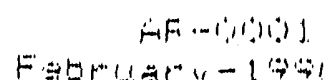

ATTACHMENT $K$.

Cincimnati Fan

Cat. No. A48B

Cincinnati Fan Model FG-10A

CFM and EHF vs Static Firessure Data 


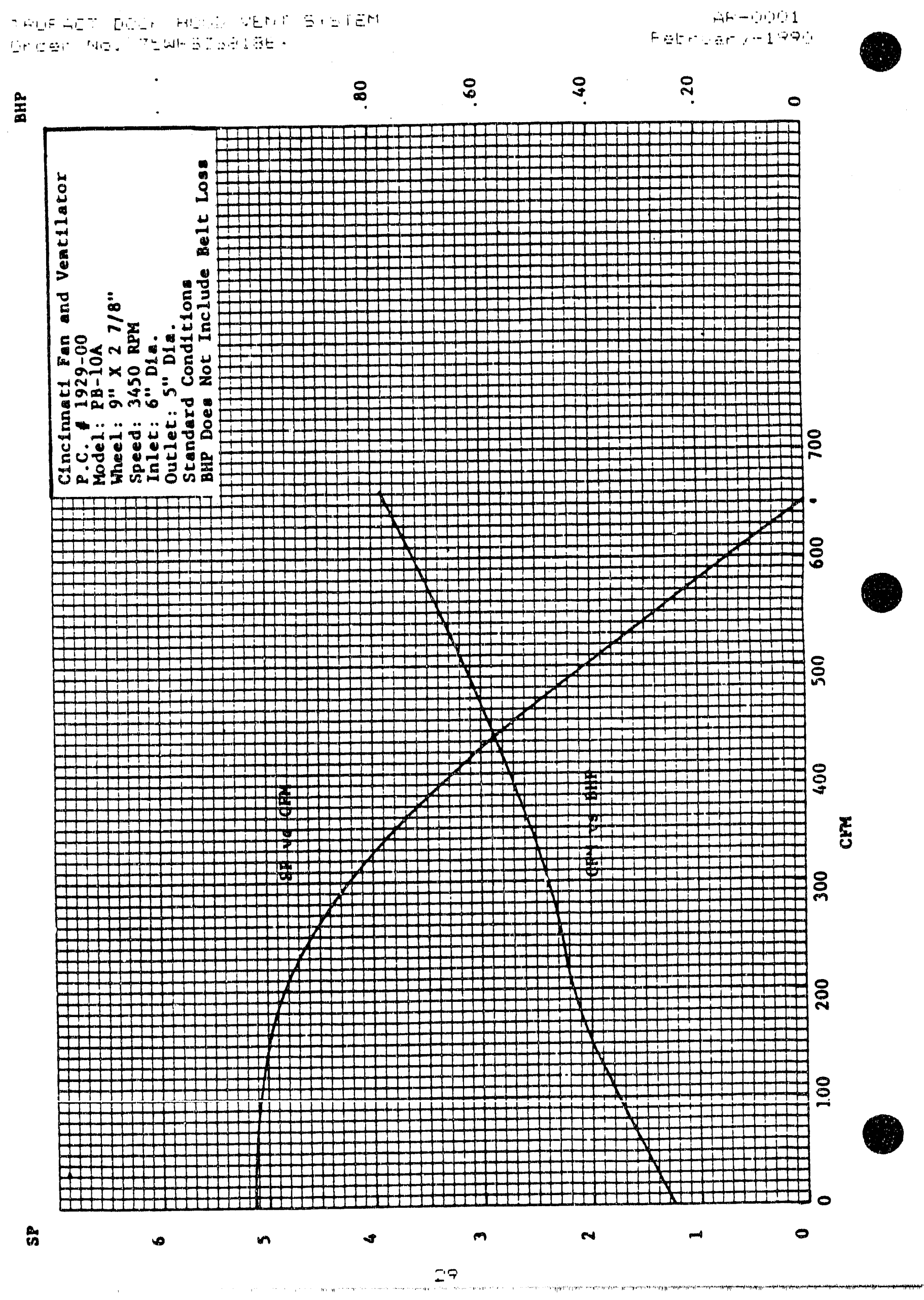




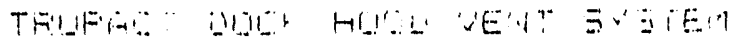

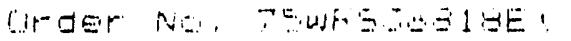

\section{PB SERIES DIRECT DRIVE RATING TABLES at 3450 RPM}

CFM and BMP at Static Pressure Shown

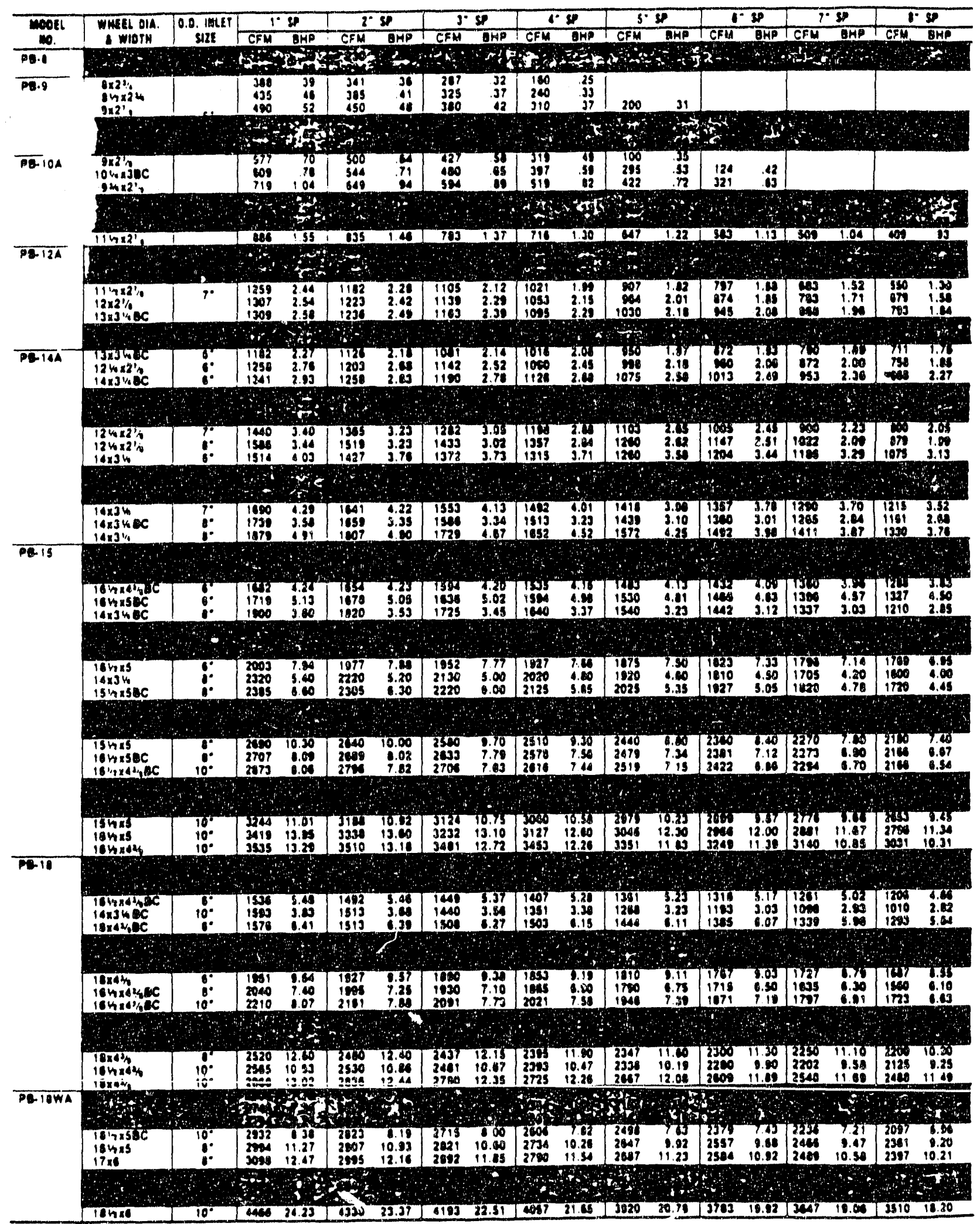

Ratings at $70^{\circ} \mathrm{F} ., .075$ Density, Sea Level

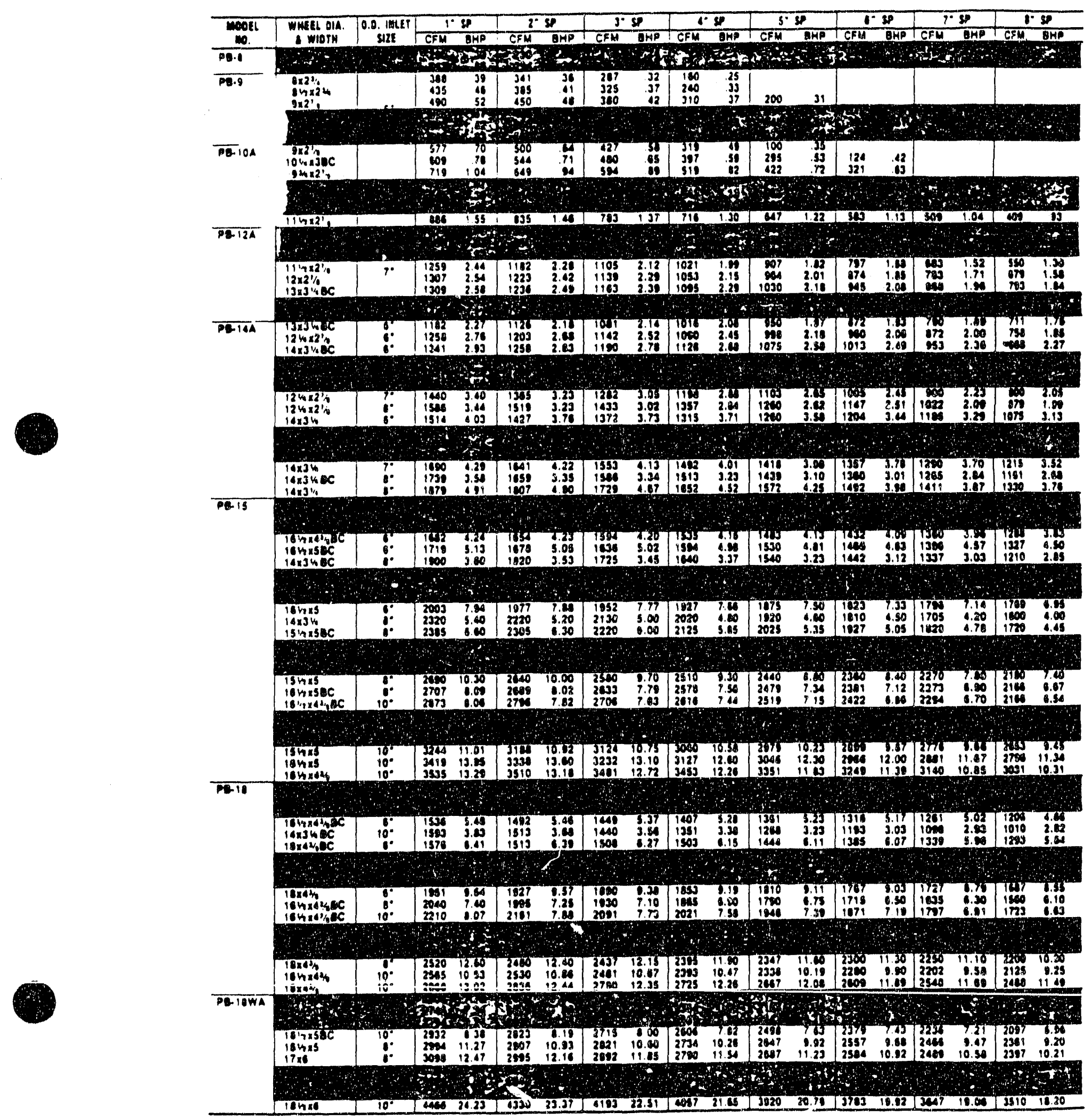




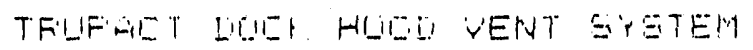

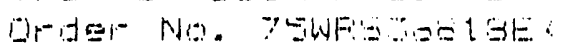

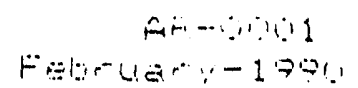

ATTACHMENT L

ASHFAE Handbook

1981 Fundamentals

Table $[-1$

Velocities vs Velocity fressures 


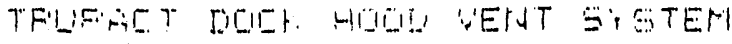

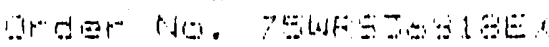

$A F F-1101$

$F=15+1,400$

Duct Design

Table C.1 Velocidea vs. Velocity Presures

\begin{tabular}{|c|c|c|c|c|c|c|c|c|c|}
\hline $\begin{array}{l}\text { Velocity, } \\
\text { fper }\end{array}$ & $\begin{array}{l}\text { Velocity } \\
\text { Presisare, } \\
\text { in. } \mathrm{H}_{2} \mathrm{O}\end{array}$ & $\begin{array}{c}\text { Velocity, } \\
\text { fpen }\end{array}$ & $\begin{array}{l}\text { Velocity } \\
\text { Presoure, } \\
\text { la. } \mathrm{H}_{2} \mathrm{O}\end{array}$ & $\begin{array}{c}\text { Vetodty, } \\
\text { pom }\end{array}$ & $\begin{array}{l}\text { Velodty } \\
\text { Prasure, } \\
\text { ia. } \mathrm{H}, \mathrm{O}\end{array}$ & $\begin{array}{l}\text { Velacity, } \\
\text { Ppm }\end{array}$ & $\begin{array}{l}\text { Velodty } \\
\text { Prasure, } \\
\text { la, } \mathbf{H}, \mathbf{O}\end{array}$ & $\begin{array}{c}\text { Veloctiy, } \\
\text { Ppar }\end{array}$ & \\
\hline $\begin{array}{l}300 \\
390 \\
400 \\
450 \\
500\end{array}$ & $\begin{array}{l}0.01 \\
0.01 \\
0.01 \\
0.01 \\
0.02\end{array}$ & $\begin{array}{l}2050 \\
2100 \\
2150 \\
2200 \\
2250\end{array}$ & $\begin{array}{l}0.26 \\
0.27 \\
0.29 \\
0.30 \\
0.32\end{array}$ & $\begin{array}{l}3800 \\
3850 \\
3900 \\
3950 \\
4000\end{array}$ & $\begin{array}{l}0.90 \\
0.92 \\
0.95 \\
0.97 \\
1.00\end{array}$ & $\begin{array}{l}3550 \\
5600 \\
5650 \\
5700 \\
5750\end{array}$ & $\begin{array}{l}1.92 \\
1.95 \\
1.99 \\
2.02 \\
2.05\end{array}$ & $\begin{array}{l}7300 \\
7350 \\
7400 \\
7450 \\
7500\end{array}$ & \\
\hline $\begin{array}{l}550 \\
600 \\
700 \\
700 \\
750\end{array}$ & $\begin{array}{l}0.02 \\
0.02 \\
0.03 \\
0.03 \\
0.04\end{array}$ & $\begin{array}{l}2300 \\
2350 \\
2400 \\
2450 \\
2500\end{array}$ & $\begin{array}{l}0.33 \\
0.34 \\
0.36 \\
0.37 \\
0.39\end{array}$ & $\begin{array}{l}4050 \\
4100 \\
4150 \\
4200 \\
4250\end{array}$ & $\begin{array}{l}1.02 \\
1.05 \\
1.07 \\
1.10 \\
1.13\end{array}$ & $\begin{array}{l}5800 \\
5850 \\
5900 \\
5950 \\
6000\end{array}$ & $\begin{array}{l}2.10 \\
2.13 \\
2.17 \\
2.21 \\
2.24\end{array}$ & $\begin{array}{l}7550 \\
7600 \\
7650 \\
7700 \\
7750\end{array}$ & 3.74 \\
\hline $\begin{array}{r}800 \\
850 \\
900 \\
950 \\
1000\end{array}$ & $\begin{array}{l}0.04 \\
0.05 \\
0.05 \\
0.06 \\
0.06\end{array}$ & $\begin{array}{l}2590 \\
2600 \\
2650 \\
2700 \\
2700\end{array}$ & $\begin{array}{l}0.41 \\
0.42 \\
0.44 \\
0.49 \\
0.47\end{array}$ & $\begin{array}{l}4300 \\
4350 \\
4400 \\
4450 \\
4450\end{array}$ & $\begin{array}{l}1.15 \\
1.18 \\
1.21 \\
1.23 \\
1.23\end{array}$ & $\begin{array}{l}6050 \\
6100 \\
6150 \\
6200 \\
6250\end{array}$ & $\begin{array}{l}2.28 \\
2.32 \\
2.36 \\
2.40 \\
2.49\end{array}$ & $\begin{array}{l}7800 \\
7850 \\
7900 \\
7950 \\
8000\end{array}$ & $\begin{array}{r}3.79 \\
-\quad 3.24 \\
3.89 \\
3.94 \\
3.99\end{array}$ \\
\hline $\begin{array}{l}1050 \\
1100 \\
1150 \\
1200 \\
1250\end{array}$ & $\begin{array}{l}0.07 \\
0.08 \\
0.08 \\
0.09 \\
0.10\end{array}$ & $\begin{array}{l}2800 \\
2850 \\
2900 \\
2950 \\
3000\end{array}$ & $\begin{array}{l}0.49 \\
0.51 \\
0.52 \\
0.54 \\
0.56\end{array}$ & $\begin{array}{l}4550 \\
4600 \\
4650 \\
4700 \\
4750\end{array}$ & $\begin{array}{l}1.29 \\
1.32 \\
1.39 \\
1.38 \\
1.41\end{array}$ & $\begin{array}{l}6300 \\
6350 \\
6400 \\
6450 \\
6500\end{array}$ & $\begin{array}{l}2.47 \\
2.51 \\
2.99 \\
2.59 \\
2.63\end{array}$ & $\begin{array}{l}8050 \\
8100 \\
8150 \\
8200 \\
8250\end{array}$ & $\begin{array}{l}4.04 \\
4.09 \\
4.14 \\
4.19 \\
4.24\end{array}$ \\
\hline $\begin{array}{l}1300 \\
1350 \\
1400 \\
1450 \\
1500\end{array}$ & $\begin{array}{l}0.11 \\
0.11 \\
0.12 \\
0.13 \\
0.14\end{array}$ & $\begin{array}{l}3050 \\
3100 \\
3190 \\
3200 \\
3250\end{array}$ & $\begin{array}{l}0.98 \\
0.60 \\
0.62 \\
0.64 \\
0.66\end{array}$ & $\begin{array}{l}4900 \\
4850 \\
4900 \\
4930 \\
5000\end{array}$ & $\begin{array}{l}1.44 \\
1.47 \\
1.50 \\
1.53 \\
1.56\end{array}$ & $\begin{array}{l}6550 \\
6600 \\
6550 \\
6700 \\
6750\end{array}$ & $\begin{array}{l}2.67 \\
2.71 \\
2.76 \\
2.80 \\
2.84\end{array}$ & $\begin{array}{l}8300 \\
8350 \\
8400 \\
8450 \\
8500\end{array}$ & $\begin{array}{l}4.29 \\
4.35 \\
4.40 \\
4.45 \\
4.50\end{array}$ \\
\hline $\begin{array}{l}1550 \\
1600 \\
1650 \\
1700 \\
1750\end{array}$ & $\begin{array}{l}0.15 \\
0.16 \\
0.17 \\
0.18 \\
0.19\end{array}$ & $\begin{array}{l}3300 \\
3350 \\
3400 \\
3450 \\
3500\end{array}$ & $\begin{array}{l}0.58 \\
0.70 \\
0.72 \\
0.74 \\
0.76\end{array}$ & $\begin{array}{l}s 0 s 0 \\
\$ 100 \\
\$ 150 \\
\$ 200 \\
\$ 250\end{array}$ & $\begin{array}{l}1.59 \\
1.62 \\
1.65 \\
1.69 \\
1.72\end{array}$ & $\begin{array}{l}6800 \\
6850 \\
6900 \\
6950 \\
7000\end{array}$ & $\begin{array}{l}2.88 \\
2.92 \\
2.97 \\
3.01 \\
3.05\end{array}$ & $\begin{array}{l}8350 \\
8600 \\
8650 \\
8700 \\
8750\end{array}$ & $\begin{array}{l}4.96 \\
4.61 \\
4.66 \\
4.72 \\
4.77\end{array}$ \\
\hline $\begin{array}{l}1800 \\
1850 \\
1900 \\
1950 \\
2000\end{array}$ & $\begin{array}{l}0.20 \\
0.21 \\
0.22 \\
0.24 \\
0.25 \\
\end{array}$ & $\begin{array}{l}3550 \\
3600 \\
3650 \\
3700 \\
3750\end{array}$ & $\begin{array}{l}0.79 \\
0.81 \\
0.83 \\
0.85 \\
0.88\end{array}$ & $\begin{array}{l}\$ 300 \\
\$ 350 \\
\$ 400 \\
\$ 450 \\
\$ 500 \\
\end{array}$ & $\begin{array}{l}1.75 \\
1.78 \\
1.82 \\
1.85 \\
1.89 \\
\end{array}$ & $\begin{array}{l}7050 \\
7100 \\
7150 \\
7200 \\
7250\end{array}$ & $\begin{array}{l}3.10 \\
3.14 \\
3.19 \\
3.23 \\
3.28 \\
\end{array}$ & $\begin{array}{l}8800 \\
8850 \\
8900 \\
8950 \\
\$ 000\end{array}$ & $\begin{array}{r}4.83 \\
4.88 \\
4.94 \\
4.99 \\
5.09 \\
\end{array}$ \\
\hline
\end{tabular}


To: Radidactive Waste Handling Eng.

ATT: T. Garcia/L. Tackson.

\begin{tabular}{|c|c|c|}
\hline RURCHASE OROER/CONTRACT NO. & $\begin{array}{l}\text { OESIGN OOCUMENT NO } \\
E \angle O-K 1 Z Z\end{array}$ & HWOR ASSEMBLY ORAWING NO. \\
\hline EQUIPMENT NO./FACIUTY NO. & RESPQNSIPLE ENGINEER 13 ZC6'90 & RESPONSIGLE DEPARTMENT \\
\hline ORIGIVGTOR APPROVAL/OATE & $\begin{array}{l}\text { RESPONSE REOUIRED DATE } \\
16 \text { 'ZE } 90\end{array}$ & REF. EOT'S \\
\hline
\end{tabular}

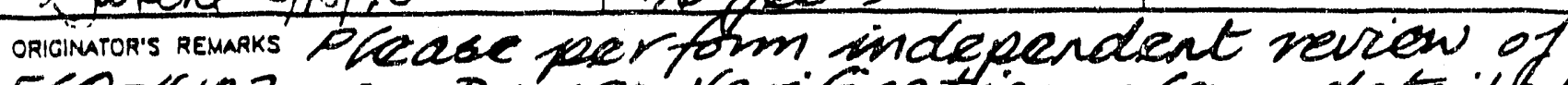
Eco-4127 pen Design Verification plan detailed in memo ref HA:90.04036 (copy extached)

AODRESSEES REMARKS

\begin{tabular}{|c|c|c|c|c|c|c|c|c|c|}
\hline \multicolumn{10}{|c|}{ DATA TRANSMITTED } \\
\hline \multirow[b]{2}{*}{$\begin{array}{l}\text { TEM } \\
\text { NO. }\end{array}$} & & & & \multirow[b]{2}{*}{ TTLE OR OESCRIPTION } & $A$ & 8 & $c$ & 0 & $\varepsilon$ \\
\hline & DOCLLMENT NO. & $\begin{array}{l}\text { REV. } \\
\text { NO. }\end{array}$ & $\begin{array}{l}\text { SHT. } \\
\text { NO. }\end{array}$ & & 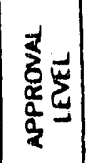 & 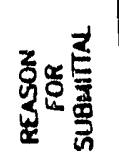 & 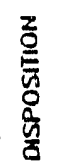 & & \\
\hline \multirow[t]{3}{*}{1} & ECO-4127 & & & mavface aluctwork & & 3 & & & \\
\hline & & & & Getween Trupact HVS & & & & & \\
\hline & & & & SC4 Frea HWAC systeu. & & & & & \\
\hline \multicolumn{4}{|c|}{ 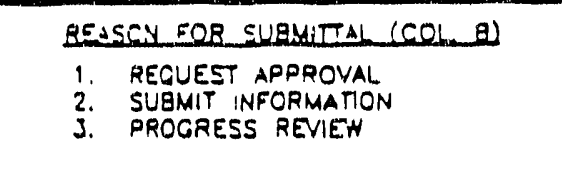 } & \multicolumn{6}{|c|}{ 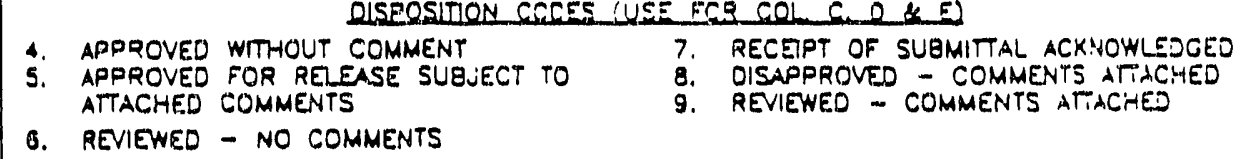 } \\
\hline
\end{tabular}

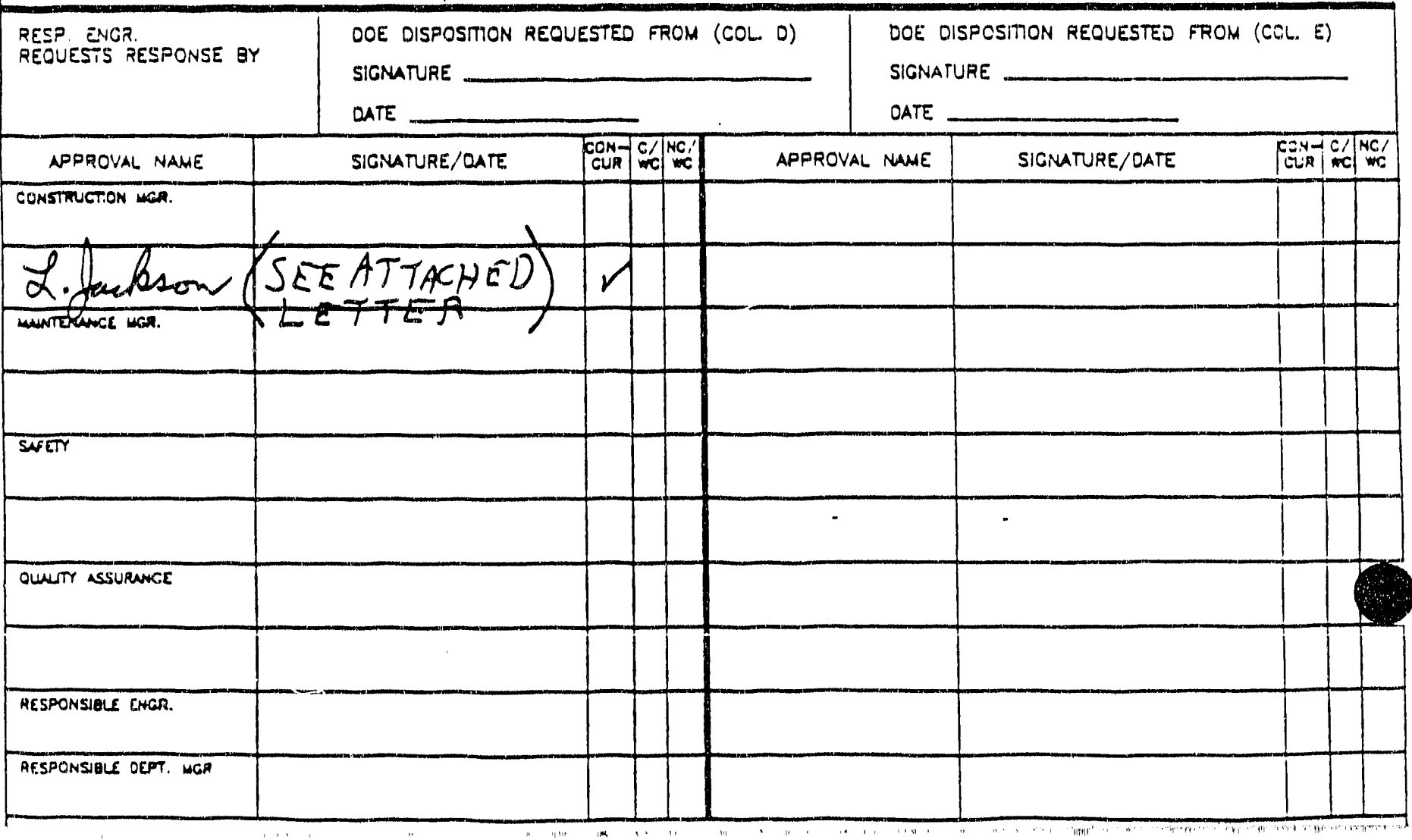


"ifi Engineering

VINI 887-8194

Oale February 27, 1990

SHWAC: INDEPENDENT REVIEN OF HOOD VENT SYSTEM HVAC OUCTING
J. J. Garcia
G. W. Poh 1
T. W. Halverson
K. A. Ealdon
cc: A. E. Gallegos
M. J. Leroch

Engineering Design and Systems (EDS), 2012 S. 314 th St., Federal Way, WA, 98003, is the basic supplier of the Hood Vent System (excluding ductwork). EDS designed the entire system which included sizing of the ductwork system. However, the EDS scope does not include detail design, routing under the TRUPACT docks or attachment to the HUAC system.

The major ductwork routing path, in general, was per specification 0-0070. Specifics of the routing path were jointly finalized during an interface meeting with EDS which included Radioactive Waste Handling and Facilities \& Construction Engineering.

The principal scope of this review (of submitted package principally consisting of sketches from which ductwork drawings will be generated) was to determine if collective sizing information provided by the EDS preliminary design package has been correctly interpreted and applied.

An independent review was performed by the undersigned in accordance with WP 09-018 (DESIGN VERIFICATION). The design has been reviewed and found adequate for performing the intended function as specified per Design Specification D-0070. The HVAC ducting details as depicted per submitting sketches are consistent with the design basis.

Q.Jaekson

Radio Active Waste Handling Engineering

jn

$H A: 90: 7074$ 
:nm Engineering

ivis 887-8163

$\because$ February 1, 1990

SIJge: TRUPACT HOOD VENT SYSTEM DUCTWORK INTERFACE WITH CH AREA HVAC SYSTEM

T. W. Halverson

cc: K. Ealden

As required by procedure WP 09-018, Design Verification, Facility and Construction Engineering submits for your concurrence, the design verification plan for the inlet manifold duct and $\mathrm{CH}$ area HVAC system interface duct associated with the Trupact Hood Vent System.

Design Verification Plan:

Descriotion of Equipment - The inlet manifold duct will be located beneath a Trupact II dock and will provide connections for component * parts of the THUS.

The $\mathrm{CH}$ area HVAC system interface duct will provide the ducted connection from the THVS fan to existing $\mathrm{CH}$ area HVAC system exhaust duct.

\section{Scope}

The scope of the verification $p l a n$ is to provide independent review of the design of the inlet manifoid duct and the $\mathrm{CH}$ area HVAC system interface duct.

\section{Reviewers}

The independent review is to be carried out by the Radioactive Waste Handling Engineering Cognizant Engineer for the Trupact Hood Vent System.

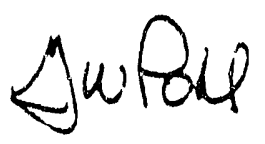

G. W. Poh1, Manager

Facility \& Construction Engineering

\section{KAE:rs}

$H A: 90: 04036$

I do do not_concur with the verification plan.

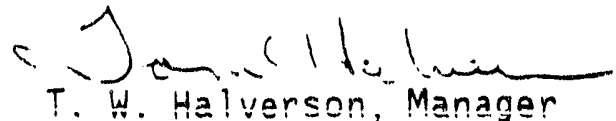

T. W. Halverson, Manager

Engineering 


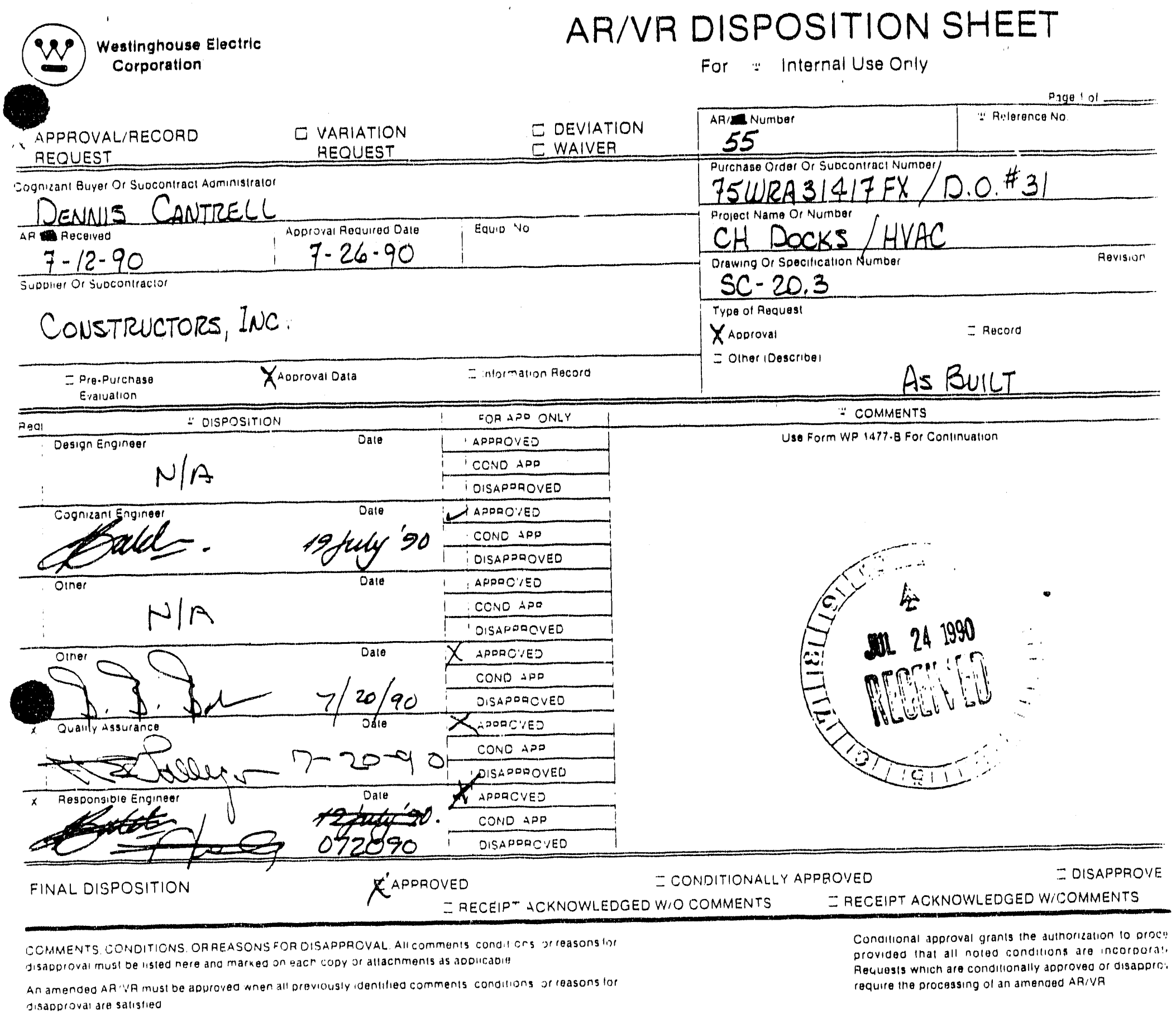




\section{APPROVAL/VARIATION REQUEST}

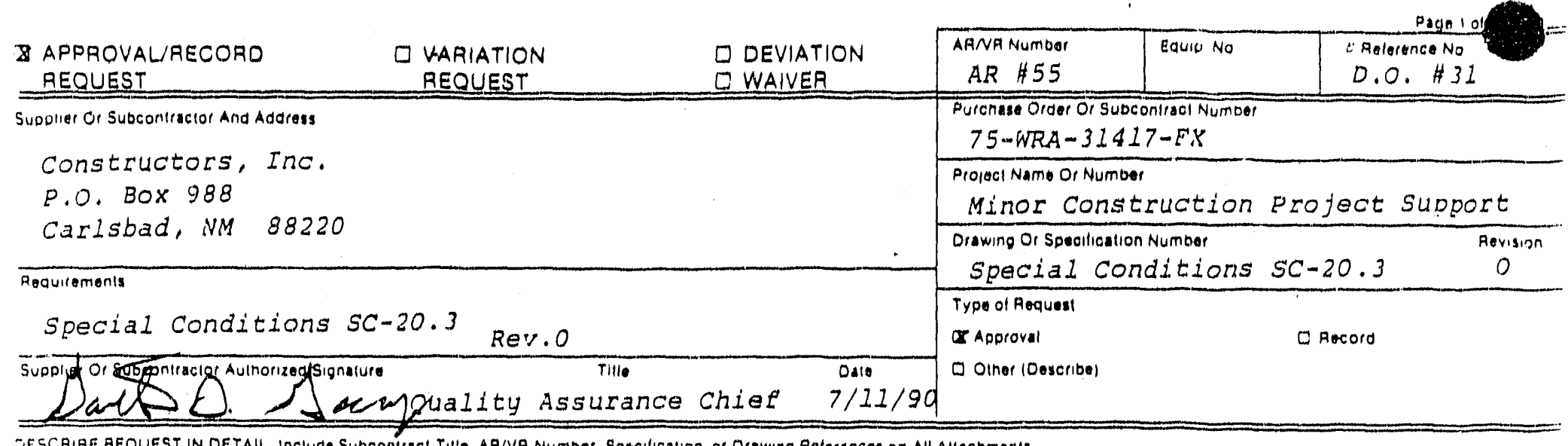

JESCRIBE AEQUEST IN DETAIL. Include Subconitract Tille. AA/VA Number. SDecilication, or Orawing Feterences on All Allachmenis

Please find attached: Drawings of "Work As-Built for Delivery Order \#31".

* PLEASE NOTE: Measurements highlighted in yellow are those that changed from

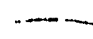
original drawings.

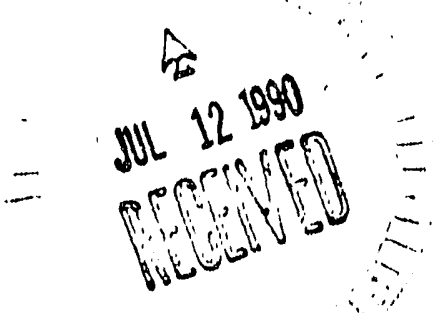

\begin{tabular}{|c|c|c|c|}
\hline DISPOSITION OF APPAOYAL REQUEST: & $\square$ CON & APROVED & G OISAPPROVED \\
\hline DISPOSITION OF RECORD REQUEST & D RECEIPT ACKNOWLEDGED W/O COMMENT3 & D RECEI & ED W/COMMENTS \\
\hline
\end{tabular}

Comments. Condilions. Or Reasons For Disapproval

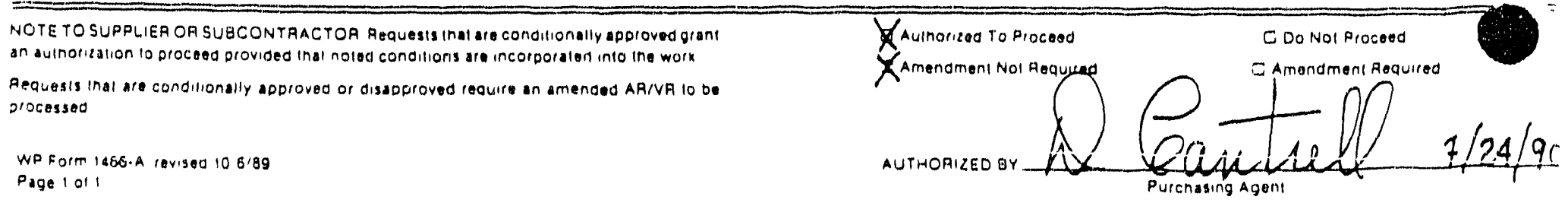




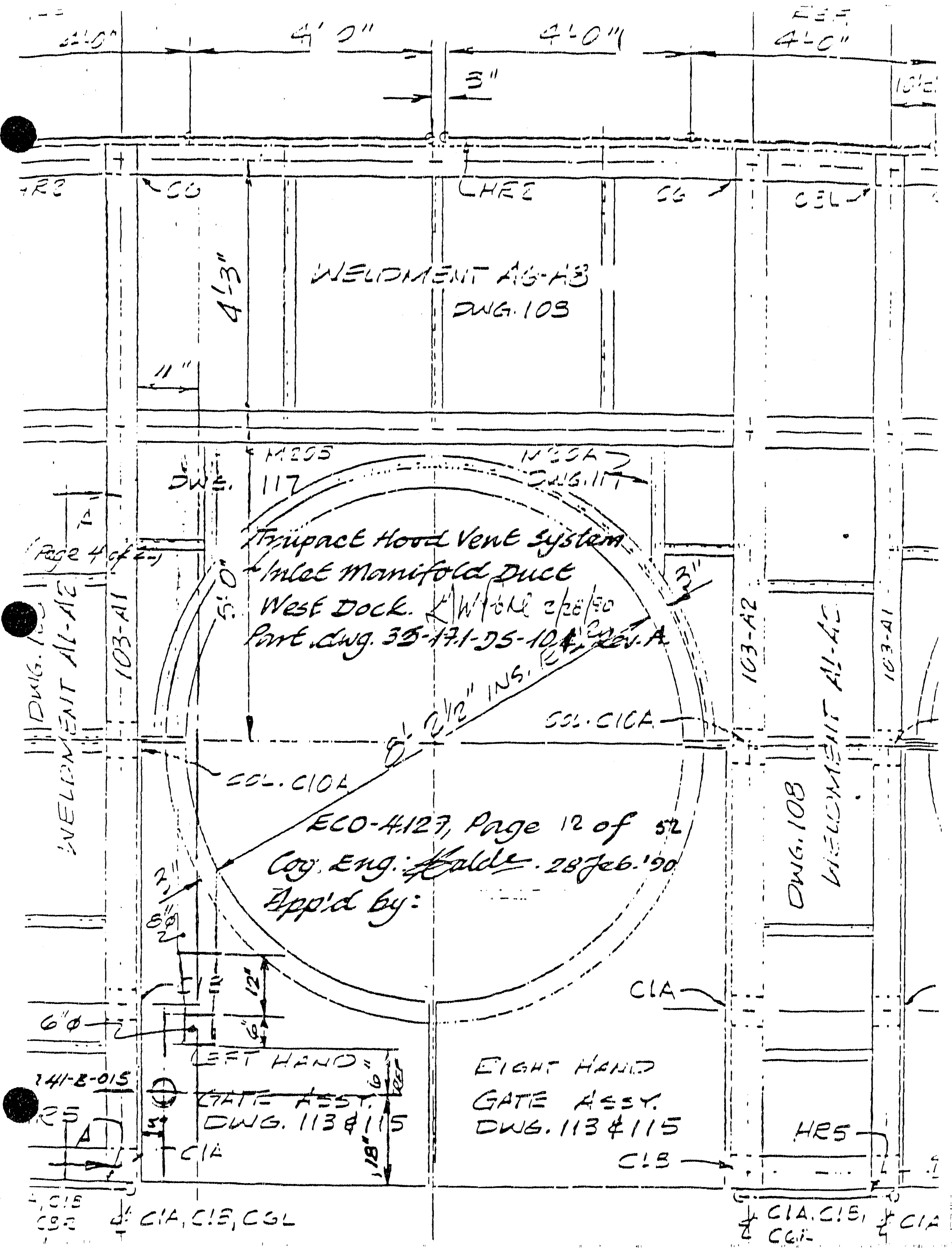




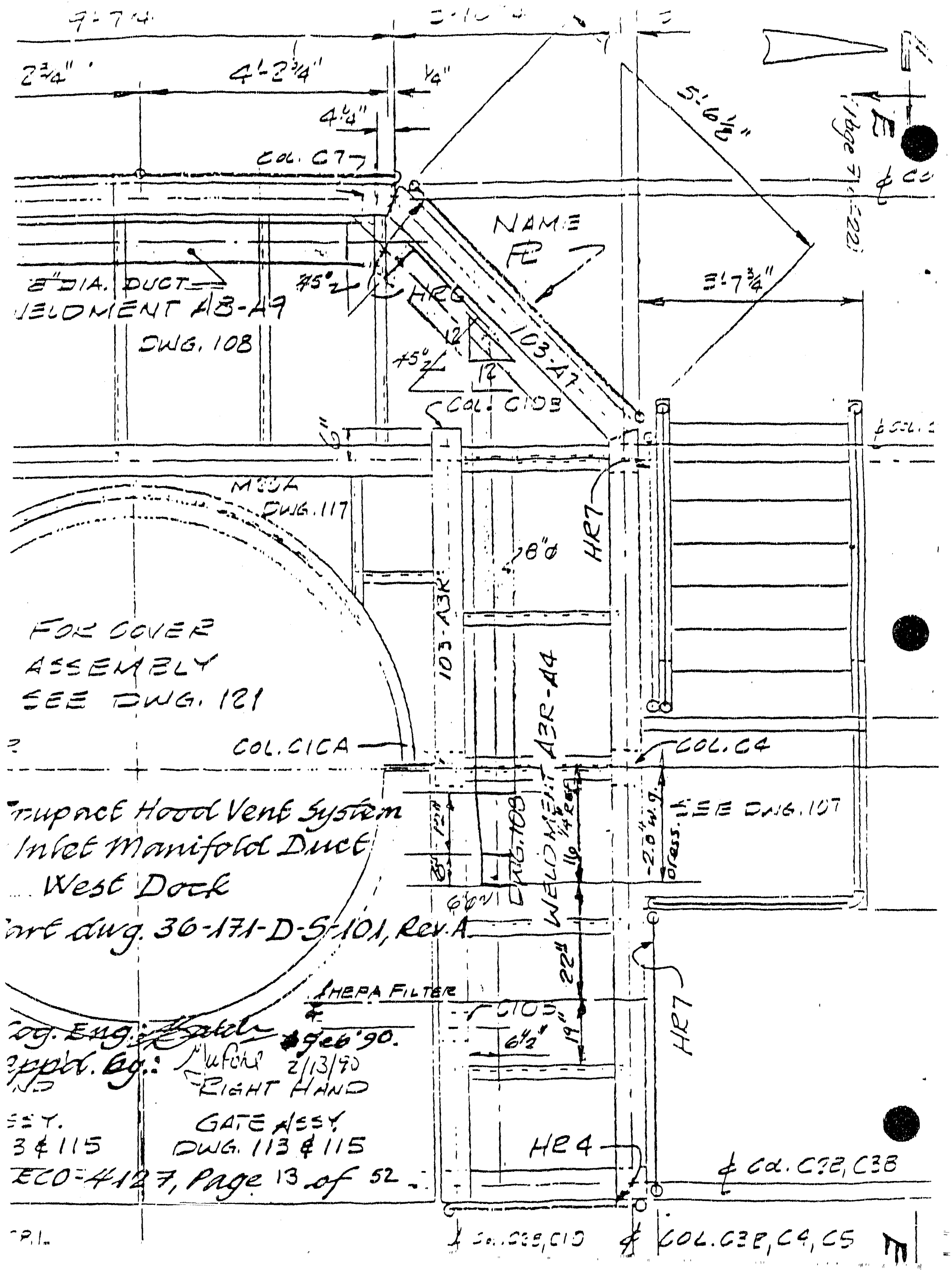




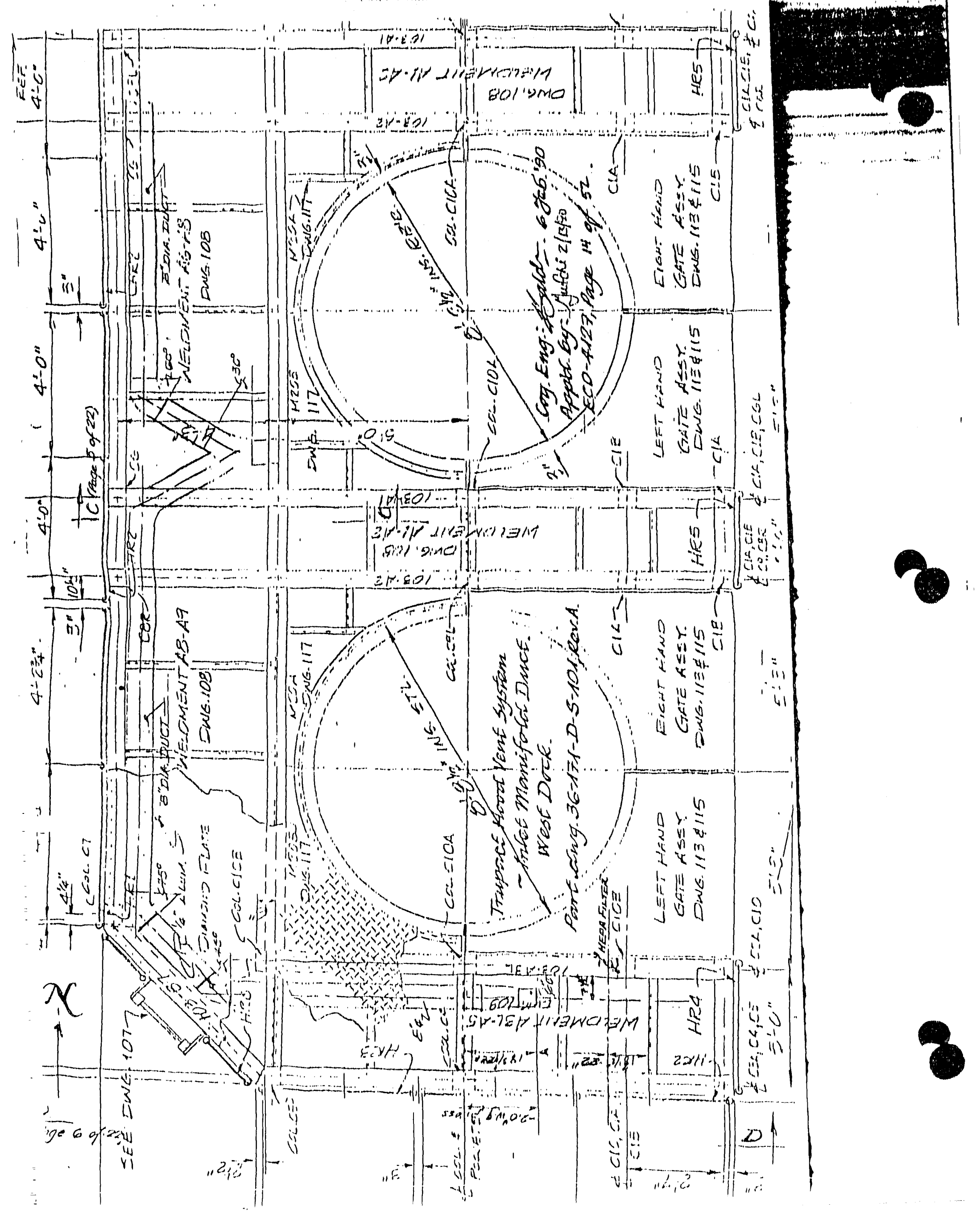




\section{Exs:
B:0.
of 52}

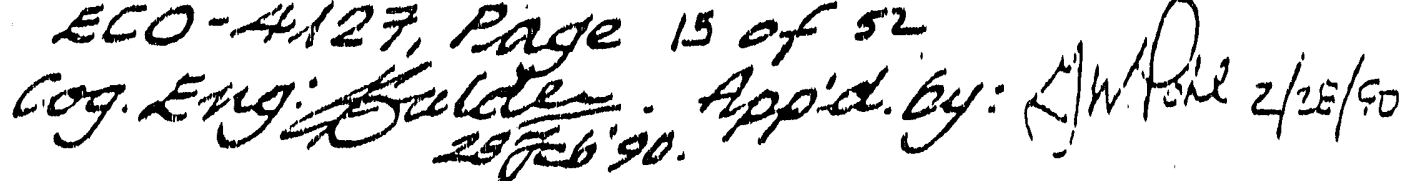

Truspace thood Vent Syoten.

$C H$ area HWAC intarfouce ducet.

West Dock

Pant axig. 36-131-0.5-102, lev. 4.

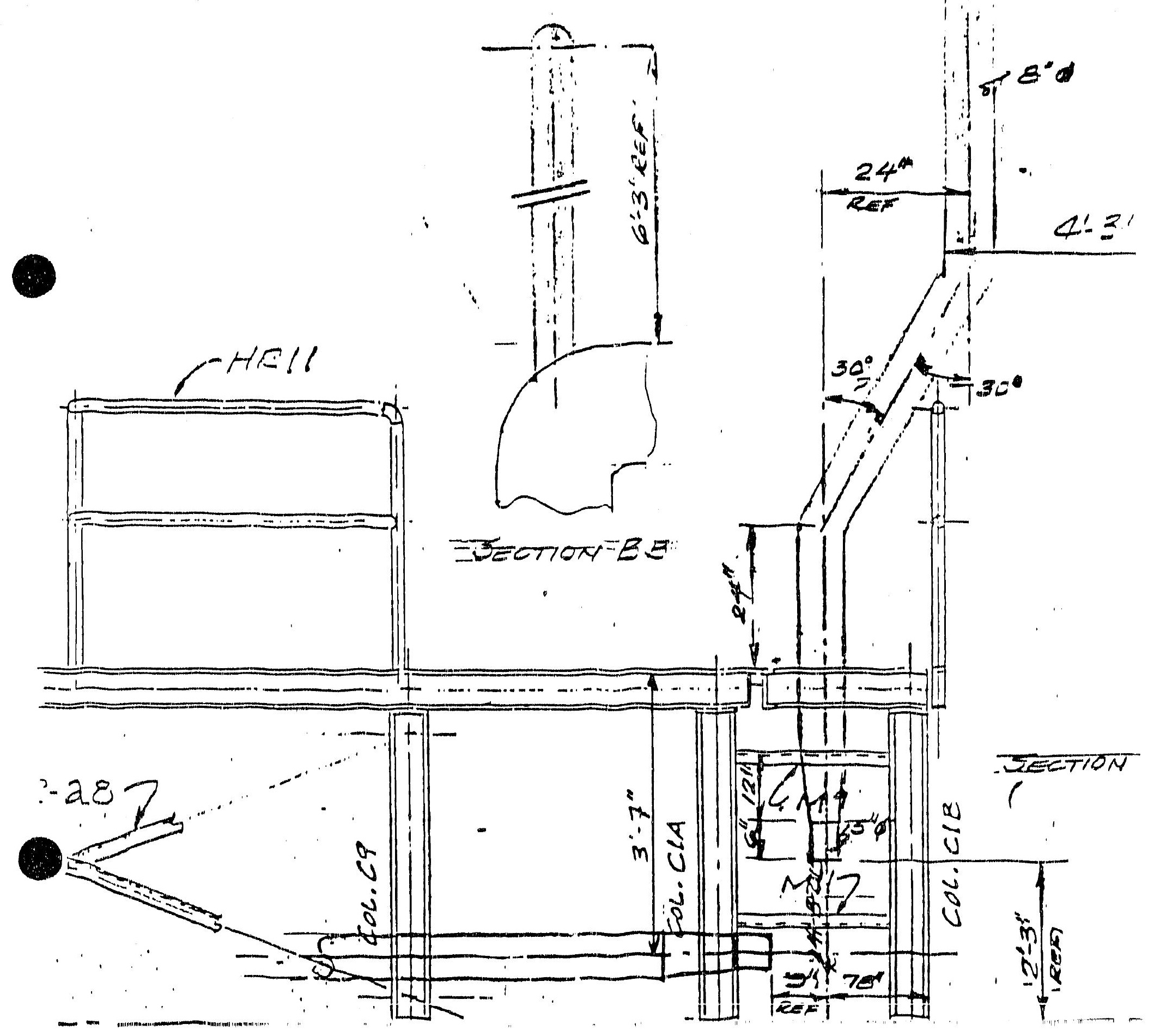



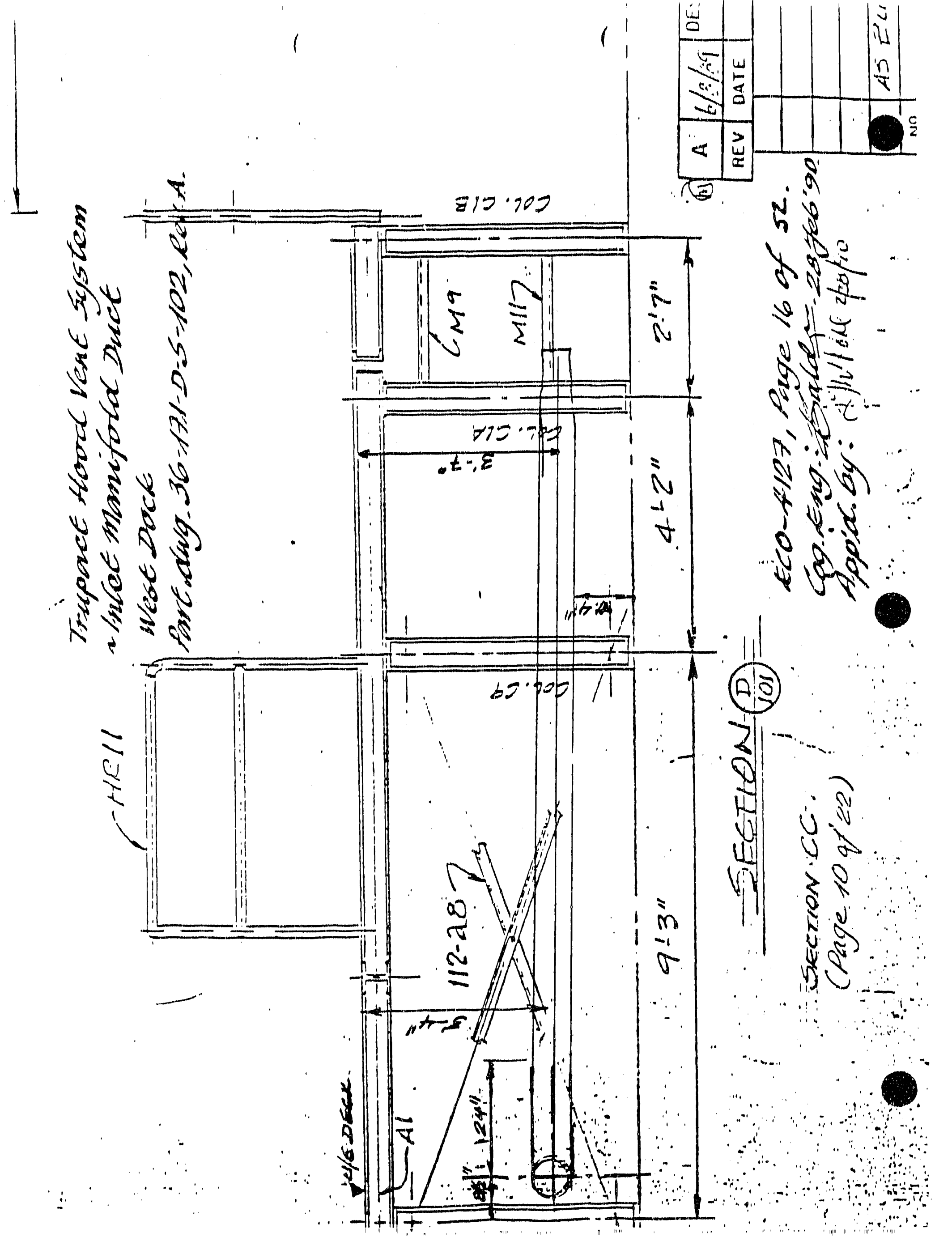


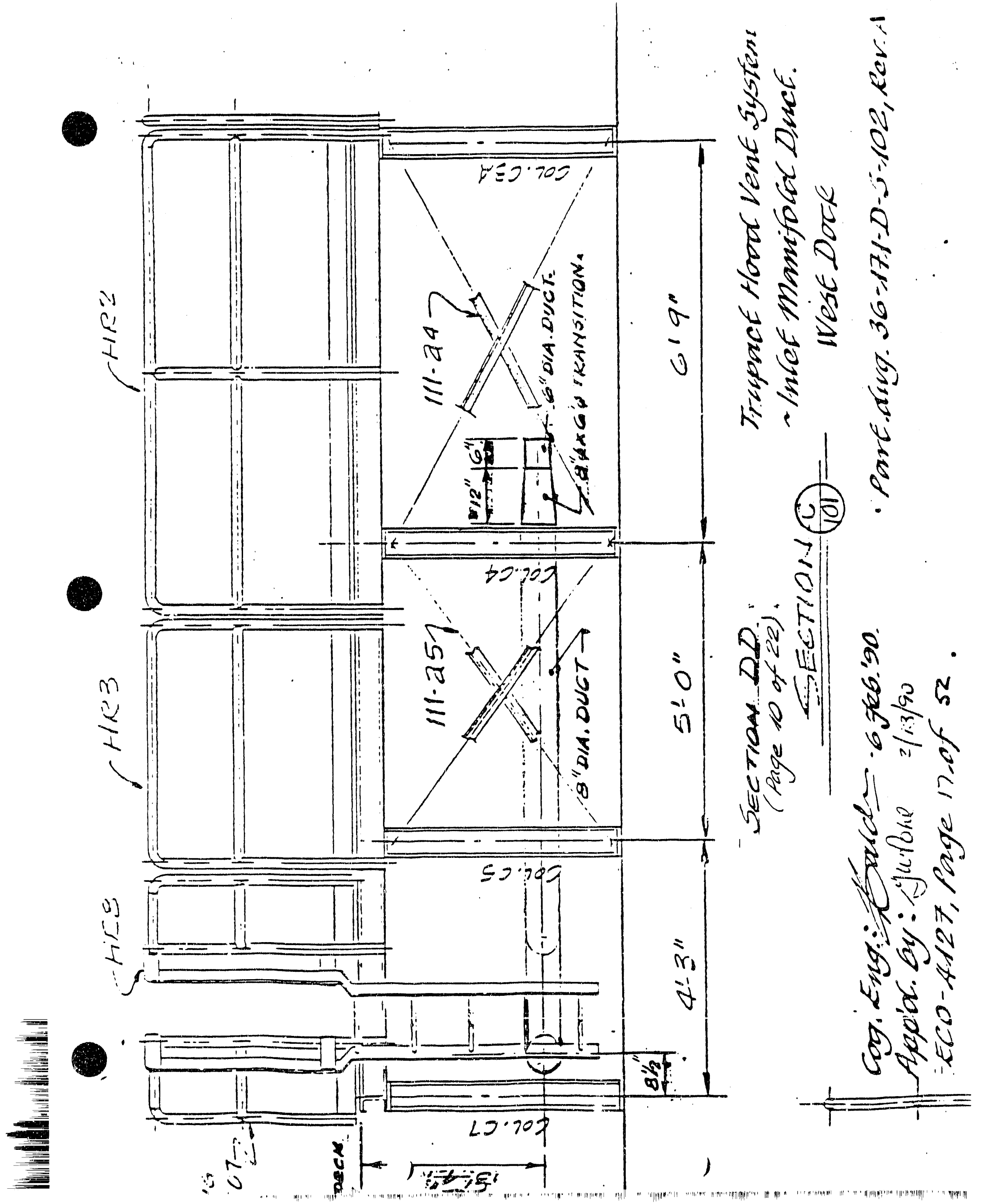




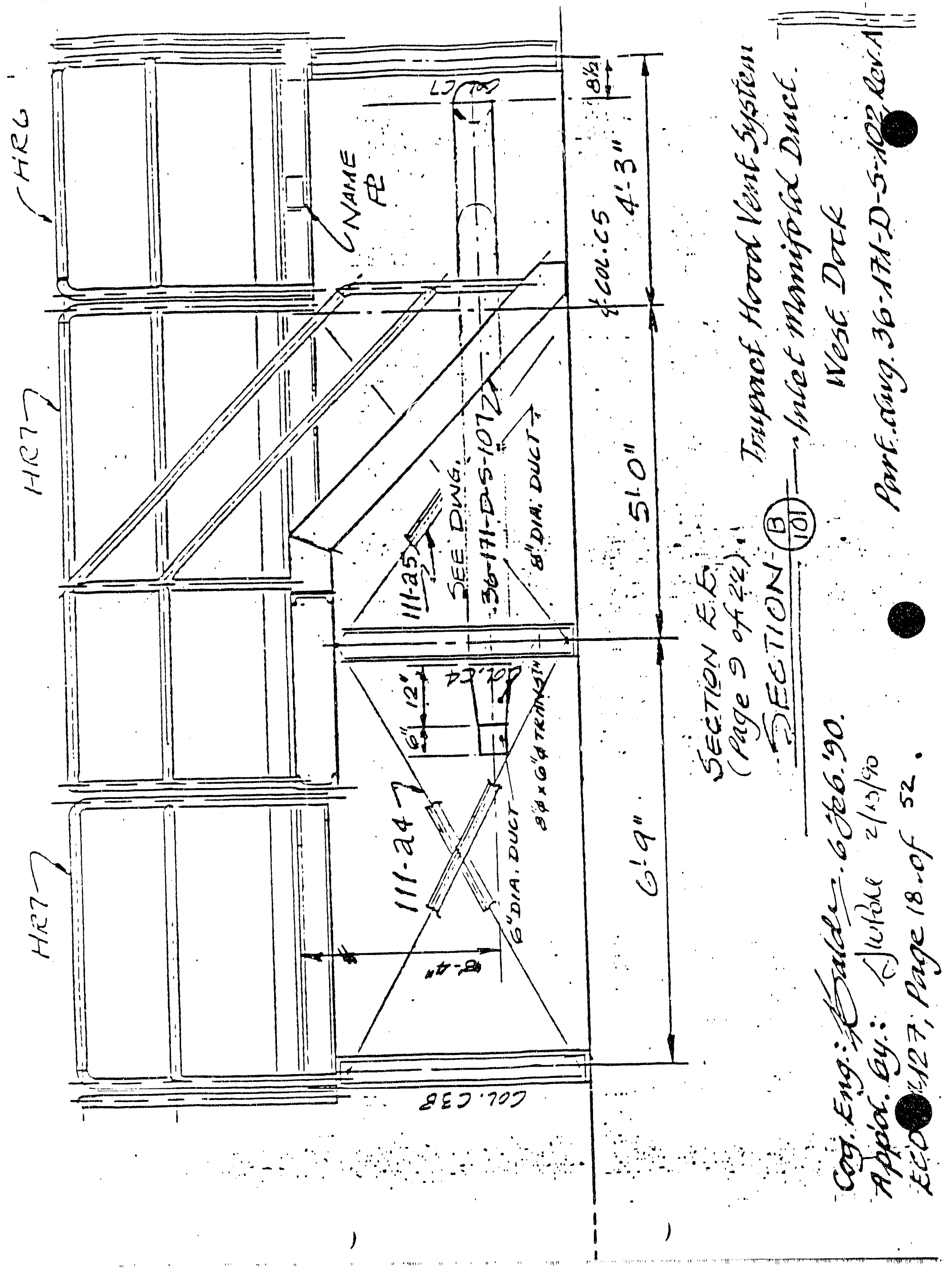




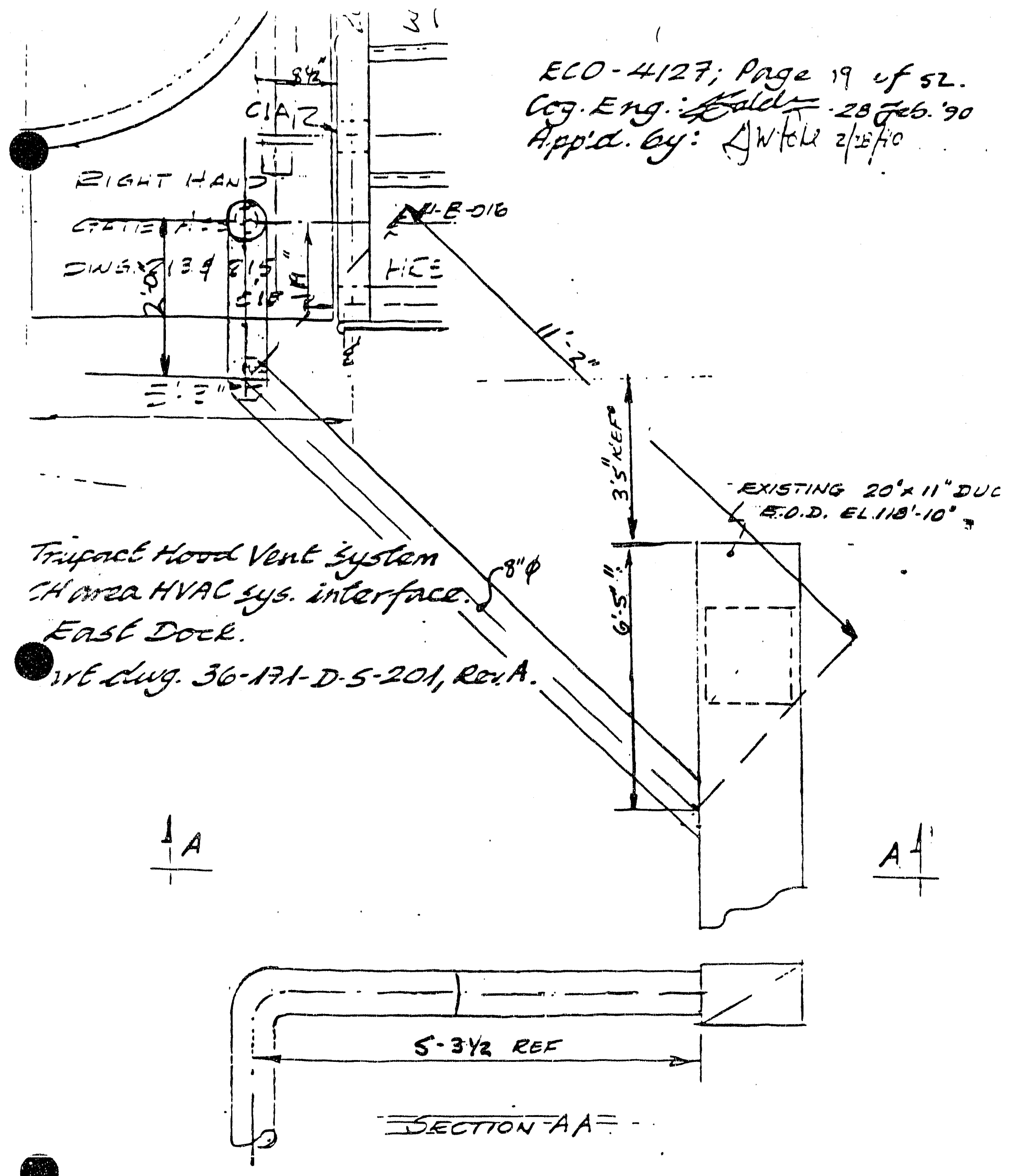




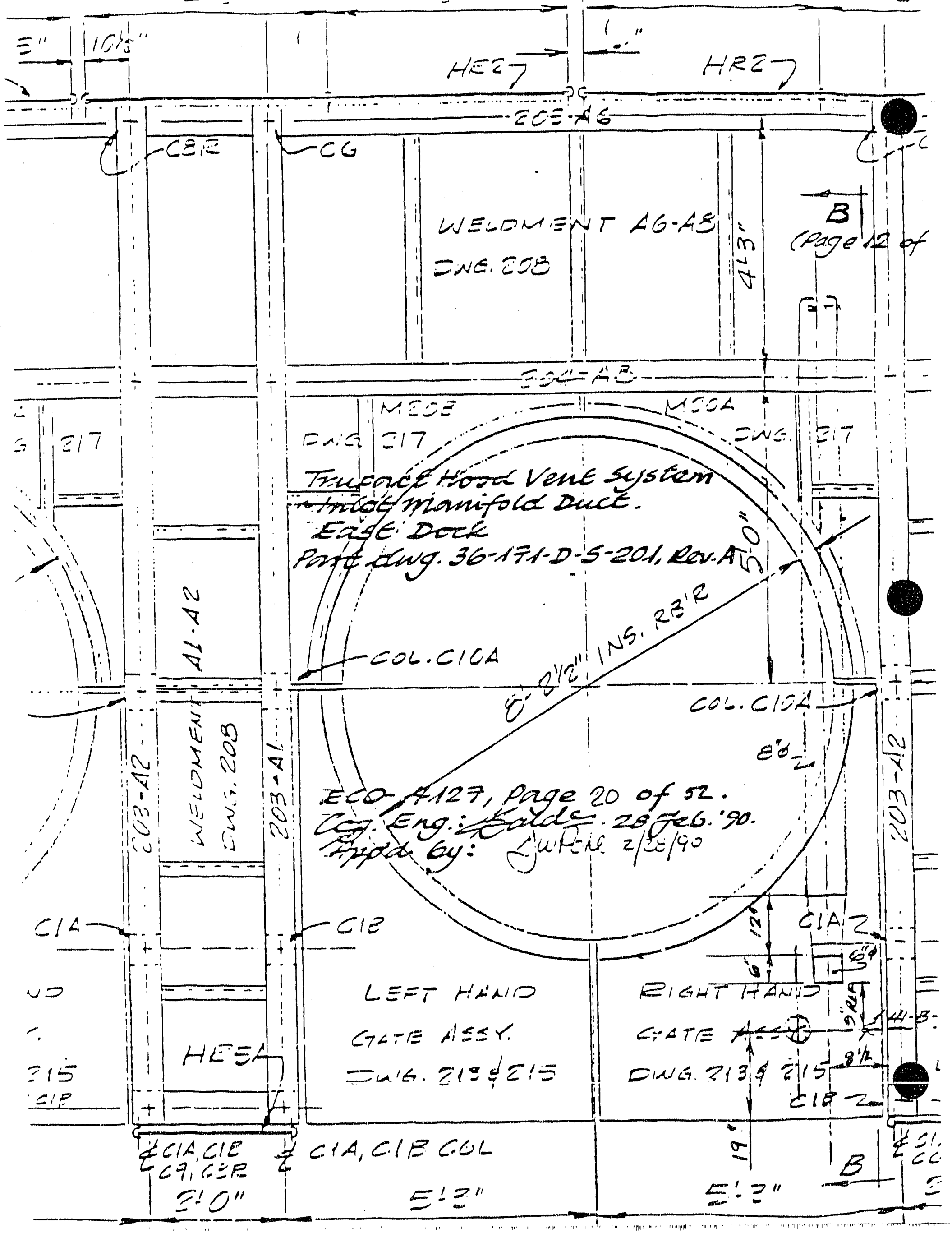




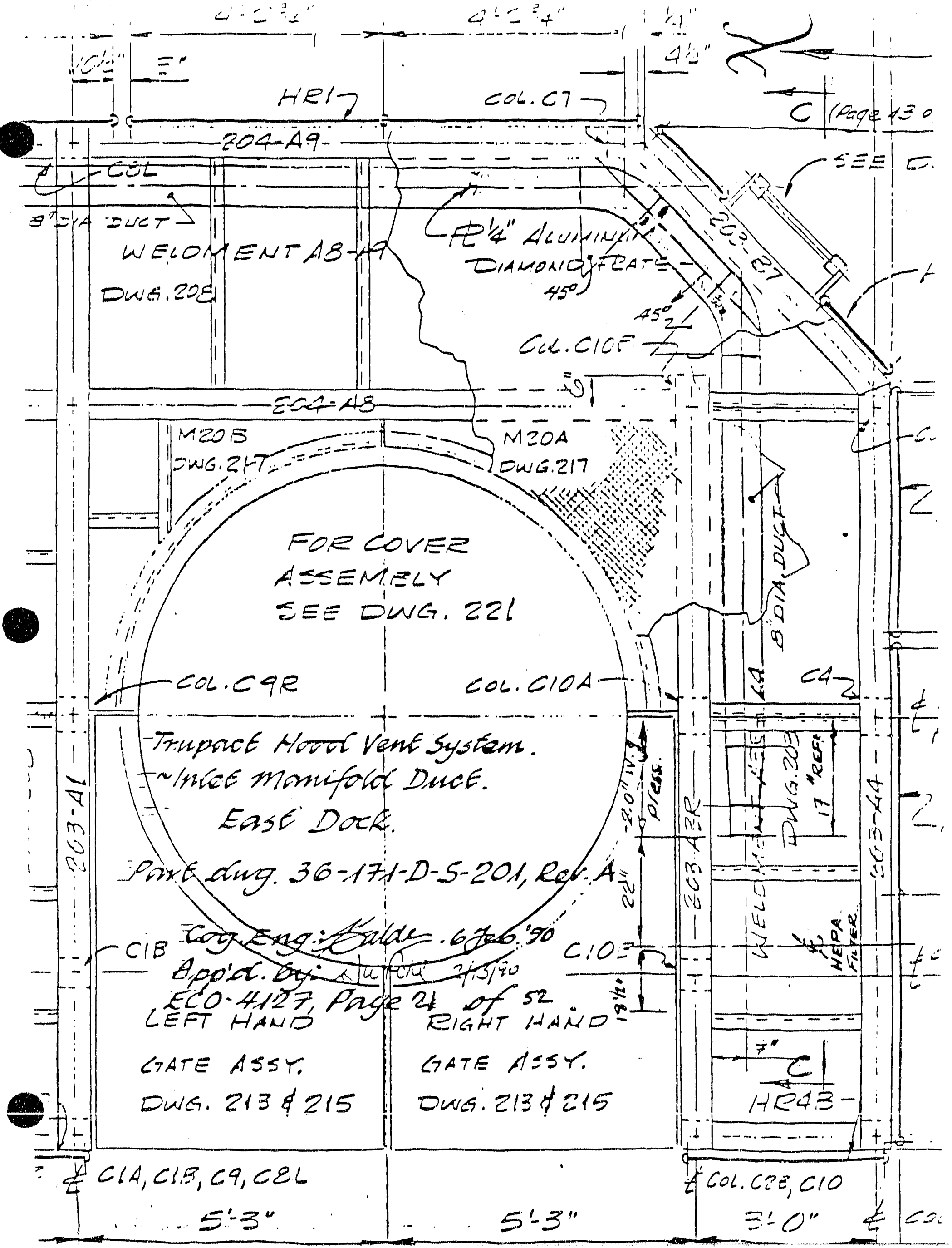




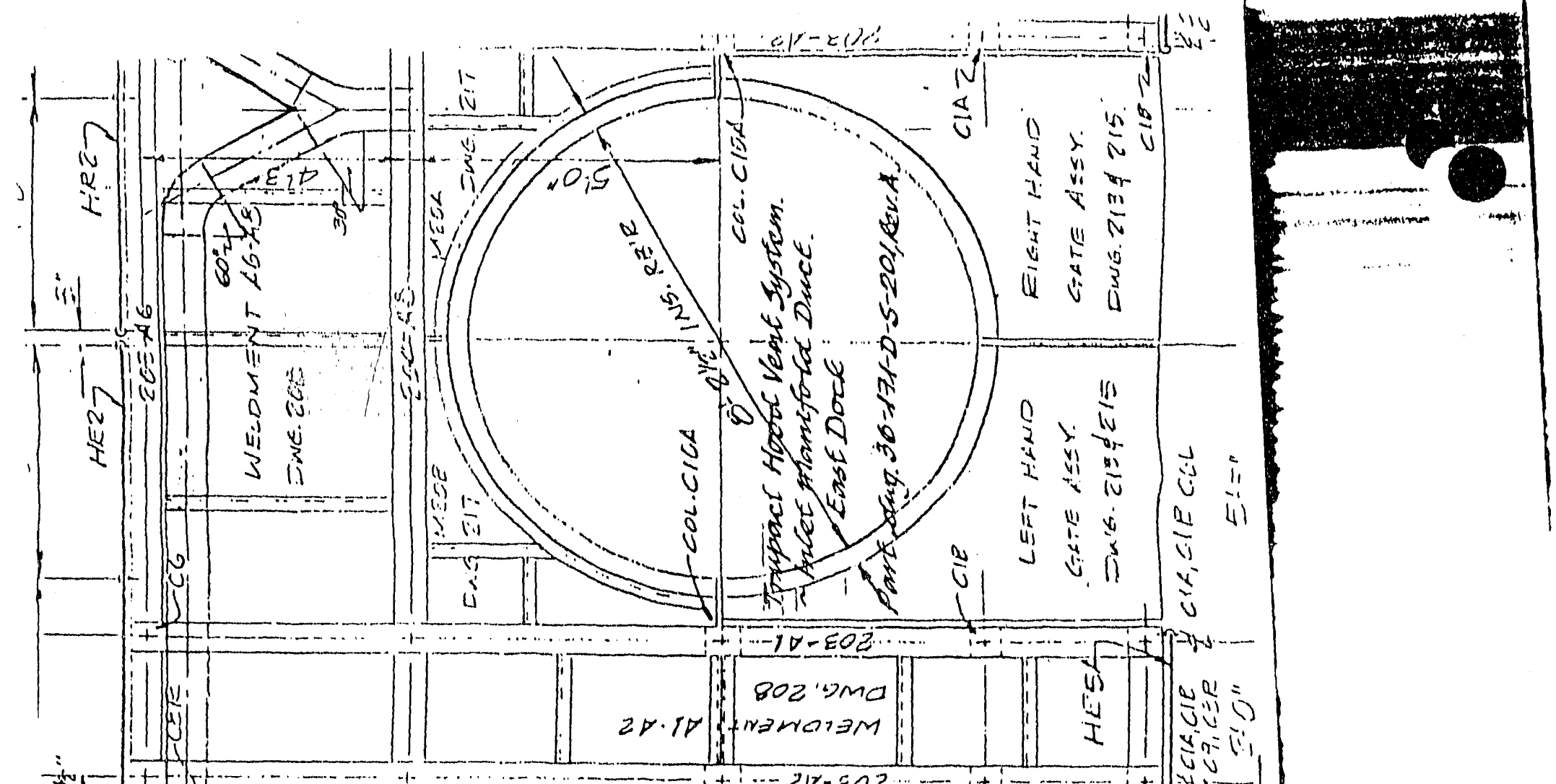

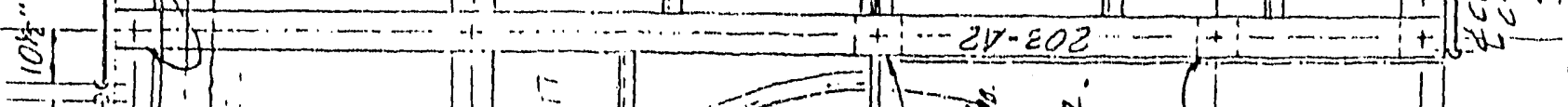

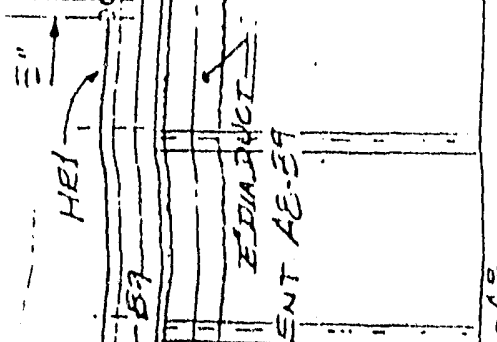

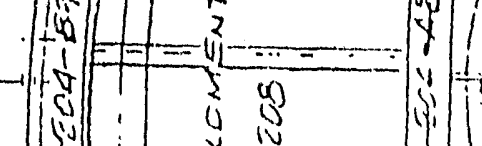
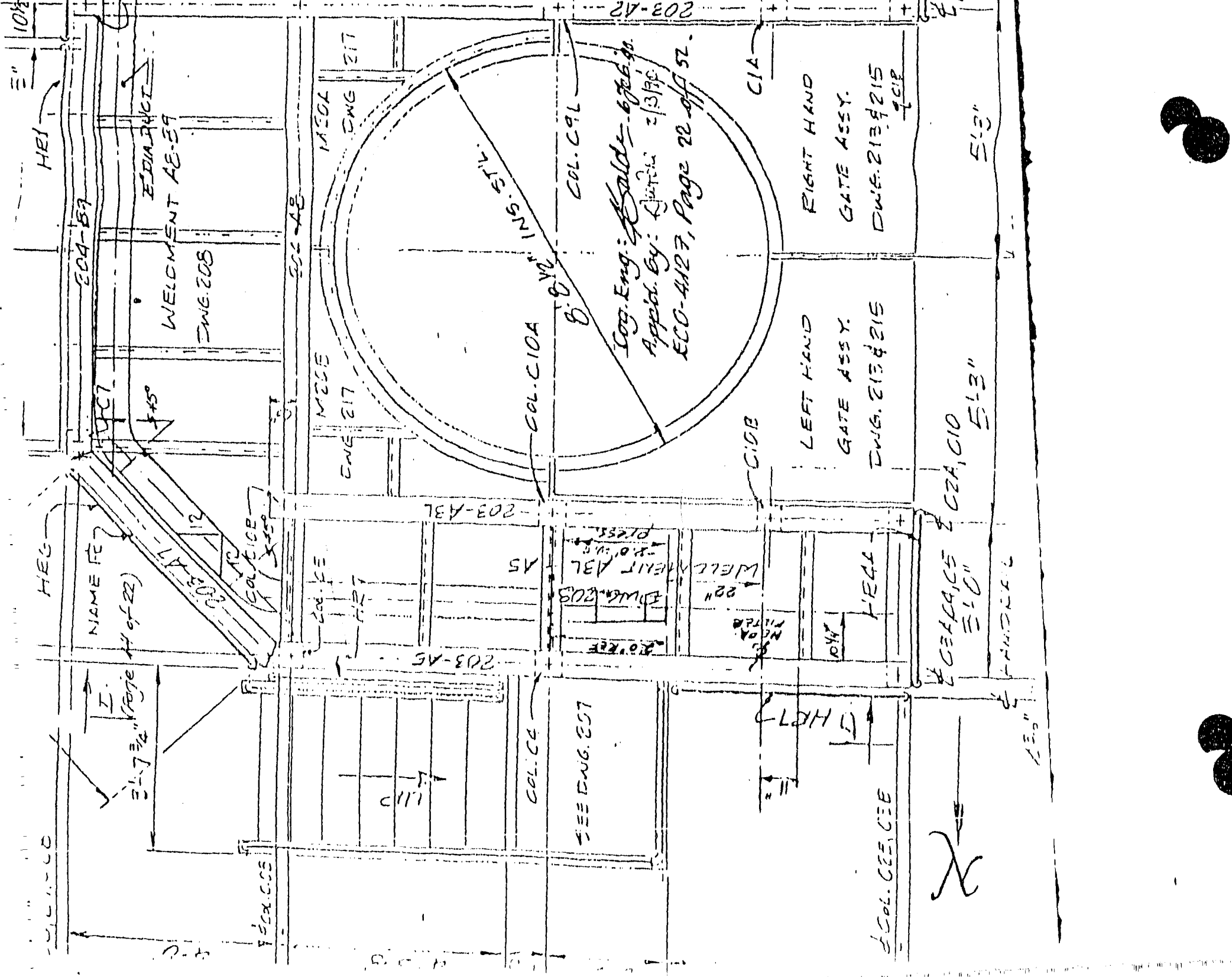


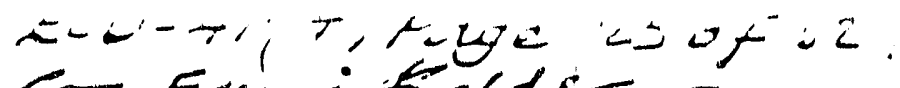

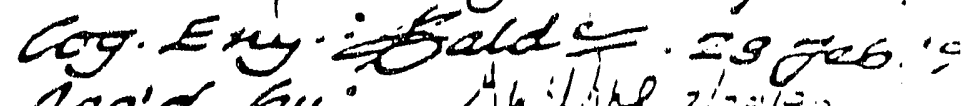

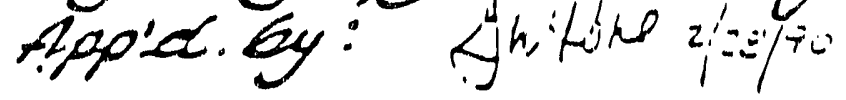

Tripact Hood Vent Systen.

- Inlet Manifold Duet

Ease Dock

Powedug. 36-1?1-5-5-202, pur. A.

$\rightarrow$
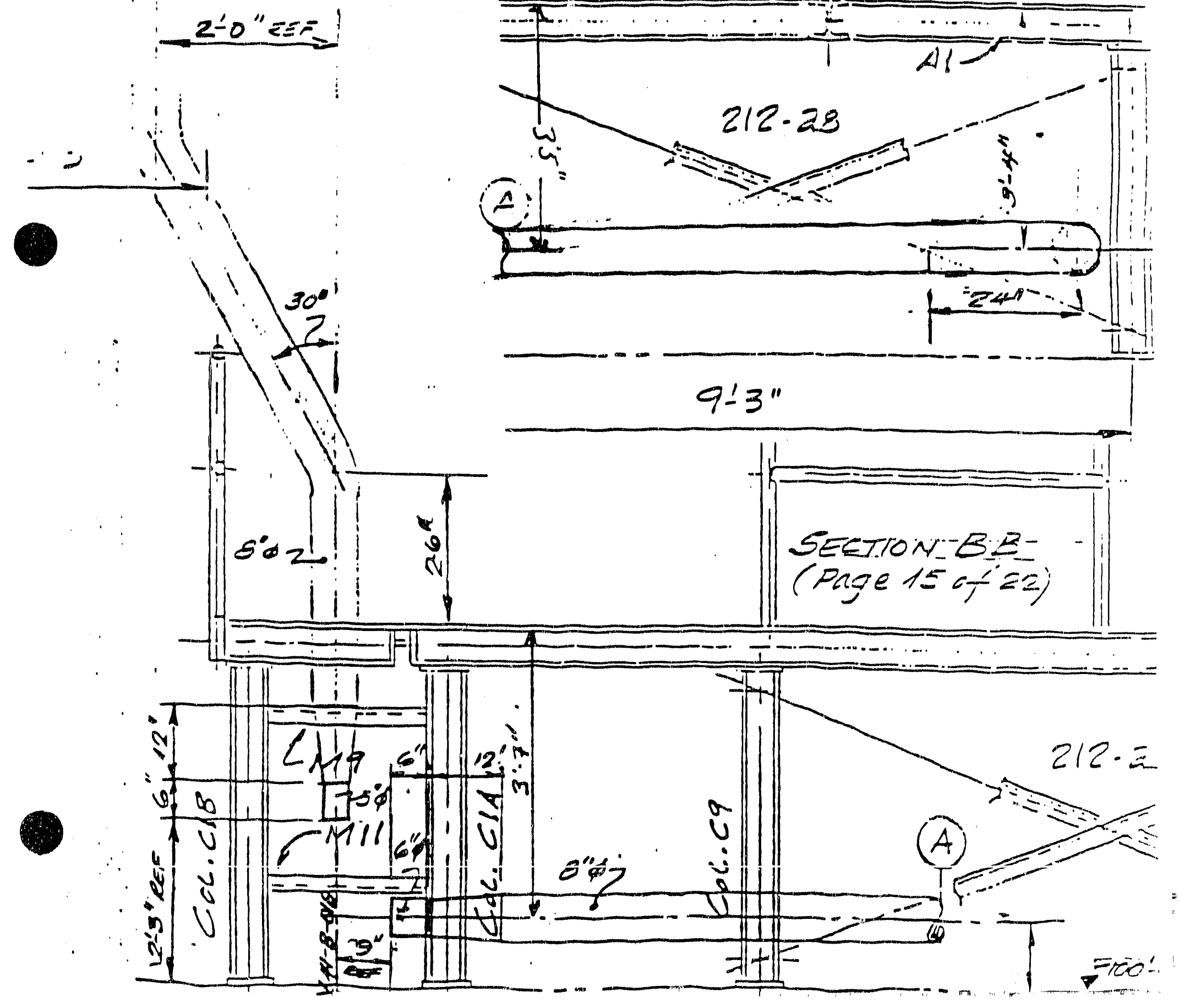


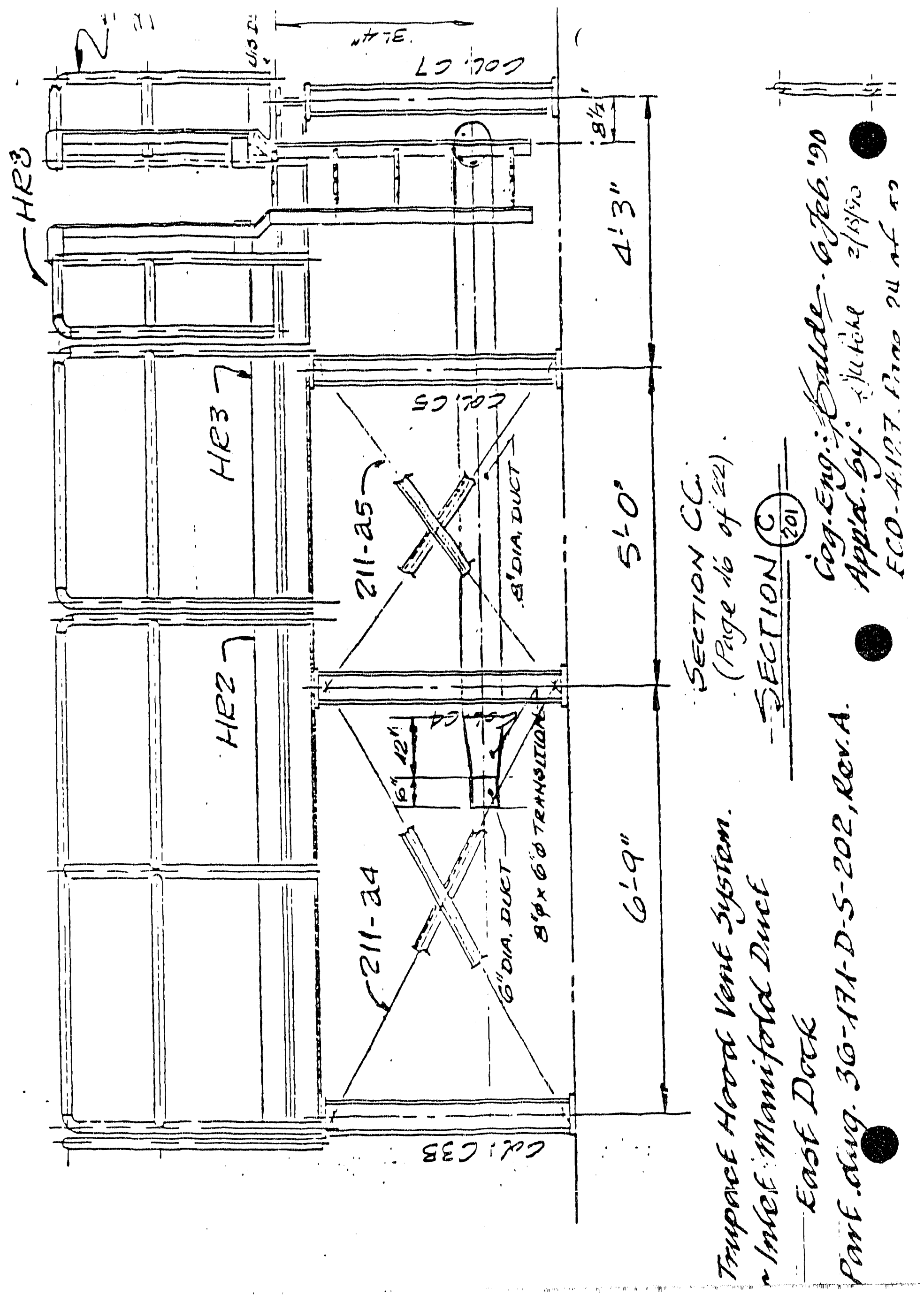




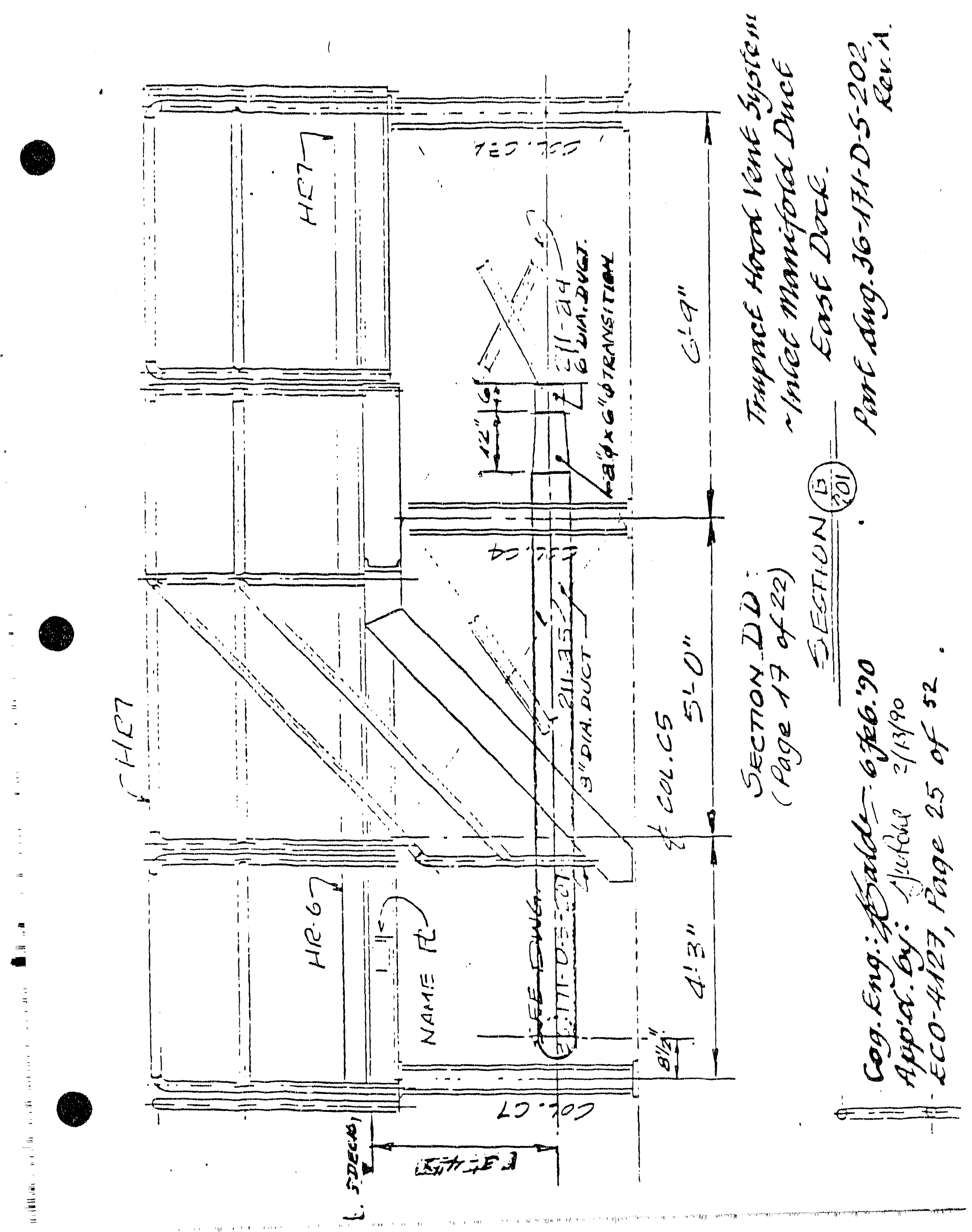




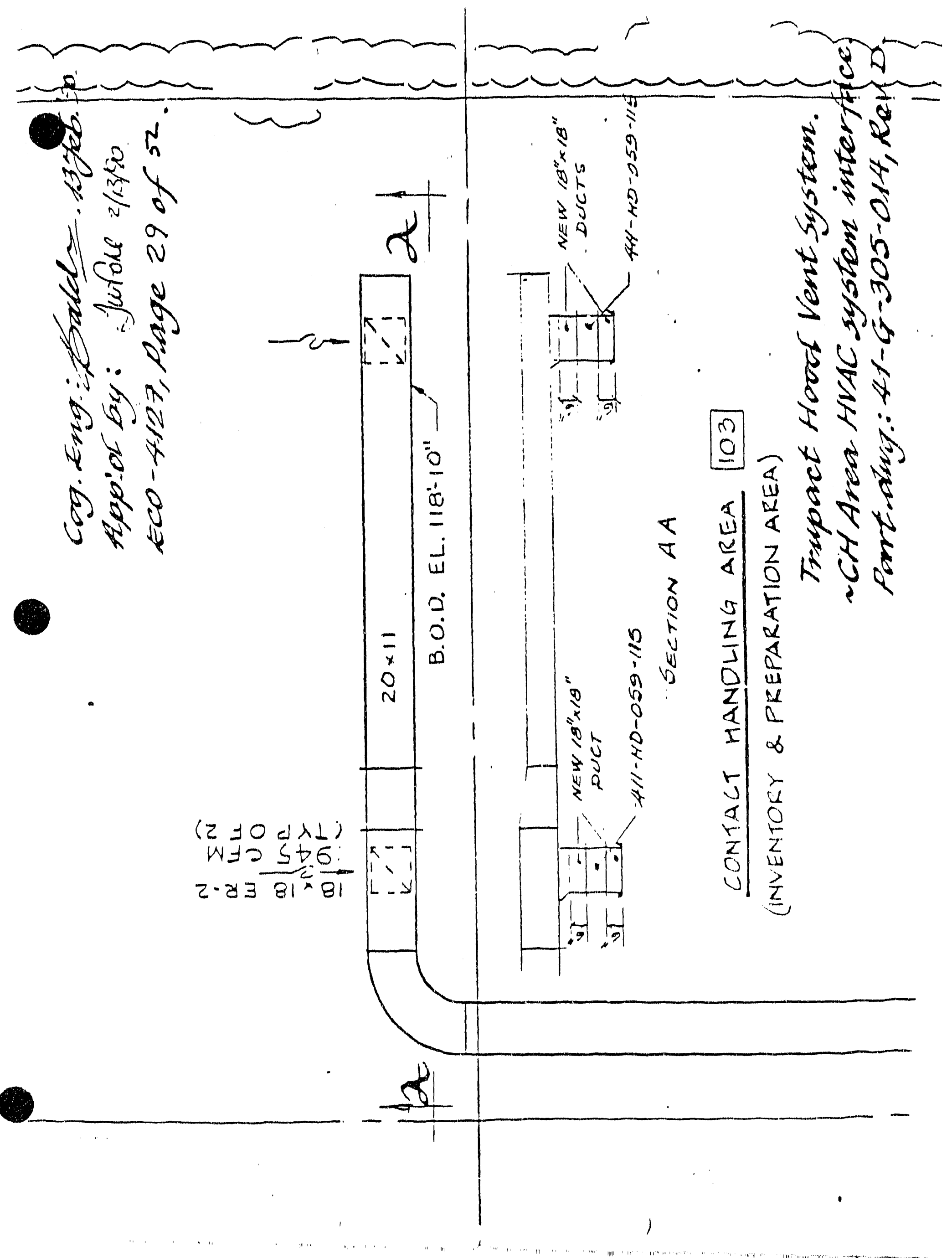




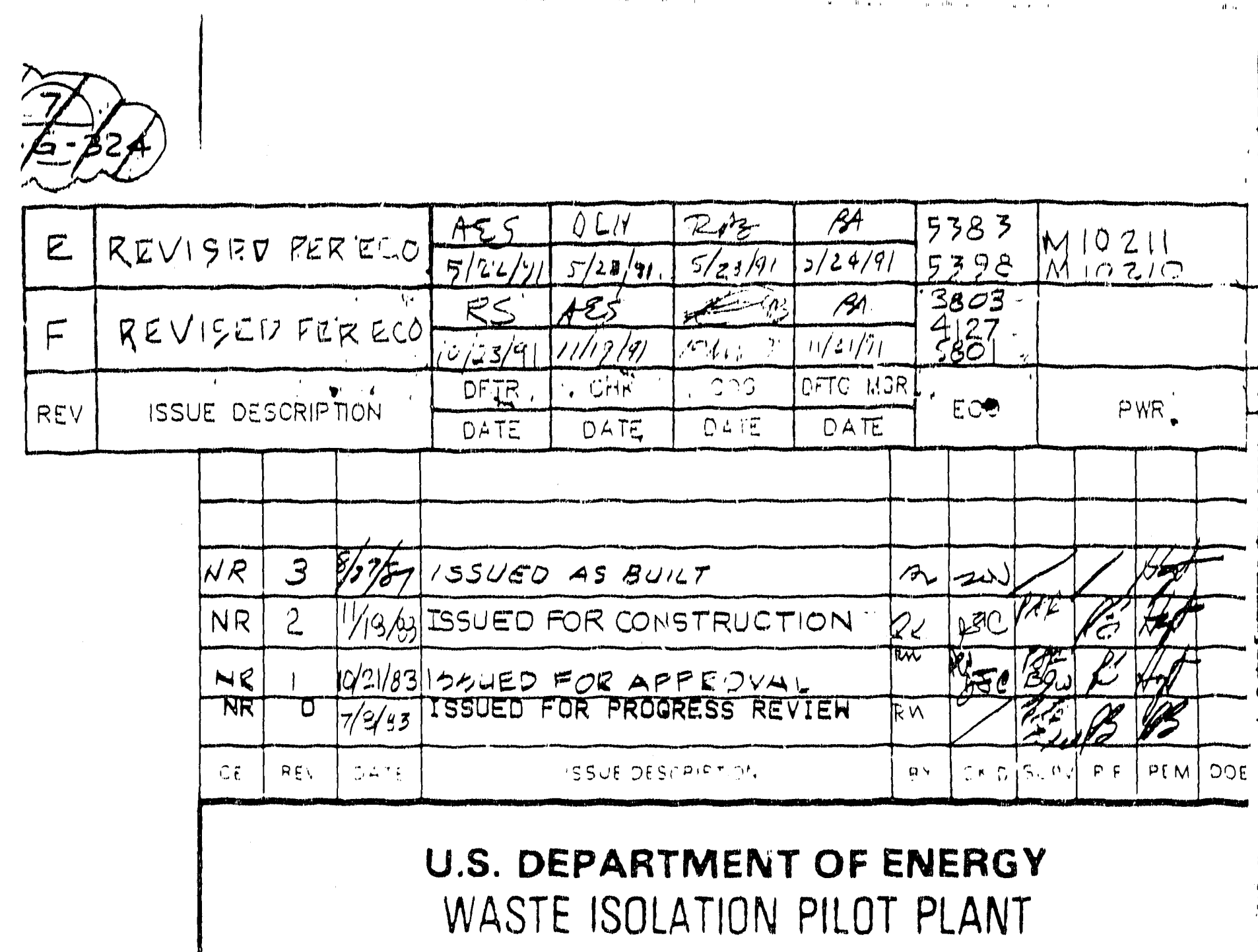

\section{SYSTEM}

HV01/02

\section{BECHTEL}

intoinis

WASTE HANDL ING BLDG 411

PIPIVG \& HVAC ARRANGEMENT

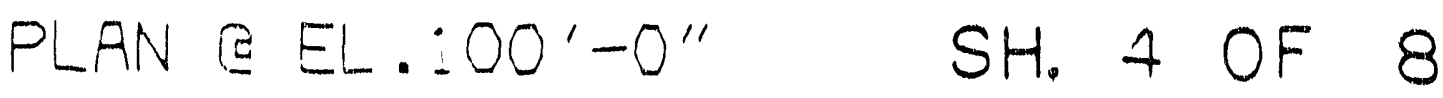

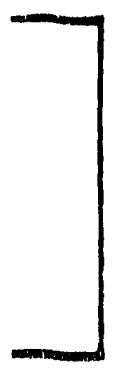

12484

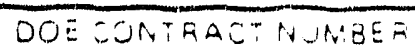

DE-AC04-79AL10751
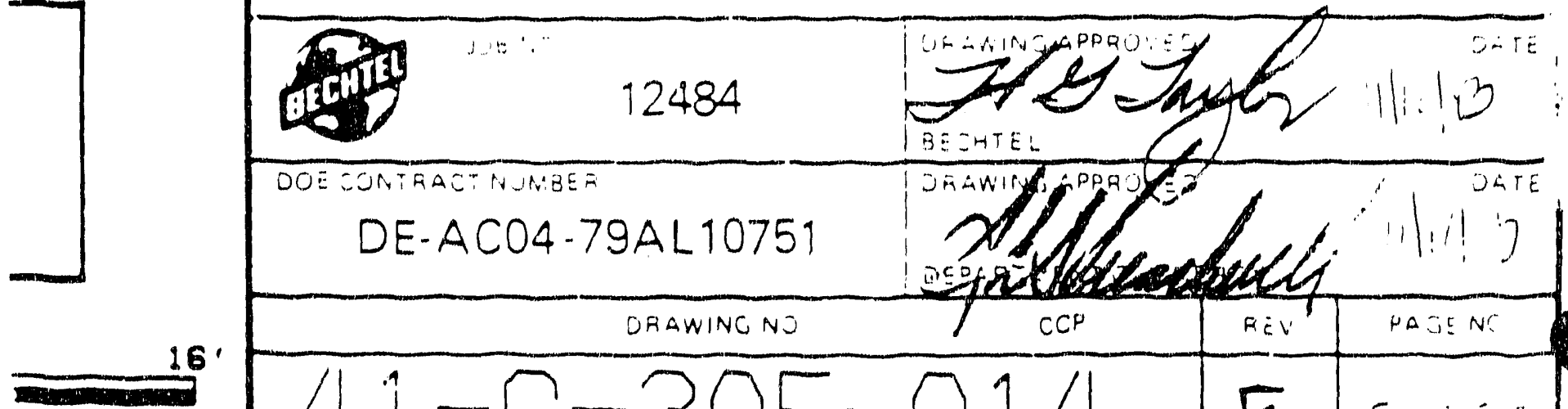

$41-6-305-014$




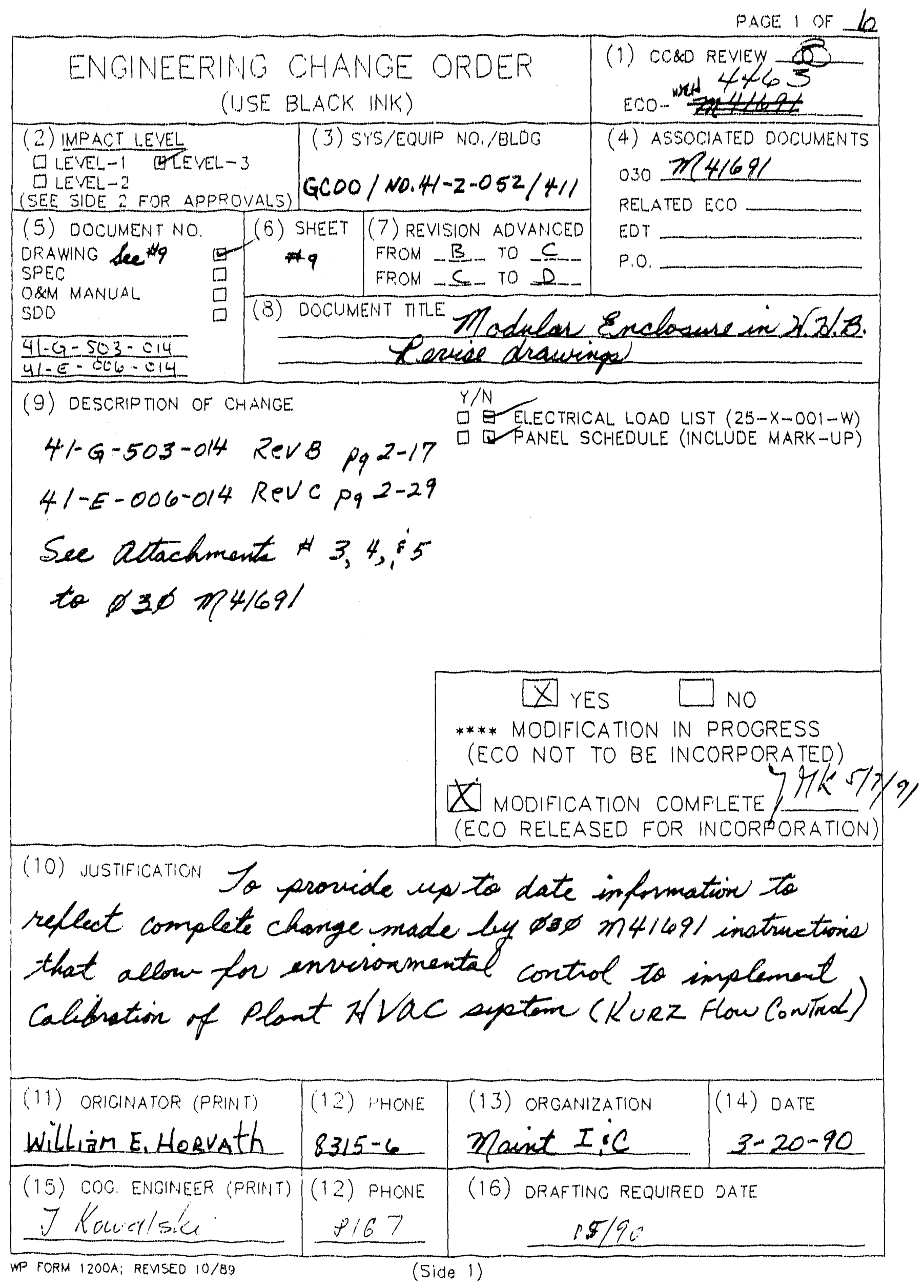


(17) RELATEO CHANGES, WNENATE THE DOCUMENTS, INSTRUCTIONS OR PROCEUUURES (OTHER THAN THE ORAMNIGS DP. DOCUNENTS IOENTIFIED IN EITHEF 5 OP. 3) THAT WILL EE AFFETEO GY THE CHANGE OESCRIBED HW ELOCK 9 . ENTER THE OOCUMENT MUMBER'SI IN BLOCK 18.

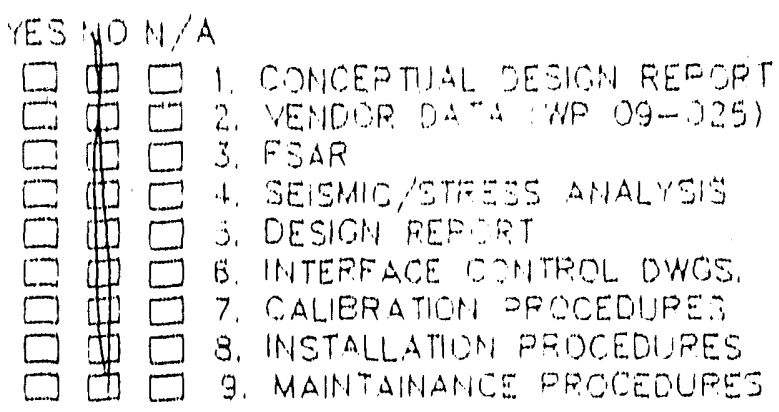
TESNONAA

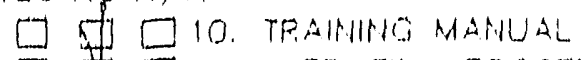

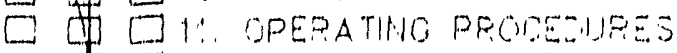
口耳

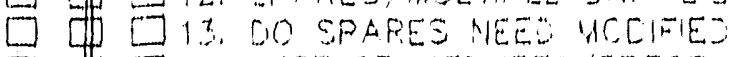

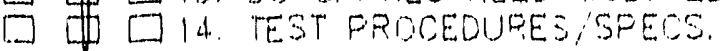

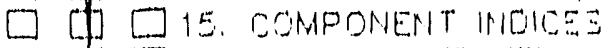
$\square$ G $\square$ 16. ASME COCEO ITENS
$\square \emptyset \square$ 17. HIMAN FACTOR CONSEEFATIONS
口回 $\square$ 13. COMPUTER SOFTHARE

(18) PELATEO COCUMENT HO; INSTRUSCTON NO, ICENTIFEE IN BLOCK 17 CHANGES TO OOCUMENTS LISTTO II BLOCK 19 WILL HOT GE NICOPRORATEO BY THIS ECO).

\section{OOCUNENT NO /PEVISION}
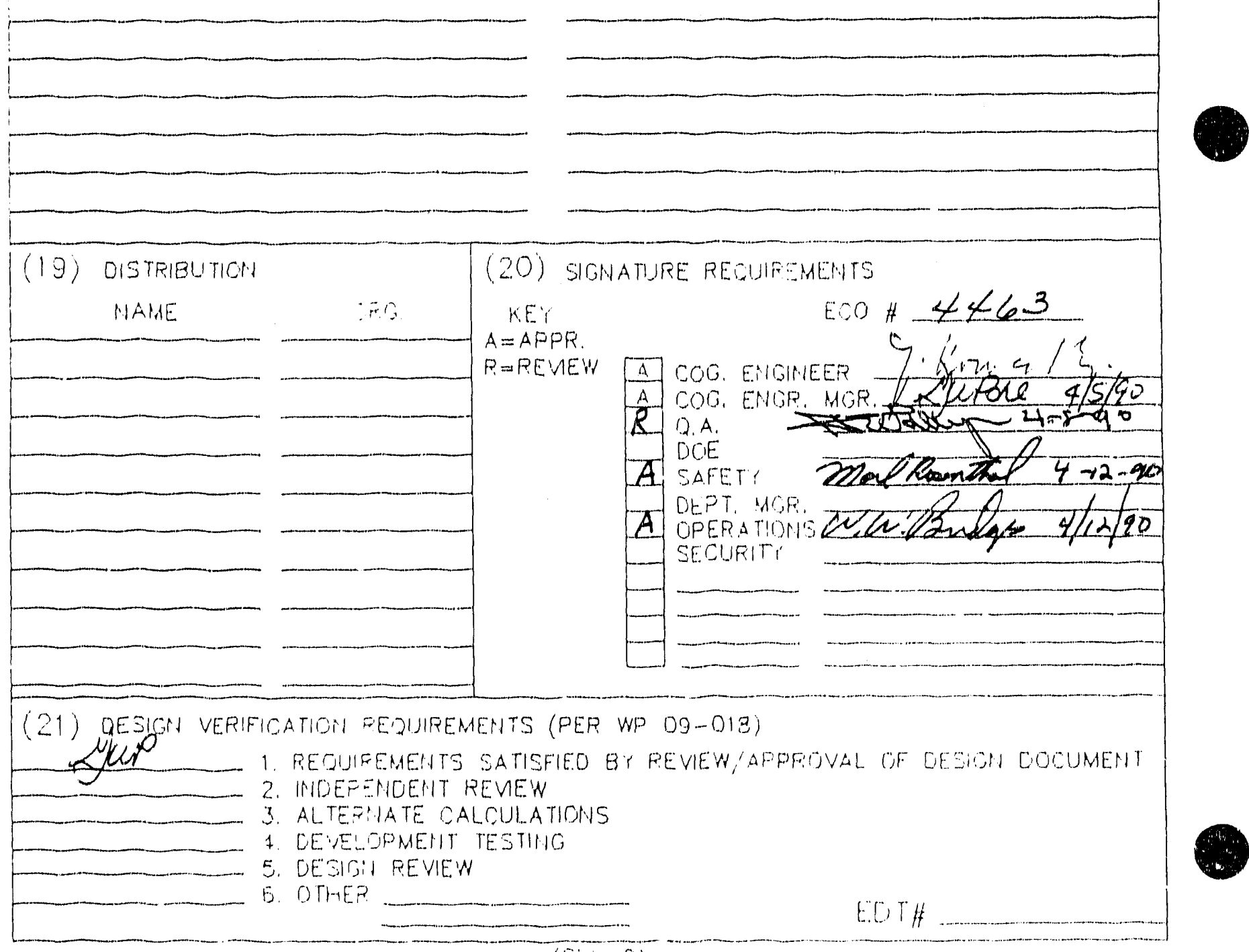


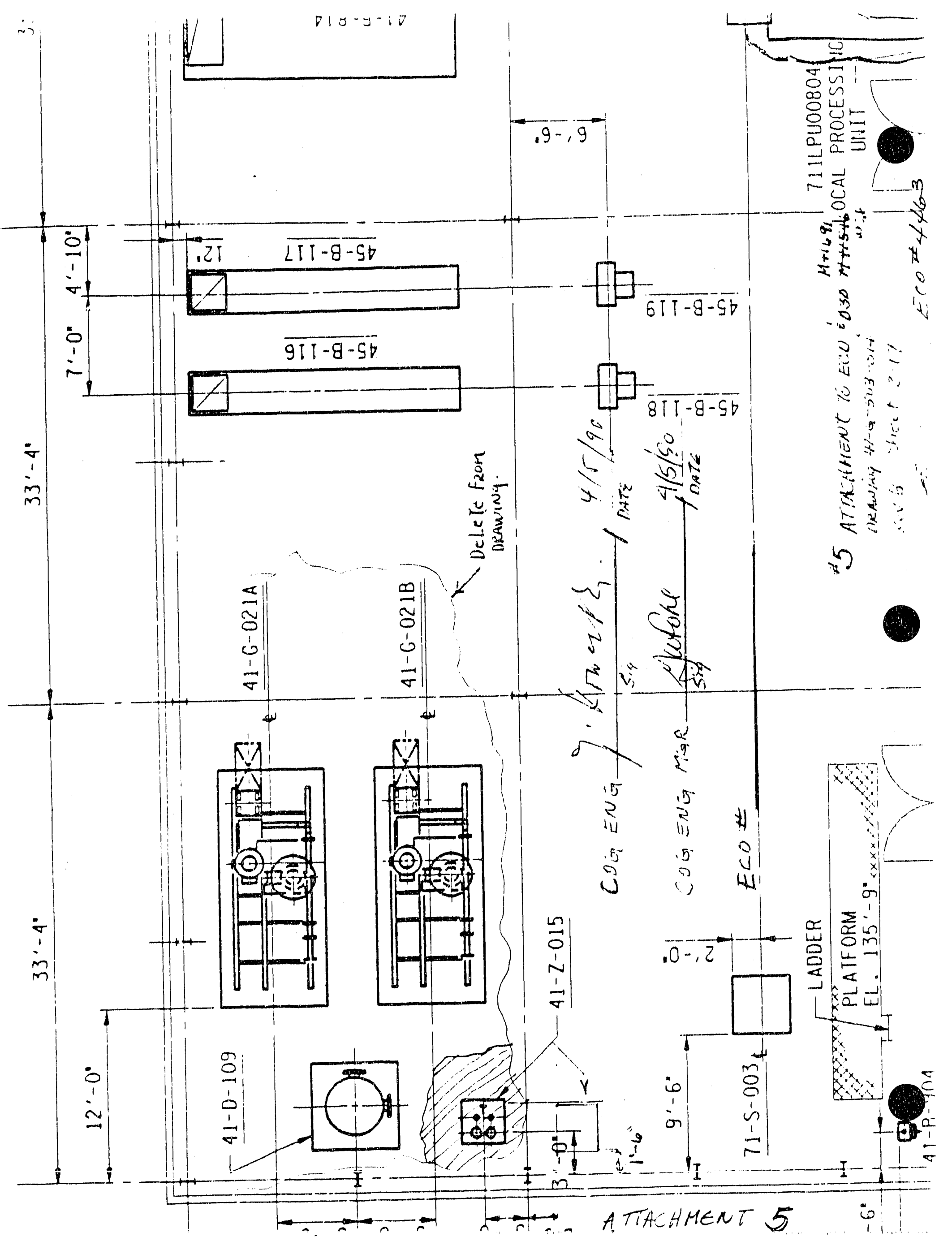




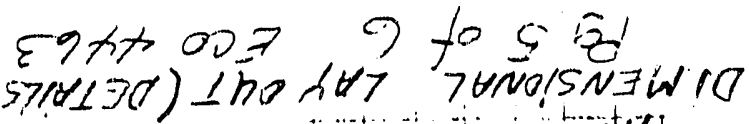

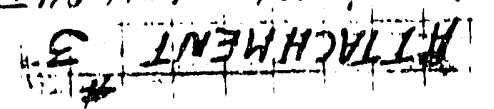
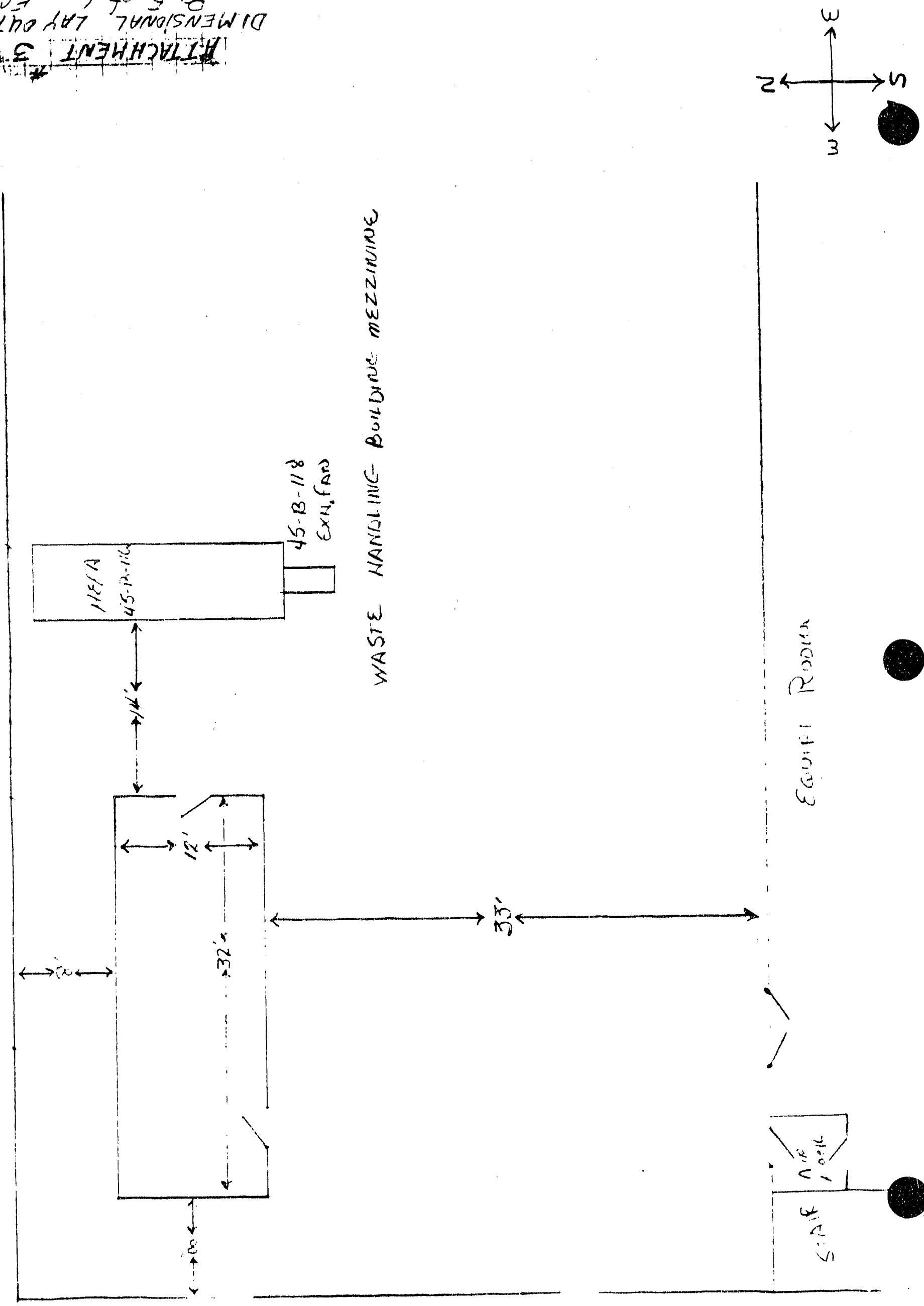

$\frac{2}{2}$

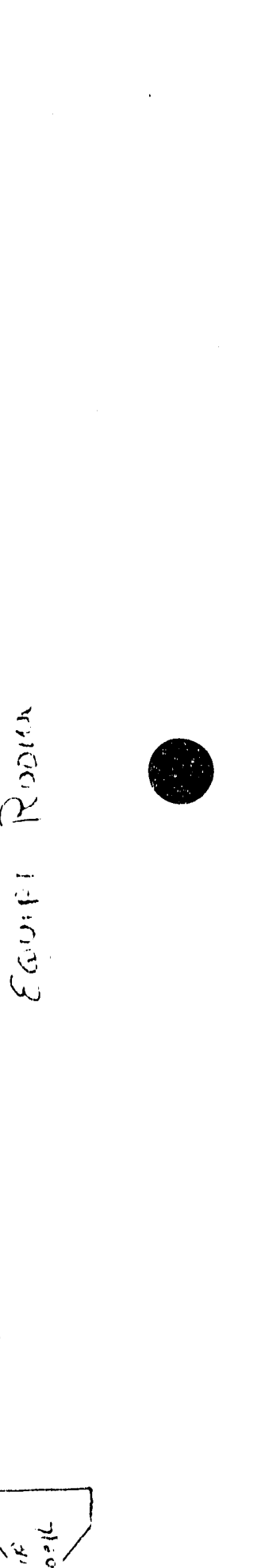

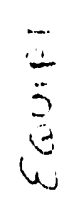

$\gamma$

I

$\backslash \underset{1}{2}$

u

i) 


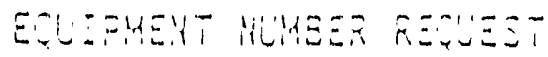

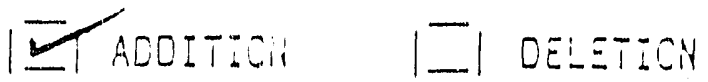

1. EUTHEVT MUEZR NO.

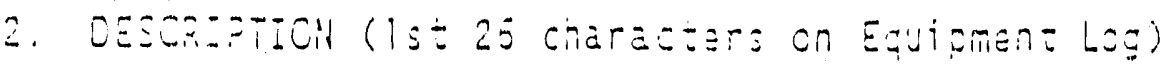

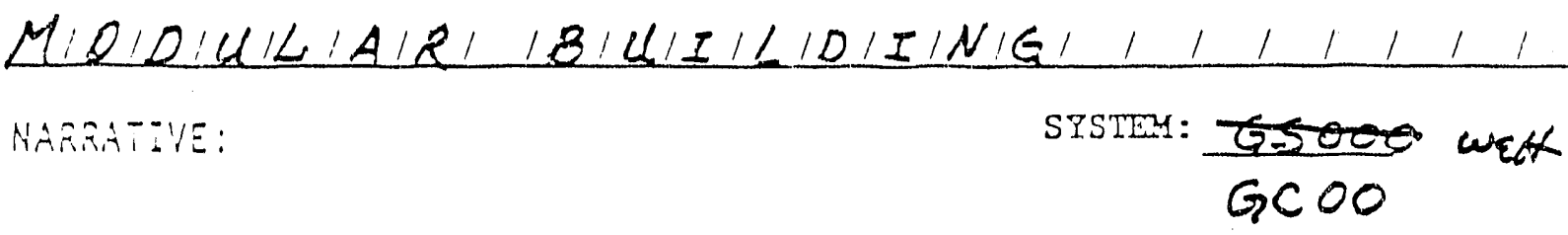

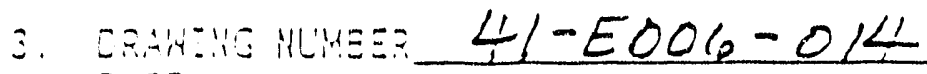

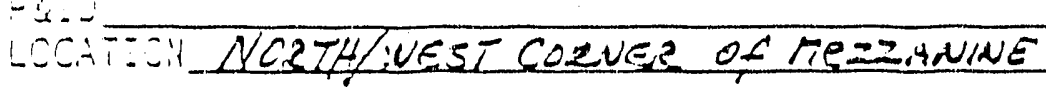

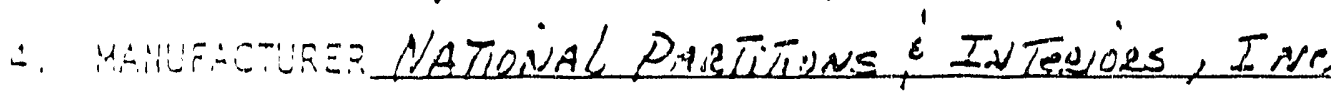

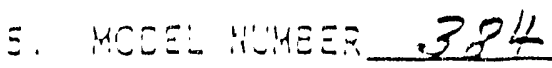

SEFEAL NLLEER N/A

E. RELATEC CO SFEC MUHEER

7. FURCHEREUUEZTUN UUEER PR $356 \% 8$

OATE FURCHASED

CHACEACET. WUEER $\frac{2113.00}{\text { WAS } 24501}$

3. COG MCR/EUGIUEER

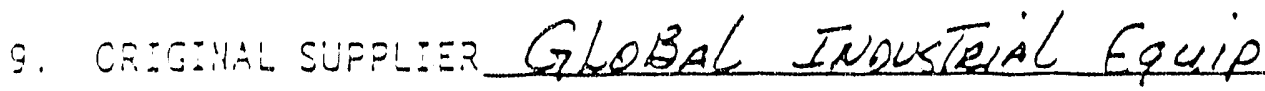

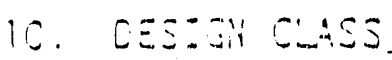
GLALITIY COOE

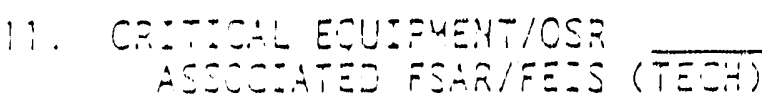
YEE

12. SFIAE FIRTS IEEVTIFEEJ YES FCSBIELE SUFFLIER GLODBAL INDUSTRIAL EqUiP

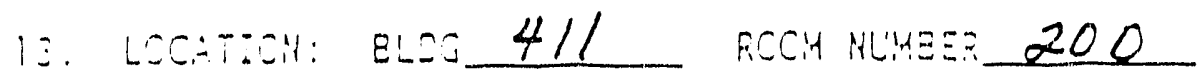

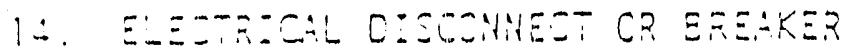

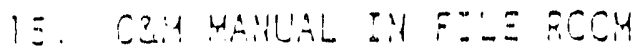
Y 5 NO

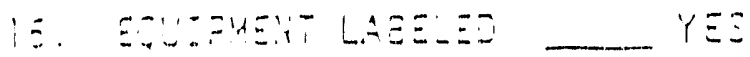

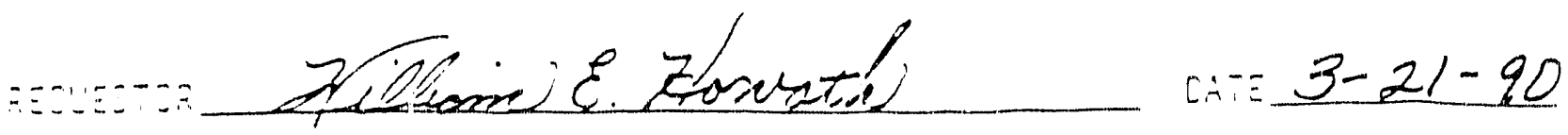

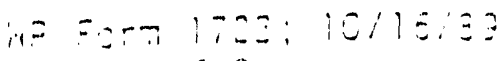

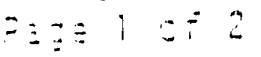

ECD $4+63$

Fige 6 of 6 
PAGE 1 OF $: i^{\prime}$

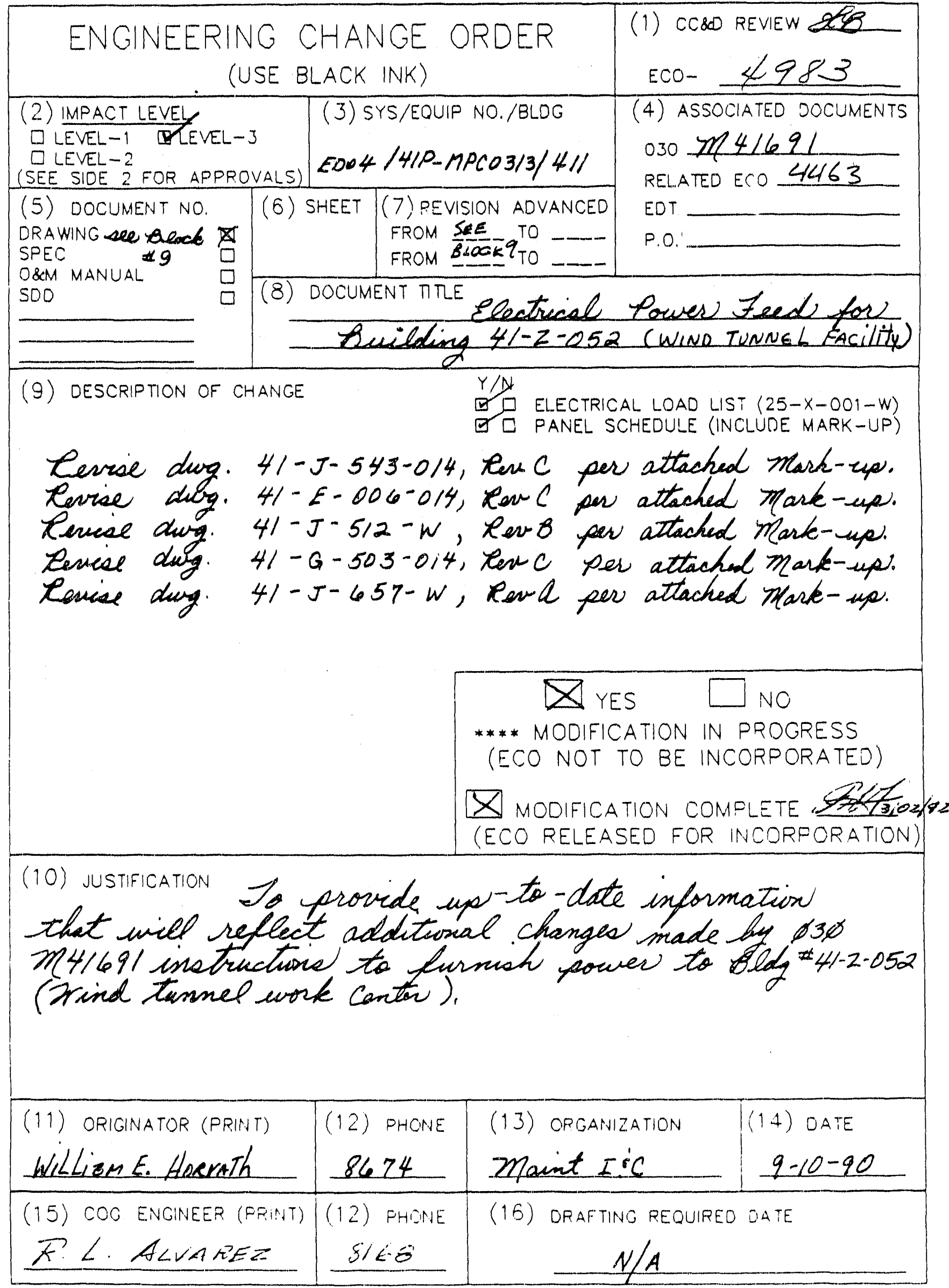


(17) RELATED CHANGES: INDICATE THE DOCUMENTS, INSTRUCTIONS OR PROCEUURES (OTHER THAN THE DRAWNGS OR DOCUMENTS IDENTIFIED IN EITHER 5 OR 9) THAT WILL BE AFFECTED BY THE CH.ANGE DESCRIBED IN BLOCK 9. ENTER THE DOCUMENT NUMBER(S) IN BLOCK 18.

YES NON/A

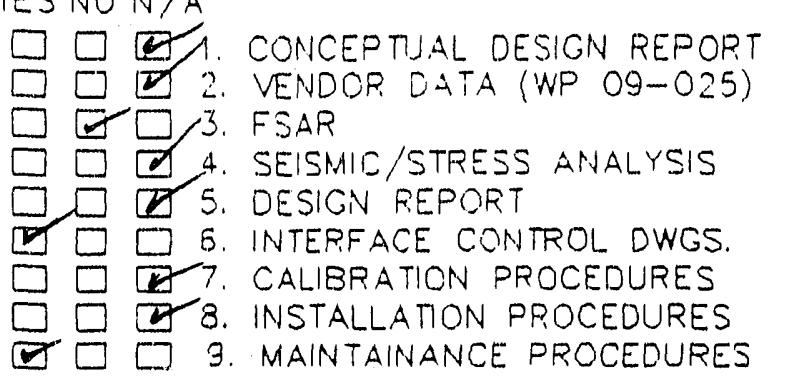

YES NO N/A

$\square \square \square$ 10. TRAINING MANUAL

$\square \square$ 11. OPERATINC PROCEDURES

$\square \square$ 12. SPARES/MULTIPLE UNIT LISTINGS

$\square$ 13. DO SPARES NEED MODIFIEO

XUR $\triangle 14$. TEST PROCEDURES/SPECS.

$\square \square$ 15. COMPONENT INDICES

$\square \square$ 16. ASME CODED ITEMS

$\square \square$ 17. HUMAN FACTOR CONSIOERATIONS

$\square \square$ 18. COMPUTER SOF TWARE

(18) RELATED DOCUMENT ND.; INSTRUCTION NO.; IDENTIFIED IN BLOCK 17. (CHANGES TO DOCUMENTS LISTED IN ELOCK 18 WILL NOT BE INCOPRORATED BY THIS ECO).

\section{COCUMENT' NO. REVISION}

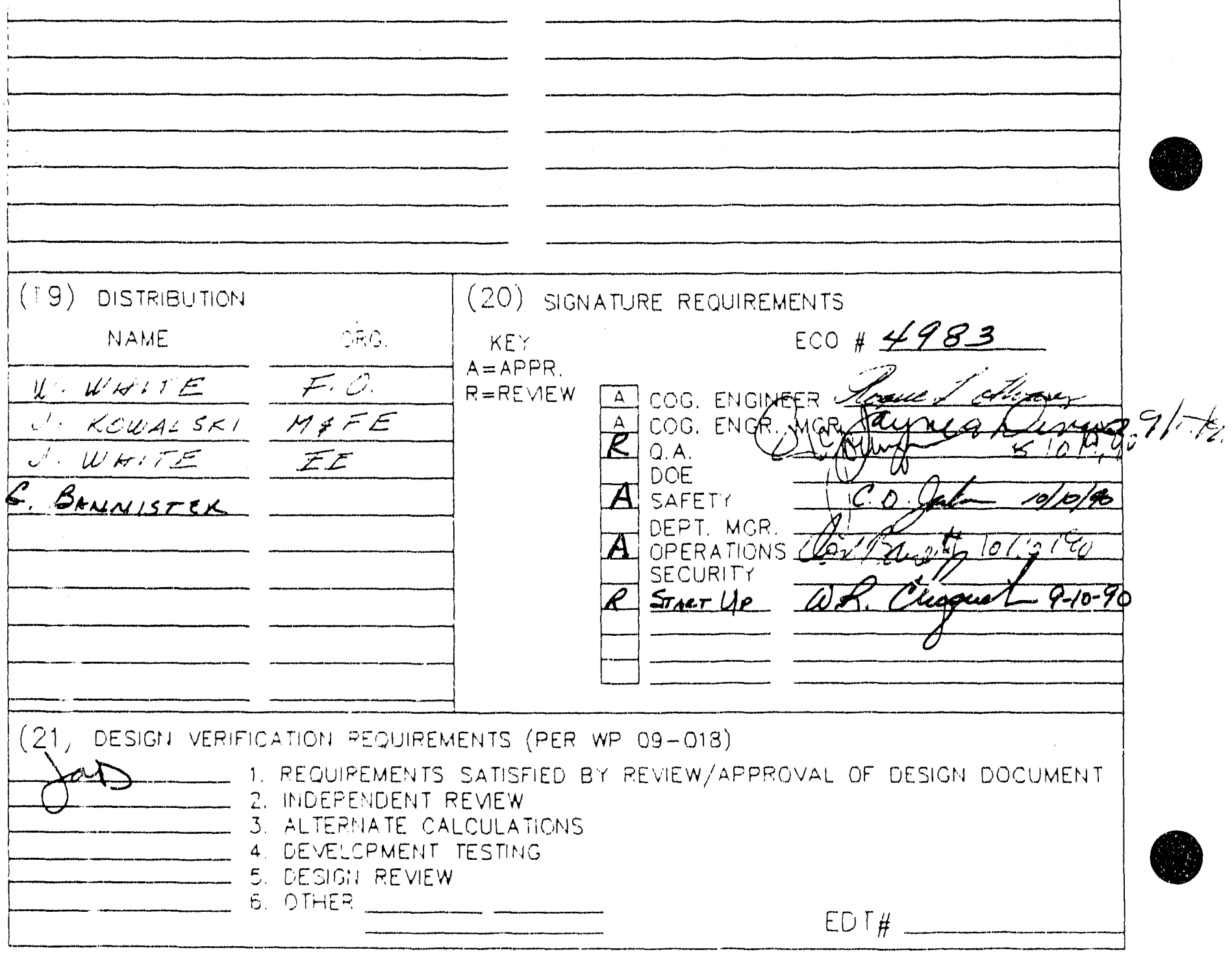




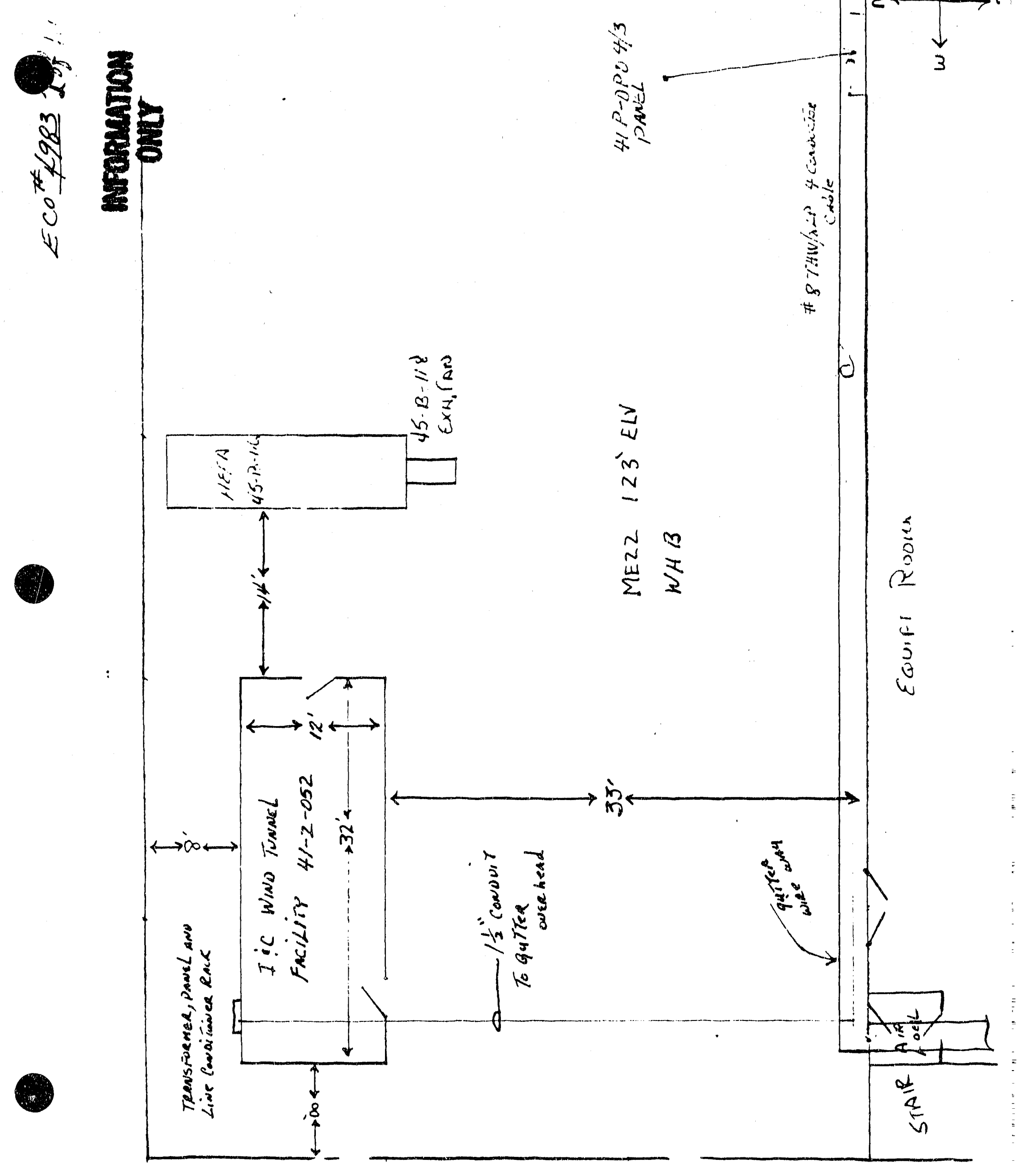




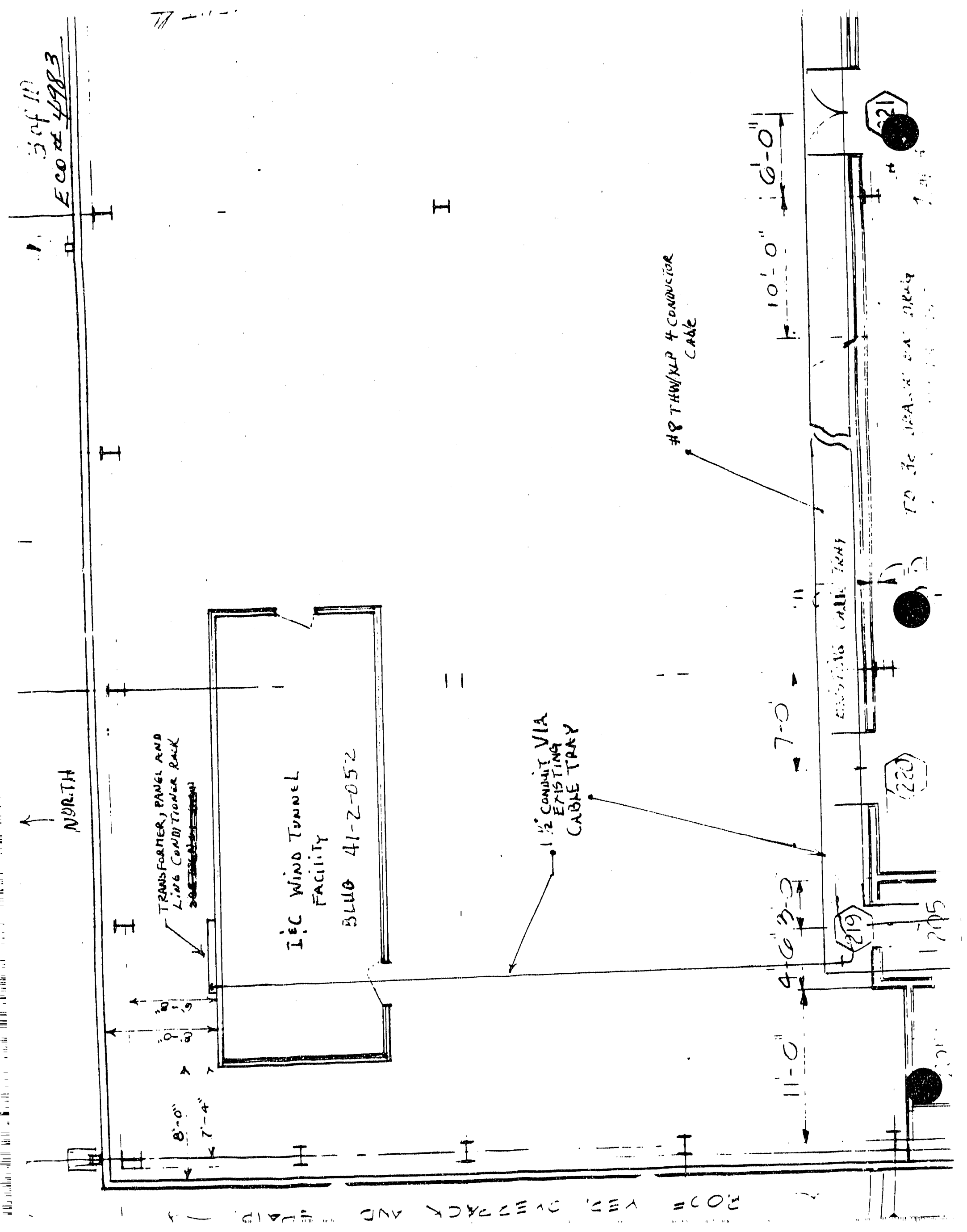


-

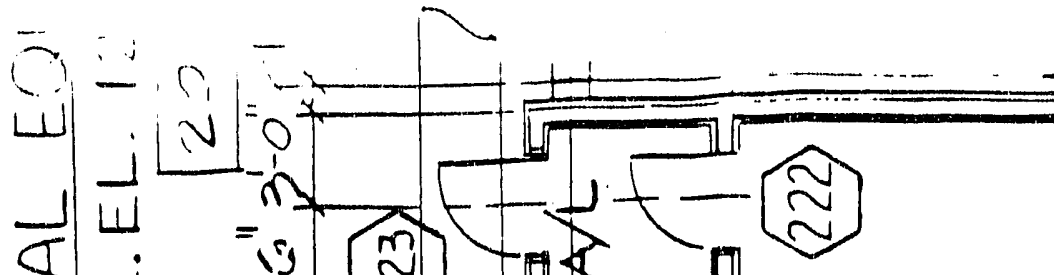

$i$

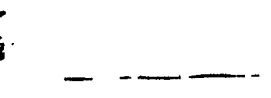

$-$

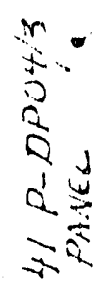

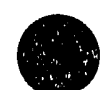

突|

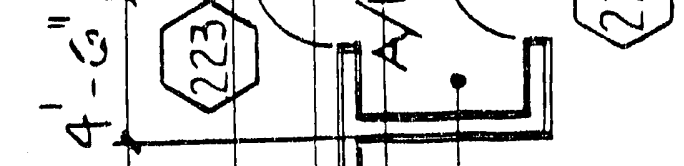

$-$

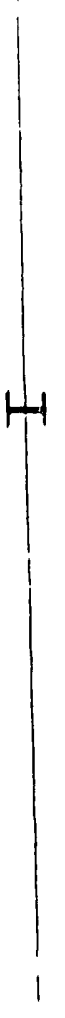

|il

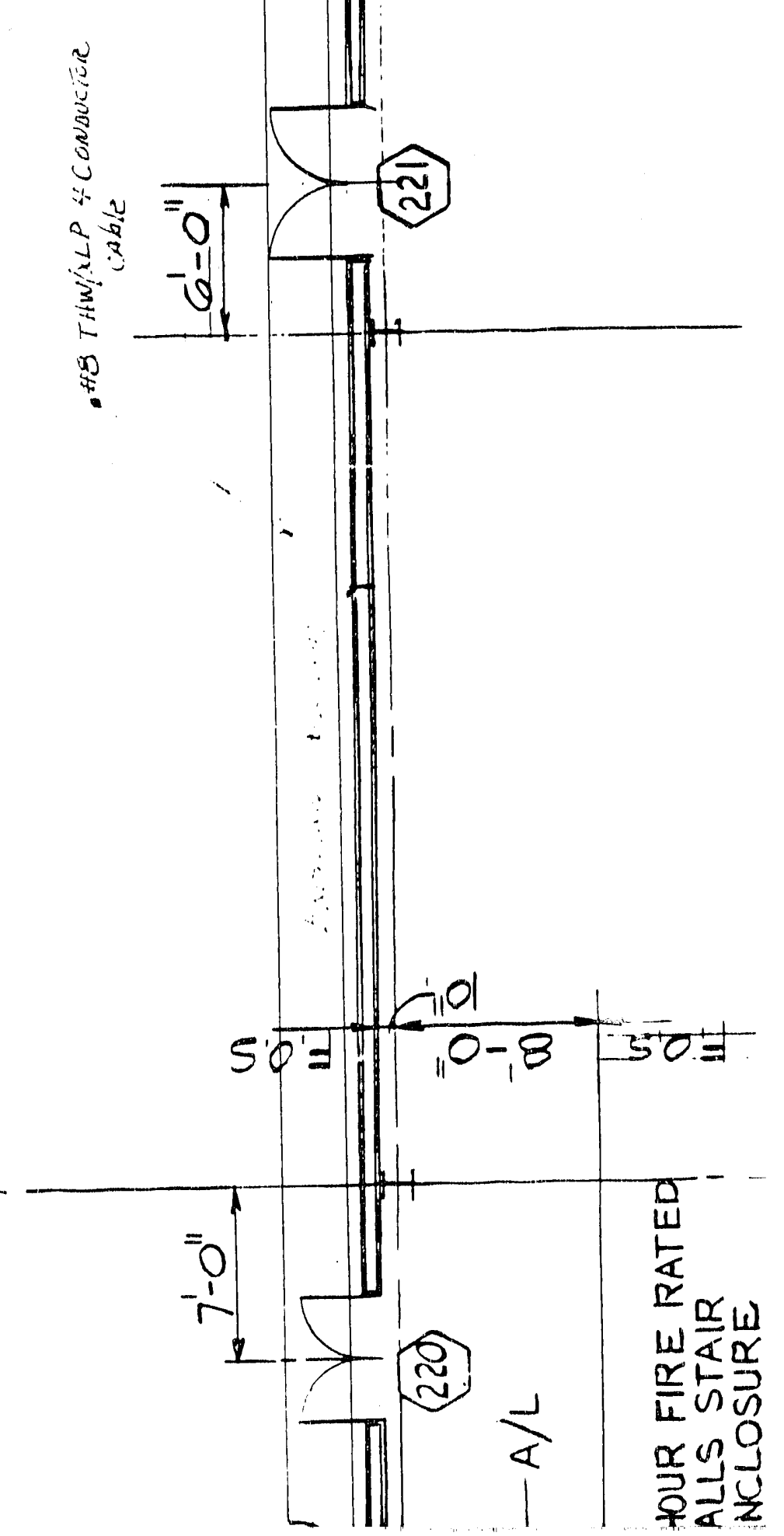




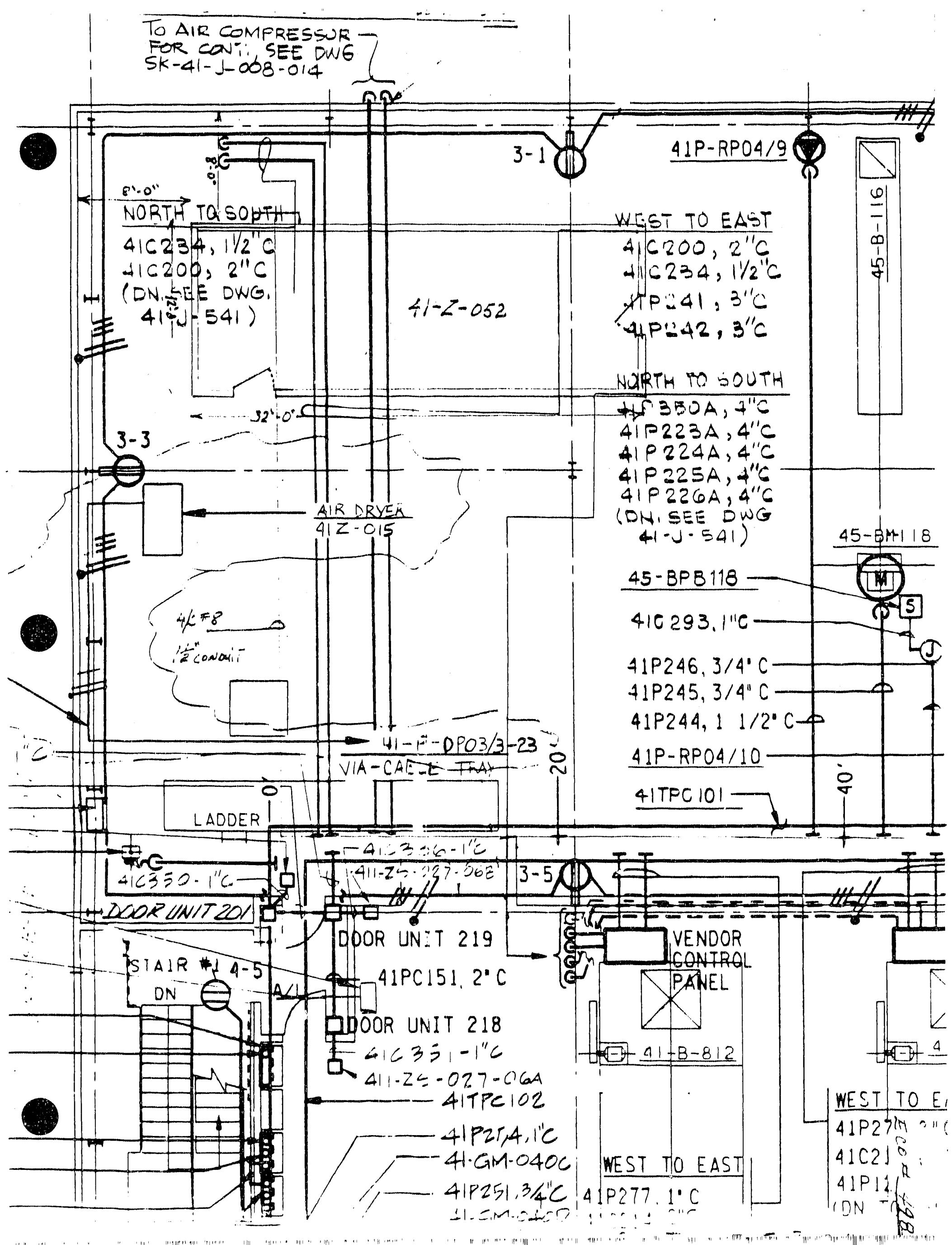




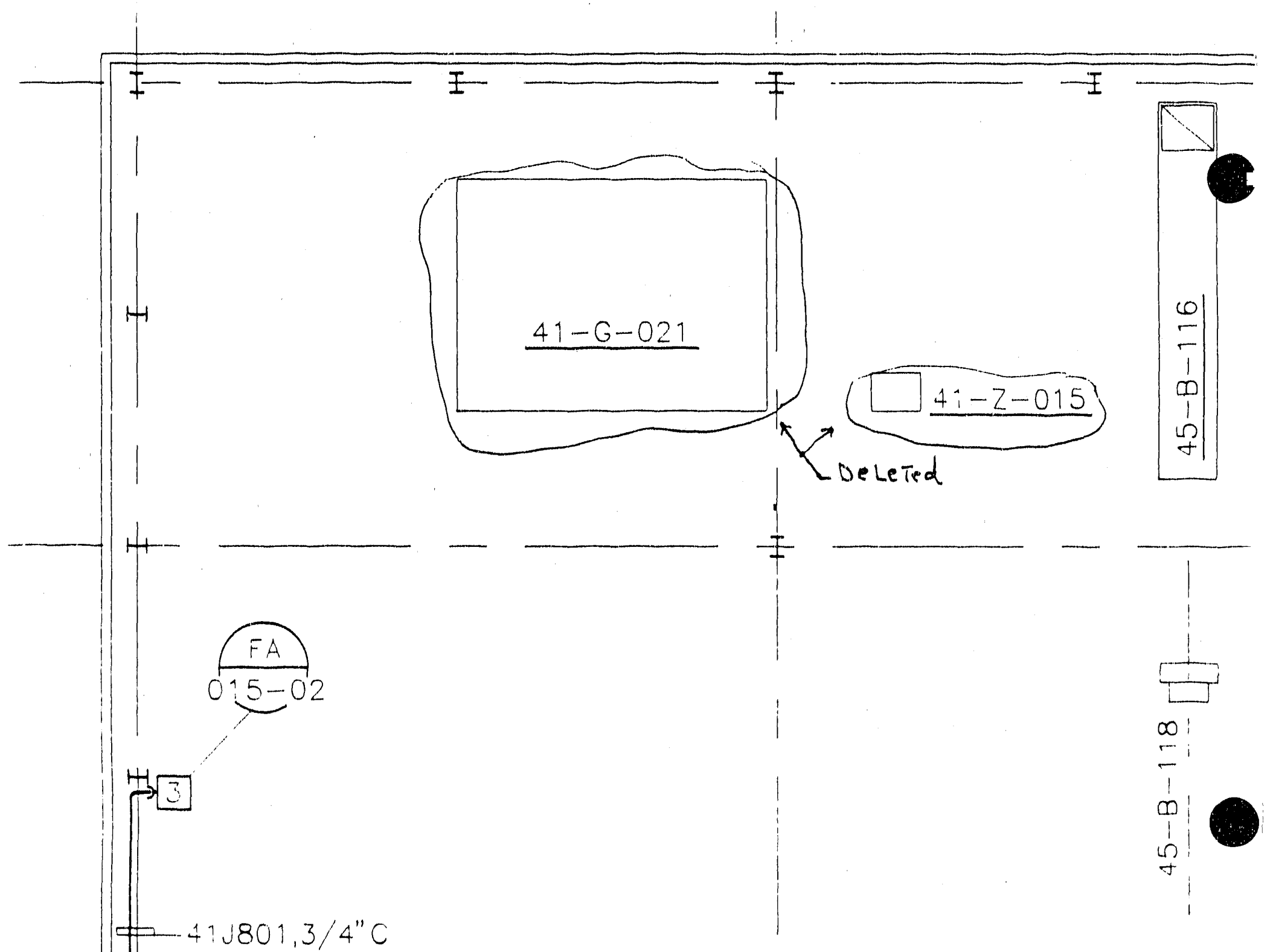

MECHANICAL EQUIPMENT

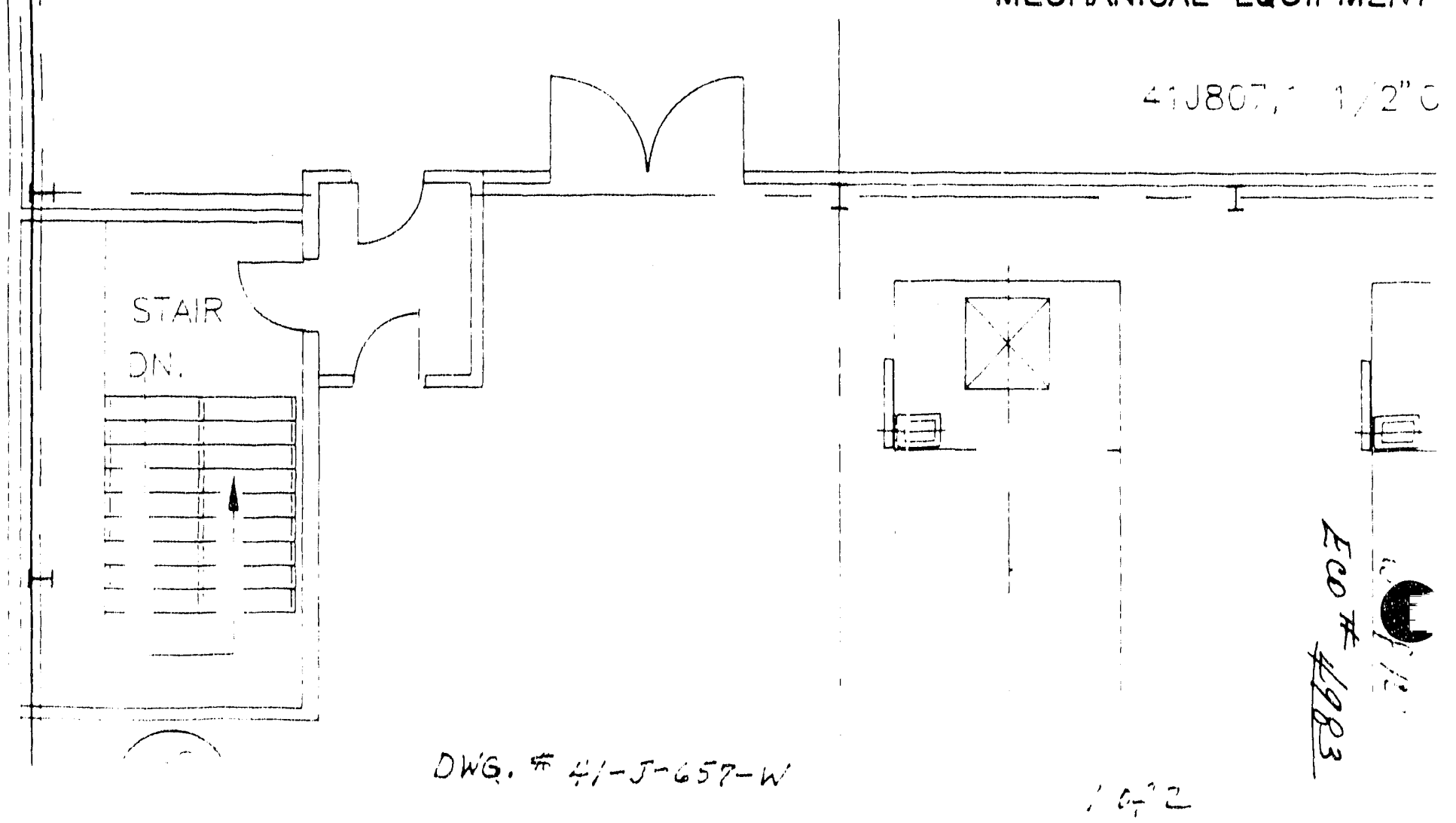




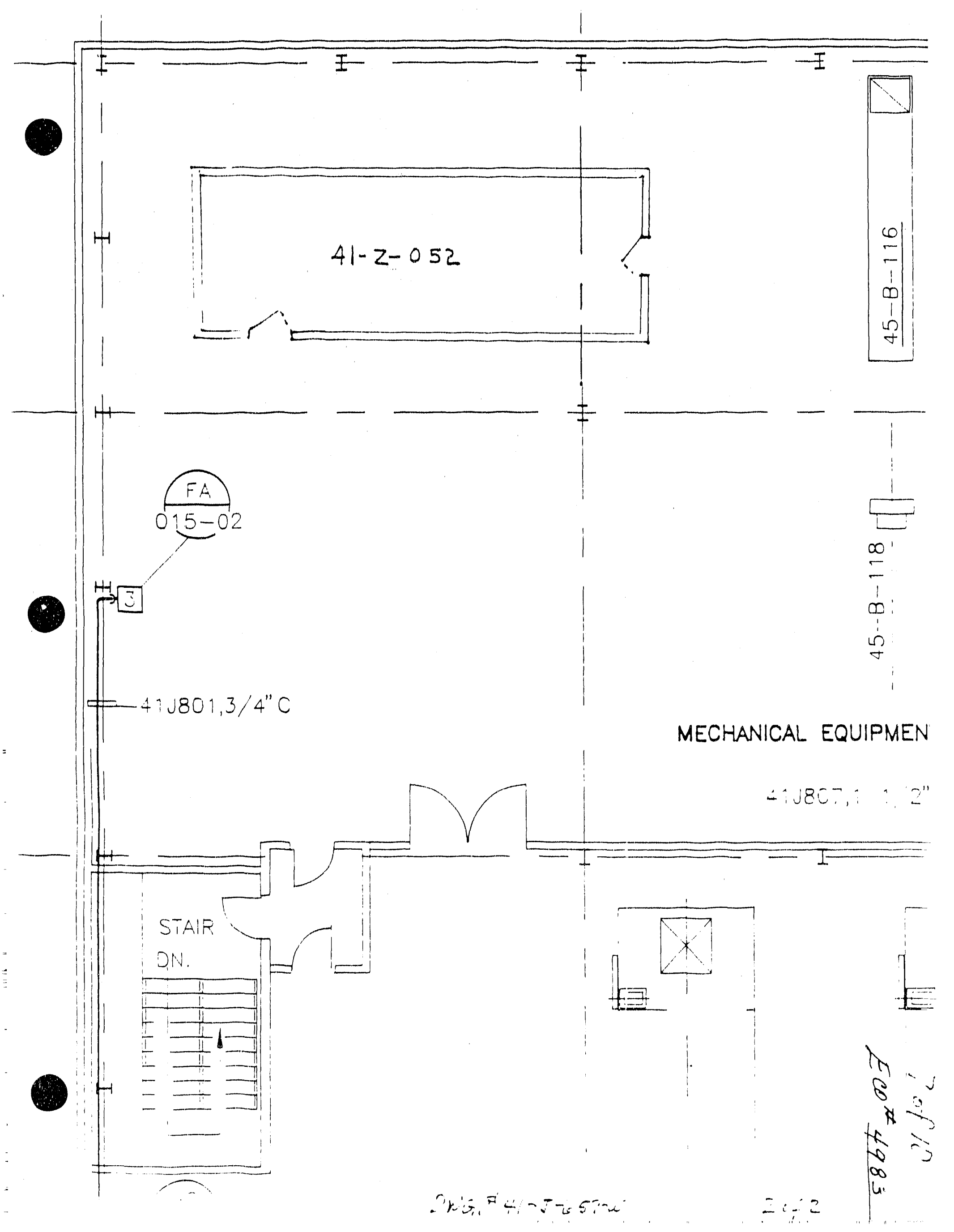



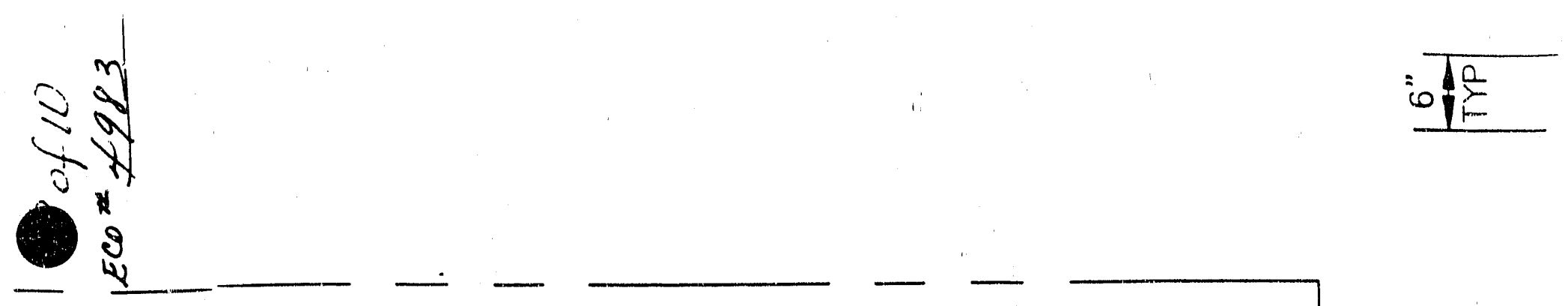

$\because$ HEL $\quad H P-D, P O 4 / 3$

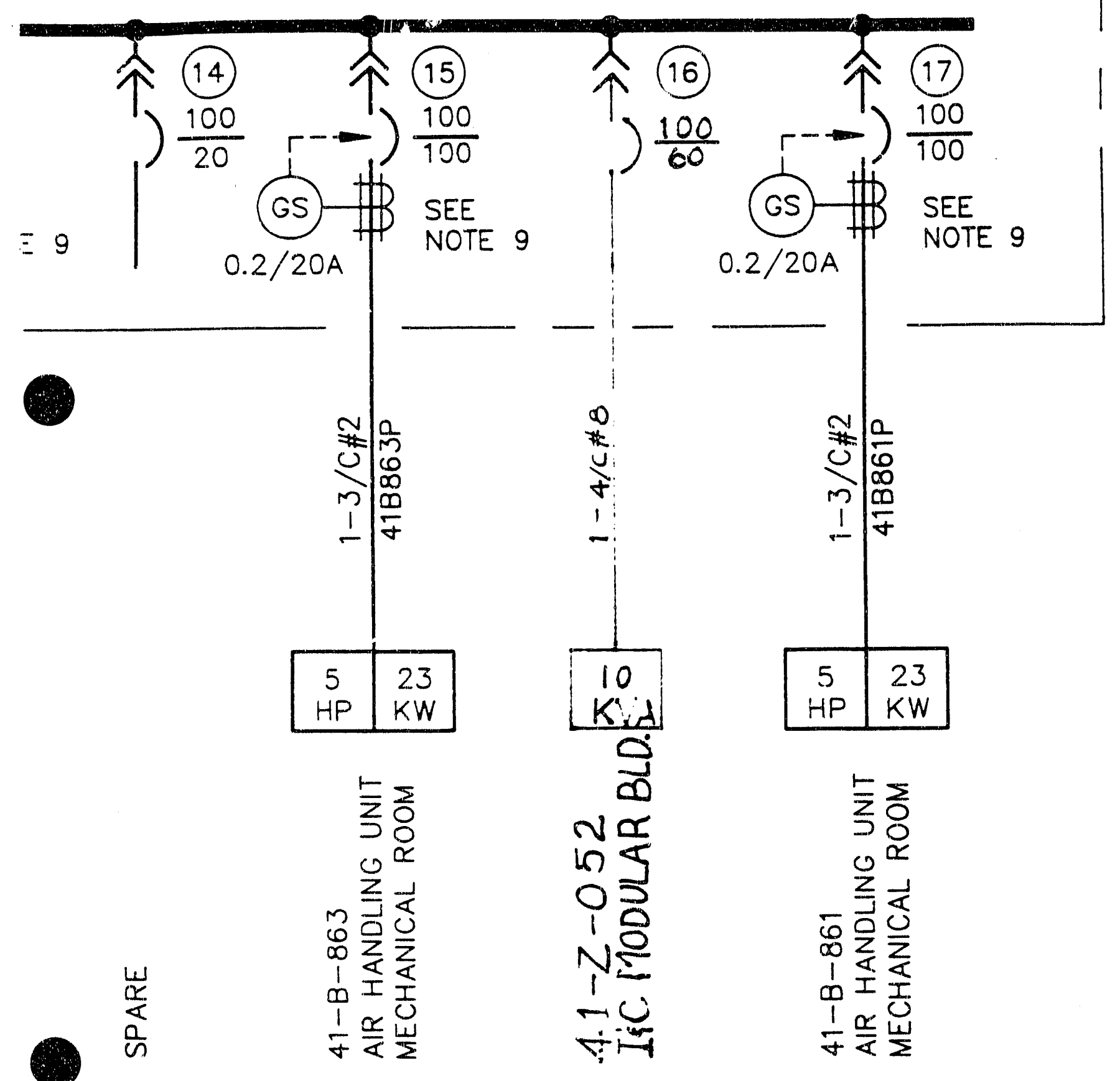

$D W G$ T1-J-5.2-W 


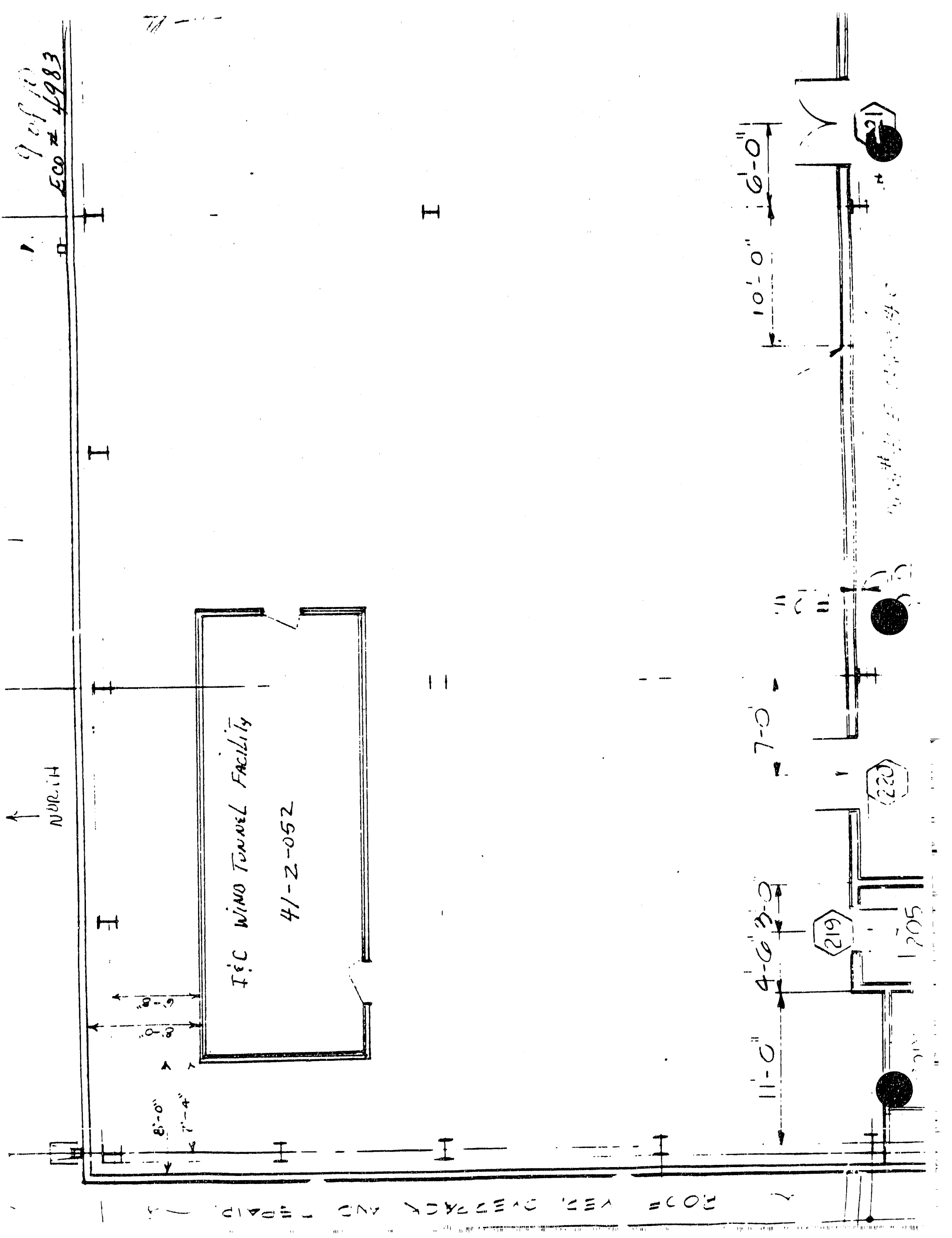




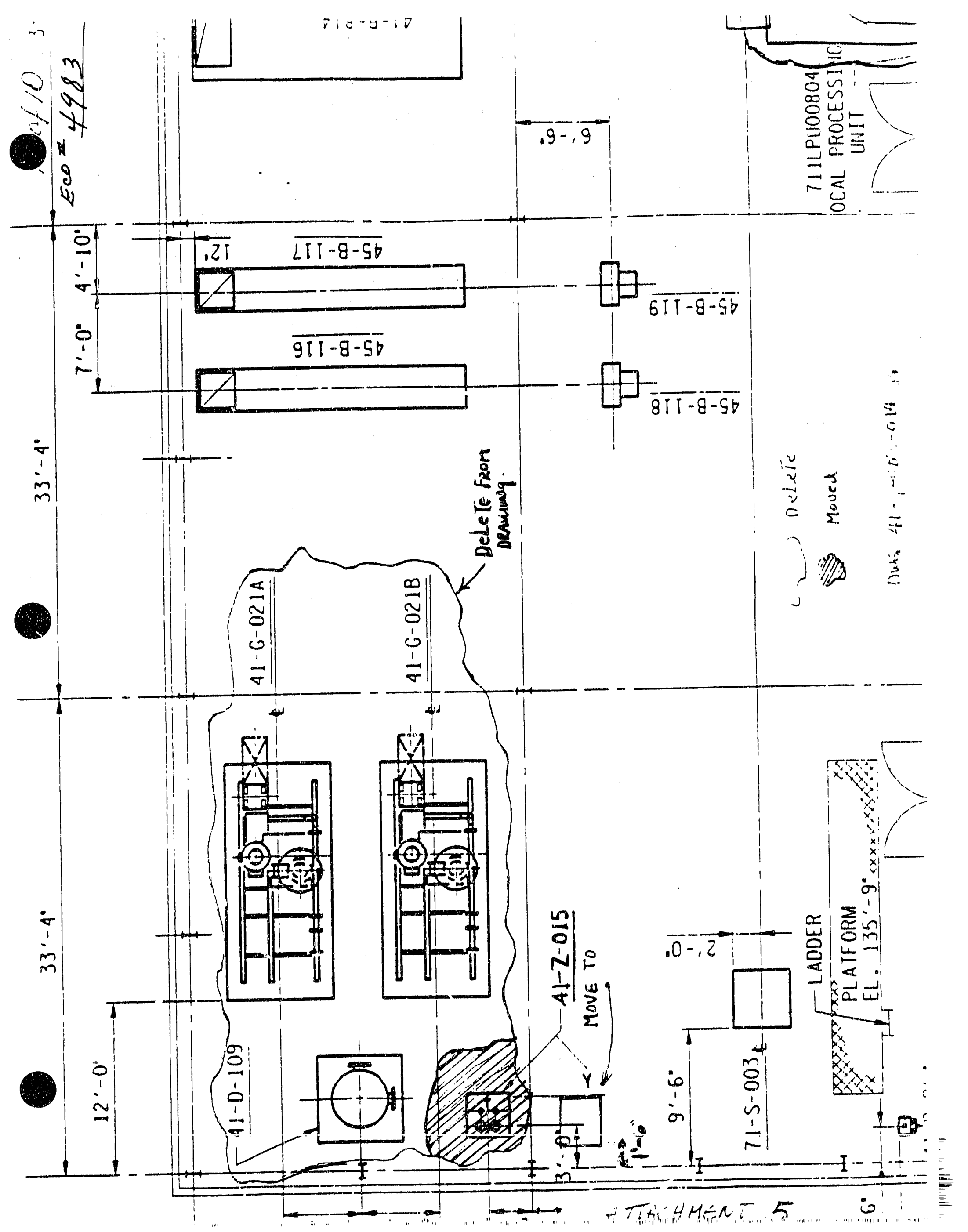


ECO 4 480

ATTACHMENT 2

WP 09-021. Rev. 2
Page 1 of 2

EQUIPMENT NUMBER REQUEST

IE T addition II Deletion

1. EQUIPMENT NUMBER $4 / P-M P C 03 / 3$

2. DESCRIPTION ( 1st 26 characters on Equipment Log)

MIIINIII IPIOIWIEIRI I GIEINITIELAI

NARRATIVE:

SYSTEM: EDO 4

3. DRAWING NUMBER $41-5-543-0 / 4$ P\&ID LOCATION WHF. REVEL ILS' MEZZANINE MECHANICAL AREA

4. manufacturer square " $D$ " Company

5. MODEL NUMBER MPZIDSUDE

SERIAL NUMBER__ NSA

6. RELATED CCP N/A SPEC NUMBER

7. PURCHASE REQUISITION NUMBER $N / A$

DATE PURCHASED

PURCHASE COST

CHARGE ACCT. NUMBER

8. COG MGR/ENGINEER Jane DAVIS/ALVAREZ

9. ORIGINAL SUPPLIER

10. DESIGM CLASS QUALITY CODE

11. CRITICAL EQUIPMENT/OSR YES ${ }_{\text {SPECS }}$ ASSOCIATED FSAR/FEIS (TECH) SPECS

12. SPARE PARTS IDENTIFIED YES POSSIBLE SUPPLIER SqUACE"D"CO

13. LOCATION: BLDG $4 / /$ ROOM NUMBER

14. ELECTRICAL DISCONNECT OR BREAKER

15. O8M MANUAL IN FILE ROOM YES No

16. EQUIPMENT LABELED YES No REQUESTOR Ztowatb DATE $9-10-90$

WP Form 1723; 4/20/90 Page 1 of 2 


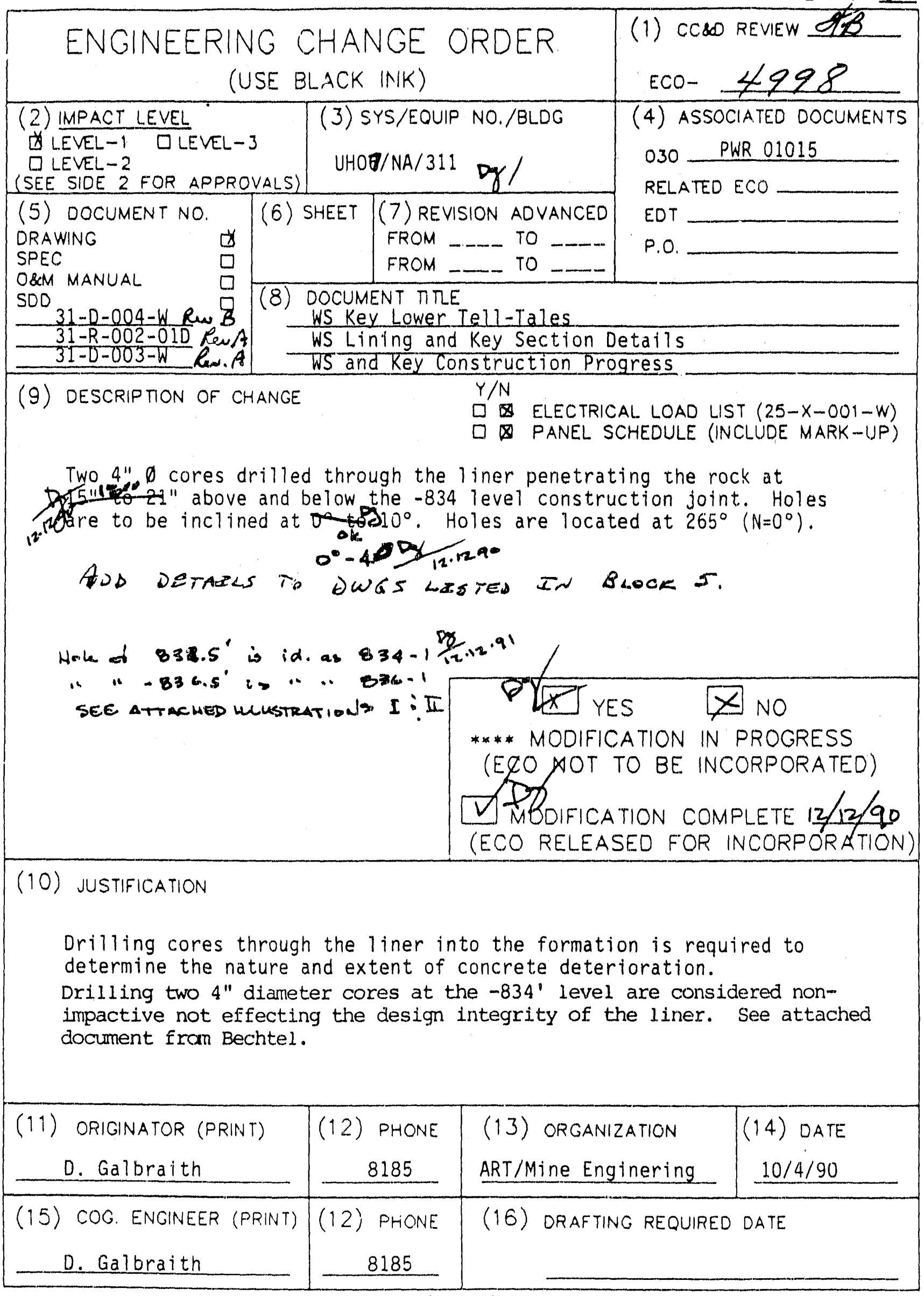


(17) RELATED CHANGES: INDICATE THE DOCUMENTS, INSTRUCTIONS OR PROCEDURES (OTHER THAN THE ORAMINGS OR DOCUMENTS IDENTIFIED IN EITHER 5 OR 9) THAT WILL BE AFFECTED BY THE CHANCE DESCRIBED IN BLOCK 9 . ENTER. THE DOCUMENT NUMBER(S) IN BLOCK 18.

YES NO N/A

$\square$ CONCEPTUAL. DESICN REPORT

$\square \square \square$ 2. VENOOR OATA (WP OS-025)

$\square \square[\bar{X}$ 3. FSAR

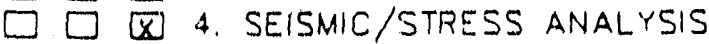

$\square \square 凶$ 5. OESICN REPORT

$\square \square \square$ I INTERFACE CONTROL OWGS.

$\square \square \square$ 7. CALIBRATION PROCEDURES

$\square \square \square$ 8. INSTALLATION PROCEDURES

$\square \square \square$ 9. MAINTAINANCE PROCEDURES
YES NO N/A

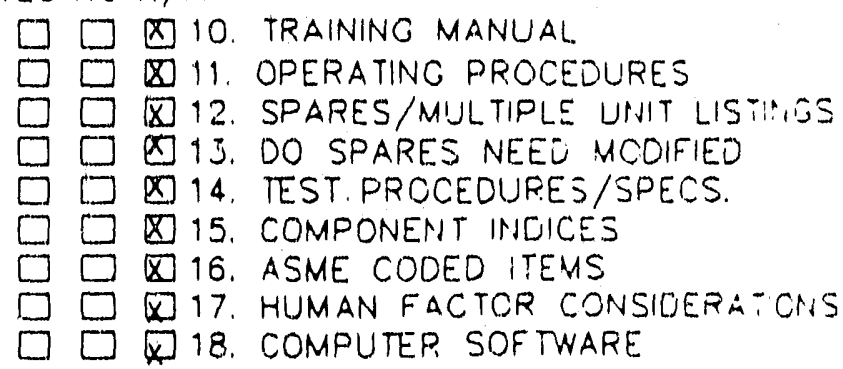

(18) PELATED DOCUMENT NO.; INSTRUCTON NO; IDENTIFIED IN BLCIKK 17. ICHANGES TO DOCUMENTS LISTED IN BLOCK 18 WILL NOT BE INCOPRCRATED BY THIS ECO).

DOCUMEN'. NO LREVISION

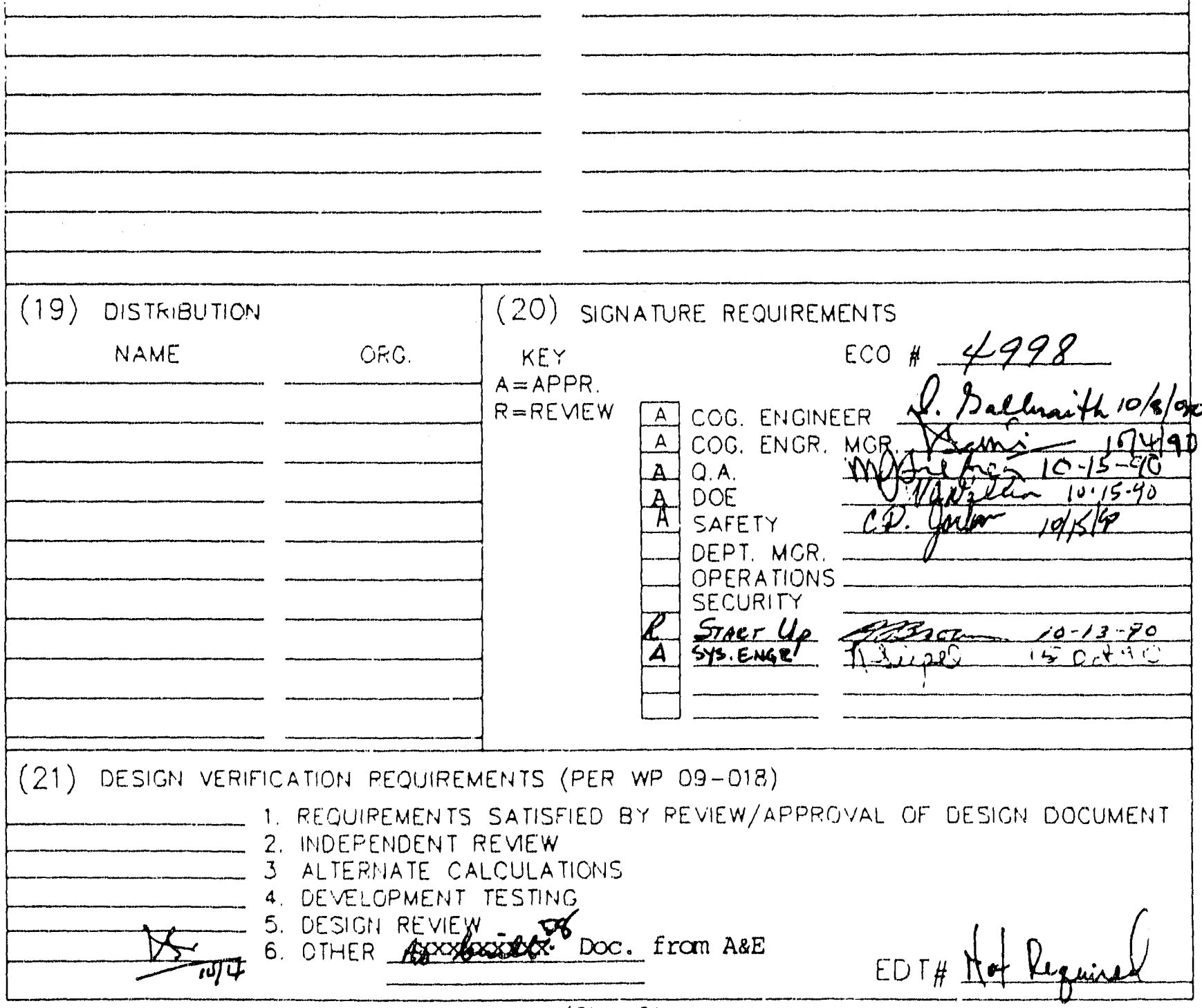




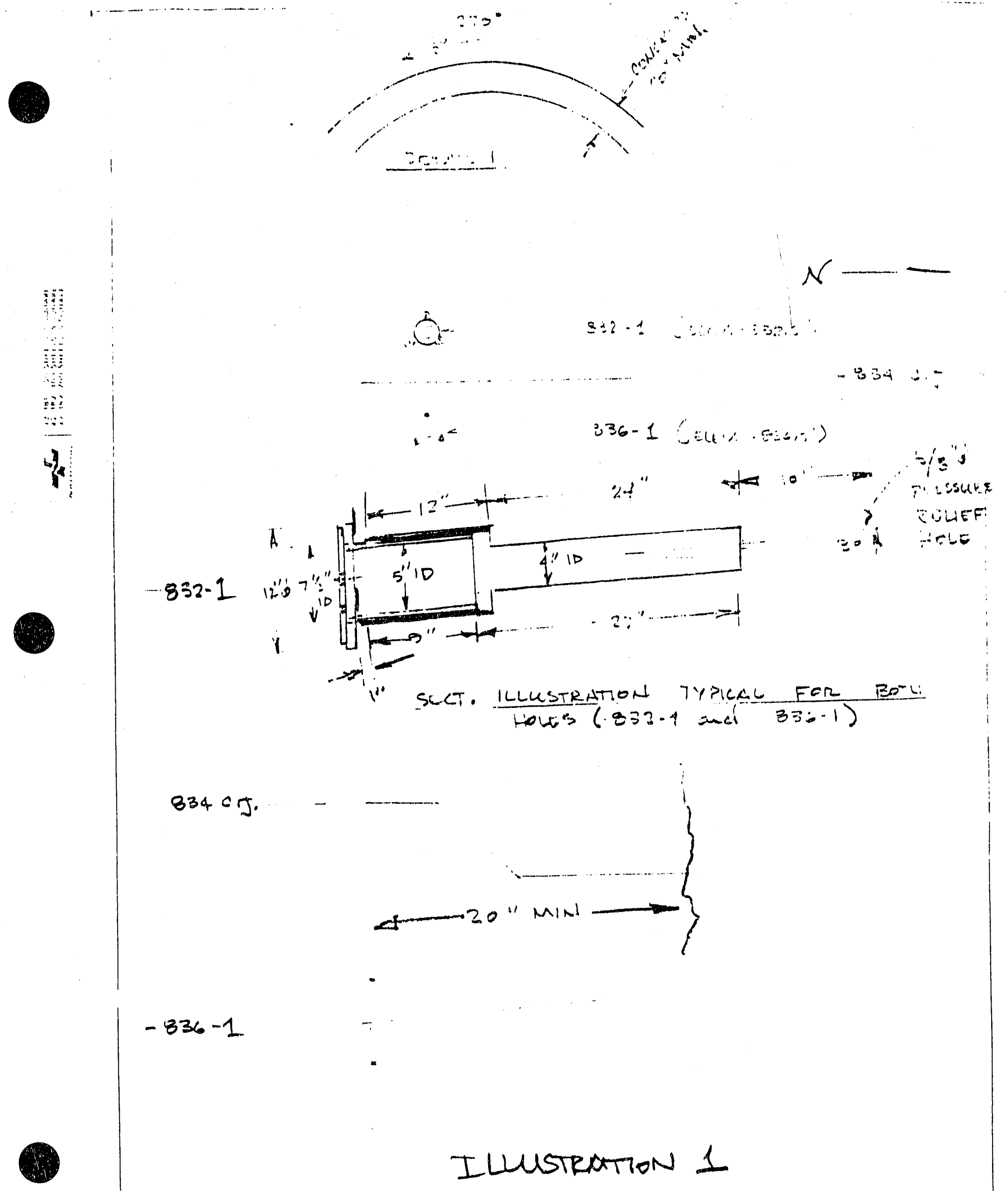




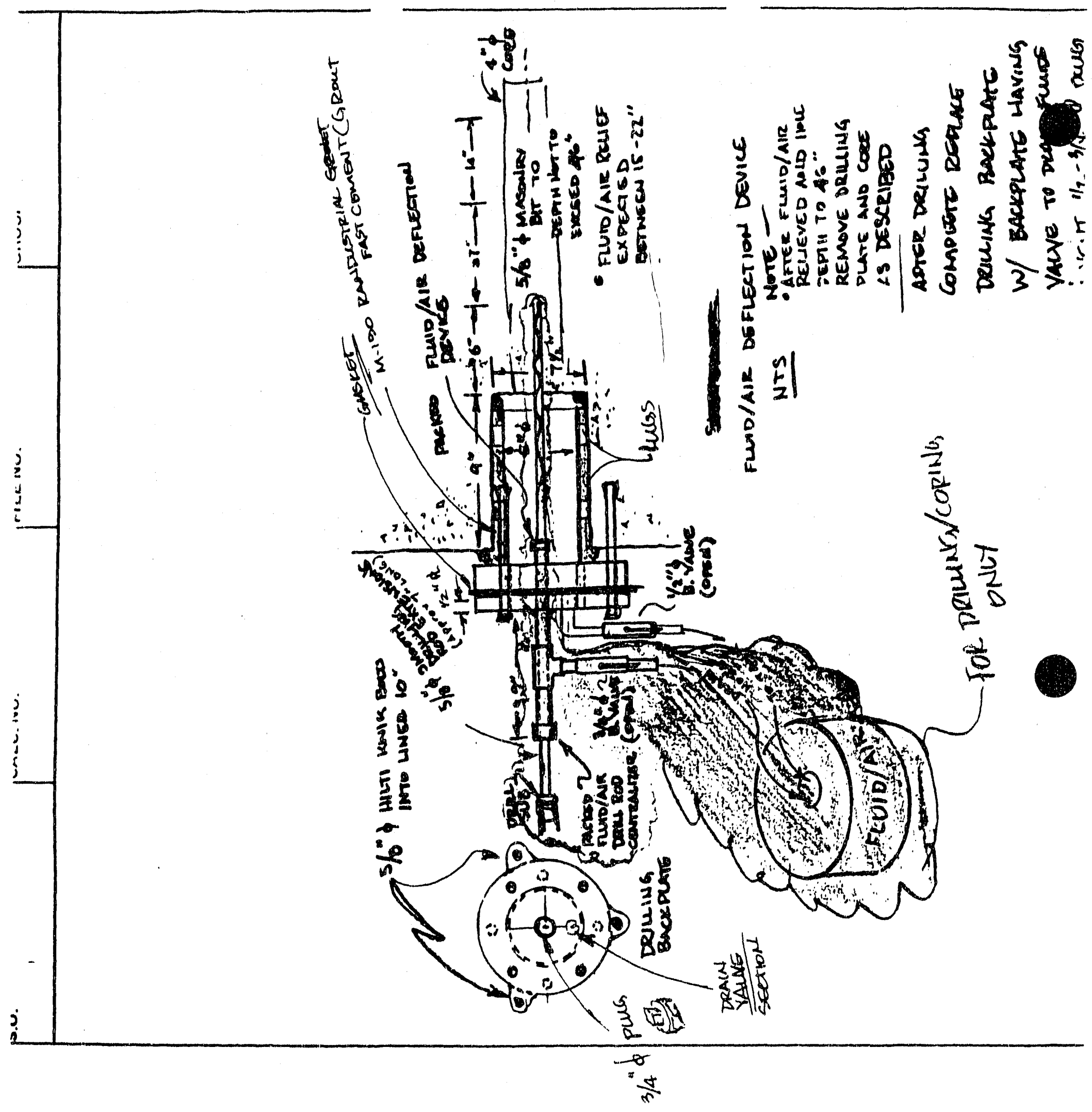

ILUSTRATION II 
OCT 85 '90 14:3E SECHTEL GRO S.F.

Becticel National, Inc.

Syome Enoincers - Consunuctors

Fity Beala Streat

San Franciscon Calitoritin

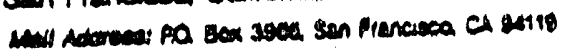

October 5, 1990

Westinghouse Electric Corp.

Waste Isolation Division

P. O. Box 2078

Carlsbad. N.M. 88221

Attention: Dick Scharinger

Sr. Procurement Sciecialist

Subject: Bechtel Job. No. 20585-002 WEC/WIPP Project

WEC P. O. Number 75WGMO1520SG

Task 006. Waste Shaft Key Concrete

Dear Mr. Scharinger:

On Monday, October 1, 1990, I endeavored to contact Hardy Bellows to obtain a clarification and better understanding of the scope of Task 006 us outlined in your letter of intent to extend the Bechtel subcontract to December 31, 1990.

On October Ist, I didn't reach Hardy but did receive calls from Don Galbraith and Subash Sethie. Don explained that orders were issued to investigate any deterioration of the concrete in the Waste Shaft Key and determine the causes. Two cored holes were to be drilled immediately, one above and one below the construction joint at the 834 level.

1 agreed that core drilling the two $3^{\prime \prime}$ or $4^{\prime \prime}$ diameter cores through the concrete and into the rock would not be detrimental to the integrity of the key or liner. The holes should have an edge distance to the construction joint of at least two hole diameters. If blowout preventors could not be readily obtained, the coring should be discontinued at Jeast one holo diameter before reaching the concreterock contact and a small pilot hole drilled through the concrete and into the rock. Drillers are not to stand behind or in line with the diill and the drill should be anchored to the wall. The holes should also 
Mr. Dick Scharinger

Westinghouse Electric Corp.

October 5, 1990

Page 2

be located to miss the rebar which is indicated on the design drawiags to be immediately below level 834 .

(See Drawing 31-R-002-01D).

I also discussed the possible cause(s) of any deterioration of the concrete. From my last inspection of the concrete koy earlier this year, it appeared that some of the inside surface of the concreke key had areas $1 / 8$ to $1 / 4$ inches deep where the cement constituent had been leached out, leaving a sand like finish. When this $1 / 8$ to $1 / 4$ inch surface was scrapped off, the concrete was very hard and sound. Based on several known conditions during construction, 1 have postulated the following events that could have caused this surface condition:

1. The waste shaft liner was cast/placed from the top down which is a conventional shaft construction procedure. This method, bowever, requires the next section below to be poured up against the already placed construction joine above which makes it very difficult to obtain a good tight joint.

2. The Waste Shati Key area was excavated after the liner above was complete and was poured in lifts from the bottom up with the final lift poured up against the already poured joint at the 834 level. At this time, the poured concrete in the key was green, i.e., just poured, when the forms were stripped. The piezometric bead was building up behind the liner and the brine solution was flowing through some of the joints and defects and running freely down the inside face of the concrete liner and freshly poured concrere key.

If the fresh concrete surfaces including patchwork and the joint at 834 level were not protected from the brine solution freely flowing over the surfaces, it is possible that the surface cement content could bave been leached by this action. 
Mr. Dick Scharinger

Westinghouse Electric Corp.

October 5, 1990

Page 3

Maybe this concept could bo verified by casting a small slab of concrete and as soon as the concrete could stand by itself, say 12 to 24 hours, place it in a container having brine solution at the bottom. Then with a pump circulate the brine over the concrete specimen surface to determine if the same condition that is being observed on

the key would develop on the specimen. The question bere is, can . enough indigenous brine be obtained to perform this experiment?

I have just received a sketch faxed from Don Galbraith, indicating the

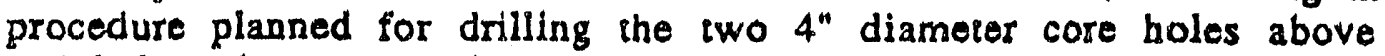
and below the construction joint at the 834 level. I agree with the procedure indicated. It appears that the location of the rebar determined in the field is lower than that shown on the design drawing.

This investigation may extend for more than 30 days. I will cover Bechtel's estimate of the manhours for Task 006 under separate correspondence.

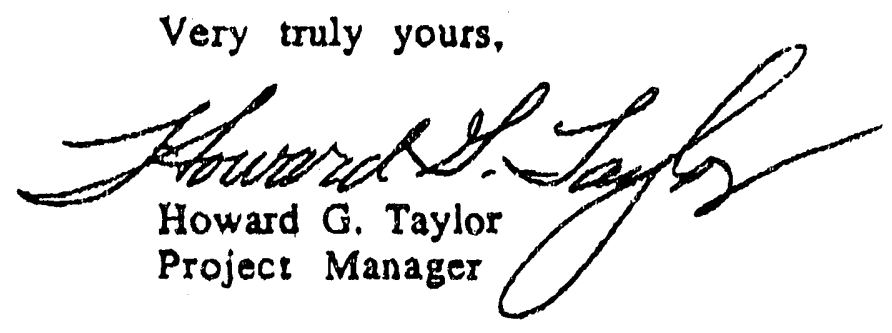

HGT:Id

cc: Don Galbraith 
$735011 \mathrm{~W}$

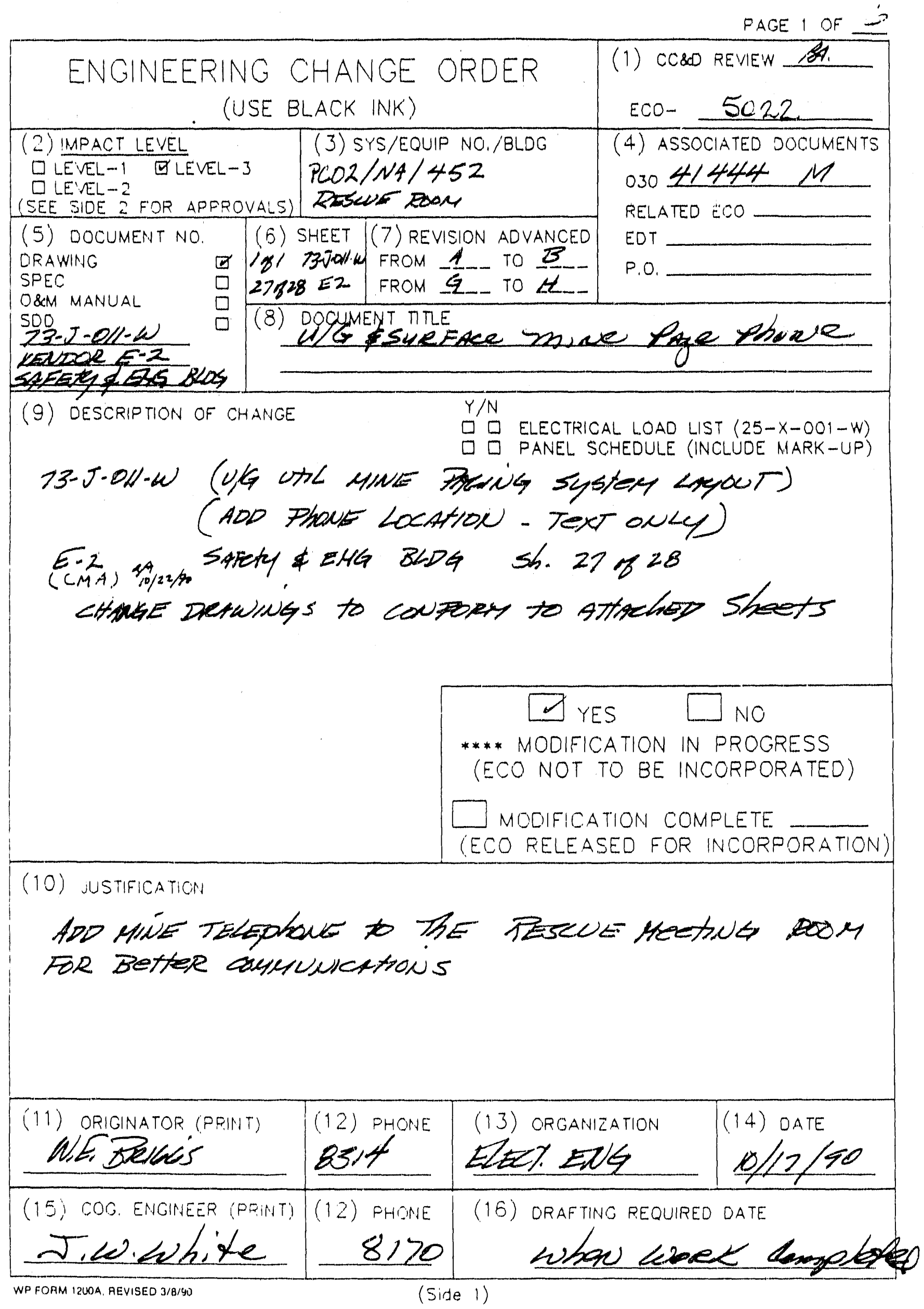


(17) RELATED CHANGES: INDICATE THE DOCUMENTS, INSTRUCTIONS OR PROCEUURES (OTHER THAN THE DRAMNISS OR DOCUMENTS IUENTIFIED IN EITHER 5 OR 9) THAT WILL BE AFFECTED BY THE CHANGE DESCRIBED IN BLOCK 9 . ENTER THE DOCUMENT NUMBER(S) IN BL.OCK 18.

YESNDNIA

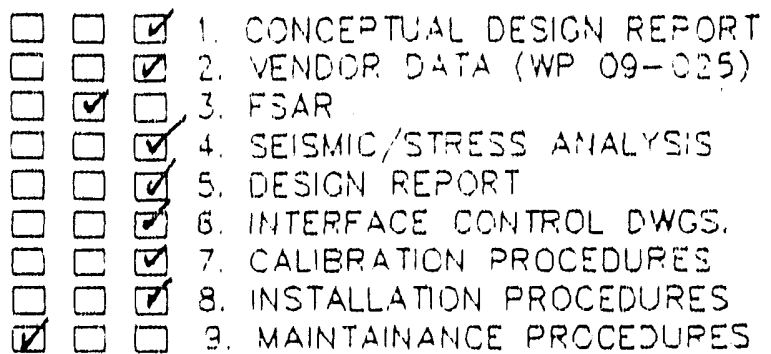

YES NO N/A

$\square \square \square 10$. TRAINING MANUAL

$\square \square 11$. OPERATING PROCEDURES

$\square \square \square$ 12. SPARES/MULTIPLE UNIT LISTINOS

$\square \square \square 13$. DO SPARES NEEO MOOIFIED

$\square \square 14$. TEST PROCEDURES/SPECS.

$\square \square \square$ 15. COMPONENT INICICES

$\square \square$ 16. ASME CODED ITEMS

$\square \square$ 17. HUMAN FACTOR CONSIDERATIONS $\square \square$ 18. COMPUTEP. SOF TWARE

(18) PELATEO OCCIUMENT NO:; INISTRUCTION NO:; IDENTIFIED IN BLOCKK 17. (CHANGES TO DOCUMENTS LISTEO IN ELOCK 19 WILL NOT BE INCGPRORATED BY THIS ECO).

\section{DOCLMEIT NO /REVISION}

9- BUG selteON

12 - WIIIE ROST

13 - wille HoS

15 - Relfouen Tarason
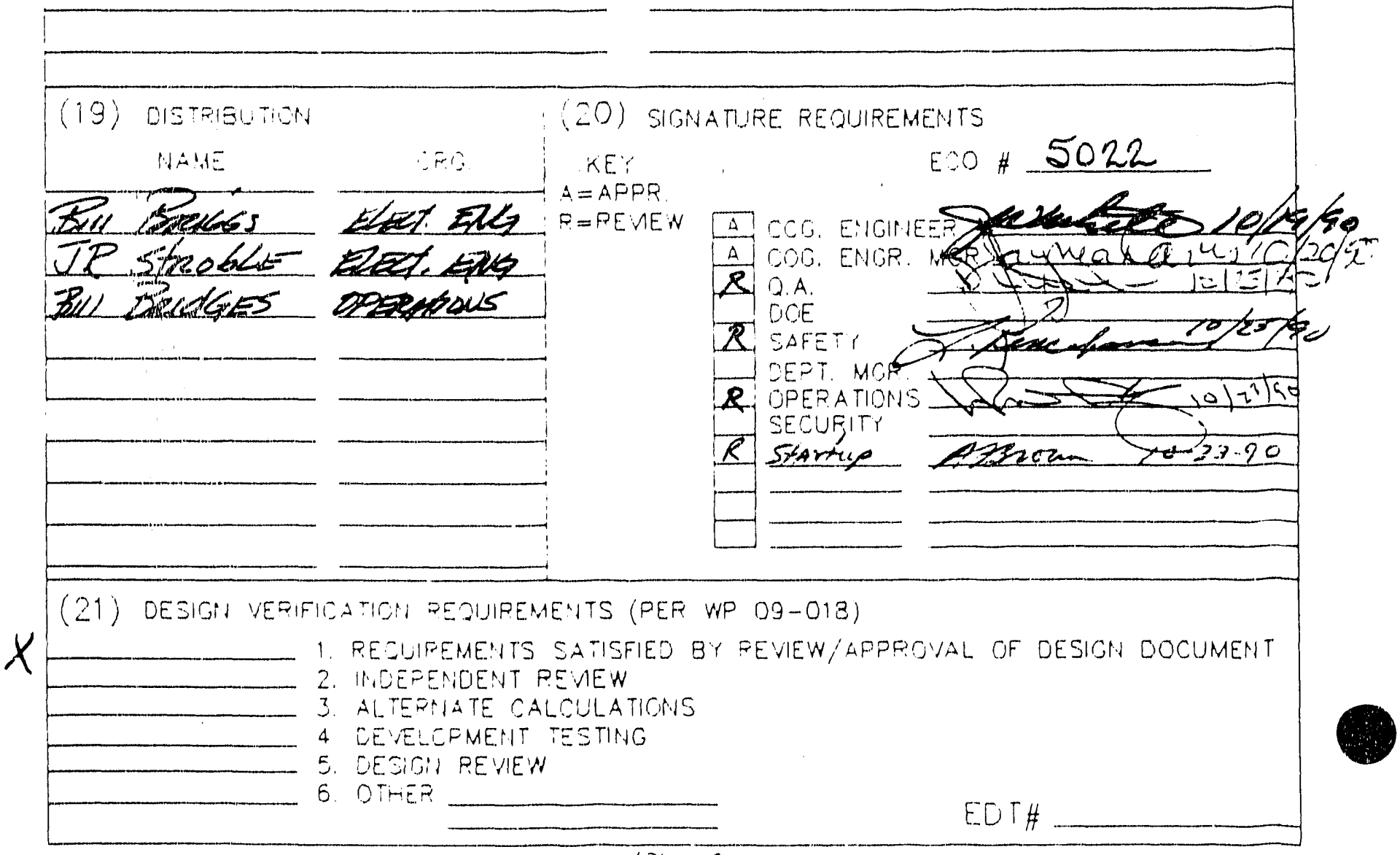


\section{SURFACE MINE PHONE LOCATIONS}

SNL PHONES

$B-49-B L D G$. $911 \mathrm{~F}$

CAL LAB1 - BLDG. $911 E$

SNL OFFICE - BL.DG. 459A

\section{AIS SHAFT}

BLDG. 362

COLLAR -- BLDG. 361
SH SHAFT $\sum 73-J-021-W$
COLLAR - HEADFRAME 371
1ST LEVEL UP - HEADFRAME 371
LAMPHOUSE BLDG. $384 A$
HOISTMAN - BLDG. 384

WASTE HANDLING BUILDING - BLDG. $411 \sum 73-J-019-W 1, W 2$

CONVEYANCE LOADING ROOM - ROOM 116

COLLAR AREA - ROOM 117

WASTE HOIST CONTROL ROOM - ROOM 204

5TH FLOOR HOIST TOWER - ROOM 800

4TH FLOOR HOIST TOWER - ROOM 600

3RD FLOOR HOIST TOWER - ROOM 400

SUPPORT BUILDING - BLDG. $451 \sum 73-J-020-W$

SHAFTS SUPERINTENDENT - ROOM 118

SHAFTS FOREMAN - ROOM 118

BRASS ROOM - ROOM 119

MINE SUPERINTENDENT - ROOM 137

MINE FOREMAN - ROOM 137

CMS CONTROL ROOM - ROOM 230 - 2 PHONES

DOSIMETRY LAB - ROOM 130 (TEST LINE ONLY)

ROOM 105 - U/G OPS

EORTR BEINEEN SUPPORT BLDG. \& WASTE HANDLING BLDG.

SAFETY AND EMERGENCY SERVICES - BLDG. 452

COMMUNICATIONS ROOM - EOC

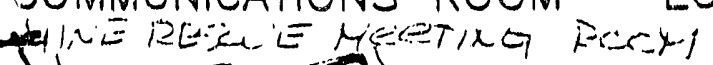

CORE STORAGE WAREHOUSE - BLDG. 459 OFFICE

CONSTRUCTION MGT. \& MAINTENANCE COMPLEX - BLDG. 911

EXPERIMENTAL OPS MANAGER'S OFFICE 


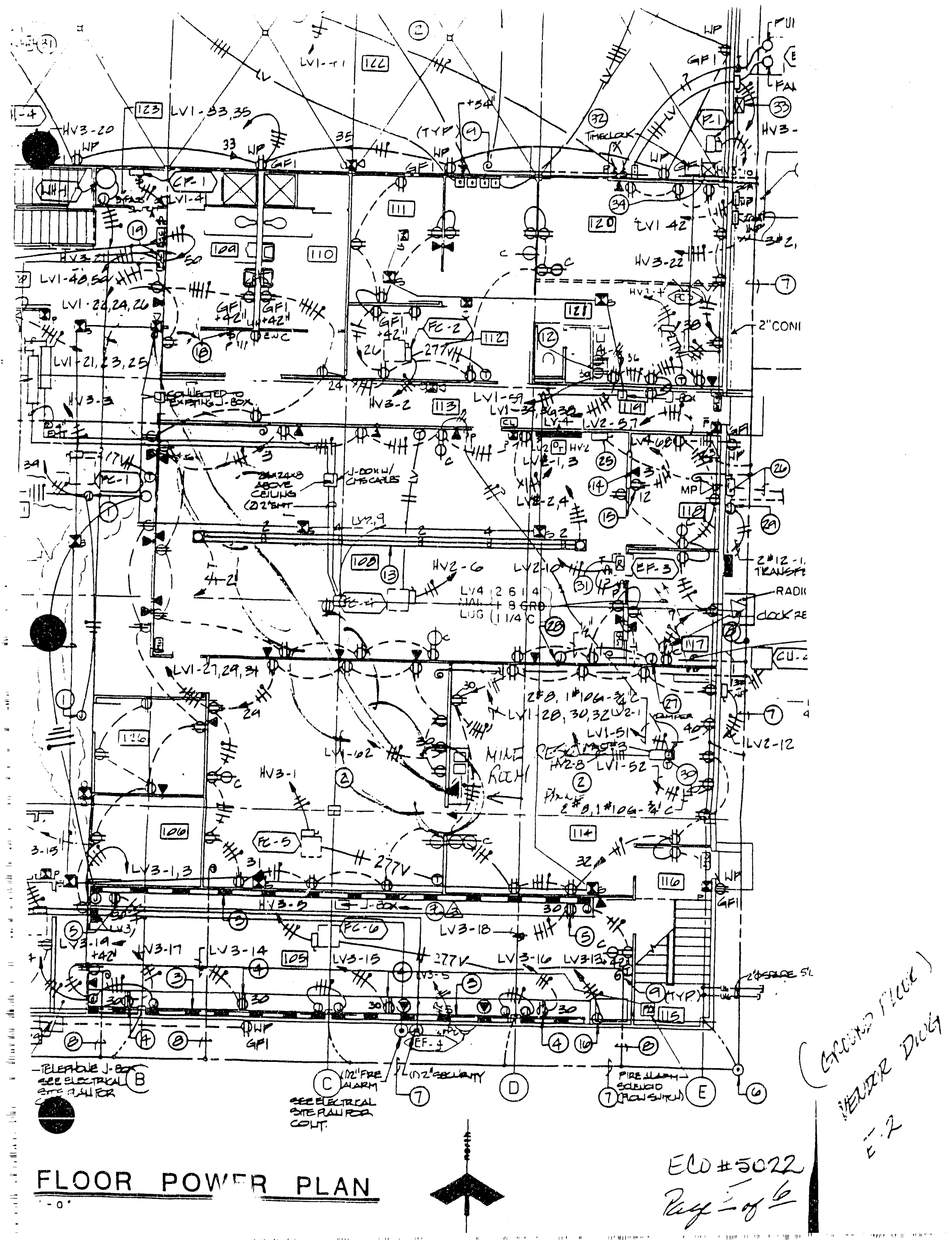




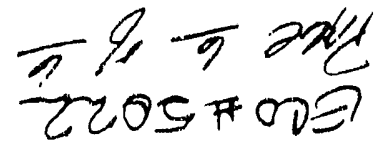

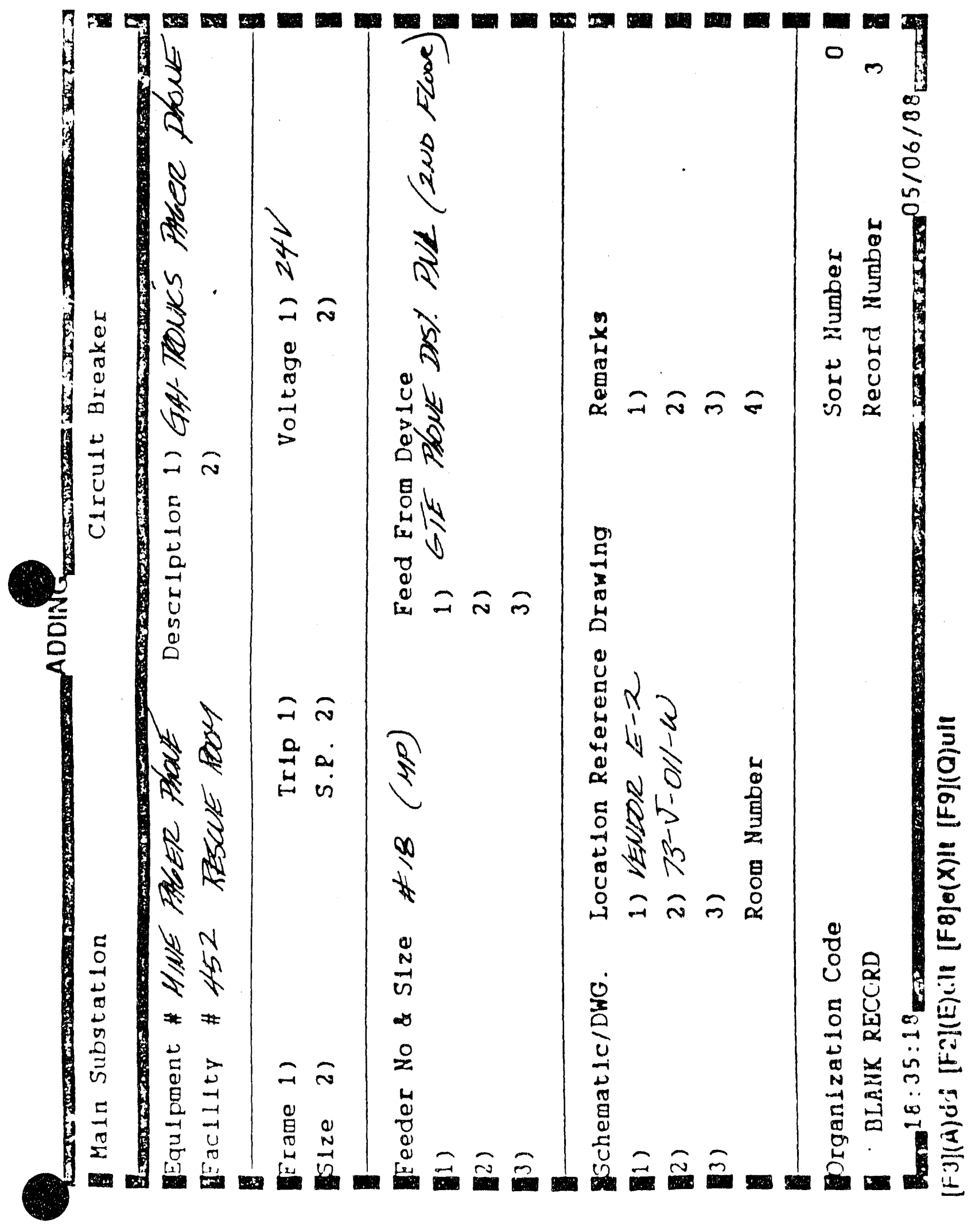


$546004 w$

PAGE 1 OF 2

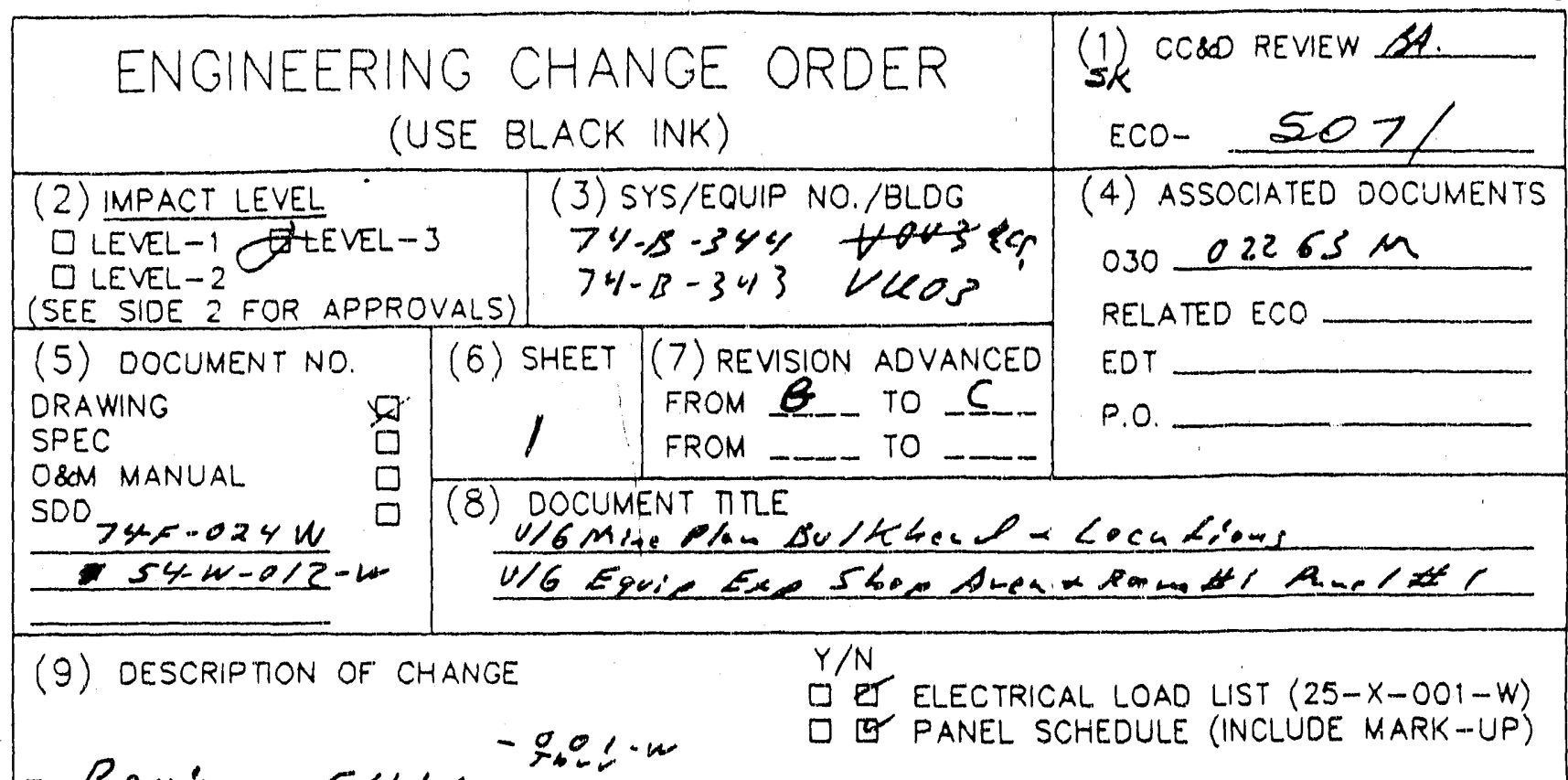

- Revise 5yw-0izw to swow cacatron of BULKHESPS >4

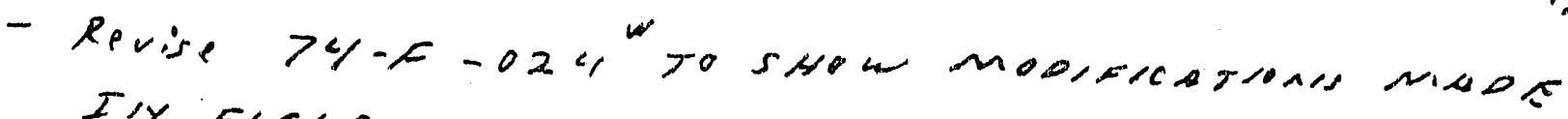

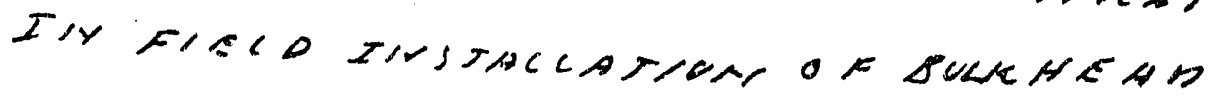

- Dil mas a cucarean.

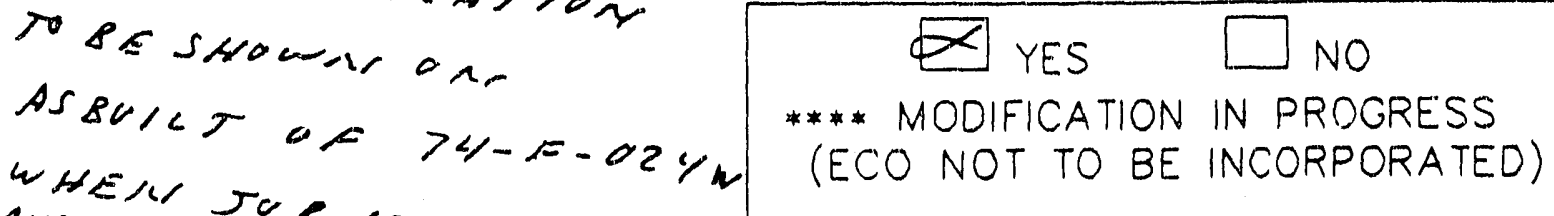

WHEM TOS IS COM CONE.
AND MOD 15 MODIFICATION COMPLETE
(ECO RELEASED FOR INCORPORATION)

(10) JUSTIFICATION

- Instr ll ation of pueglannoph bultehcads

- Asbrild to keep ventilatiro duawios crume

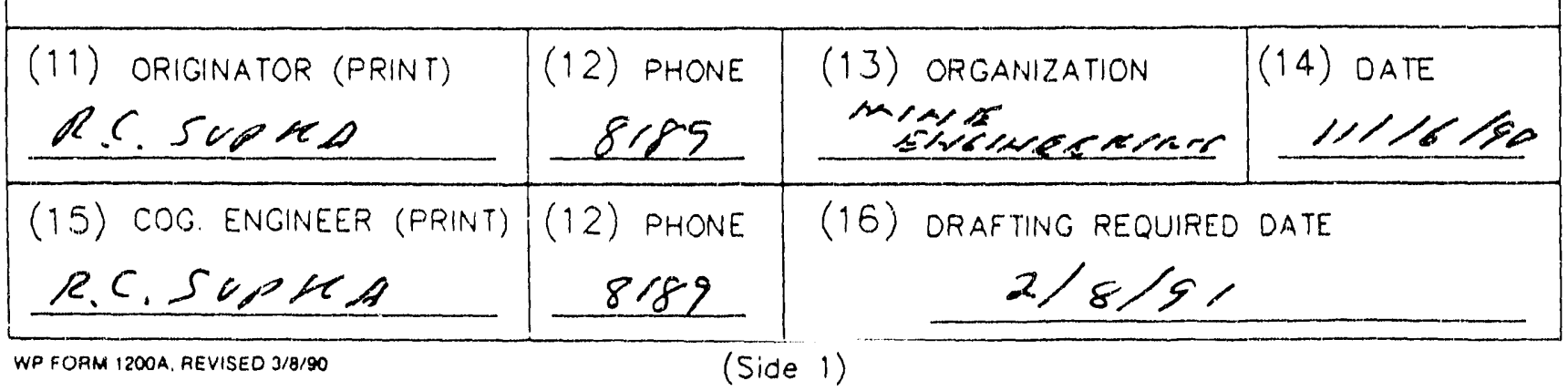

WP FORM 1200A. REVISEO 3/8/90 (Side 1) 
(17) RELATED CHANGES: INOICATE THE DOCUMENTS, INSTRUCTIONS OR PROCEUURES (OTHEP THAN THE DRAMHIGS DR DOCUMENTS IDEN TIFIED IN EITHER 5 OR 9) THAT WILL EE AFFECTED BY THE CHANGE DESCRIBED IN BLOCK 9 . ENTER THE DOCUMENT NUMBER(S) IN ELOCK 18.

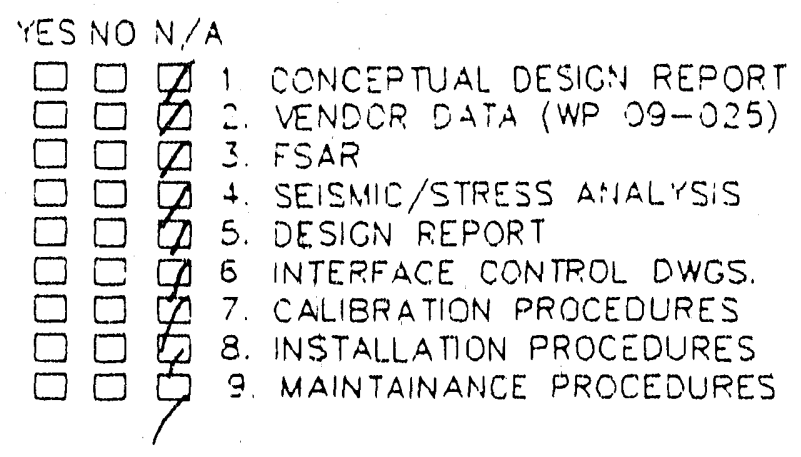
YES NON/A

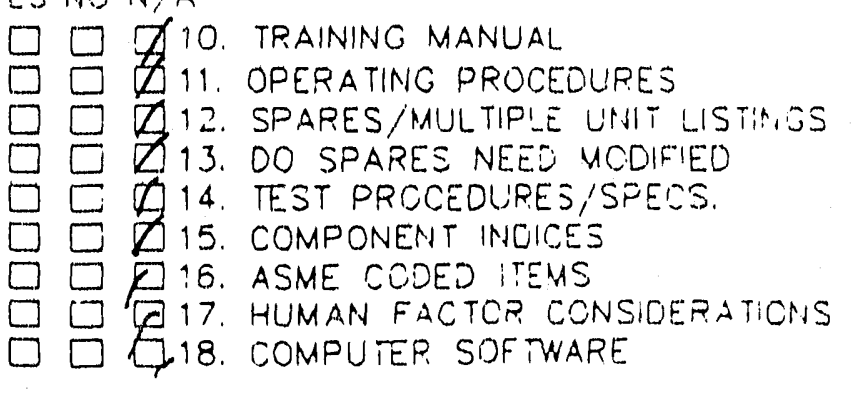

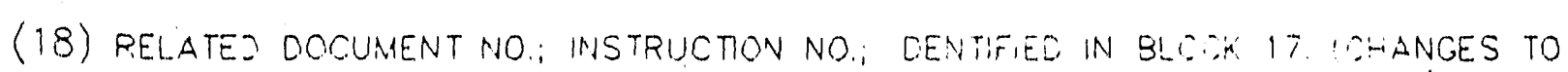
DOCUMEVIS LISTED IN ELOCK 18 WILL NOT 5F. INICCPRORATEJ GY THIS ECO).

\section{DOCUMEN' NO /RE:"SION}

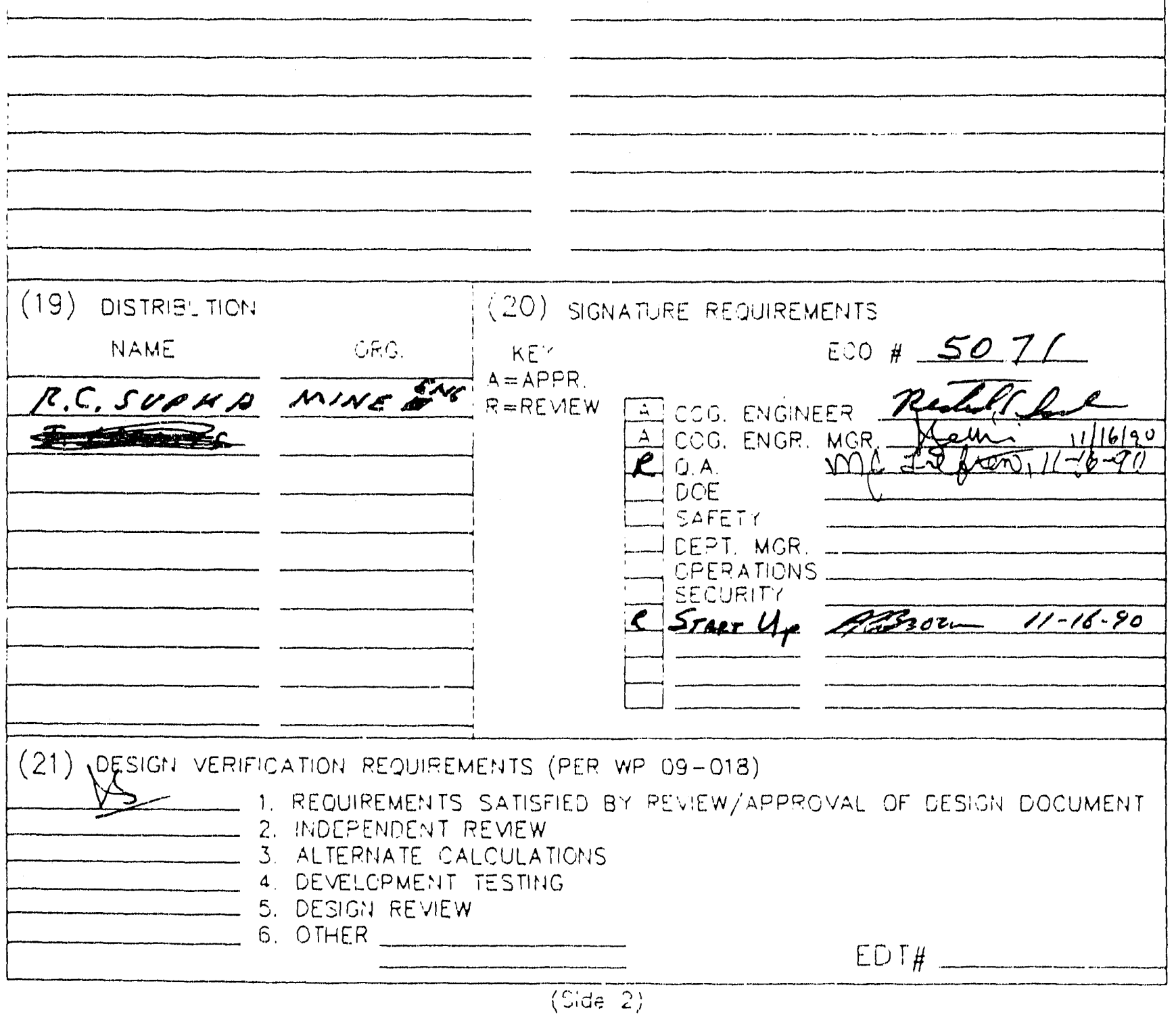


PAGE 1 OF $\approx$

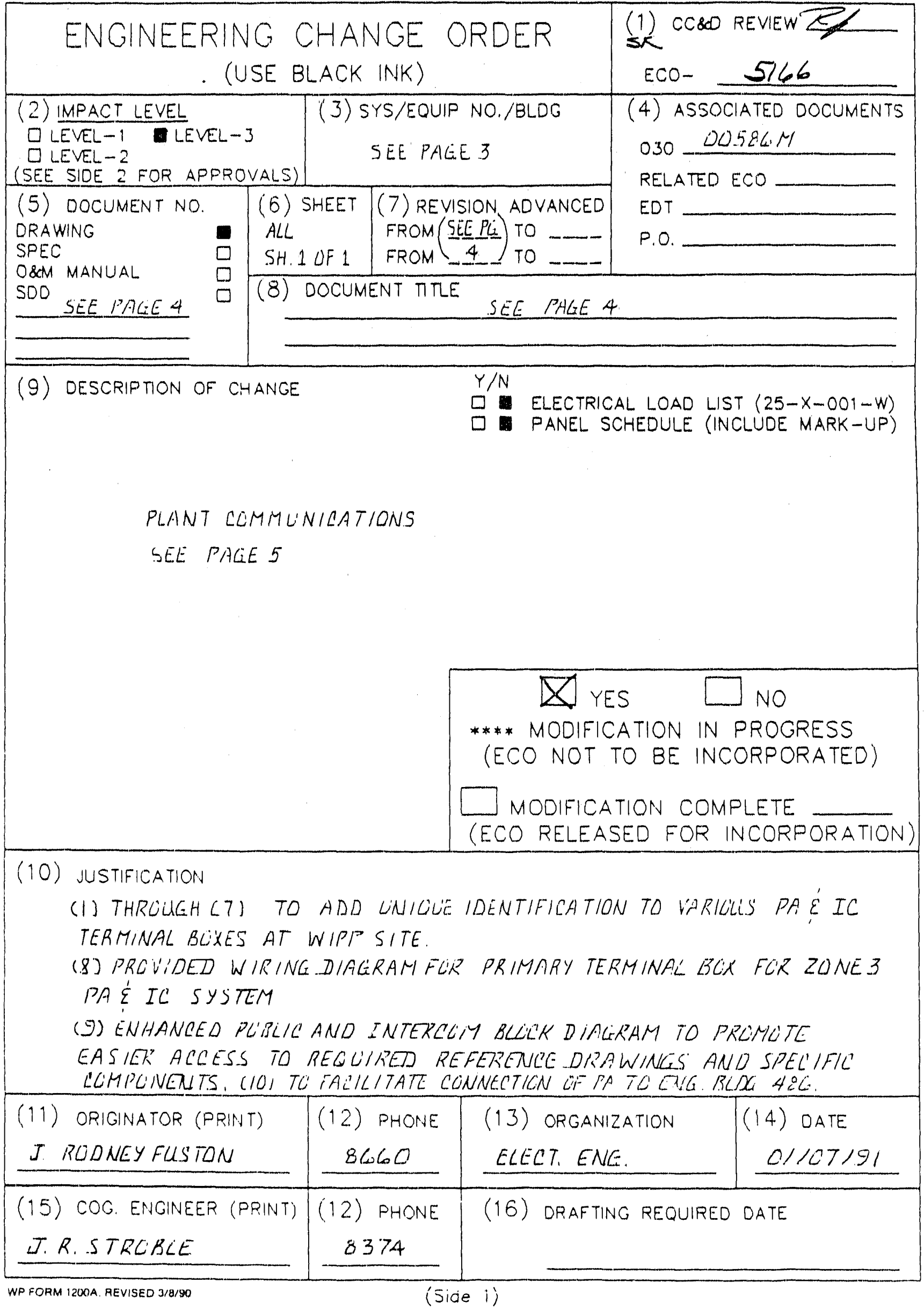


(17) RELATED CHANGES: INDICATE THE DOCUMENTS, INSTRUCTIONS OR PROCEUURES (OTHER THAN THE DRAMNGS OR DOCUMENTS IDENTIFIED IN EITHER 5 OR 9) THAT WILL. BE AFFECTED BY THE CHANGE DESCRIBED IN BLOCK 9. ENTER THE DOCUMENT NUMBER(S) IN BLOCK 18.
YESNON/A

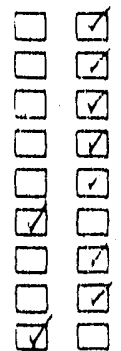
$\begin{array}{ll}0 & \square \\ \nabla & \square \\ \nabla & \square \\ \square & \square \\ \square & \square \\ \square & \square \\ \square & \square\end{array}$
1. CONCEPTUAL DESIGN REPORT
2. VENDOP. DATA (WP O9-O25)
3. FSAR
4. SEISMIC/STRESS ANALYSIS
5. OESIGN REPORT
6. INTERFACE CCNTROL OWGS.
7. CALIBRATION PROCEDURES
8. INSTALLATION PROCEDURES
3. MAINTAINANCE PROCEDURES
YES NO N/A
$\square \square \square$ 10. TRAINING MANUAL
$\square \square \square 11$. OPERATING PROCEOURES
$\square \square$ 12. SPARES/MULTIPLE UNNIT LISTINGS
$\square \square \square 13$. DO SPARES NEED MODIFIED
$\square \square \square$ 14. TEST PROCEDURES/SPECS.
$\square \square \square$ 15. COMPONENT INOICES
$\square \square$ 16. ASME CODED ITEMS
$\square \square \square$ 17. HUMAN FACTOR CONSIDERATIONS
$\square \square \square$ 18. COMPUTER SOFTKARE

(18) RELATED DOCUMENT NO.; INSTRUCTION NO.; IDENTIFIED IN BLOCK 17. (CHANGES TO DOCIMENTS LISTED IN BLOCK 18 WILL NOT BE INCOPRORATED BY THIS ECO).

\begin{tabular}{|c|c|c|}
\hline HC & IR STRUUHLE & $B y+H 15 E 20$ \\
\hline$\$ 9$ & $D$ SLHCEN & MAINT \\
\hline$\# 11$ & BILL WHITE & SLRFALE LP \\
\hline$\$ 14$ & B LUHILLLLIN & $5 / 2$ \\
\hline Hi. & R. JCHNSCN & $E L E D$ \\
\hline
\end{tabular}

\begin{tabular}{|l}
\hline \\
\hline (19) DISTRIEUTION
\end{tabular}

\begin{tabular}{|c|c|c|}
\hline \multicolumn{2}{|c|}{ (19) DISTRIEUTION } & $(20)$ SIGN \\
\hline & $\because 50$. & \multirow{9}{*}{$\begin{array}{c}K E Y \\
A=A P F R . \\
P=R E V E N\end{array}$} \\
\hline JA STRLIBLE & ELELT ENG & \\
\hline -D SCIKLEN & MAINT & \\
\hline B WHIT & SLR CPS & \\
\hline B $\angle H I C L E L I N$ & $5 / 4$ & \\
\hline R JCIHNSCN & $C L^{\prime} \leqslant D$ & \\
\hline & & \\
\hline & & \\
\hline & & \\
\hline
\end{tabular}

\section{NO. /REVISION}

(21) DESIGN VERIFICATION FEDIJIREMENTS (PER WP 09-018)

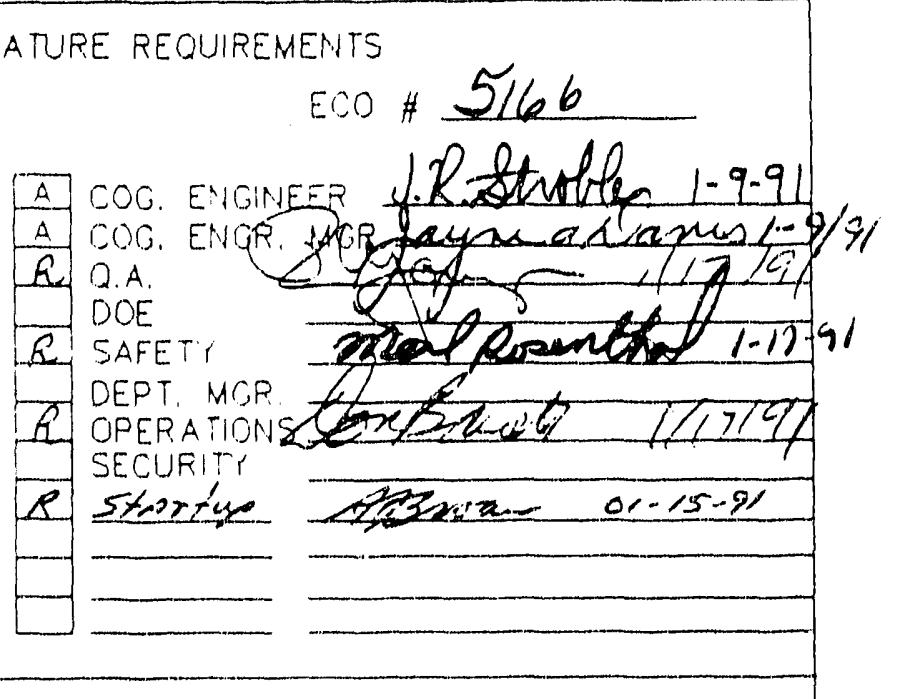

OOD - 1. RECUIFEMEITS SATISFIED EY REVIEW/APPROVAL OF OESIGH DOCUMENT

2. WNDEFENDENT REVEW

aLTEPIATE CALCULATIONS

4E VELCPMENT TESTING

5. OESIOH REVIEW

6. DTHE?

EOTH 


\begin{tabular}{|c|l|l|c|}
\hline $\begin{array}{c}\text { ECO } \\
\text { CONTINUATION } \\
\text { SHEET }\end{array}$ & \multicolumn{2}{|l|}{ DOCUMENT NO. $\#$} \\
\cline { 2 - 3 } & $\begin{array}{l}\text { DATE } \\
0 / 10 \% / 91\end{array}$ & $\begin{array}{l}\text { PAGE } 3 \\
\text { OF } 2 i^{3}\end{array}$ & $5 / 66$ \\
\hline
\end{tabular}

(3) CONTINUED

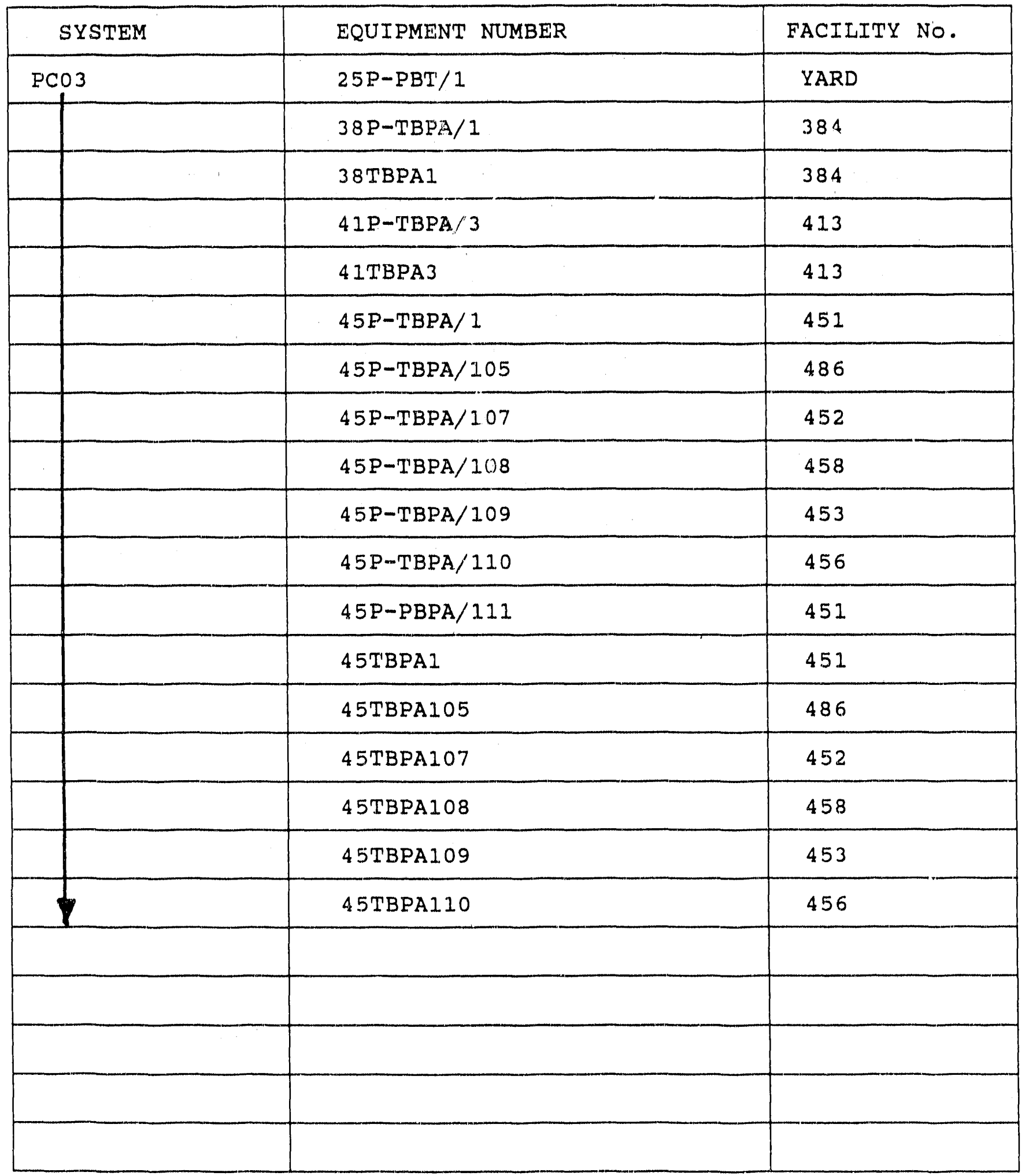




\begin{tabular}{|l|l|l|c|}
\hline $\begin{array}{c}\text { ECO } \\
\text { CONINUATION } \\
\text { SHEET }\end{array}$ & \multicolumn{2}{|l|}{ DOCUMENT NO. } & ECO \# \\
\cline { 2 - 4 } & $\begin{array}{l}\text { DATE } \\
01 / 07 / 91\end{array}$ & $\begin{array}{l}\text { PAGE } \\
\text { OF 21 }\end{array}$ & $5 / 66$ \\
\hline
\end{tabular}

\begin{tabular}{|c|c|c|c|}
\hline (5) DWG. NO. & (7) & FROM/TO & (8) DOCUMENT TITLE \\
\hline $\begin{array}{l}73-J 805-W \\
\text { SH. } 1 \text { OF } 1\end{array}$ & $B$ & & $\begin{array}{l}\text { SAFETY AND EMERGENCY BLDG } \\
\text { PA\& IC SYSTEM } \\
\text { GROUND AND 2ND FLOOR PLAN }\end{array}$ \\
\hline $\begin{array}{l}73-J-014-W \\
\text { SH. } 1 \text { OF } 1\end{array}$ & B & & $\begin{array}{l}\text { SURFACE LAYOUT } \\
\text { PLANT COMMUNICATIONS }\end{array}$ \\
\hline $\begin{array}{l}73-J-0.15-W \\
\text { SH. I OF } 1\end{array}$ & B & & $\begin{array}{l}\text { GUARDHOUSE \& SECURITY } \\
\text { BLDG } 458 \\
\text { PLANT COMMUNICATIONS }\end{array}$ \\
\hline $\begin{array}{l}73-J-016-W \\
\text { SH. } 1 \text { OF } 1\end{array}$ & B & & $\begin{array}{l}\text { WATER PUMPHOUSE BLDG } 456 \\
\text { PLANT COMMUNICATIONS }\end{array}$ \\
\hline $\begin{array}{l}73-J-017-W \\
\text { SH. } 1 \text { OF } 1\end{array}$ & C & & $\begin{array}{l}\text { PLANT COMMUNICATIONS } \\
\text { EXHAUST FILTER BUILDING } \\
41.3\end{array}$ \\
\hline $\begin{array}{l}73-J-020-W \\
\text { SH. } 1 \text { O OF } 1\end{array}$ & A & & $\begin{array}{l}\text { SUPPORT BLDG } 45 \pi \\
\text { PLANT COMMUNICATIONS }\end{array}$ \\
\hline $\begin{array}{l}73-J-022-W \\
\text { SH. I OF } 1\end{array}$ & B & & $\begin{array}{l}\text { WAREHOUSE/SHOPS BLDG } 453 \\
\text { PLANT COMMUNICATIONS }\end{array}$ \\
\hline $\begin{array}{l}73-J-025-W \\
\text { SH. I OF } 1\end{array}$ & B & & $\begin{array}{l}\text { PUBLIC ADDRESS \& INTERCOM } \\
\text { BLOCK DIAGRAM \& MASTER } \\
\text { CONTROL CONSOLE } \\
\text { WIRING DIAGRAM } 73-\mathrm{P}-006\end{array}$ \\
\hline
\end{tabular}




\begin{tabular}{|c|c|c|c|}
\hline \multirow{2}{*}{$\begin{array}{c}\text { ECO } \\
\text { CONTINUATION } \\
\text { SHEET }\end{array}$} & \multicolumn{2}{|c|}{ DOCUMENT NO. } & \multirow{2}{*}{$\begin{array}{l}\text { ECO \# } \\
\qquad 5166\end{array}$} \\
\hline & $\begin{array}{l}\text { DATE } \\
01 / 0 \% / 4,\end{array}$ & $\begin{array}{l}\text { PAGE } 5 \\
O F=21\end{array}$ & \\
\hline
\end{tabular}

(9) CONTINUED FROM PAGE 1

1. Add unique identification to PA \& IC terminal box(es) to See page(s) $\frac{47}{4}$.
2. Add unique identification to PA \& IC terminal box (es) to drawing 73-J-014-W. See page(s) $\frac{\varepsilon, 9}{}$. 3. Add unique identification to PA \& IC terminal box(es) to drawing 73-J-015-W. See page(s) 16

4. Add unique identification to PA \& IC terminal box(es) to drawing 73-J-016-W. 5. Add unique identification to PA \& IC terminal box(es) to drawing 73-J-017-W.

6. Add unique identification to PA \& IC terminal box(es) to drawing 73-J-020-W. See page (s) $13,1 / 4$. 7. Add unique identification to PA \& IC terminal box(es) to drawing 73-J-022-W. See page(s) i5, 16. 8. Provide wirling diagram for PA \& IC terminal box $45 \frac{5-T B P A}{2} 1$ in support Bullding 451 to drawing 73-J-020-W. See page i 7

9. Revise public address and intercom block diagram to indicate the addition of Engineering Bullding 486 and unique identification of various PA \& IC terminal boxes to drawing $73-J-025-W$.

See page 18 .

10. Revise public address condult layout in support Bullding 451 to drawing 73-J-020-W.

See page (s) 19,20,21. 

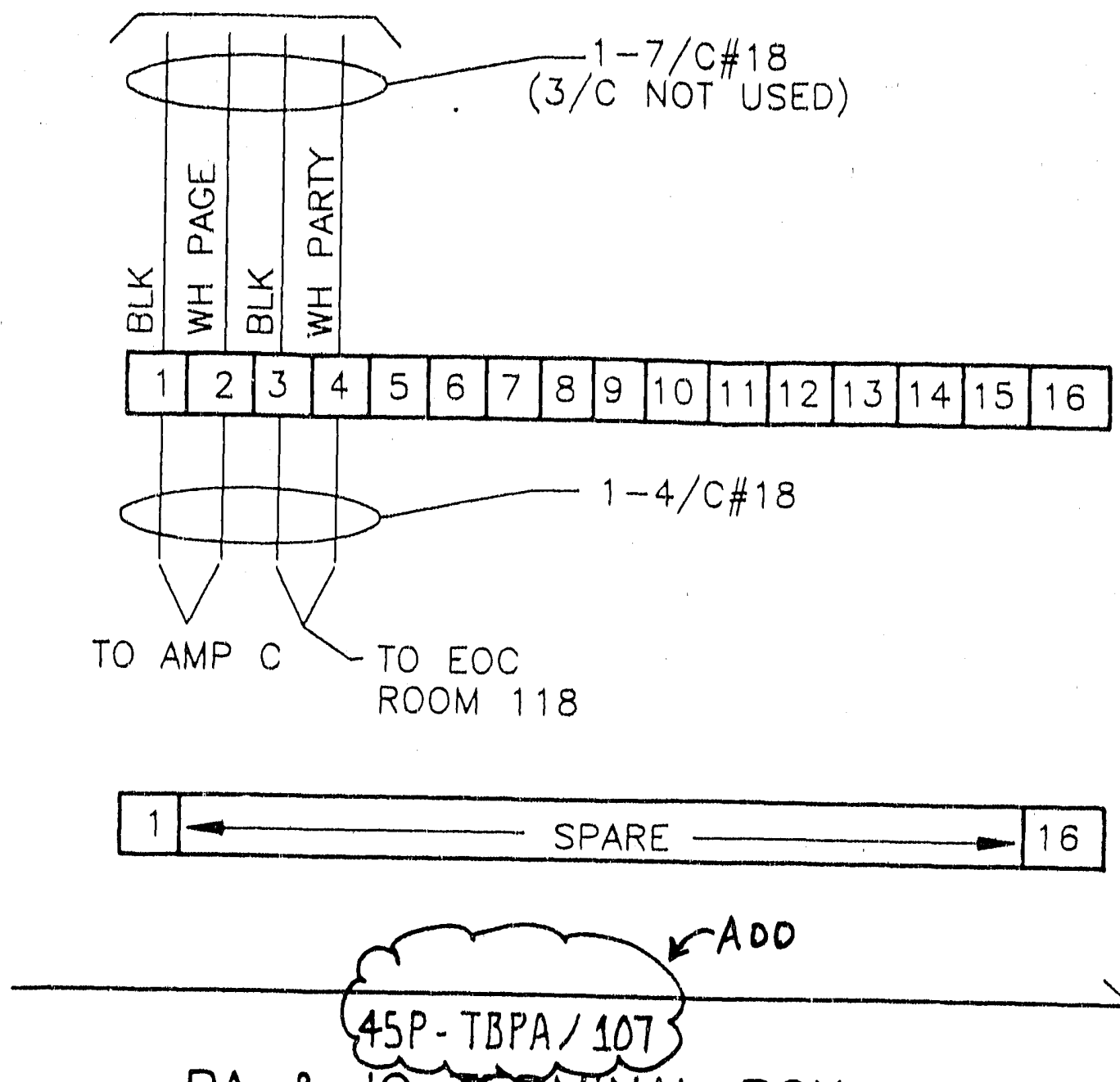

PA \& IC TERMINAL BOX

CABLE ENTRY FROM SUPPORT BUILDING

PANEL 45P-TBPA/ 1 ROOM 104 2" C, $1-7 \mathrm{C \# 18}$
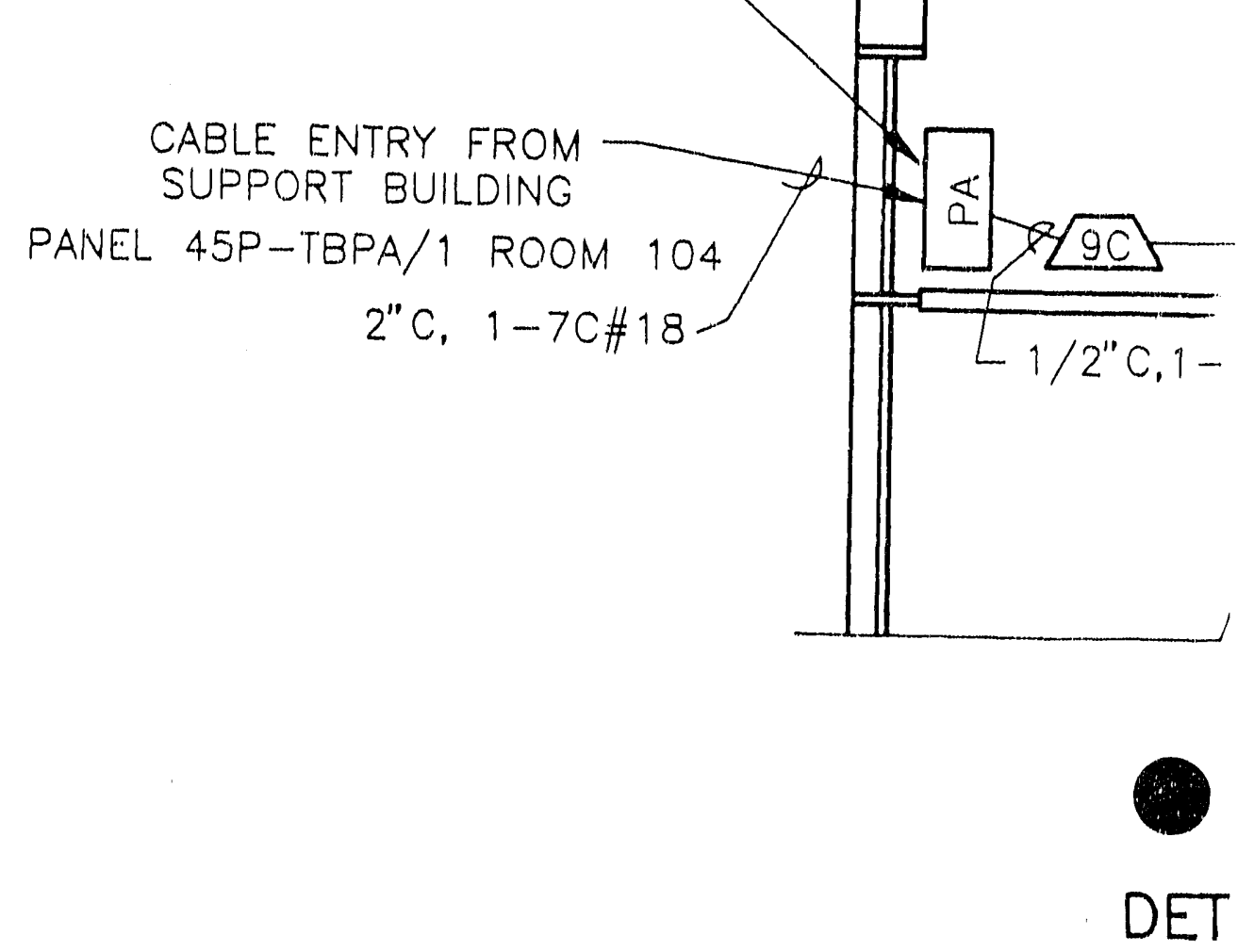

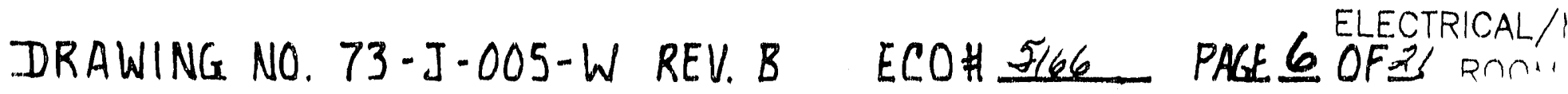


TO SUPPORT BUILOING PANEL 45P-TBPA/1

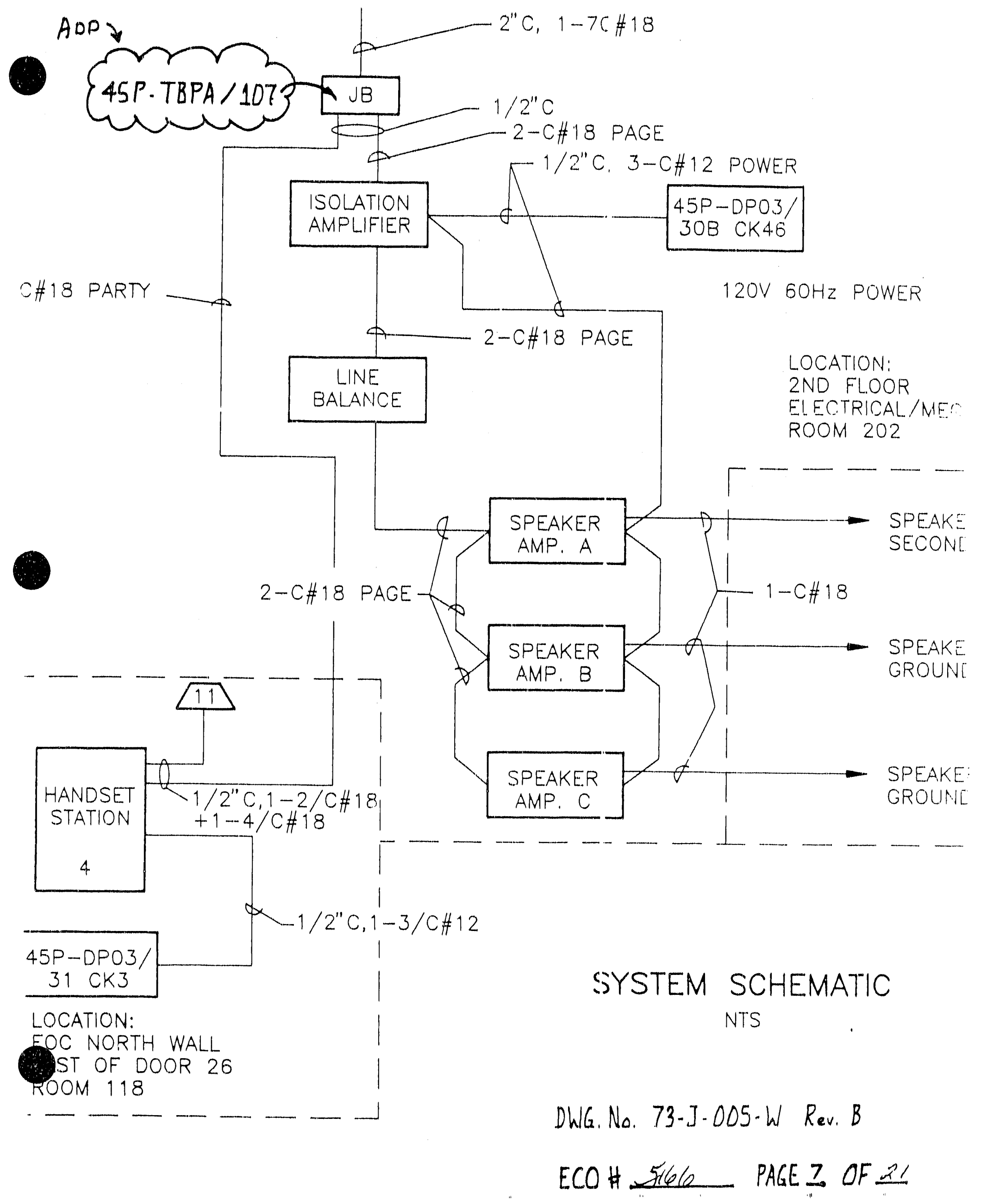




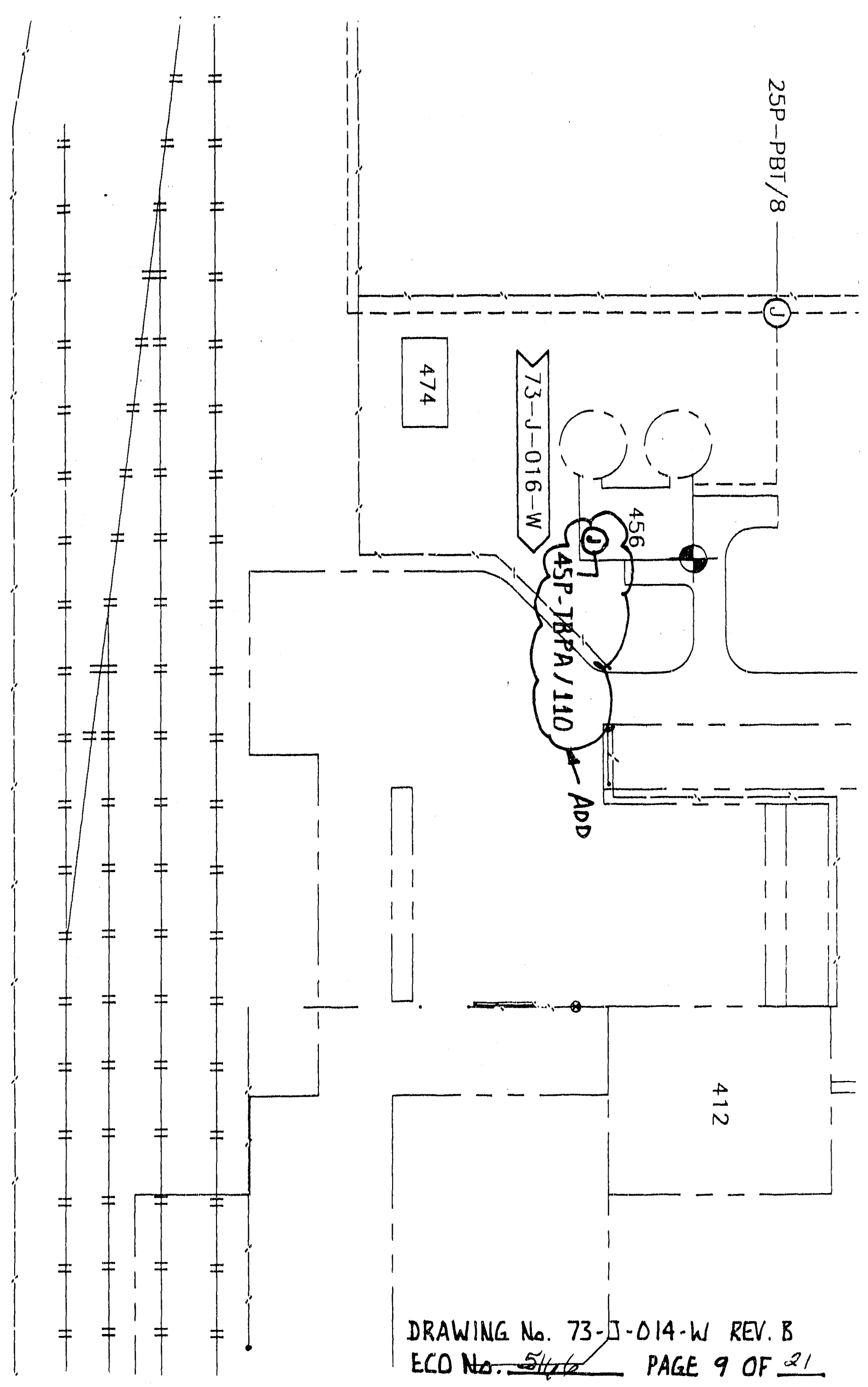




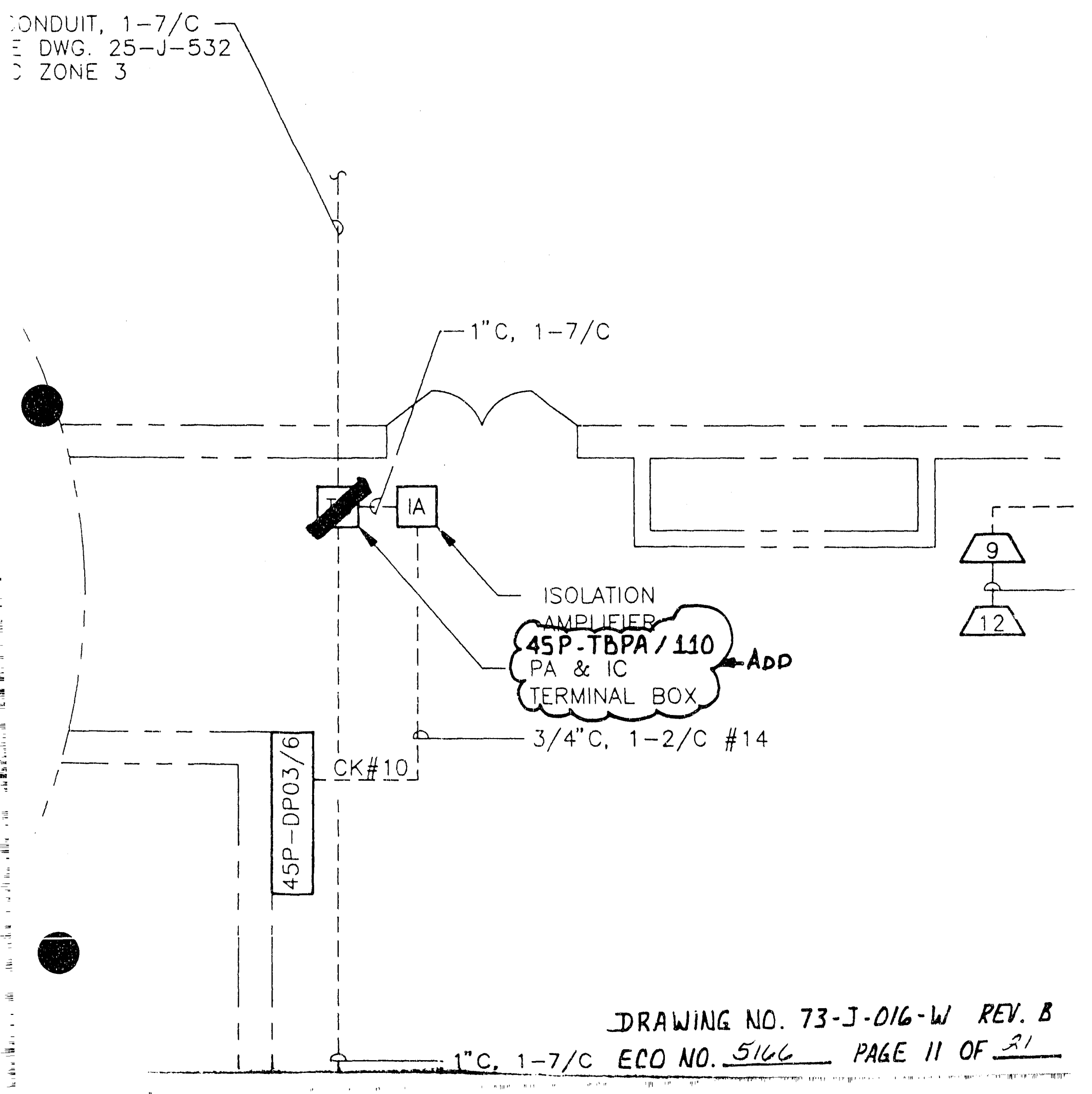




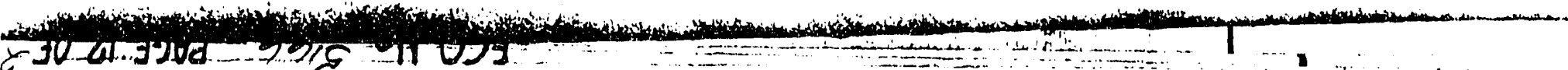

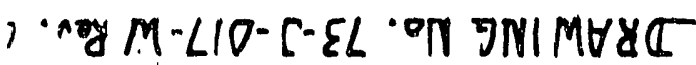

$\frac{1}{0}$

O

$\sum^{\infty}$

1

0

1

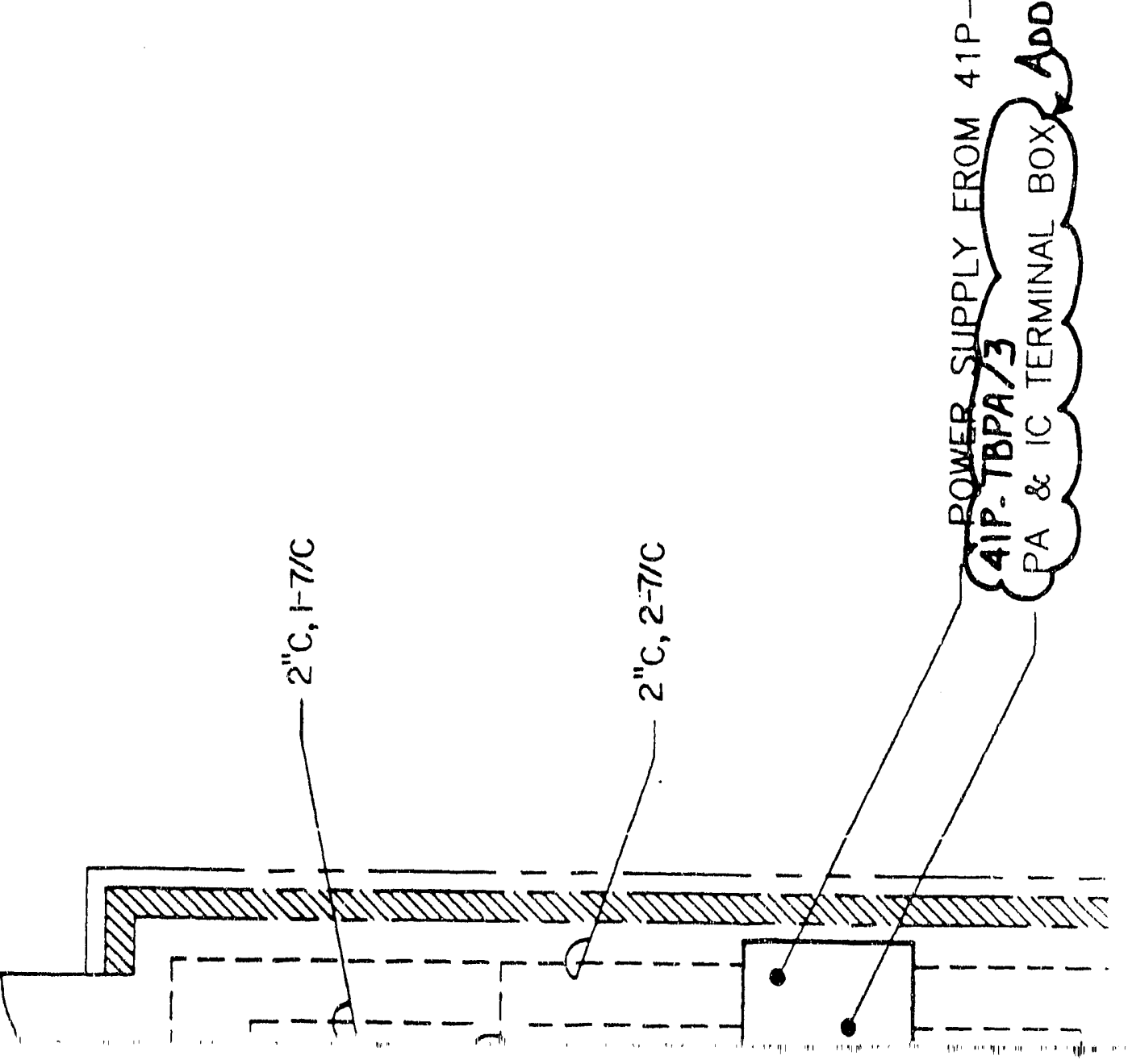




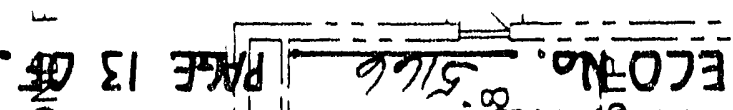

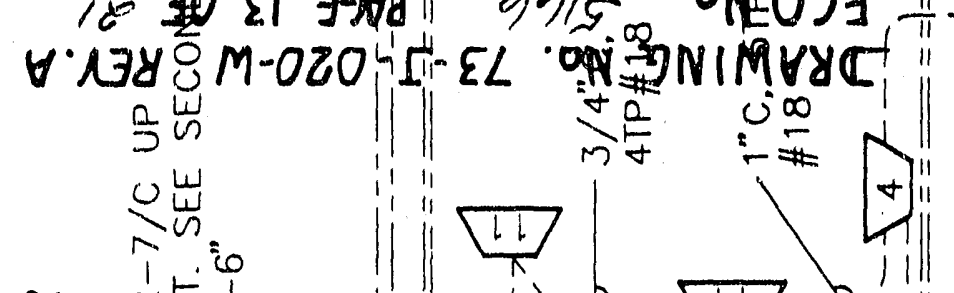

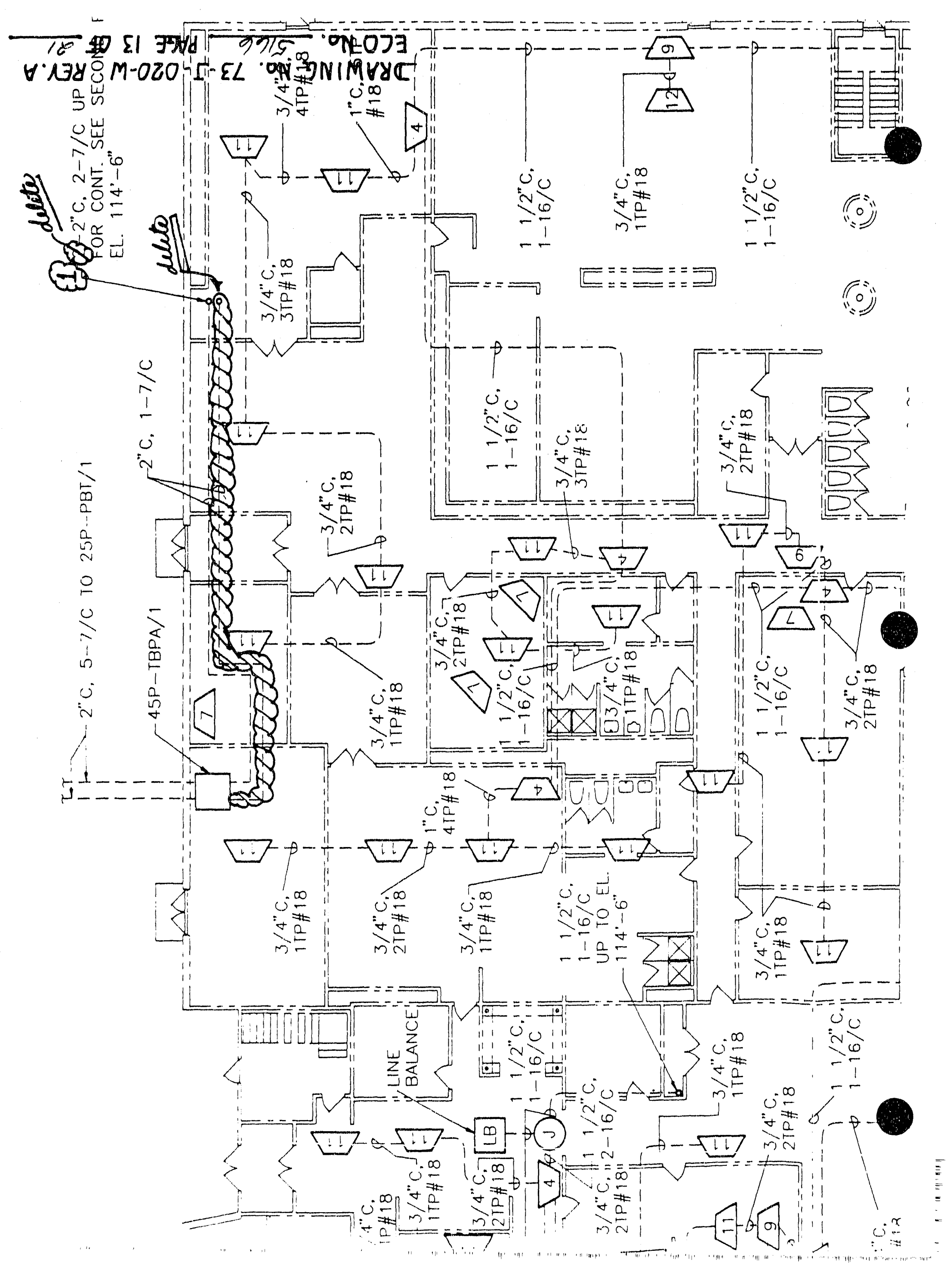




\section{$m$}

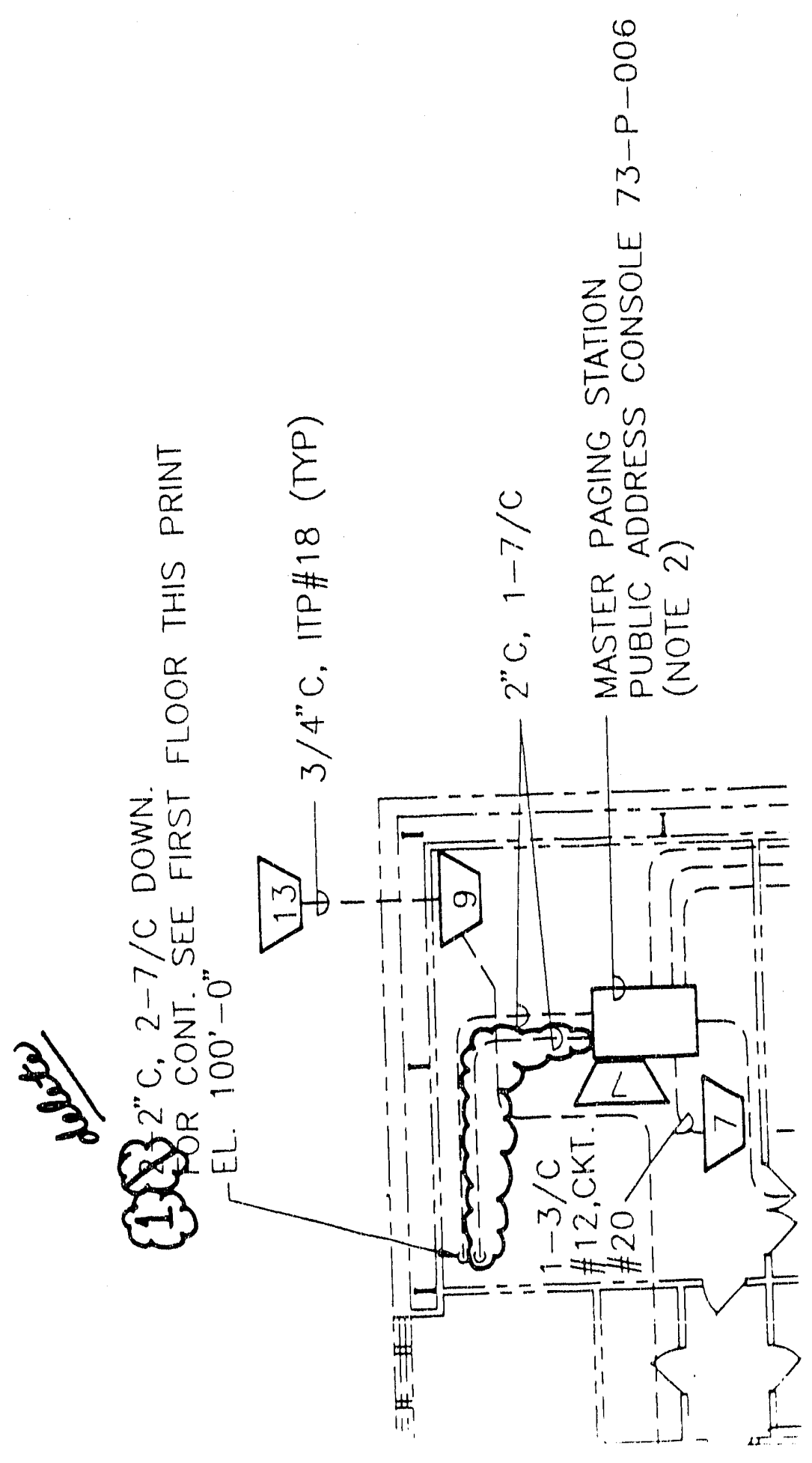




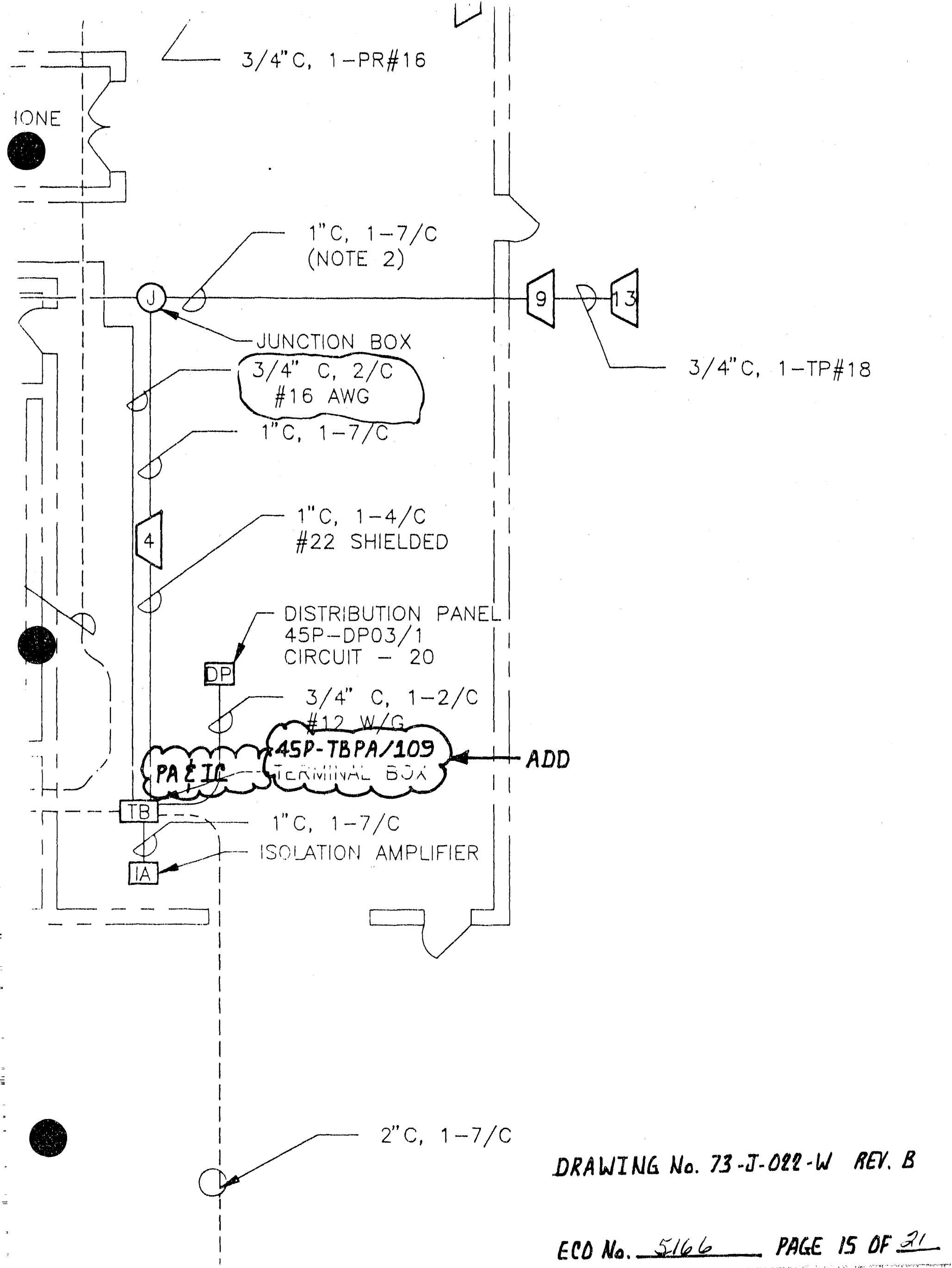



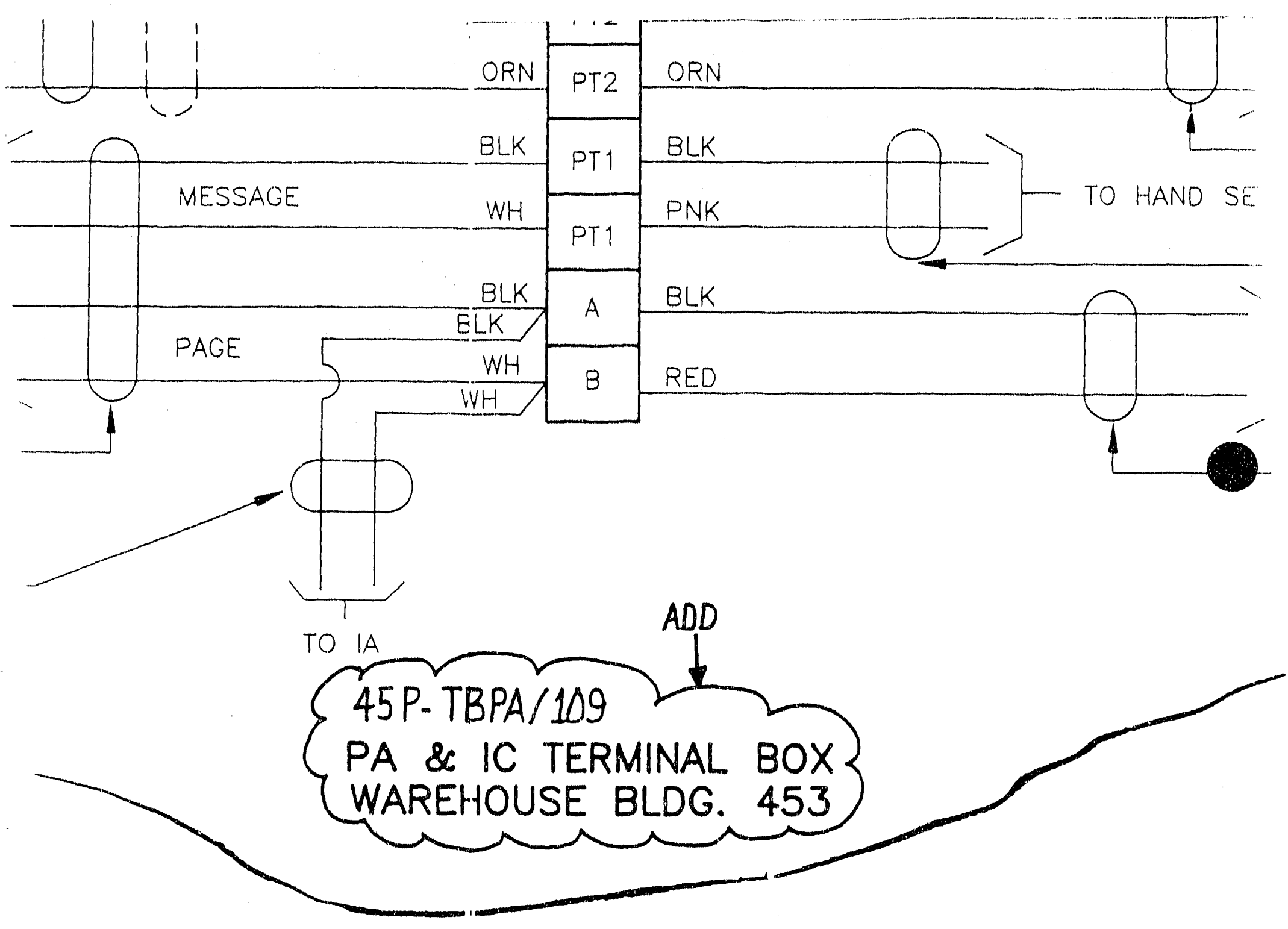

6

DRALIINGE NG. 73-J-A22.W Rev. B ECO No. 5166 PAGE 16 OF 


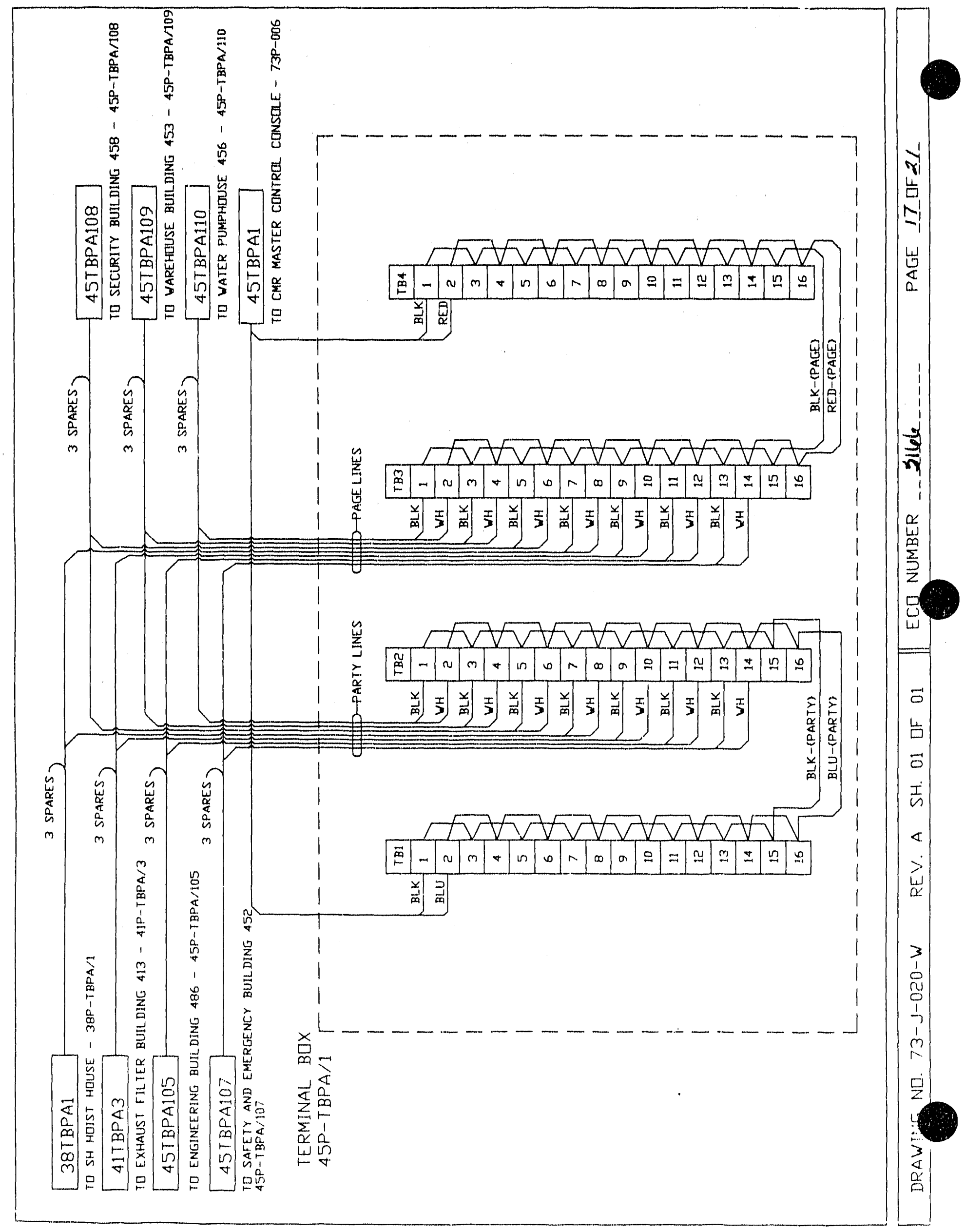




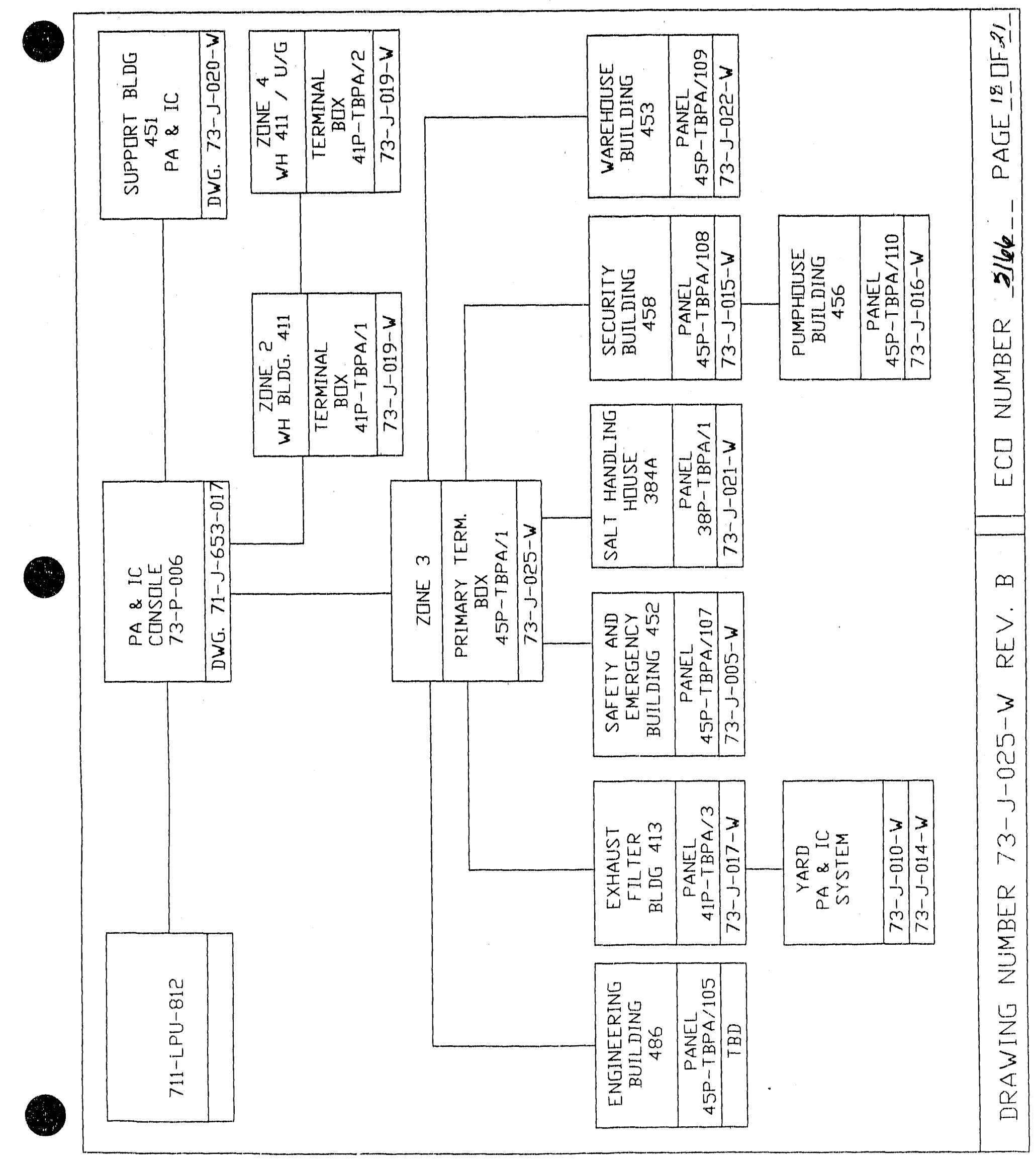




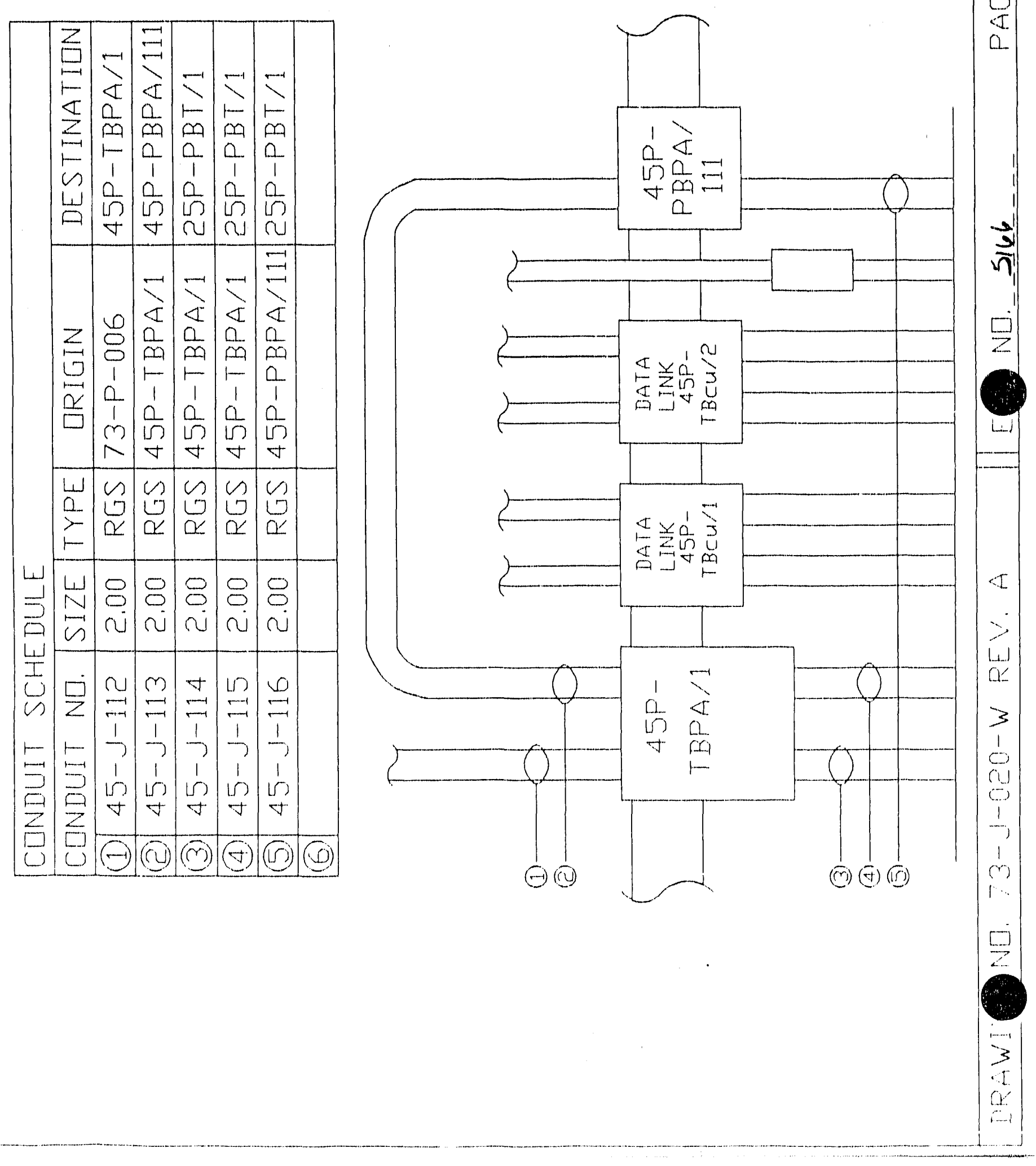



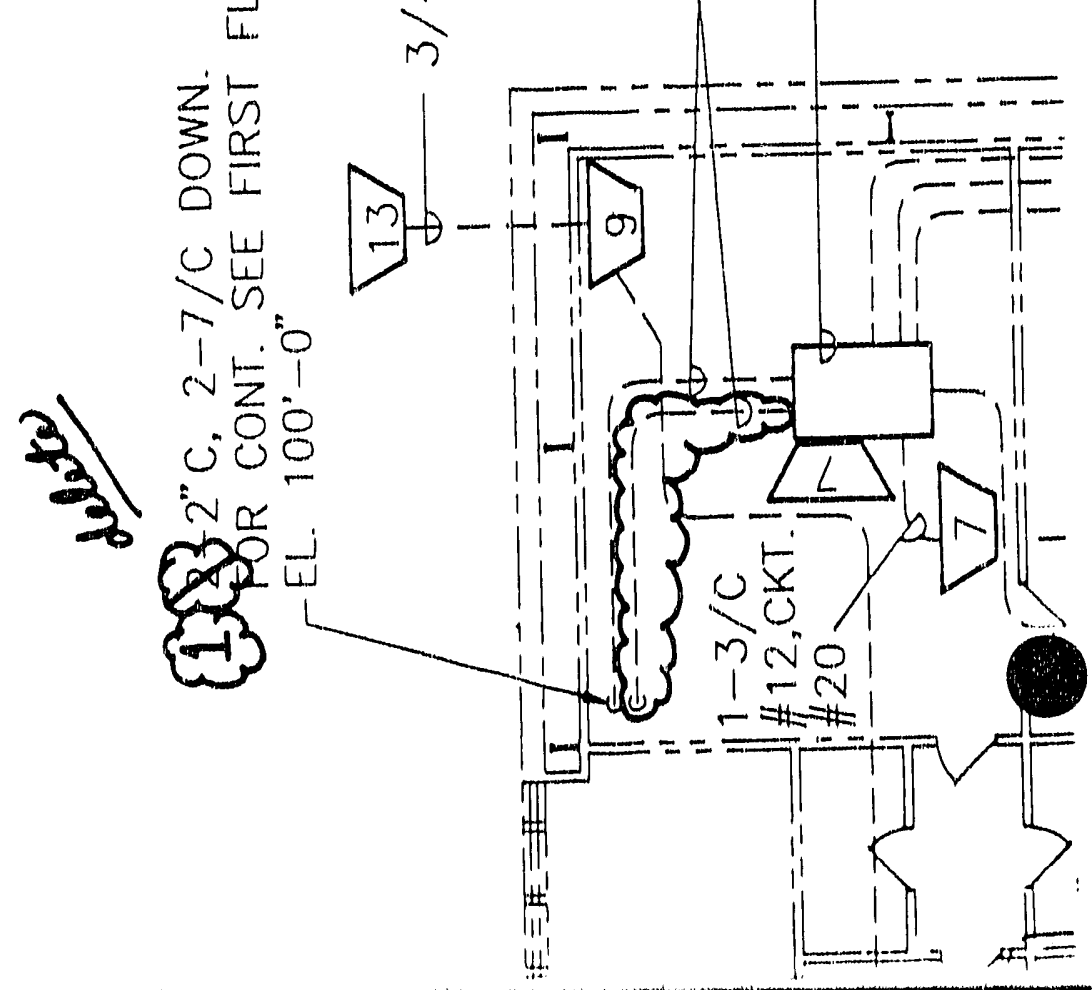


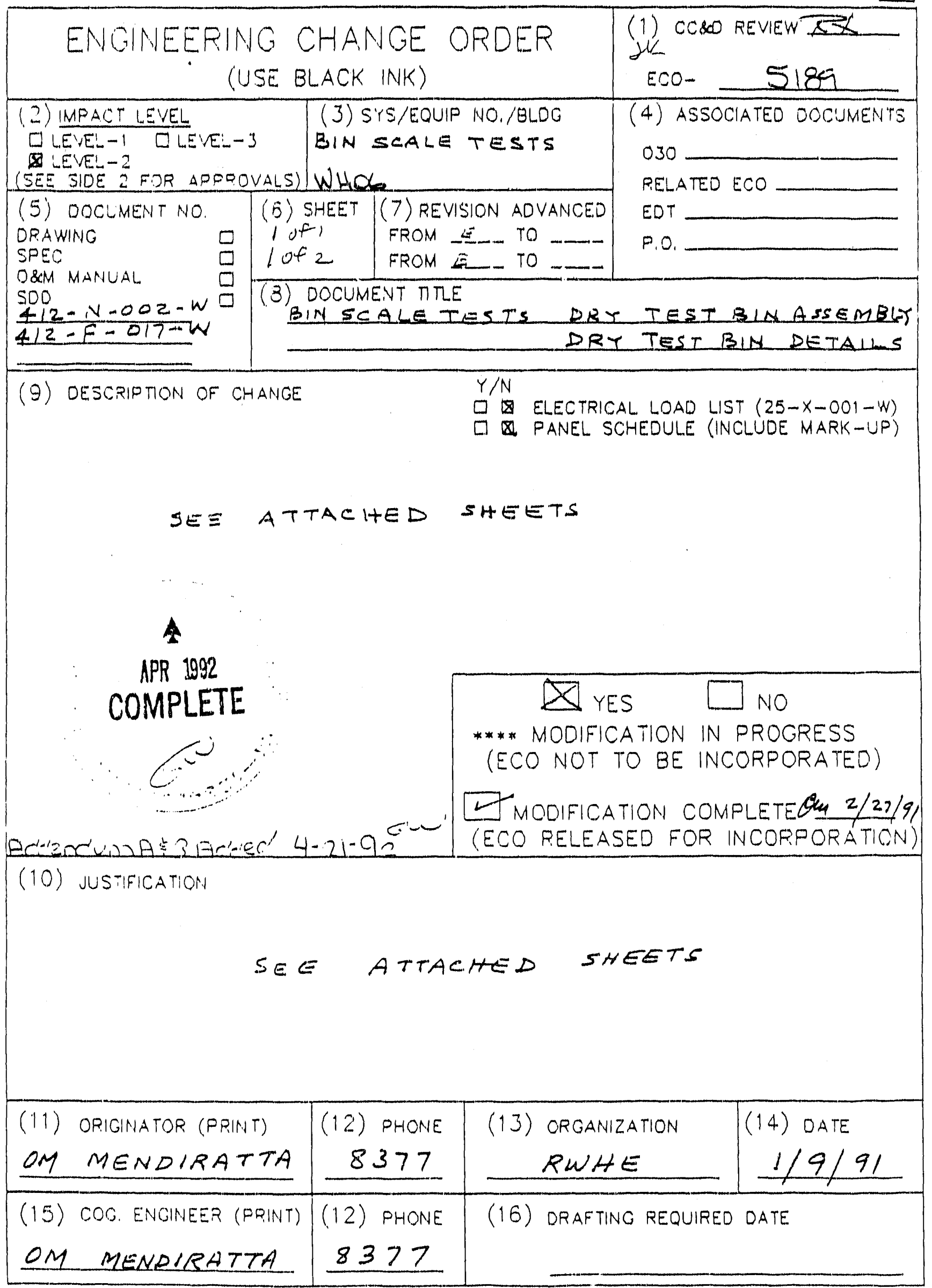


(17) REIATED CHANGES: INIOICATE THE DOCUMENTS, INSTRUCTIONS OR PROCEUURES (OTHER THAN THE ORAMMIGS OR DOCUMENTS IDENTIFIED IN EITHER 5 OR 9)

THAT WILL BE AFFECTED BY THE CHANGE DESCPIEED IN GLOCK 9 . ENTE? THE DOCUMENT NUMEER(S) IN BLOCK 18.

YESNON/A

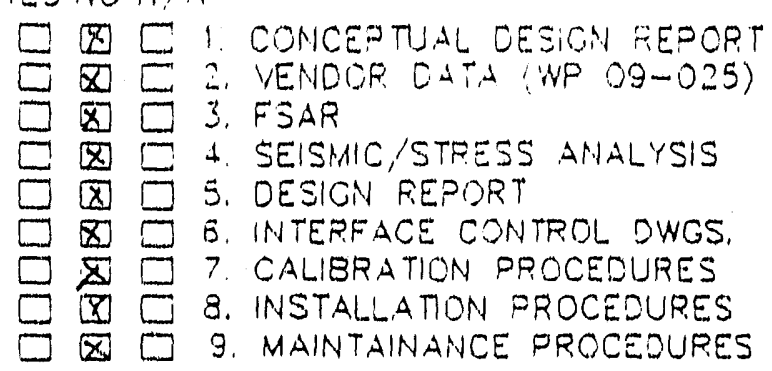

YES NIO N/A

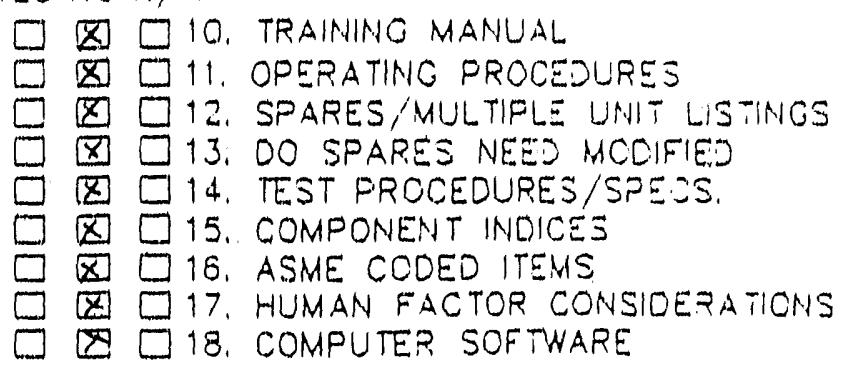

(18) FE: ATEO OOCUMENT NOO: INSTRUCTON NO:; IDENTIFIEO IN BLOCK 17. (CHANGES TO DOCUMENTS LISTED IN BLOCK 19 WILL NOT GE INCCPRORATED BY THIS ECO).

\section{DORUMENT NO /REVISION}

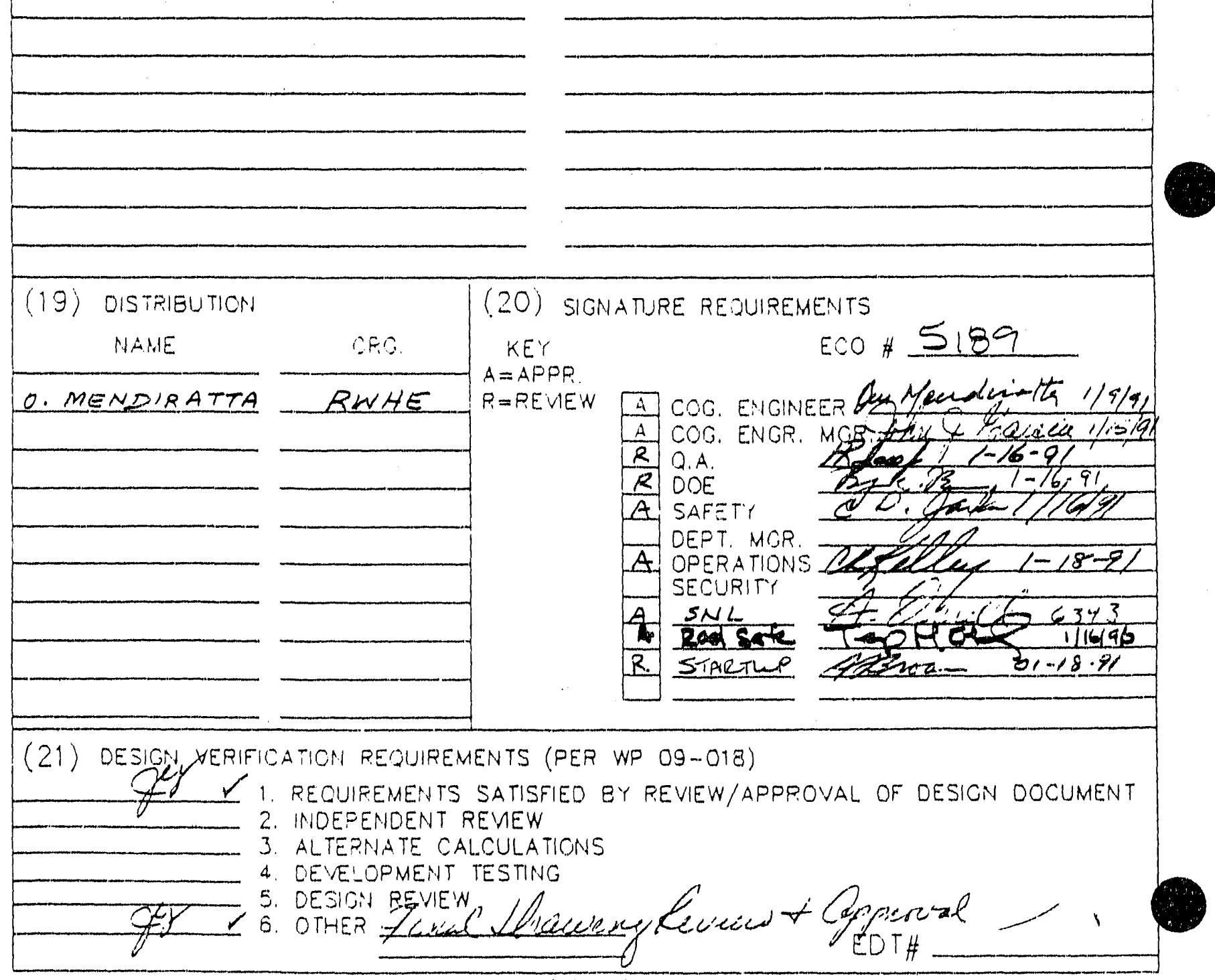

(Side 2) 


\section{ENGINEERING CHANGE ORDER CONTNULATON SHEET}

DOCUMENT NO.

$4 / 2-N-002-W$
$4 / 2-F-017-W$

(9) DESCRIPTION OF CMANGE

1. REVISE DETAII 1, DRAWING \&12-N-002-W AS SHOWN AND IABEI THE DETAIL, PB-018 ONLY".

"FOR TEST BINSYPB-009 THROUGH

$S / N$

$1 / 2 "$ BREATHER FILTER-

"'2FEMALE NUT (SS-8-VCR-1

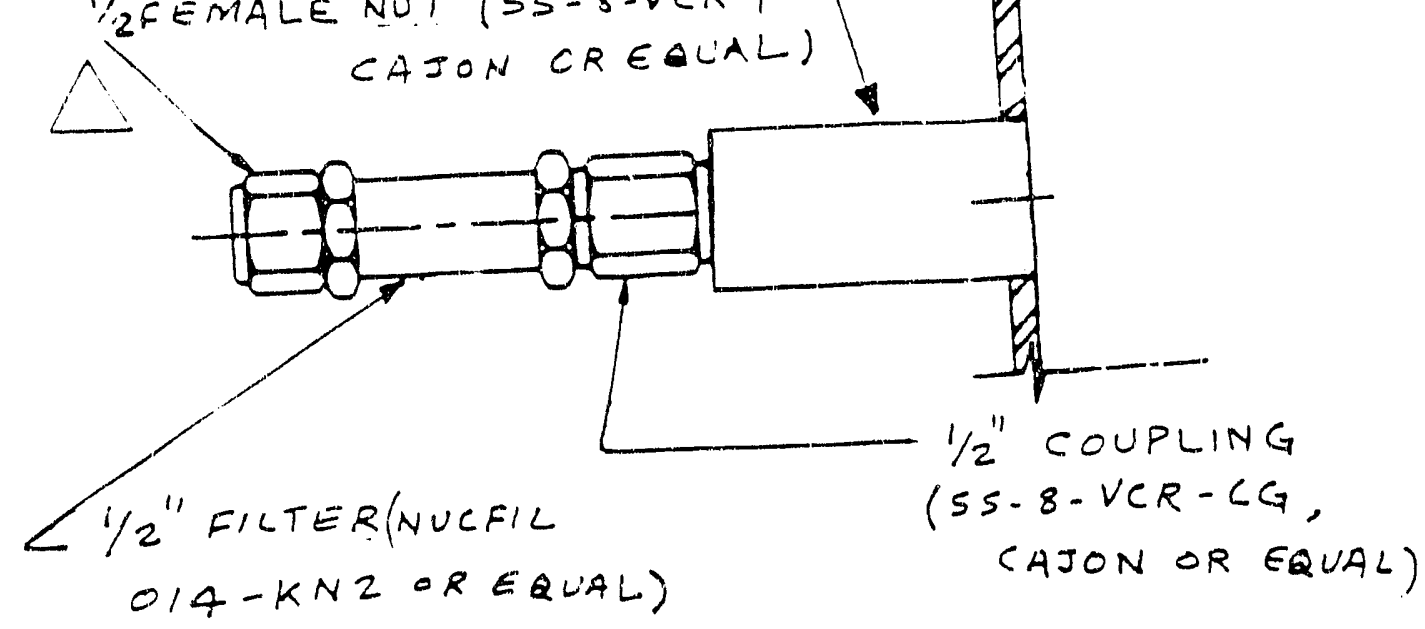




\section{ENGINEERING CHANGE ORDER CONTINUATION SHEET}

\begin{tabular}{|c|c|}
\hline DOCUMENT NO. & $\begin{array}{l}1-002-W \\
F-017-W\end{array}$ \\
\hline DATE $1 / 9 / 91$ & $\begin{array}{l}\text { PAGGE } \\
4 \text { of } 5\end{array}$ \\
\hline
\end{tabular}

2. ADD DETAII ON DRAWING 412-N-002-W TO SHOW TRANSPORT FIITER (BREATHER FILTER) CONNECTION, LABEL DETAII, "FOR TEST BINS $V$ PB-O19 AND ONWARD". $S / N$

$1 / 2 "$ "CAPTURED (FENALE) NUT ( $55-3-V C R-1$ CATONDR ERUAL)

$1 / 2$ "FILTER! NUCFIL) $014-K N 2$ OR EQUAL)

$\triangle 1 / 2 "$ FEMALE NUT $1 / 2$ FEMALE NUT , TAON OR EQUAL)
(SS-8-VCR-1, CAJON

$1 / 2$ "SOCKET WELD GLAND (SS-8-VER-3, CAJON OR EQUAL)

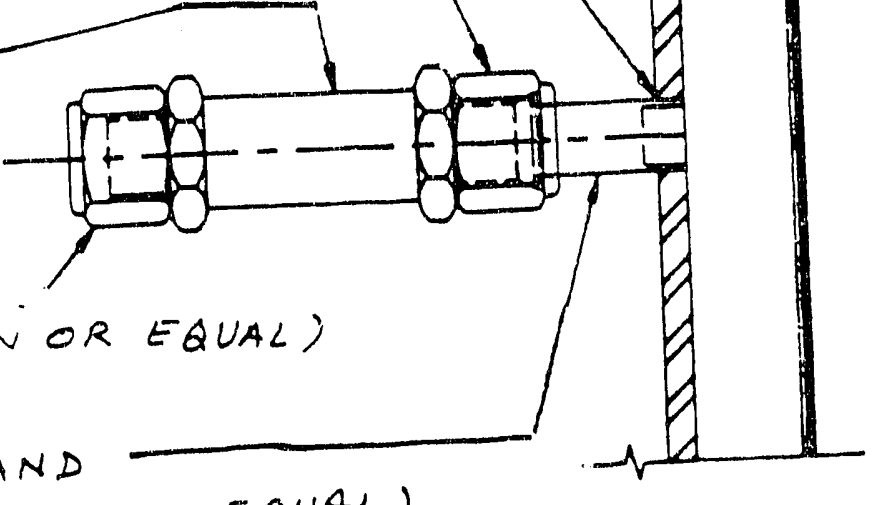




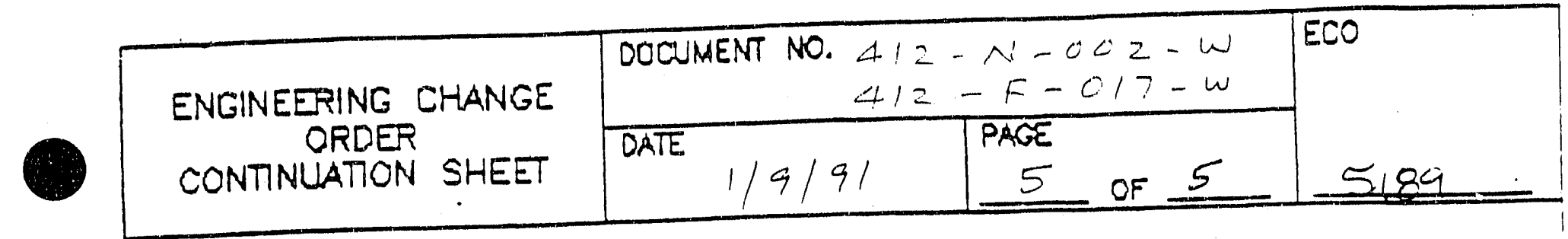

3. REVISE NOTE 15, DRAWING 412-N-002-W, "TRANSPORT FIITER TO BE FITTED WITH A FEMALE NUT AT THE FABRICATION SHOP, THIS FEMALE NUT TO BE REPIACED WITH A CAP NUT AT THE WIPP SITE PRIOR TO DOWNLOADING OF THE BIN." (NOTE: NOTE LOCATOR TRIANGLES ARE MARKED ON THE ATTACHED SKETCHES).

4. ADD A NOTE TO DRAWING 412-N-002-W, "ALI VCR CONNECTIONS SHAIL BE MADE WITH PROPER SIZE GASKET, PREFERABLY HELD IN A GASKET RETAINER ASSEMBLY." CROSS REFERENCE THIS NOTE WITH THE BIIL OF MATERIAI, ITEM DESCRIPTION FOR THE GASKET.

5. ADD TO THE DRAWING 412-N-002-W, BIIL OF MATERIAL, THE GASKETS AS INDICATED BELOW:

1/2" GASKET RETAINER ASSEKBLY (NI-8-VCR-2-GR-VS, CAJON OR EQUAL); RUANTITY = ONE PER CONNECTION; NOTE: FOLLOW VENIJU DIRECTIONS FOR REPEATED USE OF THE SAME ASSEMBLY .

1" GASKET RETAINER ASSEMBLY (NI-16-VCR-2-GR-VS, CAJON OR EQUAL); QUANTITY = ONE PER CONNECTION; NOTE: FOLIOW VENDOR DIRECTIONS FOR REPEATED USE OF THE SAME ASSEMBLY .

6. REVISE AIL OTHER DETAIIS ON THE DRAWINGS IISTED IN COLUMN 5, TO REFIECT CHANGES PER THIS ECO.

\$10)

\section{JUSTIFICATION}

WEIDING OF THE FILTER HOUSING TO THE BIN WAIL VOIDS DOP CERTIFICATION FOR THE FIITER MEDIA PERFORMED EARLIER (BEFORE WELDING). 


\section{ENGINEERING CHANGE ORDER \\ ADDENDUM SHEET}

Page 1 of

1. Addendum $A$ to ECO Number: 5189 Drawing Number: $412-F-017$

2. Description of change:

$412-F-017-W 1:$

- add 1/8" $\times 45^{\circ}$ chamfer to trems 18 and 9 at detalls 3 and 4.

- Change $15 / 16 " 12$ to 15/16-12 at detall 3.

- change 9/16"18 to 3/4"-16 at detall 4.

- change. 38 dimension to .41 at detail 4.

- change o. 44 dimension to R.88 at petail 4.

- abditional dimensions of .88 and.62 requireo at DETAILS 3 AND 4.

- change welding desighations at elevatron viens, detalls 2A And 2B, "valve mount assembly-GR4, and $1 / 2$ "valve MOUNT ASSEMBLY- GR-3.

- ADO NOTE 20.

412-F-017-W2:

- change $9 / 16-18$ to $3 / 4-16$ at detall of Item 16.

- ado reference to note 20 at item 20.

- remove counterbore and incorporate countersink at DETDAL OF ITEMS 16 AND 24.

\section{Approvals}

\begin{abstract}
Cognizant Engineer:
CC\&D Mgr. /Desig. Rep.:

Other Approval:
\end{abstract}

Other Approval::
Qu $10,-12+216$

Signature

Signayire

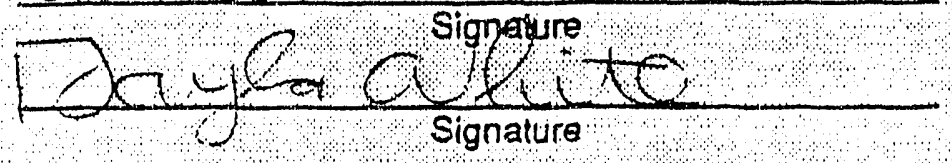

Signature

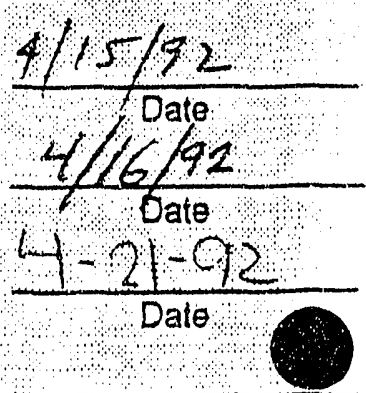

Dato 

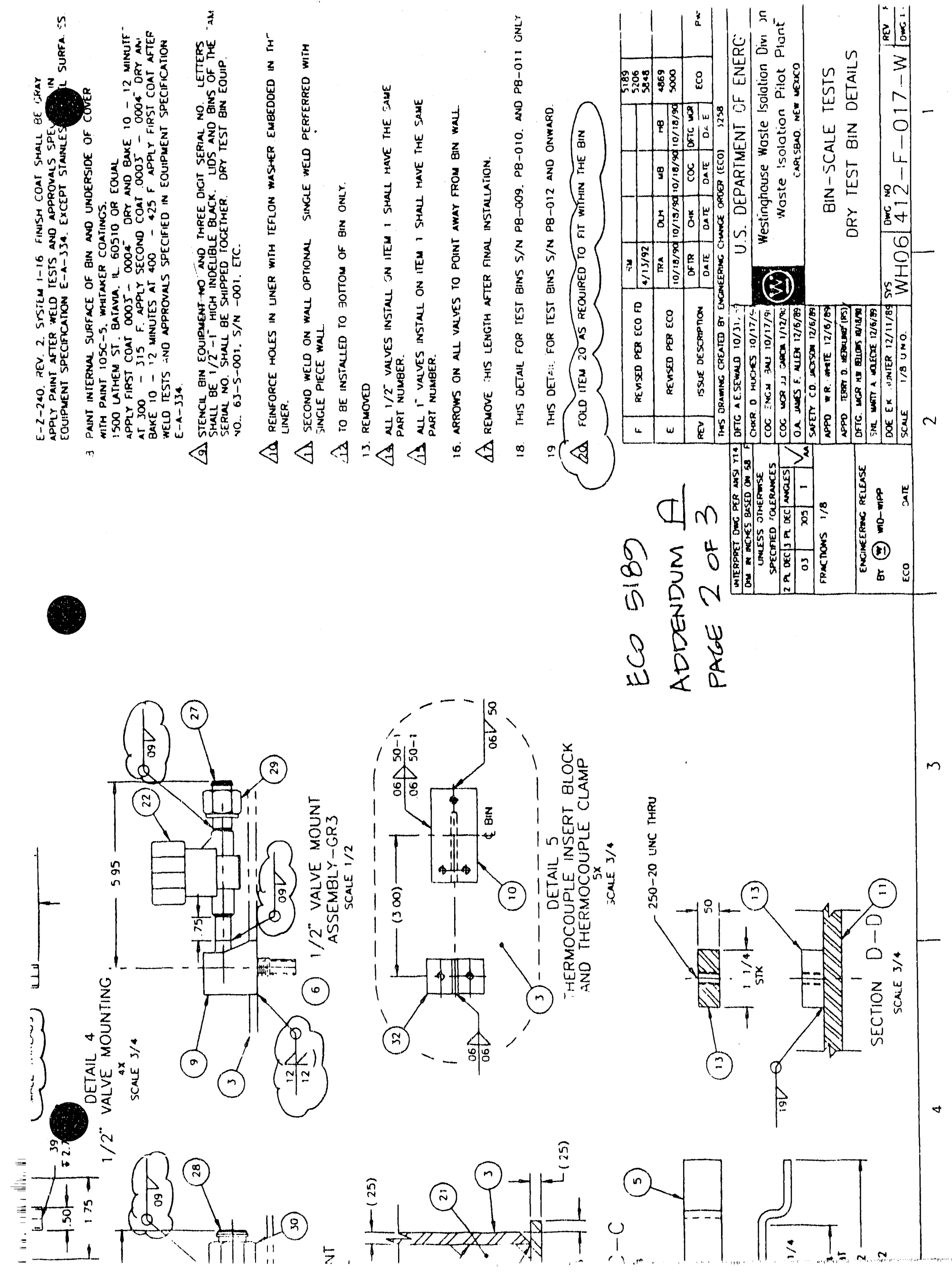


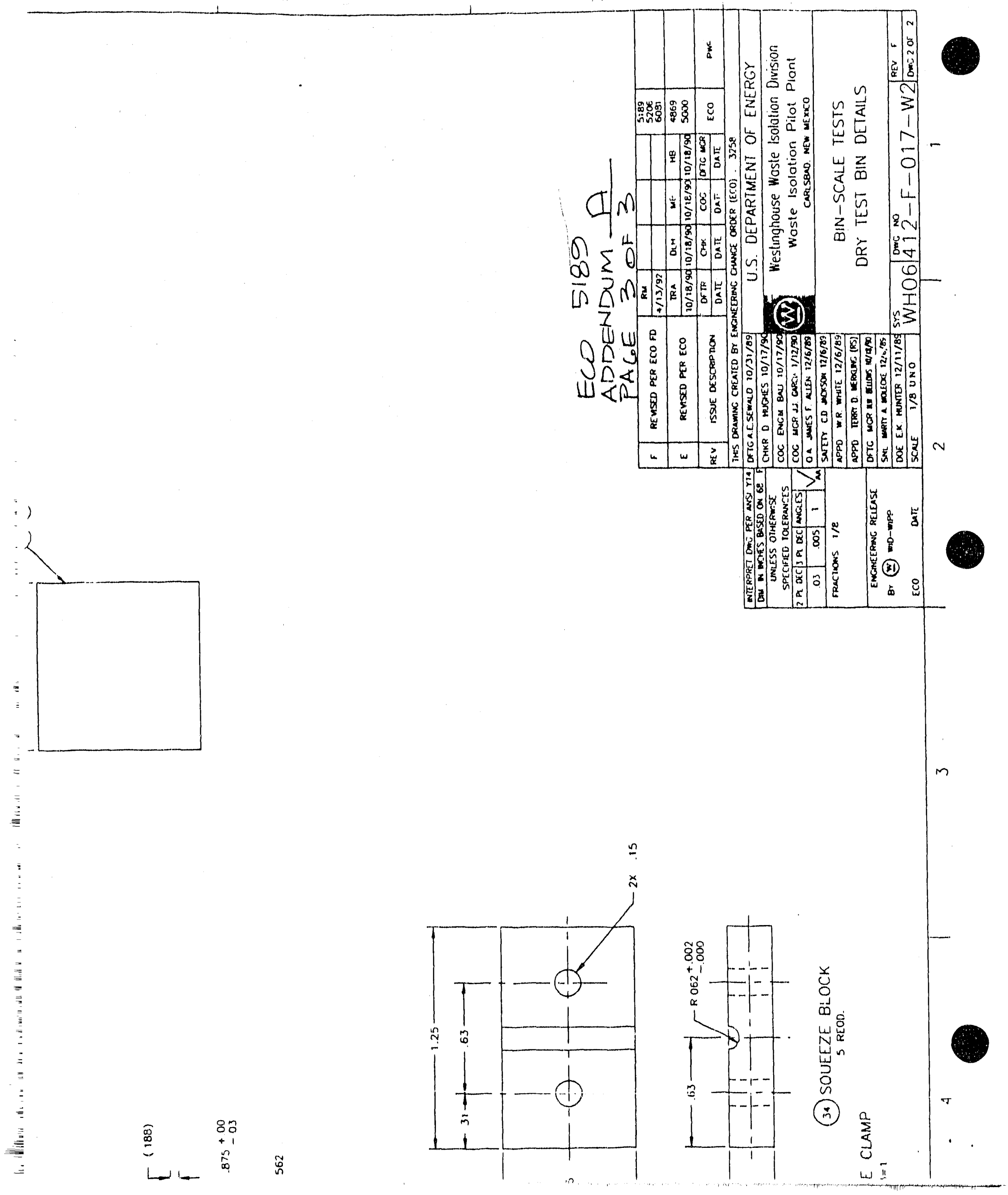


ENGINEERING CHANGE ORDER

ADDENDUM SHEET

Page 1 of 2

1. Addendum $Q$ to ECO Number: 5189 Drawing Number: $412-N-009-w$

2. Description of change:

ABOLTLW OF MODIFIED NUEFL FILTER, \#OI4KHZ, (HALl MACHINE DRWG. NO. HMW-OI4KNZ) 4 placES to $1 / 2$ " valve connetron. at view boD and AT SETON A $\triangle A$.

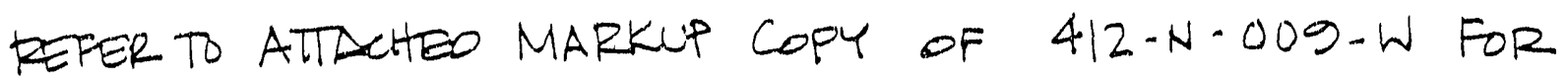
adDitional clarifIcation.

ITEMS 4,5, 14, AND 17 SHOULD BE IN CLUDED WITH Group I AT BILL OF MATERIAL.

3. Approvals

Cognizant Engineer:

CC\&D Mgr Design Rep.

Other Approval:

Other Approval::
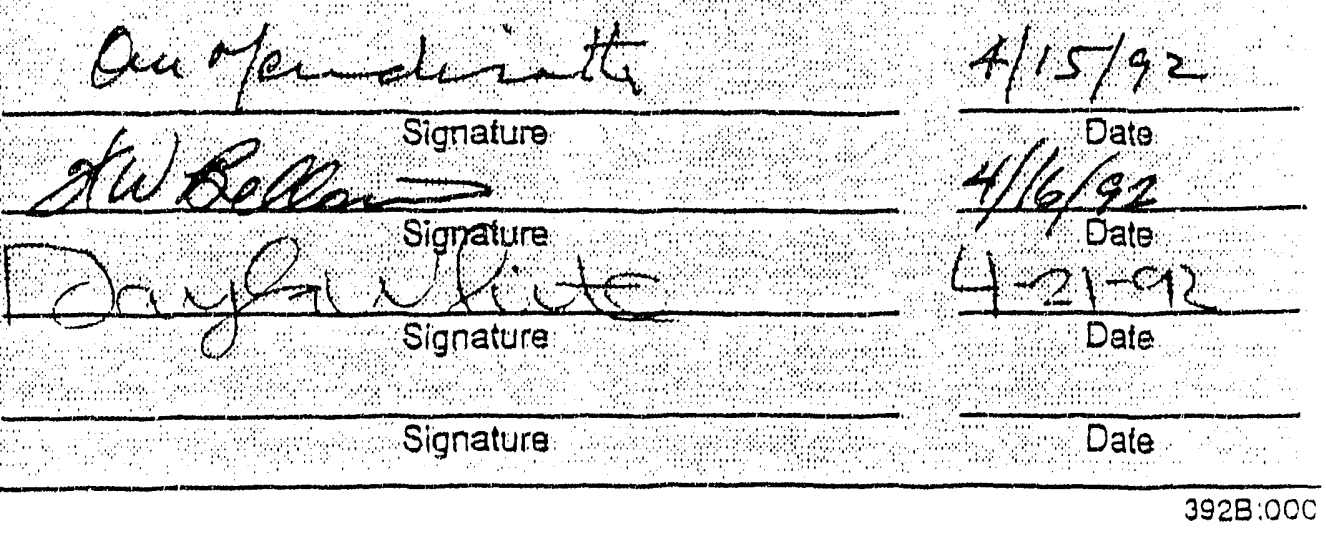
vip Fum 2020; 3/13/32
Page f of 1

3928:00 


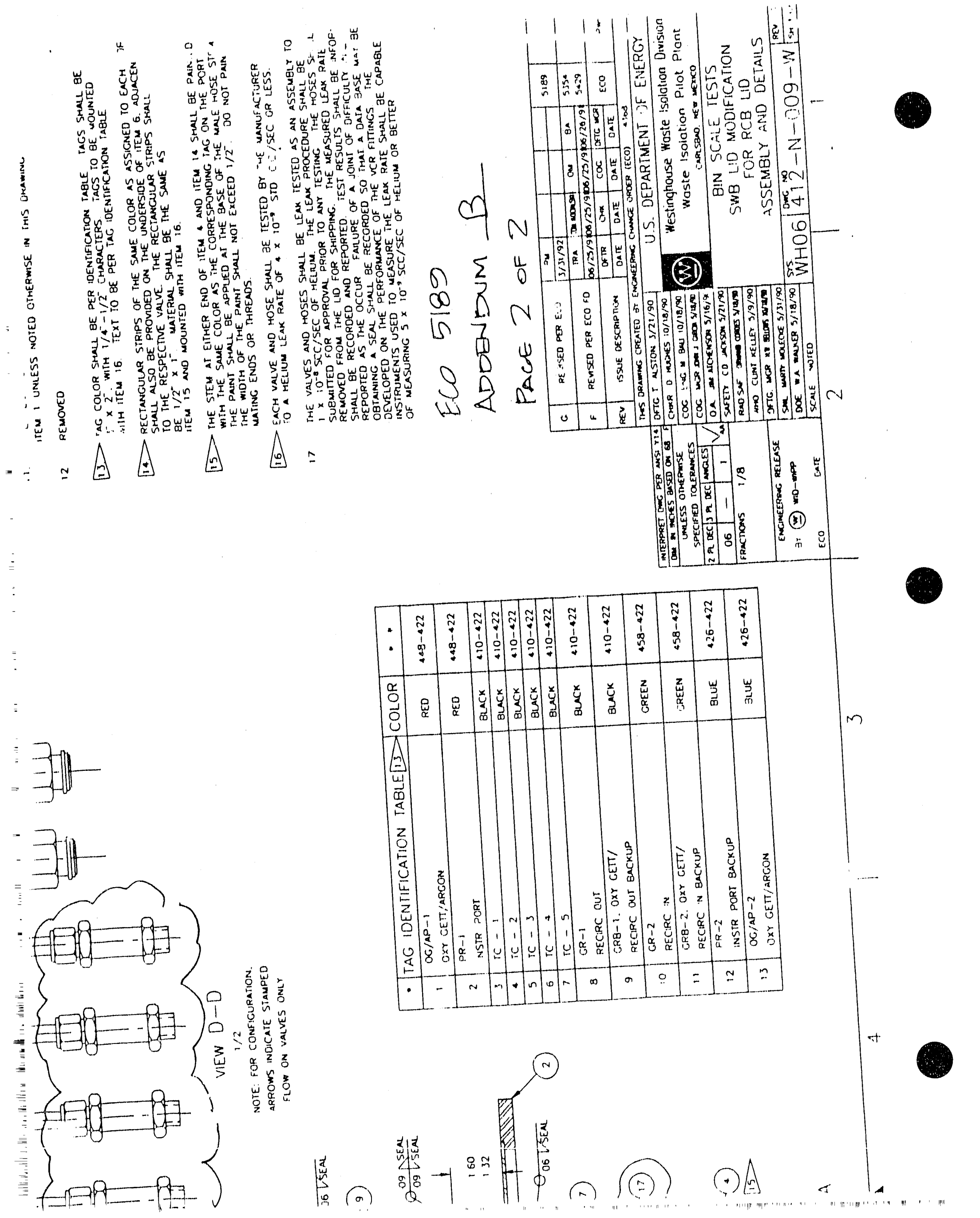


S. LINER MATERIAL SHALL GE POLYETHYLENE, NOMINAL MMICKNELSS: US $30^{*}$ LINER SHALL NOT RELEASE ANY GASES BETWEEN 70' F AND 90' $\mathrm{F}$.

6. REMOVED

7. PREPARE AND PAINT EXTERNAL SURFACES OF BIN PER SPECIFICATION E-Z-240, REV, 2, SYSTEM 1-16. FINISH COAT SHALL BE GRAY. APPLY PAINT AFTER WELD TESTS AND APPROVALS SPECIFIED IN EQUIPMENT SPECIFICATION E-A-334, EXCEPT STAINLESS STEEL SURIFACES.

8. PAINT INTERNAL SURFACE OF BIN AND UNDERSIDE OF COVER WITH PAINT 105C-5, WHITAKER COATINGS, 1500 LATHEM ST, BATAVIA, IL, 60510 OR EQUAL. APPLY FIRST COAT .000 $3^{\prime \prime}-.0004^{\prime \prime}$ DRY ANO BAKE $10-12$ MINUTES AT $300^{\circ}-315^{\circ}$ F. APPLY SECOND COAT .0003" - .0004" DRY AND BAKE 10 - 12 MINUTES AT $400^{\circ}-425^{\circ} \mathrm{F}$. APPLY FIRST COAT AFTER WELD TESTS AND APPROVALS SPECIFIED IN EQUIPMENT SPECIFICATION $E-A-334$.

9. STENCIL BIN EQUIPMENT NO. AND THREE DICIT SERIAL NO. LETTERS SHALL BE $1 / 2^{\prime \prime}-1^{\prime \prime}$ HIGH INDELIBLE BLACK. LIDS AND BINS OF THE SAME SERIAL NO. SHALL EE SHIPPED. TOQETHER, DRY TEST BIN EQUIP, NO.: $6.3-S-001, S / N-001, E T C$.

1d REINFORCE HOLES IN LINER WITH TEFLON WASHER EMBEDDED IN THE LINER.

1. SECOND WELD ON WALL OPTIONAL. SINGLE WELL PERFERRED WITH SINGLE P!ECE WALL.

11. TO BE INSTALLED TO BOTTOM OF BIN ONLY.

13. REMOVED

14. ALL 1/2" VALVES INSTALL ON ITEM 1 SHALL haVe tHE SAME. PART NUMBER.

15 aLL 1" VALVES INSTALI ON ITEM 1 SHaLl. haVE THE SAME PART NUMBER.

16. ARROWS ON ALL VALVES TO POINT AWAY FROM BIN WALL.

A REMOVE THIS LENGTH AFTER FINAL INSTALLATION.

18. THIS DETAIL FOR TEST BINS S/N PB-009, PB-010. AND PB-011 ONLY.

19. THIS DETAIL FOR TEST BINS S/N PB-012 ANO ONWARD.

2d FOLO ITEM 20 AS REQUIRED TO FIT WITHIN THE BIN.

\begin{tabular}{|c|c|c|c|c|c|c|c|}
\hline \multirow{2}{*}{$\mathrm{F}$} & \multirow{2}{*}{ REUSED PER ECO FD } & RM & 1485 & Toun & 218 & \multirow{2}{*}{$\begin{array}{l}5189 \\
5206 \\
5848\end{array}$} & \\
\hline & & $4 / 15 / 92$ & $3 / 15192$ & 1471592 & $4 / 16102$ & & \\
\hline \multirow{2}{*}{ E } & \multirow{2}{*}{ REUSED DER ECO } & TRA & $D L H$ & $M B$ & $\mathrm{HB}$ & \multirow{2}{*}{$\begin{array}{l}4869 \\
5000\end{array}$} & \\
\hline & & $10 / 18 / 90$ & $910 / 18 / 9$ & $10 / 18 / 90$ & $10 / 18 / 90$ & & \\
\hline \multirow{2}{*}{ REV } & \multirow{2}{*}{ ISSUE OESCRIPTION } & DFTR & $\mathrm{CHK}$ & $\mathrm{COO}$ & OFTG MGR & \multirow{2}{*}{$E C O$} & \multirow{2}{*}{ PWR } \\
\hline & & $\overline{D A T E}$ & DATE & $\overline{\text { DATE }}$ & $\overline{D A T E}$ & & \\
\hline
\end{tabular}

INIERPRET OWC PER ANSI Y14 DFTC A.E.SEWALD $10 / 31 / 8$ DIM. IN INCHES QSSED ON 68 F F CHKR. D. HUGHES $10 / 17 / 90$ UNLESS OTHERWISE SPECIFIED TOLERANCE: 2 PL UEC 3 PL OEC $/$ ANGLES 7 COG, MGR J., GARCU $1 / 12 / 90$ \begin{tabular}{|l|l|l|l|l|}
\hline 03 & \pm .005 & $\pm 1^{\circ}$ & Q.A. JAMES F. ALIEN $12 / 6 / 89$ \\
\hline
\end{tabular}

FRACTIONS $\pm 1 / 8$ SAFETY C.D. JACKSON $12 / 6 / B 9$
APPD W.R. WHITE $12 / 6 / 89$ APPD TERPY D. MERKLING (RS)

ENGINEERING RELEASE DFTC. MGR H.W. ELLOWS 10/18/30 BY (II); WD-WPP

\section{U.S. DEPAFTMENT OF ENERGY}

$\rightarrow$ Westinghouse Waste Isolation Division Waste Isolation Pilot Plant CARLSBAD, NEW MEXICO

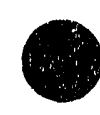

(1)
ans.

\section{BIN-SCALE TESTS DRY TEST BIN DETALS}

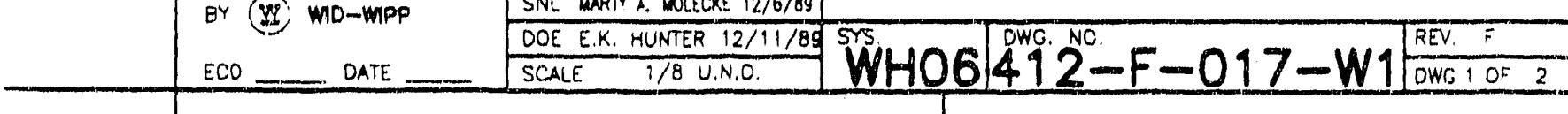




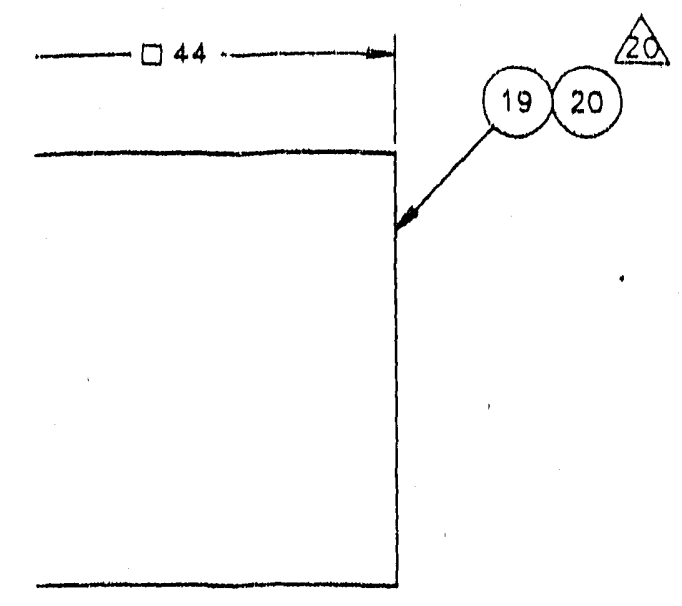

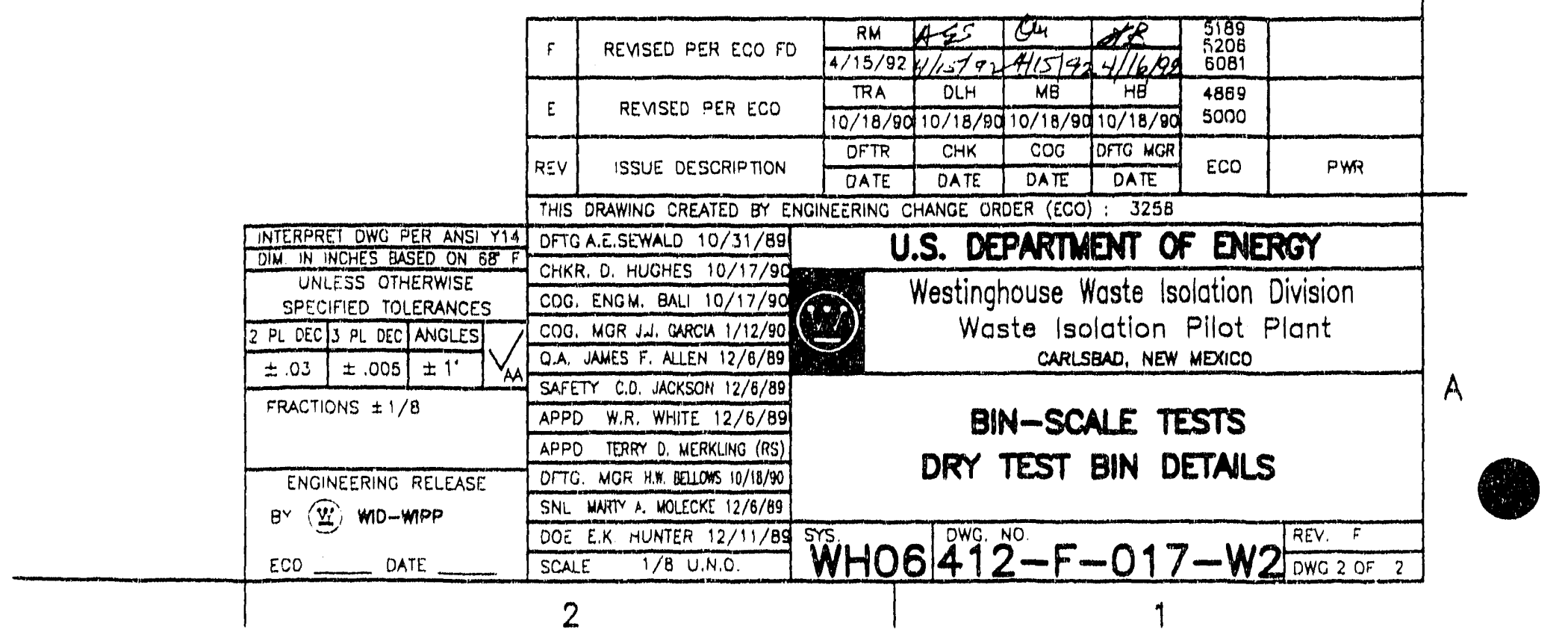




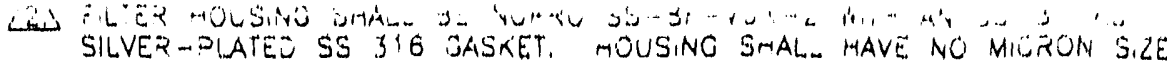
OR OTHER SPECIFICATION STAMPEO ON IT, DISCARD THE NUPRO

FILTER ELEMENT IN THE HOUSINO.

3. FIBERgOARD LINERS TAPED TOGETHER AT TAB END WITH ITEM 18.

4. SHIP ITEM 4 PLACEO INSIDE ITEM 2, NO SHARP BEINDS ON GASKET,

5. TAOS TO BE RED WITH WHITE LETTERING ON A $3^{\prime \prime} \times 2^{*}$ TAO, WITH $1 / 4^{\prime \prime}-$ $1 / 2 "$ "HARACTERS, TAGS TO EE MOUNTED WITH ITEM 20, TEXT OF EACH TAO SHOWN IN TAO IDENTIFICATION TABLE.

6. REMOVEO

7. REMOYED

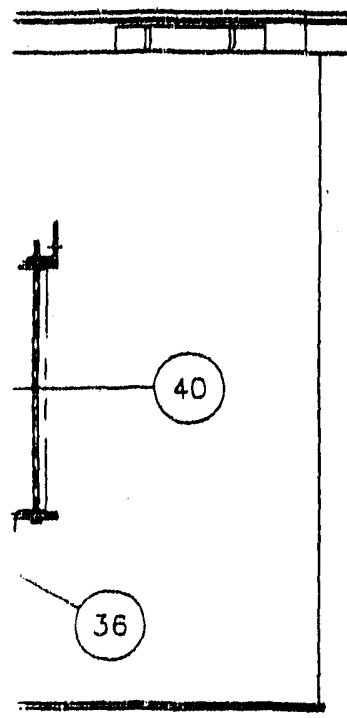

8. REMOVEO

9. STANDARD HEX-HEAD BOLTS WITH INTEGRAL WASHERS, BOLTS SHALL BE $1 / 2-13$ UNC $\times 1-1 / 4$ LO. WITH AN INTEGRAL FLAT WASHER $1^{\prime \prime}$ DIAMETER, 10. EAVE TOP OF ITEM 12 LDOSE AFiER INSTALLING ITEMS 13,14, 29, \& 30

1. STENCIL BIN EOUIPMENT NO. AND THREE DIGIT SERIAL NO, LETTERS SHALL BE $1 / 2^{\prime \prime}-1^{\prime \prime}$ HIGH INDELIBLE BLACK, LIDS AND BINS OF THE. SAME SERIAL NUMBER SHALL EE SHIPPED TOGETHER, SOLID WASTE GIN EQUIP. NO.: 63-S-001, S/N -001, ETC. PS/SC BIN EQUIP, NO.: 63-S-004, $S / N-001, E T C$

A. SANDIA NATIONAL. LABS, TO SUPPLY AND INSTALL ITEMS 23, 24, 25, 26, AND 27 PER PROCEDURES APPROVED BY $W-W 10$.

13. TIGHTEN TO 30 FT-LB TORQUE.

44. STENCIL WORDS "MAX GROSS WEIGHT 3,200 LES." LETTERS SHALL BE $1-2^{\prime \prime}$ HIGH, INDELIELE BLACK, ON NEAR AND FAR SIDE OF BIN, STENCILED AFTER PAINTING BIN.

TRANSPORT FILTERS (ITEM 3B) TO BE. FITTED WITH A FEMALE NUT AT THE FABRIGATION SHOP. THIS NUT WILL BE REPLACED WITH A CAP NUT AT THE WIPP SITE PRIOR TO DOWN-LOAUING OF THE BIN.

16. ALL VCR CONNECTIONS SHALL EE MATED WITH PROPER SIZE GASKET, PREFERABLYY HELD IN A GASKET RETAINER ASSEMELY (ITEM 32, ITEM 33).

17. FOLLLOW VENDOR DIRECTIONS FOR REPEATED USE OF THE SAME ASSEMELY,

3)

S8. FILTER MEDIA SHALL BE REMOVEO FROM THE NUPRO FILTER HOUSING (ITEM 21) FOR THE PROOUCTION BINS S/N PB-009 THROUGH PQ-018.

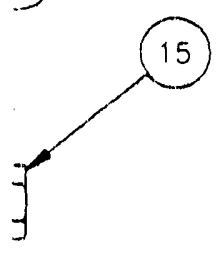

A CUT WIRE CLOTH INTO 20 FT. LONG PIECES. FOLD INTO SIX APPROXIMATELY 40" LONG ACCORDIAN STYLE BENDS. LOAD 3 PIECES (60 L.F.) OF THE" FOLDED WIRE CLOTH DIRECTLY ONTO THE GAS MANIFOLD ASSEMBLY (DWC. NOS. 412-M-OO5-W AND 412-M-007-W). INSTALL PRIOR TO SHIFMENT OF BIN TO GENERATOR SITE.

SEMMLLY

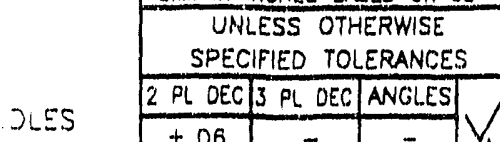
RET OWG PER ANSI Y14 DFTG A.E.SEWALD 10/30/89 DIM. IN INCHES GASED ON 6 ES F COO MGR J GARCA $1 / 12 / 90$ Q.A, JAMES F. ALLEN 12/8/89 FRACTIONS: $\pm 1 / 8$ SAFETY C.O. JACKSON $12 / 6 / 80$ TOROUE \pm 2 FT-LB or +2 IN $-L B$ ENGINEERINR RELEASE QY W. MD-WPP ECO DATE ADPD TERRY O MERKLING (RS) DTO. MORF EELLOWS $10 / 18 / 90$ SNI WAATN A. WCLECKI 12/6/B9

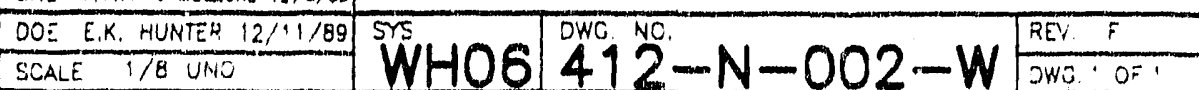

U.S. DEPARTMET OF ENERGY

Westinghouse Waste Isolation Division Waste Isolation Pllot Plant CNILSEAD, NEW MEXICO

BIN-SCALE TESTS DRY TEST BIN ASSEMBLY 
8 TO BE INSTALI..ED AT WIPP AT TIME OF LIO INSTALLATION ON RCG.

9. ITEM 4 ANO ITEM 14 TO BE SHIPPED WITH ITEM 1 BUT NOT ATTACHED.

10. AFTER INSTALLING ITEM 10 IN ITEM 2, MATCH MACHINE THE GROOVES OF ITEM 10 INTS ITEM 2 .

11. THE REQUIREMCNTS SPECIFIED IN SPEC, E-1-343 SHALL APPLY TO ITEM 1 UNLESS NOTED OTHEFIWISE IN THIS ORAWING.

12. REMOVED

13 - TAO COLOR SHALL BE TER IOENTIFICATION TABLE. TAOS SHALL GE $3^{\prime \prime} \times 2^{\prime \prime}$ WITH $1 / 4^{\prime \prime}-1 / 2^{\prime \prime}$ CHAFACTERS. TAOS TO BE MOUNTED WITH ITEM 16. TEXT TO BE PER TAC IDENTIFICATION TABLE.

$14->$ REOTANGLLAR STRIPS OF THE SAME SOLOR AS ASSIONED TO EACH PORT SHALL ALSO GE PROVIDED ON THE UNDERSIDE OF ITEM 6 , AOJACENT TO THE RESPECTIVE VALVE, THE RECTANOULAR STRIPS SHALLL BE $1 / 2^{\prime \prime} \times 1^{\prime \prime}$. MATEFIAL SHALL BE THE SAME AS

ITEM 15 AND MOUNTED WITH ITEM 18.

15 - THF. STEM AT EITHER END OF ITEM 4 AND ITEM 14 SHALL GE PAINTED WITH THE SAME COLOR AS THE CORRESPONOINO TAG ON THE PORT. THE PAINT SHALL BE APPLIED AT THE BASE OF THE MALE HOSE STEM, THE WIDTH OF THE PAINT SHALL NOT EXCEED $1 / 2^{\prime \prime}$. DO NOT PAINT MATING ENDS OR THREAOS.

110 $>$ EACH VALVE AND HOSE SHAL. EE TESTED GY THE MANUFACTURER TO A HELIUM LEAK RATE OF $4 \times 10^{-9}$ STD. C.C./SEC OR LESS.

17. THE VALVES ANO HOSES SHALL BE LEAK TESTED AS AN ASSEMGLY TO $1 \times 10^{-8}$ SCO/SEC OF HELIUM. THE LEAK PROCEDURE SHALL BE SUSMITED EOR APPROVAL PRIOR TO ANY TESTING, THE HOSES SHALL GE 2EWOVED FROM THE LIO FOR SHIPPING. THE MEASURED LEAK RATE SHAL. $9 E$ REZORDED AND REPORTED. TEST RESULTS SHALL GE INFORMALLYY REDORTEO AS THE OCCUR, FAILURE OF A JOINT OF DIFFICULTY IN DITAINING A SEAL SHALL BE RECORDED SO THAT A DATA BASE MAY DE SEVE'OOPOD ON THE DERFO PMANCE OF THE VCR FITTINCS. THE INSTRUMENTS USED TO MEASURE THE LEAK RATE SHALL BE CAPAELE OF MEASURING $5 \times 10^{\circ}$ SCC/SEC OF HELIUM OR BETTER.

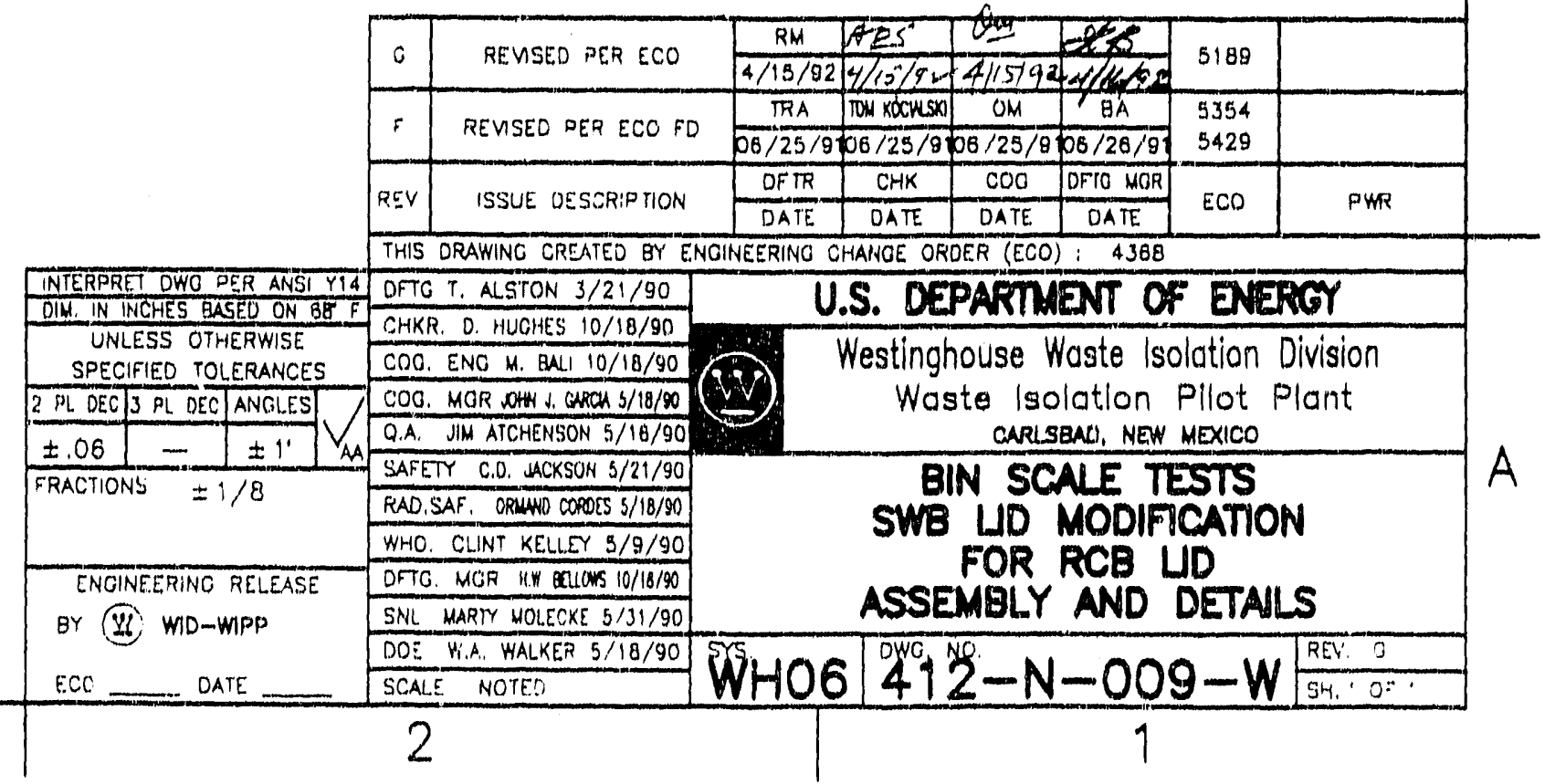


OR/G,NAL ENGINEERING CHANGE ORDER

1. ECO No.: 5204

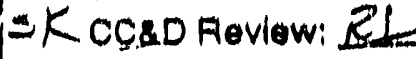

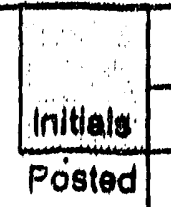

2. Impact Luvel $1 \square \quad 2 \square \quad 3$ \& $4 \square$

3. System: $E C O /$ Equipment No.: N/A Buileting: Roads

4. Assoclated Documents:

PWR $M-04424$

ECP $2-G(9)-14$

P.O.

Others

\section{Document Typo:}

Drawing $24-C-14 c i-022$ \&

Speciflation $24 i \cdot 143 \cdot 022$

Spocification $24 \cdots c-145-622$

Vendor Data $2.4 \cdot C-147-022$

SDD $24.0 .144-022$ $04 \cdot 0 \cdot 010-w$

Others

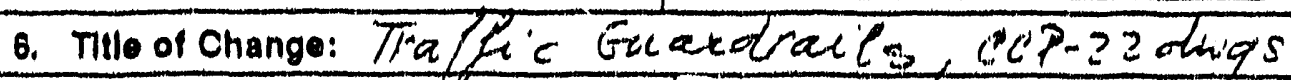

7. Originator: (print) Ext. No.:

Department:

Dato:

T.Kowe/sike

स167 HaCE

C)/

a. Cognizgnt Engineer: (prini) Ja "Kowediske.

9. Desortption of Change:

Yes No

No Component indices change required (if yes, attach sheets)

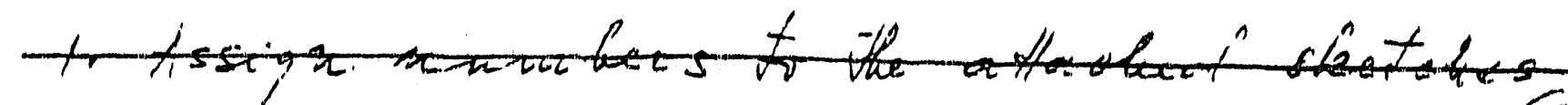

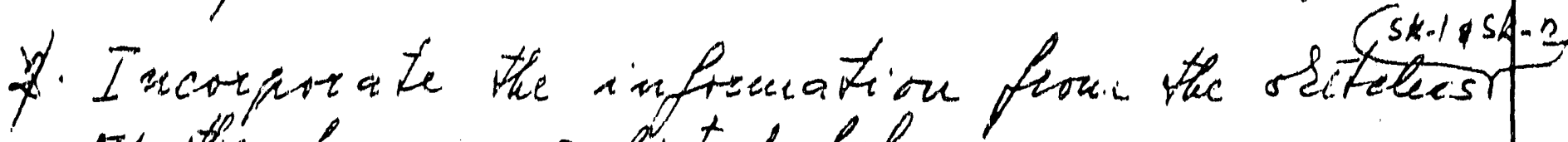

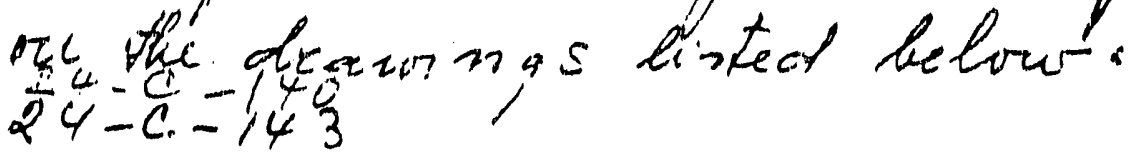

$24-e-145$

$24-5-14 a-70$ st dedae $\ell\left(s k-2 m g_{y}\right)$

$24-c-010-8 k e c t / 42$

Qa Drawing Change Sheet atiached

ab Design Docurrientation Sheet attached

90 Vendor Data Change Sheel attached

10. Yos Houlkli/2t/9!

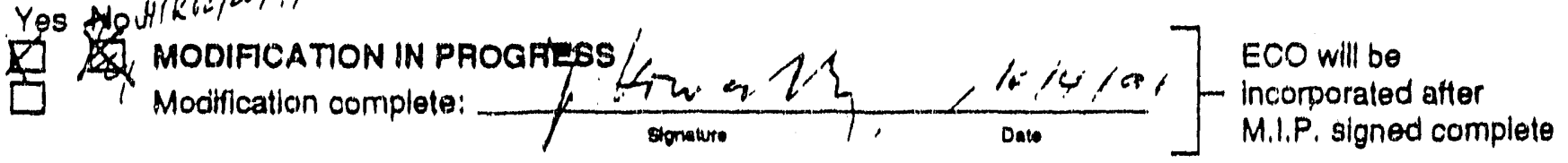

口. Change drawing per as-buill markup dated:

Change drawing per ECO-provided dala

Temporary modification

11. Design Verification Requlrements: (por WP 09-018)

EDT No.:

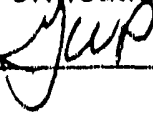

1. Requirements satisfied by review/approval of design document

2. Independent review

3. Allemate calculations

4. Development testing

5. Design review

6. Other:

12. Addendum Shoot added: 
13.. Justiflcation

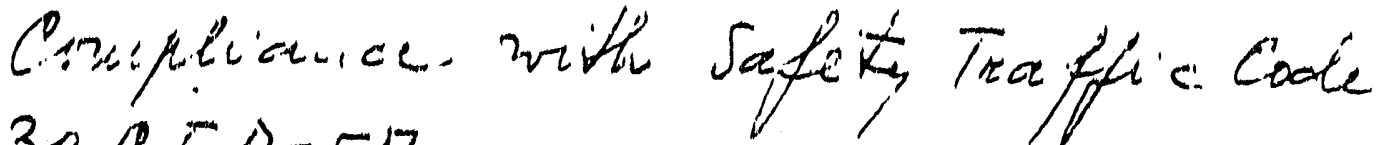

$$
\begin{aligned}
& 30 \text { C R R - }
\end{aligned}
$$

14a. Administratlve Tracking

$\begin{array}{lll}\text { Yes NA } & & \text { YES NA } \\ \square \square & \text { 1. FSAR } & \square \\ \square & \text { 2. Calibration Procedures } & \square \\ \square \square & \text { 3. Maintenance Procedures } & \square \square \\ \square & \text { 4. Computer Software } & \square \square \\ \square & \text { 5. Operations Procedures } & \square \square\end{array}$

6. Startup/Acceptance Test

7. Test Requirement \& Spec.

8.

9.

10.

15. Signature Requirements $\begin{gathered}\text { KEY } \\ \text { A-APPR. } \\ \text { R.MEVIEW } \\ \text { S.SIGN NEW }\end{gathered}$

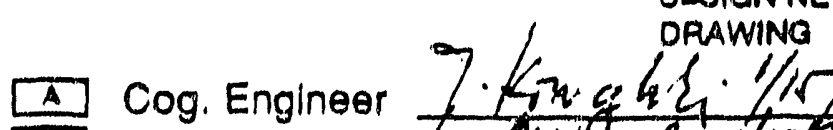

A Cog. Eng. Mgr.

[a Startup

[B] $O A$

$\square$ DOE

[A] Safety

$\square$ Dept. Manager

[R] Operations

$\square$ Security

$\square$ SNL
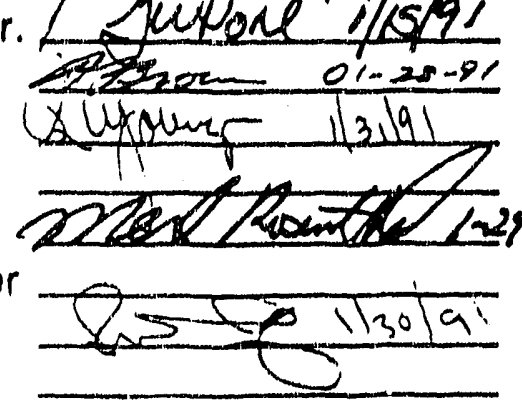

16. Distrlbute as Marked

Maintenance mavoatokn

Ops. Support mandatory

Startup

Facility Operations

U/G Operations

Orlg./Design Engr.

Cog. Engineur

Others 


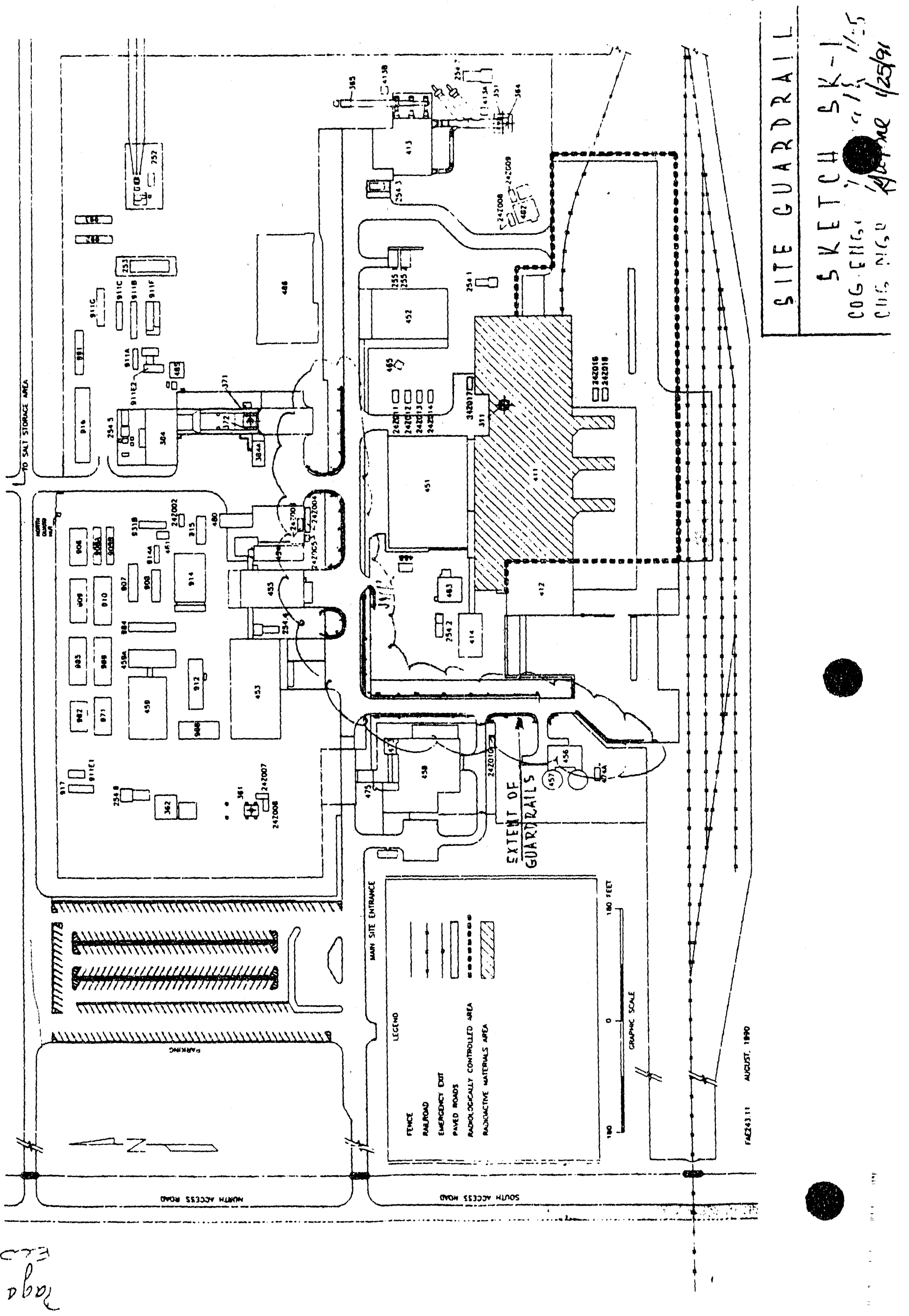




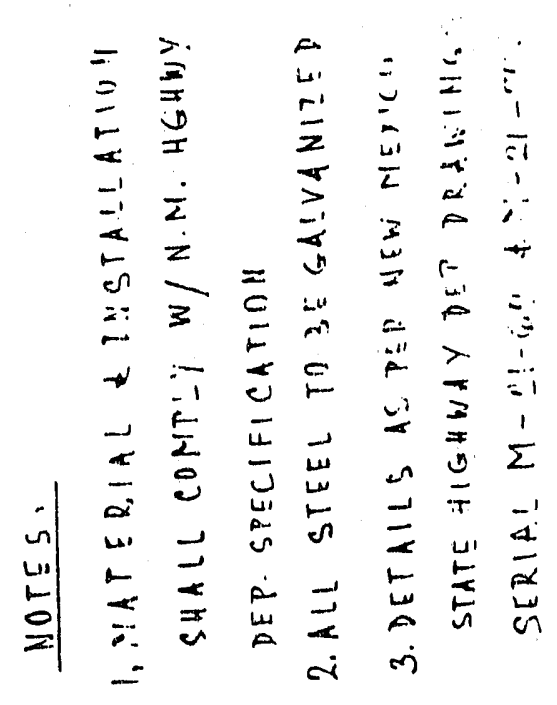

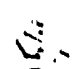

$5 \frac{\pi}{\sqrt{2}}$

Cin

, ‥

$=1$
$=5$
$\therefore$

-

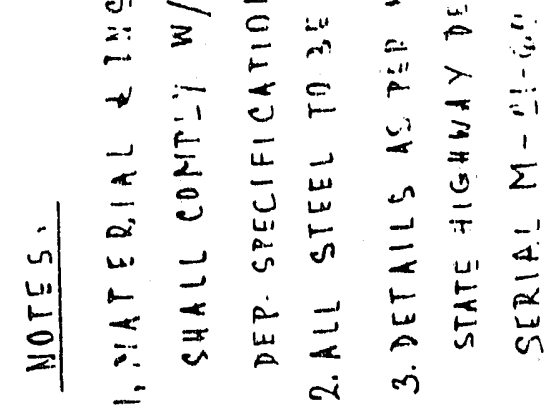

$\begin{array}{ll}2 \\ 5 \\ 0 \\ \vdots \\ 3 \\ 0 \\ 0 \\ 0 \\ 0 \\ 3 & = \\ 2 & 0 \\ 5 & 0 \\ 2 & 0 \\ 2 & 0 \\ 0 & 0\end{array}$

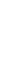
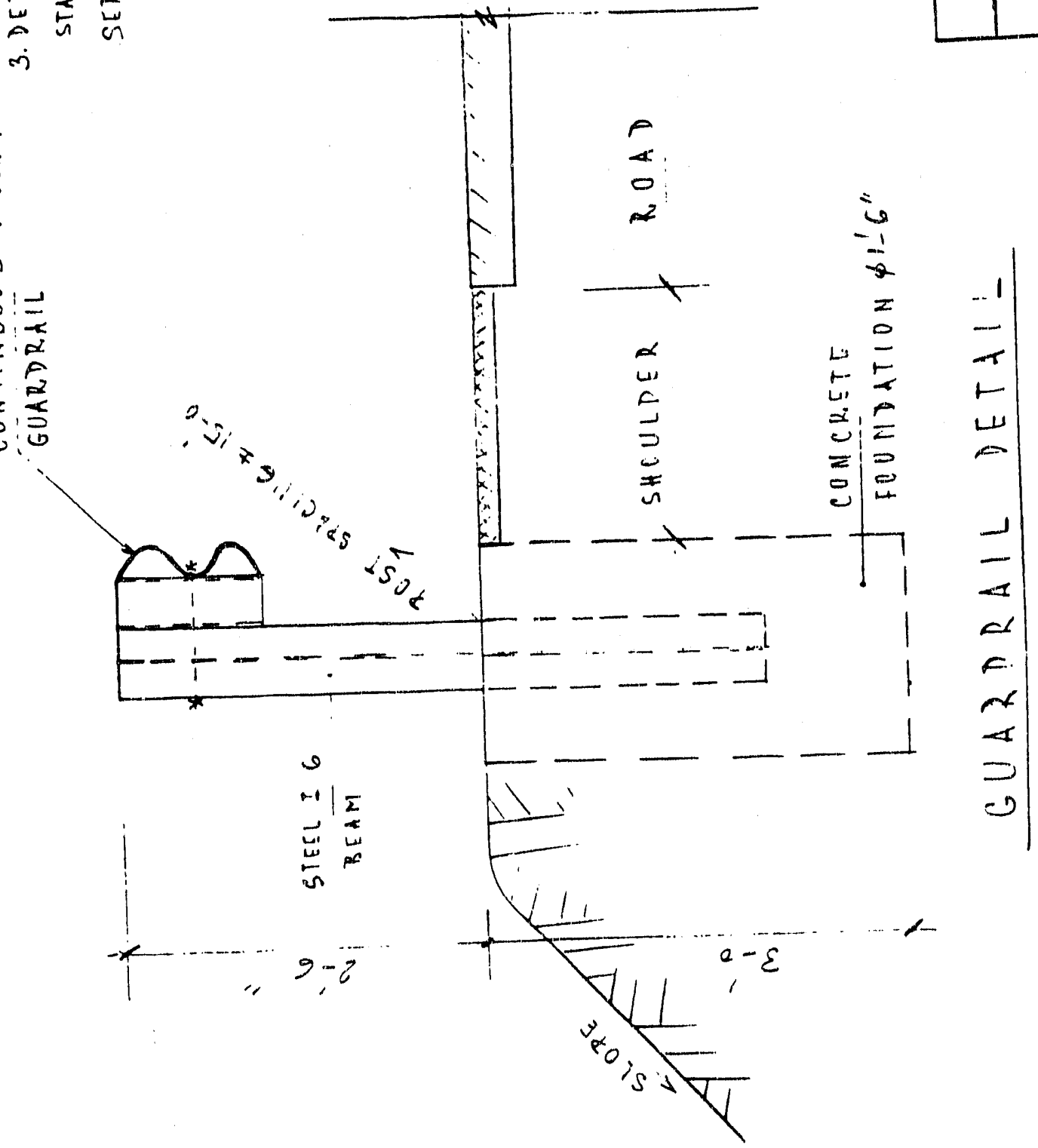

$\Rightarrow f \times$

L

s

$\begin{array}{ll}19 & 4 \\ 0 & 0\end{array}$

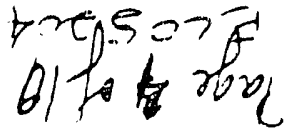


Page 5 of 10

$9 a$

DRAWING CHANGE SHEET

(1 SHEET PER DRAWING)

1. Drawing: $24-c-140-022$ ECO Number: 5204

2. ECO Search List:

3. Description of Change:

Show location of the guardrails as per-attaclued sketch SK-1.

4. Drawing cog. Engineer Approval: \& Hwect/4i Date: $1 / 24 / 91$

5. Cover Sheet Block (CC\&D Use ONt)

Received from EFR:

Date Assigned:

Assigned to:
Drafting Started:

Drafting Completed:

Return to EFR:

(Same as data bose entry)
Initials / Date

Initials / Date

Initials / Date

WP Form 2017; 12/29/90

1290:B0006

Page 1 of 1 


\section{DRAWING CHANGE SHEET}

(1 SHEET PER DRAWING)

1. Drawing: $24-c-143-022$ ECO Number: 5204

2. ECO Search List:
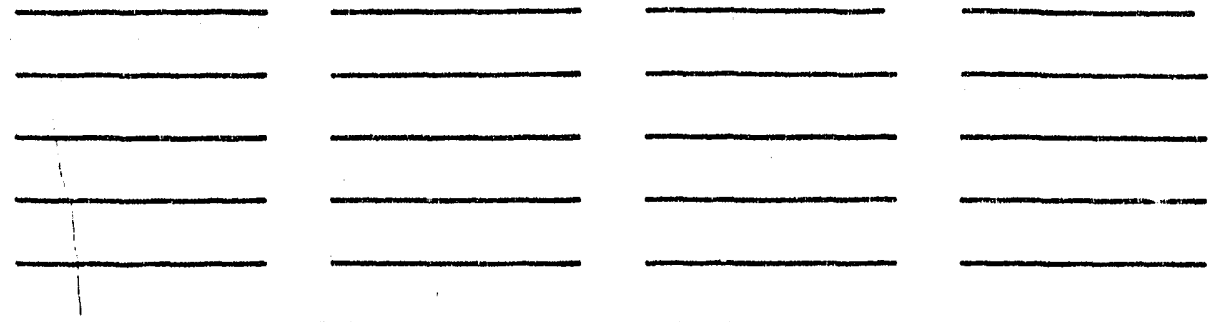

3. Description of Change:

Show lecatise of the guardiails as fier a tioulecol sketah sk-1.

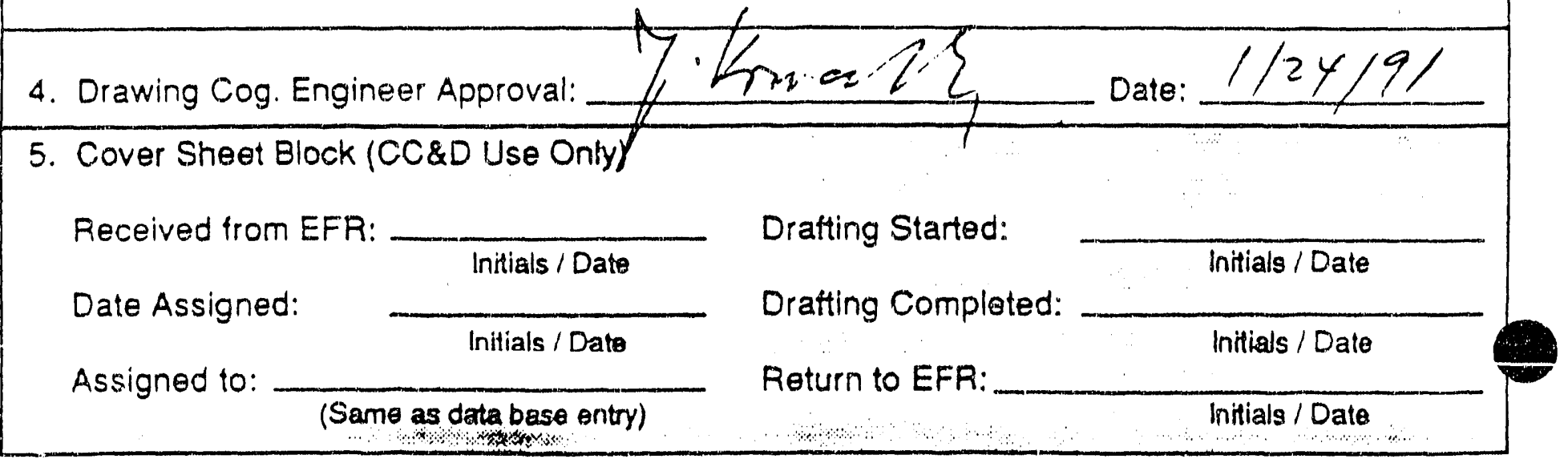


page dip of 10

$9 a$

DRAWING CHANGE SHEET

(1 SHEET PER DRAWING)

1. Drawing:

$24-C-145-022$

ECO Number: 5204

2. ECO Search List:

3. Description of Change:

Shin- lineation of the guardrails as per. the attached skatole SK-1.

4. Drawing Cog. Engineer Approval:

Date:

$1 / 24 / 91$

5. Cover Sheet Block (CC\&D Use Only)

Received from EFR:

Date Assigned:

Assigned to:
Drafting Started:

Drafting Completed:

Return to EFF:

Initials / Date

(Sane as data base entry)

Initials / Date

Initials / Date
Initials / Date

Initials / Date

WP Form 2017; 12/29/90

1290:80006

Page 1 of 1 


\section{DRAWING CHANGE SHEET}

(1 SHEET PER DRAWING)

1. Drawing: $24 \div c-14 Z-0.22$

ECO Number: 5204

2. ECO Search List:
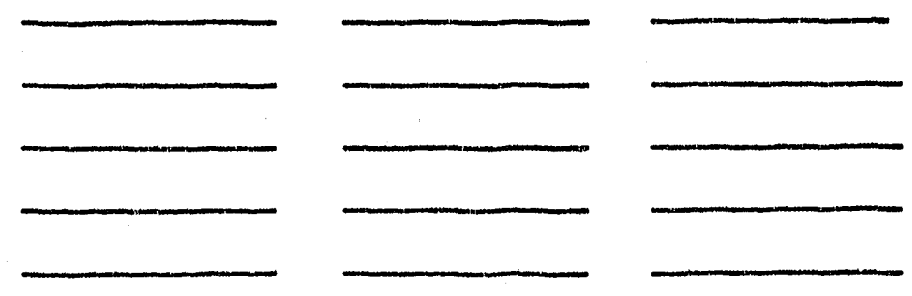

3. Description of Change:

Shin lication of the quatidail's as per the affoducd sfectch sk-1.

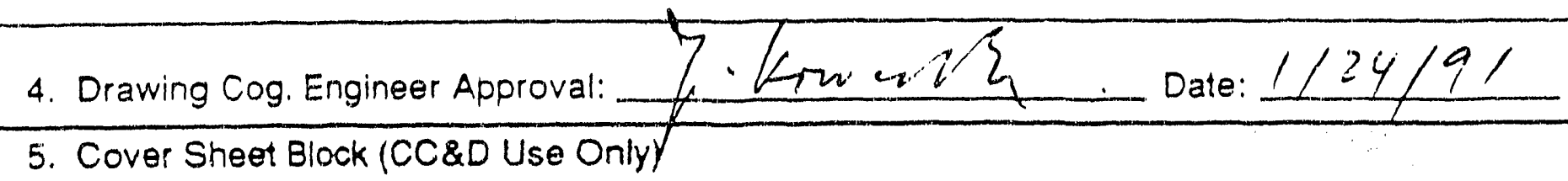
Received from EFR: Drafting Started:

Date Assigned: Initials / Date

Âssigned to: Initials / Date Drafting Completed: Return to EFR: Initials / Date Initials / Date 


\section{DRAWING CHANGE SHEET \\ (1 SHEET PER DRAWING)}

1. Drawing: $24-C-149-022$ ECO Number: 5.2C4

2. ECO Search List:
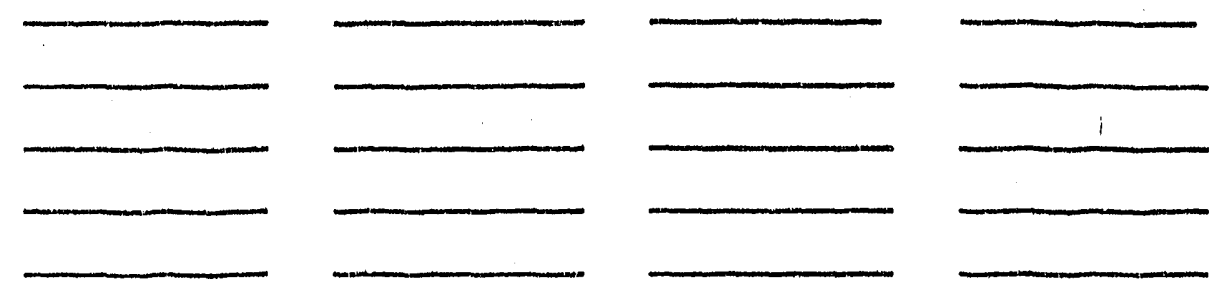

3. Description of Change:

Stow. the guardrail detail as per a tiaclual sketel $S K-2$.

4. Drawing Cog. Engineer Approval: 7 . Shwa 1/\}. Date: $1 / 24 / 71$

5. Cover Sheet Block (CC\&D Use Only)

Received from EFR:

Initials / Date

Drafting Started:

Date Assigned:

Initials / Date

Assigned to:

(Samí as data bace entry)

Initials / Date

Drafting Completed:

Inttials / Date

Return to EFR:

Initials / Date 


\section{DRAWING CHANGE SHEET}

(1 SHEET PER DRAWING)

1. Drawing: $24-c-010 \mathrm{~N}$ sheet $1 \% 2$ ECO Number: 5204

2. ECO Search List:
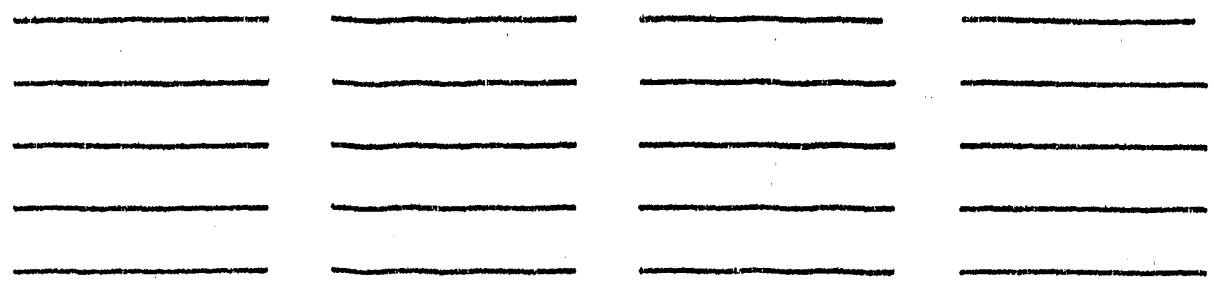

3. Description of Change:

Shrw lication of the guardiarls as fer the roketole sk-1. attacked?

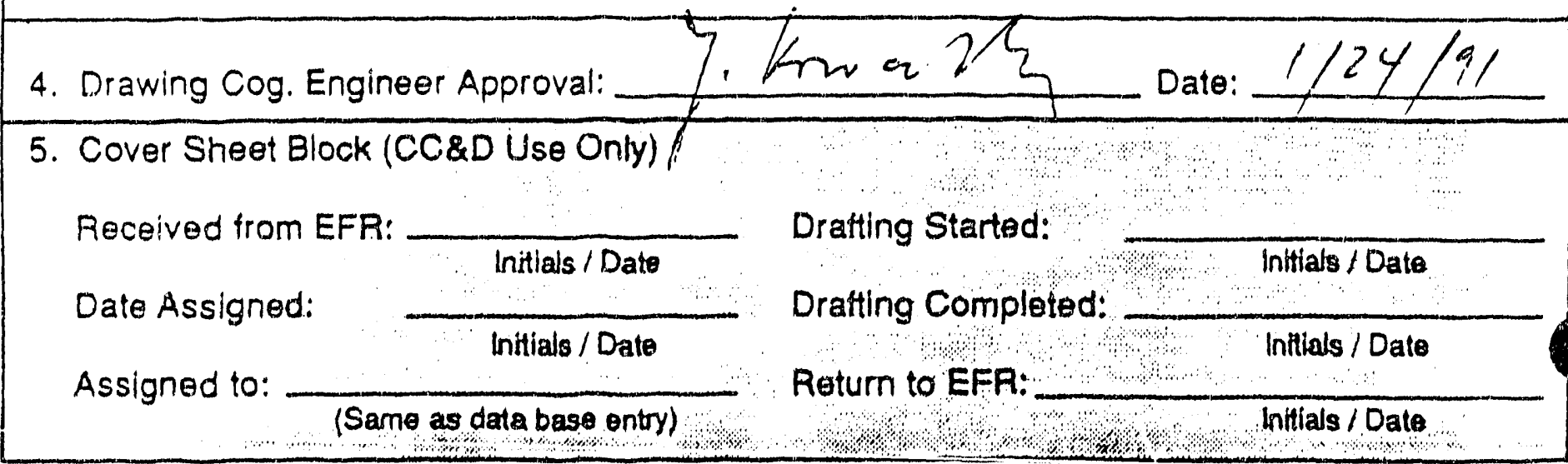




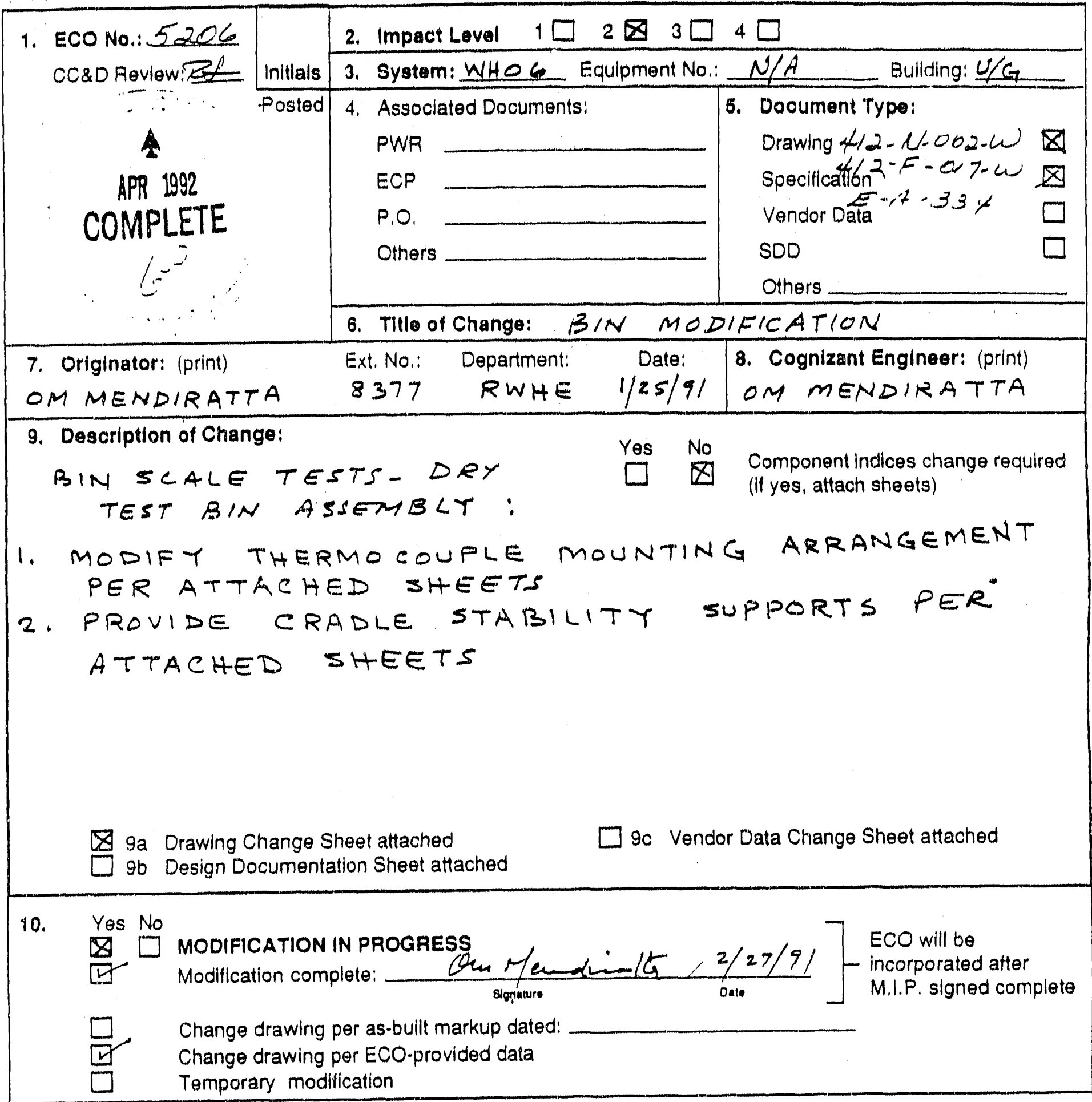

11. Design Verification Requirements: (per WP 09-018)

EDT No.:

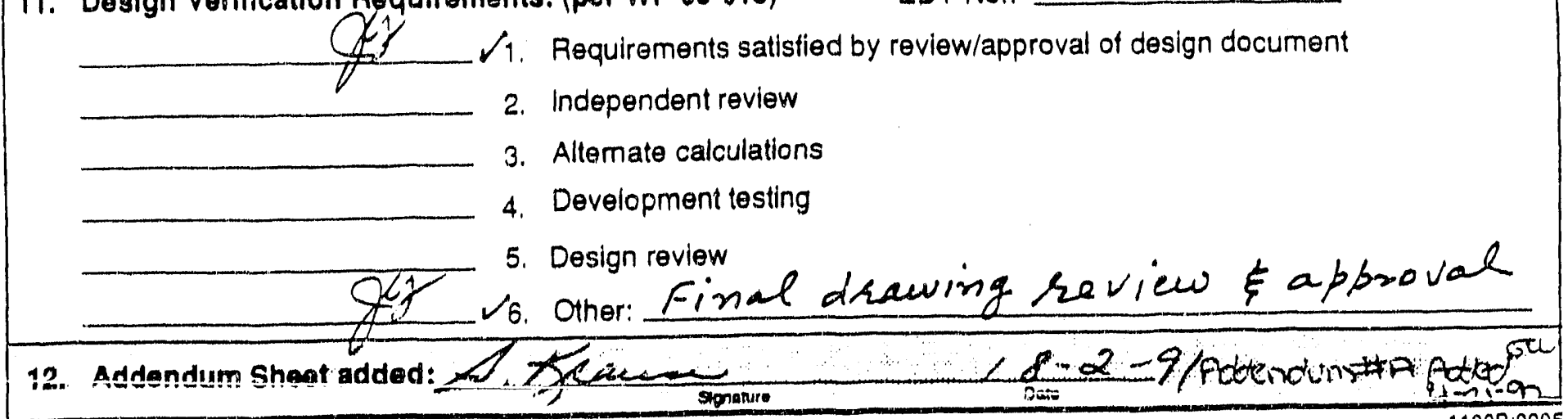


13. Justiflcation

1. SNL request to install thermocouples on the extermal bin wall. Solved sue of potential leak paths with bin internal installation configuration. 2. Cradle stability supports are being provided to reduce rocking and accidental damage to the valves by the filter assy.

\section{Administrative Tracking}

YES N/A

1. FSAR

2. Calibration Procedures

3. Maintenance Procedures

4. Computer Software

5. Operations Procedures

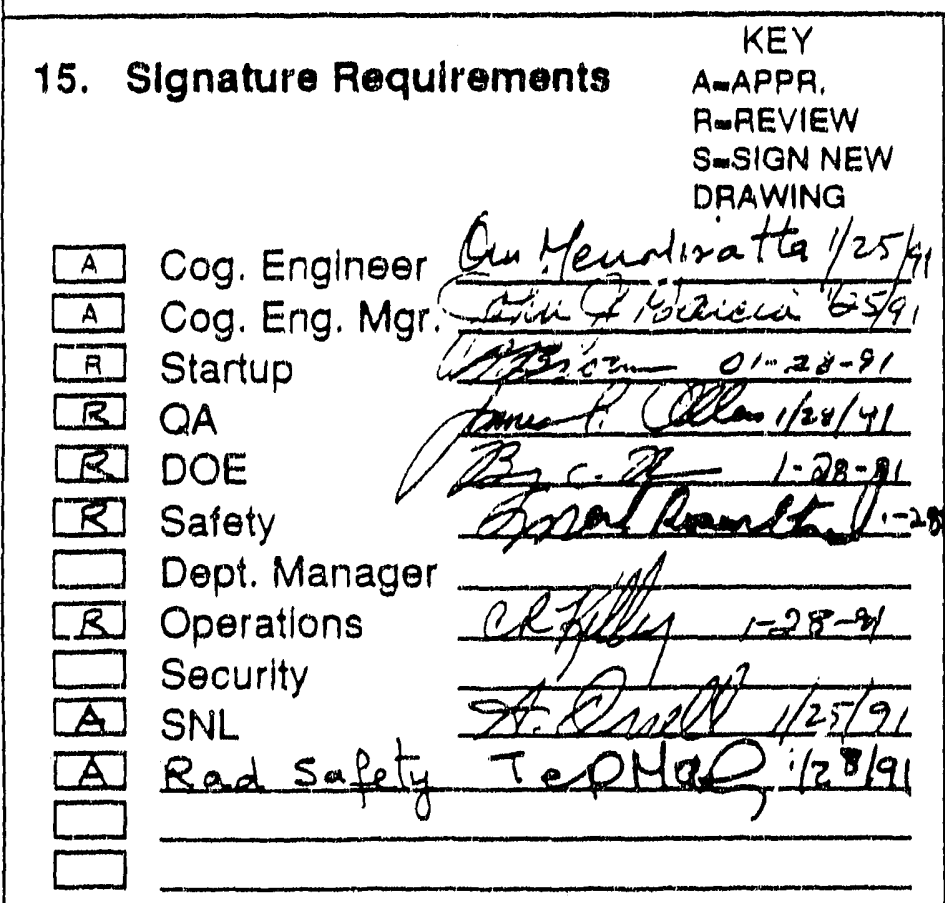

Y'ES N/A

$\square \otimes$ 6. Startup/Acceptance Test

$\square \otimes$

7. Test Requirement \& Spec.

8.

9.

10.

\section{Dlstribute as Marked}

Maintenance (MAMDATORY)

Ops. Support (mandatoRy)

Startup

Facility Operations

U/G Operations

Orig./Design Engr.

Cog. Engineer

Others 
Page 3 of 13

$9 a$

DRAWING CHANGE SHEET

(1 SHEET PER DRAWING)

1. Drawing:

$412-x-002-W$

ECO Number:

5206

2. ECO Search List: 5189

3. Description of Change:

Revise drawing 4/2-N-00z-w, RevilE, per attached sheets for $i$, thermos couple mounting arrangement, (ii) cradle support.

4. Drawing Cog. Engineer Approval: Dew Heidi rata

Date: $1 / 25 / 91$

5. Cover Sheet Block (CC\&D Use Only)

Received from EFR:

Date Assigned:

Assigned to:
Initials / Dato

Initials / Dato

(Sane as data base entry)
Drafting Started:

Drafting Completed:

Return to EFP:
Initiate / Dato

Finials / Dato Initials / Dato

WF Form 2017; $12 / 29190$

$1290: 800 x$

Page 1 of 1 
Page 4 of 18

$9 \mathrm{a}$

DRAWING CHANGE SHEET

(1 SHEET PER DRAWING)

1. Drawing: $4.12-F-0 / 7-w$

ECO Number: 5206

2. ECO Search List: 5189

3. Description of Change:

Revise drawing 4/2-F-017-w, Rev. E, per attached sheets fro (i) thermocouple mantling details (ii) Cradle support details.

4. Drawing Cog. Engineer Approval: Au Mendivith Date: $1 / 25 / 91$

5. Cover Sheet Block (CC\&D Use Only)

Received from EFR:

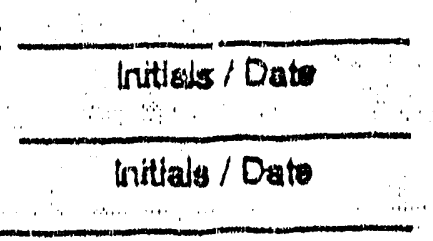
Drafting Started:

Drafting Completed: Return to EFR:

Assigned to:

(Same as data base entry) $\quad$ Initials / Date

Initiate / Date

Date Assigned:

Initials / Dato

WP Form 2017; 12229190

$1290: 8000$

Page 1 of 1 


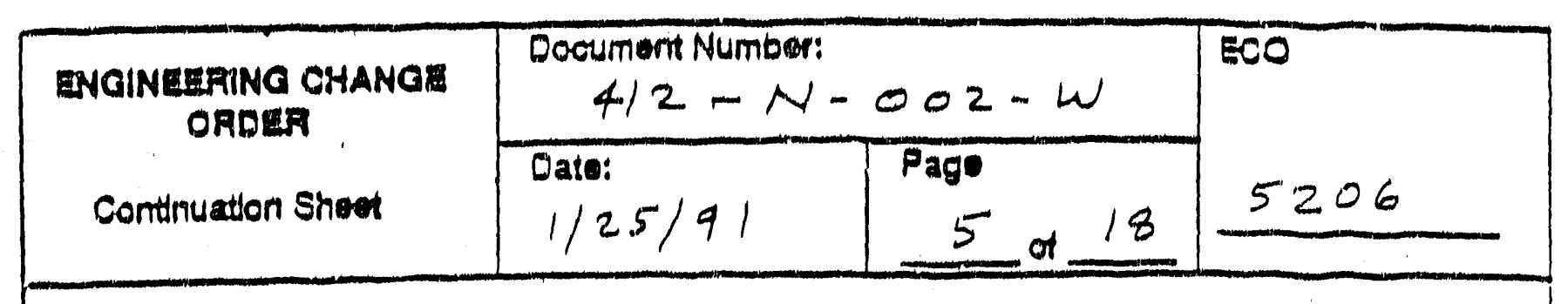

1. Delete item 7 from the B.O.M.

2. Delete thermocouple mounting arrangement shown on Detail -1.

3. Delete note 8

4. Delete therme couple ports on the View "TC LOCATIONS VIEW $c-c$ "

5. Delete thermocouple ports and coils under the VIew "TC LOCATIONS VIEW $c-c "$ (DE)

6. Delete thermocouple location and emfiguration enveloped by bubble for Detail -1 (E-7)

WP Form 1200; $12 / 22800$
Page 3 of 3

$11908: 00$ 


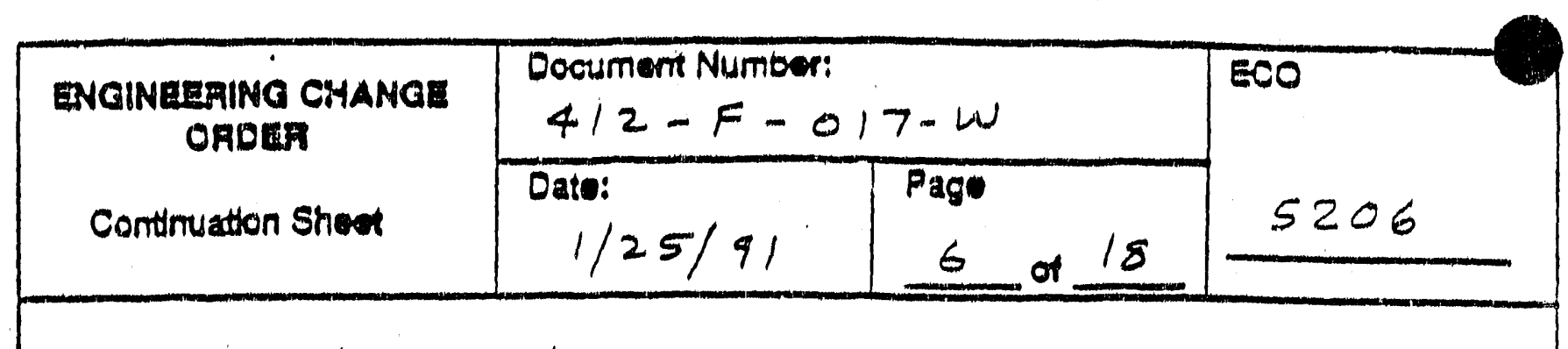

7. Delete item 10 tram B. O.M.

9). Delete Detail 5 "Thermocouple Mounting " (ci)

9. Delete thermocouple ports in the bin side -view $(F-7)$

WP Form 1200; $12 / 22890$

$11908: 000$ !

Pine 3 of 3 


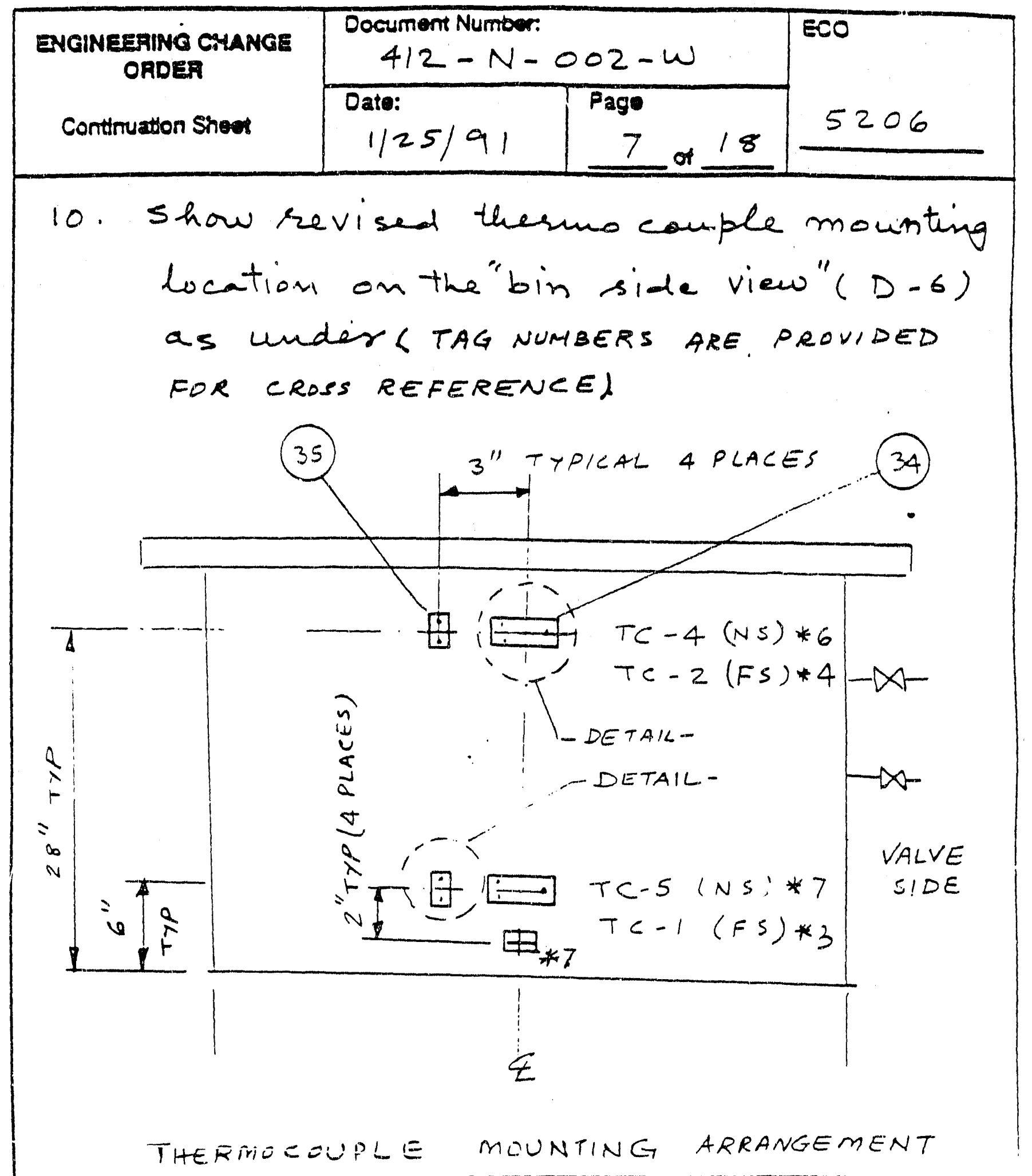




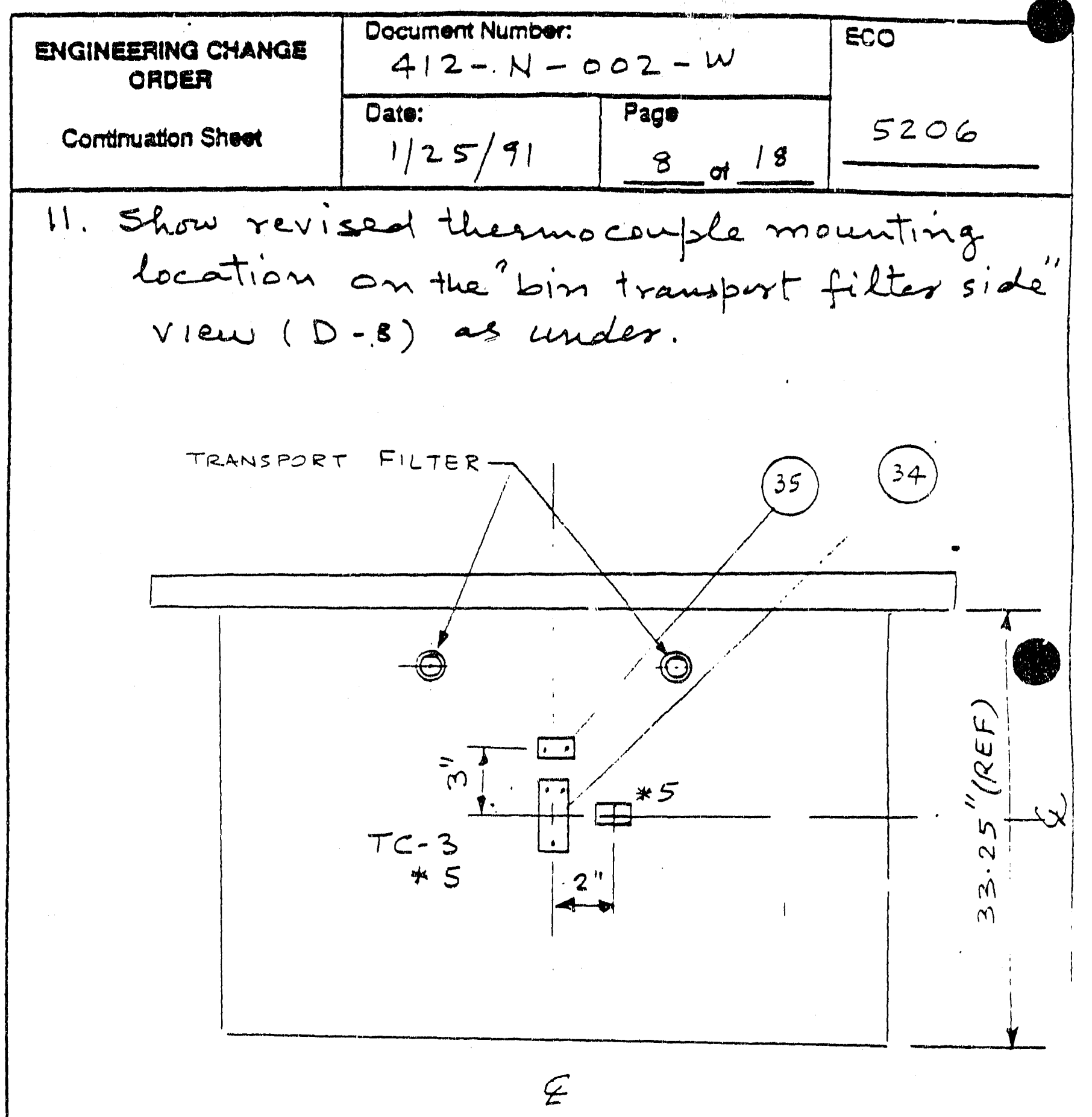

THERMOCOUPLE MOUNTING ARRANGEMENT

TRANSPORT FILTER SIDE

WP Form 1200; 1222800

11908.000

Pug. 3 of 3 


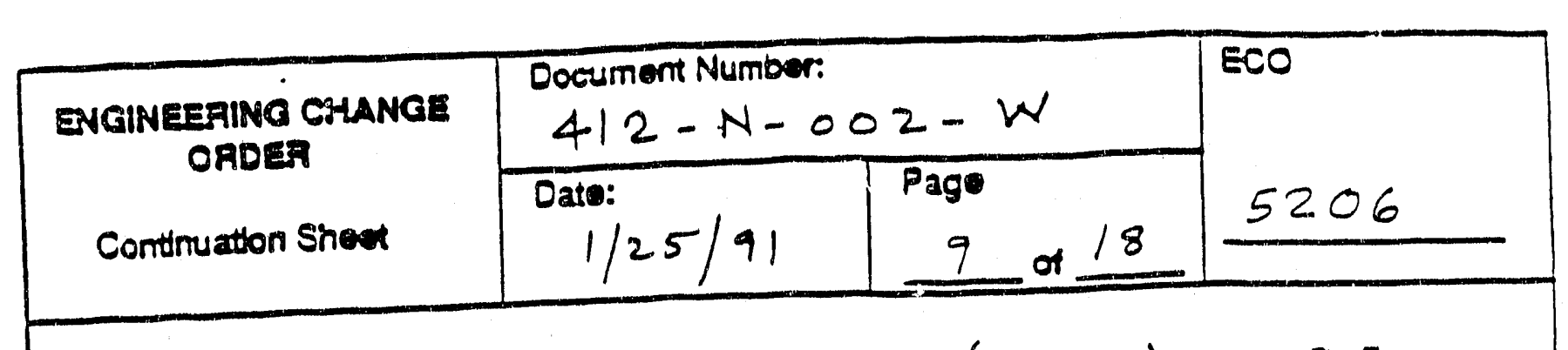

12. Add item 34 and 35 (number as appropriate) to the B.O.M.:

(i) \#34; Qty $=5 ;$ THERMOCOUPLE

Insert block; $412-F-017-H \times x ;$.

$$
\text { SS } 304 L
$$

(ii) \#35;Qty $=5 ;$ THERMOCOUPLE CLAMP;

$$
412-F-017-H \times x ; 5 s 304 L
$$

11908:000s

WP Form 1200: 12/2890

11908 


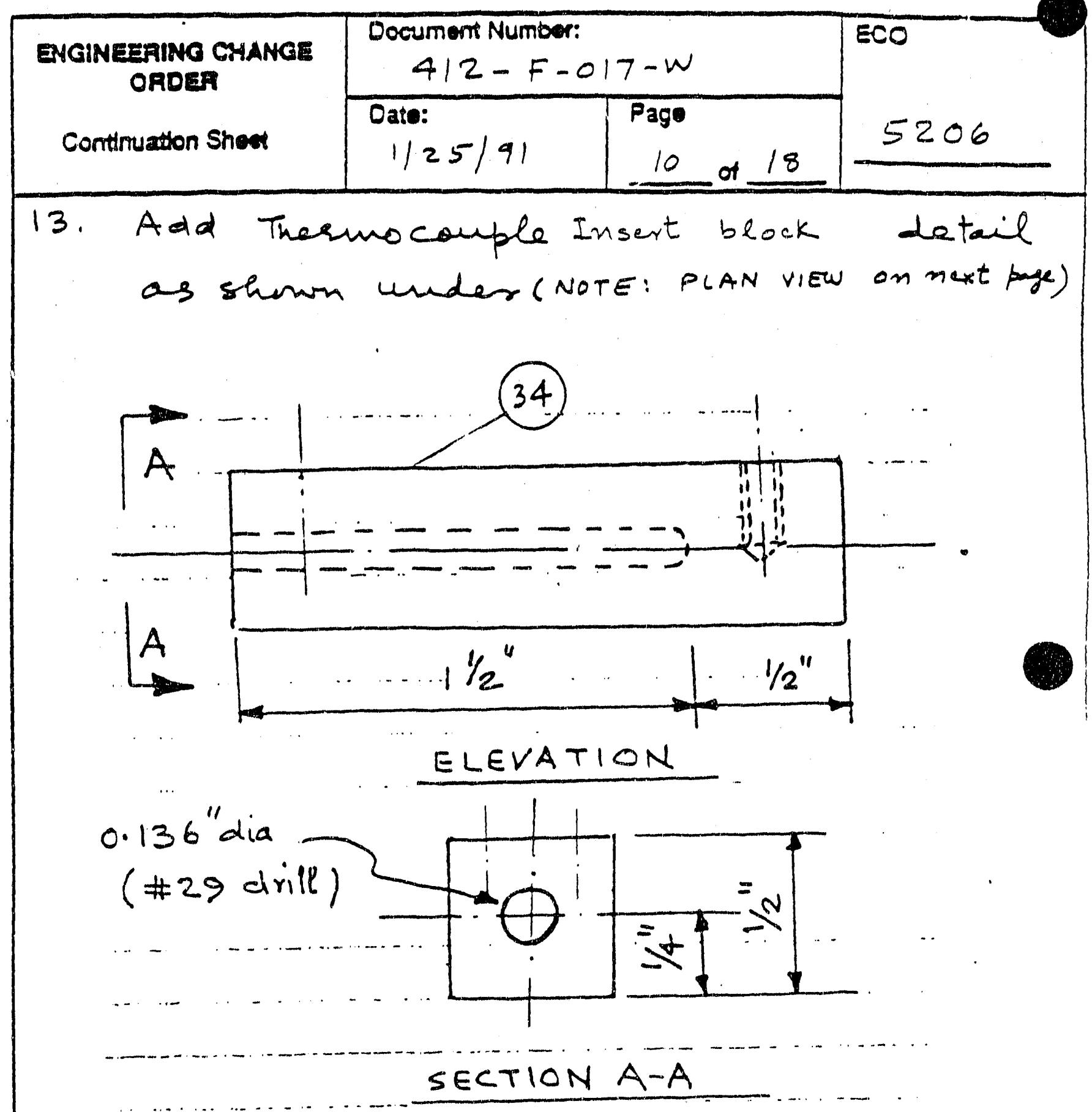

WP Form 1200; $12 / 29100$

11909.00

Page 3 of 3 


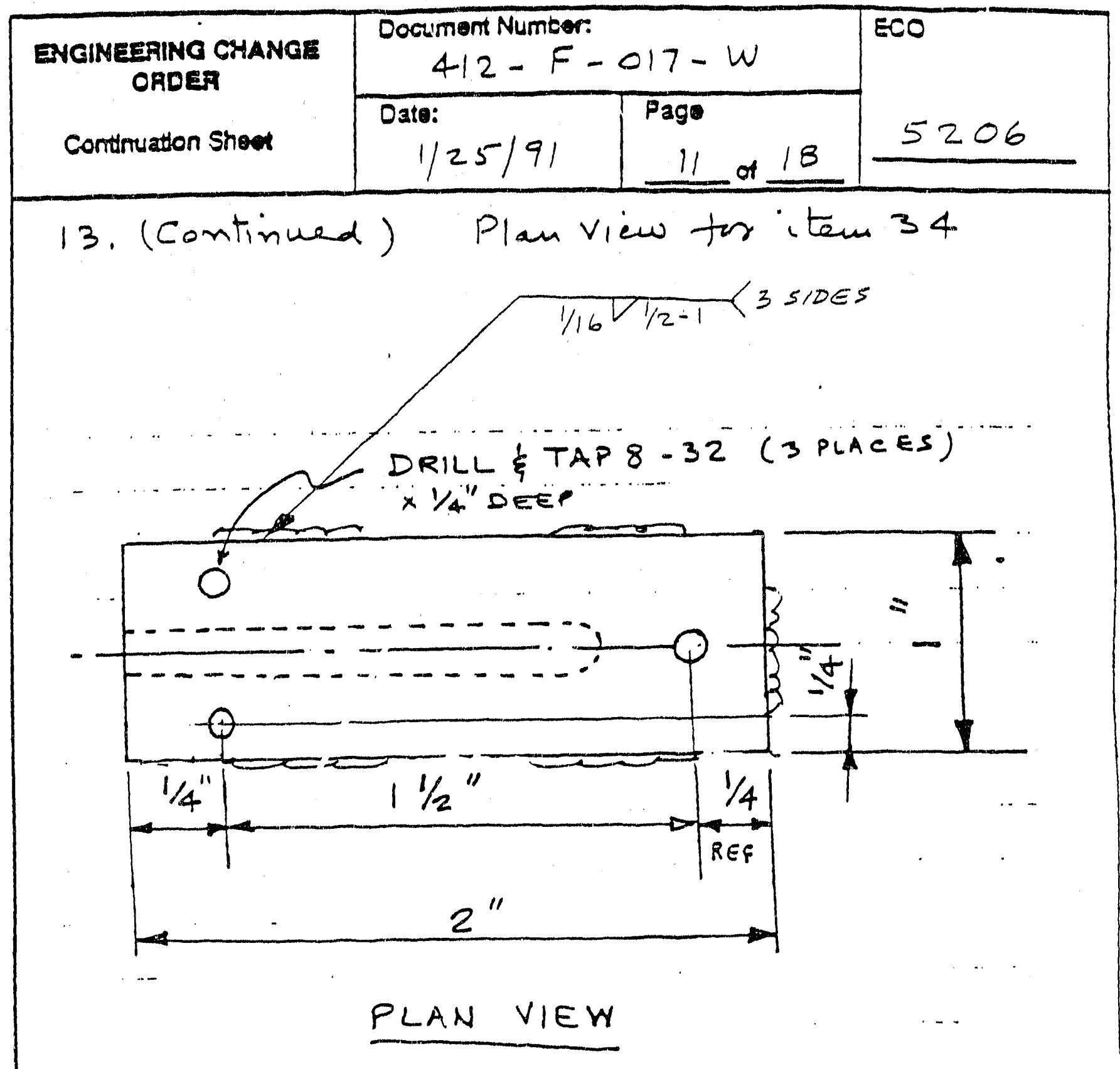

14. Indicate "item 34 to bin wall" weld: $\frac{1}{16} F ; 1 / 2^{\prime \prime} L, 5$ Places ( see location in plan view)

WP Farm $1200 \cdot 12 / 2890$

$11908: 006$

Page 3 of 3 


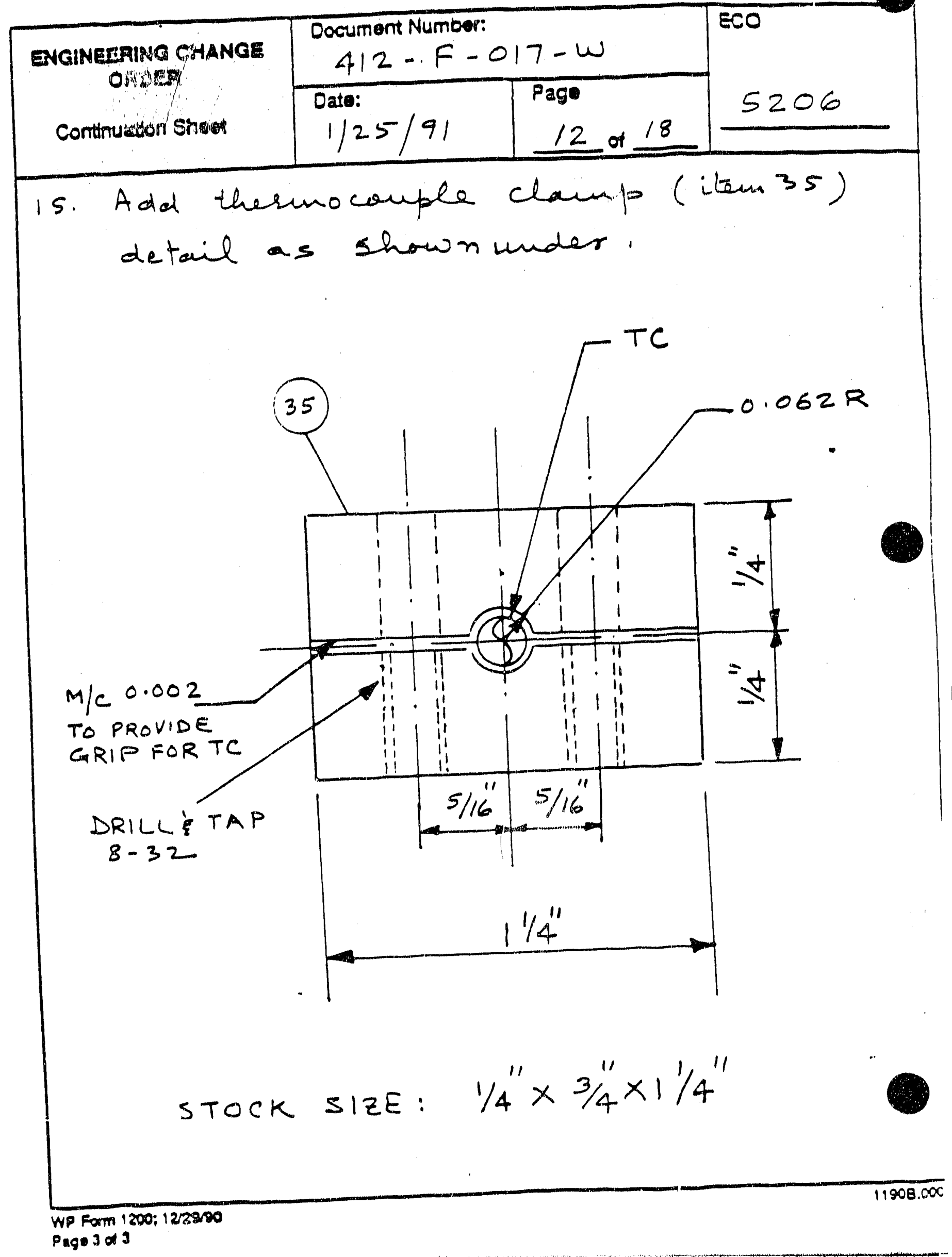




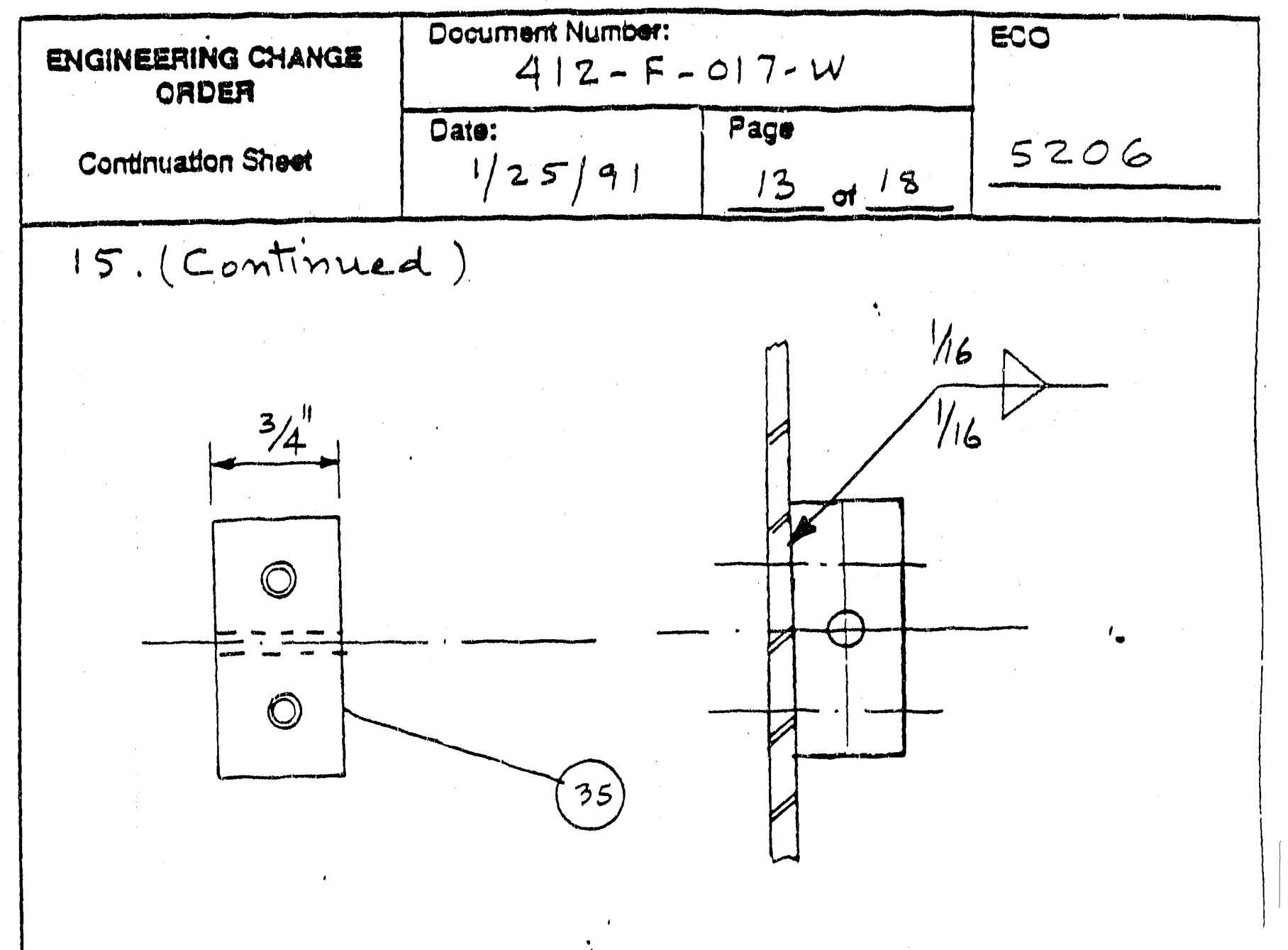

16. Add item 36, Hex Socket Head stainless steal Cap screw $\times 1 / 2 " \lg ; Q t_{y}=10$ (tor use with item 35)

WP Form 1200; 12229190

11908.006:

Page 3 of 3 


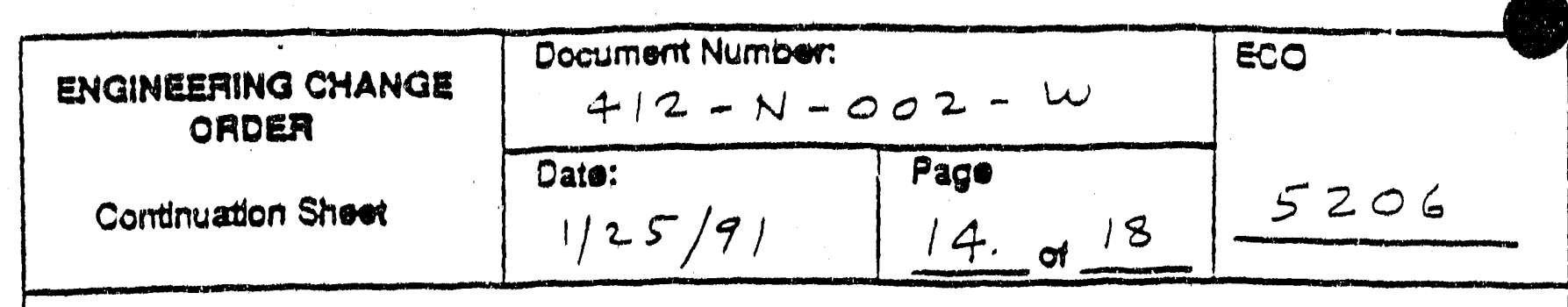

17. Revise dimension $31 / 2^{\prime \prime}$ tor stenciling words "Max Gross Weight 3,200 lbs", to $20^{\prime \prime}$ in the bin side view (E-5)

18. Add $\angle 22^{\prime \prime} \times 1 \frac{1}{2} \times 1 / 4^{\prime \prime} \times 1^{\prime \prime} \lg$ to the BOM as item 3 .

$$
\begin{aligned}
& \text { \#37; Qty }=2 ; \text { Cradle support; } \\
& 412-F-017-H x x ; \text { ASTMA-36 }
\end{aligned}
$$

WP Form 1700: 1222900

11900.006

Page 3 of 


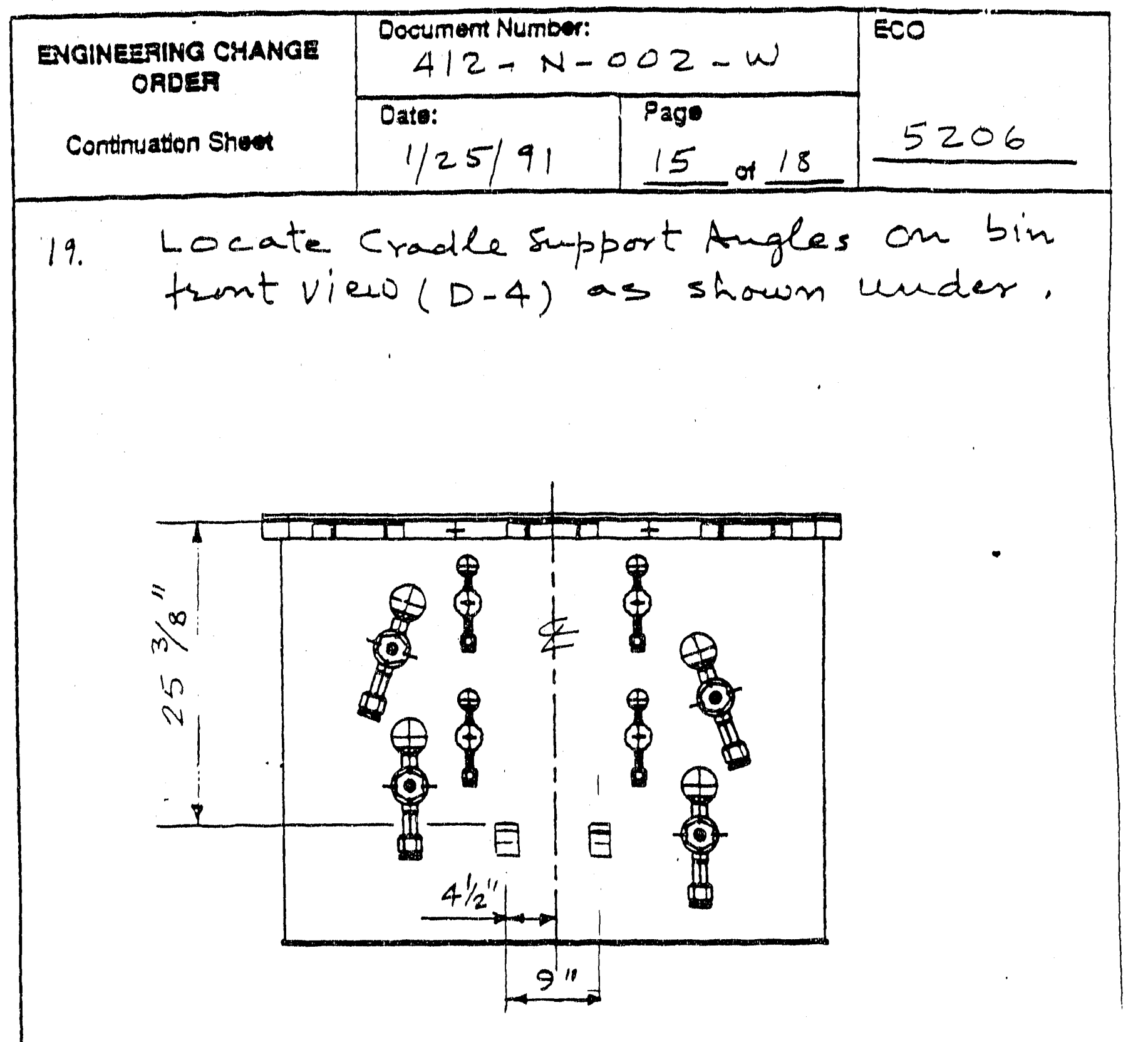

20. Add Enlarged view as shown on next page to locate cradle support angle on dig 412-F-017-w

WP rom 1200; 12229100

$11908.000:$

Page 3 of 3 


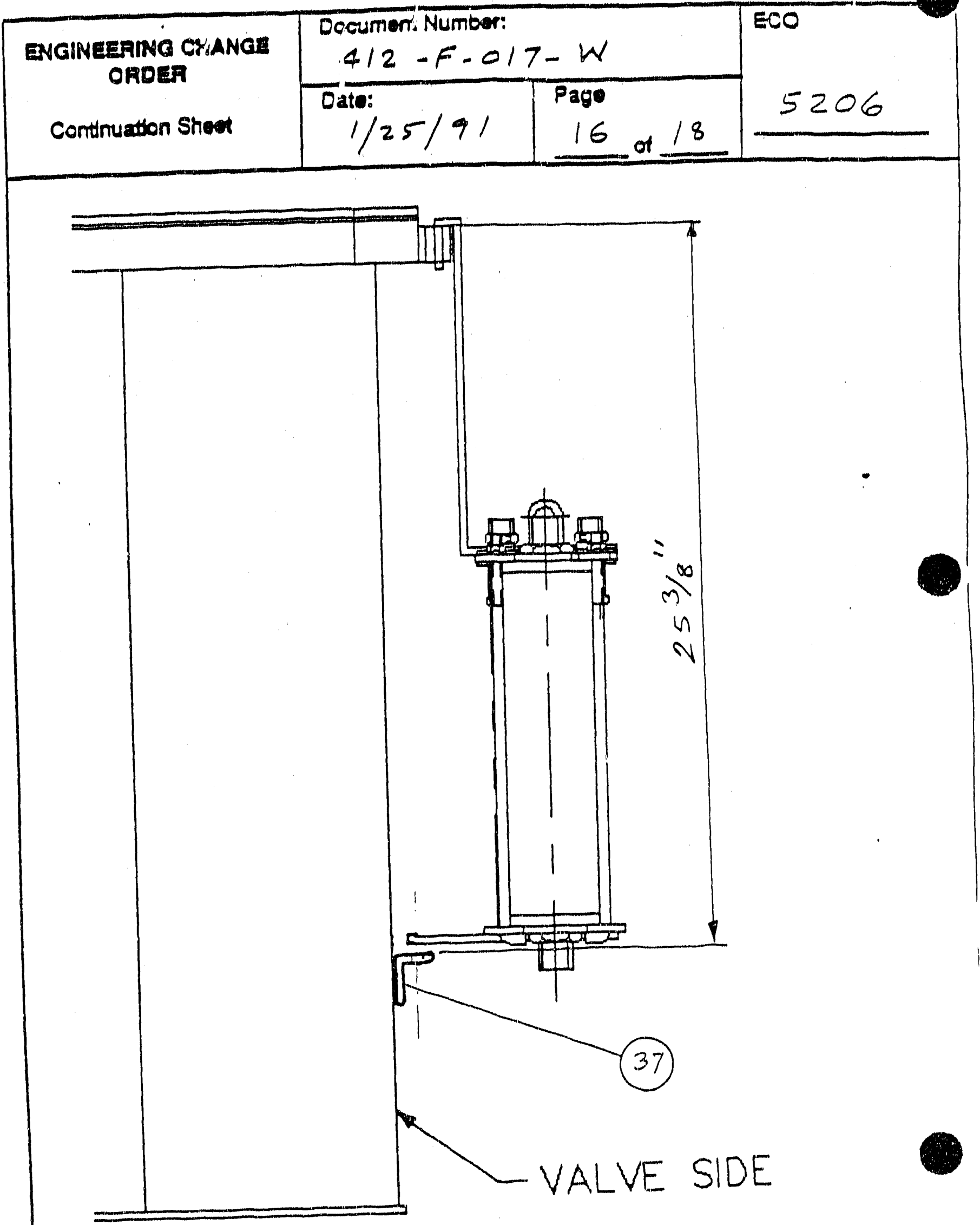




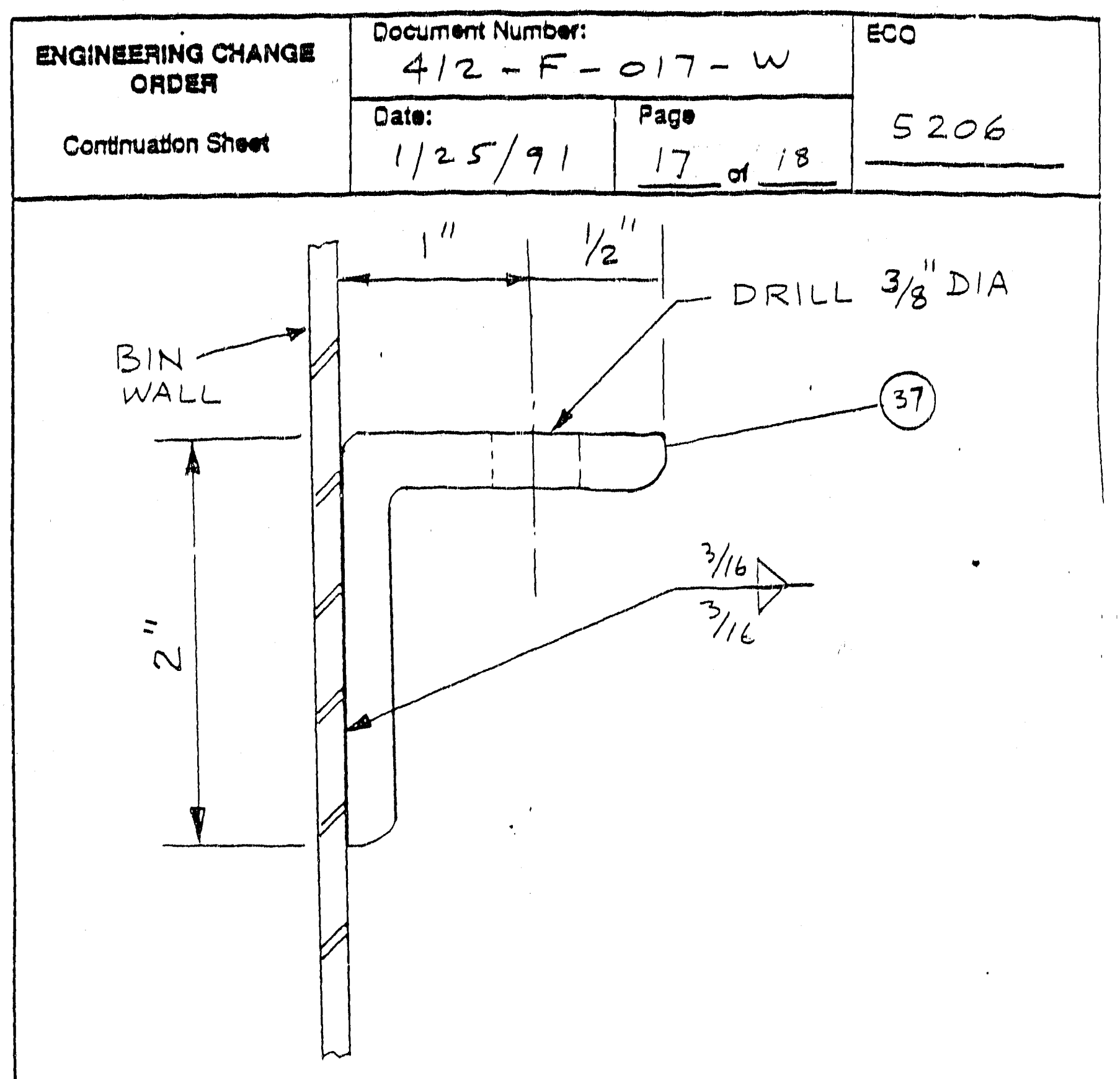

21. Add detail for item 37 , as shown above.

WP Form icier; iciasise
Page 3 of 3

$11908: 000$ 


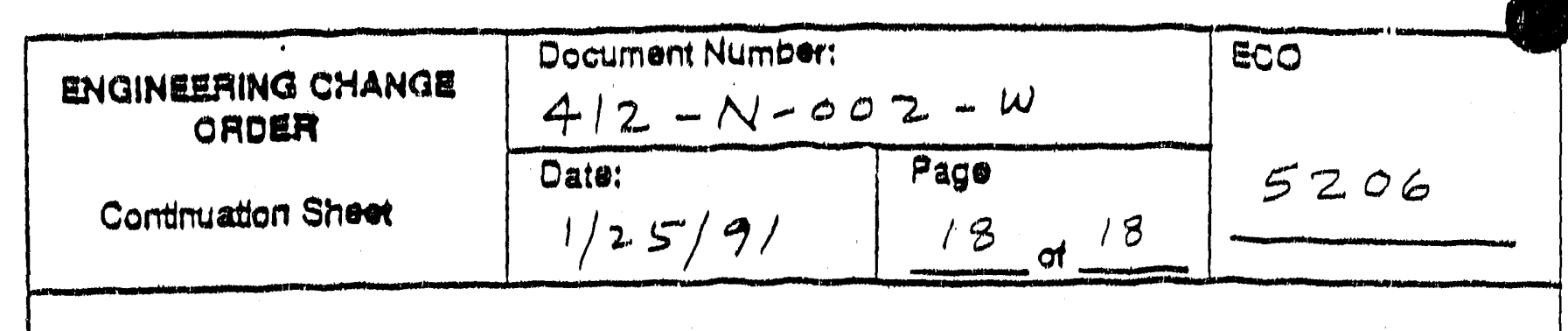

22. Editorial changes:

(i) Delete last tor lines of note 2 , Filter element Technology, INC."

(ii) Add a note" Filter media shall be removed from the NuPRd filter housing. (item 21) for the production bins $S / N P B-009$ through $P B-018$.

(iii) Revise Part name/ Description for item 21 in B.0.M. to read" Breather Filter Housing."

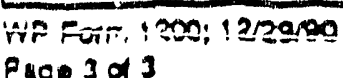

11908.0065

Fug e 3 al 3 
ENGINEERING CHANGE ORDER

ADDENDUM SHEET $\neq-1$

SPECIFICATION:

$E-A-334$

1. Addendum Sheet to ECO Number: 5206

Drawing Nurnber:

2. Description of change:

(1) List specification E.A-334 in section 5 of $E C D \rightleftharpoons 5206$.

(2) Delete reference to the internally counted thermocouples. Call it as Externally mounted, where necessary. (eng. Delate para 3,3.16 last items,. Thermocouple ports and the following note; revise 3.3 .17 (page 6) to stale: "externally mounted (thermocouples)

Note: The approved scope of ECO \#5206 is not changed. This addendum references an affected document omitted from the orignial ECO.

(3) Replace pages 6 and 7 of spec. E-A-334, Rev .1 with attached pages.

3. Approvals

Cognizant Engineer:

CC\&D Mgr. /Design. Rep.

Other Approval:

Other Approval:: $O A$

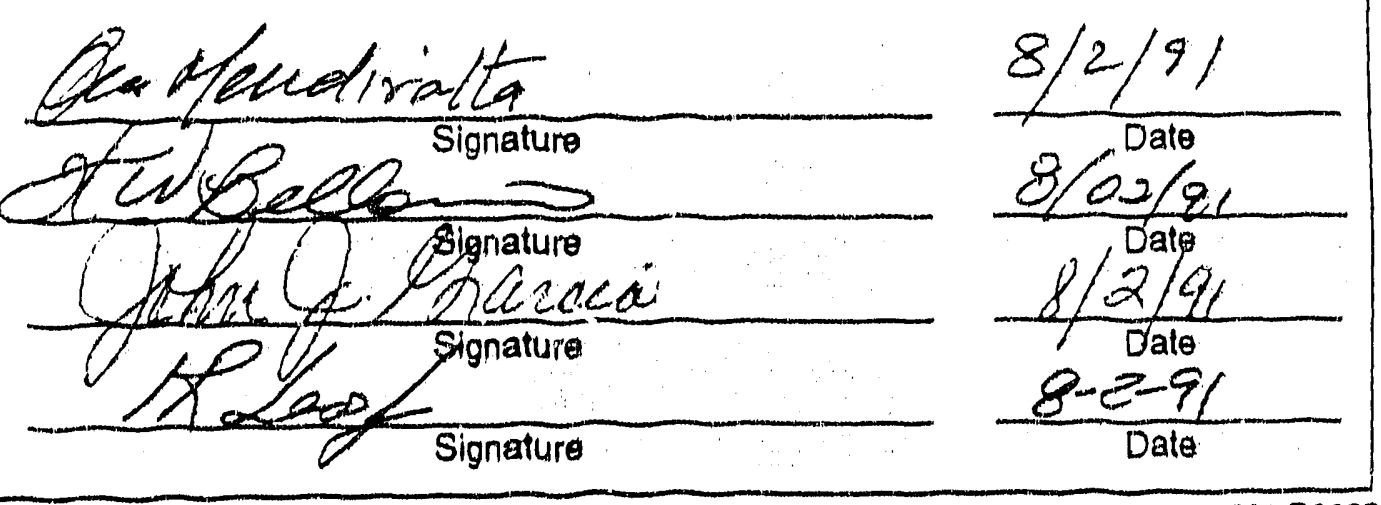

WP Form 2020; 12/29/90

1290:B0009

Page 1 of 1 
Equtoment

Pressure

Rellef Valves

Brine injec.

tion Parts

Pressure

Gauges

Brtine Sam-

pling Ports

Gas Injection

Qxygen

Sensing/Gas

Sample Port
To prevent the bin's internal

pressure from exceeding 0.6 psig.

For the equipment that w111

inject brine into the bin.

To monttor the bin's internal pressure.

For the equipment that will take brine samples out of the bin.

For the equipment that w11 inject gases into the bin.

For sensing the oxygen in the bin. An inlet and an outlet are required. The same ports will be used to connect the sampling apparatus to. The sampling apparatus is not within the scope of this specification.
Number

2

2 mintmum

2

2 minimum

2

1 Inlet,

1 outlet
Oxygen

Gettering

Port

To remove the oxygen in the bin.

An inlet and an outlet are

1 Inlet, required.

Tharmocoupto

For tharmocouplos to monitor

I Outlet

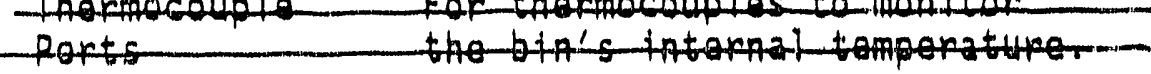

5

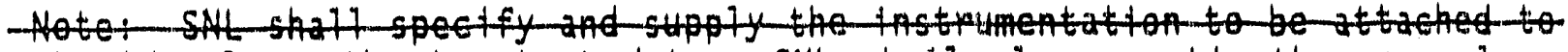

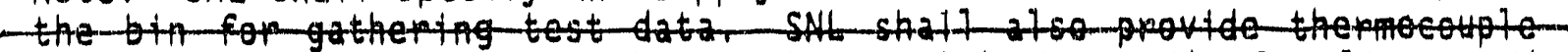
instatlation procodures to tho supptior and instruct tho supption-on the installation.

3.3.17 The bin shall be designed to allow the monitoring of its temperature throughathermocouples reading at five points on the bin floor and walls. The location of the points shall be as below.

a. One at the diagonal center of the floor

b. Two at the horizontal center of one wal1, 6" and 30" above the floor

c. Two at the horizontal center of the opposite wall, 6" and 30 " above the floor 


$$
\left(y /\left.\left.3\right|^{n}\right|^{9}\right.
$$

3.3 .18 The thermoles stl bo-protoctod from tho corrosive aloments that wil resido in tho bin. If 2 liner is 14 sed to protect the bin walls and flow Lfrom corrosion, thon tho thomocouples shall bo insortad botwoon tho linor ind tho-ivalls or floor

3.3.19 If plastic materials are used in the bin, such as for gaskets and liners, if any, these materials shall be fire-resistant.

3.3.20 The bin shall be designed such that it can be made from standard metals; for example: steel conforming to ASTM A36.

3.3.21 The bin shall be constructed of materials that do not release VOCs or other gases that will contaminate the gas samples to be drawn from the bin.

\section{Particulate Filters}

3.3.22 Gases from the bin shall be filtered for radioactive contamination. This shall be achieved by means of one or more particulate filter(s). The paragraphs that follow in this section pertain to the requirements imposed on each particulate filter.

The bin has two sizes of particulate filters: small and large. Some requirements below are common to both. Where the requirements of one are different form the other, they are so stated.

\section{3 .23 NQA-1}

The extent to which NQA-1 applies to the bin supplier shall also apply to the filter manufacturer(s). The extent to which NQA-1 applies is specified elsewhere in this specification.

\subsubsection{Dimensions}

Sinall filter: The filter shall be cylindrical with outside dimensions not exceeding $2^{\prime \prime}$ in diameter and $4^{\prime \prime}$ long. Large Filter: The filter shall be cylindrical with dimensions not exceeding $4^{\prime \prime}$ diameter and $16^{\mathrm{N}}$ long. If a larger diameter becomes necessary, one of the two filter ports shall be offset from the filter's centerline such that the port's axis is $4^{\prime \prime},+0,-1 / 8^{\prime \prime}$ from the nearest edge of the filter. For both small and large filters, inlet and outlet shall be interchangeable, and the outside dimensions shall include the parts specified below.

\subsubsection{Ports}

There shall be only two ports on the filters: an inlet and an outlet. Small Filter: Both ports shall be $1 / 2^{n}$ Swagelok tube fittings or equal. Large Filter: Both ports shall be $1^{n}$ Swagelok tube fittings or equal.

\subsubsection{Air Flow Capacity}

Small Filter: The minimum capacity of the filter shall be $200 \mathrm{cc} / \mathrm{min}$ at 1 " of water gage pressure drop across the filter using air. Large filter: The minimum capacity of the filter shall be 500 liters/min at $1^{\prime \prime}$ of water gage pressure drop across the filter using air. For both filters, the filter 
SPEC. NO. $E-1-334$

REVISION NO.

REVISION DATE $01-28-92$

SYSTEM WH06

BIN FOR BIN-SCALE TESTS

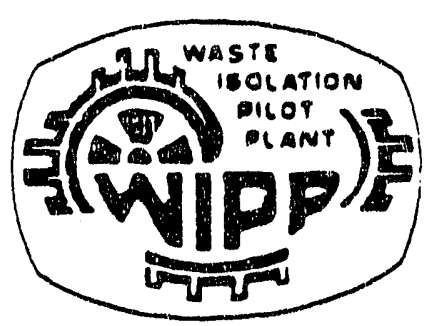

WASTE ISOLATION PILOT PLANT

Westinghouse Electric Corporation

Carlsbad, New Mexico 88220 


\section{ENGINEEFING CHANGE ORDER \\ ADDENDUM SHEET}

Page 1 of 2

1. Addencum $\Rightarrow$ to ECO Number: 5206 Drawirg Numcer: $\frac{412-F-017-W}{412-N-002-W}$

2. Description of change:

ECO 5206, MCDIFICATON \#1O AT PAGE 7 OF 18 SHOULD APPLY TO 412-F-017-W in ADDITICN TO 412-N-COZZ-W.

ECO5=06, MCDIFICATON +11 AT PAGE 8 OFI8 SHOULP APPLY TO 412-F-017-W IN ADDITCW TO $412-N \cdot 002-W$.

ECO5206, MODIFICATCL $\$ 12$ AT PAGE 9 OF 18 SHOULD APPLY TO 412.F-017.W IN ADDITCN TO 412.N-002-W ANB SHOULD READ:

12. ADD: ITEM *10, QTY. 5; THERMOCOUPLE IN SERT BLOCK AND ITEM \#31, QTY. 5 ; THERMOCOUPLE CLAMP ASSEMBLY TO owe. $412-F-017-W$.

ADD: ITEM 34 , QTY. 10; SOCKET HEAD CAP SCREN \#9125IA192 MSMASTER CARR CR EQUAL AND ITEM $\$ 35$, QTY.S; SQUEEZE BLOCK \#412-F-OI7-WI-H34 TO DWG. 412-N.002-W.

ECO 5200, MODIFICATION 18 aT PAGE 14 OF 18 should APPLY TO 412-F-017-W IN ADDITIOW TO 412-N-CO2-W.

ECO 5206, MODIFLCATOW \# I9 AT PAEE 15 OF 18 SHOULO APPLY TO 412.F-017-W $1 \mathrm{~W}$ ADDITRON TO $412-N-002 \cdot \omega$.

E0 5206, MODIFLCATEN \$20 AT PAGES 15 ANDI6 OF 18 SHOULD BE SHOWN AT 412-N-00Z-W RATHER THAN 412-F-017-W CONTINUED AT SHEET 2 of 2.

\section{Approvals}

Cognizant Engineer:

CC\&D Mgr. IDesig. Rep.:

Other Approval:

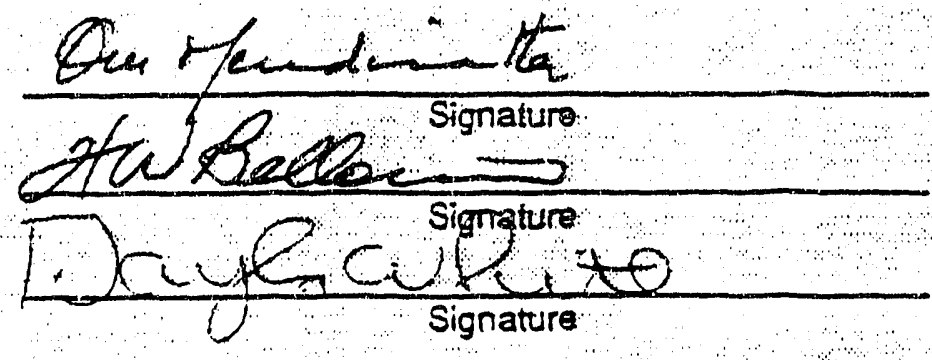

$4 / 15 / 92$

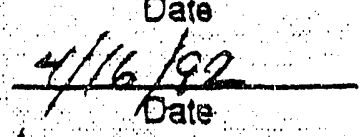

$\frac{421-92}{\text { Date }}$

Other Approval:: 
ENGINEERING CHANGE ORDER

ADDENDUM SHEET

Page 2 of 2

1. Addendum to ECO Number: 5206 Drawing Number: $\frac{412-F-017-n}{412-N-002-n}$

2. Description of change:

CONTINUE O FROM PALE I OF 2

ITEM NUMBERS SPECIFIED IN ECO 5206 , MODIFICATIONS

$$
10,11,12,13,14,15,16,18,20,21,22 \text {, MAY NOT BE }
$$

tile same as the item numbers implemented

INTO THE DRAWINGS 412 -F-OI7-W AND

$$
412-N-002-W \text {. }
$$

Modification 16 AT PAGE 13 of 18 To ECO 5206 SHOULD APPLY TO 412-N-0OZ-W RATIERTHAN $412-F-017-W$.

3. Approvals

Cognizant Engineer:

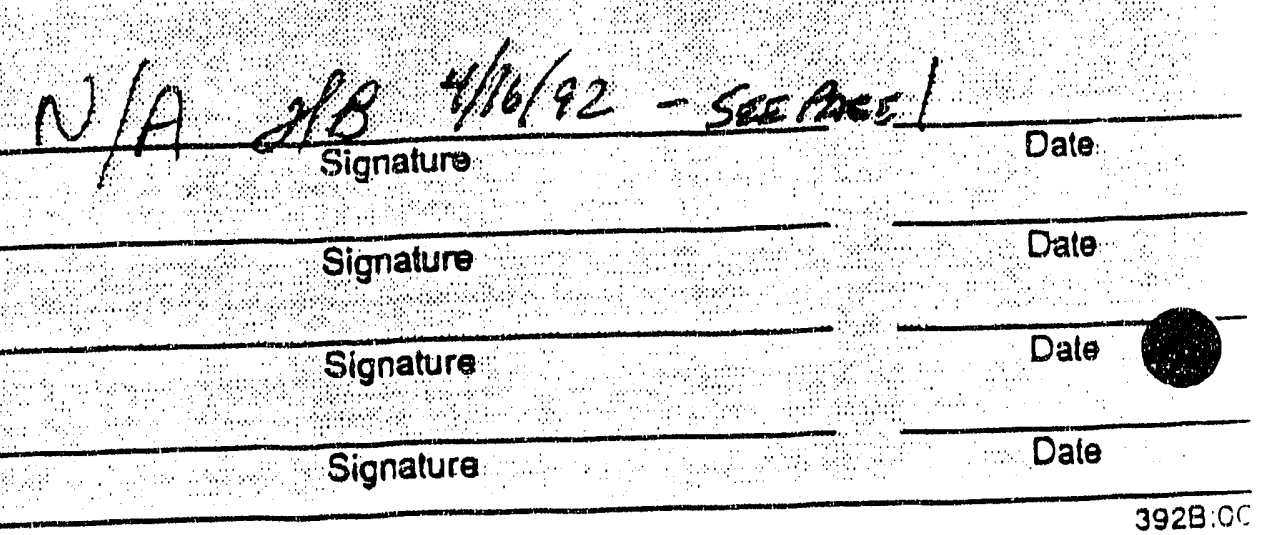

CC\&D.Mgr. /Desig. Rep.:

Other Approval:

Other Approval::

$\frac{\text { Signature }}{\text { Signature }}$

392B: OC

WP Form 2020; 3/19/92

Page 1 of 1 


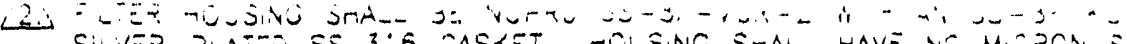
-CLSING STAL- MAVE VE MISZCN SIZE OR OTHER SPECIFICATION STAMPEO ON IT. DISCARD THE NUPRO FILTER ELEMENT IN THE HOUSING

4. FIBERBOARD LINERS TAPED TOGETHER AT TAB END WITH ITEM 18.

4. SHIP ITEM 4 PLACED INSIDE ITEM 2. NO SHARP BENDS ON GASKET.

5. TAGS TO BE RED WITH WHITE LETTERING ON A $5 \times 2 \times$ TAG, WITH $1 / 4^{*}-$ $1 / 7^{\prime \prime}$ CHARACTERS. TAGS TO BE MOUNTED WITH ITEM 20. TEXT OF EACH TAG SHOWN IN TAG IDENTIFICATION TABLE.

6. REMOVED

7. REMOVED

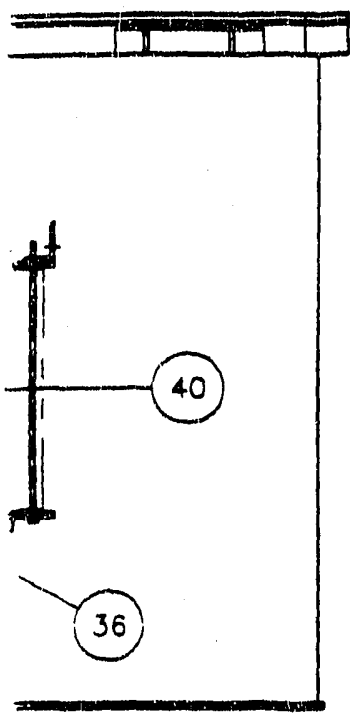

8. REMOVED

9. STANDARD HEX-HEAD BOLTS WITH INTEGRAL WASHERS. BOLTS SHALL BE 1/2-13 UNC $\times 1-1 / 4$ LG. WITH AN INTEGRAL FLAT WASHER 1" DIMMETER.

D. IEAVE TOP OF ITEM 12 LOOSE AFEER INSTALIIINC ITEMS 13, 14, 29, \& 30.

41 STENCIL BIN ECUIPNENT NO. ANO THREE DIGIT SERIAL NO. LETTERS SHALL BE $1 / 2^{\prime \prime}-1^{\prime \prime}$ HIGH INDELIBLE BLACK. LIDS AND BINS OF THE SAME SERIAL NUIMBER SHALL BE SHIPPED TOGETHER, SOLID WASTE BIN EQUIP. NO.: $63-5-001, \mathrm{~S} / \mathrm{N}-001$, ETC. PS/SC BIN EQUIP. NO.: 63-S-004, $S / N-001$, ETC.

42. SANDIA NATIONAL LABS. TO SUPPLY ANO INSTALL ITEMS 23, 24, 25, 26, AND 27 PER PROCEDURES APPROVED BY W-WID.

4 TIGHTEN TO $30 \mathrm{FT}-L B$ TORQUE.

44. STENCIL WORDS "MAX GROSS WEIGHT 3.200 LBS."

LETTERS SHALL BE $1-2^{*}$ HIGH, INDELIBIE BLACK, ON NEAR ANO FAR SIDE OF BIN, STENCILED AFTER PAINTING BIN.

45. TRANSPORT FILTERS (ITEM 38) TO BE FITTED WITH A FEMALE NUT AT THE FABRICATION SHOP. THIS NUT WILL BE REPLACED WITH A CAP NUT AT THE WIPP SITE PRIOR TO DOWN-LOAOING OF THE BIN.

16. ALL VCR CONNECTIONS SHALL BE MATED WITH PROPER SIZE GASKET, PREFERABLY HELD IN A GASKET RETAINER ASSEMBLY (ITEM 32, ITEM 33).

17. FOLLOW VENDOR DIRECTIONS FOR REPEATED USE OF THE SAME ASSEMBLY.

i)

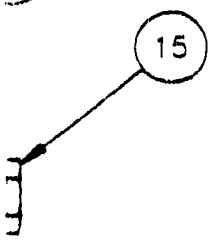

68. FILTER MEDIA SHALL BE REMOVED FROM THE NUPRO FILTER HOUSING (ITEM 21) FOR THE PRODUCTION BINS S/N PE-0O9 THROUGH PQ-018.

A OUT WIRE CLOTH INTO $20 \mathrm{FT}$. LONG PIECES FOLO INTO SIX APPROXIMATELY $40^{\prime \prime}$ LONG ACCORDIAN STYLE BENDS. LOAD 3 PIECES (6O L.F.) OF THE FOLDED WIRE CLOTH DIRECTLY ONTO THE GAS MANIFOLD ASSEMBLY (DWO. NOS. $4: 2-M-005-W$ AND 412-M-007-W). INSTALL PRIOR TO SHIPMENT OF BIN TO GENERATOR SITE.

SEMBLY

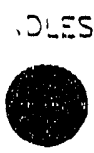

INIERPRET OWC PER MNSI Y14 OIM. IN INCHES QSSED ON $6{ }^{\circ}$

UNLESS OTHE.RWISE SPECIFIED TOLERANCES 2 PL DEC 3 PL OEC ANGLES

\begin{tabular}{ll|l}
\hline \pm .06 & - & - \\
\hline FRACTIONS: $\pm \mathrm{i} / \mathrm{B}$
\end{tabular}

TOROUTS: $\pm 1 / 8$ or +2 IN-LE

ENGINEERING RELEASE

QY (II) MO-MPP

ECO

OATE

\begin{tabular}{|c|c|c|c|c|c|c|c|}
\hline \multirow{2}{*}{$F$} & \multirow{2}{*}{ REVSED PER ECO FD } & RM & 055 & on & 24 & \multirow{2}{*}{$\begin{array}{r}5189 \\
5206 \\
5846\end{array}$} & \\
\hline & & $4 / 15 / 92$ & $41,5 / 82$ & 415192 & $21 / 5 / 92$ & & \\
\hline \multirow{2}{*}{$\varepsilon$} & \multirow{2}{*}{ REVISEC PER ECO FD } & $\mathrm{DLH}$ & TRA & $M B$ & $\mathrm{HE}$ & \multirow{2}{*}{$\begin{array}{l}4869 \\
5000\end{array}$} & \\
\hline & & $10 / 18 / 90$ & $10 / 17 / 90$ & $10 / 17 / 90$ & $10 / 18 / 90$ & & \\
\hline \multirow{2}{*}{ REV } & \multirow{2}{*}{ ISSIJE DESCRIPTION } & OFTR & $\mathrm{CHK}$ & $\operatorname{coc}$ & DFTG MCR & \multirow{2}{*}{ ECO } & \multirow{2}{*}{ PWR } \\
\hline & & DATE & DATE & DATE & DATE & & \\
\hline
\end{tabular}

OFTG A.E.SENALD 10/30/89

CHKR, TONY ALSTON 10/17/90

COG. ENG M. BNU $10 / 17 / 90$

COG. MGR Ja. GARCA 1/12/90

Q.A. JANES F. NLEN 12/8/89

SAFETY C.D. JACKSON 12/6/89

APPO W.R. WHITE $12 / 6 / 89$

APPO TERPY D. WERKUNG (RS)

OFTC. MGRT BELLOWS 10/18/90

SNL WART $A$ WOLCKE $12 / 6 / 69$

U.S. DEPARTINT OF ENEREY

Westinghouse Waste Isolation Division

Waste Isolation Pilot Plant CARLSBAO. NEW MEXICO

BAN-SCNE TESTS DEY TEST BIN ASSEMBLY

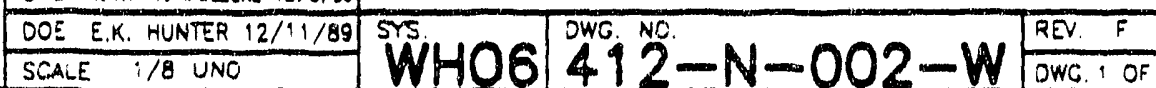




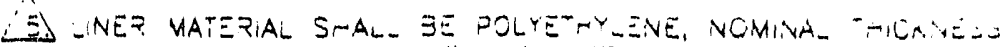

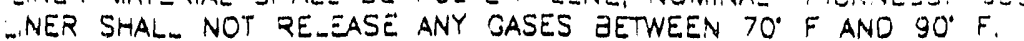

6. REMOVED

7. PREPARE AND PAINT EXTERNAL SURFACES OF BIN PER SPECIFICATION E-Z-240, REV, 2, SYSTEM 1-16. FINISH COAT SHALL BE GRAY. APPLY PAINT AFTER WELD TESTS AND APPROVALS SPECIFIED IN EQUIPMENT SPECIFICATION E-A-334, EXCEPT STAINLESS STEEL SURFACES.

8. PAINT INTERNAL SURFACE OF BIN AND UNDERSIOE OF COVER WITH PAINT $105 \mathrm{C}-5$, WHITAKER COATINGS, 1500 LATHEM ST., BATAVIA, IL. 60510 OR EQUAL. APPLY FIRST COAT .0005" - .0004" ORY AND BAKE 10-12 MINUTES AT $300^{\circ}-315^{\circ} \mathrm{F}$. APPLY SECOND COAT .0003 - .0004" DRY AND BAKE 10 - 12 MINUTES AT $400^{\circ}-425^{\circ} \mathrm{F}$. APPLY FIRST COAT AFTER WELD TESTS AND APPROVALS SPECIFIED IN EQUIPMENT SPECIFICATION $E-A-334$.

9. STENCIL BIN EOUIPMENT NO AND THREE DIGIT SERIAL NO. LETTERS SHALL BE $1 / \tau^{\prime \prime}-1^{\prime \prime}$ HIGH INDELIBLE BLACK, LIDS AND BINS OF THE SAME SERIAL NO. SHALL BE SHIPPED TOGETHER. DRY TEST BIN EQUIP. NO.: $63-S-001, S / N-001$, ETC.

10 REINFORCE HOLES IN LINER WITH TEFLON WASHER EMBEDDED IN THE LINER.

4. SECOND WELO ON WALL OPTIONAL. SINGLE WELO PERFERRED WITH SINGLE PIECE WALL.

$\triangle \lambda$ TO BE INSTALLED TO BOTTOM OF BIN ONLY.

13. REMOVED

14. ALL $1 / 2^{n}$ VALVES INSTALL ON ITEM 1 SHALL HAVE THE SAME PART NUMBER.

19. all 1" Valves install on item I shall have the same PART NUMBER.

16. ARROWS ON ALL VALVES TO POINT AWAY FROM BIN WALL.

Ad REMOVE. THIS LENGTH AFTER FINAL INSTALLATION.

18. THIS DETAIL FOR TEST BINS S/N PB-009, PB-010, AND PB-011 ONLY.

19. THIS DETAIL FOR TEST BINS S/N PB-012 AND ONWARD.

Ld FOLD ITEM 20 AS REQUIRED TO FIT WITHIN THE BIN.

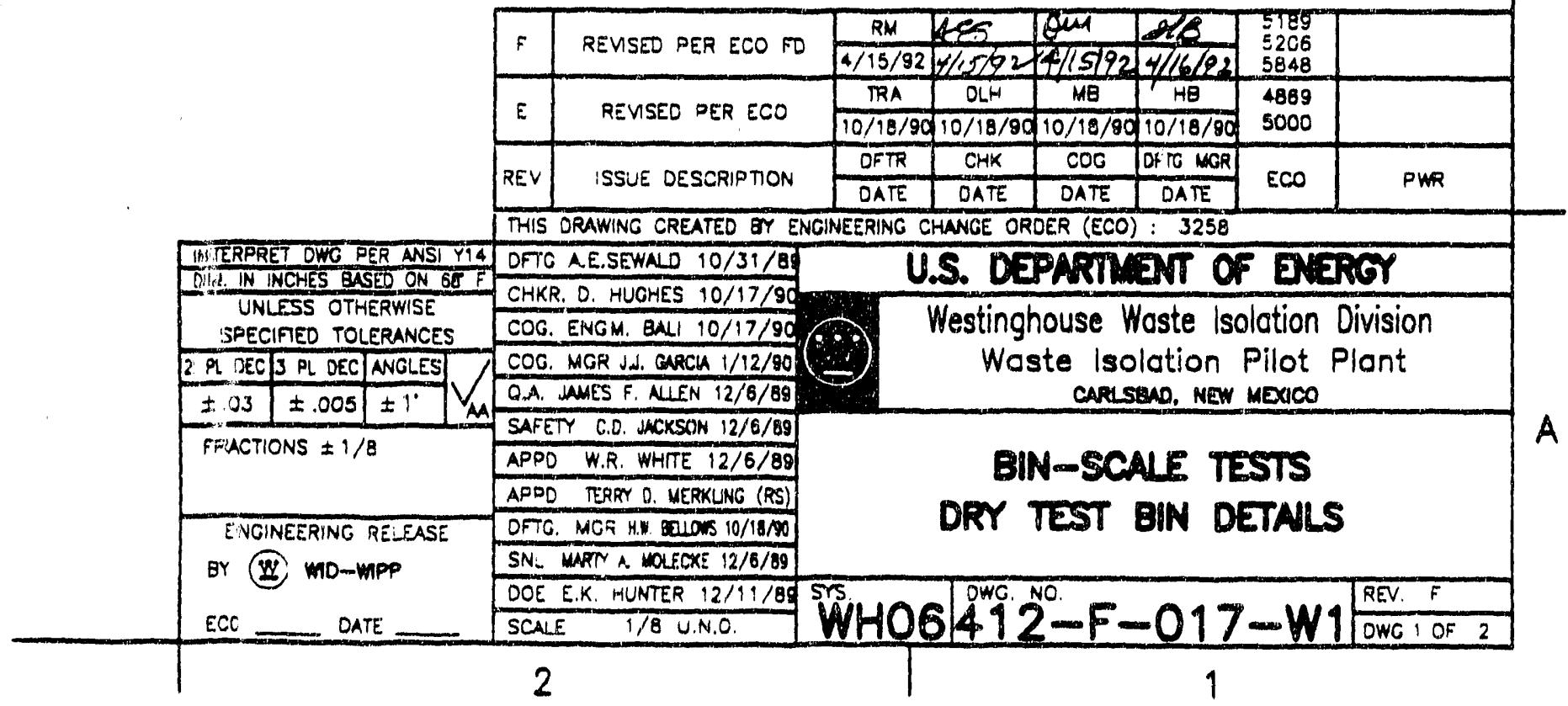




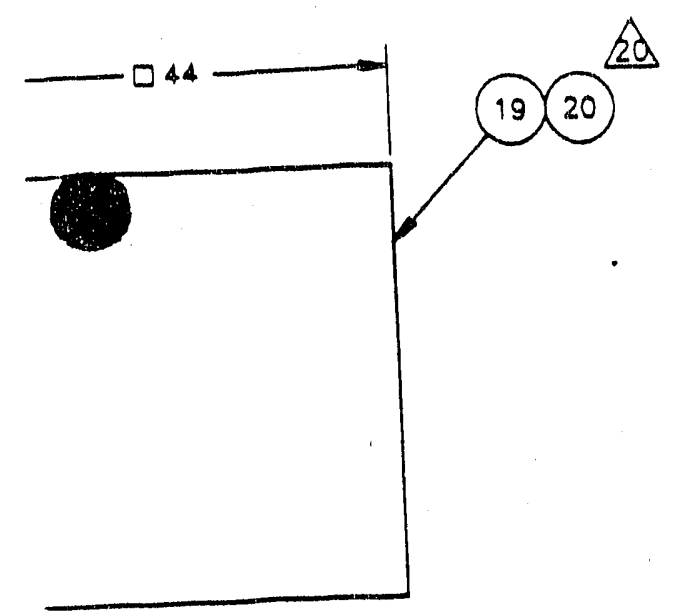

\begin{tabular}{|c|c|c|c|c|c|c|c|}
\hline \multirow[b]{2}{*}{$F$} & \multirow[b]{2}{*}{ REUSED PER ECO FD } & RM & $4 \leq 5$ & 24 & exp & \multirow{2}{*}{$\begin{array}{l}5189 \\
5206 \\
6081 \\
\end{array}$} & \\
\hline & & $4 / 15 / 92$ & $4 / 1<>2$ & 41579 & $4 / 1619 d$ & & \\
\hline \multirow{2}{*}{$\underline{E}$} & \multirow{2}{*}{ REUSED PER ECO } & $\pi R$ & $\mathrm{OLH}$ & $\mathrm{ME}$ & $\mathrm{HE}$ & \multirow{2}{*}{$\begin{array}{l}4889 \\
5000 \\
\end{array}$} & \\
\hline & & $10 / 18 / 90$ & $10 / 18 / 9$ & $10 / 18 / 90$ & $10 / 18 / 90$ & & \\
\hline RפV & \multirow{2}{*}{ ISSUE DESCRIPTION } & OFTR & CHK & $\mathrm{COC}$ & OFTC MCR & \multirow{2}{*}{ ECO } & \multirow[t]{2}{*}{ PWR } \\
\hline & & $\frac{\text { OATE }}{\text { ERING C }}$ & $\frac{\text { DATE }}{\text { WGE } O}$ & $\frac{\text { DATE }}{R \text { R (ECO }}$ & $\frac{\text { DATE }}{3258}$ & & \\
\hline
\end{tabular}

INTERPRE OWO PER ANSI Y14 OFTG A.E. SEWALD 10/31/89

DIM IN INCHES BSSED ON ES F CHKR. D. HUGHES 10/17/90. UNLESS OTHERWISE SPECIFIED TOLERANCES 2 PL DEC 3 FL OEC ANGLES $\pm .03 \pm \pm .005 \pm 1^{\circ} \quad V_{A A}$

FRACTIONS $\pm 1 / 8$

NGINEERING RELEASE

BY (y) MO-MPP

ECO

DATE
COG. ENCM. BALI 10/17/90

QA. JAMES F. NLEN 12/6/89

SAFET! C.D. WCASON 12/6/89

APPD W.R. WHITE 12/6/89

APPD TERRY D. MERTUNG (RS)

DFTG. MGR H.W. BLIOW 10/18/90

SNL WATT A WOLECXE $12 / 8 / 89$

DOE E.K. HUNTER 12/11/QS SCALE
COG. MGR Jad. CARCA 1/12/90
U.S. DEPARTMENT OF ENEROY

Westinghouse Waste Isolation Division

Waste Isolation Pilot Plant CARLSEND, NEW MEXICO

\section{BIN-SCALE TESTS}

DRY TEST BIN DETALS

$\left\{\begin{array}{l}\text { BY (ㅍ) MO-MPP } \\ \text { ECO DATE }\end{array}\right.$




\section{A $001 W$}

\section{ENGINEERING CHANGE ORDER}

USE BLACK INK
2. Impact Love
$1 \square$
3 [4 4
$4 \square$

1. ECO No.5. 92

SKEC\&D Review 2 道

Initials

Posted

3. System: 10 , Equipment No.:

4. Associated Documents:

PWR CI5.34-M

ECP

P.O.

Others

\section{Document Type:}

Drawing d

Specification

Vendor Data

SDD

Others 1$)\left(71 \cdot x \cdot A C 1-w^{\prime}\right.$

6. Title of Change: iNSITLL L, BAATION X.M TRS

7. Originator: (print)

Ext. No.: Department: Date:

TOE SA, T

S285

M\$L

$=2 / 28 / 9$

8. Cognizant Engineer: (print)

9. Description of Change:

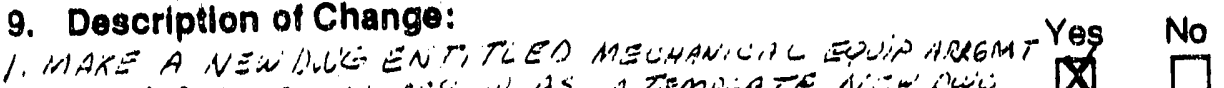

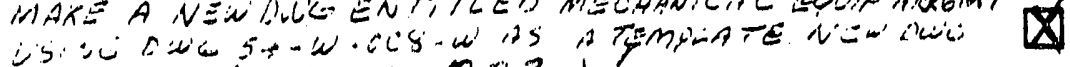

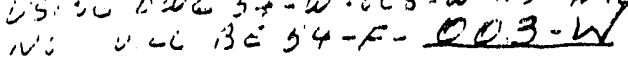

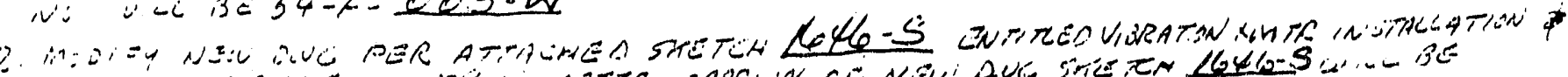
Mather un

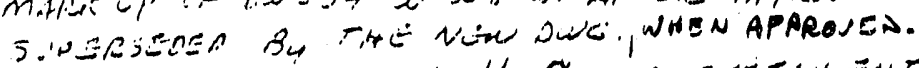

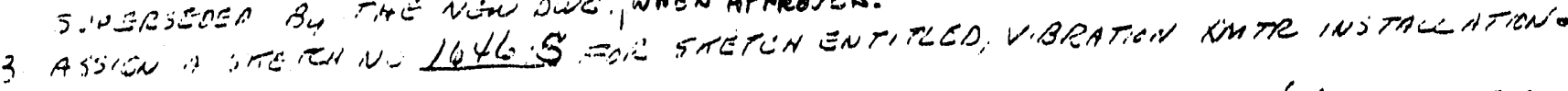

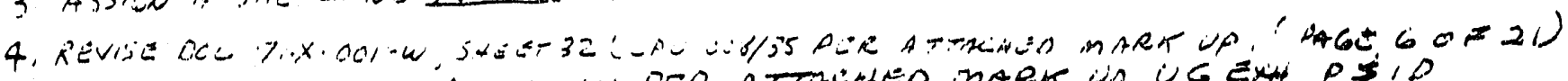

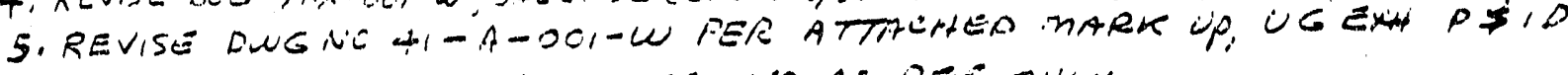

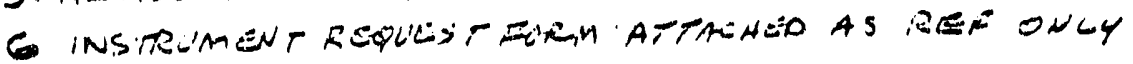

9a Drawing Change Sheet attached

9c Vendor Data Change Sheet attached

9b Design Documentation Sheet attached

10. Yes No iTENZZ

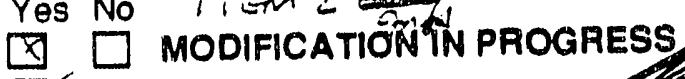

$\square$ Modification complete:

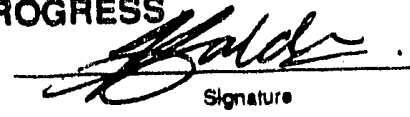

ECO will be

Charge drawing per as-built markup dated:

$\square \quad$ Charge drawing per as-built markup data

[ Temporary modification

11. Design Veriflcation Requirements: (per WP 09-018)

EDT No.:

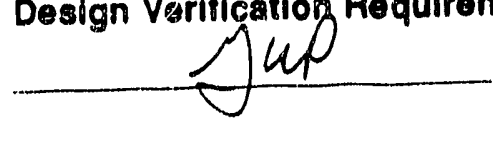

1. Requirements satisfied by review/approval of design document

2. Independent review

3. Altemate calculations

4. Development testing

6. Other: Review/approval of drawing

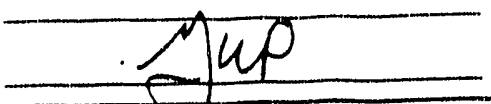

12. Addendum Sheet added:

Simenture 


\section{Justification}

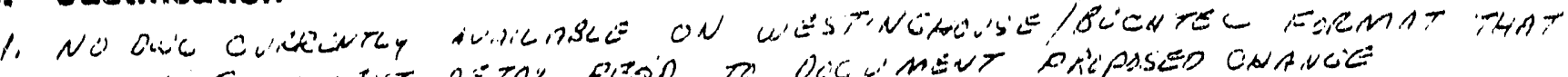

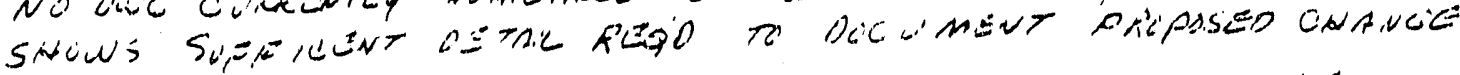

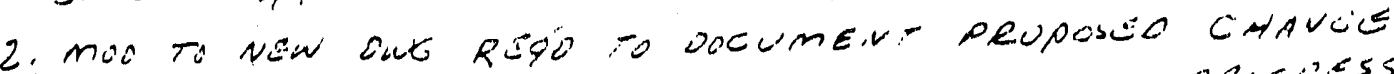

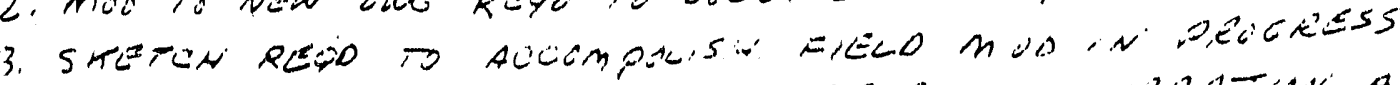

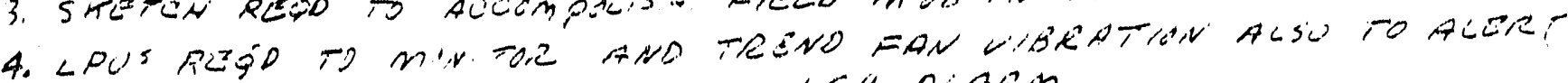
CIMR TO SINUT DOULV EAW UN WICA BLARM.

5. TO INLERORATE MOD IN PROCRESS WMTIL INSTALLATON TO THE APPROPIATE P\$ZD OUG

\section{Administrative Tracking}

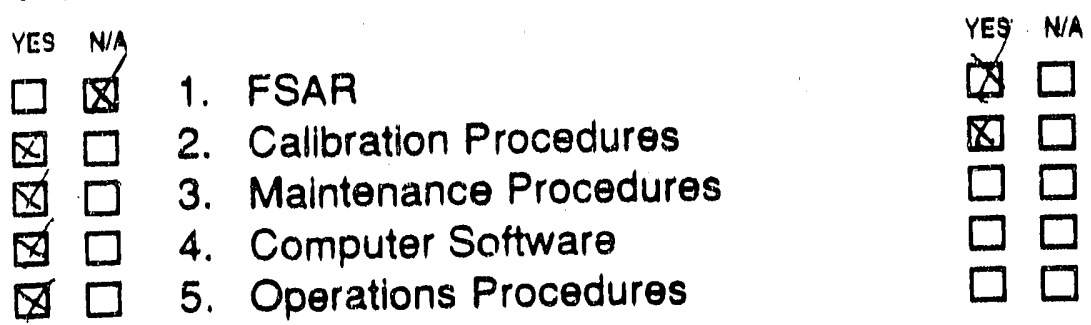

ES' N/A

6. Startup/Acceptance Test

$\square$ 7. Test Requirement \& Spec.

8.

9.

10.

\begin{tabular}{|l} 
15. Slgnature Requirements \\
\end{tabular} $\begin{aligned} & \text { KEY } \\
& \text { AAPPR. } \\
& \text { RAREVIEW } \\
& \text { SASIGN NEW } \\
& \text { DRAWING }\end{aligned}$

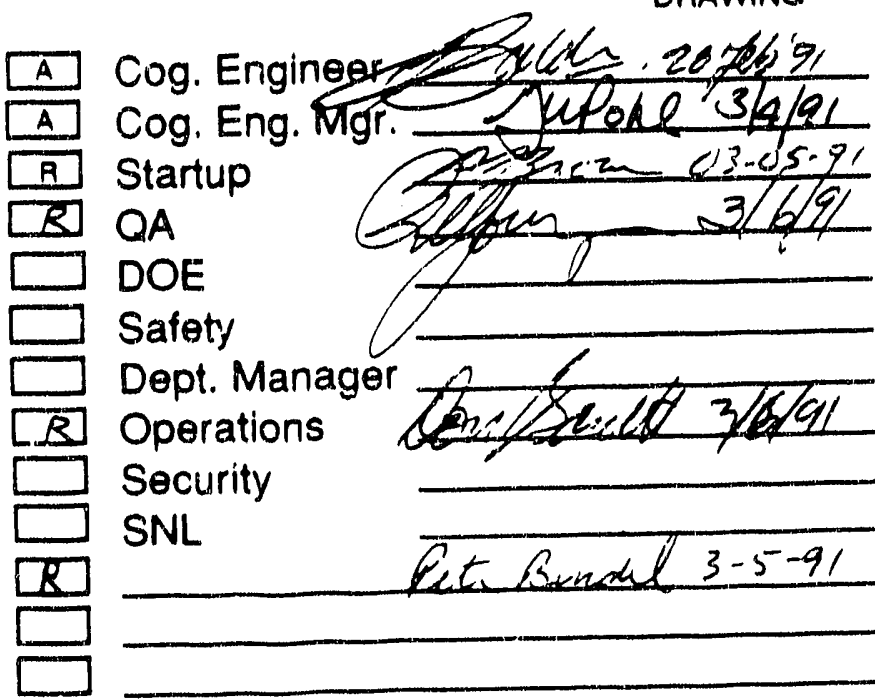

\section{Distribute as Marked}

Maintenance (MANDATOAY) Ops. Support (MANDATORY) Startup

Facility Operations

U/G Operations

Orig./Design Engr.

Cog. Engineer

Others $P \Leftrightarrow E$ BलOEL 
1. Drawing: $Z 1-x-00 /-w$, SHEET 32 ECO Number: $\frac{5292}{P, 46 E^{2}}$

2. ECO Search List: Nave
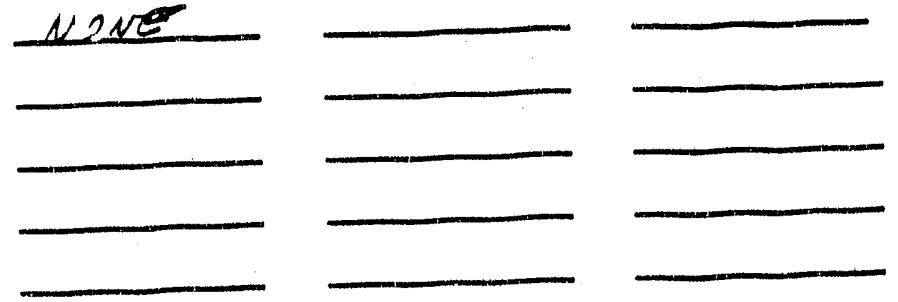

3. Description of Change:

REVISE SHEET 32 PER ATTALHED MARK UP OF SAEET 32

\section{Pris Sundil $3-5-91$}

4. Drawing Cog. Engineer Approval:

Date: 28 te6.'91.

5. Cover Sheet Block (CC\&D Use Only)

Recoived from EFR: Initiels / Date

Date Assigned: Initisto / Dato Assigned to:

Drafting Started:

Drafting Completed: Ratumto EFR:
Initiald / Dato

Initiale I Dato Initiala / Date 
1. Drawing: $54-5-C O 3-W$ ECO Number: $\frac{5292}{P_{A 6}+40,16}$

2. ECO Search List: NONE
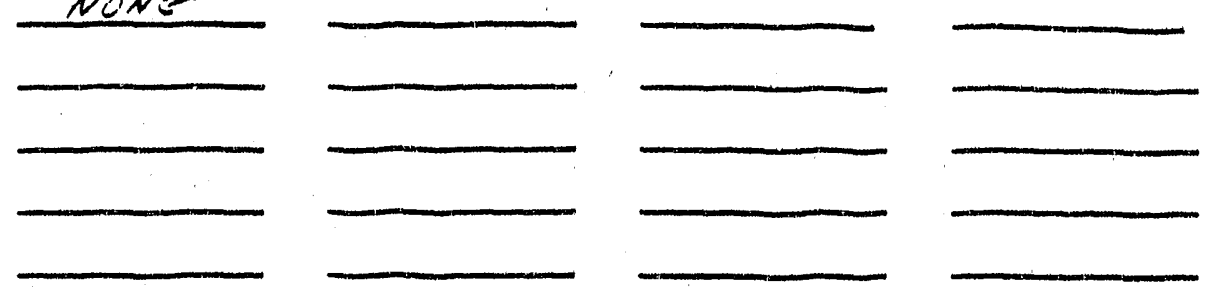

3. Description of Change:

dO AEEMSE NizW OW'

305h TEMPLATE OI= 54-W-OOS-W, REVISED PER MART

OF 5U-W-OOW-W AND PER ATTACWLA STETCW LGLE-S ENTITLEO VIBRATION XMTR INSTALLATIUN.

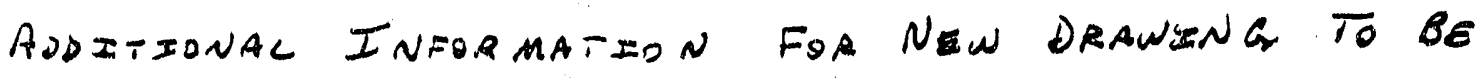

Provided By Cog. Enganeser After Complatan of FIELD WORK.

4. Drawing Cog. Engineer Approvali

Date: 28 Aeb. '91

5. Cover Sheet Elock (CC\&D Use OnIy)

Received from EFR:

Initials $t$ Date

Date Assigned:

Intiliats t Date

Assigned to:

(Same as data base ontry)

Dratting Started:

Dratting Completed:

Retum to EFA:
Initials / Dato

Initials / Date

Initials t Date 


\section{9a}

\section{DRAWING CHANGE SHEET}

(1 SHEET PER DRAWING)

1. Drawing: $41-A-001-\omega^{\prime}$

ECO Number: $\frac{5,292}{\text { PACE } 50=20}$

2. ECO Search List:

$495+(M)$

3. Description of Change:

REVISE PGIO DWW LIAA-OUI-W PLP. ATTRCHEO DWL $M A R K$ UP TO REFLCCT ADDITTAN OF VIBRATION XMTRS TO $41-B-700$ A $B$ FANS

4. Drawing Cog. Engineer Approval: Date: 28 és.91

5. Cover Sheet Block (CC\&D Use Only)

Recoived from EFR:

Date Assigned:

Assigned to:
Dratting Started:

Dratting Completed:

Reium to EFR:
Initials / Date

Initiaks / Date

Initials / Date 

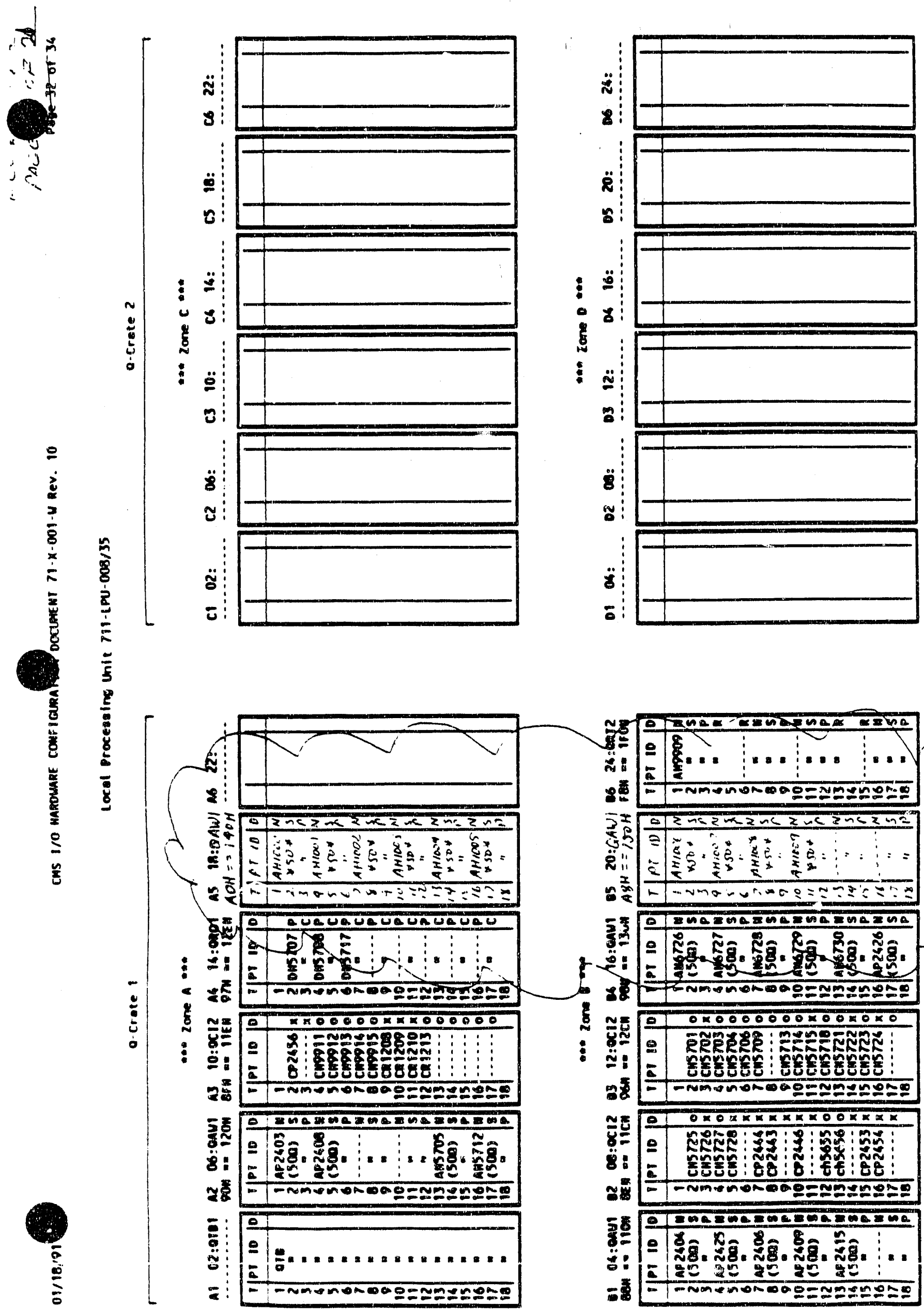

of

Pages CONTINUATION OF RESOLUTION

Work Request No.

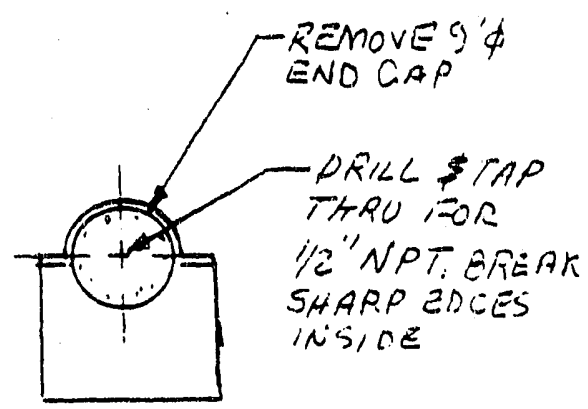

VIEW B-B
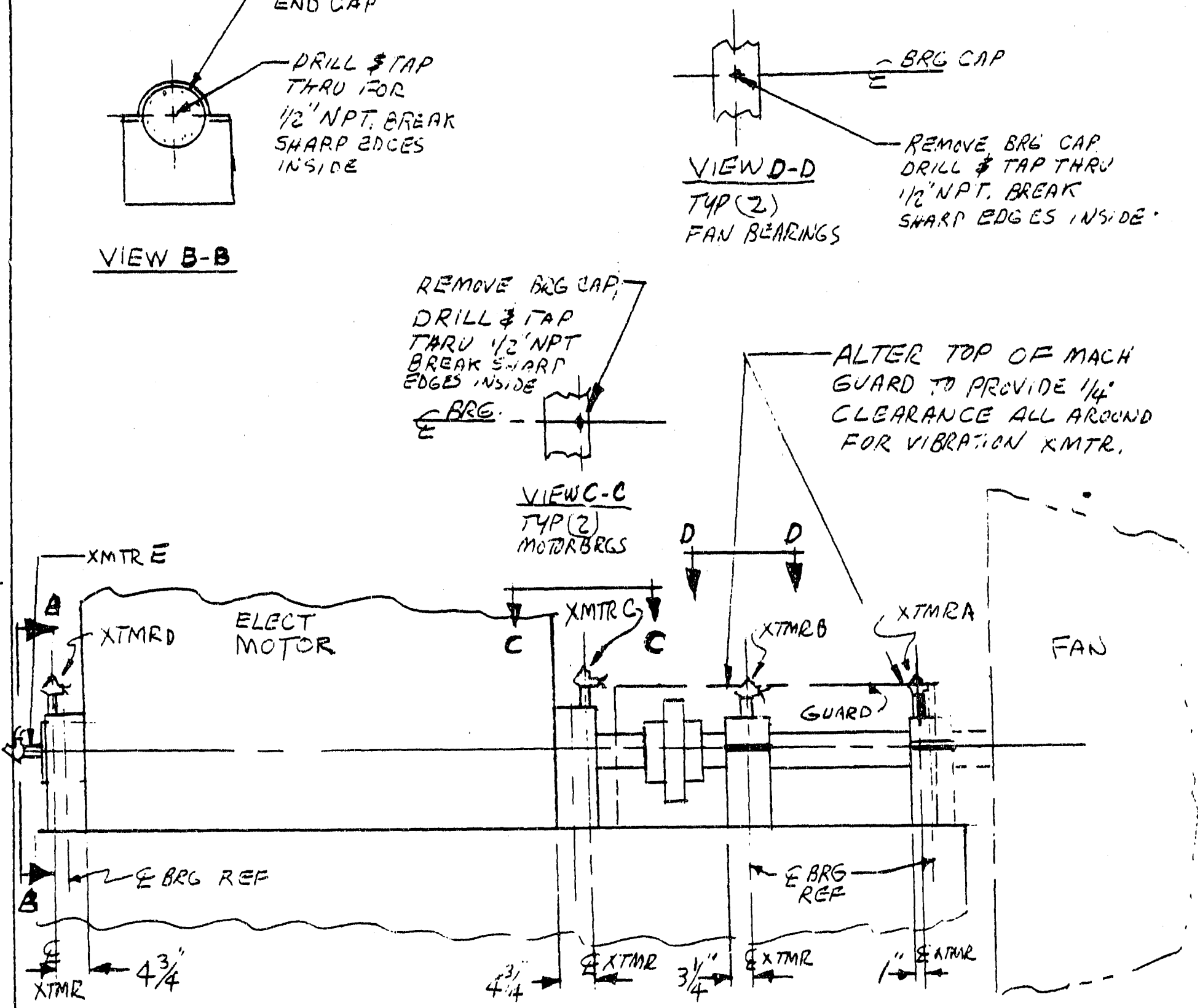

VIEWA-A

PARTIAL ELEV VIEW

VIBRATION XMTR. INSTALLATLEN AI-B-70C A \& B FANS

NOTE: REMOVE BRG CAPS

END PLATE PER VIELUB-B

C.C D-D . PERFORM WURK IN SHOP. CLEAN INSIDE BRG CAP\& END PLATE CAREFUCLY BEFORE PEPLACINC.
SHETCH NO 1646 -S DES ENGR foe Hart 2/28/91 CoG ENGR calle 28 ta6."91 Co6 EitsR MER Muphe s/qlq, ECOS292 AAGC 7 OF 2 


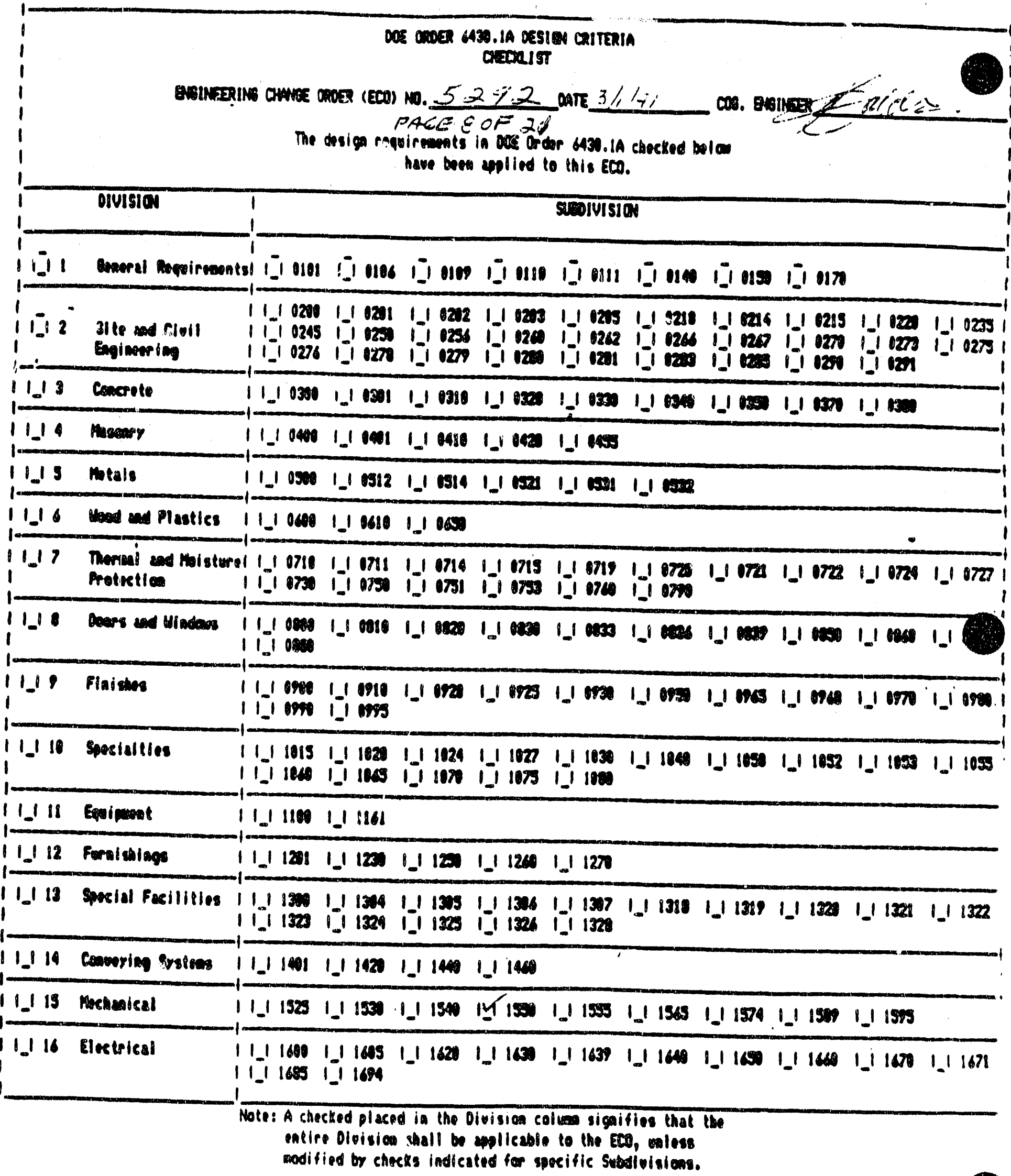


$4 M L L$

D CHANGE

UESI r UKM

ש U. . . . div

1. INSTRUMENT NUMBERI 4/3-YT-307-10A

2. SYS/SUBSYSTEM VUO

3. DESCRIPTIONI VIBRATION TRANSMITTER

4. LQDP NUMBER _

5. ECP NUMBER 2 - VU90-60

6. INPUT RANGE $0-1.0$ IPS

7. DUTPUT RANGE 4-20MA

\section{CMS SETPOINTS}

\begin{tabular}{|c|c|c|}
\hline \multicolumn{3}{|c|}{ 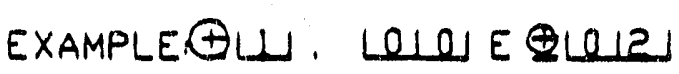 } \\
\hline \multicolumn{3}{|c|}{ HI ALARM } \\
\hline LIMIT & . & لــ \\
\hline DBND & 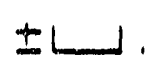 & L $E \pm=310$ \\
\hline LO & $\pm \longleftarrow ـ$ & 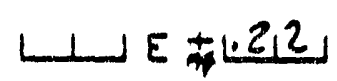 \\
\hline DBND & $\pm \amalg$. & 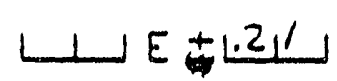 \\
\hline ENGR & $\pm L$ & IPS \\
\hline
\end{tabular}

10. LUCAL SETPQINTS NOT APPLEABLE EXAMPLEGUU. LULU E GLLLL HI ALARM

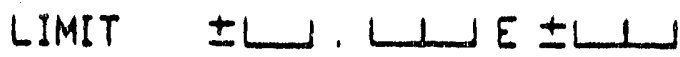

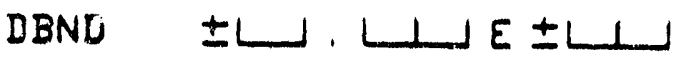

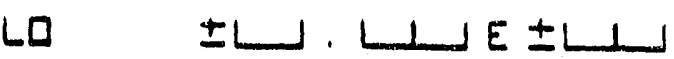

DBND \pm J. I I E E I

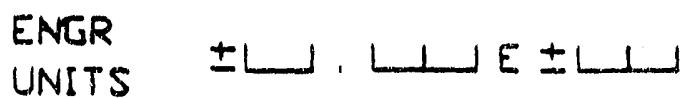

11. MANUFACTURER METRIX LNSTRUMENT CO

12. SERIAL NUMBER $N / A$

14. LOCATION DRAWING $54-\omega-008-\omega$

16. DESIGN CLASS IISB

17. BLDG NUMBER $N / A$

19. ASSOCIATED PANEL QR SUBEQUIPMENT ND. TBD 20. OSR/LCO EQUIPMENT YES - NQ X FOR

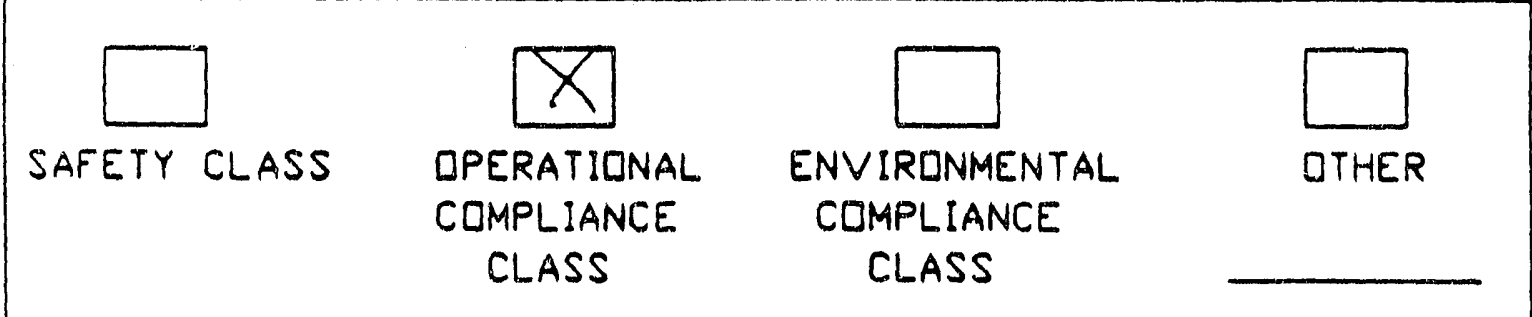

21. ELECTRICAL POWER FRIM TRPOAL TBD

22. CAL./PM PROCEDURE NUMBER $N / A$

23. IF CHANGING INST. NUMBER, WHAT IS RELATED ECO NUMBER N/A

24. REMARKS:

$N / A$

NOTE, DO NOT LEAVE ANY BLANKS. USE N/A IF IT NDN APPLICABLE. REQUESTIR JOE HART DATE 2/37/9I ECO 5292 
$\checkmark$ CHANCE

1. INSTRUMENT NUMBERI $413-Y$ Y $307-10 \beta$ 2. SYS/SUBSYSTEM VUC

3. DESCRIPTIONI VIBRATION TRANSMITTER

4. LOOP NUMBER 10

5. ECP NUMBER $\underline{2-V U 90-6 \sigma}$

6. INPUT RANGE $0-1.0$ IPS

7. OUTPUT RANGF. 4-20MA

9. CMS SETPOINTS

\begin{tabular}{|c|c|}
\hline \multicolumn{2}{|c|}{ 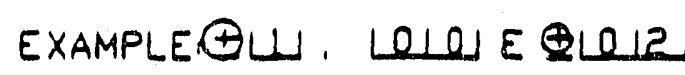 } \\
\hline \multicolumn{2}{|c|}{ HI ALARM } \\
\hline LIMIT & 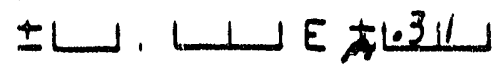 \\
\hline DBND & $\pm \amalg .4$. $E$. \\
\hline L & $\pm \amalg$. \\
\hline DBND & 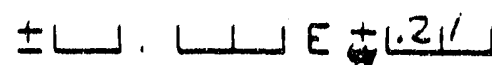 \\
\hline $\begin{array}{l}\text { ENGR } \\
\text { UNITS }\end{array}$ & 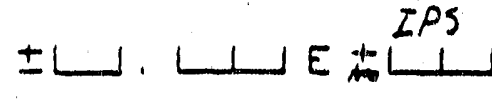 \\
\hline
\end{tabular}

10. LUCAL SETPOINTS

\begin{tabular}{|c|c|}
\hline EXAMP & 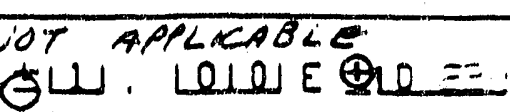 \\
\hline HI AL. & \\
\hline LIMIT & I \\
\hline DBND & $\pm L ل$ ， لـL \\
\hline LQ & 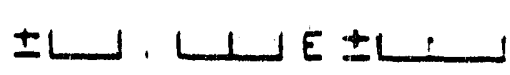 \\
\hline DBND & $\pm L ل$. \\
\hline $\begin{array}{l}\text { ENGR } \\
\text { UNITS }\end{array}$ & E \\
\hline
\end{tabular}

11. MANUFACTURER METRIX INSTEUMENT Co

12. SERIAL NUMBER $N / A$

14. LOCATIIN DRAWING $5-\omega-6 C 8-\omega$

16. DESIGN CLASS IILB

17. BLDG NUMBER $N / A$
13. MODEL NUMBER $548 \div-$

15. P\&ID DRAWING $\% /-A-\cdots=1-w$

18. RODM NUMBER N/A

19. ASSOCIATED PANEL QR SUBEQUIPMENT NO. TBD 20. OSR/LCQ EQUIPMENT YES - NO X FUR

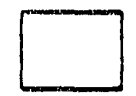

SAFETY CLASS

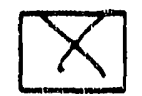

DPERATIONAL COMPLIANCE

CLASS

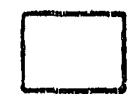

ENVIRONMENTAL COMPLIANCE

CLASS

21. ELECTRICAL POWER FRIM TH TBD

22. CAL./PM PROCEDURE NUMBER $N / A$

23. IF CHANGING INST, NUMBER, WHAT IS RELATED ECD NUMBER $N=$

24. REMARKS: $N / A$

NDTE, DO NDT LEAVE ANY BLANKS. USE N/A IF IT NON APPLICAB= REQUESTOR JOE HAFT DATE 2/37/F 
1. INSTRUMENT NUMBER:4/3-YT-307-10C 2. SYS/SUBSYSTEM VUOI

3. DESCRIPTIONI VIBRATION TRANSMITTER

4. LDOP NUMBER 72012

5. ECP NUMBER 2 - VU90-60

6. INPUT RANGE $0-1.0$ IPS

7. DUTPUT RANGE $4-20 \mathrm{MA}$

\section{CMS SETPOINTS}

\begin{tabular}{|c|c|}
\hline \multicolumn{2}{|c|}{ 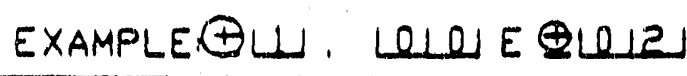 } \\
\hline \multicolumn{2}{|c|}{ HI ALARM } \\
\hline LIMIT & 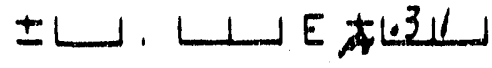 \\
\hline DBND & 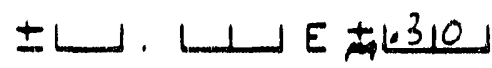 \\
\hline LQ & 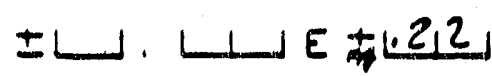 \\
\hline DBND & 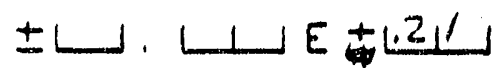 \\
\hline $\begin{array}{l}\text { ENGR } \\
\text { UNITS }\end{array}$ & 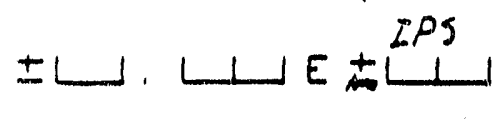 \\
\hline
\end{tabular}

10. LDCAL SETPDINTS

NOT APPLCABLE

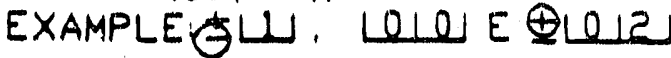

HI ALARM

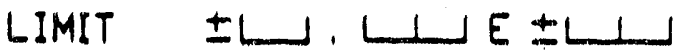

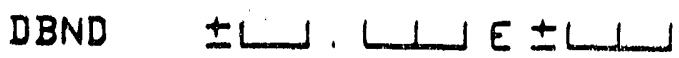

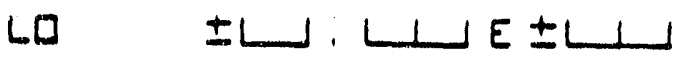

DBND $\pm L 」, L \perp E \pm L \perp$

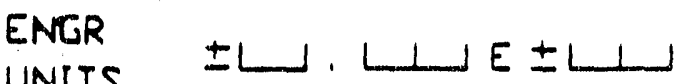

11. MANUFACTURER METRIX LNS TRUMENT CO

12. SERIAL NUMBER $N / A$

14. LOCATION DRAWING $54-\omega^{\prime}-008-\omega$

16. DESIGN CLASS IICB

17. BLDG NUMBER $N / A$

19. ASSICIATED PANEL OR SUBEQUIPMENT NO. TBD 20. OSR/LCD EQUIPMENT YES _ ND X FOR

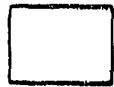

SAFETY CLASS

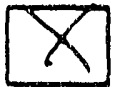

DPERATIONAL COMPLIANCE

CLASS

13. MODEL NUMBER $5484 \mathrm{C}$

15. P\&ID DRAWING $4 /-A-C C /-W$

18. ROOM NU

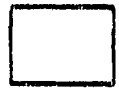

ENVIRONMENTAL COMPLIANCE CLASS

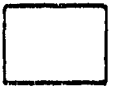

DTHER

21. ELECTRICAL FIWER FRIM AHP-OPJTE TBO

22. CAL./PM PROCEDURE NUMBER

N/A

23. IF CHANGING INST, NUMBER, WHAT IS RELATED ECO NUMBER N/A 24. REMARKS $N / A$

NOTE, DO NOT LEAVE ANY BLANKS. USE N/A IF IT NON APPLICABLE. REQUESTOR JOE HAFT DATE $2 / 37 / 9 \%$ 
D CHAN

1. INSTRUMENT NUMBERI 4/3-YT-307-100 2. SYS/SUBSYSTEM VUOI

3. DESCRIPTIIN VIBRATION TRANSMITTER

4. LODP NUMBER L to

5. ECP NUMBER 2-VU90-60

6. INPUT RANGE $Q-1.0$ ZPS 7. IUTPUT RANGE 4-20MA

\section{CMS SETPOINTS}

\section{EXAMPLEQUU, LEL E ELLU]}

\section{HI ALARM}

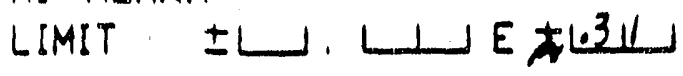

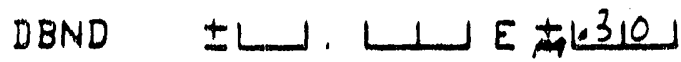

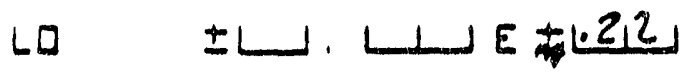

DBND $\pm \longleftarrow$. J $E \pm 2 J$

ENGR IPS

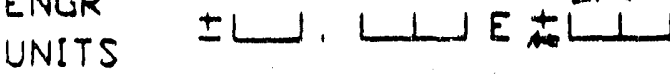

10. LDCAL SETPLINTS

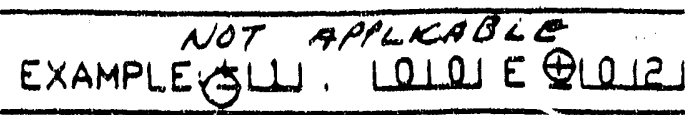

HI ALARM

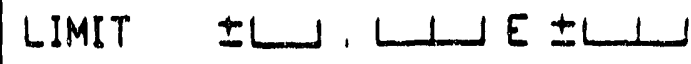

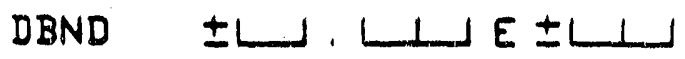

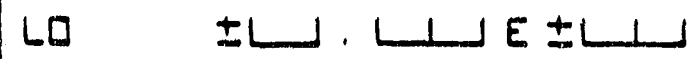

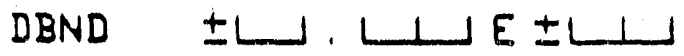

ENGR

UNITS $\pm L, L \perp E \pm L \perp$

11. MANUFACTURER METRIX INSTRUMENT CO

12. SERIAL NUMBER $N / A$

14. LOCATION DRAWING 54-

16. DESIGN CLASS IIZB

17. BLDG NUMBER $N / A$

19. ASSOCIATED PANEL QR SUBEQUIPMENT ND. TBD 20. OSR/LCD EQUIPMENT YES _ ND X FOR

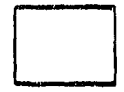

SAFETY CLASS

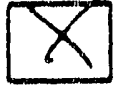

DPERATIONAL COMPLIANCE CLASS
13. MODEL NUMBER $5484 \mathrm{C}$

15. P\&ID DRAWING $4 /-A-C C 1-W$

18. ROQM NUMBER N/A 
¿CHANGE INSTR, I MNHEK KEQUESI FORM UULLEIIUN

1. INSTRUMENT NUMBERIA/3-YT-20OZ-.10E 2. SYS/SUBSYSTEM VUOI

3. DESCRIPTION VIBRATION TEUEIMITTER

4. LIOP NUMBER

5. ECP NUMBER 2-VU90-60

6. INPUT RANGE $0-1.0$ ZPS

7. DUTPUT RANGE 4-20MA

9. CMS SETPOINTS

\begin{tabular}{|c|c|}
\hline \multicolumn{2}{|c|}{ EXAMPLE@LL, , } \\
\hline \multicolumn{2}{|c|}{ HI ALARM } \\
\hline LIMIT & $\pm L$ J \\
\hline DBND & 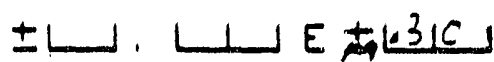 \\
\hline LQ & 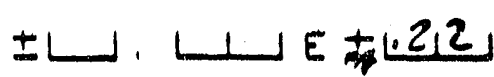 \\
\hline DBND & 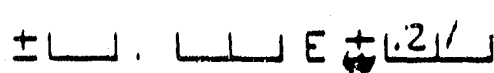 \\
\hline $\begin{array}{l}\text { ENCR } \\
\text { UNITS }\end{array}$ & 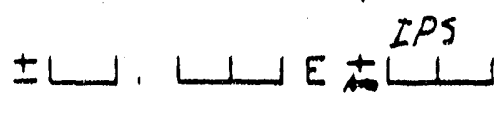 \\
\hline
\end{tabular}

10. LICAL SETPDINTS

\begin{tabular}{|c|c|}
\hline EXAMP & 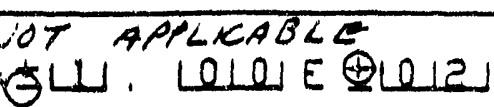 \\
\hline HI AL & \\
\hline LIMIT & $\pm L ل$ J J \\
\hline DBND & 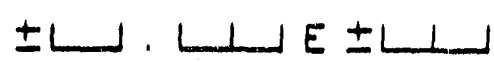 \\
\hline LQ & 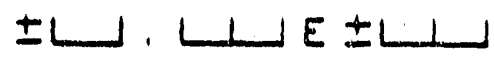 \\
\hline DBND & 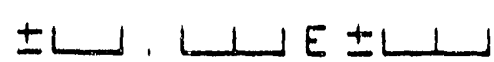 \\
\hline $\begin{array}{l}\text { ENGR } \\
\text { UNITS }\end{array}$ & 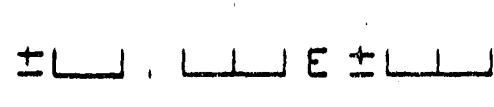 \\
\hline
\end{tabular}

11. MANUFACTURER METRIX CAS :?UMENT ${ }^{2} 0$

12. SERIAL NUMBER $N / A$

14. LDCATION DRAWING $\$ 4-\omega-C E S-\omega$

16. DESIGN CLASS IIEB

17. BLDG NUMBER $N / A$
13. MODEL NUMBER $5484 \mathrm{C}$ 15. P\&ID DRAWING $4 /-A-C C /-W$

18. RODM NUMBER N/A

19. ASSOCIATED PANEL OR SUBEQL=OMENT NO. TBD 20. DSR/LCD EQU:PMENT YES _ NQ X FUR<smiles>C1CCC1</smiles>

SAFETY CLASS

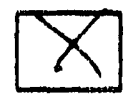

DPERATIONAL COMPLIANCE CLASS

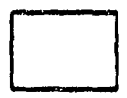

ENVIRLNMENTAL COMPLIANCE

CLASS

$$
\text { CLASS }
$$

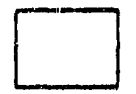

DTHER

21. ELECTRICAL POWER FROM H TBD

22. CAL./PM PROCEDURE NUMBE ₹ $N / A$

23. IF CHANGING INST, NUMBER, W-ATT IS RELATED ECD NUMBER N/A 24. REMARKS $N / A$

NUTE, DO NOT LEAVE ANY BLANKE USE N/A IF IT NON APPLICABLE. REQUESTOR JOE HA:DATE 2/77/9 


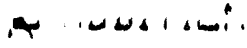

CHANCE

INS K KUMEIY, NUMBER "NHESI RUKM

1. INSTRUMENT NUMBERI4/3-YT-307-1/4

2. SYS/SUBSYSTEM VUOI

3. DESCRIPTIINI VIBRATION TRANSMITTER

4. LOLP NUMBER

5. ECP NUMBER 2-VU90-60

6. INPUT RANGE $0-1.0205$

7. IUTPUT RANGE 4-20MA

9. CMS SETPQINTS

\begin{tabular}{|c|c|c|}
\hline \multicolumn{2}{|c|}{ EXAMPLE@UلU } & 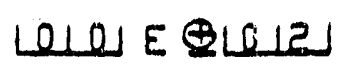 \\
\hline \multicolumn{3}{|c|}{ HI ALARM } \\
\hline LIMIT & لـــــ & 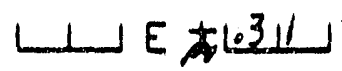 \\
\hline DBND & I & L $E \pm 310$ \\
\hline LQ & \pm & 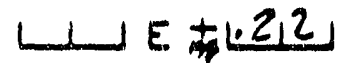 \\
\hline DBND & \pm & $L \perp E \pm .211$ \\
\hline $\begin{array}{l}\text { ENGR } \\
\text { UNITS }\end{array}$ & \pm & L \\
\hline
\end{tabular}

10. LICAL SETPOINTS

\begin{tabular}{|c|c|}
\hline EXAMPI & 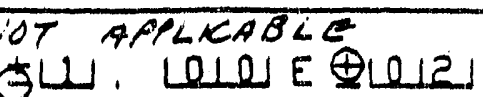 \\
\hline$H I A L$, & \\
\hline LIMIT & 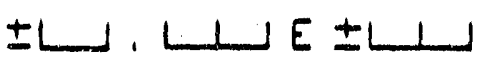 \\
\hline DBND & 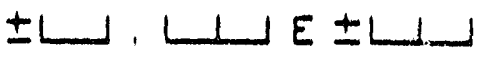 \\
\hline L & $\pm L$ JUL \\
\hline DBND & $\pm \sqcup, \sqcup \sqcup, \sqcup \pm \sqcup$ \\
\hline $\begin{array}{l}\text { ENGR } \\
\text { UNITS }\end{array}$ & الســـا \\
\hline
\end{tabular}

11. MANUFACTURER METRIX INSTRUMENT C'e

12. SERIAL NUMBER

$N / A$

14. LOCATION DRAWING $\$-\omega-O C 8-\omega$

16. DESIGN CLASS IILR

17. BLDG NUMBER $N / A$

19. ASSOCIATED PANEL IR SUBEQUIPMENT ND. TBD 20. QSR/LCD EQUIPMENT YES — NG X FUR

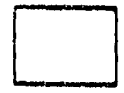

SAFETY CLASS

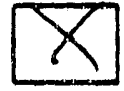

DPERATIONAL COMPLIANCE

CLASS

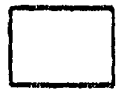

ENVIRINMENTAL COMFLIANCE

CLASS

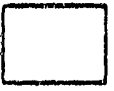

DTHER
13. MUDEL NUMBER $5484 \mathrm{C}$

15. PQID DRAWING 4/-A-OC/-W

18. ROQM NUMBER N/M 
1. INSTRUMENT NUMBER:413-YT-307- $11 B$

2. SYS/SUBSYSTEM VUOI

3. DESCRIPTIINI VIBRATION TRANSMITTER

4. LQOP NUMBER I 11

5. ECP NUMBER 2 -VU90-60

6. INPUT RANGE $0-1.2$ IPS

7. DUTPUT RANGE 4-20MA

9. CMS SETPOINTS

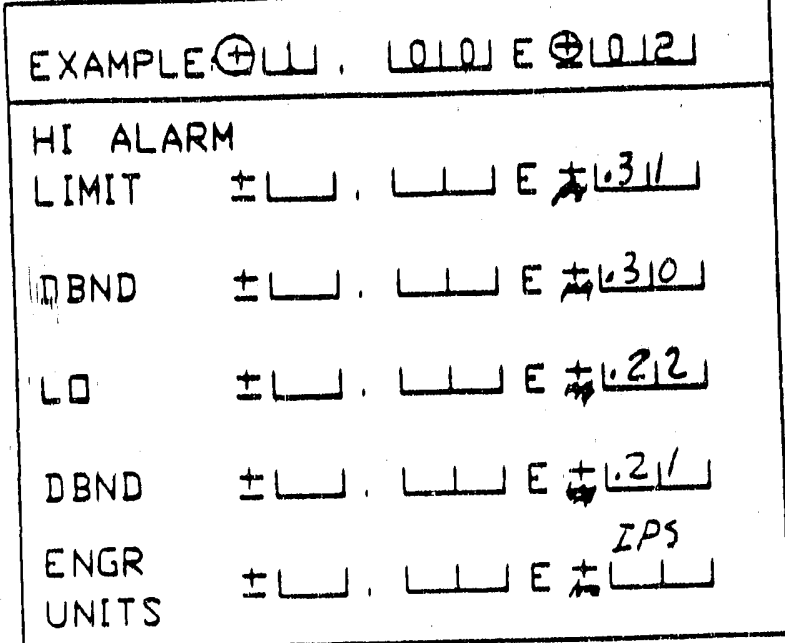

10. LOCAL SETPOINTS

\begin{tabular}{|c|c|}
\hline EXAMPI & 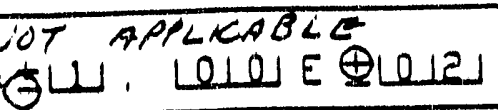 \\
\hline HI ALA & \\
\hline LIMIT & 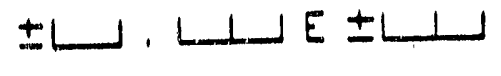 \\
\hline DBND & 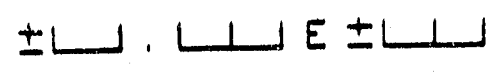 \\
\hline L & 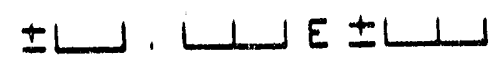 \\
\hline DBND & 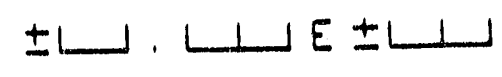 \\
\hline $\begin{array}{l}\text { ENGR } \\
\text { UNITS }\end{array}$ & $\pm ـ ـ ـ$ \\
\hline
\end{tabular}

11. MANUFACTURER METRIX LMSTRUMENT COO

12. SERIAL NUMBER

$N / A$

14. LOCATION DRAWING $54-w^{\prime}-608-\alpha^{\prime}$

16. DESIGN CLASS IILB

17. BLDG NUMBER $N / A$

19. ASSDCIATED PANEL IR SUBEQUIPMENT ND.

18. RODM NUMBER N/A 20. QSR/LCD EQUIPMENT YES - ND X FOR

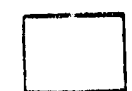

SAFETY CLASS

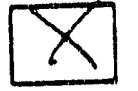

DPERATIONAL COMPLIANCE CLASS

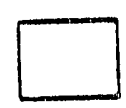

ENVIRLNMENTAL CIMPLIANCE

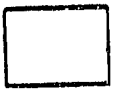

DTHER

CLASS

21. ELECTRICAL PQWER FRIM TBD

22. CAL./PM PROCEDURE NUMBER $N / A$

23. IF CHANGING INST, NUMBER, WHAT IS RELATED ECD NUMBER N/A 24. REMARKS: $N / A$

NUTE, DO NOT LEAVE ANY BLANKS. USE N/A IF IT NON APPLICABLE. REQUESTIR TOE DATE 2/37/9i 
CHANEE

1. INSTRUVENT NUMBER:4/3-YT-301- //C

2. SYS/SUBSYSTEM VYOI

3. DESCRIF:-IIN VIBRATION TRANSMITTER

4. LQOP N.MMBETR ZEZ 11

5. ECP NUMBER 2-VU90-60

6. INPUT FNANEE $0-1.0$ IPS 7. DUTPUT RANGE 4-20MA

9. ZMMS SETPOINTS

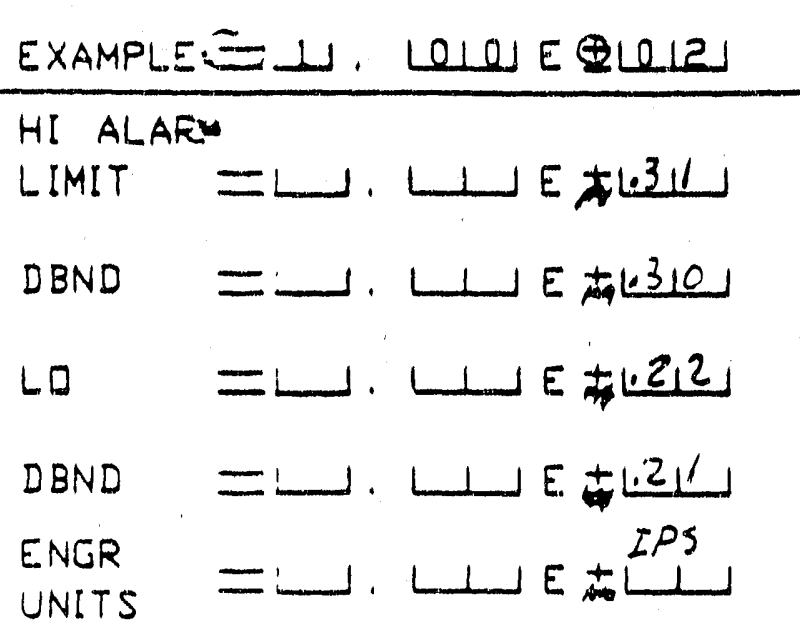

10. LICAL SETPOINTS

\begin{tabular}{|c|c|}
\hline \multicolumn{2}{|c|}{ 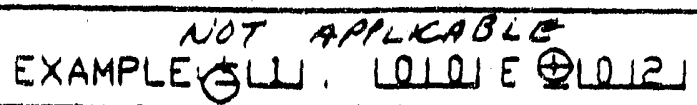 } \\
\hline \multicolumn{2}{|c|}{ HI ALARM } \\
\hline LIMIT & 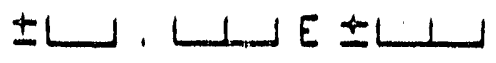 \\
\hline DBND & Iلـ \\
\hline LD & $\pm ـ ل$ J J J \\
\hline DBND & $\pm L ل$. J \\
\hline $\begin{array}{l}\text { ENTR } \\
\text { UNITS }\end{array}$ & $\pm L ـ ـ$ \\
\hline
\end{tabular}

11. MANUF -:-TURER METRIX INSTFUMENT L ${ }^{2}$

12. SERI- NLMBER $N / A$

14. LOCA- =N LRAWING $54-\omega^{\prime}-608-W$

16. DESIG. ILASS IILB

17. BLDG UJMBER $N / A$
13. MODF!. NUMBER $5484 C^{\circ}$

15. P\&ID DRAWING $41-A-C C 1-W$

18. ROOM NUMBER N/A

19. ASSDE:-TED PANEL QR SUBEQUIPMENT NO TRD 20. OSR/LCD EQUIPMENT YES - ND X FUR

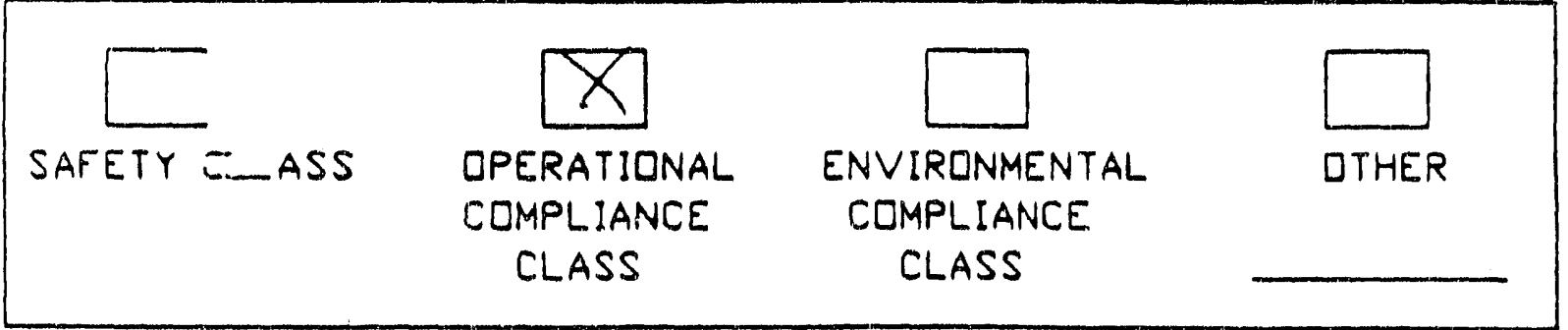

21. ELEC-T::DAL POWER FROM HTP TBD

22. CAL. $=U$. PROCEDURE NUMBER N/A

23. IF C-MUGING INST, NUMBER, WHAT IS RELATED ECQ NUMBER N/A

24. REMÁ: : : $N / A$

NQTE: IE NOT LEAVE ANY BLANKS. USE N/A IF IT NON APPLICABLE. =:-IUESTOR JOE HAFT DATE $2 / 37 / 9 ;$ 
'

1. INSTRUMENT NUMBER: $413-Y T-307-11 D$

2. SYS/SUBSYSTEM YUWI

3. DESCRIPTIONI VIBRATION TRANSMITTER

4. LUDP NUMBER $\neq 0 \approx 11$

5. ECP NUMBER 2-VU90-60

6. INPUT RANGE $0-1.0$ IPS

7. DUTPUT RANGE 4-20MA

9. CMS SETPOINTS

\begin{tabular}{|c|c|}
\hline \multicolumn{2}{|c|}{ EXAMPLEAUL, LOLU E } \\
\hline \multicolumn{2}{|c|}{ HI ALARM } \\
\hline LIMIT & 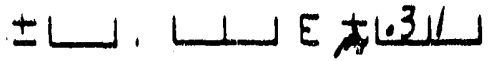 \\
\hline DBND & $\pm \amalg, L \perp E \pm 1$. \\
\hline LD & $\pm \amalg \cdot L \perp E \pm 2,12$ \\
\hline DBND & 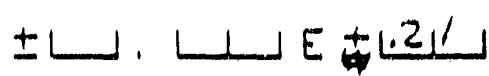 \\
\hline $\begin{array}{l}\text { ENGR } \\
\text { UNITS }\end{array}$ & $\pm{ }^{\prime},{ }^{I P S}$ \\
\hline
\end{tabular}

10. LICAL SETPINTS

\begin{tabular}{|c|c|}
\hline EXAMP & 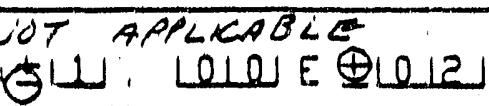 \\
\hline HI AL & \\
\hline LIMIT & 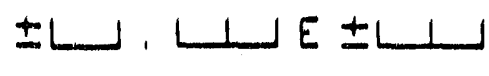 \\
\hline DBND & 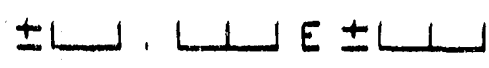 \\
\hline L & 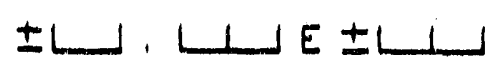 \\
\hline DBND & $\pm \amalg . \sqcup$ ل \\
\hline $\begin{array}{l}\text { ENGR } \\
\text { UNITS }\end{array}$ & $\pm ـ ـ ـ ـ$ \\
\hline
\end{tabular}

11. MANUFACTURER METRIX INSTRUMENT CO

12. SERIAL NUMBER $N / A$

14. LQCATIION DRAWING $54-\omega^{\prime}-608-\omega$

16. DESIGN CLASS IITB

17. BLDG NUMBER $N / A$
13. MODEL NUMBER $5484 \mathrm{C}$

15. P\&ID DRAWING $4=A-001-W$

18. ROQM NUMBER N/A

19. ASSICIATED PANEL QR SUBEQUIPMENT ND. TBD 20. OSR/LCQ EQUIPMENT YES _ NO X FOR

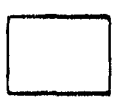

SAFETY CLASS

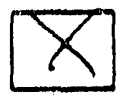

DPERATIONAL COMPLIANCE

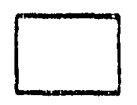

ENVIRDNMENTAL COMPLIANCE

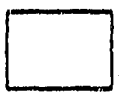

DTHER

$$
\text { CLASS CLASS }
$$

21. ELECTRICAL POWER FROM HPOPOSE TBO

22. CAL./PM PROCEDURE NUMBER $N / A$

23. IF CHANGING INST, NUMBER. WHAT IS RELATED ECD NUMBER N/A

24. REMARKS: $N / A$

NQTE, DO NOT LEAVE ANY BLANKS, USE N/A IF IT NON APPLICABLE. REQUESTOR JOE HART DATE2/37/9 


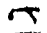

घ CHANGE

1. INSTRUMENT NUMBER:413-YT-307-11E

2. SYS/SUBSYSTEM VUOI

3. DESCRIPTIJNI VIBRACION TRANSMITTER

4. LDLP NUMBER 11

5. ECP NUMBER 2-VU9O-60

6. INPUT RANGE $0-1,0$ IPS

7. DUTPUT RANGE 4-20 MA

9. CMS SETPQINTS

\begin{tabular}{|c|c|}
\hline \multicolumn{2}{|c|}{ EXAMPLE®Uل, } \\
\hline \multicolumn{2}{|c|}{ HI ALARM } \\
\hline LIMIT & 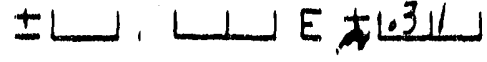 \\
\hline DBND & 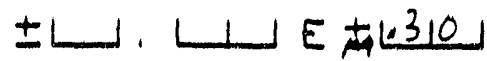 \\
\hline LQ & 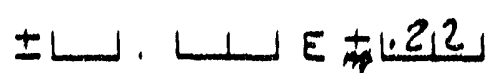 \\
\hline DBND & $\pm \amalg$. \\
\hline $\begin{array}{l}\text { ENGR } \\
\text { UNITS }\end{array}$ & $\pm L \cdot L$ \\
\hline
\end{tabular}

10. LICAL SETPOINTS

\begin{tabular}{|c|c|}
\hline \multicolumn{2}{|c|}{ 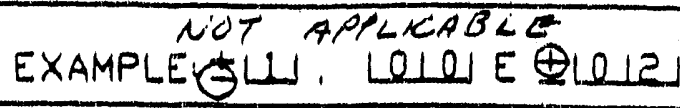 } \\
\hline \multicolumn{2}{|c|}{ HI ALARM } \\
\hline LIMIT' & 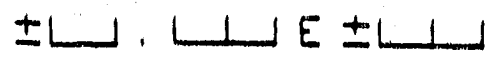 \\
\hline DBND & 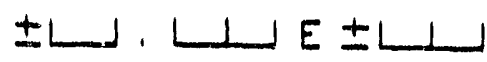 \\
\hline LQ & 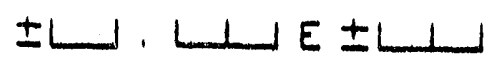 \\
\hline DBND & لس \\
\hline $\begin{array}{l}\text { ENGR } \\
\text { UNITS }\end{array}$ & J \\
\hline
\end{tabular}

11. MANUFACTURER METRIX LASTFUMENT L'O

12. SERIAL NUMBER $N / A$

14. LICATION DRAWING $54-\mu^{\prime}-\cos -\mu^{\prime}$

16. DESIGN CLASS $\mathbb{Z L B}$

17. BLDG NUMBER $N / A$
13. MODEL NUMBER $5 \neq 84 \mathrm{C}$

15. P\&ID DRAWING $4 /-A-C C 1-W$

18. ROQM NUMBER N/A

19. ASSUCIATED PANEL DR SUBEQUIPMENT NO. TBD 20. OSR/LCD EQUIPMENT YTS - NO X FOR<smiles>C1CCC1</smiles>

SAFETY CLASS

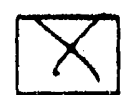

DPERATIONAL COMPLIANCE

CLASS

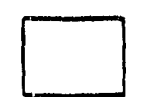

ENVIRONMENTAL CDMPLIANCE

21. ELECTRICAL PUWER FROM TBD

2.). CAL./PM PROCEDURE NUMBER $N / A$

23. IF CHANGING INST, NUMBER, WHAT IS RELATED ECO NUMBER N/A 24. REMARKS: $N / A$

NOTE, DO NOT LEAVE ANY BLANKS, USE N/A IF IT NON APPLICABLE. REQUESTOR JOE HAST DATE $2 / 37 / 91$ 
NHEN FILTRATION MOD: IS INITIAIE'D BY CAM SIGNAL, THE FOLLO'NING IVENTS OCCUR:

a) ISOLATION DAMPERS HD- JO1A, HD-0018, HD-002A, AND HD-002B CLOSE. TME TWO IS DLATION DAMPERS HD-OO3A AND HD-0O3B ARE NORMALLLY CLC:SED.

1) $41-B-700 A$. NO/OR 41-9-700B STOP,

¿) OF THE FANS 860-A, 860-6, OR 860-C WILL START AUTOMATCALLY.

1) ISOLATION DAMPERS AT THE INLET AND OUTLET OF HEPA FILTER UNITS OPENS DNERTING EXHAUST AIR THROUGH THE FILTERS.

IN LOSS OF OFFSITE FOWER, ALL FANS STOP, ONLY ONE OF THE THREE ANS 860-A, 860-B, (R 860-C CAN BE STARTED MANUALLY AFTER THE MERGENCY DIESEL GENERATOR IS IN OPERATION. THE SYSTEM WILL PERATE IN THE FILTRAIION MODE DURING LIOSS OF OFFSITE POWER.

L FANS CAN BE STAFTED OR STOPPED, EITHER FROM THE LOCAL PANEL 1 THE EXHAUST FILTER BUILDING. BOTH FANS $41-B-700 A$ \& $B$ CAN E STOPPED ONLY FROA THE CMR BUT NOT STARTED.

TATUS OF BUTTERFLY 'IALVES HD-001A, HD-001日, HD-002A, VD HD-002B ARE MOHITORED FROM THE LOCAL PANEL AND THE CMR.

JTERFACE IS SHOWN OV ELECTRICAL SCHEME 41-J-404-348.

SL-10, FSL-11, AND, SL-12 SHALL BE LOCATED IN 413LP30701K. SL-10, FSL-11, AND I:SL $\cdots 12$ AND EXISTING FAL-10, FAL-11, AND $A L-12$ IN $413 L P 05601$.

IAMPERS HD-003A, HO-003日 ARE NORMALLLY CLOSED, OPEN ONLY WHEN "ANS 41-B-700A AND 41-B-700B ARE OUT OF SERVICE, AND FILTRATION IODE IS TO BE EYPASSED. THEREFORE USE OF FANS $41-B-860 A$, $1-8-8608$, OR 41-8-860C ARE ACCESSED DIRECTLY THROUGH OUTLET ENUM, FILTER BYPASSED AND USED FOR U/G VENTILATION.

RESSURE CONTROL -WASTE HOIST TOWER

IT 201-101 IS USED "O MONITOR ANO CONTROL W.H.T. PRESSURE NEG (TNE) BY CONTROLLING EXHAUST FOR 41-B-700-A OR B

, WG YOU HAVE WN ALARM IN CMR

.50 IN WG ONE(1) 706 U/G FAN WILL SHUT DOWN

.75 IN WG BOTH 700 J/G FANS WILL SHUT DOWN

IRAWINGS SUPERCEDED PER ECO 4229:

$41-F-056-0.9$

$41-F-307-3 \cdot .8$

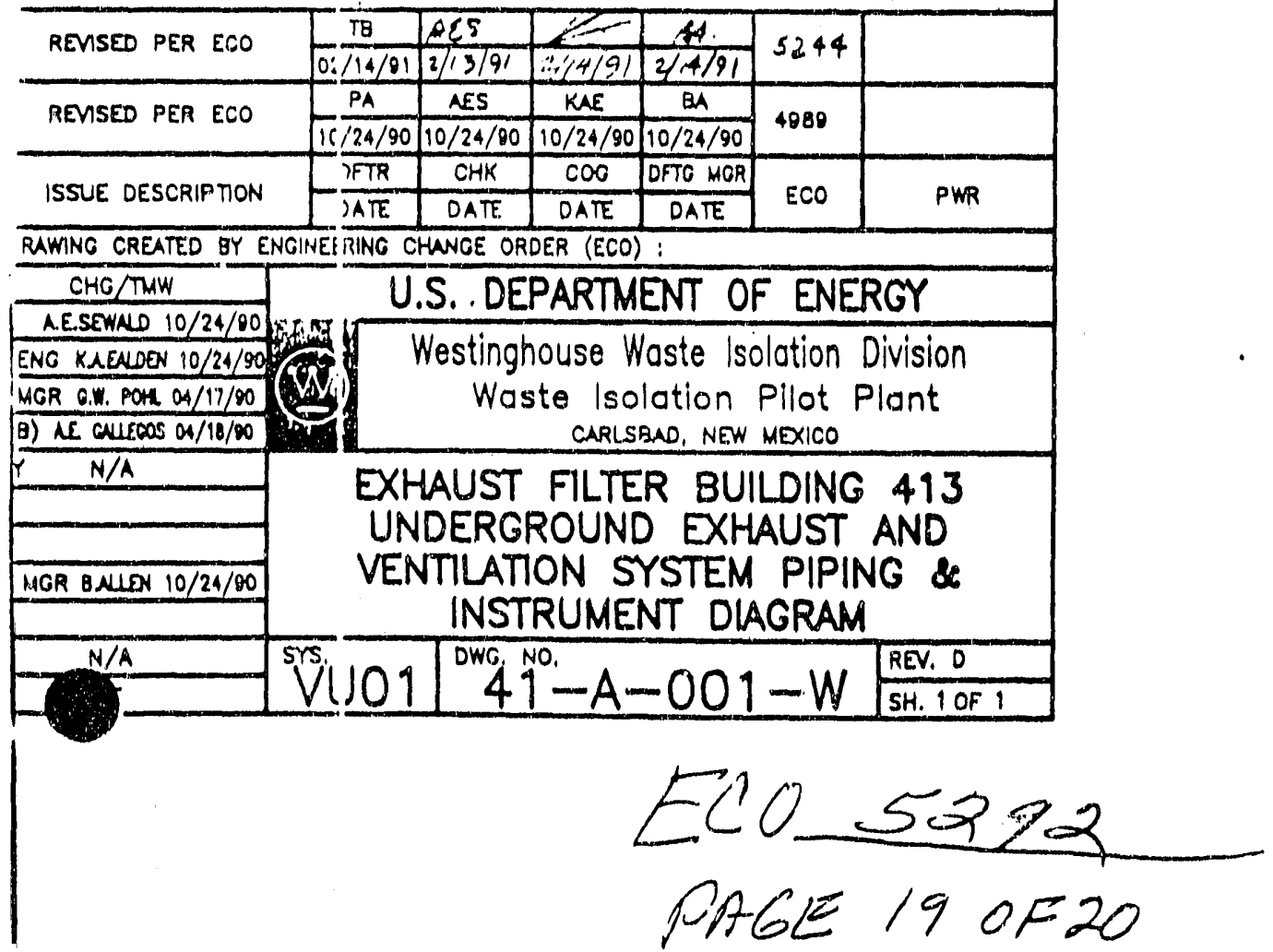




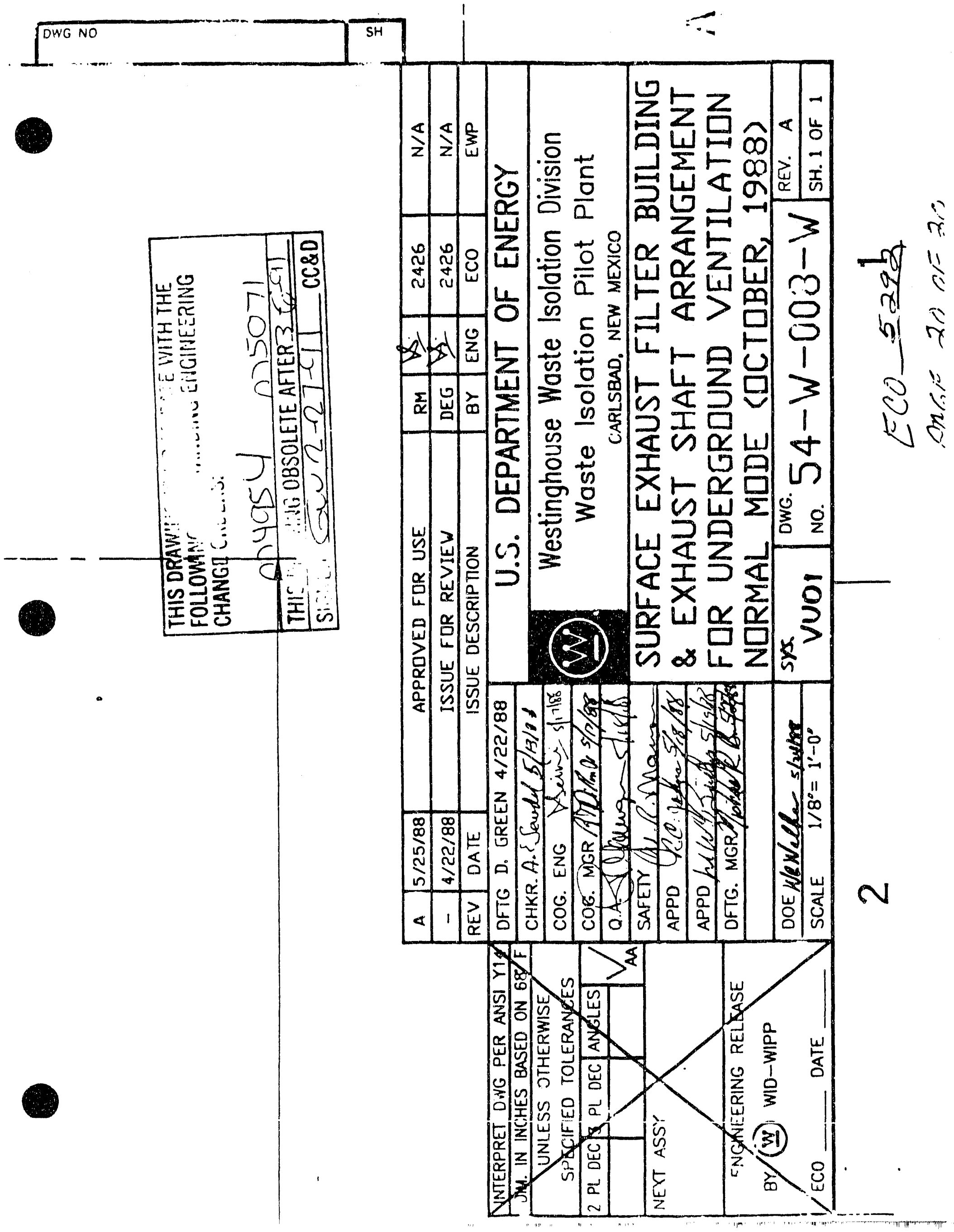


REDUCE THE COST AND COMPLEXITY
OF VIBRATION MONITORING WITH
THESE TWO WIRE, LOOP POWERED
VIBRATION TRANSMITTERS.

Two models are available. The Model $5484 \mathrm{C}$ is the non-indic. ing version and can be supplied with a screw cover elbow fitting for connecting field wiring. The Model $5491 B$ is the indicating version and comes with an integral $2 \frac{1 / 2}{2}$ digit LCD indicator for local vibration readout.

Simply mount the transmitter into a single tapped hole in the machine case, connect its two wires into a 4-20 ma current !nop, and it will transmit the machine's vibration level io your milliamp monitor, data logger or computer.

Employing no moving parts, the basic iransmitter is all solid state and epoxy encapsulated in a zinc plated steel housing. The LCD indicator is packaged in a sealed module that can be positioned in y0 increments within the elbow fitting to allow proper viewing when the transmitter is installed.

Both units are weatherproof and suitable for use in hazardous locations. Each transmitter is factory calibrated to the nameplate sensitivity. However, when necessary, the span control can be field adjusted.
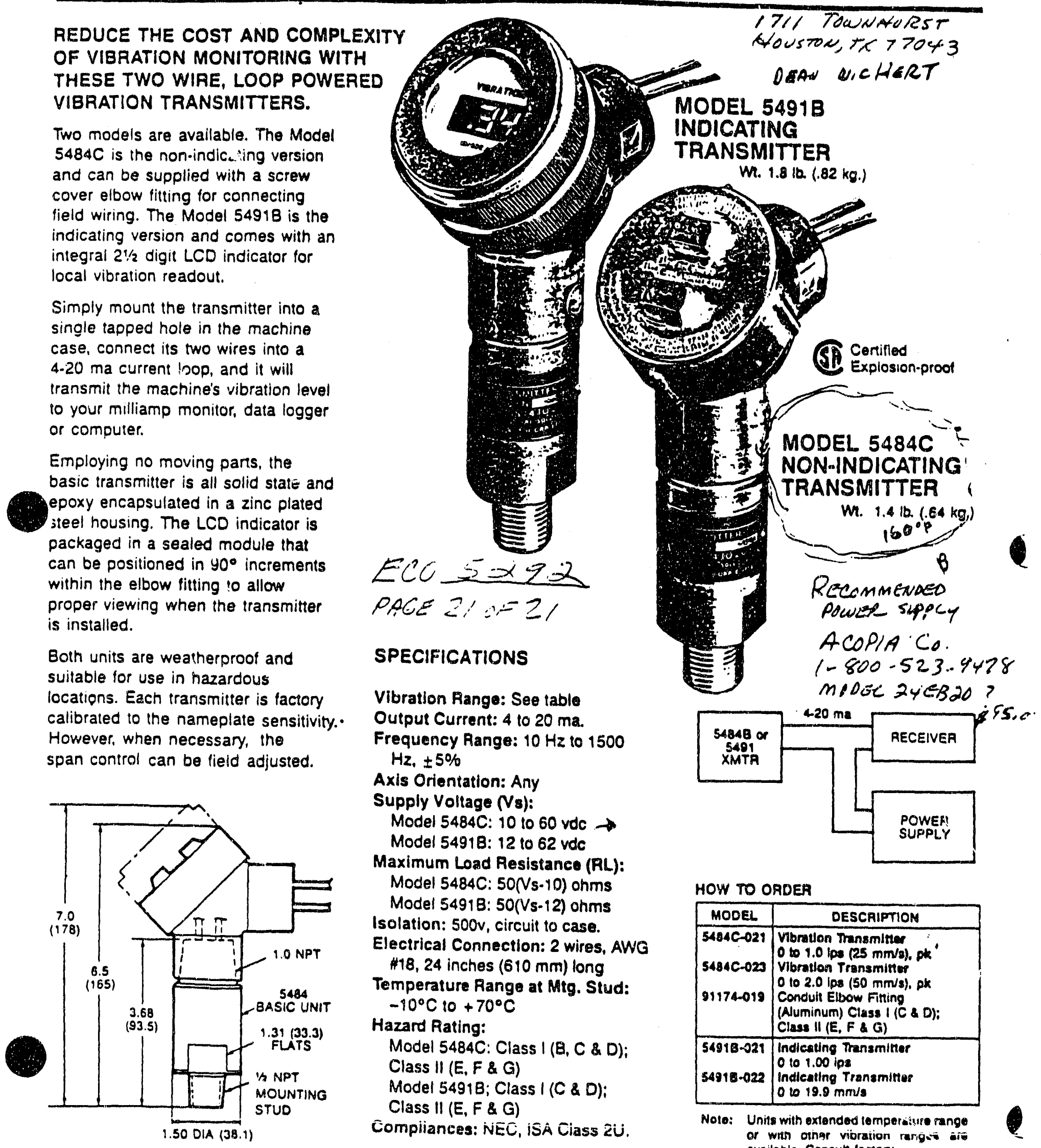

Maximum Load Resistance (RL): Model 5484C: 50(Vs-10) ohms Model 5491B: 50(Vs-12) ohms Isolation: 500v, circuit to case.

Electrical Connection: 2 wires, AWG $\$ 18,24$ inches $(610 \mathrm{~mm})$ long

Temperature Range at Mig. Stud: $-10^{\circ} \mathrm{C} 10+70^{\circ} \mathrm{C}$

Hazard Rating: Model 5484C: Class I (B, C \& D); Class II (E. F \& G)

Model 5491B; Class I (C \& D); Class II (E, F \& G)

Compiiances: NEC, ISA Ciass Żi.

HOW TO ORDER

\begin{tabular}{|c|c|}
\hline MODEL & DESCAIPTION \\
\hline $\begin{array}{l}5404 C-021 \\
5484 C-023 \\
91174-019\end{array}$ & $\begin{array}{l}\text { Vibratlon Transmitte } \\
0 \text { to } 1.0 \text { los }(25 \mathrm{~mm} / \mathrm{s}) \text {, pk } \\
\text { Vibratlon Transmitter } \\
0 \text { to } 2.0 \text { (ps (50 mm/s), pk } \\
\text { Conduit Elbow Fitting } \\
\text { (Aluminum) Class ( (C \& D): } \\
\text { Class II (E, F \& G) }\end{array}$ \\
\hline $\begin{array}{l}54918-021 \\
54918-022\end{array}$ & $\begin{array}{l}\text { Indleating Transminter } \\
0 \text { to } 1.00 \text { ips } \\
\text { indleatling Transmittur } \\
0 \text { to } 19.9 \mathrm{~mm} / \mathrm{s}\end{array}$ \\
\hline
\end{tabular}

Noto: Units with extended temperciure range or whis oinar vioration rarigso aio available. Consult factory. 
1. ECO No.: $\leqq .27 \neq$

$5 K C C \& D$ Review: $E \mathcal{L}$

\begin{tabular}{|l|l|}
\hline \multirow{4}{*}{ Initials } & 2. Impact Lovel $1 \square \quad 2 \square$ \\
\cline { 2 - 3 } Posted & 3. System: CFO 2 Equipment No.: \\
4. Associated Documents: \\
PWR R-O/ 33 \\
ECP \\
P.O. \\
Others
\end{tabular}

$4 \square$

5. Document Type:

Drawing $110 \times 7-5$ Specification

Vendor Data

SDD

Others

6. Title of Change: liaste laudiers flfice-relocation

7. Originator: (print) " Ext. No.: Department: Date: J. Kovialsie

9. Description of Chango: PIET M\&C.E.

8. Cognizant Engineer: (print) J. Kowals is.
9. Yos No/ Component indices change required (if yes, attach sheets)

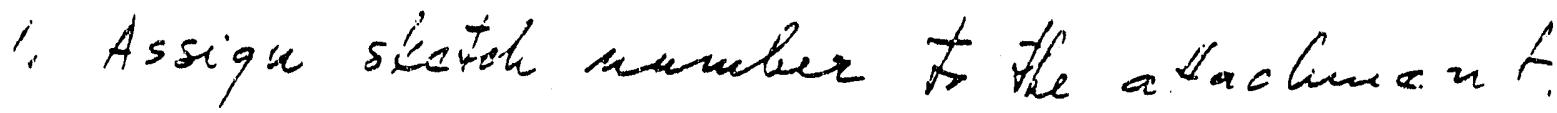

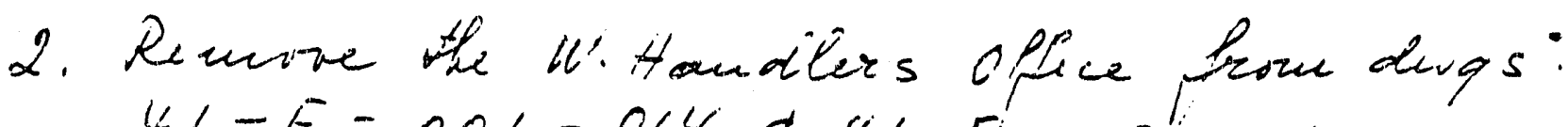
$41-E-001-014 \notin 41-E^{\prime}-003-014$

3. Slun relocated offices ou dugs. 41-E-600-021

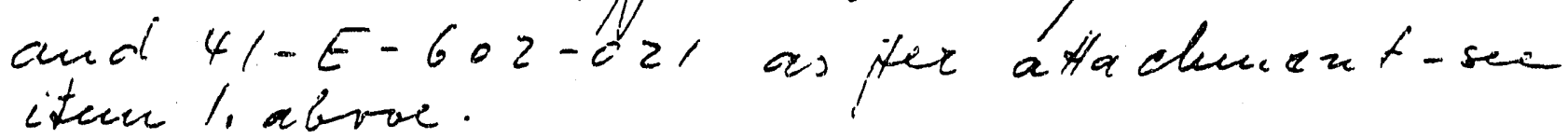

Ya Drawing Change Sheet attached $\quad \square$ 9c Vendor Data Change Sheet attached 9b Design Documentation Sheet attached

10. Yes No

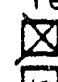
MOOIFICATION IN PROGRESS/
Modification complete:

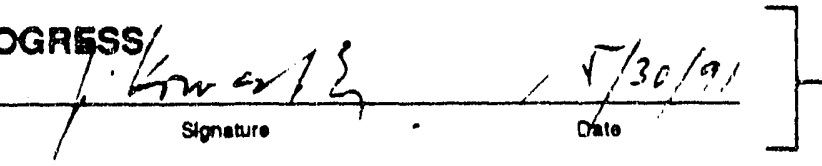
ECO will be
E
Modicalion complote:

uilt markup dated:

Change drawing per ECO-provided data

Temporary modification

11. Design Verification Requirements: (per WP 09-018)

EDT No:

Wramhat to 25.CAll 1. Requirements satisfied by review/approval of design document

2. Independent review

3. Altemate calculations

4. Development testing

5. Design review

6. Other:

12. Addendum Sheat addod:

6. Other:




\section{Justification}

White Handiers offices tiane to he nureol

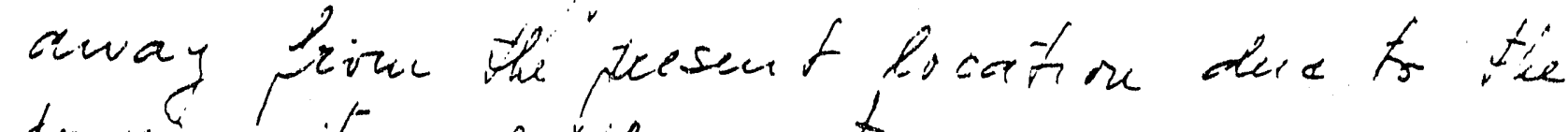
troxiunty os the wastio

\section{Administra!lve Tracking}

$\begin{array}{lllll}\text { YES N/A } & & \text { YES NA } & \\ \square & \text { 1. FSAR } & \square \square & \text { 6. Startup/Acceptance Test } \\ \square \bigotimes & \text { 2. Calibration Procedures } & \square \square & \text { 7. Test Requirement \& Spec. } \\ \square \bigotimes & \text { 3. Maintenance Procedures } & \square \square & \text { 8. } \\ \square \bigotimes & \text { 4. Computer Software } & \square \square & 9 . \\ \square & \text { 5. Operations Procedures } & \square \square & 10.2\end{array}$

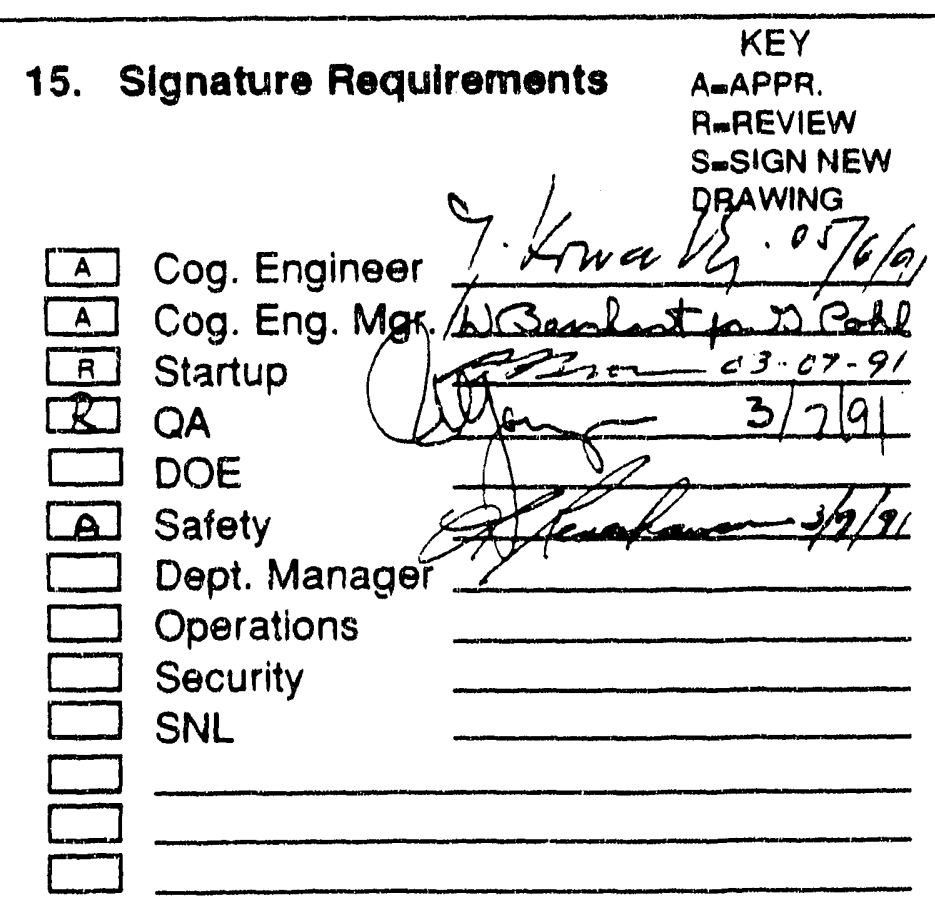

16. Distribute as Marked 
1. Drawing: $141-E-001-014$

2. ECO Search List: $\not 4 \alpha 2 \geqslant(M)$

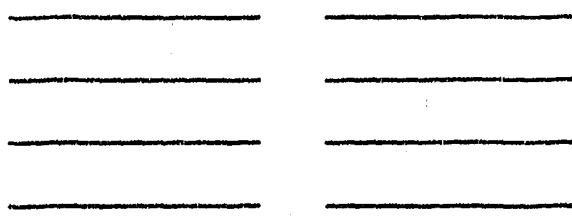

ECO Number: 5294

3. Description of Change:

Reurve the waite Handlers Office.

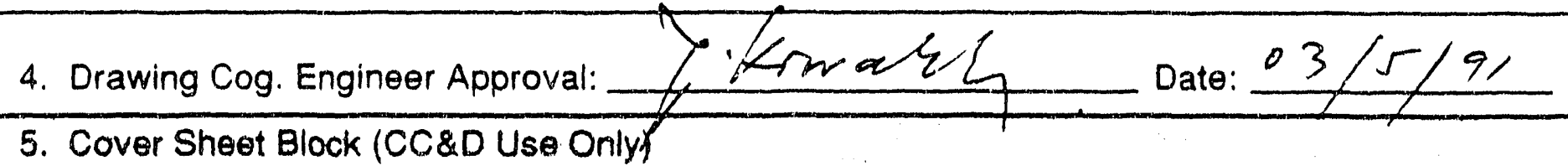

Received from EFR:

Date Assigned:

Initials / Date

Initials / Dato

Assigned to:
Dratting Started:

Inipials / Date

Drafting Completed:

Return to EFF:
Initials / Date

Initials / Date 
9a

DRAWING CHANGE SHEET

(1 SHEET PER DRAWING)

1. Drawing: $\quad 41-5-003-014$

ECO Number: 5294

2. ECO Search List: $41,2.2(n)$
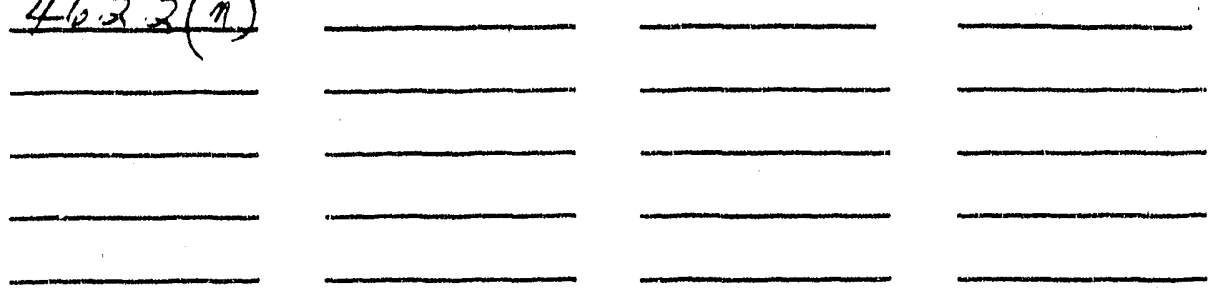

3. Description of Change:

Reur ove ithe Warte thandlers iffice

4. Drawing Cog. Engineer Approval:

t. Hur a 18

Date: $03 / 6 / 9 /$

5. Cover Sheet Block (CC\&D Use Only)

Received from EFR:

Initials / Date

Date Assigned:

Initials / Date

Assigned to:

(Same as data base entry)

Drafting Started:

Drafting Completed:

Return to EFF:

Iniflals / Date

Initials / Dato

Initials / Date 
$9 a$

DRAWING CHANGE SHEET

$\operatorname{pg} 5$ of?

(1 SHEET PER DRAWING)

1. Drawing: $41-E-600-021$ ECO Number: 5294

2. ECO Search List: NONE

3. Description of Change:

show haste Handlers office in location as per stets" no

4. Drawing Cog. Engineer Approval:

Date: $03 / 6 / 9$

5. Cover Sheet Block (CC\&D Use Only)

Received from EFR:

Date Assigned:

Assigned to:
Drafting Started:

Drafting Completed:

Initials / Date

Initials / Date

Return to EFF:

Initials / Date

(Same as data base entry)

1290:B0006

WP Form 2017; 12/29/90

Page 1 of 1 
$9 \mathbf{a}$

DRAWING CHANGE SHEET

$\log 6$ of $?$

(1 SHEET PER DRAWING)

1. Drawing: $41-E^{-}-602-021$ ECO Number: 5.294

2. ECO Search List: slave

3. Description of Change:

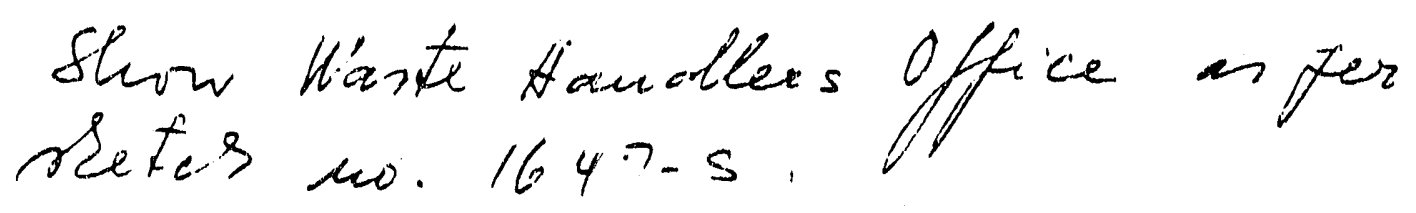

4. Drawing Cog. Engineer Approval:

Date: $03 / 6 / 91$

5. Cover Sheet Block (CC\&D Use Only)

Received from EFR:

Date Assigned:

Assigned to:
Drafting Started:

Drafting Completed:

Initials / Date

Initials / Date

Return to EFA:

Initials / Date

WP Form 2017; 12/29/90

1290:B0006

Page 1 of 1 


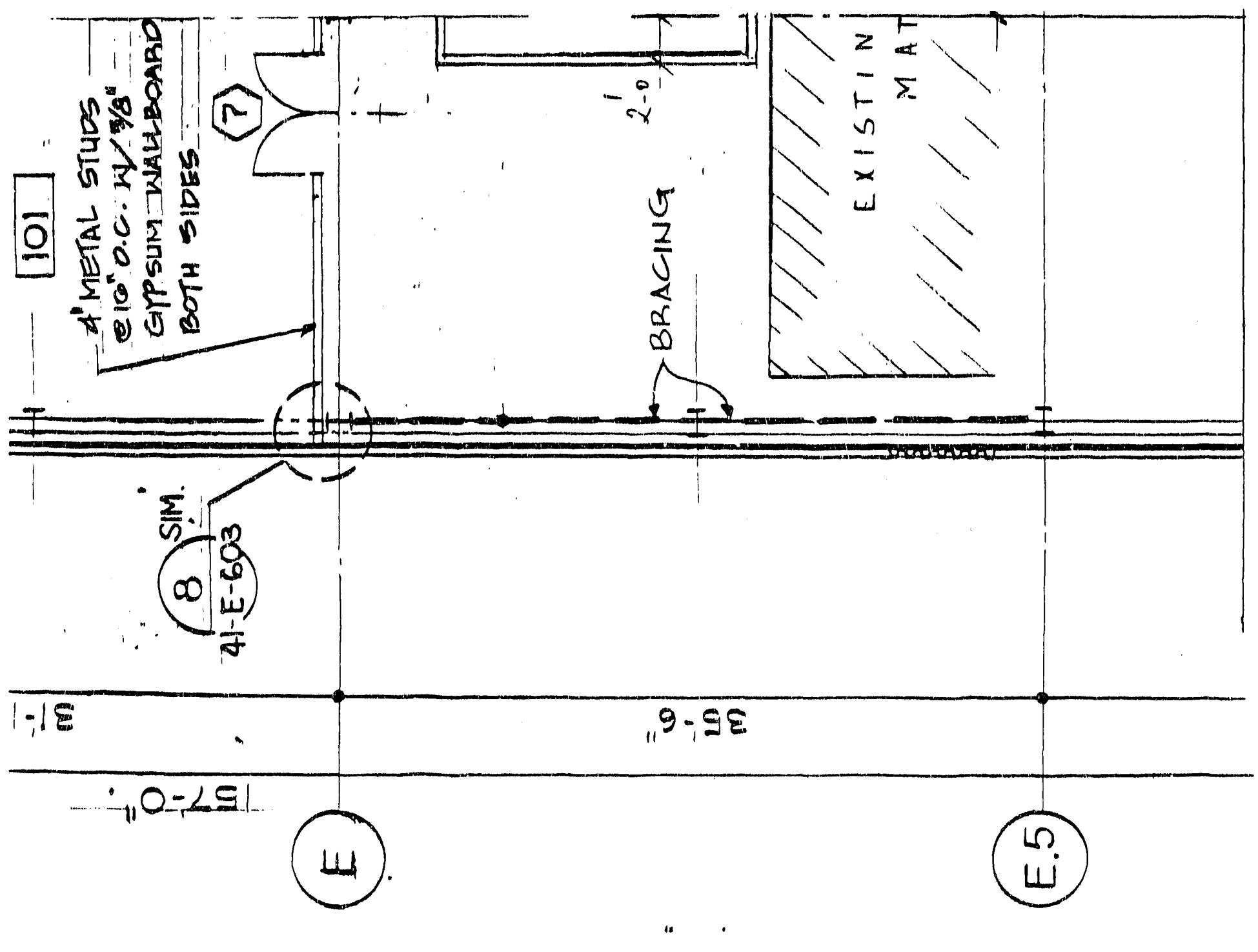

un

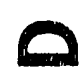


-1 : WHB HST TWR-EL SLBS PLNS AT EL, 18506 \&

\begin{tabular}{|c|c|c|c|c|c|c|c|c|}
\hline & \multirow{2}{*}{$F$} & \multirow{2}{*}{ REVISEDI:RECO } & $T 13$ & 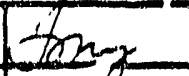 & seTiC & $B H$ & \multirow{2}{*}{5294} & \multirow{2}{*}{$1,15.5:$} \\
\hline & & & 11111 & $01 / 04192$ & $6111,: 109$ & $1 / 141112$ & & \\
\hline & \multirow{2}{*}{$E$} & \multirow{2}{*}{ REVISED PLR ECO } & $T<$ & {$[: 1$} & $T+11$ & 2 & & \\
\hline & & & $\therefore \quad \therefore$ & &. & & & \\
\hline \multirow{2}{*}{ CFSO } & \multirow[b]{2}{*}{ RSEV } & \multirow[b]{2}{*}{ ISSUE DESCRIPTION } & DFTR & $\mathrm{CHK}$ & $\operatorname{COG}$ & DTTG MGR & \multirow{2}{*}{ ECO } & \multirow[b]{2}{*}{ PWR } \\
\hline & & & DATE & DATE & DATE & DATE & & \\
\hline
\end{tabular}

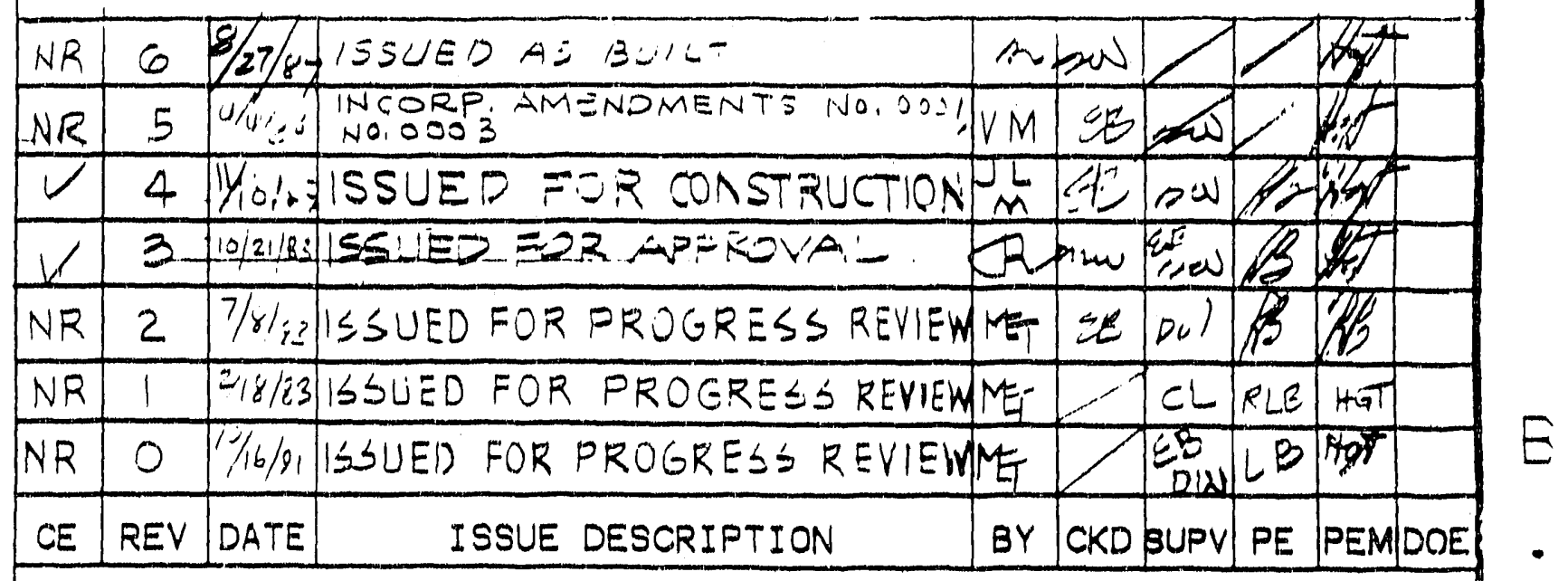

\section{U. S. DEPARTMENT OF ENERGY WASTE ISOLATION PILOT PLANT}

SYSTEM CFO2 GCO2

\section{BECHTEL}

SAN FRANCISCO

WASTE HANDL ING BUILDING NO.411

ARCHITECTURAL

GENERAL KEY PLANS

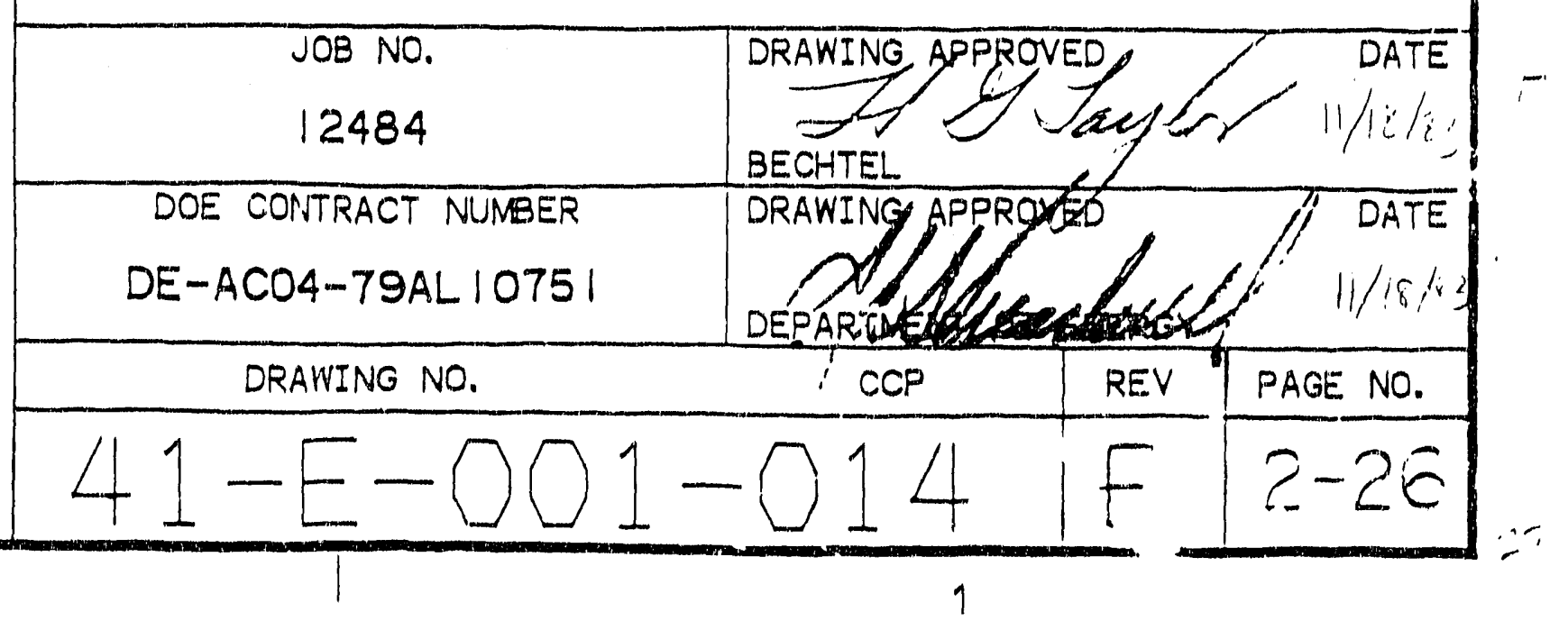




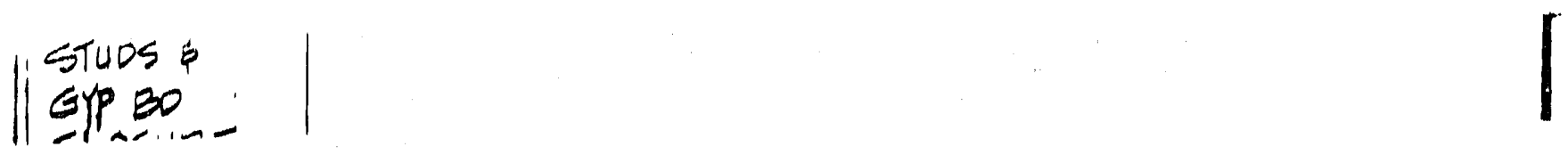

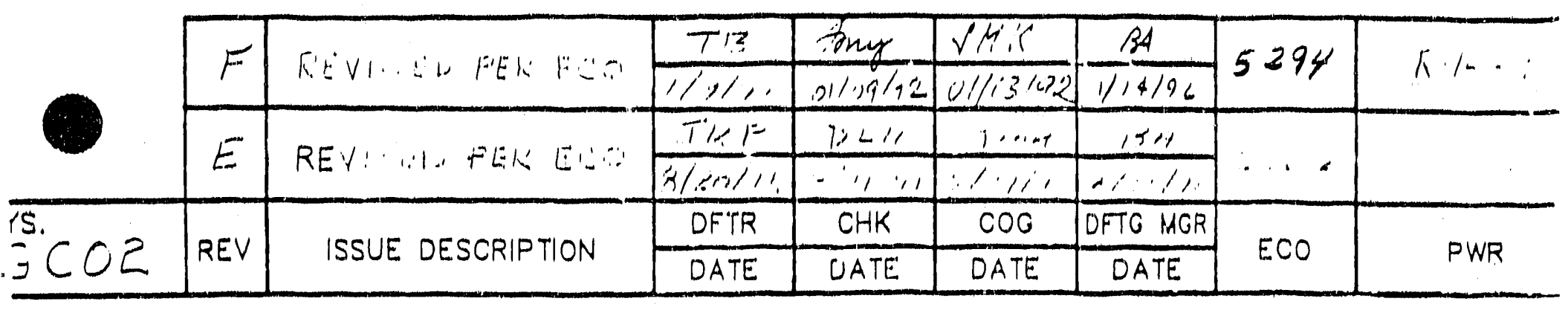

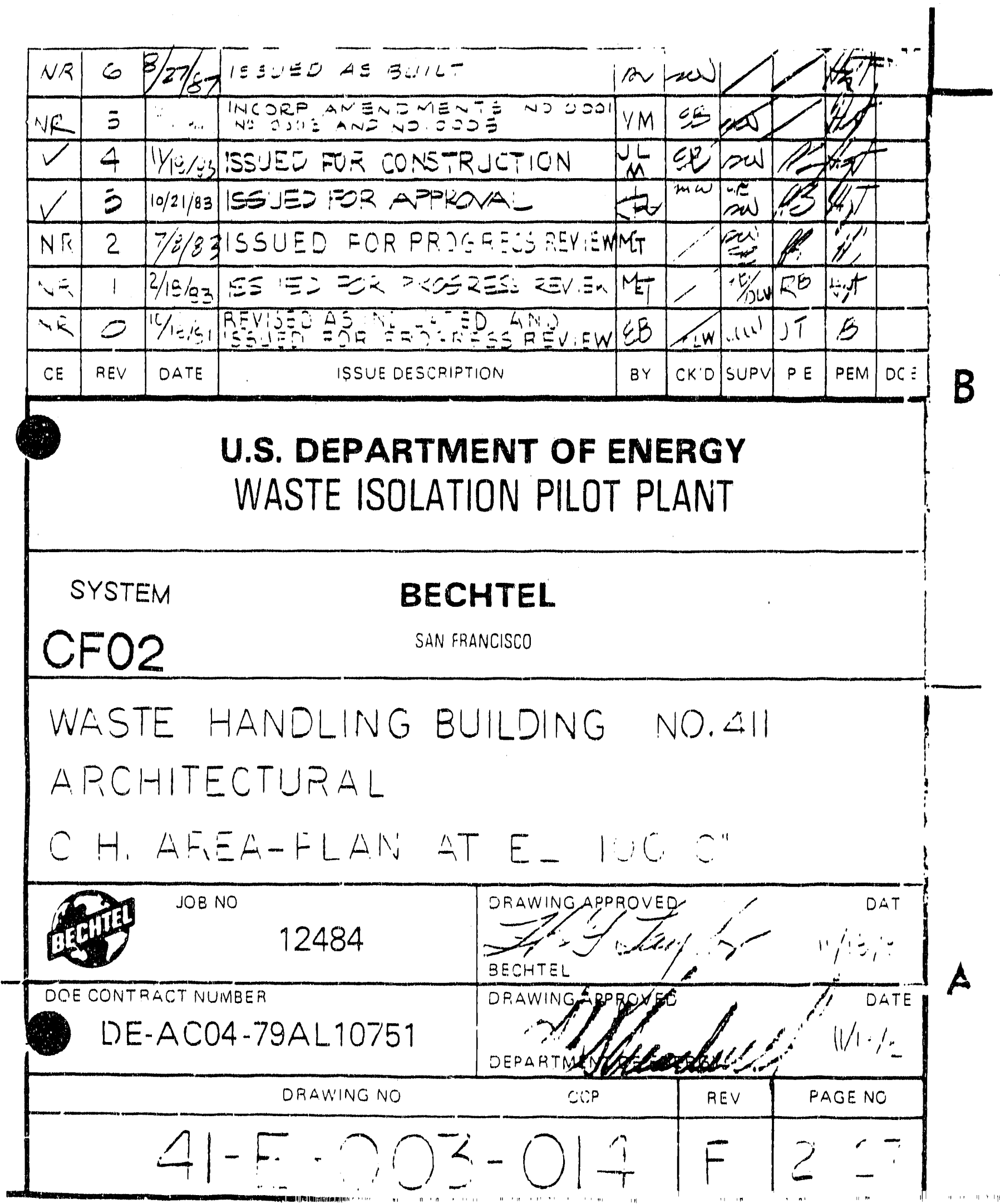




\section{ENGINEERING CHANGE ORDER}

USE BLACK INK

Page 1 of 3

1. ECO No.: 5.298

TCC\&D Review: $2 \mathcal{L}$

\begin{tabular}{|l|l|}
\hline & 2 \\
\cline { 2 - 2 } & 3 \\
\hline Posted & 4
\end{tabular}

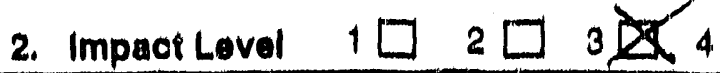

3. Syatem: $A \cup O L$ Equipment No:

4. Associated Doouments:

PWR 10605

ECP

P.O.

Others

NLA Bullding: $U / 6$

\section{Document Type:}

Drawing $S /-w-1,-w-w$

Specificallon

Vendor Data

SDD

Others

6. Title of Change: CIR13 iNjTALLATLW AT EXP. LUدMJ

7. Originator: (print)

Ext. No.: Department:

Date:

8. Cognizant Engineer: (print)

J. GON $=4 \operatorname{coc}$

MIN CANG $3 / 7 / 4$

3. Gon IAUEL

9. Deseription of Change:

Yes No component indises change required

(if yes, attach sheots)

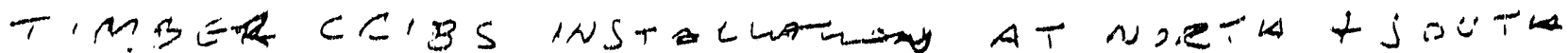

ENJS OF CHPCR:MEW:A KOAMJA2,A3+is

9a Drawing Change Sheet attached

9c Vendor Data Change Sheet attached

3b Design Dooumentation Sheet attached

10. Yes No
¿ MODIFICATION IN PROGRESS
Modification complete:
ECO will be
incorporated after
M.I.P. signed complete

$\square \quad$ Change drawing per as-bullt markup dated:

Change drawing per ECO-provided data

Temporary modification

11. Design Veriflcation Requirements: (per WP 09-018)

EDT No:

S.

1. Fequirements satisfied by review/approval of design dooument

2. Independent review

3. Alterriate calculations

4. Development testing

5. Design reviaw

6. Other:

12. Addendum Sheet added: 


\section{Justification}

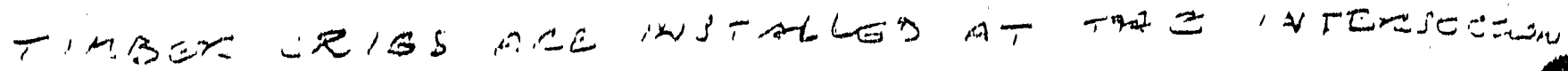

O R⿴囗十丁:A

$\because \rightarrow=r$ -

\section{Administratlve Tracking}

YES N/A

1. FSAR

$\square \square$ 2. Calibration Procedures

$\square$ 3. Maintenance Procedures

$\square$

4. Computer Sottware

$\square \square$

5. Operations Procedures

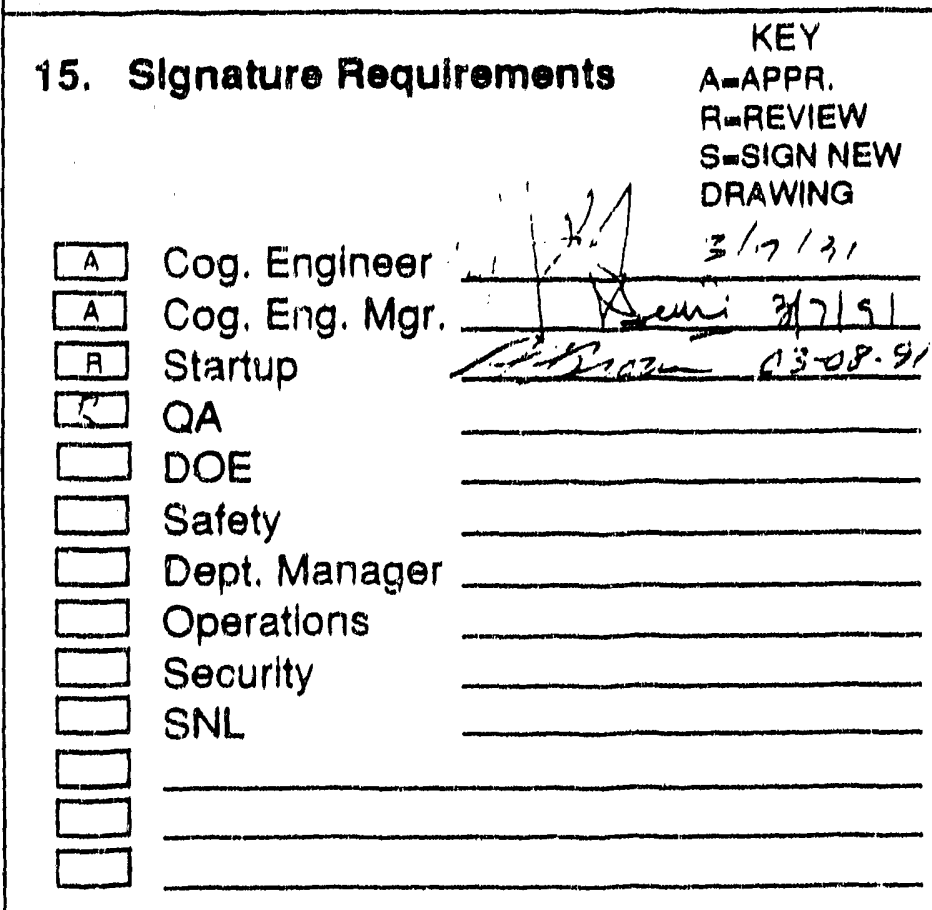

\section{Distribute as Marked}


$9 a$

(1 SHEET PER DRAWING)
1. Drawing:
S1-.w-10=-w REVA

ECO Number:

5299

2. ECO Search List: NONE
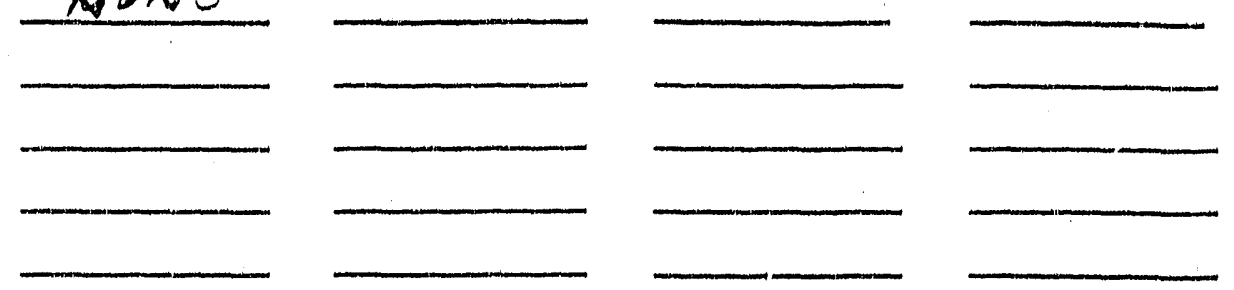

3. Description of Change:

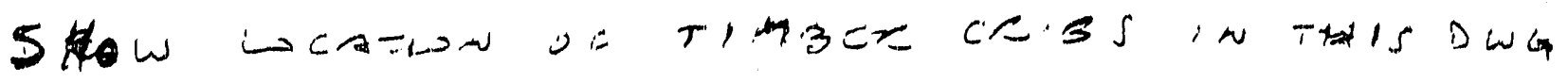

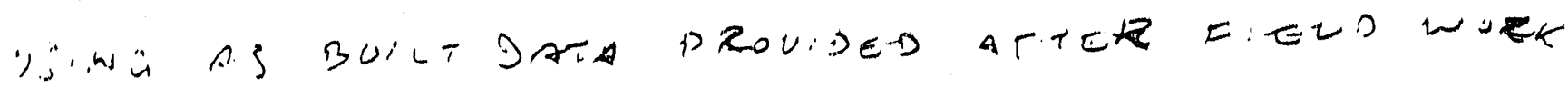

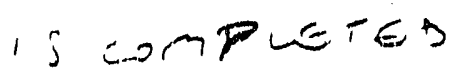

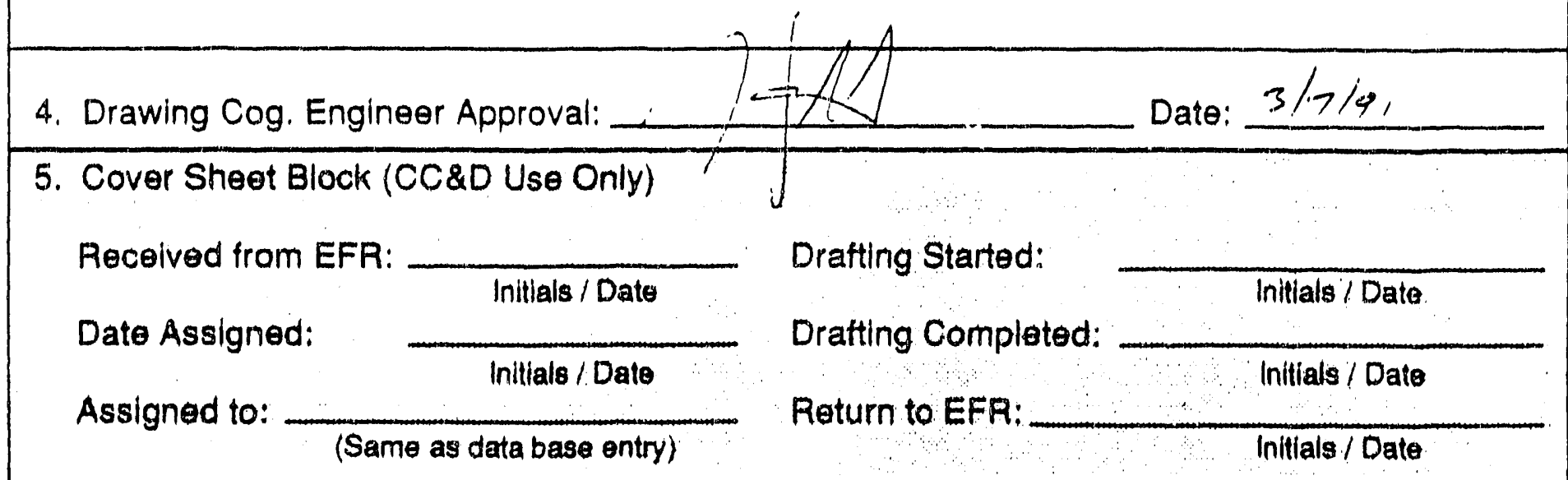


ENGINEERING CHANGE ORDER

USE BLACK INK

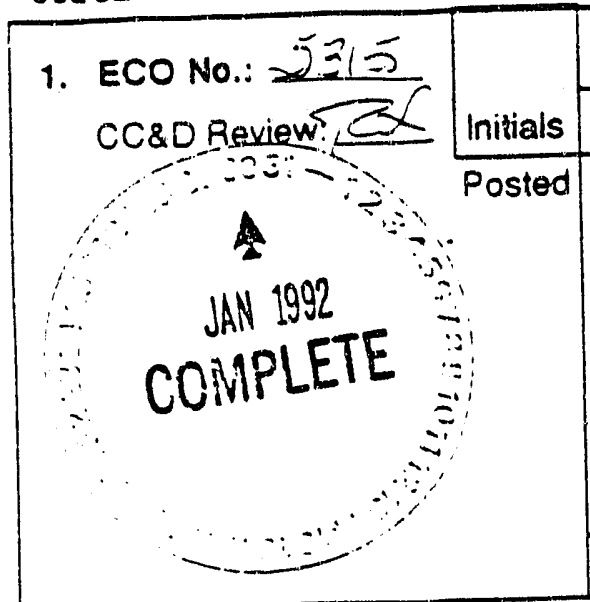

2. Impact Level $1 \square \quad 2 \square \quad 3 \square 4$

4.

3. System: $1 / 40$ Equipment No: $1 / \%$ Building: $6 / 5$

4. Associated Documents:

PW R Ci4i2,

EDP $1-W+Q 1-O$

P.O. $\perp A$

Others
5. Document Type:

Drawing $5=-L-C 心 \ddot{U} \cdot \mathbb{V}$

Specification

Vendor Data

SOD

Others

6. Title of Change: ANCACLP FCR $2^{\text {" }}$ DISCOS

Ext. No.: Department: $\quad$ Date: 8. Cognizant Engineer: (print)

7. Originator: (print)

9. Description of Change:

Com Niendirastiz

Yes No

Component indices change required (if yes, attach sheets)

Make a crowing of a brace for each of the $2^{\prime}$ drops for the

VOC manifold

in Room 1. Use the attacked sketchy.

drawing, will be and additional siret or detail on drawing $52-\angle-002-W$.

Q. ga Drawing Change Sheet attached

90 Vendor Data Change Sheet attached

ib Design Documentation Sheet attached

10. YeS No $\square$ MODIFICATION IN PROGRESS

Modification complete:

Change drawing per as-built markup dated:

Change drawing per ECO-provided data

Temporary modification

11. Design Verification Requirements: (per WP 09-018)

EDT No::

1. Requirements satisfied by review/approval of design document

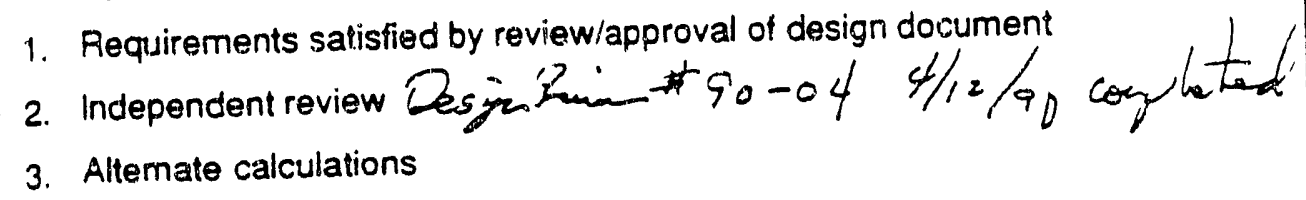

4. Development testing

5. Design review

6. Other:

12. Addendum Shot added:

Dat

11908:0005

WP Form 1200; $12229 / 90$

Page 1 of 3 
ECO No.: 3 3.

Page 2 of 3

13. Justification

The 9-foot 2"-tubing drops from the VCC moinifdl need to be lanced. attacked sketch with provide the required support and acijyt for he room closure.

14. Administrative Tracking

1. FSAR

2. Calibration Procedures

3. Maintenance Procedures

4. Computer Software

5. Operations Procedures
YES NRA

6. Startup/Acceptance Test

7. Test Requirement \& Spec.

8.

10.

15. Sign
A
$\square$
$\square$
$\square$
$\square$
$\square$
$\square$
$\square$

KEY

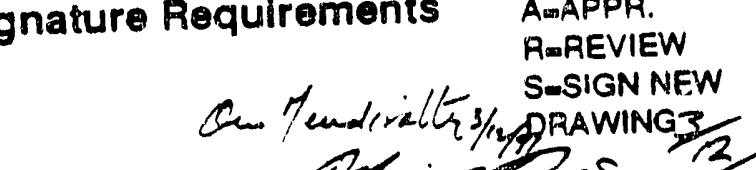

16. Distribute as Marked

Maintenance MaNDaTORY)

Cog. Engineer

Startup

DA

Safety

Operations

Security

SN

WP Form 1200; 12/29/90
Ops. Support MaNDATORY)

Startup

Facility Operations

U/G Operations

Orig./Design Engr.

Cog. Engineer

Others

11908:0005a

Page 2 of 3 
$9 a$

DRAWING CHANGE SHEET

(1 SHEET PER DRAWING)

1. Drawing: $52-\alpha-102-h$

ECO Number: 5315

2. ECO Search List:

3. Description of Change:

Add the bracket shown in the attached sketch, SK-010391, to the subject drawing. Dimensions are to be field determined.

4. Drawing Cog. Engineer Approval: Date: $3 / 14 / 91$

5. Cover Sheet Block (CC\&D Use Only)

Received from EFR:

Dale Assigned:

Assigned to:
Initials / Date Initials t Dato

(Same as data base entry)

Drafting Started:

Drafting Completed:

Initials / Date

Return to EFR:

Initials/ Dato

Initials/ Date

WP Form 2017; 12/29/90

1290:80006

$P$ age 1 of 1 


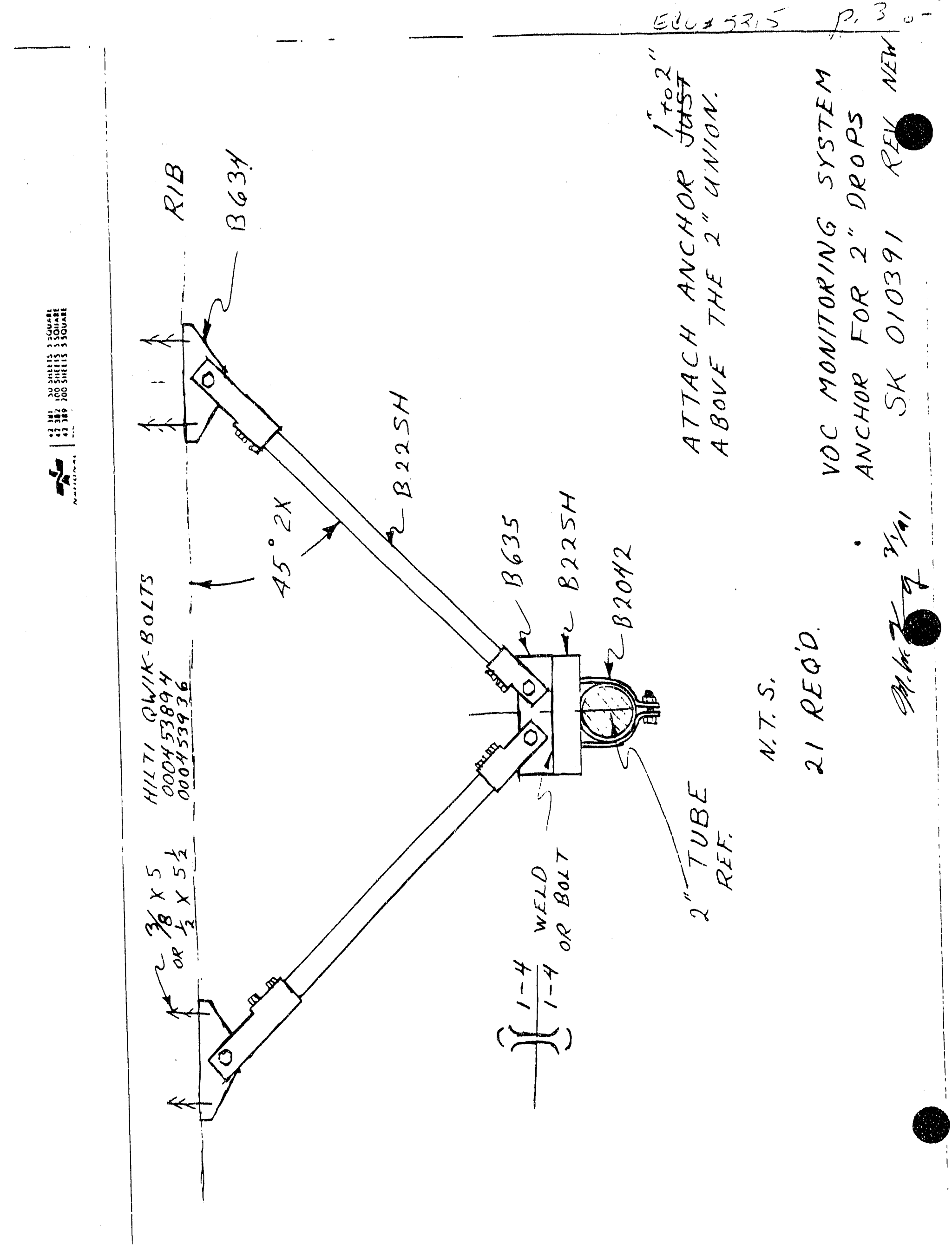




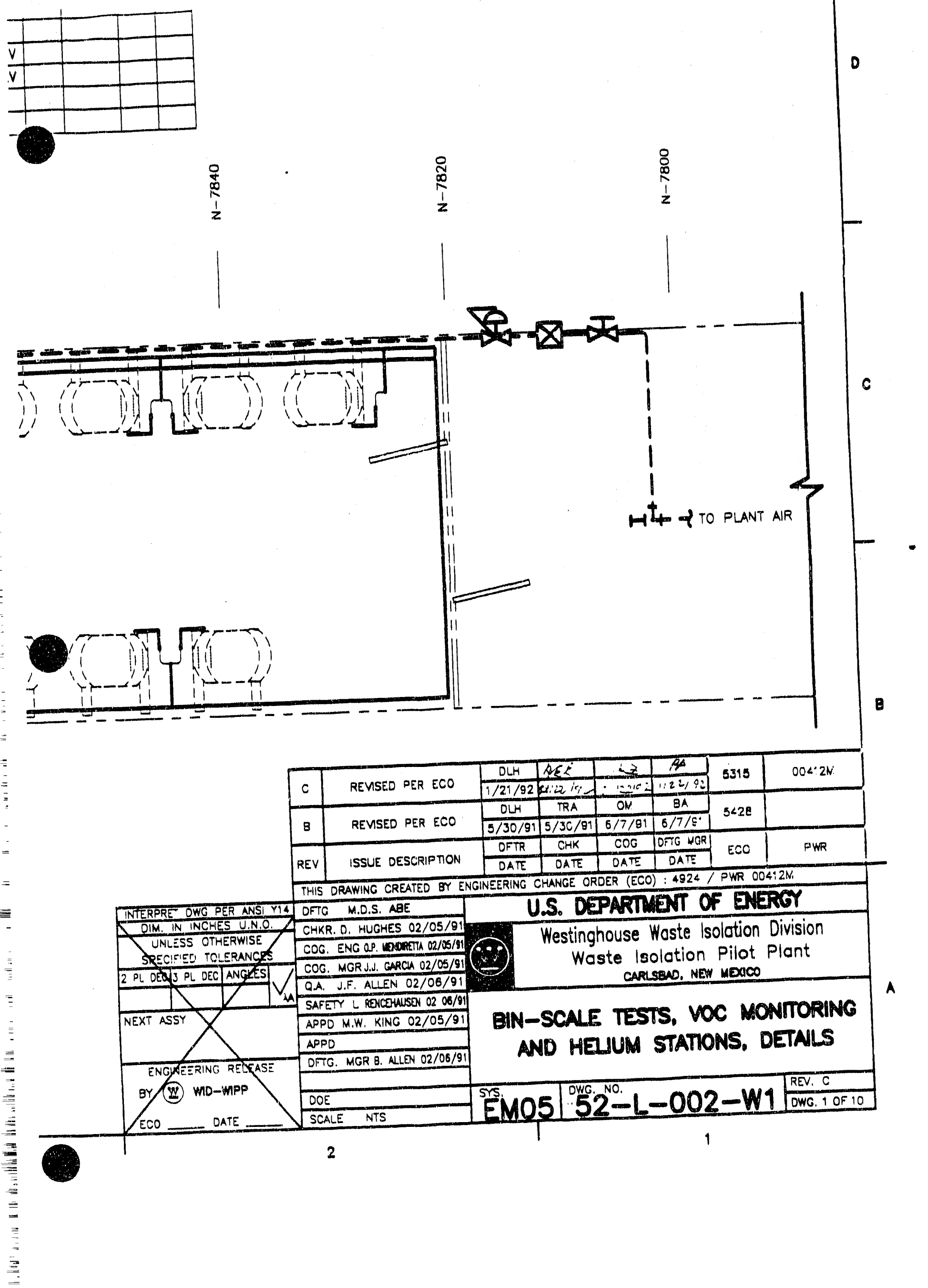




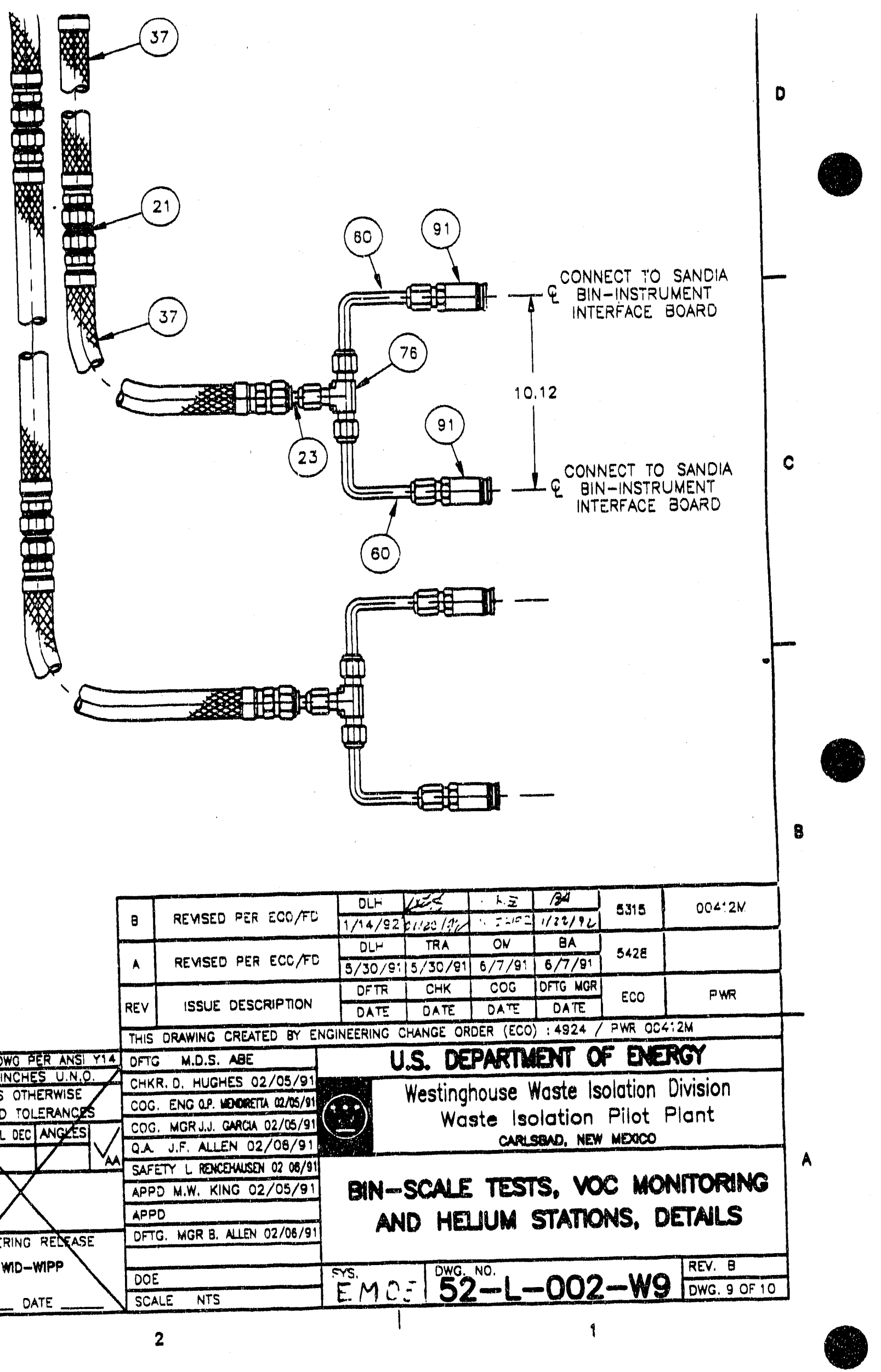


12. Addendum Sheor addod: Stonature $\longrightarrow$ Dafe 


\section{Justification}

DOE/AL Onder 5480.7 requines autornatic fiv protection in areas where the dollar value exceeda one million dallara.

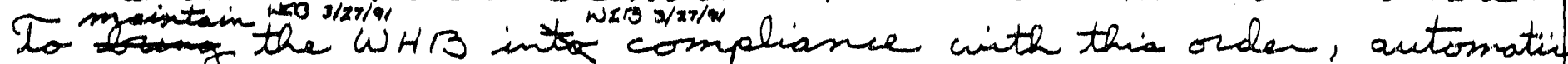
prie protection is meeded in the "ent portal".

\section{Administrative Tracking}

YES N/A

YES N/A

$\square$ 1. FSAR

$\bigotimes \quad$ 2. Calibration Procedures

$\triangle$ 3. Maintenance Procedures

$7 \otimes$ 4. Computer Software

$\otimes$ 5. Operations Procedures:

$\square \square$

$\square$

$\square \square$

$\square \square$

$\square \square \quad 10$.

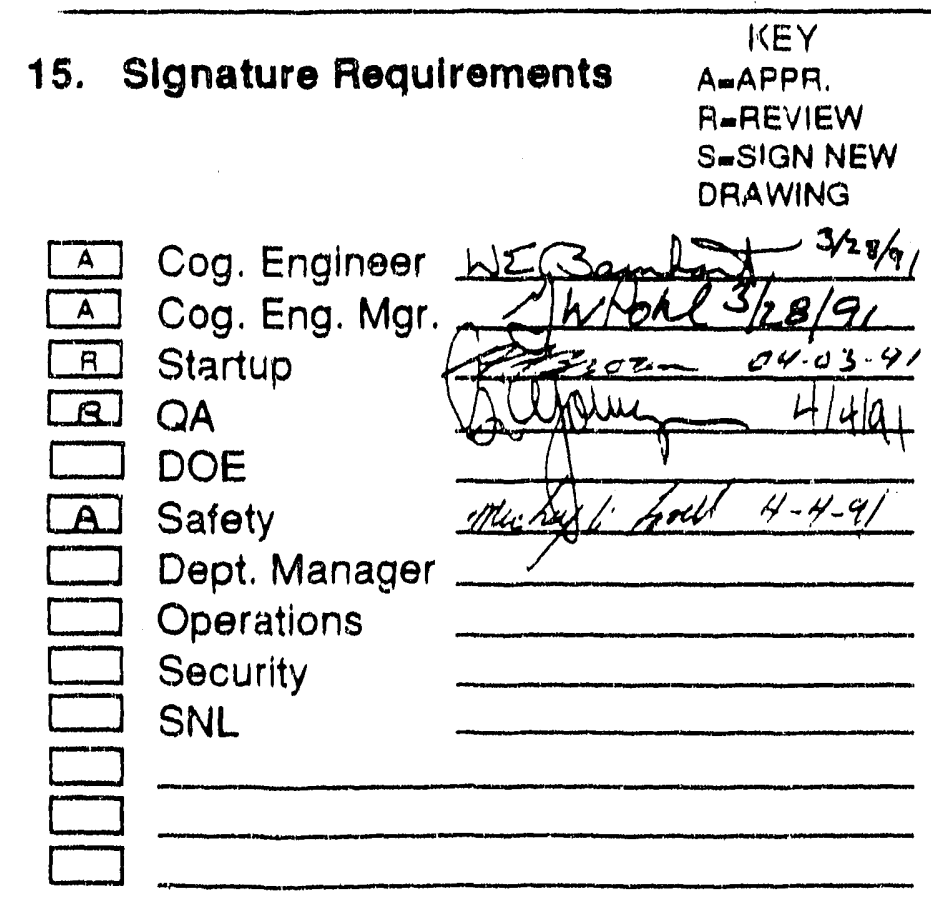

6. Startup/Acceptance Test

7. Test Requirement \& Spec.

8.

9.

KEY
A-APPR.
R-REVIEW
S-SIGN NEW
DRAWING

$2 / 28 / 9$

A

a

Cog. Eng. Mgr.

$Q A$

Safety

Dept. Manager

Operations

Security

SNL

\section{Distribute as Marked}

2 Maintenance (MANDATORY)

$\sum$ Ops. Support (MANDATOPY)

Startup

Facility Operations

U/G Operations

Orig./Design Engr.

Cog. Engineer

Others

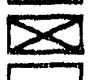

Safty - Miskng bavell 


\begin{tabular}{|c|c|c|c|}
\hline \multirow{2}{*}{$\begin{array}{c}\text { ENGINEERING CHANGE } \\
\text { ORDER } \\
\text { Continuation She日t }\end{array}$} & \multicolumn{2}{|c|}{ Document Number: } & \multirow{2}{*}{$\begin{array}{l}\text { ECO } \\
5353\end{array}$} \\
\hline & $\begin{array}{l}\text { Date: } \\
\quad 3 / 28 / 91\end{array}$ & 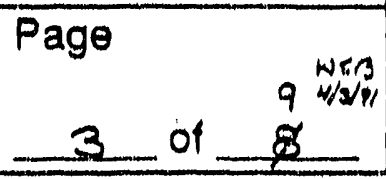 & \\
\hline
\end{tabular}

1. Provide a sketch number for the attached skettih: $1653-5$

2. Following mod. complation, reviae dung 41-5.003-W, sht. 2 to reflect thia change.

3. Following mod completion, nemove the attached aketef from the active dug regiater. 


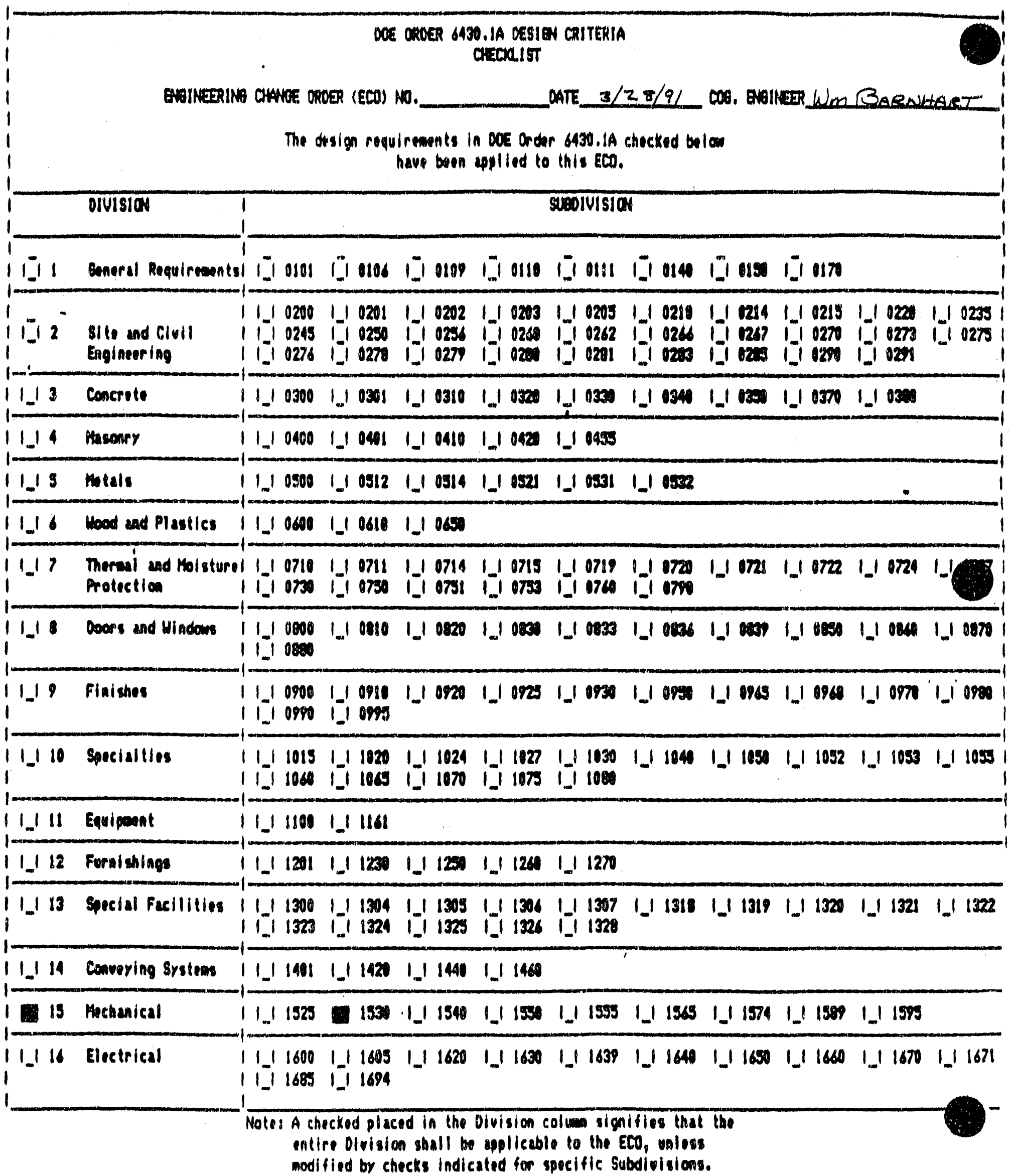


1. Drawing:

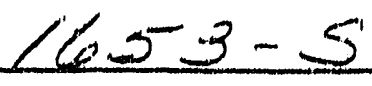

2. ECO Search List:
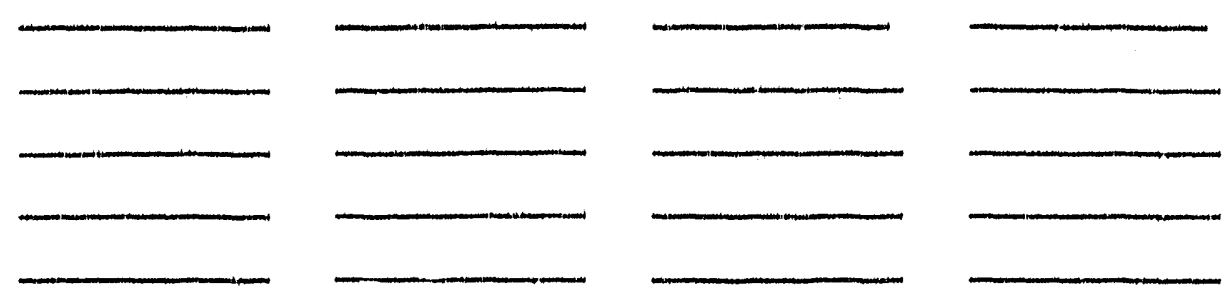

3. Description of Change:

Provide a setich number for the shitul "Exit Poital Sprinklen Piping". see attached paye 6.

4. Drawing Cog. Engineer Approval: LLE Bem hast Date:

$4 / 3 / 91$

5. Cover Sheet Block (CC\&D Use Only)

Recelved from EFR:

Date Assigned:

Assigned to:
Drafting Started:

Irittials / Dato

$$
\text { (Same as data base entry) }
$$

Dratting Completed:

Initials / Date

Inillials / Date Retum to EFF: 


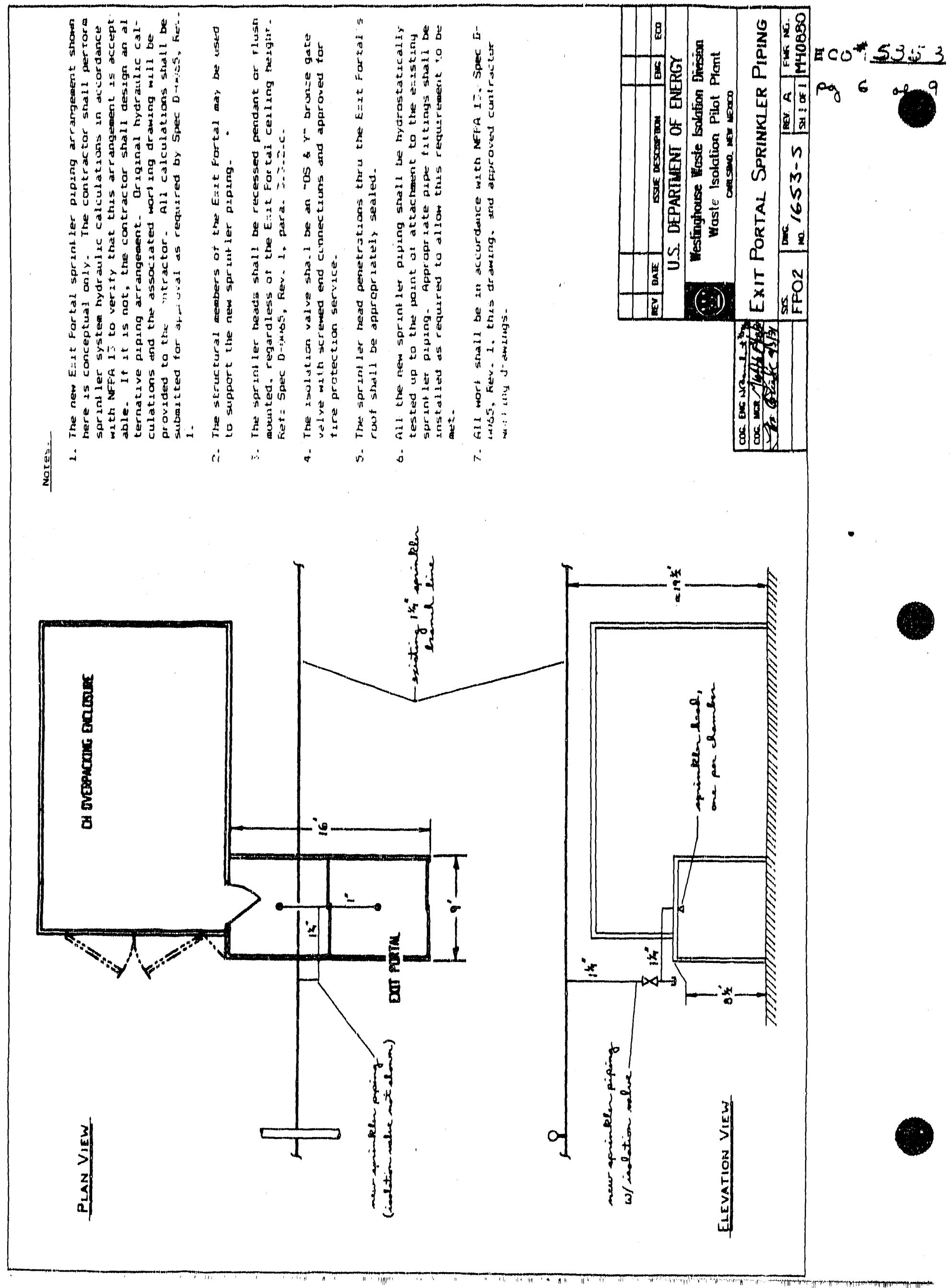


$9 a$

DRAWING CHANGE SHEET

(1 SHEET PER DRAWING) $\operatorname{pg} \&$ of $\$$
7 出
$4 / 3 / 91$

1. Drawing: 41-5:003.42, Rave C, sht 2 ECO Number: 5.3 .53

2. ECO Search List:
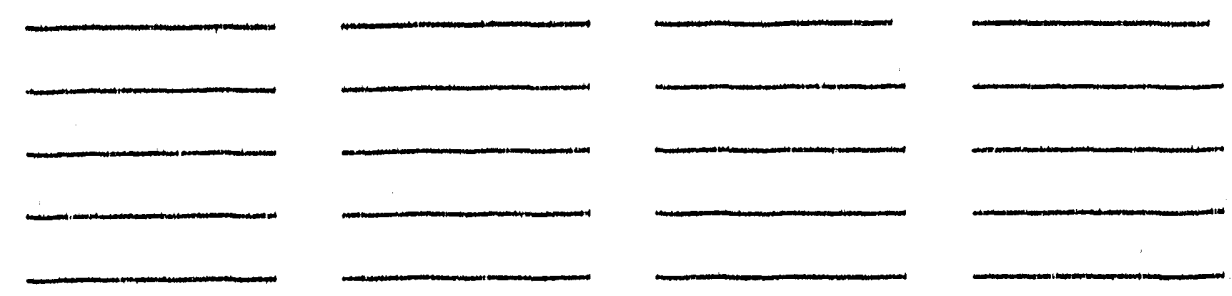

3. Description of Change:

Reviae dug. to show the footprint of the exit poital $\left(9^{\prime} \times 16^{\prime}\right)$ and the new sprinklen syatem pipsing associatad with it. See attahed mankup, page 8 .

4. Drawing Cog. Engineer Approval: W $\mathrm{L}$ BambentDate: $3 / 28 / 91$

5. Cover Sheet Block (CC\&D Use Only) Recelved from EFR: Initlals / Date Date Assigned: Inittals / Date Assigned to:

Drafting Started:

Dratting Completed:

Return to EFF: 


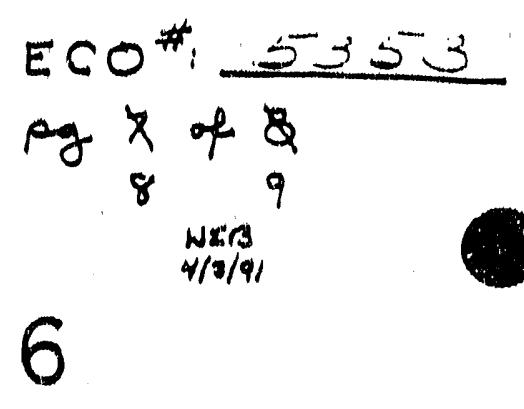

1. add "footpmint" of exit portal to floopelan.

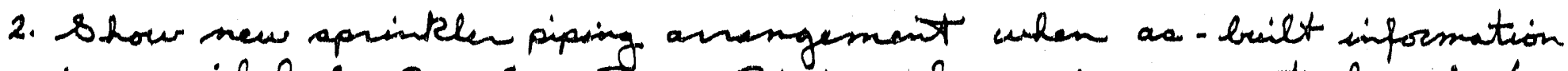

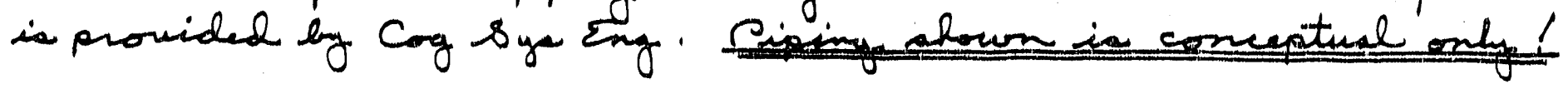

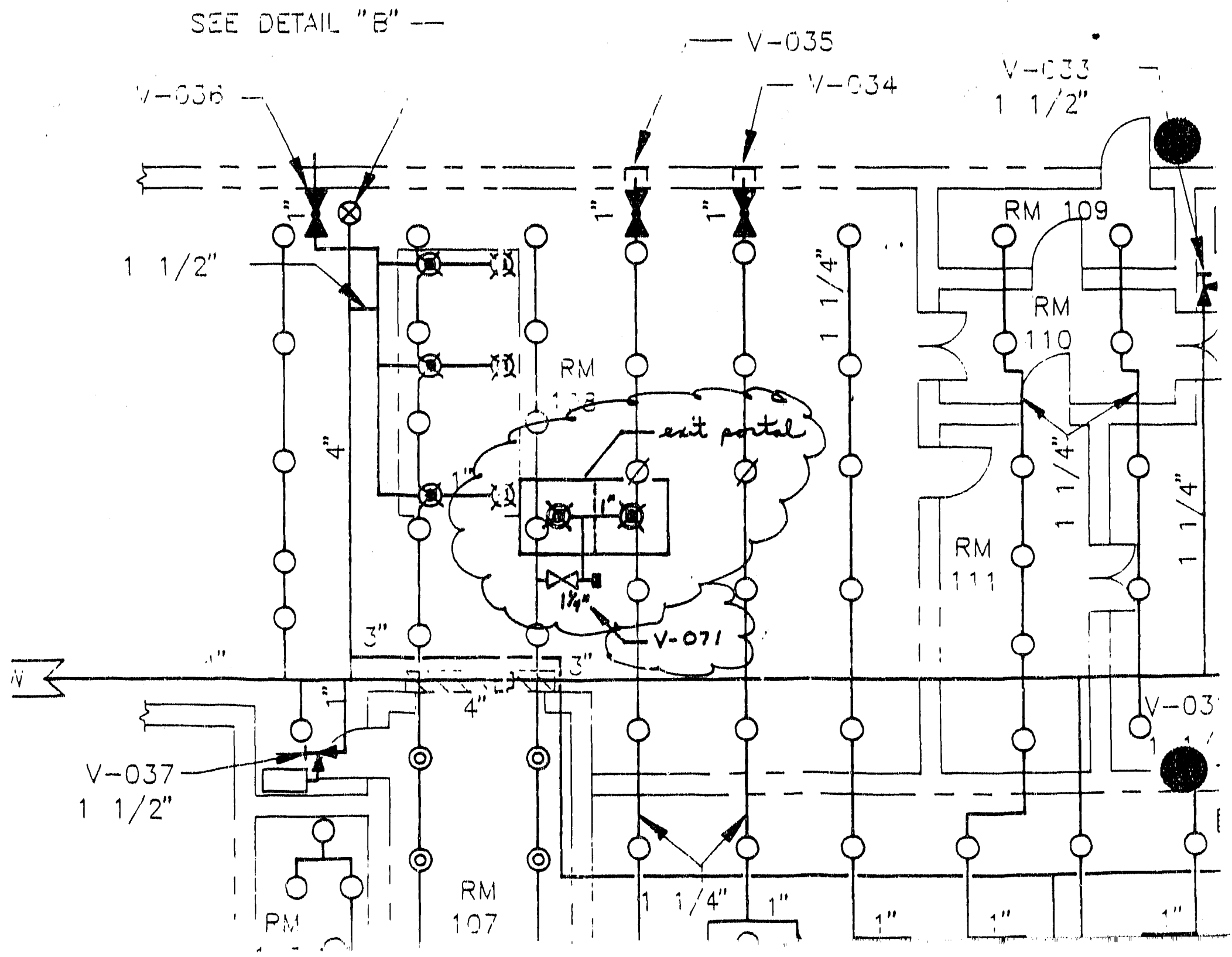




$$
\begin{aligned}
& \text { ECO \# : }
\end{aligned}
$$

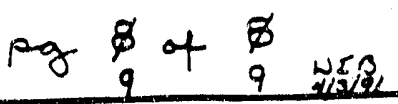

\section{VALVE IDENTIFICATION SHEET}

\section{NEW VALVE $\square$ REVISD DATA $\square$ VALVE REMOVED}

1. Tag Number: $E \omega-4 U-V-O T$ 2. Size:

3. Pressure:

4. Building:

411

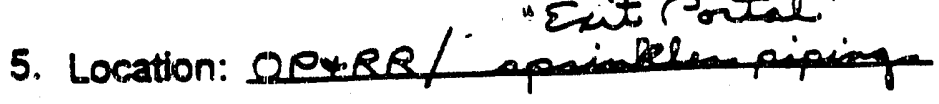

6. Valve Type:

Gate

7. Valve Operator:

HAND

8. Valve Bonnet:

9. Manufacturer:

10. Catalog No.:

11. Body:

12. Trim:

13. Ends:

14. Piping Code:

NEPA 13

15. Seis. Class:

Na

16. Working Pressure:

150 PSIG

17. Working Temporature:

$80^{\circ} \mathrm{F}$

18. Normal Valve PositionfFull Open: $x$. Full Closed:

$\%$ Throttled:

19. Spec. Number: NA

20. P.O. Number:

NA

21. Design Class:

III 3

22. P\&10 $4 i-5-003-w$. Sh.:

2 Zone:

23. Plan Drawing Number:

$N A$

Sht: Zone:

24. Isometric Drawing Number:

NA

25. Piping Line Number:

$N A$

26. Document Providing Information 030 ECO 5353 EWP

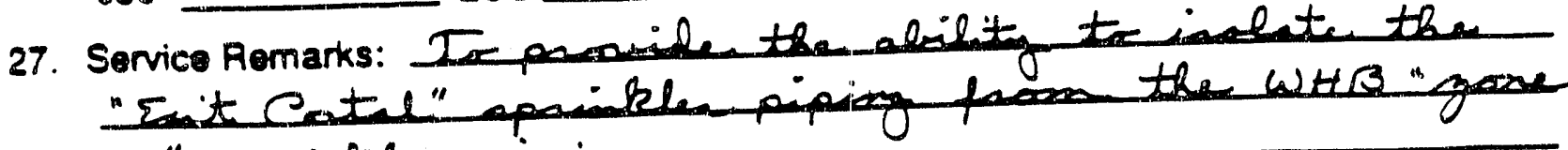
2" apuinkla papicy $\frac{\text { blE } 3 \text { aashast }}{\text { Intormation by }}$

$3 / 26 / 91$ Daro

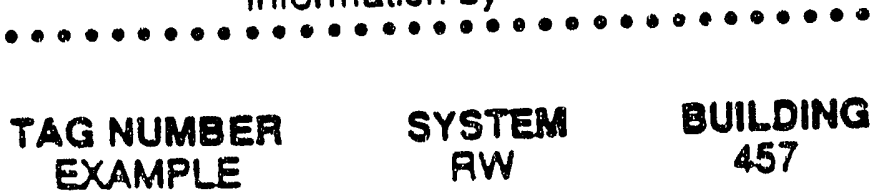

INDICATES

EXAMPLE RW

VALVE

V

NUMBER 001 


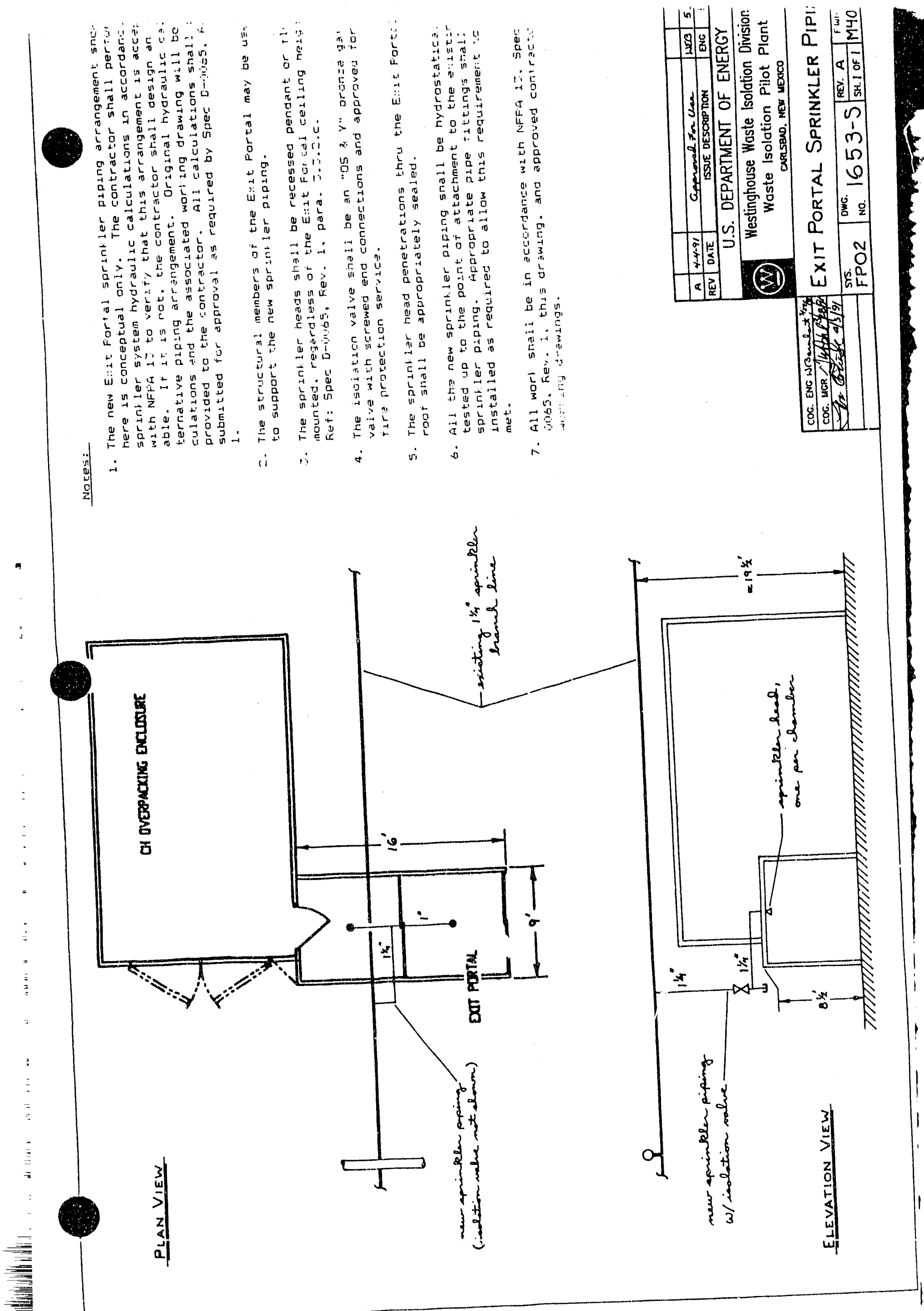




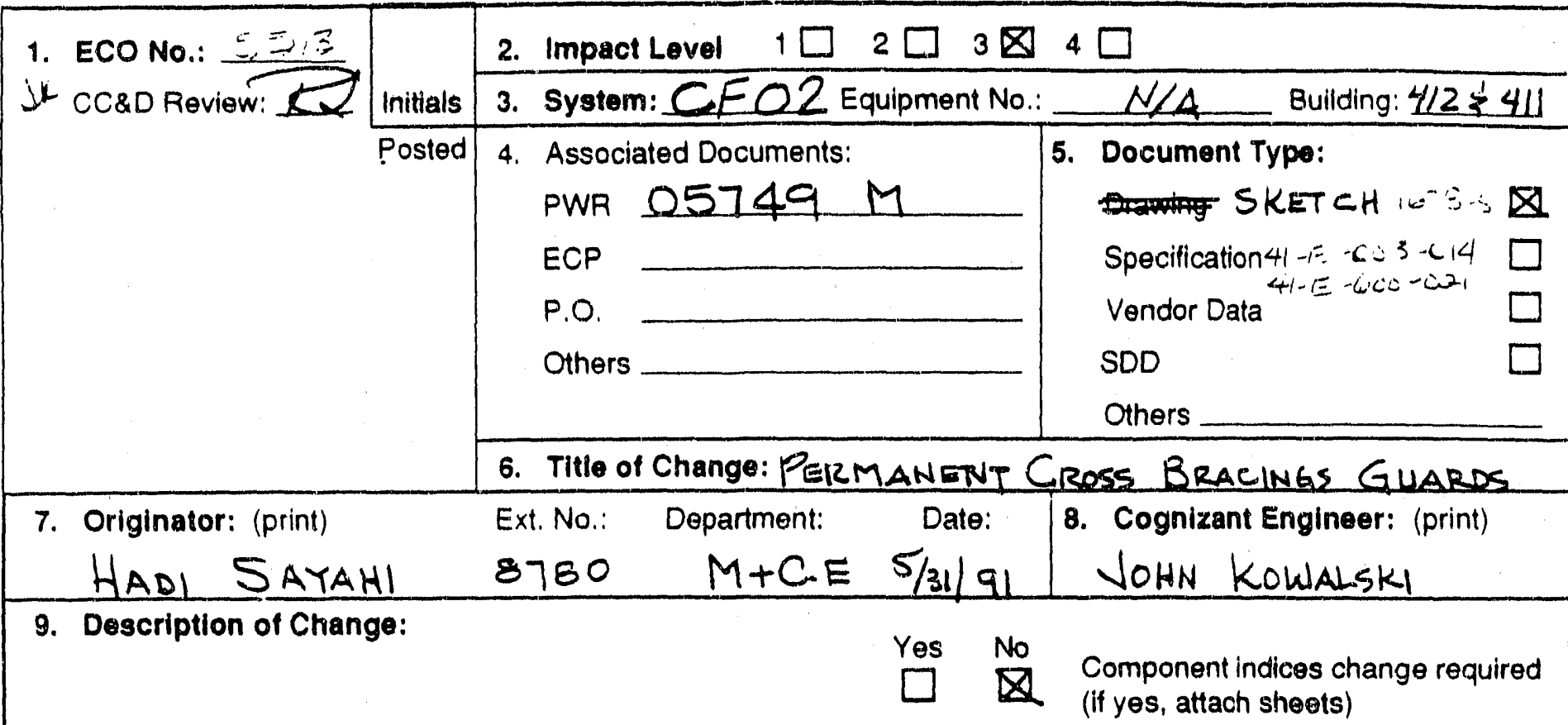

- assigin a number for the attached permanent cross BRACINGS GLARDS SKETCH. 11,-7E-S

- after completion of the job, incorporate (as bullt) new ADDITIONS ON AFFECTED DRALINGS. SEE ATTACHED 9 a SHEETS.

- SUPERCEDE SKETCH \#ibiż-s.

9a Drawing Change Sheet attached

9c Vendor Data Change Sheet attached

9b Design Documentation Sheet attached

10. Yes No
$\square \square$ MODIFICATION IN PROGRESS
$\square \square$ MODIFICATION IN PRO
Change drawing per as-ouilt markup dated:
Change drawing per ECO-provided data
Temporany modification

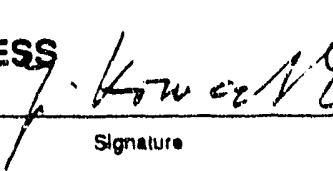

Ale

11. Design Veriflcation Reguirements: (per WP 09-018)

EDT No: :

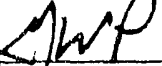

1. Requirements satisfied by review/approval of design document

2. Independent review

3. Alternate calculations

4. Development testing

5. Design review

6. Other:

12. Addendum Sheot added: 


\section{Justification}

TO PREVENT PERSONNEL INVURY AND to SATISFY OSHA REEQUIREMENTS.

14. Administrative Tracking

YES N/A

1. FSAR

$\square$ 冈

2. Calibration Procedures

3. Maintenance Procedures

4. Computer Software

5. Operations Procedures

$\square \otimes$

$\square \square$

$\square \square$

15. SIgnature ReY

15. Signature Requirements

\section{$A=A P P R$.}

R-REVIEW

SISIGN NEW

DRAWING

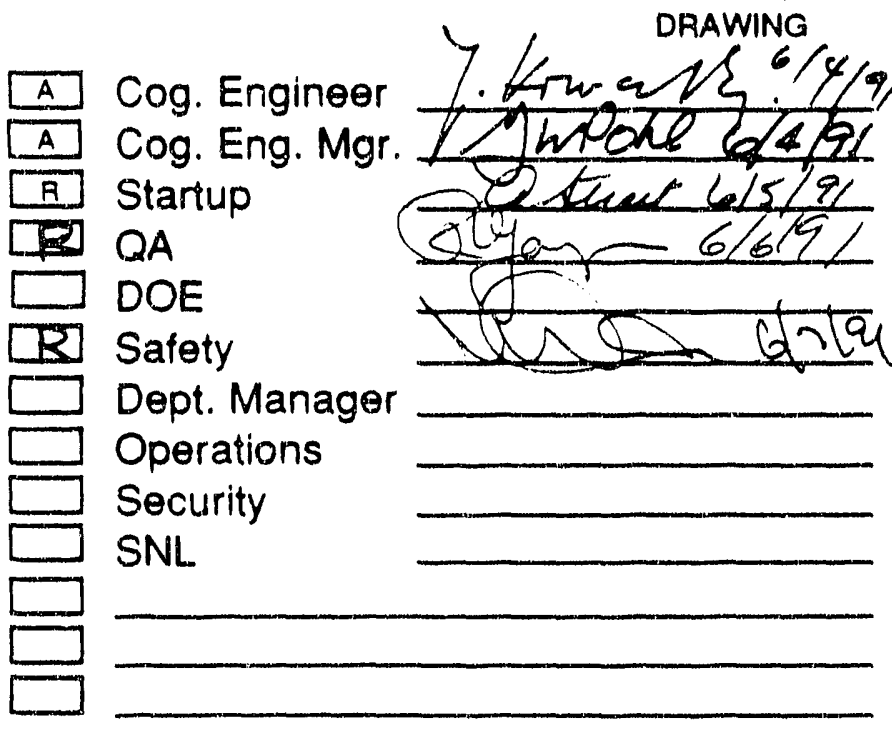

YES N/A

$\square$ 6. Startup/Acceptance Test

$\square \otimes$ 7. Test Requirement \& Sper.

$\square \otimes$

$\square \square \quad 9$.

$\square \square \quad 10$
16. Distributo as Marked

$\approx$ Maintenance (MANDATORY)

Ops. Support (MANDATORY)

Startup

Facility Operations

$U / G$ Operations

Orig./Design Engr.

Cog. Engineer

Others 


\begin{tabular}{|c|c|}
\hline The & 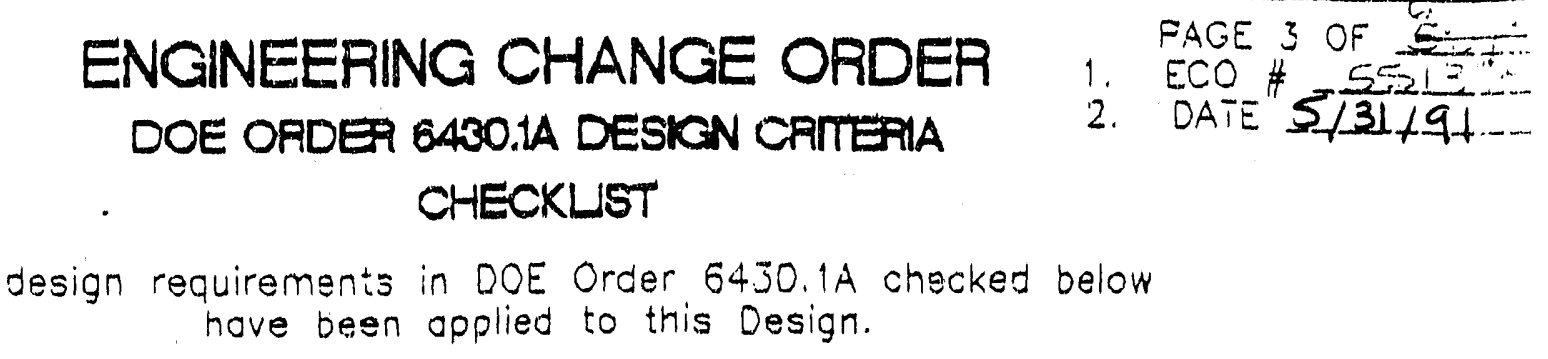 \\
\hline DIVISION & SUBOIVISION \\
\hline Q1 General Requirements & $\square 0101 \square 0106 \square 0109 \square 0110 \square 0111 \square 0140 \square 0150 \square 0170$ \\
\hline$\square^{2} \quad \begin{array}{l}\text { Site and Civil } \\
\text { Engineering }\end{array}$ & 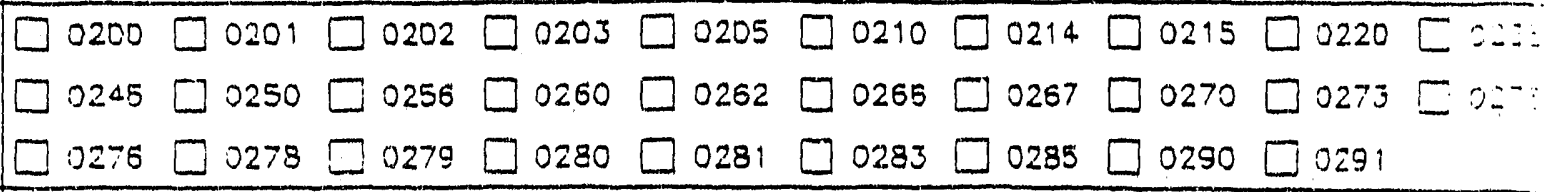 \\
\hline [3. Concrete & {$[0300 \square 0301 \square 0310 \square 0320 \square 0330 \square 0340 \square 0350 \square 0370 \square 0380$} \\
\hline$\square^{4}$ Hosonry & $\square 0400 \square 0401 \square 0410 \square 0420 \square 0455$ \\
\hline$\$ 5$ Metols & $\square .0500 \bigotimes 0512 \square 0514 \square 0521 \square 0531 \square 0532$ \\
\hline D6 Wood and Plastics & $\square 0600 \square 0610 \square 0650$ \\
\hline $\begin{array}{l}\square^{7} \text { ihermol and Moisture } \\
\text { Protection }\end{array}$ & 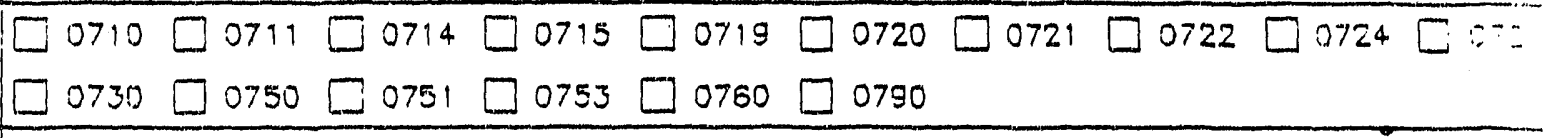 \\
\hline$\square \varepsilon$ Doors and Windows. & $\begin{array}{l}\square 0800 \square 0810 \quad \square 0820 \square 0830 \quad \square 0833 \square 0836 \square 0839 \square 0850 \square 0860 \square .0^{\circ} \\
\square 0880\end{array}$ \\
\hline Finighes & $\begin{array}{l}\square 0900 \square 0910 \square 0920 \square 0925 \square 0930 \square 0950 \square 0965 \square 0968 \square 0970 \Xi: 8: \\
\square 0990 \square 0995\end{array}$ \\
\hline$\square 10$ Specialties & $\begin{array}{l}\square 1015 \square 1020 \square 1024 \square 1027 \square 1030 \square 1040 \square 1050 \square 1052 \square 1053[\cdots \\
\square 1060 \square 1065 \square 1070 \square 1075 \square 1080\end{array}$ \\
\hline$\square 11$ Equipment & $\square 1100 \square 1161$ \\
\hline$\square 12$ Furnishings & $\square 1201 \square 1230 \square 1250 \square 1260 \square 1270$ \\
\hline$\square 13$ Special Facilities & $\begin{array}{l}\square 1300 \square 1304 \square 1306 \square 1305 \square 1307 \square 1318 \square 1319 \square 1320 \square 1321 \square 1: \\
\square 1323 \square 1324 \square 1325 \square 1325 \square 1328\end{array}$ \\
\hline$\square 14$ Conveying Systems & $\square \quad 1401 \square 1420 \quad \square 1440 \quad \square 1460$ \\
\hline$\square 15$ Mechanical & $\square 1525 \square 1530 \square 1540 \square 1550 \square 1555 \square 1565 \square 1574 \square 1589 \square 1595$ \\
\hline$\square 15$ Electrical & $\begin{array}{l}\square 1600 \square 1605 \square 1620 \square 1630 \square 1639 \square 1640 \square 1650 \square 1655 \square 1660 \square 10^{-} \\
\square 1671 \square 1685 \square 1694\end{array}$ \\
\hline 4. $\square$ NOT APPLLCAELE & No portion of DOE Order 6430.1A is applicable to this Design. \\
\hline 5. $\square$ AS-BUILT & built field ve \\
\hline
\end{tabular}

NOTE: A check placed in the Division column signifies that the entire Division shall be applicable to the Design, uriless modified by checks indicated for specific Subdivisions.

WP FORM 1200: PAGE 3 OF 4 
$9 a$

DRAWING CHANGE SHEET

PAEE $40+C$

(1 SHEET PER DRAWING)

1. Drawing: No $41-E-003-014$ ECO Number: $55 / 3$

2. ECO Search List:
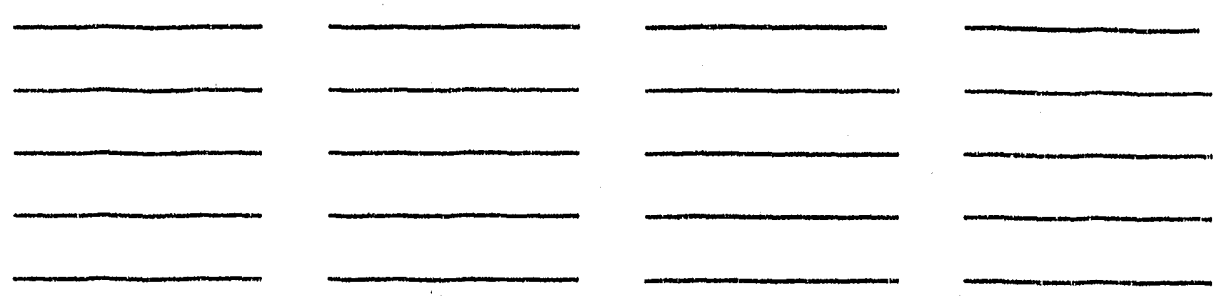

3. Description of Change:

SHOWJ (AS BUILT) LOCATION OF NEW BRACINGS GNARDS ON PLAN AND ALSO REDRAW THE TYPICAL DETAIL, PER SKETCH NO.

4. Drawing Cog. Engineer Approval: 7. Knwa/ Date: $6 / 4 / 9$

5. Cover Sheet Block (CC\&D Use Only)

Received from EFR: Initials / Dake

Date Assigned:

Assigned to: Initials / Date

(Same as data base entry)
Dratting Started:

Drafting Completed:

Roturn to EFP:
Initials / Date

Initials / D.to

Initials / Date 
$9 a$

DRAWING CHANGE SHEET

(1 SHEET PER DRAWING)

1. Drawing: Ne. $41-E-600.021$

ECO Number: 513

2. ECO Search List:

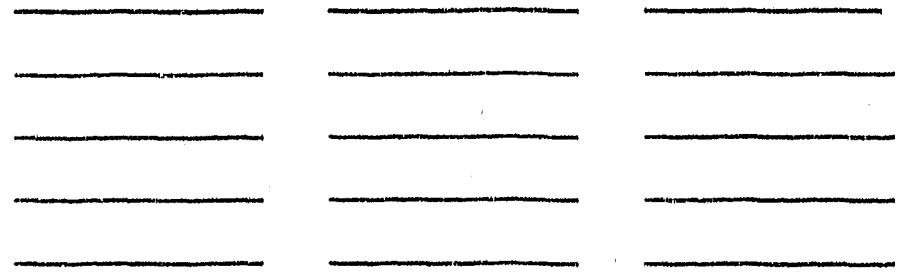

3. Description of Change:

SHOW (AS BUILT) LOCATION OF NEW BRACINGS GUARDS ON PLAN AND ALSO REDEAN THE TYPICAL DETAIL, PER SUETCH NO

4. Drawing Cog. Engineer Approval: $\{$ Krwa 2$\}$ Date: $6 / 4 / 91$ 5. Cover Sheet Block (CC\&D Use Only)

Received from EFR: Initials / Date Drafting Started:

Date Assigned: Initials / Dale

Assigned to:

(Same as data base entry) Inillals / Date

Drafting Completed: Return to EFF: Inilials / Date Initials / Date 


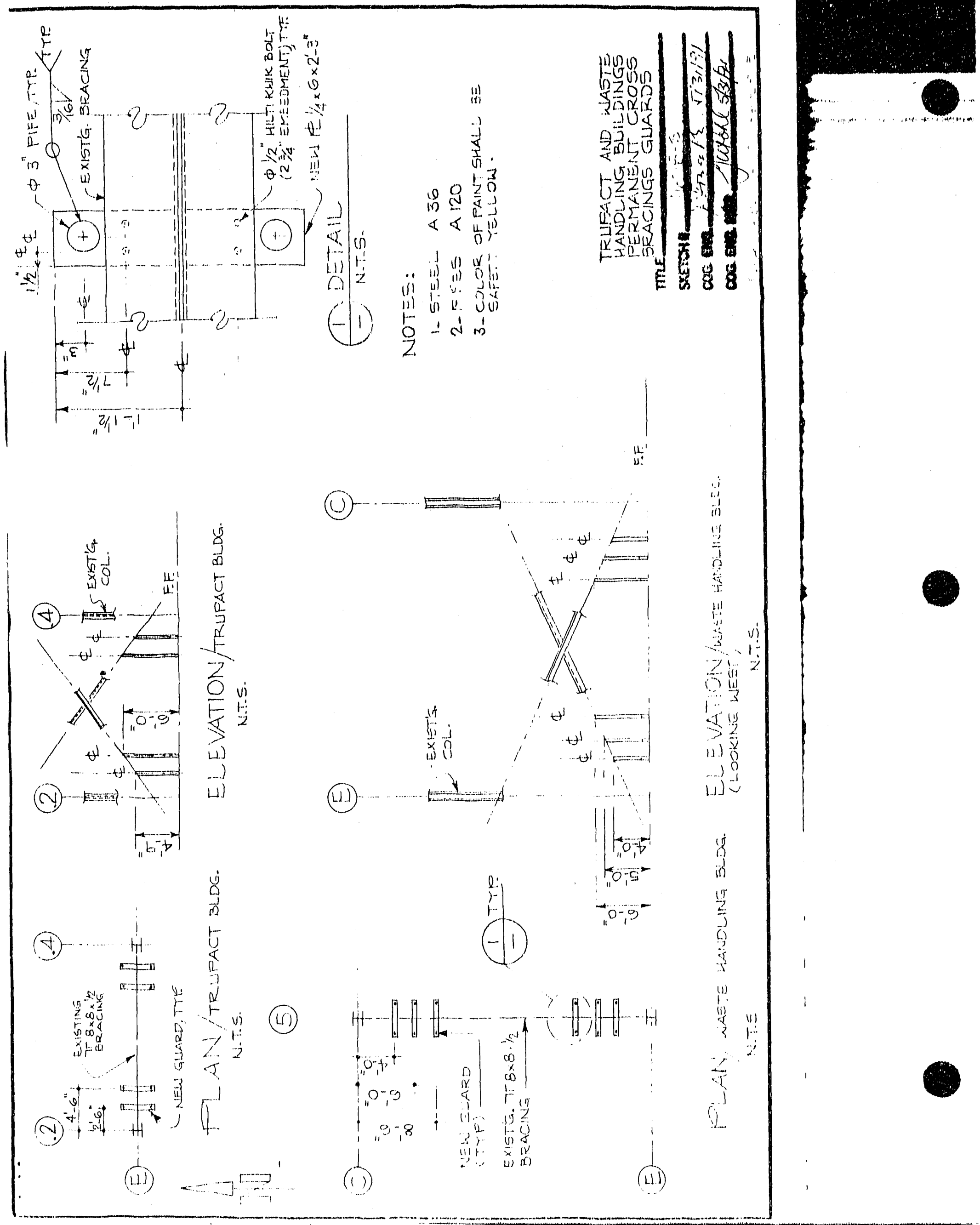




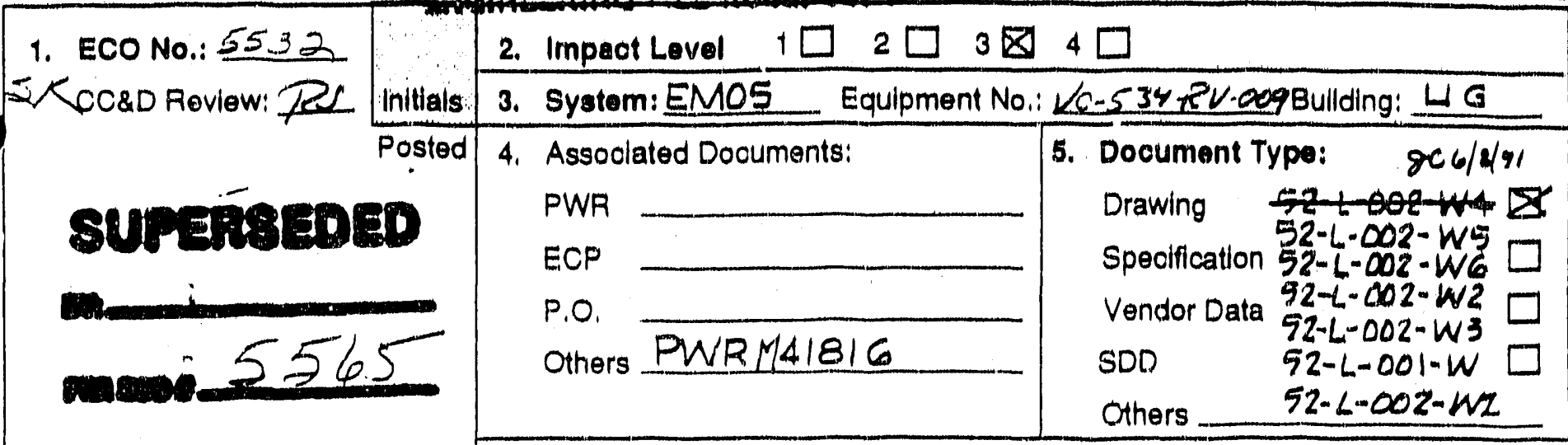

6. Titlo of Change: VOC 10 MODIFICATIONS

7. Originator: (print) Ext. No.: Department: Date: 1 8. Cognizant Englneer: (print)

JERRY CAMP 8750 EE 6.7-91 J.R.STROBLE

9. Description of Change: Yes No
$\square \quad \begin{aligned} & \text { Component indices change required } \\ & \text { (if yes, attach sheets) }\end{aligned}$

(i) CHANGE TLBING CONFIGLRATION TD

PRESSURE RELLEF VALVE 534.9647/91 VC-534-RV.009

AS SHOWN ON ATTACHED SHEETS.

(2) ADD FLAG NOTE AS SLIOWN ON ATTACHED SHEETS.

ADD NOTE TO SHEET I (SZ-L-OOZ-WI). DRAFTING TO ZZR'DETERMA NOTE NO.

Q: AD ALL TLBING FROM THE MAIN CARBON BED ge. $6 / 5 / 91$

OUTLET TO THE SAMPLCR INLET LS WRAPPED

WITH HEAT TPPE. (3.25 WATTS PER SQUARE INCW)

Q 9a Drawing Change Sheet attached

9b Design Documentation Sheet attached

9c Vendor Data Change Sheet attached

10. Yes No J18 $13-21$

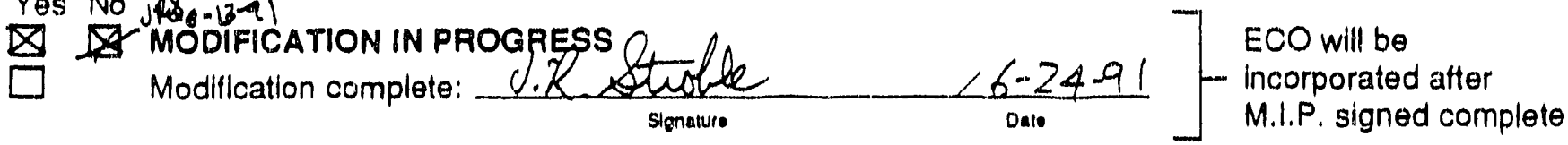

Q Change drawing per as-built markup dated: NEW ECQ

Change drawing per ECO-provided data

Temporary modification

11. Design Verification Aequirements: (por WP 09-018)

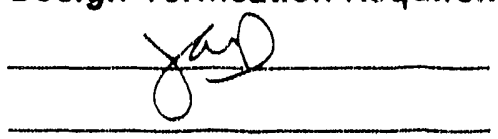

1. Requirements satisfied by review/approval of design document

2. Independent review

3. Altemate calculations

4. Development testing

5. Design review

6. Other:

12. Addandum Sheet added: 
13. Justification

(1) THIS THBING CLANGE WILL PROVIDE GREATER PROTECTION AGAINST MANIEOLD OVER PRESSLIRIZATION.

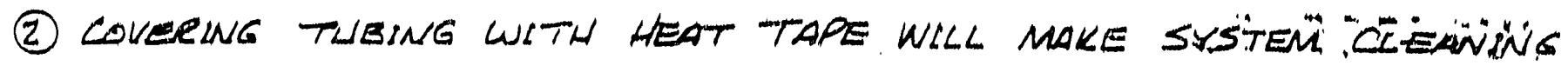
AND CERTIFICATION EASIER.

\section{Administrative Tracklng}

YES N/A

1. FSAR

2. Calibration Procedures

3. Maintenance Procedures

4. Computer Sottware

5. Operations Procedures

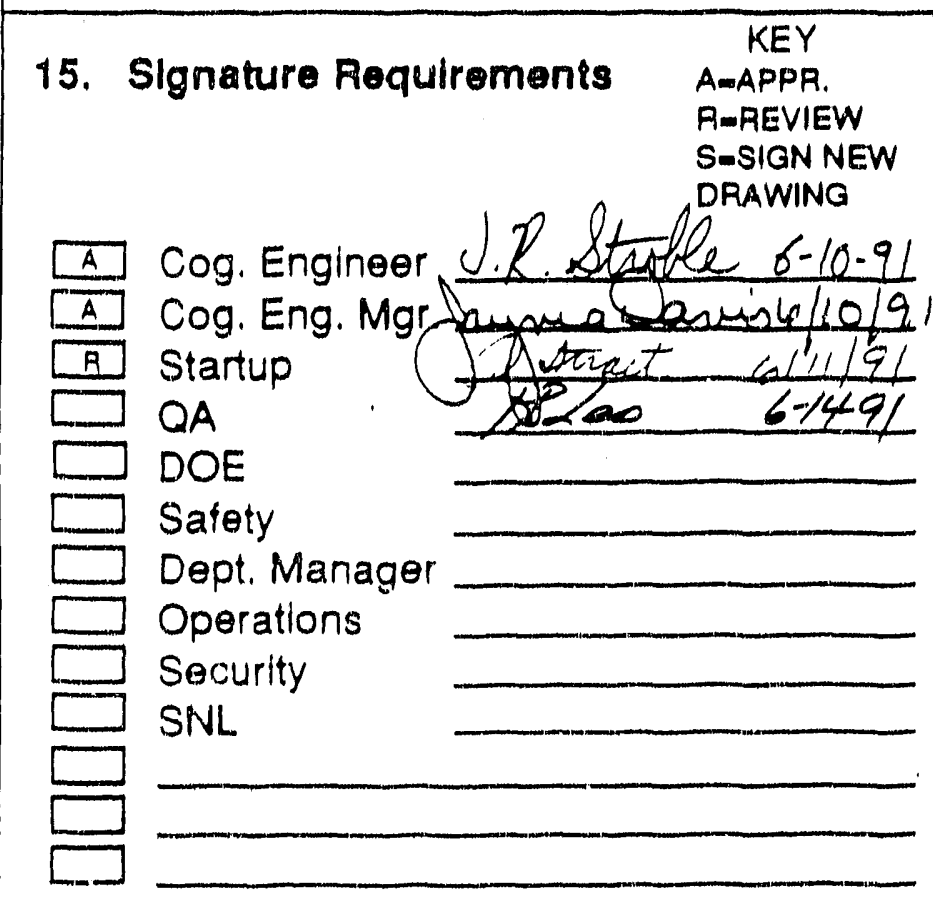

YES NA

$\square \square$

$\square$

$\square \square$

6. Startup/Acceptance Test

7. Test Requirement \& Spec.

8.

9.

10.

\section{Distribute as Marked}

Maintenance MANDATOAY)

Ops. Support MANDATOAY

Startup

Facility Operations

U/G Operations

Orig./Design Engr.

$\triangle$ Cog. Engineer

Others

H.P. Cos

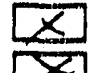
TERRY CAMP 


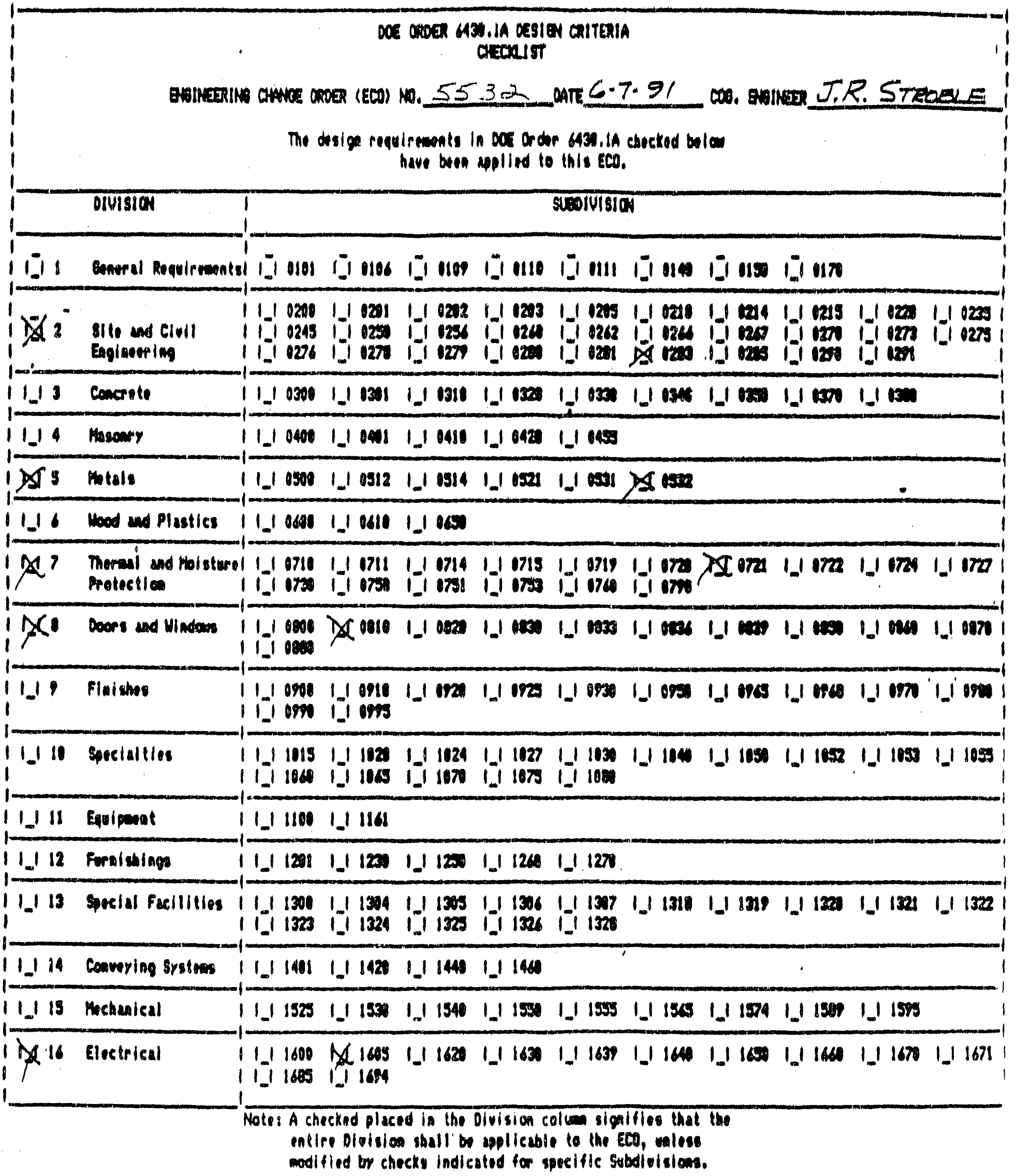




\section{9a}

DRAWING CHANGE SHEET

(1 SHEET PER DRAWING)

1. Drawing: 52-L-00/-WI ECO Number: 5532

2. ECO Searoh Llst:

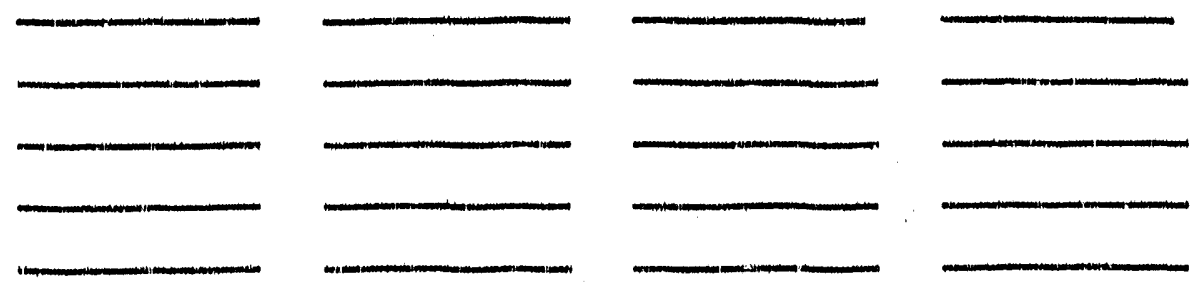

3. Description of Change:

(1) ADD THE FOLLOWING FLAG NOTE TO SHEET I OF 10: (DRAFTLNG TO DE TERMINE NOTE NLMBER)

A: ALL TUBING FROM THE MAIN CARBON BED OLTLETT TO THE SAMPLER LWIT INLET IS WRAPPED WITH HEAT TAPE * (3.25 WATTS PER S QULARE LNCH).

4. Drawing Cog. Engineer Approval: IR thutbe Date: $6-10-91$

5. Cover Sheet Block (CC\&D Use Only)

Rocolved from EFR: Intitials / Date

Date Assigned: Initials / Dato

Assigned to:

Drafting Started:

Dratting Completed:

Return to EFR:
Iniflals / Dato

Inilials / Dato

Inilials / Date 
$9 \mathbf{a}$

\section{DRAWING CHANGE SHEET}

(1 SHEET PER DRAWING)

1. Drawing:

$52 \cdot L \cdot 00 Z \cdot W 2$

2. ECO Search Llst:

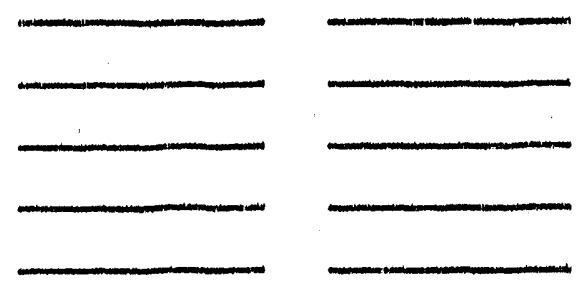

ECO Number:

5532
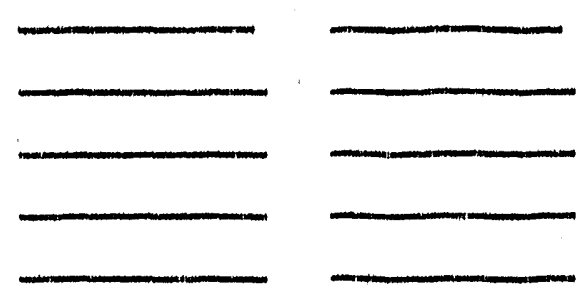

3. Description of Change:

(1) REVISE TLBING TO VC-534.RV-DO9 (ZONG B-7) AS SHOWN ON SHEET 6 OF 14 . ALL OTHER DETAILS REMAIN SAME.

(2) ADD FLAG NOTE AT ZONE B.7 AS SHOWN ON SHEET 6 OF 14 .

4. Irawing Cog. Engineer Approval: UR Stufle Date: $-6-10-91$

5. Cover Sheet Block (CC\&D Use Only)

Received from EFR: Initials / Date

Date Assigned: Intilals / Date

Assigned to:

Drafting Started:

Drafting Completed:

Initiale / Dats

Initials/ Dato

Return to EFF:

Inifiada / Date 


\section{DRAWING CHANGE SHEET}

(1 SHEET PEF DRAWING)

1. Drawing: $\quad 52 \cdot L \cdot 002 \cdot W 3$

ECO Numbar: 5532

2. ECO Searoh List:
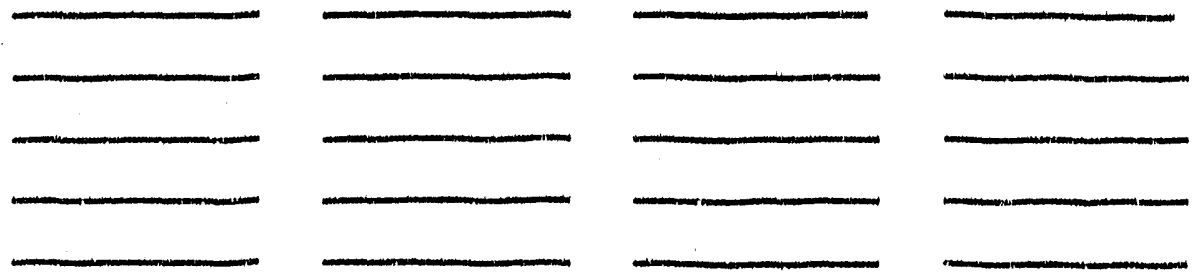

3. Description of Change:

(1) REVISE TUBING TO VC-534-RV-DO9 (ZONE B-7) AS SHOWN ON SHEET S OF 14 .

(2) $\triangle D D$ FLAG NOTE AT ZONE B.7 AS SHOWN ON SHEET 8 OF 14.

4. Drawing Cog. Engineer Approval: LR ftuflele Date: $6-10-91$

5. Cover Sheet Block (CC\&D Use Only)

Recelved from EFR:

Date Assigned:

Assigned to:
Drafting Startod:

Drafting Completod:

Intidial / Date

Return to EFR:
Inlitial / Date

Initials / Dato

Initiale / Dato 
$9 a$

DRAWING CHANGE SHEET

(1 SHEET PER DRAWING)

1. Drawing: $52 \cdot L-002 \cdot W 5 \quad$ ECO Number: $\$ 532$

2. ECO Search List:
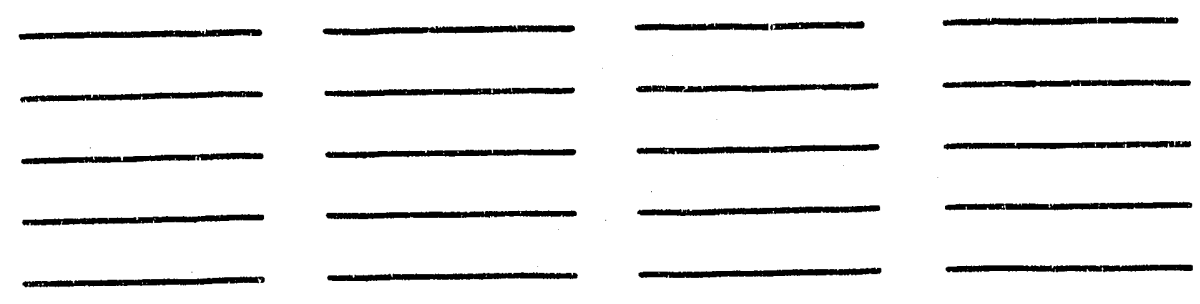

3. Description of Change:

(1) CHANGE FIELD OF DHG AS SHOWN ON SHEET 10 OF 14. ALL OTWER DETAILS REMAN SAME.

4. Drawing cog. Engineer Approval: J.R. Stuothe

Date:

$6-10-91$

5. Cover Sheet Block (CC\&D Use Onty)

Received from EFR:

Initials / Date

Dratting Started:

Date Assigned:

Initials / Dato

Assigned to:

(Samo as data base entry).

Drafting Completed:

Initials / Deto

Initials / Date

Retum to EFR:

Initials / Date 


\section{$9 a$}

\section{DRAWING CHANGE SHEET}

(1 SHEET PER DRAWING)

1. Drawing:

$52 \cdot 1.002 \cdot w 6$

ECO Number: 55.32

2. ECO Search List:
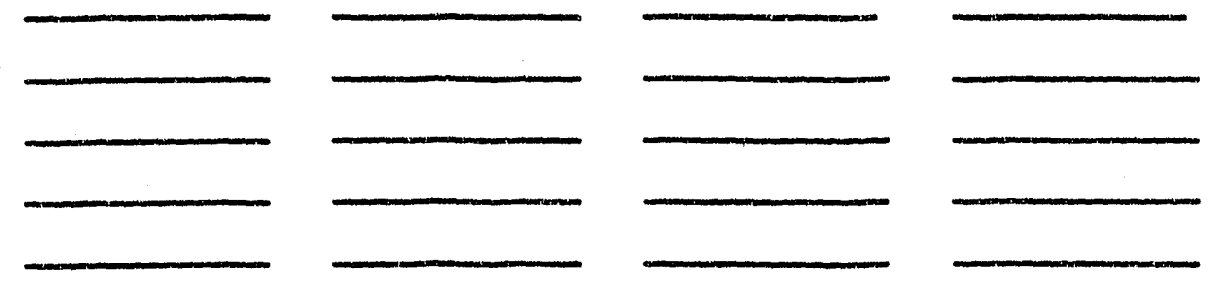

3. Description of Change:

(1) CWAMEE FIELD DF TWG AS SHOWN ON SHEET 12 OF 14 . ALL OTHER DETALLS PEMACN SAME.

4. Drawing Cog. Engineer Approval: d. R. strolle

Date: $6-10-91$

5. Cover Shert Block (CC\&D Use Only)

Received from EFR:

Initials / Dato

Date Assigned:

Initiol / Date

Assigned to:

(Seme as data bese entry)

Drafting Started:

Drafting Completed:

Ratum to EFR: 


\section{$9 \mathbf{a}$ \\ DRAWING CHANGE SHEET \\ (1 SHEET PER DRAWING)}

1. Drawing: $52 \cdot L \cdot 001-W$

2. ECO Search List:

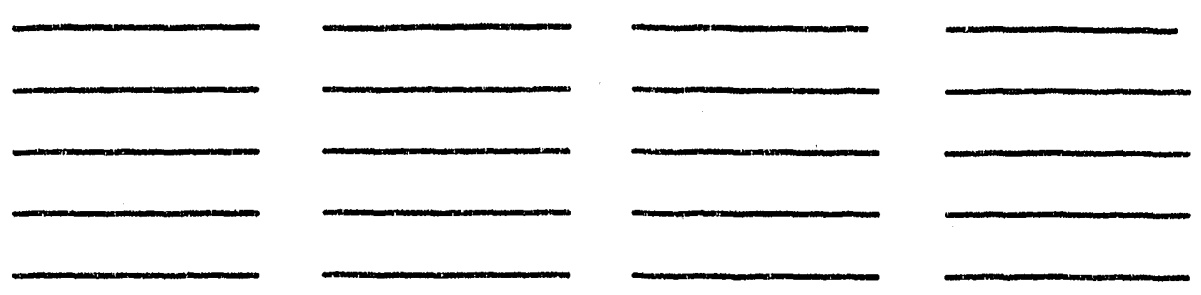

3. Description of Change:

(1) REVISE FIELD OF DWG AS SHOWN ON SHEET 14 OF 14. ALL OTHER DETALLS REMAIN SAME.

4. Drawing Cog. Engineer Approval: $d . K$. Stulle

Date: $6-10-91$

5. Cover Sheet Block (CC\&D Use Onty)

Received from EFR:

Date Assigned:

Mิssign tôt
Initials / Dato

Initiats / Date

(Same as data base entry)
Drafting Started:

Drafting Completed:

Repurn to EFR:
Initiala / Data

Initizis / Date

Initials / Date 


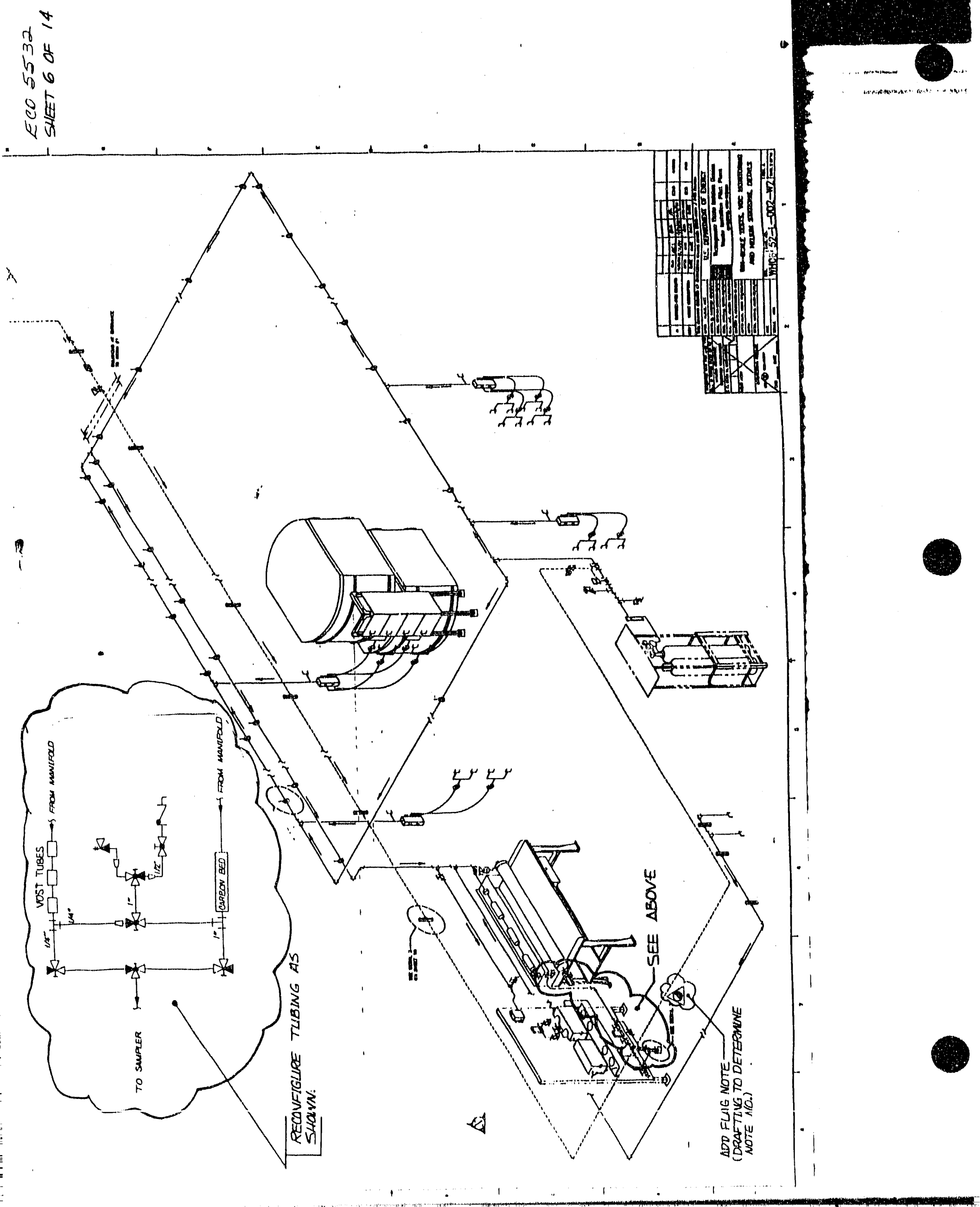




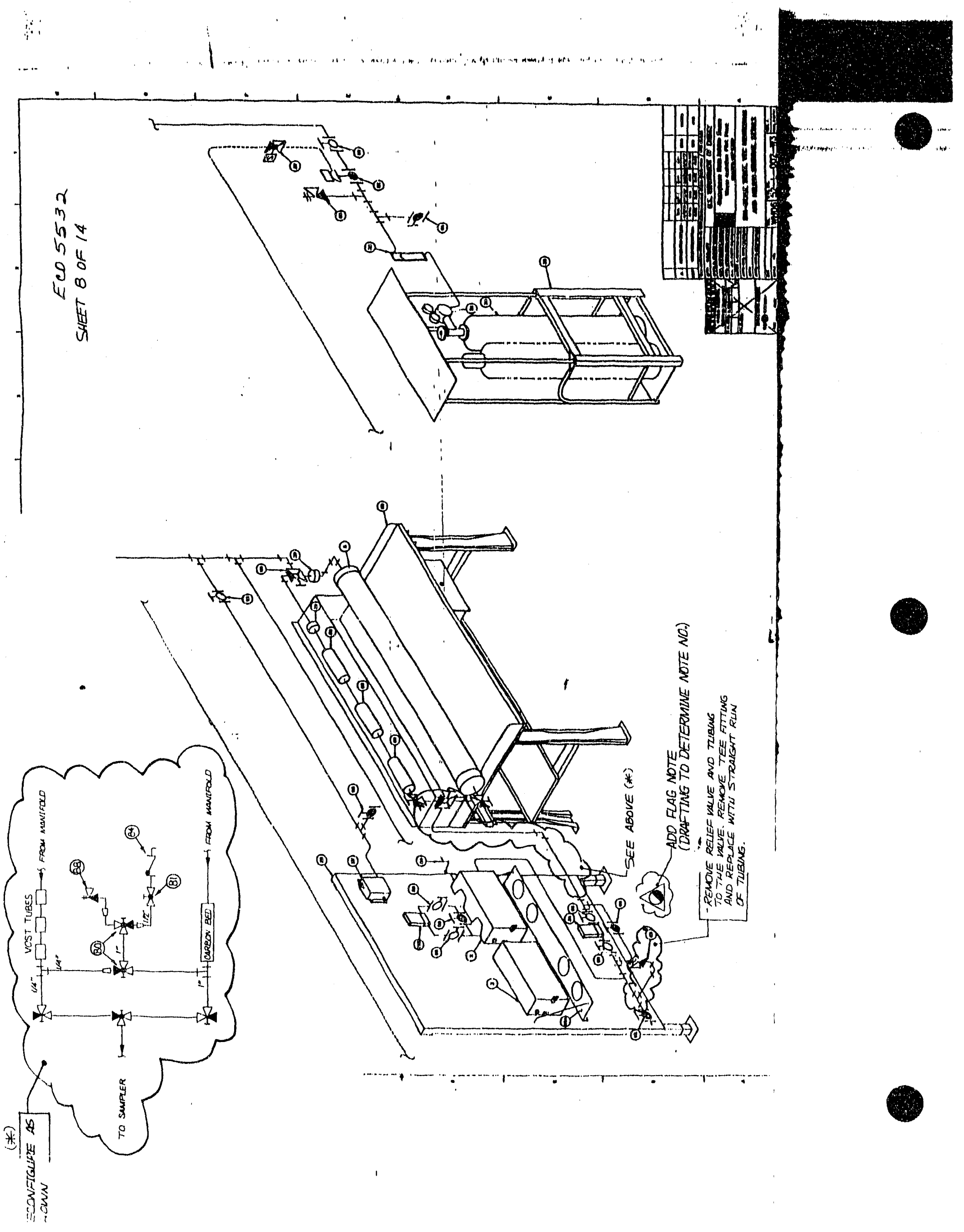




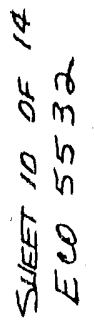

$$
\text { (B) }
$$

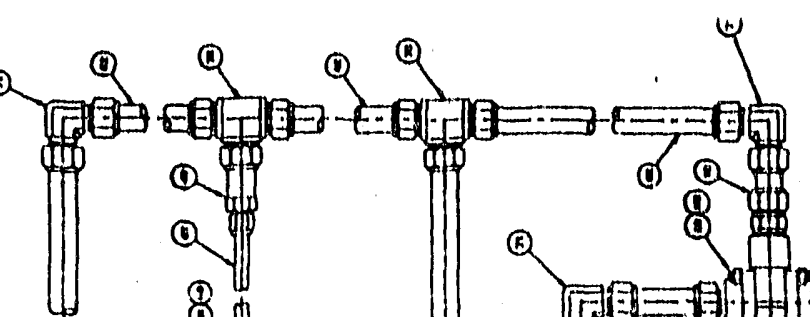

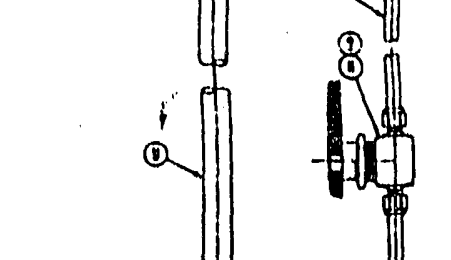

a
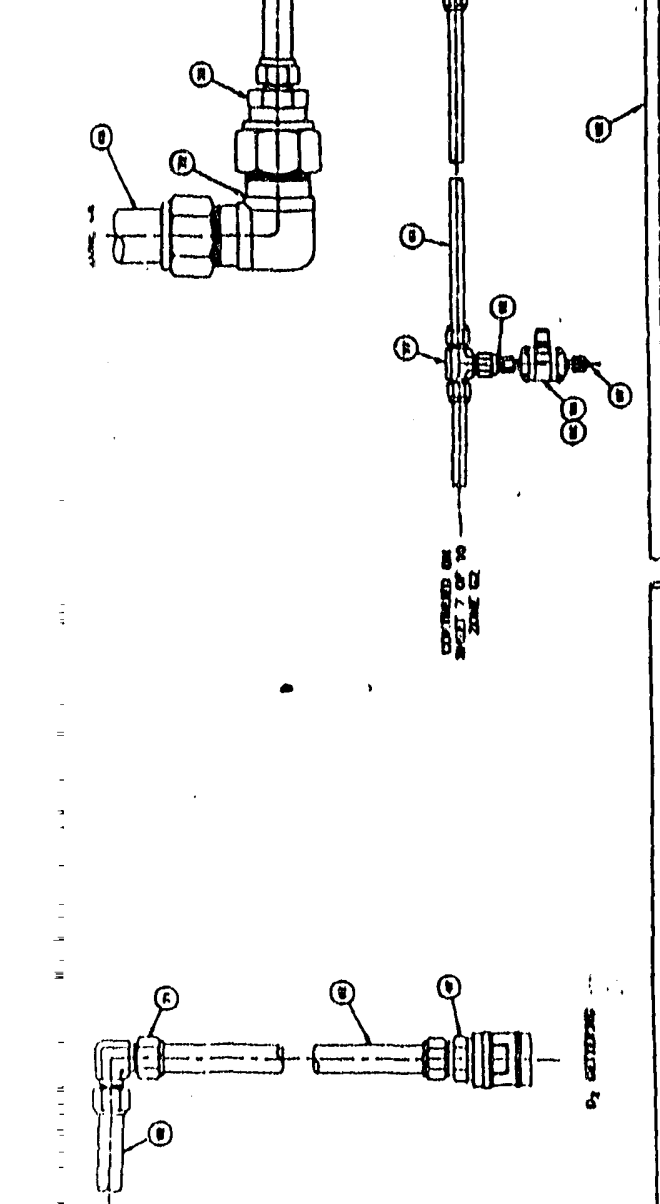

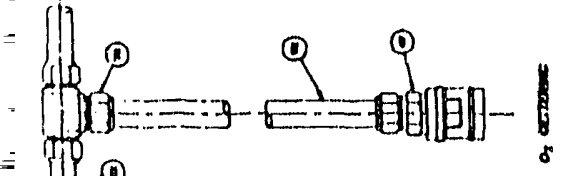

tho

H: 2 -

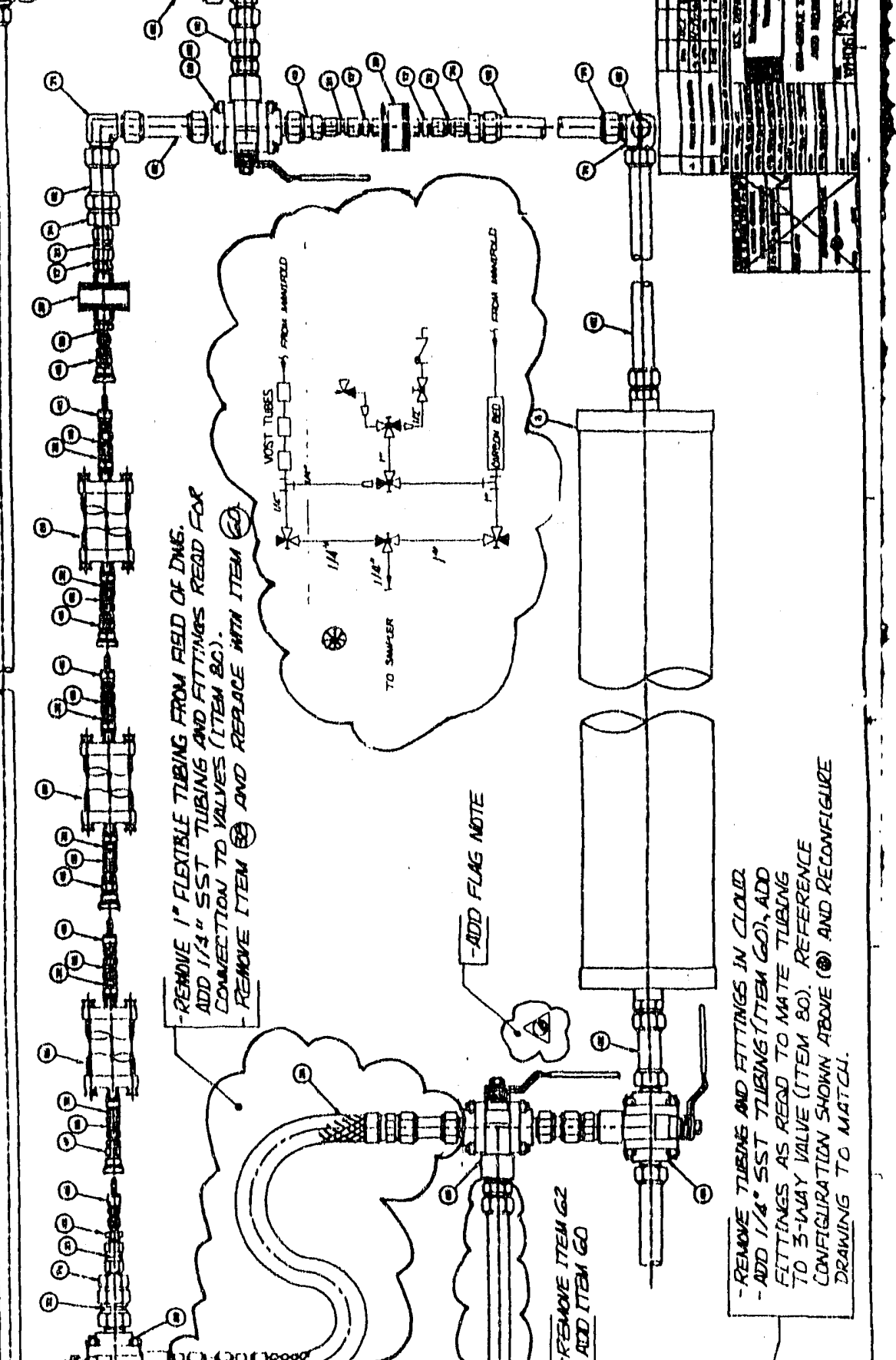




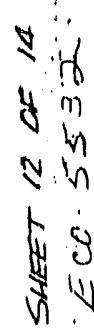

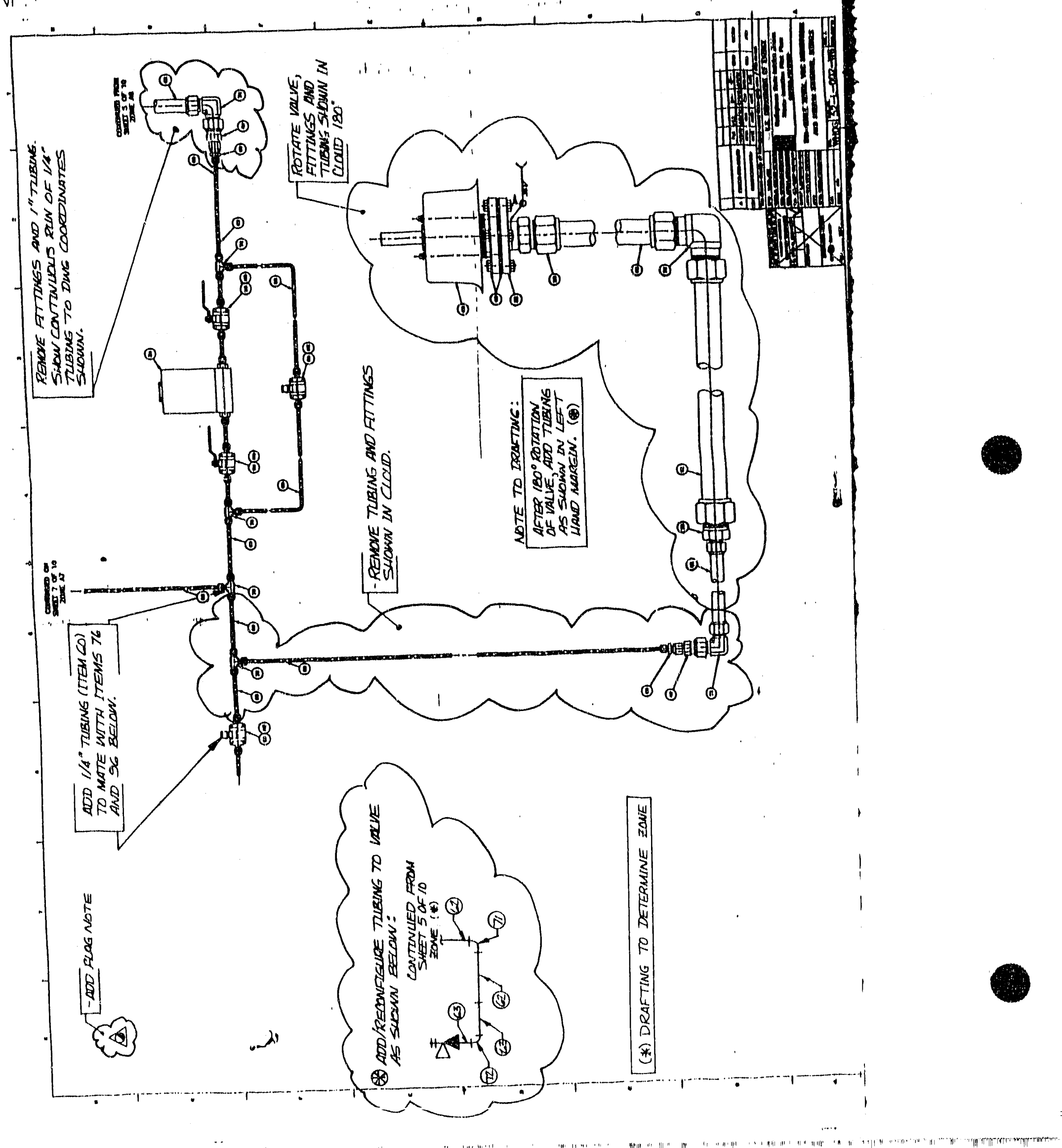




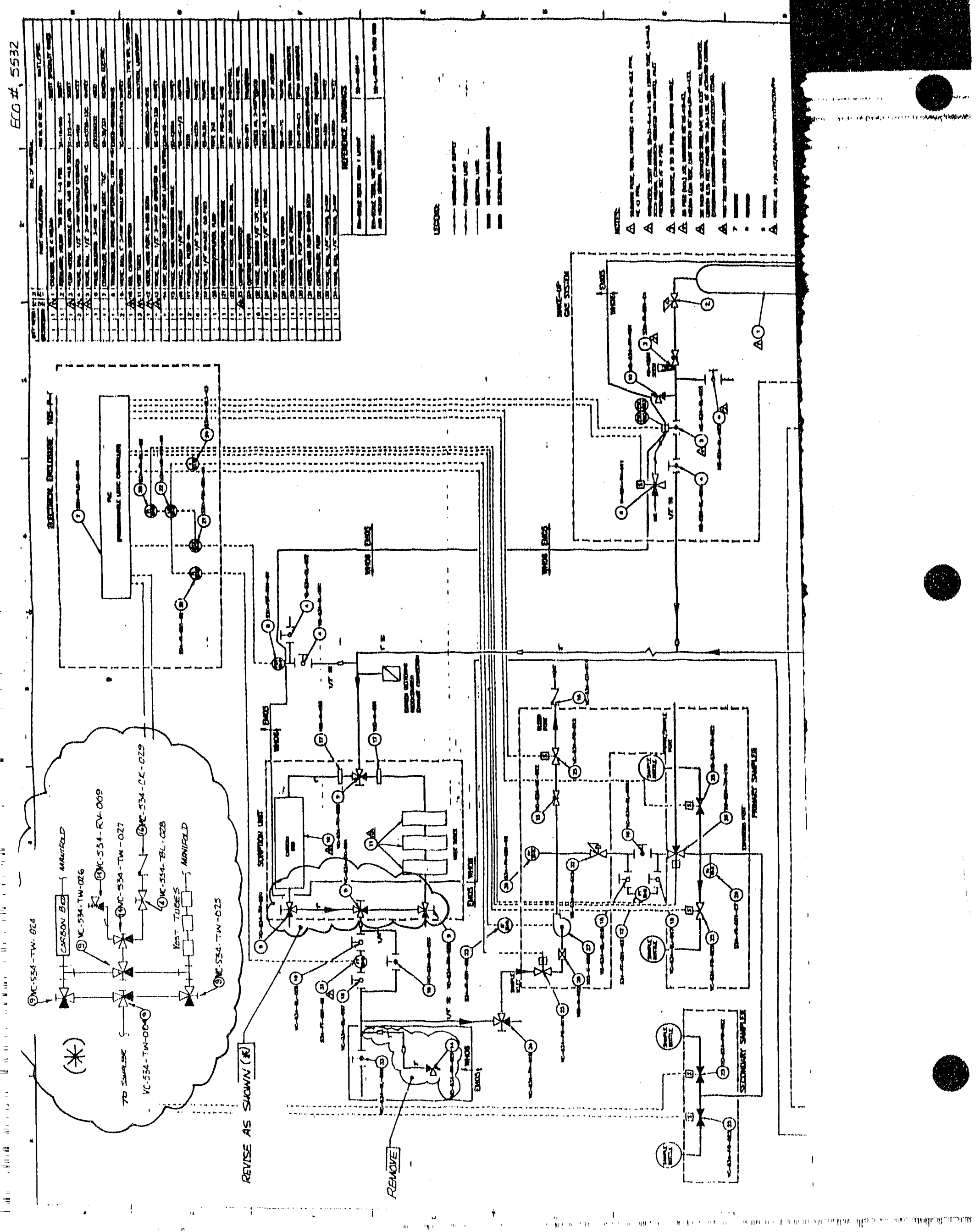


1. ECO No.: $=-1 i$ ir CC\&D Reviowit $f$

\begin{tabular}{|c|c|}
\hline \multirow[b]{2}{*}{ Initials } & 2. Impact Level $1 \square \quad 2 \square 3 \square$ \\
\hline & 3. System: Hvo1/CFOz. Equipment No. \\
\hline \multirow[t]{5}{*}{ Posted } & 4. Associated Documents: \\
\hline & $M 40880$ \\
\hline & ECP \\
\hline & P.O. \\
\hline & Others \\
\hline
\end{tabular}

$4 \square$

6. Document Type:

Drawing

Speciflication

Vendor Data

SDD

Others

6. Title of Change: $C_{-}-B_{\text {uiltion }}$

7. Originator: (print) Ext. No.: Department: Date: Wm BarnHART 8169 MtCE

9. Description of Change:

Th Yes No Component indices change required The following durga nesd to be $\triangle \square$ (if yos, attach shoots) remised to shour the addition of one or mone of these items : Ovempacte Emeloame, Exit Pontal, $11-R-080$.

$$
\begin{array}{llll}
41-B-001-\omega, \text { sht 2 } & 41-E-013-014 & 41-6-122-014 & 41-5- \\
41-E-001-014 & 41-F-022-014 & 41-6-302-014 & 509-014 \\
41-E-000-014 & 41-6-120-014 & 41-6.501-014 &
\end{array}
$$

The following durge need to be revised to shour that a referenced durg hac been superseded: $41-3-\infty 1-\omega$, sht 1

9a Drawing Change Sheet attached

9c Vendor Data Change Sheet attached

9b Design Documentation Sheet attached

10. Yes No

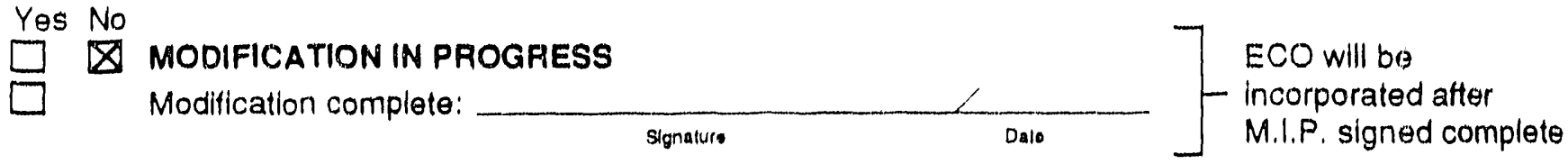

Change drawing per as-bullt markup dated:

Change drawing per ECO-provided data

Temporary modification

11. Design Verificgtion Requirements: (per WP 09-018)

EDT No:

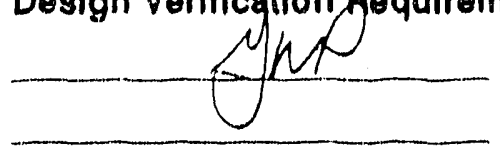

1. Requirements satisfled by review/approval of design document

2. Independent review

3. Altemate calculations

4. Development testing

5. Design review

6. Other:

12. Addendum Shoot added: 


\section{Justiflcation}

The cluge meed to be reviced to replact existing site conditione..

\section{Administratlve Tracking}

YES N/A

$\square$ 1. FSAR

$\square \bigotimes$ 2. Calibration Procedures

$\square$ 3. Maintenance Procedures

$\square$ 4. Computer Software

D 5. Operations Procedures

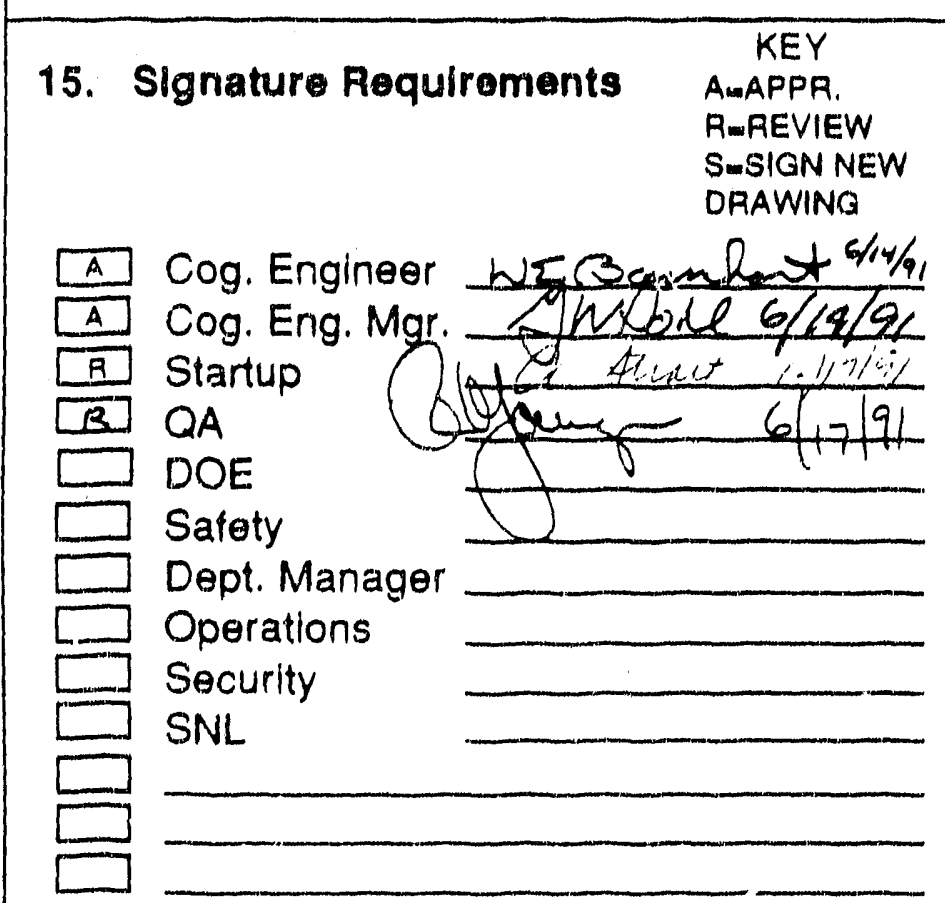

9.

10.

16. Distribute as Marked 


\section{DOE ORDEA 6430.1A DESICN CRITERIA CHECKLST}

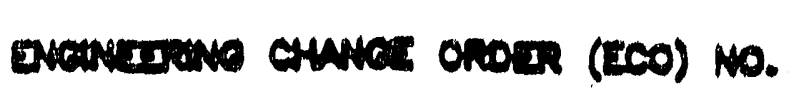 $\frac{551}{\log 3+32}$
DATE

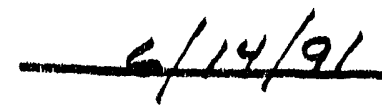
cocinzunt ENewat WD BASNHART

The design requiruments in DOE Ordur 6430.1A chooked bolow heve been applied to this Deaign.

\begin{tabular}{|c|c|}
\hline DNATON & SUEOMSKON \\
\hline 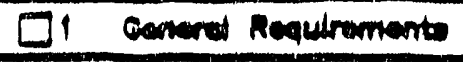 & $\square 0101 \square 0100 \square 0101 \square 0110 \square 0111 \square 0140 \square 0130 \square 0170$ \\
\hline Q2 Sto and ard & 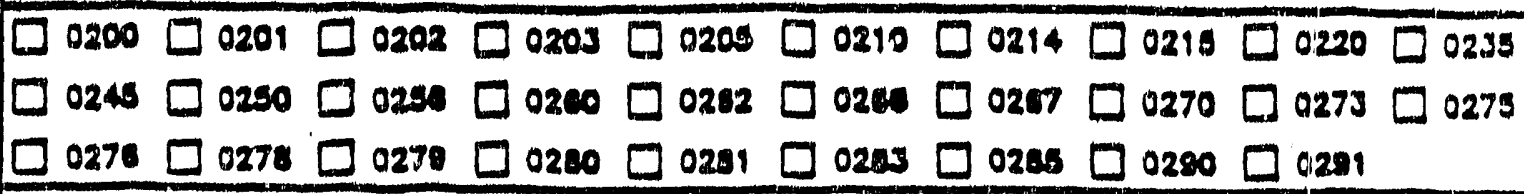 \\
\hline$\square^{3}$ Conerote & $\square 0300 \square 0301 \square 0310 \square 0320 \square 0330 \square 0340 \square 0350 \square 0370 \square$ a1380 \\
\hline Q4 Maseony & $\square 0400 \square 0401 \square 0410 \square 0420 \square 0435$ \\
\hline Qs wers & $\square 0000 \square 0012 \square 0514 \square 0521 \square 0531 \square 0532$ \\
\hline D6 Wood and Plantlea & $\square 0600 \square 0010 \square 0000$ \\
\hline [7. Tharmet end Motriture & $\begin{array}{l}\square 0710 \square 0711 \square 0714 \square 0718 \square 0710 \square 0720 \square 0721 \square 0722 \square 0724 \square 0727 \\
\square 0730 \square 0750 \square 0751 \square 0753 \square 0700 \square 0700\end{array}$ \\
\hline Q. Deare and Whedows & $\begin{array}{l}\square 0000 \square 0010 \square 0020 \square 0030 \square 00030 \square 0030 \square 0030 \square 0850 \square 0060 \square 0870 \\
\square 0000\end{array}$ \\
\hline$\square \cdot$ Pundunes & 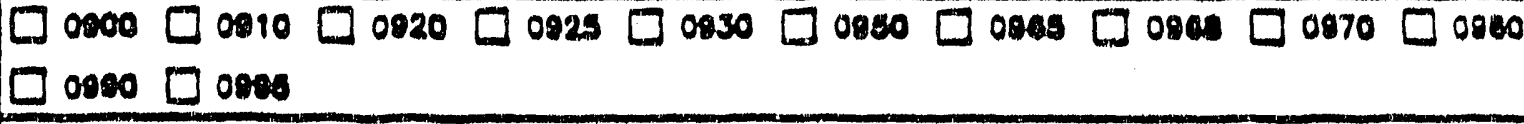 \\
\hline Q10 Speration & $\begin{array}{l}\square 1015 \square 1020 \square 1024 \square 1027 \square 1030 \square 1040 \square 1050 \square 1052 \square 1053 \square 1056 \\
\square 1000 \square 1005 \square 1070 \square 1074 \square 1080\end{array}$ \\
\hline Dil Cevipmeant & $\square 1100 \square 1181$ \\
\hline Q12 Fumishingen & $\square 1201 \square 1230 \square 1250 \square 1200 \square 1270$ \\
\hline Q13 spooded Factitition & $\begin{array}{l}\square 1300 \square 1304 \square 1305 \square 1300 \square 1307 \square 1318 \square 1310 \square 1320 \square 1321 \square 1322 \\
\square 1323 \square 1324 \square 1325 \square 1320 \square 1328\end{array}$ \\
\hline Q14 Convosing Syotems & $\square 1401 \square 1420 \square 1440 \square 1440$ \\
\hline Q15 Mentenied & 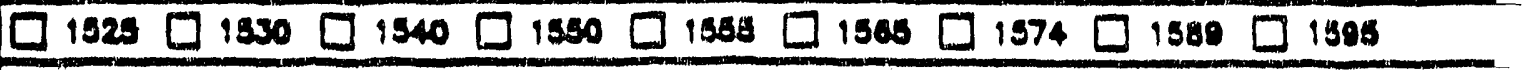 \\
\hline Q 10 Ebed & $\begin{array}{l}\square 1800 \square 1608 \square 1820 \square 1030 \square 1630 \square 1040 \square 1850 \square 1680 \square 1670 \square 167 \\
\square 1680 \square 1604\end{array}$ \\
\hline
\end{tabular}

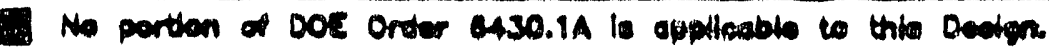

NOTE: A check placed in the Diviaton column ignifice thet the entire OMladon shall be opplicable to the Deaign unteas

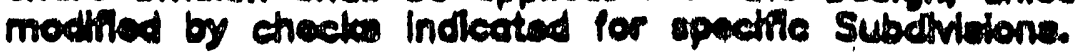


1. Drawing: $41-3-001-02$, sht L, Rear $C$ ECONumber: $\frac{5-51}{\text { py } 4 \text { of } 32}$

2. ECO Searoh Llst:
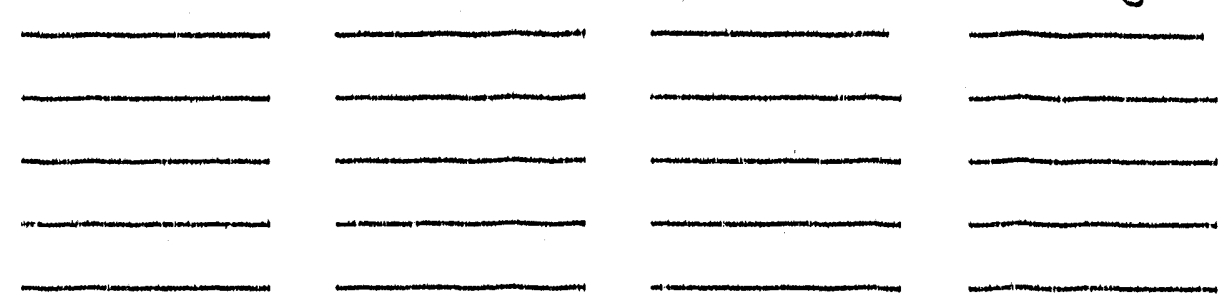

3. Descriptlon of Change:

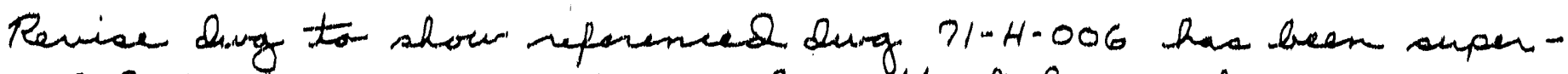
aded by dury 105-J-004-W. See attachal makkup.

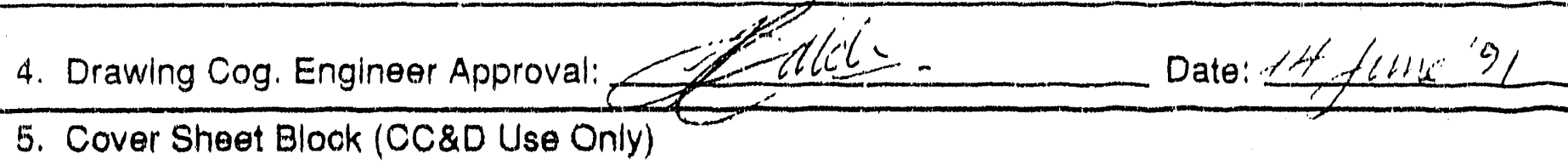

Fecelved from EFR: Initlals / Date

Date Assigned:

Assigned to:
Initials / Date

(Same as data base entry)
Dratting Started:

Drafting Completed:

Return to EFF:
Initials / Date

Inilials / Date

Inifials / Date 


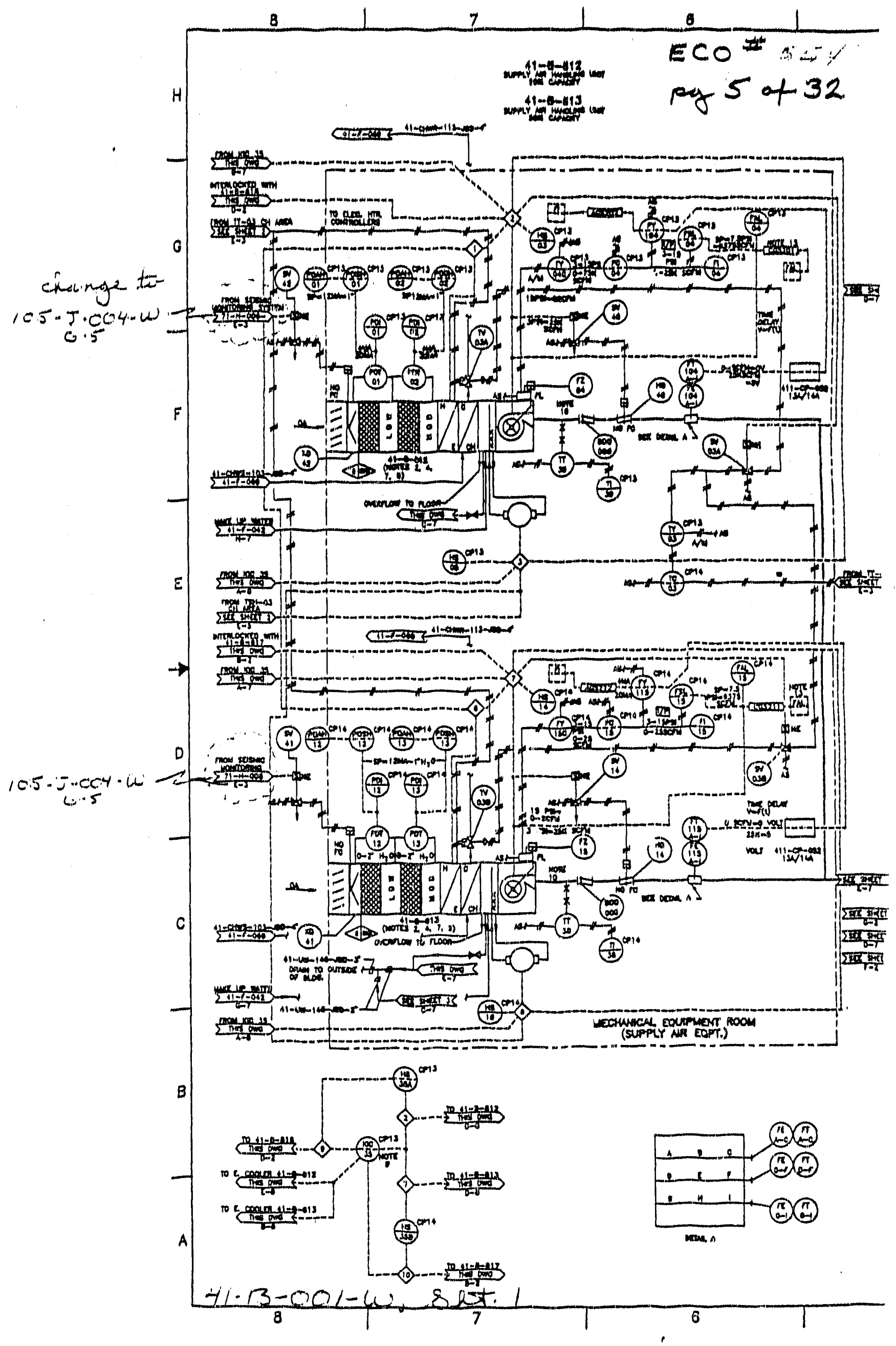


9a

DRAWING CHANGE SHEET

(1 SHEET PER DRAWING)

1. Drawing: $41-3-021-C), 8 h+2$, Rare C ECO Number:

2. ECO Search Llst:
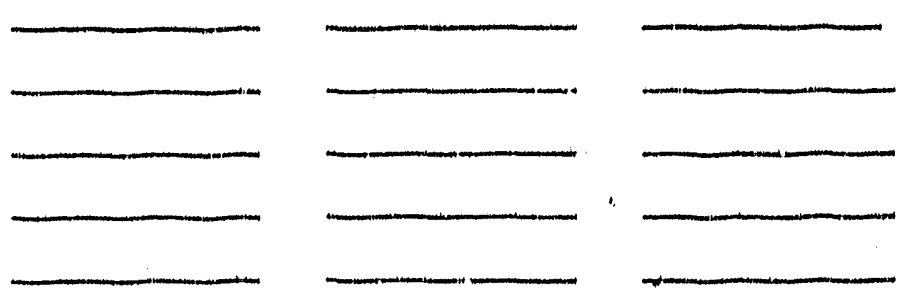

3. Description of Change:

Reviac durg to show referenced duy 1/-H-006 has been supenseded by dury 105-J-004- $\omega$.

Reuice durg to show addition of Exit Pontal w/HEPA filters and POI' $32-35$.

see attached markeup.

4. Drawing Cog. Engineer Approval: Cover Sheet Block (CC\&D Use Onty) Date: $14,1.14:$ ?

Recelved from EFR: Initials / Date

Date Assigned:

Assigned to:
Drafting Started:

Drafting Completed:

Peturn to EFP:
Initials / Date

Inillals / Date

Initlals / Date 
ches

$41-0-930$

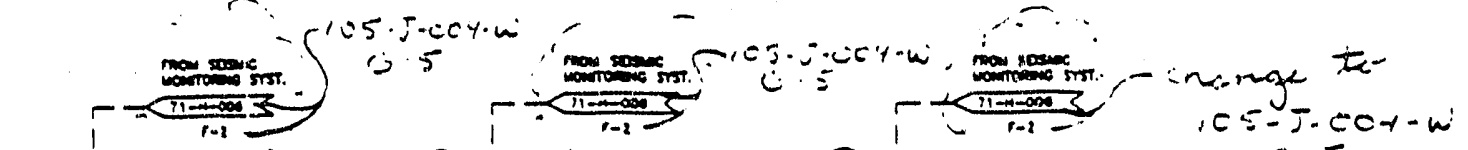

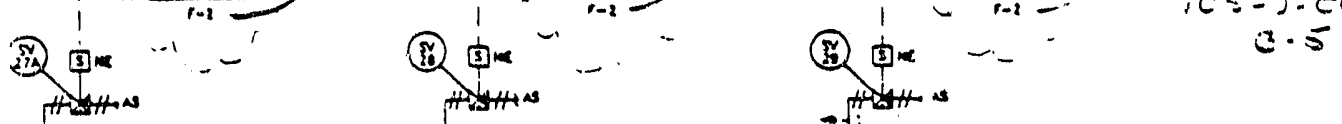

a. 5

Now

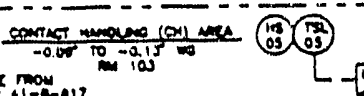

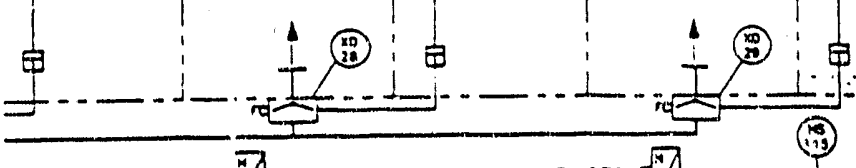

$\frac{11-9-938}{(0.5)}$
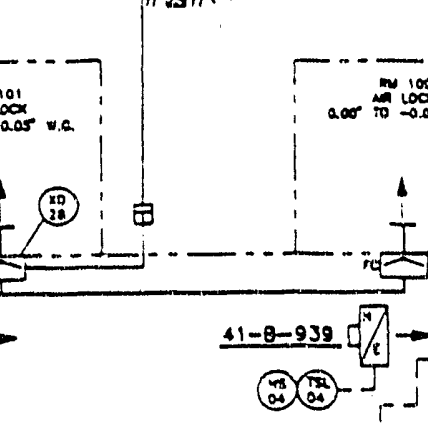

(1)

$+7$

cmong
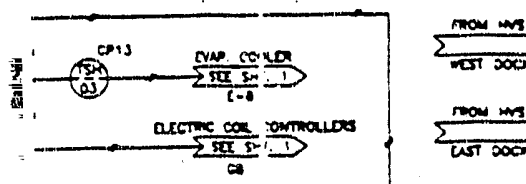

(

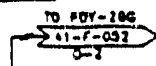

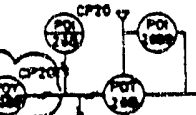

(2)

(9i)

1,

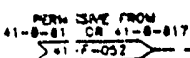

$\sum_{\text {Wis } \infty 00}^{\text {nom }}$

(28)

thex

ancisingan

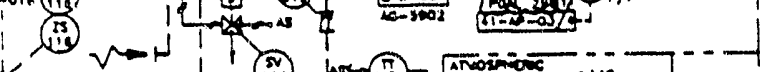

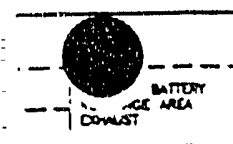

(iii)

$(190$

(요료

IT

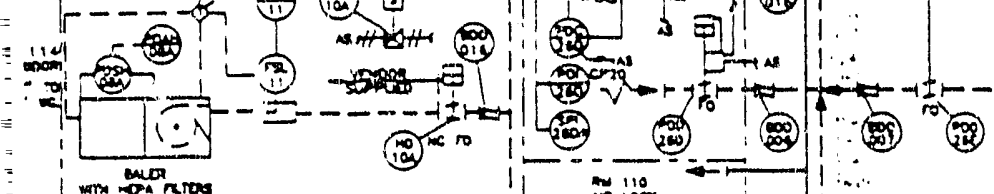

1

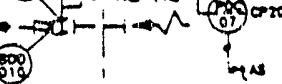
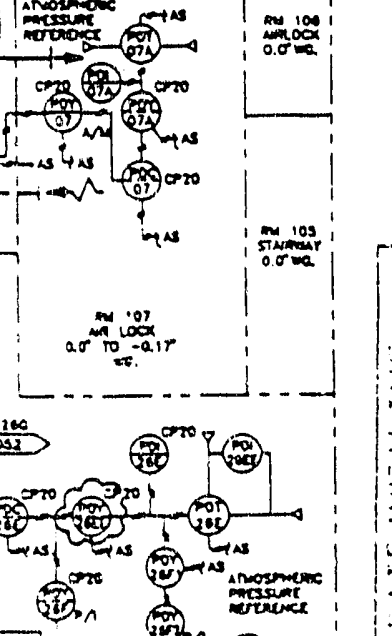

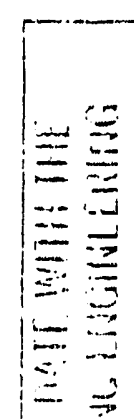

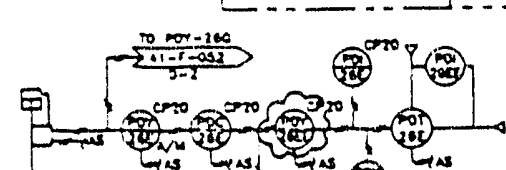

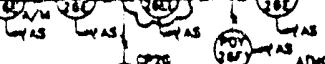
6

प्यक्ण

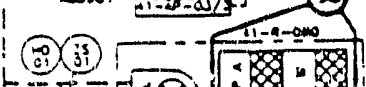

=|

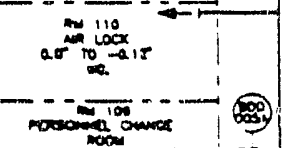

(3)

$\rightarrow-\frac{T}{T}(18)$
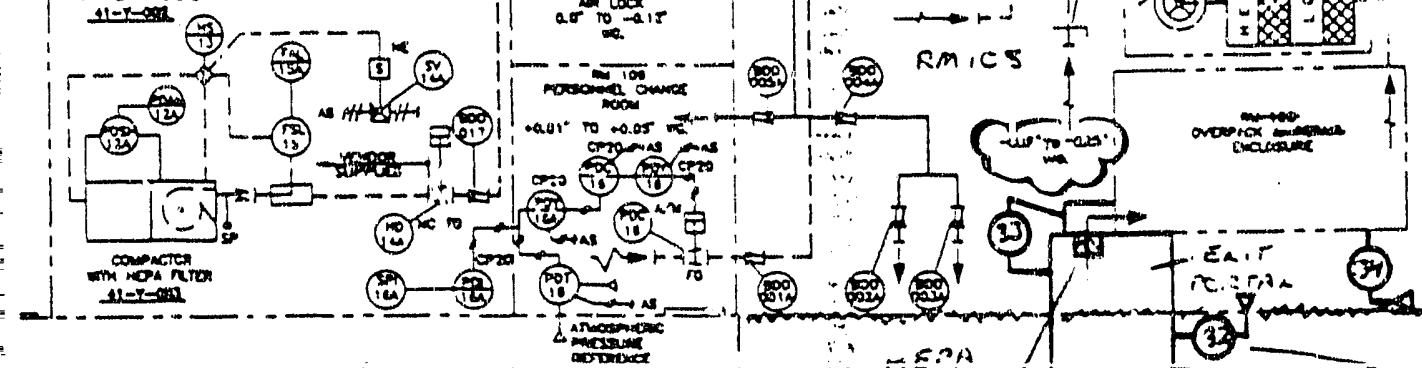

(ioc)

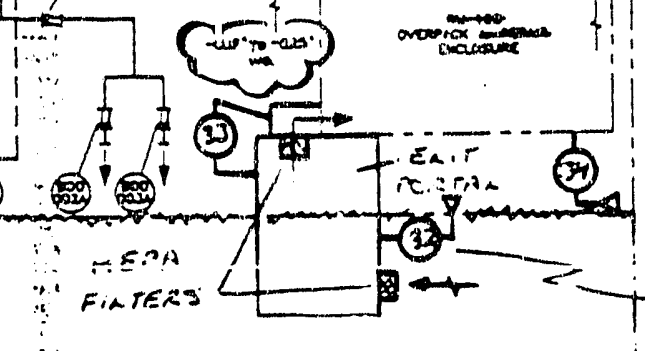

endenge Ren 105 te

cliew ididitern if

pontón

$54,-B^{4}-\infty,-i,{ }^{4}-8 \alpha=2$

2

T

il incinumant mumprea showr ane to be popecien lyg "PDE".

MNTE HWOUNG ELOC. 41

Fivo1 $41-8-001-W \mid \frac{1}{x i 0}$ 


\section{$9 \mathbf{a}$ \\ DRAWING CHANGE SHEET \\ (1 SHEET PER DRAWING)}

1. Drawing: $41-3-001-\omega$, sht 3, Rew 3 ECO Number: $554 /$ $\operatorname{pg} 8$ of 32

2. ECO Search List:
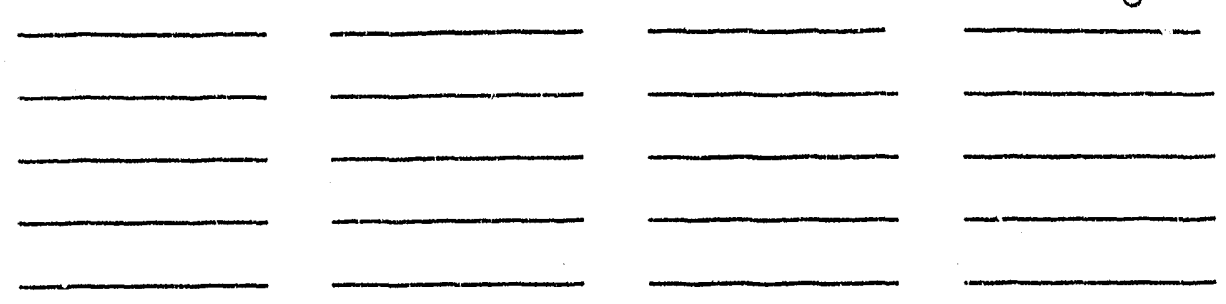

\section{Description of Change:}

Revise dug to show sefersinced dung 71-11-006 has been superseded by dury 105-5-004-W. See attached mankup.

4. Drawing Cog. Engineer Approval:

Date: 14 fini 91

5. Cover Sheet Block (CC\&D Use Only)

Received from EFR: Initials / Date

Dâté Ássignกล:

Initials / Dato

Assigned to:

(Same as data base entry)

Drafting Started:

Drafting Completed:

Return to EFR: Initials / Date Initials / Date Initials / Date 


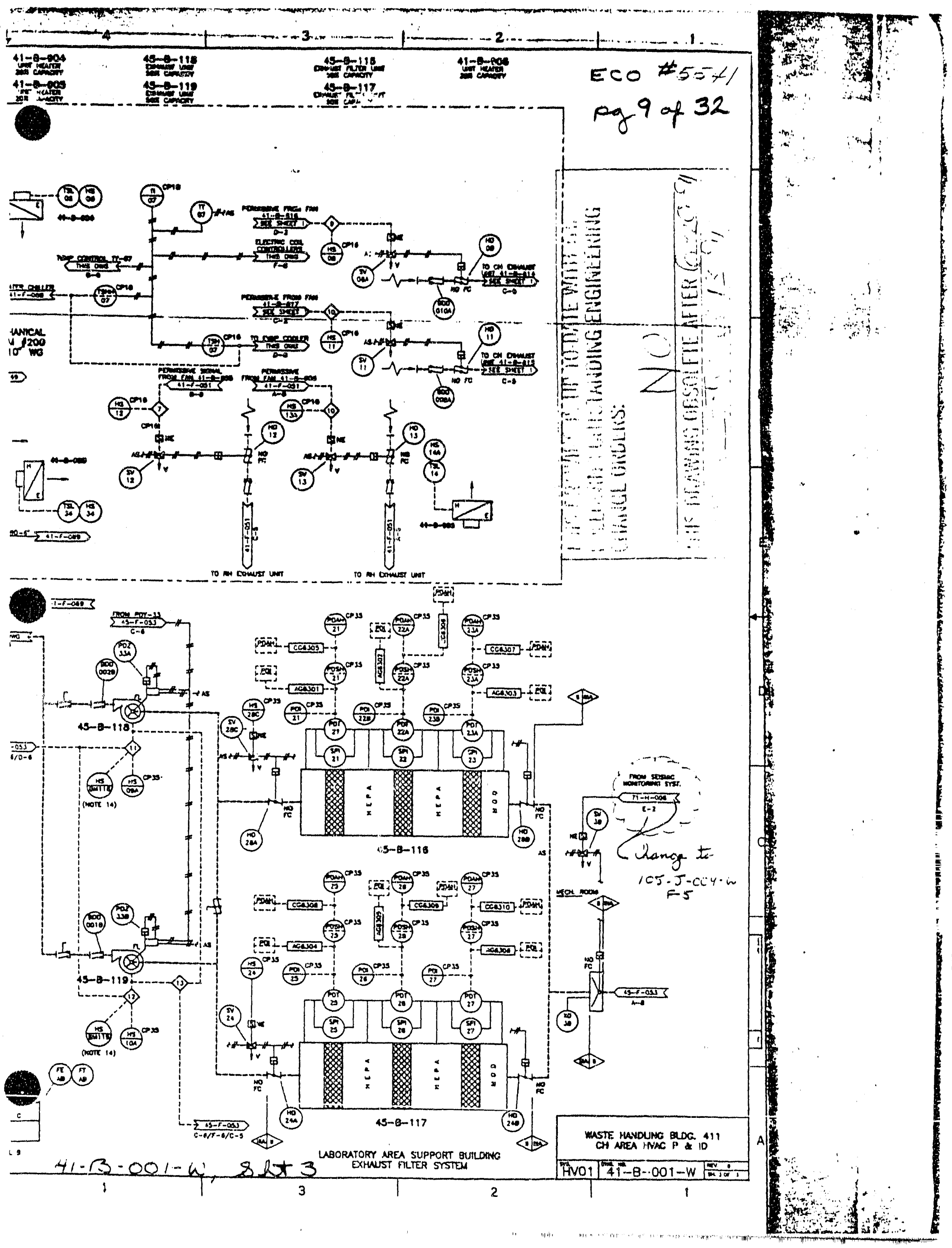




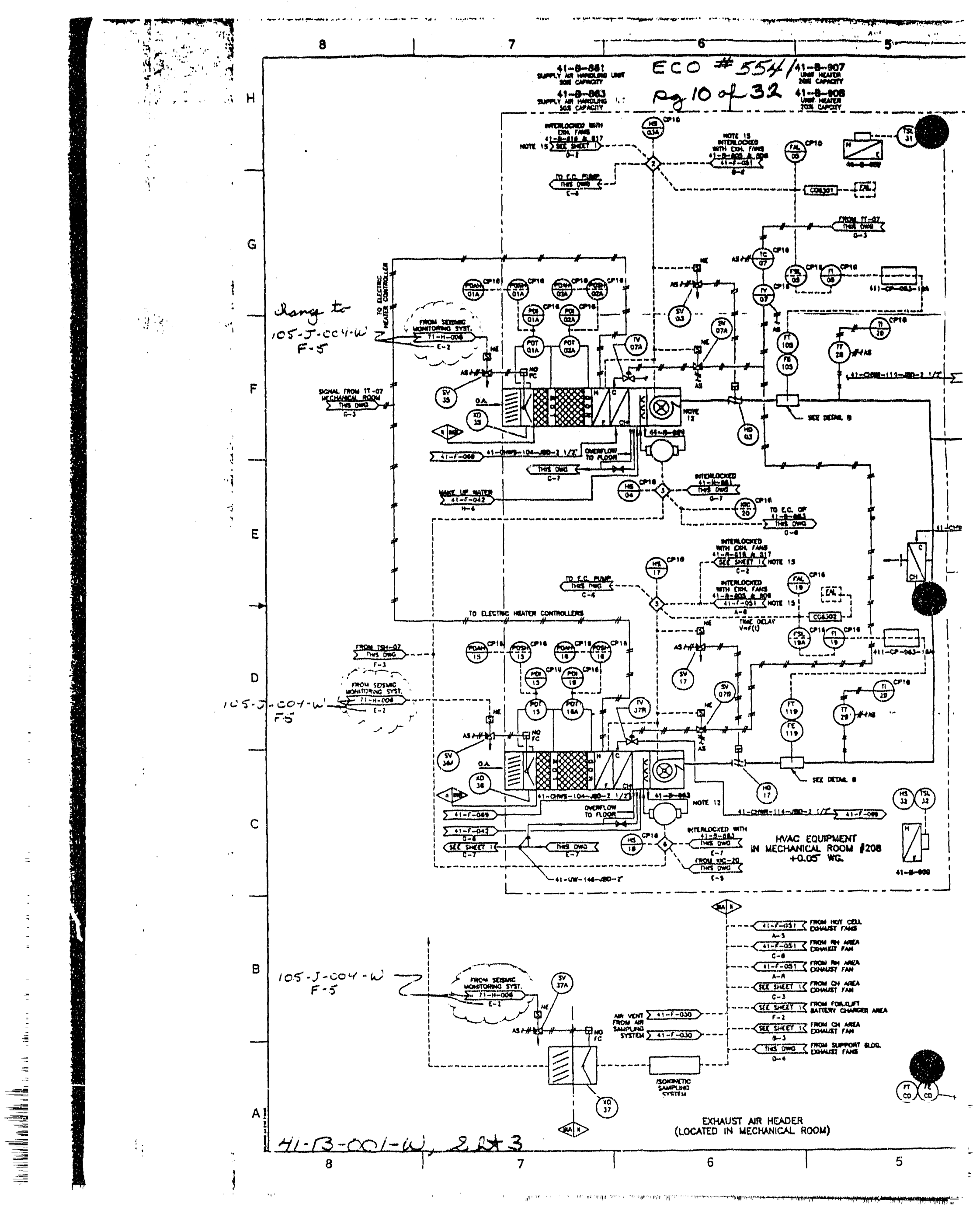




\section{$9 a$}

\section{DRAWING CHANGE SHEET}

(1 SHEET PER DRAWING)

1. Drawing: H1-.E-001.014, Rearo ECO Number: pg 11 of 32

2. ECO Search List: 4622
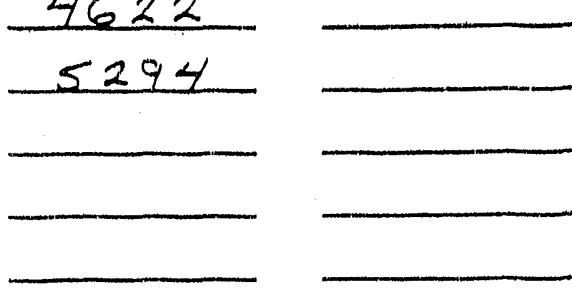

3. Description of Change:

Revise dung to chow footprint for "Ovapack Encloane" and "Exit Poutal". Delete "Waste \#andling Office". See attached markup.

4. Drawing Cog. Engineer Approval: 7. frw a $1 / 2$ Date: $6 / 14 / 9 /$

5. Cover Sheet Block (CC\&D Use Only)

Received from EFR:

Date Assigned: Initials / Date Initials / Date

Assigned to:
Drafting Started:

Drafting Completed:

Return to EFR:
Initials / Date

Initials / Date

Initialo / Date 

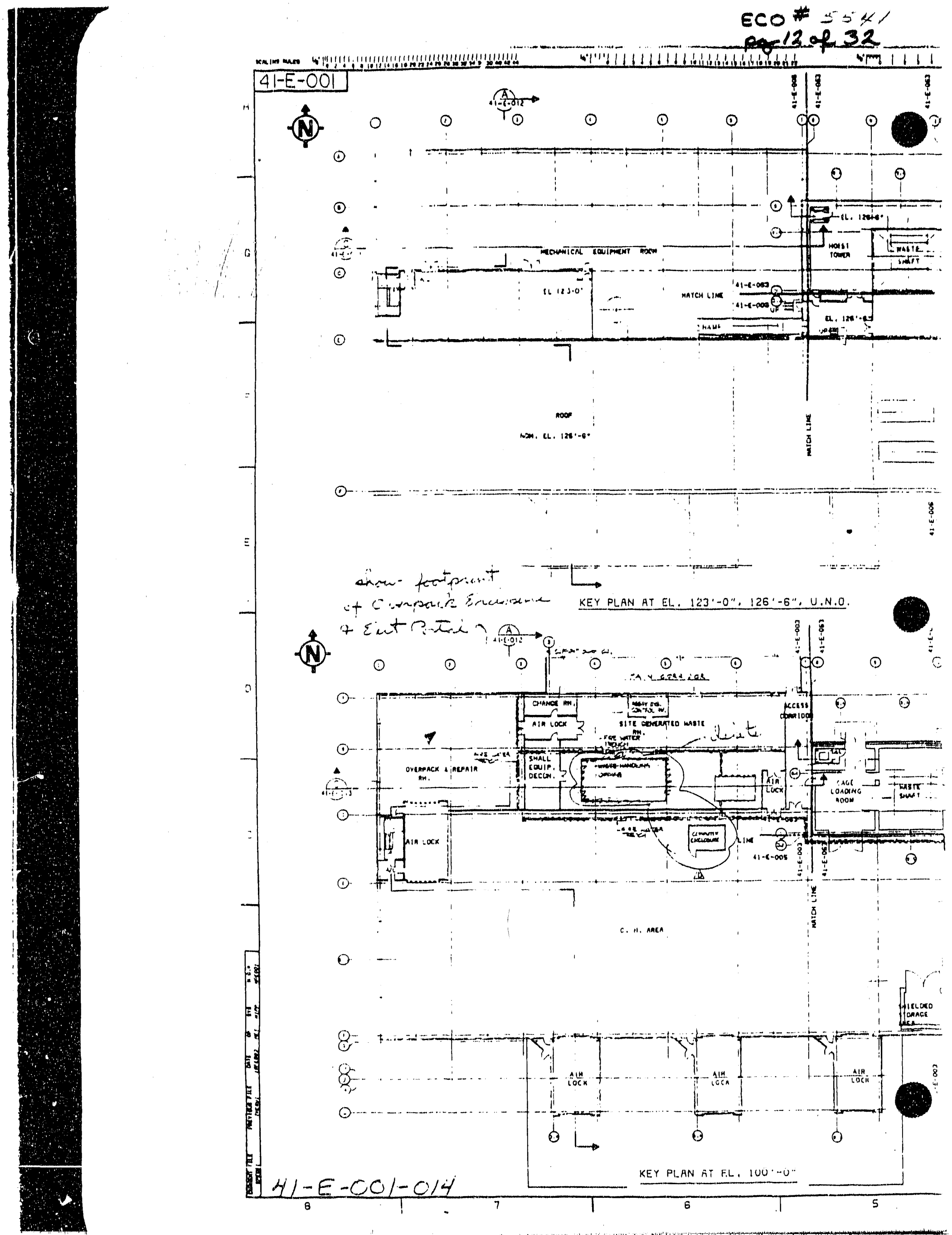
$9 a$

DRAWING CHANGE SHEET

(1 SHEET PER DRAWING)

1. Drawing: $41-E-003-0 / 4, \operatorname{Re}=0$

ECO Number: 5541

pg 13 of 32

2. ECO Search List: 4632

5294

3. Description of Change:

Reviae dug to shour forotprint for "Overpack Enclosuc" and "Exit Portal". Bilete "Wacte \#andling Office". She attached mankup.

4. Drawing Cog. Engineer Approval: 7. Km a d Date: $6 / 14 / 9 /$

5. Cover Sheet Block (CC\&D Use Only')

Received from EFR:

$$
\text { Initials / Date }
$$

Date Assigned: Initials / Dato

Assigned to:
Drafting Started:

Drafting Completed:

Initials / Date

Initials / Date

Return to EFR:

Initials : Date 

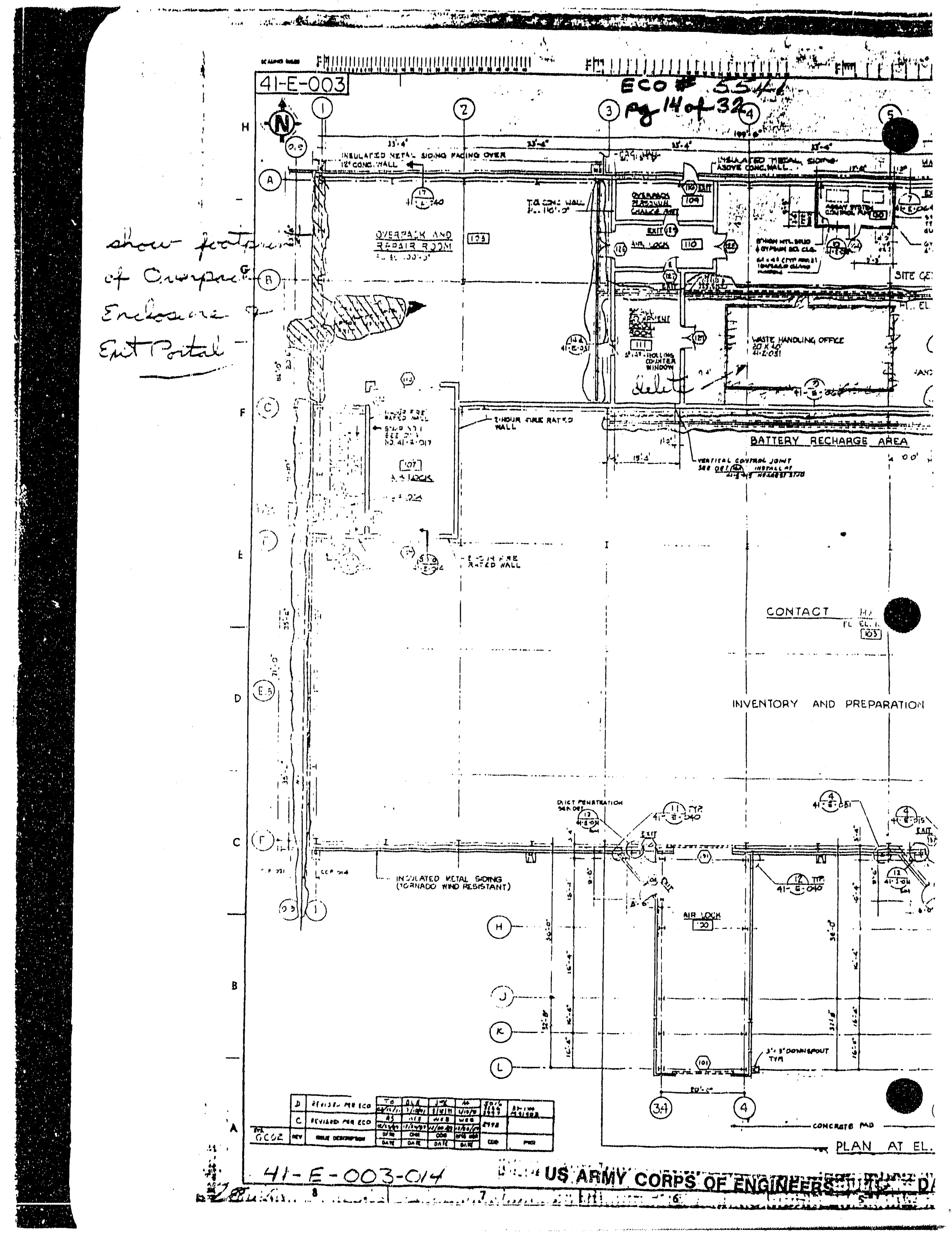
9a

DRAWING CHANGE SHEET

(1 SHEET PER DRAWING)

1. Drawing: $41-E-0 / 3=0 / 4, \operatorname{Rev}=0$ ECO Number: $\log 15$ of 32

2. ECO Search l.ist: $50 / 6$
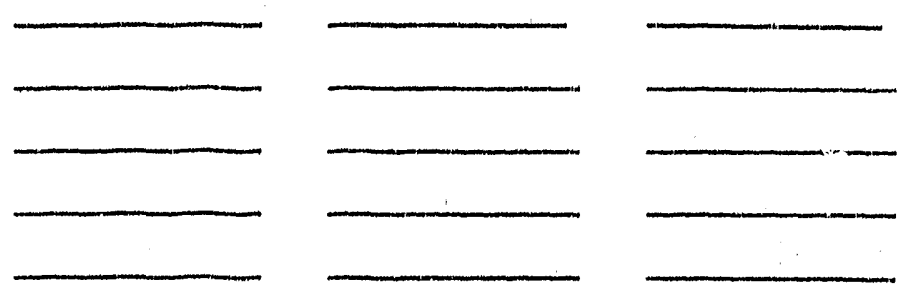

3. Description of Change:

Remise durg to ahour "Omaspacte Encloame" and "Exitiportal". see attachas monleup.

4. Drawing Cog. Engineer Approval: 7 . Frw ov $1 / 3$

Date: $6 / 14 / 9 /$

5. Cover Sheet Block (CC\&D Use Only)

Received from EFR: Initials / Date

Date Assigned:

Assigned to: Initiais / Dale
Drafting Started:

(Same as data base entry)
Drafting Completed:

Initials / Date

Initials / Date

Return to EFR:
Initials / Date 


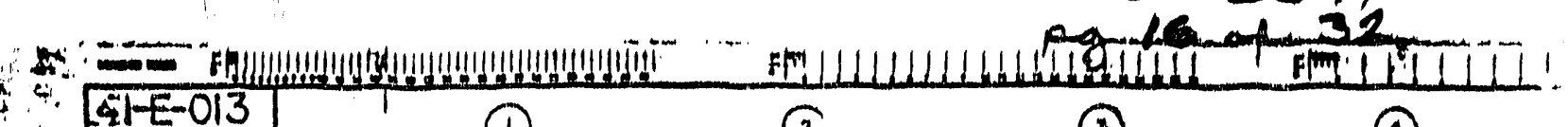

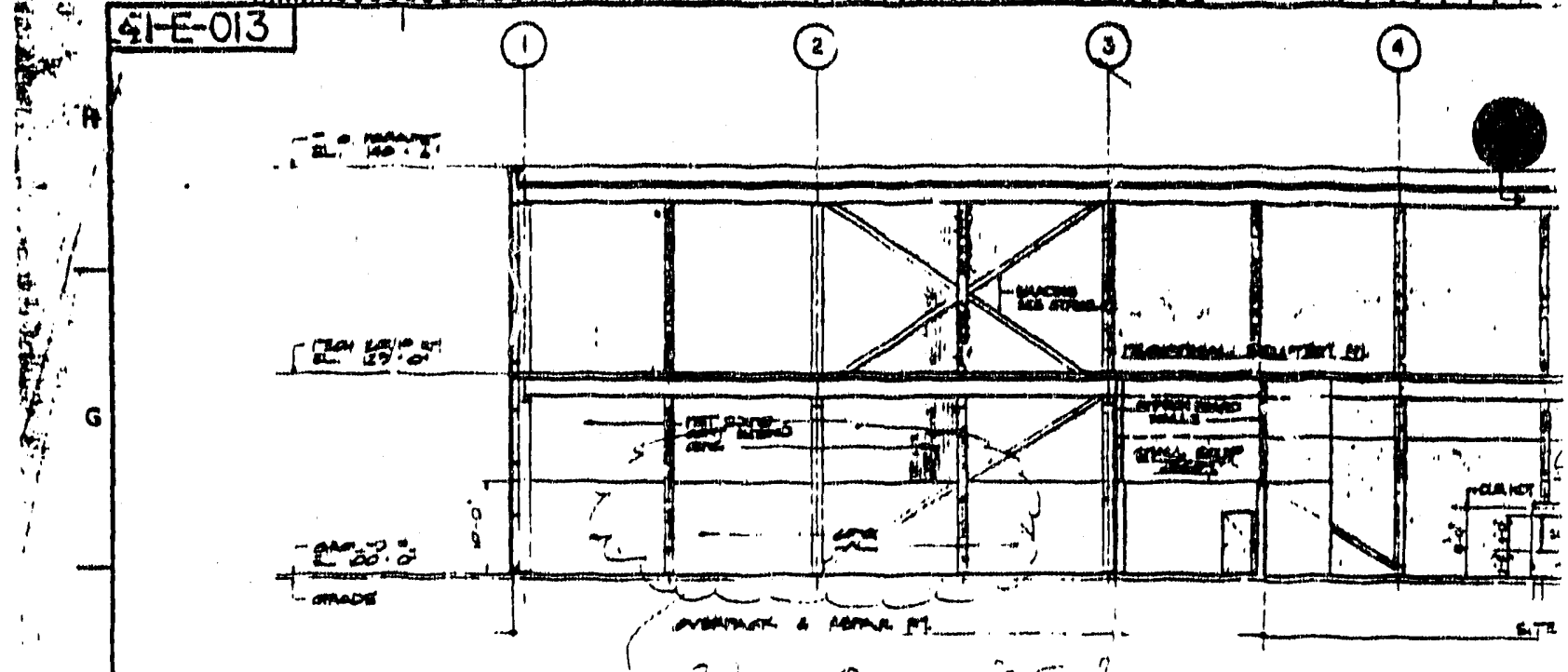

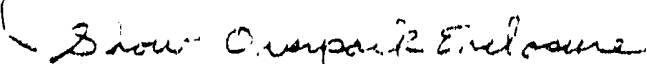
(8)
* Eut Pritue.
(9)

(10)

SECTION OCO

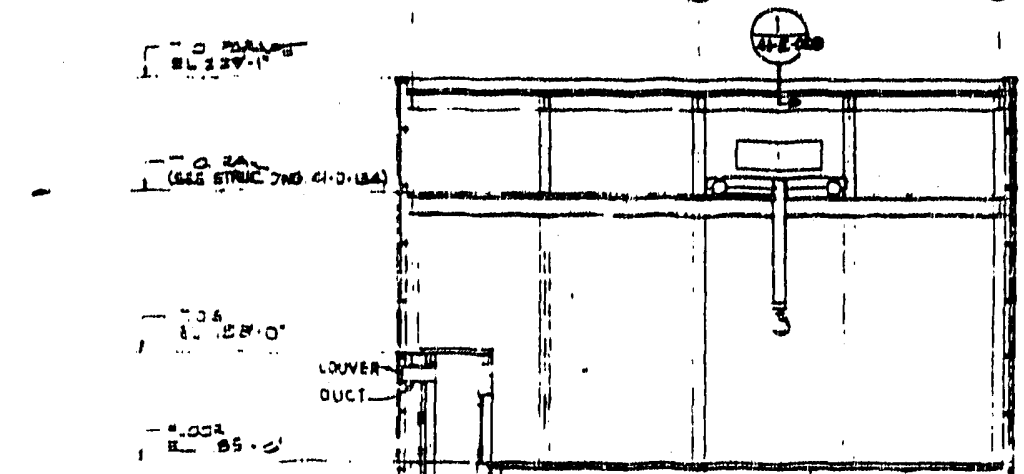

(7)

D

c

$+1.96$

\section{4.}

(7)

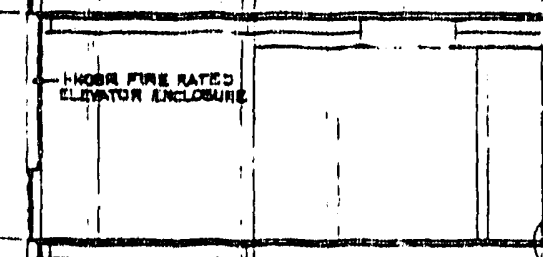

(11)

(12)

समिक्षित

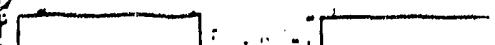

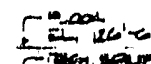

ating

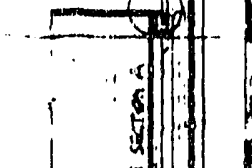

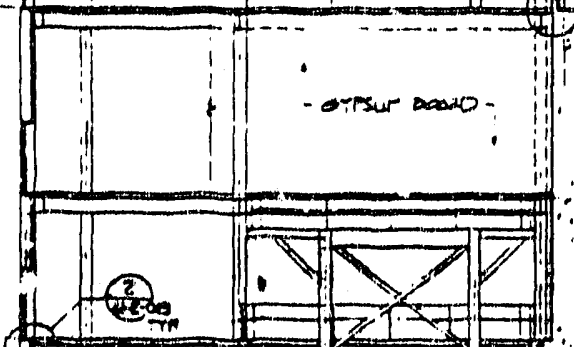

.

$\therefore$

5

reares:-5:
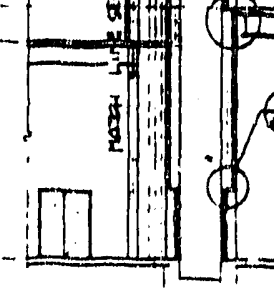

:

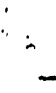

$\therefore$

$4 /-E-0 / 3-0,4$

SESTION QR

. 


\section{$9 a$}

\section{DRAWING CHANGE SHEET}

(1 SHEET PER DRAWING)

1. Drawing: $41-F=022-0 / 4$ Ren ECO Number:

2. ECO Search Llst:
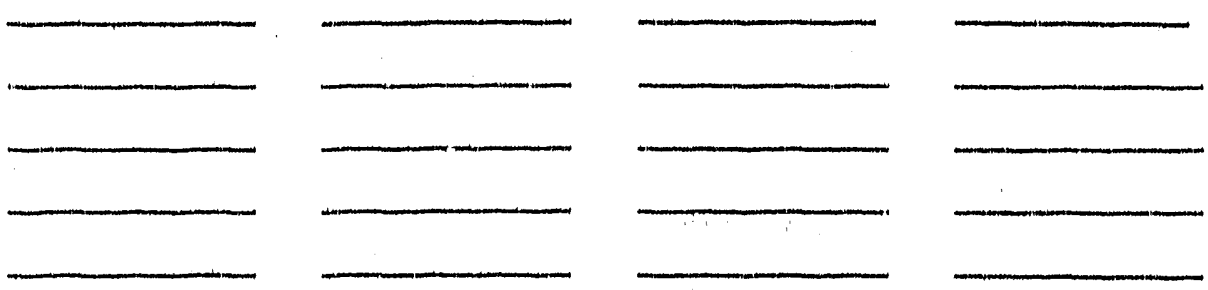

3. Description of Change:

Tevise dung to chow the addition of the "Exit Portal" to the "Overpack Encloome". Ad2 "41-R-080" to top of durg. Bee attached mankeup.

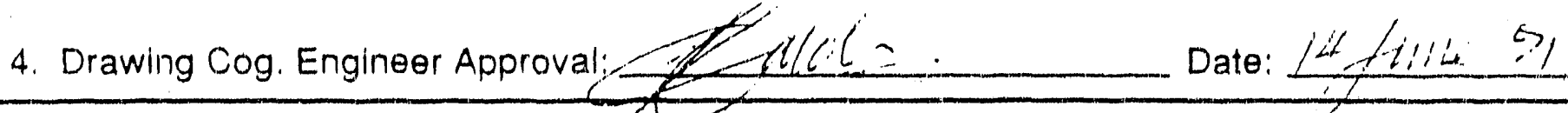

5. Cover Sheet Block (CC\&D Use Only)

Received from EFR:

Drafting Started:

Date Assigned: Initials / Date

Assigned to: Initials / Date

Dratting Completed:

Fieturn to EFR:

Initials / Date

(Same as data base entry) Inifials / Date 


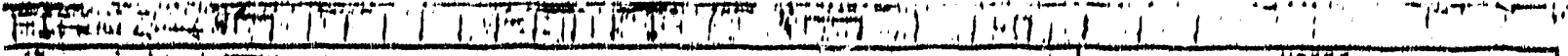

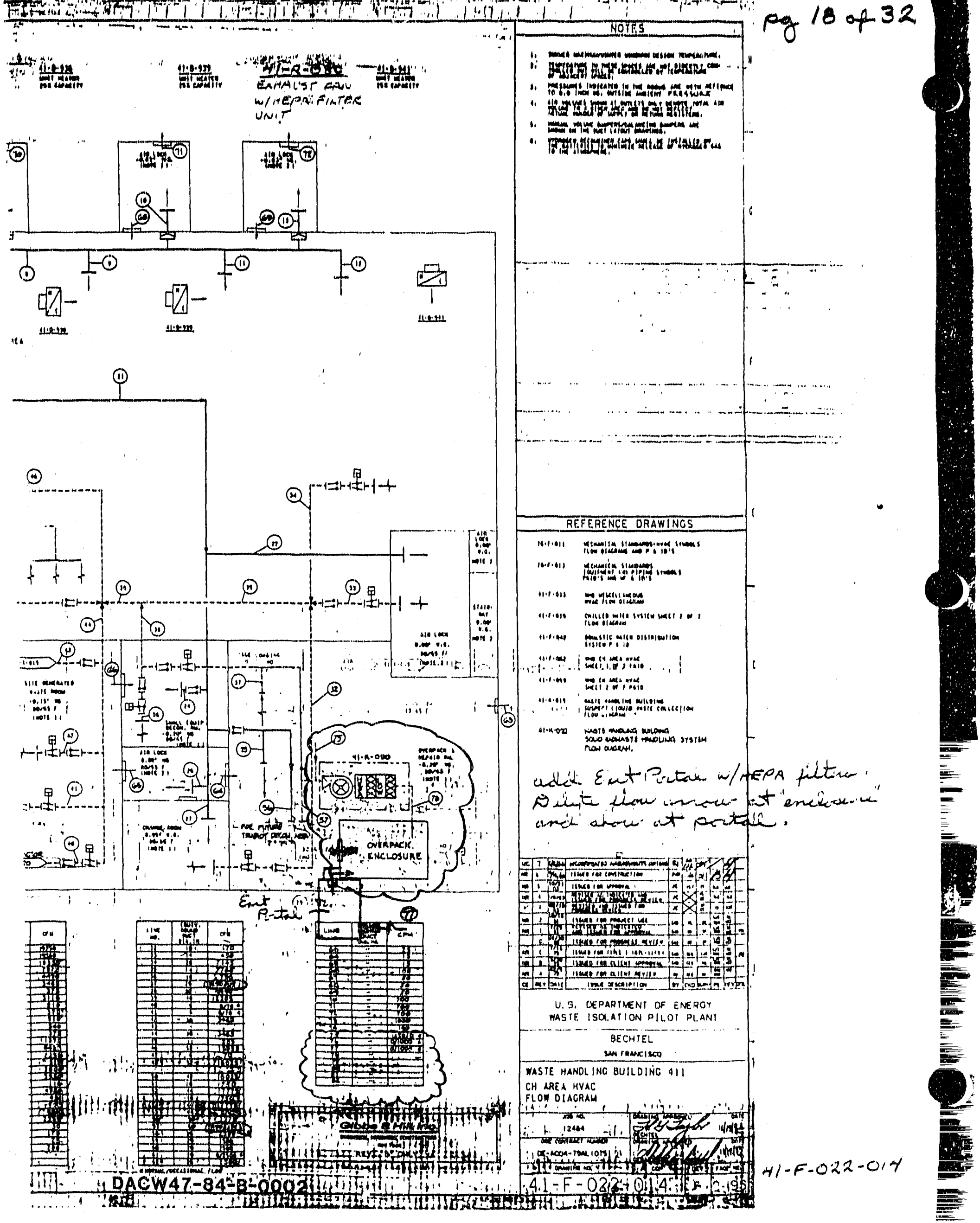




\section{$9 \mathbf{a}$}

\section{DRAWING CHANGE SHEET}

(1 SHEET PER DRAWING)

1. Drawing: $41-0-120-014$, Rere

ECO Number: $55+1$

pg 19 of 32

2. ECO Search List: 4622
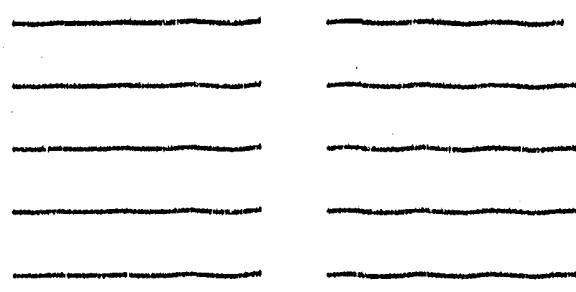

3. Description of Change:

Reviae durg to show "O verpock Enchrane", "Exit Portal", and "H1-R-080". Delete outhatid information. See attached maiteup

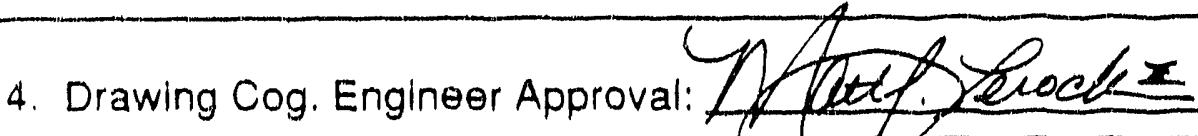
Date: $6 / 14 / 91$

5. Cover Sheet Block (CC\&D Use Only)

Received from EFR: Initlals / Date

Dratting Started:

Date Assigned: Drafting Completed:

Assigned to: Initials / Daie

Return to EFF: 


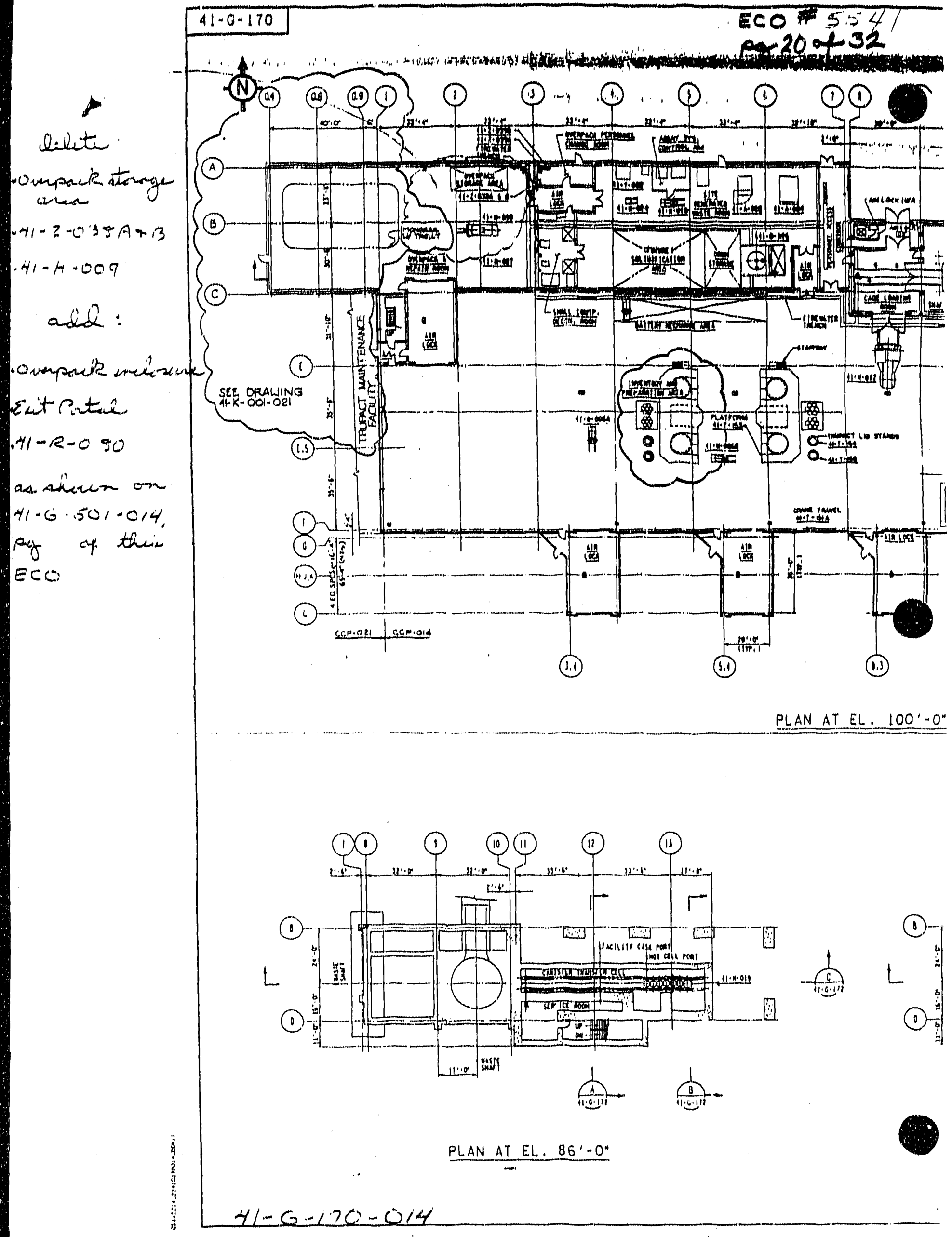


1. Drawing: $41-6-122-0 / 4, R_{e}=B$ ECO Number: 5541

2. ECO Search List:
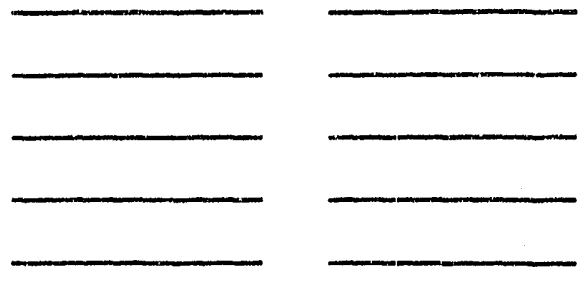

3. Description of Change:

Reviae duy to ahow "Overpack Enuloane", Exit Portal", and "41-R-080". Delete outdated information. See attached markup.

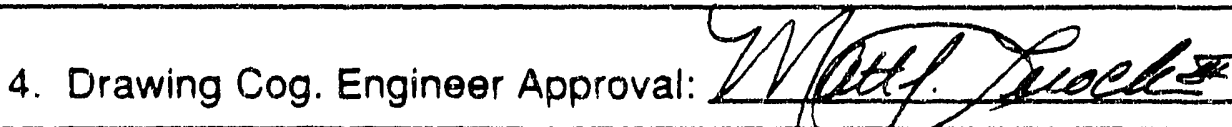

5. Cover Sheet Block (CC\&D Use Only)

Received from EFR Initials / Date

Date Assigned:

Assigned to:
Initials / Dale

(Same as data base entry)
Dratting Started:

Drafting Completed:

Date: $6 / 14 / 91$ Return to EFF: 


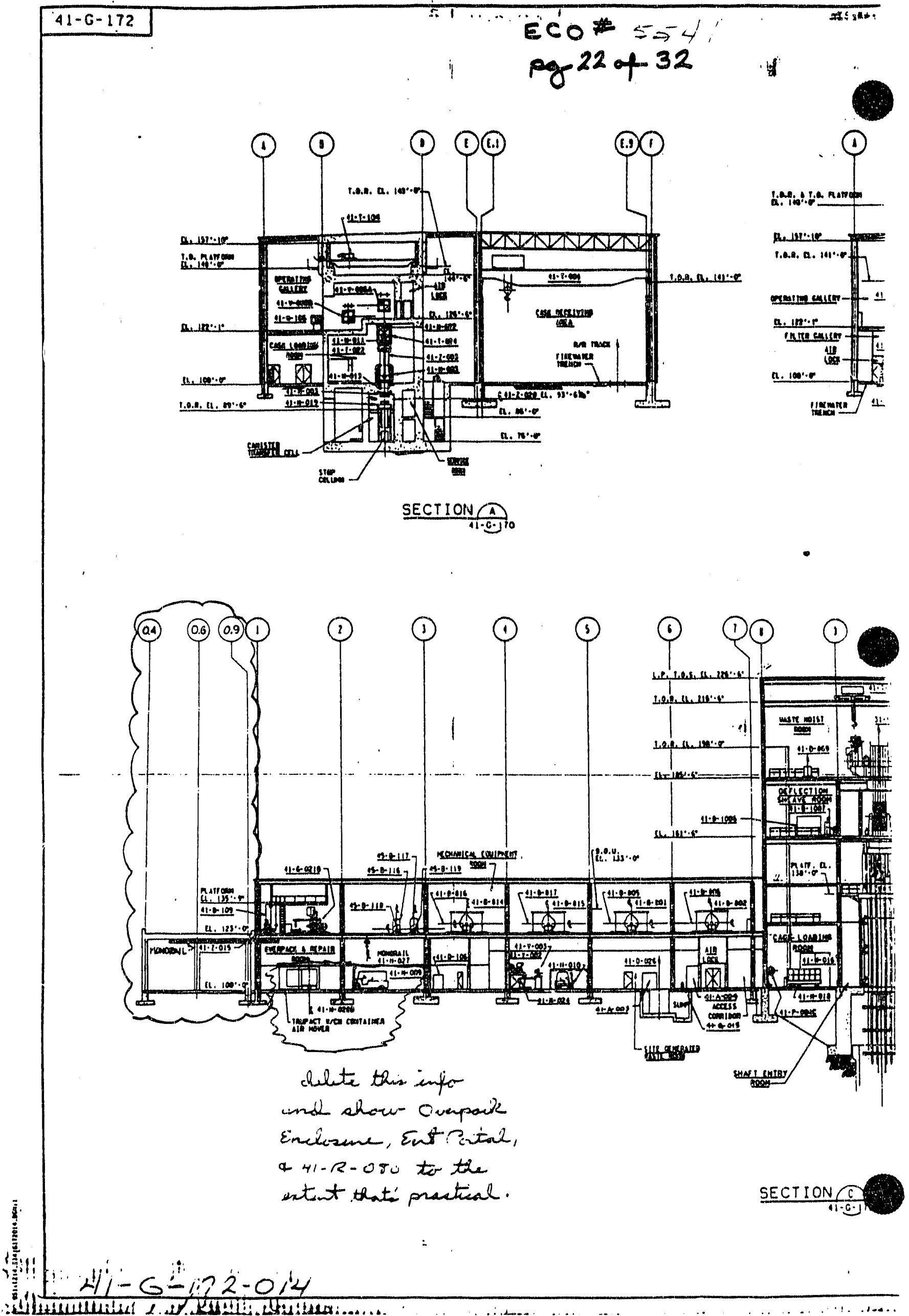




\section{$9 a$}

\section{DRAWING CHANGE SHEET}

(1 SHEET PER DRAWING)

1. Drawing: $4 i 1-6-302-0 / 4, R_{e} G$ ECO Number:

2. ECO Search List: 3992

3. Description of Change:

Tevise the durg to show the addition of the "Exit Poatal" to the "Overpack Enclosure". See attahed makup.

4. Drawing Cog. Engineer Approval: Cover Sheet Block (CC\&D Use Onty) Date: If ficki ?

Received from EFR:

Date Assigned:

Initials / Date Initials / Date

Assigned to:
Drafting Started:

Dratting Completed:

Return to EFR:

Inilials / Date

Initials / Date 


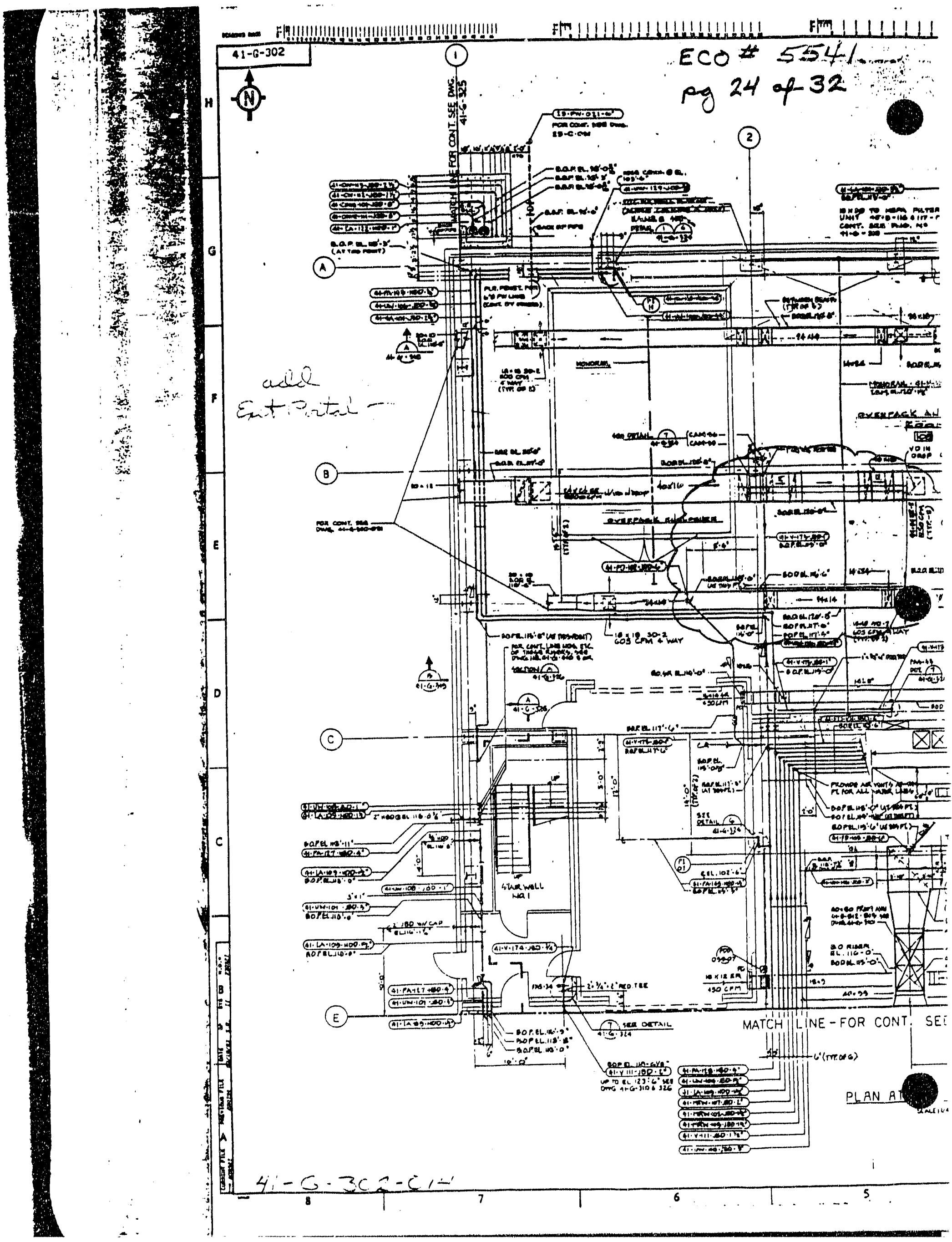




\section{$9 \mathbf{a}$ \\ DRAWING CHANGE SHEET \\ (1 SHEET PER DRAWING)}

1. Drawing: $41-6-501-0 / 4$, Rer C

ECO Number:

2. ECO Search List: 4622

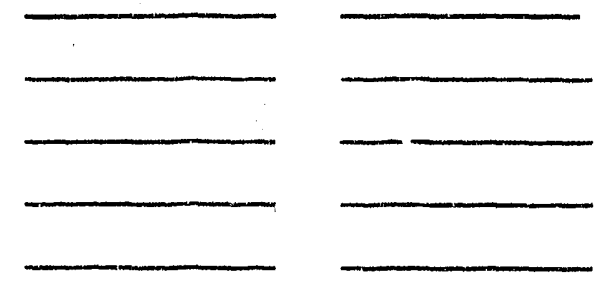

3. Description of Change: Teviae durg to show updated information concerning "Ext
Poutal" and "41-R-080". See attached mankup.

4. Drawing Cog. Engineer Approval: 7 / $/ 4 m$ a. $1 / 4$ Date: $6 / 14 / 91$

5. Cove: Sheet Block (CC\&D Use Only)

Received from EFR:

Date Assigned:

Assigned to:
Drafting Started:

Drafting Completed:

Return to EFP:
Initials / Date

Initials / Date

Initials / Date 


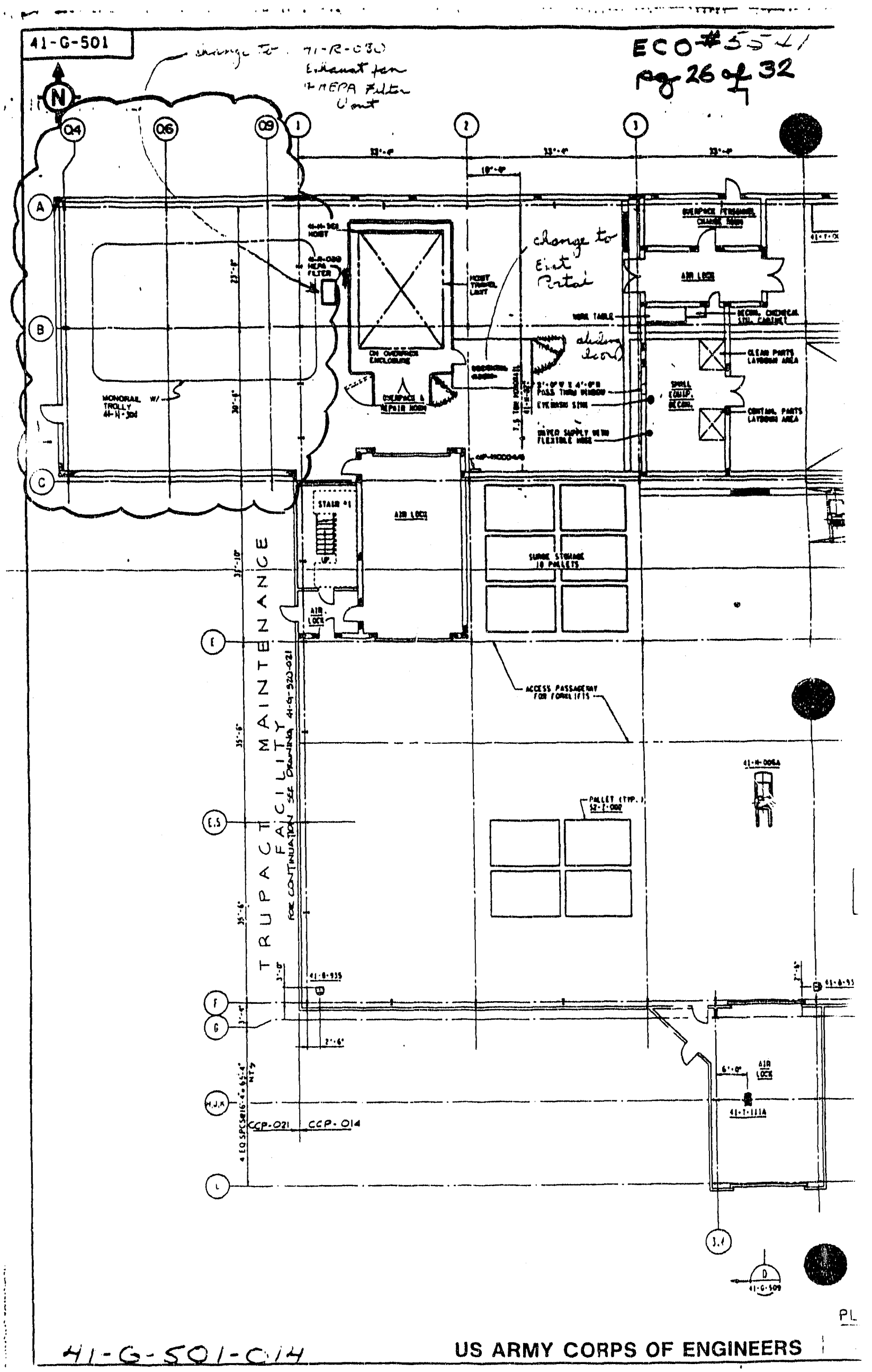




\section{$9 a$ \\ DRAWING CHANGE SHEET \\ (1 SHEET PER DRAWING)}

1. Drawing: $4 i-6-509-014$, Rear 3

ECO Number: 5.541

2. ECO Search List: pg 27 of 32
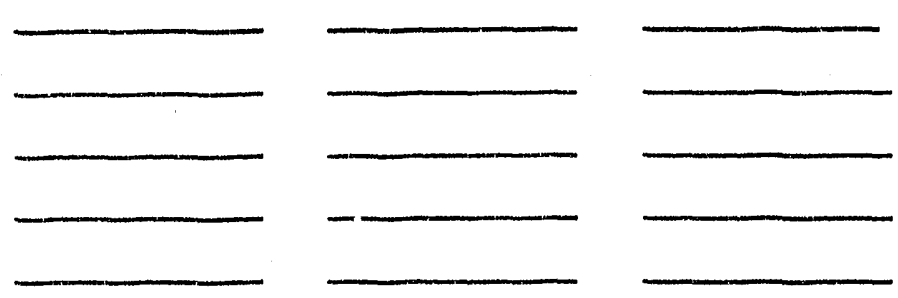

3. Description of Change:

Tevice dug to show "Overpack Enclooure", "Exit Poutal", and "4/-R-080". See attached mankup.

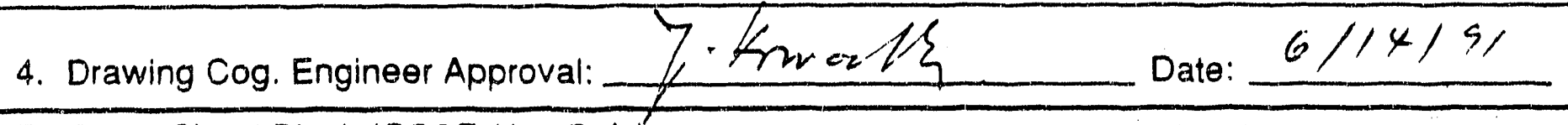

5. Cover Sheet Block (CC\&D Use Only)

Received from EFR:

Initials / Date

Date Assigned:

Assigned to:
Initials / Date

(Same as data base entry)
Drafting Started:

Drafting Completed:

Return to EFR:
Initlals / Date

Initials / Date

Initials / Date 

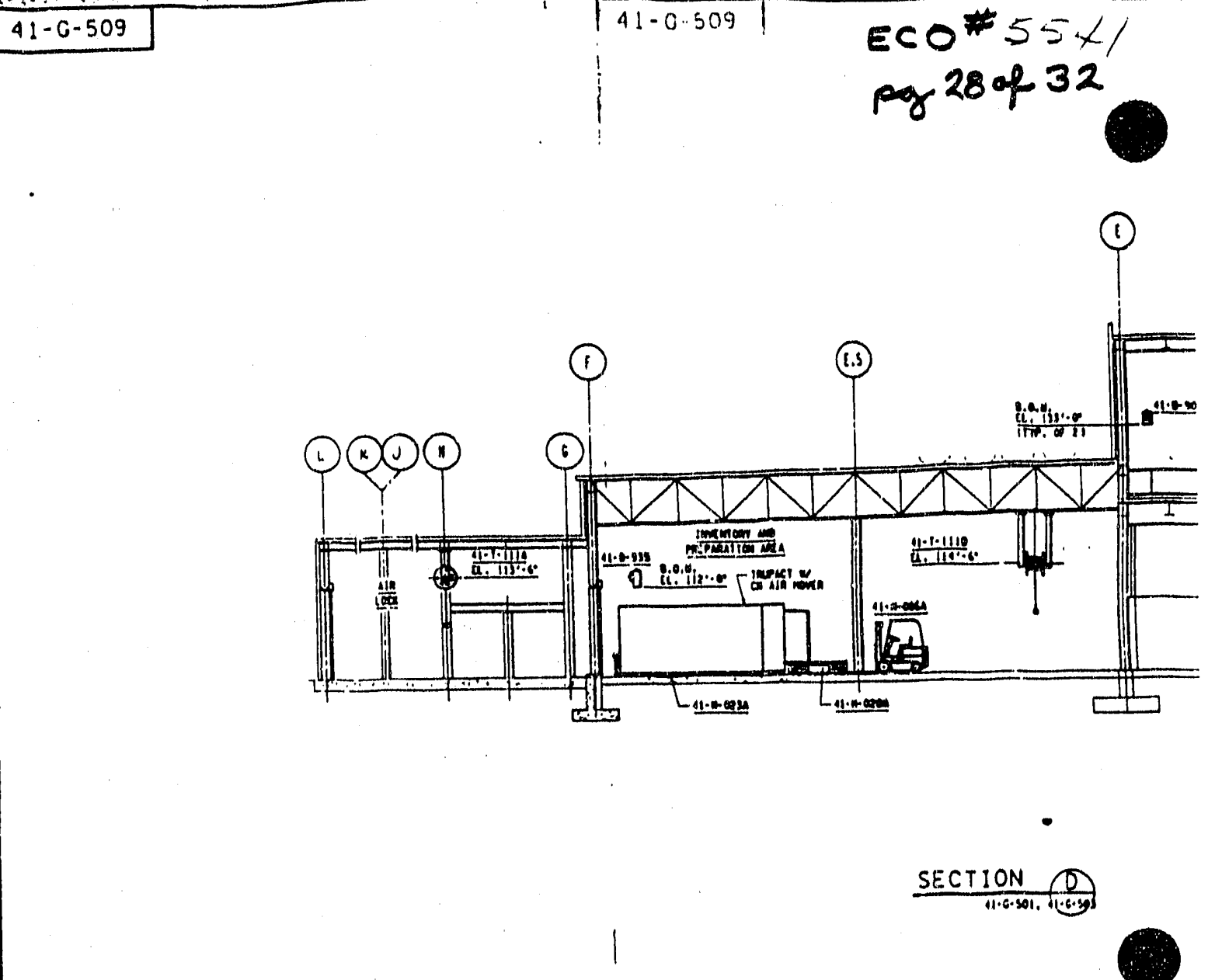

SECTION

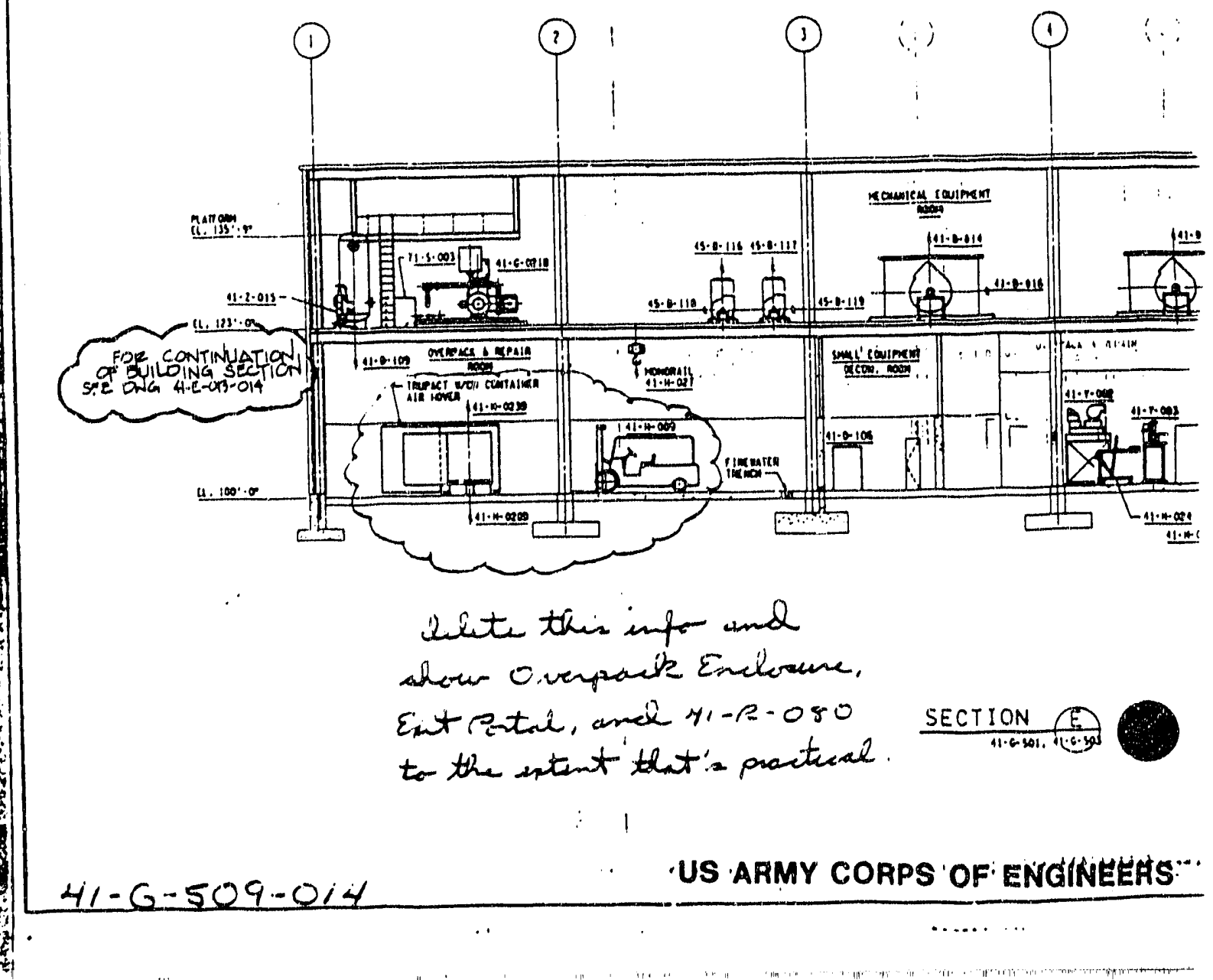


$E C O \#=\ldots$

$\operatorname{pg} 29$ of 32

\section{INSTRUMENT NUMBER REQUEST}

1. Instrument Number $411-P D I-001-32$

2. Description Pressure DLeferentlah lnolcator Narrative: Local diff presanc indication for inlet HEPA filter inatallation for the Enit rostal of the $\mathrm{CH}$ Ovapack Enclosure.

3. Subequipment ExIT PorTah lNhET HEPA EUTERS

4. Loop Number

5. Crawing Number

pris Orawing Number

$41-3-001-\omega-w^{2}$

6. System $\mathrm{HVOl}$

7. Cus point None

3. Range $0-4^{\prime \prime} \omega .6$.

9. Cuszut Type/Range None

10. $S \equiv$ : Points Nove

11. Cal./PM Procadure Number

12. Manufacturer Dwyer

13. Model Numiger 2004 Serial Number

14. Eosign Ciass III $B$

15. Cititical Equipment Yes $-\frac{x}{N O}$

16. Lasztion: Building 411 Rcom Numier 108

17. Eiactrical Power From $N A$

18. C3it Manual in file Room Yes $\frac{x}{n o}$

19. Coznizant Manager/Engineer PoHh/Eahoead

20. Eauipment Labeled No REmarks:

Requestor Wm Barajhart Date $-6 / 10 / 91$ WP Form 1870; $10 / 17 / 89$ 
ECO

Pg 30 of 32 hage 1 or 2 Re

INSTRUMENT NUMBER REOUEST

1. Instrument Number $411-P D I-001-33$

2. Description PRESSURE DLEFERENTIOb LNOLCATOR

Narrative: Local diff. presaure indication for inlet HEPA filter installation for the CH Overpack Enclosune.

3. Subequipment CH OVERPACK ENChoSURE INLET HEPA ELATERS

4. Leop Number

5. Crawing Number

PQID Orawing Number

$41-\sqrt{3}-021-6)$

6. System HVO

7. Cus Point NONE

8. Iypange $0-4 " \omega . G$.

9. Citsut Type/Range NONE

10. Set Points NONE

11. Cal./PM Procedure Number

12. Manufacturer DWYER

13. Model Numier 2004 Serial Number

14. Cesign Class III $B$

15. Citical Equipment Yes $-X$

16. Lasztion: Building 411 Room Number 108

17. Eiectrical Power from NA

18. Csid Manual in Flle Room Yes $-\frac{x}{n o}$

19. Cognizant Manager/Engineer POHb LEALDEN

20. Equipment Labeled Yes Renarks:

Requestor Wm Barnhart Date $6 / 10 / 91$ WP Form 1870; 10/17/89 
$E<0 \# 5.54$

$$
\begin{aligned}
& \text { pg } 31 \text { of } 32 \text { ATTACHMEIT } 3 \\
& \text { WP 09-021, RQ\%, } 1 \\
& \text { Page } 1 \text { of } 2
\end{aligned}
$$

\section{INSTRUMENT NUMBER REQUEST}

1. Instrument Number $411-e 0 I-001-34$

2. Description PRESSURE DIEFERENTIAL INeICATOR Narrative: hocal diff. pressune indication fou the $\mathrm{CHO}$ Overpacte Enclosure in relation to the Owenpacte \& Repain Thoom.

3. Subequipment $C H$ OVERPACK ENChOSURE

4. Loop Number

5. Crawing Number

P\&ID Orawing Number

$41-3-021-\omega$

6. System HVOL

7. Cus Point NONE

8. $0-4 " \omega .6$.

9. Cuszut Type/Range NONE

10. Set Points

11. Cal./PM Procedure Number

12. Menufacturer $D \omega Y \in R$

13. Medal Number 2004 Serial Number

14. Cesign Class II $B$

15. Cititical Equipment Yos $\frac{x}{x}$ No

16. Lesation: Building HL1 Room Number 108

17. Eiectrical Power from $N A$

18. CQ4 Manual infifle Room Yes $x$ No

19. Cognizant Manager/Engineer POHL/EALDEN

20. Eguipment Labeled Yes $x$ No Remarks:

Reques tor SM BARNHART Date $6 / 10 / 2$ WP Forin 1870; 10/17/89

Page 1 of 2 
INSTRUMENT NUMEER REOUEST

1. Instrument Number $411-P D I-001-35$

2. Description PRESSURE DIFEERENTIAH LNOLCATOR Narrative: Loeal differential preasure indication acrowa HEPA filter howaing, for both roughing and HEPA filters.

3. Subequipment $41-8-080$

4. Loop Number

5. Crawing Number

Peid Drawing Number $41-3-001-\omega$

6. System $\mathrm{HVOL}$

7. Cus point NONE

8. hertange $0-4$ "wirg.

9. Cutzut Type/Range NONE

10. Set Points None

11. Ca1./PM Procedure Number

12. Manufacturer DWYER

13. Medel Number 2004 Serial Number

14. Casign Class III $B$

15. Citical Equipment Yes $\frac{x}{n o}$

16. Lesztion: Bujlding 411 Roon Number 108

17. Eiectrical Power From NA

18. Csit Manual if Fll ? Room Yes $\frac{x}{x}$ No

19. Cognizant Manager/Engineer PoHh LELOEN

20. Equipment Labeled Yes No Remarks:

Requestor Wm BarNHART Date $6 / 10 / 91$ WP Form 1870: 10/17/89 


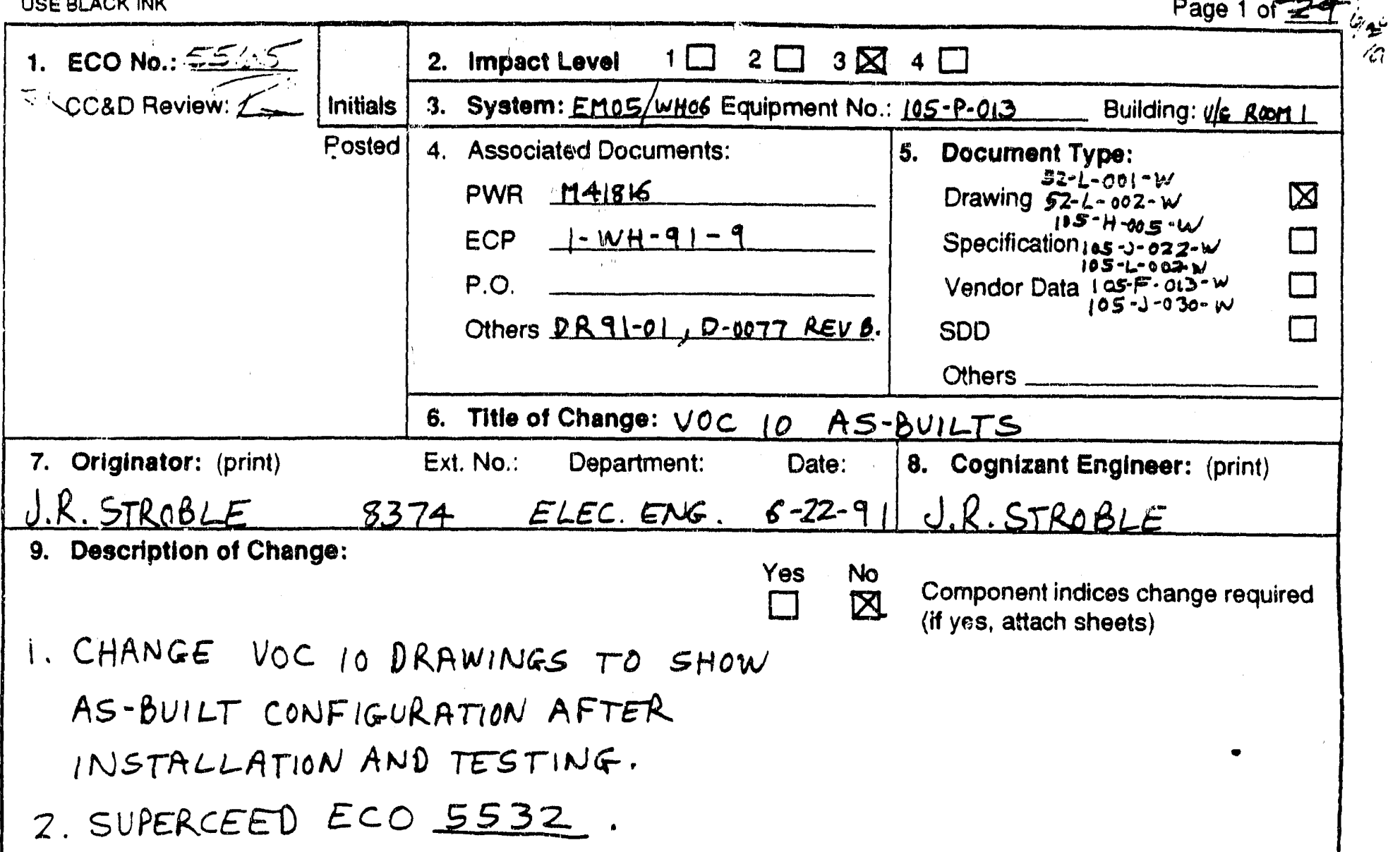

Q Sa Drawing Change Sheet attached 9b Design Documentation Sheet attached

9c Vendor Data Change Sheet attached

$\left.\begin{array}{rl}\text { 10. } & \text { Yes No } \\ \square & \begin{array}{l}\text { MODIFICATION IN PROGRESS } \\ \text { Modification complete: }\end{array} \\ \square & \begin{array}{l}\text { Change drawing per as-built markup dated: } \\ \square\end{array} \\ \square & \begin{array}{l}\text { Change drawing per ECO-provided data } \\ \text { Temporary modification }\end{array}\end{array}\right] \begin{aligned} & \text { ECO will be } \\ & \text { incorporated after } \\ & \text { M.I.P. signed complete }\end{aligned}$

11. Design Verification Requirements: (per WP 09-018) EDT No.:

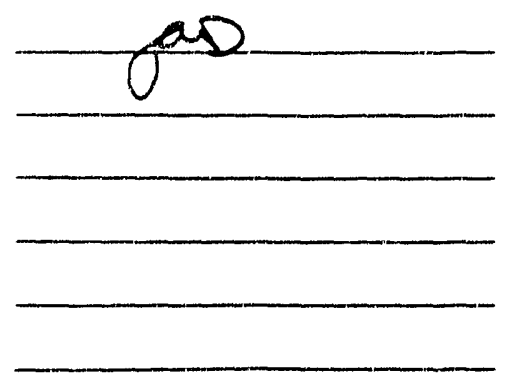

1. Requirements satisfied by review/approval of design document

2. Independent review

3. Altemate caiculations

4. Development testing

5. Design review

6. Other:

12. Addendum Sheat aciora: 
ECONo: 554.5

13. Justifica:ion

1. TO SHOW AS-BUILT CONFIGURATTION

2. ALL OF THE CHANGES IN ECO 5532

ARE AS-BUILT \& INCLUDED IN THIS ECO.

\section{Administrative Tracklng}

YES N/A

$\triangle \square$ 1. FSAR

$\otimes \square$ 2. Calibration Procedures

$\nabla \square$ 3. Maintenance Procedures

$\square$ 4. Computer Software

$\otimes \square$ 5. Operations Procedures

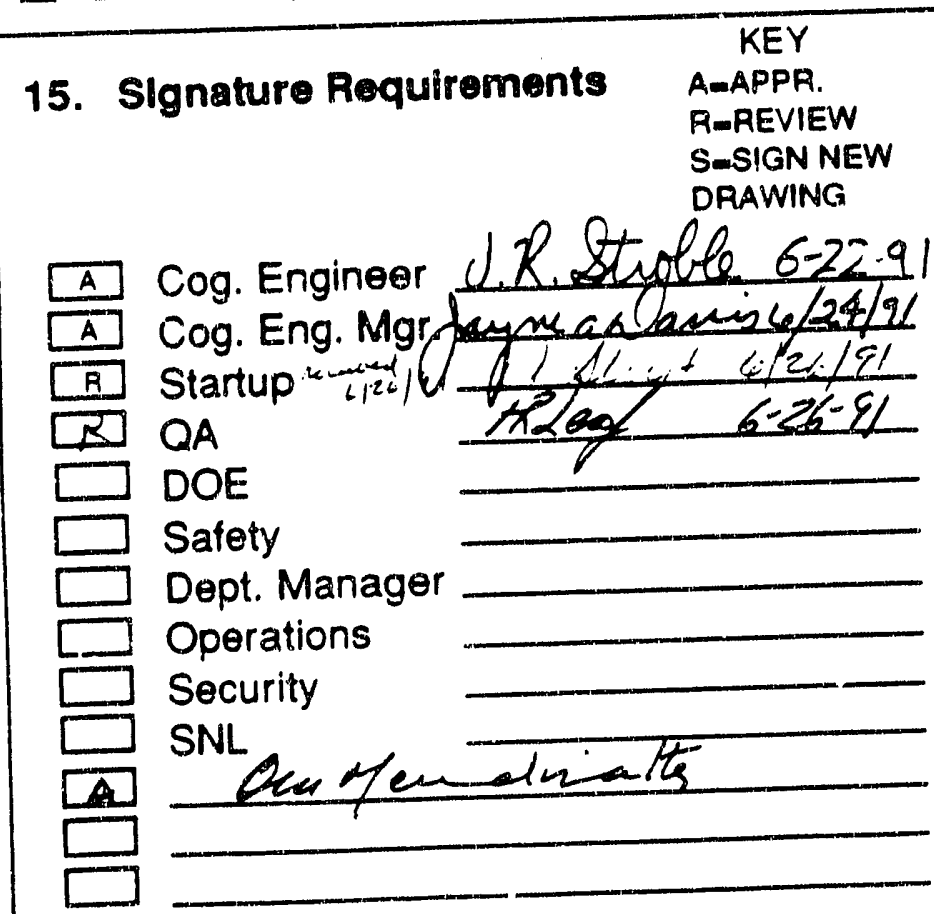

YES NA

$\square$ 田

$\square \otimes$

$\square \square$

$\square \square$

$\square \square 10$

\section{Distribute as Marked}

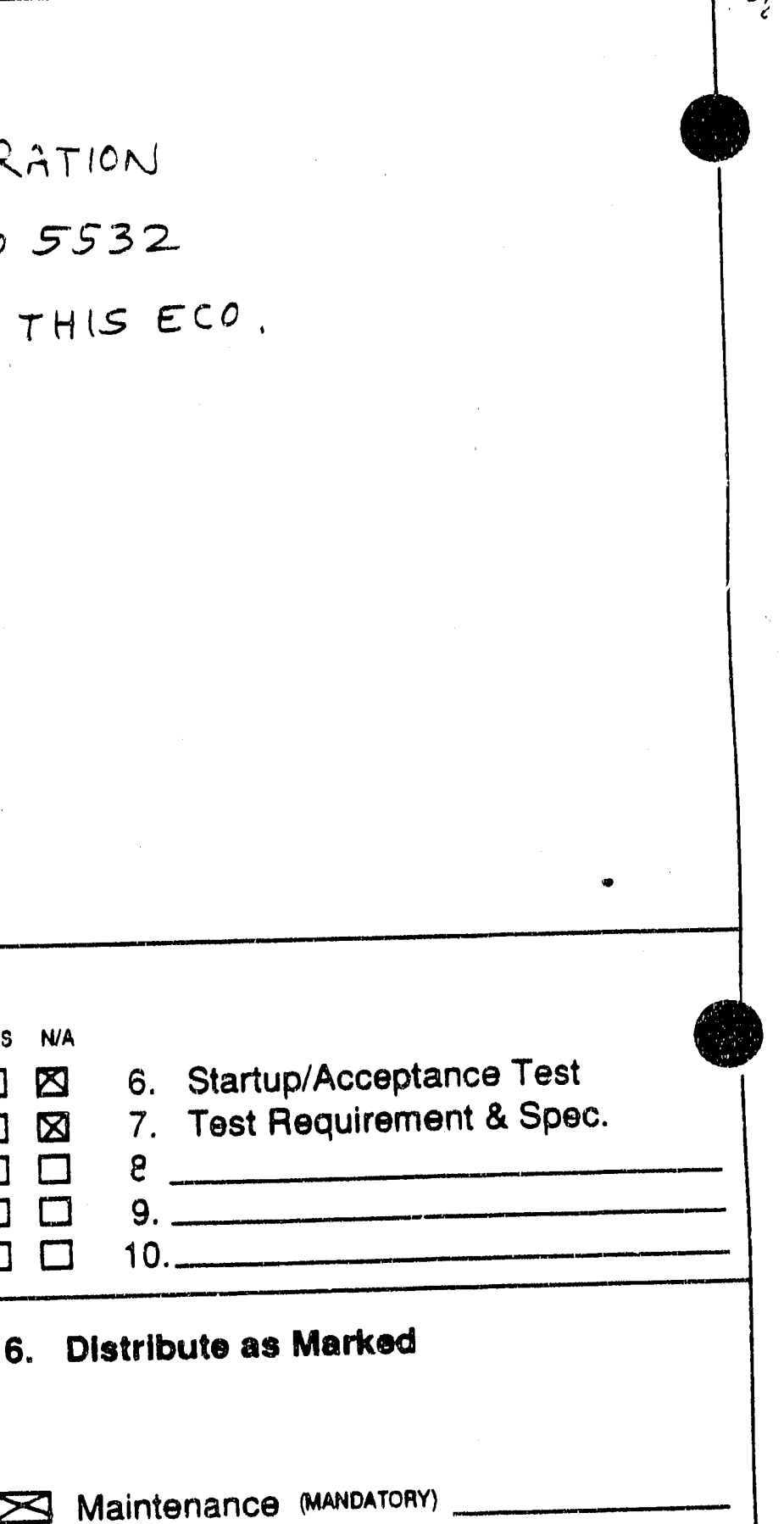

$\triangle$ Maintenance (MANOATOAY)

$\triangle$ Ops. Support MANOATORY

$\square$ Startup

$\square$ Facility Operations -

$\square$ Orig./Design Engr. Cog. Engineer T.R. STROQR

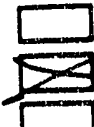
Others

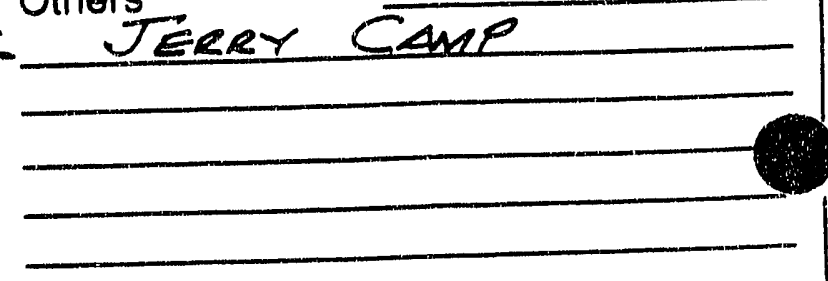


Filler C.L.6430.1A

$$
\begin{aligned}
& \text { ECO } \\
& 30 \text { I } \\
& 30 F 29 \\
& \text { Jpes } \\
& \text { sucsoty 27. } \\
& 6-2+-91 \quad 424 / a 1
\end{aligned}
$$

DOE OCOER SA30.LA OESIEN COITERIA

$$
\text { areanist }
$$

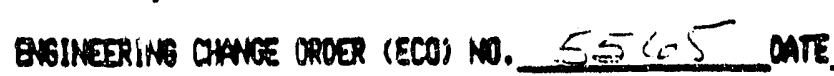
m. U.R. Strobe

The design requireaents in DoE ordor 6430.1A chected bola have been saplled to this ECD.

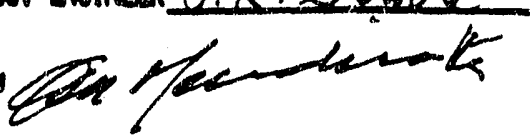

1

OIVISIO

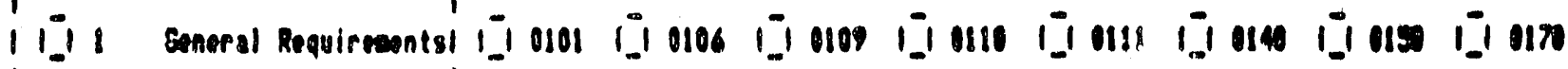

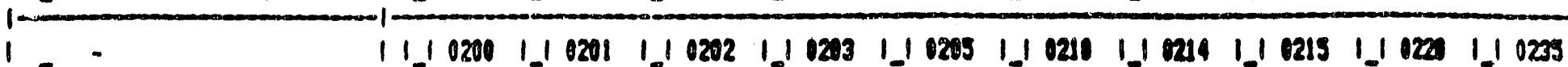

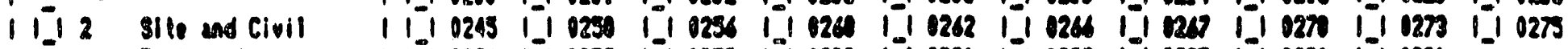

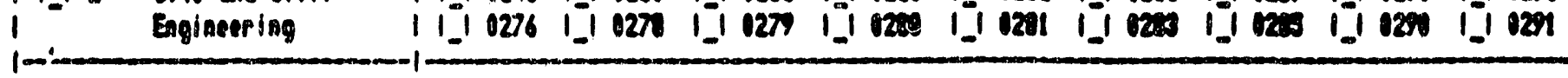

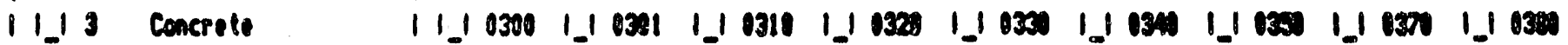

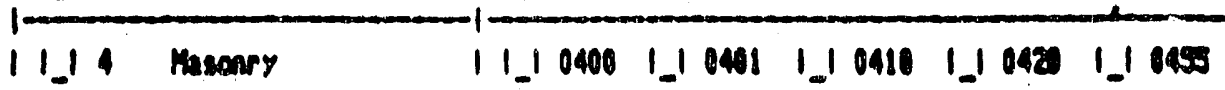

10

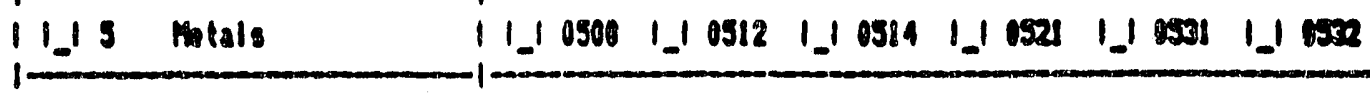

i.16 and Plastics 1 1,10600 1,10610 1,10650

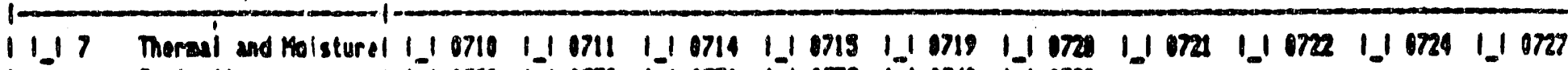

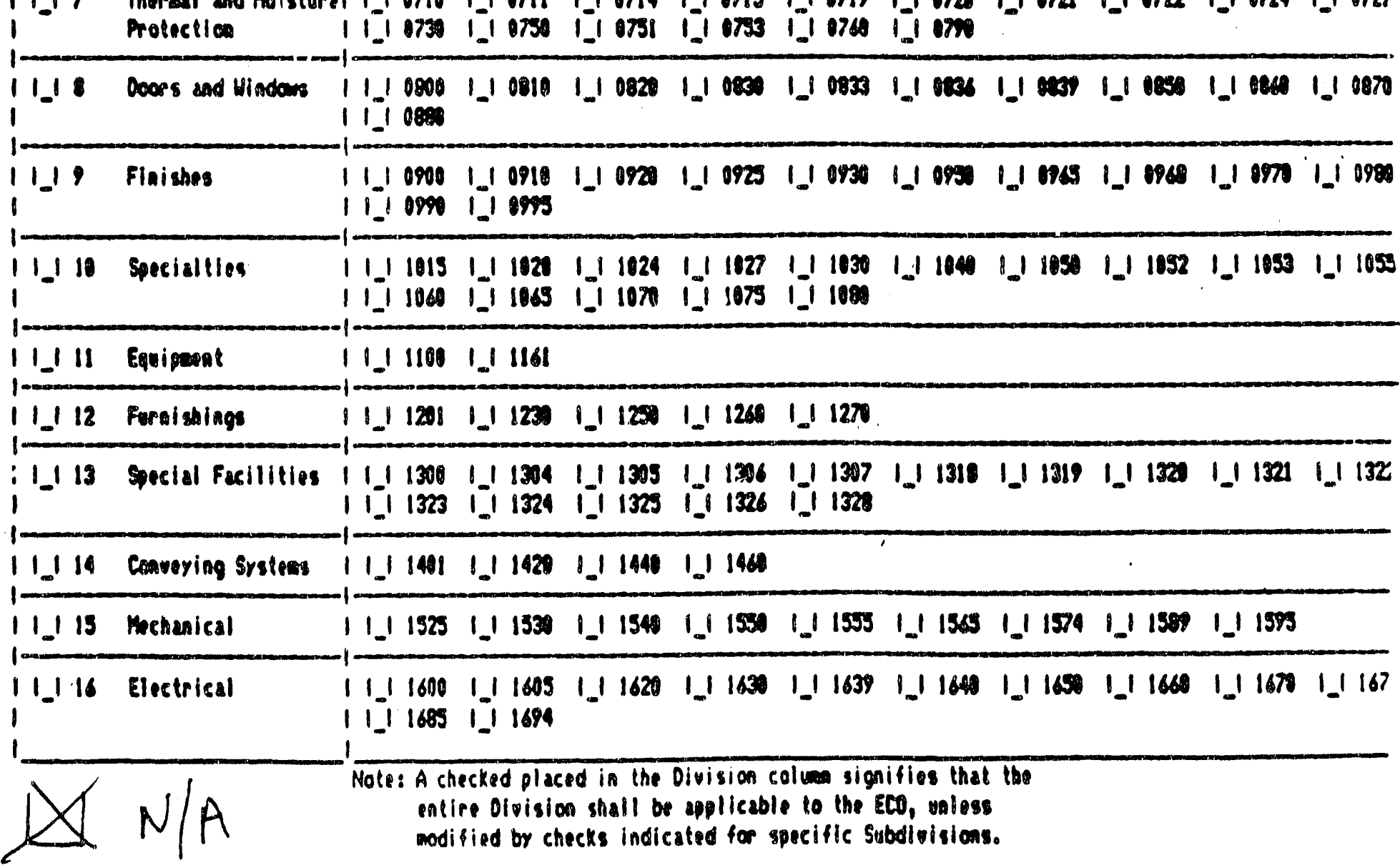


1. Drawing: 52-L-001-W

ECO Number: 554.5

2. ECO Search List:

3. Description of Change:

1. PRESSURE RELIEF VALVE (VC-534-RV-009):

A. MOVE TO UPSTREAM OF VALVES VC-534-TW-024 425

B. RUN OFF 3-WAY VALVE VC.534-TW-027 ON ONE PORT

C. PUt a 2-way Valve + a check value on other PoRT

2

D. TO ALLOW FOR MANIFOLD RELIEF DURING CLEANING \& CERTIFICATION.

CHANGE QTY. FOR ITEMS:

4

9

16

3. CHANGE 15 MICRON FILTER IN ITEM 28 TO JUST HOUSING (NO FILTER).

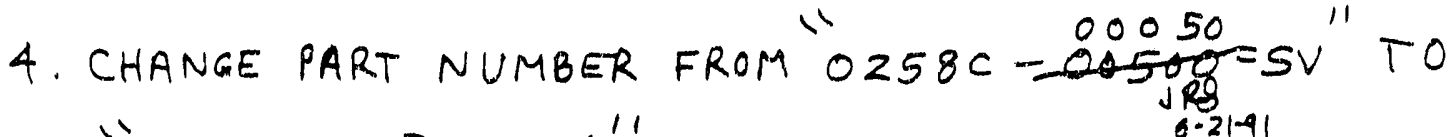
"O258C-00500-SW".

SEE ATtACHED PAGES

4. Drawing Cog. Engineer Approval:

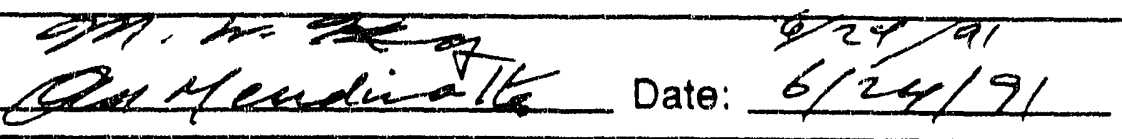

5. Cover Sheet Block (CC\&D Use Only)

Received from EFR: Initials / Date

Date Assigned: Initials / Date

Assigned to:

(Same as data base entry)

Drafting Started:

Drafting Completed:

Initials / Date

Return to EFR:

Initials / Date

Initiais / Date 


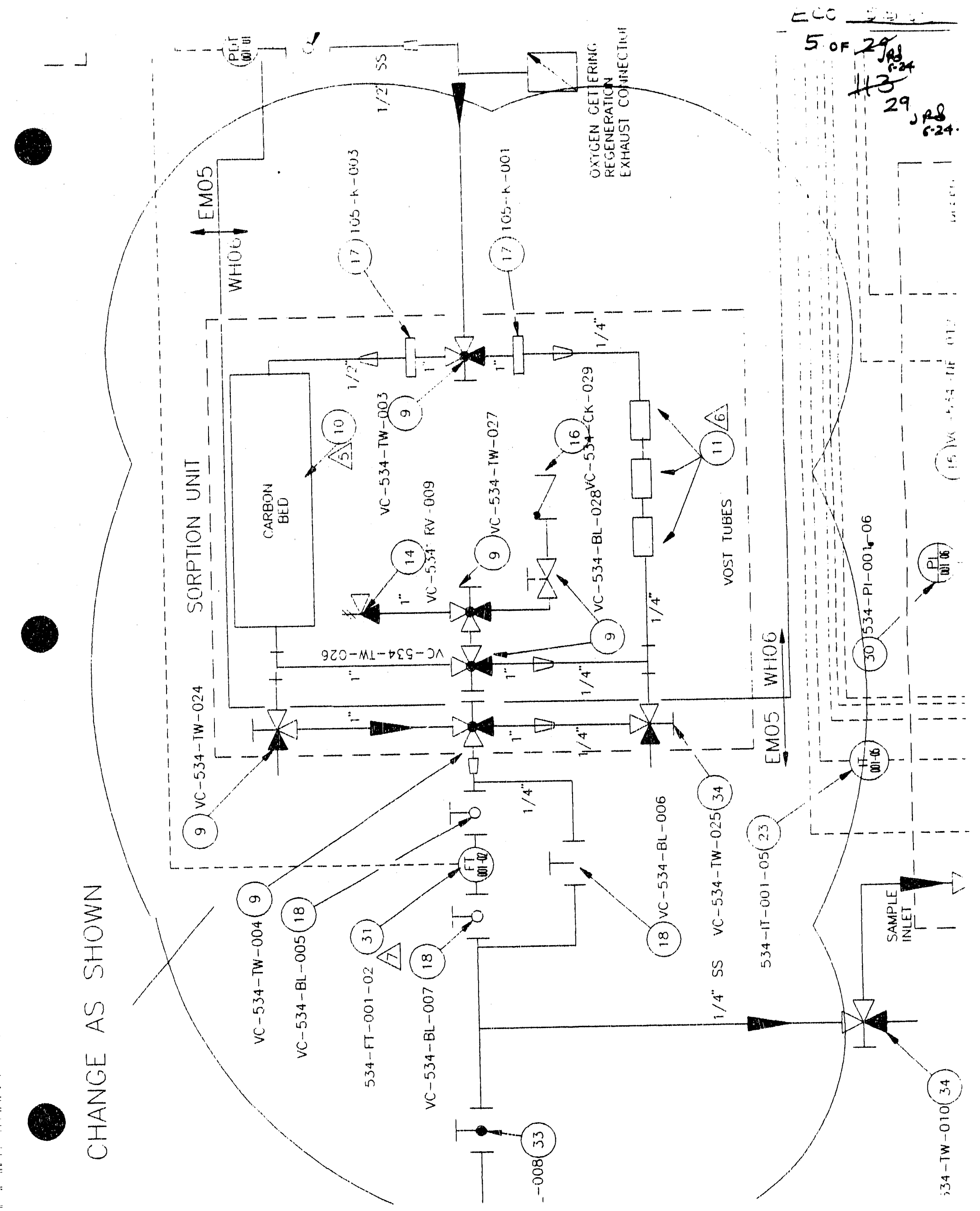



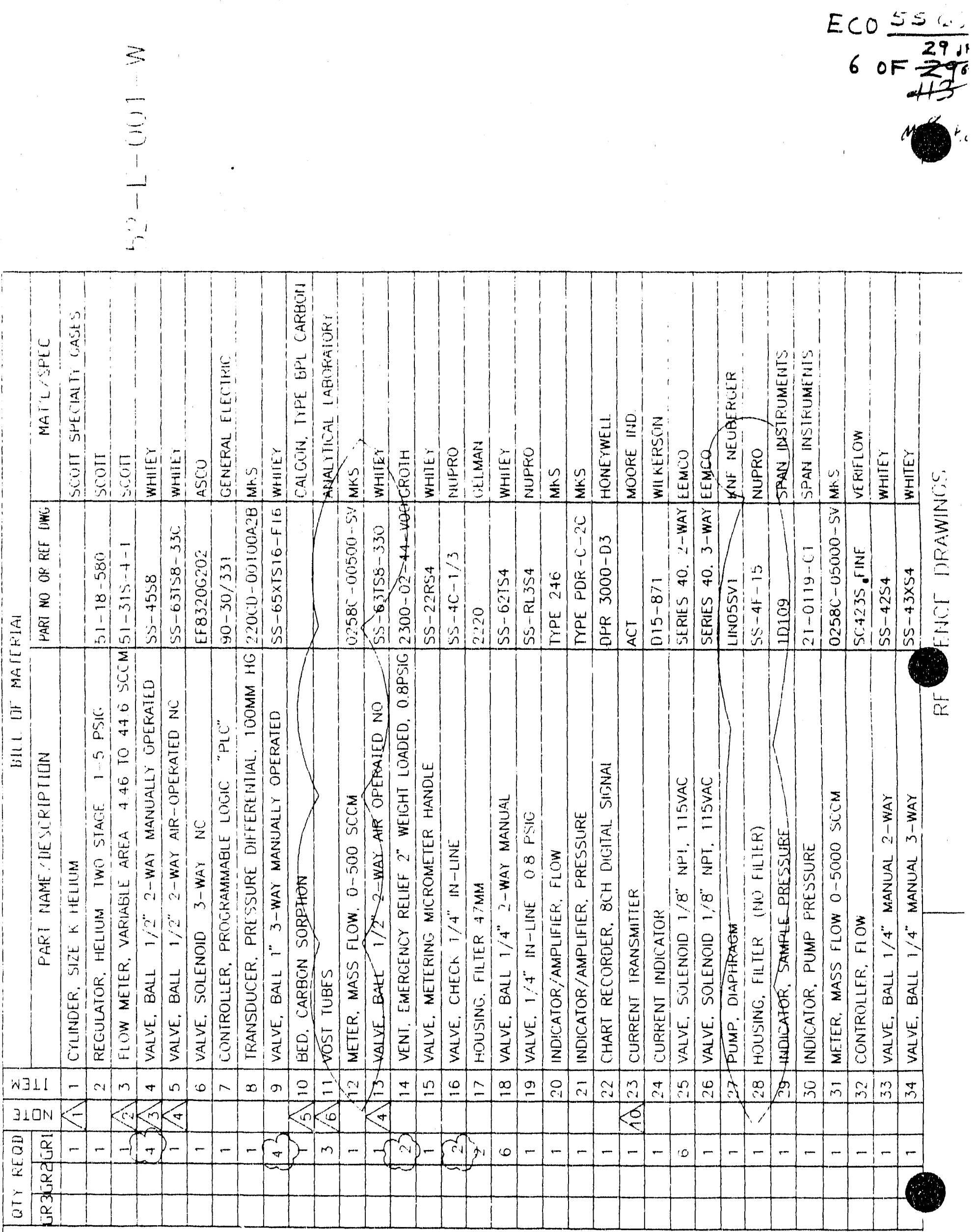
1. Drawing: $52-L-002-W 2$

ECO Number: 554.5

2. ECO Search List: 5532
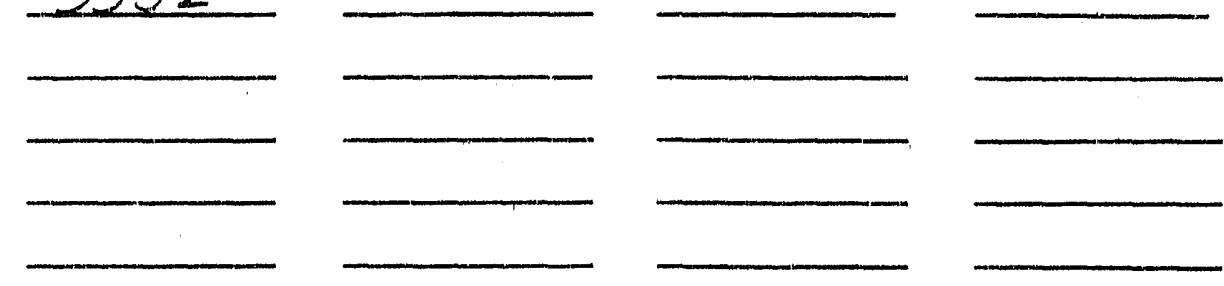

3. Description of Change: SEE ATTACHED PAGES

1. CHANGE tHE CONF IGURATION BETWEEN THE CARBON BED AND THE SAMPLER:

A. MOVE THE pRESSURE RELIEF VALVE TO JUST DOWNSTREAM OF BOTH THE CARBON BED \& THE VOST TUBES.

B. HAVE a 3-way VALVE befORE the PRV, TO ROUTE FLOW TO EITHER THE PRV OR THRU A CHECK VALVE $\psi$ ISOLATION VALVE ADDED.

C. HAVE FLOW COME FROM EITHER THE CARBON BED OR THE VOST TUBES AS BEFORE.

2. ADD A NOTE TO READ:

ALL TUBING FROM THE MAIN CARBON BED OUTLET TO THE SAMPLER UNIT IS WRAPPED WITH HEAT TAPE (3.25 WATSS PER SQUARE (NCH). THERE ARE OUTLETS FOR THIS TAPE ON THE SAMPLERRACK 3. ADD THE HEAT TAPE CONTROL BOX TO THE RACK.

4. MOVE THE "TEE" FOR THE OXYGEN GETTERING SYSTEM TO THE MANIFOLD FROM THE CARBON BED SIDE OF THE ROOM TO HELIUM SIDE OF THE ROOM.

4. Drawing Cog. Engineer Approval:

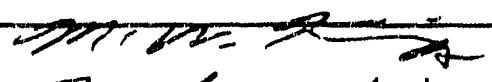

5. Cover Sheet Block (CC\&D Use Only)

Received from EFR: Initials / Date

Date Assigned:

Assigned to:

(Same as data base entry)

Drafting Started:

Drafting Completed: Initials / Dato Initials / Date

Return to EFR: Date: $6 / 24 / 2$ 
teplaced ty ackendun

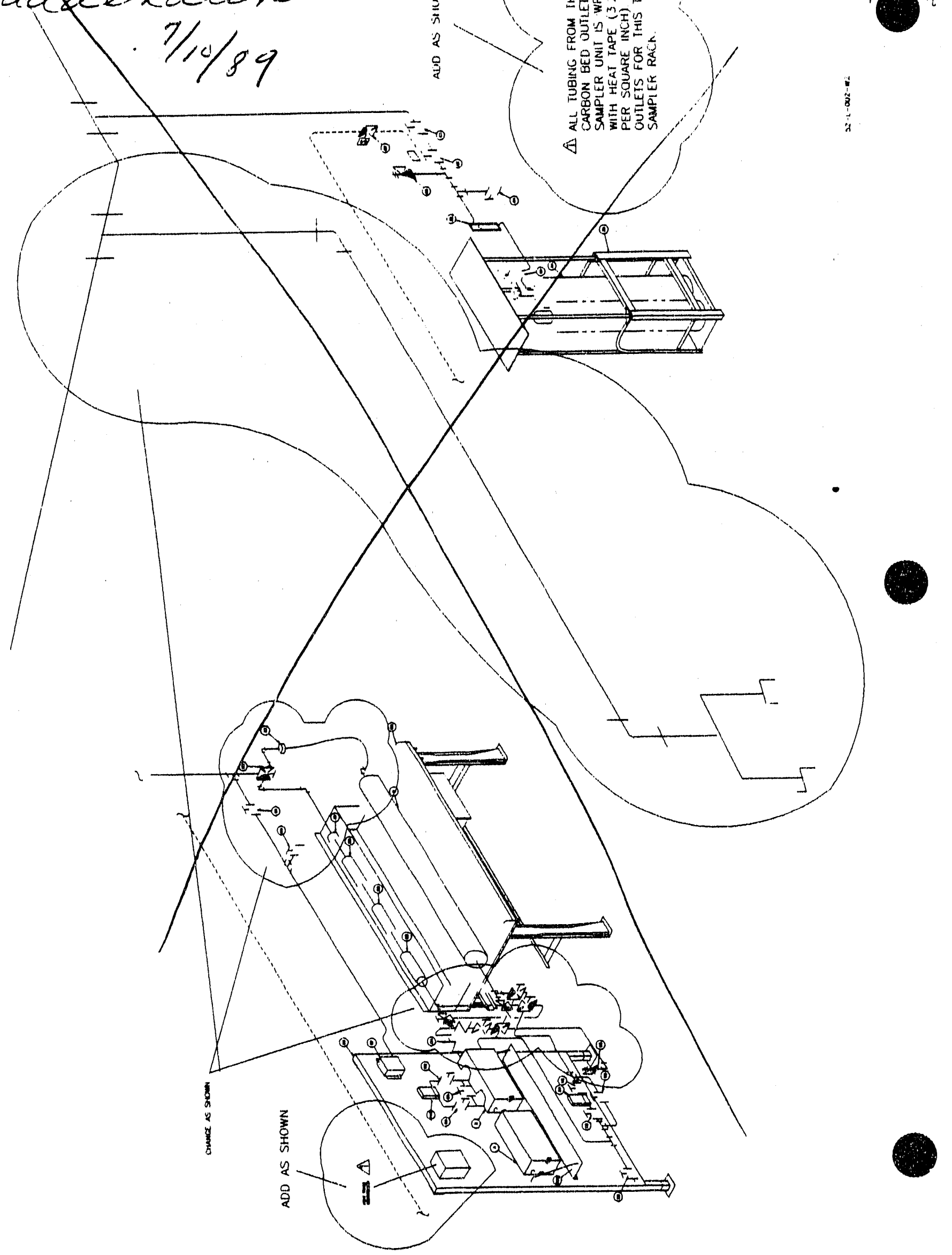




\section{$9 a$ \\ DRAWING CHANGE SHEET \\ (1 SHEET PER DRAWING)}

1. Drawing: $5 \dot{Z}-L-002-W 3$ ECO Number: 5565

2. ECO Search List: $\quad 5532$
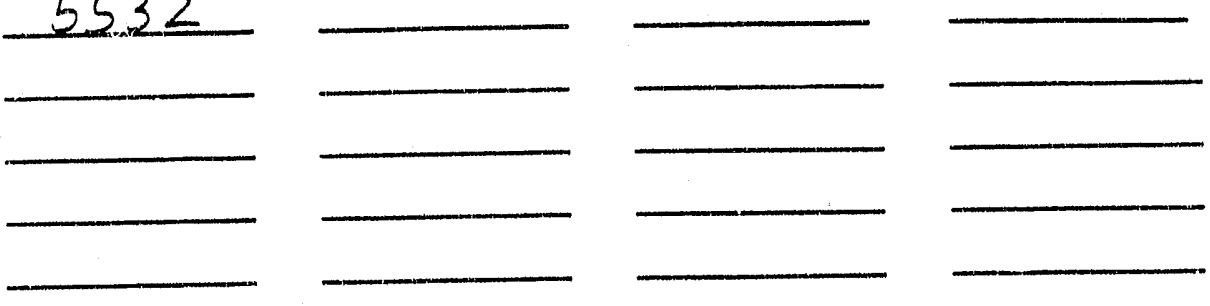

3. Description of Change:

SAME AS I. AND 3. ON SHEET 9 a OF DRAWING 52-L-OO2-WZ OF THIS ECO.

\section{SEE ATTACHED PAGES}

4. Drawing Cog. Engineer Approval: Cun Afendicte Date: $6 / 2,4 / q$,

5. Cover Sheet Block (CC\&D Use Only)

Received from EFR:

Date Assigned:

Assigned to:
Initials / Date

Initials / Date

(Same as data base entry)
Drafting Started:

Dratting Completed:

Return to EFF:
Initials / Date

Initials / Dato

Initials / Date 


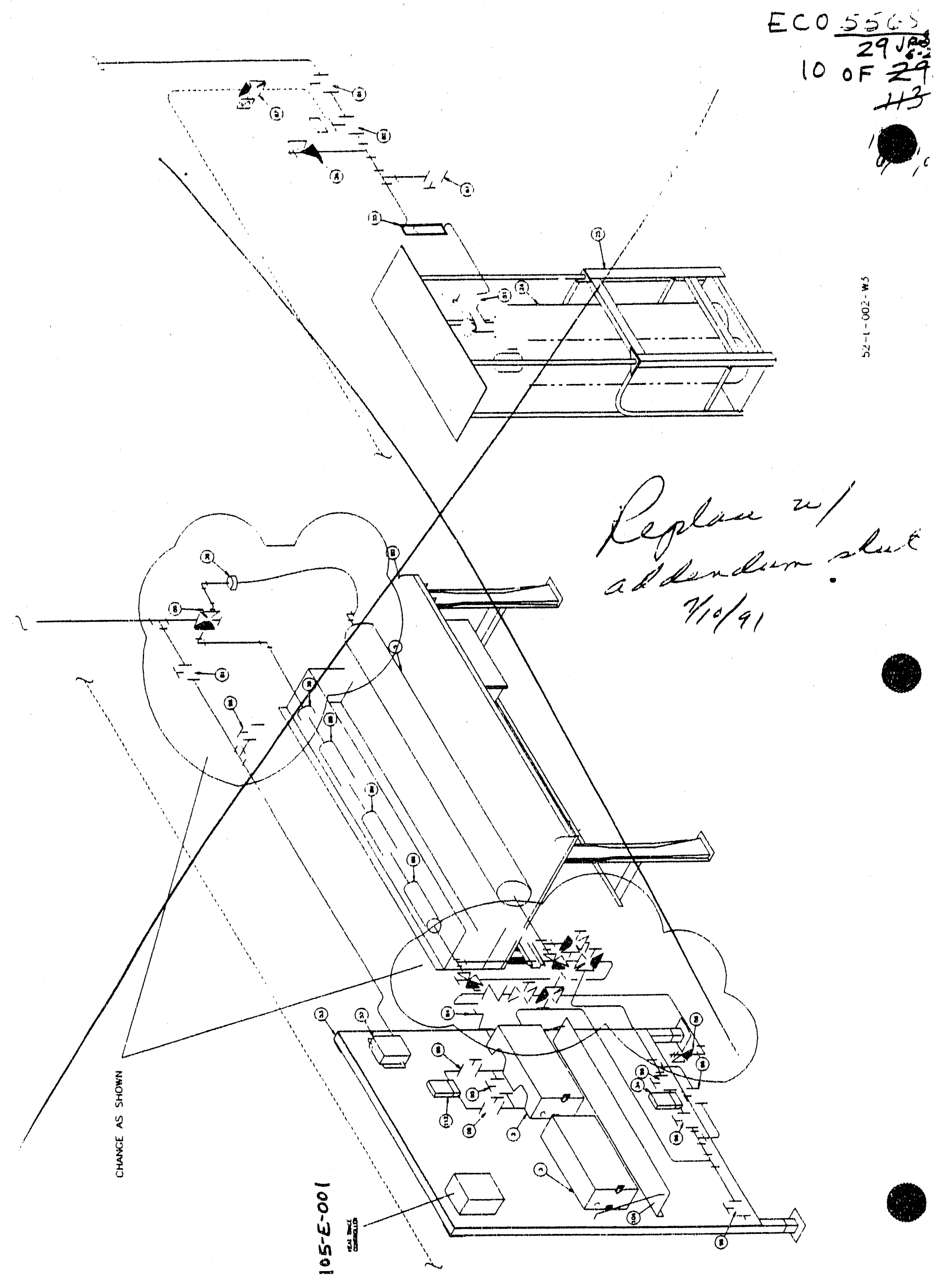




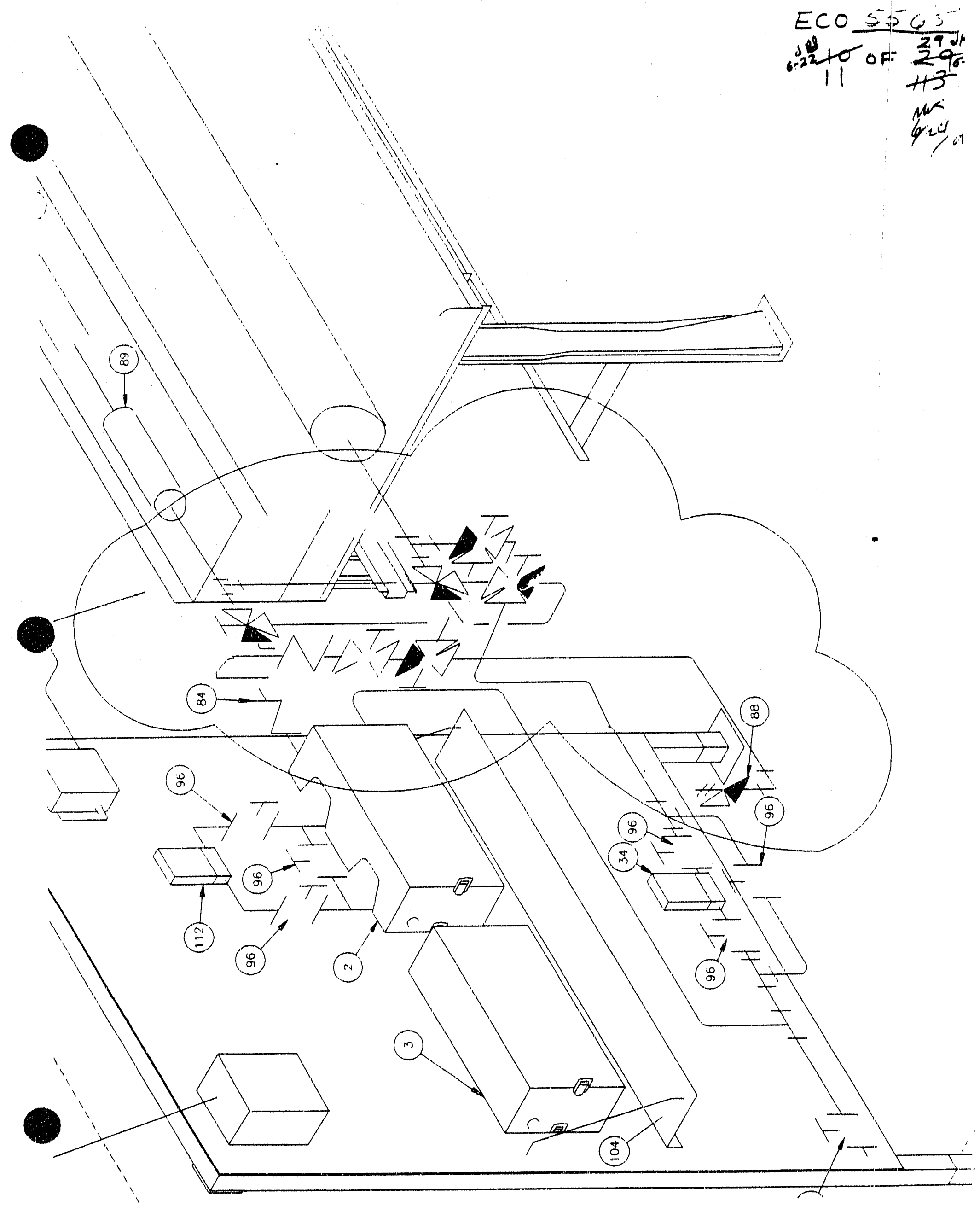


1. Drawing:

2. ECO Search List: 5532

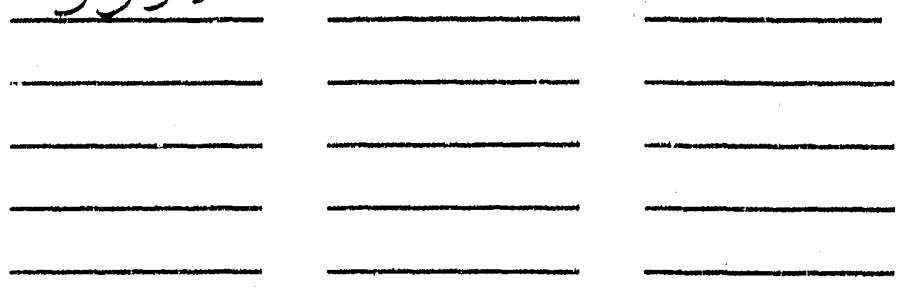

3. Description of Change:

SAME AS I. ON SHEET 9 a OF DRAWING 52-L-OOZ-WZ OF THIS ECO,

see a tiached page

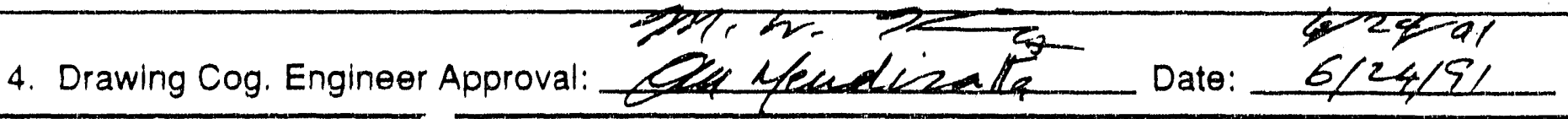

5. Cover Sheet Block (CC\&D Use Only)

Received from EFR:

Date Assigned:

Assigned to:
Drafting Started:

Initials / Date

Initials / Date

(Same as data base entry)
Initials / Date

Drafting Completed:

Return to EFA:
Inilials / Dato

Initials / Date 


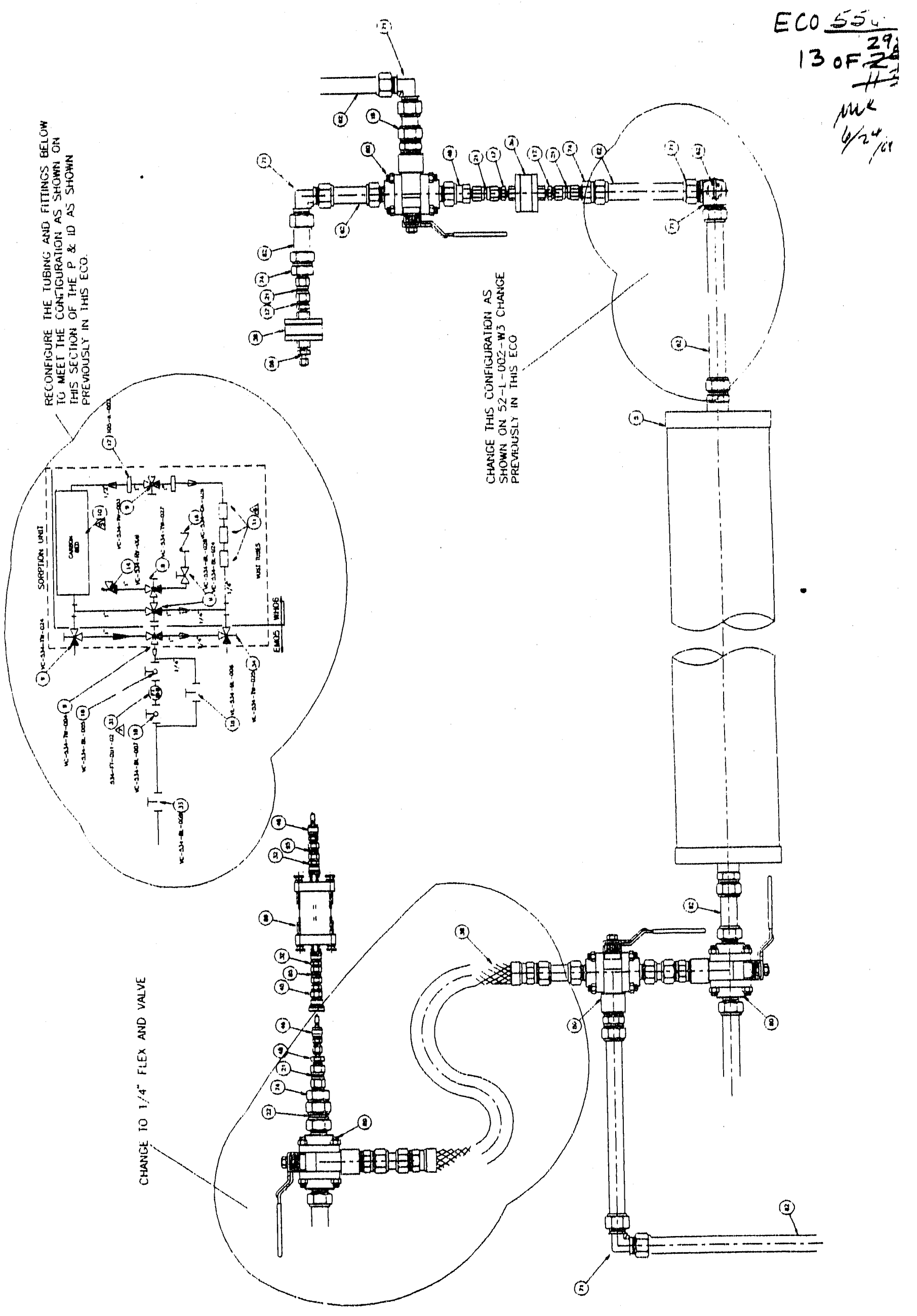




\section{$9 a$}

1. Drawing: $5 z-L-00 z-W 6$ ECO Number: 554.5

2. ECO Search List: 5532
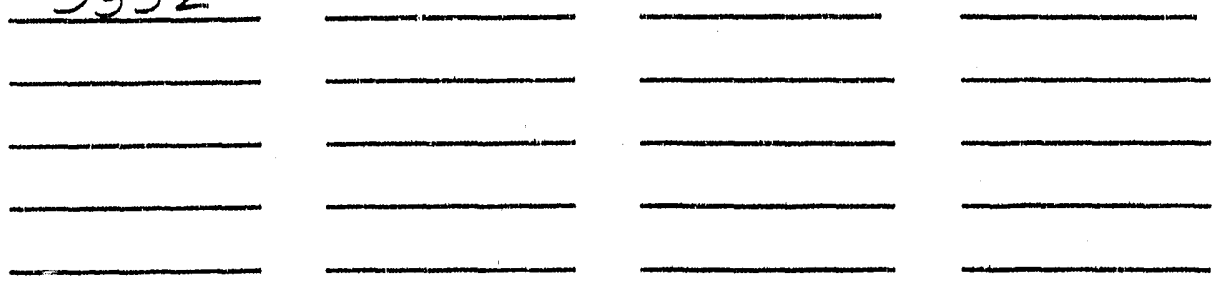

3. Description of Change:

$$
\begin{aligned}
& \text { MOVE THE PRV AND TUBING TO } 52-L-002-W 5 \text {. } \\
& \text { REPLACE TEE }
\end{aligned}
$$

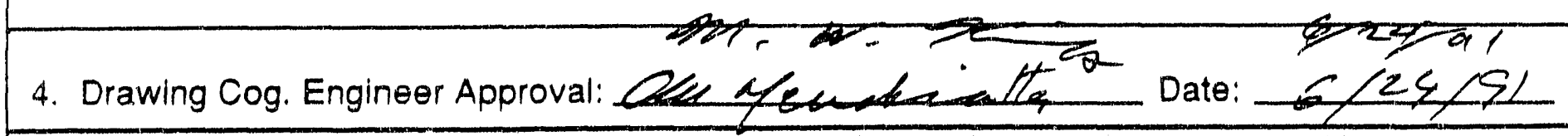

5. Cover Sheet Block (CC\&D Use Only)

Received from EFR: Initials / Date

Date Assigned:

Assigned to:
Initials / Dato

(Same as data base entry)
Drafting Started:

Drafting Completed: Initials / Date Initials / Dato Return to EFR: Initials / Date 


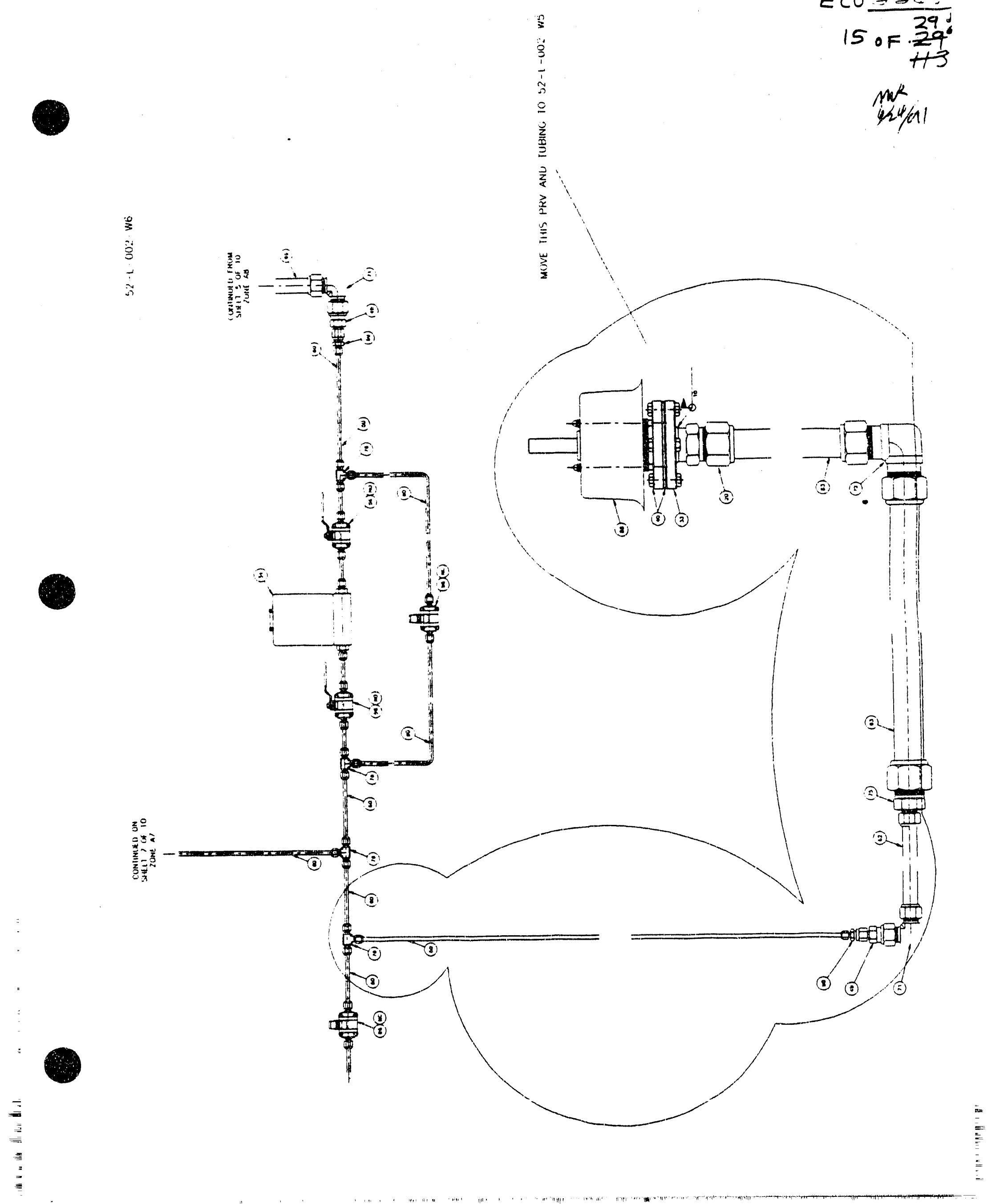


$9 \mathbf{a}$

DRAWING CHANGE SHEET

(1 SHEET PER DRAWING)
ECO $\frac{5365}{16 \text { of } \frac{29}{29}+\frac{125}{1+24}}$

$w^{2}+4$

1. Drawing: $105-F-013-W$ ECO Number:

5565

2. ECO Search List:

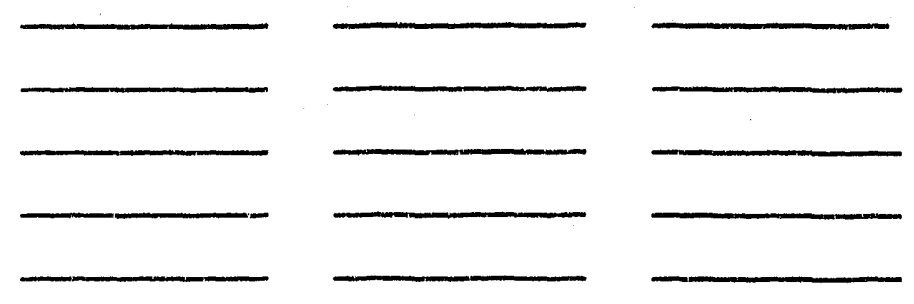

3. Description of Change:

ADD the instrument and Valve number tags TO THIS DRAWING AS SHOWN ONTHE ATTACHED PAGE

4. Drawing Cog. Engineer Approval: d.R. Sturble

5. Cover Sheet Block (CC\&D Use Only)

Received from EFR:

Date Assigned:

Assigned to:
Initials / Date Initials / Date

(Same as ciaia dase ontuî)

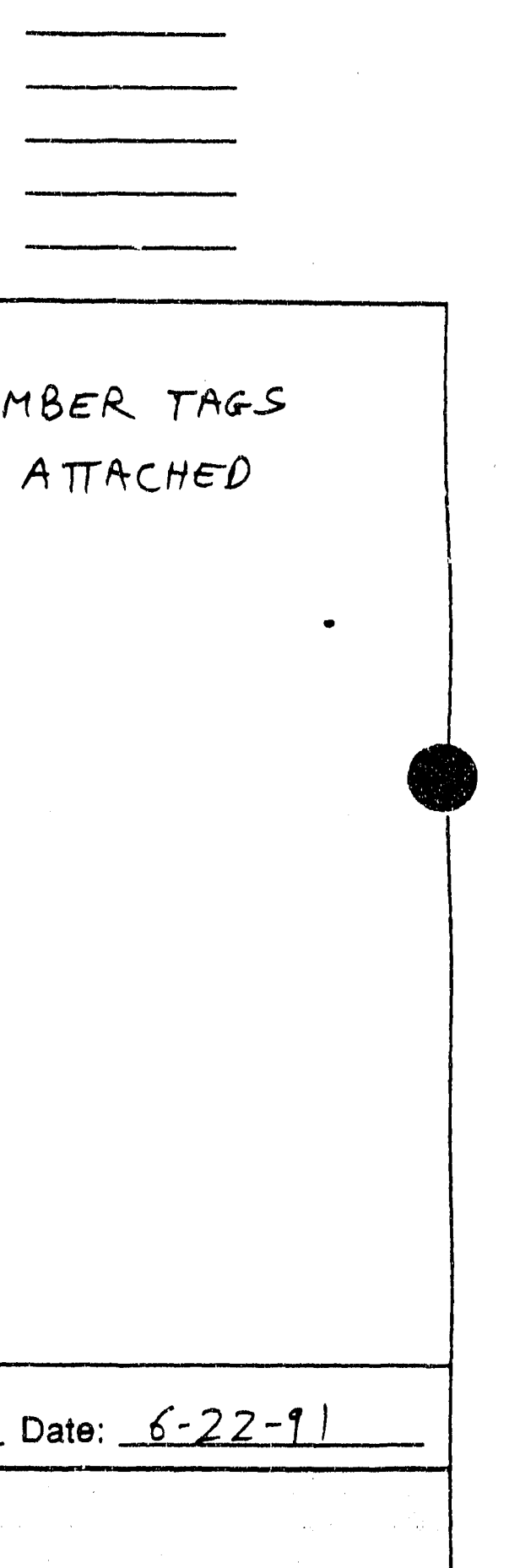
Date: $6-22-91$

Drafting Started:

Drafting Completed:

Return to EFR:
Initials / Date

Initials / Daie

Initials / Date 


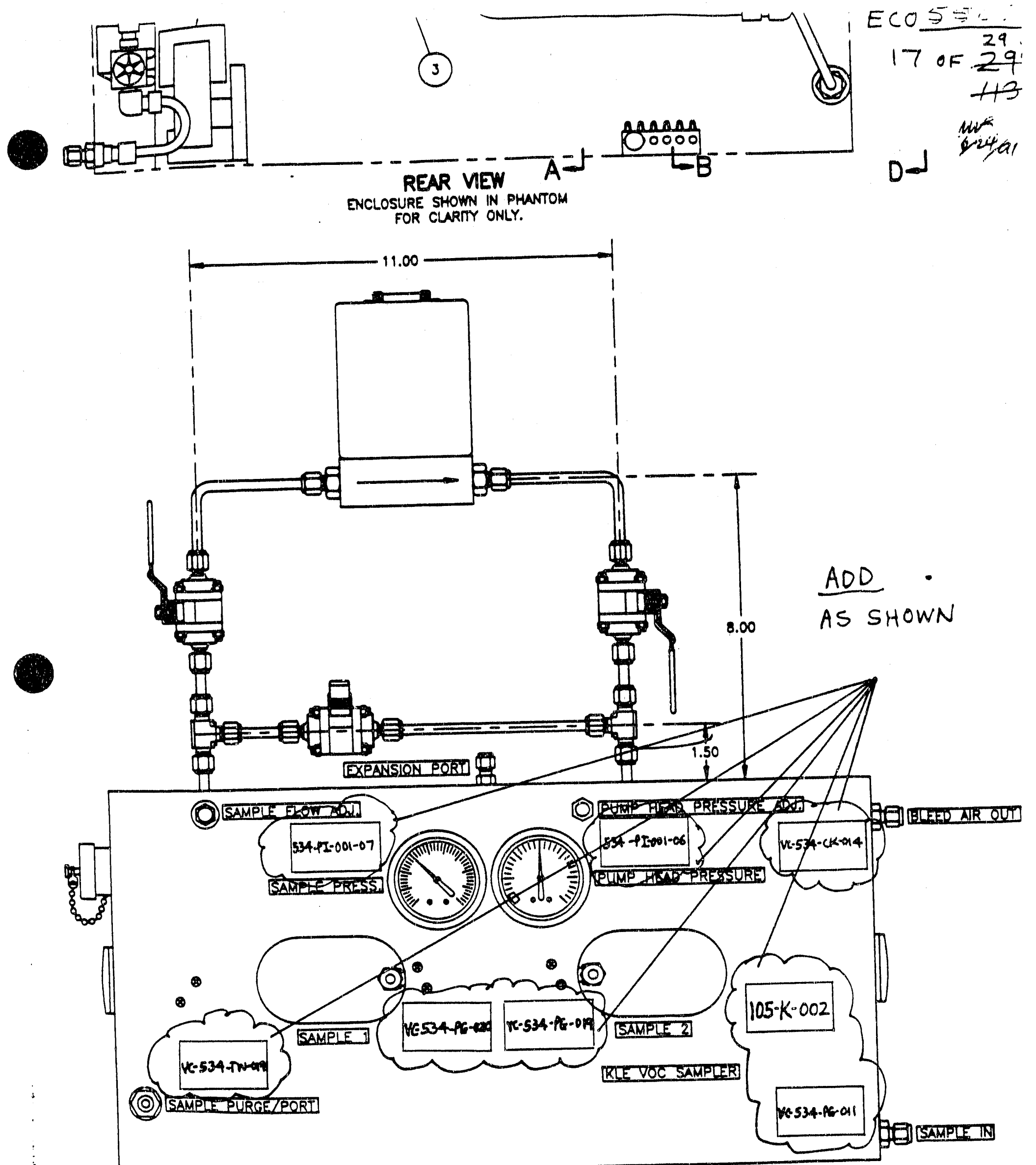

\section{FRONT VEW}


1. Drawing:

ECO Number: $5 \leqslant 65$

2. ECO Search List:

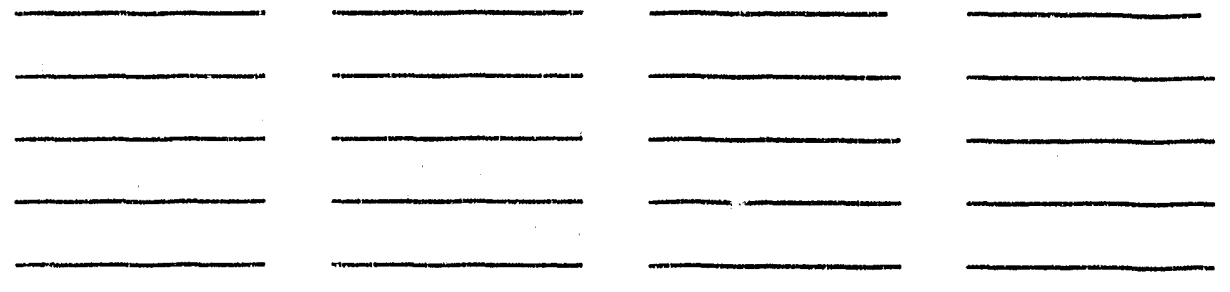

3. Description of Change:

1. EXCHANGE "CRI" \& "CRZ" DESIGNATIONS

2. CORRECT THE PRIORITY ALARM DESIGNATIONS

3. ADD HALFSHELL NUMBER IN LPU

4. ADO SYSTEM DESIGNATIONS

5. ADD RESISTOR TO 105.H-001-05 LOOP,

PLC TERMINALS 11 \& 13

6. ADD SCT-02 TO 105-H-001-01 LOOP ( $\pm 10 \mathrm{~V}$ OUT)

7. CHANGE TERMINAL BLOCK DESIGNATIONS

IN 105-H-001-02 LOOP

8. "PRIORITY I" TO "HIGH PRIORITY" \& "PRIORITY 2" TO "LOW PRIORITY".

SEE ATtACHED PAGES

4. Drawing Cog. Engineer Approval: J.R. Ltublle

Date: $6-22-91$

5. Cover Sheet Block (CC\&D Use Only)

Received from EFR:

Date Assigned:

Assigned to:
Drafting Started:

Initials / Date

Initials / Date

(Same as data base entry)
Initials / Date

Drafting Completed:

Return to EFR:
Initials / Dato

Initials / Date 


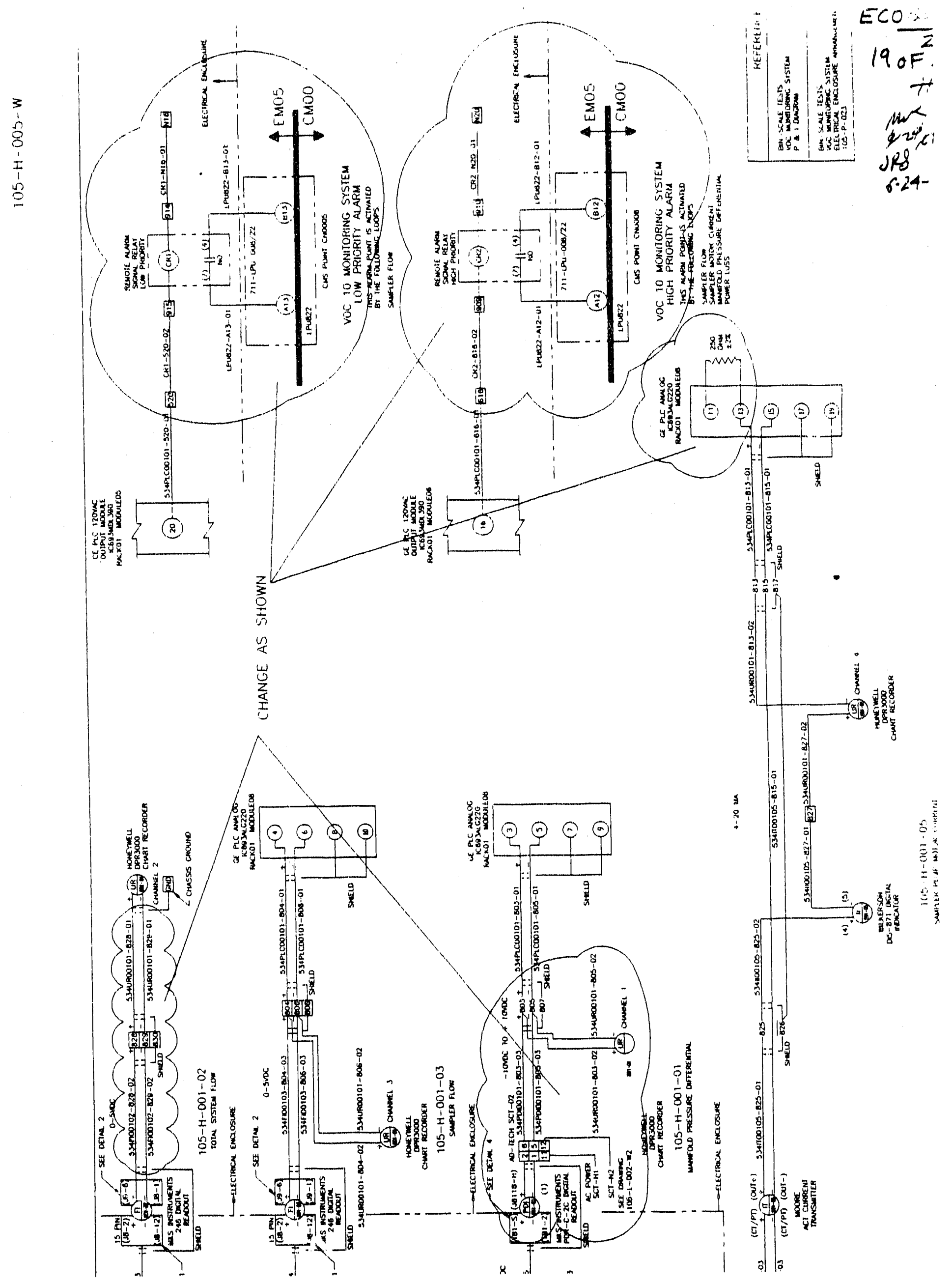




\section{$9 \mathrm{a}$}

1. Drawing: $105-L-002-W 2$ ECO Number: 5565

2. ECO Search List:
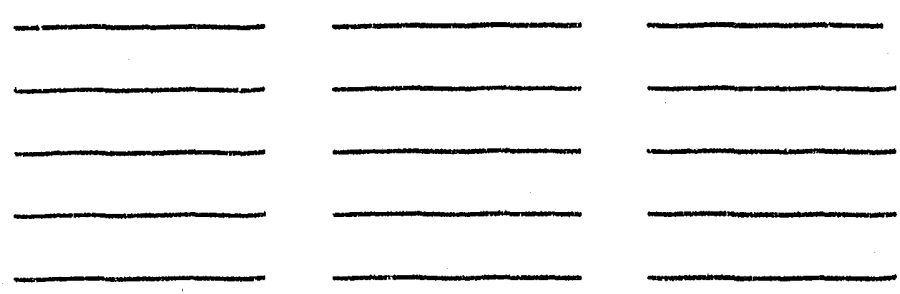

3. Description of Change:

1. ADD WIRING FOR THE SIGNAL CONDITIONING TRANSMITTER (SCT) AS SHOWN ON THE ATTACHED PAGES.

2 . EXCHANGE "CRI" * "CRZ" DESIGNATION.S

3. ADD A ISA CIRCUIT BREAKER IN-LINE BEFORE THE LINE PROTECTOR

4. ADD SYSTEM DESIGNATOR ON BLOCK DIAGRAM

\section{SEE ATTRCHED PAgES}

4. Drawing Cog. Engineer Approval: U.R. Stuoble Date: $6-22-91$

5. Cover Sheet Block (CC\&D Use Only)

Received from EFR: Initials / Date

Date Assigned:

Assigned to:

Initials / Date
Drafting Started:

(Same as data bese entry)
Dratting Completed:

Return to EFR: Initials / Date initials / Dato Initlals / Date 


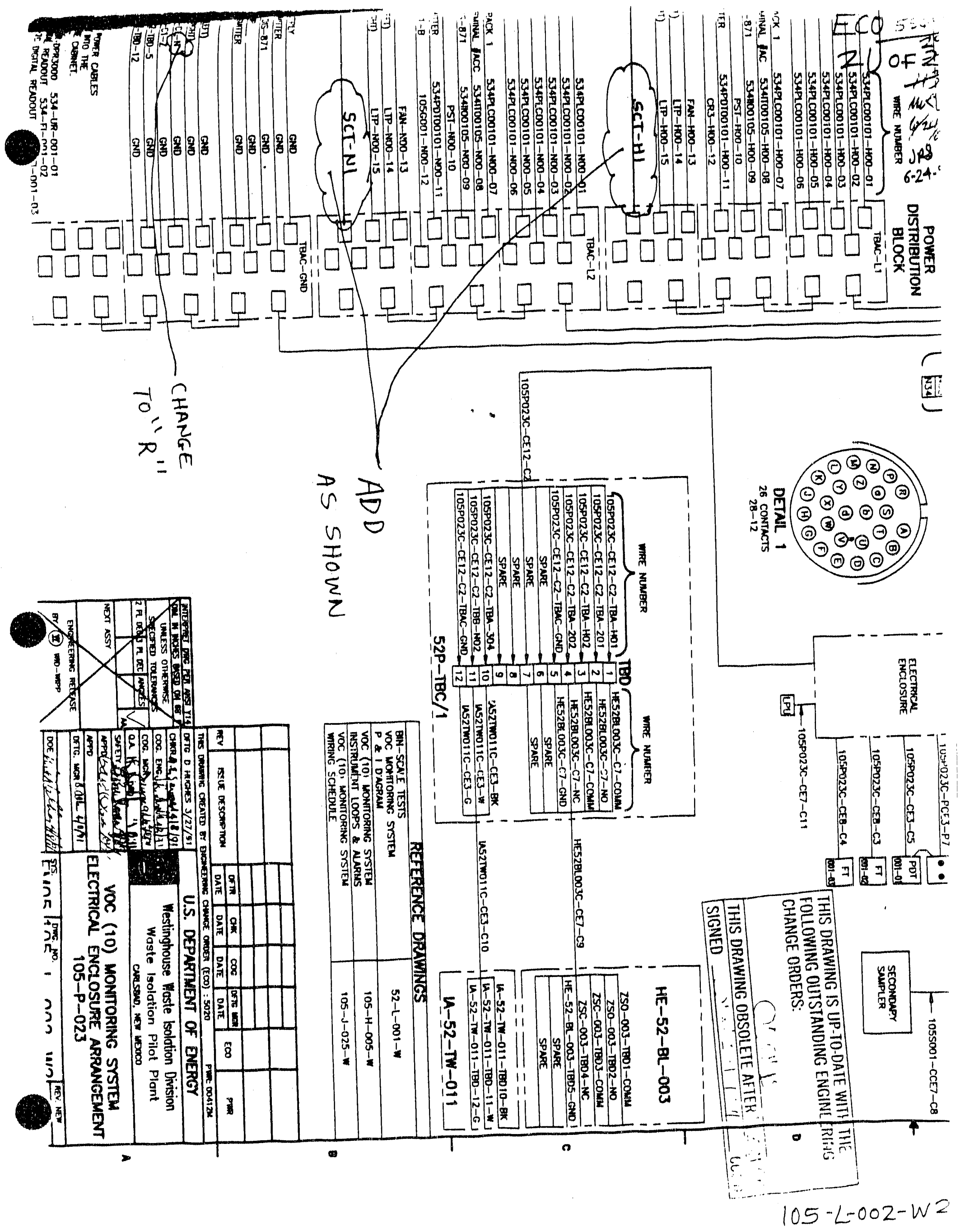




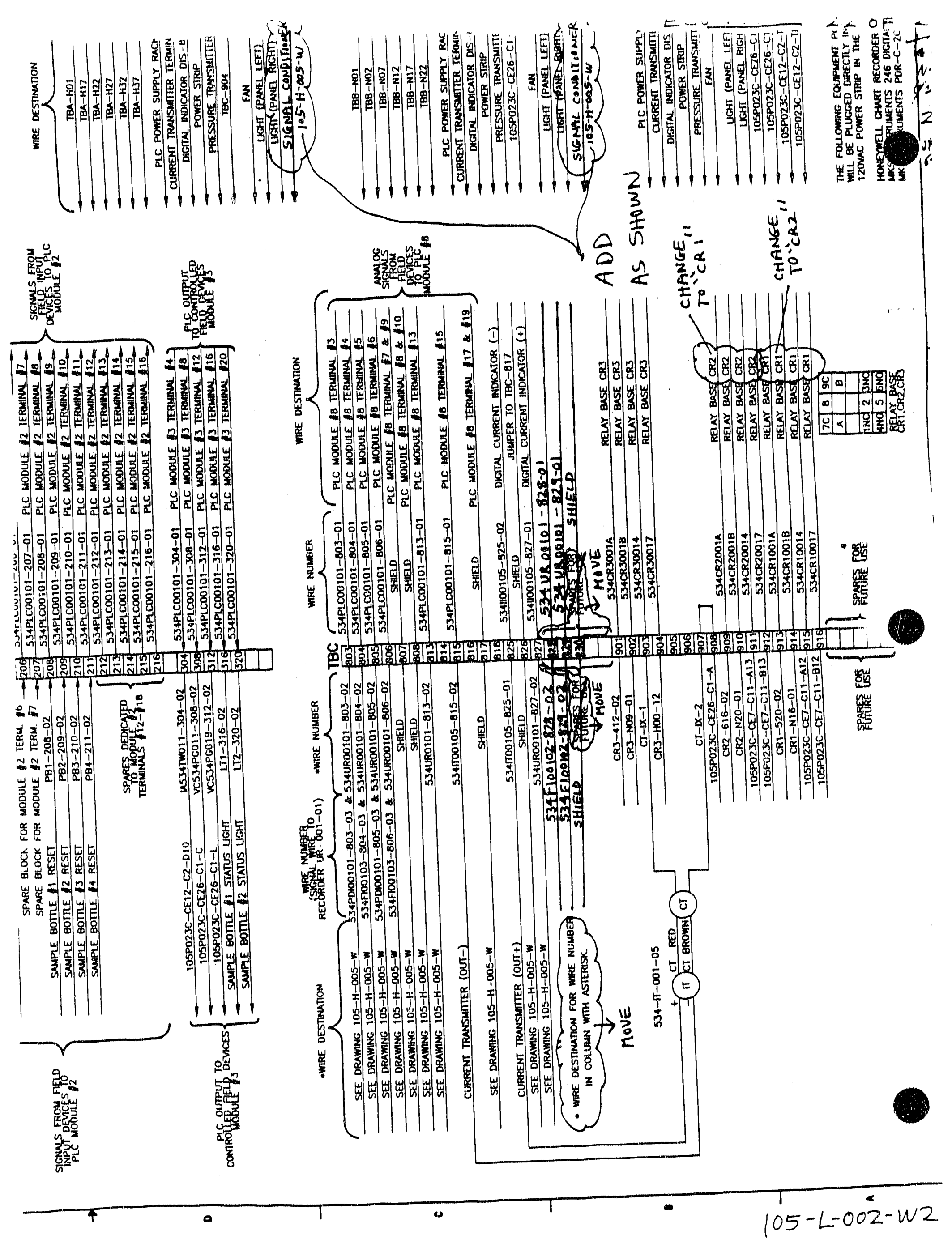


Z(n-200-7-50)
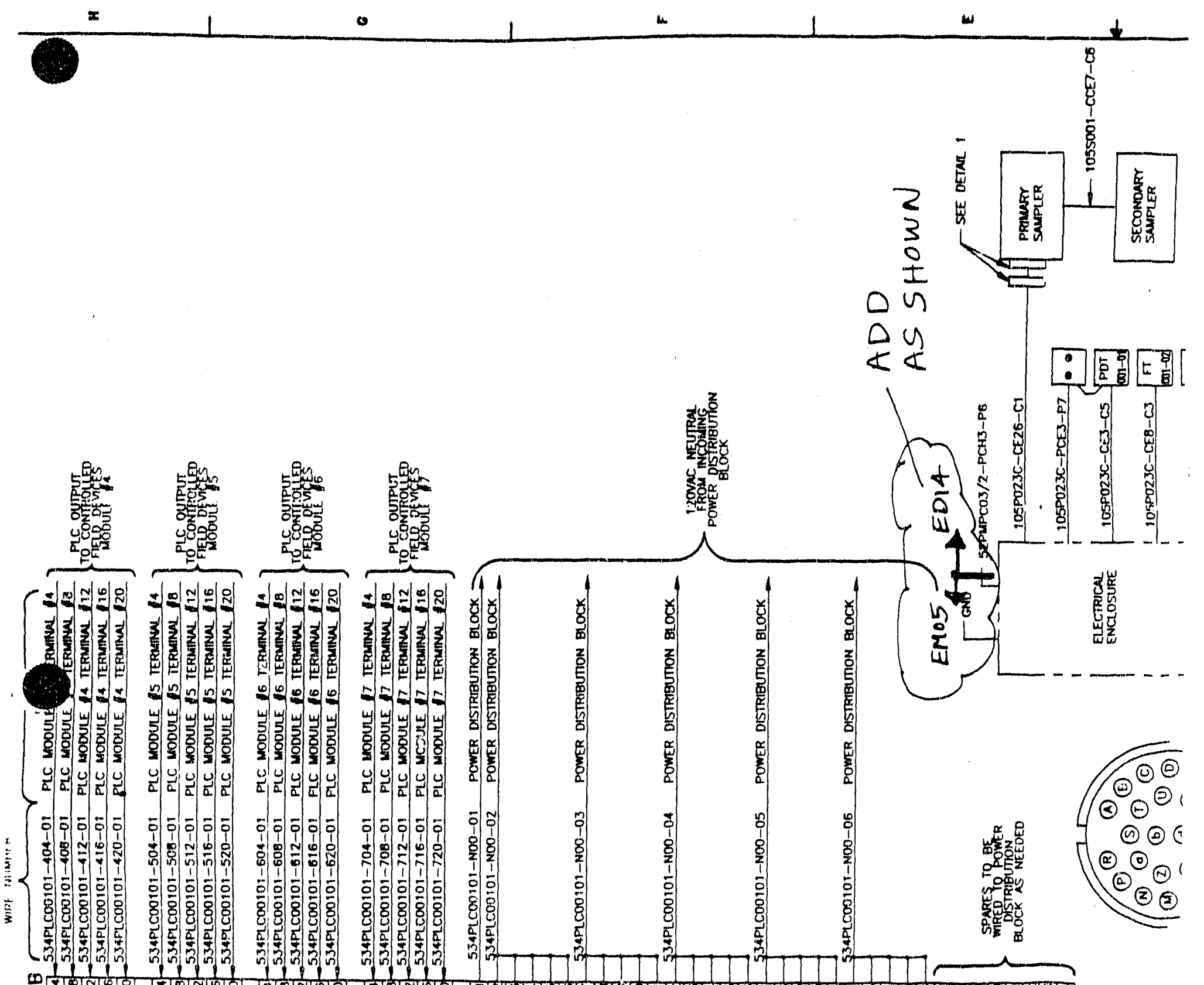

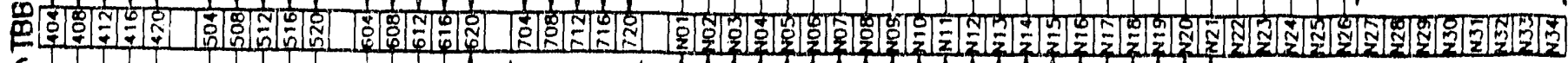

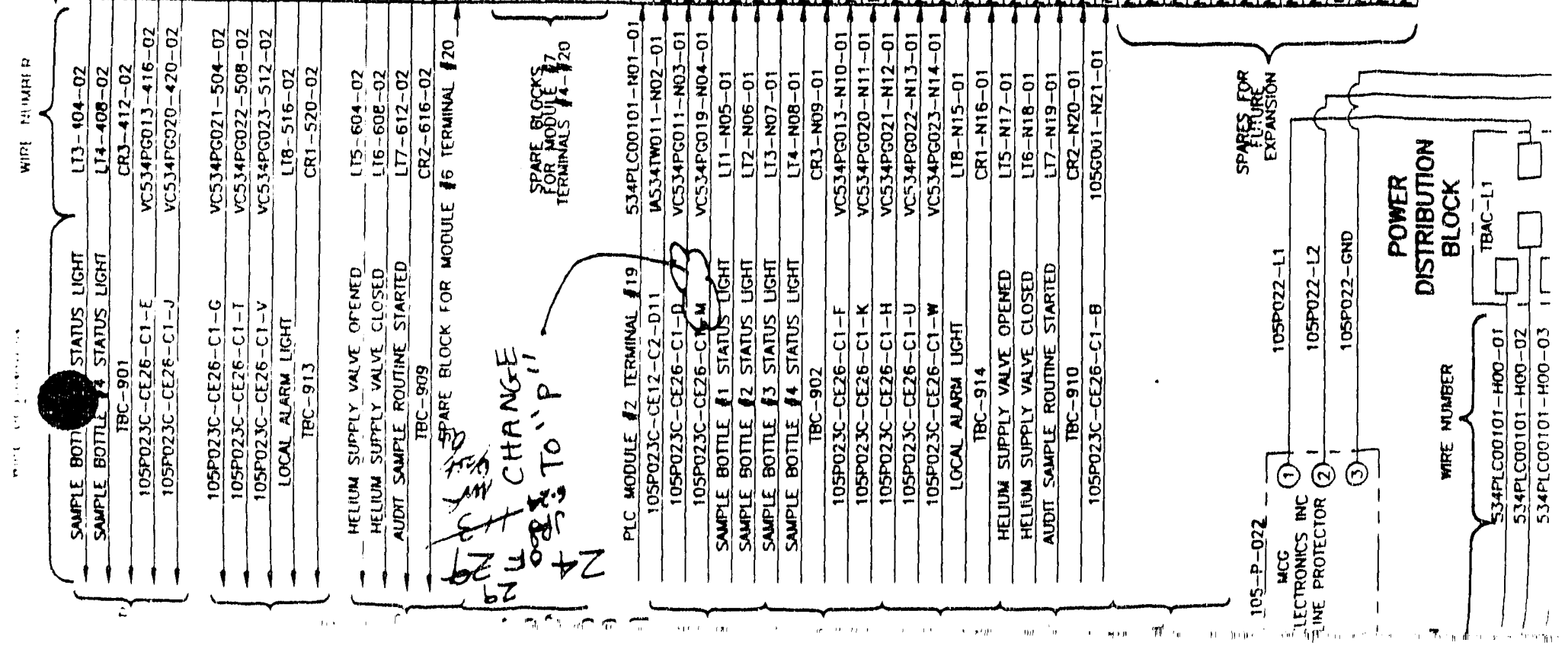


1. Drawing: $105-2-022-w$ ECO Number: 5545

2. ECO Search LIst:
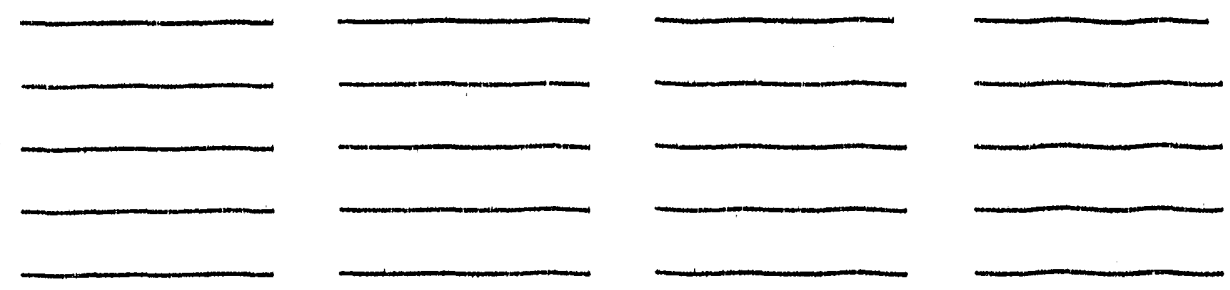

3. Description of Change:

$$
\begin{aligned}
& \text { 1. EXCHANGE "CRI" \& "CRZ" DESIGNATIONS } \\
& \text { 2. CHANGE "1" * "2" PRIORITY TO "HIGH"\& "LOW". }
\end{aligned}
$$

$$
\text { see attached pages }
$$

4. Drawing Cog. Engineer Approval: d. R. stutulfe

Date: $6 \cdot 22:-91$

5. Cover Sheet Block (CC\&D Use Only)

Received from EFR:

Date Assigned:

Assigned to:
Initials / Date

Initials / Date

(Same as data base entry)
Drafting Started:

Dratting Completed:

Return to EFF:
Initials / Date

Initials / Date

Initials / Date 


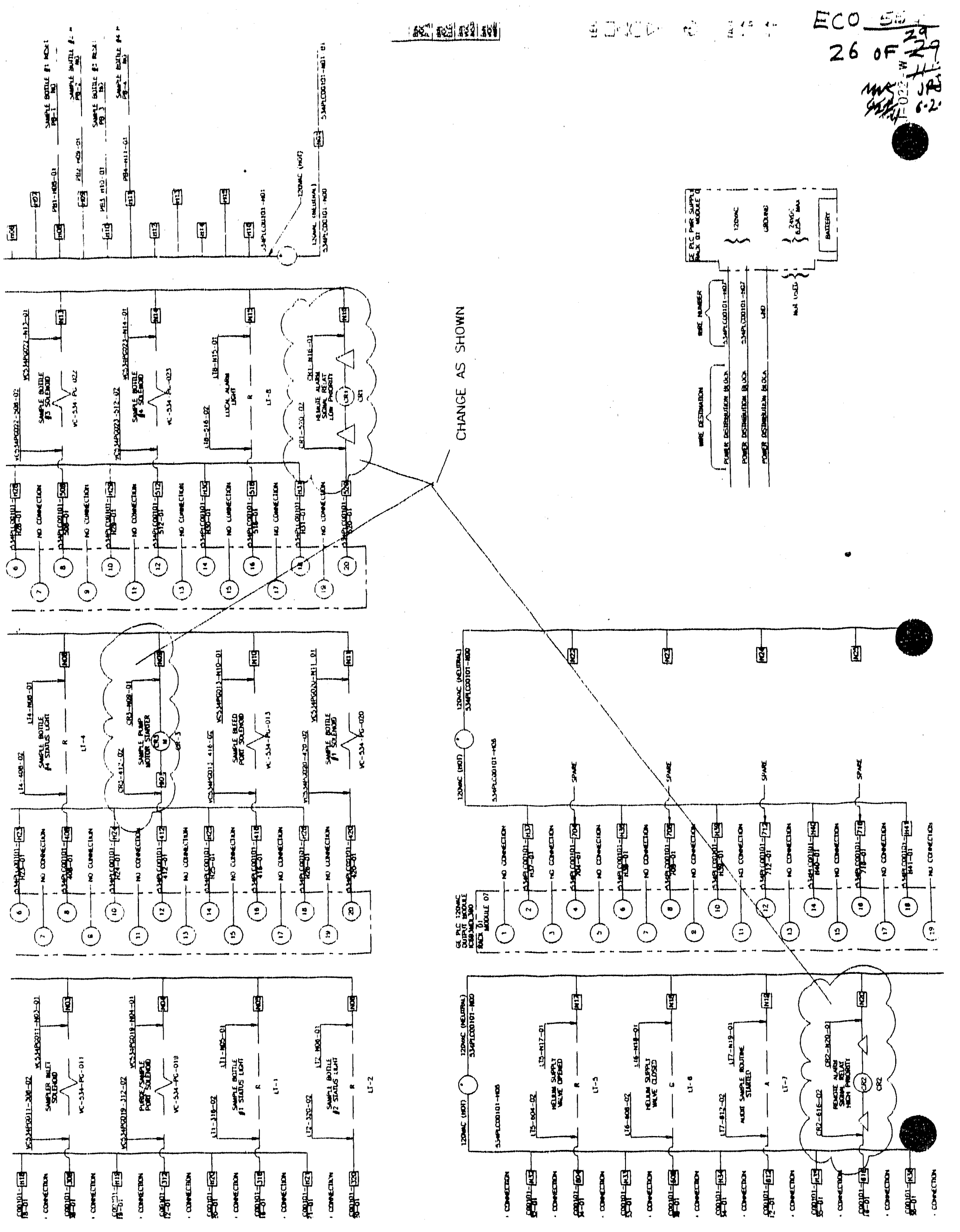


1. Drawing: $105-2-030-w$ ECO Number:

5565

2. ECO Search Llst:
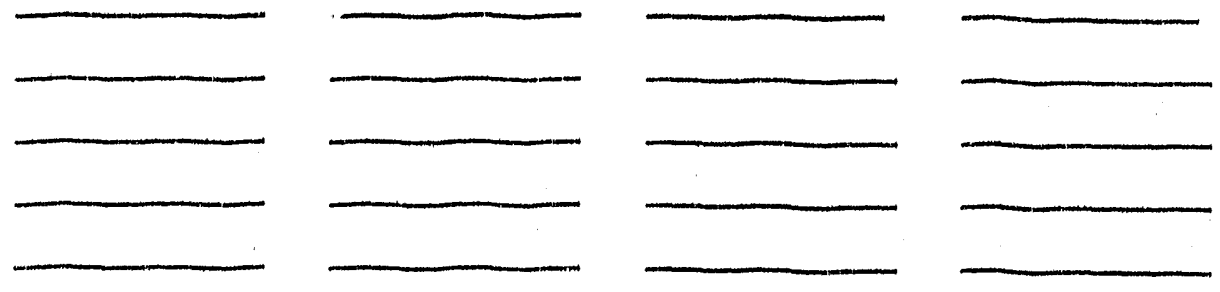

3. Description of Change:

1. MOVE THE WIRES FROM "M" ${ }^{\prime \prime} " N$ " TO "P " ${ }^{\prime \prime}$ "R" ON THE INPUT CONNECTOR,

2. ADD THE DIODE \& CAPACITOR CIRCUIT FOR 54.

\section{see attached pages}

4. Drawing Cog. Engineer Approval: L. K. Sturbe Date: $6-22-91$

5. Cover Sheet Block (CC\&D Use Only)

Received from EFR: Initials / Date

Date Assigned:

Initials / Dato

Assigned to:

Drafting Started:

Drafting Completed:

Roturn to EFF:
Initials / Dato

Initials / Date

Initials / Date 

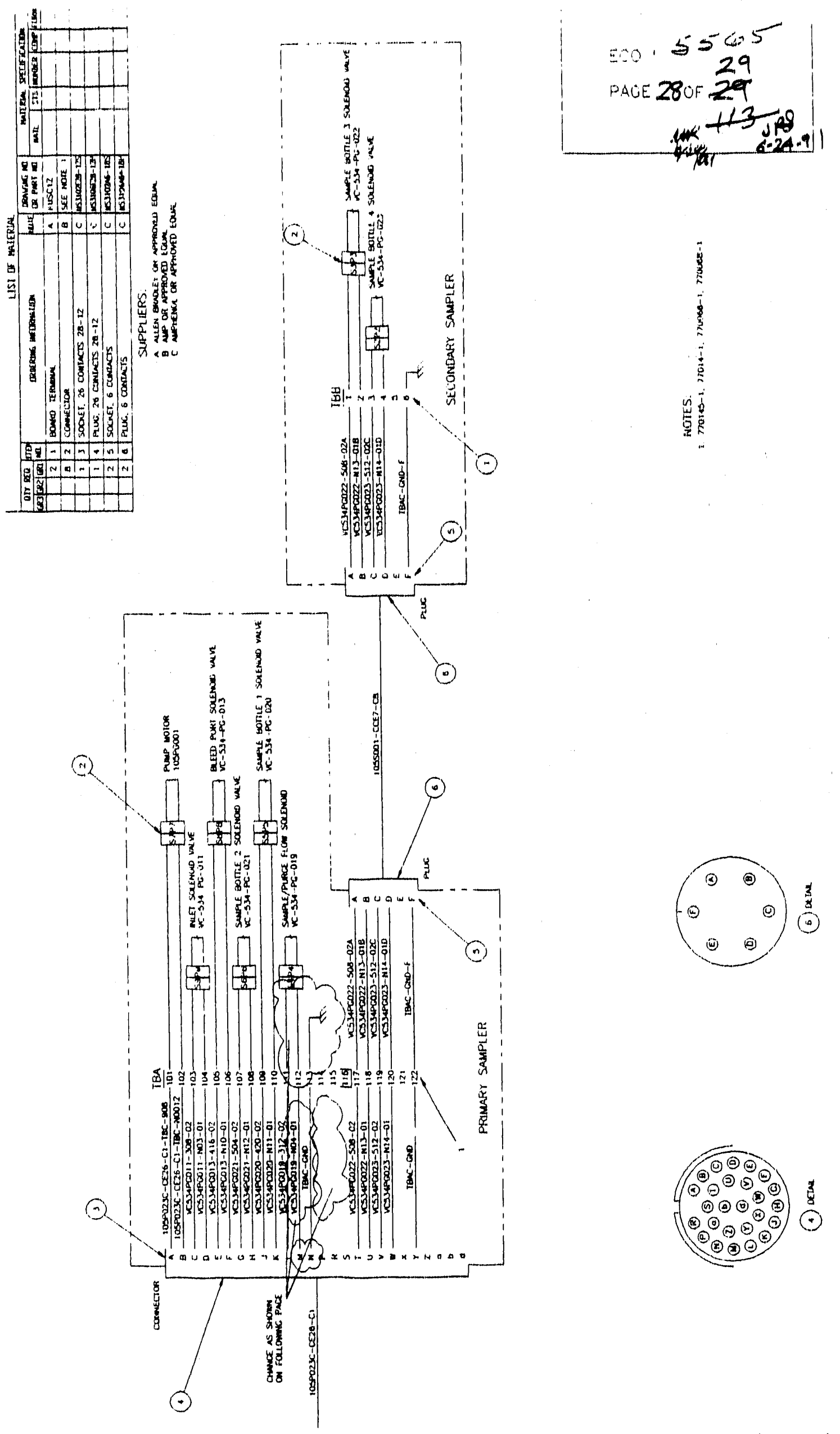


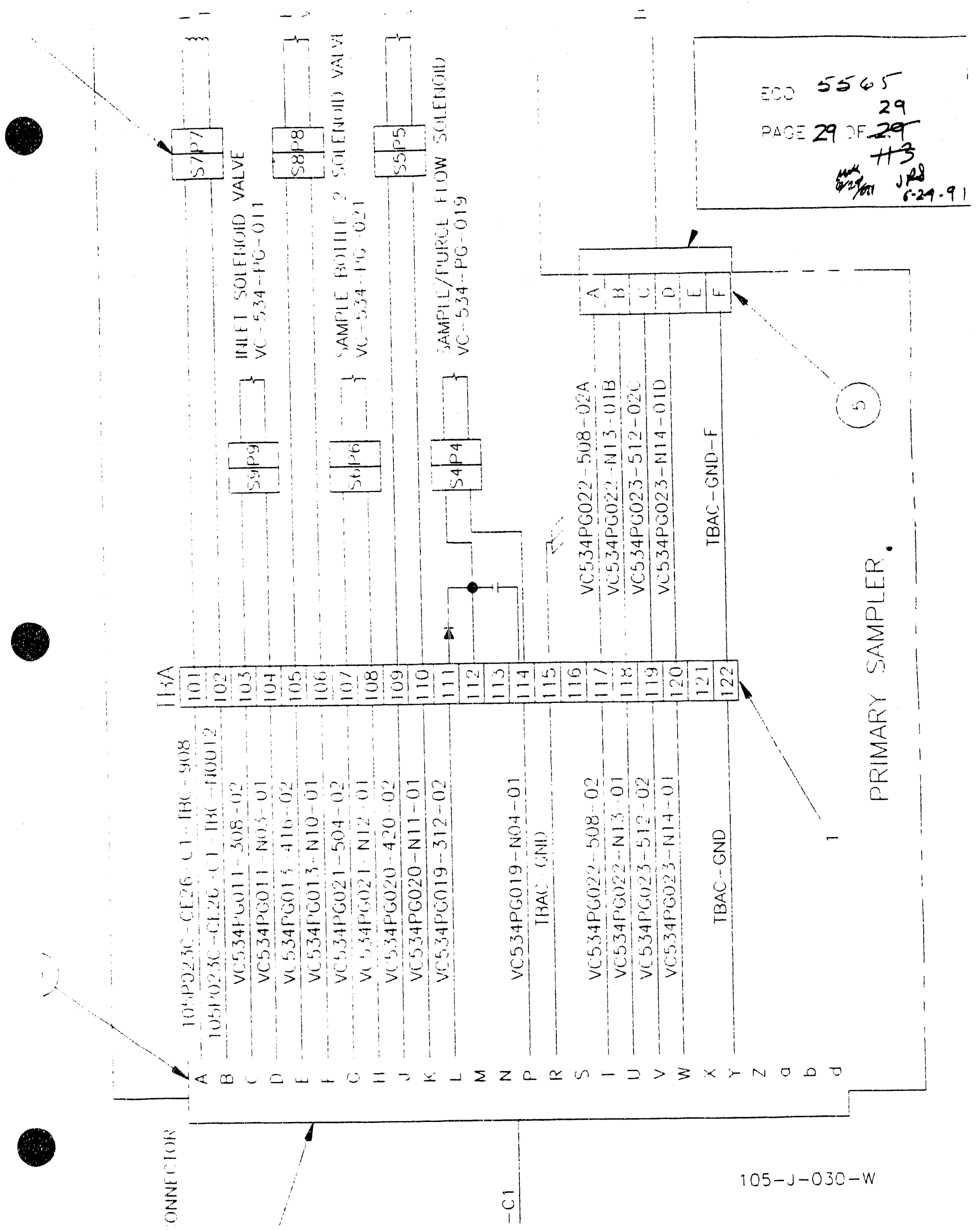




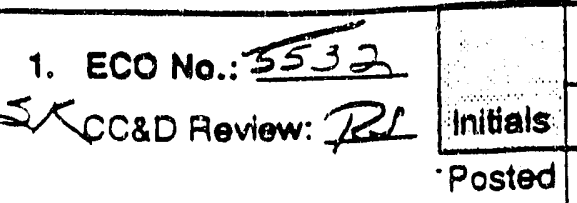
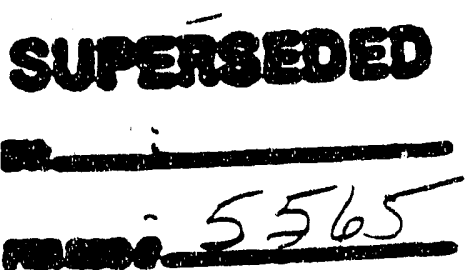

2. Impact Level $1 \square \quad 2 \square \quad 3 \square 4 \square$

3. System: EMOS Equipment No.: $K C-534 \pi V$-oogBuilding: $L G$

4. Associated Documents:

PWR

ECP

P.O.

Others PWRM41816
5. Document Type: $\quad g c 6 / 4 / 91$ Drawing $5 z \div \square$ 52-L- - D2-W5 Specitication $52-L-\infty 02-W 6$ Vendor Data $52-L-\infty 2-W 2$ Vendor Data 52-L-D02-W3 SDD $\quad 52-6-001-W$ Others $\quad 52-L-\infty 2-W Z$

6. Title of Change: VOC 10 MODLFICATLONS

7. Originator: (print) JERRY CAMP
Ext. No.: Department:

8750

EE
Date: $6-7-91$
8. Cognizsant Engineer: (print) J.R.STROBLE

9. Description of Change:

(i) CHANGE TUBING CONFIGLPATION TO

Yes No Component indices change required (if yes, attach sheets;

PRESSURE RELIEF VALVE 534-geG/91 VC-534-RV-DO9

AS SHOWN ON ATTACHED SHEETS.

(2) $A D D$ FLAG NOTE AS SLIOWN ON ATTACHED SHEETS.

ADD NOTE TO SUEET I (52-L-OOZ-WI). DRAFTING TO DSRDEREWW NOTE NO.

Q: AO ALL TUBING FROM THE MAIN CARBON BED

OUTLET TO THE SAMPLPR INLET LS WURAPDED

WITL HEAT TAPE. ( 3.25 WATTS PER SQUVRE (NCH)

Q 9a Drawing Change Sheet attached

10. Yes No j\&s-13-41
$\triangle$ BO MODIFICATION IN PROGRESS
Modification complete:

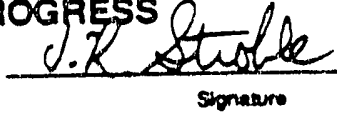
$\frac{6-24-91}{\text { Dan }}$
ECO will be
someanse

$\triangle$

Change drawing per as-built markup dated: NEW ECQ

Change drawing per ECO-provided data

Temporary modification

11. Design Verification Roquirements: (per WP 09-018)

EDT No.:

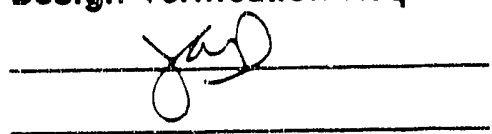

1. Requirements satisfied by review/approval of design document

2. Independent review

3. Altemate calculations

4. Development testing

5. Design review

ธ. Oher:

12. Addendum Sheat added: 


\section{ENGINEERING CHANGE ORDER \\ ADDENDUM SHEET}

1. Addendum Sheet to ECO Number: 5565 Drawing Number: $52-L-00 z-w z$

2. Description of change:

Replace page $s$ of the eco with the one attached. a 3-way valve was left off OF THIS PAGE BY MISTAKE. ITS SHOWN ON PAGE 5 OFTHEETIN PHID DRAWING 52-L-001-W. the valve is 534-TW-010.

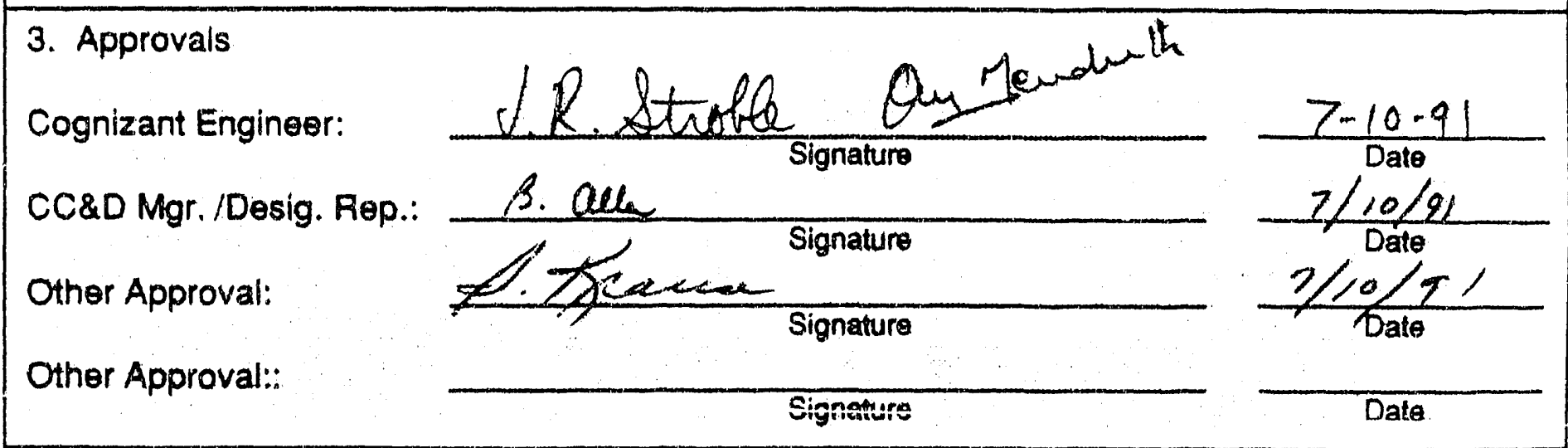


ECO 5565

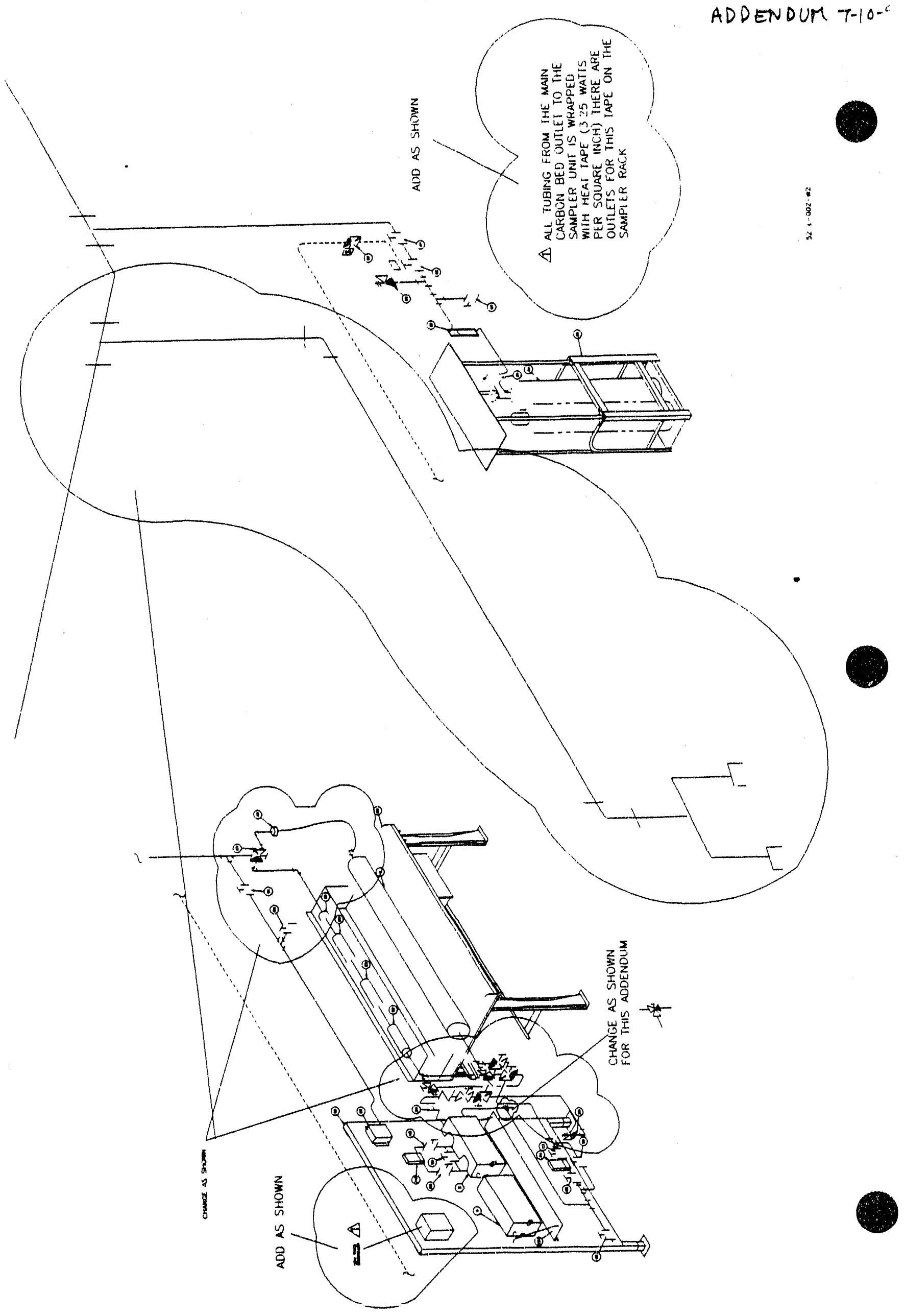


ENGINEERING CHANGE ORDER

ADDENDUM SHEET

1. Addendum Sheet to ECO Number: -5565

Drawing Number: $52-L-002-w 3$

2. Description of change:

Replace page 10 of the eco with the one attached. a 3-way valve was left OFF OF THIS PAGE BY MISTAKE. ITS SHOWN ON PAGE 5 OF THE ECO IN PaID DRAWING 52-L-001-W. THE VALVE IS 534-TW-010.

3. Approvals

Cognizant Engineer:
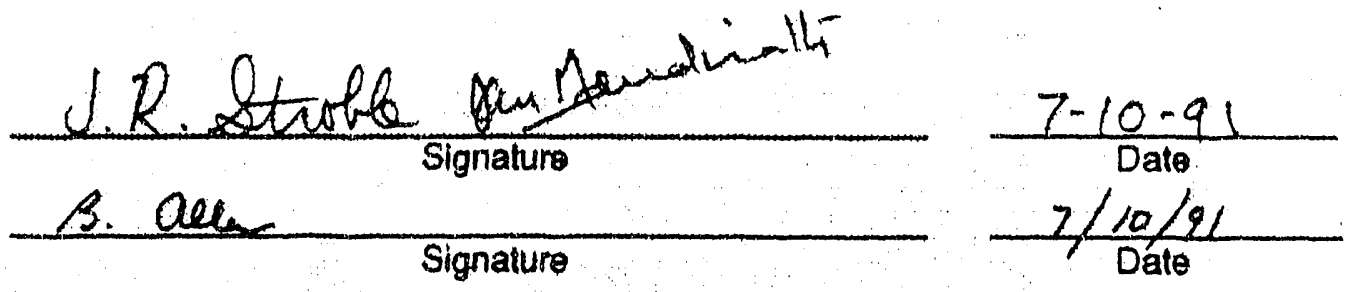
CC\&D Mgr. /Design. Rep.: B. Dew

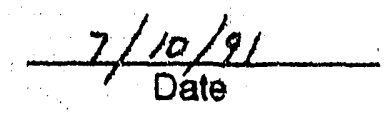

Other Approval:

Other Approval::

Signature

Signature
Date.

Dale

WP Form 2020; $12 \sqrt{2} \overline{9} / \overline{9} 0 \overline{0}$

1290:B0009

Page 1 of 1 


$$
\text { (3) }
$$<smiles>CCCCC(C)C</smiles><smiles></smiles>

$\wedge$<smiles>[CH]</smiles>

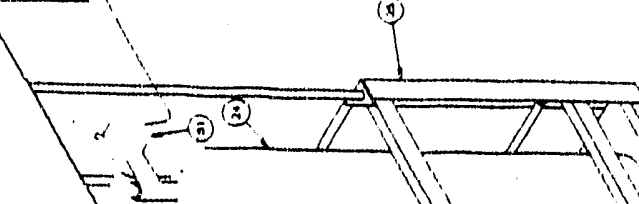

$-2$
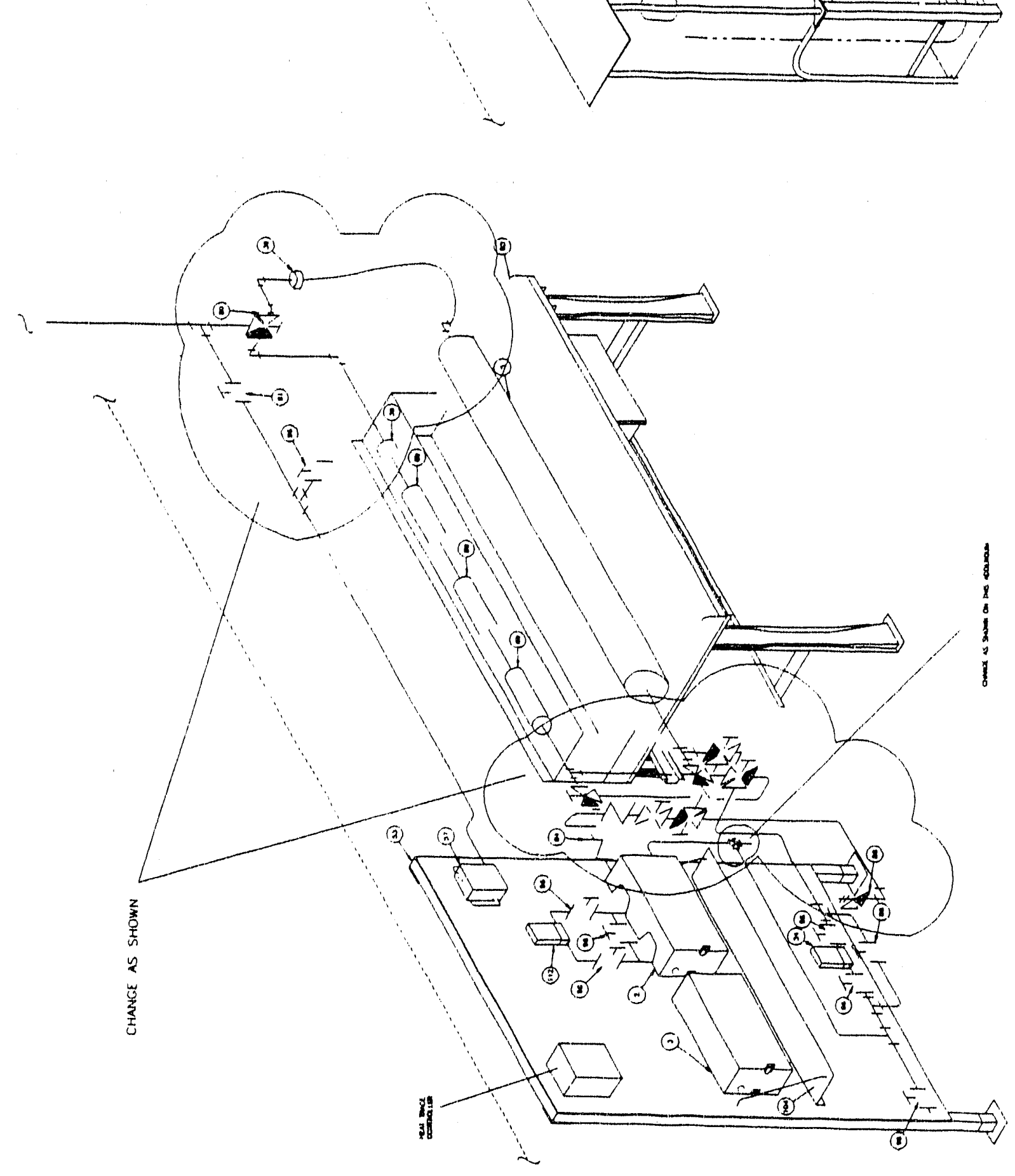

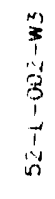


ENGINEERING CHANGE ORDER

ADDENDUM SHEET

1. Addendum Sheet to ECO Number: 5565 Drawing Number: $52-1-001-w$

2. Description of change: SEE ATTACHED PAGES

1. delete the 'A $\Delta$ ' note marker. the Note has beEN DELETED, BUT THE MARKER STILL APPEARS ON THE DRAWING.

2. ADD A BOUNDARY BETWEEN THE WH0.6 MANIFOLD AND SANDIA NATIONAL LABS OXYGEN METERING SYSTEM.

3. VALVE HE -534-BL-004 SHOULD BE SHOWN AS NORMALLY OPEN.

3. Approvals

Cognizant Engineer:

CC\&D Mgr. /Design. Rep.:

the Approval:

Other Approval::

WP Form 2020; 12/29/90

Page 1 of 1

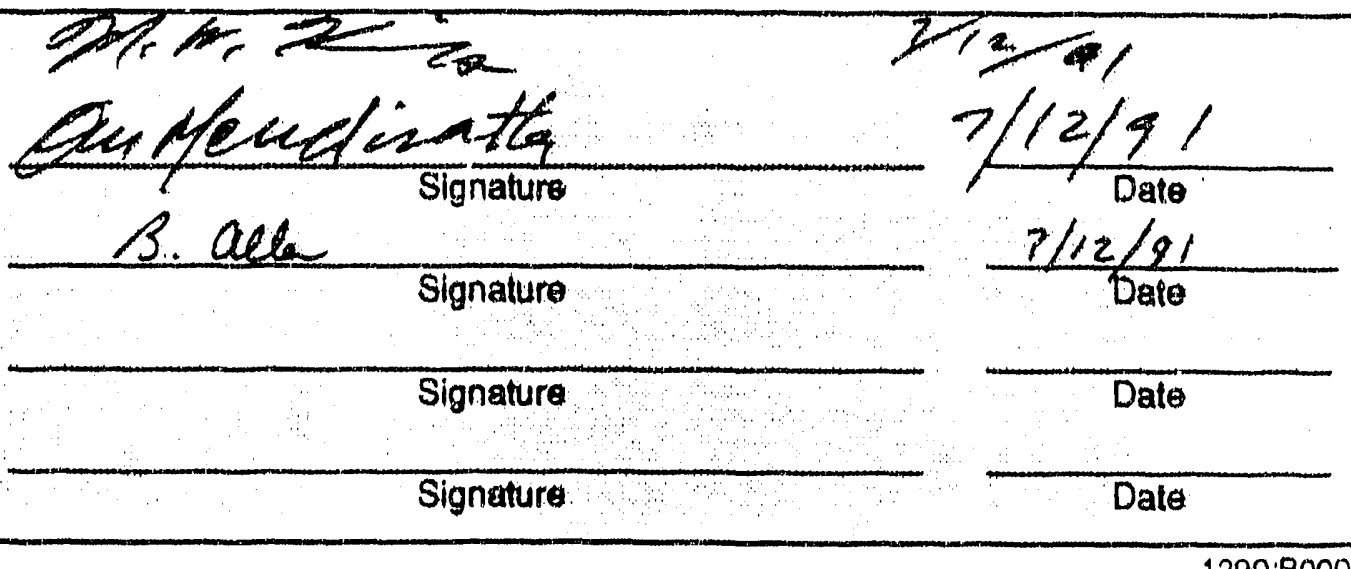

$1290: 80009$ 


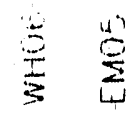

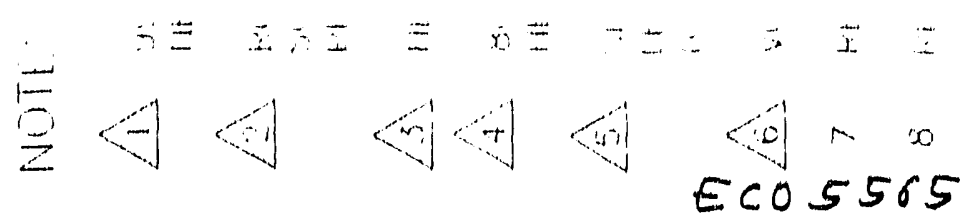

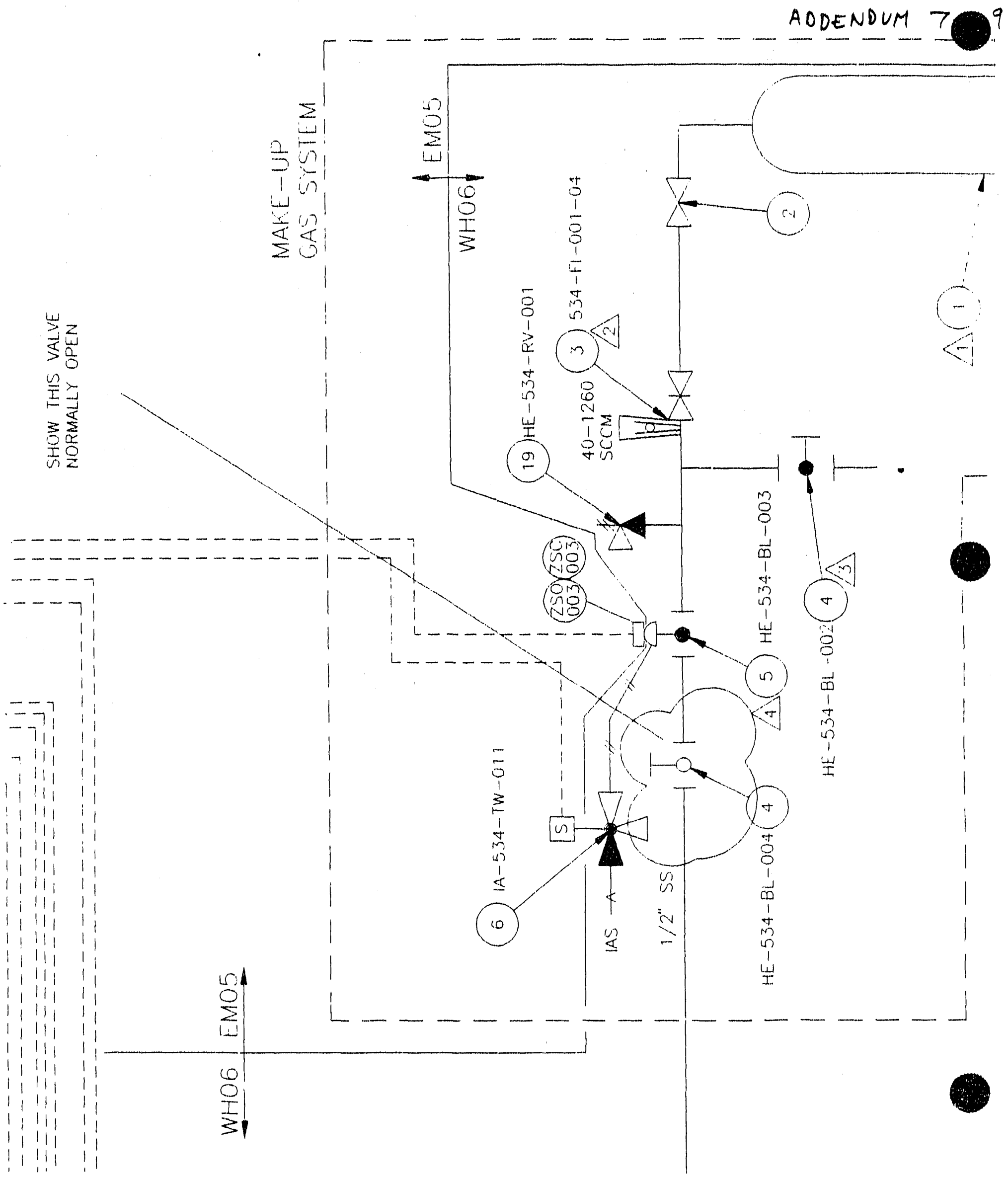




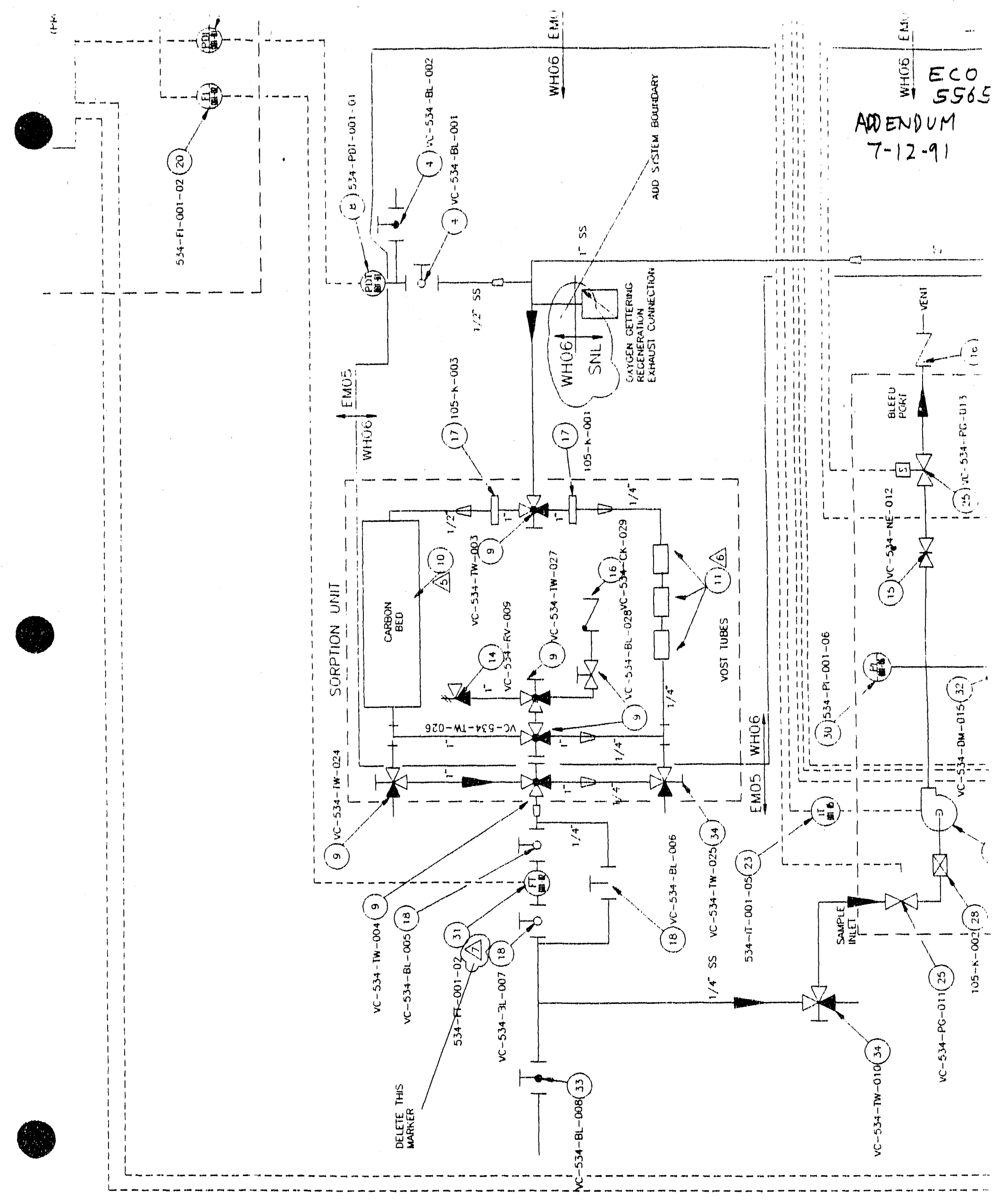


PAGE 10F2.

ENGINEERING CHANGE ORDER $9-|2-9|$ ADDENDUM SHEET

1. Addendum Sheet to ECO Number: 5565 Drawing Number: $52-L-002-W$

2. Description of change: CHANGE THE DESCRIPTION AND PART NO.
FOR ITEM 70 FROM "UNION, ELBOW $1 / 2 " \mathrm{~s}$ " $5-810.9 " 1 "$ TO "UNION, TEE $1 / 2$ " SS-810-3!" THE ITEM 70 IS SHOWN ON 52-L-OO2-W4 \& IS CORRECT, BUT THE DESCRIPTION AND PART NO. ARE INCORRECT ON THIS DRAWING.

3. Approvals

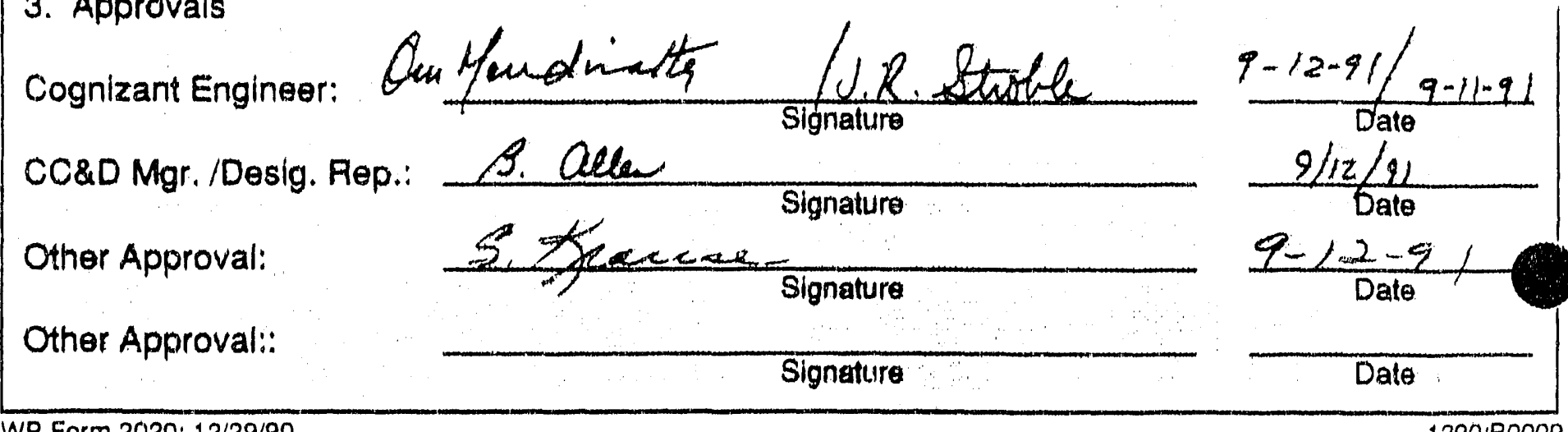

WP Form 2020; $12 / 29 / 90$

$1290: 80009$

Page 1 of 1 
ECC :

PAGE 2 OF 2

ADDENDUM $9-12.9$.

$52-L-002-w 1$

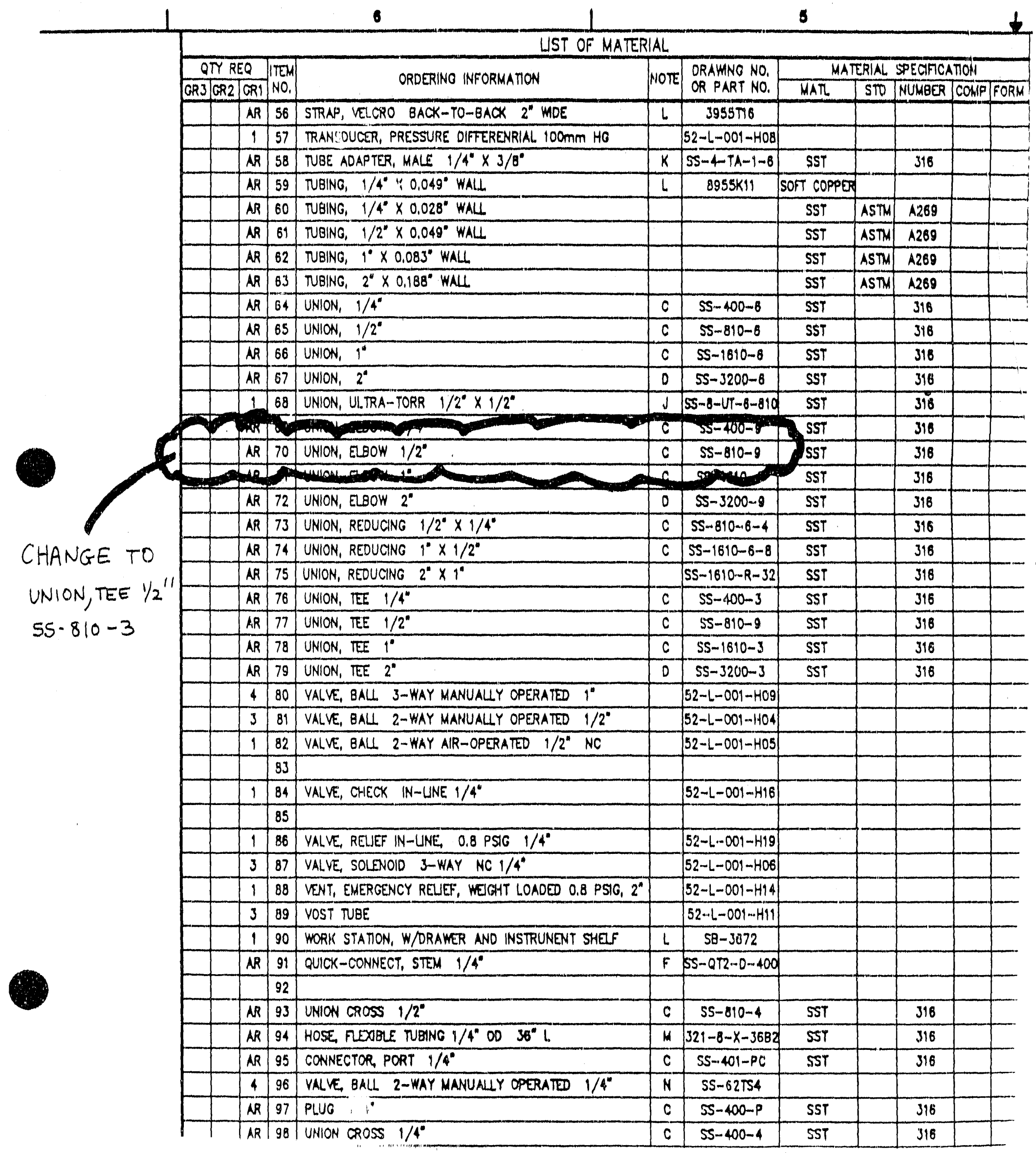


1. ECO NO.: 5 G 2.5 CC\&D Review: Initials Posted

\section{Impact Level $1 \square \quad 2 \square \quad 3 \square 4 \square$}

3. System: EUES Equipment No: $V C-534 \cdot 7 W-\Delta 24$ Bullding: $L G$

4. Assoclated Doouments:

PWA 12672 ECP

P.O.

Others

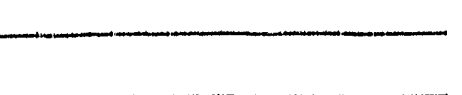

\section{Document Typo:}

Drawing $\Xi 2+i+\Delta L i \cdot V L$

Specification

Vendor Data

SOD
Others

6. Title of Changn: ADDLTICN CF TLUBING DWNSTLNA OF" CAZBCAN BED

7. Originator: (print) Ext. No.: Department: Date: 1 8. Cognizant Engineer: (print)

\section{Description of Change:}

$(52-L-C O 2-W S)$

(A) ADDITICN CF FLEXIBLE STEEL TLBLNG $7-18-9 /$ J.R.STROBLE

DINNSTREAM CF CAREBN BED.

$\left(52 \cdot L-C O L^{2}-W I\right)$

(B) ADDITION CF FLEXIBLE STEEL TLBUK TO BILL OF MATL.

Q9a Drawing Change Sheet attached

9b Design Documentation Sheet attached

10. Yes No
$\frac{\mathbb{Q}}{\square}$
$\square$ MODIFICATION IN PROGRESS
Modification complete:

Yes No

Component indices ohange required

(if yes, attach sheets)

$\square \quad \square$

(1)




\section{Justification}

THIS CHAAMGE IS REGLLIRED TO ALLOW GRERATLONS

EASIER REPLACENIENT OE THE CHRENN BET.

\section{Administratlve Tracking}

YES N/A

$\square$ 1. FSAR

$\square$ 2. Calibration Procedures

$\square$

$\square \square$

$\square$

3. Maintenance Proceifures

4. Computer Software

5. Operations Procedures

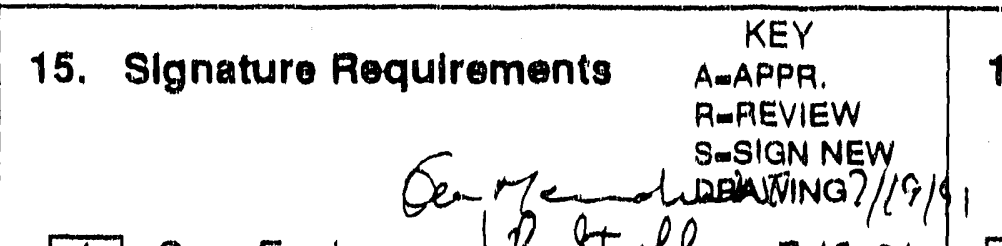

QA

DOE

Satety

Dept. Manager

Operations

Security

SNL

BWHE WHOr COS Qm Me finth?/1499

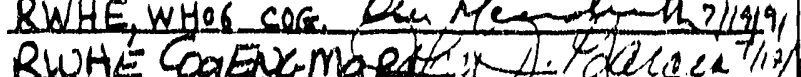

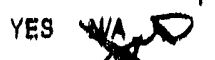

$\square$. 6

$7 \mid 2 2 \longdiv { 9 | }$

$\square$ 7. Test Requirement \& Spec.

$\square \square \quad 8$

$\square \square \quad 9$

$\square \square 10$.

\section{Distrlbute as Marked}

$\square$ Maintenance (MANDATOAY)

Ops. Support MANDATORY) Startup

Facility Operations

U/G Operations

Drig./Design Engr.

Cog. Engineer

Others

TERRY CAMP 


\section{ENGINEERING CHANGE ORDER DOE ORDER 6430.1A DESIGN CRITERIA}

\section{CHECKLUT}

The design requirenents in OOE Order 6430.1A checked below hove bean applied tig this Design.

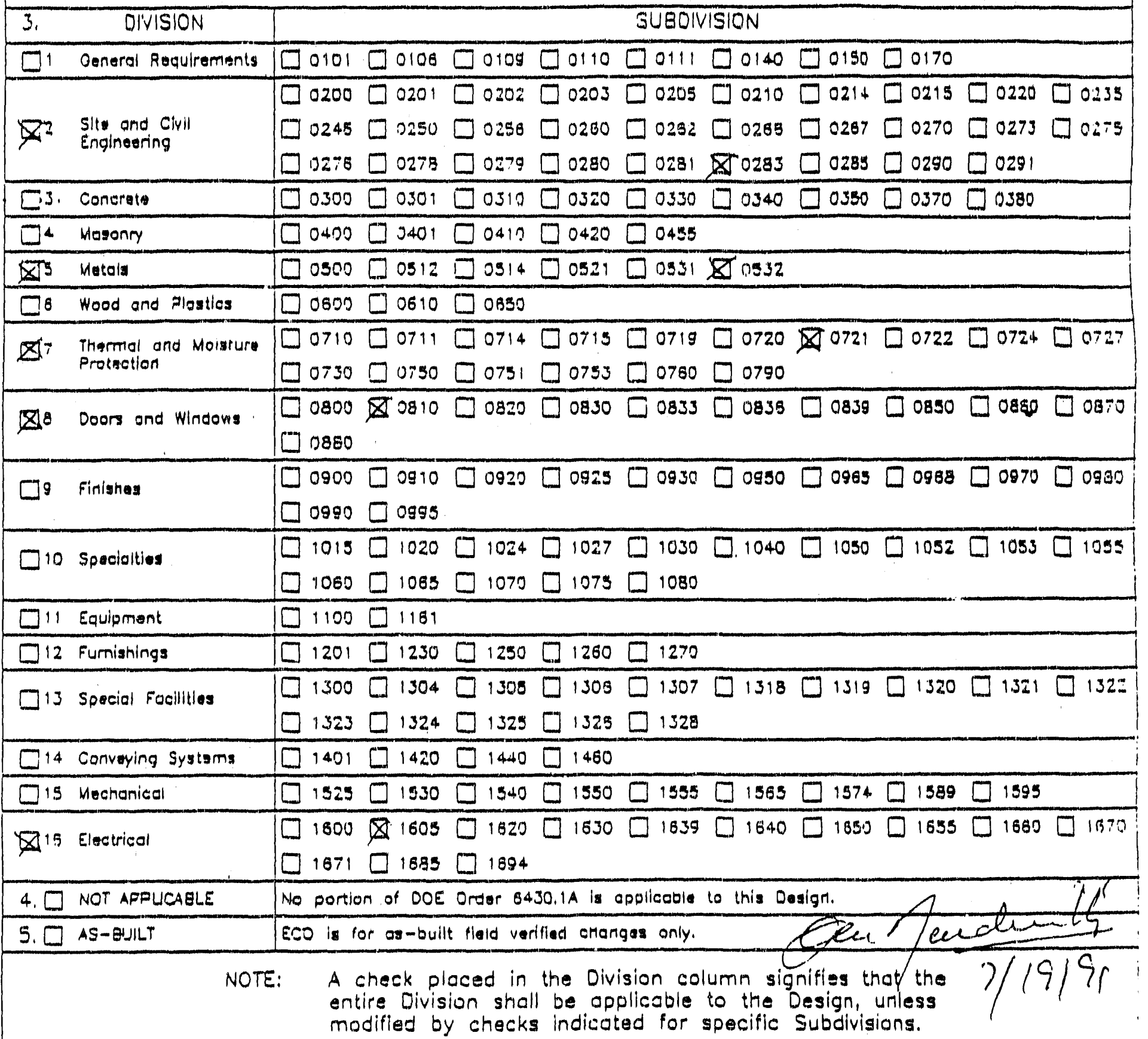

COMMENTS:

WF FORN 1200: PACE I OF 4 
$9 a$

DRAWING CHANGE SHEET

(1 SHEET PER DRAWING)
1. Drawing:
$52 \cdot L-002-W 5$
ECO Number:
5625

2. ECO Search List:

3. Description of Change:

WITHECO 5565 SH 13 CF 29 ADO FLEXBLE STAWLES STEEL TLBING (SWAGELDK P.N. SS-12H0-6-5/2) AND (2) $3 / 4 " X 1^{\prime \prime}$ CONNECTLONS AT EACN END. ADD AS SHONN BELOW.

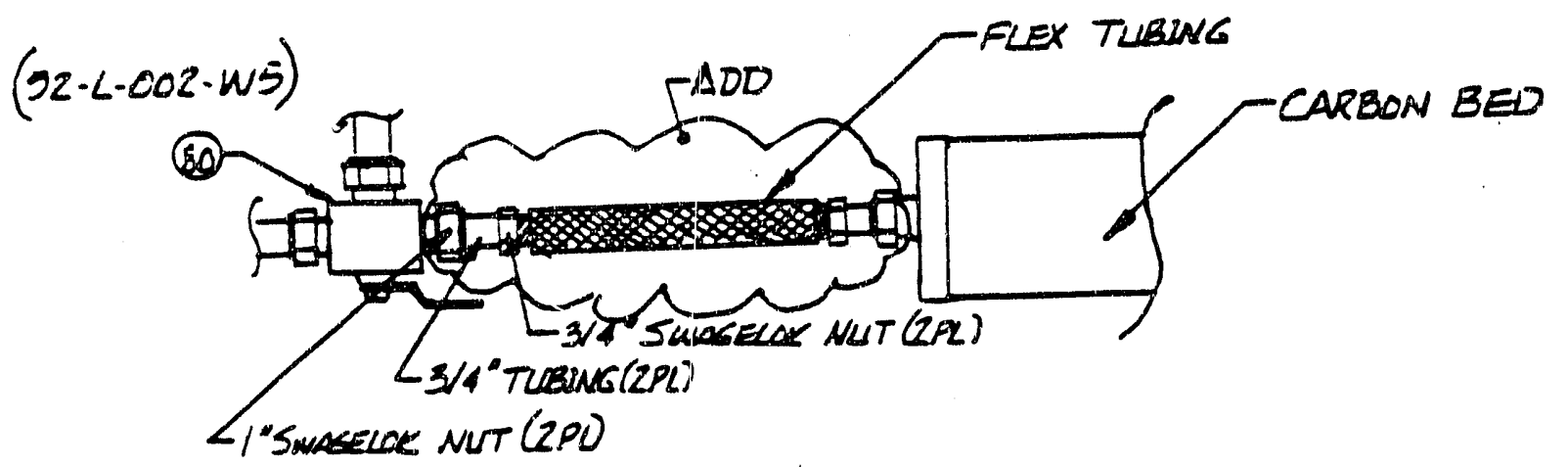

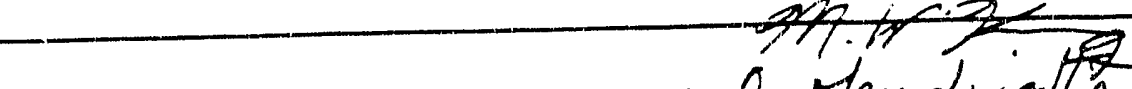

4. Drawing Cog. Engineer Approval: Dem Mendivala Date: 1/22/91

5. Cover Sheet Block (CC\&D Use Only)

Received from EFR: Initials / Date

Date Assigned:

Assigned to:
Initiats i Dats

(Same as data base entry)
Drafting Startod:

Drafting Completed:

Return to EFR:
Initials / Date

Initials / Date

Initials / Date 
$9 a$

DRAWING CHANGE SHEET

(1 SHEET PER DRAWING)

1. Drawing:

$52 \cdot L-002 \cdot W I$

2. ECO Search List:

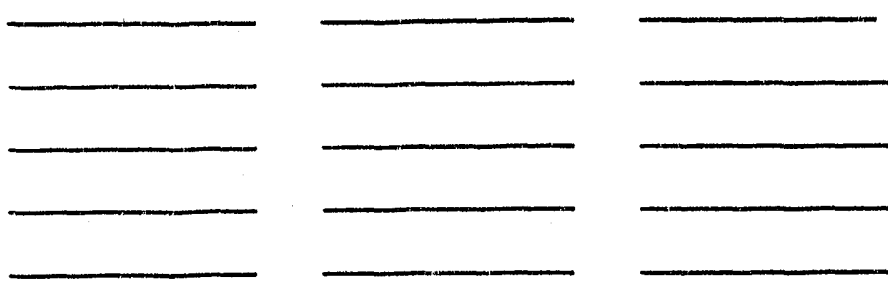

ECO Number: 5625

3. Description of Change:

ADD FLEXIBLE STAINLES STEEL TUBING, SLUAGELOK
P.N. SS-12HU-LISII TO BILL OF MATL.

4. Drawing Cog. Engineer Approval: Den Heudiratty Date: $7 / 22 / 91$

5. Cover Sheet Block (CC\&D Use Only)

Received from EFR:

Initials / Date

Date Assigned:

Initials / Date

Assigned to:

(Same as clata base entry)

Drafting Started:

Drafting Completed:

Initials / Date

Initials / Dato

Returit to Erron:

Initials / Date 
1. ECONo.5し $7\lfloor\mid \quad$ 2. Impact Lovel $1 \square \quad 2 \square \quad 3 \square \quad 4 \square$ CC\&D Review: $P$ In Initials

3. System: $G \subset \otimes Q$ Equipment No:: $N / A$ Building: $N / A$

4. Associated Documents:

PWR

ECP

P.O.

Others

6. Title of Change: CONSOLIDATION OF SITE DRAWINGS

7. Originator: (print)

Ext. No.: Department:

Date:

RICK MAYNARD

\section{Document Type:}

Drawing

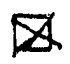

Specification

Vendor Data

SDD

Others

$C C \$ D \quad 7 / 26 / 91$

8. Cognizant Engineer: (print) 8905 JoHn Kowalski

\section{Description of Change:}

GENERATE NEW DRAWINGS:

$$
\begin{array}{ll}
24-c-020-W & \text { WIPP SITE AND VICINITY } \\
24-c-022-W & \text { WIPP SITE PLAN } \\
24-c .024-W & \text { WIPP SITE FENCE PLAN AND DETAILS } \\
24-c-026-W & \text { WIPP SITE UTLITIES } \\
24-C .028-W & \text { WIPP SITE FINISH GRADING AND PAVING }
\end{array}
$$

$凶$ 9a Drawing Change Sheet aftached

9b Design Documentation Sheet aftached

10. Yes No
$\square$ MODIFICATION IN PROGRESS
[ Modification complete:

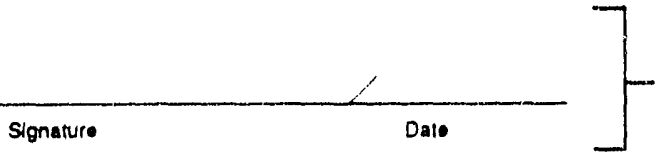
ECO will be
Signature

$\square \quad$ Change drawing per as-built markup dated:

Change drawing per ECO-provided data

Temporary modification

11. Design Veriflcatlon Requirements: (per WP 09-018)

EDT No.:

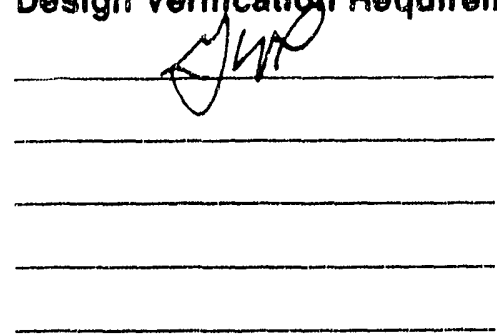

1. Requirements satisfied by review/approval of design document

2. Independent review

3. Altemate calculations

4. Development testing

5. Design review

6. Other:

12. Addendum Shear added: 


\section{Justification}

CONSOLIDATION OF EXISTING SITE-RELATED DRAWINGS INTO A MINIMUM QUANTITY OF WORKING DRAWINGS WILL FACILITATE IMPROVEO PROFICIENCY IN FUTURE UPDATES.

\section{Administrative Tracking}

YES N/A

$\square \pitchfork$ 1. FSAR

2. Calibration Procedures

3. Maintenance Procedures

4. Computer Software

5. Operations Procedures

KEY

15. SIgnature Requirement's

A=APPR,

R.REVIEW S-SIGN NEW DRAWING

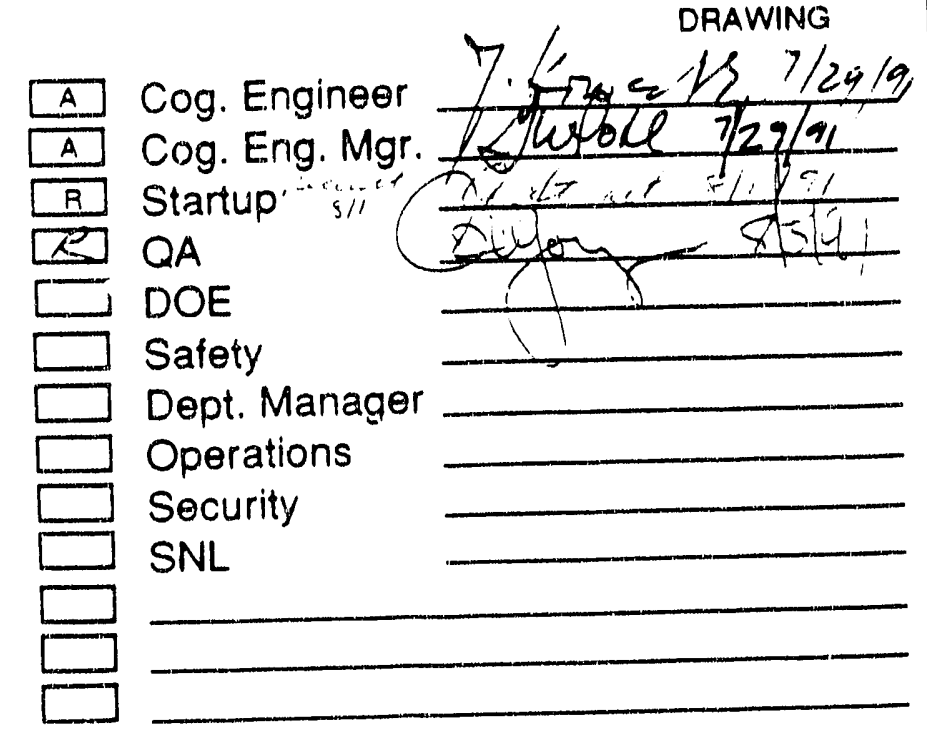

YES N/A

$\square \nsubseteq$ 6. Startup/Acceptance Test

$\square$ 7. Test Requirement \& Spec.

$\square$ 古 8 .

口办 9

$\square$

10.

\section{Distribute as Marked}

E Maintenance (MANDATORY)

Ops. Support (MANDATORY)

Startup

Facility Operations

U/G Operations

Orig./Design Engr.

Cog. Engineer

Others 


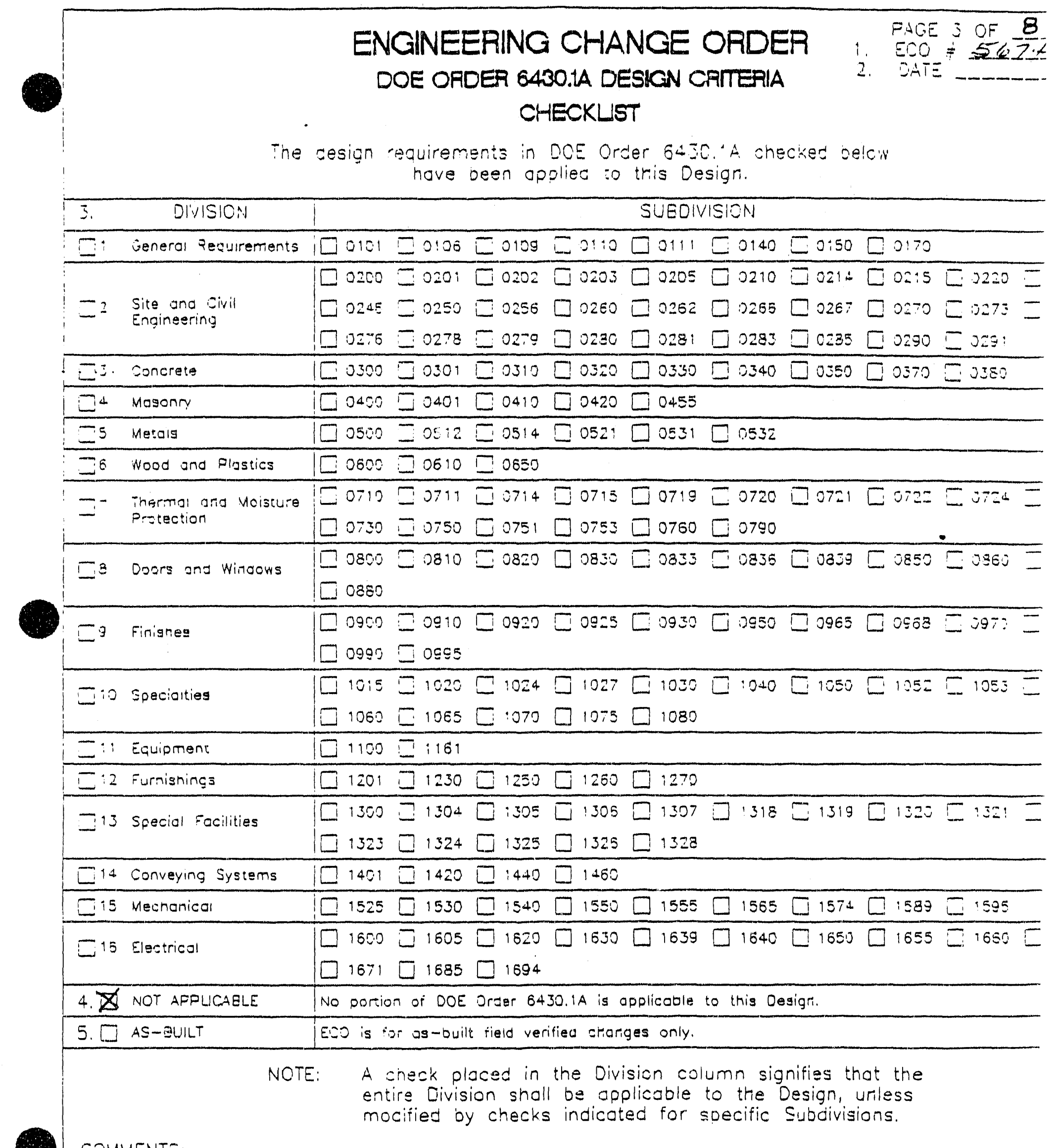

COMNIENTS:

Ho SopN 1200: pare 3 gF: 


\section{$9 \mathbf{a}$}

\section{DRAWING CHANGE SHEET}

(1 SHEET PER DRAWING)

1. Drawing: $24-C \cdot 020 \cdot W$ ECO Number:

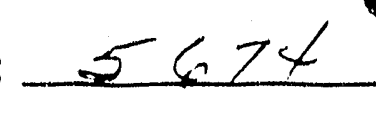

2. ECO Search List:
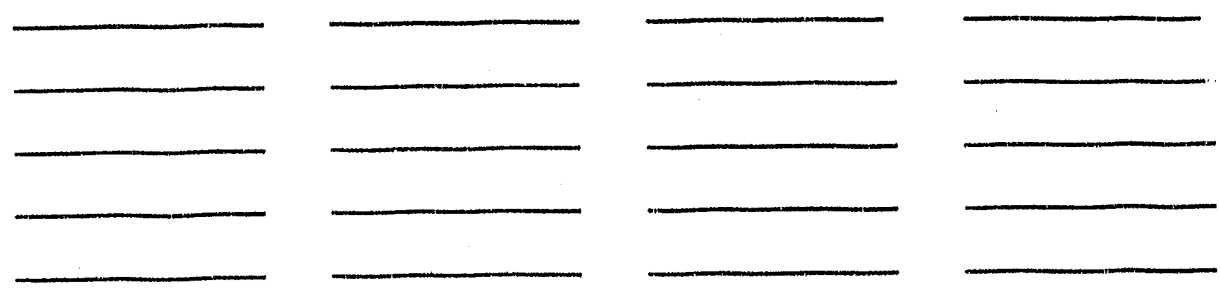

3. Description of Change:

NEW DRAWING, "WIPP SITE AND VICINITY," INCORPORATING APPROXIMATEY 500 SQ. MILES OF AREA BORDERING THE WIPP SITE; INCLUDING TOPOGRAPHL INFORMATION, COUNTY AND STATE ROADS, ACCESS ROADS, AND SEETLN MARKERS.

SHEET 2 IS to INCORPORATE AN ENLARGEO DETAML OF THEE D.o.E. Exclusive Use AREa from INfOrmation on SHEET 1.

UPON APPROVAR OF 24-C-OZO-W, SUPERCEDE DRAWINGS:

$$
\begin{aligned}
& 24-c-041-022 \\
& 24-c-041-34 c
\end{aligned}
$$

4. Drawing Cog. Engineer Approval:

$7.40 w 4 k$

Date: $7 / 29 / 91$

5. Cover Sheet Block (CC\&D Use Only)

Received from EFR:

Initials / Date

Däte Assigned:

Assigned to:
Initials / Date

(Same as data base entry)
Drafting Started:

Drafting Completed:

Return to EFR:
Initials / Date

Initials / Dato

Initials / Date 


\section{$9 a$}

DRAWING CHANGE SHEET

(1 SHEET PER DRAWING)

1. Drawing: 24:C-O22-W ECONumber: 5474

2. ECO Search List:

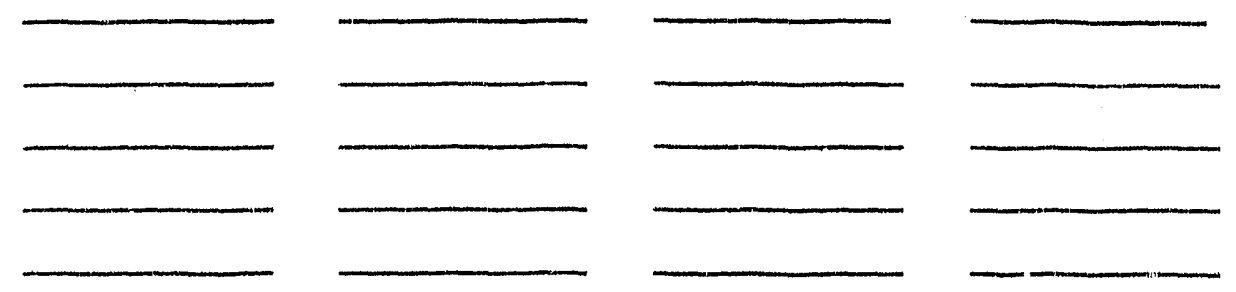

3. Description of Change:

NEW DRAWING INCORPORATING DRAWINGS 24-C.0O9-W, 24. C.140-022, and any available as.built information.

UPOW APPROVAL OF $24.0 .022-\omega$, SUPERCEDE DRAWINGS:

24.C. $009-w$

$24-c \cdot 001-022$

$24-C \cdot 001-34 C$

$24-c \cdot 140-022$

4. Drawing Cog. Engineer Approval: 7 . Fiw a /

5. Cover Sheet Block (CC\&D Use Only)

Received from EFP:

Initials / Date

Date Assigned:

Initials / Dato

Assigned to:

(Same as data base entry)
Drafting Started:

Dratting Completed:

Initials / Date

Inilials / Date

Return to EFR:

Initials / Date 
$9 a$

\section{DRAWING CHANGE SHEET}

(1 SHEET PER DRAWING)

1. Drawing: $24: C-024-W$

ECO Number: $54><$

2. ECO Search List:
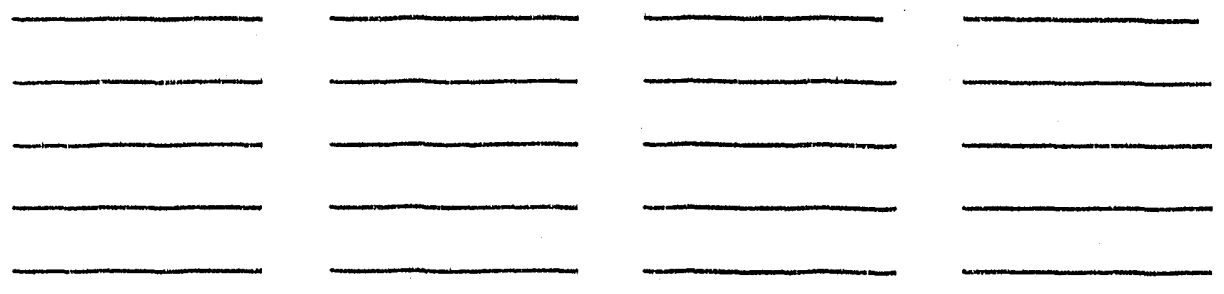

3. Description of Change:

NEW DRAWING INCORPORATING DRAWING 24-C.147-022

and any aVAILAble as-built Information. Subgeqvent

SHEETS WILL BE ADDED AS REQUIRED TO INJCORPORATE

additional fencing plans and Details.

UPON APPROVAL OF 24-c.024-W, SUPERCEDE DRAWINGS:

$$
\begin{aligned}
& 24-C-147-022 \\
& 24-C-102-34 c \\
& 24-C-102-022 \\
& 24-C-102-1 F_{c}-5 \\
& 24-c-102-005 \\
& 24-c-102-05 A \\
& 24-c-102-009 \\
& 23-c-177-005 \\
& 24-c \cdot 107-009
\end{aligned}
$$

4. Drawing Cog. Engineer Approval: 7. Tw a 4 \&

Date: $7 / 29 / 91$

5. Cover Sheet Block (CC\&D Use Only)

Received from EFR:

Initials / Date

Date Assigned:

Assigned to:
Drafting Started:

Drafting Completed:

Return to EFR:
Initlals / Date

Inillials / Date

Initials / Date 
$9 \mathbf{a}$

DRAWING CHANGE SHEET

(1 SHEET PER DRAWING)

1. Drawing: 24.C.026-k ECO Number: 5474

2. ECO Search List:
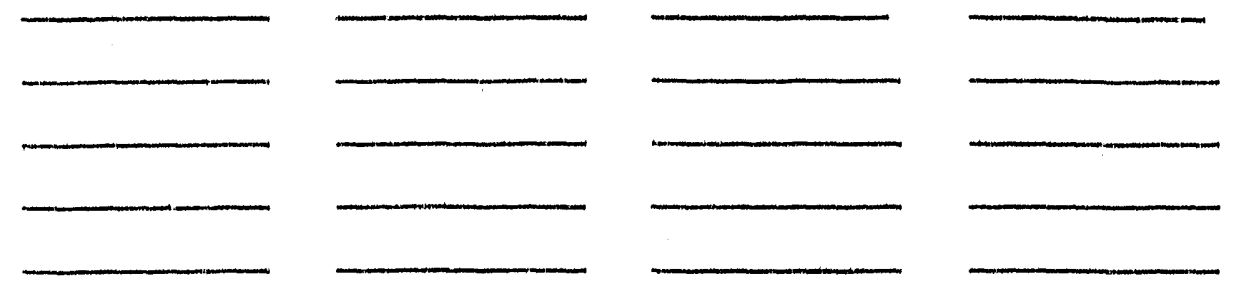

\section{Descriptlon of Change:}

NEW DRAWING INCORPORATING EXISTING WIPP SITE

UTILITY SEXTANT DRAWINGS; 24-C. OII. W, 24-C-OI2-W, 24-c-013-w, 24-c-014-w, 24-c-015-w, AND 24-c-016-w AS 24-C.026-1A, SHEETS $1-6$.

UPON APPPOVAL OF $24-6.026-W_{1}$ SHEETS $1-6$, SUPERCEOE DRAWINGS:

$$
\begin{aligned}
& 24-c-011-w \\
& 24-c-012-w \\
& 24-c-013-w \\
& 24-c-014-w \\
& 24-c-015-w \\
& 24-c-016-w
\end{aligned}
$$

4. Drawing Cog. Engineer Approval:

H. frwale $\{$.

Date:

5. Cover Sheet Block (CC\&D Use Only)

Received from EFR: Initials / Date

Date Assigned:

Assigned to: Initials / Date

(Same as data base entry)
Drafting Started:

Drafting Completed:

Return to EFP:
Initials / Date

Inifials / Dato

Initials / Date 


\section{$9 a$}

\section{DRAWING CHANGE SHEET}

(1 SHEET PER DRAWING)

1. Drawing: $24: C \cdot 028-w$

2. ECO Search LIst:

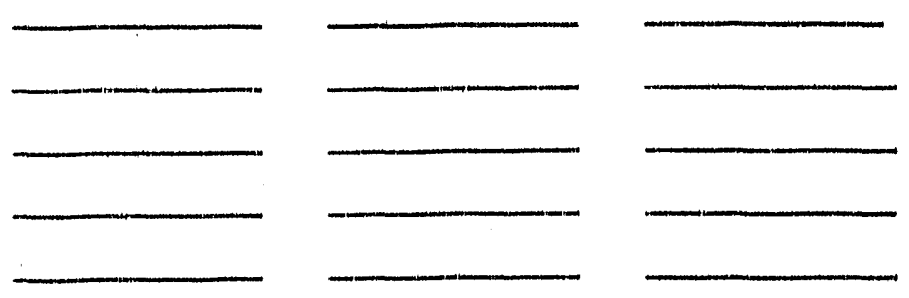

ECO Number:

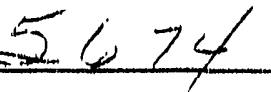

3. Descriptlon of Change:

NEW DRAWING INCORPORATING EXISTING WIPP SITE FINISH GRADING AND PAVING PLANS; $24 . c-008-W$, $24-c-010-w, 24-c \cdot 143-022,24-c-145-022, A \omega D$ $24 . c \cdot 146 \cdot W$ AS DRAWING $24-C-028-W$, SHEETS I-6.

UPON APPROVAL OF $24-c-028-w$, SHEETS $1-6$, SUPERCEDE DRAWINGS:

$\begin{array}{ll}24-c-008-w & 23-c-175-005 \\ 24-c-010-w & 23-c-175.05 A \\ 24-c-143-022 & 23-c-176-005 \\ 24-c-145-022 & 23-c-176.05 A \\ 24-c-146-022 & \end{array}$

4. Drawing Cog. Engineer Approval:

7. thmath Date: $7 / 2.4 / 91$

5. Cover Sheet Block (CC\&D Use Only)

Recelved from EFR:

Date Assigned:

Assigned to:

$$
\text { (Same as data base entry) }
$$

Drafting Started:

Drafting Completed:

Return to EFF:
Initials / Date Initials / Date Inifials / Date 
ENGINEERING CHANGE ORDER

USE BLACK INK

Page 1 of

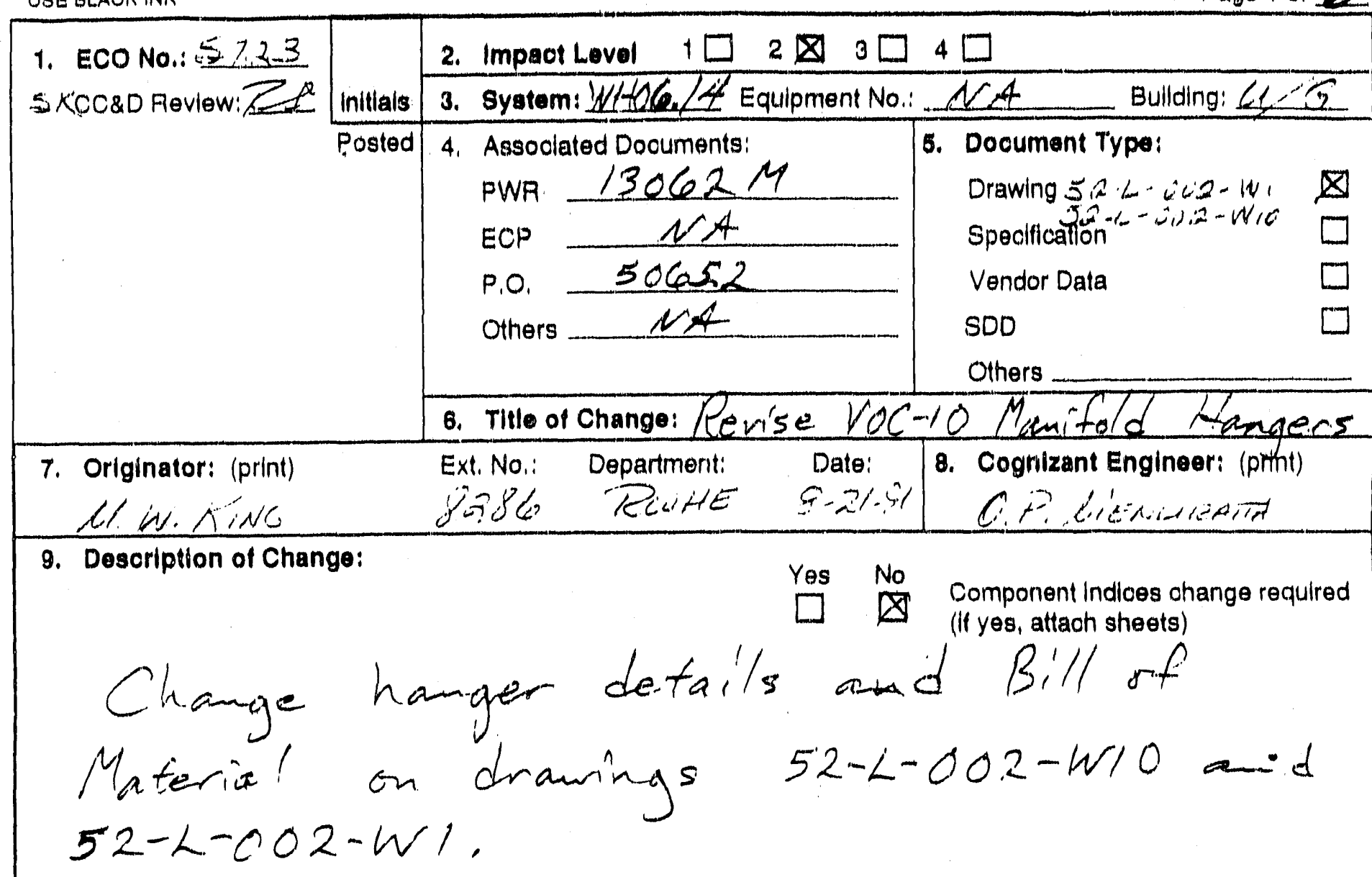

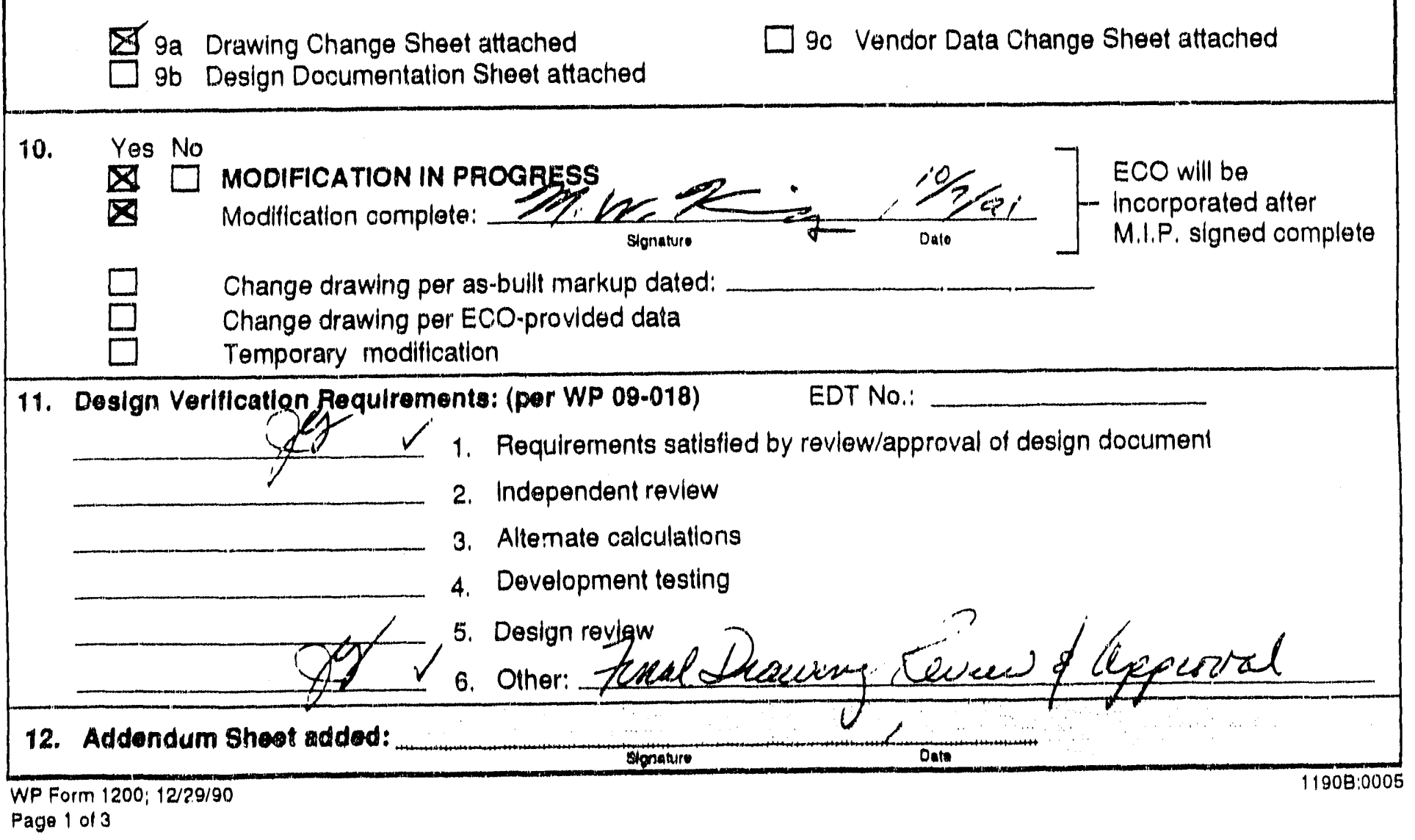




\section{Justification}

These chamges are required to lower the loc-10 man, fold its thes ofi back sapportin in keom!

\section{Administrative Tracking}

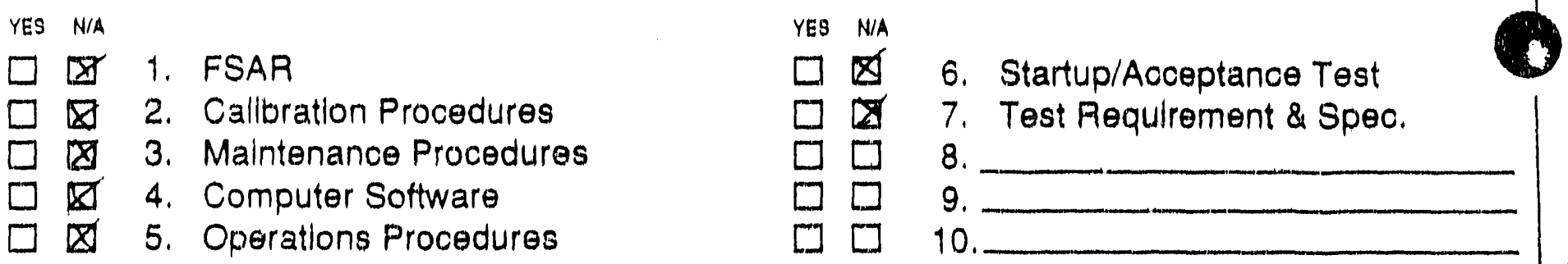

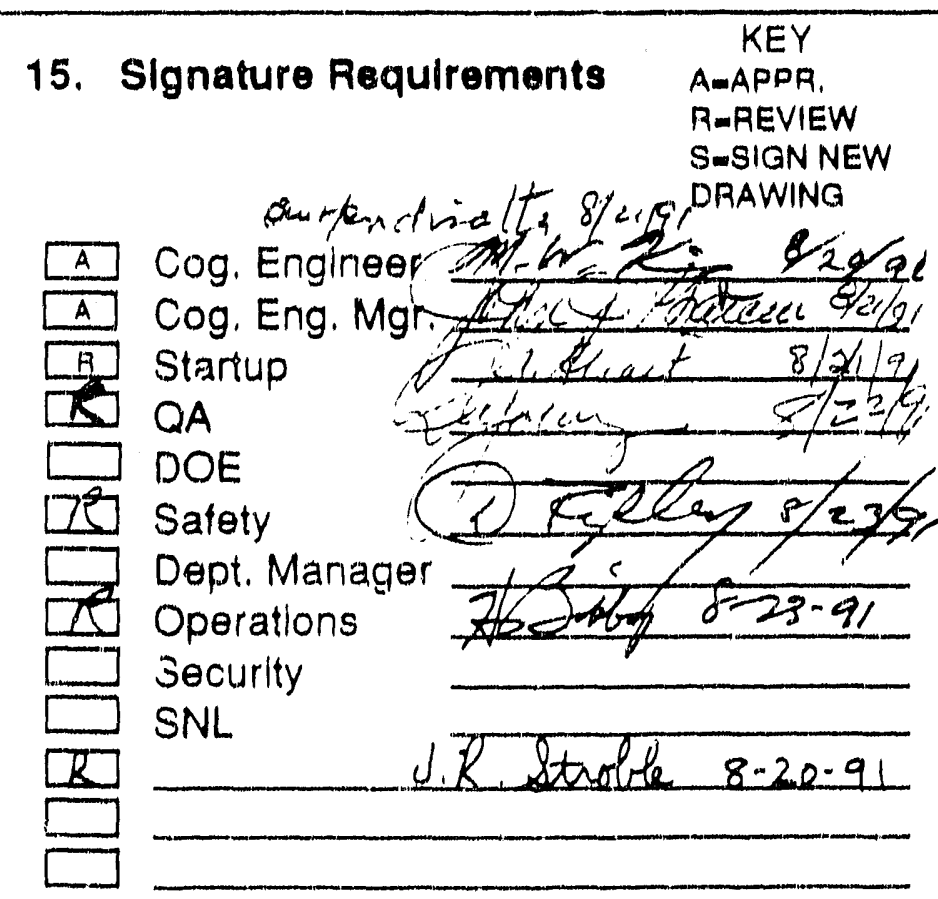

16. Distribute as Marked 
3 : 6

$9 a$

DRAWING CHANGE SHEET

(1 SHEET PER DRAWING)

1. Drawing: $52-2-002-W 1$ ECO Number: 5723

2. ECO Search List:

3. Description of Change:

Revise the Bill of Material as follows

Change item 36 to $14 "$ MGAIKEY CLAP
w/ 58 "DA HOLE 52 EA
Add 9/32" GALVANIZED ALLOY CHAIN GRADE 80 OR EQUAL

$250 \mathrm{FT}$

4. Drawing Cog. Engineer Approval:

5. Cover Sheet Block (CC\&D Use Only)

Received from EFR:

Date Assigned:

Assigned to:
Drafting Started:

Drafting Completed:

Return to EFA:

(Same as data base entry)

Initials / Date

Return to EFA:
Date: $8-20-91$

3) 21191

Initials / Date

Initials / Date

Initials / Date

WP Form 2017; 12/29/90

Page 1 of 1

$1290: B 0006$ 
4046

$9 a$

DRAWING CHANGE SHEET

(1 SHEET PER DRAWING)

1. Drawing: $52-4-002-w / 10$ ECO Number: -57 ㄴ? 3

2. ECO Search List:

3. Description of Change:

Revise Detail I per the attacked marked print.

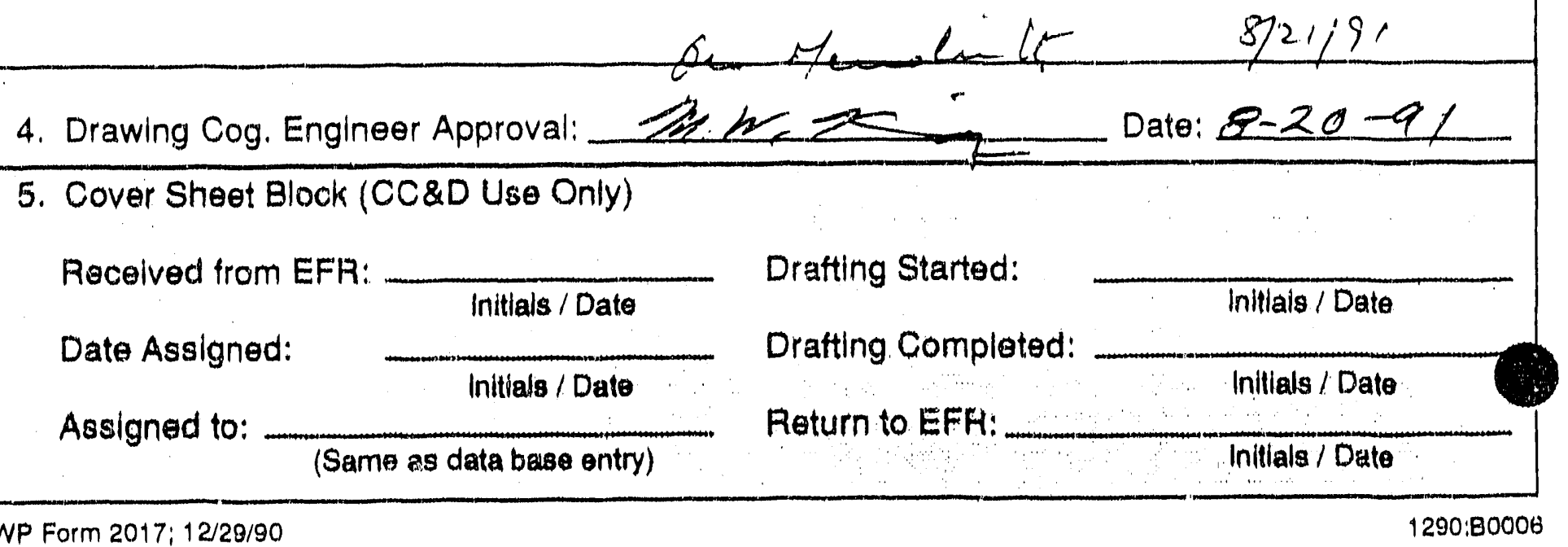

Page 4 of 1 

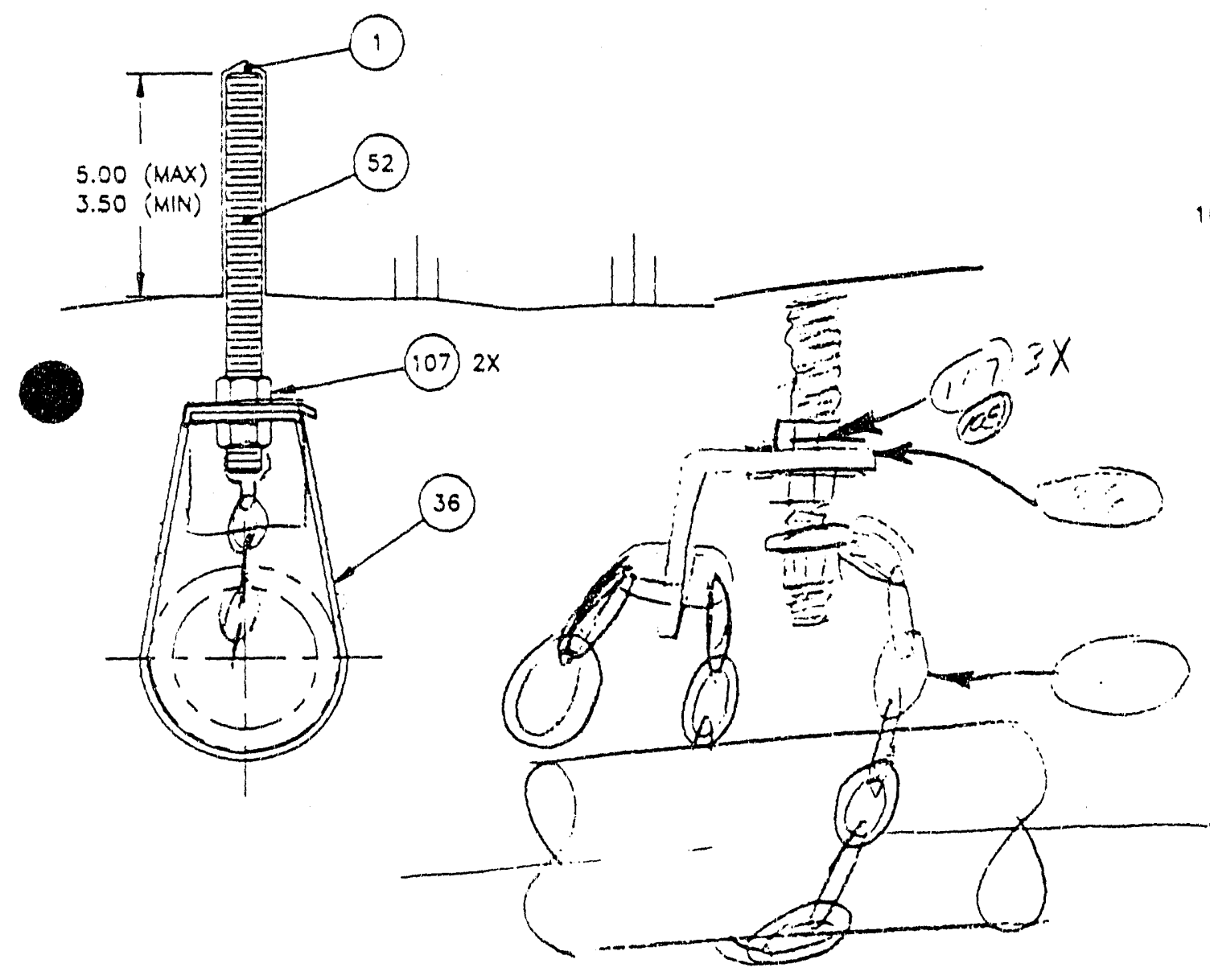

DETAIL 1

PIPE HANGER

(SEE NOTE 1)

DETAIL 2

RIB MOUNTED TUBING SUPPORT (SEE NOTE 2) 


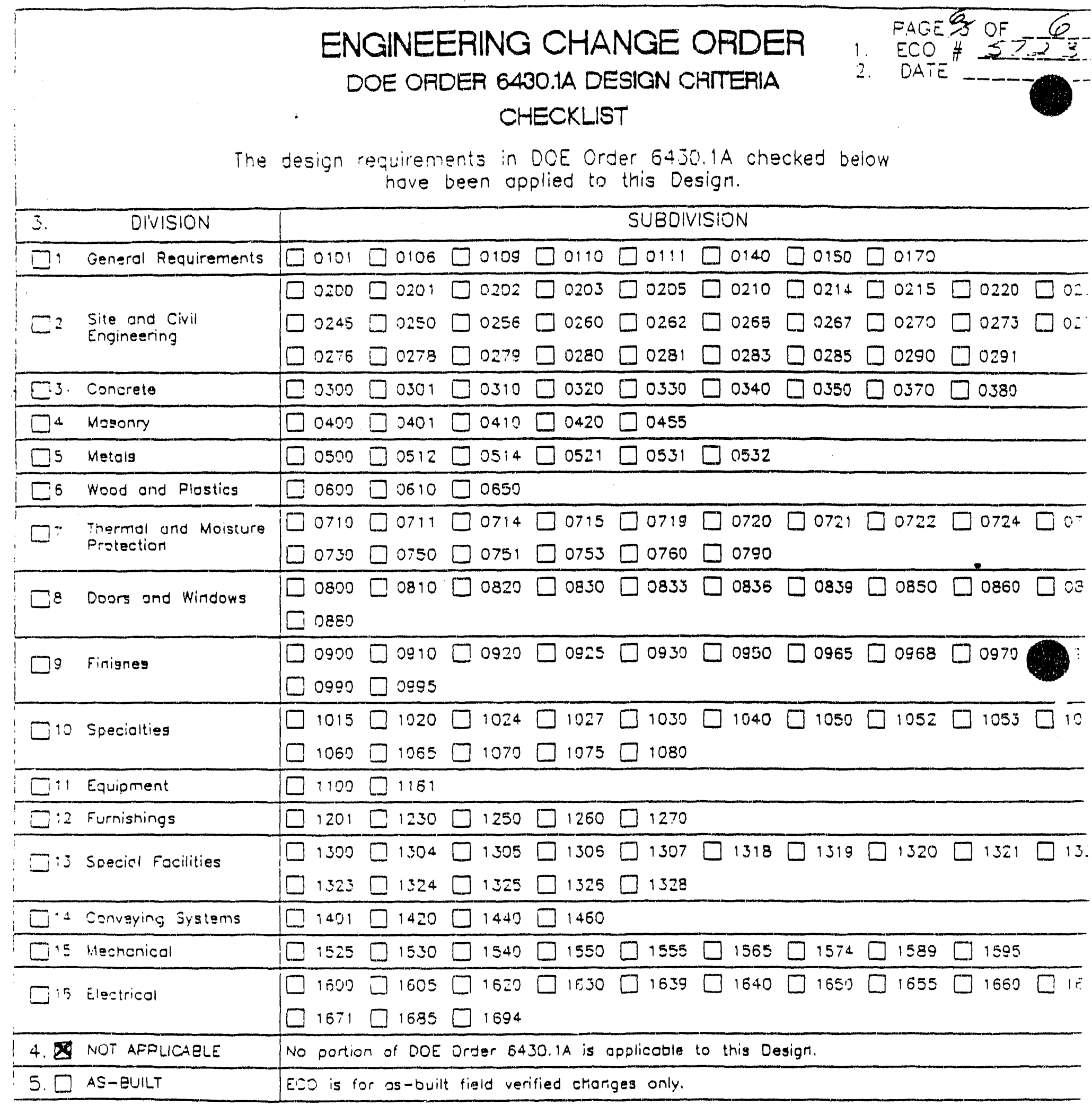

NOTE: A check placed in the Division column signifies that the entire Division shall be applicable to the Design, uniless modified by checks indicated for specific Subdivisions.

COMMENTS: 
1. ECO No.: $\leqq 241$

$\because N$ CC\&D Review: $P$ s

Posted

2. Impect Level $1 \square \quad 2 \square \quad 3 \square 4$

3. System: WHCl $\$$ Equipment No.:

NA Building: $4 G$

4. Associated Documents: $20 \% / 27 / 9$

5. Document Type:

PWR

R. 4

ECP

$1<A$

P.O.

$N A$

Others

$-$

Drawing $52-\operatorname{coc} 2-\omega / 1 \quad \square$

Specification

Vendor Data

6. Title of Change: Man, Iold 6

7. Originator: (print) Merle King

Ext. No.: Department:

Date: RWHE

8. Cógnizant Engineor: (ornt) SDD

Others

9. Description of Change:

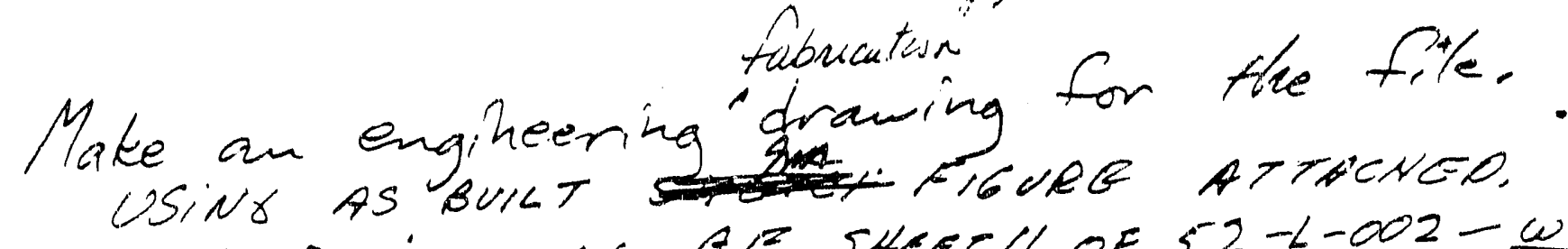
THE DRAWIAT WIL BL SHEETII OF $52-\angle-002-W 1$

9a Drawing Change Sheet attached 9c Vendor Data Change Sheet attached

9b Design Documentation Sheet attached

10. Yes No

Yes No
$\square \quad$ MOCIFICATION IN PROGRESS
Modification complete:

Signature

Yes No

Component indices change required

$\square$

(if yes, attach sheets)

Om Mendiratta 


\section{Justification}

Create a drawing from manifold blocks for the VOC-10 sustem.

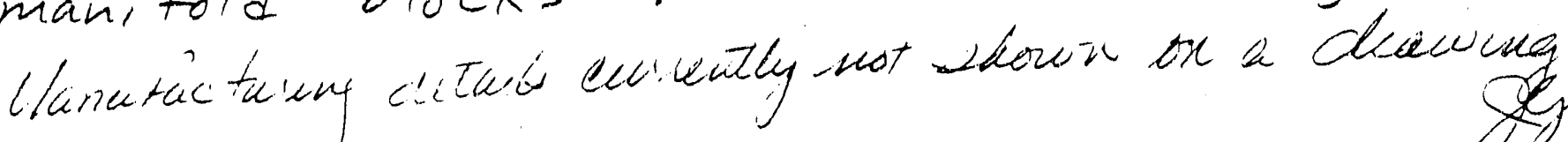

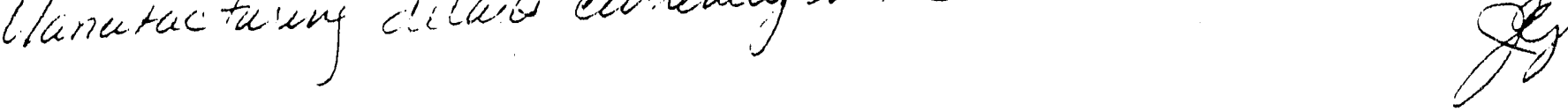

14. Administrative Tracking YES N/A

Q \ 1. FSAR

$\triangle$ 2. Calibration Procedures

3. Maintenance Procedures

4. Computer Software

5. Operations Procedures

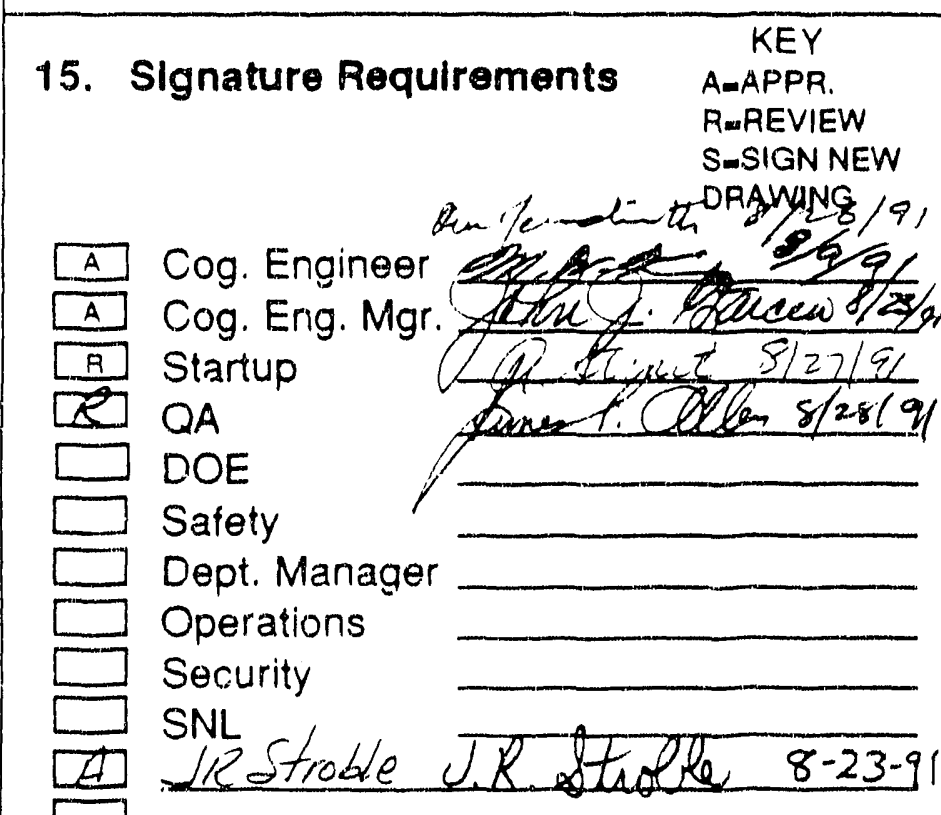

16. Distribute as Marked

Maintenance (MANDATORY)

Ops. Support (MANOATORY)

Startup

Facility Operations

U/G Operations

Orig./Design Engr. M. Kih

Cog. Engineer

Others

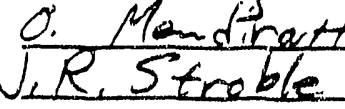




\section{DOE ORDER 6430.1A DESIGN CRTERIA CHECKLIST}

ENGINEERING CHANGE ORDER (ECO) NO. Y TLLIE

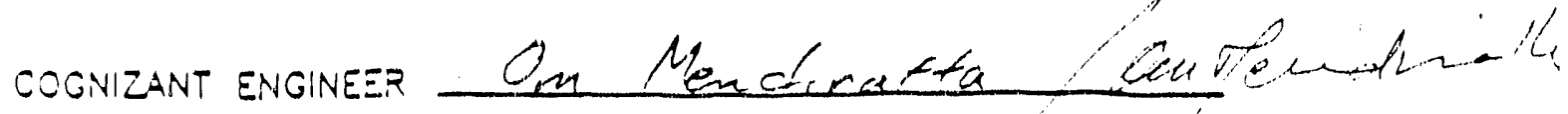

The design requirements in DOE Order 6430.1A checked below have been applied to this Design.

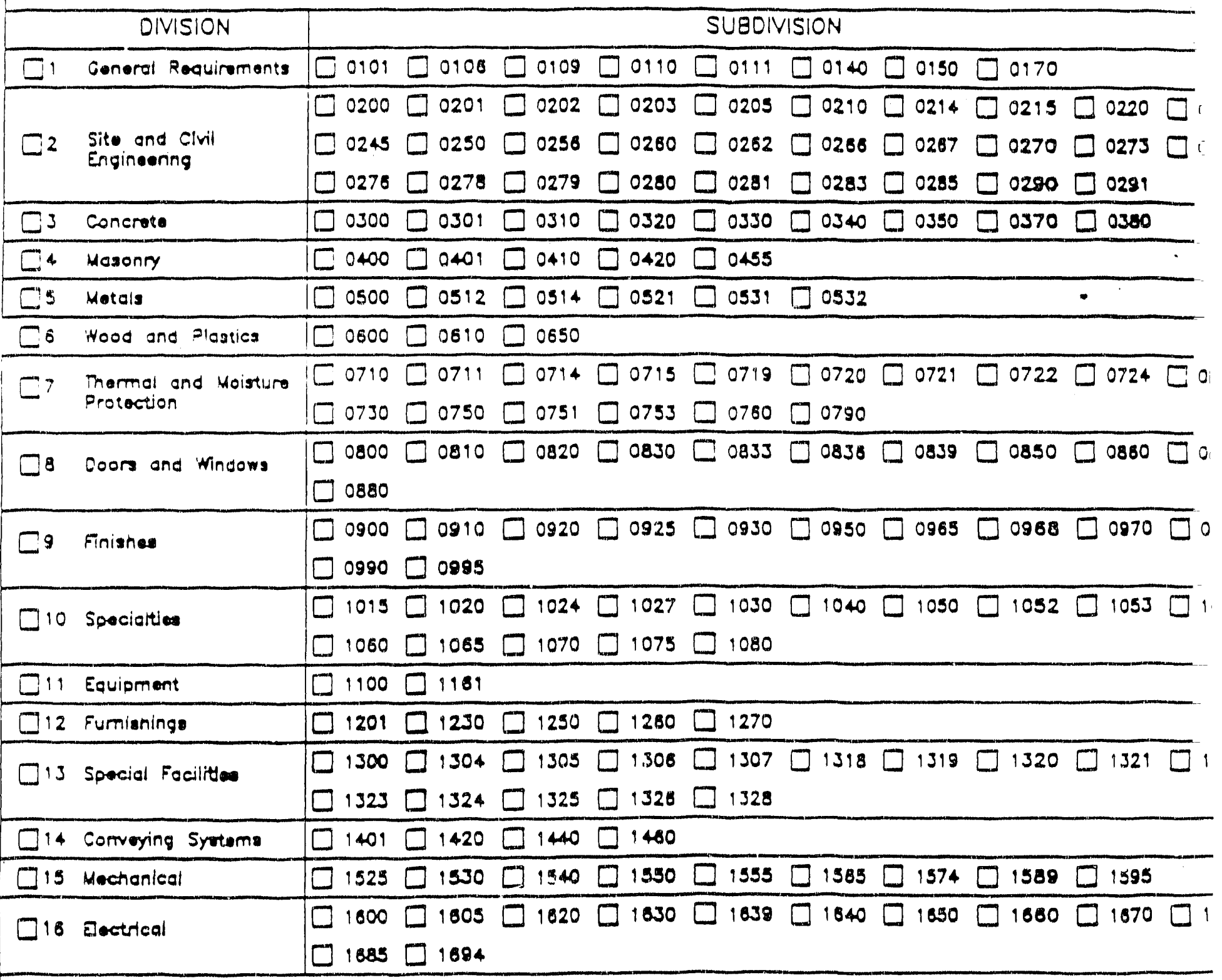

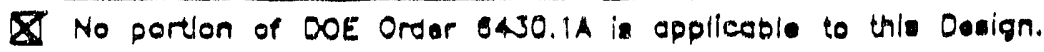

NCTE: A check plcced in the Division column signifies that the entire Division shall be applicable to the Design, unless modified by checks indicoted for specific Subdivisions. 


$$
\begin{aligned}
& 4 \text { of } 7 \\
& E \cos 54 \text {, }
\end{aligned}
$$

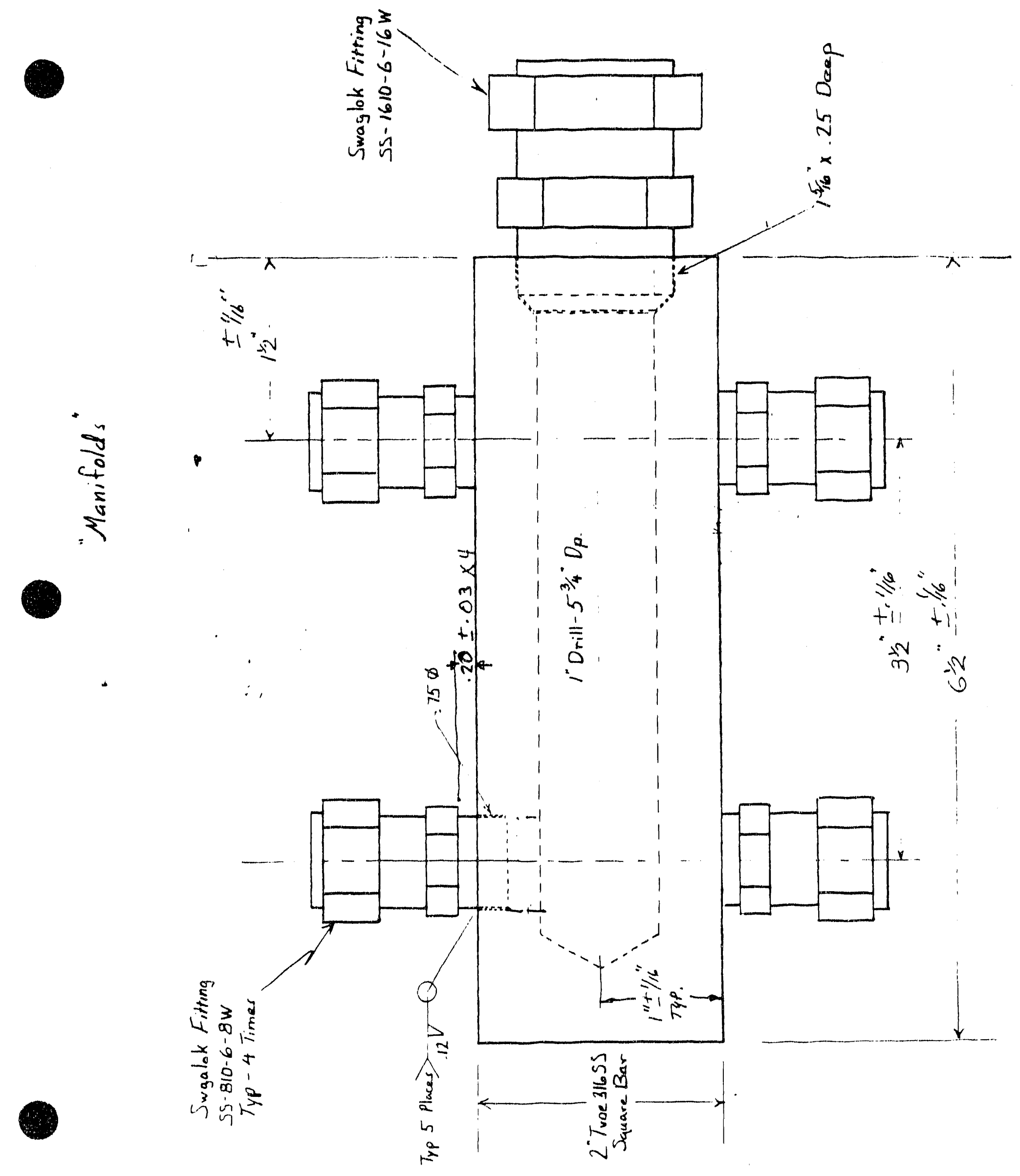




$$
\begin{aligned}
& 5 \text { at, } \\
& \text { ECe } 5 x \text {, ? }
\end{aligned}
$$

\section{NOTES :}

1. GTAW PER ASME B\&PV CODE SECTION VIII USING WELD FILLER METAL PER AWS A5.9.

2. LIQUID PENETRANT TEST WELDS PER ARTICLE 6 OF SECTION $V$ OF ASME B\&PV CODE.

3. WELDER SHALL BE QUALIFIED PER SECTION 'IX OF ASME B\&PV CODE.

4. THE ASSEMBLY SHALI BE VISUALIY CLEAN. NO VOLATILE ORGANIC COMPOUNDS MAY BE USED FOR CLEANING. DETERGENT WITH A HOT WATER RINSE OR A SIMILAR PROCESS IS SUGGESTED. 
6 ot 4

$9 a$

DRAWING CHANGE SHEET

$\varepsilon / w^{2}$

(1 SHEET PER DRAWING)

1. Drawing: $52-L-002-u$ fin $\mathrm{m}^{2} / 2 / \mathrm{al}$ ECO Number: 5241

2. ECO Search List:

3. Description of Change:

Create a fabrication drawing from the attached sketch. DWO no ir o BE SHEET "I OF ", OWE $52-\angle-002-W$ H $_{\text {m }}$

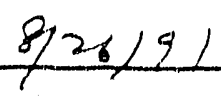

4. Drawing Cog. Engineer Approval: Date: $8-23-91$

5. Cover Sheet Block (CC\&D Use Only)

Received from EFR:

Date Assigned:

Assigned to:
Drafting Started:

Drafting Completed:

Return to EFR:
Initials / Date

Initials / Dato

(Same as data base entry)

Initials / Date

WP Form 2017; $12 / 29 / 90$

1290;B0006

Page 1 of 1 
$9 \mathrm{a}$

1 of of

DRAWING CHANGE SHEET

(1 SHEET PER DRAWING)

1. Drawing: $52-\alpha-002-W /$ the ECO Number: 5741

2. ECO Search List:

3. Description of Change:

Add the drawing number $5^{2-c}$ created by this ECO to item 41 of the List of Material.

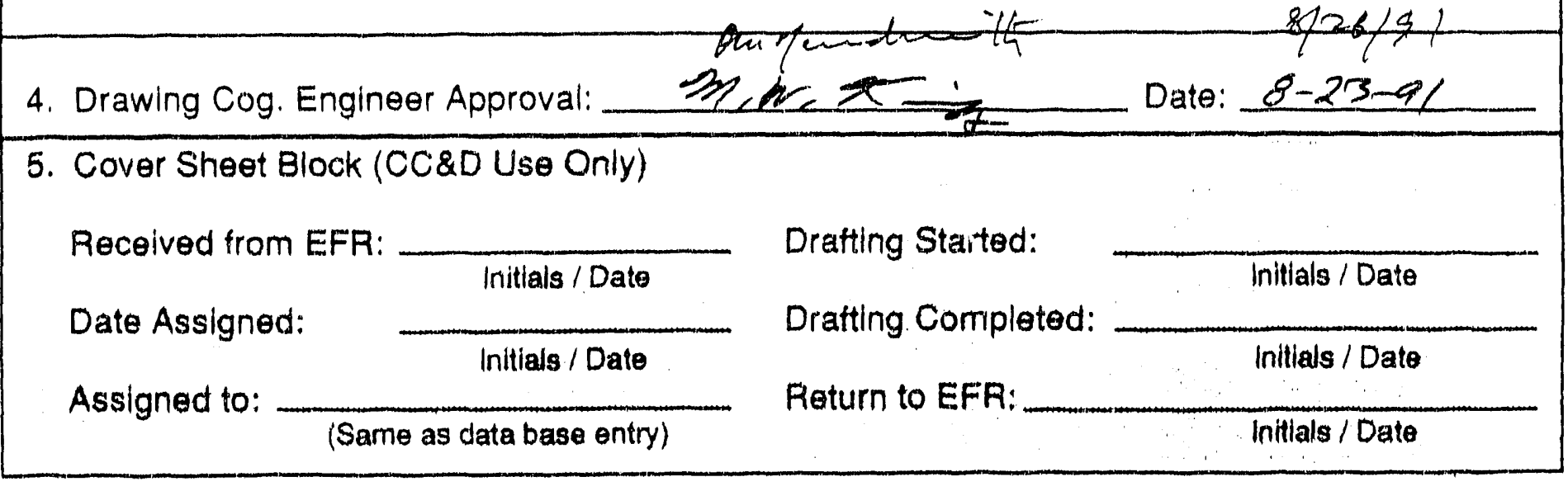

WP Form 2017; 12/29/90

1290:B0006

Page 1 of 1 
ENGINEERING CHANGE ORDER

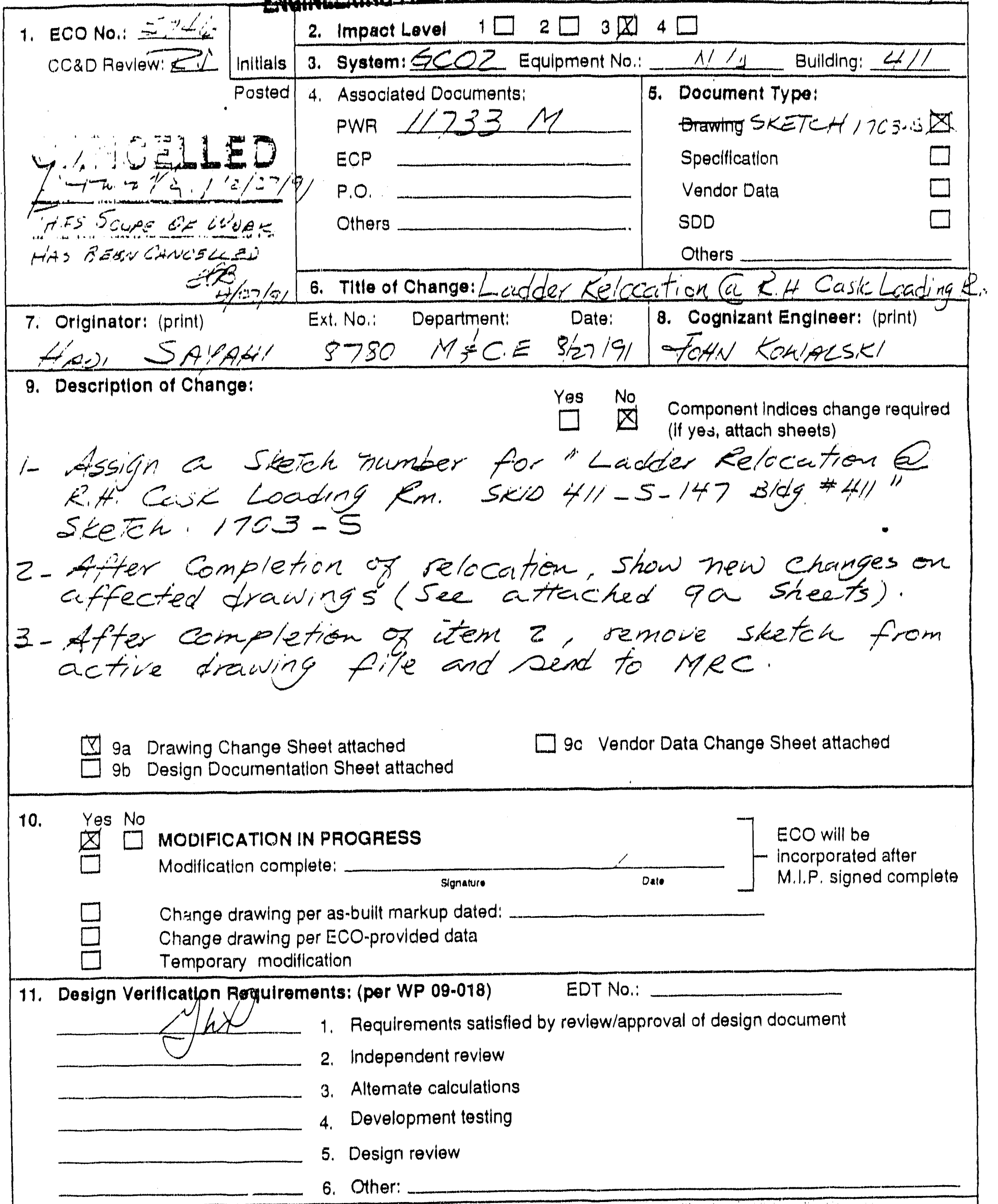

12. Addendum Sheot added: 
13. Justification

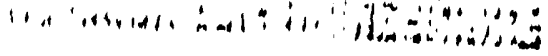

To satisfy Osith reguirements.

14. Administrative Tracking

YES NAA

1. FSAR

2. Calibration Procedures

3. Maintenance Procedures

4. Computer Software

5. Operations Procedures
YES N/A

$\square \square$

$\square \square$

$\square$

$\square \square$
7. Test Requilement \& Spec.

8.

9. 10.

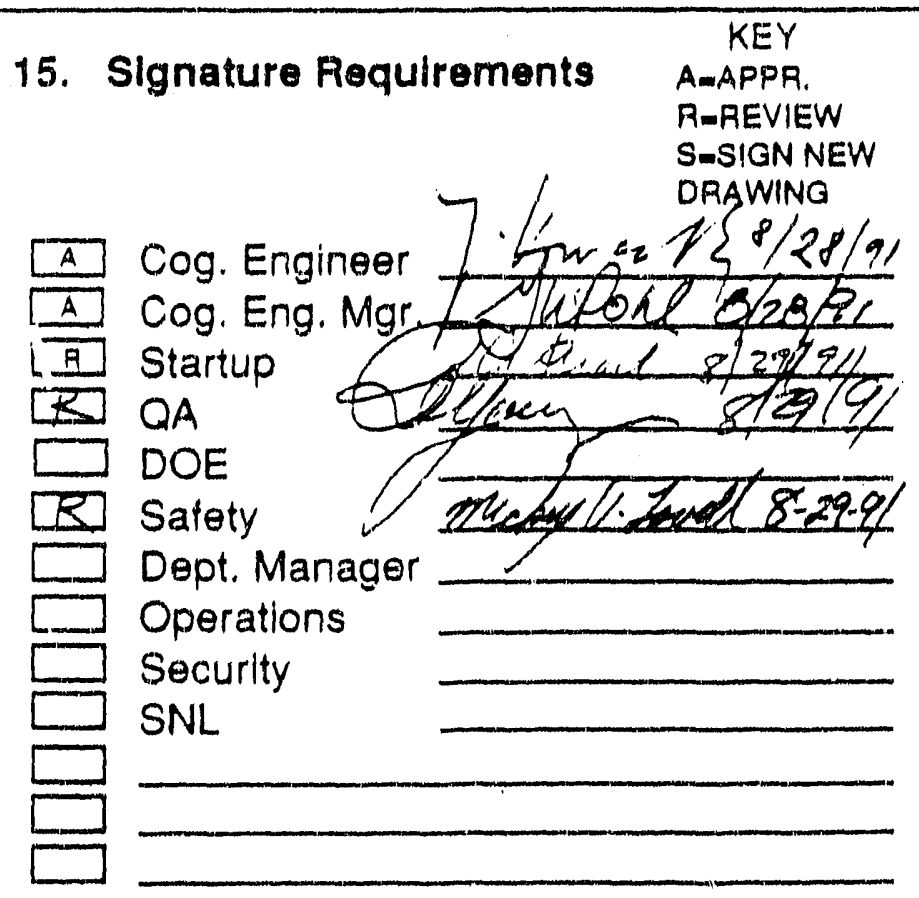

16. Distribute as Marked

D Maintenance (MANDATORY)

2 Ops. Support (MANDATOAY)

$\square$ Startup

$\square$ Facility Operations

$\square$ U/G Operations

Orig./Design Engr.

\$2 Cog. Engineer

$\square$ Others 


\section{ENGINEERING CHANGE ORDER DOE ORDEA 6430.1A DESH IN CATTERIA CHECKLOT}

The design recuiremerit: in DoE order b4 $30.1 \mathrm{~A}$ crecked below have osen applied to tmis Design.

\begin{tabular}{|c|c|c|}
\hline 3 & DIVISION & SUEOIVISION \\
\hline$\overline{-1}$ & General Rocuirements & {$[\square 0101 \square 0100 \square 0109 \square 0110 \square 011: \square 0140 \square 0150 \square 0170$} \\
\hline$\overline{7}$ & $\begin{array}{l}\text { Site and Eivil } \\
\text { Eng̣ineering }\end{array}$ & 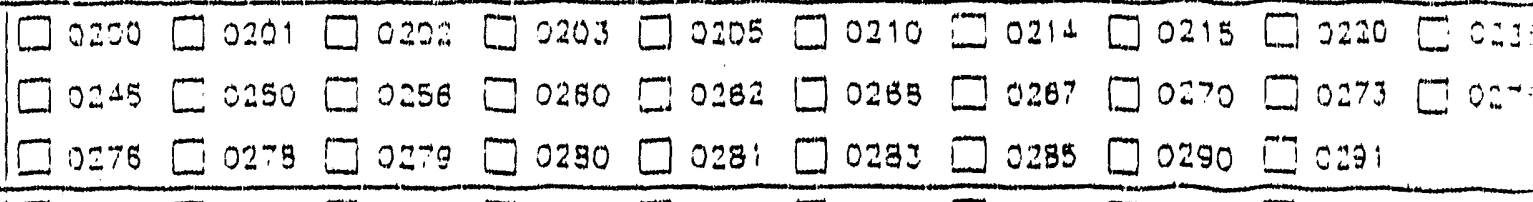 \\
\hline-3 & Conerete & $\mid \square 0300 \square 0301 \square 0310 \square 0320 \square 0330 \square 0340 \square 0350 \square 0370 \square 0380$ \\
\hline 三山 & Wagonry & $\square 0400 \square 0401 \square 0410 \square 0420 \square 0455$ \\
\hline 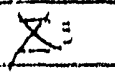 & Hetalg & {$\left[\begin{array}{l}0500 \square 0012 \square 0514 \square 0521 \square 0531 \square 0532 \\
\end{array}\right.$} \\
\hline-6 & Wood and Planties & $\square 0600 \square 0610 \square 0650$ \\
\hline 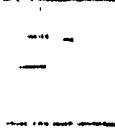 & $\begin{array}{l}\text { "ing:Tal and Moisiura } \\
\text { propestion }\end{array}$ & $\begin{array}{l}\square 0712 \square 0711 \square 0714 \square 0713 \square 0719 \square 0720 \square 0721 \square 0722 \square 0724 \square 07 \\
\square 0730 \square 0750 \square 0731 \square 0753 \square 0760 \square 0790\end{array}$ \\
\hline $\bar{z}$ & Cosry and Windows & 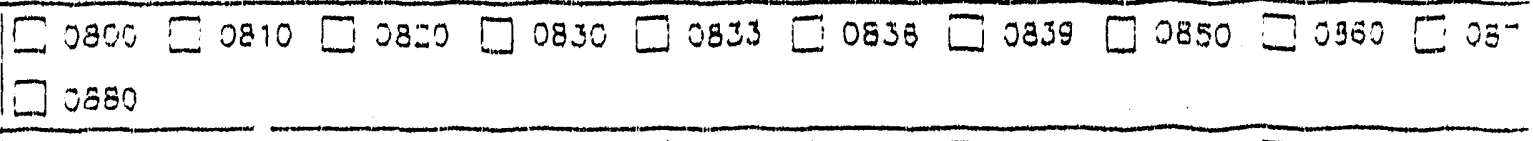 \\
\hline$\ldots$ & Finigrieg & $\begin{array}{l}\square 0900 \square 0910 \square 0920 \square 0925 \square 0932 \square 0950 \square 0965 \square 0968 \square 9970 \Xi 693 \\
\square 0900 \square 0995\end{array}$ \\
\hline 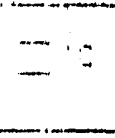 & iclties & 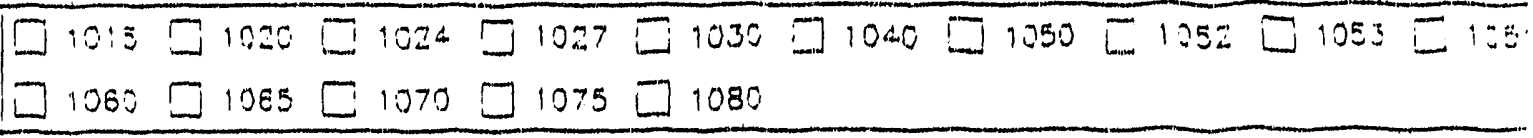 \\
\hline & Ezwipment & $\square 1100 \square: 161$ \\
\hline $\bar{z}:$ & Furnisnings & $1 \square 120: \square 1230 \square 1250 \square 1250 \square 1270$ \\
\hline$\because z$ & Special Facilities & $\begin{array}{l}\square 1300 \square 1304 \square: 305 \square 1306 \square 1307 \square 1318 \square 1319 \square 1320 \square: 121 \square 13 \\
\square 1323 \square 1324 \square 1325 \square 1325 \square 1328\end{array}$ \\
\hline$\because \div$ & Convaying Systems & {$[140: \square 1420 \square: 440 \square 1460$} \\
\hline$-\vdots$ & Mecnanical & $\square 1525 \square 1530 \square: 340 \square 1550 \square 1555 \square 1505 \square 1574 \square 1589 \square: 595$ \\
\hline$\because \overline{3}$ & Electrical & $\begin{array}{l}\square 1600 \square 1605 \square 1620 \square 1630 \square 1639 \square 1640 \square 1650 \square 1855 \square 1650[16 \\
\square 1031 \square 1685 \square 1604\end{array}$ \\
\hline$\therefore \square$ & NOT APPLLCABLE & No porion of DOE Orage 6430,1A is applicatle to this Design. \\
\hline$\Xi \square$ & $A S-Z U I L T$ & ECO is ior as-ouilt field verified \\
\hline
\end{tabular}

NOTE: A chesk placed in the Division column signifies that the antire Division shall be applicable to the Design, unless modified by checks indicoted for specific Subdivisions.

OWMENTS: 
$9 a$

$r+145$

DRAWING CHANGE SHEET

(1 SHEET PER DRAWING)

1. Drawing: $41-\Delta-021=014$ ECO Number: $574 i$

2. ECO Search LIst:

3. Description of Change:

Show (AS BUILT) new ladder location and delete existing location at R.H. cask loading $R_{m}$. as fer Sk e, no. 1703 -S.

4. Drawing Cog. Engineer Approval: Date: $8 / 28 / 91$

5. Cover She ot Block (CC\&D Use Only)

Received from EFR:

Date Assigned:

Assigned to:
Drafting Started:

Drafting Completed:

Return to EFP:

Initials / Date

Initials / Date

Initials / Date

Initials / Date

(Same as data base entry)

Iniflala/Date

WP Form 2017; 12/29/90

1290:80006

Page 1 of 1 
$9 a$

DRAWING CHANGE SHEET

(1 SHEET PER DRAWING)

1. Drawing: $41-1)-144=014$ ECO Number: 574.0

2. ECO Search List:

3. Description of Change:

Show (AS BUILT) new ladder location and delete existing location at R.H. cask loading $R_{m}$ as per Sk. no. 1103 -s:

4. Drawing Cog. Engineer Approval:

Date: $P / 2 P / P /$

5. Cover Sheet Block (CC\&D Use Only)

Received from EFF:

Date Assigned:

Assigned to:
Drafting Started:

Initials / Date

Initials / Date

(Same as data base entry)
Drafting Completed:

Return to EFF:
Initials / Date

Initials $/$ Date

Initials / Date

WP Form 2017: 12/29/90

1290:B0006

Page 1 of 1 
$9 a$

P. $6 / 14$

DRAWING CHANGE SHEET

(1 SHEET PER DRAWING)

1. Drawing: $41-G-170=014$ ECO Number: $57 \leq 4$

2. ECO Search List:

3. Description of Change:

Show (as-built) new ladder location at R.H. Cask loading Room as per Sk. no. $1703-s$

4. Drawing Cog. Engineer Approval: Date: $c p / 2 p / q /$

5. Cover Sheet Block (CC\&D Use Only),

Received from EFR:

Date Assigned:

Assigned to:

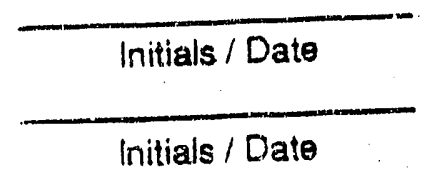

Same as data base entry
Drafting Started:

Drafting Completed:

Return to EFR:
Initials/ Date

Initials ! Date

Initials / Date

WP Form 2017; 1229190

$1290: 80005$

Page 1 of 1 
$9 a$

DRAWING CHANGE SHEET

(1 SHEET PER DRAWING)

1. Drawing: $41-G-508-014$ ECO Number: 57 tie

2. ECO Search List:

3. Description of Change:

Show (AS BUILT) new ladder location and delete existing location at R.H. cask loading $R_{m}$ as per SK. No. 1703 - S

4. Drawing Cog. Engineer Approval: Date: $p / 2 p / 9 /$

5. Cover Sheet Block (CC\&D Use Only)

Received from EFR:

Date Assigned:

Âšsignied to:
Drafting Started:

Initials / Date Initials / Date

(Same as data base entry)

213,14 


\section{DRAWING CHANGE SHEET}

(1 SHEET PER DRAWING)

1. Drawing: $41-G-455-014$

ECO Number: $57<1$.

2. ECO Search List:
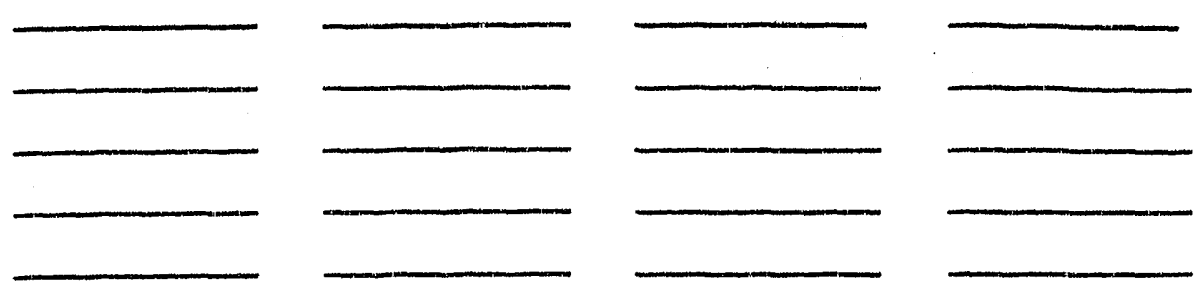

3. Description of Change:

Show (as built) new ladder location at R.At.

caskle loading form as per sk. no. 1703 -s.

4. Drawing Cog. Engineer Approval:

7. Fine 11

5. Cover Sheet Block (CC\&D Use Only)

Received from EFR:

Date Assigned:

Assigned io:
Initials / Date

Initials / Date

(Same as data base entry)
Drafting Started:

Dratting Completed:

Return to EFR:
Initials / Dato

Initials / Date Initials / Date 
$9 a$

$7.9 / 1314^{14.5}$

\section{DRAWING CHANGE SHEET}

(1 SHEET PER DRAWING)

1. Drawing: $41-G=502=014$ ECO Number: 5716

2. ECO Search List:
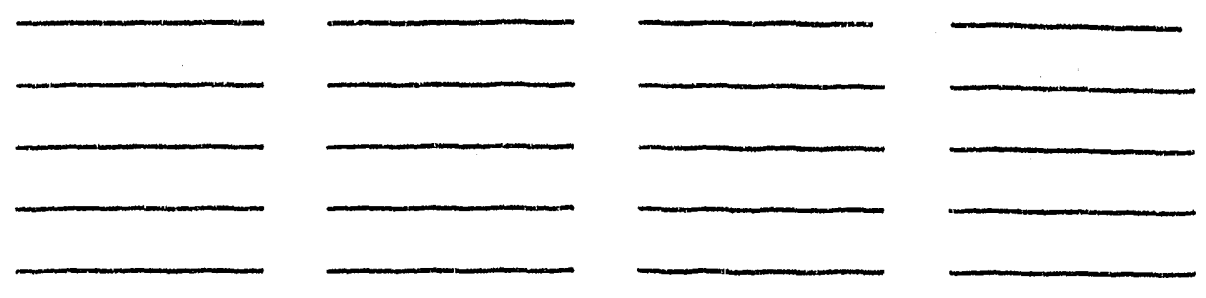

3. Description of Change:

show (as built) new ladder location at R.A. cask loading $E_{m}$. as per $5 k$. no. $1703-5$.

4. Drawing Cog. Engineer Approval: Tr Lma is $1 q_{q}$ Date: $8 / 2 p / q 1$

5. Cover Sheet Block (CC\&D. Use Only) /

Recoived from EFR:

$$
\text { Initials / Date }
$$

Date Assigned:

Initials + Date

Assigned to:

Ihilials / Dale

(Sânị as data basa ontry)

Drafting Started:

Drafting Completed:

Return to EFR: 
$9 a$

$1.10 / 1314^{H \cdot S}$

DRAWING CHANGE SHEET

(1 SHEET PEA DRAWING)

1. Drawing: $41-G=510-014$ ECO Number: 5741

2. ECO Search List:

3. Description of Change:

Show (as built) new ladder location at R.H. cask loading $E_{m}$ as per sk no. $1703-5$.

4. Drawing Cog. Engineer Approval:

Date: $8 / 24 / 9 /$

5. Cover Sheet Block (CC\&D Use Only)

Received from EFR:

Date Assigned:

Assigned to:
Drafting Started:

Drafting Completed:

Return to EFR:

(Same as data base entry)
Initials / Date

Initials / Date:

Initials /. Date

WP Form 2017; 12/29/90

1290:80006

Page 1 of 1 
ga

$5.11 / 2514^{17.5}$

DRAWING CHANGE SHEET

(1 SHEET PER DRAWING)

1. Drawing: $41=E-005-014$

ECO Number: 5716

2. ECO Search List:

3. Description of Change:

Show (as built) new ladder location at R.H cask loading tm. as per Sk. no. 1703 - S.

4. Drawing Cog. Engineer Approval:

Date: $8 / 28 / 9 /$

5. Cover Sheet Block (CC\&D Use Only)

Received from EFR:

Date Assigned:

Assigned to:
Initials / Date

Initials / Date

(Same as data base entry)
Drafting Started:

Drafting Completed:

Initials/ Date

Initials / Date

Return to EFR:

Initials / Date

WP Form 2017; $12 / 29 / 90$

1290:B0006

Page 1 of 1 
$9 a$

$1.12 / 13 / 4+5$

DRAWING CHANGE SHEET

(1 SHEET PER DRAWING)

1. Drawing: $4 /-G-453.014$ ECO Number: $57<16$

2. ECO Search List:

3. Description of Change:

Show (as built) new ladder location Cask Loading Loom as per 5k.no. 1703-s.

4. Drawing Cog. Engineer Approval: Date: $8 / 2 p / 91$

5. Cover Sheet Block (CC\&D Use Only)

Received from EFR:

Date Assigned:

Assigned to:

(Same as data base entry)

Drafting Started:

Drafting Completed:

Return to EFR:
Initials / Date

Initials / Date

Initials / Dato

. Initials / Date

WhF Fornix $2017 ; 12 / 23 / 90$

1290:80006

Page 1 of 1 
$9 a$

P. $13 / 14$

DRAWING CHANGE SHEET

(1 SHEET PER DRAWING)

1. Drawing: $41-G-172-0 / 4$ ECO Number:

2. ECO Search List:

3. Description of Change:

Show (a s-built) new ladder location at

$R_{4}$. cask loading Room as fer

Sk. no. 1703-5

4. Drawing Cog. Engineer Approval:

Date:

$8 / 2 p / 91$

5. Cover Sheet Block (CC\&D Use Only)

Received from EFR:

Date Assigned:

Assigned to:
Drafting Started:

Drafting Completed:

Initials/ Date Initials t Date

(Same as data base entry)

Initials / Dato:

Return to EFR:

Initials / Dato

WP Form 2017; 12/29/90

1290:80006

Page 1 of 1 


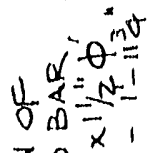

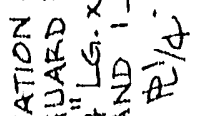

Uुज

Aी

造诘

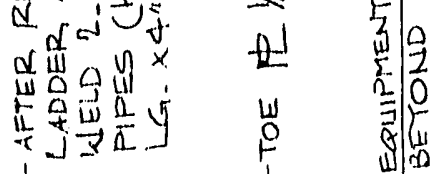

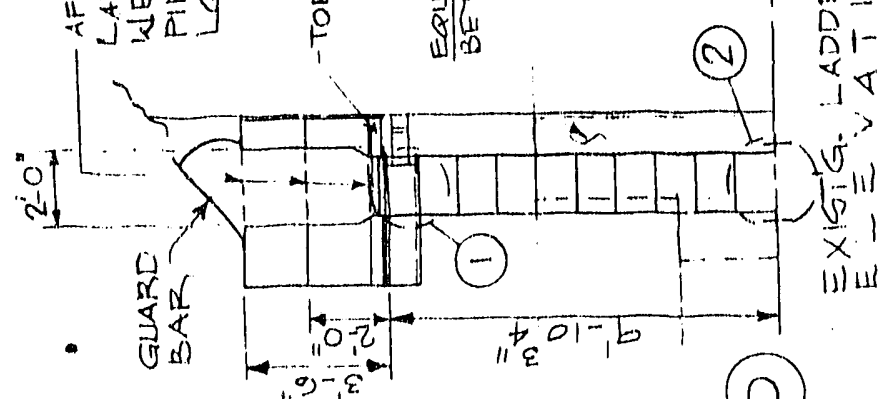

(
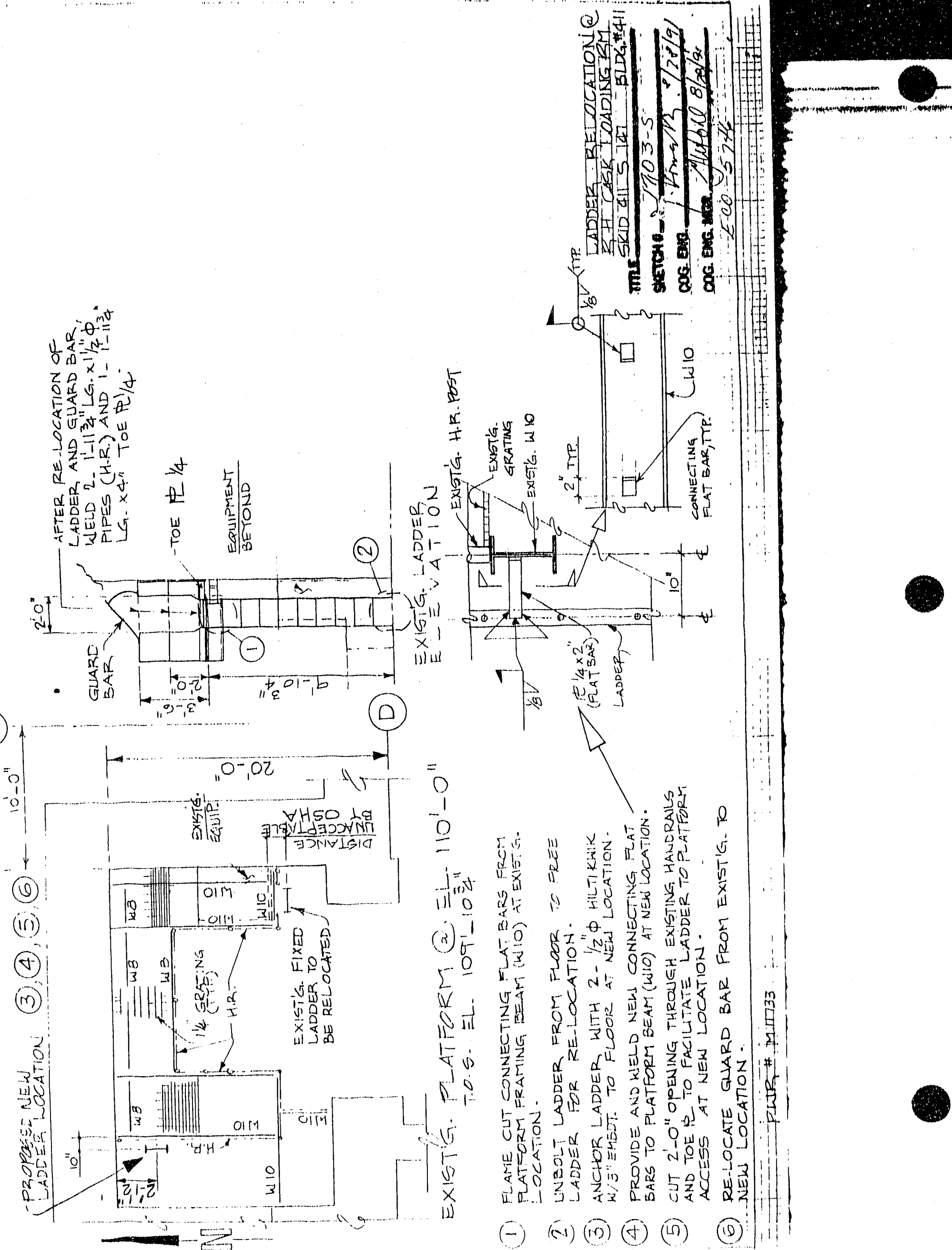

ant $\frac{1}{5}$

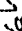
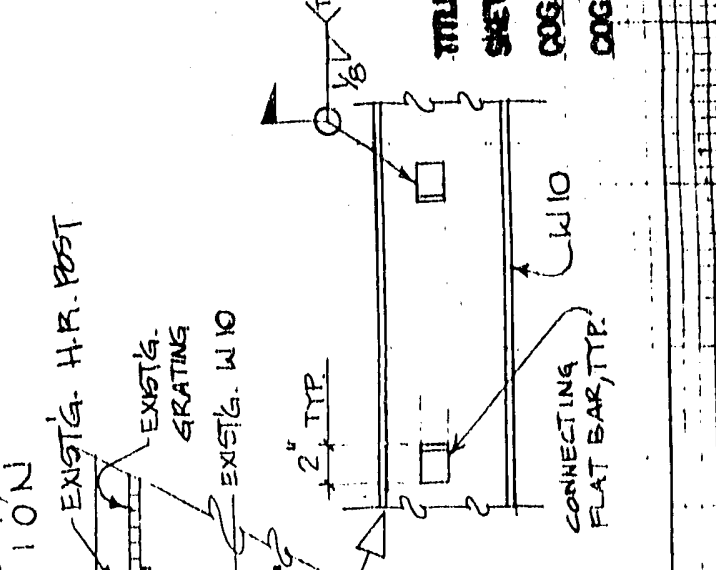

(4)

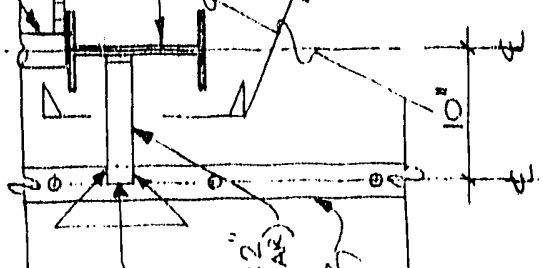

$1=0$ 
1. ECO No.: 57 ? IA CC\&D RevlewiZf

7. Originator: (print) $\perp$ RODNEY FL'STDN

Initials

2. Impact Level

3. System: PCU? Equipment No:

4. Assoclated Documents:

PWF M17272

ECP

P.O.

Others

\section{Document Type:}

Drawing $73 \cdot \mathrm{J} \cdot 02 \mathrm{~L} \cdot \mathrm{Wl}$ $73 \cdot \tau \cdot 022-W 2$ Spocification $73-J E_{14}-k$, Veridor Date SDD

Others

6. Title of Change: PA FUR LUHSE 453 \& NLU QLAD D/3
8. Cognizant Engineer: (print) $I R O D N E Y$ FLISTON

\section{Description of Chango}

ELEO FE/EE $\quad 9 / 12 / 1$

Date:

Yes No
Component indices change required (if yes, attach she日ts)

A DRAWING NO 73 I.CRL.W RLV B (A SHETT AA \& AB INCLUDED)

(1) ADD CONDUIT AND JLNCTION BOXES TO DWG

(2) ADD IN.LERLLND PLLL ISLX TO DWG

(3) ALD CLINDLIT SCHEDLLE

(4) AOD EGLIPWLNT SCHODLCE

(5) AID JLIVITILN BLCX SCHEDULE.

B DRAWINE ND.73.J-LI4 W REV B

(I) PLAN WIEW CF DLLT BANK SYSTEM

(2) SECTION VIEZUS OF DLLTT BANK PLLL BCIXES

$\square$ 9a Drawing Change Sheet attached

9b Design Documentation Sheet attached

$\square$ 9c Vendor Data Change Sheet attached

10. Yes No

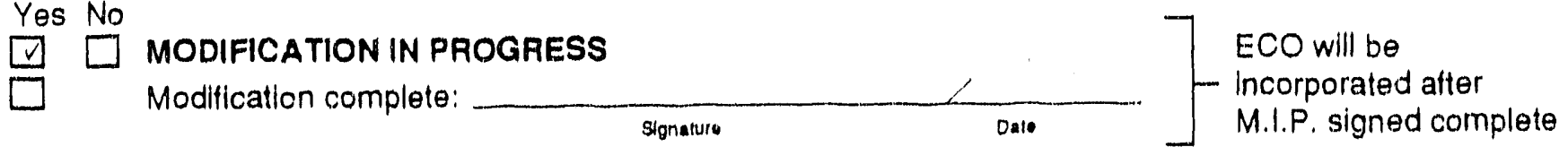

Change drawing per as-bullt markup dated:

Change drawing per ECO-provided da!a

Temporary modification

11. Design Verification Requirements: (per WP 09.018)

EDT No::

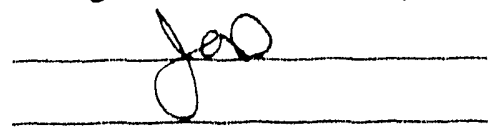

1. Requirements satisfied by review/approval of design document

2. Independent review

3. Altemate calculations

4. Development testing

5. Design reviow

6. Other:

12. Addendum Sheet added: 


\section{Justification}

TO PROVIDE ENGINEZRING ANO INSTALLATLLN DETAILS FLK NEZV

PLELIL ADDRESS CLMIUNENTS TO BE ADDED $R$ F' FALILITY 4.53

\section{Administrativo Tracking}

YES N/A

$\square \square$ 1. FSAR

$\square \square$ 2. Calibration Procedures

$\square$ 3. Maintenance Procedvies

$\square \square$ 4. Computer Software

$\square \square$ 5. Operations Procedures

15. SIgnature Requirements

$A=A P P R$

RøREVIEW

S-SIGN NEW

DRAWING

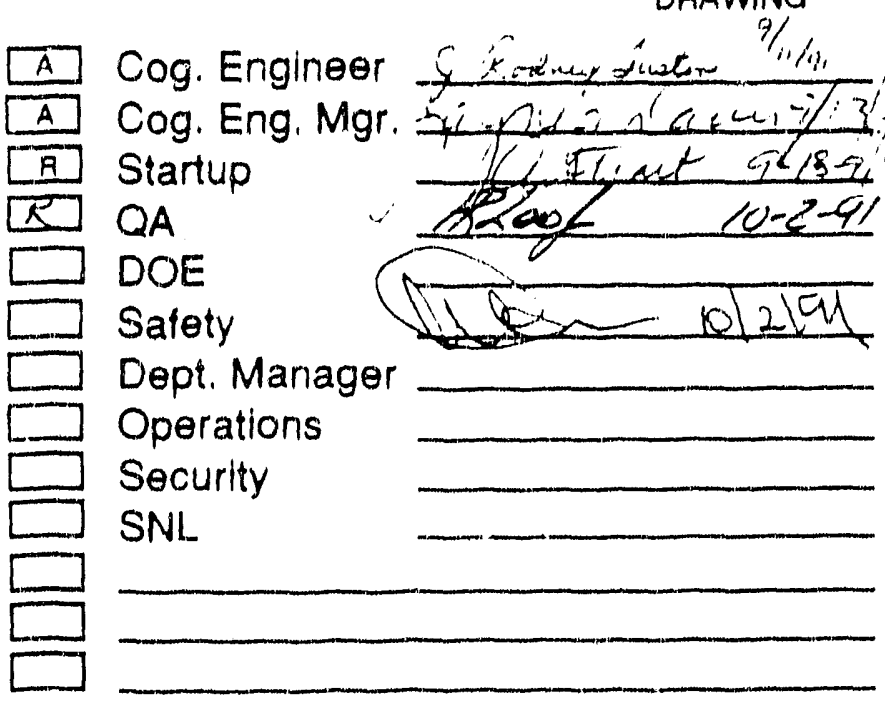

YES NA CAS i+1 \& - "I

If 6. Startup/Acceptance Test

$\square \square$ 7. Test Requirement \& Spec.

$\square \square 8$.

$\square \square \quad 9$

$\square \square \quad 10$.

\section{Distribute as Marked}

Maintenance MANDaTORY)

Ops. Suppor (MANDATORY)

Startup

Facility Operations

U/G Operations

Orig./Design Engr.

Cog. Engineer

Others CCiD

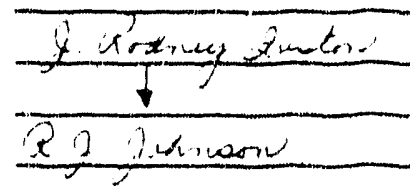




\section{ENGINEERING CHANGE ORDER DOE ORDER 64:30.1A DESIGN CRTTEFIA \\ CHECKLIST}

PACE 3 OF 14

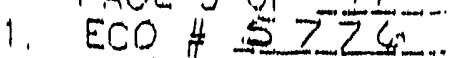

2. DATE

The design reguirements in DOE Order 64301 1A checked below have been applied to this Design.

\begin{tabular}{|c|c|c|}
\hline & DIVISION & SUBDIVISION \\
\hline$\nabla 1$ & Goneral Roqulrements & $\square 0101 \square 0106 \square 0109 \square 0110 \square 0111 \square 0140 \square 0150 \square 0170$ \\
\hline$\square^{2}$ & $\begin{array}{l}\text { Site and Clvil } \\
\text { Engineering }\end{array}$ & 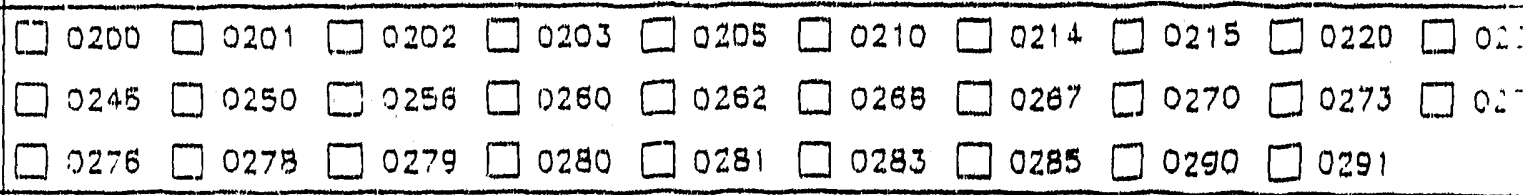 \\
\hline$\square 3$ & Concrete & $\square 0300 \square 0301 \square 0310 \square 0320 \square 0330 \square 0340 \square 0350 \square 0370 \square 0380$ \\
\hline$\square^{4}$ & Masonry & $\square 0400 \square 0401 \square 0410 \square 0420 \square 0455$ \\
\hline$\square 5$ & Metals & $\square 0500 \square 0512 \square 0514 \square 0521 \square 0531 \square 0532$ \\
\hline$\square 6$ & Wood and Plostics & $\square 0600 \square 0610 \square 0650$ \\
\hline$\square^{7}$ & $\begin{array}{l}\text { Thermal and Moisture } \\
\text { Pro:ectiori }\end{array}$ & 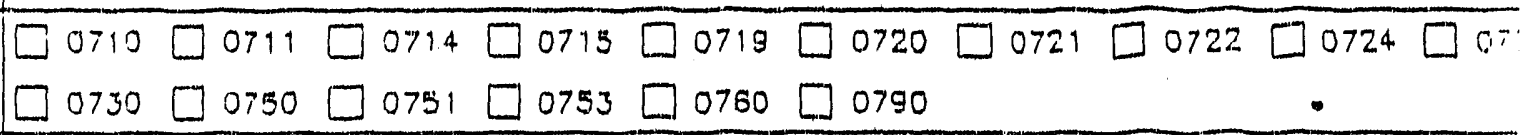 \\
\hline$\square^{8}$ & Doors and Windows & $\begin{array}{l}\square 0800 \square 0810 \square 0820 \quad\left[0830 \quad \square 0833 \quad \square 0836 \square 0839 \square 0850 \square 0860 \square 00^{\circ}\right. \\
\square 0880\end{array}$ \\
\hline$\square 9$ & Finighes & 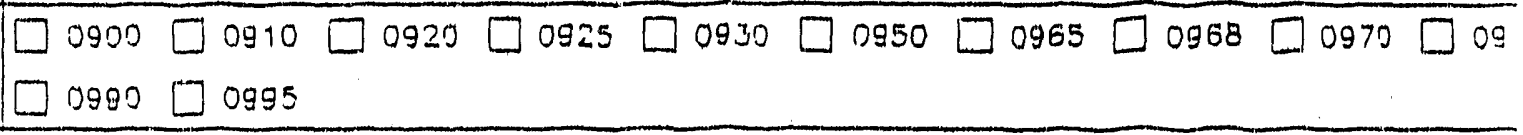 \\
\hline$\square 10$ & itigs & 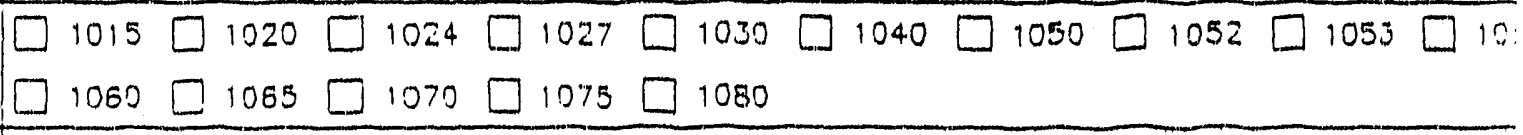 \\
\hline$\nabla 11$ & Equic & $\square 1100 \square 1161$ \\
\hline$\square 12$ & Furnishings & $\square 1201 \square 1230 \square 1250 \square 1260 \square 1270$ \\
\hline Eij & Special Facilities & $\begin{array}{l}\square 1300 \square 1304 \square 1305 \square 1300 \square 1307 \square 1318 \square 1319 \square 1320 \square 1321 \square 13 \\
\square 1323 \square 1324 \square 1325 \square 1325 \square 1328\end{array}$ \\
\hline$\square^{11}$ & Conveying Systems & $\square 1401 \square 1420 \square 1440 \square 1460$ \\
\hline$\square^{15}$ & Hechanical & $\square 1525 \square 1530 \square 1540 \square 1550 \square 1555 \square 1565 \square 15 i 4 \square 1589 \square 1505$ \\
\hline$\nabla_{15}$ & Electrigal & 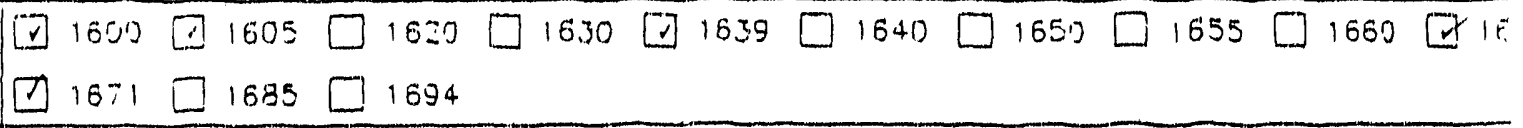 \\
\hline 4. $\square$ & NOT AFPLICAELE & No portion of DOE Draer $6430.1 \mathrm{~A}$ is applicoble to this Design. \\
\hline$\Xi \square$ & ASG-EUILTT & -built figid y \\
\hline
\end{tabular}

NOTE: A check placed in the Division column signifieg that the entire Division shall be applicable to the Design, unless modified by checks indicated for specific Subdivigions.

COMMENTS: 


\section{$9 \mathrm{a}$}

\section{DRAWING CHANGE SHEET}

(I SHEET PER DRAWING)

1. Drawing: $7.3 \cdot \mathrm{J}: 020 \cdot \mathrm{W}$

ECO Number:

5776

2. ECO Search List:
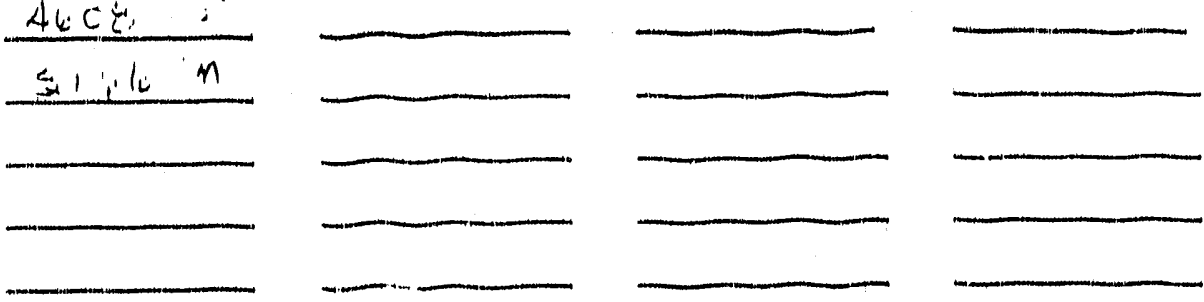

3. Description of Change:

\section{A. ADD CONDUIT $25 \cdot \mathrm{J} \cdot 540$ TO DWG. SEE PAGE 5 \\ $25 \cdot 5 \cdot 576$}

B. ADD JUNCTION BOX 25P. TBPA/144 TO DWG. SEE PAGE 5.6

C. ADD IN-LERCLND DLLL. BCX TO DWE - $25 P$ - PBJC. 133 SLE PAGE 6 .

D ADD CONDUIT SCHETULLE TO OWG. SEE PAGE 1

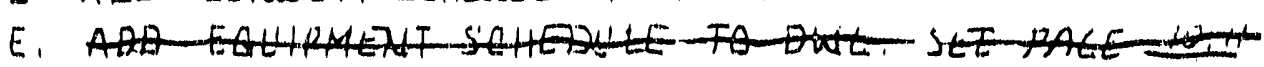

$8239 / 13 / 91$

F. ADD JUINRTION BOX SCIHDDULE TO DWE. SEE PAEE 89

G. $28239 / 13 / 91$

H. ADD YARD CONDUIT LAYCUT. SEE PAGE L

I. ADD CONDULIT 25.S-36.1 TO DWG. SEE PAGE 6

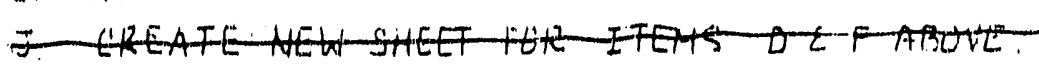

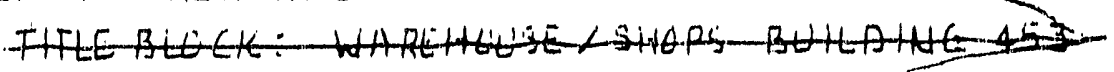

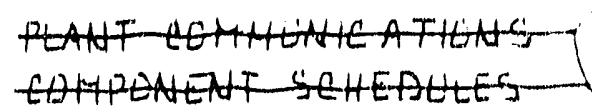

4. Drawing Cog. Engineer Approval:-2Rrdruy zuntix Date: 9/:2/9,

5. Cover Sheet Block (CC\&D Use Only)

Received from EFF:

Date Assigned:

Assigned to:

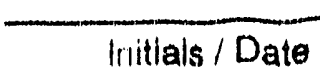

Initials / Date

(Same as data base entry)
Drafting Started:

Drafting Completed:

Return to EFF:
Inifials / Date

Inilials / Date

Iniflals / Date 


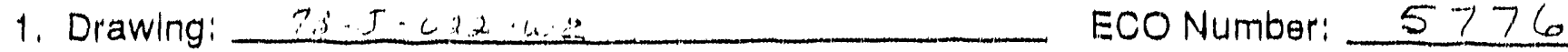

2. ECO Search Llst:
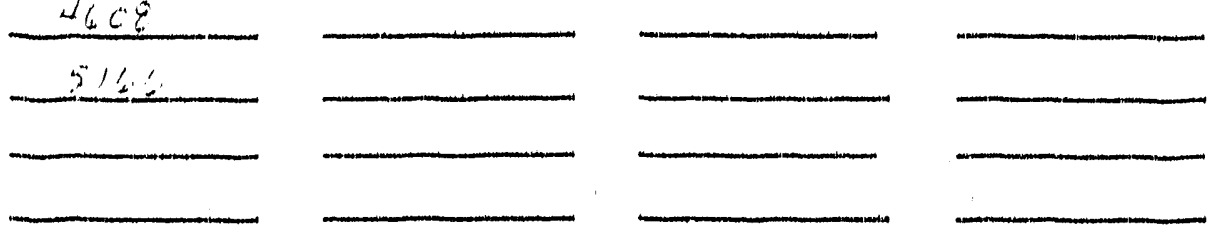

3. Description of Change:

A. LREATL A NLLE SUET FOR 7HIS DRAW: 'WE

口Q U U DUS DEF AF SHET 4 A OF 43

OF THIS ECO

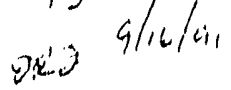

TITIL BLEKK: WAREHCLSE/ SHLPS SE BLILDINE 453

ILANT CUMMILNIIIATILNSS

CUMPONEAT SCWEDULES.

4. Drawing Cog. Engineer Approval: 


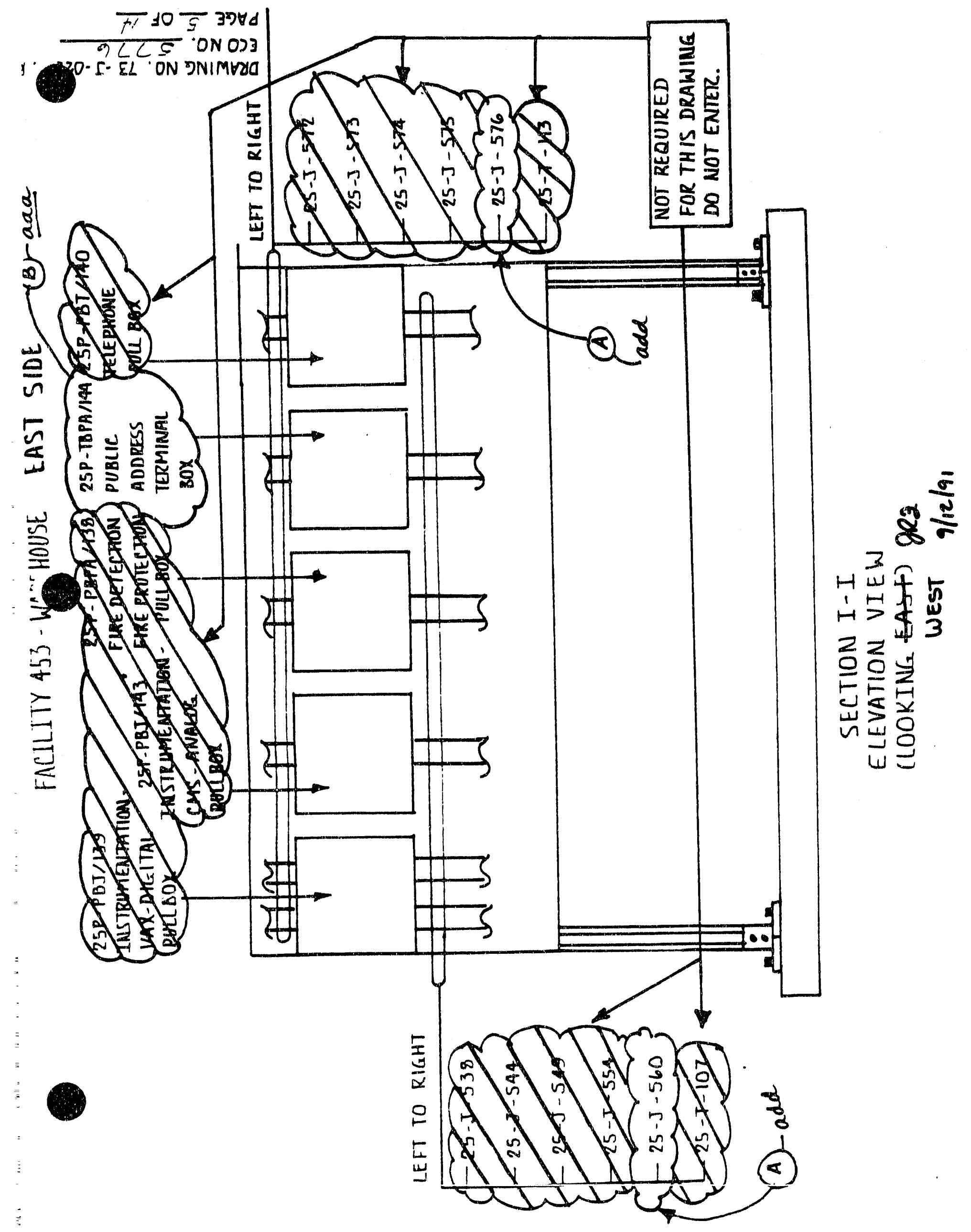




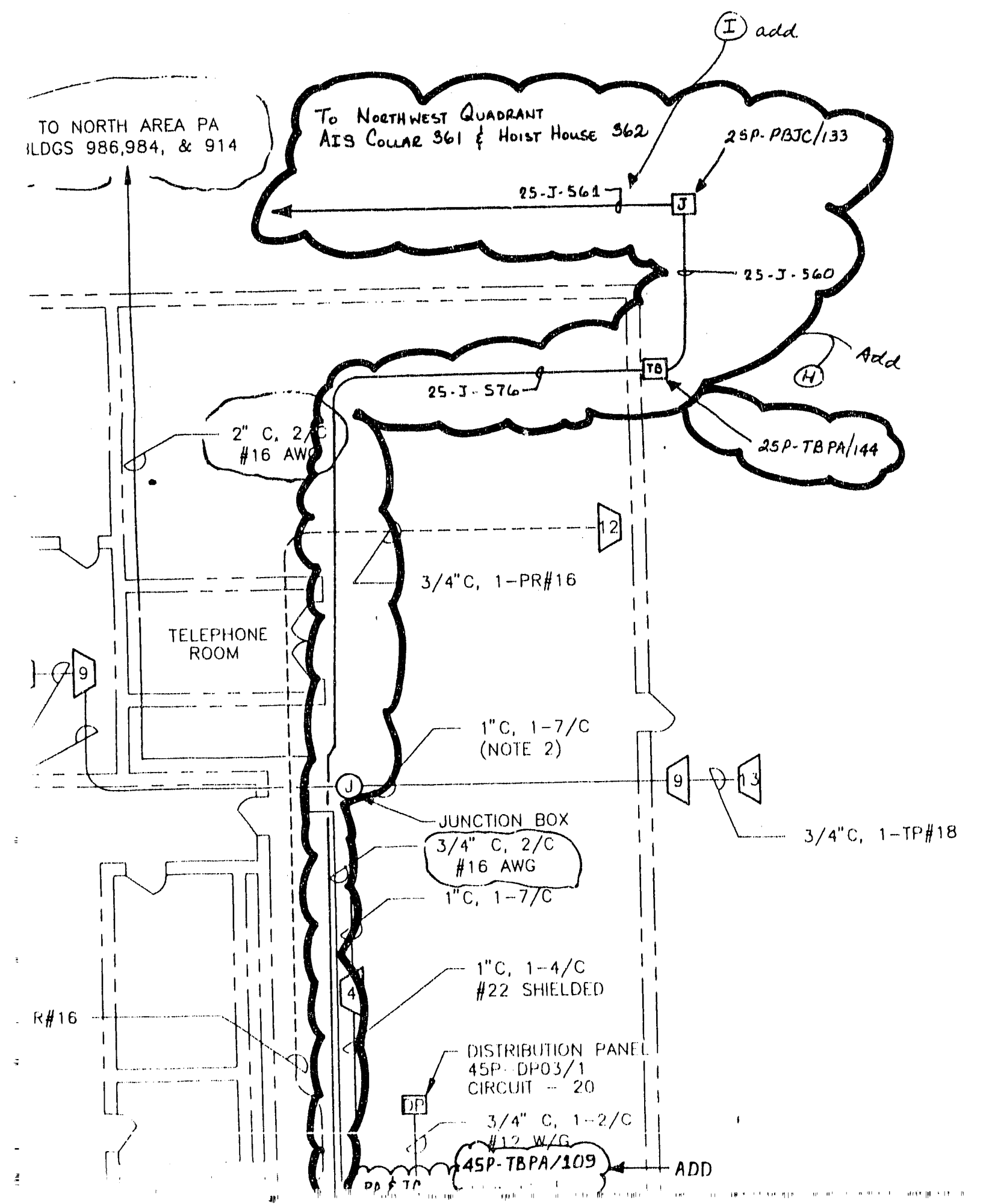

$1 \varepsilon$

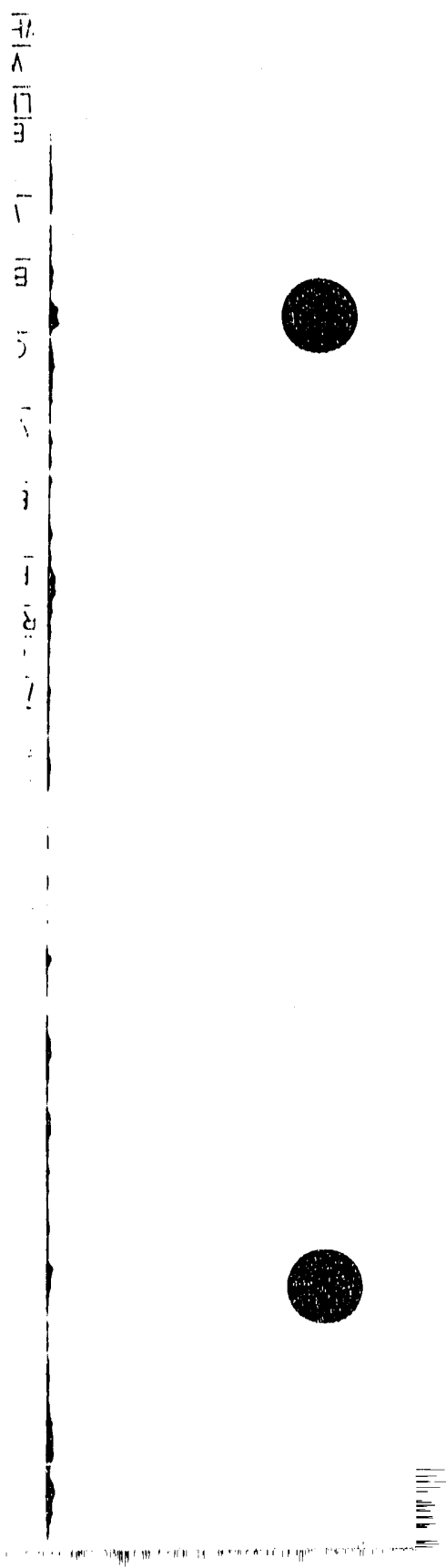




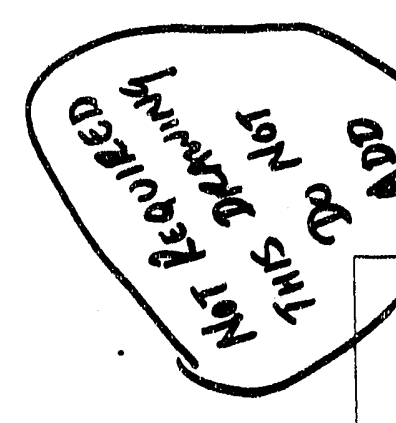




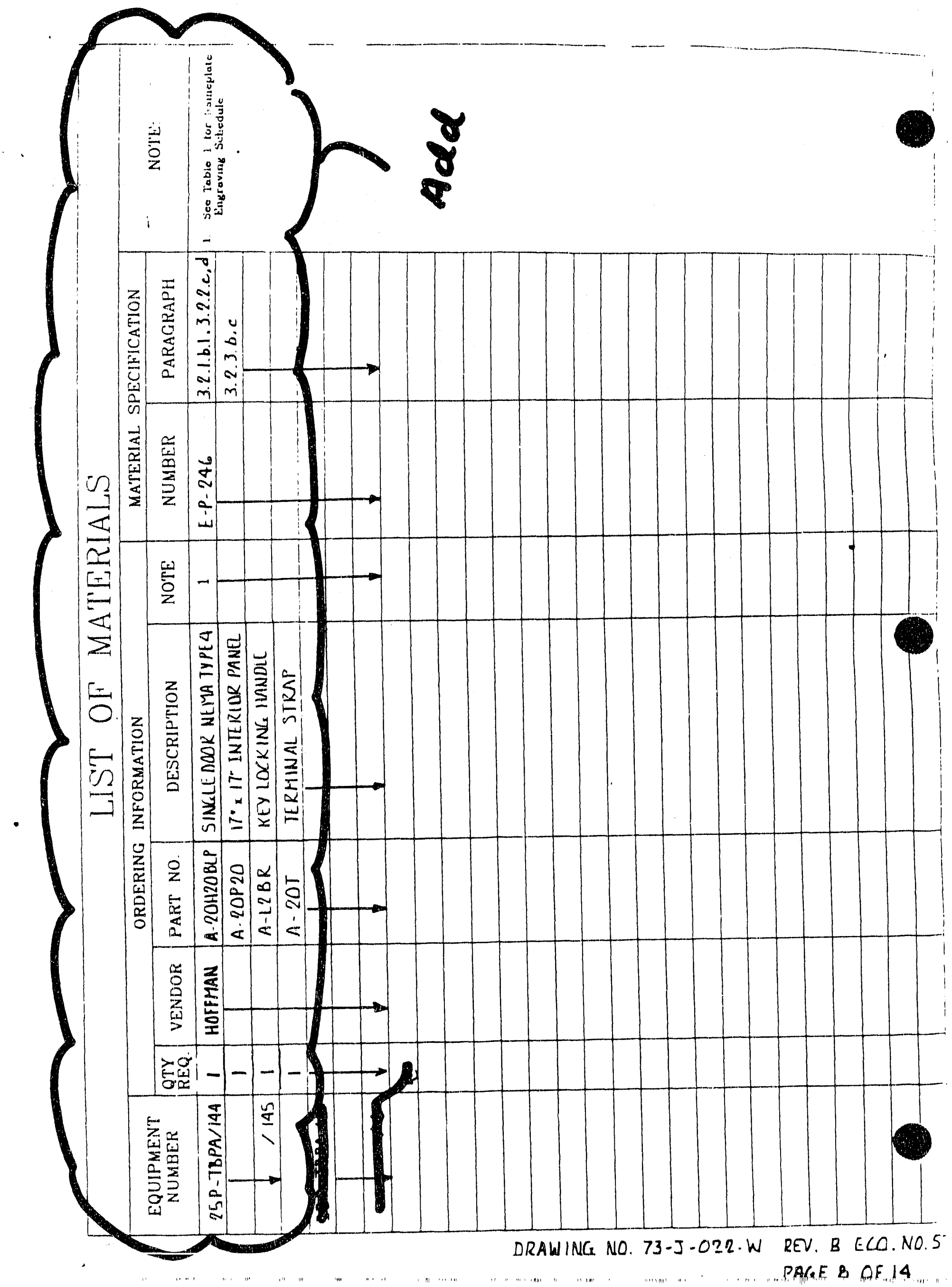




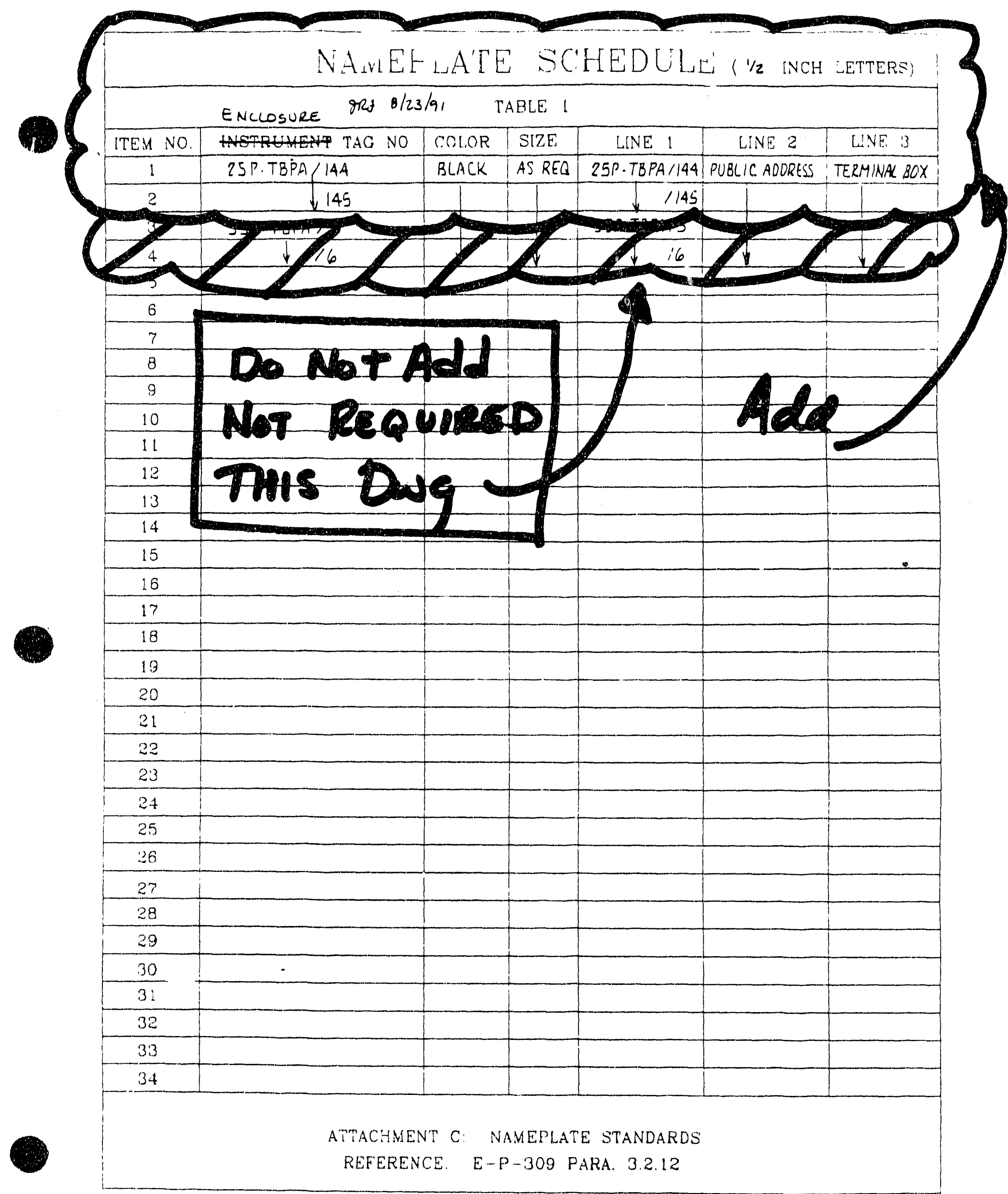

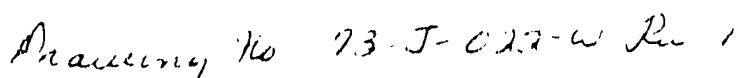

$$
\begin{aligned}
& \text { ECO He } 5726
\end{aligned}
$$

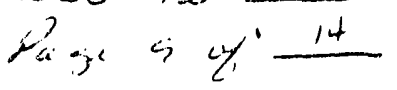


$9 a$

DRAWING CHANGE SHEET

(1 SHEET PER DRAWING)

$$
\text { Paye } 15 \text { of } 14
$$

1. Drawing: $73 \cdot \mathrm{J} \cdot \dot{\mathrm{C} / 4}-\mathrm{W}$

ECO Number: $\quad 5776$

2. ECO Search List:
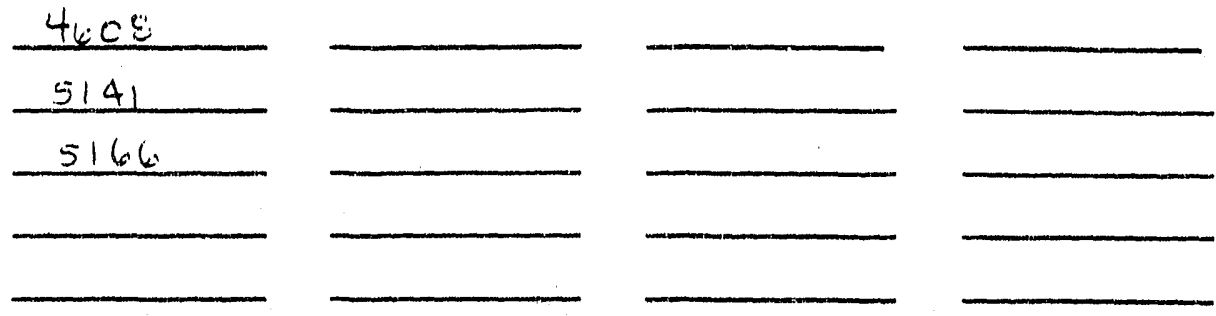

3. Description of Change:

A. ADD THE FOLLOWINE IN.GROUND PULL BOXES. SEE PAGE t" $" 3 x 2 \% / 3 / 4$, $25 P \cdot P B J L / 133$

$$
\begin{aligned}
& 134 \\
& 135 \\
& 136 \\
& 7137
\end{aligned}
$$

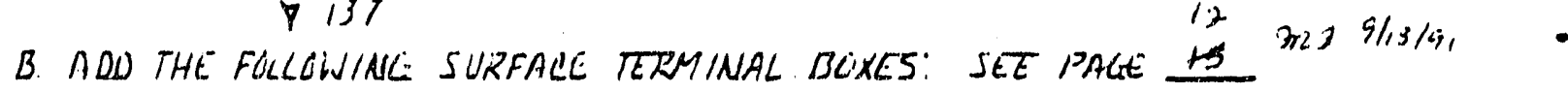
25P.TBPA/144 33P-TBPA/5

C. ADD THE FOLLLWING CONDUIT. SEE PAGE HETS $9239 / \% / 11$

$$
\begin{array}{cc}
25.5 .560 & 33.5 .005 \\
\text { to } & \downarrow 006
\end{array}
$$

$25-.5-.565$

D. ADD CLNDLIT SLHEDULE TL DLUG. SEE PAGE HE

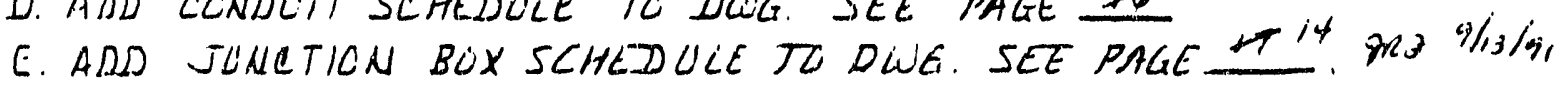

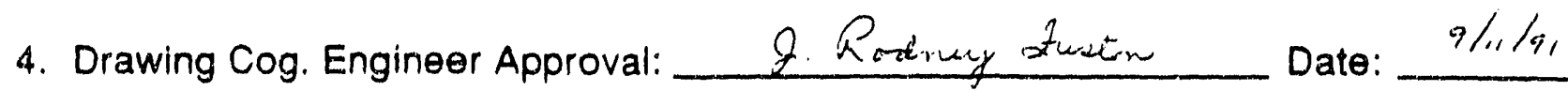

5. Cover Sheet Block (CC\&D Use Oniy)

Received from EFR:

Date Assigned:

Assigned to:
Dratting Started: Initials / Date Initials / Date

(Same as data base entry)
Drafting Completed:

Return to EFR:
Initials / Date

Initials / Date

Initials / Date 


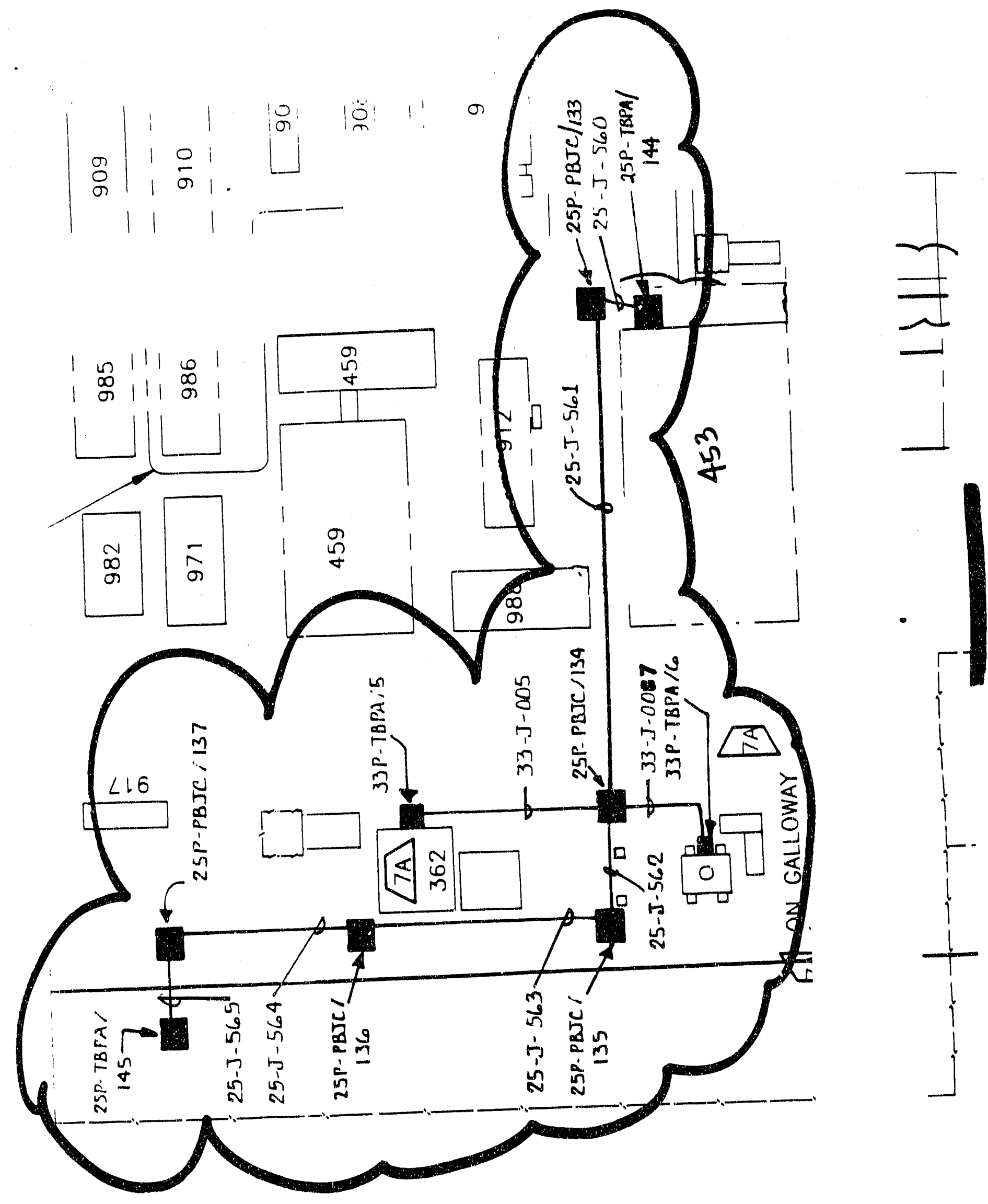

DRAWING NO. 73-J-O14-W REV.B Fi 3 ECO NO. 5776 $9 / 131 \%$ PAGE it LF 14 


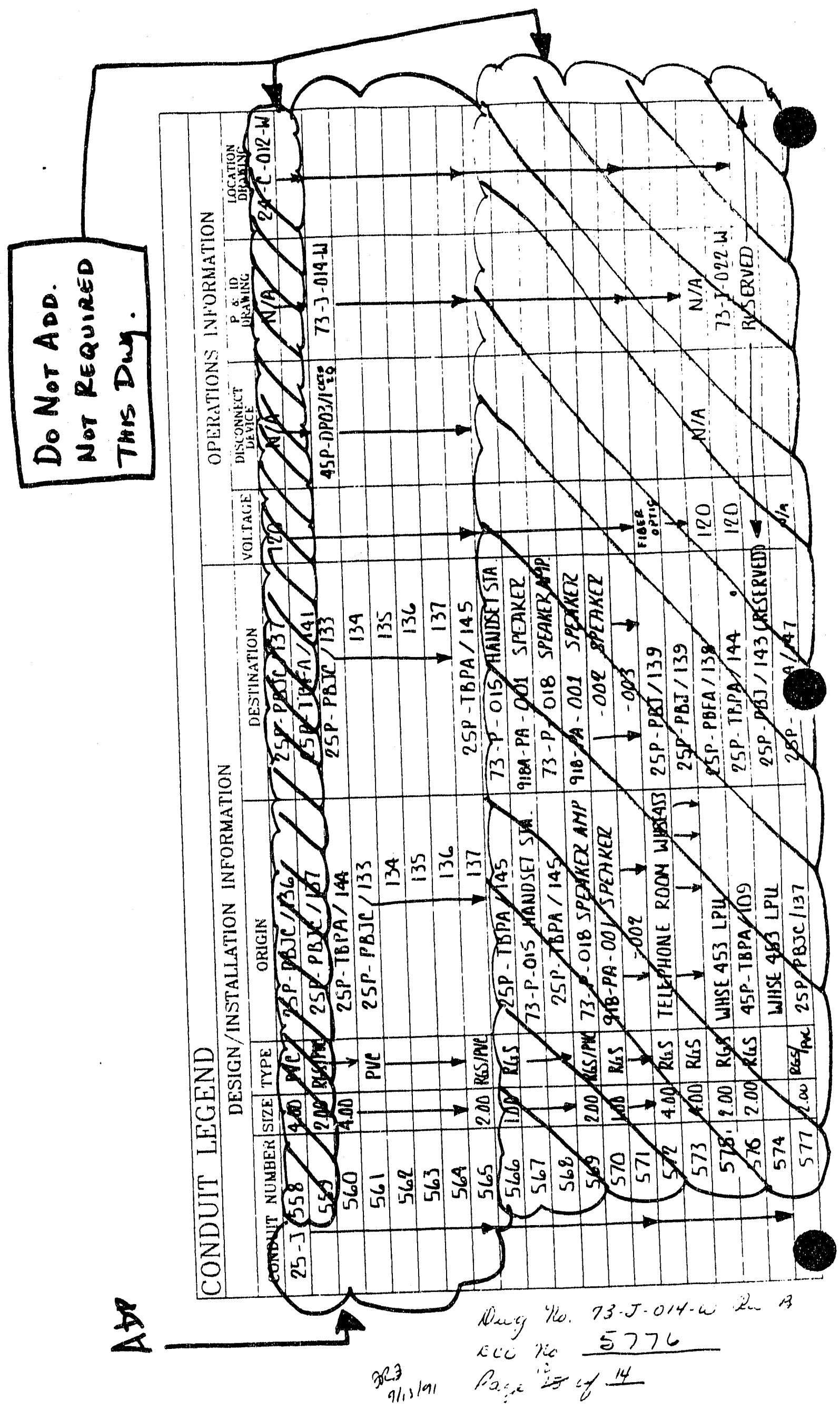




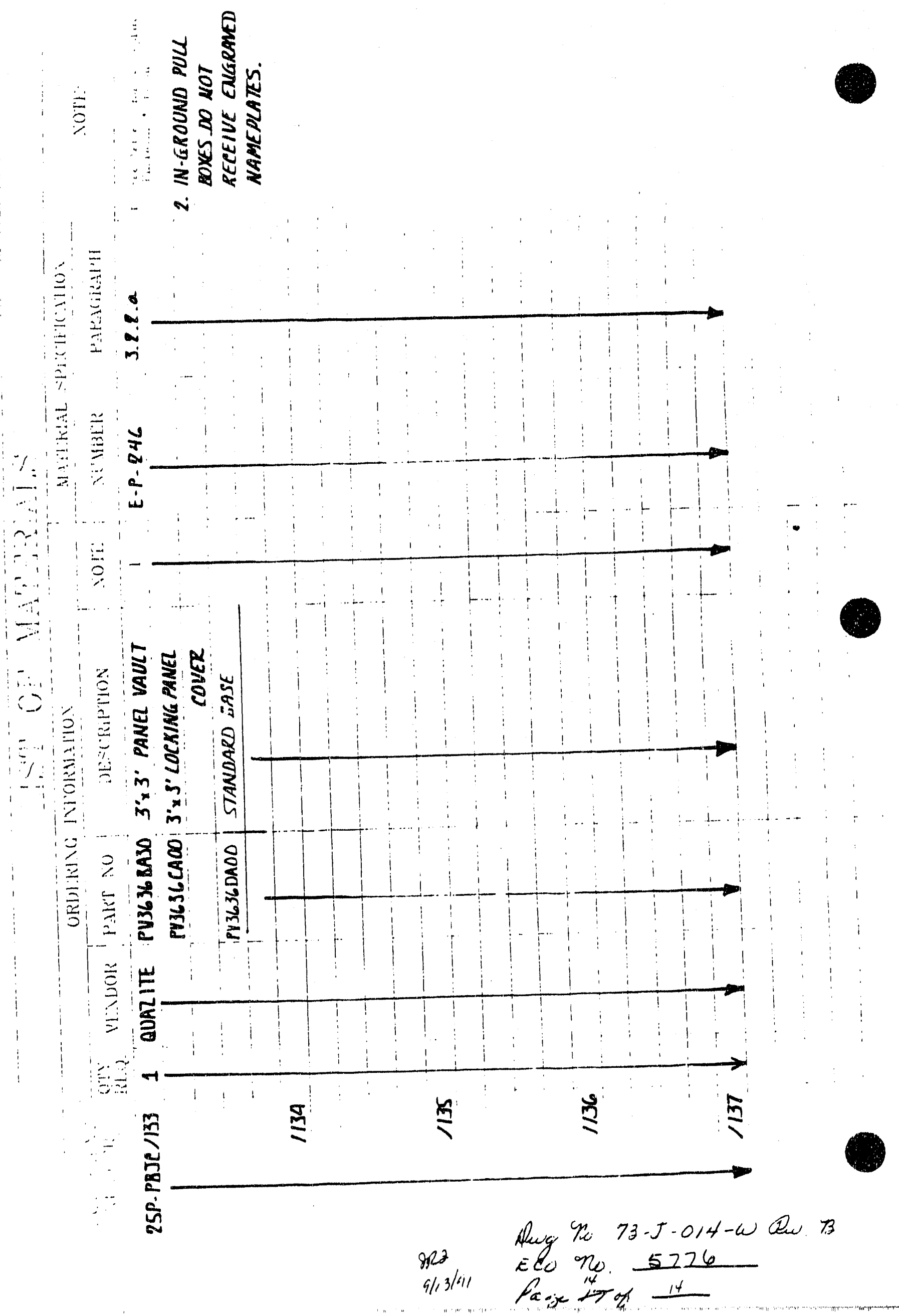




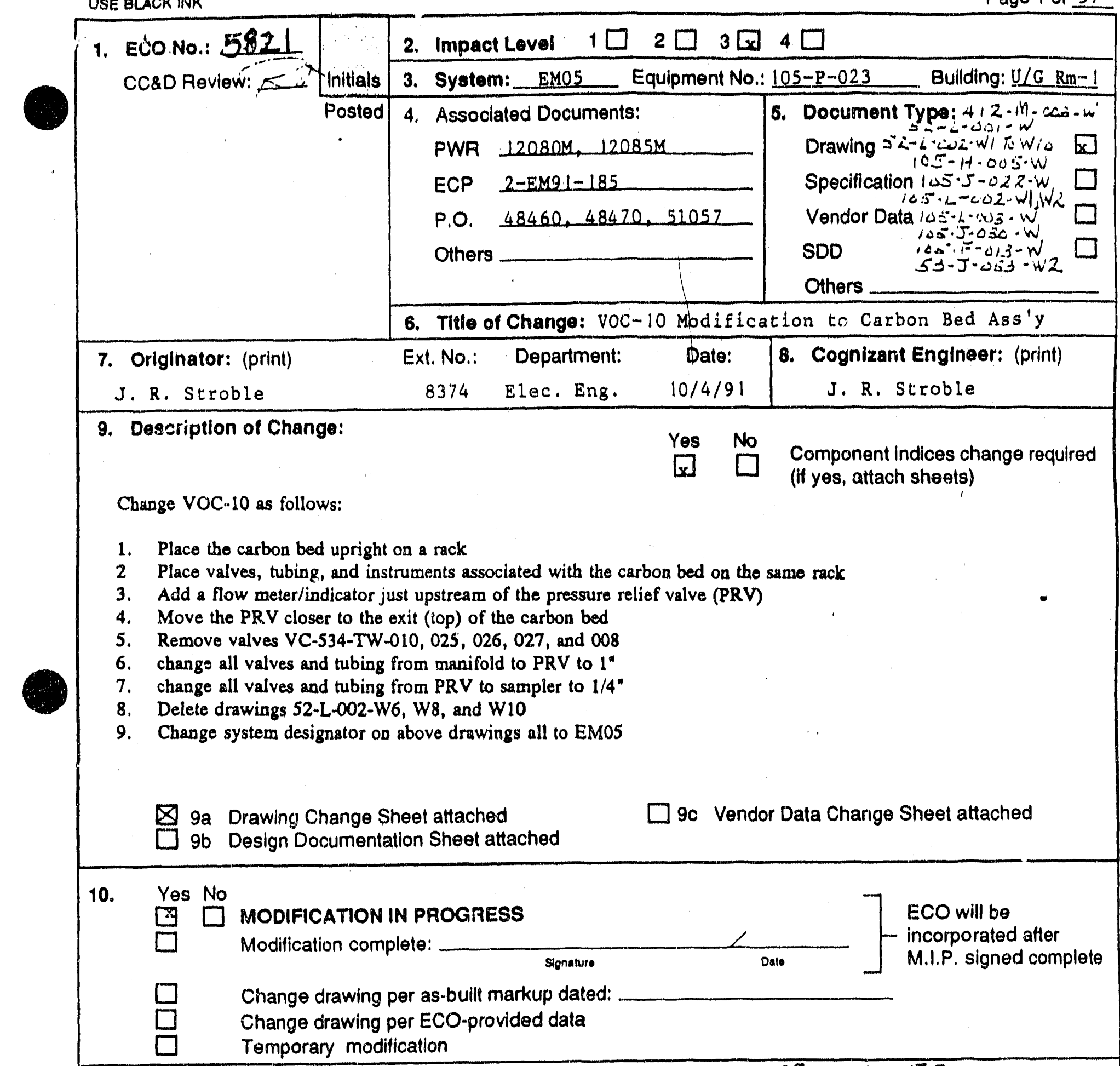

11. Design Verification Requirements: (per WP 09-018) EDT Ho.: EqL-3/9;EqL-283

1. Requirements satisfied by review/approval of design document

CxTED's $E-21-312, E 21-283$

2. Independent review

3. Altemate calculations

4. Development testing

5. Design review

6. Other:

12. Addendum Sheor added: 


\section{Justiflcation}

1. Loverting the carbon bed will prevent the possibility of gases bypassing the carbon due to settling.

2. Associated components will need to be close to the carbon bed.

3. If the PRV opens, the amount of gas released will be unknowa.

4. A 1" flow path was chosen to remain consistent with the existing system upstream of the carbon bed. This also reduces the number of pressure gradients in the systern.

5. These valves are no longer necessary (See EDT E91-319).

6. Same as number 4 above.

7. 1/4" valves and line will increase the efficiency of the cleaning process.

8. This information was needed for construction, but is not needed for configuration control.

\section{Administra!lve Tracking}

YES NA

[x $\square$ 1. FSAR

$凶 \square$ 2. Calibration Procedures

3. Maintenance Procedures

4. Computer Software

冈

5. Operations Procedures

$(D \& A T)$
YES NA
凹
冈
6. Startup/Acceptance Test
$\square \square 8$.
$\square \square 9$.
$\square \square \quad 10$.
7. Test Requirement \& Spec.

15. SEY

15. Signature Requirements A-APPR. R-REVIEW S-SIGN NEW DRAWING

$A$

A

A

$\square$

[A]

-

$\square$

$A$

A
Cog. Engineer Cog. Eng. Mgr Startup QA DOE Safety Dept. Manager Operaticns Security SNL $D \& A T$ RWHE MGR<smiles>C1CC2CCC1C2</smiles>
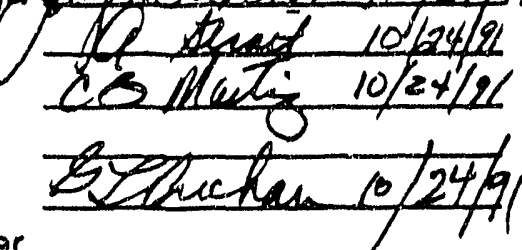
241

16. Distribute as Marked 


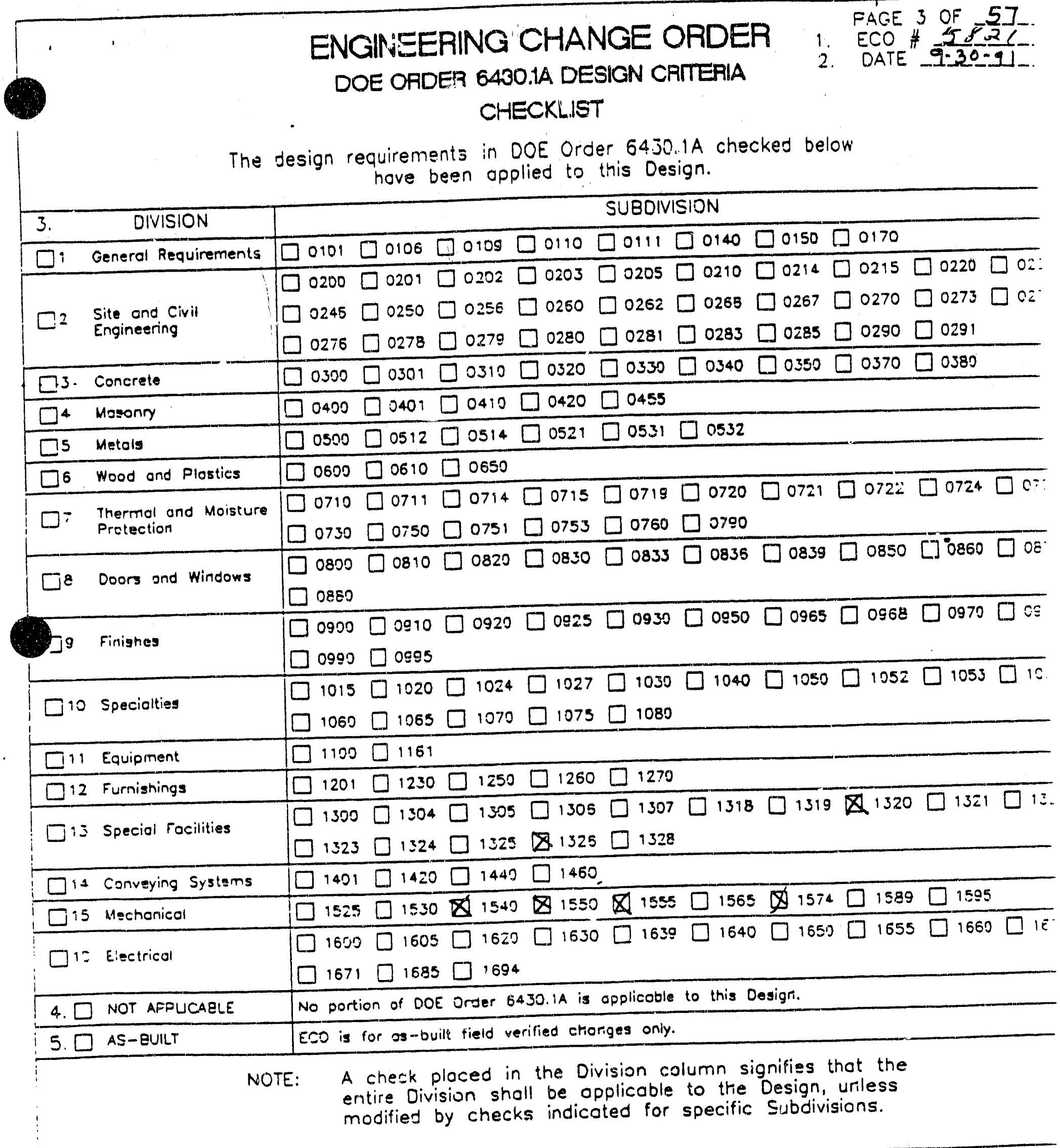

COMMENTS: 
1. Drawing: 52-L-001-W ECO Number:

2. ECO Search List:

3. Description of Change:

1. CHANEE THE PIPING SIZE AND ARRANGEMENT FROM THE CARBON BED + VOST TUBES TO THT SAMPLER.

2. Delete VALVES VC-534-TW-010,025, $26+027,0008$ 3. ADd a flow meter and threE z-WAY valves. 4. DELETE SySTEM BOUNDARIES BETWEEN EMOS \& WHO6. (THE WHOLE SYSTEM 9 DRAWINGS ARE NOW EMOS) 5. CHANGE BILL OF MATERIALS. 6. ADD DRAWING REFERENCES. 7. CHANGE SYSTEM DESIGNATDR TO JUSTEMOS SEE ATtAached pages.

4. Drawing Cog. Engineer Approval: U.R. Stuthle 5. Cover Sheet Block (CC\&D Use Only) Received from EFR: Initials / Date Date Assigned: Initials / Date Assigned to:

Drafting Started:

Drafting Cornpleted:

Return to EFR:
Initials / Dato Initials / Date Initials / Date Date: $|0-7-9|$ 


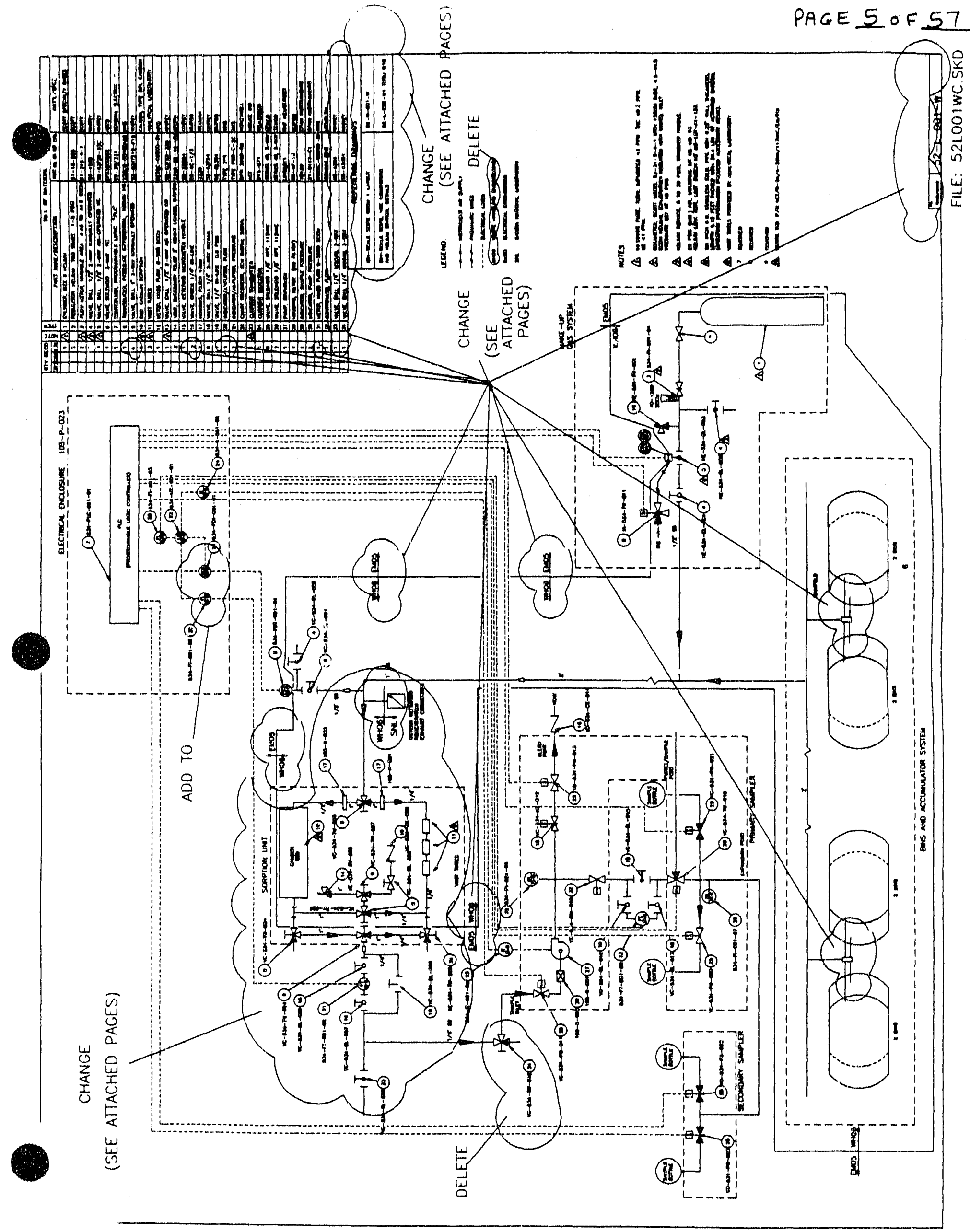


PAGE 6 OF 57

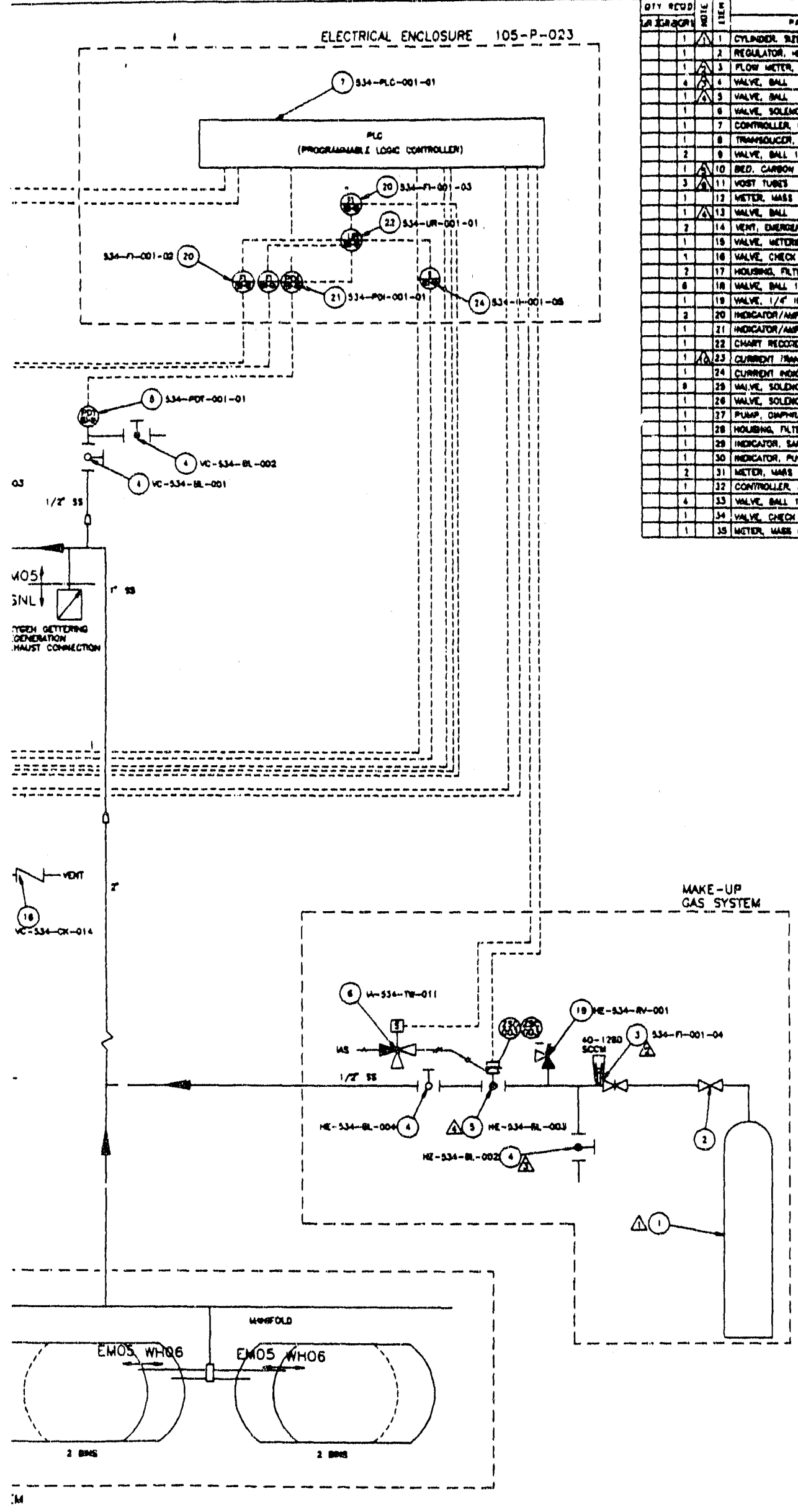

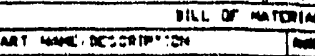
$-000 x / \quad$ m/2/20

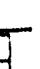




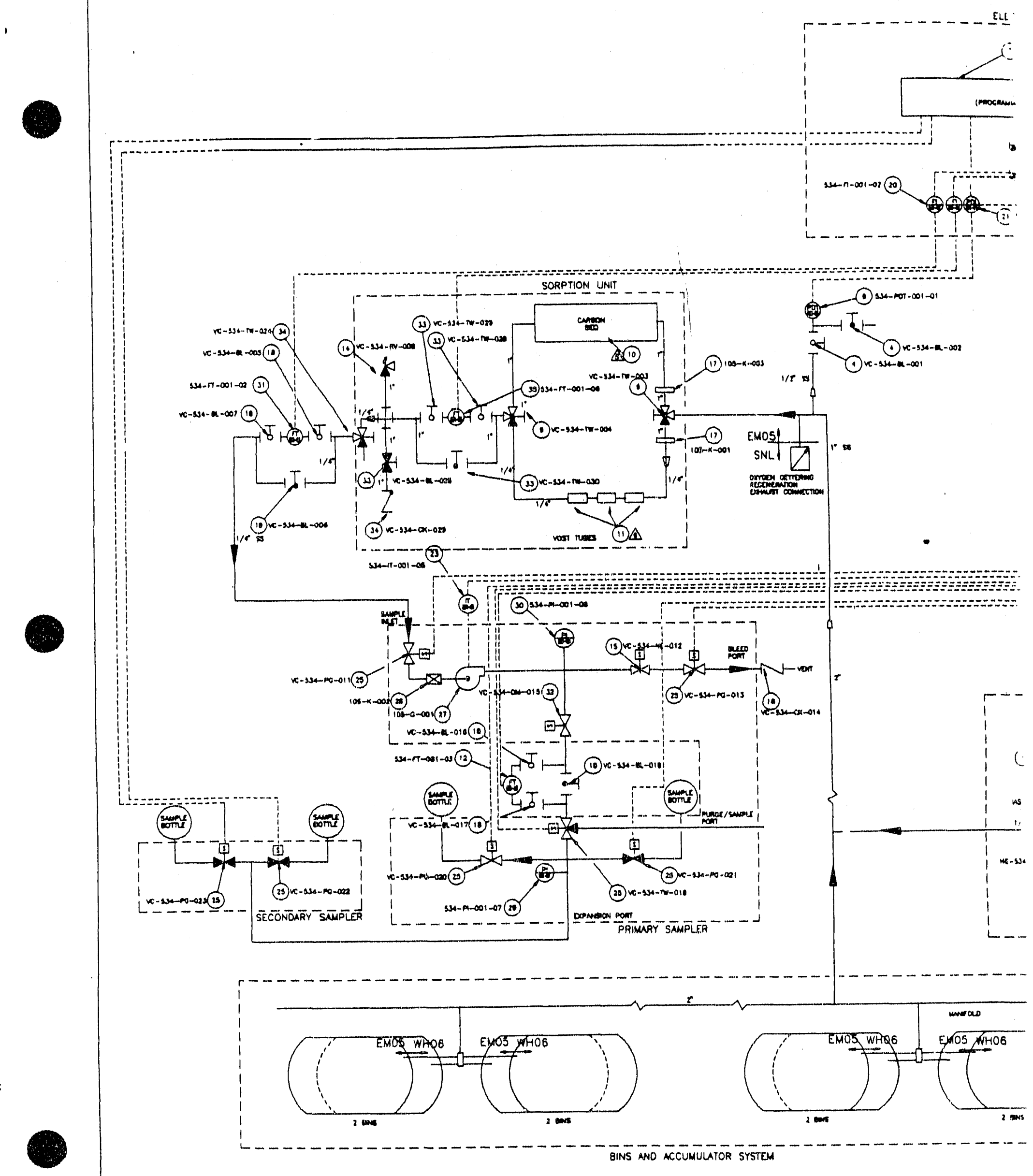


1. Drawing: $52-L-002-W \mid$ ECO Number:

5821

2. ECO Search List:
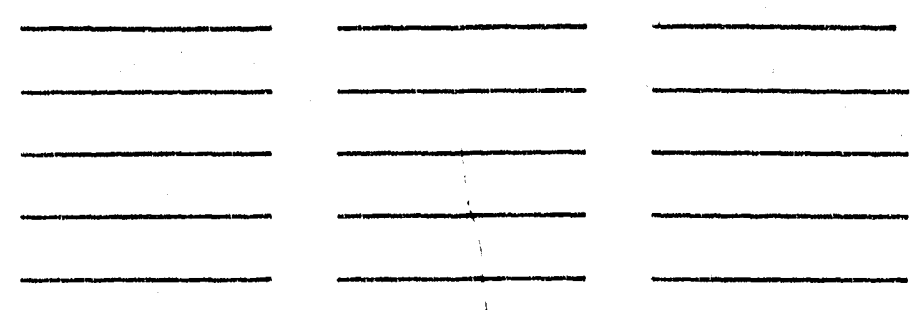

3. Description of Change:

1. CHANGE THE SYSTEM DESIGNATOR TO EMO5

2. change the title to:

$$
\begin{aligned}
& \text { BINSCALE TESTS, VOC(10) MONITORING SYTEM } \\
& \text { PANEL-1, ROOM-1 LAYOUT }
\end{aligned}
$$

3. CHANGE THE MATERIALS LIST OHATAS SHOWN ON ATACHED PAGES

4. change the "table" to a "rack

4. Drawing Cog. Engineer Approval: J.R. Stuble Date: $|0-7-9|$

5. Cover Sheet Block (CC\&D Use Only)

Recelved from EFR:

$$
\text { Initials / Date }
$$

Date Assigned:

Assigned to: Initials / Date

$$
\text { (Same as data base entry) }
$$

Dratting Started:

Drafting Completed:

Return to EFR:
Initials / Date

Initials / Date

Intitals / Date 


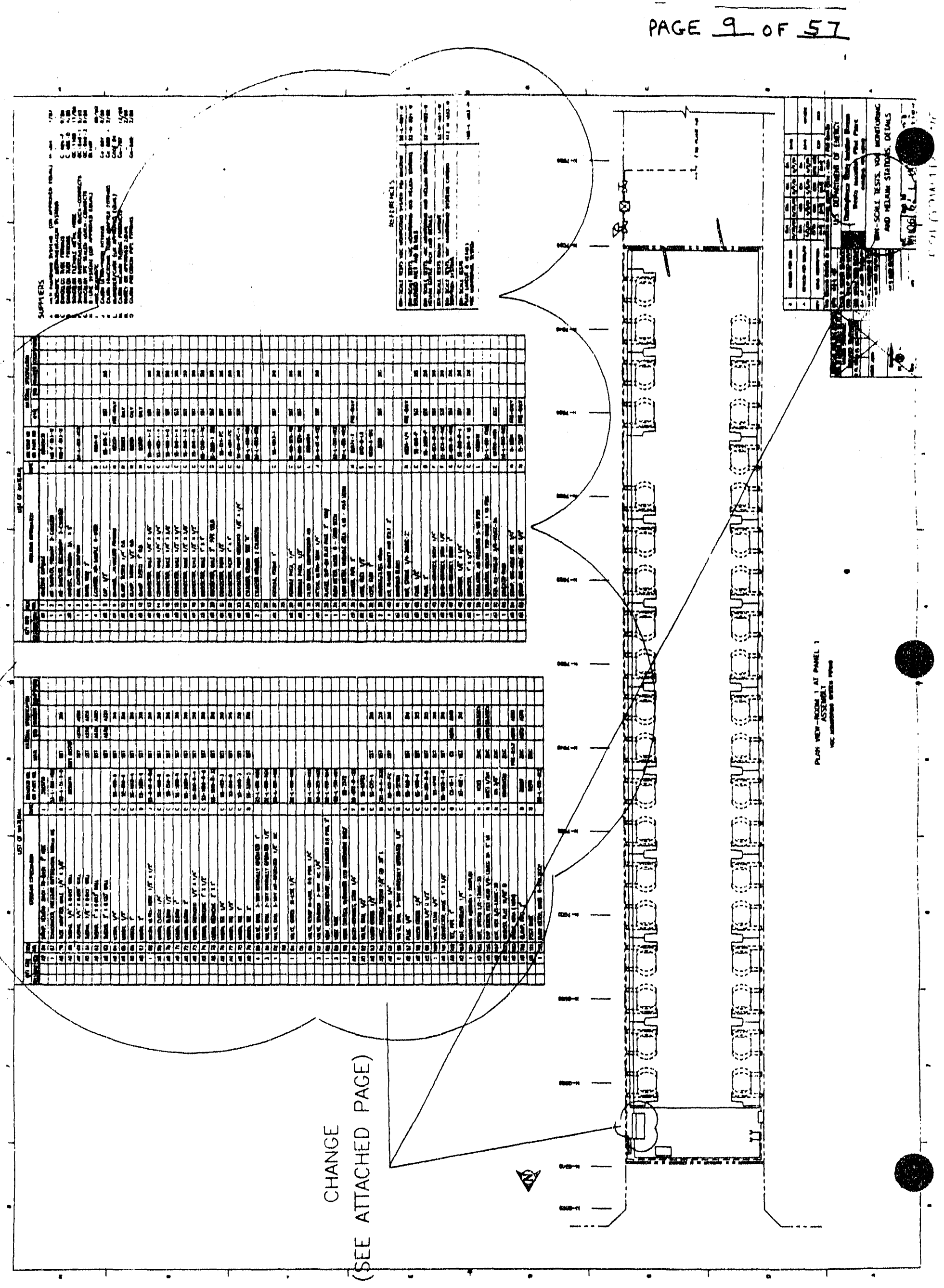


PAGE 10 OF 5$]$

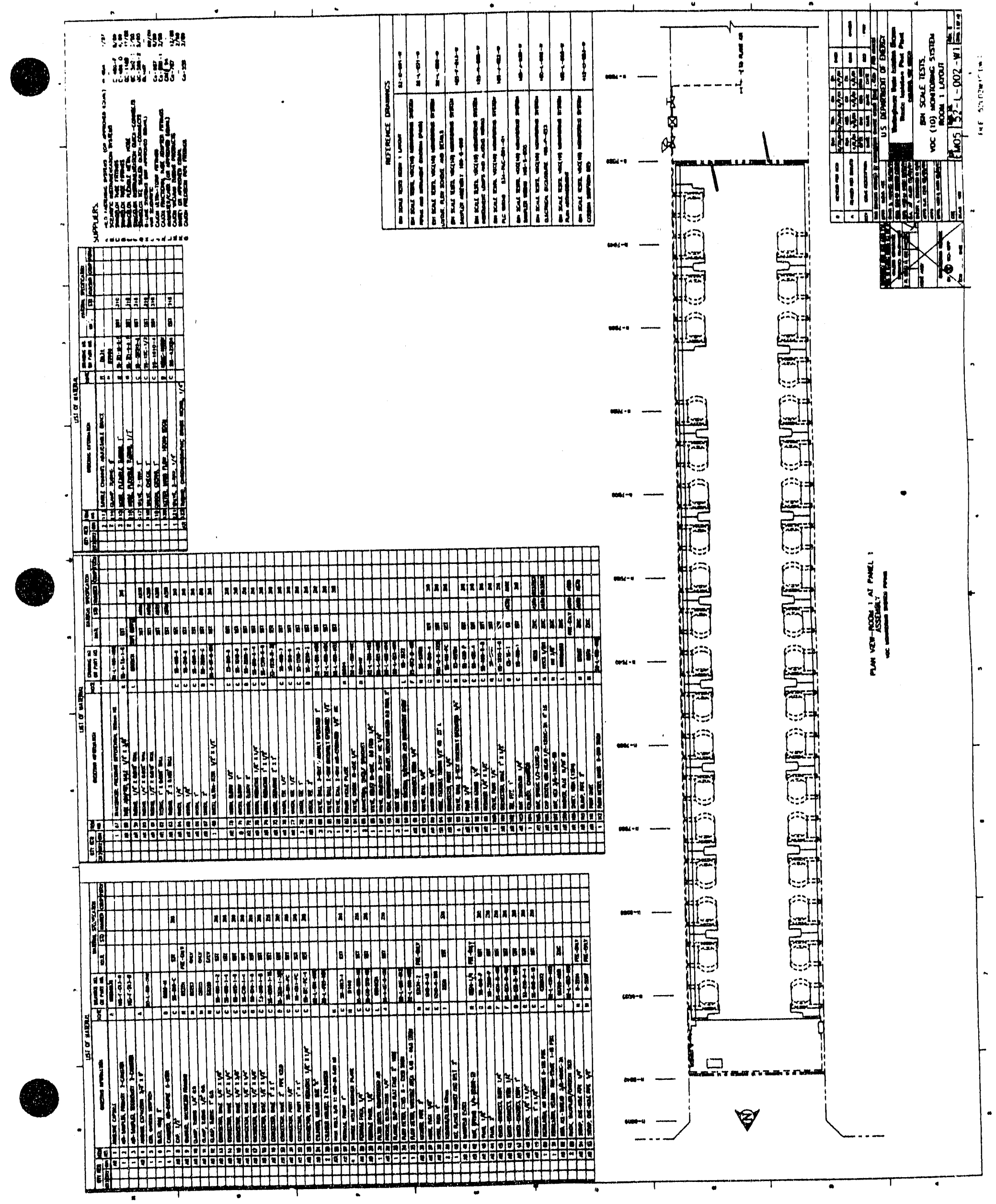




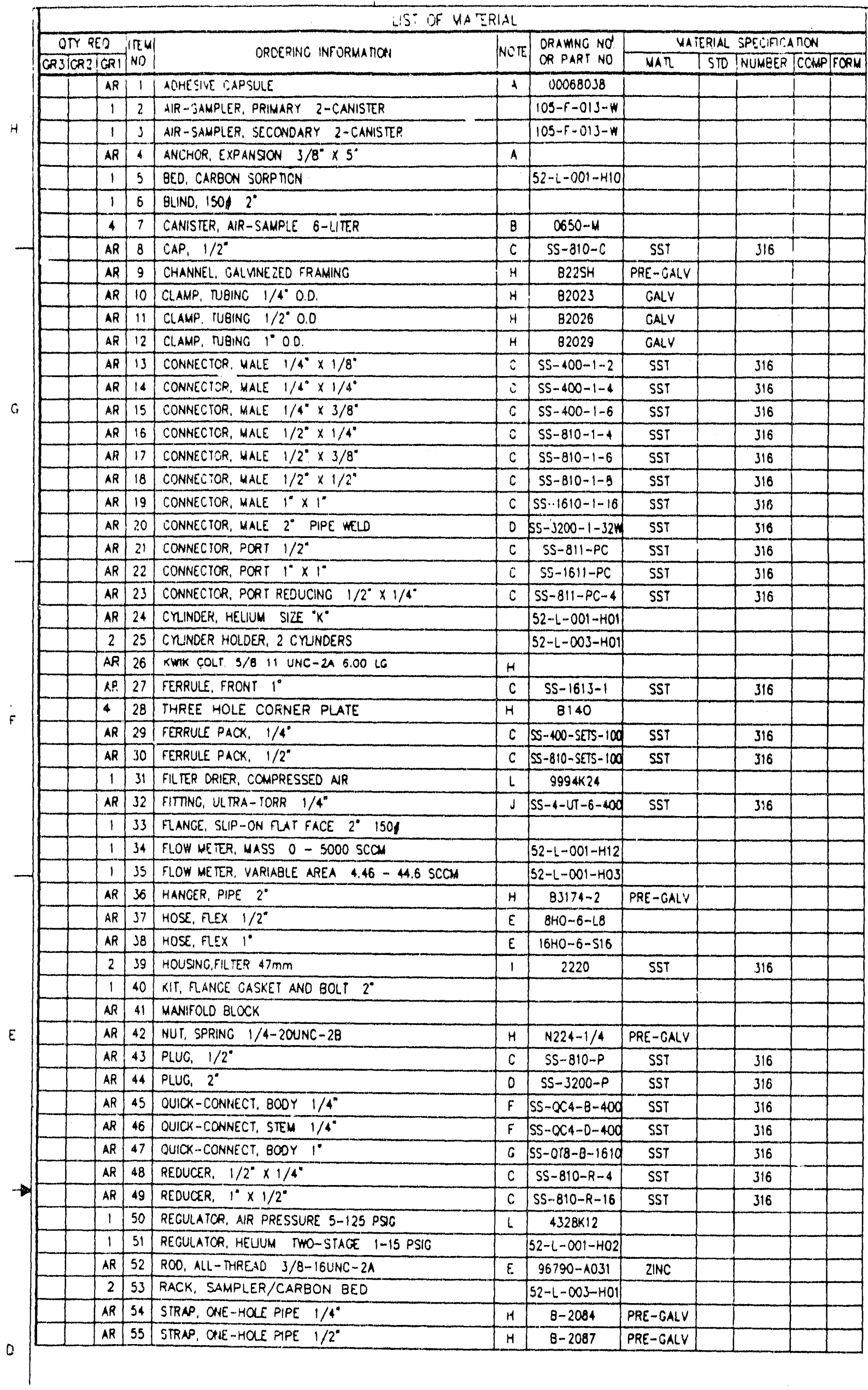




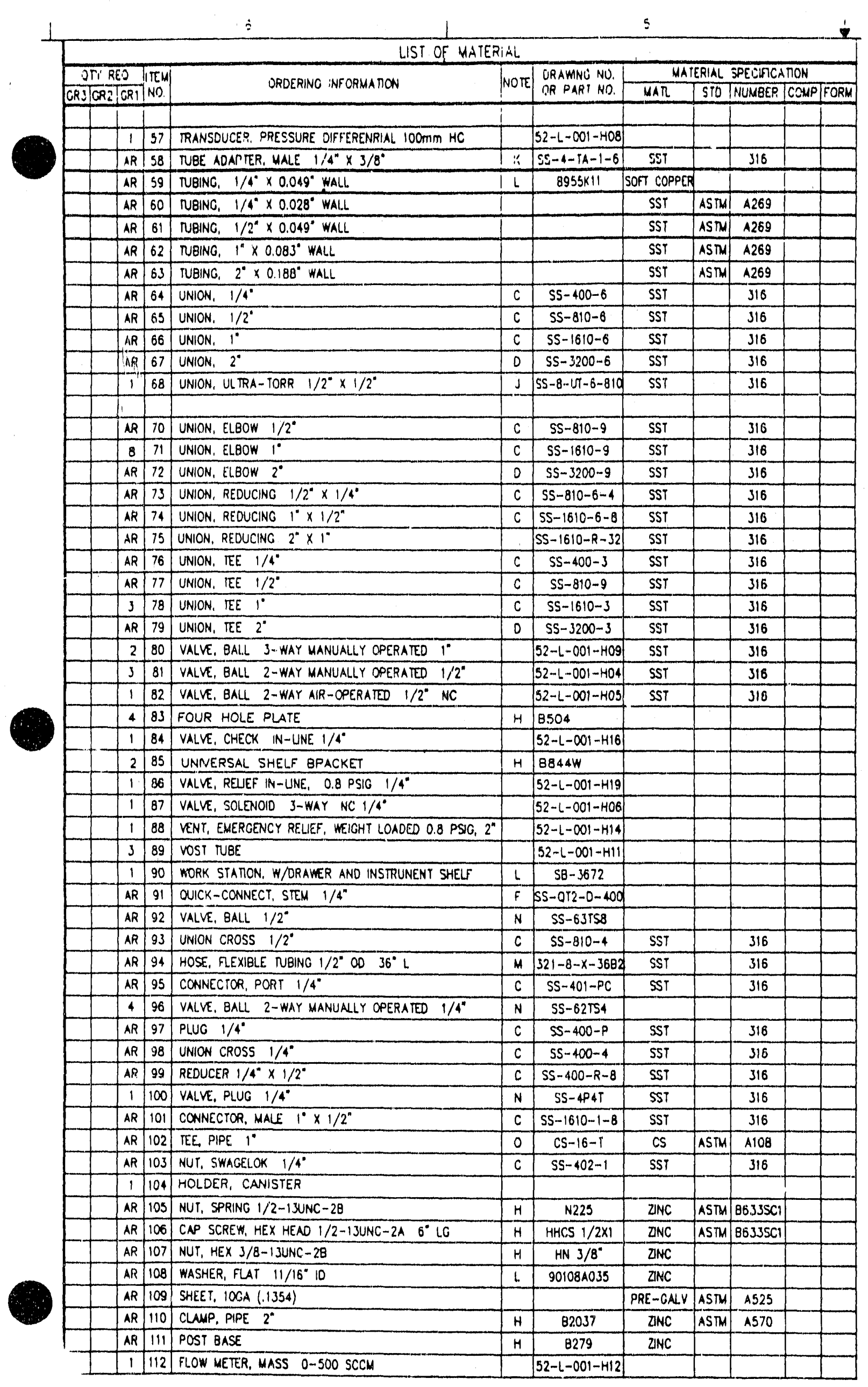




\begin{tabular}{|c|c|c|c|c|c|c|c|c|c|c|}
\hline & & & LIST OF MATER & IAL & & & & & & \\
\hline QTYR & & & & NOTE & DRAWING NO. & & ERIAL & SPECIFICA & TION & \\
\hline CR3 CR2 & GR1 & NO. & ORUERING INF URMAIION & jNOIE & OR PART NO. & MAT & 510 & NUMBER & CCMP & FOFM \\
\hline & 2 & 113 & SINGLE CHANNEL ADJUSTABLE BRACE & $H$ & 8634 & & & & & \\
\hline & 2 & 114 & CLAMP, TUBING, $6 "$ & $H$ & 82069 & & & & & \\
\hline & 3 & 115 & HOSE, FLEXIBLE TUBING, $1 "$ & $M$ & $55-321-16-x-?$ & SST & 316 & & & \\
\hline & 2 & 1116 & HOSE, FLEXIBLE TUBING, $1 / 4^{\prime \prime}$ & M & $55-321-4-x-?$ & SST & 316 & & & \\
\hline & 4 & 117 & VALVE, 2-WAY, $1^{\prime \prime}$ & C & $S S--65 T S 16-U L$ & SST & 316 & & & \\
\hline & 1 & 118 & VALVE, CHECK, 1" & $\mathrm{C}$ & $S S-16 C-1 / 3$ & SST & 316 & & & \\
\hline & 1 & 119 & UNION, CROSS, 1" & $\mathrm{C}$ & $S S-1610-4$ & SST & 316 & & & \\
\hline & 1 & 120 & METER, MASS FLOW, 10000 SCC.M & $B$ & $0358 \mathrm{C}-10005 \mathrm{~V}$ & & & & & \\
\hline & 1 & 121 & VALVE, 3-WAY, $1 / 4^{\prime \prime}$ & $\mathrm{C}$ & $55-42 \times 54$ & SST & 316 & & & \\
\hline & AR & 122 & TUBING, CHROMATIGRAPHIC GRADE NICKEL, $1 / 4 "$ & & & & & & & \\
\hline
\end{tabular}


$9 a$

DRAWING CHANGE SHEET

(1 SHEET PER DRAWING)

1. Drawing: 52-L-002-WZ

ECO Number:

5821

2. ECO Search List: $\mathbf{5 5 6 5}$

3. Description of Change:

1. Change the SYSTEM DEsignator tO EMOS

2. change the title to:

BIN SCALE TESTS, BAOA-ÄC (10) MONITORING SYSTEM

LAYOUT AND FLOW ARRAETENT SCHEME

3. USING THE SAME CONFIGURATIONASON THIS

DRAWING (SYMBOLS FOR VALVES, FLOW, \$ STRUCTURES),

REPLACE THE CARBON BED ARRANGEMENT

on the table to an arrangement

WITH THE ATTACHED PAGE.

4. Drawing Cog. Engineer Approv: : J.R. Atrobk

Date: $10-7 \cdot 91$

5. Cover Sheet Block (CC\&D Use Only)

Received from EFR:

Date Assigned:

Assigned to:
Initials / Date

Initials / Date

(Same as data base entry)
Drafting Started:

Drafting Completed:

Roturn to EFR: initials / Date

Inilials / Date

Initials/ Date 


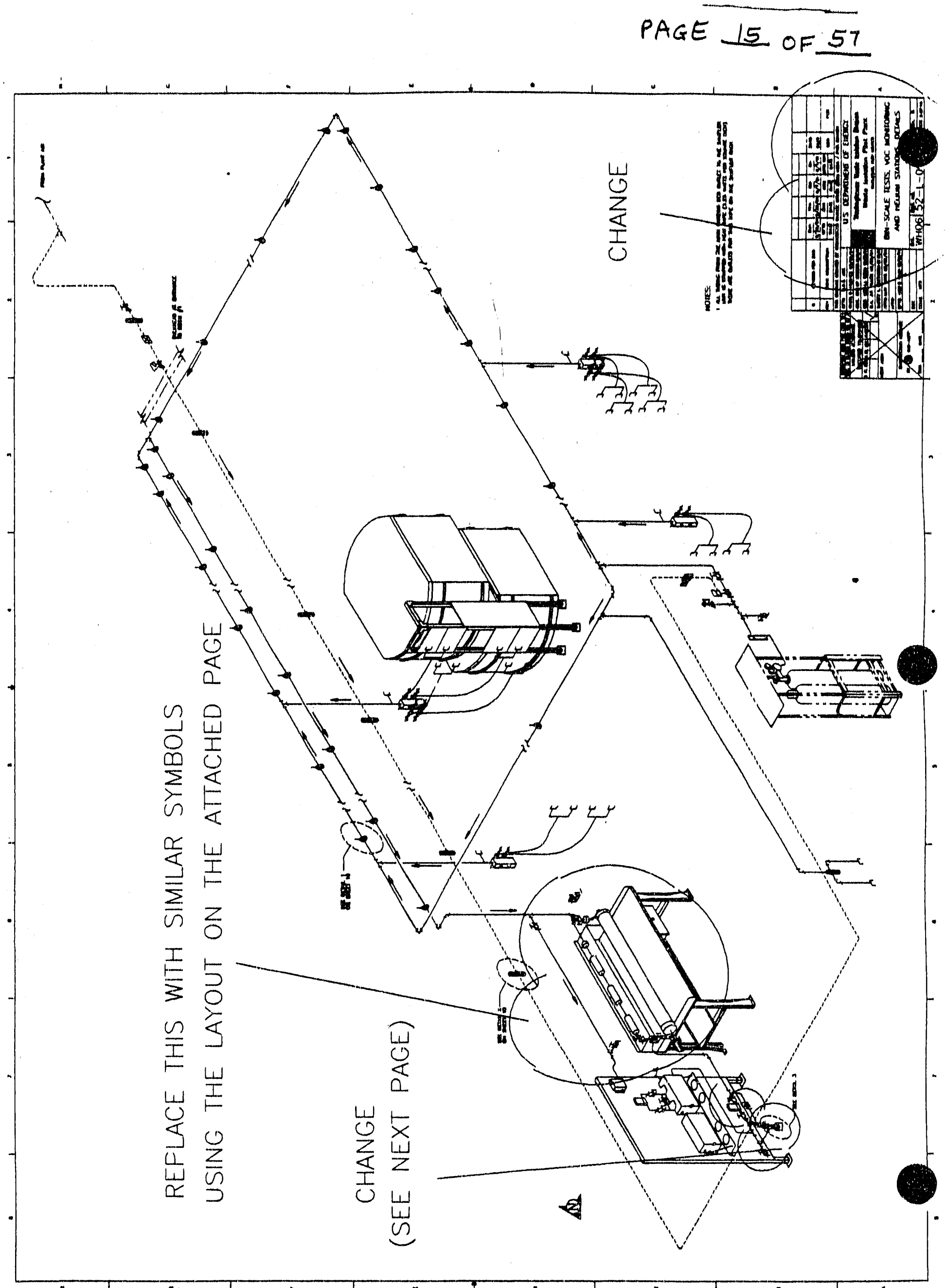


PAGE 16 of 57

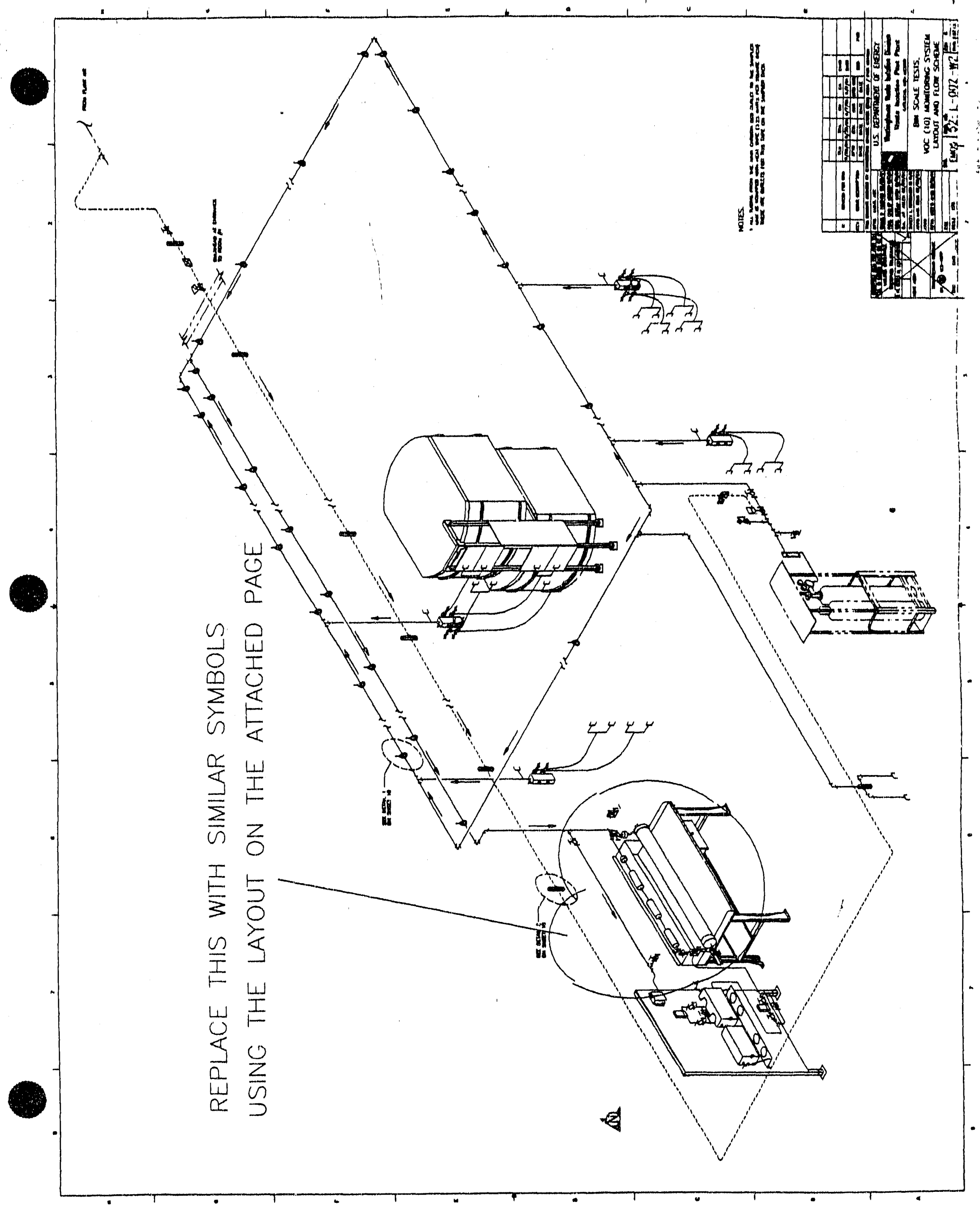


PAGE 17 OF. 57

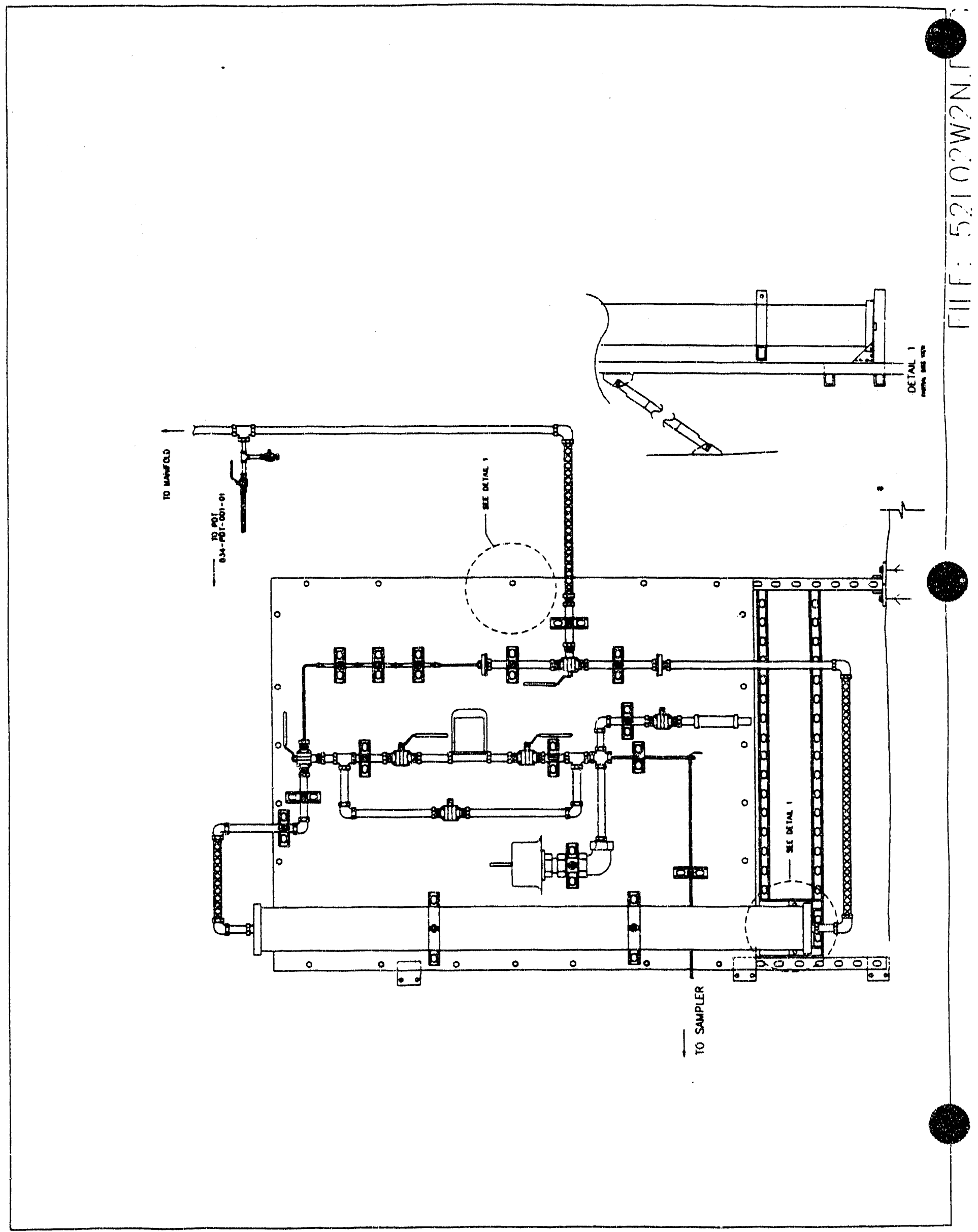


1. Drawing: $5 z-L-002-W 3$ ECO Number: 5821

2. ECO Search List:

3. Description of Change:

1. CHANGE the SYSTEM dESIGNATOR TO EMOS 2. change the title to:

BIN SCALE TESTS, VOC (10) MONITORING SYSTEM LAYOUT AND FLOW SCHEME

3. USING THE SAME CONFIGURATION AS ON THIS DRAWING (SYMBOLS FOR VALVES, FLOW, \& STRUCTURES), REPLACE THE CARBON BED ARRANGEMENT ON THE table to an arrangement With the attached PAGE. NOTE: PUT THE APPROPRIATE ITEM NUMBER ON THE PARTS.

4. Drawing Cog. Engineer Approval: d.R. Stroble Date: $10-7-91$

5. Cover Sheet Block (CC\&D Use Only)

Received from EFR:

Date Assigned:

Assigned to:

(Same as data base entry)
Orafting Started:

Initials / Date

Initials / Dato

Drafting Completed:

Return to EFR:
Initials / Dale

Initials / Date

Initals: / Date 
PAGE 19 OF 57

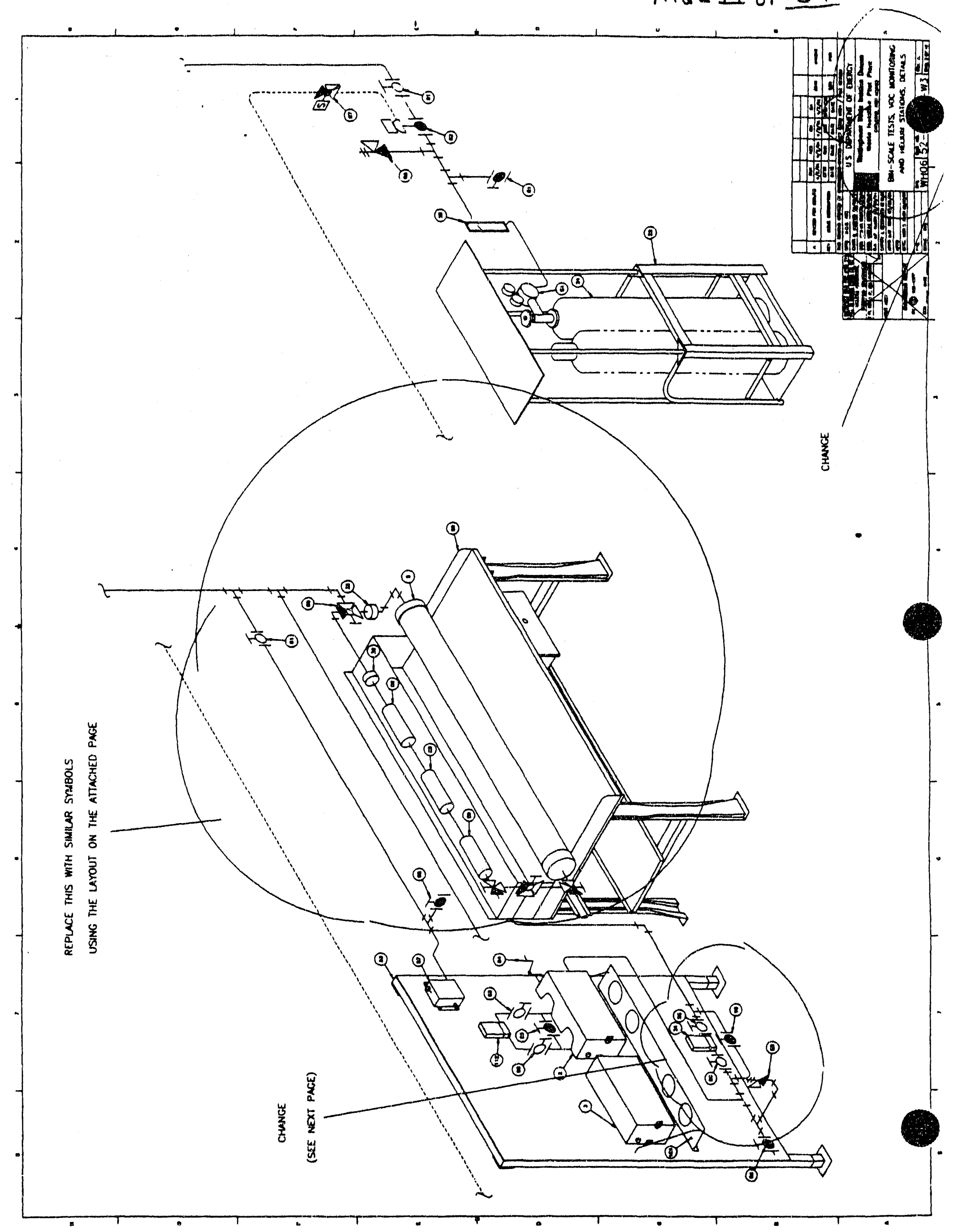


PAGE 20 OF 57.

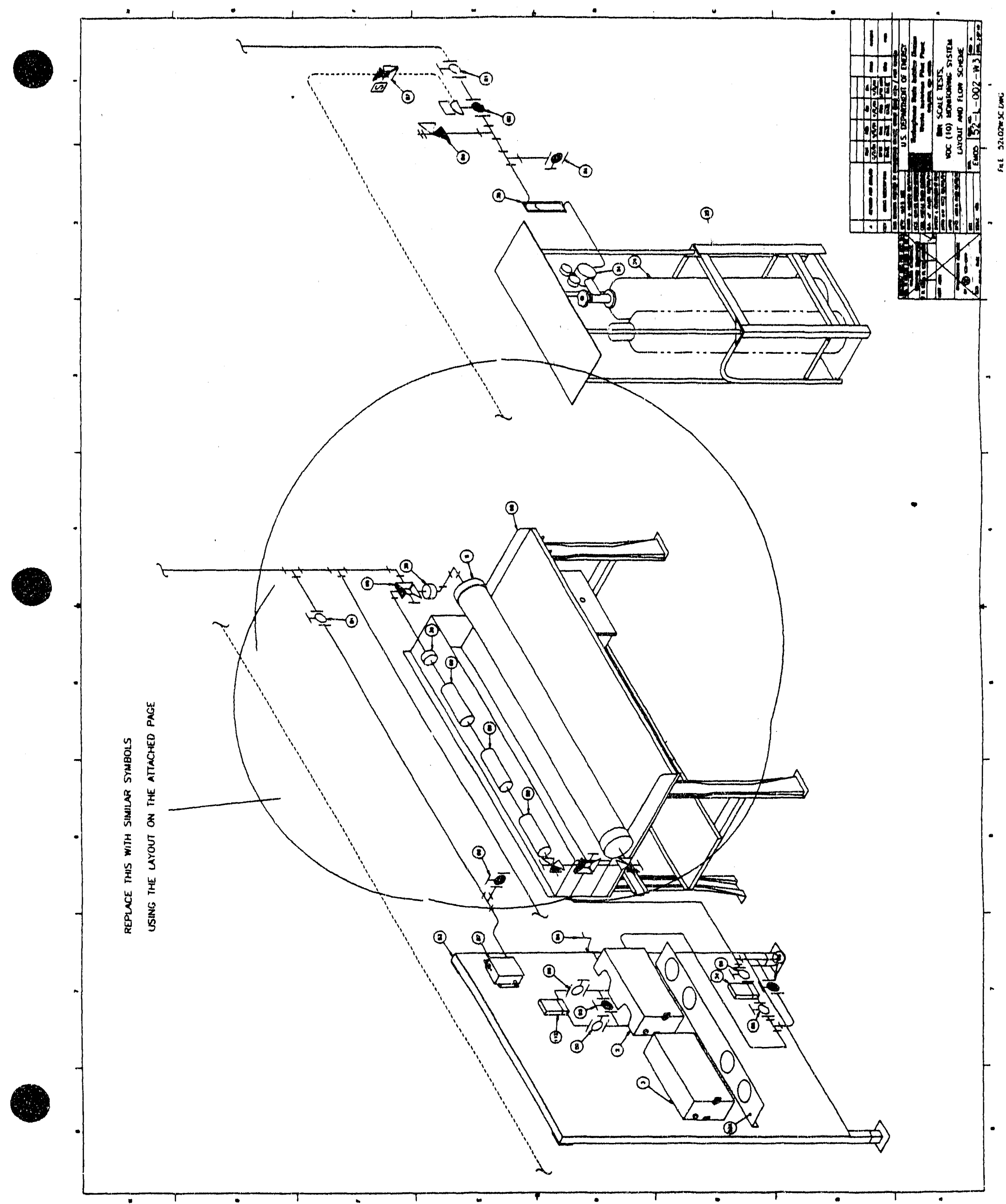


PAGE 21 OF 57

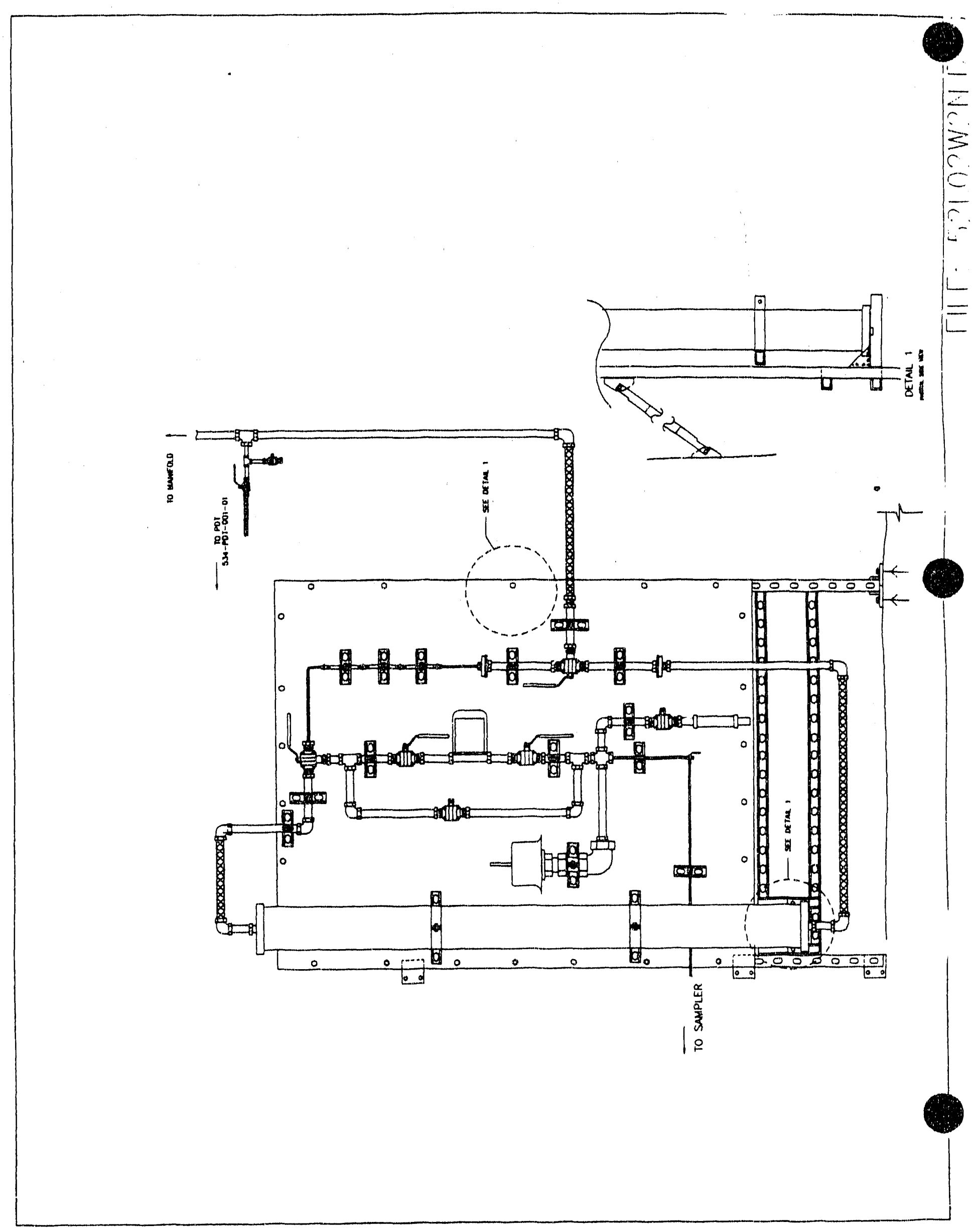




\section{$9 \mathbf{a}$}

\section{DRAWING CHANGE SHEET}

(1 SHEET PER DRAWING)

1. Drawing: 52-L-002-W4

ECO Number: $5+21$

2. ECO Search List:

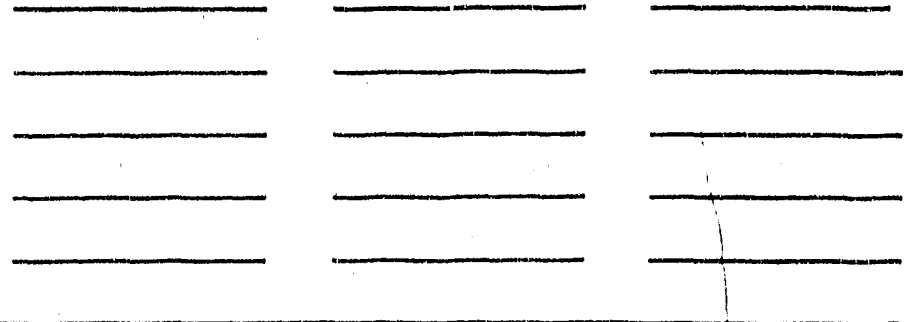

3. Description of Change:

1. Delete deTAILS ON 2 " TUBING.

2. ADO INFORMATION ON 52-L-OOZ-W8 TO

THIS DRAWING.

3. CHANGE SYSTEM TO EMOS \& TITLE TO:

BIN SCALE TESTS, VOC (10) MONITORING SYSTETM HELIUM SYSTEM DETALS

SEE ATTACHED PAGE (S)

4. Change "TEe 's" From ITEM "70" T0" 77 "

4. Drawing Cog. Engineer Approval: J.R. Stroble

Date: $10-7-91$

5. Cover Sheet Block (CC\&D Use Only)

Recelved from EFR:

Date Assigned.

Assigned to:
Drafting Started:

Initials / Date

Initials / Date

(Same as data base entry)
Initials / Date

Drafting Completed:

Return to EFR:
Initials / Dato

Inifials / Date 
PAGE 23 OF 57

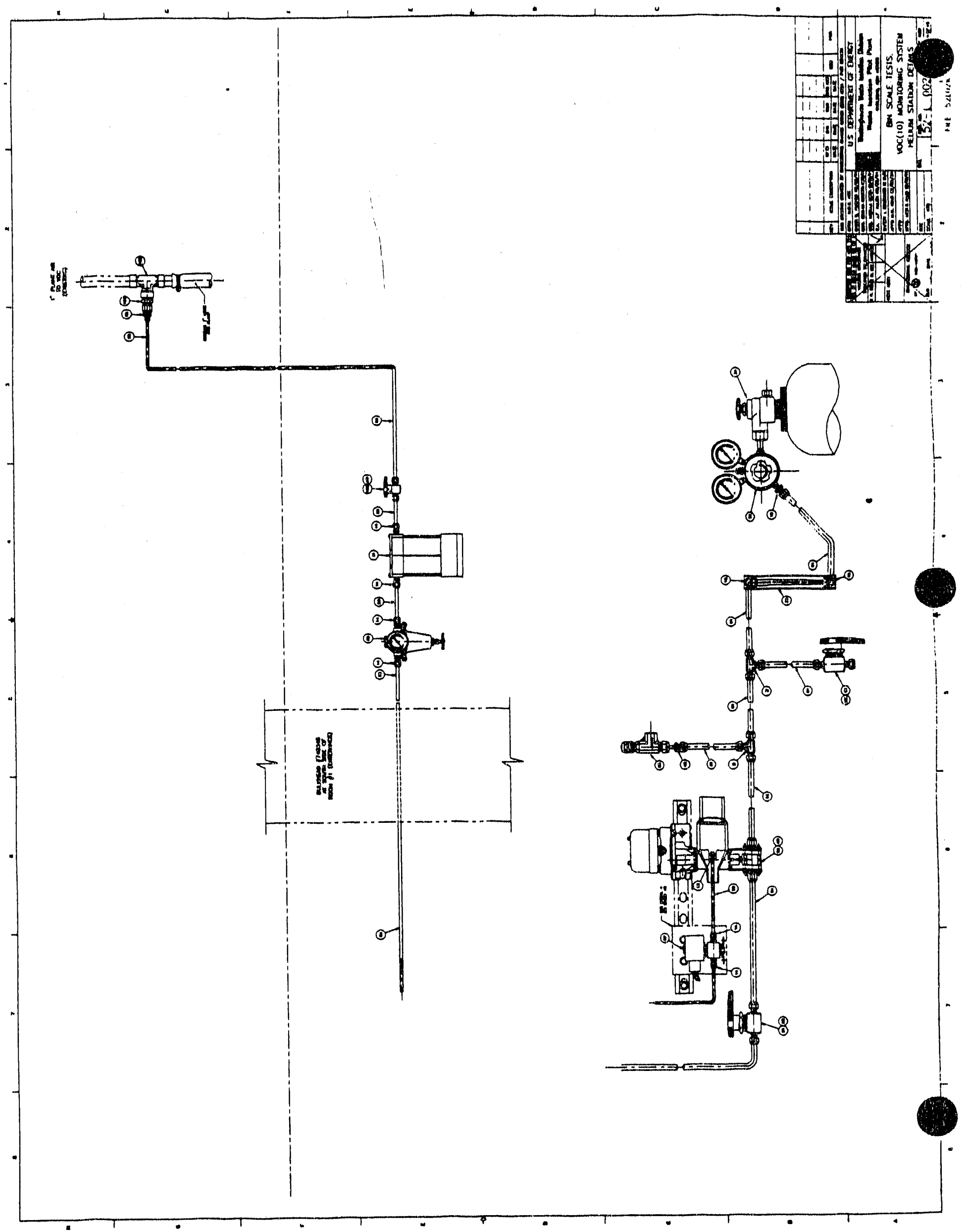




\section{DRAWING CHANGE SHEET}

(1 SHEET PER DRAWING)

1. Drawing: $52: L=002-W 5$ ECO Number:

5821

2. ECO Search List: 5565
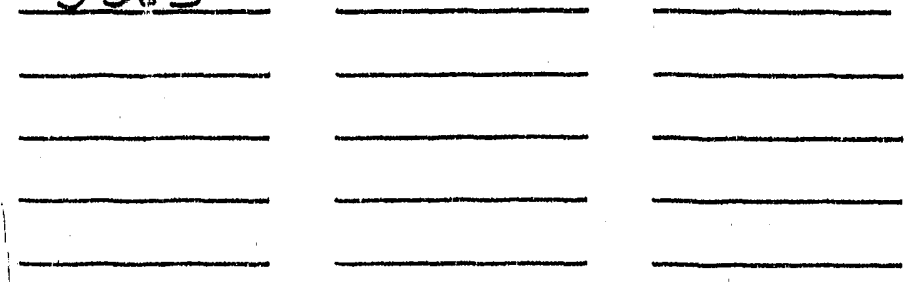

3. Description of Change:

1. EXChANGE THE DETAILED PIPING INFORMATION ON THIS DRAWING WITH the attached page.

2. CHANGE THE SYSTETI DESIGNATOR TO EMOS

3. change the title to:

BIN SCALE TESTS, VOC(IO) MONITORING SYSTETI CARBON BED RACK ARRANGEMENT

4. Drawing Cog. Engineer Approval: U.R. Ltuoble Date: $10-7-9$

5. Cover Sheet Block (CC\&D Use Only)

Received from EFR:

Initials / Date

Date Assigned:

Initials / Date

Assigned to:

(Same as data base entry)

Drafting Started:

Dratting Completed:

Return to EFA:
Initials / Date

Initials / Date

Iniffals / Dafo 


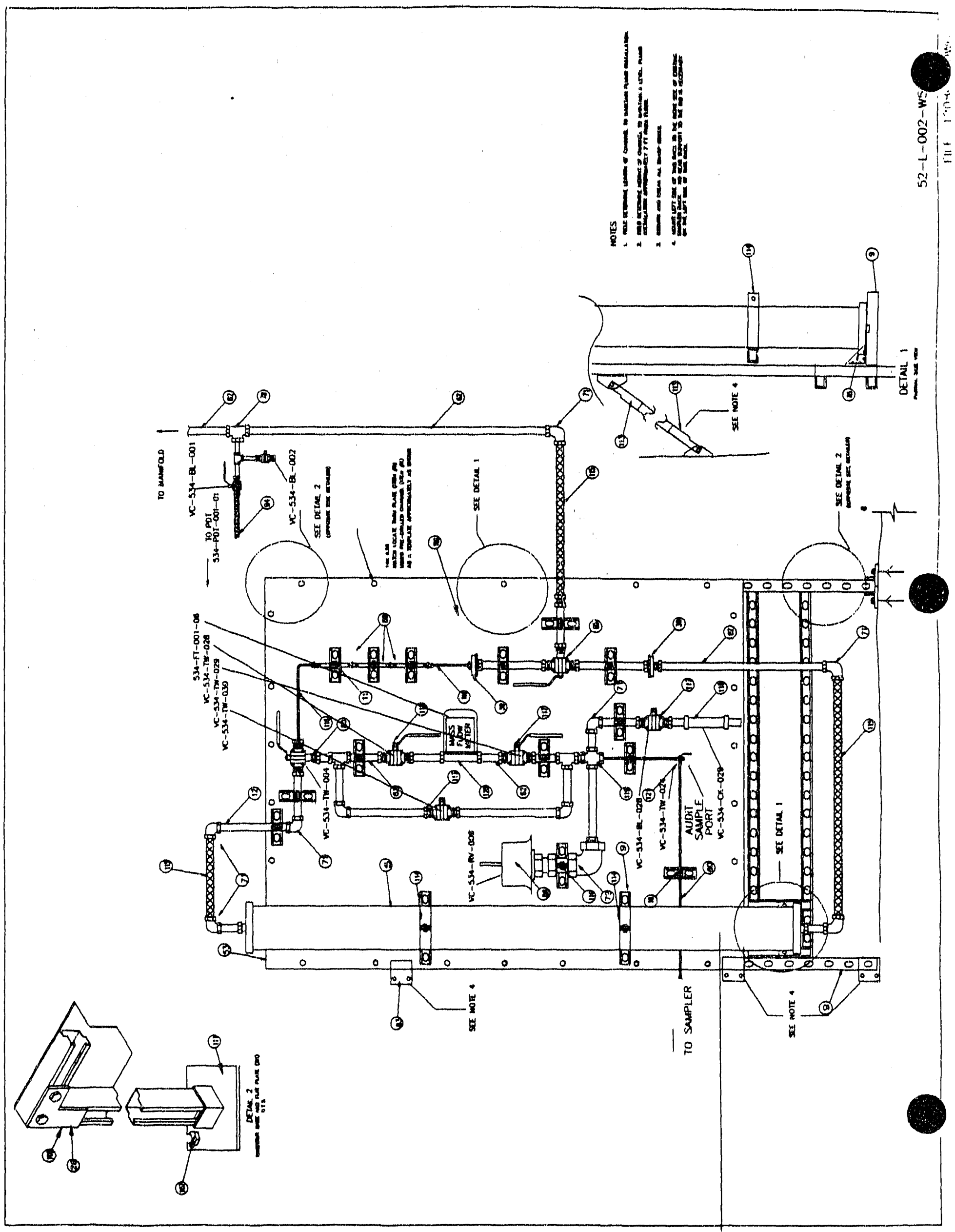




\section{DRAWING CHANGE SHEET}

(1 SHEET PER DRAWINCi)

1. Drawing: $52-1-002-w 6$ ECO Number: 5821

2. ECO Search List: 5565

3. Description of Change:

$$
\begin{aligned}
& \text { DELETE THIS DRAWING. PUT THIS } \\
& \text { INFORMATION ON 52-L-OCZ-W7. }
\end{aligned}
$$

4. Drawing Cog. Engineer Approval: U.R. Stuoble Date: $10-7-91$

5. Cover Sheet Block (CC\&D Use Oniy) Received from EFR: Initials / Date Date Assigned: Initials / Date Assigned to:

Drafting Started:

Drafting Completed:

Return to EFR:
Initials / Date

Inilials / Dale

Inttials / Date 
(1 SHEET PER DRAWING)

1. Drawing: $52-1-002-w 7$ ECO Number: 5521

2. ECO Search List:
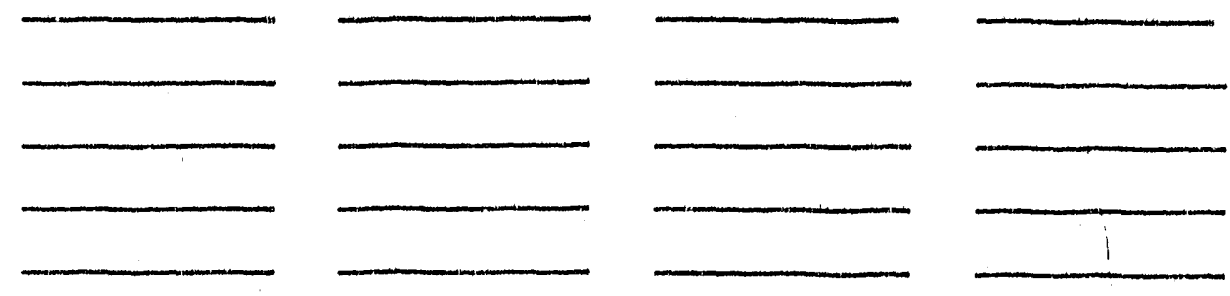

3. Description of Change:

1. ADD THE INFORMATION ON 52-L-OOZ-W6 TO THIS DRAWING. SEE A TTACHED PAgE(S).

2. CHANGE THE SYSTEM DESIGNATOR TO EMOS

3. change the titlle to:

BIN SCALE TESTS, VOC (IO) MONITORING SYSTEM SAMPLER RACK DETAILS

4. change $1 / 4$ " Flexible tubing to 1/4" chromatographic GRADE NICKEL TUBING

4. Drawing Cog. Engineer Approval: U.R. Stroble Date: $|0-7-9|$

5. Cover Sheet Block (CC\&D Use Only) Recelved from EFR: Initials / Date Date Assigned: Initials /. Dato Assigned to:

Dratting Started:

Drafting Completed:

Return to EFF:
Inilials / Dato

Initials / Dato

Initials / Date 
PAGE 28 OF 57

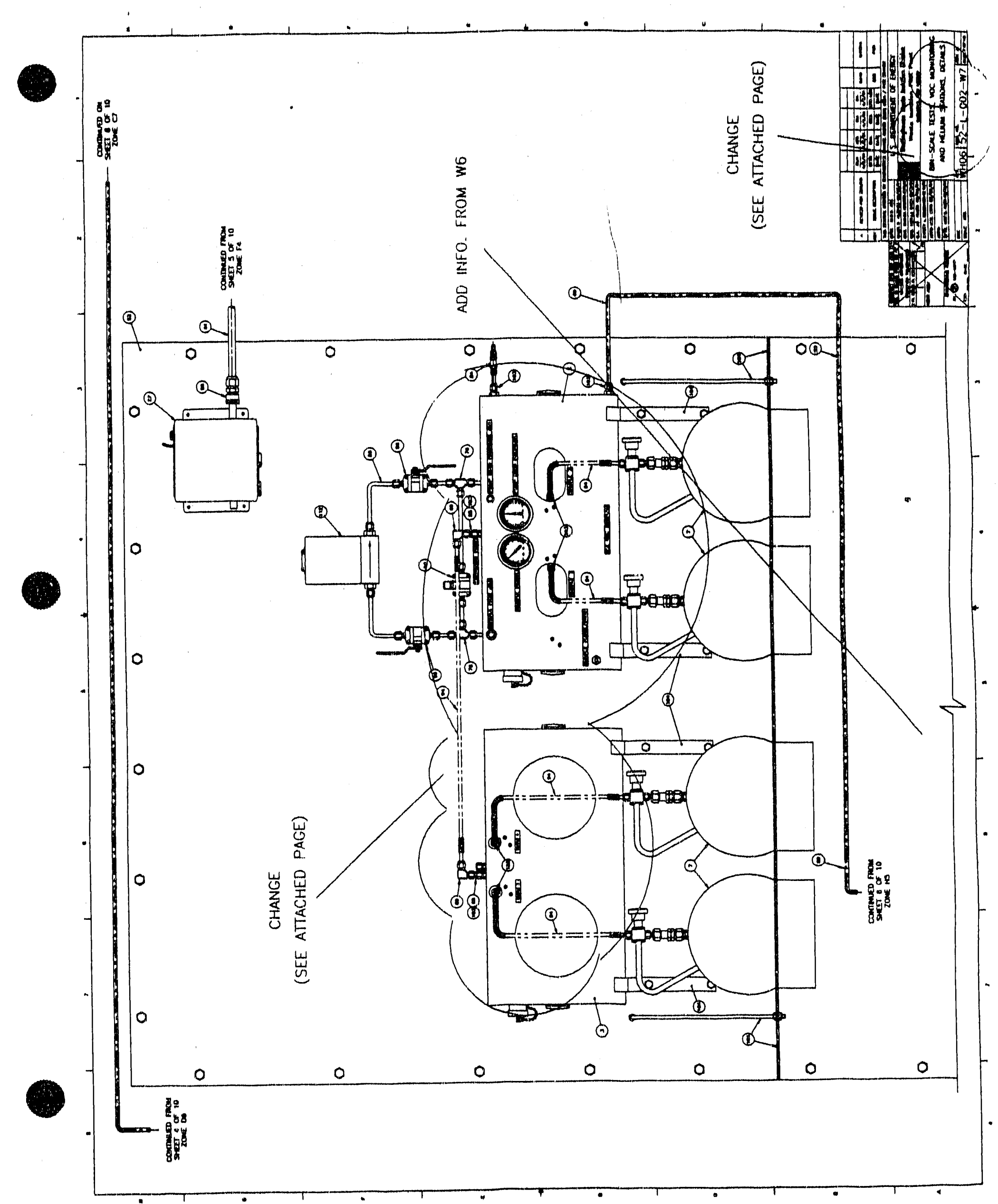


PAGE 29 OF 57

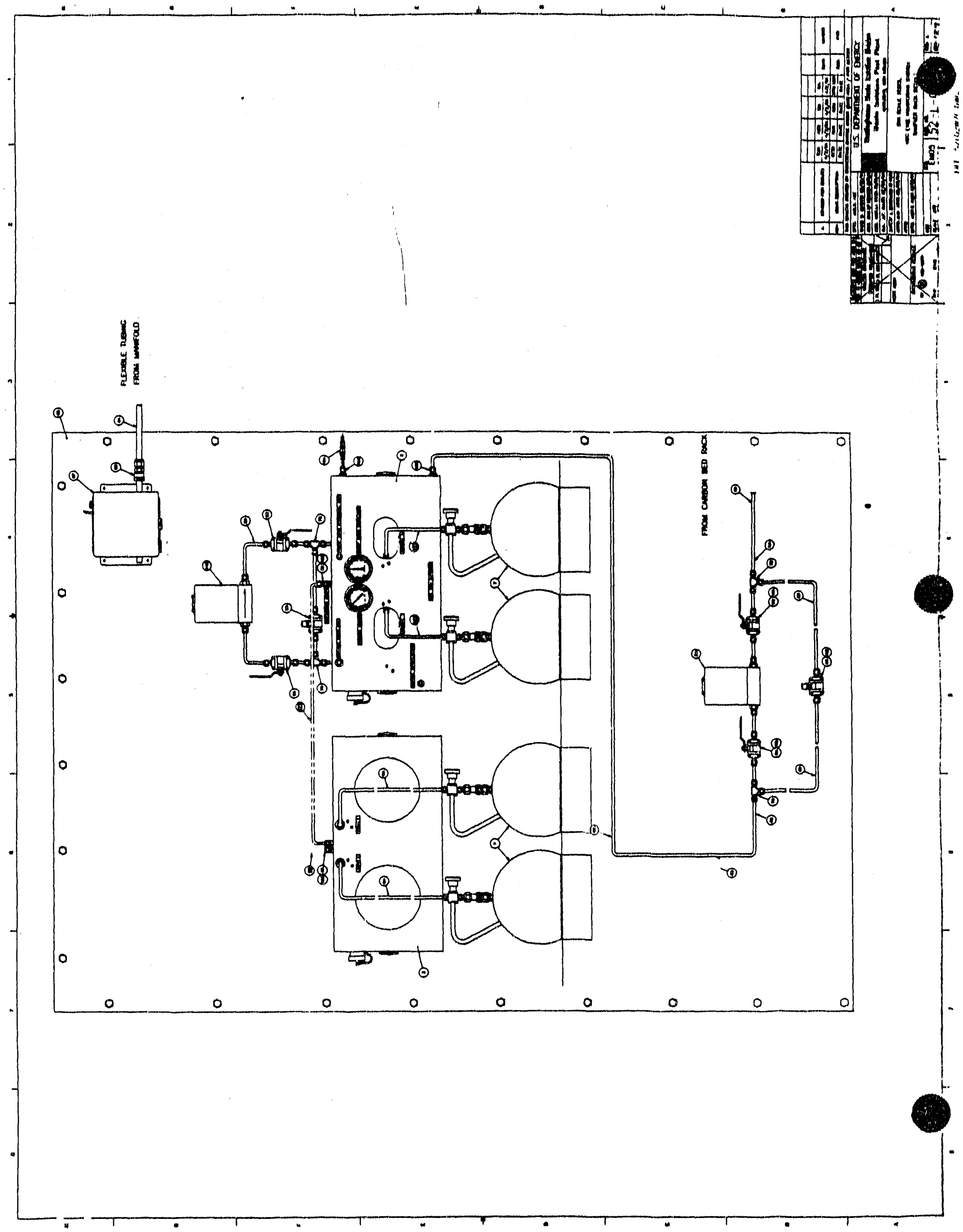




\section{DRAWING CHANGE SHEET}

(" SHEET PER DRAWING)

1. Drawing:

. 52-L.002-w8

ECO Number:

5821

2. ECO Search List:
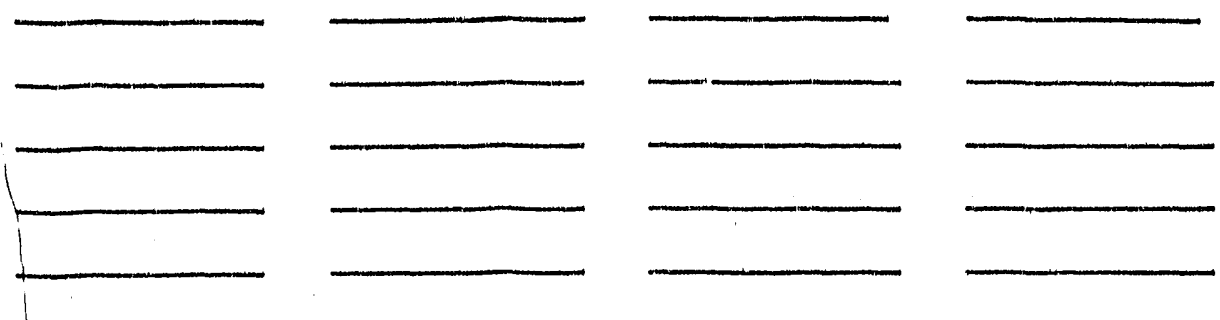

3. Description of Change:

DELETE THIS DRAWING. PUT THIS INFORMATION $O N \quad 52-L-002-W 4$.

4. Drawing Cog. Engineer Approval: J.R. Stuoble Date: $10-7-9 \mid$

5. Cover Sheet Block (CC\&D Use Only)

Recolved from EFR: Initials / Date

Date Assigned:

Assigned to:

Initials / Dato
Drafting Started:

(Same as data base entry)
Drafting Completed:

Iniflals / Date

Initials 7 Date

Return to EFR: 
1. Drawing:

$52-1-002-w 9$

ECO Number:

2. ECO Search List:
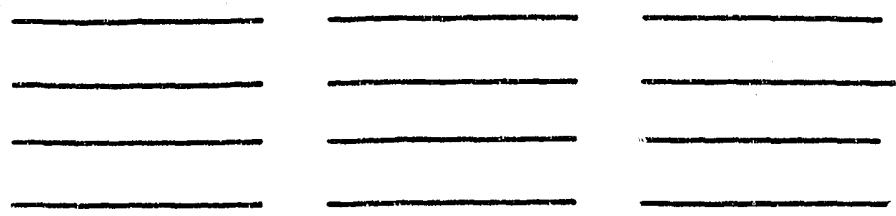

3. Description of Change:

1. Change the system designator to emos

2. change the title to:

BINSCALE TESTS, VOC (10) MONITORING SYSTETY BIN CONNECTION \& RISER DETAILS

$$
J H_{10-4-91}
$$

SEE A TACHED PAGE

4. Drawing Cog. Engineer Approval: J.R. \&tiofh

Date: $10-7-91$ 
1. Drawing:

$52-6-002-W 10$

ECO Number:

5821

2. ECO Search List:
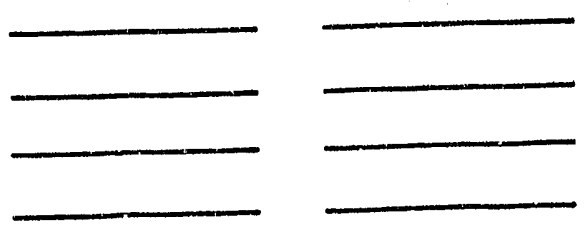

3. Description of Change:

$$
\text { delete this DRAWING }
$$

4. Drawing Cog. Engineer Approval: U.R. Stuoble Date: $\mid 0-7-9)$ 
1. Drawing:

$53-J-0.53-W 2$

ECO Number:

5821

2. ECO Search List:
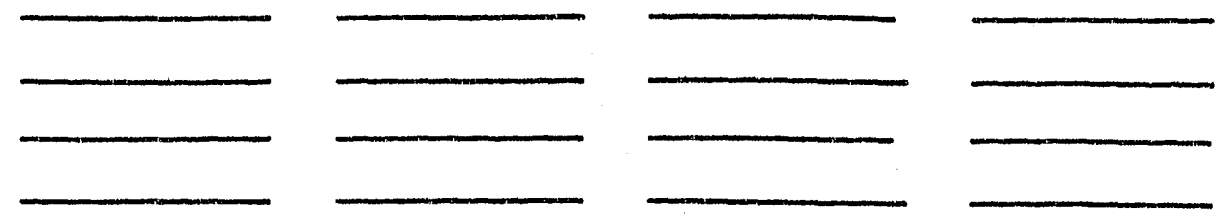

3. Description of Change:

1. Change the table for vOC (10) tO a rack.

4. Drawing Cog. Engineer Approval:

Date: $(c) / 6 / p)$ 
ga

DRAWING CHANGE SHEET

(1 SHEET PER DRAWING)

Page 34 of 57

1. Drawing:

$105-F-013-W$

ECO Number: 5821

2. ECO Search List:

3. Description of Change:

1. change the drawing title to:

Bin scale tests, Voc (10) monitoring system SAMPLER ASSEMBLY 105-5-008

4. Drawing Cog. Engineer Approval: J.R. Ltwobl

Date: $10-7-9 \mid$

WP Form 2017; 06/24/91

Page 1 of 1

1290:80006 
1. Drawing: $105-H-005-W$ ECO Number: 5821

2. ECO Search List:
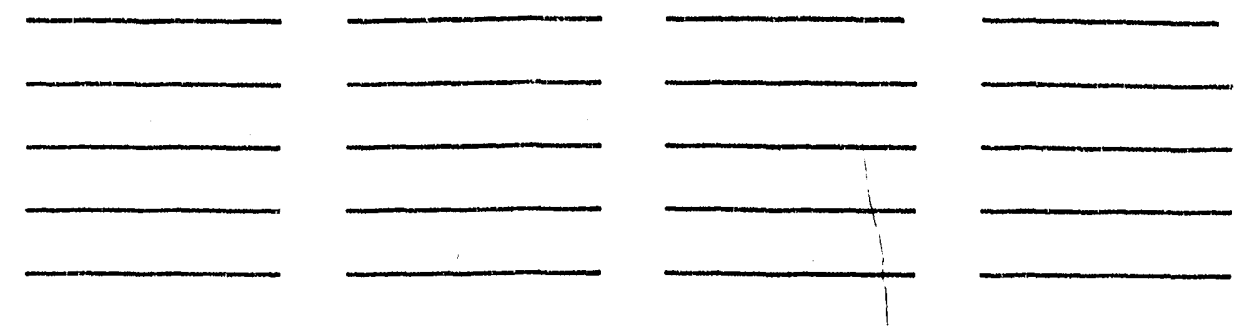

3. Description of Change:

1. ADD FLOW LOOP 105-H-001-06 AS SHOWN.

2. ADD TO REFERENCE DRAWING.

SEE ATTACHED PAGES

4. Drawing Cog. Engineer Approval: J.R. Stroble Date: $10 \cdot 2-91$

5. Cover Sheet Block (CC\&D Use Only) Received from EFR: Initials / Date Date Assigned: Initials / Dato Assigned to:

Drafting Started:

Drafting Completed:

Return to EFA:
Initials / Date

Initials / Date

Initials/ Date 
PAGE 36 OF 57

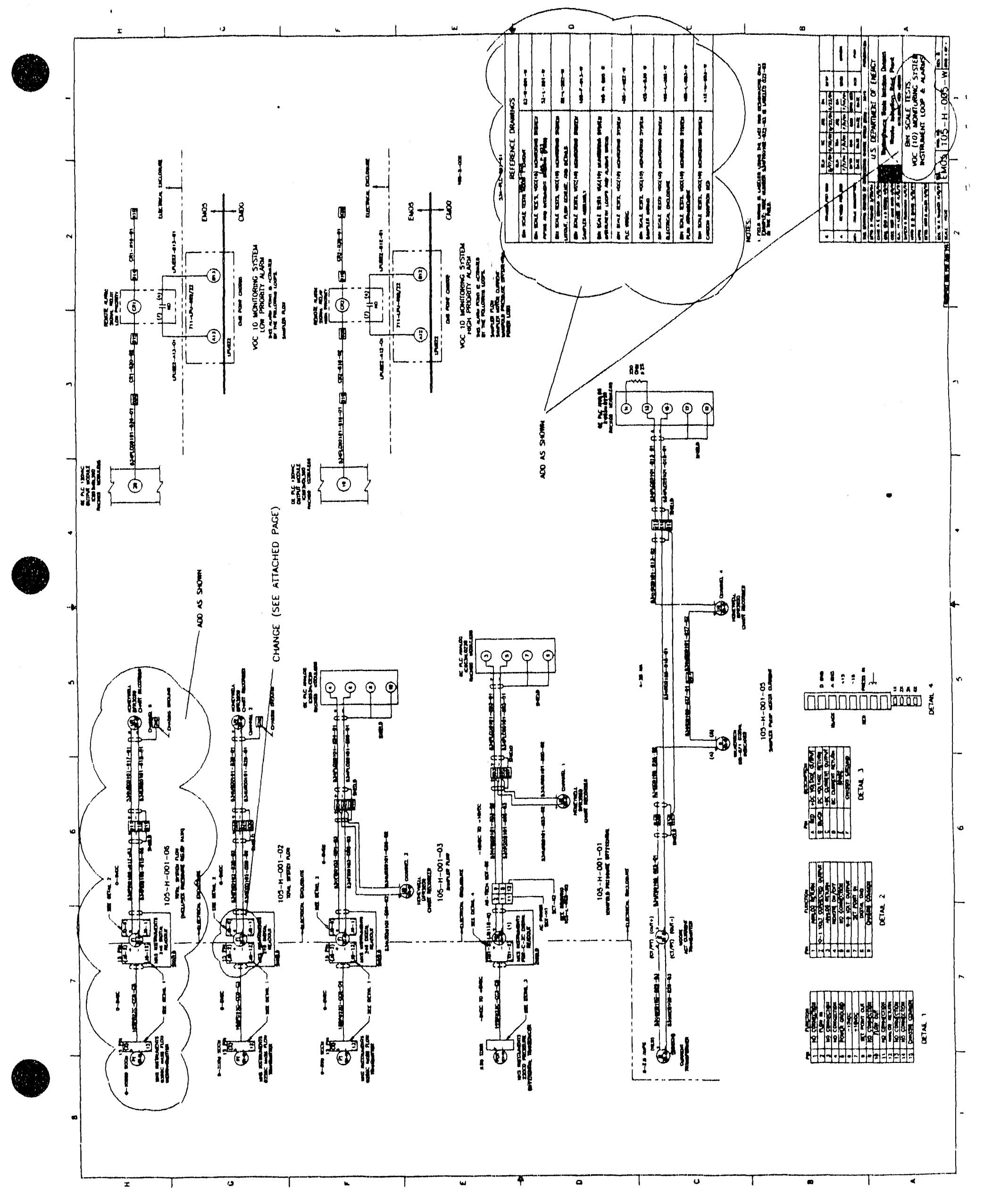




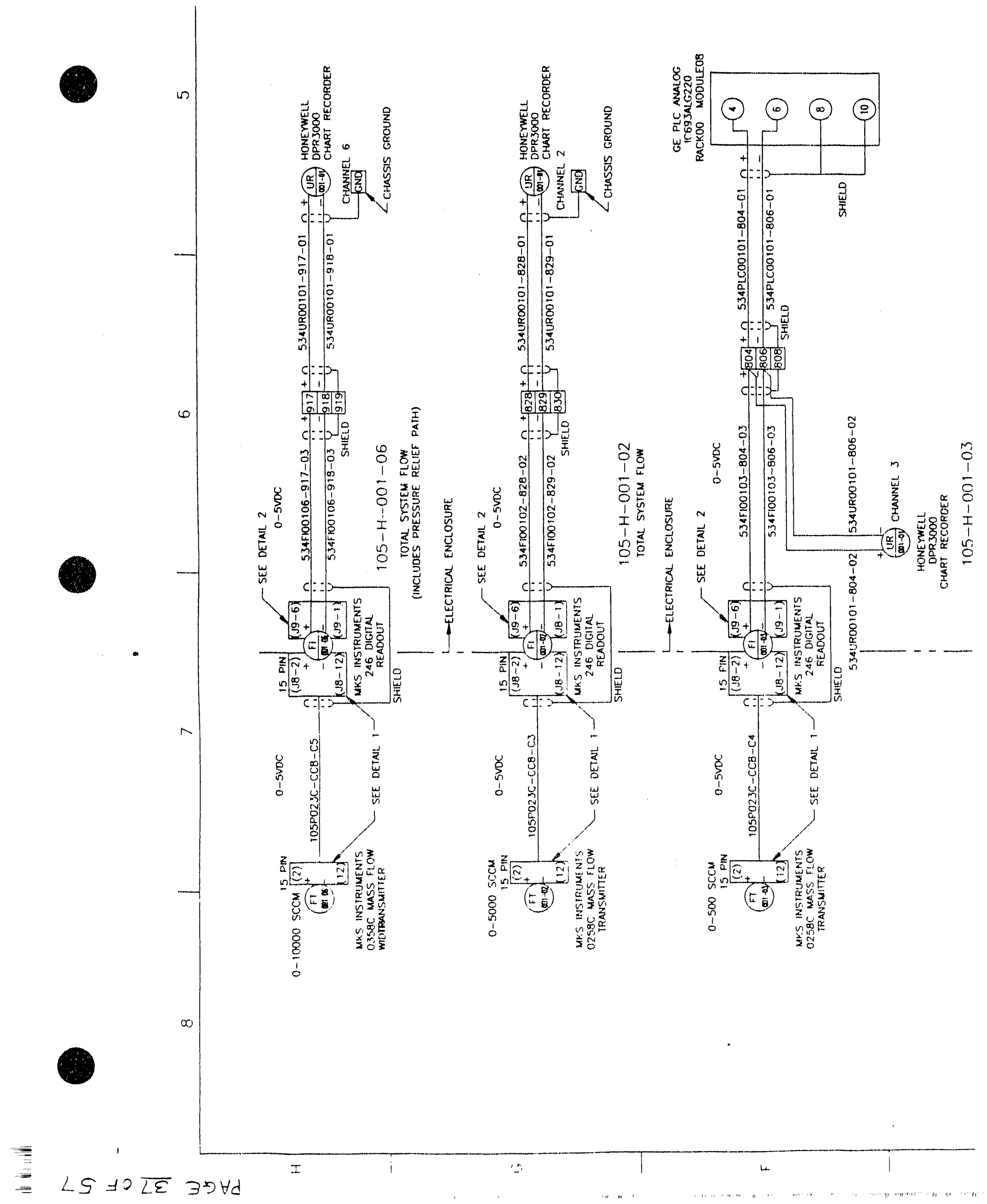




\section{$E C O \geq \cdots$ \\ PAGE 38 OF聚 107}

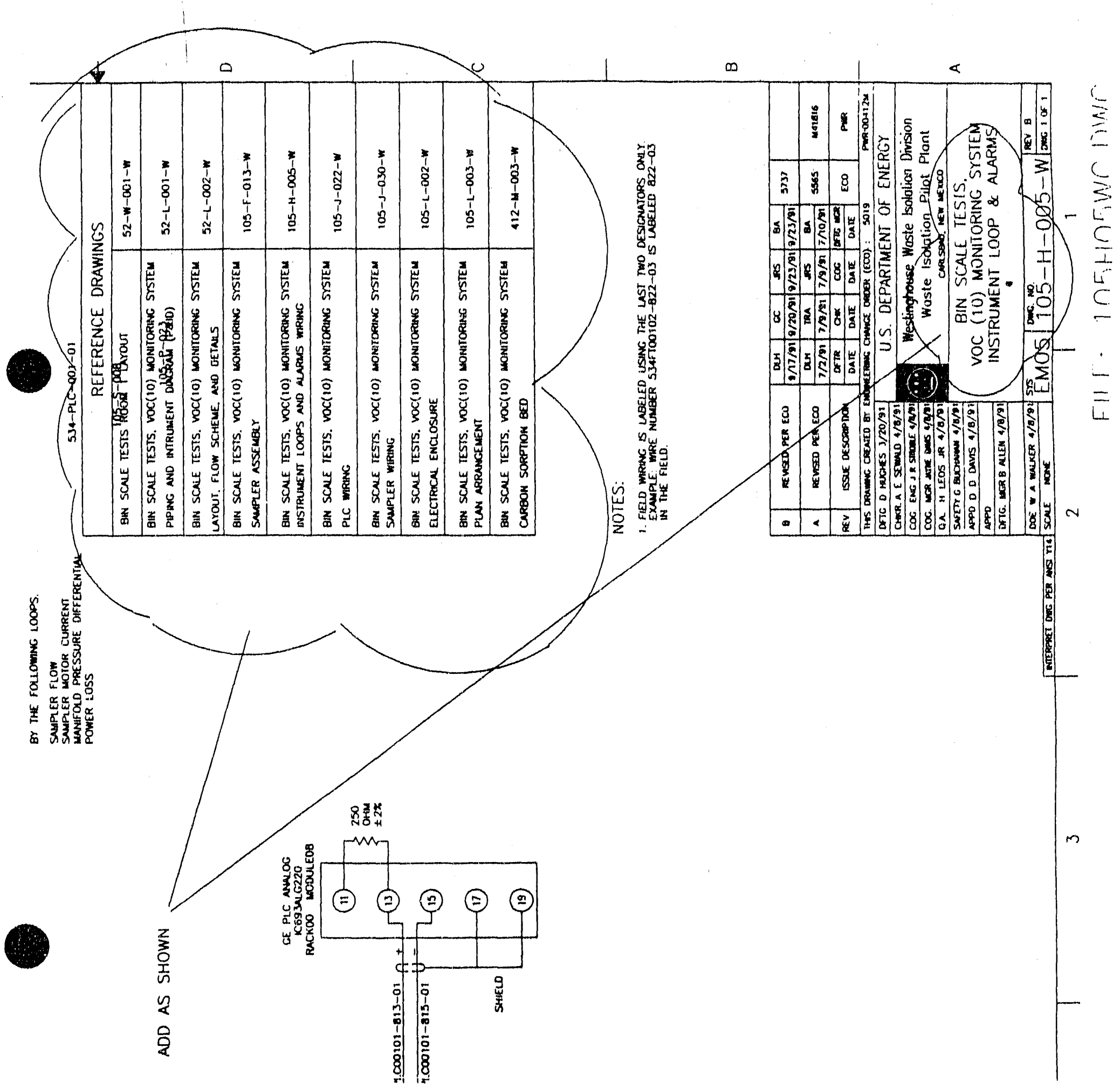




\section{DRAWING CHANGE SHEET}

(1 SHEET PER DRAWING)

1. Drawing:

2. ECO Search List:
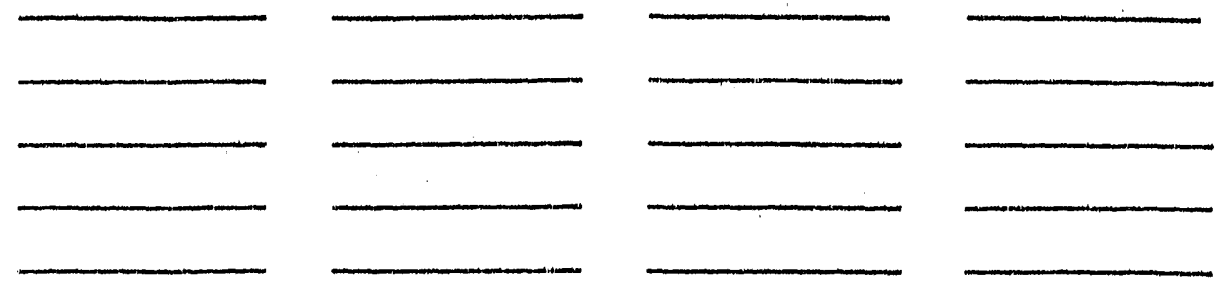

3. Description of Change:

1. CHANGE REFERENCE DRAWINGS.

2. Change TitLe TO:

BIN SCALE TESTS, VOC (10) MONITORING SYSTEM PLC WIRING 534-PLC-001-01

4. Drawing Cog. Engineer Approval: U.R. Strolde Date: $|0-7-9|$

5. Cover Sheet Block (CC\&D Use Only)

Received from EFR: Inilials / Date

Date Assigned:

Assigned to:
Dratting Started:

Dratting Completed:

Return to EFA:
Initials / Date

Initials / Date

Initials / Date 


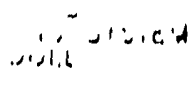

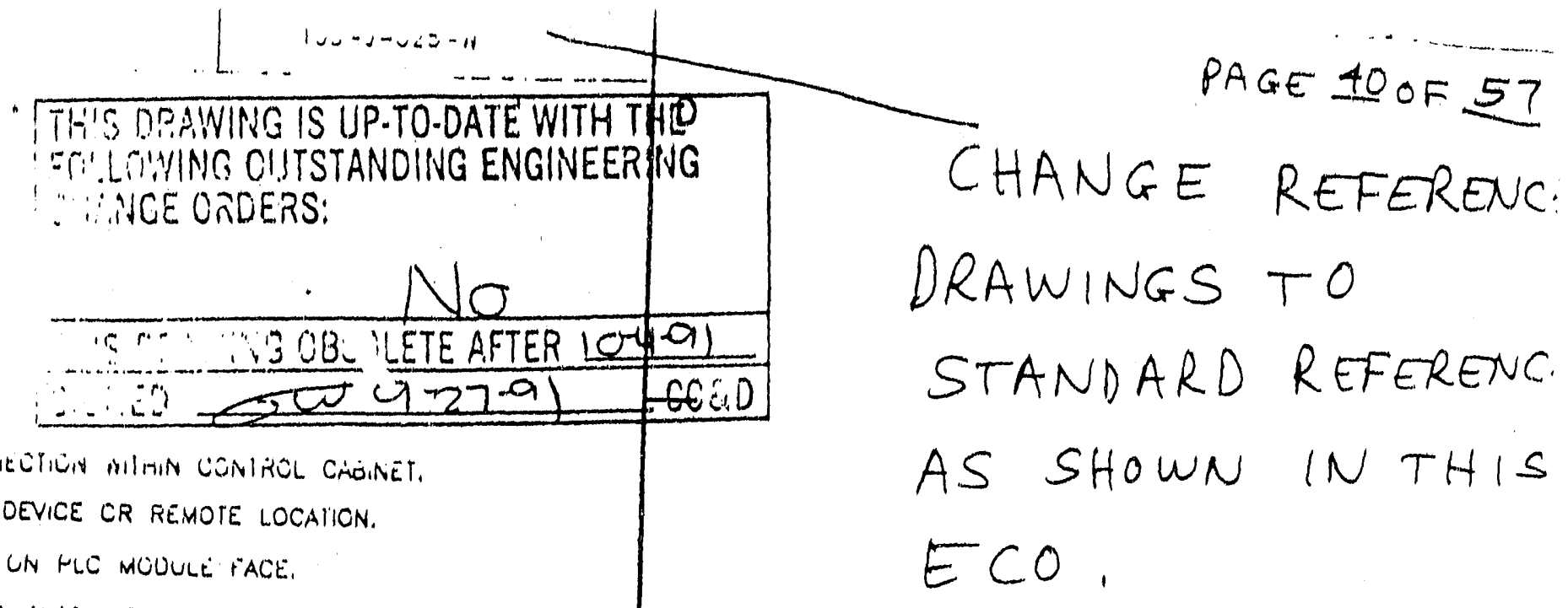

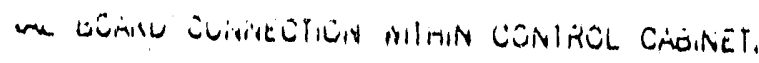

LULN AT RILLO DEVICE CR REMOTE LOCAMION.

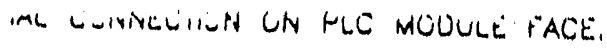

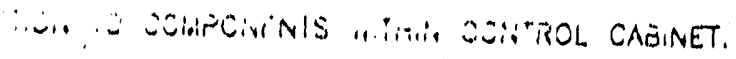

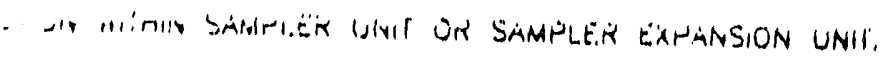

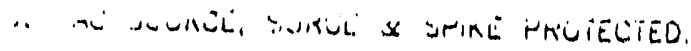

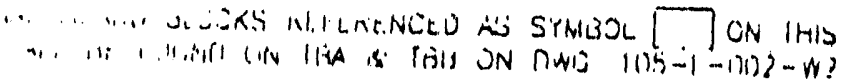

IUYIOUTICN, AND RELAY NUMBERYS ON THIS DRAWING ARE - Lutid GY 105-P-023.

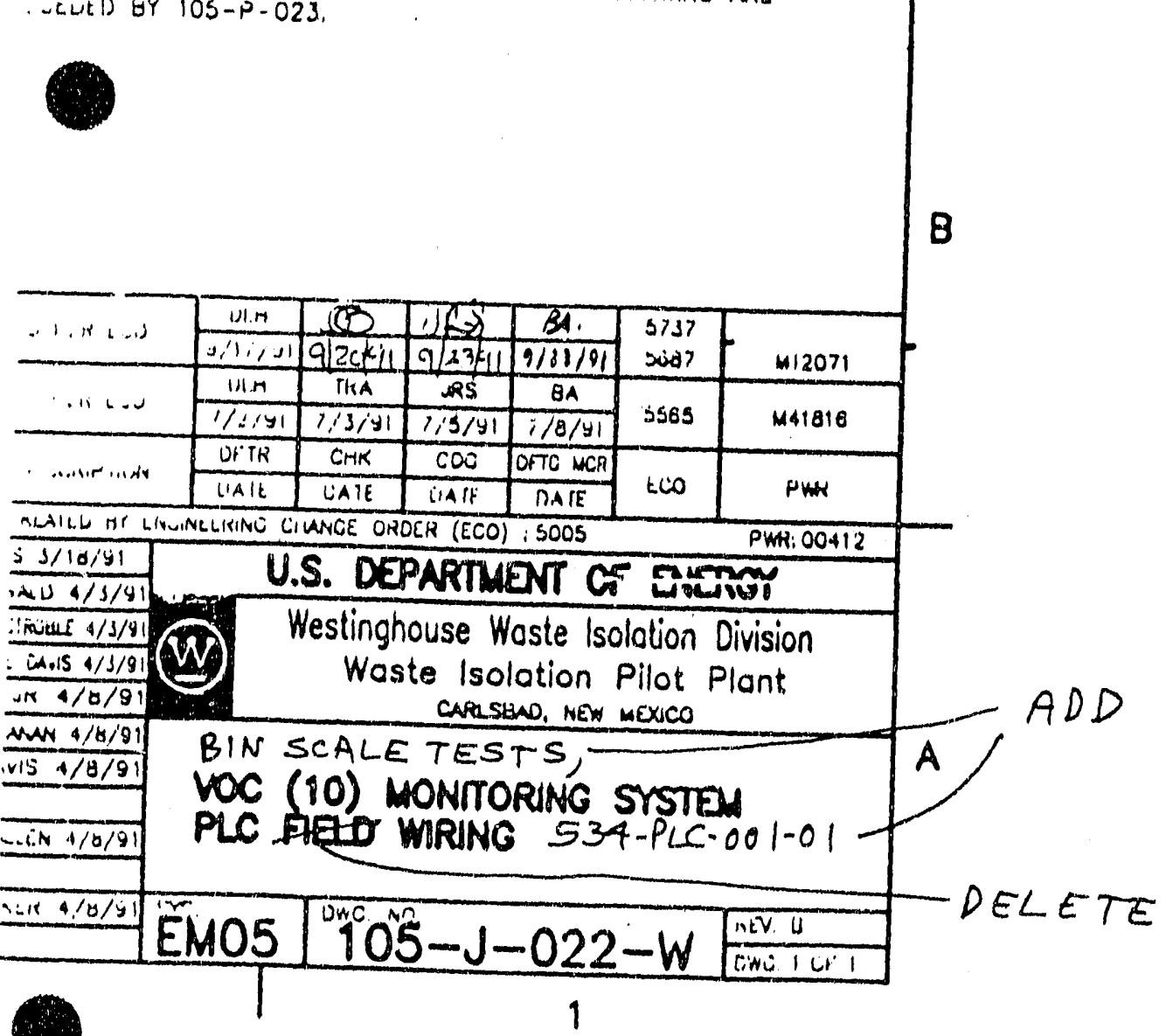




\section{$9 a$}

1. Drawing:

$105-1.022-w$ ECO Number:

2. ECO Search List:
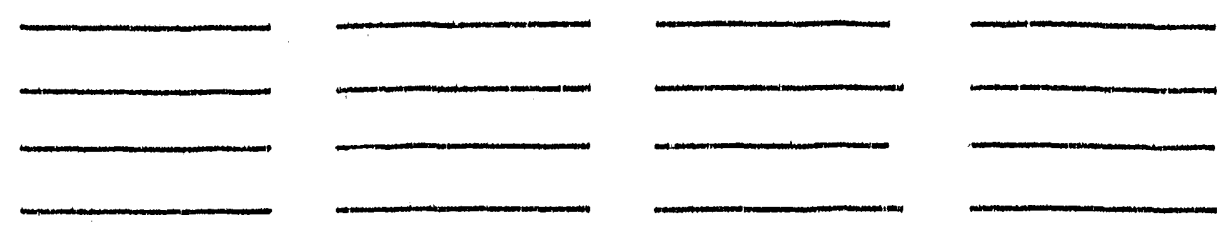

3. Description of Change:

1. CHANGE THE TITLE TO:

BIN SCALE TESTS, VOC (10) MONITORING SYSTEM PLC WIRING 534-PLC-001-01

4. Drawing Cog. Engineer Approval: L.R. Stroble Date: $10-7-11$ 
1. Drawing: $105-J-030-w$ ECO Number: 5821

2. ECO Search Llst:
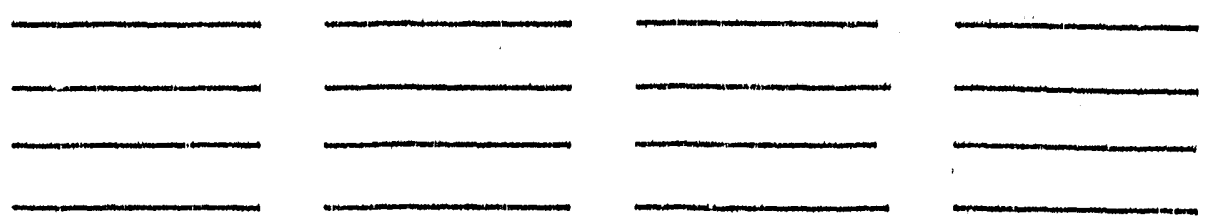

3. Description of Change:

1. change the title to:

BIN SCALE TESTS, VOC(10) MONITORING SYSTEM SAMPLER WIRING.

4. Drawing Cog. Engirieer Approval: d.R. Stucthe Date: 


\section{DRAWING CHANGE SHEET}

(1 SHEET PER DRAWING)

1. Drawing: 105-L-002-WI___ ECO Number: 5821

2. ECO Search List:
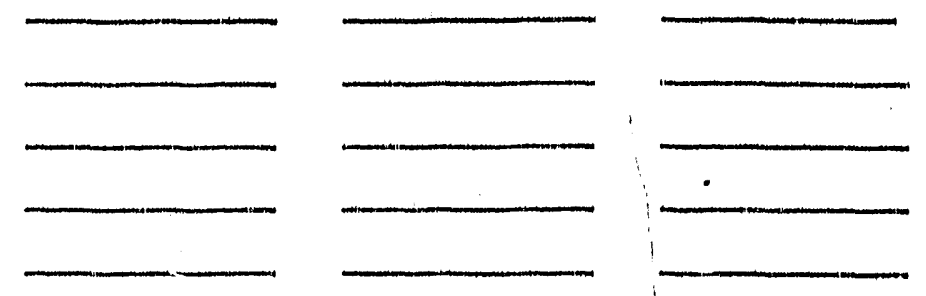

3. Descriptlon of Change:

1. MOVE LIGHTS AND BUTTONS SHOWN INSIDE CABINET ONLETT TO THE RIGHT SIDE, AND ADD ANOTHER DISPLAY ((7)

IN THEIR PLACE.

2. ADD REFERENCE DRAWINGS.

3. ADD ONE BUTTON WLAGHT REMOVE THE 4 BOTTOM LIGHTS ON THE FRONT DOORS

4. CHANGE PART NO. AND DESCRIPTION OF PILOT LIGHTS TO PUSH - TO-TEST LIGHTS - PART NO. ALLEN-BRADLEY $800 T-P T 16$

\section{SEe attached pages}

4. Drawing Cog. Engineer Approval: J.R. Stuobe Date: $10-7-91$

5. Cover Sheet Block (CC\&D Use Only) Received from EFR: Initials / Date Date Assigned: Initials / Date Assigned to:

Drafting Started:

Drafting Completed:

Return to EFA:
Initials / Dato

Initials / Date

Inittals / Date 
$E C O=521$

PAGE $140 F 57$

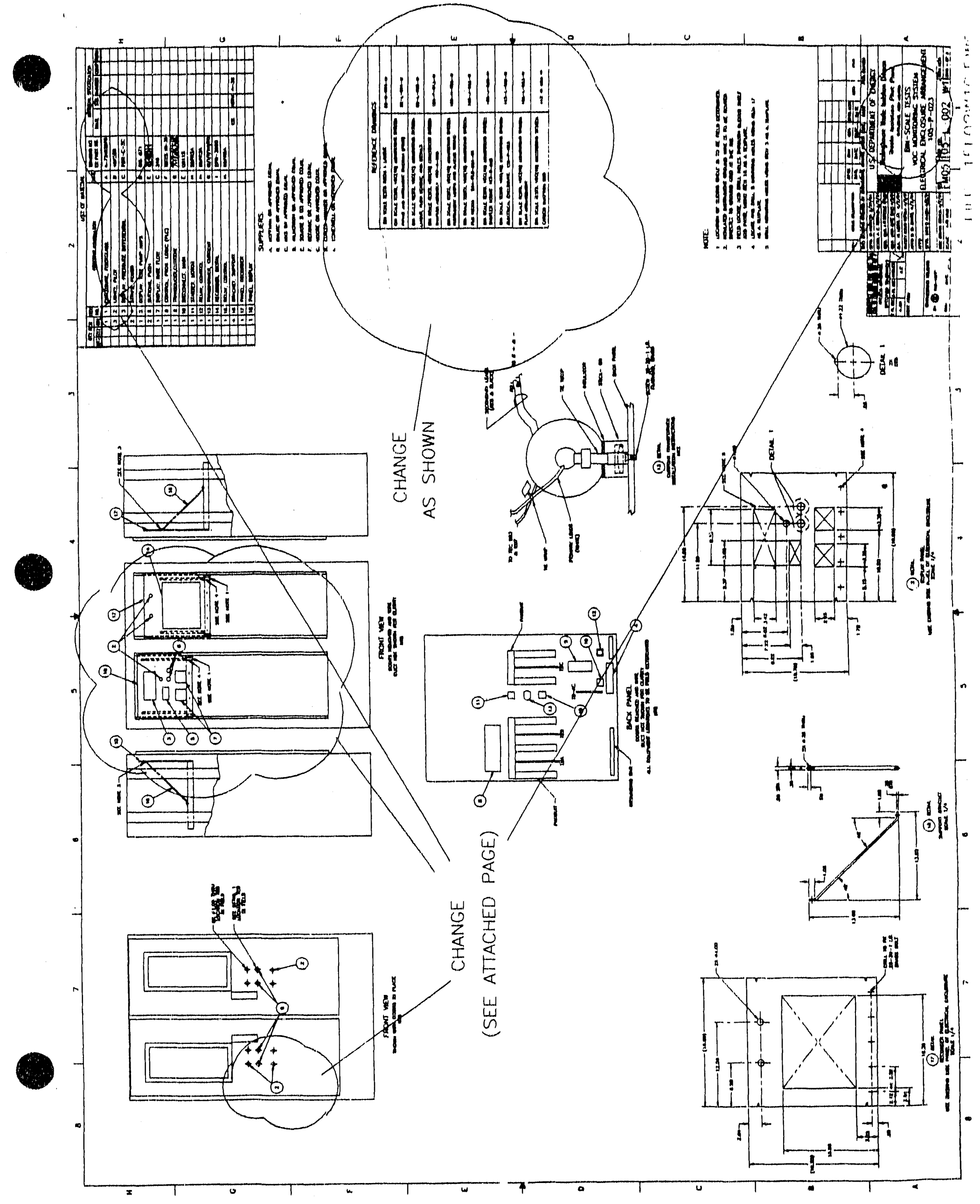




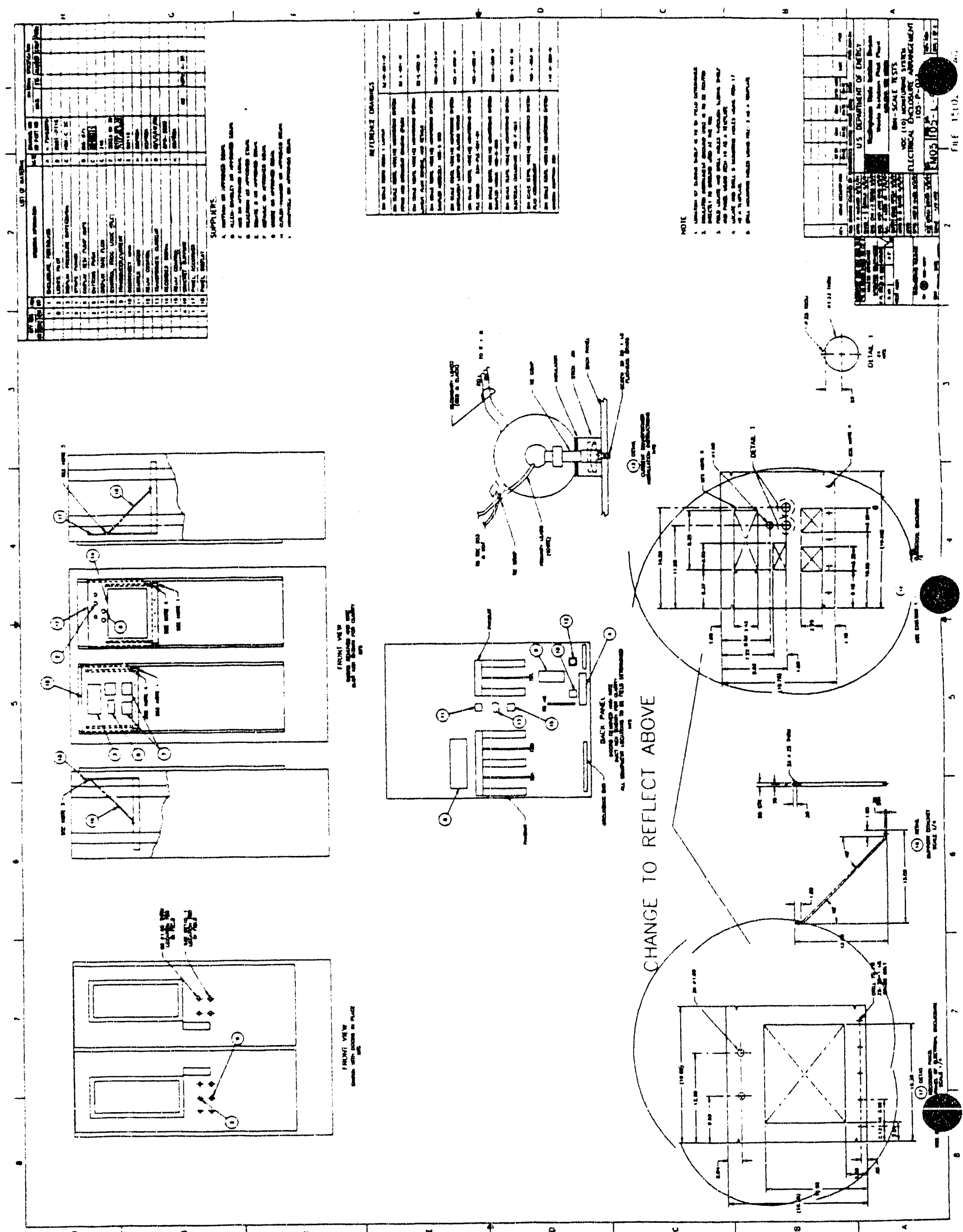




\section{9 a}

DRAWING CHANGE SHEET

(1 SHEET PER DRAWING)

1. Drawing:

$105-L-002-W 2$

ECO Number: $5 \times 21$

2. ECO Search List:
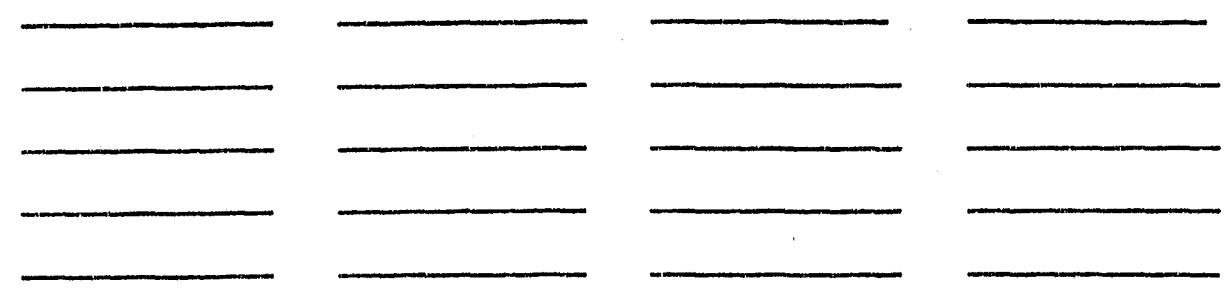

3. Description of Change:

1. DELETE REFERENCE DRAWINGS

2. CHANETHE TITLE TO:

BIN SCALE TESTS, VOC (10) MONITORING SYSTEM

ELECTRICAL ENCLOSURE WIRING 105-P-023

3. ADD WIRES TO TBC AS SHOWN.

SEE ATTACHED PAGES

4. Drawing Cog. Engineer Approval: J.R. Stroble

Date: $10-7-91$

5. Cover Sheet Block (CC\&D Use Only)

Received from EFR:

Date Assigned:

Assigned to:
Initials / Date

Initiais / Daito

(Same as data base entry)
Drafting Started:

Drafting Completed:

Return to EFA:
Initials / Date

Iniliale r Date

Initials / Date 
ECO $55 x$

PAGE 47 OF 57

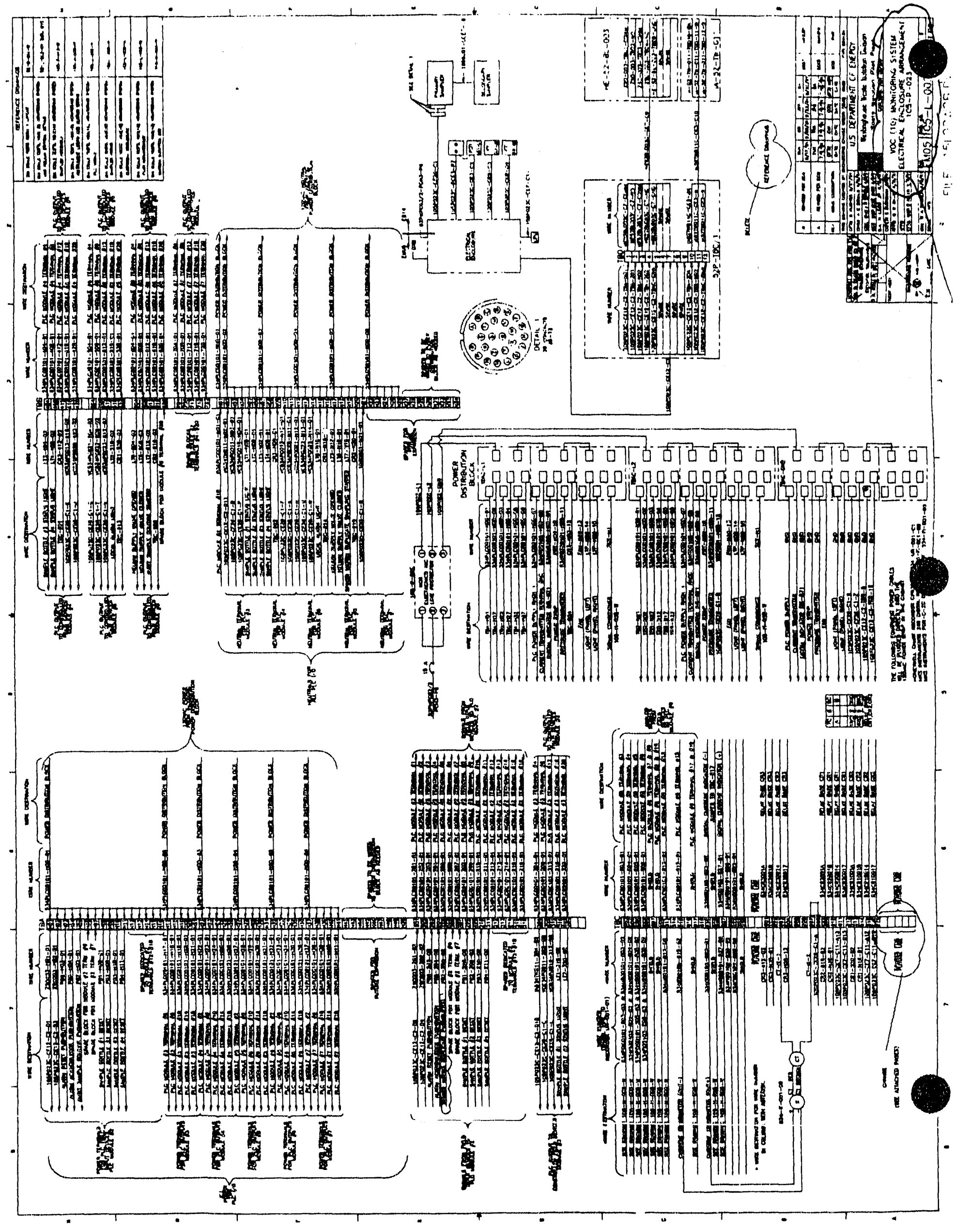


$E C O=521$
PAGE $480 F 57$

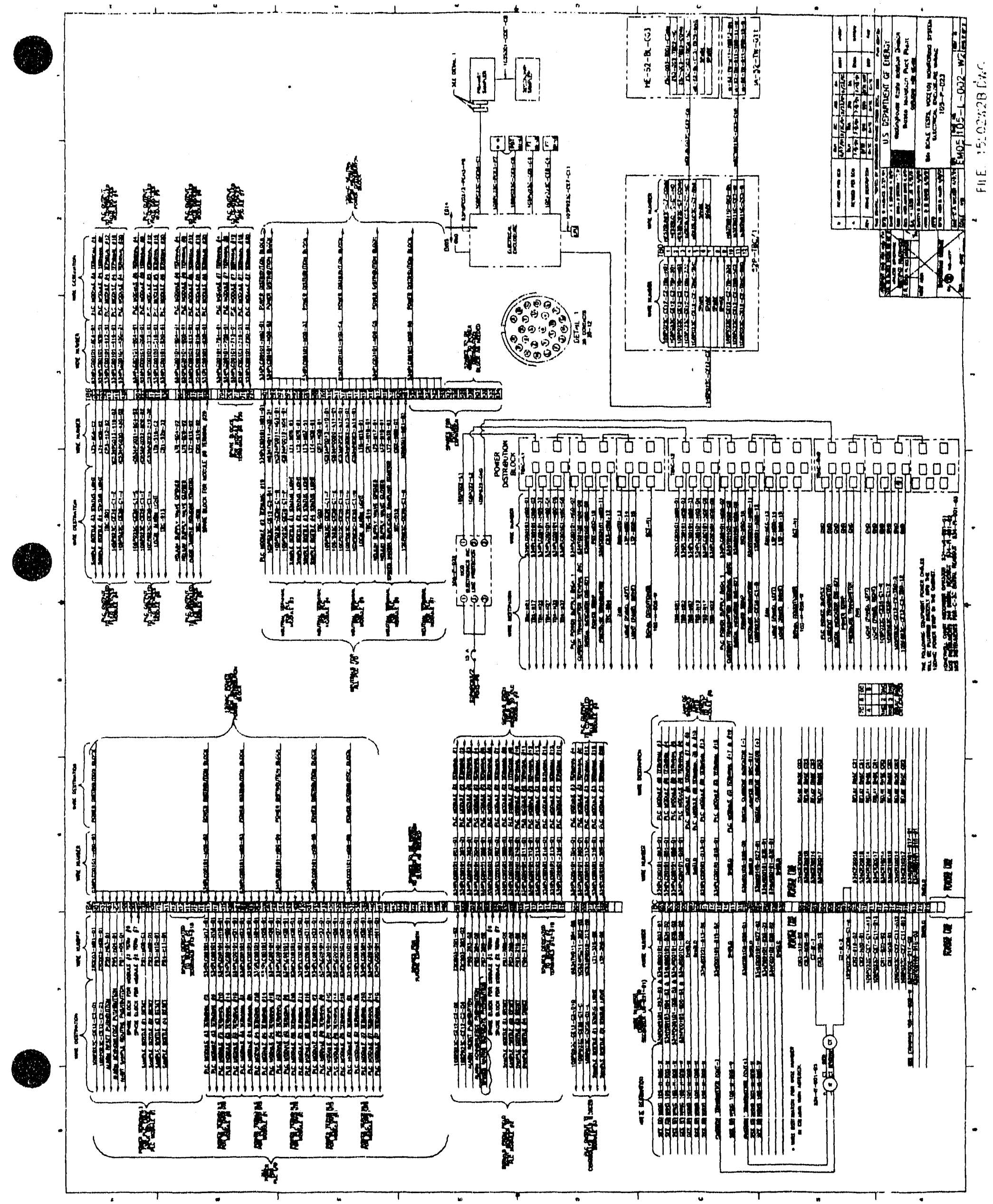




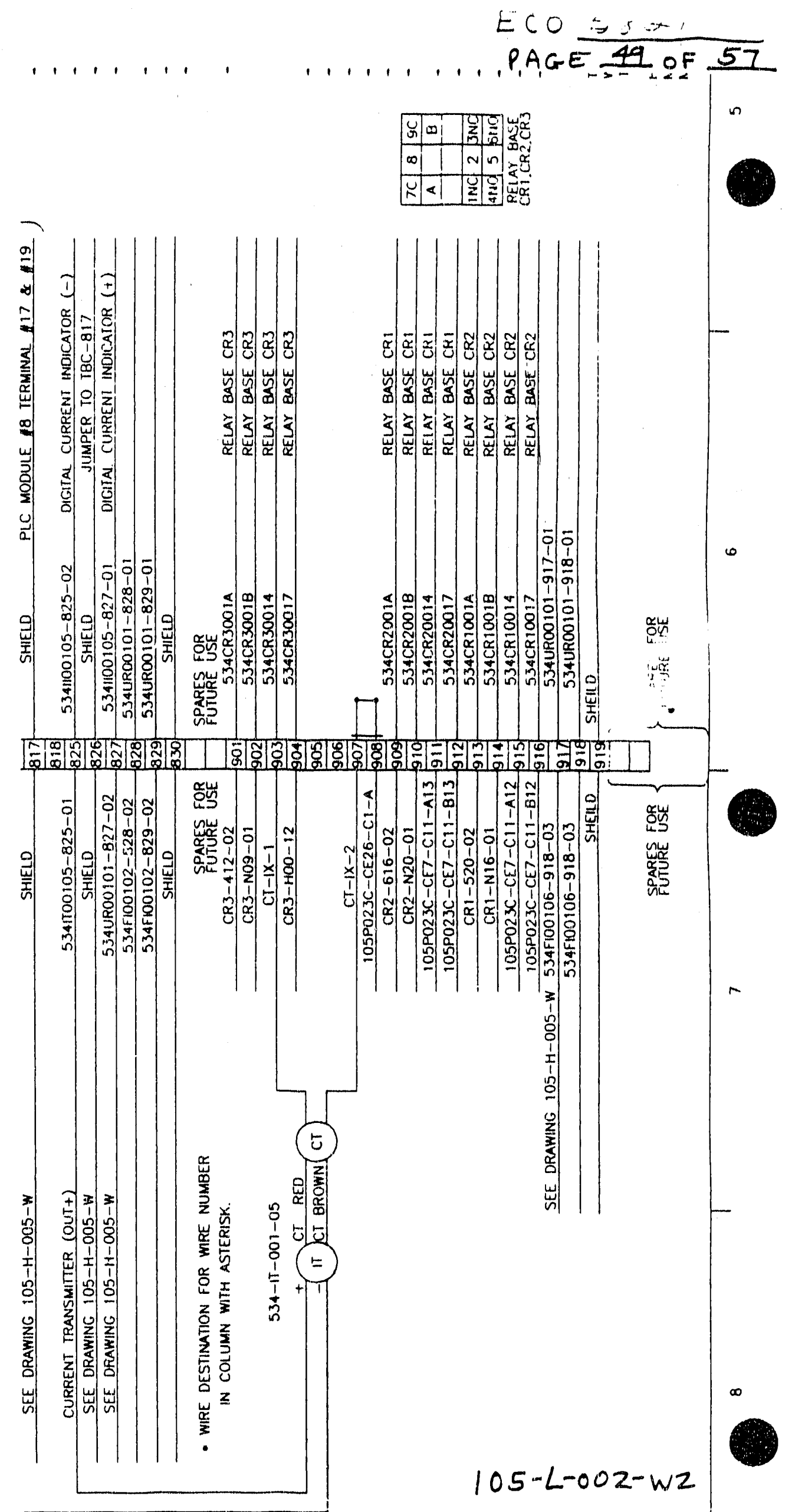




\section{$9 a$}

\section{DRAWING CHANGE SHEET}

(1 SHEET PER DRAWING)

1. Drawing:

$105-L-003-W$

ECO Number:

5821

2. ECO Search List:
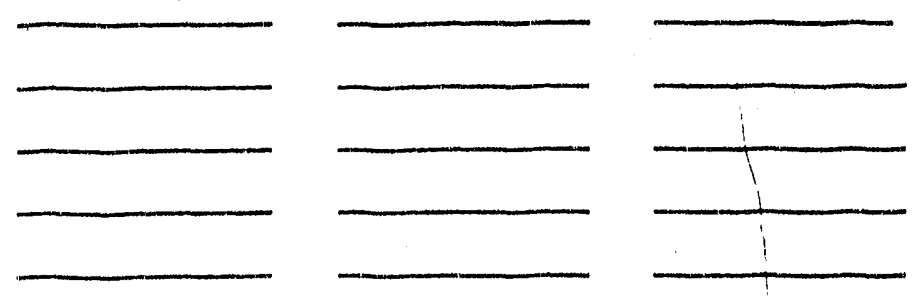

3. Description of Change:

1. CHANGE THE 'BENCH" TO A RACK SIMILAR TO THE "SOLENOID RACK".

2. THANGE DESCRIPTION "SOLENOID RACK" TO 'SAMPLER RACK".

3. move the "Electrical enclosure to the EAST.

\section{SEE A TTACHED PAGES}

4. Drawing Cog. Engineer Approval: U.R. Stroble Date: $10-7-91$

5. Cover Sheet Block (CC\&D Use Only)

Received from EFR:

Date Assigned:

Assigned to:
Initials / Date

Initials / Dalo

(Same as data base entry)
Drafting Started:

Drafting Completed:

Return to EFF:
Initials / Date

Initials / Date

Initials / Date 


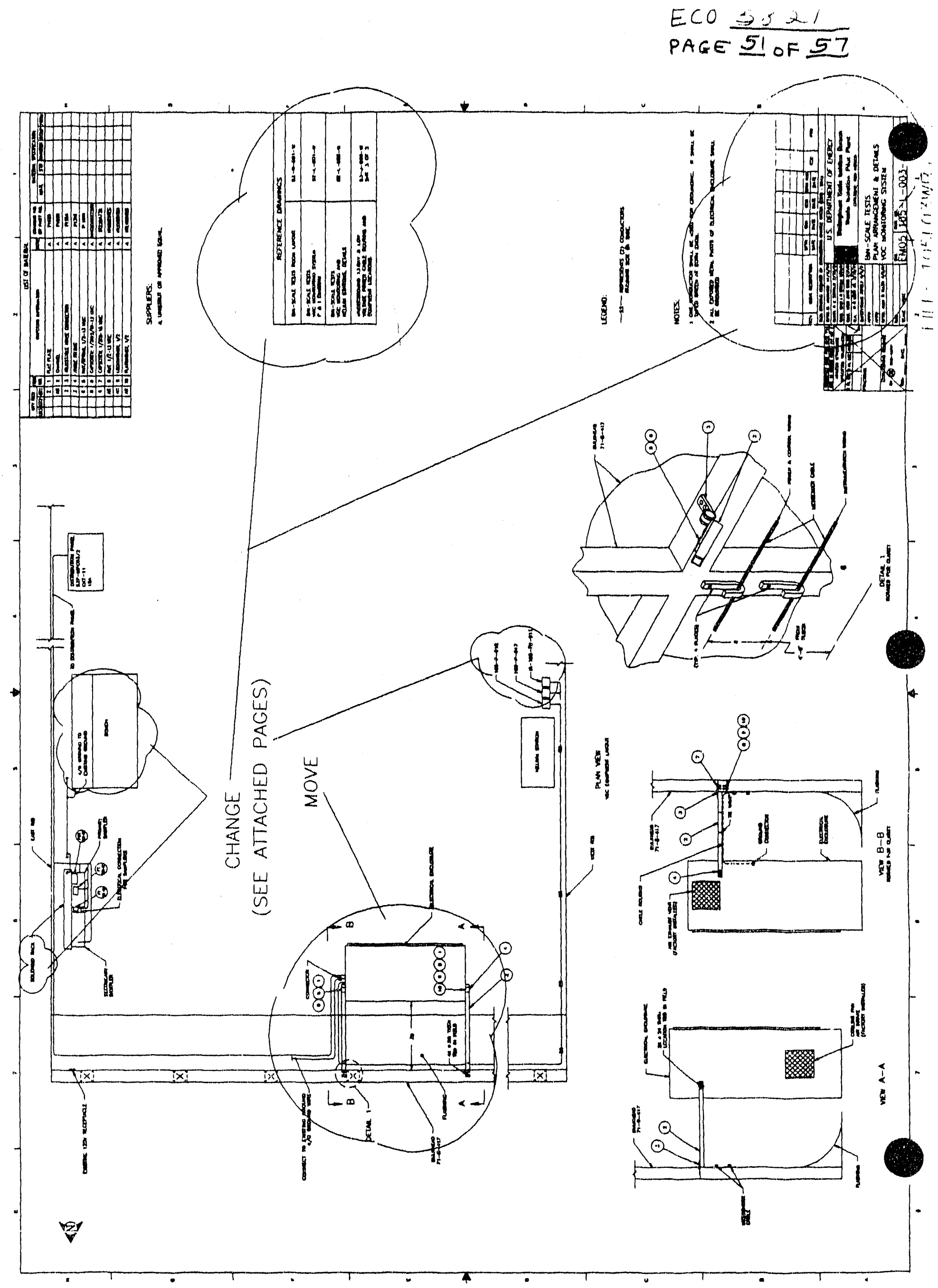


ECO $\$ 1$
PAGE 52 OF 57
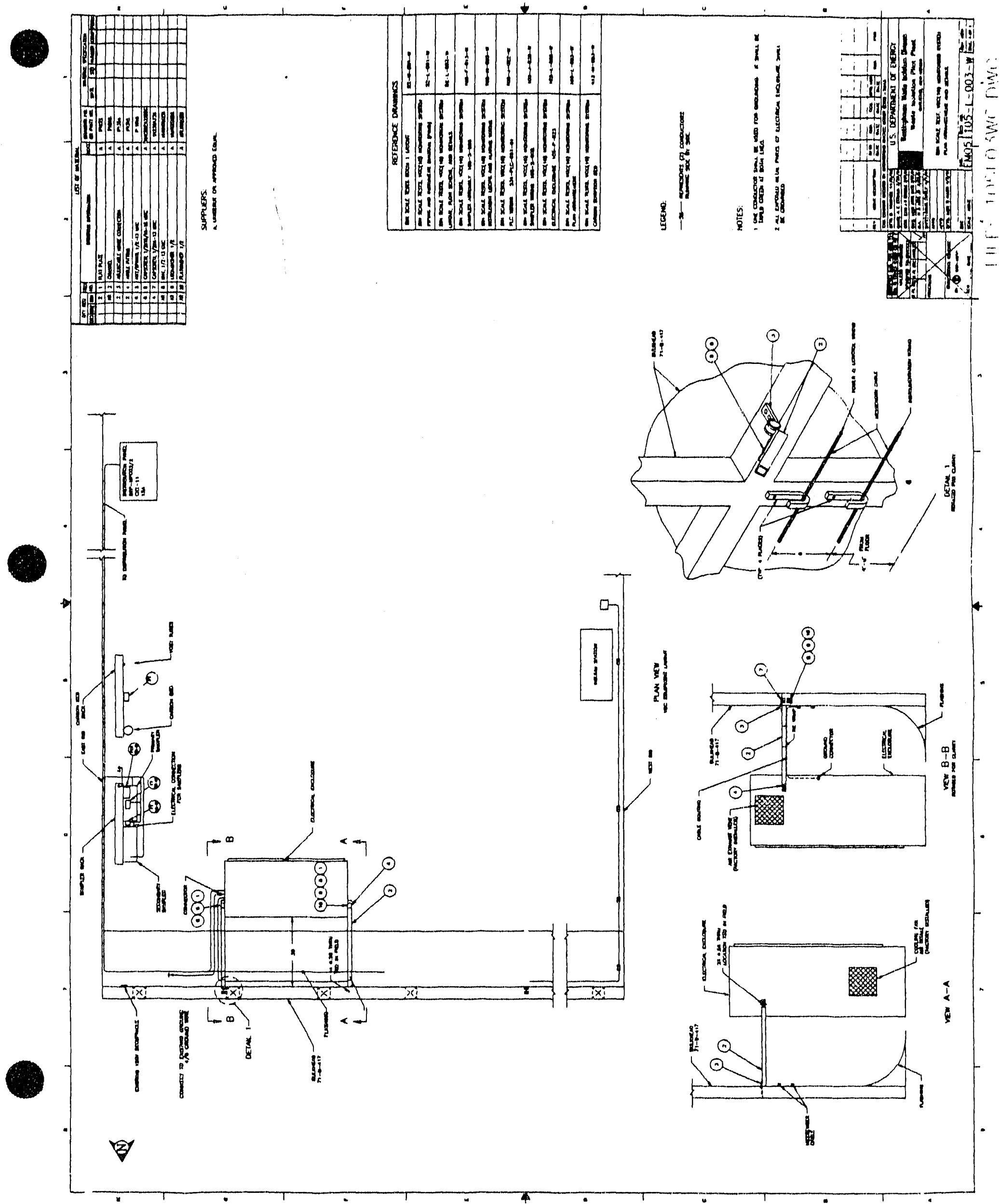
1. Drawing:

$412-M-003-W$ ECO Number:

2. ECO Search LIst:
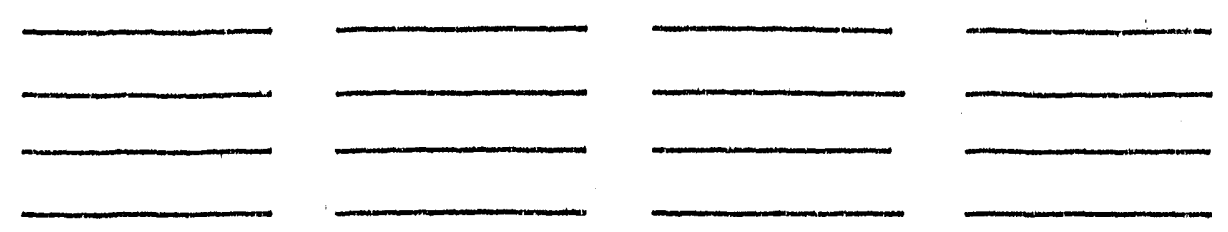

3. Description of Change:

1. CHANGE TITLE TO:

BIN SCALE TESTS, VOC (IO) MONITORING SYSTETM CARBON SORPTION BED

2. CHANGE SYSTEM DESIGNATOR TO EMO5

4. Drawing Cog. Engineer Approval: J.R. Strofk Date: $10-7-91$ 


\section{VALVE IDENTIFICATION SHEET}

\section{NEW VALVE $\square$ REVISED DATA $\square$ VALVEREMOVED $\square$}

1. Valve Number: $V C=534-T W-010$

2. System: EMO5

3. Building/Location: U/G,PANEL-1,RM-1

4. Sizo: $-1 / 4^{11}$

5. Pressure: 100 PSI

6. Valve Typo: BALL 3-WAY

7. Valve Operator: MANUAL

8. Valve Bonnet: $N / A$

9. Manuiacturer: SWAGE LOK (WHITEY

10. Catalog No.: $55-43 \times 54$

11. Body: $55-316$ 12. Trim: $55-316$

13. Ends: $-55-316$

14. Piping Code: NA

15. Seis. Class: N/A

16. Working Pressure: AIM (OPSIC)

17. Working Temperalure: $85^{\circ} \mathrm{F}$ (CARBON BEO TO SAMRER)

18. Normal Valve Position/Full Open: $X \quad$ Full Closed: $\%$ Throttled:

19. Spec. Number: $2-0077$ 20. P.O. Number:

\section{$N / A$}

21. Design Class: IIIA

22. $P \& 1 D$ : $52-2-001-W$ Sht.: Zone:

23. Plan Drawing Number: $52-L-002-w$ Sht.: Zone:

24. Isometric Drawing Number: $52-L-002-w$

25. Piping Line Number: $N / A$

26. Document Providing Information $030 \quad M 41816$ ECO 5346.5565 EWP

27. Service Remarks:

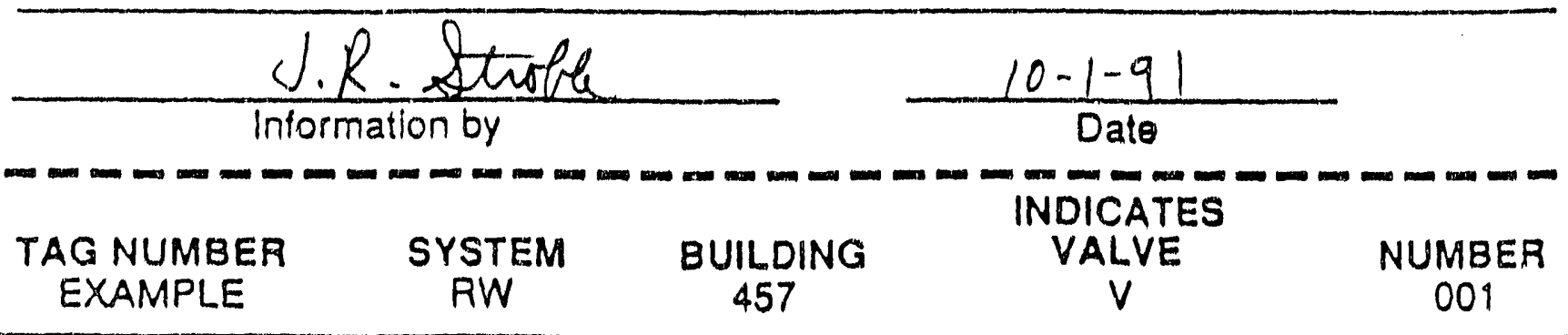




\section{VALVE IDENTIFICATION SHEET}

\section{New VAlVe $\square$ ' REVISEd data $\square$ VALVEREMOVEd $\square$}

1. Valve Number: VC.534-TW-025 2. System: EM05

3. Bullding/Location: $4 / C$, PANEL-1, RM-1 4, Size:

5. Pressure: 100 PSI 6. Valve Typo: B'ALL 3-WAY

7. Valve Operator: MANUAL

9. Manutacturer: SWAGELOK (WHITEY) 10. Catalog No.: SS-65XT616-E16

11. Body: $S S-316 \quad$ 12. Trim: $S S-316$ 13. Ends: $55-316$

14. Piping Code: 15. Sels. Class: N/A N/A

16. Working Pressure: - ATM (QPS1G) 17. Working Temperature: $85^{\circ} \mathrm{E}$

18. Normal Valve Position/Full Open: $\ldots$ Full Closed: __ _ Throttled:

19. Spec. Number: 20 . P.O. Number: $N / A$

21. Design Class: IIIA

22. P\&ID: $52-L-001-W$

Sht.:

Zone:

23. Plan Drawing Number: $52-L-002-W$

Shl.:

Zone:

24. Isometric Drawing Number:

$52-L-002-W^{\prime}$

25. Piping Line Number:

N/A

26. Document Providing Information

$030 \_$M41816 ECO $5346 / 5565$ EWP

27. Service Remarks:
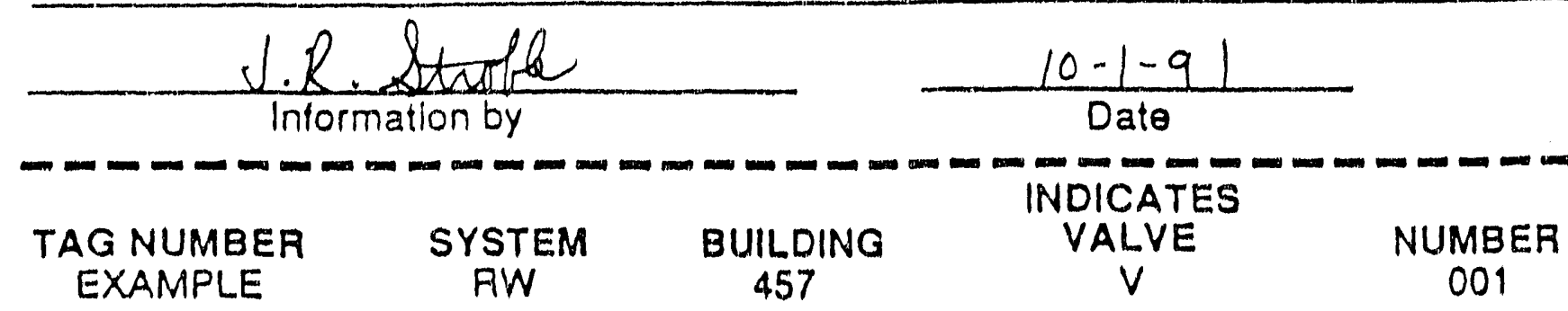


\section{VALVE IDENTIFICATION SHEET}

new VAlve $\square$ ReVised data $\square$ VAlverenoved $\square$

1. Valve Number: $Y C-534-T W=026$

3. Bullding/Locallon: H/Ge, PANEL-1, RM-1

2. System: EMO5

5. Pressure: 100 PSI

4. Sizo:

7. Valvo Operator: MANUAL

6. Valve Typo: BALL 3-WAY

9. Manufacturer: SWACELOK (WHITEY)

8. Valve Bonnet: $N / A$

11. Body: SS-316

12. Trlm: $S S-316$

10. Calalog No.: $55-65 \times$ T $16 \cdots E 16$

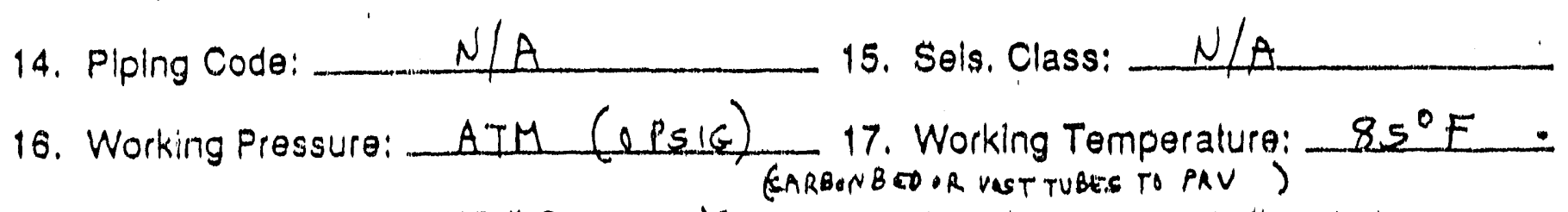
18. Normal Valve PositionfFull Open: $\_$_ Full Closed:

$\%$ Throttled:

19. Spec. Number: D. 0077 20. P.O. Number:

$N / A$

21. Design Class: IIA

22. P\&ID: $52-6-001-w$

Sht.: Zone:

23. Plan Drawing Number:

$52-1-002-w$ Sht.: Zone:

24. Isometric Drawing Number: $52-6-002-w$

25. Plping Line Number: $N / A$

26. Document Providing Intormation $030 \quad M 41816$ ECO $5346 / 5565$ EWP

27. Service Remarks:

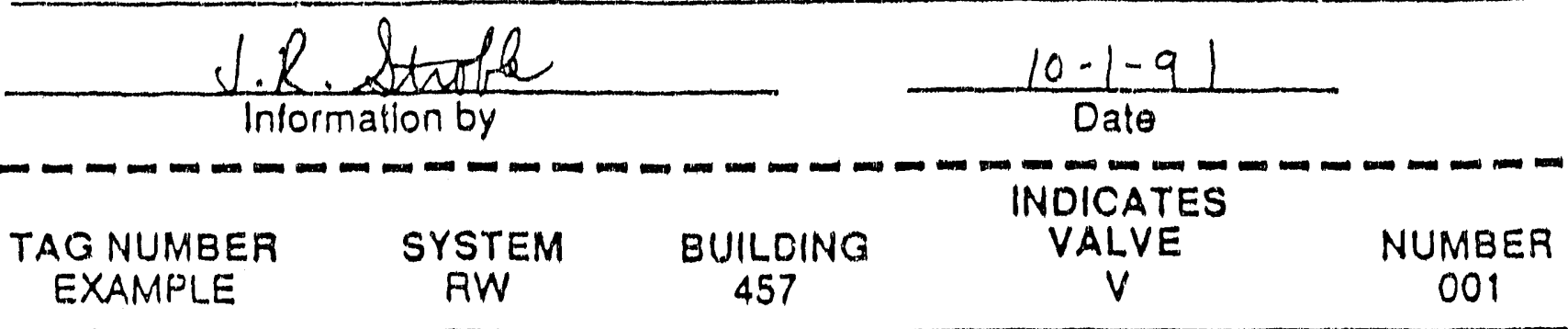




\section{VALVEIDENTIFICATION SHEET}

NEN VALVE $\square$ REVISED data $\square$ VALVEREMOVED $\square$

1. Valve Number: VC:534-TW-02T

2. System: EMO5

3. Bullding/Location: $\psi / C$, PANELW $1, R M=1$

4. Size:

5. Pressure: -

PSI

6. Valve Typo: B'BLL 3-WAY'

7. Valve Operator: MANUAL

9. Manufacturer: SWAGELOK (WHITEY)

8. Valve Bonnet: $N / A$

10. Catalog No.: $55-65 \times T$ T6 $16-E 16$

11. Body: SS-316 12. Trim: $5 S-3$

13. Ends: $5 S-316$

14. Piping Code: $N / A$

15. Sois. Class:

$N / A$

16. Working Pressure: ATM (OPSIG) 17. Working Temperature: $85^{\circ} \mathrm{F}$.

18. Normal Valve PositlorvFull Open: $\perp$ Full Closed: $\%$ Throttled:

19. Spec. Number: $-D \cdot 0077$ 20. P.O. Number: N/A

21. Design Class: III $A$

22. $P \& 10$ : $52-L-001-W$ Sht.: Zone:

23. Plan Drawing Number: $-52-L-002-W$ Sht.: Zone:

24. Isometric Drawing Number: $52-L-002-W$

25. Piping Line Number: $N / A$

26. Document Providing Information $030 \_$M41816 ECO $5346 / 5565$ EWP

27. Service Remarks:

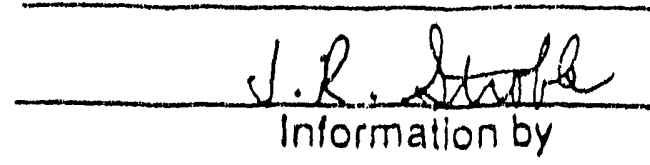

informalion by

TAG NUMBER

EXAMPLE

\section{SYSTEM}

RW

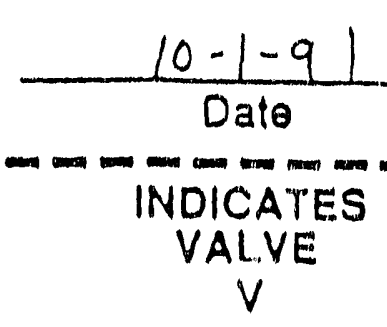

457
NDICATES

$\checkmark$
NUMBER 001 
2. Impact Level $1 \square \quad 2 \square \quad 3 \square$

Page 1 of 13

3. System:Eeq/Eeez Equipment No.:

4. Assoclated Documents:

PWR

$12002 M$

ECP

NA

P.O.

Others

$4 \square$

\section{Others}

(2)

\section{Title of Chango:}

7. Originator: (print)

Ext. No:: Department: Date:

\section{Dooument Type:}

Drawing $171+-S Q$

Speciflcation $25 \cdot F-003-\omega$

Vendor Data $24-C-015-\omega$

SDD

Others

\section{WmBaen 8169 Mace}

\section{Description of Change:}

$3 \operatorname{ldg} 4743$ ia to he relocates $\otimes \square \square$ Component indices change required from ite temporary location weat of $3 \mathrm{ldg} 456$ to ito permunent foundation within the fraz. Mat. Facility.

Following the lelg 's relocation, its spinkler system will be connected to an exiating Fas piping stubup with neur permanent sprinkler aystom supply piping (a riecu). Thia meur piping cuill have an isolation value, pressura gage, Rain, and proviaione for tie-in of $3 \operatorname{lgg} 474 A$ (fictine). The lelog's temporany FW provinions will be removed.

$\bigotimes 9 a$ Drawing Change Sheet attached $\square 9 c$ Vendor Data Change Sheet attached

9b Design Documentation Sheet attached

10. Yes No

$\square \square$ MODIFICATION IN PROGRESS

$\underset{\text { signalues }}{<}-$

ECO will be

incorporated atter

M.I.P. signed compiete

$\square \quad$ Change drawing per as-built markup dated:

Change drawing per ECO-provided data

Temporary modification

11. Design Verifjcallon Requirements: (por WP 09-018)

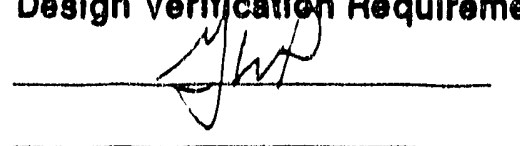

1. Requirements satisfied by review/approval of design document

2. Independent review

3. Altemate calculations

4. Development testing

5. Design review

6. Other:

12. Addendum Shoot added: 


\section{Justification}

The Hay. Mat Facility uas decigned with prowisiona for $B \log 47.43$ to be pecmanentiy located there. Thio "change" will make $3 \log 4743$ a permanent part of the stay. Mat. Facility as intended.

Changes to the blog's sprinkle syatem are bering. made to comply cuith "coder requirementa.

\section{Administrative Tracking}

YES N/A

1. FSAR

2. Calibration Procedures

3. Maintenance Procedures

4. Computer Software

YES N/A

$\square \otimes$

$\square \otimes$

$\square \otimes$

5. Operations Procedures

$\begin{array}{ll}\text { 15. Signature Requirements } & \text { KEY } \\ & \text { A-APPR. } \\ & \text { R.REVIEW } \\ & \text { S-GIGN NEW } \\ & \text { DRAWING }\end{array}$

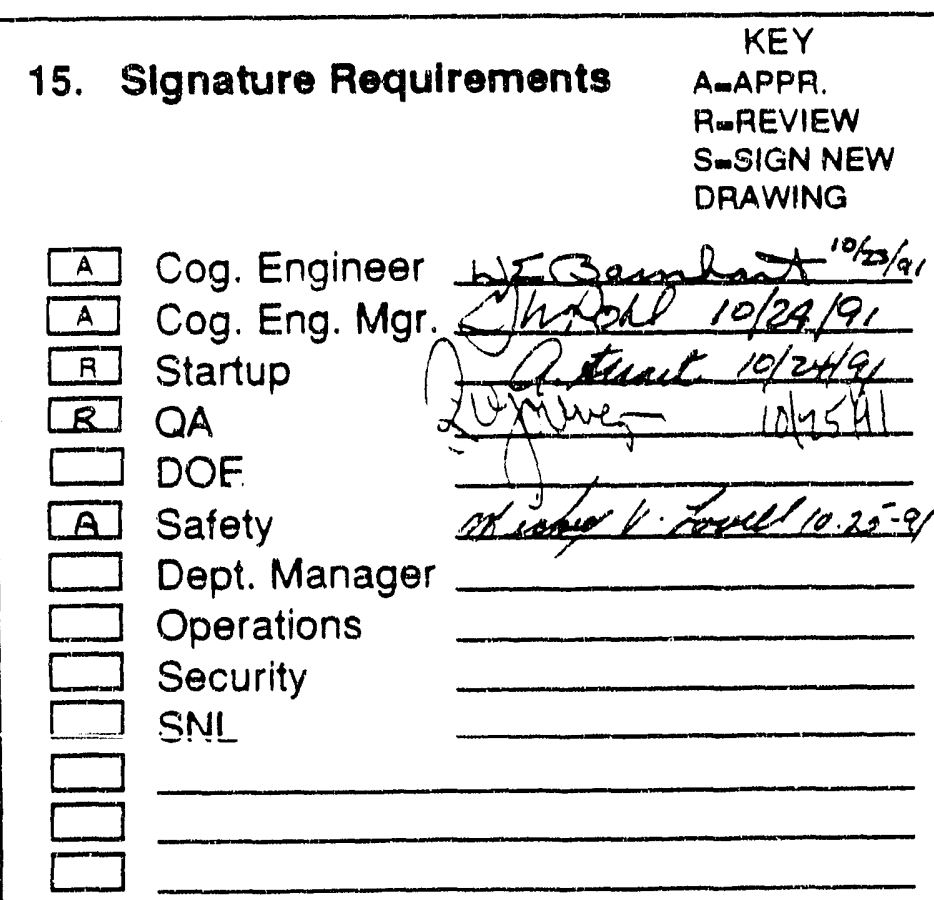

16. Distribute as Marked

8. we $12-116$

$\square \square \quad 9$.

0. 


\section{ENGINEERING CHANGE ORDER DOE ORDEF 6430.1A DESIGN CRITERIA CHECKLIST}

The design equilenen:s in DOE Order 64Ji. IA checked joiow nove ueen applied to this Design.

\begin{tabular}{|c|c|c|}
\hline 3 & DIVISION & SUBOIVISION \\
\hline$\square 1$ & General Requir & $\square 0101 \square 0106 \square 0109 \square 0110 \square 0111 \square 0140 \square 0150 \square 0170$ \\
\hline$\square 2$ & $\begin{array}{l}\text { Site and Civil } \\
\text { Engineering }\end{array}$ & 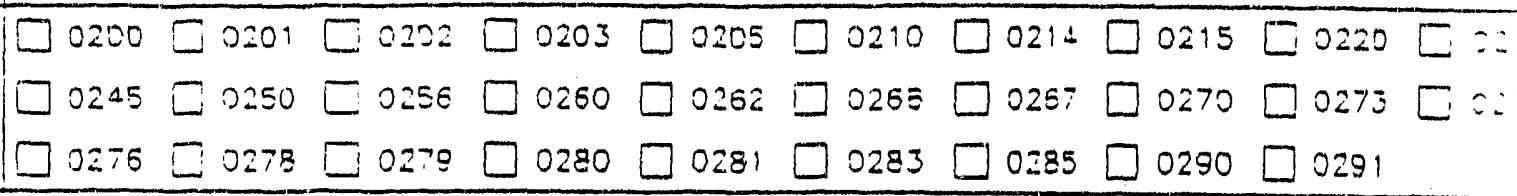 \\
\hline E3. & Concrete & $\square 0300 \square 0301 \square 0310 \square 0320 \square 0330 \square 0340 \square 0350 \square 0370 \square 0380$ \\
\hline$\square^{4}$ & Masonry & $\square 0400 \square 0401 \square 0412 \square 0420 \square 0455$ \\
\hline$\square 5$ & Metols & $\square 0500 \square 0512 \square 0514 \square 0521 \square 0531 \square 0532$ \\
\hline$\square 6$ & Wood and Plostics & $\square 0600 \square 0610 \square 0650$ \\
\hline$\square^{-}$ & $\begin{array}{l}\text { Tharmal and Moisture } \\
\text { pretection }\end{array}$ & 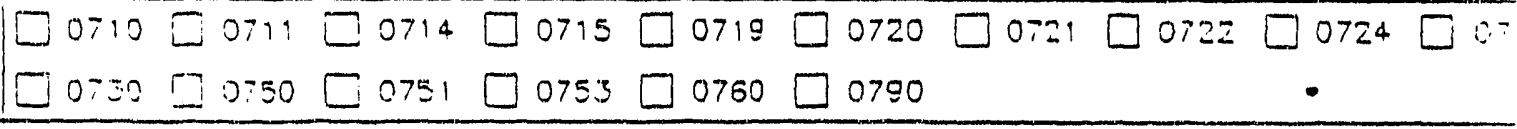 \\
\hline$\square^{\mathrm{a}}$ & Ooors and Windows & $\begin{array}{l}\square 0800 \square 0810 \square 0820 \square 0830 \square 0833 \square 0835 \square 08.39 \square 0850 \square 0860 \square .8 \\
\square 0880\end{array}$ \\
\hline$\square^{9}$ & Finignes & $\begin{array}{l}\square 0900 \square 0910 \square 0920 \quad \square 0025 \quad \square 0930 \quad \square 0950 \quad \square 0965 \quad \square 0968 \quad \square 0970 \square \\
\square 0990 \square 0995\end{array}$ \\
\hline$\Xi^{10}$ & Specialties & $\begin{array}{l}\square 10: 5 \square 1020 \square 1024 \square 1027 \square 1030 \square 1040 \square 1050 \square 1052 \square 1053 \square 10 \\
\square 1060 \square 1065 \square 1070 \square 1075 \square 1080\end{array}$ \\
\hline Q11 & Equioment & $\square 1100 \square 1161$ \\
\hline$\square: 2$ & Furnishings & $\square 1201 \square 1230 \square 1250 \square 1260 \square 1270$ \\
\hline$\square 15$ & Special Focitities & $\begin{array}{l}\square 1300 \square 1304 \square 1305 \square 1305 \square 1302 \square 1318 \square 1319 \square 1320 \square 1321 \square 13 \\
\square 1323 \square 1324 \square 1325 \square 1325 \square 1328\end{array}$ \\
\hline$\square^{14}$ & Conveying Systems & $\square 1401 \square 1420 \square 1440 \square 1460$ \\
\hline Dis & Meshanical & $\square 1525 \square 1530 \square 1540 \square 1550 \square 1555 \square 1505 \square 1574 \square 1589 \square 1505$ \\
\hline$\square^{15}$ & Elertrical & $\begin{array}{l}\square 1600 \square 1605 \square 1620 \square 1630 \square 1639 \square 1640 \square 1650 \square 1655 \square 1600 \square \\
\square 1671 \square 1685 \square 1694\end{array}$ \\
\hline 4. $\square$ & NOT AFPLICAELE & No portion of DOE DrJer $6430.1 \mathrm{~A}$ is adplicable to this Designi. \\
\hline $5 . \square$ & $A-$ - QUILT & Eso is for as-built field verified choriges only. \\
\hline & & $\begin{array}{l}\text { A check placed in the Division column signifies that the } \\
\text { entire Division shall be applicable to the Design, unless } \\
\text { modified by checks indicated for specific Subdivisions. }\end{array}$ \\
\hline
\end{tabular}

IOMMENTS: 
1. Drawing: $1714-5$ ECO Number: 58.30

2. ECO Search List:
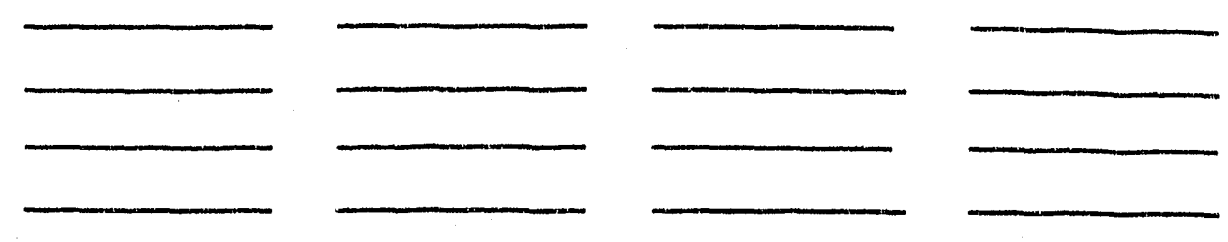

3. Description of Change:

Provide a sketch number for the skctch "Blog. 474B Relocation". Siee attached page 6.

4. Drawing Cog. Engineer Approval: b Date: $10 / 33 / 91$ 


\begin{tabular}{|c|c|c|c|}
\hline \multirow{2}{*}{$\begin{array}{c}\text { ENGINEERING CHANGE } \\
\text { ORDER } \\
\text { Continuation She日t }\end{array}$} & \multicolumn{2}{|c|}{$\begin{array}{l}\text { Document Number: } \\
-5 / 25-F-003-\omega / 24-C-0 / 5-\omega\end{array}$} & \multirow{2}{*}{$\begin{array}{l}\text { ECO } \\
5.730 \\
\end{array}$} \\
\hline & Date: & $\begin{array}{l}\text { Page } \\
3 \text { of } 13 \\
\end{array}$ & \\
\hline
\end{tabular}

Aa part of this change, two deficionciea ciuth the bldy's aprinbler eystem cuill be correctad:

1) the sprinklen head configunation will be changed from upright to pendant to clear obatructions in the bedg'e noof.

2) an Qnspectore Teat Connection will be added to allow testing of the sprinkler syater flow suitih and alarm system.

All fire protection wake will be performed in accoschance with the attached sketch and spec. D.0065, Tlar. 1.

1. Provide a sketh number for the attached sketch: $11 / 2$-s

2. Following mod. complation, revise dunge 25-F-003-W * 24-C-015-W to reflect thia change.

3. Following mod. completion, remove the attached sketich from the active dug. segiater.

* Electrical changea to suppost selocation of $3 \mathrm{ldg} 4743$ as heing ad sused by a different ECO. 
$\frac{n}{5}$

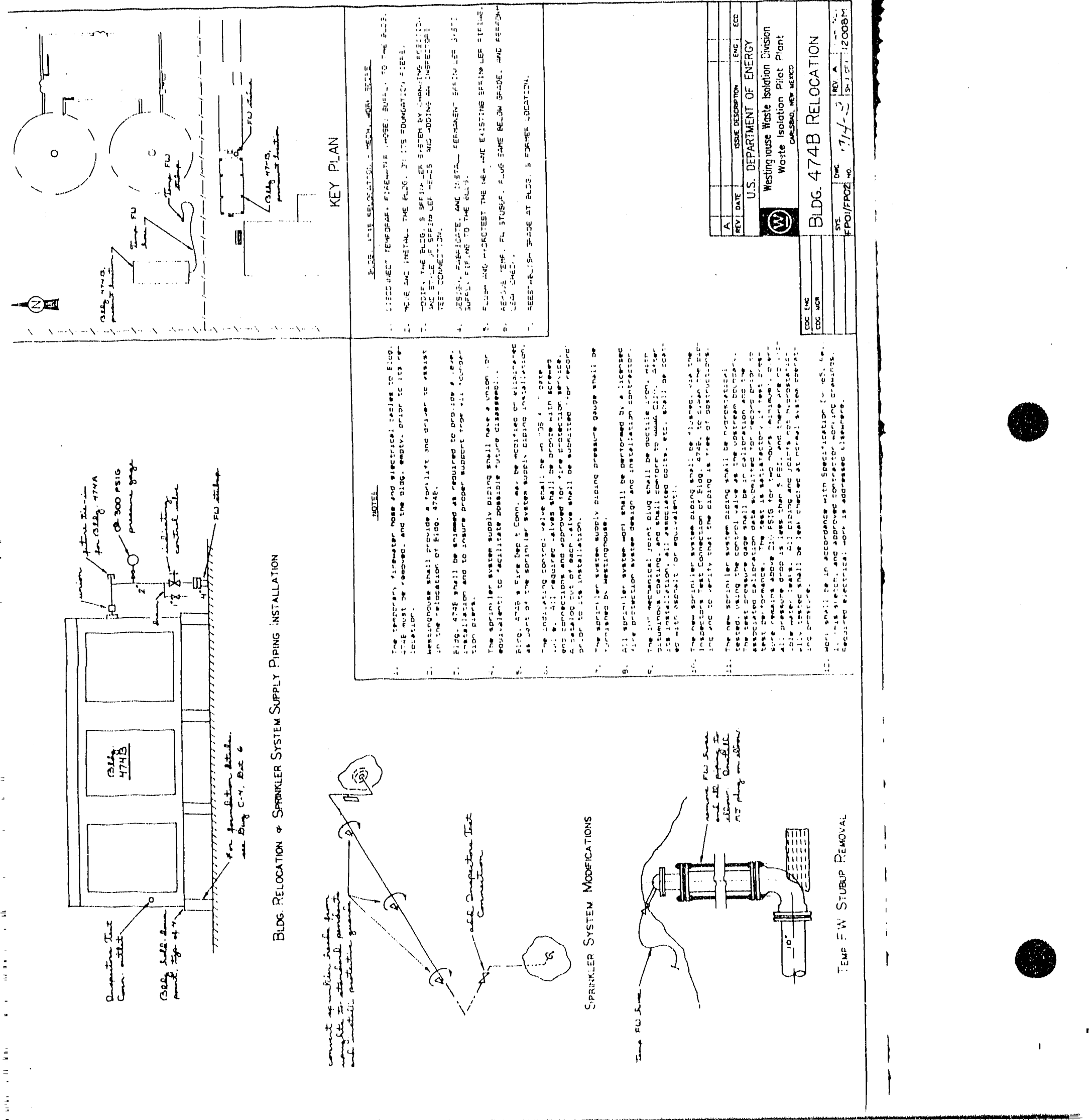


1. Drawing: 25-E-003-W, Res A ECO Number: $5: 3.30$

2. ECO Search List: $55 / 4 \quad 5 / 70 \quad 4603$

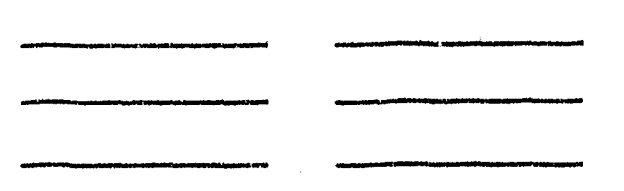

3. Description of Change:

Ravise durg. to show the following:

- selocation of $B \log 474 \beta$ to ita pesmanent foundation withirthe Hay. Mat. Facility.

- semoval of temp. fire hose and FW piping atubup.

- tie. in of $B \log 474 B$ to FW piping stubup within Hay. Mat. Facility.

* Markupa not providel becauce dug. doea not yat shour Hay. Mat. Facility.

4. Drawing Cog. Engineer Approval: W5 BaseakentDate: $10 / 23 / 91$ 
$9 a$

DRAWING CHANGE SHEET

(1 SHEET PER DRAWING)

Page 8 of 13

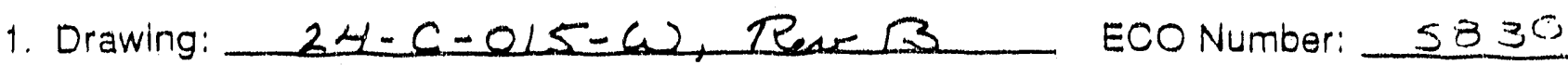

2. ECO Search List: $5795-5788 \quad 5722 \quad 5674$

$5683 \quad 3891$

3. Description of Change:

Revise dug. to show the following:

- relocation of $B \log 474 B$ to it a permanent foundation within the Hay. Mat. Facility.

- vernoval of temp. fire hove and FW piping stubup.

- tiv -in of Bldg 474B to FW piping stubup within Hag. Mat. Facility.

* Markup not provided because dug. dora not yet show Hay Mat. Facility.

4. Drawing Cog. Engineer Approval: Lbw Beamhant Date: 10/23/91

WP Form 2017; 06/24/91

1290:80006

Page 1 of 1 


$$
\begin{aligned}
& \text { ECO } \\
& \operatorname{Reg} 9 \text { of } 13
\end{aligned}
$$

\section{VALVE IDENTIFICATION SHEET}

\section{NEW VALVE $\square$ REVISED DATA $\square$ VALVE REMOVED}

1. Valve Number: $E W-25-V-007$

2. System: $\mathrm{FeOZ}$

3. Buildinglocation: YARO/BLOE 4243

4. Sizg:

$2^{\prime \prime}$

5. Pressure:

6. Valve Type:

GATE

7. Valve Operator: HANOWHEEL

8. Valve Bonnet:

9. Manufactuper: 10. Catalog No.:

11. Sody: 12. Trim:

13. Ends: Sarewen

14. Piping Code: NEPA 13

15. Sois. Class: NA

16. Working Pressure: $175 \mathrm{PS} / \mathrm{G}$ 17. Working Temperature: AmBJENT.

18. Normal Valve Position/Full Open: X Full Closed: $\%$ Throttled:

19. Spec. Number: NA 20. P.O. Number: NA

21. Design Class: Sht.: Zone:

22. P\&ID: $\Delta A$

Sht.: Zone:

23. Plan Drawing Number:

NA

$\triangle A$

24. Isometric Drawing Number: $\Lambda A$

25. Piping Line Number:

26. Document Providing Intormation 030 L2008M ECO EWP

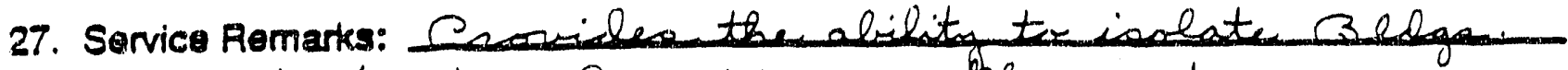

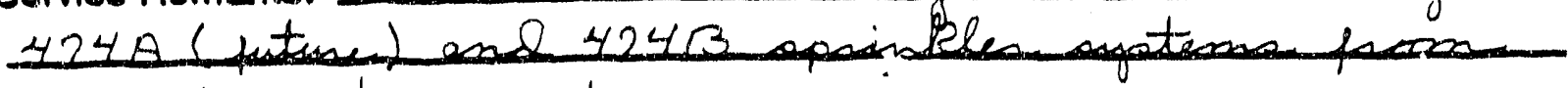
the fiseswates engteon

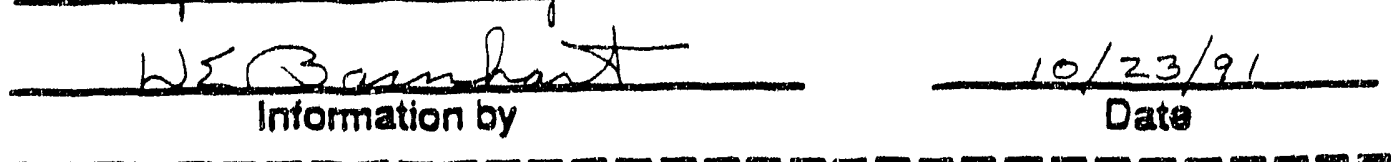

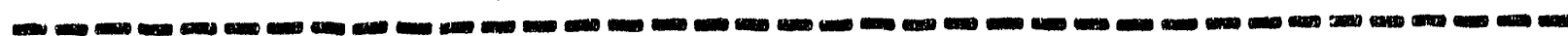
TAG NUMBEA EXAMPLE SYSTEM RW

BUILDING
INDICATES VALVE $\checkmark$ 001 


$$
\begin{aligned}
& \text { ECC } F \quad 5=; \\
& \text { pog } 10 \text { of } 13
\end{aligned}
$$

\section{VALVE IDENTIFICATION SHEET}

\section{NEW VALVE $\square$ \\ REVISED DATA \\ VALVE REMOVED}

1. Valvo Number: $E W-25-V-008$ 2. System: FPO2

3. BuildingrLocation: YABD/BLOE $Y Z 4 B$

4. Sizs:

5. Pressure:

6. Valve Type:

Grobe

7. Valve Operator: HANOWHEEL

8. Vaive Bonnet:

9. Manufacturer: 10. Catalog No::

11. Body: 12. Trim:

13. Ends: SCREWEO

14. Piping Code: NEPA 13

15. Sels. Class: $\Lambda A$

16. Working Pressure: 175 PSIG 17. Working Tomperaturs: AMOLENT-

18. Normal Valve Position/Full Open: Full Closed: $-x$ \% Throttled:

19. Spec. Number: NA 20. P.O. Number: $\Delta A$

21. Design Class: III $B$

22. P\&ID: $\triangle A$ Sht: Zone:

23. Plan Drawing Number: $N A$ Sht.: Zone:

24. Isometric Drawing Number: NA

25. Piping Line Number: $N A$

26. Document Providing Intormatton

$$
030 \text { 12008M ECO }
$$
EWP

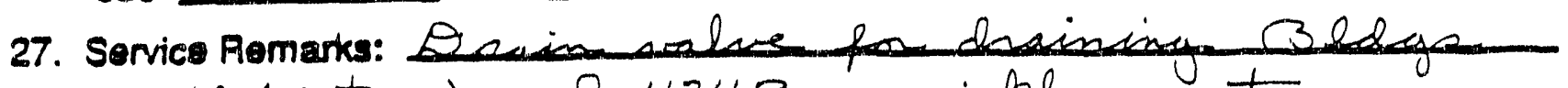

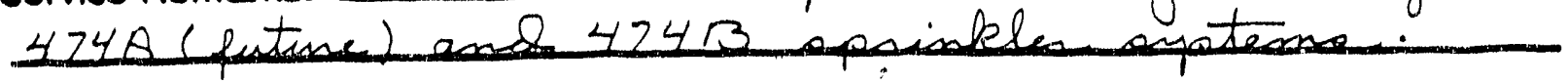

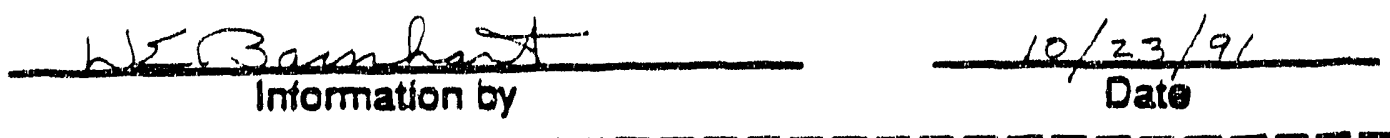

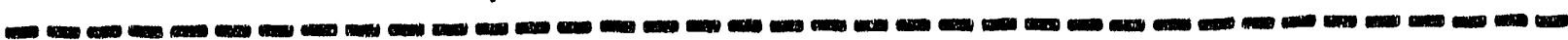

TAG NUMBEA EXAMPLE

SYSTEM
RW

BUILOING

457 INDICATES

VALVE

$\checkmark$
NUMEER 001 


$$
\begin{aligned}
& \text { ESC : } 53= \\
& \text { Figll of } 13
\end{aligned}
$$

\section{VALVE IDENTIFICATION SHEET}

\section{NEW VALVE $\square$ \\ REVISED DATA \\ VALVE REMOVED}

1. Valve Number: $F W-25-V-009$

3.

3. Building/Location: YARQ/BLOE $474 B$.

2. System: EPO2

5. Pressure:

4. Siza: $1 / 4^{\prime \prime}$

7. Valve Operator: HANOWHEEL

6. Valve Type: Grobe

9. Manufacturer:

8. Valve Bonnet:

11. Body: 12. Trim: 10. Catalog No.:

14. Piping Code: NFPA 13 15. Sels. Class:

13. Ends: Screwer

16. Working Pressure: 175 es/6 17. Working Tomporature: ANOBLEN2E-

18. Normal Valve Posittion/Full Open: $\times$ Full Closed: \% Throttlod:

19. Spec. Number: $N A$ 20. P.O. Number: $N A$

21. Design Class: III 3

22. P\&ID: $N A$ Sht: Zone:

23. Plan Drawing Number: $\Delta A$ Sht.: Zone:

24. Isometric Drawing Number: $\Delta A$

25. Plping Lne Number: $N A$

26. Document Providing Information $03012008 M$ ECO EWP

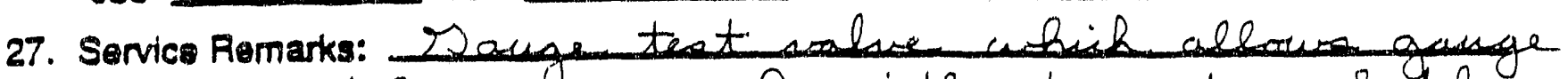

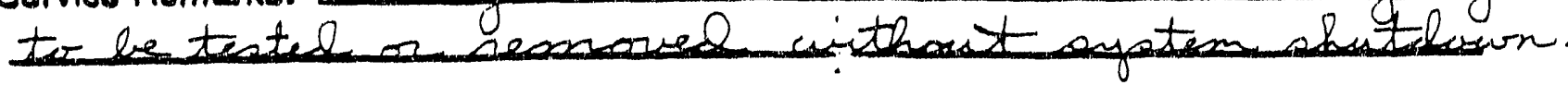
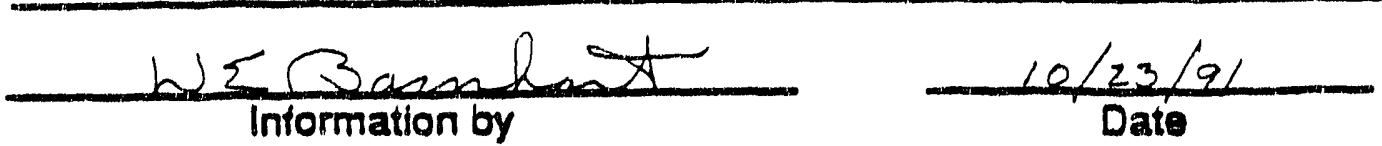

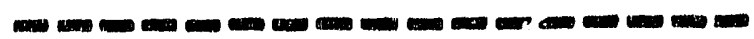

TAG NUMEER
EXAMPLE

SYSTEM

RW

BUILDING

457

INDICATES

VALVE

V

NUMEEA 001 


\section{VALVE IDENTIFICATION SHEET}

\section{NEW VALVE $\square$ REYISED DATA $\square$ VALVE REMOVED $\square$}

1. Valve Number: $E W-4243-V=021$

2. System:

EPOZ

3. Bullding/Location:

$4 2 4 \longdiv { 3 }$

4. Size:

5. Pressure:

6. Valve Typo:

GLOBE

7. Valve Operator:

HANDWLHEE

8. Valve Bonnet:

9. Manufacturer: 10. Catalog No.:

11. Body:

12. Trim:

13. Ends: Sarewer

14. Piping Code:

NEPA 13

15. Seis. Clans:

NA

16. Working Pressure: 125 PS/6 17. Working Temporature: AmOLENT.

18. Nomal Valvo Posttion/Full Open: Full Closed: $-x$ - Throttled:

19. Spec. Numbor: $\triangle A$

20. P.O. Number: $\triangle A$

21. Design Class: $I I \sqrt{3}$

22. P\&ID: $\triangle 2 A$ Sht.: Zone:

23. Plan Drawing Number: $N A$ Sht.: Zone:

24. Isometric Drawing Number: $N A$

25. Piping Lne Number: $\triangle A$

26. Docume it Providing Information 030 L2008M ECO EWP

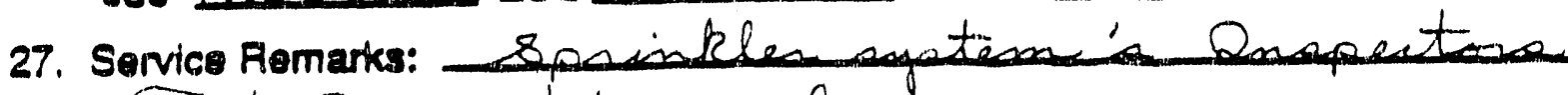
Test Consestion walse

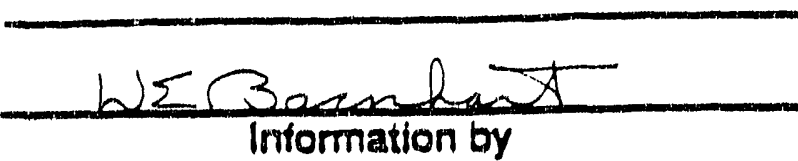

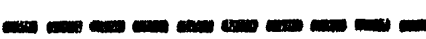

TAG NUMBEA EXAMPLE

\section{SYSTEM}

AW

$$
\frac{10 / 23 / 91}{\text { Dato }}
$$

INDICATES

VALVE

V
NUMBER

001 


$$
\text { Eg } 13 \text { of } 13
$$

\section{INSTRUMENT NUMGER REOUEST}

1. Instrument Number

$$
25-P I-001-01
$$

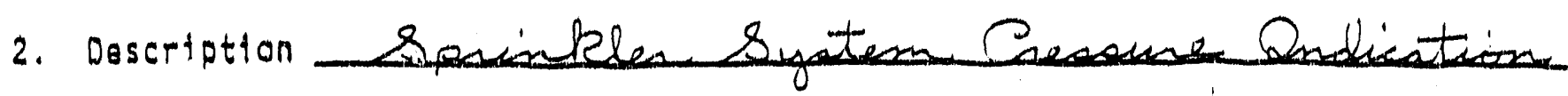
Narrative: Presacm indication for eprinkler systema in Bedga $474 \mathrm{~A}$ (future) and $474 \mathrm{~B}$.

3. Subequipment NA

4. Loop Number $N A$

5. Crawing Number NA peID Drawing Number NA

6. System EPO2

7. CyS Point $N A$

8. Inout Type/Range $0-300$ es 16

9. Clisut Type/Range NA

10. Sat Points $N A$

11. Ca1./PM Procedura Number

12. Manufacturer

13. Madel Numbar Serial Number

14. Casign Class IIII 3

15. Cittical Equigment Yes $\frac{x}{N o}$

16. Lecation: Buflding Room Number

17. Eiectrical Power from

18. CSil Manual iff file Room Yes

19. Cognizant Manager/Engineer DoHL/BarnharT

20. Equipment Labeled Yes $x$ No Remarks: Yage to de inatalled ly pur \#12008M sketeh 1214-s

Requestor WEBasent. Date $10 / 23 / 91$ WP Form 1870: $10 / 17189$

Page 1 of 2 


\section{Justification}

In the past, dual train operation of the main HVol system has resulted in deformation of the system exhaust duct downstream of the room pressure control dampers, due to the orlgtnal design under estimatirig the negative pressure that would be developed in the ducts.

The prevention of gimultaneals operation of the trains is currentiy achieved administratively. The internal. ORR review considered that this was lnadequate in the long term and that the associated fans should be interlocked to prevent simultaneous operation under all control conditions.

\section{Administratlve Tracking}

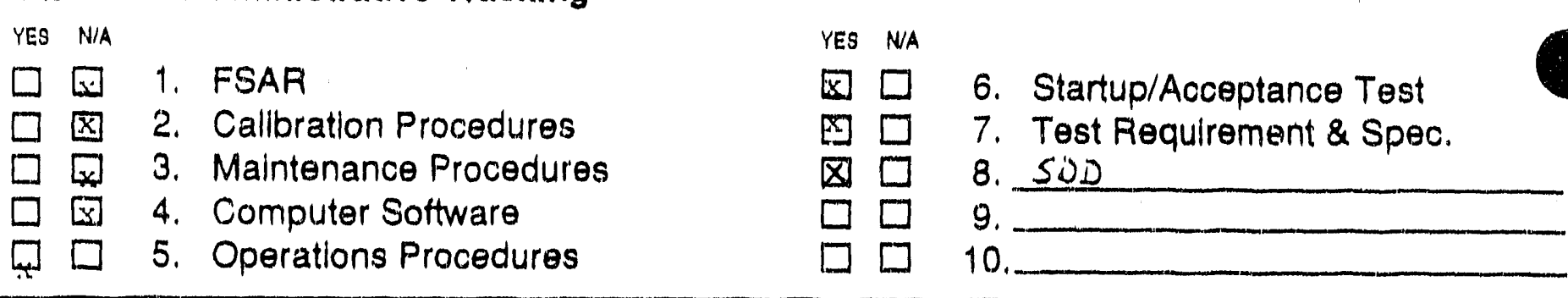

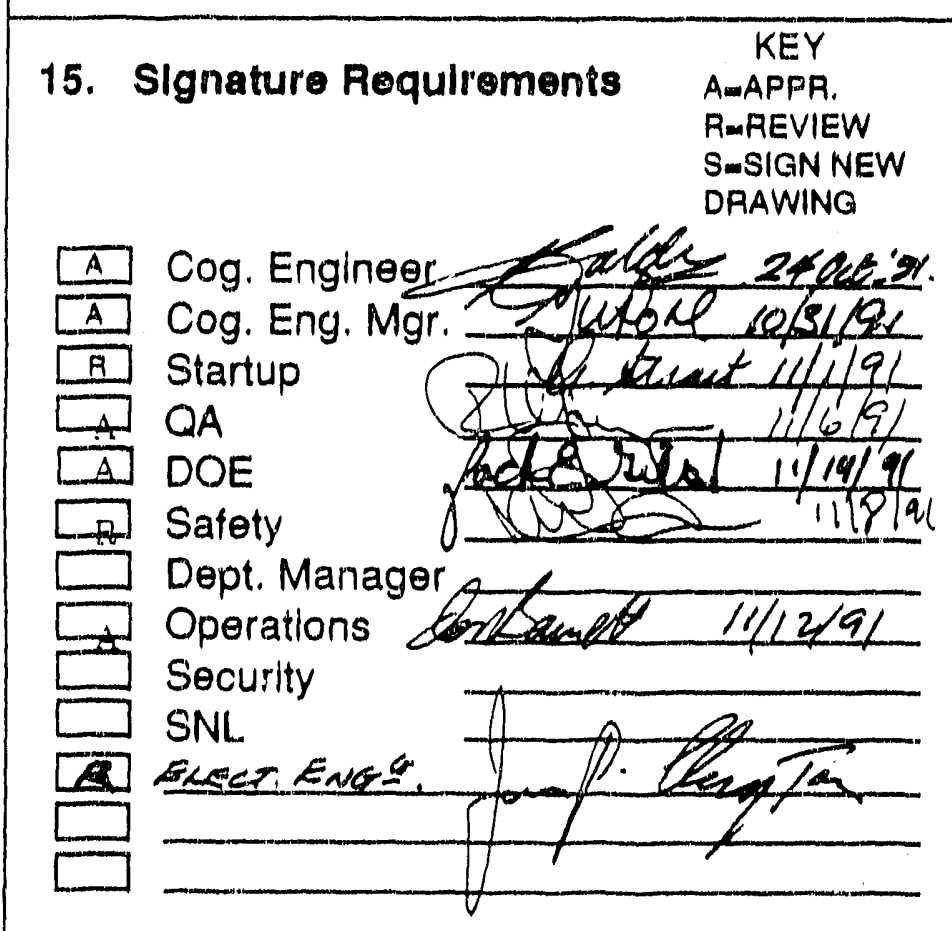

\section{Distribute as Marked}

Maintenance (MANDATORY) Ops. Support (MANOATORY)

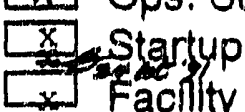

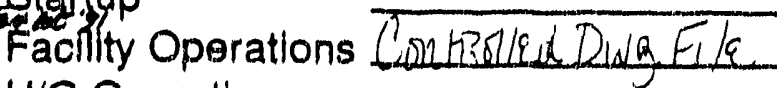
$U / G$ Operations Orig./Design Engr.

Cog. Engineer

Others 
1. Drawing: $+1-\mathrm{J}-032-\mathrm{W} 1$

ECO Number: 5845

2. ECO Search List:

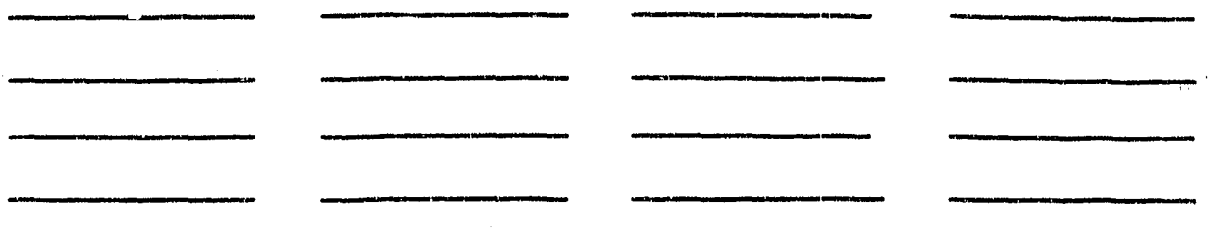

3. Description of Change:

On HS-052-25 change labeliing of wire no.21 as shown marked up on page 4 of 31 .

4. Drawing Cog. Engineer Approval:

Date: 24 Qet.' 91 . 


\section{ENGINEERING CHANGE ORDER \\ DOE ORDER 6430.1A DESIGN SARTERIA \\ CHECKLIST}

The design ravenen:s in oOE Order 6430,1 A checked beick
nove bean applied to this oesign.

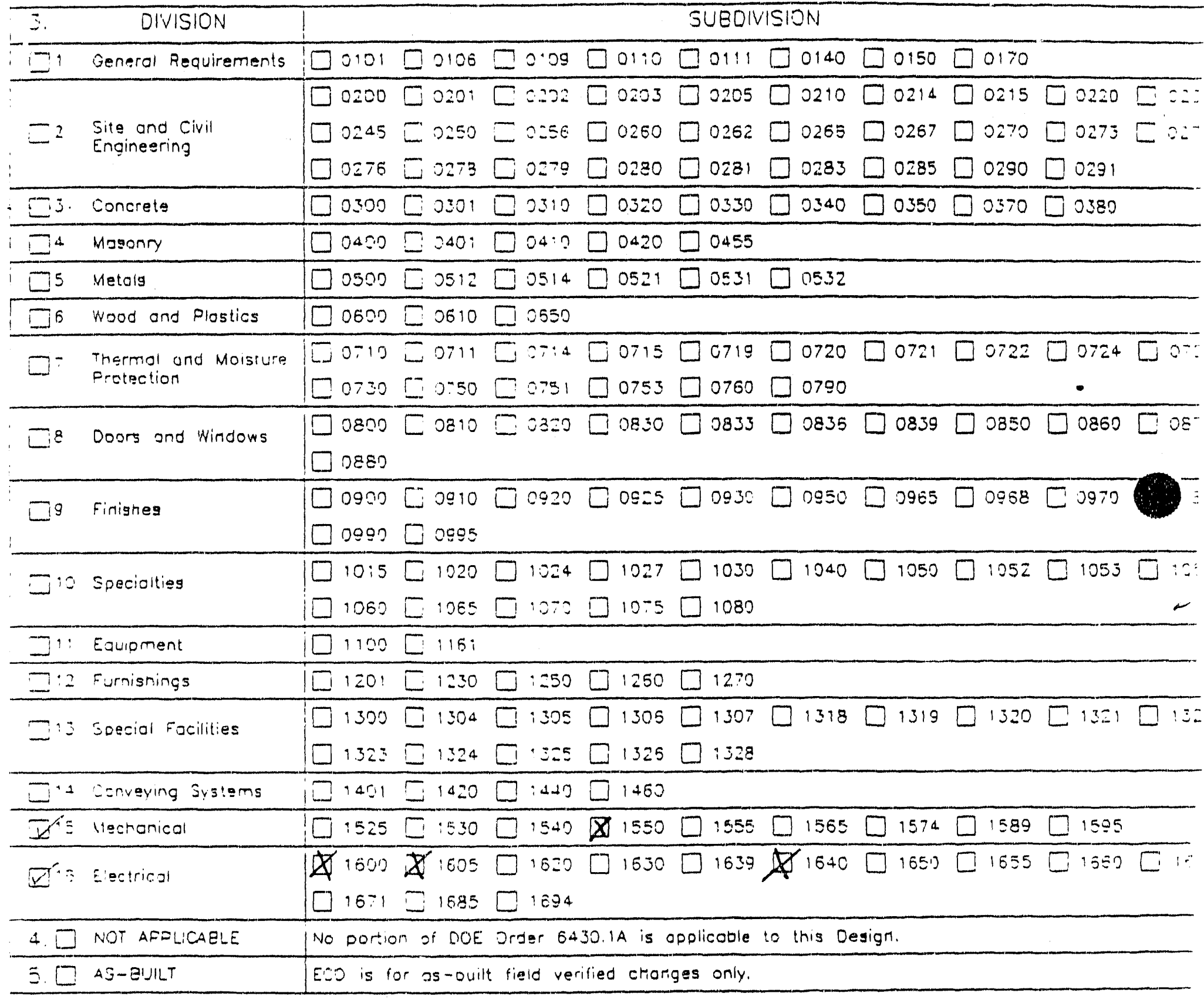

NOTE: A cheak placed in the Division column signifies that the entire Division shall be applicable to the Design, uriless modified by checks indicoted for specific Subdivigions.

COMMENTS: 


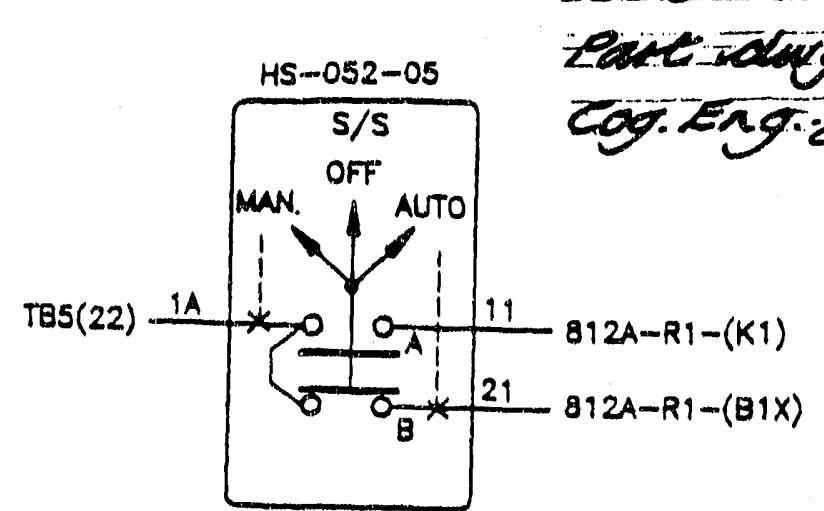

(13)

SCHENE 498812A
FECO - 5845, eage squ $32-$

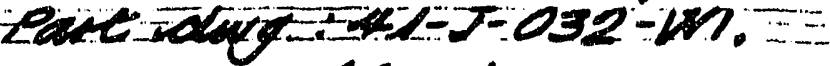

carteng. Sulde

17 oct:'91.

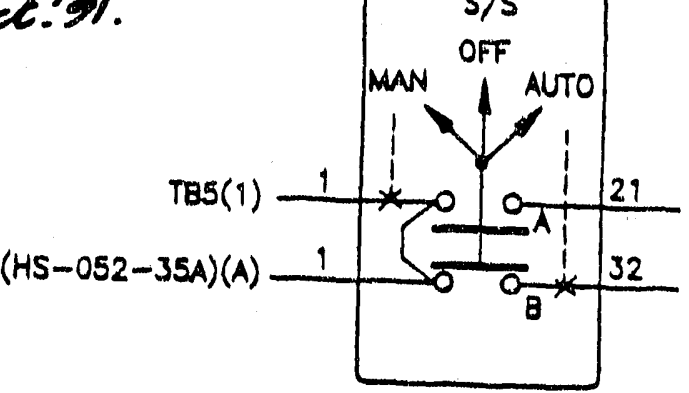

13

SCHEME 418812

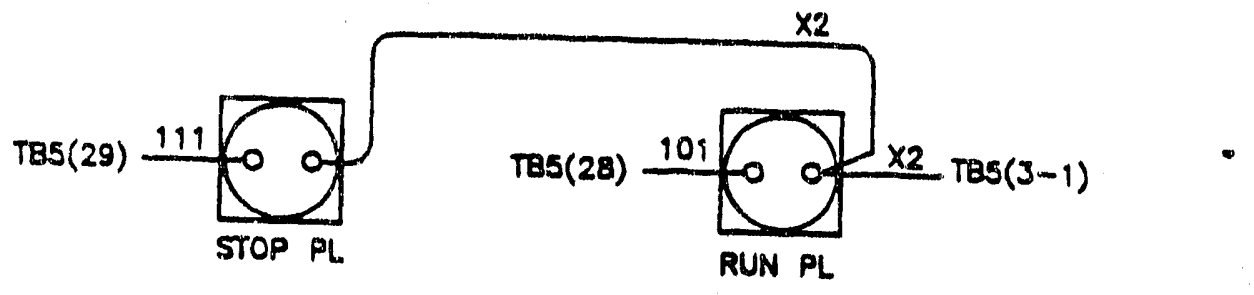

(8)

(7)

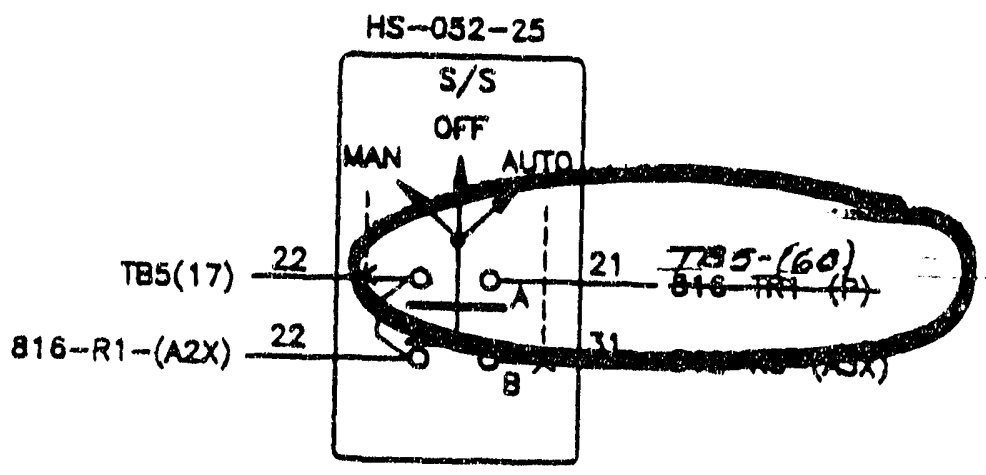

(13)

SCHEME \$18816

WIRING DLAGRAN-FRONT PANEL REAR VEW 
1. Drawing: $41-J-032-W 2$ ECO Number: $5 \& 45$

2. ECO Search List:
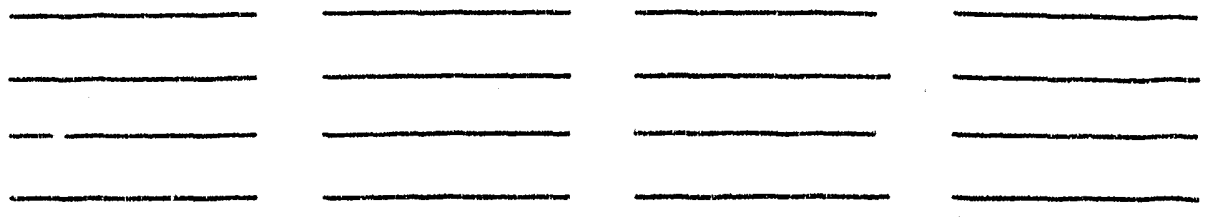

3. Description of Change:

On Scheme 41B816 make revistons as follows:

a) Timing Relay TR.1, change labelling on wire no. 21 and wire number;

b) Timing Relay TR2, change labelling on wire no. 21; both as shown marked up on page 6 of 31 .

4. Drawing Cog. Engineer Approvel: Date: 
1. Drawing: $41-J-032-W 3$ ECO Number: 5845

2. ECO Search List:
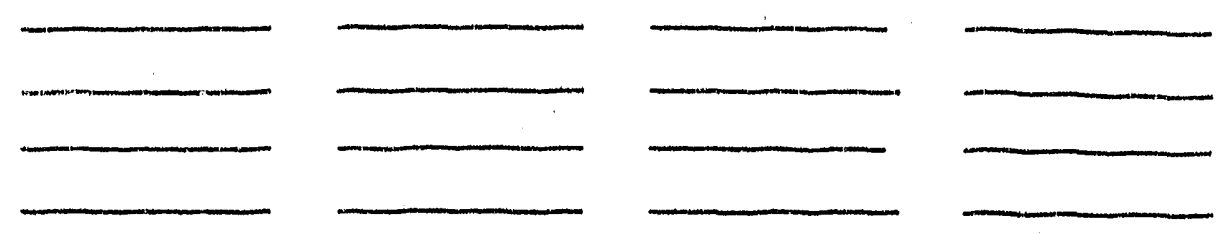

3. Description of Change:

On TB5 make changes as shown marked up or page 8 of 31 .

4. Drawing Cog. Engineer Approval: Date: 


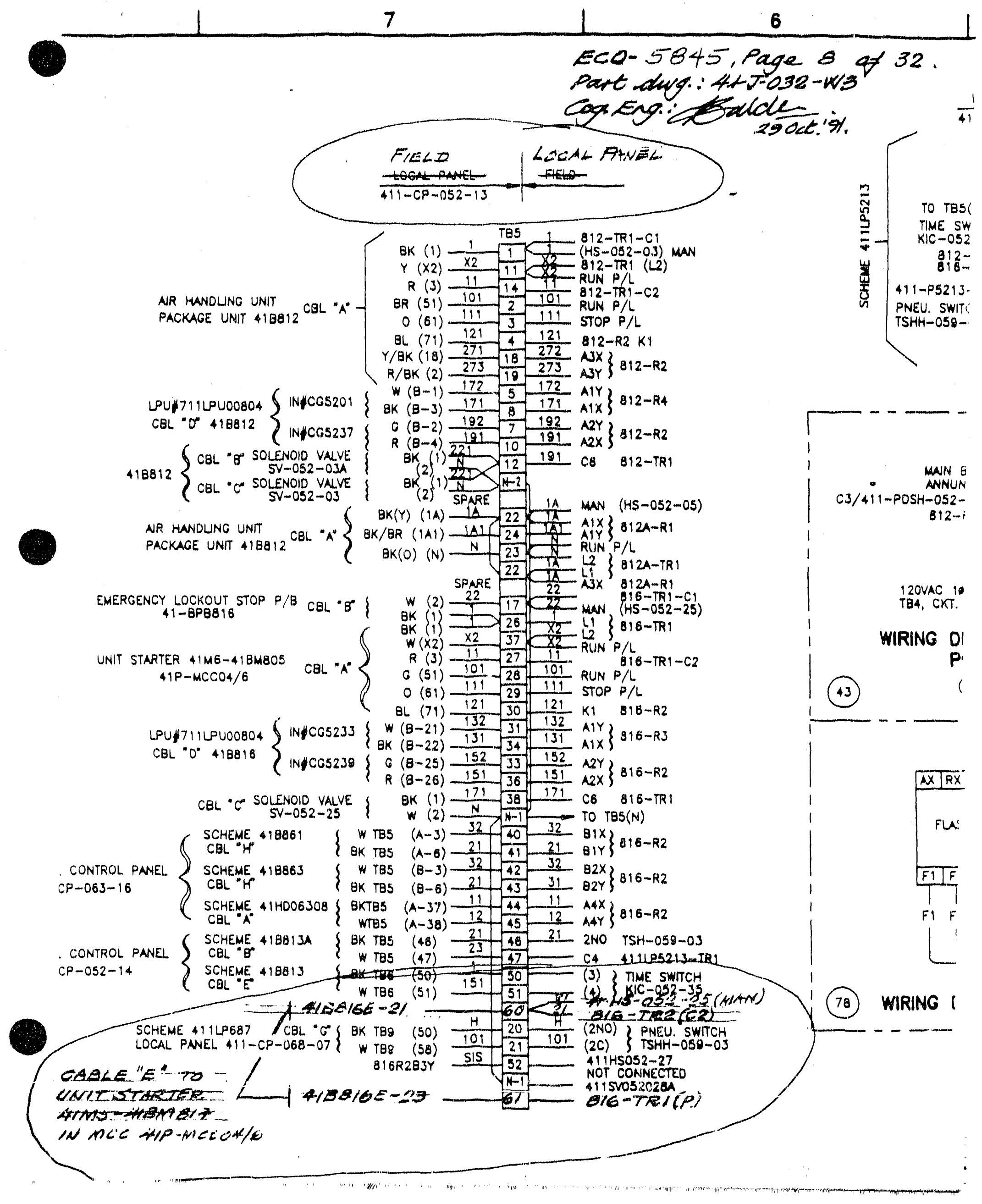


1. Drawing: 41-J-032-W5 ECO Number: 5845

2. ECO Search List:
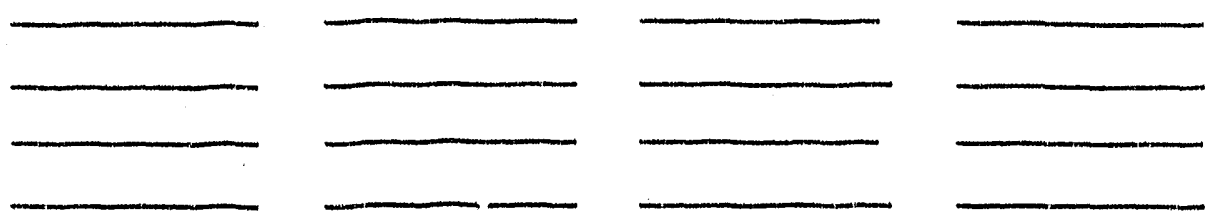

3. Description of Change:

For scheme $41 B M 816$ make the following changes:

a) Revise Schematic Diagram as shown marked up on page 10 of 31 .

b) Revise Block Diagram as shown marked up on page 11 of 31.

4. Drawing Cog. Engineer Approval:

Date: 


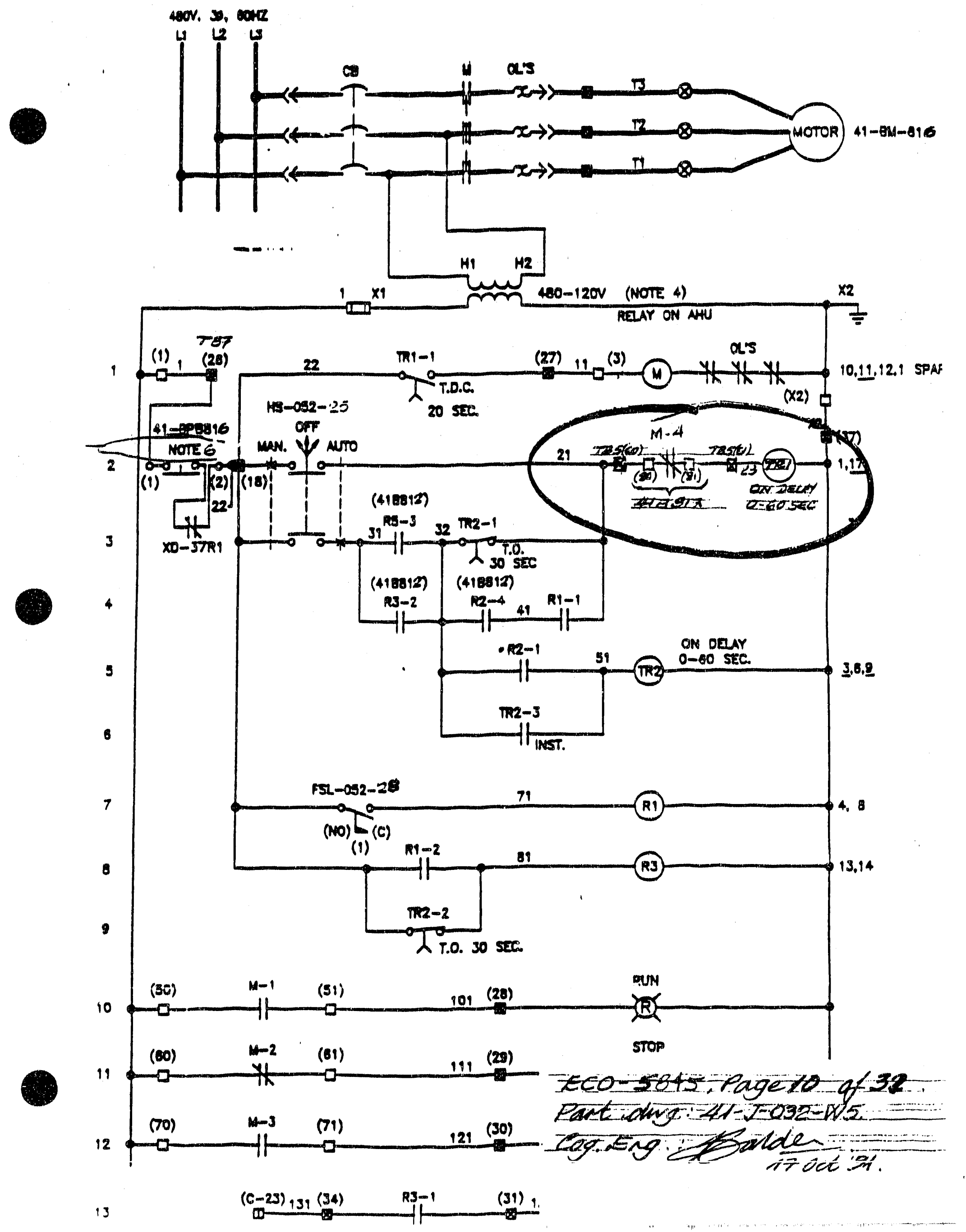



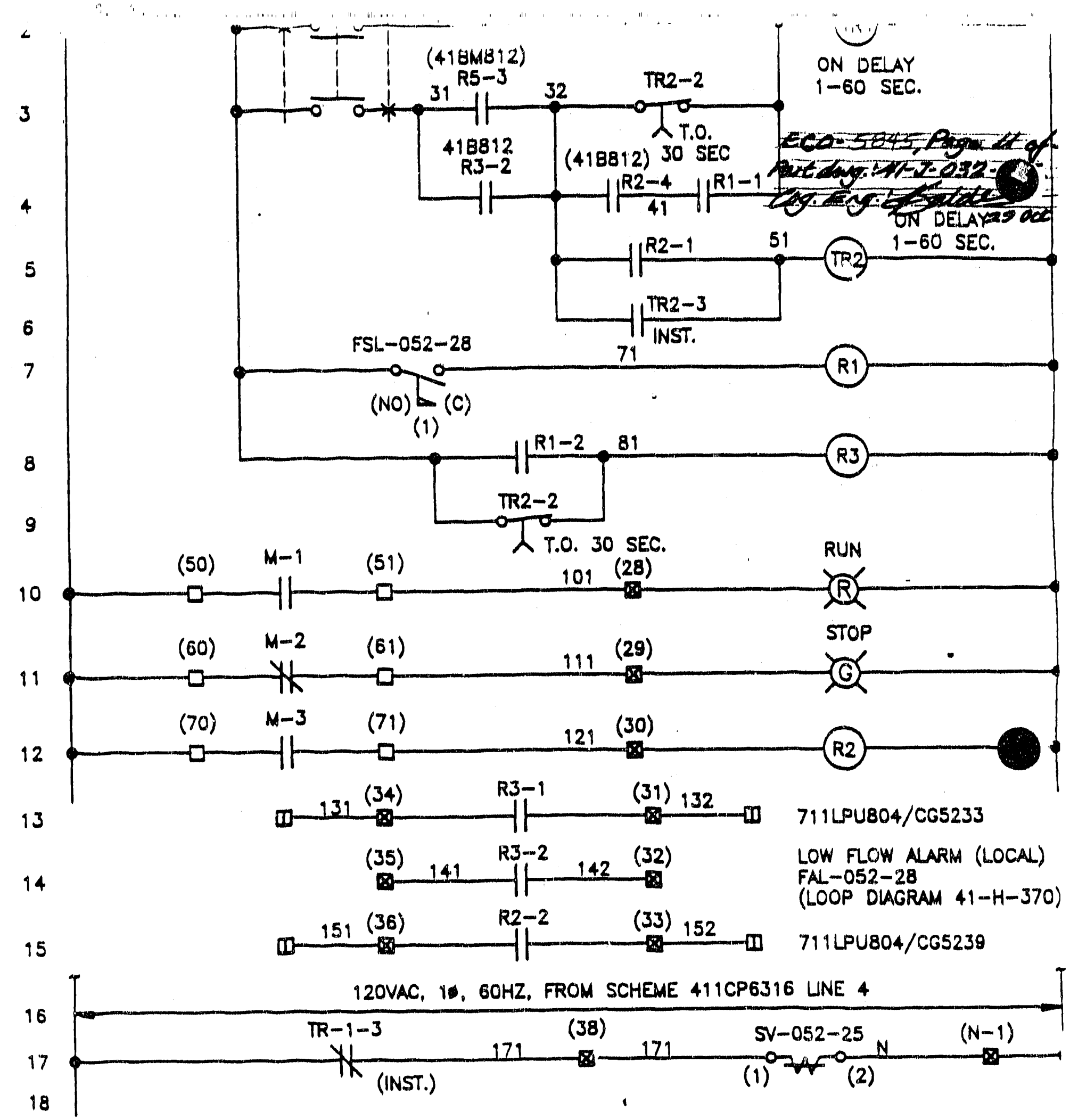
19 8

BLK. ON WALI OF $419-C P-052-13 \quad$ T1, T2, T3 $-1$

(A) CCE-7 1. $\times 2,11,101$. 111,121, ISP
$5 V-052-25$

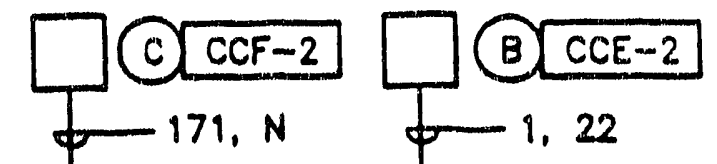

(D)

LOCAL CONTROL PANEL $411-C P-0.52-13$

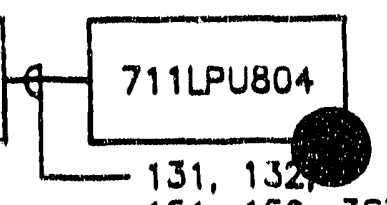

$151,152,35 P$ 


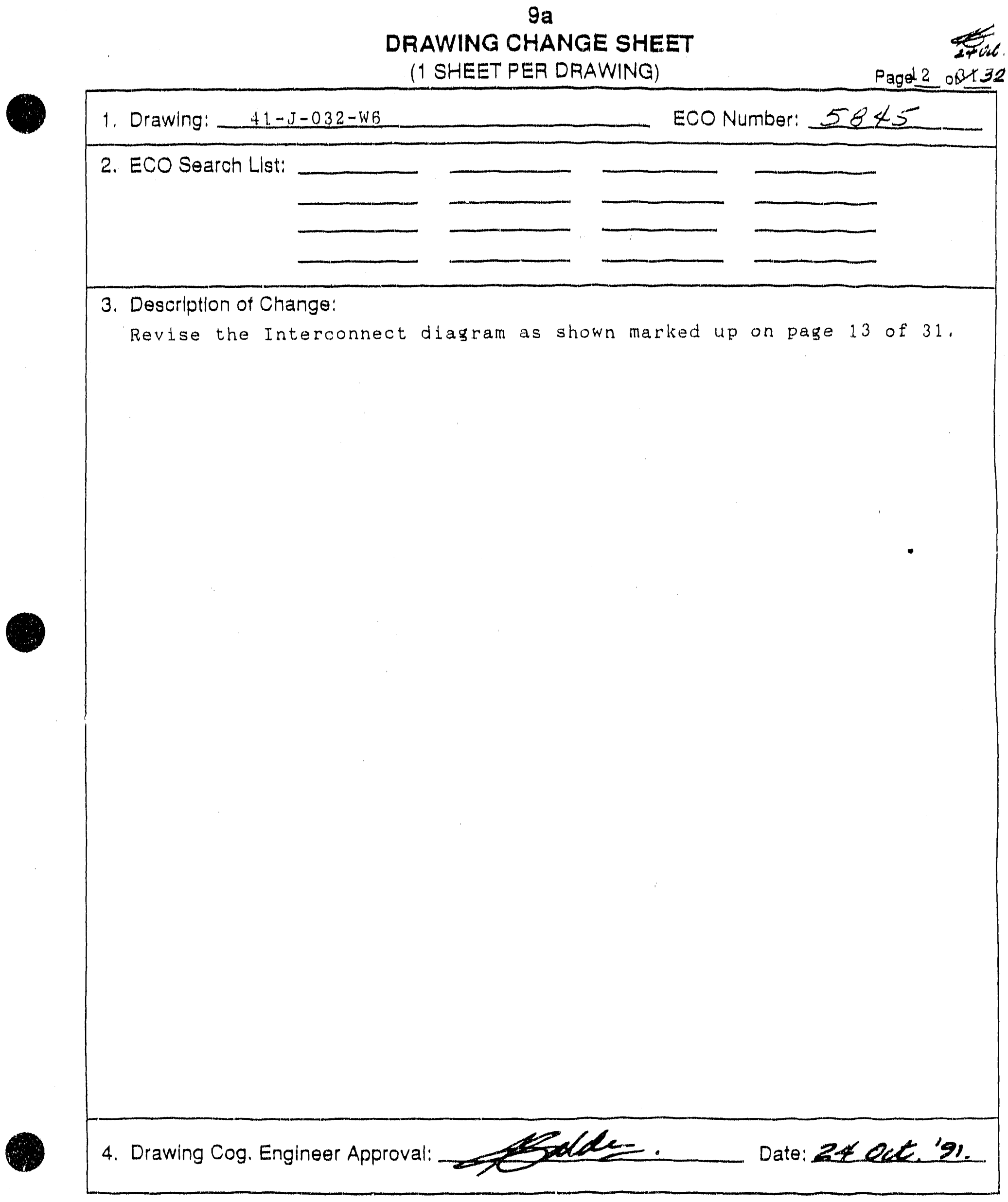

WP Form 2017; 06/24/91

1290:80006

Page 1 of 1 


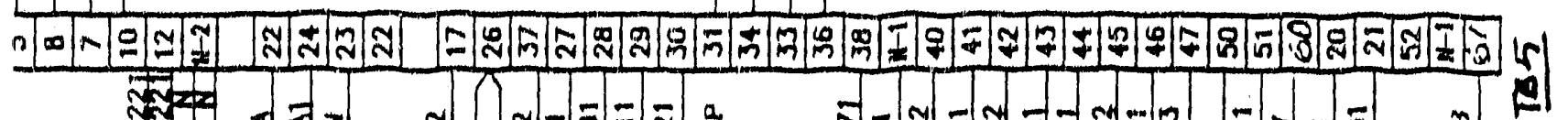

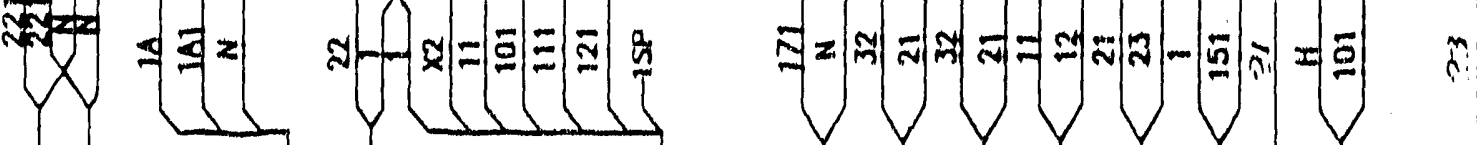

a

$\pm$
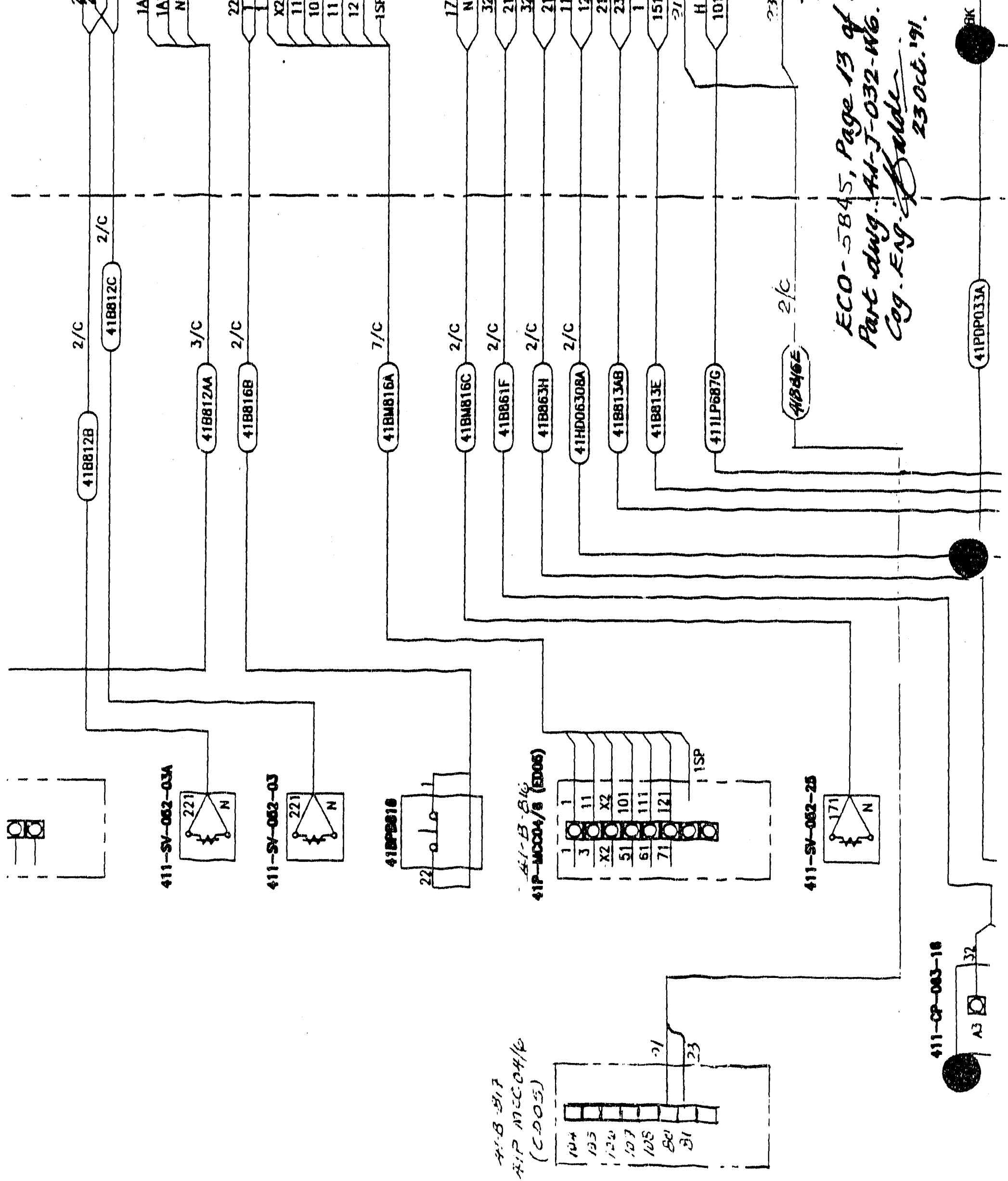
1. Drawing: $41-B-001-W 1$

ECO Number:

$5 R 45$

2. ECO Search List:
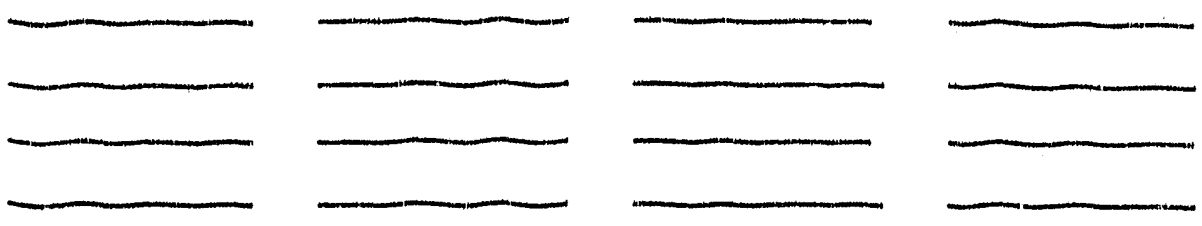

3. Description of Change:

Revise P, \& I. D, as follows:

a) For fan $41-B-818$ as shown marked up on page 15 of 31 .

b) For fan 41-B-817 as shown marked up on page 29 of 31 .

4. Drawing Cog. Engineer Afproval:

Date: 24 Od. ' 91 


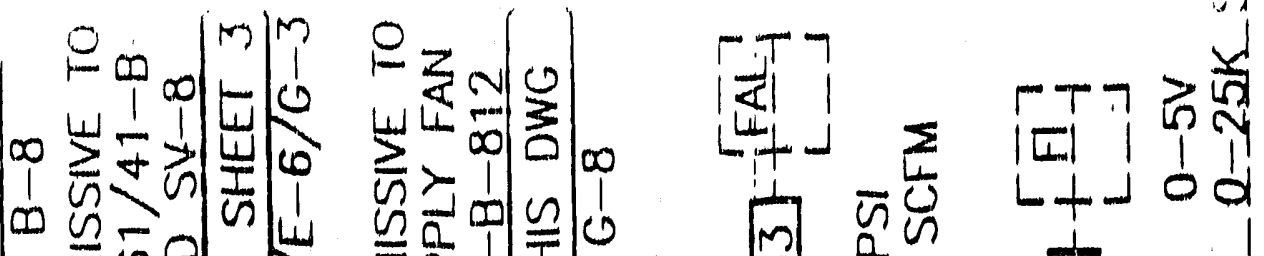

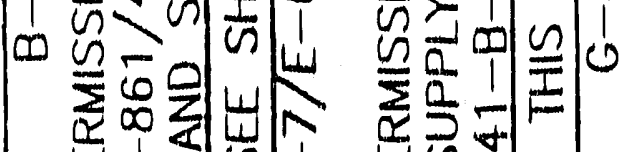

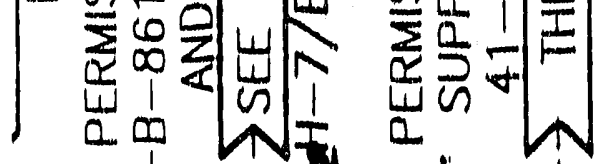


$9 a$

DRAWING CHANGE SHEET

(1 SHEET PER DRAWING)

1. Drawing: 41-H-152-014

ECO Number: 5845

2. ECO Search List:
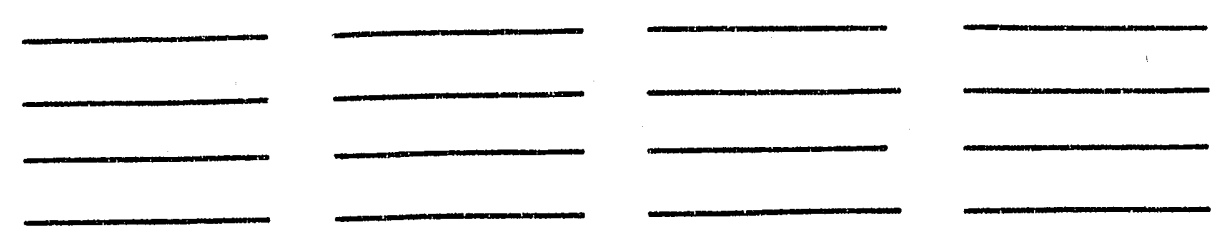

3. Description of Change:

Revise Control Logic diagram as follows:

a) For fan 41-B-816 as shown marked up on page 17 of 31 .

b) For fan 41-B-817 as shown marked up on page 30 of 31 .

4. Drawing Cog. Engineer Approval: 


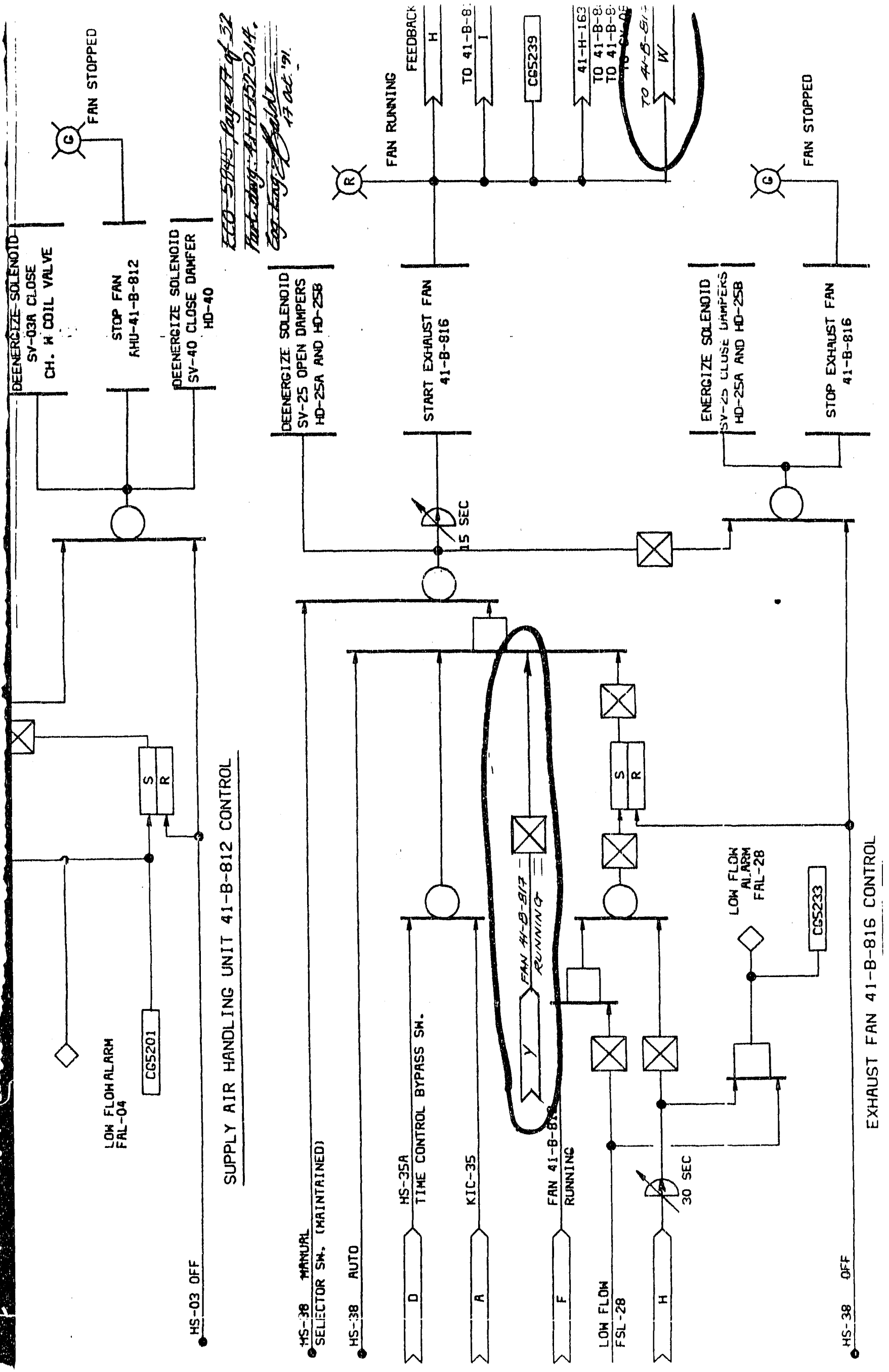


$9 a$

DRAWING CHANGE SHEET

1. Drawing:

ECO Number:

5845

2. ECO Search List:
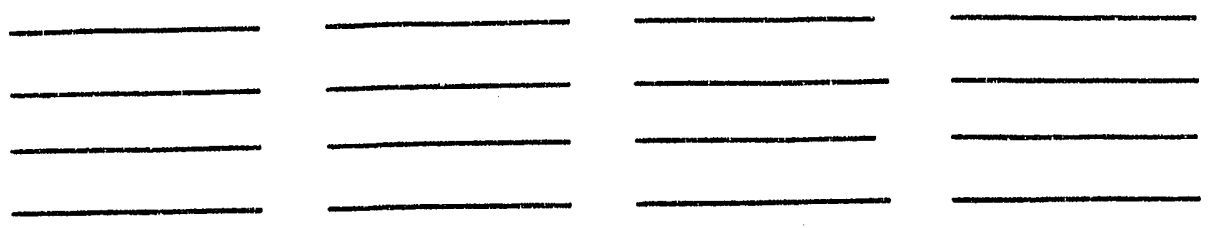

3. Description of Change:

On HS-052-32 change labelling of wire no. 21 as shown marked up on page 19 of 31 .

4. Drawing Cog. Engineer Approval: 
9 a

1. Drawing: $41-J-047-W 3$ ECO Number: $58+5$

2. ECO Search List:

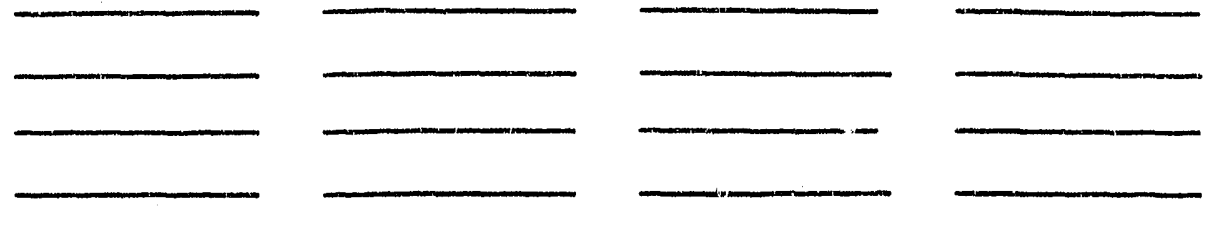

3. Description of Change:

On Scheme 41 B817 make revisions as follows:

a) Timing Relay TR1, change labelling on wire no. 21 and wire number;

b) Timing Relay TR2, change labelling on wire no. 21; both as shown marked up on page 21 of 31 .

4. Drawing Cog. Engineer Approval: 


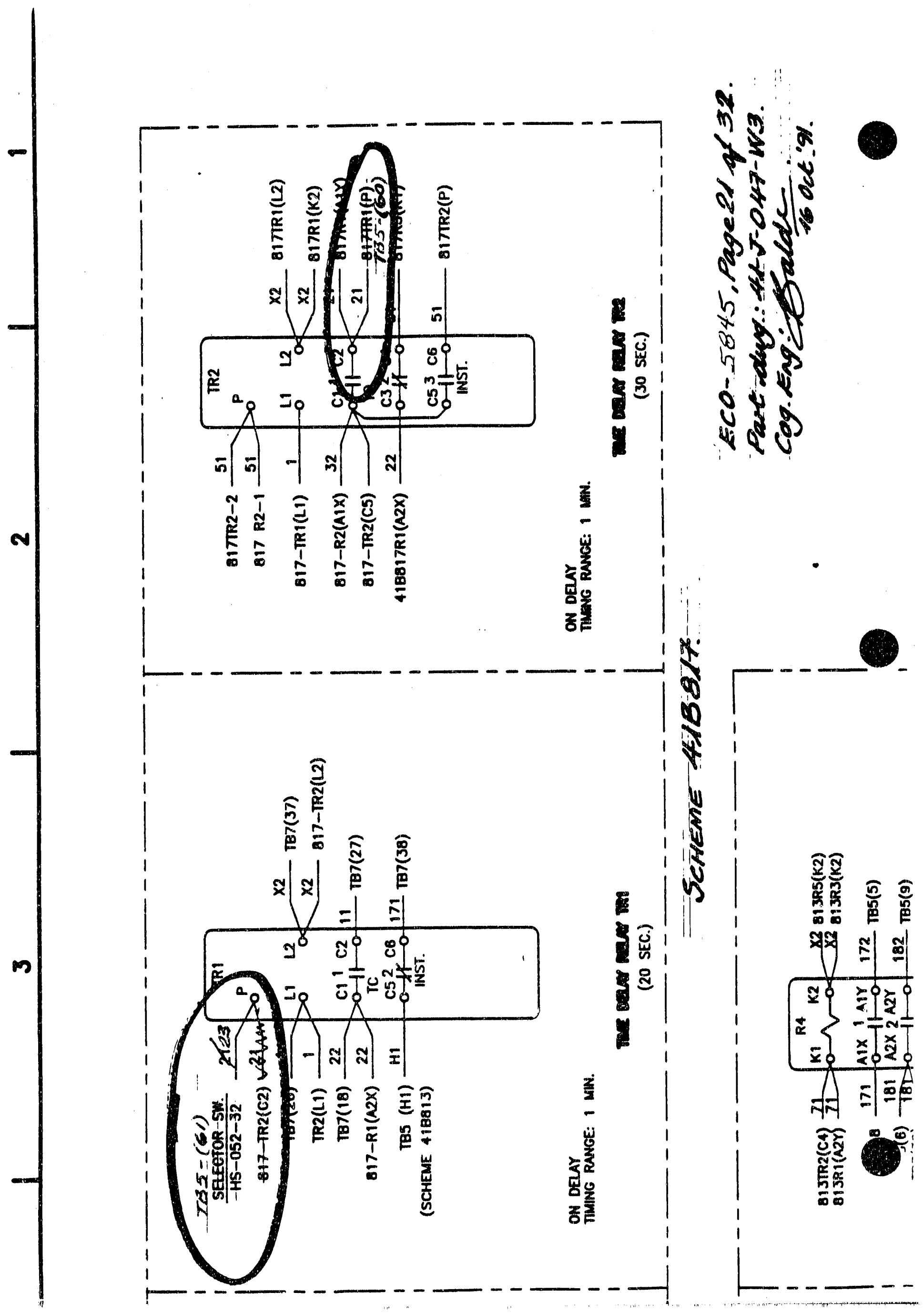


1. Drawing: $41-\mathrm{J}-047-\mathrm{W5}$

ECO Number: 5845

2. ECO Search List:
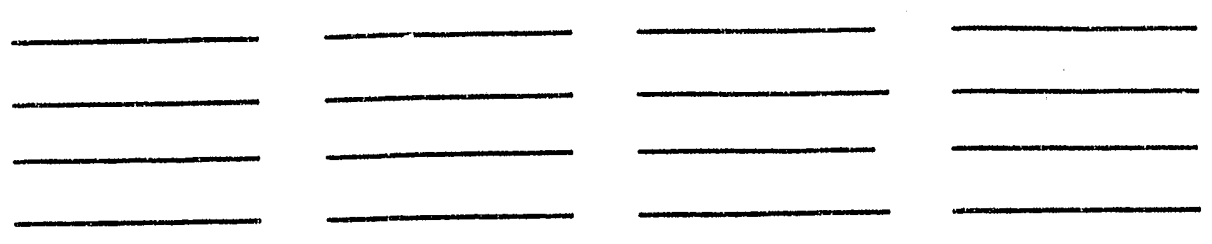

3. Description of Change:

On TB5 make changes as shown marked up on page 23 of 31 .

4. Drawing Cog. Engineer Approval: 
$1+5 \quad+4$

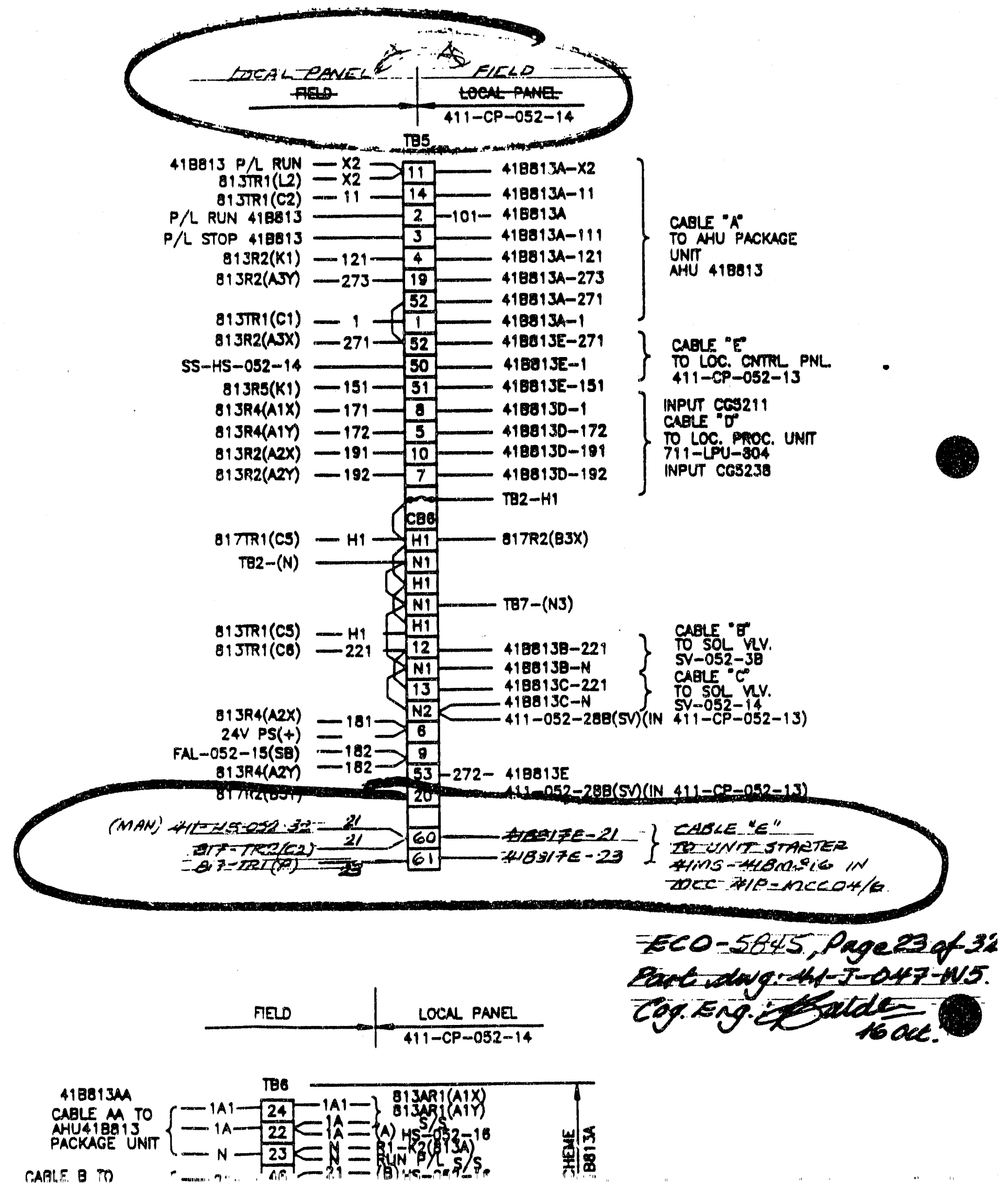


$9 a$

DRAWING CHANGE SHEET

(1 SHEET PER DRAWING)

1. Drawing: 41-J-047-W7

ECO Number:

5815

2. ECO Search List:

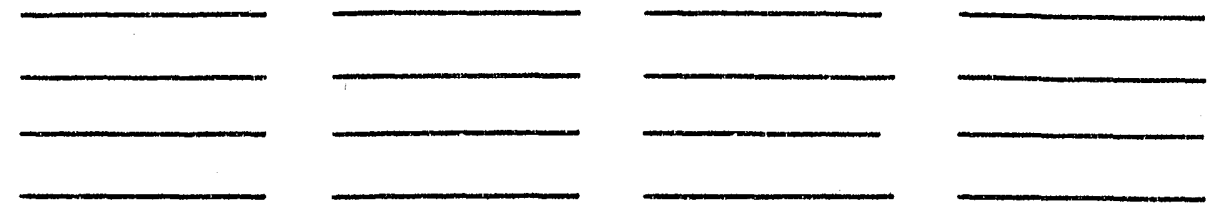

3. Description of Change:

For Scheme $41 \mathrm{BM} 817$ make the following revisions:

a) Revise Schematic Diagram as shown marked up on page 25 of 31 .

b) Revise Block Diagram as shown marked up on page 26 of 31 .

4. Drawing Cog. Engineer Approval: 


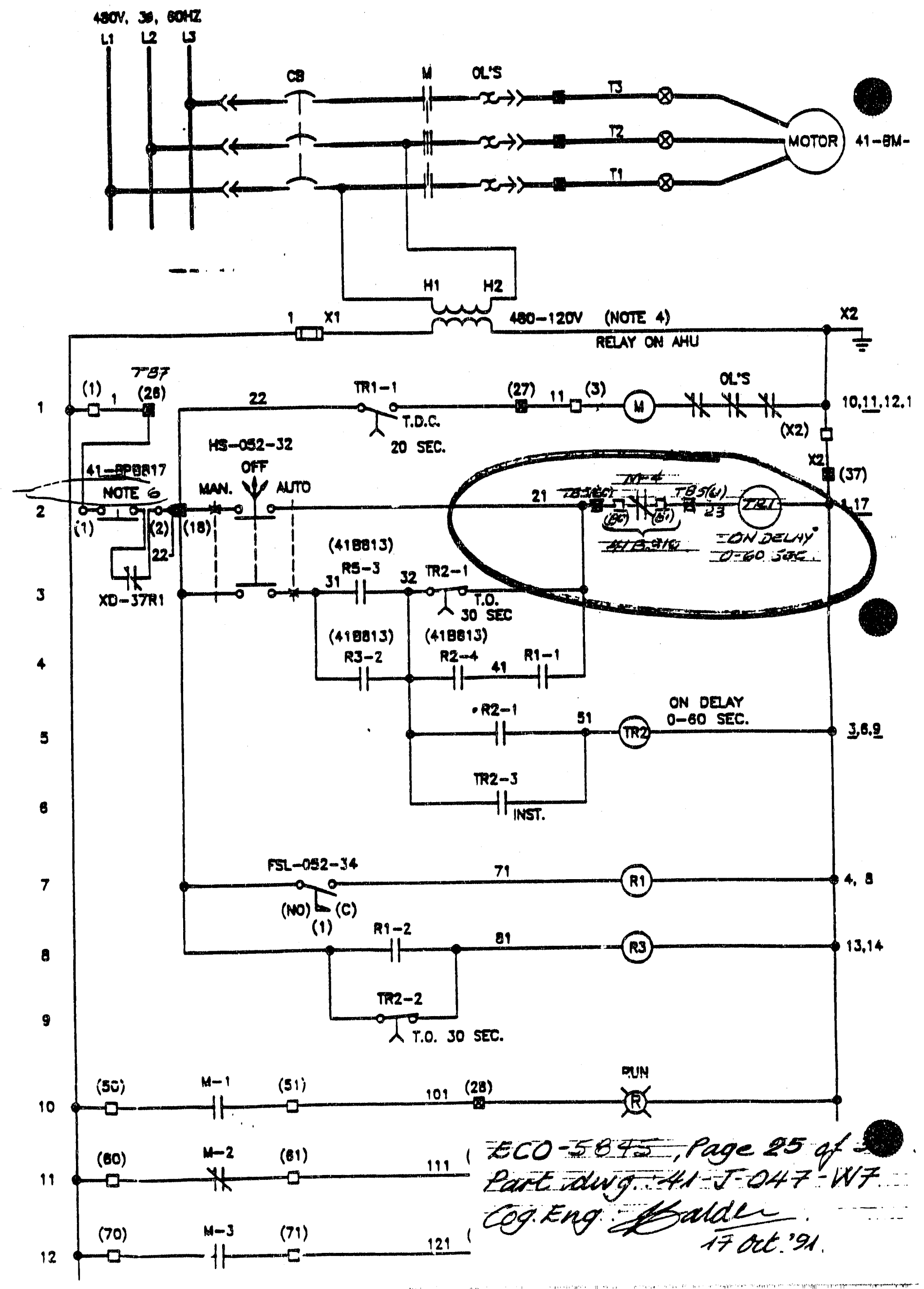




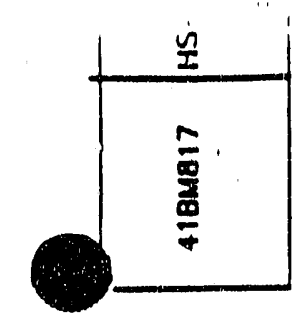

圈
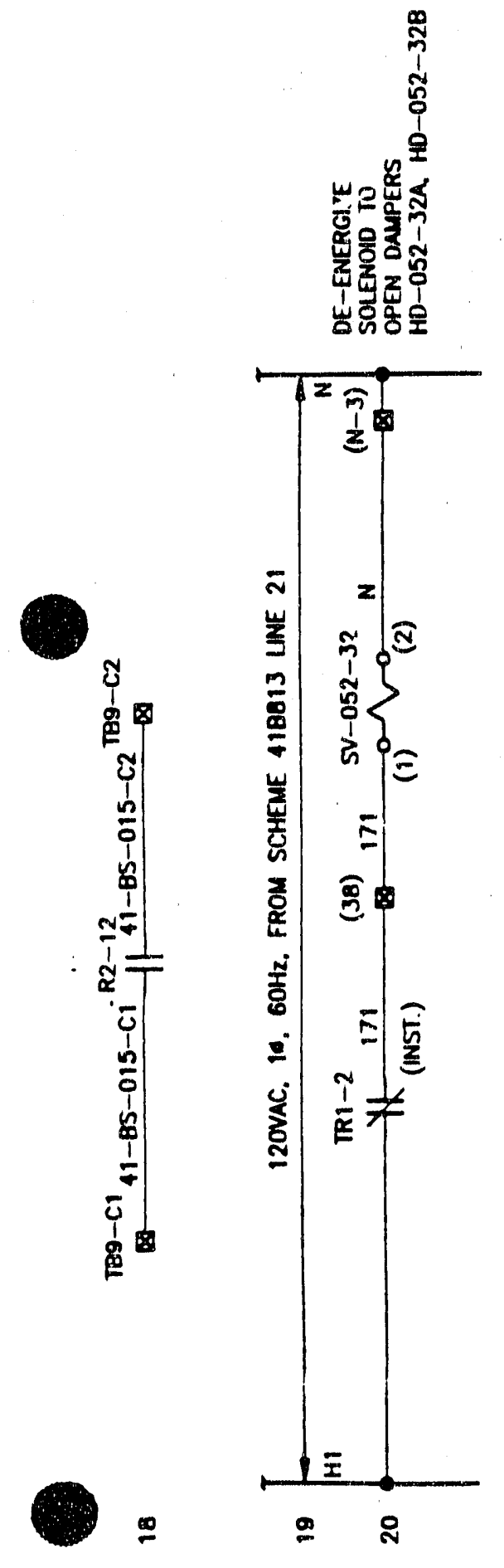

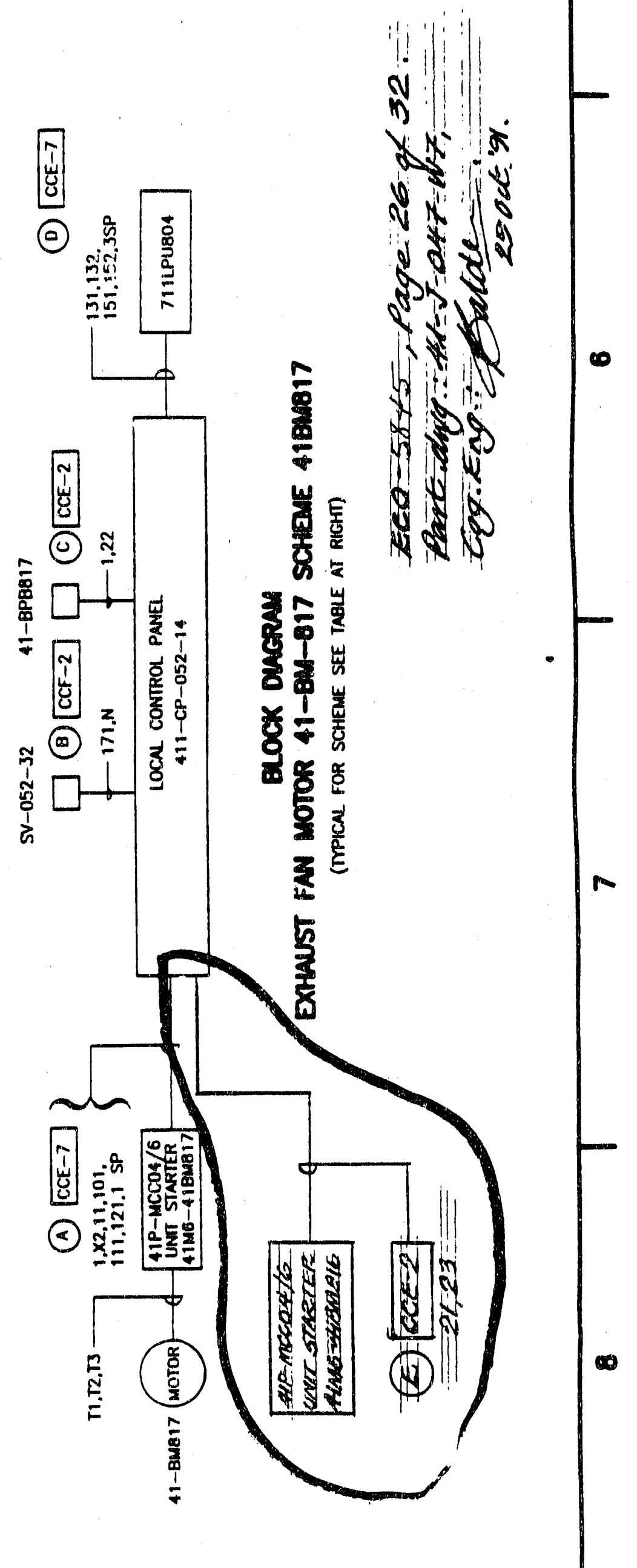


1. Drawing:

$41-J-047-W 8$ ECO Number: $58+5$

2. ECO Search LIst:
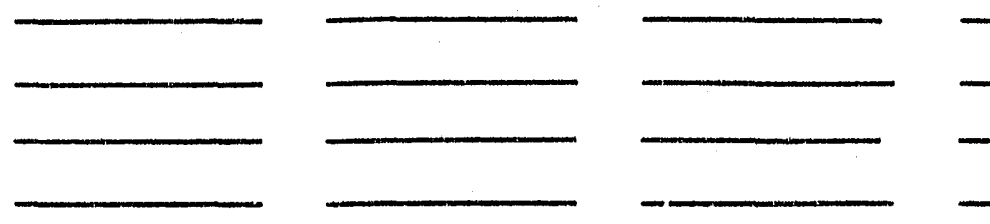

3. Description of Change:

Revise the Interconnect Diagram as shown marked up on page 28 of 31 .

4. Drawing Cog. Engineer Approval:

Date: 


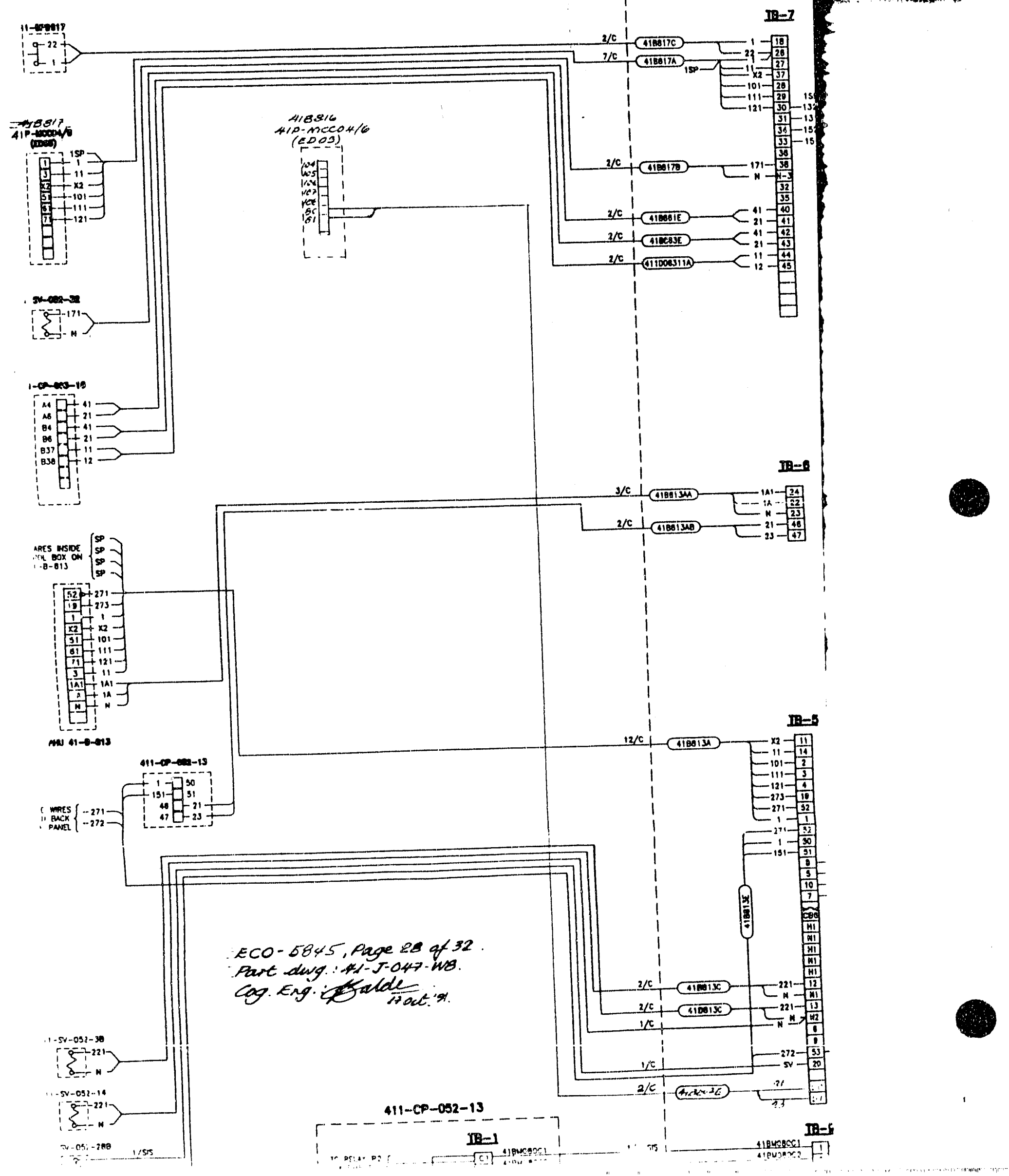




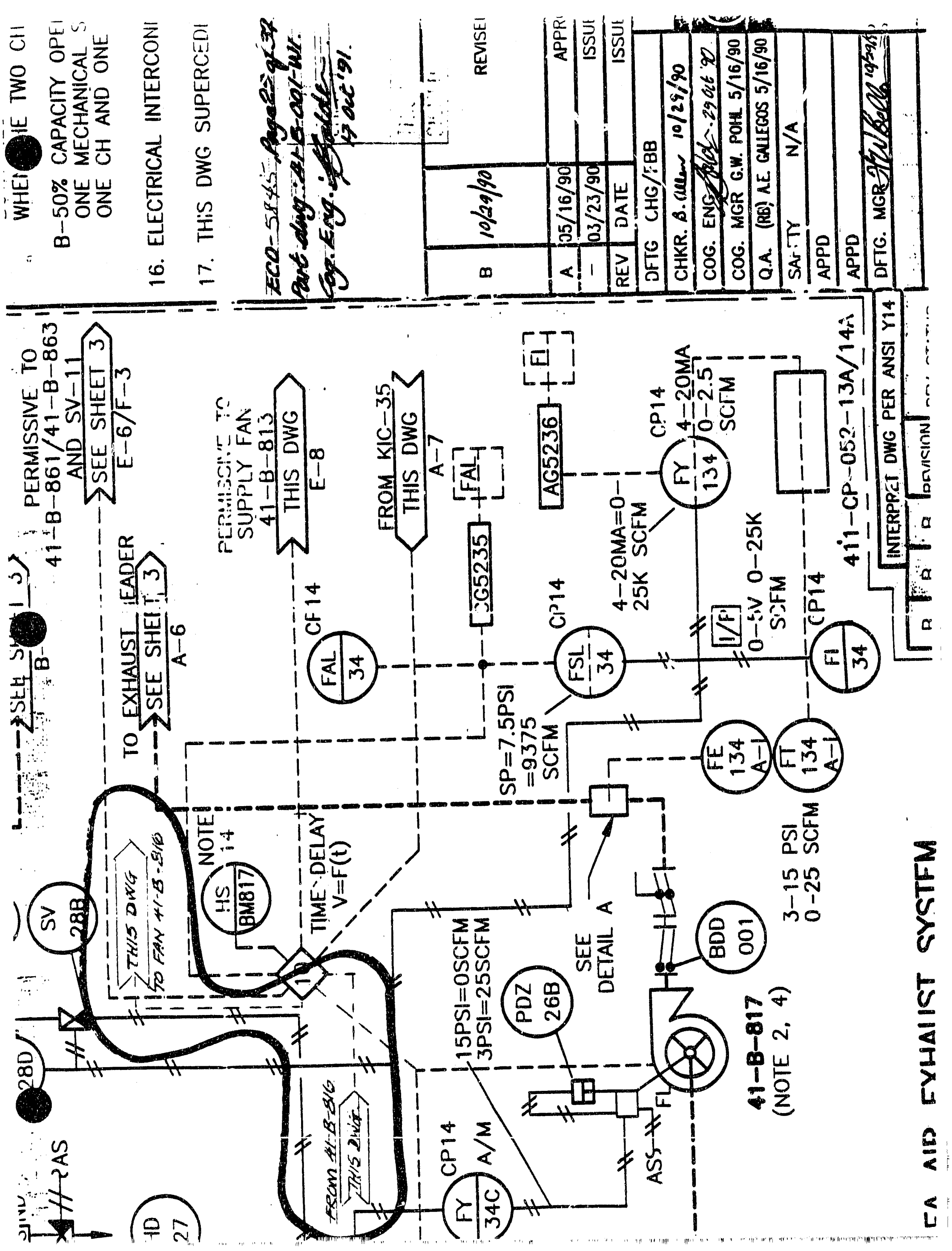




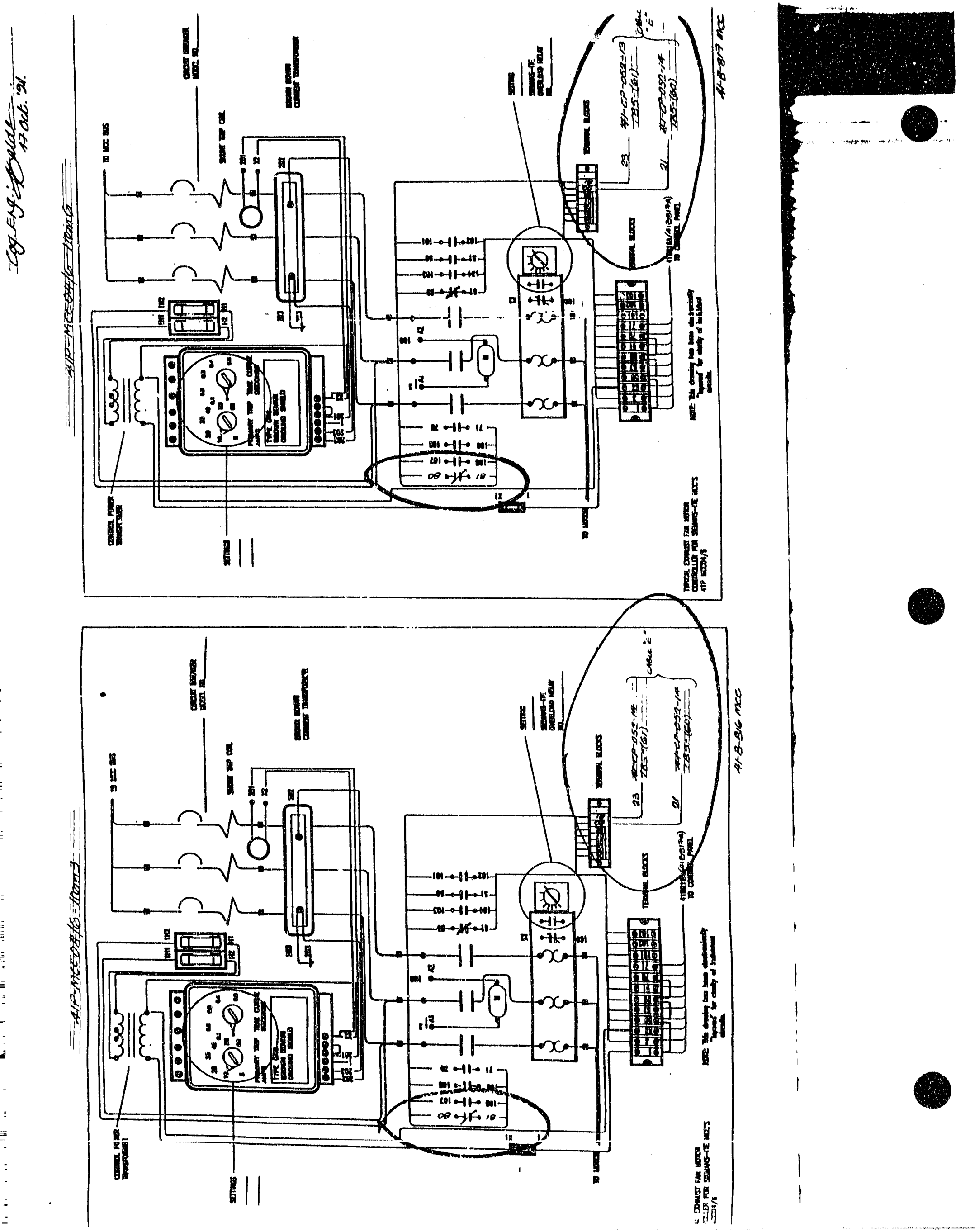




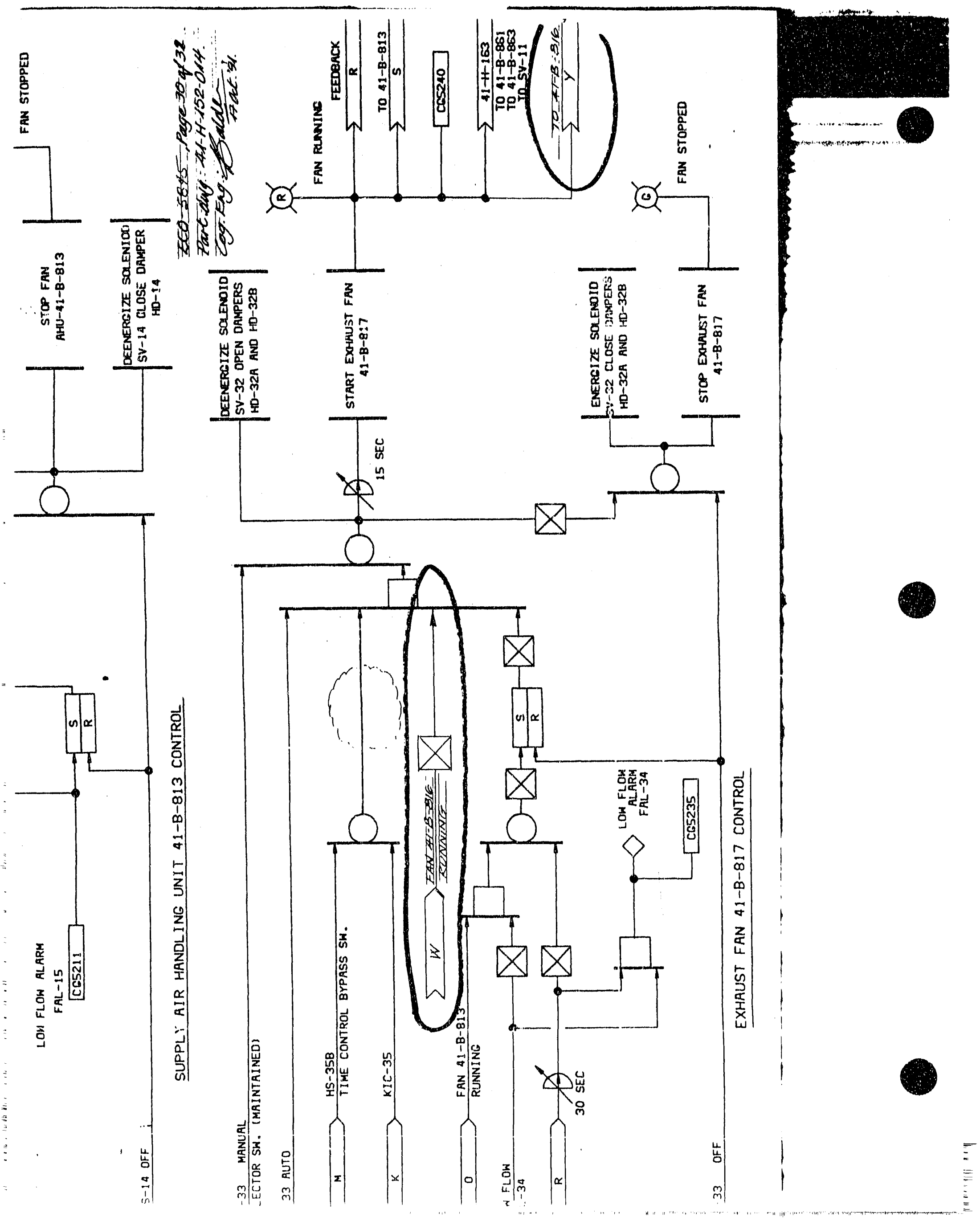


Eco- $5 x^{\circ}$, Page 32 of 3.

gb

DESIGN DOCUMENT CHANGE SHEET

(1 SHEET PER SYSTEM DESIGN DESCRIPTION REQUIRED)

1. Title and Document Number: HVAC System Design description, SDD-HVOO

2. Changes: Add HVO1 system interlock to prevent simultaneous operation of ventilation trains.

3. Markups attached (Note: Pages must be revised to reflect actual change as implemented)

4. Description of change:

Add paragraph in the appropiate control section to describe the requirement for interlocking the HV01 system trains to prevent simultaneous operation.

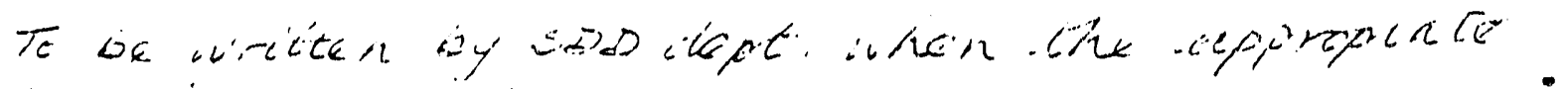

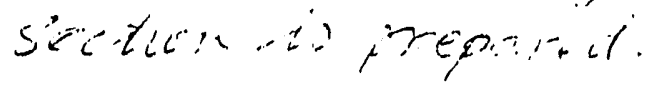

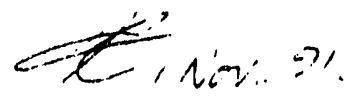

5. Posted by:

Signature

240 ac. " 4

Date

WP Form 2018; 12/29/90

$1290: B 0007$

Page 1 of 1 


$$
\begin{aligned}
\text { HHACHMET to } \\
\text { ECO } 5845 \\
282
\end{aligned}
$$

Please inclicate your concurrence with this plan by your signature below.

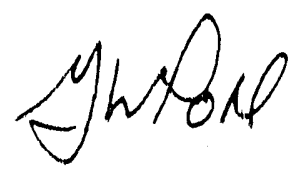

G. W. Pohl, Manager

Mechandeal Construetion Ingineoring

Ijw

I do $\bar{X}$ do not $\square$ concur with this Design Verification plan.

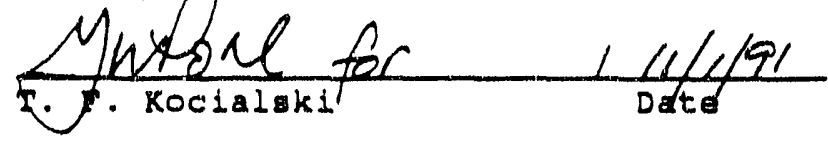

IAA:91:2467 

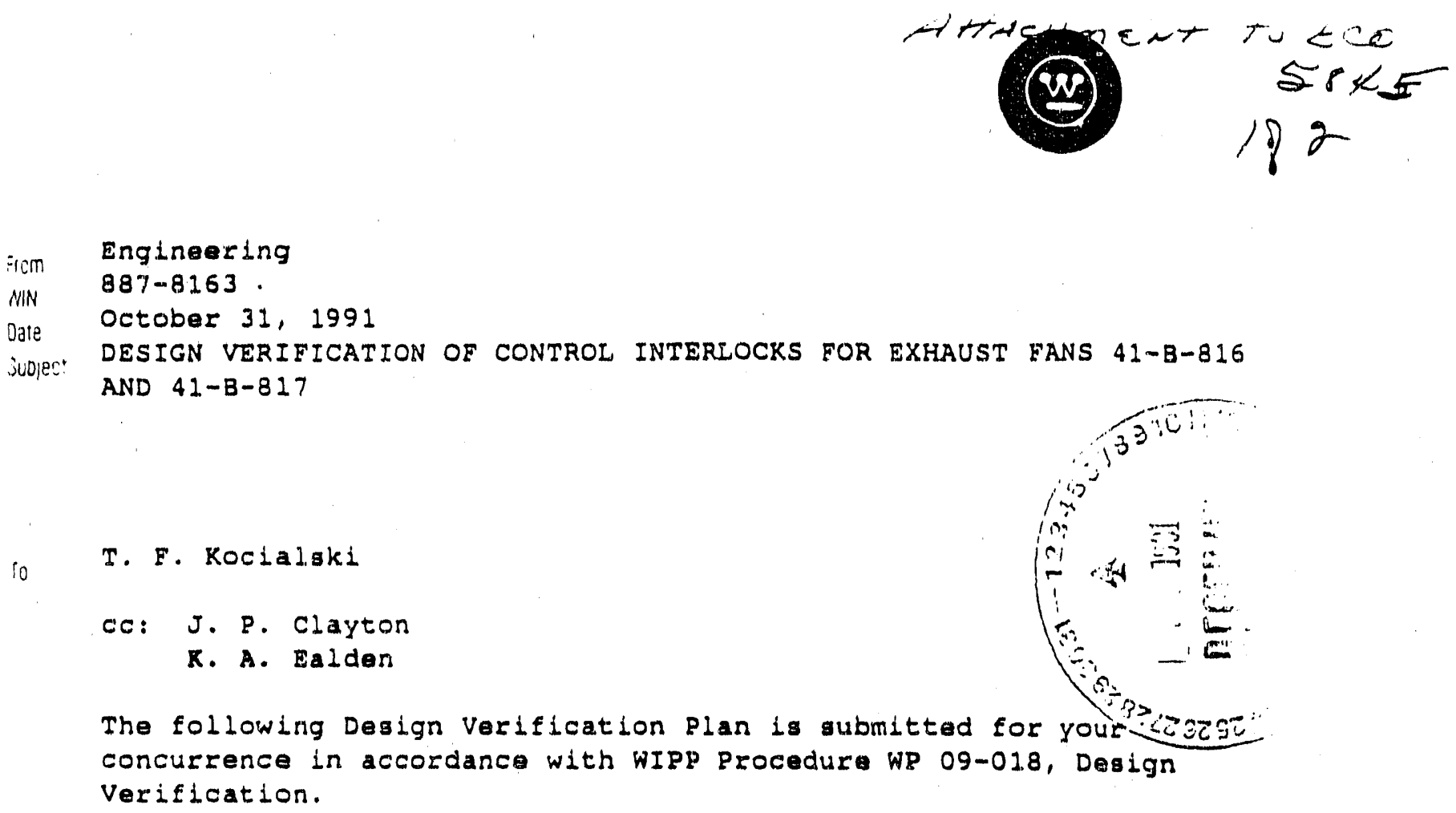

The following Design Verification Plan is gubmitted for your 32309 concurrence in accordance with WIPP Procedure WP 09-018, Design Verification.

\section{Background}

Dual train operation of the maln Contact Handled (CH) area Heating, Ventilation, and Air Conditioning (HVAC) system has resulted in deformation of the system exhaust duct downatream of the room pressure control dampers, due to the original design under estimating the negative pressure that would develop in the ducts. The prevention of aimultaneous operation of the traing i currently achieved adminiatratively. The internal Operational Readiness Review (ORR) considered that this was inadequate in the long term and that the asbociated fans should be interlocked to prevent simultaneous operation under all conditions.

\section{Design Verification}

The proposed deaign is to provide interlocks between 41-B-816 and 41-B-817 fans to prevent simultaneous operation of both $\mathrm{CH}$ HVAC system ventilation trains. The interlocks are to be provided by using a spare, normally closed, contact on the respective exhaust fan motor starter auxiliary relay. The control logic was designod by Kaith Ealden, system cognizant engineer. The design verification will be an Independent Review performed by Jim Clayton of the Electrical Engineering section. $\mathrm{Jim}$ is the degignated electrical support engineer and is knowledgeable in the HVAC area. Jim was not directly involved in the design effort. Jim's verification of the design will be noted by his signature on the Engineering change order. 
ENGINEERING CHANGE ORDER

ADDENDUM SHEET $\#$ ।

Page $\perp$ of 1

1. Addendum Sheet to ECO Number: .5845

Drawing Number: $41-v=0,32 \cdot 4$

2. Description of change: On pages 3 t 4 of 32 change drawing reference number
to $41-5-032-w^{2}$.

3. Approvals

Cognizant Engineman:

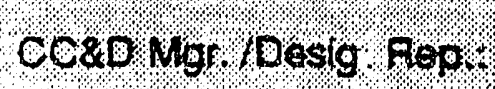

Other Approval:

Other Approvals:

Sonotoro

Signature

Dak:

WP Form 2020; 06/24/91

$1290: 8000$

Page 1 of 1 


\section{ENGINEERING CHANGE ORDER \\ ADDENDUM SHEET \#2}

Page L of 1

1. Addendum Sheet to ECO Number: 5845 Drawing Number: $41-5.032 \cdot$ W

2. Description of change:

on pages $5<6$ of 32 change drawing reference to
read Hiv.032-13

\section{Approvals}

Cognizant Engineor:

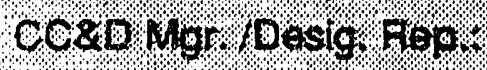

Other Approval:

Other Approval:
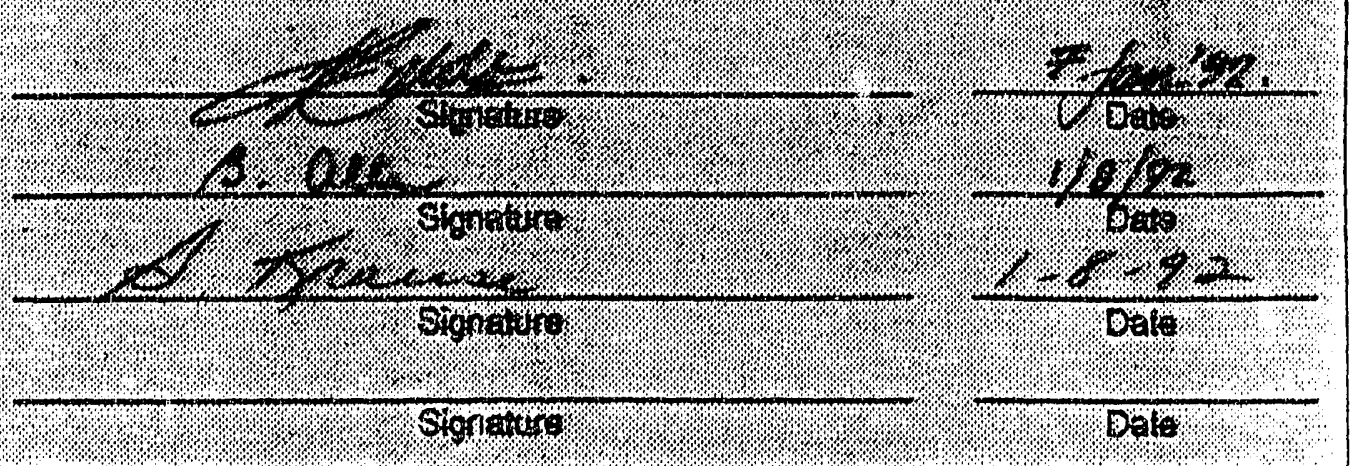


\section{ENGINEERING CHANGE ORDER}

ADDENDUM SHEET $\star 3$

Page_L of 1

1. Addendum Sheet to ECO Number:

5845

Drawing Number: $44-\sqrt{-1} 32-$

2. Description of change:

An pages $7 \% 8$ of 32 change drawing reference to
read 41-5-03\%-W4.

3. Approvals.

CognizanitEngheon:

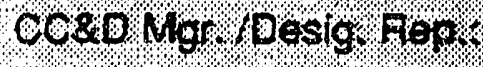

Other Approvals

Other Approval:

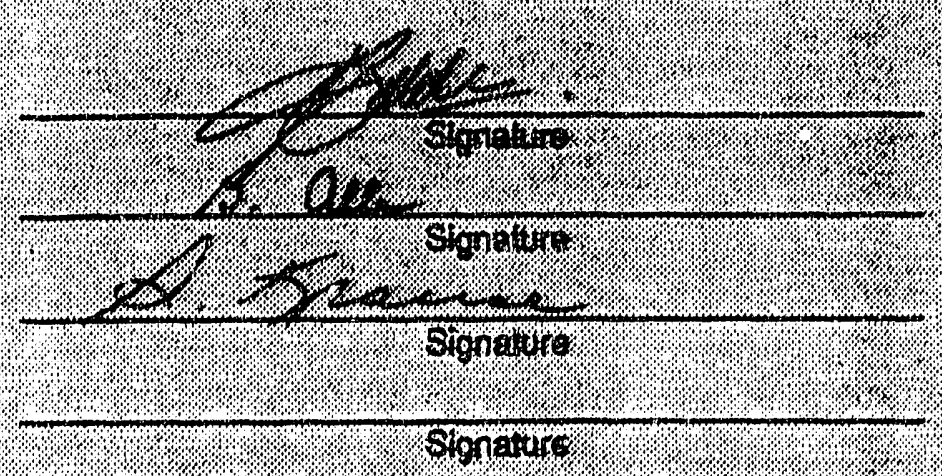

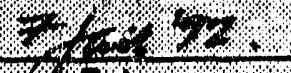

120.0

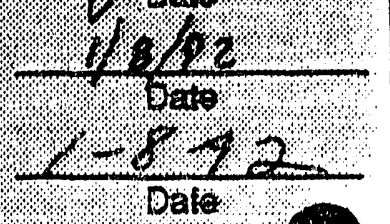

Sionatuse

Date 
ENGINEERING CHANGE ORDER

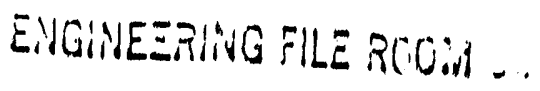

USE BLACK INK

Page 1 of $X$

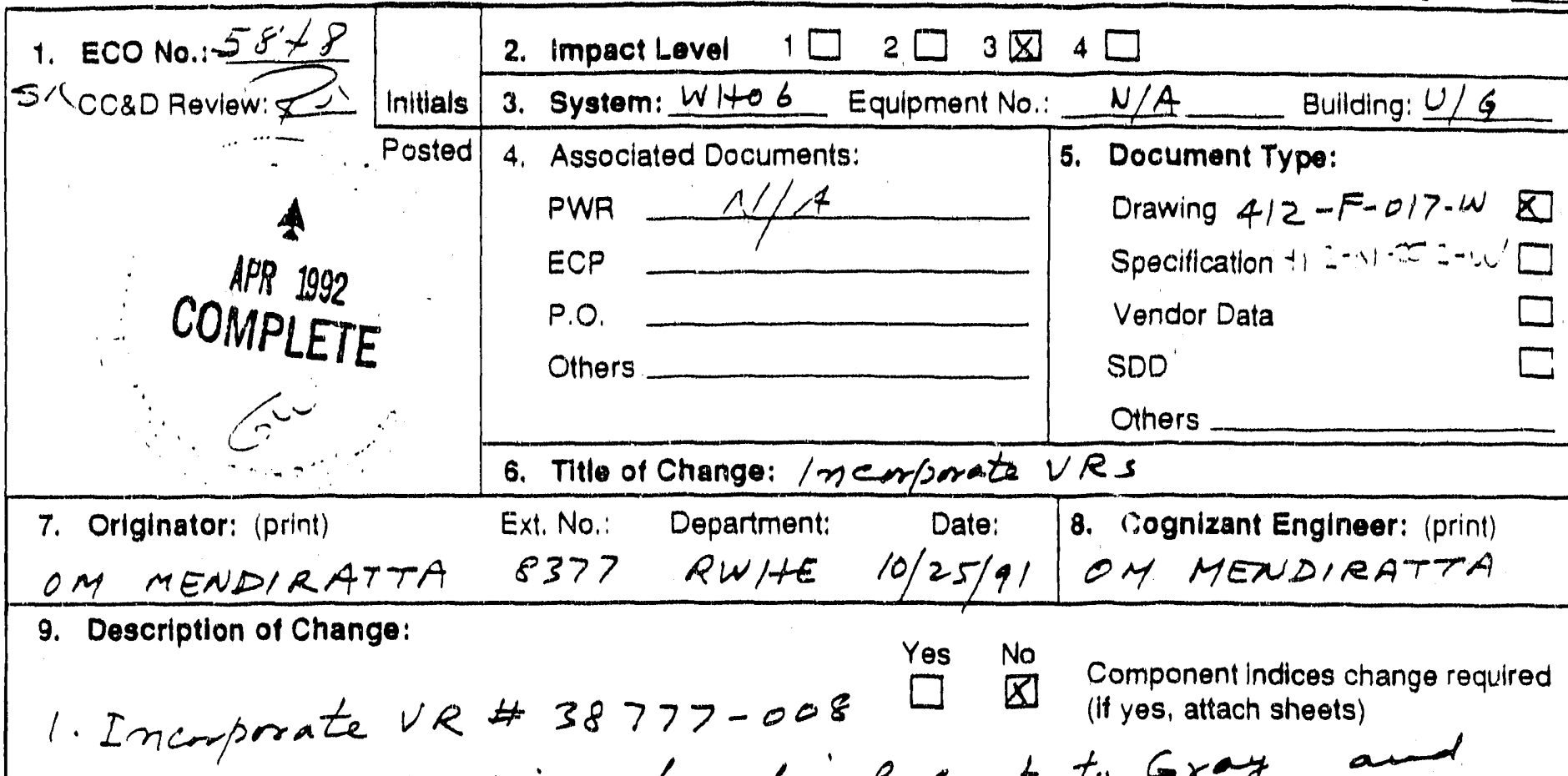

Ir change in bin color fun ge coat to Gray, add tor revision to The Identification table.

2. Fricerporate $V R$ t $3877-010$ their deletes Gasket Retainer Plate, \#23.

\a Drawing Change Sheet attached Design Documentation Sheet attached

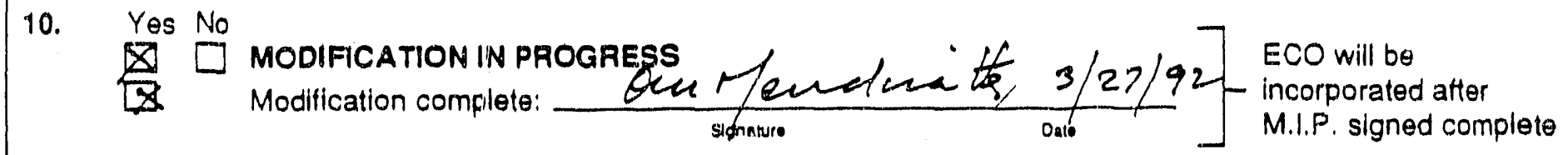

Change drawing per as-built markup dated Change drawing per ECO-provided data Temporary modification

allen Requirements: (per WP 09-018) EDT No.:
\[ \text { 1. Requirements satisfied by review/approval of design document } \] 2. Independent review

3. Alternate calculations

4. Development testing

5. Design review

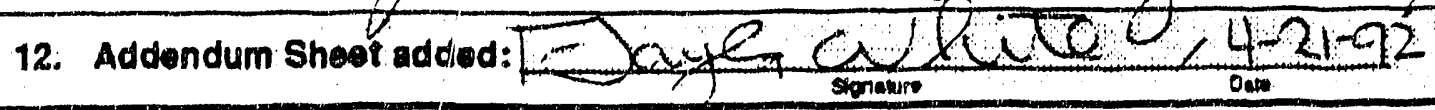

WP Form 1200; 12/29/90
Page 1 of 3

11906:0005

Page 1 of 3 
13. Justification

Incerporated previumby aplaroved $V R s$.

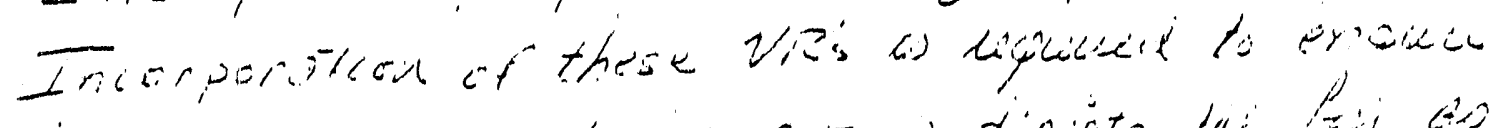

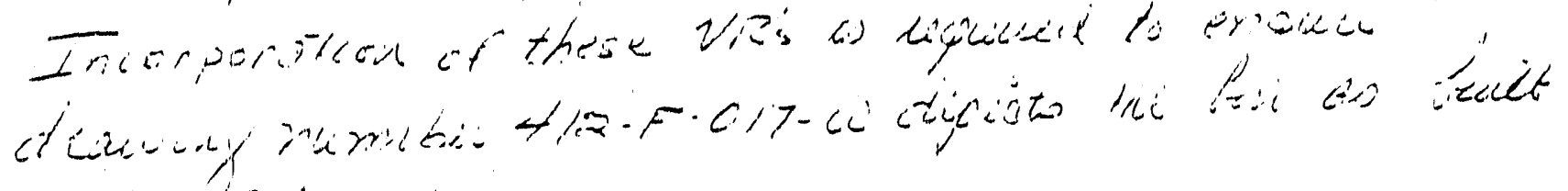

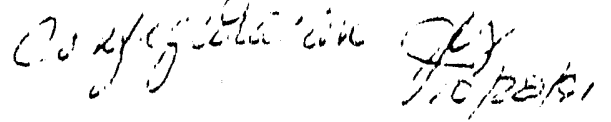

14. Administrative Tracking

YES N/A YES N/A

$\square$ 1. FSAR $\square \square$

2. Calibration Procedures $\square \square$

$\square$ 3. Maintenance Procedures

$\square \square$

4. Computer Sottware

$\square \square$

5. Operations Procedures

$\square \square \quad 10$.

\section{Signature Requirements}

R-REVIEW
SMSIGN NEW

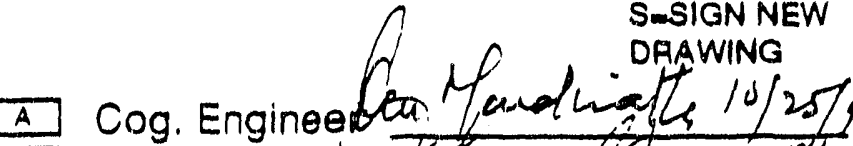

$A$

A

[1]

$\square$

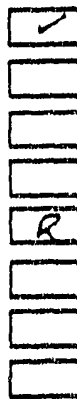

Cog. Eng. Mǵr Lhx 1 towned

Startup

QA

DOE

Safety

Dept. Manager

Operations

Security

SNL
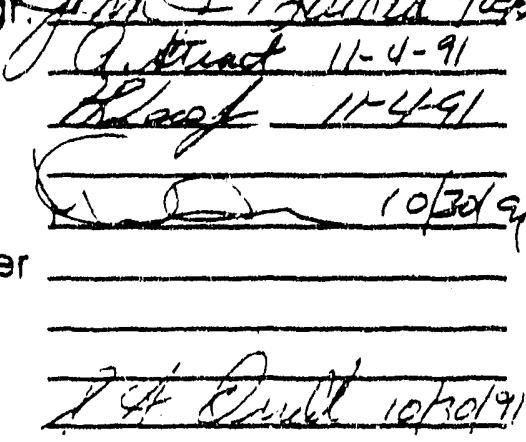

\section{Distribute as Marked}

Maintenance (MANDATORY)

Ops. Support MANDATOAY)

Startup

Facility Operations

U/G Operations

Orig./Design Engr.

Cog. Engineer

Others

SNL $1 A$. Orred

aA $C H \cdot L e \operatorname{Les}$ 


\section{ENGINEERING CHANGE ORDER DOE ORDER 6430.1A DESICN CRITERIA \\ CHECKLST}

The eesign recuirements in DOE Order E4J0.1A checked below nove been coviled to this Design.

\begin{tabular}{|c|c|c|}
\hline $\bar{Z}$ & DIVISION & SLEOIVISION \\
\hline $\bar{z}$ & General Pequirements & 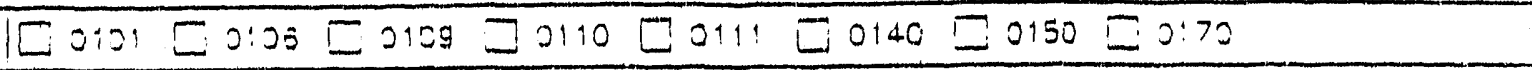 \\
\hline & & {$[\square 0220 \Xi 2201 \square 0222] 0203 \square 0205 \square 0210 \square 0214[0215 \square 2220[223$} \\
\hline$\ldots$ & Sitg ama Divil & {$[0245 \Xi 0250[0256] 0260[0252 \quad[0265 \square 0267[0270$} \\
\hline & & $=020500278 \square 0270 \square 0280 \square 0231 \square 0253 \square 0235 \square 0290 \Xi 0231$ \\
\hline 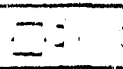 & incrate & 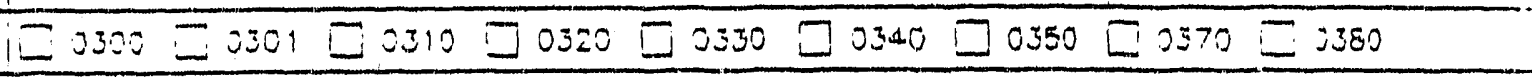 \\
\hline$\overline{-4}$ & Mesonn & 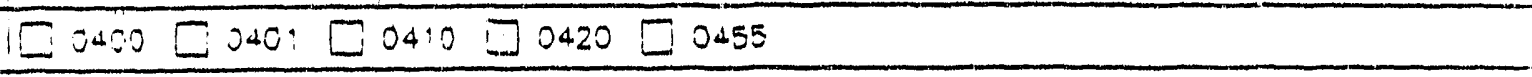 \\
\hline 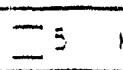 & Marolg & $50500=0512 \square 0514 \equiv 0521 \square 0531 \square 0532$ \\
\hline $\bar{E}$ & Wroo ane Plostics & $-2000[0610 \square 0050$ \\
\hline-1 & ing-mal ane Moisturs & 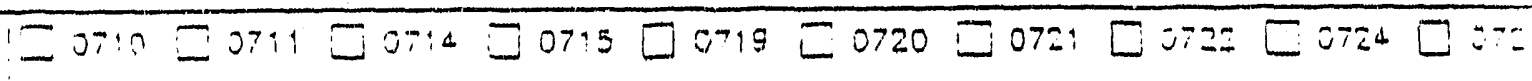 \\
\hline & $=-$ section & {$[030 \square 0750 \square 0751 \square 0753 \square 0760 \square 0790$} \\
\hline & Doors and Wirdows & 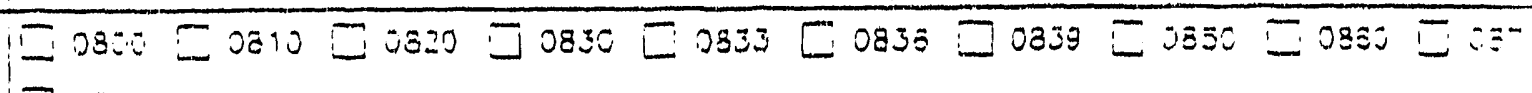 \\
\hline & & II 2000 \\
\hline & $=$ nignes & 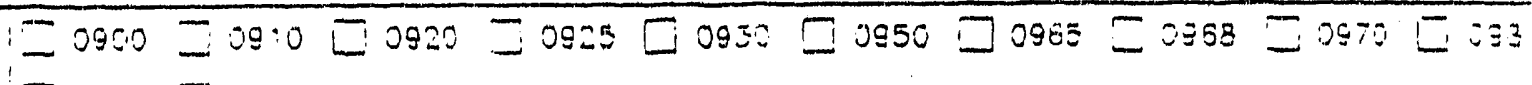 \\
\hline & & $I 500052995$ \\
\hline$-\cdots$ & steciolties & 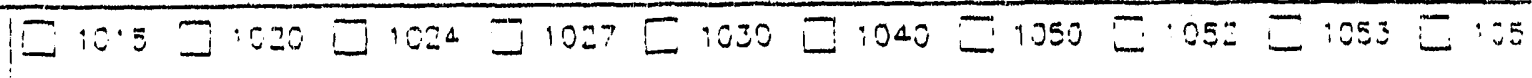 \\
\hline & & $=000 \equiv 005 \Xi 1070 \Xi 1075 \square 080$ \\
\hline & Esuipmen: & $5 \cdot 00 \div 0:$ \\
\hline$=3$ & $=$-nignings & $\Xi 1201 \Xi 1230 \square 1250 \square 1250[1270$ \\
\hline & Starial Focilities & 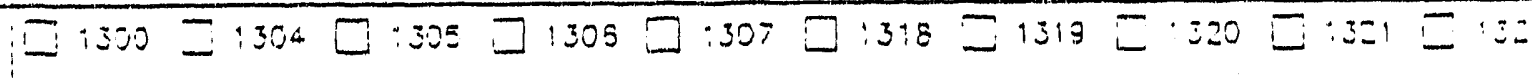 \\
\hline & 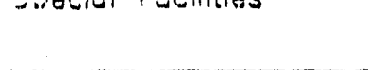 & $\Xi 1325 \beth 1324 \square: 325 \square 1325 \square 1328$ \\
\hline$=-\therefore$ & Conveying Sysiams & II:: $\square 1420 \square: 440 \square 1460$ \\
\hline$=-3$ & Wheneniso: & 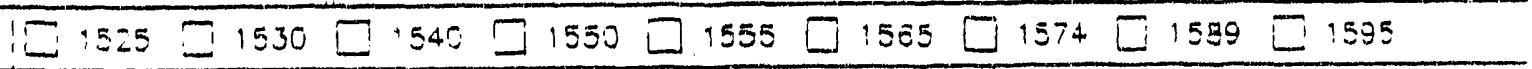 \\
\hline$=\cdot \overrightarrow{3}$ & تEcricol & 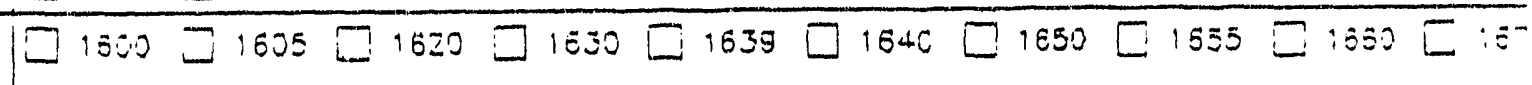 \\
\hline & & $\square 1071 \square 1685 \square: 694$ \\
\hline$-\Sigma$ & NOT AFOLUCAELE & No ocrion of DOE Dragr 6-to.iA is opolicable to this Cesign. \\
\hline$\equiv$ & $A S-3 ! ! 1 L T$ & Ezo is for as-ouilt fiend veritied smarigas only. \\
\hline & & $\begin{array}{l}\text { A sneck placed in the Division column signifies that the } \\
\text { entire Livision shall be opplicable to the Design, uriless } \\
\text { mooitiej by check indicated for, specific Subdivisions. }\end{array}$ \\
\hline
\end{tabular}

$\because 2004: 200 ; \quad 245 z 325=$ 
DRAWING CHANGE SHEET

(1. SHEET PER DRAWING)

Page 4 or 8

1. Drawing: $4 / 2-E-0 / 7-W$

ECO Number: $\$ 8+8$

2. ECO Search List:

3. Description of Change:

Incorporated bin V Rs \#387>7.008 and $38777-010$ for change in paint color and removal of gasket retainer plate.

4. Drawing Cog. Engineer Approval

Date: $10 / 25 / 9$

WP Form 2017; 06/2 4/91

1290:800C

Page 1 of 1 


\section{AR/VR DISPOSITION SHEET}

Mentinghouse Elestrite

por Internal Usoorly

¿afpacval acccas AEOUEST

Xuapiation

C CEviailon

ansowen

$17877-008$

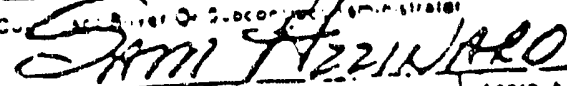
$1 /-16-90 \quad 1 / 25-901$

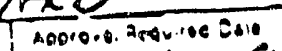
Se. 60

HA VER

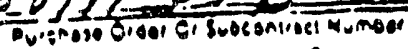
$17 z$ H

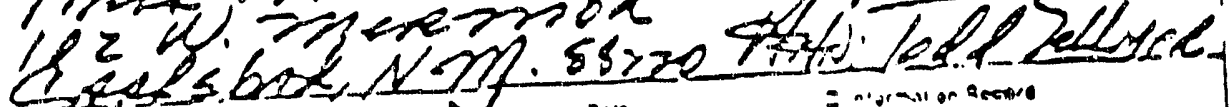

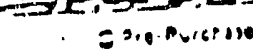 a.oijalion

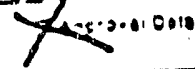 \\ $=$ n'or an or arento}

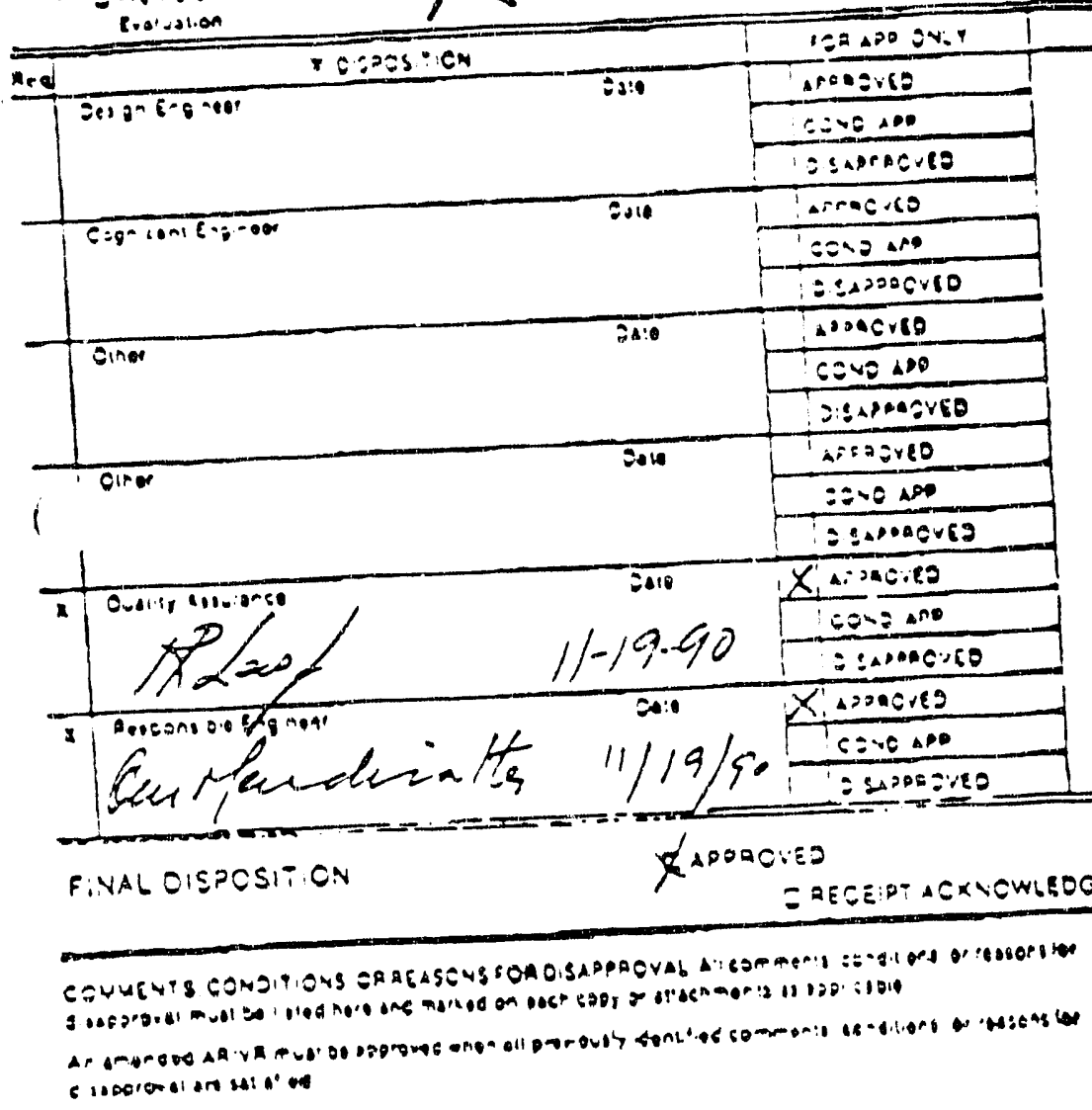

- CEN WENTS

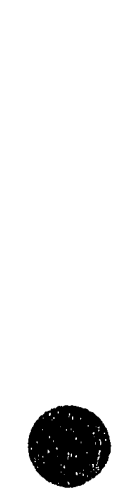



IEOUEST

$$
\begin{aligned}
& \text { VARIATION } \\
& \text { REQUEST }
\end{aligned}
$$
ECD $5:+8$ 608

Supplier Or Subcontrector And Addros

Hall Vachine \& Wielding Co., Inc.

102 W. Mernod

Carlsbad, NM 88220

Requirements

1. Note on Drawing

Supolier Or SutconirgerogAjimorized Signoture 7 le Sel Exe?

Tislo

Q.A. Dept.

Do10

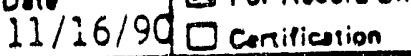

Murchese Order Ot Subconirace Number

75-WSA-38777-EX

DESCRIBE REOUEST IN DETAIL: Include Trik, Number and Revision To All Aruchments, Specification or Drawing Reforencos

1. Note $\| 7$ on drawing $\| 412-F-017-W$ Revision $E$, calls for the color of the external coating of the Bin Assembly to beytite. The final coat of the Bin was decided to bu Crey. This decision was made by Westinghouse Engineering group.

2. Dug. Who6 4:2-N-002-W, tag identification table, label \#9 \& 11 are modified to read as follows:
9 GRB-1
$\$ 11$
GRB-2
Recirc Out
Recirc in
Eackup
Backup

Dug. WHOS 412-:N-002-W, stencil Bin serial number, revise dimension $6 \pm$ to read $27.5 \pm \frac{1}{2}$

DISPOSITION: DAPPAOVED DCONDITIONALLYAPPAOVED D DISAPPROVED

Condisions, Exceplions, or Resions For Disupproval

A: TO SUPPLIER OR SUBCOATRACTDA. RRquers thot ale condition.

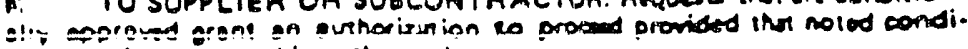
ions are incorpormed inio the work.

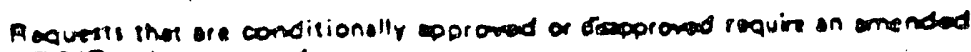
AANR Io De procueded.

WP Form iA 5 ? $\square$ Auithorizer To Prociod

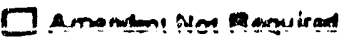
AUTHOA12EORY $\square$ Do Nor Precoud 2 


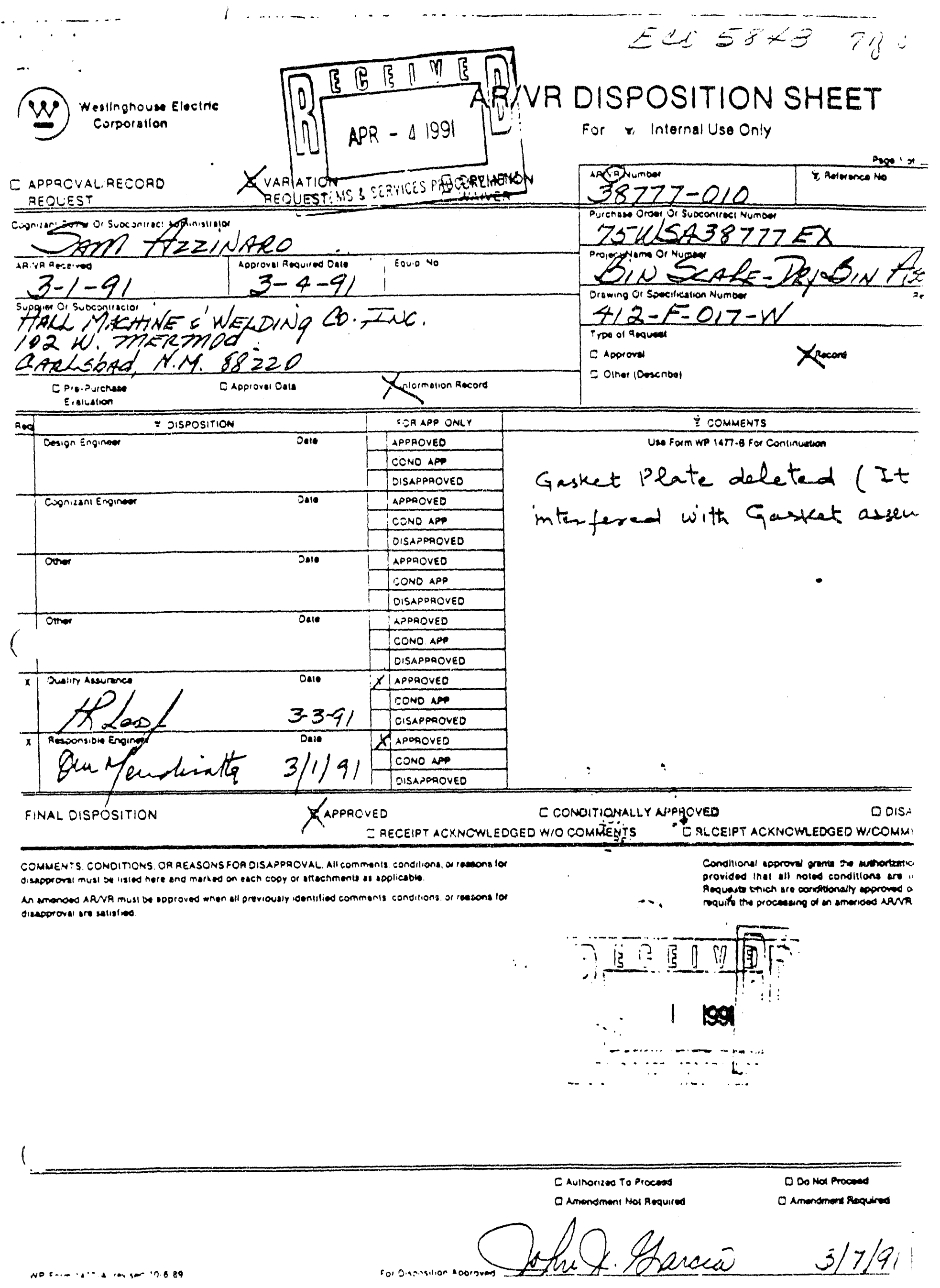


$\frac{\operatorname{Man} R}{\operatorname{Ca}}$

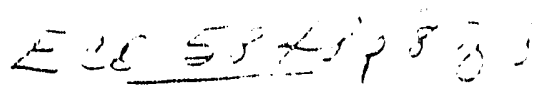

\section{APPROVAL / VARIATION REQUEST}

W) Worlingrours Elacinte

corporation

Pope 1 is

OMPRCVAL DVARIATION
MLOUEST

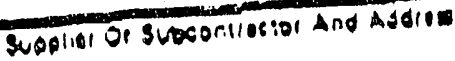

Hall Machle Aeidlax Co., ine.

102 wast Mermod

Carlsbad, W 88220

Traulioments

1) ondt Item 23

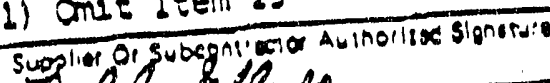

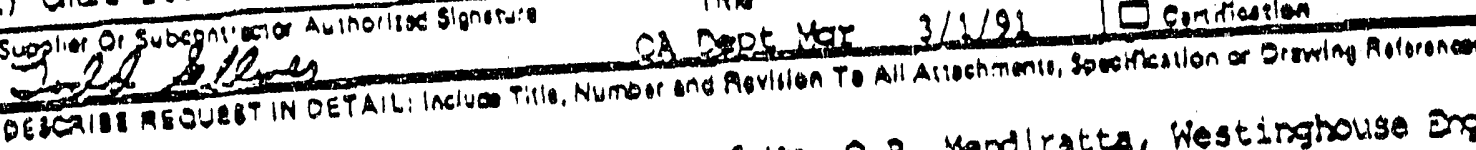

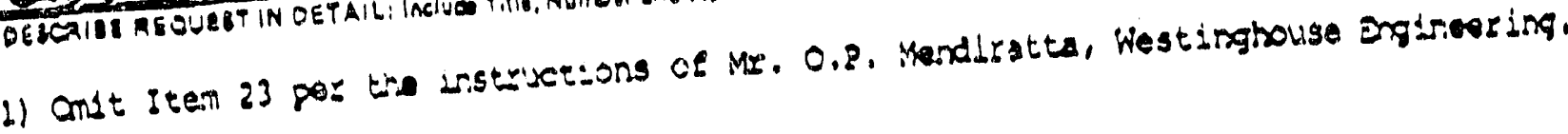

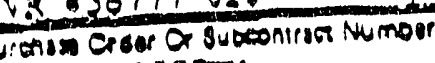

75:RA23897TEX

Bin Scalo - Ory Tast Bin iasenbly

Jowing $\alpha$ sopoirkition Number

412. -017-H, Rev. E

Trpa ol inguren

$\square$ moletal $\square$ Prosedse

Da sor foesid Only J Oinop lDeseribul

OISPCSITION: N NPPOVEO CONCITICAALLY APPROVEO

Conditiom. Exesptions, or Anesors Por OWd Dor oval

NOTE TO sUr?

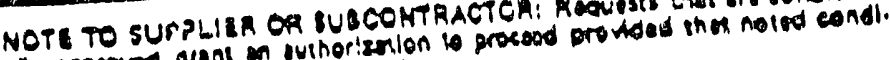
aly coreved grant ime the work.

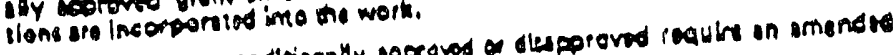
Aoquars ind ore cendre

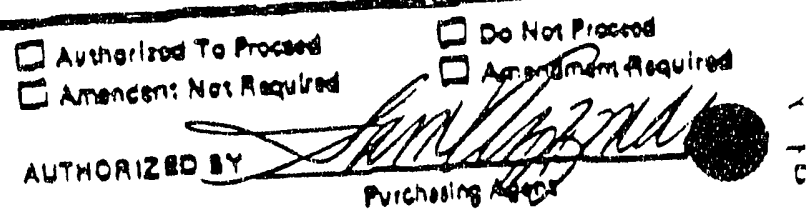
ANA io be procusel. 
ENGINEERING CHANGE ORDER

ADDENDUM SHEET

Page 1 of 1

1. Addendum to ECO Number: 5843

Drawing Number: $412-N-002-1 \mathrm{~N}$

2. Description of change:

InCORPORATE VR $38777-008$ ITEM \#2 WTO DRAWING 412-N-DO2-W; MODIFYING TEE IDENTRLZARON table at labels 9 am il and Relocating STENCIL BIN SERIF NUMBER AS SFELIFED AND OMIT ITEM 17.

ReMove ITEM 28 AND REAPED NOTE 6

ado. Angular dimension of $20^{\circ}$ to Tho I" valves at valve side elevation of bin assembly.

ADD ITEM 41, 60 LF. OF WIRE CLOTH, MSMaster-CARR \# gzigt3iz or equal and related note lg.

3. Approvals

Cognizant Engineer:
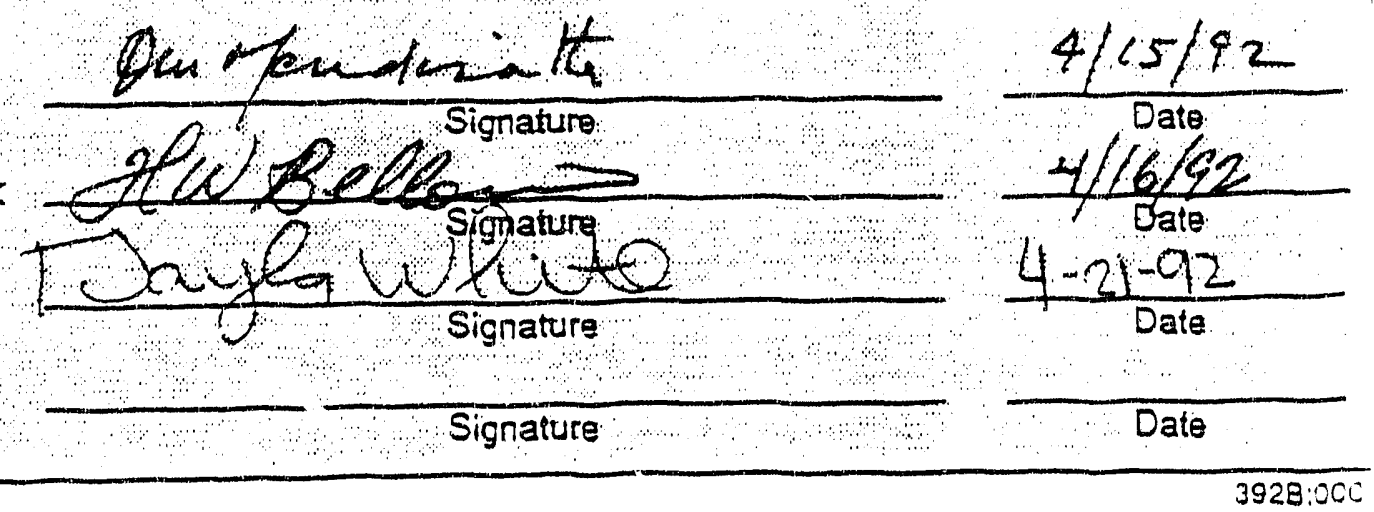

WP Form 2020; 3/19/92

$3928: 0 C \mathrm{C}$

Page 1 of 1 


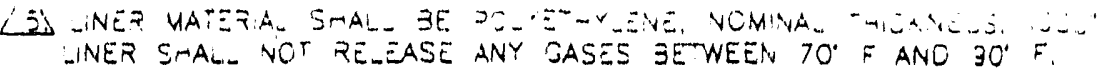

6. REMOVED

7. PREPARE AND PAINT EXTERNAL SURFACES OF BIN PER SPECIFICATION E-2-240, REV. 2, SYSTEM 1-16. FINISH COAT SHALL BE GRAY. APPLY PAINT AFTER WELD TESTS AND APPROVALS SPECIFIED IN EQUIPMENT SPECIFICATION E-A-334, EXCEPT STAINLESS STEEL SURFACES.

8. PAINT INTERNAL SURFACE OF BIN ANO UNDERSIDE OF COVER WITH PAINT 105C-5, WHITAKER COATINGS,

1500 LATHEM ST. BATAVIA, IL, 60510 OR EQUAL.

APPLY FIRST COAT .0005 - .0004" ORY AND BAKE $10-12$ MINUTES AT $300^{\circ}-315^{\circ} \mathrm{F}$. APPLY SECOND COAT .0003" $-.0004^{\prime \prime}$ DRY ANO BAKE 10 - 12 MINUTES AT $400^{\circ}$ - 425 $\mathrm{F}$. APPLY FIRST COAT AFTER WELD TESTS AND APPROVALS SPECIFIED IN EQUIPMENT SPECIFICATION $E-A-334$.

A STENCIL BIN EOUIPMENT NO. AND THREE DIGIT SERIAL NO. LETTERS SHALL BE $1 / 2^{\prime \prime}-1^{\prime \prime}$ HIGH INOELIBLE BLACK. LIDS AND BINS OF THE SAME SERIAL NO. SHALL BE SHIPPED TOGETHER. DRY TEST BIN EQUIP. NO.: $63-S-001, S / N-001$, ETC.

18. REINFORCE HOLES IN LINER WITH TEFLON WASHER EMBEDDED IN THE LINER.

A SECOND WELD ON WALL OPTIONAL. SINGLE WELD PERFERRED WITH SINGLE PIECE WALL.

12 TO BE INSTALLED TO BOTTOM OF BIN ONLY.

13. REMOVED

IS ALL $1 / 2^{\prime \prime}$ VALVES INSTALL ON ITEM 1 SHALL HAVE THE SAME PART NUMBER.

19. ALL 1" VALVES INSTALL ON ITEM 1 SHALL hAVE THE SAME PART NUMBER.

16. ARROWS ON ALL VALVES TO POINT AWAY FROM BIN WALL.

A REMOVE THIS LENGTH AFTER FINAL INSTALLATION,

18. THIS DETAIL FOR TEST BINS $S / N$ PB-009, PB-010. AND PB-011 ONLY.

19. THIS DETALL FOR TEST BINS S/N PB-O12 AND ONWARD.

20 FOLD ITEM 20 AS REQUIRED TO FIT WITHIN THE BIN.

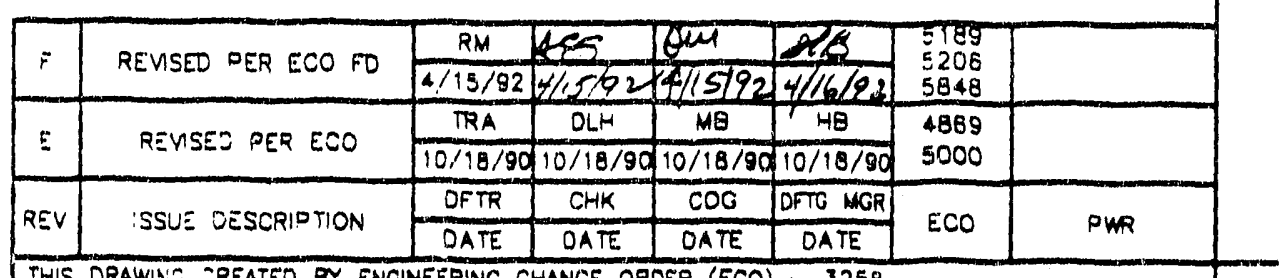

THIS DRAWING SREATEO BY ENGINEERING CHANGE OROER (ECO): 3258

INTERPRE DWC PER ANSI YIA DIM IN INCHES GASED ON 68 UNLESS OTHERWISE SPECIFIED TOLERANCES 2 PL DEC 3 PL OEC ANGLES

\begin{tabular}{|l|l|l|l|}
\hline \pm .03 & \pm .005 & $\pm 1^{\circ}$ & \\
\hline
\end{tabular}

AA Q.A. JAMES F. ALIEN 12/6/89

FRACTIONS $\pm 1 / B \quad$ APPD W.R. WHITE $12 / 6 / 89$

ENGINEERING RELEASE

BY $M D-M P P$

ECO - OATE.

U.S. DEPARTMENT OF ENERGY

Westinghouse Waste Isolation Division Waste Isolation Pilot Plant CARLSEAO. NEW MEXICO

APPD W.R. WHAITE 12/6/89

APPD TERRY Q. NERKLUNG (RS)

DFTC. MGR H. Balaw $10 / 18 / 90$

SNL WATY A. MOLECXE 12/6/89

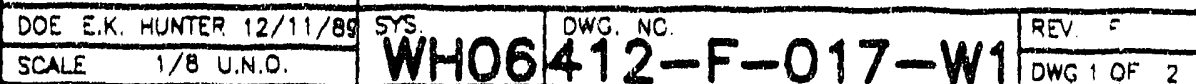

BIN-SCALE TESTS DRY TEST BIN DETALS 


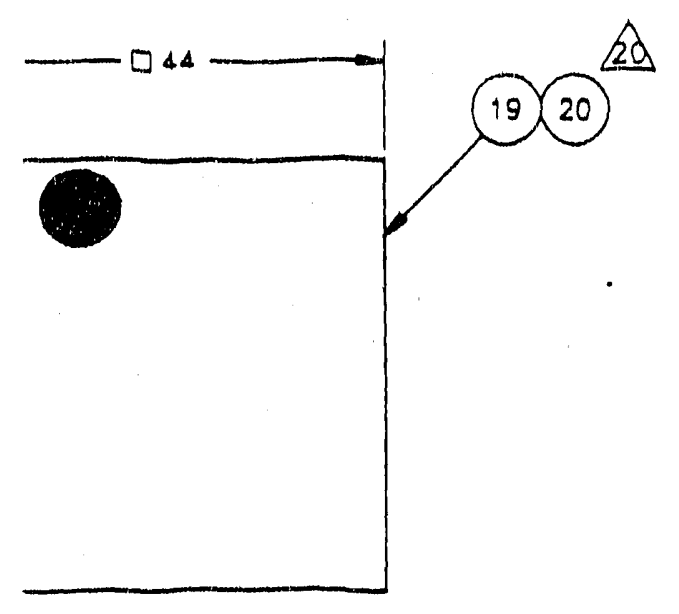

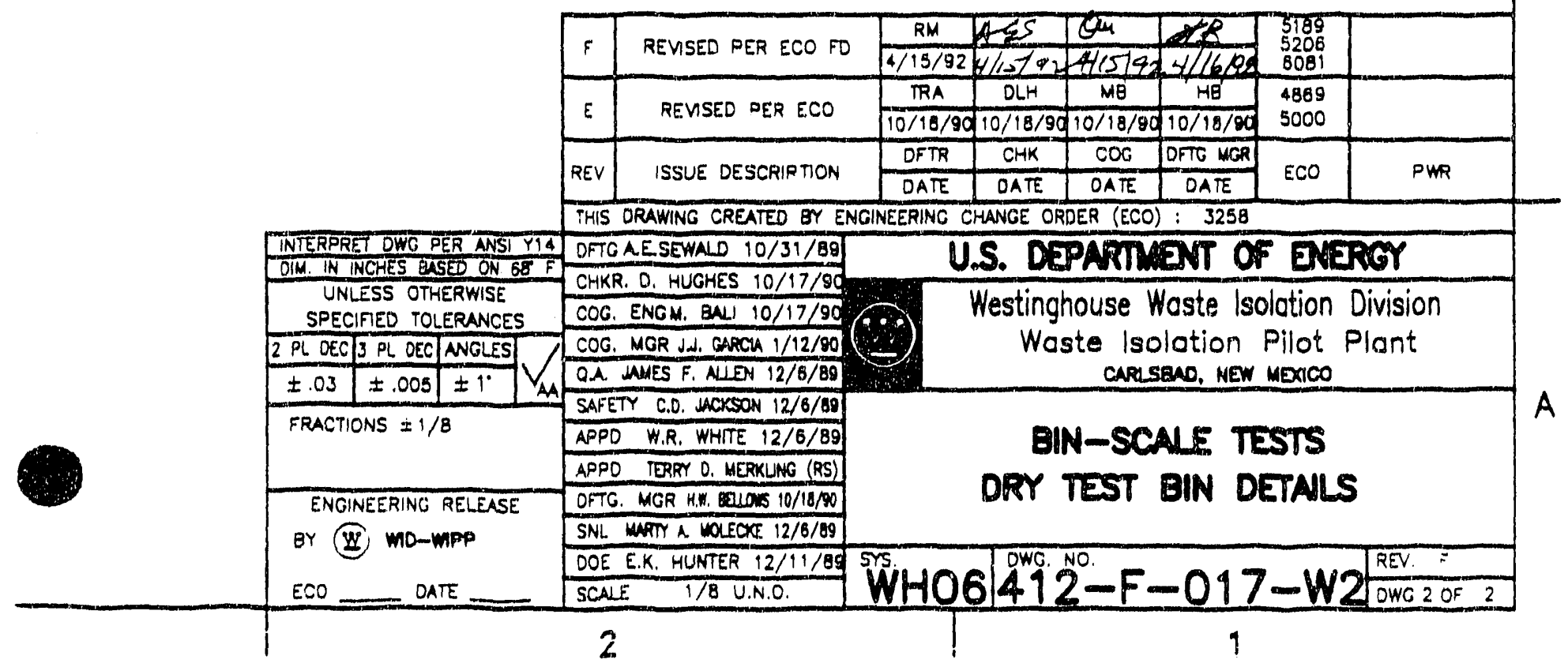




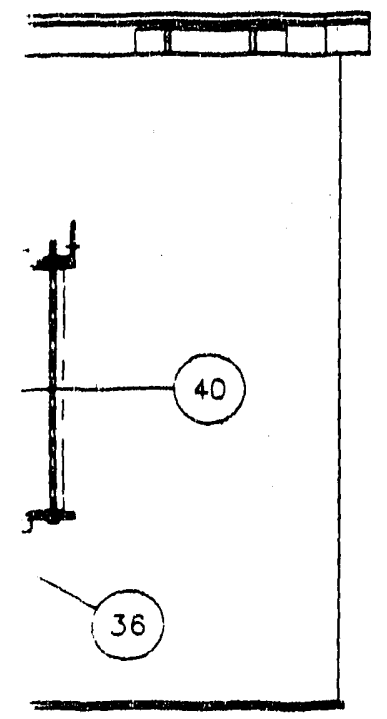

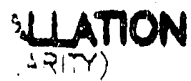

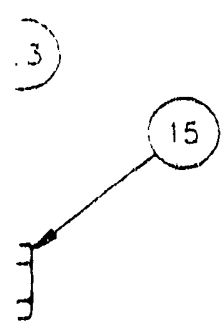

Lin = L ON DISUARD THE NUPRO

FILTER E_EVENT IN THE HOUSING.

3. Figerboard LiNers taped tOGETHER at TAB END WITH ITEM 18.

4. SHIF TTEM 4. PLACED INSIOE ITEM 2. NO SHARP BENDS ON GASKET.

5. TAOS TO GE RED WITH WHITE LETTERING ON A $3^{\prime \prime} \times 2^{n}$ TAG, WITH $1 / 4^{* \prime}-$ $1 / 2^{\prime \prime}$ CHARACTERS. TAGS TO BE MOUNTED WITH ITEM 20. TEXT OF EACH TAG SHOWN IN TAG IDENTIFICATION TABLE.

6. REMOVED

7. REMOVED

8. REMCVED

今. STANOARC HEX-HEAD BOLTS WITH INTESRAL WASHERS, BOLTS SHALL BE $1 / 2-13$ UNC $\times 1-1 / 4$ LG. WITH AN INTEGRAL FLAT WASHER $1 "$ DIAMETER,

A. EAVE TOP CF ITEM 12 LOCSE ATTER INSTALLING ITEMS 13, 14, 28, \& 30

A) STEVCIL BIN EC JIPMENT NO. AND THRE E DIOIT SERIAL NO. LETTERS SHAL $Q E, 1 / 2^{n} \ldots 1^{\prime \prime}$ HIGH INDELIBLE BLACK. LIDS AND BINS OF THE SAME SERIAL NUMEER SHALL BE SHIPPED TOGETHER. SOLID WASTE GIN EQUIP. NO.: 63-5-001, S/N -001, ETC. PS/SC BIN EQUIP. NO.: 63-S-004, $S / N-001, E T C$

12 SANDIA NATIONAL ABS, TO SUPPLY AND INSTALL ITEMS 23,24,

25, 26, AND 27 PER PROCEDURES APPROVED BY $W-W I D$.

43. TIGHTEN TO 30 F-LB TORQUE.

AS STENCIL WOROS "WAX GROSS WEIGHT 3,200 LBS" LETTERS SHALL BE $1-Z^{*}$ HIGH, INDELIBLE BLACK, ON NEAR ANO FAR SIDE OF BIN, STENCILED AFTER PAINTING BIN.

A5. TRANSPORT FIITERS. (ITEM 38) TO BE FITTED WITH A FEMALE NUT AT THE FABRICATION SHOP. THIS NUT WILL BE REPLACED WITH A CAP NUT AT THE WIPP SITE PRIOR TO DOWN-LOADING OF THE BIN.

16. ALL VCR CONNECTIONS SHALL BE MATEO WITH PROPER SIZE GASKET, PREFERABLY HELD IN A GASKET RETAINER ASSEMELY (ITEM 32, ITEM 33).

17. FOLIOW VENDOR DIRECTIONS FOR REPEATED USE OF THE SAME ASSEMBLY.

(8) FILTER MEDIA SHALL GE REMOVED FROM THE NUPRO FILTER HOUSING (ITEM 21) FOR THE PRODUCTION BINS S/N PB-OO9 THROUGH PQ-018.

92 CUT WIRE CLOTH INTO $20 \mathrm{FT}$. LONG PIECES. FOLD INTO SIX APPROXIMATELY $40^{\prime \prime}$ LONG ACOORDIAN STYLE BENDS. LOAD 3 PIECES (6O L.F.) OF THE FOLDED WIRE CLOTH DIRECTLY ONTO THE GAS MANIFOLD ASSEMELY (DWG. NOS. 4:2-M-005-W AND 4:12-M-007-W). INSTAL- PRIOR TO SHIPMENT OF BIN TO GENERATOR SITE.

JEMBLY

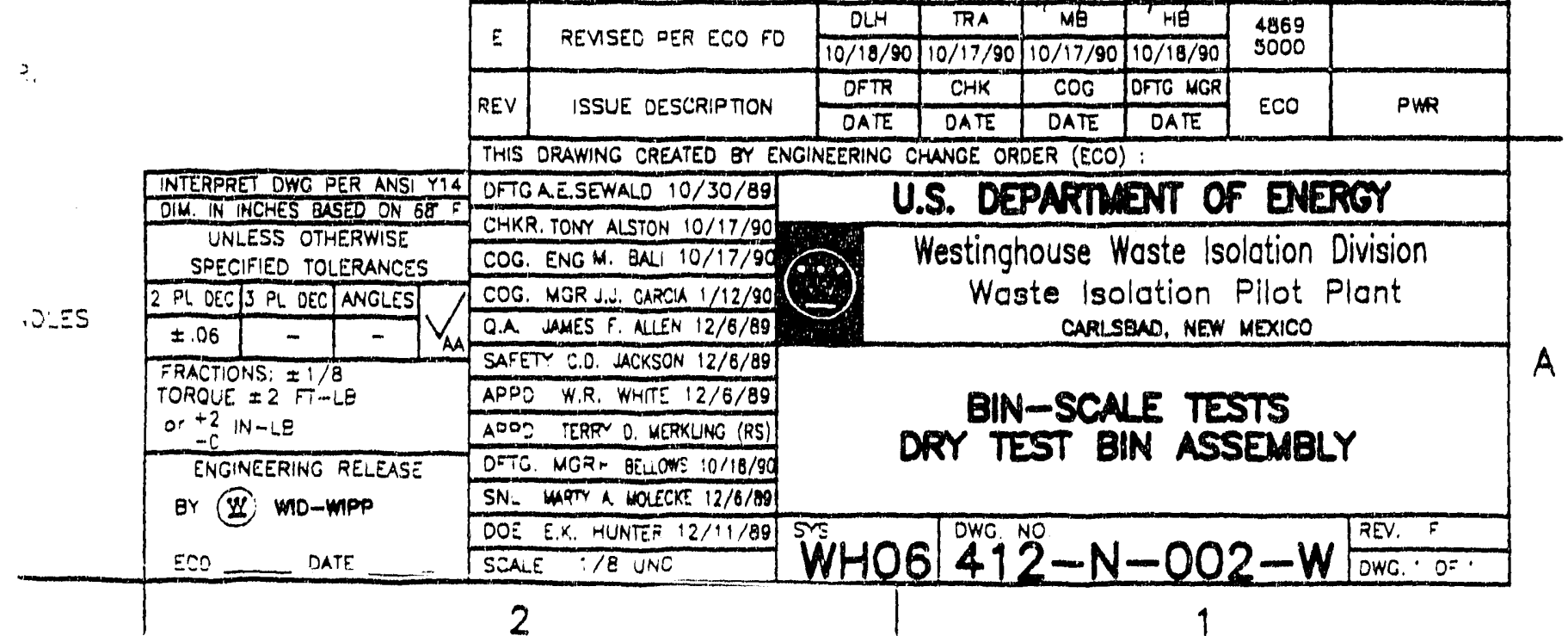




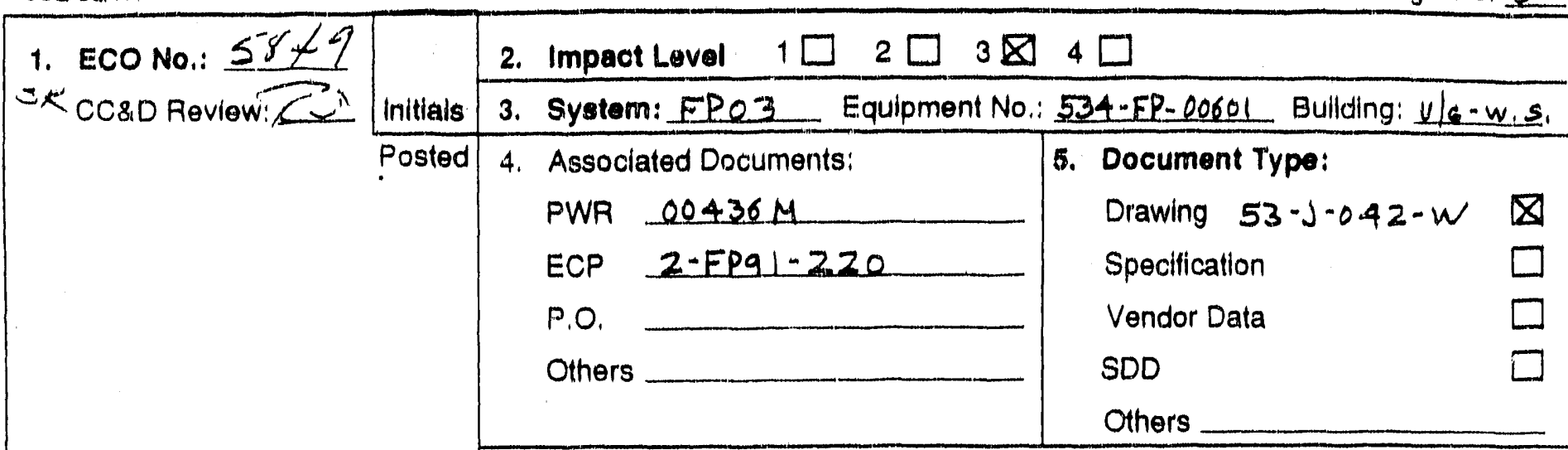

6. Title of Change: REMOVE THERMAL DETECTORS IN 5700 \& 51000

7. Originator: (print) J.R.STROBLE
Ext. No:: Department: 8374

\section{ELEC. ENG. $|1-|-9 \mid$}

8. Cognizant Engineer: (print)

\section{Description of Change:}

Yes No

No
U.R.STROBLE

Component indices change required (if yes, attach sheeis)

REMOVE THE THERMAL DETECTORS IN U/G DRIFTS S700\&SI000 BETWEEN E140 \& E300.

$\triangle$ 9a Drawing Change Sheet attached

9c Vendor Data Change Sheet attached

9b Design Documentation Sheet attached

10. Yes No
$\bigotimes \square$ MODIFICATION IN PROGRESS
Modification complete:
U.R. statle
$\left.\frac{4-6-92}{0.10}\right]$
ECO will be

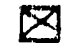

Change drawing per as-built markup dated:

$\square$ Change drawing per ECO-provided data

Temporary modification

11. Desigh Verification Requirements: (per WP 09-018)

EDT No::

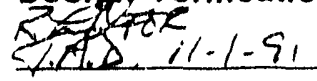

1. Requirements satisfied by review/approval of design document

2. Independent review

3. Alternate calculations

4. Development testing

5. Design review

6. Other:

12. Addendum Sheet added:

Sonarus 0 


\section{Justiflication}

These detectors are not Required. THEy caUse INADUERTANT ALARMS AND CONFUSION ON THE APPLICABILITY OF FSAR CHAPTER 10 LCO STATEMENT ON "THERMAL DETECTORS" IN THE "RMA"! SEE APPROVAL OF ECP 2-FP91-220.

\section{Administrative Tracking}

YES N/A

$\triangle \square$ 1. FSAR

$\square$ 2. Calibration Procedures

3. Maintenance Procedures

4. Computer Sottware

$\triangle \square$ 5. Operations Procedures

$\begin{array}{ll}\text { 15. Signature Requlrements } & \text { KEY } \\ & \text { A-APPR, } \\ & \text { RMPEVIEW } \\ \text { SwSIGN NEW } \\ \text { DPAWING }\end{array}$

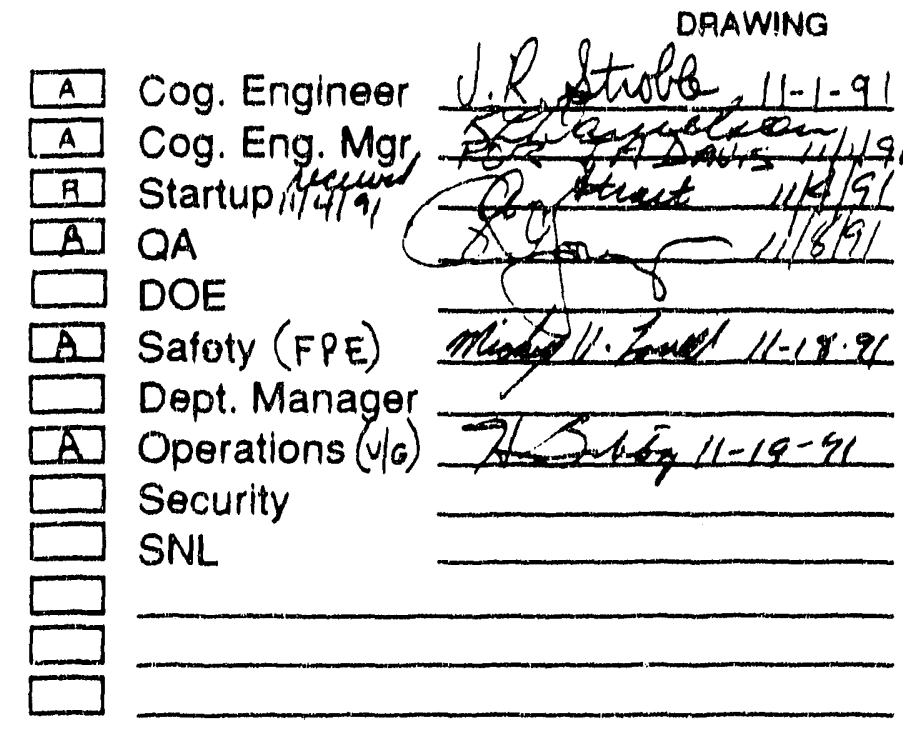

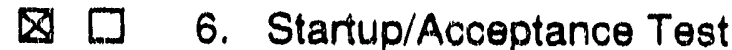

$\square$

$\square \square$

7. Test Requirement \& Sper.

8.

9.

10.

\section{Distribute as Marked}

Maintenance (MANDatopy)

Ops. Support (MANDATORY)

Startup

Facility Operations

U/G Operations Lintiolled Dug. Fils

Orig./Design Engr.

Cog. Engineer

Others 


\section{ENGINEERING CHANGE ORDER DOE ORDER 6430.1A DESIGN CRITERIA CHECKLIST}

The design requirements in DOE Order 6430.1A checked below hove been opplied to this Design.

\begin{tabular}{|c|c|c|}
\hline & DIVISION & $\bar{N}$ \\
\hline$\square 1$ & General Require & $\square 0101 \square 0106 \square 0109 \square 0110 \square 0111 \square 0140 \square 0150 \square 0170$ \\
\hline$\square 2$ & $\begin{array}{l}\text { Site and } C \\
\text { Engineering }\end{array}$ & 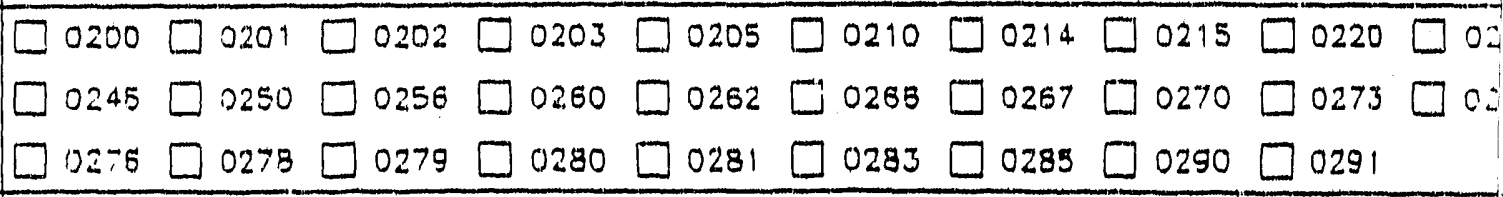 \\
\hline$\square 3$. & Concrets & $\square 0300 \square 0301 \square 0310 \square 0320 \square 0330 \square 0340 \square 0350 \square 0370 \square 0380$ \\
\hline$\square 4$ & Masonn & $\square 0400 \square 0401 \square 0410 \square 0420 \square 0455$ \\
\hline$\square^{5}$ & Motals & $\square 0300 \square 0512 \square 0514 \square 0521 \square 0531 \square 0532$ \\
\hline$\square^{6}$ & Wood and Plostles & $\square 0600 \square 0610 \square 0650$ \\
\hline$\square^{\top}$ & $\begin{array}{l}\text { Thermal and Moisture } \\
\text { Pratection }\end{array}$ & 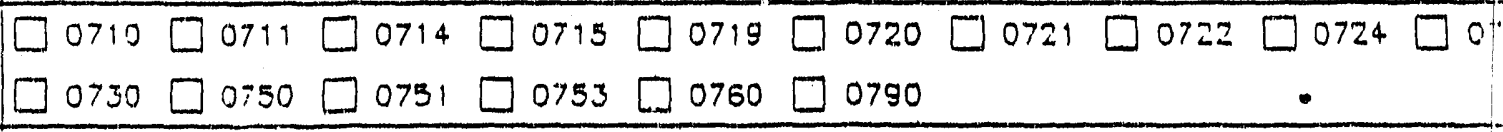 \\
\hline$\square 8$ & Doors and Wiridows & $\begin{array}{l}\square 0800 \square 0810 \square 0820 \square 0830 \square 0833 \square 0836 \square 0839 \square 0850 \square 0860 \square 0 \\
\square 0880\end{array}$ \\
\hline$\square 9$ & & $\begin{array}{l}\square 0900 \square 0910 \square 0920 \square 0925 \square 0930 \square 0950 \square 0965 \square 0968 \square 0970 \square 0 \\
\square 0990 \square 0995\end{array}$ \\
\hline$\square 10$ & ses & $\begin{array}{l}\square 1015 \square 1020 \square 1024 \square 1027 \square 1030 \quad \square 1040 \square 1050 \square 1052 \square 1053 \square 1 \\
\square 1060 \square 1065 \square 1070 \square 1073 \square 1080\end{array}$ \\
\hline$\square^{11}$ & Equipment & $\square 1100 \square 1161$ \\
\hline$\square^{12}$ & Furnisnings & $\square 1201 \square 1230 \square 1250 \square 1260 \square 1270$ \\
\hline$\square 13$ & Special Facilities & $\begin{array}{l}\square 1300 \square 1304 \square 1305 \square 1305 \square 1307 \quad \square 1318 \square 1319 \square 1320 \square 1321 \square 1 \\
\square 1323 \square 1324 \square 1325 \square 1325 \square 1328\end{array}$ \\
\hline$\square^{11}$ & Conve & $\square 1401 \square 1420 \square 1440 \square 1460$ \\
\hline$\square 15$ & H:ch & $\square 1525 \square 1530 \square 1540 \square 1550 \square 1555 \square 1565 \square 1574 \square 1589 \square 1505$ \\
\hline$\square 19$ & Ele & $\begin{array}{l}\square 1600 \square 1605 \square 1620 \square 16.50 \square 1639 \square 1640 \square 1650 \square 1655 \square 1660 \square \\
\square 1671 \square 1635 \square 1694\end{array}$ \\
\hline $4 . \nabla$ & NOT AFPLIC & No portion of DOE Orser $6430.1 \mathrm{~A}$ is applicable to this Design. \\
\hline 5. $\square$ & AS-EUILT & ECO is for as-built field verified \\
\hline
\end{tabular}

NOTE: A check placed in the Division column signifies that the entire Division shall be applicable to the Design, unless modified by checks indicated for specific Subdivisions.

COMMENTS: 
1. Drawing:

2. ECO Search Llst:
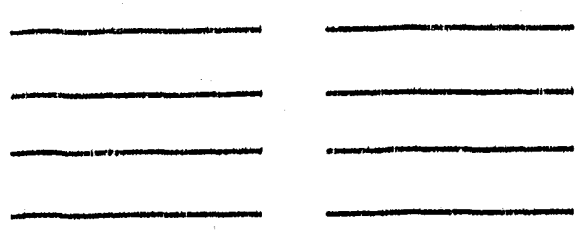

3. Description of Change:

DELETE 00601-TD-202 \& 00601-TD-203\&00601-TD-301 FROM thE LADDER DIAGRAM.

DELETE TD 202, TD 203, \& TD 301 AND THEIR. SYMBOLS FROM THE FLOOR PLAN.

SEe a tiached pages

4. Drawing Cog. Engineer Approval: Date: 
ZONE 1

ZONE 2

PAGE 5 OF 6

ZONE 3

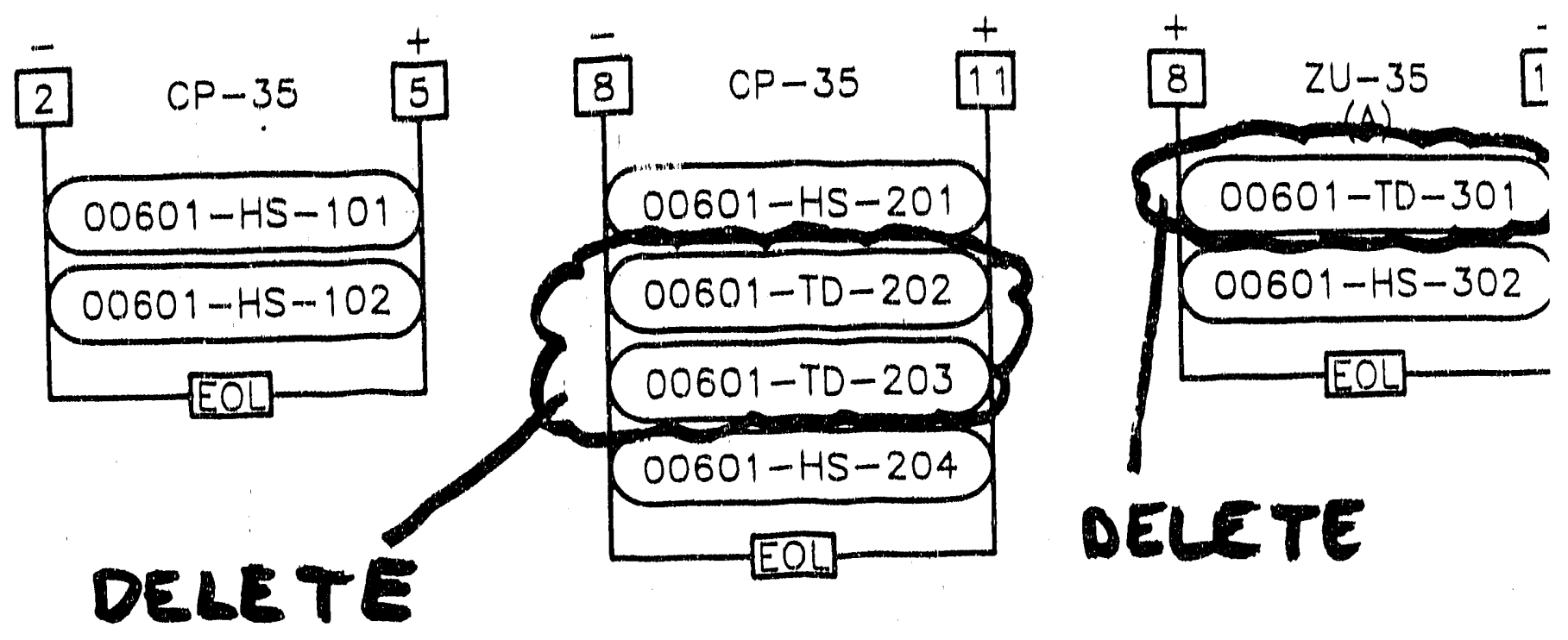

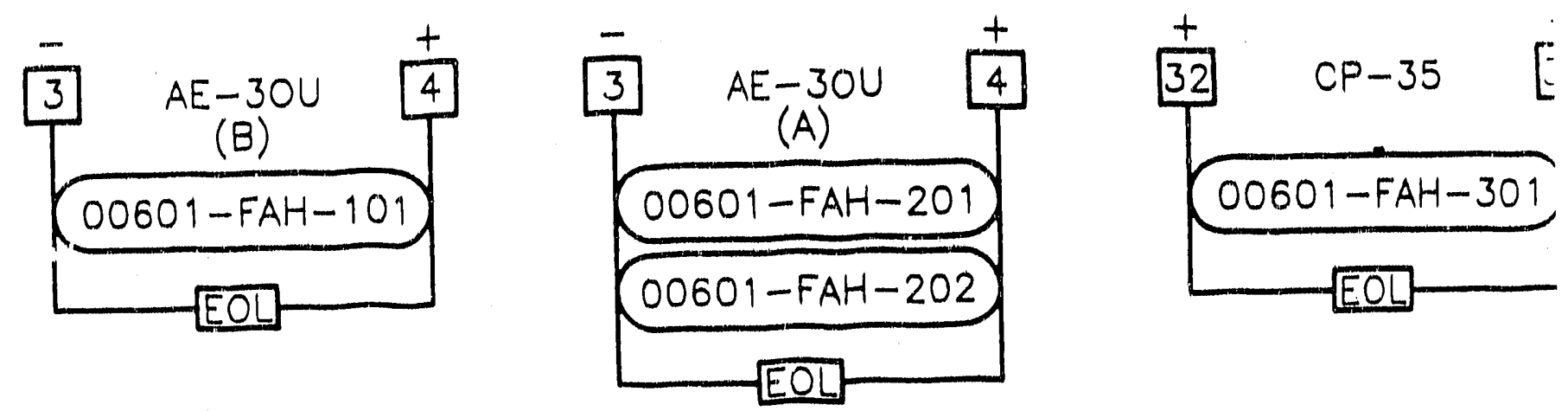

53-J-042-W

REV.E. 


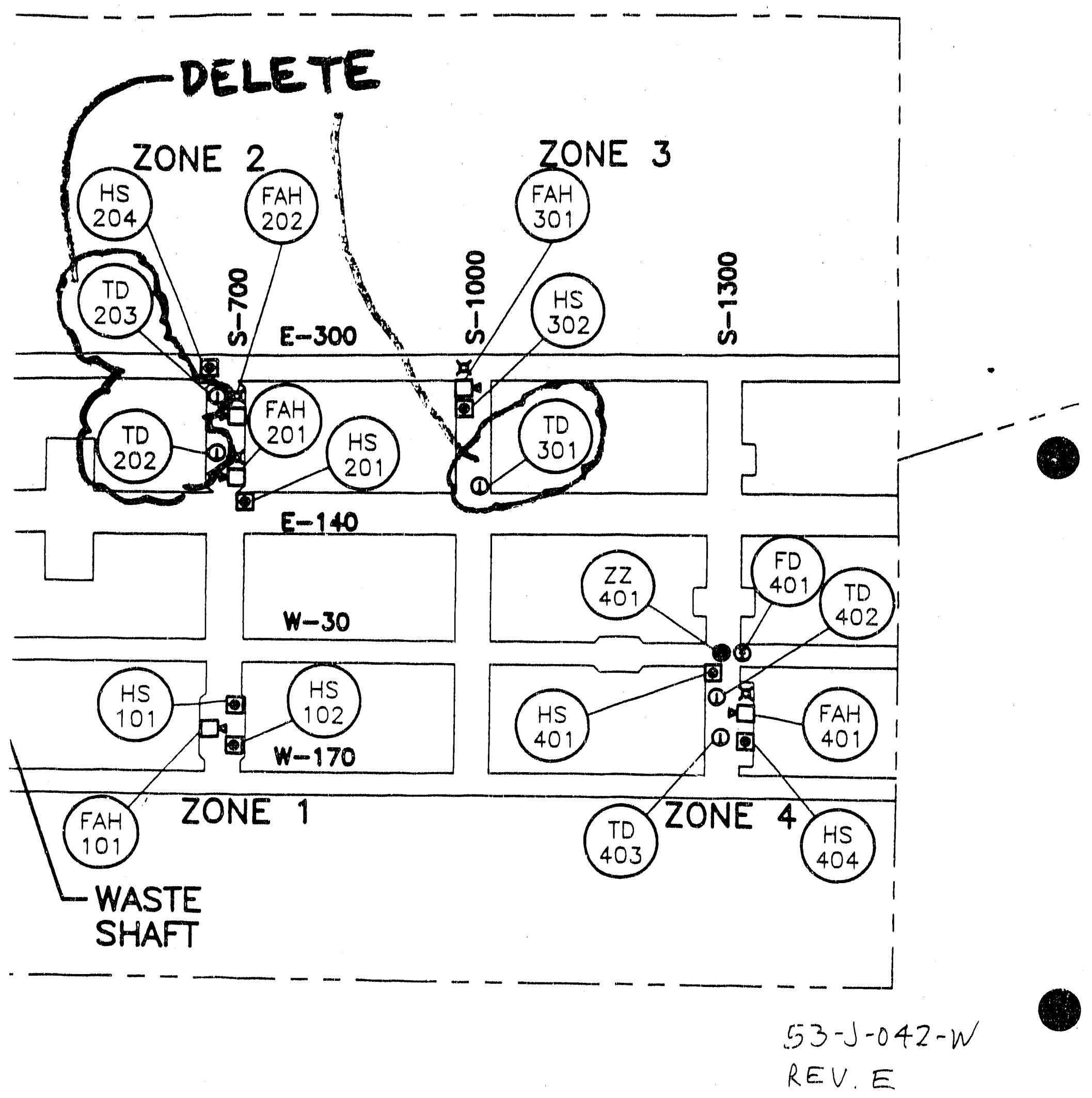


ENGINEERING CHANGE ORDER ENGINEERING FILE BOCM ROP

USE BLACK INK

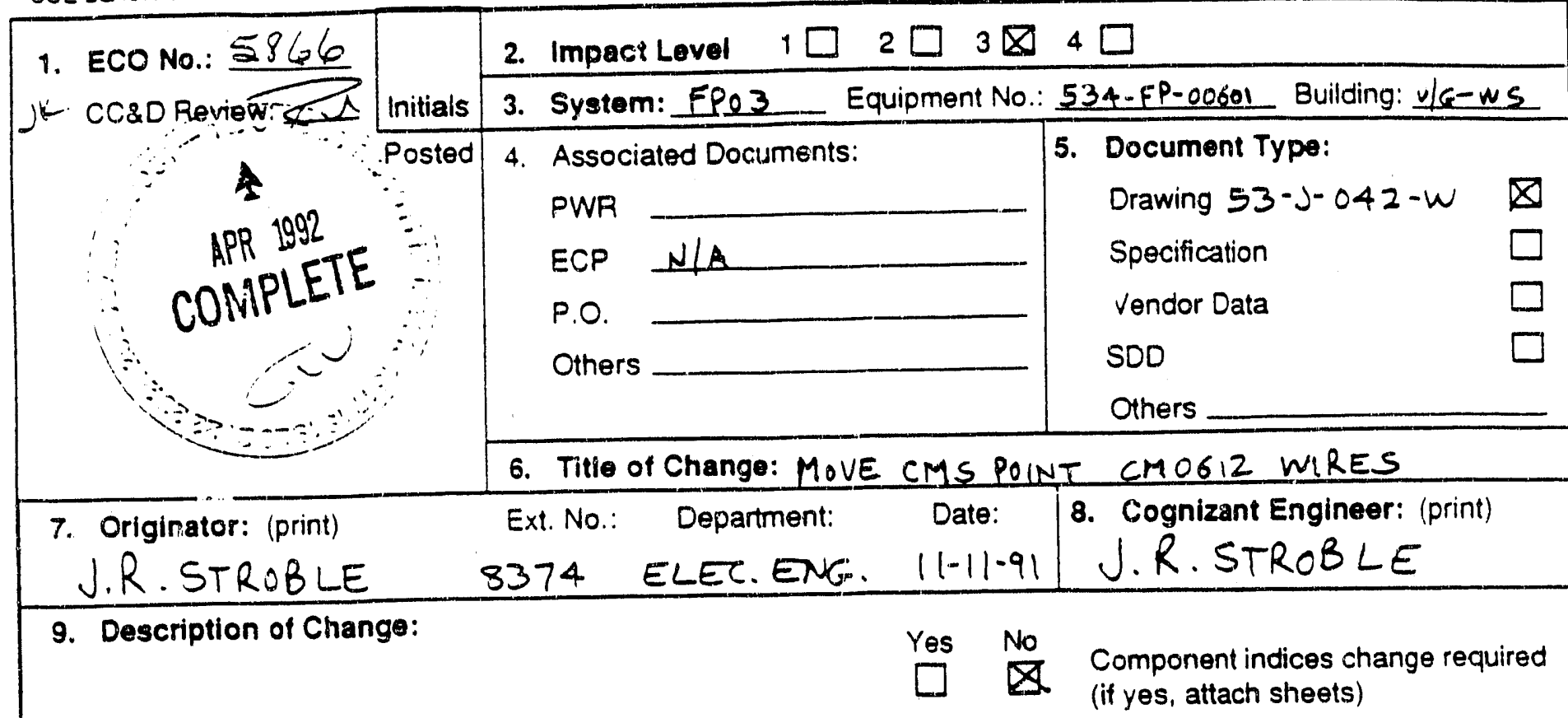

MOVE the WIRES tO ACTUATE CMS POINT CMOGIZ IN FIRE PANEL $534-F P-00601$ TO ANOTHER RELAY.

$\triangle$ 9a Drawing Change Sheet attached $\square$ 9c Vendor Data Cnange Sheet attached 9b Design Documentation Sheet attached

10. Yes No

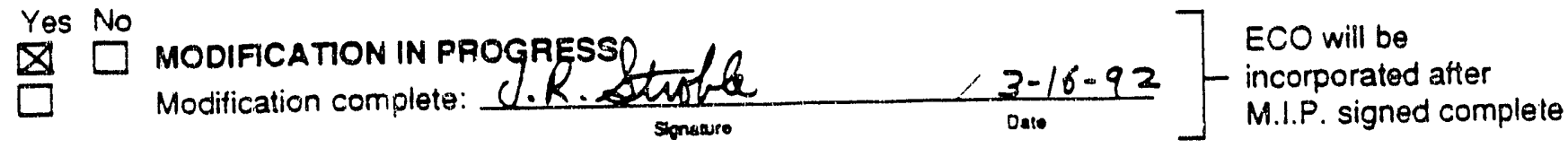

$\otimes \quad$ Change drawing per as-built markup dated: $3-16-92$

Change drawing per ECO-provided data

Temporary modification

11. Design Verification Requirements: (per WP 09-018)

EDT No.:

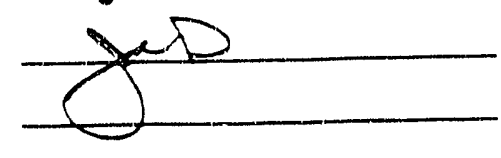

1. Requirements satisfied by review/approval of design document

2. Independent review

3. Altemate calculations

4. Development testing

5. Design review

6. Other:

12. Addendum Shoet added:

6. Oher. 


\section{Justification}

THE POINT DOESN'T COME IN UPON A FIRE ALARM. maintenance foUnd relay was bad, and a REPLACEMENT BOARD WILL HAVE TO BE ORDERED.

\section{Administrative Tracking}
YES N/A
1. FSAR
2. Calibration Procedures
YES NA
区
3. Maintenanre Procedures
凶
$\square \otimes$
$\square \square$
$\otimes$
$\square$ 5. Oomputer Software
$\square \square$
$\square \square \quad 10$

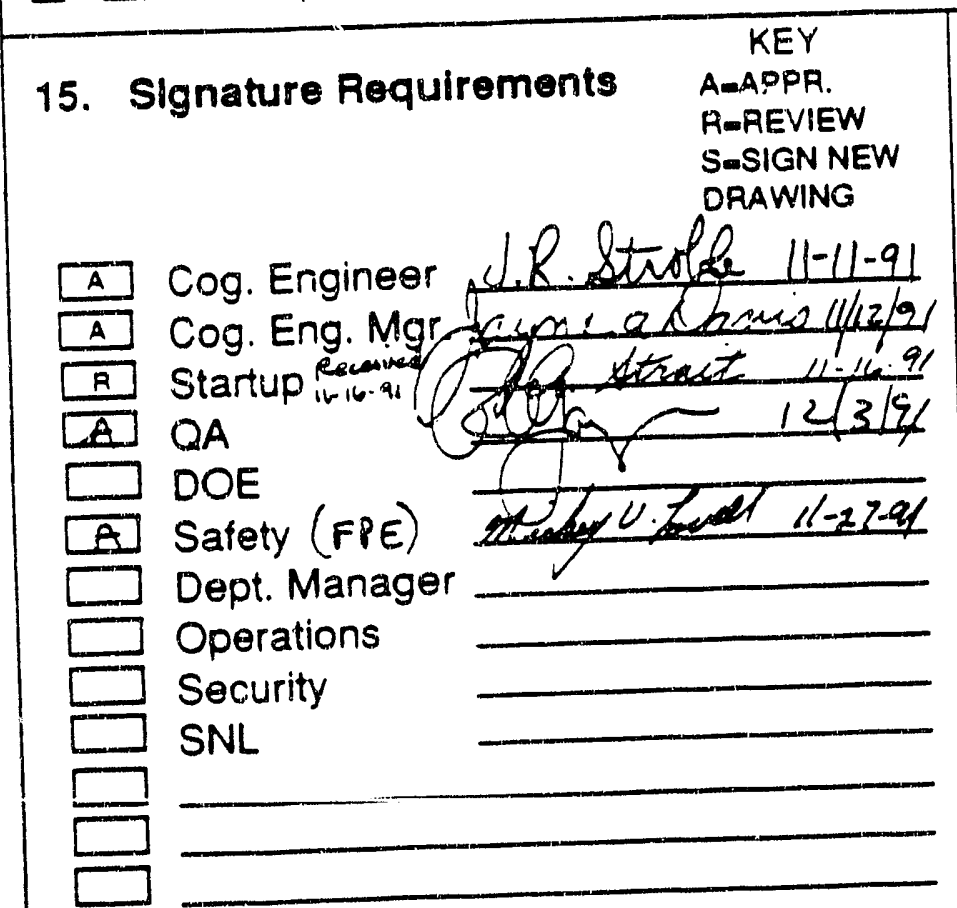

\section{Distribute as Marked}

Maintenance (manoATORY Ops. Support MaNOATORY' Startup

Facility Operations

[2] U/G Operations Cintrelled Din. Fils

Orig./Design Engr.

Cog. Engineer

Others

ULG ELEC. R GUERRA 


\section{ENGINEERING CHANGE ORDER DOE ORDER 6430.1A DESICN CRTTERIA \\ - CHECKLIST}

FAGE 3 OF -5

1. ECO \# $586 \overline{6}$

2. OATE -IL-IL-II

The design requiremenis in DOE Orcer 64j0.1A checked below hove been opplied to this Design.

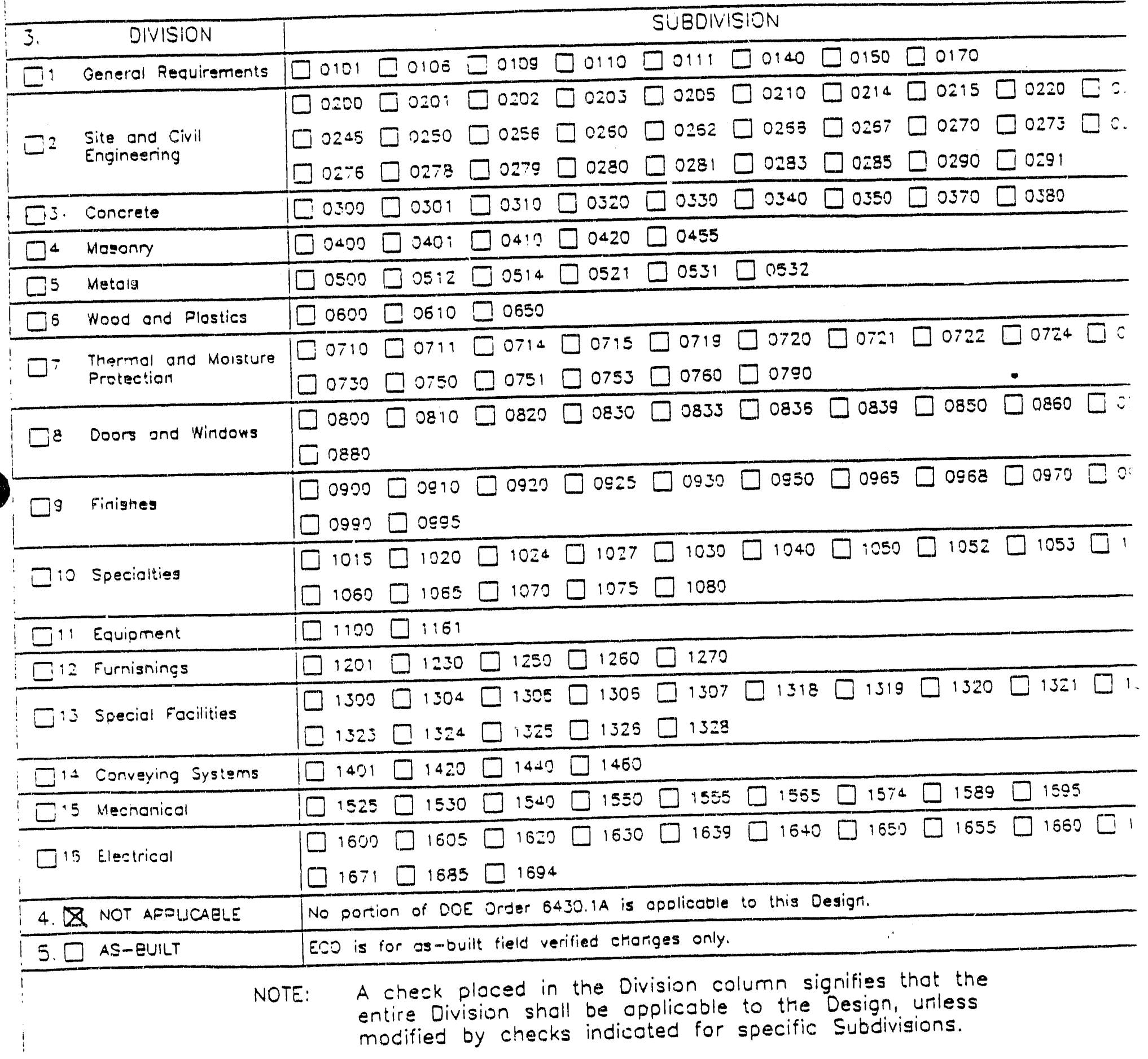

COMMENTS: 
1. Drawing: $53-1-042-W \quad$ ECO Number: 5866

2. ECO Search List:

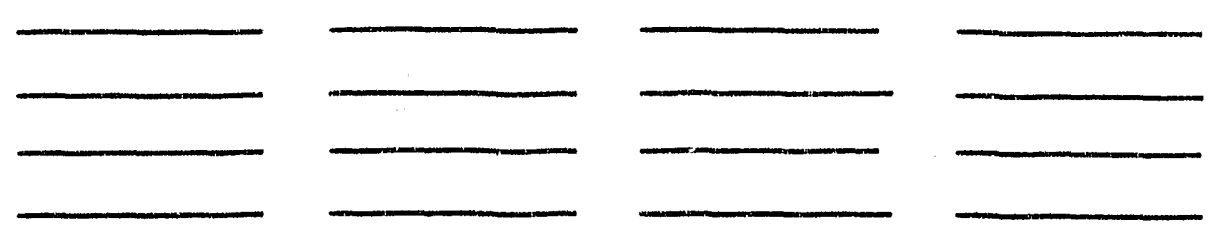

3. Description of Change:

MOVE WIRES CONNECTED TO SR-33/17 \& SR-33/18 $(534 F P 00601 J-21+534 F P 00601 J-22)$ TO SR-33/23\&SR-33/24 RESPECT IVELY.

4. Drawing Cog. Engineer Approval: J.R. Stutle Date: 
ENGINEERING CHANGE ORDER

ADDENDUM SHEET

Page 1 of -

1. Addendum Sheet to ECO Number: $5866 \quad$ Drawing Number: $53-1-042$ -

2. Description of change: RePLACE PAGE 5 OF THIS ECO WITH attACHED PAG

REPLACE THE SR-33 RELAY BOARD WITH AN

SR-35 RELAY BOARD, AND CHANGE THE WIRING

as shown on the attached pages.

JUSTIFICATION: MAINTENANCE HAD TO REPLACE THE SR-33 BOARD DUE TO A MALFUNCTIONING RELAY. PYROTRONICS NO LONGER MAKES. THIS BOARD, SO THE SR-35 WAS AN APPROVED SUBSTITUTE. SEE PWT 158285 .

3. Approvals
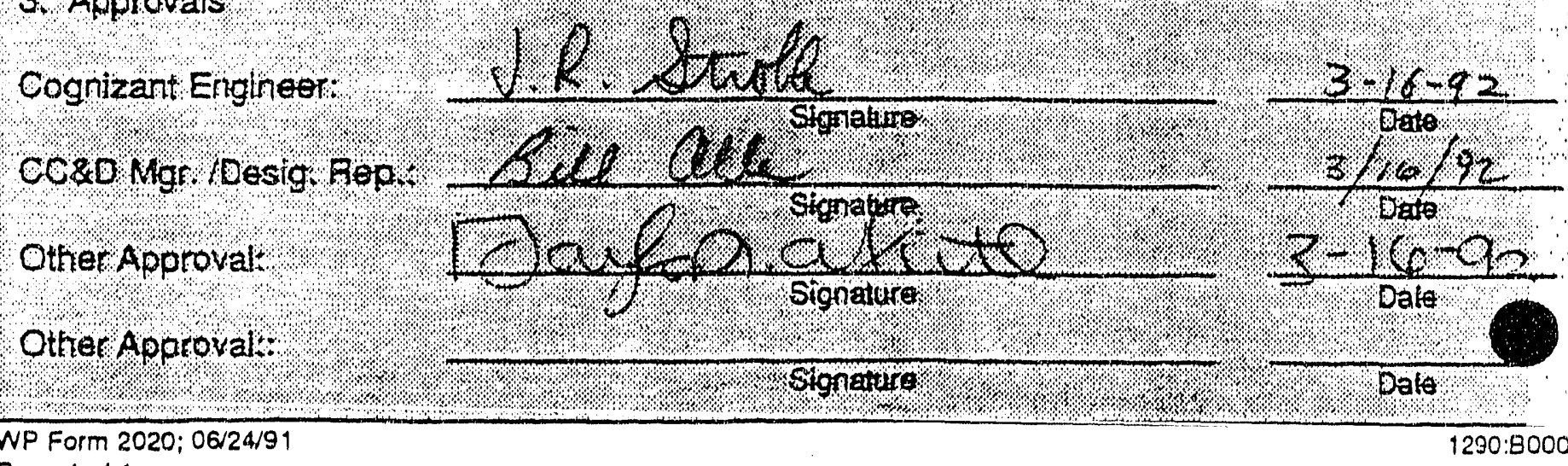

Page 1 of 1

$290: 8000$ 
$\frac{3}{3}$

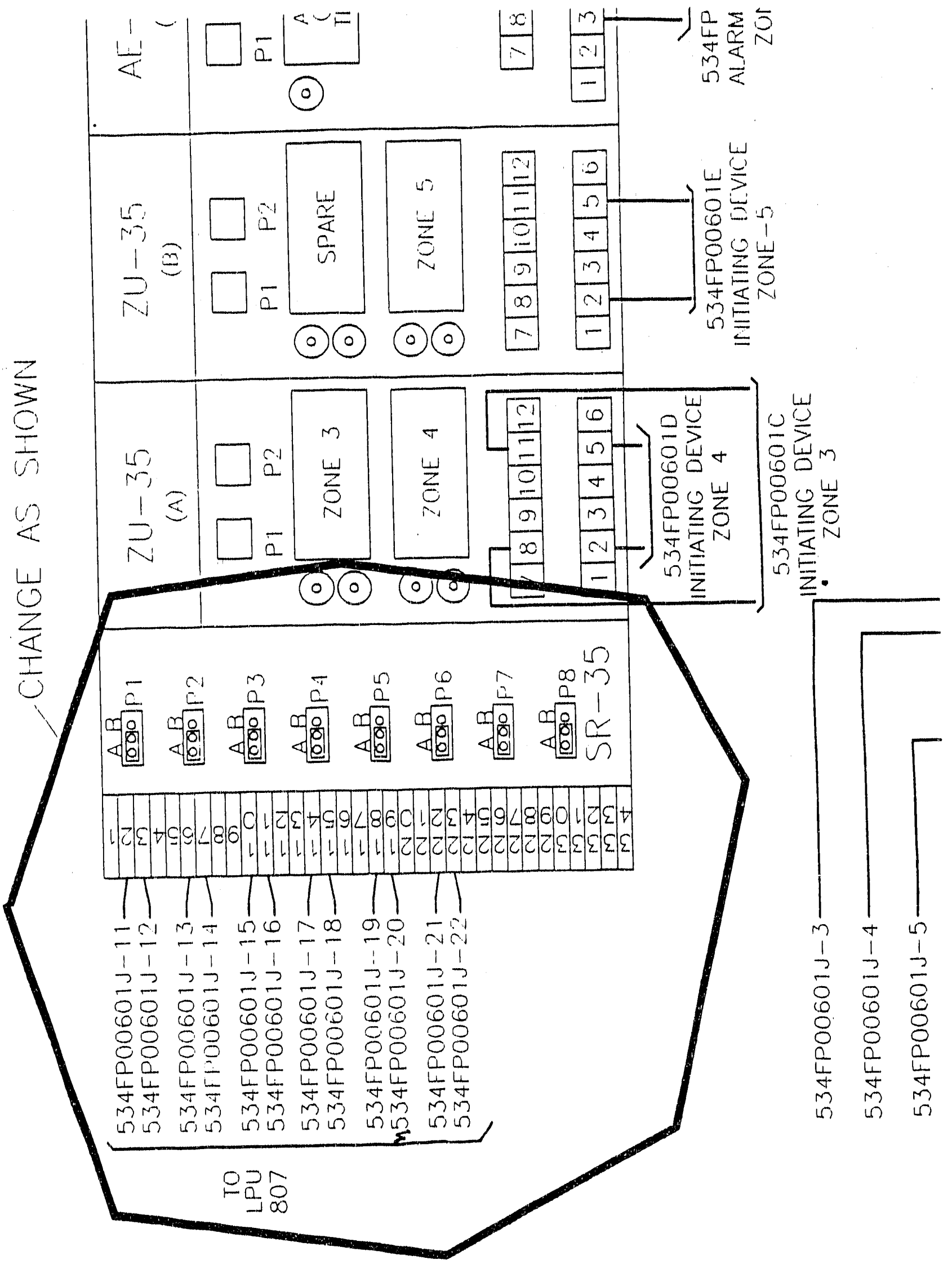


$\equiv 00 \quad 5860^{\circ}$

ADDENDUM $3 \cdot 16$.

PAGE 3 OF 3

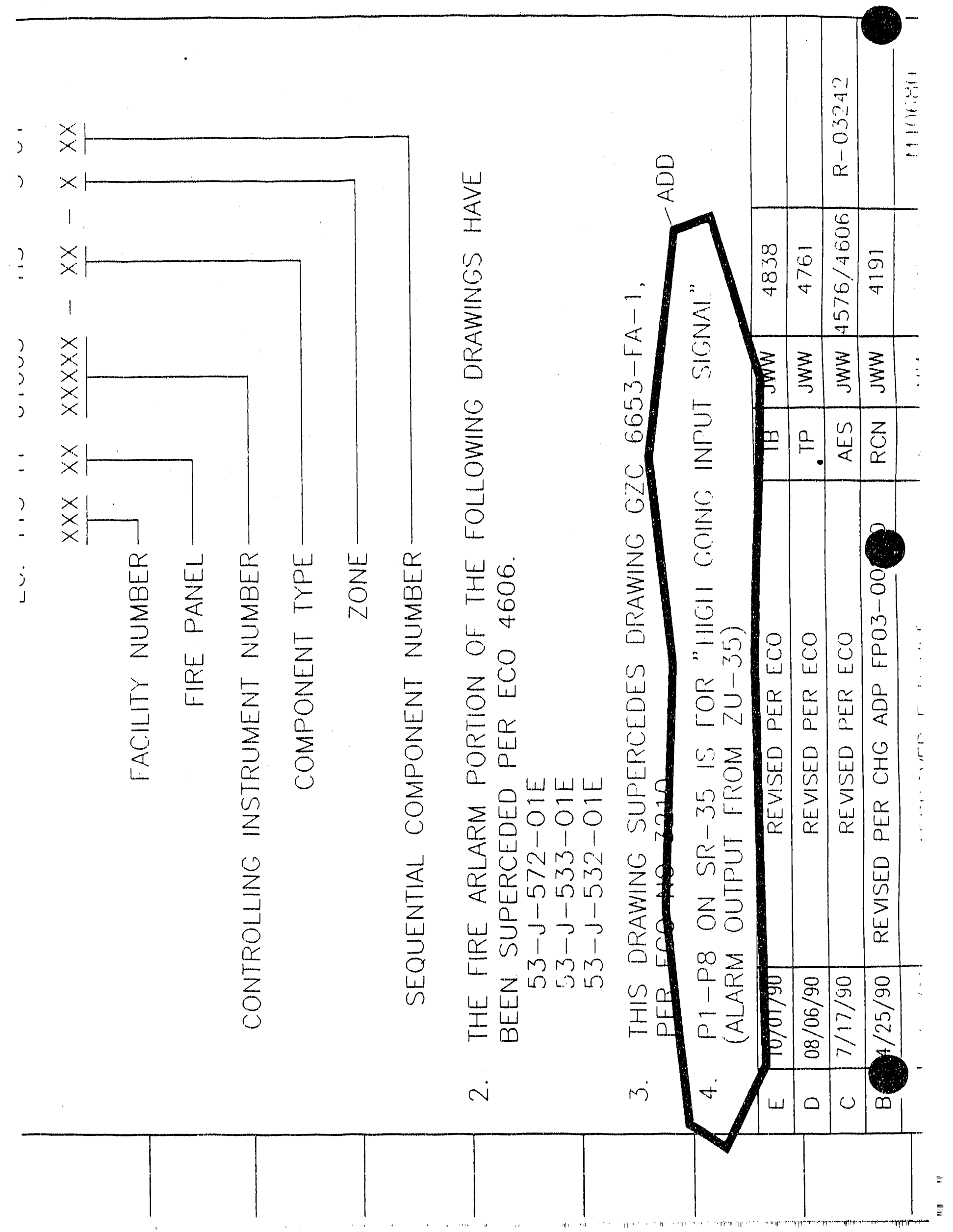




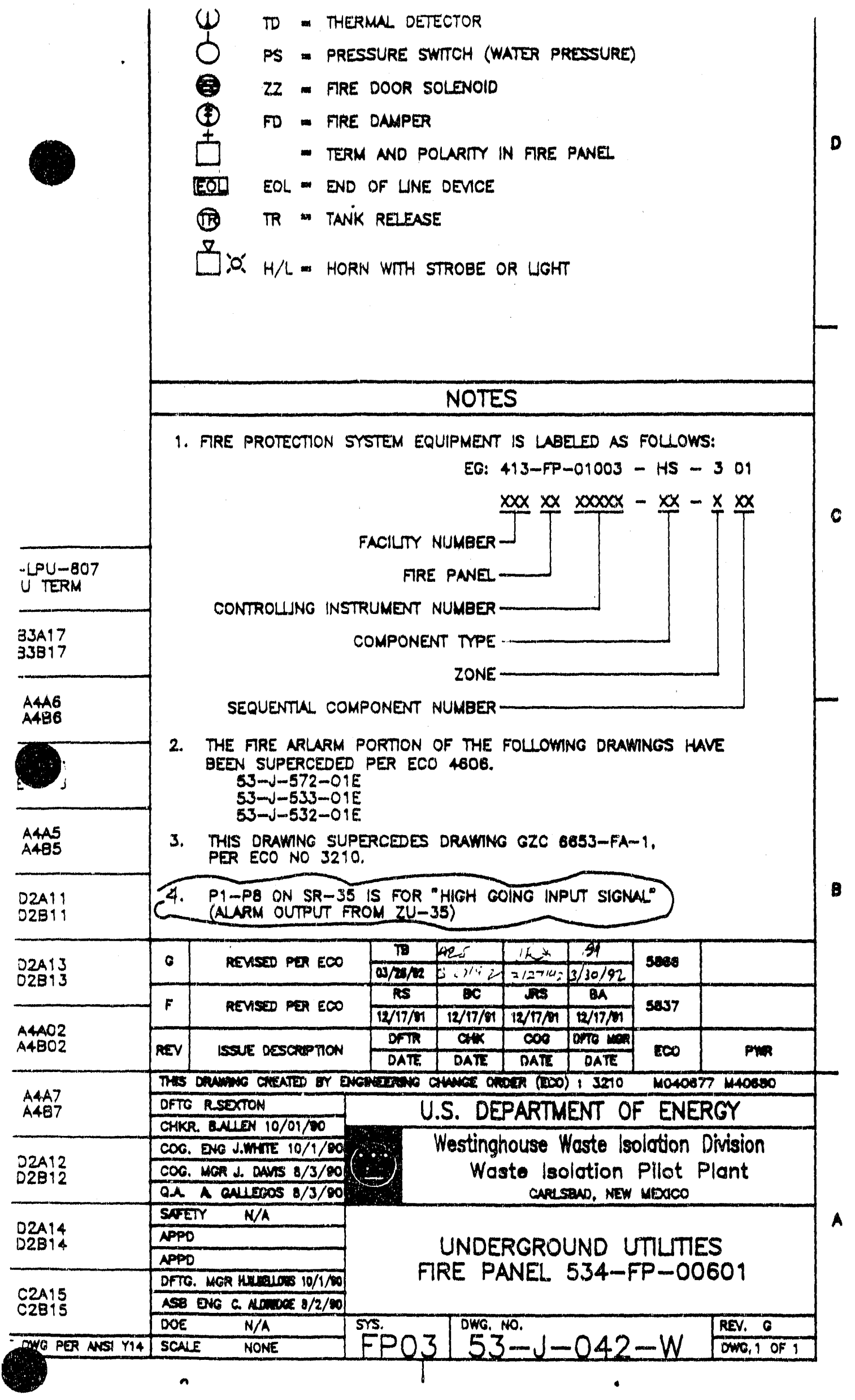




\begin{tabular}{|c|c|c|c|c|}
\hline \multirow{2}{*}{$\begin{array}{l}\text { 1. ECO No.: } \frac{5373}{\sqrt{3}} \\
-i, c \text { CC\&D Review: }\end{array}$} & \multirow[b]{2}{*}{ Initials } & \multicolumn{3}{|c|}{ 2. Impact Love! $=1 \square, 2 \square, 3 \rrbracket 4 \square$} \\
\hline & & 3 & System: Equipment No.: & 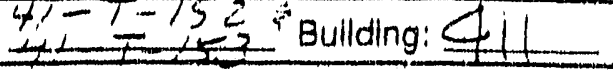 \\
\hline & Posted & 4 & Associated Documents: & 5. Document Type: \\
\hline & & & PWA $M=17295$ & 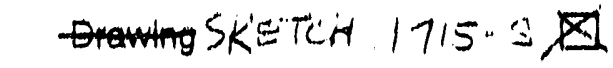 \\
\hline & & & ECP & Specification \\
\hline & & & P.O. & Vendor Data \\
\hline & & & Others & SDD \\
\hline & & & & Others __ \\
\hline
\end{tabular}

6. Titlo of Change: ANLACR TEUUPACT DOCKS (

7. Originator: (print) Ext. No.: Department: Date: 1 8. Cognizant Engineer: (print) LAD, SAYAHI S78C: M\&CE $11 \%$ MI F. KOWALSKI

\section{Description of Change:}

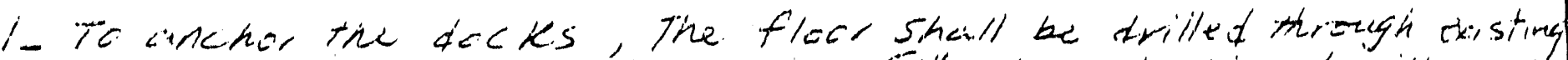
ciliamn basie pre. dralled hiles, then so"g botts be placed with aw

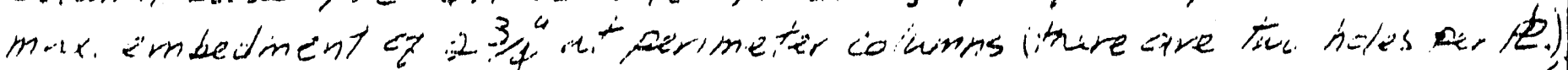

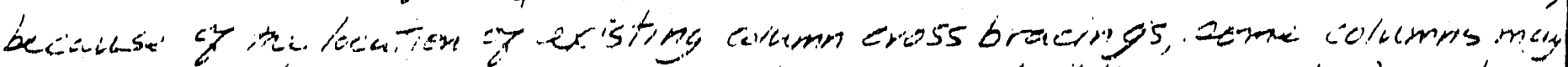

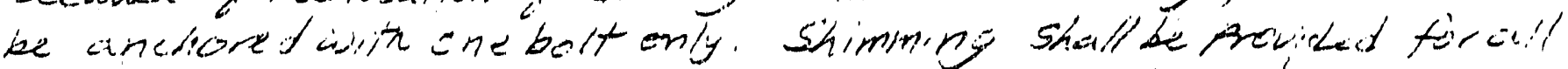

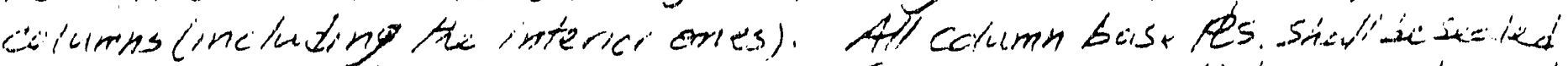

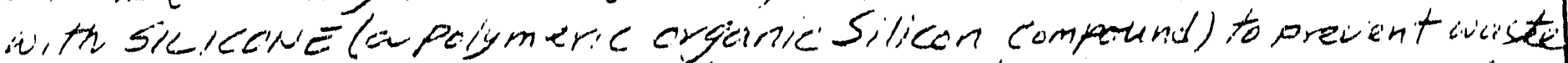

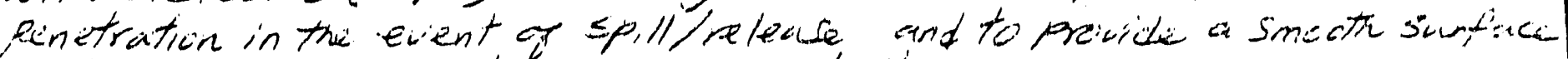

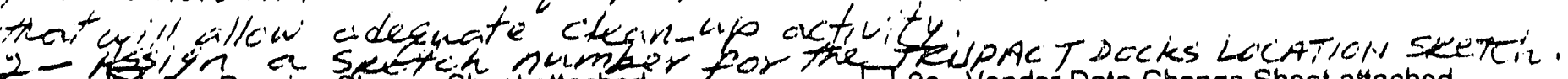
2 - S 3 $\square 96$ Design Documentation Sheet attached

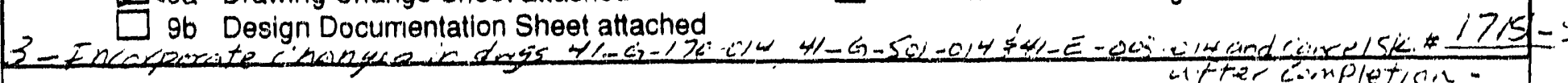

10. Yes No
$\square$ Y No
MODIFICATION IN PROGRESS
Modification complete:
signalure
up dated:
Change drawing per as-built markup dated:
Temporary modification

ECO will be

11. Design Verification Requirements: (per WP 09-018)

EDT No.:

$$
\text { wese for swerle }
$$

1. Requirements satisfied by review/approval of design document

2. Independent review

3. Altemate calculations

4. Development testing

5. Design review

6. Other:

\section{Addendum Sheot added:}




\section{Justification}

Artexisting state (nut anchored to the floor) bath checks are vilnerable to aceident, and ciny relatively atrong impact will cause the dociks to whitt/maveluterally.

14. Administratlve Tracking

YES N/A

$\square$ 1. FSAR

$\square$

2. Callibration Procedures

3. Maintenance Procedures

4. Computer Sottware

5. Operations Procedures

YES N/A

$\square \otimes$

$\square$

$\square$

$\square \square$

$\square$
6. Startup/Acceptance Test

7. Test Requirement \& Spec.

8.

9.

10.

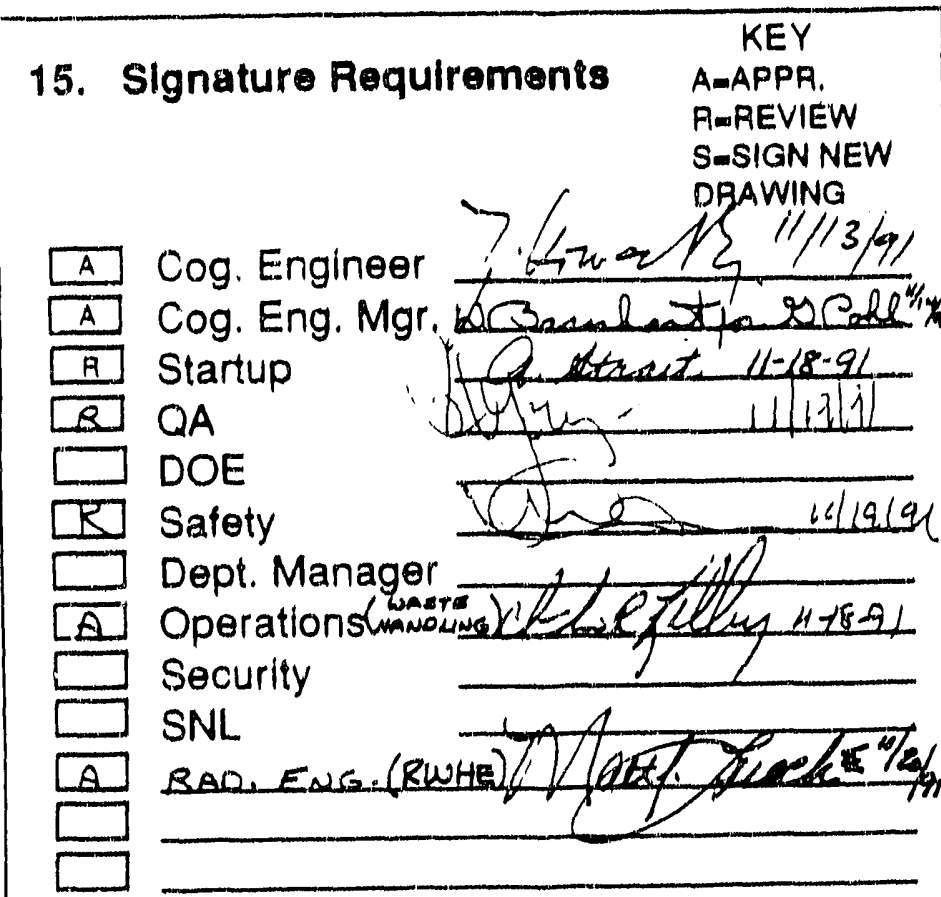

16. Distribute as Marked 


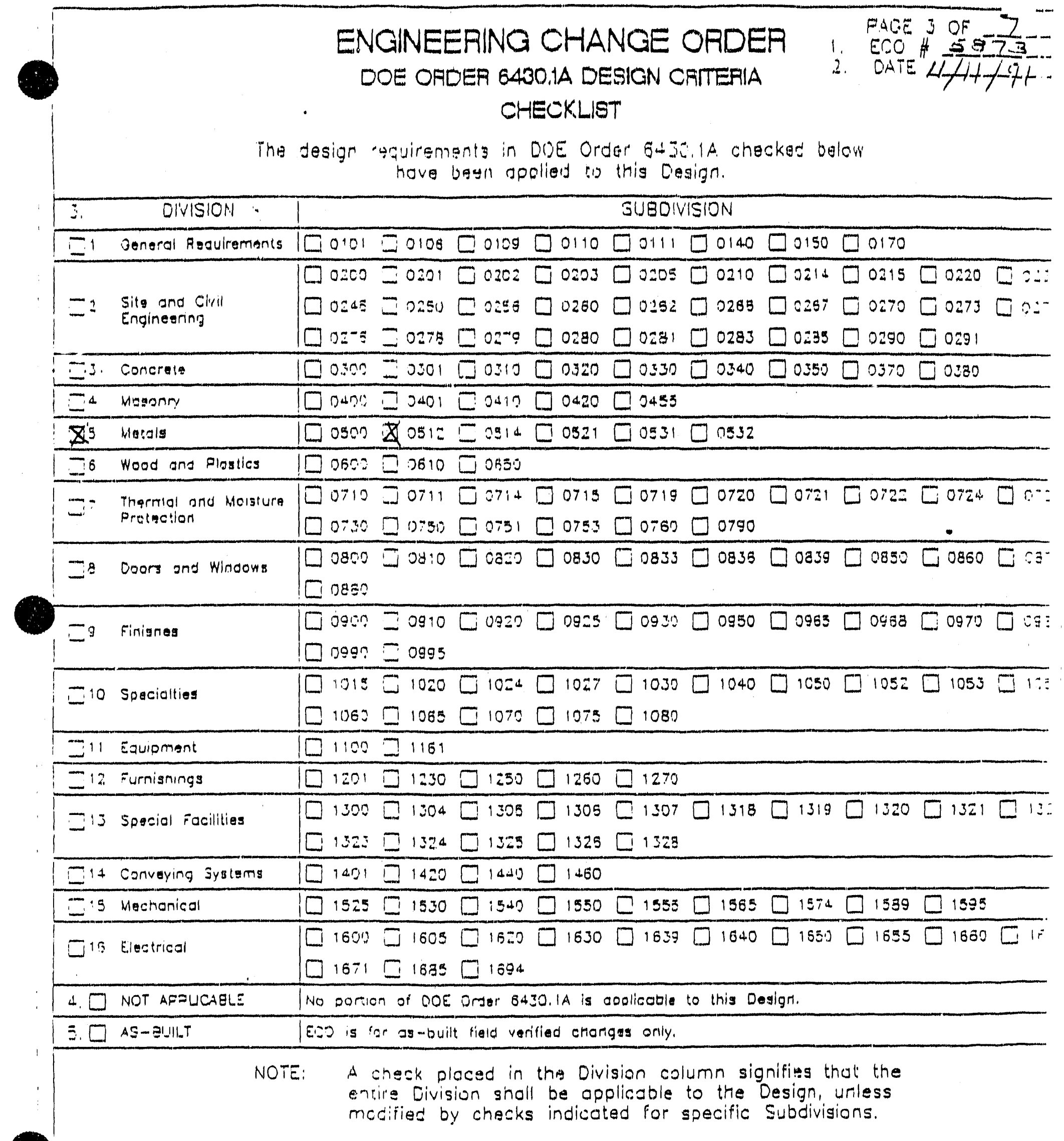

COMNENTS:

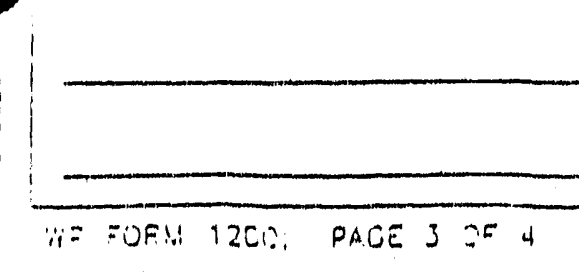




\section{9a}

\section{DRAWING CHANGE SHEET}

(1 SHEET PER DRAWING)

1. Drawing: $41-67-120-214-$ ECO Number: 5373

2. ECO Search List:
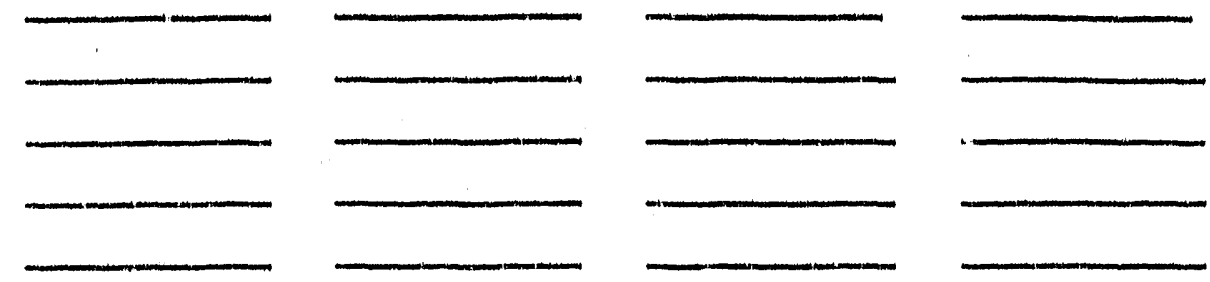

3. Description of Change:

Show iocation of TRUPACT DCiCKS 41-T-152 $541-T-153$ As per sketin \#-1715-S

4. Drawing Cog. Engineer Approval:

5. Cover Sheet Block (CC\&D Use Only)

Recelved from EFR:

Date Assigned:

Initials / Date

Assigned to: Initials / Date

(Same as data base entry)
Drafting Started:

Drafting Completed:

Return to EFR:
Initiale / Date

Inilials / Date

Inifials / Date 
$9 a$

DRAWING CHANGE SHEET

(1 SHEET PER DRAWING)

1. Drawing: $41-6-501-0144$ ECO Number: 5873

2. ECO Search List:
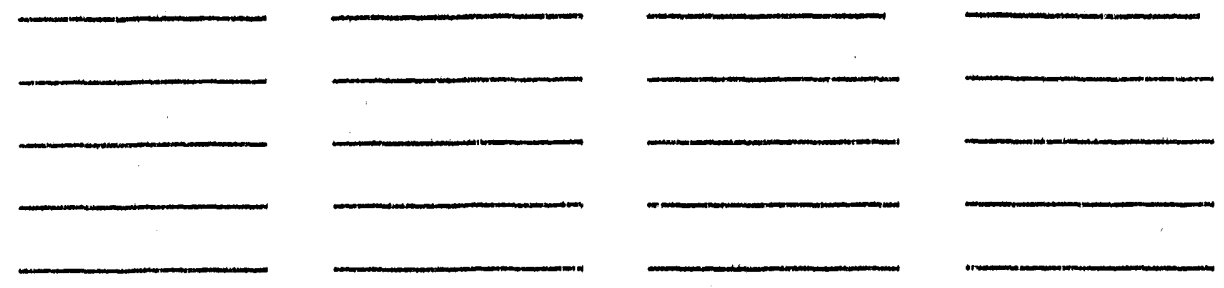

3. Description of Change:

Shaw location of TRUPACT Docks 41-T- 152 $\{41-T-153$. 4s per sketch \#1715-5

4. Drawing Cog. Engineer Approval:

$7 \cdot \operatorname{trn} 2\}$

Date:

$11 / 14 / 91$

5. Cover Sheet Block (CC\&D Use Only)

Received from EFR: Initials / Date

Date Assigned:

Assigned to: Initials / Dato

(Same as data base entry)
Dratting Started:

Dratting Completed:

Return to EFF: 


$$
t<\& 7
$$

$9 a$

DRAWING CHANGE SHEET

(1 SHEET PER DRAWING)

1. Drawing: $41-E-\mathrm{CO} 3-014$ ECO Number: 5373

2. ECO Search List:

3. Description of Change:

Show location of TRUPACT Dock 41-T-152 $\$ 41-T-153$ (in dotted lines). Per sketch number $1715-5$

4. Drawing Cog. Engineer Approval: Date: $\||/ 4 / 9|$

5. Cover Sheet Block (CC\&D Use Only)

Received from EFR:

Date Assigned:

Assigned to:
Drafting Started:

Drafting Completed:

Initials / Date

Initials / Date Initials / Date

Return to EFA:

Initials / Date

Initials / Dato

WP Form 2017: 12/29/90

1290:B0006

Page 1 of 1 


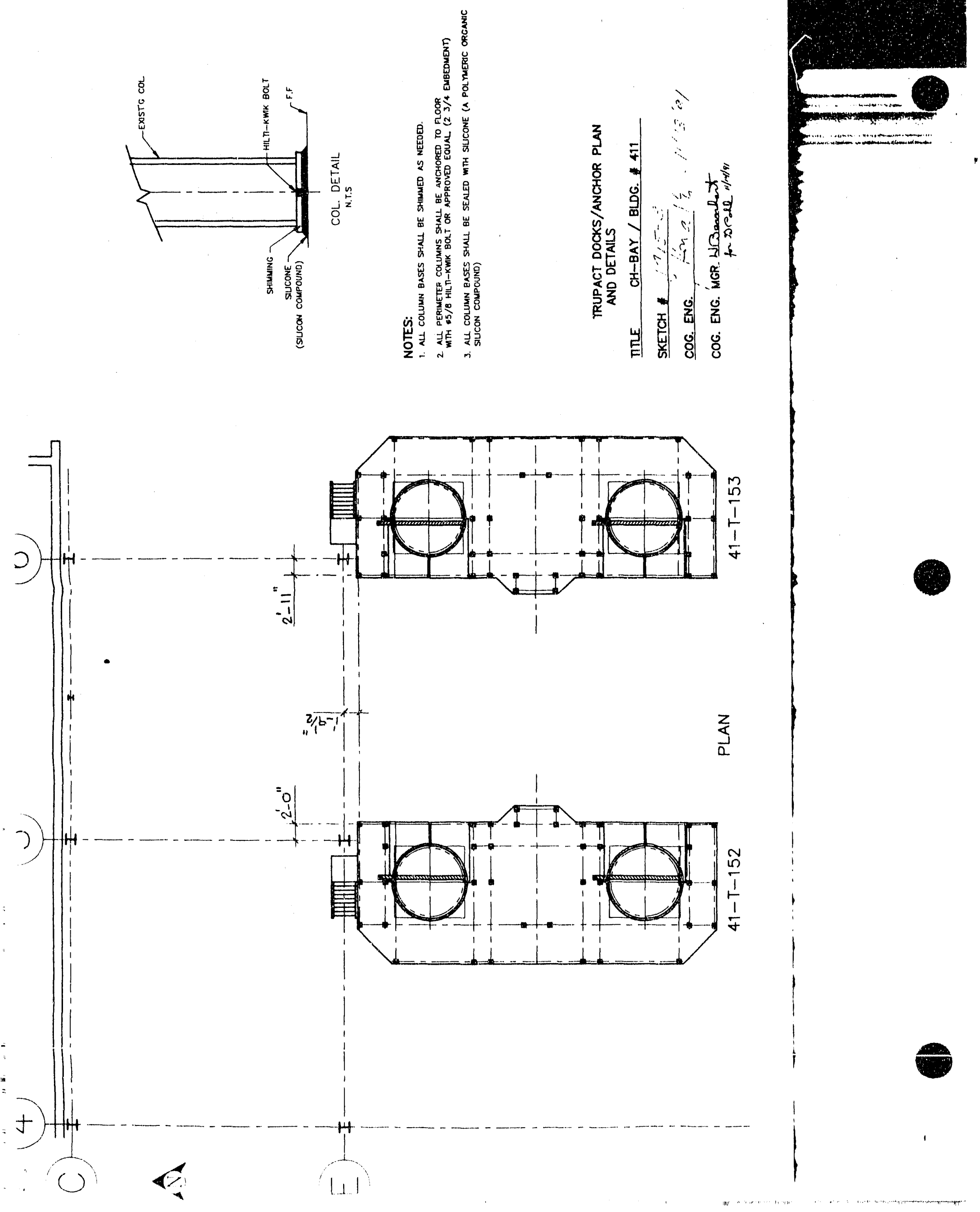




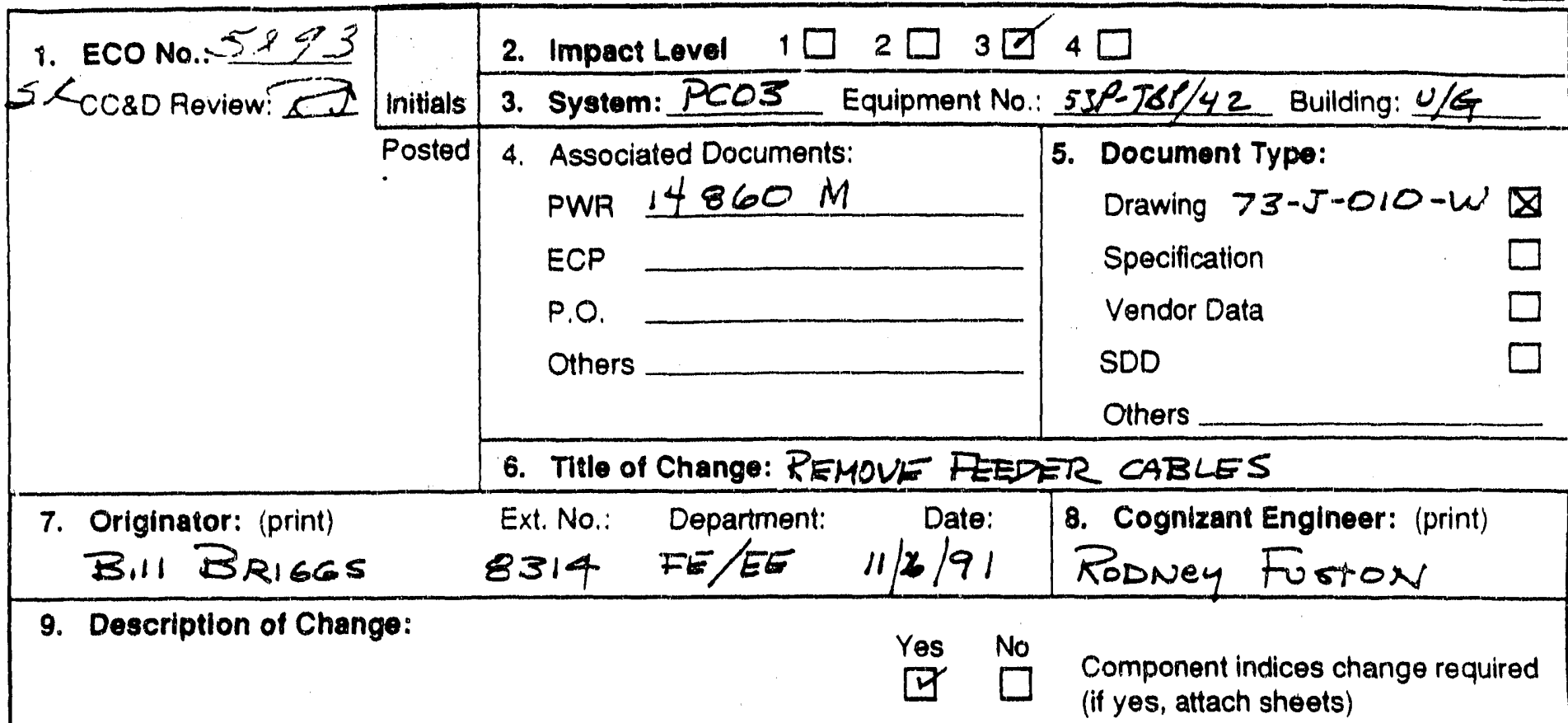

CHANGIE DRAWING $73-J-D I O-W$ TO SHOW ADDITION OF 2 JUNCTION BOXES AND "ABANDONED IN PLAC" OF 2 CABLES $\$$ PhONES iN ROOMS 2 \& OF N-1400 SEF ATAChED Sh EETS
$\square 9 a$
Drawing Change Sheet attached
9c Vendor Data Change Sheet attached
9b Design Documentation Sheet attached

10. Yes No

$\begin{array}{ll}\square=S & \text { No } \\ \square & \begin{array}{l}\text { MODIFICATION IN PROGRESS } \\ \text { Modification complete: }\end{array} \\ \square & \begin{array}{l}\text { Change drawing per as.buili markup dated: } \\ \square\end{array} \\ \square & \begin{array}{l}\text { Change drawing per ECO-provided data } \\ \text { Temporary modification }\end{array}\end{array}$

11. Design Verification Requirements: (per WP 09-018)

EDT No.:

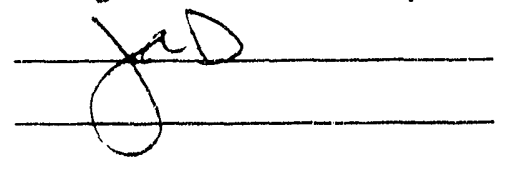

1. Requirements satisfied by review/approval of design document

2. Independent review

3. Altemate calculations

4. Development testing

5. Design review

6. Other:

12. Addendum Sheot added: 


\section{Justification}

The BACK IS COMING IN IN ROOMS $2 \$ 3$ OFF N 1400

DRIFT IT IS NECESSARY tO RE-ROUTE ThE FEEDERS TO ThESE AREA PHONES - IF ThE ROOF FALLS NOW

ThE GAI-TRONICS SYSTEM COULD BE KNOCKED OUT

\section{Administrative Tracking}

YES N/A

$\square \bowtie$ 1. FSAR

$\square \square$ 2. Calibration Procedures

$\square \square$ 3. Maintenance Procedures

$\square$ 4. Computer Sottware

5. Operations Procedures

15. Signature Requirements

\section{KEY}

A.APPR.

R.REVIEW

SuSIGN NEW

DRAWING

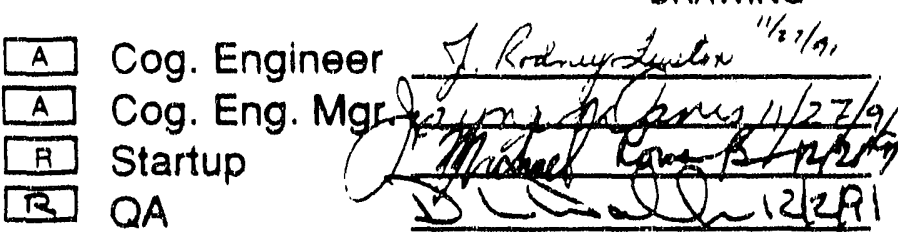

DOE

\section{[B] Safety}

Dept. Manager

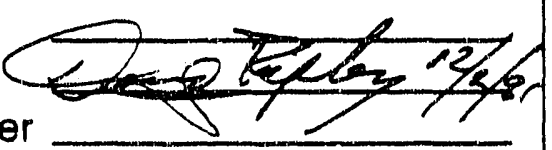

Operations

$12 / 2 / 4$

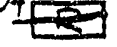

Security

SNL
YES NA

$\square \bigotimes$ 国 Startup/Acceptance Test

$\square \bigotimes$ 7. Test Requirement \& Spec.

$\square \square 8$.

$\square \square 9$.

$\square \square \quad 10$.
16. Distribute as Marked

Maintenance (MANDATORY)

Ops. Support MANOATORY)

Startup

Facility Operations

U/G Operations

Orig./Design Engr.

Cog. Engineer

Others 


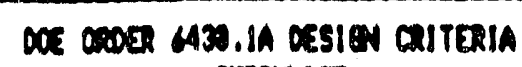

arears

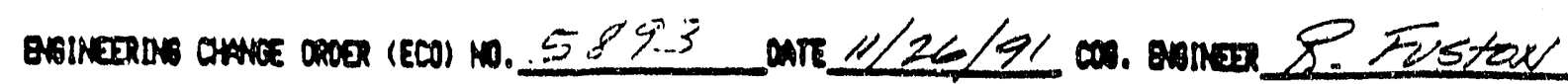

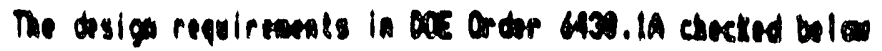
have been applled to thls $\mathrm{Eco}$.

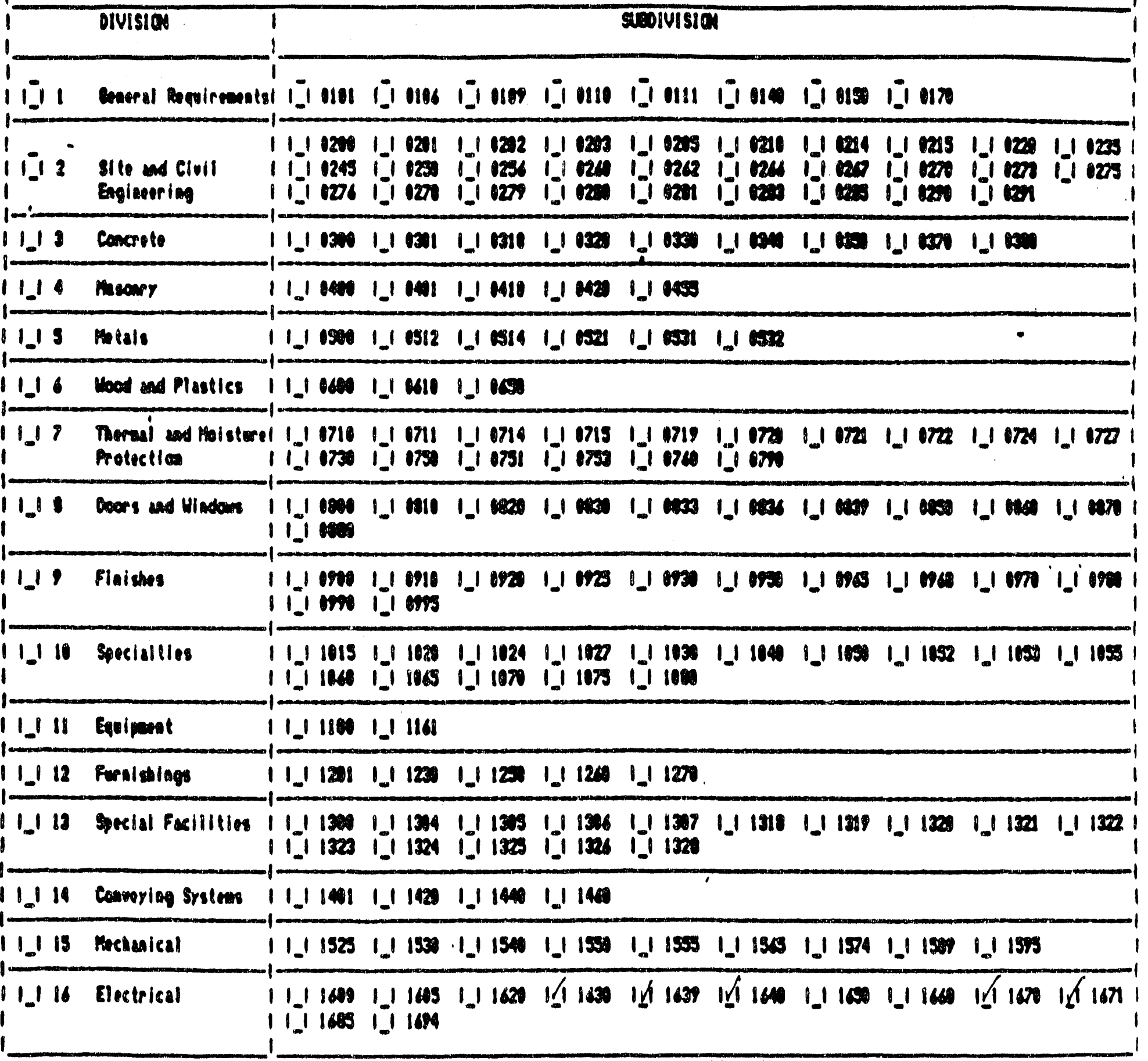

Bole: A chected placed in the Oivision colven sigaifles that the

extire Division stall be spollcable to the ECO, walose

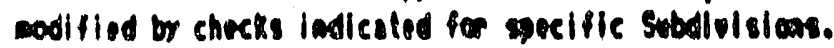


1. Drawing: $13-v \div 010-w$

ECO Number: 589.3

2. ECO Search List:
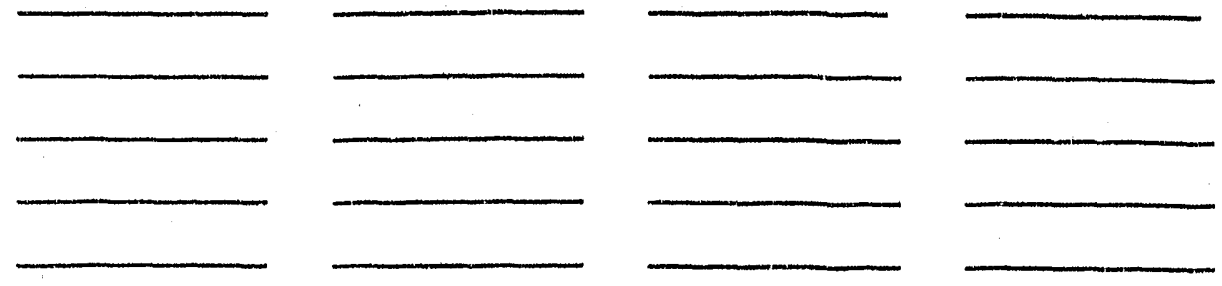

3. Description of Change:

CHANGE DRAWING 73-J-010-W TO REFLECT RENOVL OF FEEDER CABLES to FOOMS 243 ON N-1400 DRE FT ShOW DEVICES $\Rightarrow$ SPBLES ABANDONED IN PLACE

4. Drawing Cog. Engineer Approval: f Ridnuy fuetion Date:

$11 / 27 / i 1$

5. Cover Sheet Block (CC\&D Use Only)

Received from EFR:

Date Assigned:

Assigned to:
Initials / Date Initials / Date
Drafting Started:
Drafting Completed:
Return to EFA: (Samie as duata tasấ entriy)
Initials / Dato Initials / Date Inifingls ! Date 
$\varepsilon 6+5 \neq 4$
-585

1.

an

$\because 4)$

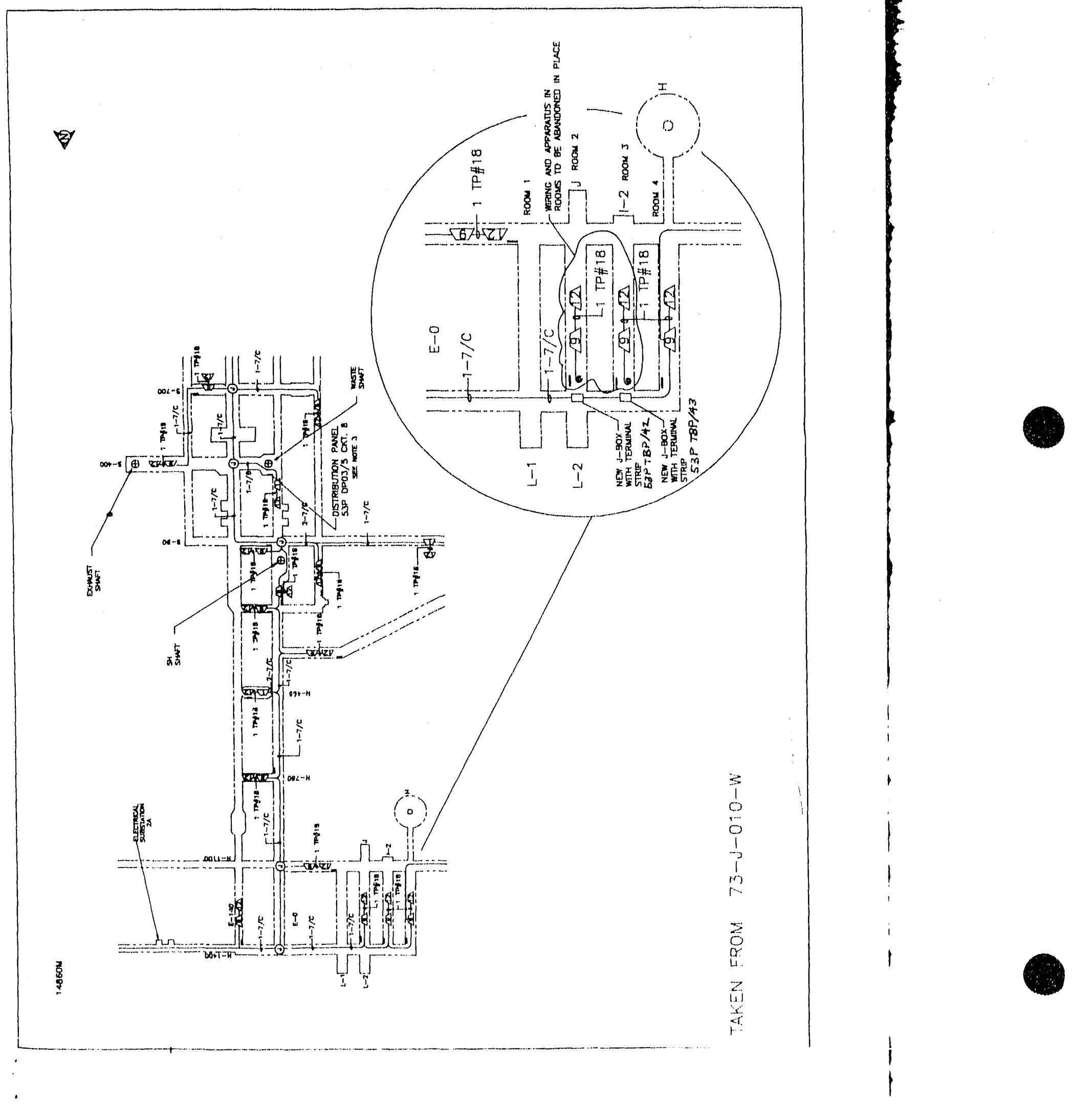



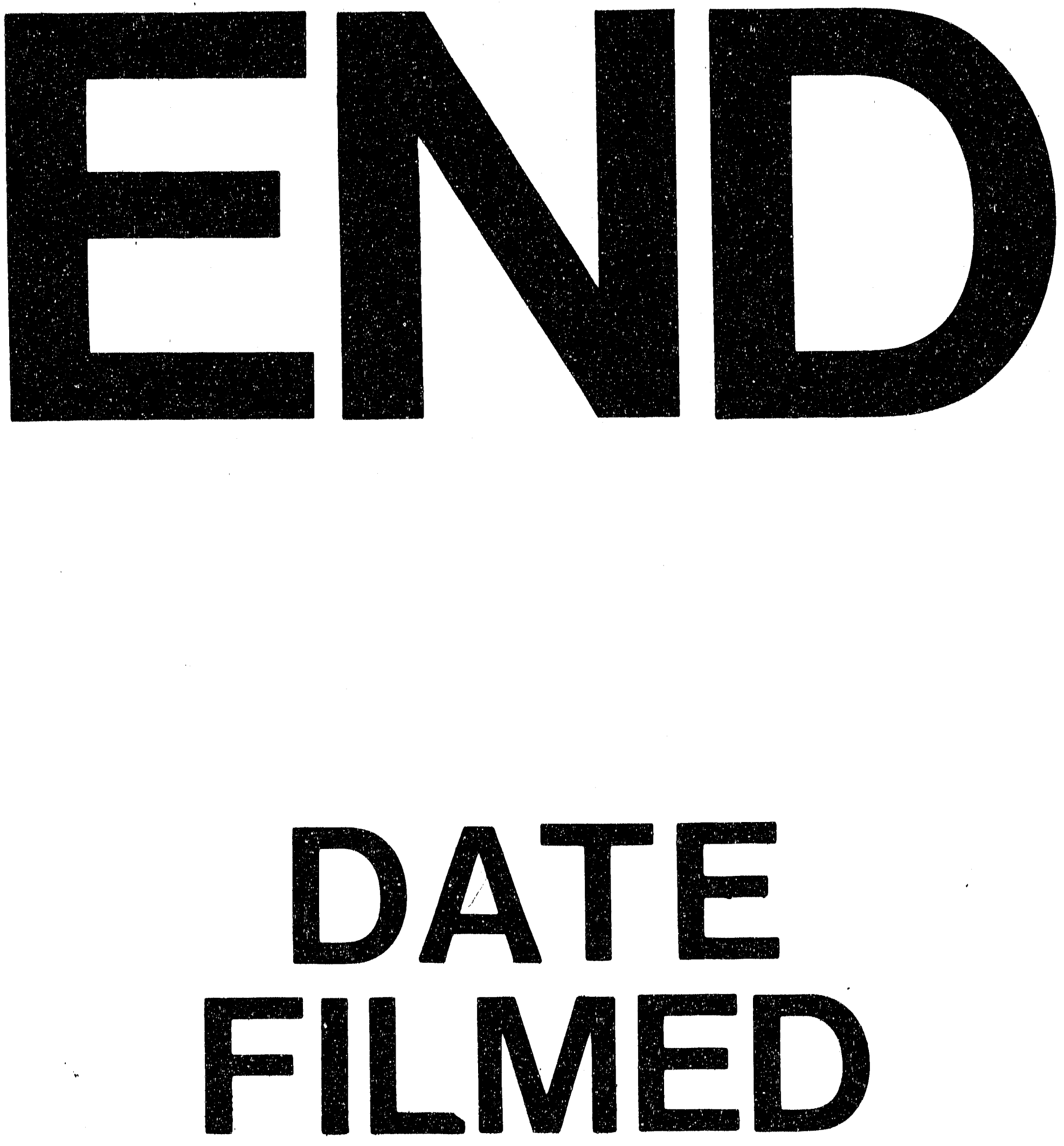

1

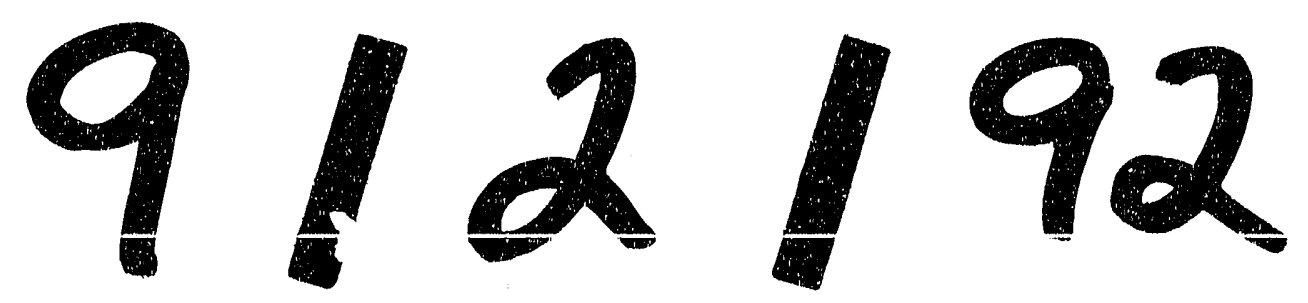




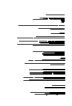

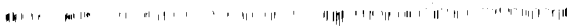

